
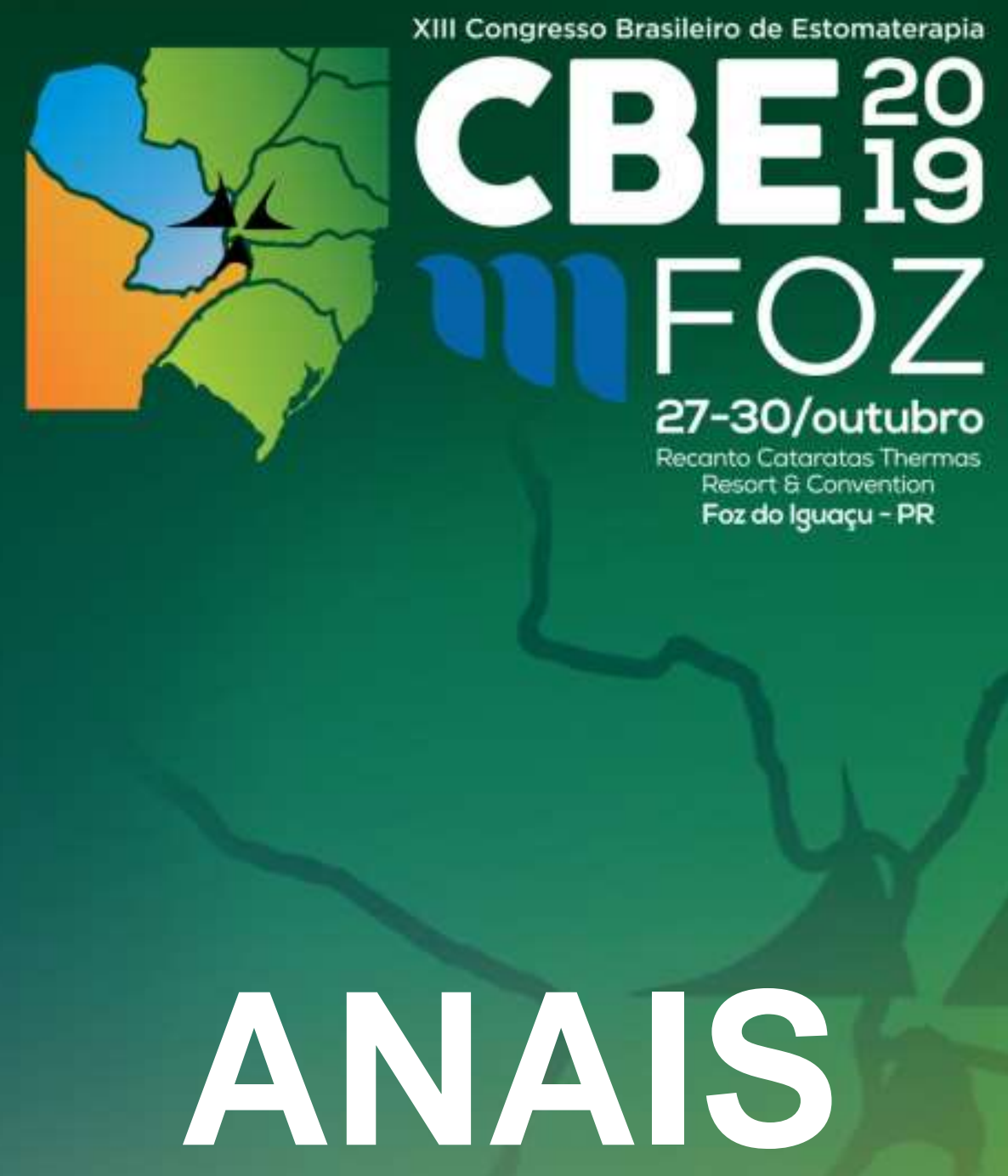

ISSN: 2525-4952
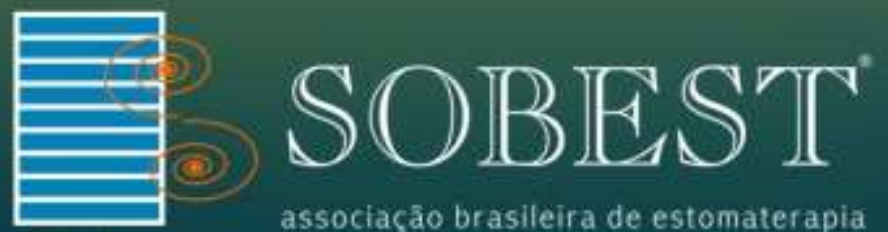


\title{
ADAPTAÇÃO DE BANHEIRO CONVENCIONAL PARA A NOVA CONDIÇÃO VIVENCIADA POR PESSOAS COM ESTOMIA: RELATO DE EXPERIÊNCIA.
}

\author{
Author(s): $\quad$ ARTHUR HENRIQUE ALMEIDA DE LIMA ${ }^{1}$ \\ Institution(s) ${ }^{1}$ IENF - Instituto de Enfermagem (Rua Roso Danin, 257 - Canudos/Belem - PA)
}

\begin{abstract}
Introdução: A técnica da estomia consiste na abertura de um órgão por meio de um ato cirúrgico, formando uma boca que passa a ter contato com o meio externo para eliminações de secreções, fezes e/ou urina4. A perda do controle esfincteriano, com eliminação involuntária das fezes e urina leva a necessidade de conviver com um equipamento coletor aderido ao abdome, o que os expõe a vivência de diversos constrangimentos sociais. Quando uma pessoa torna-se uma pessoa com estomia, ela passa por algumas transformações em sua vida, e uma delas é a necessidade de um banheiro adaptado, que é o principal ambiência que sofre alterações para atender às suas necessidades. Porém esse tipo de adaptação é raríssimo de se encontrar. Infelizmente, quando se constrói banheiros para portadores de necessidades especiais, geralmente as pessoas só se lembram dos cadeirantes, e se esquecem de que existem deficiências diversas, cada uma com especificidades diferentes5. Muitas pessoas com estomia hesitam em sair de suas residências e em ter uma vida social ativa, pois se preocupam em como esvaziar do seu equipamento coletor fora de suas casas. Para uma pessoa com estomia pode ser estressante utilizar banheiros públicos e pode causar pânico o fato de lidarem com os eventuais vazamentos de dejetos ou urina em banheiros públicos. O ideal seria que esses banheiros fossem instalados em hospitais, casas geriátricas, clínicas e todos os prédios públicos5. Objetivos: Descrever a experiência de Estomaterapeuta na contrução de um banheiro convencional adaptado a pessoas com estomias. Material e Métodos: Trata-se de um relato de experiência, com observação participativa da vivência sobre a adaptação de um banheiro convencional para a nova condição vivenciada por pessoas com estomia, realizado nos meses de novembro de 2015 a janeiro de 2016, no Serviço de Atenção à Pessoas Estomizadas, Belém-Pa. Resultados e Discursão: Assim como em alguns Estados, o Pará também disponibiliza de um Serviço de Atenção à pessoa Estomia, tendo como objetivo prestar uma assistência qualificada, humanizada e profissional, buscando a reabilitação das pessoas com estomias intestinais e urinários com ênfase na orientação para o autocuidado, prevenção de complicações e fornecimento de equipamentos coletores e adjuvantes de proteção e segurança. Este Serviço atende pessoas com estomia da Capital, de outros Municípios do Estado. Atualmente o Serviço conta com uma equipe multidisciplinar. No entanto, apesar do Serviço ser referência para o Estado, também não oferecia um banheiro adaptado para as pessoas com estomia. Fator que contribuiu como estímulo para a construção do banheiro adaptado, foi que durante a vivência profissional no serviço, foi observado e ouviu-se relatos das pessoas com estomia, que os mesmos evitam ir ao serviço para recebimento do equipamento coletor, consultas e reavaliação com os profissionais da equipe, devido a necessidade de ir ao banheiro com frequência por conta da sua condição. Conclusão: diante de todas as dificuldades que o sistema de saúde apresenta, ainda é possível através da dedicação e compromisso profissional, respeito e responsabilidade prestar uma assistência humanizada, visando à qualidade de vida das pessoas com estomia.
\end{abstract}

\section{Keywords: ESTOMIA, ESTOMATERAPIA, AMBIÊNCIA, QUALIDADE DE VIDA}

\section{Referências Bibliográficas}

Referências: 1. Bechara RN, Bechara MS, Bechara CS, Queiroz HC, Oliveira RB, et al. Abordagem multidisciplinar do ostomizado. Rev Bras Coloproct. 2005; 25 (2):146-149. 2. Fayrs, P.M.D. Quality of life: assessment, analysis and interpretation. Chichister: John Wiley, 2000. 168 p. 3. Furlani, R.; ceolim, M.F. Conviver com um ostoma definitivo: modificações relatadas pelo ostomizados. Rev. Bras. Enferm. v.55, n.5, p.586-91, 2002. 4. Gemelli, L.M.G; zago, M.M.F. A interpretação do cuidado com o ostomizado na visão do enfermeiro: um estudo de caso. Rev. Latino-am Enfermagem, v.10, 2002. 5. Yamada, C.; yamada, C. A importância da existência de banheiros adaptados para uma pessoa ostomizada.

Disponível em: 


\title{
DIAGNÓSTICO SITUACIONAL DA REDE DE ATENÇ̃̃o A SAÚDE DAS PESSOAS OSTOMIZADAS NO DEPARTAMENTO REGIONAL DE SAÚDE - DRS10- PIRACICABA
}

\author{
Author(s): Andreia Aparecida De Luca Moore Bonello ${ }^{1}$ \\ Institution(s) ${ }^{1}$ SES- SP - Secretaria Estadual da Saude SP (Rua Maranhao 279 Limeira)
}

\begin{abstract}
Introdução - A Atenção à Saúde das Pessoas Ostomizadas no âmbito do Sistema Único de Saúde tem como princípio a integralidade no cuidado. Este modulo de atenção deve ser composto por ações desenvolvidas com ênfase na Atenção Básica, por meio de intervenções especializadas de natureza interdisciplinar, contando com estrutura especializada. Partindo desse pressuposto faz necessário à organização das unidades de saúde; a definição de fluxos, a articulação e apoio matricial entre essas unidades incluindo a rede hospitalar.

Objetivos - Este trabalho teve como objetivo realizar um diagnóstico da rede de atenção à Saúde das Pessoas Ostomizadas no âmbito do Departamento Regional de Saúde de Piracicaba - DRS10.

Metodologia - Estudo quantitativo transversal, de caráter descritivo, feito com os responsáveis pelo programa de atenção ao portador de ostomia de cada município da área de abrangência do DRS10 - Piracicaba. A coleta de dados foi realizada por meio do envio do instrumento via endereço eletrônico do serviço de atendimento aos ostomizados. As informações foram obtidas por meio de um questionário semiestruturado, elaborado conjuntamente pelos profissionais do programa no âmbito regional (ARE-Limeira). A análise dos dados foi realizada por meio da descrição da situação referida por cada município e apresentados em tabelas. A elaboração do instrumento de pesquisa englobou a articulação dos aspectos técnicos com a realidade local.

Resultados: A atenção aos ostomizados é desenvolvida tanto em unidades básicas de saúde, como em unidades de especialidades. Na grande maioria dos municípios o programa fica sob a responsabilidade do profissional enfermeiro contando com uma equipe reduzida de profissionais atrelada ao perfil da não exclusividade desses para ações do programa. Em relação à origem dos pacientes os serviços públicos são relevantes. Todos os municípios referiram não dispor de referencia para reversão e que esta se da a partir do médico que atendeu o cliente e do vinculo desse profissional e acontece de maneira independente do programa de atenção aos ostomizados.

Conclusão: A atenção em ostomias nos diferentes municípios está implantada e sendo executada, mas apresenta uma lacuna entre o real e o ideal. Essa divergência constitui um espaço de trabalho que merece atenção para sua organização e qualificação, mas que de forma alguma, inviabiliza o que vem sendo construído pelos diferentes locais de execução do programa.
\end{abstract}

Keywords: Estomoterapia, Pessoa Estomizada, Rede de Atenção

\section{Referências Bibliográficas}

Brasil. Portaria SAS/MS no 400 de 16 de novembro de 2009. Estabelece Diretrizes Nacionais para a Atenção à Saúde das Pessoas Ostomizadas no âmbito do Sistema Único de Saúde - SUS. Diário Oficial da União 18 de nov 2009; Seção 1. 


\title{
CONHECIMENTO DO ESTOMATERAPEUTA OU ENFERMEIRO SOBRE A REALIZAÇÃO DA IRRIGAÇÃO DE COLOSTOMIA.
}

\author{
Author(s): $\quad$ ARTHUR HENRIQUE ALMEIDA DE LIMA ${ }^{1}$ \\ Institution(s) ${ }^{1}$ IENF - Instituto de Enfermagem (Rua Roso Danin, 257 - Canudos/Belem - PA)
}

\begin{abstract}
Introdução: A irrigação de colostomia é o método usado para a regulação da atividade intestinal da pessoa com colostomia. Isso é alcançado pelo uso da lavagem intestinal realizada por meio da estomia, com intervalos regulares, introduzindo-se um volume líquido planejado no intestino grosso, sendo a água, à temperatura corporal, para limpar o intestino grosso, e que possibilita controlar a eliminação de fezes pela colostomia por um período regular1. O déficit nas regiões do país de profissionais Estomaterapeutas ou Enfermeiros capacitados pela a falta de conhecimento teórico e prático do procedimento de irrigação da colostomia, tem gerado a fragmentação da assistência e desinformação das pessoas com colostomia. Objetivo: Conhecimento dos estomaterapeutas ou enfermeiros sobre a realização da irrigação de colostomia2. Material e Método: Pesquisa de desenvolvimento metodológico, com abordagem quantitativa. Foram 60 profissionais participantes das cinco Regiões do Brasil, 55\% Estomaterapeutas e 45\% Enfermeiros. A coleta dos dados aconteceu no período de 09/2017 a 01/2019. Aplicaram-se um instrumento, organizados em questionário com 30 perguntas objetivas. Os dados foram analisados pela estatística descritiva3. Resultados e Conclusões: Os resultado da avaliação dos profissionais, constatou-se a análise quantitativa obtendo estatisticamente $55 \%$ dos Estomaterapeutas apenas $15 \%$ tem conhecimento teórico e prático do procedimento para realizar a autoirrigação e $45 \%$ dos Enfermeiros apenas 5\% tem conhecimento do mesmo procedimento. A pesquisa identificou que é pequena a quantidade de profissionais que conhece o procedimento da autoirrigação da colostomia. A pesquisa ainda apontam que $50 \%$ do total dos profissionais da pesquisa trabalham no serviço de atenção a pessoa com estomia. Conclui-se que nesta pesquisa, existe a necessidade da realização de cursos e treinamentos para promover uma melhor assistência e orientação as pessoas com colostomia para realizar a autoirrigação. Em seguimento à capacitação desses profissionais, a presença de um Estomaterapeuta nessa equipe implicaria na busca desses conhecimentos e oferecendo dessa maneira uma assistência especializada e a possibilidade de reabilitação da pessoa com colostomia e garanta a real atenção integral na melhora da qualidade de vida e a inclusão social da pessoa com costomia através da autoirrigação. Esses resultados possibilitam e nos motivam a desenvolver atividades que possam contribuir com a capacitação dos profissionais, tendo em mente que o conhecimento científico é a base para o faze-lo. O desenvolvimento desta pesquisa permitiu também descrever como está sendo realizado o atendimento as pessoas com colostomia na saúde pública do Brasil. Dessa forma, é importante a realização de outras pesquisas para constatação do déficit de conhecimento, a fim de melhorar a assistência de Enfermagem.
\end{abstract}

\section{Keywords: ESTOMATERAPEUTA, ENFERMEIRO, COLOSTOMIA, QUALIDADE DE VIDA}

\section{Referências Bibliográficas}

1. Cesaretti IUR, Santos VLCG, Schiftan SS, Vianna LAC. Irrigação da colostomia: revisão acerca de alguns aspectos técnicos. Acta Paul Enfer. 2008;21(2): 339-44. 2. SANTOS, V.L.C.G; CESARETTI, I.U.R. Assistência em Estomaterapia: cuidando de pessoas com estomia - São Paul: Editora Atheneu, 2015. 3. POLIT D.F.; BECK C.T. Fundamentos de pesquisa em enfermagem: avaliação de evidências para as práticas da enfermagem. Ta Ed. Porto Alegre (RS): Artmed; 2011. $669 \mathrm{p}$. 


\title{
IRRIGAÇÃO DA COLOSTOMIA: ASPECTOS TÉCNICOS INERENTES AO PROCEDIMENTO E O PAPEL DO ENFERMEIRO.
}

\author{
Author(s): $\quad$ Oscar Cassavilani ${ }^{1}$, Andreia Aparecida de Luca Moore Bonello ${ }^{2}$ \\ Institution(s) ${ }^{1}$ FIEL - Faculdades Integradas Einstein de Limeira (R. Raul Machado, 134, Vila Queiroz, \\ Limeira.), ${ }^{2}$ FIEL - Faculdades Integradas Einstein de Limeira (R. Raul Machado, 134, Vila \\ Queiroz, Limeira.)
}

\begin{abstract}
Introdução: Estomias intestinais constituem em intervenções cirúrgicas realizadas, tanto no cólon como no intestino delgado e consiste na exteriorização de um segmento intestinal, através da parede abdominal, criando assim uma abertura artificial para a saída do conteúdo fecal. A realização de estomas faz parte do tratamento cirúrgico de diversas doenças. Dentre as situações clínicas que podem desencadear a necessidade da realização cirúrgica de uma estomia, o câncer de cólon e reto parece ser a mais prevalente. A confecção de um estoma acarreta em modificações não somente na imagem corporal do paciente, mas em todos os seus aspectos biopsicossociais e espirituais, podendo influir desfavoravelmente em sua qualidade de vida. Na perspectiva do cuidado de enfermagem na integralidade a irrigação constitui um recurso importante na reabilitação do portador de estomias, possibilitando-Ihes o controle intestinal mais efetivo, com reflexos para a sua qualidade de vida.
\end{abstract}

Objetivos: Estudar os aspectos inerentes ao procedimento de irrigação em portadores de estomias intestinais, identificando o papel do profissional enfermeiro nesse processo.

\begin{abstract}
Metodologia: Trata-se de um estudo teórico no qual se utilizou a pesquisa descritiva de caráter bibliográfico com investigação sobre o tema em livros, na biblioteca virtual da Saúde, nas bases de dados Scielo e outros sites acadêmicos utilizando os descritores Estomias, Irrigação, Enfermagem.
\end{abstract}

\begin{abstract}
Resultados: No decorrer do estudo verificamos que a abordagem da enfermagem contempla o cuidado integral do paciente estomizado propiciando a sua autonomia para o enfrentamento da sua condição promovendo assim a sua reinserção social. A irrigação constitui um recurso importante na reabilitação de pessoas estomizadas, possibilitando-lhes o controle intestinal mais efetivo, com reflexos em sua qualidade de vida. O papel do enfermeiro frente à irrigação de colostomia prioritariamente é promover a independência do estomizado, elevando sua autoestima, propiciando uma vida mais digna e com mais qualidade, através do ensino do método de controle intestinal. Sendo relevante neste processo o papel de educador exercido pelo profissional enfermeiro.
\end{abstract}

Conclusão: A irrigação constitui um recurso importante na reabilitação de pessoas estomizadas, tendo a enfermagem, dentro da perspectiva do cuidado integral, o papel de educador como relevante na sua ação resgatando assim a autonomia do portador de estomia. O conhecimento adquirido com esta pesquisa nos inspira a prosseguir neste caminho e a enfrentar novos desafios, em prol da construção de conhecimentos para o aperfeiçoamento do cuidado em estomias.

Keywords: COLOSTOMIA, ENFERMAGEM, ESTOMATERAPIA, IRRIGAÇÃO

\section{Referências Bibliográficas}

Cesaretti IUR, Santos VLCG, Vianna LAC. Qualidade de vida de pessoas colostomizadas com e sem uso de métodos de controle intestinal. Rev Bras Enferm $2010 \mathrm{Jan} / \mathrm{Fev}$;63(1):16-21. Maruyama SAT, Barbosa CS, Bellato R, Pereira WR, Navarro JP. Auto-irrigação - estratégia facilitadora para a reinserção social de pessoas com colostomia. Rev Eletr Enf 2009 Set;11(3):665-673. Santos VLCG, Cesaretti IUR. Assistência em Estomaterapia: cuidando de pessoas com estomia. 2. ed. São Paulo: Atheneu,; 2015. 


\title{
A IMPORTÂNCIA DA PARTICIPAÇÃO DA EQUIPE MULTIPROFISSIONAL NOS GRUPOS DE APOIO A PESSOAS COM ESTOMIAS
}

\author{
Author(s): $\quad$ Rosaura Soares Paczek ${ }^{1}$, Alessandra Garcia Figueiredo Agostini ${ }^{1}$, Carla Dipra Pereira ${ }^{1}$, Deise \\ Schmitz Oliveira ${ }^{1}$, Jenny Milner Moskovics ${ }^{1}$, Giulia Pedroso Perini ${ }^{2}$, Vania Maria Frantz ${ }^{1}$ \\ Institution(s) ${ }^{1}$ SMS/PMPA - Secretaria Municipal de Saúde/ Prefeitura de Porto Alegre (Rua Capitão \\ Montanha,37 Porto Alegre/RS), ${ }^{2}$ ESP RS - Escola de Saúde Pública do Rio Grande do Sul \\ (Avenida Ipiranga, 6311 Porto Alegre/RS)
}

\begin{abstract}
Introdução: Primitivamente, o primeiro momento em que o homem se reuniu para formar um grupo originou-se no enfrentamento de um perigo comum, real ou imaginário, que ameaçava sua sobrevivência. Os grupos de apoio podem ser caracterizados como uma versão moderna, de pessoas que buscam no agrupamento a tentativa de unir forças para defender-se de um perigo, a doença, que é desconhecida, fora de controle e ameaçadora. Quando um indivíduo adoece, adoece como sujeito, mas continua a pertencer ao grupo familiar, comunidade social, classe socioeconômica, entre outros. $\mathrm{O}$ adoecimento envolve todos os aspectos físicos, emocionais, sociais, morais e espirituais do sujeito. O grupo de apoio propõe-se a troca de experiências, sob a coordenação de um profissional, a fim de partilhar as emoções, problemas em comum e ser suporte a cada elemento do grupo, portanto, é uma relevante ferramenta de acolhimento e cuidado a pessoas com estomias, contribuindo para o processo de aprendizagem, adaptação e aceitação de sua condição. A reunião de pessoas com necessidades semelhantes favorece o intercâmbio de experiências e a reflexão, aliviando sentimentos de tristeza e solidão. Campos (2015) refere que em muitos casos, não é possível recuperar a saúde em todos seus aspectos físicos, mas o grupo tem um efeito mais amplo do que a recuperação das perdas materiais, pois o fato de saber que não se está sozinho em determinada situação, já atua como elemento positivo no indivíduo.Objetivos: Relatar a experiência da realização de grupos de apoio a pessoas com estomias com a participação da equipe multiprofissional de um serviço de estomaterapia, na cidade de Porto Alegre/ RS. Material e método: O grupo é aberto a pacientes e familiares/cuidadores, sendo realizado mensalmente, com a participação da equipe multiprofissional (enfermagem, psicologia, nutrição, serviço social e medicina). Sua divulgação ocorre por ocasião do atendimento aos usuários e por meio de cartazes no serviço. A temática abordada e a dinâmica do grupo são pré-definidas pela equipe. Geralmente, são realizadas rodas de conversa, palestras e atividades que envolvam todos os participantes,valorizando o aprendizado de novas estratégias de adaptação para bem viver com a estomia. Resultados: O grupo tem promovido a mútua ajuda entre os participantes, favorecida, especialmente, pela sua heterogeneidade. Os participantes com maior tempo de vivência com a estomia costumam apoiar muito os mais novatos, encorajando-os no enfrentamento de sua doença e/ou condição e oferecendo-lhes boas sugestões práticas. As atividades voltadas à valorização pessoal auxiliam na melhora da autoestima e autoaceitação dos participantes e, além disso, a presença de profissionais de diferentes especialidades tem colaborado para a apropriação de informações e esclarecimento de dúvidas. Conclusão: $O$ grupo tem se constituído num importante elemento de aproximação entre profissionais e usuários, assim como fortalecedor da sua rede de apoio. Os participantes relatam um melhor enfrentamento de sua situação e observa-se uma crescente reinserção social e a retomada de suas atividades cotidianas. É uma ferramenta relevante na promoção de saúde dos usuários e na melhora de sua qualidade de vida.
\end{abstract}

Keywords: Cuidados de enfermagem, Estomia, Grupos de apoio

\section{Referências Bibliográficas}

Graciete S. Marques et all. A vivência de pessoas com estomia intestinal no grupo de apoio em um Hospital Universitário . Revista HUPE, Rio de Janeiro, 2016;15(2):113-121 doi: 10.12957/rhupe.2016.28235 Miranda L, Rivera FJU, Artmann E .Trabalho em equipe interdisciplinar de saúde como um espaço de reconhecimento: contribuições da teoria de Axel Honneth. Physis [Internet]. 2012 [citado 2019 Mai 10] ; 22( 4 ): 1563-1583. Disponível em: http://www.scielo.br/scielo.php?script=sci_arttext\&pid=S0103-73312012000400016\&lng=en. http://dx.doi.org/10.1590/S0103-73312012000400016 Neto JLF, Kind L. Práticas grupais como dispositivo na promoção da saúde. Physis [Internet]. 2010 Dec [citado 2019 Mai 10] ; 20( 4 ): 1119-1142. Disponível em: http://www.scielo.br/scielo.php?script=sci_arttext\&pid=S0103-73312010000400004\&lng=en. http://dx.doi.org/10.1590/S0103-73312010000400004. CAMPOS EMP. Suporte Social: Da teoria à prática. In: SANTOS, Vera Lúcia Conceição de Gouveia; CESARETTI, Isabel Umbelina Ribeiro (Org.). Assistência em Estomaterapia: Cuidando de Pessoas com Estomia. 2. ed. São Paulo: Atheneu, 2015. Cap. 26. p. 407-416. 


\title{
MODELO DE ADAPTAÇÃO DE ROY: APLICABILIDADE EM PESSOAS COM ESTOMIAS INTESTINAIS
}

\author{
IRAKTANIA VITORINO DINIZ ${ }^{1}$, ANA ELZA OLIVEIRA DE MENDONÇA ${ }^{2,2}$, Arthur \\ Author(s): Vitorino Di Pace ${ }^{4,4}$, Celio Maroja Di Pace Neto ${ }^{4}$, Isabelle Katherinne Fernandes da Costa ${ }^{2}$, \\ Simone Helena Oliveira da Silva ${ }^{1}$, Maria Julia Guimarães Oliveira Soares ${ }^{1}$ \\ Institution(s) ${ }^{1}$ UFPB - UNIVERSIDADE FEDERAL DA PARAIBA (Campus I - Lot. Cidade Universitaria, PB, \\ 58051-900), ${ }^{2}$ ufrn - universidade federal do rio Grande do norte (Av. Sen. Salgado Filho, 3000 - \\ Lagoa Nova, Natal - RN, 59078-900), ${ }^{3}$ FCM - Faculdade de Ciências Médicas da Paraiba (BR-230 \\ Km 9 - Amazonia Park, Cabedelo - PB, 58106-402), ${ }^{4}$ UNIPE - CENTRO UNIVERSITÁRIO DE \\ JOÃO PESSOA (Rodovia BR-230,km 22, s/n - Água Fria, João Pessoa - PB, 58053-000)
}

\begin{abstract}
RESUMO: As teorias exibem conhecimentos específicos e são elaborados pelos próprios profissionais que a executam, conferindo caráter científico à enfermagem na área da saúde1. O Modelo de adaptação de Roy (MAR), entende o indivíduo como sistema capaz de se adaptar. A pessoa é receptora dos cuidados de enfermagem; e a meta da enfermagem é a promoção de respostas adaptativas em relação aos quatro modos adaptativos (fisiológico, autoconceito, função de papel e interdependência)2,3. O processo adaptativo da pessoa com estomia envolve necessidades físicas, sociais e psicológicas, as quais podem apresentar-se como estímulos, ao se estabelecer a relação de seu processo adaptativo com o MAR, constituindo como um sistema de apoio fundamental para a adaptação da pessoa mediante ações educativas, orientações que estimulam o autocuidado, prevenção, tratamento de complicações2,4. Além de utilização de equipamentos adequados que possam vir a contribuir de forma positiva para a adaptação e consequentemente da qualidade de vida das pessoas com estomas intestinais. OBJETIVO: avaliar a adaptação de pessoas colostomizadas antes e após a utilização do oclusor. MÉTODO: Trata-se de uma pesquisa quase experimental, do tipo antes e depois. O estudo é recorte da Tese de Doutorado da autora, desenvolvido, no Centro de Referência a Pessoas Estomizadas do Nordeste Brasileiro. A amostra de 19 pessoas colostomizadas, selecionada por intencionalidade. Após assinatura do termo de consentimento livre e esclarecido, os participantes foram submetidos à avaliação do nível de adaptação através do instrumento já validado, a Escala do Nível de Adaptação da pessoa estomizada (ENAE), para análise utilizou a estatística descritiva, com frequências absolutas e relativas, média e desvio-padrão, e inferencial que após verificação de normalidade, para fins de comparação da intervenção antes e após utilizou o teste T pareado. Foram fixados o nível de significância $(p<0,05)$. Ressalta-se que a pesquisa foi aprovada pelo Comitê de Ética do Centro de Ciências da Saúde da Universidade Federal da Paraíba, CAAE no 8096471740000 5188, em atendimento as exigências da Resolução 466/12 do Conselho Nacional de Saúde. RESULTADOS: Ao analisarmos os escores adaptativos das pessoas colostomizadas antes e após o uso do sistema de continência, observou-se melhora dos escores em todos os domínios avaliados. Diferenças significativas foram observadas nos seguintes domínio da ENAE: Modo fisiológico ( $p$ Modo fisiológico $(p<0,001)$, Modo autoconceito ( $p<0,001$ ), modo função de papel $(p=0,015)$ e escore total $(p<0,001)$. Apenas o modo interdependência não apresentou diferença significativa $(p=0,074)$. CONCLUSÃO: Com base nos resultados,verificou-se que o oclusor é um dispositivo que melhora a adaptação de pessoas com colostomia. O Modelo teórico proposto permite que o profissional de enfermagem identifique os comportamentos ineficazes e quais os modos adaptativos são mais afetados pelo estímulo e assim traçará planos assistências mais efetivos.
\end{abstract}

\section{Keywords: Adaptação, Estomias, ENFERMAGEM, ESTOMATERAPIA, TEORIAS DA ENFERMAGEM}

\section{Referências Bibliográficas}

1. Kääriäinen M. et al. Testing and verifying nursing theory by confirmatory factor analysis. Journal Of. Advanced Nursing, v. 67, n. 5, p.1163-1172, 2011. 2. Braga CG, Silva JV. Teorias de Enfermagem. 1. ed. São Paulo: látria, p. 252,2011. 3. Roy C, Andrews HA. Teoria da Enfermagem: O Modelo de Adaptação de Roy. Lisboa: Instituto Piaget, 2001. 4. Umpiérrez AHF. Vivendo Con Una Ostomia: Percepciones y Expectativas Desde la Fenomenología Social. Texto Contexto Enferm, Florianópolis, v. 22, n. 3, p.687-694. 2013. 


\title{
QUALIDADE DE VIDA DE PESSOAS COLOSTOMIZADAS ANTES E APÓS O USO DO OCLUSOR: ESTUDO QUASE EXPERIMENTAL
}

\author{
IRAKTANIA VITORINO DINIZ ${ }^{1}$, Isabelle Katherinne Fernandes da Costa ${ }^{2}$, ANA ELZA \\ Author(s): OLIVEIRA DE MENDONÇA ${ }^{2}$, Arthur Vitorino Di Pace ${ }^{4}$, Celio Maroja Di Pace Neto ${ }^{4}$, Natalia \\ Rodrigues Pinto $^{3}$, Maria Julia Guimarães Oliveira Soares ${ }^{1}$ \\ Institution(s) ${ }^{1}$ UFPB - UNIVERSIDADE FEDERAL DA PARAIBA (Campus I - Lot. Cidade Universitaria, PB, \\ 58051-900), ${ }^{2}$ ufrn - universidade federal do rio Grande do norte (Av. Sen. Salgado Filho, 3000 - \\ Lagoa Nova, Natal - RN, 59078-900), ${ }^{3}$ FCM - Faculdade de Ciências Médicas da Paraiba (BR-230 \\ Km 9 - Amazonia Park, Cabedelo - PB, 58106-402), ${ }^{4}$ UNIPE - CENTRO UNIVERSITÁRIO DE \\ JOÃO PESSOA (Rodovia BR-230,km 22, s/n - Água Fria, João Pessoa - PB, 58053-000)
}

\begin{abstract}
RESUMO: A presença de uma estomia, implica em alterações na qualidade de vida, ao mesmo tempo em que, demanda necessidades adaptativas nos âmbitos físicos e psicossociais. Nesta perspectiva surge a necessidade de conhecer e intervir no processo adaptativo de pessoas com estomias intestinais, a fim de planejar, executar e avaliar por meio da intervenção (uso do dispositivo oclusor), a qualidade de vida destes. O oclusor funciona como uma prótese descartável e visa ocluir a colostomia em sua extremidade distal controlando a incontinência (eliminação) de fezes e gases (ruídos e odor).1,2 Frente a necessidade de melhorar a autoestima das pessoas colostomizadas e manter o controle intestinal, foi desenvolvido, em 1986, um plug descartável, denominado oclusor 3. É um tampão cilíndrico descartável, de fácil utilização, flexível, composto por espuma de poliuretano envolto por uma película hidrossolúvel pré-lubrificada com filtro de carvão ativado integrado para inibir odores 1,2. OBJETIVO: analisar a qualidade de vida e adaptação das pessoas colostomizadas antes e após uso do oclusor. MÉTODO: Trata-se de uma pesquisa quase experimental, do tipo antes e depois. O estudo é um recorte da Tese de Doutorado da autora, este foi desenvolvido, no serviço ambulatorial de atendimento a pessoas estomizadas, vinculado à Secretaria de Saúde do Município de João Pessoa. A amostra de 19 pessoas colostomizadas, selecionada por intencionalidade. Após assinatura do termo de consentimento livre e esclarecido, os participantes foram submetidos a avaliação da qualidade de vida, através do instrumento, City of Hope Qualityof Life - OstomyQuestionnaire. Para análise utilizou a estatística descritiva, com frequências absolutas e relativas, média e desvio-padrão, e inferencial que após verificação de normalidade, para fins de comparação da intervenção antes e após utilizou o teste T pareado. Foram fixados o nível de significância $(\mathrm{p}<0,05)$. Ressalta-se que a pesquisa foi aprovada pelo Comitê de Ética do Centro de Ciências da Saúde da Universidade Federal da Paraíba, CAAE no 8096471740000 5188, em atendimento as exigências da Resolução 466/12 do Conselho Nacional de Saúde. RESULTADOS: Os participantes do estudo tinham entre 41 e 79 anos de idade, média de 55,9 e desvio padrão 9,53. Entre os participantes, 57,9\% eram mulheres, casados e aposentados, $31,6 \%$ com ensino médio completo e $21,1 \%$ com nível superior, $52,6 \%$ tinham renda familiar em torno de $\mathrm{R} \$ 3000,00$. Em relação ao tempo de cirurgia para estomização observou-se que $89,5 \%$ foram submetidos, há mais de seis meses. Ao analisarmos os domínios da qualidade de vida, observou-se diferenças significativas em todos os domínios. O bem-estar social foi o domínio que apresentou maior diferença depois do uso do oclusor, com score de 53,21 antes e após 87,58 ( $p$ $<0,001)$ seguido pelo o bem-estar físico antes do uso do oclusor 43,63 e após 75,05 ( $p<0,001)$. CONCLUSÃO: Com base nos resultados, verificou-se que o oclusor é um dispositivo que pode melhorar a qualidade de vida de pessoas com colostomia.
\end{abstract}

\section{Keywords: COLOSTOMIA, ENFERMAGEM, ESTOMATERAPIA, QUALIDADE DE VIDA, REABILITAÇÃO}

\section{Referências Bibliográficas}

1.Diniz, IV, Campos, MGCA, Vasconcelos, JMB, Martins, DL, Maia, FSB, Caliri, MHL. Bolsa de Colostomia ou Sistema Oclusor: Vivência de Colostomizados. Rev. Estima, v. 11, n.2, 2016. 2.Santos, VLCG, Cezaretti, IUE. Assistência em Estomaterapia - cuidando de pessoas com estomia. 2. ed., São Paulo: Editora Atheneu, 2015. 3. Burcharth F, Ballan A, Klyberg F, Rasmussen SN. The colostomy plug: a new disposable device for continent colostomy. Lancet [internet] 1986;2: 1062-3[cited jan 18,2019] 


\title{
CORRÊNCIA DE COMPLICAÇÕES DE ESTOMAS INTESTINAIS E URINÁRIOS RELACIONADOS À DEMARCAÇÃO PRÉ-OPERATÓRIA
}

\author{
Author(s): $\quad$ Valdecir Boeno Spenazato Júnior ${ }^{1}$, Adriana Rodrigues dos Anjos Mendonça ${ }^{1}$, Geraldo Magela \\ Salomé ${ }^{1}$, Ana Cristina da Silva ${ }^{1}$ \\ Institution(s) ${ }^{1}$ UNIVÁS - Universidade do Vale do Sapucaí (Av. Prefeito Tuany Toledo, 470 - Fatima, Pouso \\ Alegre - MG)
}

\begin{abstract}
Introdução: a estomia causa diversas mudanças na vida de um paciente, como na sua autoimagem e autoestima, o que está diretamente envolvido com o atendimento pré-operatório e pós-operatório. Portanto, é importante analisar as causas do estoma, suas complicações e o motivo delas. O índice de complicações ainda é alto nesses pacientes, dificultando ainda mais a qualidade de vida deles, e podem estar relacionados com a falta de demarcação anterior à cirurgia, que é fundamental no pré-operatório para uma abertura anatomicamente adequada para a adaptação de dispositivos para a coleta de efluentes com o mínimo de desconforto. Objetivo: avaliar a incidência das complicações de estomas intestinais e urinários, e a possível correlação com a demarcação pré-operatória. Métodos: estudo observacional, transversal, retrospectivo. Foram selecionados pacientes que apresentaram complicações relacionadas aos estomas intestinais $\mathrm{e}$ urinários, maiores de 18 anos, cadastrados no SASPO durante o período de março de 2017 a outubro de 2018, que aceitarem participar da pesquisa assinando o Termo de Consentimento Livre e Esclarecido (TCLE). Também foi utilizado um formulário com informações do paciente, etiologia, cirurgia, complicações e demarcação, além dos prontuários. 0 estudo foi previamente aprovado pelo CEP sob parecer 3.132.996. Resultados: foram encontrados 75 prontuários de pacientes estomizados com complicações. As complicações encontradas e suas respectivas porcentagens foram: dermatite periestoma $(30,61 \%)$, retração $(18,37 \%)$, prolapso $(17,35 \%)$, hérnia paracolostomica $(12,25 \%)$, descolamento mucocutâneo $(10,20 \%)$, granuloma $(4,08 \%)$, Lesão com aparente exposição da alça em periestoma $(2,04 \%)$, necrose $(2,04 \%)$, sangramento $(1,02 \%)$, estenose $(1,02 \%)$, edema $(1,02 \%)$. Conclusões: a dermatite periestoma foi a complicação mais incidente, seguida de retração e prolapso. As complicações com menor incidência foram sangramento, estenose e edema.
\end{abstract}

Keywords: Complicações pós-operatórias, Demarcação, Estomas cirúrgicos, Estomaterapia, Estomia

\section{Referências Bibliográficas}

1. Aguiar ESS, et al. Complicações do Estoma e Pele Periestoma em Pacientes com Estomas Intestinais. Rev Estima. 2011 v. 9 (2): p. 22-30. 2. Almeida EJ, Silva AL. Caracterização do perfil Epidemiológico dos Estomizados em Hospitais da Secretária de Estado de Saúde do Distrito Federal. Rev Estima. 2015; v. 13 (1): p. 11-6. 3. Anderson FJ. History of enterostomal therapy. In: Broadwell DC, Jackson BS. Principles of ostomy care. Saint Louis: Mosby, 1982. p. 14-6. 4. Cataldo P. Technical tips for stoma creation in the challenging patient. Clin Colon Rectal Surg. 2008; v. 21 (1): p. $17-22.5$. Cesaretti IUR, et al. O Cuidar de Enfermagem na Trajetória do Ostomizado: Pré \& Trans \& Pós operatórios. In: Santos VLCG, Cesaretti IUR. Assistência em estomaterapia: cuidando do estomizado. São Paulo: Atheneu; 2005. p. 113-132. 


\title{
RELATO DE EXPERIENCIA E ECONOMIA COM O ANEL PLANO MOLDÁVEL EM ESTOMAS COMPLICADOS
}

\author{
Author(s): vera Lucia Cera Cusatis ${ }^{1}$, Cintia Hanate ${ }^{2}$ \\ Institution(s) ${ }^{1}$ DRS-1 - Secretaria do Estado de Saúde (Rua Antonio Meyer, no 39, Jardim Armênia Mogi das \\ Cruzes ), ${ }^{2}$ HSPE - Hospital Servidor Público Estadual (Avenida Ibirapuera,981, Vila Clementino \\ São Paulo.)
}

\begin{abstract}
Introdução: Estomia é uma palavra de origem grega que tem como significado abertura ou boca e indica a exteriorização de uma víscera oca através de algum seguimento do corpoํ. A confecção de um estoma, após demarcação pré operatória é criticamente importante para a reabilitação da pessoa com estomia, os indivíduos demarcados e educados por uma estomaterapeuta tem menos complicações e maior qualidade de vida comparados aqueles sem suporte especializado2. Complicações como hérnias, descolamento muco-cutâneo, infecções, necrose isquêmica, estenose, retrações, fistula, e lesões de pele peri estoma, principalmente dermatites de contato, ocasiona enfraquecimento da adesividade da barreira3. Os riscos de dermatites alérgicas e lesões de pele peri estomal aumentam pelas trocas frequentes dos equipamentos, aumentando os gastos com barreiras protetoras, e equipamentos. A sua permanência é inerente à escolha assertiva. 4 Os adjuvantes, placas, pastas e anéis de hidrocolóide, são complementos para estomas descritos acima, aumentando a durabilidade dos equipamentos. 5 Os anéis $100 \mathrm{~mm}$ de hidrocolóide, motivo do estudo em questão, formam barreiras protetoras extensas, corrigindo imperfeições corporais, direcionando o fluxo do efluente no equipamento coletor. $\mathrm{Na}$ Portaria $400 \mathrm{MS}$, o gasto mensal esperado atinge em média um quantitativo de 10 bolsas duas peças, 30 bolsas drenáveis uma peça, 60 bolsas fechadas, barreiras: pasta, pó, 20 anéis. Estomas complicados geram um acréscimo no custo. Objetivo: Relato de Experiência e economia com o uso do anel de hidrocolóide plano de 100mm em estomas complicados. Material e Método : Relato de Experiência de duas autoras, sobre intervenções realizadas objetivando aprofundamento teórico de situações que emergem espontânea e contingencialmente na prática profissional. Pesquisa quantitativa, análise de custos/economia, observações constatadas pelas autoras em um Centro de Referência de Atendimento a Pessoa com Estomia da Grande São Paulo. Resultados e Conclusões: Após análise da resposta do uso do anel para impedir a infiltração do efluente em doze casos com estomias diferentes, percebeu-se aumento da durabilidade do equipamento em uso, em média de 12 para 48 horas, gerando uma economia significativa, portanto o anel moldável de $100 \mathrm{~mm}$ mostrou-se um adjuvante eficiente na contenção de vazamentos do efluente.
\end{abstract}

Descritores: Estomaterapia, Equipamento/economia, Colostomia/economia, Ileostomia/economia.

Keywords: Estomaterapia, Equipamento/economia, Colostomia/economia, Ileostomia/economia

\section{Referências Bibliográficas}

1.Harb-Gama, A. Araujo, SEA. Estomas Intestinais: aspectos conceituais e técnicos. In: Santos VLCG, Cesaretti IUR. Assistência de enfermagem em estomaterapia: cuidando do ostomizado. São Paulo: Atheneu; 2005, p. 39-54. 2. Colwell JC,McNichol L, Boarini J. North America Wound,ostomy, and continence and esterostomal therapy nurses current ostomy care practice related to peristomal skin issues. J Wound Ostomy Cotinence Nurs. 2017; 44(3):257-261. 3. Santos, CHM. Et al. Perfil do paciente ostomizado e complicações relacionadas ao estoma. Rev.Bras. Coloproct., 2007; 27(1): 16-19. 4. Rolstad BS, Erwin-Toth PL. Peristomal Skin Complications: Prevention and management.Ostomy/wound management.2004;50(9):68-77. 5. Kobayashi K. Application of skin barriers to skin disorders: skin disorders accompanying retracted stomas. In: Anazawa S, Ohmura Y, Yoshikawa R. Skin barriers for stoma care: from basic theory to clinical application. Tokyo: Alcare, 2001. Cap. 5, p. 89-94. Part 2B. 


\title{
A MULHER ESTOMIZADA E SUA SEXUALIDADE: UMA REVISÃO INTEGRATIVA
}

\author{
Author(s): $\quad$ Aldrya Ketly pedrosa ${ }^{1}$, Raphaela Martins Souza ${ }^{1}$, Stefanye Rayane Silva Gusmão ${ }^{1}$ \\ Institution(s) ${ }^{1}$ UNIT AL - Centro Universitário Tiradentes - AL (Av. Comendador Gustavo Paiva, 5017 - Cruz \\ das Almas, Maceió )
}

\begin{abstract}
Introdução: O câncer do cólon e reto está entre os cinco primeiros tipos de câncer mais frequentes e ocupa o terceiro lugar, em termos de incidência para homens, e o segundo, para mulheres. As repercussões vivenciadas na vida sexual de algumas mulheres, durante o processo de adaptação à estomia, decorrem da perda do auto reconhecimento como um ser sexual e atraente para o (a) parceiro (a) representando um alto grau de impacto sobre sua qualidade de vida, isso se dá através das alterações que ocorrem no corpo dessas mulheres estomizadas estando relacionadas desde a alteração na função de algum órgão importante, que por sua vez interfere diretamente no controle dos esfíncters, na diminuição da autoestima e alterações nos hábitos sexuais. Sendo assim, as modificações corporais ocasionadas após a confecção do estoma estão diretamente ligadas à sexualidade da mulher estomizada. Objetivo: O objetivo desse estudo é conhecer e descrever os significados da sexualidade para a mulher estomizada. Metodologia: Esse estudo trata-se de uma revisão integrativa, de análise descritiva, com caráter quantitativo. Resultados: através da pesquisa realizada obteve-se 16 artigos, mas apenas 9 correspondiam à pergunta norteadora da pesquisa. Destes, apenas 07 encaixavam nos critérios de inclusão desta revisão integrativa. Os resultados foram divididos em três categorias: "Significados físicos relacionados à sexualidade"; "Significados psicoemocionais relacionados à sexualidade" e "Significados Sociais relacionados à sexualidade. Conclusão: com isso, observou-se que a cirurgia de estomização traz grandes conflitos pessoais para essas mulheres, desde o cuidado/manipulação com a estomia e com a bolsa, até a aceitação física. Grande parte das mulheres não retomaram suas atividades sexuais, trazendo assim, consequências psicoemocionais.
\end{abstract}

Keywords: Estomia, Estomaterapia, Mulher, Sexualidade

\section{Referências Bibliográficas}

Inca - instituto nacional do câncer. Estimativa de incidência e mortalidade. http://www1.inca.gov.br/estimativa/2018/casostaxas-brasil.asp. Brasil. Ministério da saúde. Portal da saúde: ostomizados.

http://portal.saude.gov.br/portal/saude/visualizar_texto.cfm?idtxt=33975\&janela=1. Alencar DC, Vera SO, Sousa GN, Araújo SNM, Silva MGP, Dantas LRO. Sexualidade e qualidade de vida da pessoa estomizada: reflexões para o cuidado de enfermagem. reonfacema. 3(4):788- 793788-793; out-dez; 2017. file://c:/users/convidado/downloads/278-917-1-pb\%20(3). Flora AD, Gomes JS. Qualidade de vida de portadores de estomia intestinal: uma revisão narrativa. ijuí - rs; 2012. http://bibliodigital.unijui.edu.br:8080/xmlui/bitstream/handle/123456789/993/tcc_co lostomia\%20pronto.pdf?sequence=1.. Mota MS, Gomes GC, Petuco VM. Repercussões no processo de viver da pessoa com estoma. biblioteca virtual em saúde - bvs, lilacs-express;2016.http://www.scielo.br/pdf/tce/v25n1/pt_0104-0707-tce-25-01-1260014.pdf. 


\title{
DERIVAÇÃO INTESTINAL POR FÍSTULAS RETO-VAGINAIS: UMA REVISÃO DA LITERATURA
}

\author{
Author(s): $\quad$ ROSAURA SOARES PACZEK ${ }^{1}$, Luisa Zadra Passberg ${ }^{3}$ \\ Institution(s) ${ }^{1}$ PMPA - Prefeitura Municipal de Porto Alegre (Rua Capitão Montanha, 27- Porto Alegre/RS), ${ }^{2}$ \\ HCPA - Hospital de Clinicas de Porto Alegre (Ramiro Barcelos, 2350- Porto Alegre/RS), ${ }^{3}$ HNSC - \\ Hospital Nossa Senhora da Conceição (Francisco Trein, 59- Porto Alegre/RS)
}

\begin{abstract}
INTRODUÇÃO: Fístulas são as comunicações existentes entre duas superfícies epiteliais. Geralmente surgem como resultado de condições patológicas ou a partir de certos tratamentos, como cirurgias e radioterapia. As fístulas retovaginais, dessa maneira, caracterizam-se como uma comunicação entre o reto e a vagina, que fazem com que gases e resíduos intestinais drenem para a vagina e/ou região vulvar de forma espontânea, apresentando grande impacto na qualidade de vida das mulheres afetadas. OBJETIVOS: Revisar a literatura produzida referente à ocorrência de fístulas reto-vaginais e à necessidade de derivação intestinal, com o intuito de aprofundar o conhecimento sobre a temática. METODOLOGIA: Revisão integrativa da literatura. Foram consultadas as bases de dados LILACS e SciELO, e publicações no site da Sociedade Brasileira de Coloproctologia. Os descritores utilizados foram: fístula vaginal, colostomia e ileostomia. Critérios de inclusão: artigos que abordam a temática do estudo, escritos em português, publicados entre os períodos de 1990 a 2017, e disponíveis on-line na íntegra. Tal período foi escolhido devido à escassez de estudos sobre a temática. A amostra final foi constituída por quatro artigos. RESULTADOS: As fístulas reto-vaginais representam menos de $5 \%$ das fístulas que acometem a região anorretal. Dentre principais causas para o seu surgimento estão os traumatismos obstétricos, como o uso inadequado do fórceps e a realização de episiotomia, além de intervenções cirúrgicas na região pélvica, tumores e radiação para o tratamento dos mesmos, e também os processos inflamatórios. O diagnóstico é feito através de exames vaginais e de toque retal, devendo-se investigar ainda o histórico da paciente e os possíveis fatores de risco aos quais ela pode ter sido exposta. Nos casos em que há pequenas fístulas, pode ocorrer cicatrização espontânea; porém, muitas delas precisam de abordagem cirúrgica1. Em casos nos quais não é possível a reconstituição das paredes onde se localiza a fístula, opta-se pela realização de ileostomias ou colostomias para que o trânsito intestinal possa ser desviado, a fístula curada e após feita a reconstrução do mesmo. Estudo realizado no ano de 2005 traz que, de uma população de 59 indivíduos estomizados, três (aproximadamente 5\%) pacientes tiveram como patologia de base para a necessidade de confecção de um estoma a fístula reto-vaginal. CONCLUSÕES: As fístulas reto-vaginais, apesar de infrequentes, representam um problema na vida das mulheres acometidas, devido à sintomatologia causada. Como tratamento nos casos mais graves, está indicada a realização de um estoma intestinal temporário. Cabe ao enfermeiro orientar e auxiliar as mulheres nos cuidados, para um melhor enfrentamento da situação.
\end{abstract}

Keywords: fístula vaginal, colostomia, ileostomia, estomaterapia

\section{Referências Bibliográficas}

ROBERTSON, S. O que é uma fístula? News Medical Life Sciences. 2015. Disponível em: . Acesso em: 25 jun. 2017. SOBRADO, C. W.; SOKOL, S. Avanço de retalho retal para o tratamento da fístula retovaginal baixa. Rev. Bras. Coloproct., v. 14, n. 4, p. 231-234, out/dez. 1994. BECHARA, R. N.; et al. Abordagem multidisciplinar do ostomizado. Rev. Bras. Colo-proct., v. 25, n. 2, p. 146-149, abr/jun. 2005. ROCHA, J. J. R. Estomas intestinais (ileostomias Estomas intestinais (ileostomias e colostomias) e anastomoses e colostomias) e anastomoses intestinais. Medicina (Ribeirão Preto), v. 44, n. 1, p.51-56, 2011. 


\title{
Repercussões da estomia intestinal para a vida da pessoa com estoma: revisão integrativa
}

\author{
FRANCISCO GLEIDSON DE AZEVEDO GONÇALVES ${ }^{1}$, Francyne Rodrigues da Costa ${ }^{1,1,1,1}$, \\ Author(s): Carla Souza de Oliveira ${ }^{1,1,1,1}$, Bianca Costa Alves ${ }^{1,1,1,1}$, Norma Valéria Dantas de Oliveira Souza \\ $1,1,1,1$ \\ Institution(s) ${ }^{1}$ UERJ - UNIVERSIDADE DO ESTADO DO RIO DE JANEIRO (Boulevard 28 de Setembro, 157 \\ / Vila Isabel, Rio de Janeiro - RJ)
}

\begin{abstract}
Introdução: A estomia é realizada por meio de procedimento cirúrgico, consistindo na exteriorização de um órgão oco para a superfície da pele como, por exemplo, algum segmento do trato digestivo, respiratório e urinário. Este procedimento resulta em alterações significativas para a vida das pessoas(1). As estomias de eliminação são as colostomias, ileostomias, urostomias, entre outras(2). Considerando esta problemática, traçou-se como objetivo do estudo: identificar a produção científica latina americana acerca da repercussão da estomia intestinal para a vida da pessoa com estomia; e discutir as repercussões da estomia intestinal na dimensão subjetiva da pessoa com estomia segundo a literatura científica captada. Método: Pesquisa qualitativa, de natureza bibliográfica, na modalidade de revisão integrativa da leitura. Os dados foram coletados através de busca na Biblioteca Virtual em Saúde (BVS), que incluiu outras bases de dados: Literatura LatinoAmericana e do Caribe em Ciência da Saúde (LILACS), Scientific Eletronic Library Online (SCIELO) e Base de Dados da Enfermagem (BDENF). O tratamento dos dados deu-se por meio da análise temática de conteúdo(3). Resultados e Discussão: Verificou-se 26 artigos científicos na íntegra, no período de 2008 a 2018, com maior quantitativo de obras em 2017, evidenciado pela publicação de 6 artigos. A maioria das produções é originada do estado de São Paulo e Rio Grande do Sul, sendo a predominância de autores enfermeiros. Discussão: Os dados revelaram que há muitos impactos para a vida da pessoa com estomia de eliminação, como: a perda da continência fecal, o que repercute na vida sexual, social e laboral, pois adicionado à incontinência ocorre à eliminação de gazes involuntariamente e a exalação de odores desagradáveis. Além disso, há a necessidade de trocas periódicas do sistema coletor, carecendo de idas frequentes ao banheiro. Esta situação restringe o convívio social e a manutenção da vida laboral, resultando em sofrimento psicofísico e na dimensão econômica do indivíduo, necessitando dos familiares para auxiliar na manutenção da subsistência material. Conclusão: Considerou-se que a amputação do segmento corporal e a realização da estomia de eliminação são eventos traumáticos que levam a alteração da imagem corporal e a mudança no estilo de vida, sobretudo, na vida laboral e social. Enfatiza-se, assim, a importância de profissionais qualificados a fim de promover um cuidado de excelência e auxiliar estas pessoas na melhor adaptação a nova condição de vida e, assim, possibilitar a retomada da vida social e laboral.
\end{abstract}

Keywords: Fatores Biopsicossociais, Repercussões, Estomaterapia, Pessoa Estomizada

\section{Referências Bibliográficas}

1. Santos VLCG; CESARETTI IUR. Assistência em Estomaterapia: cuidando do ostomizado. São Paulo: Ed. Atheneu, 2005. p. 327-334. 2. Souza MPD. et al. Estoma e vida laborativa. Rev. Estima, São Paulo, v. 5, n. 1, p. 13-20, jan./mar. 2007. 3. Bardin, L. Análise de conteúdo. 5. ed. Lisboa: Edições 70, 2011. 


\title{
AS ORIENTAÇ̃̃ES DE ENFERMAGEM DADAS A UMA CUIDADORA DE PESSOA PORTADORA DE ESTOMIA EM UNIDADE DE INTERNAÇÃO PEDIÁTRICA: UM RELATO DE EXPERIÊNCIA
}

\author{
Author(s): $\quad$ Aldrya Ketly Pedrosa ${ }^{1}$, Maíza Radely Pereira Ferreira ${ }^{1}$, Jadson Nascimento Barbosa ${ }^{1}$, Érica \\ Shyrlei da Silva Melo ${ }^{1}$ \\ Institution(s) ${ }^{1}$ UNCISAL - Universidade Estadual de Ciências da Saúde de Alagoas (Rua Dr. Jorge de Lima, \\ 113, Trapiche da Barra, Maceió - AL, 57010-382)
}

\begin{abstract}
Introdução: Um estoma é a exteriorização de uma porção de algum órgão oco por uma abertura através da cavidade, que pode ser temporária ou permanente, podendo apresentar causa congênita, temporária ou traumática'. Dentro dos cuidados prestados pelo profissional de enfermagem à pessoa estomizada, a promoção de saúde é um fazer do enfermeiro de extrema importância, pois é onde as orientações acerca dos cuidados necessários com a estomia serão dadas ${ }^{2}$. Na unidade pediátrica hospitalar tem-se buscado essa assistência, passando daquela em que o foco é a criança e sua patologia, para a centrada na família, pois a mesma é considerada a unidade primária do cuidado em questão, ampliando assim, a sistematização construída até o momento ${ }^{3}$. Diante disso, torna imprescindível a oportunidade de realizar tal ação durante a formação acadêmica do futuro profissional. Objetivo: Relatar a experiência das orientações dadas a cuidadora acerca dos cuidados com estomias, em unidade de internação pediátrica. Material e método: Relato de experiência construído por acadêmicos do sétimo período do curso de Enfermagem da Universidade Estadual de Ciências da Saúde de Alagoas, durante uma prática supervisionada em um hospital de referência em Maceió/AL. Resultados: Durante a anamnese, foi possível perceber que a cuidadora possuía pouco conhecimento acerca da condição. Durante a limpeza e troca da bolsa coletora, foram realizadas algumas orientações sobre o que seria uma estomia e qual a função da mesma. Posteriormente, foram feitas orientações acerca dos cuidados a serem tomados a fim de manter a integridade da pele e evitar complicações devido o manuseio incorreto. Especialmente, sobre como evitar a maceração da pele peri-estoma. Foram também dadas orientações gerais relacionados a alimentação, quanto ao banho e odores. Conclusão: Foi possível observar que por meio das orientações sobre os cuidados, realizadas a cuidadora, esta pode assimilar a fisiopatologia da condição, como também se tornou agente ativa nos cuidados prestados.
\end{abstract}

Keywords: Educação em saúde, Estomaterapia, Prática clínica

\section{Referências Bibliográficas}

1. Ang SGM, Hui-Chen H, Siah RJS, Hong-Gu H, Klainin-Yobas P. Stressors relating to patient psychological health following stoma surgery: an integrated literature review. Oncol Nurs Forum. 2013 Nov; 40(6):587-94. 2. Gladys AVB, Kamila MT, Paula ACSF, Santos MA, Ataíde LJ, Lima RCD. Desenvolvimento de competências gerais durante o estágio supervisionado. Rev Bras Enferm, 2012 jan-fev; 65(1): 172-8. 3. Siqueira CSS, Reis AT, Pacheco STA. Modelos de cuidado às famílias de crianças dependentes de tecnologia em contexto hospitalar. Rev Enferm UERJ, 2017; 25: 27529. 


\title{
Demarcação de Estoma : Redução de Complicações no Pós Operatório
}

\author{
Author(s): $\quad$ Patrícia Rosa da SilvaP ${ }^{1}$ \\ Institution(s) ${ }^{1}$ SMSA- BH/Creab-L - Secretaria Municipal de Saúde de Belo Horizonte- (Rua Bicas 58 Bairro \\ Sagrada Família)
}

\begin{abstract}
Introdução: Os estomas são resultantes de diferentes condições clínicas e sua confecção tem potencial significativo de complicações, que podem ser evitadas ou minimizadas com a sua demarcação previamente à cirurgia (CARVALHO, 2014; ESTEVES, 2009; OLIVEIRA, 2014). A não demarcação do estoma pode levar a diversas complicações, provocando, entre outras, necrose, retração, prolapso, dermatite e má adaptação do dispositivo coletor à pele (OLIVEIRA, 2014). Objetivo: Relacionar as condições do estoma dos pesquisados à sua demarcação previamente à cirurgia e a presença de complicações. Material e Método: Trata-se de uma pesquisa descritiva e estudo de caso, com abordagem quantitativa. A amostra foi constituída por 41 pacientes (26 mulheres, 15 homens) atendidos em julho e agosto de 2018 pela autora do estudo, que é enfermeira estomaterapeuta. A coleta de dados ocorreu por meio de questionário durante a consulta de enfermagem especializada. O projeto foi aprovado pelo Parecer oㅜ 2.665.056 do Comitê de Ética em Pesquisa da Secretaria Municipal de Saúde de Belo Horizonte. Resultados: As idades dos pesquisados variaram entre 30 e 94 anos, com média entre mulheres de 60,88 anos e entre homens de 56,50 anos. Predominou a cor branca entre os pesquisados (57,69\% das mulheres, $53,33 \%$ dos homens). A escolaridade foi mais elevada entre os homens, sendo que as mulheres apresentaram analfabetismo (3,85\%), maior contingente com ensino fundamental $(61,54 \%$ das mulheres, $46,68 \%$ dos homens), menores contingentes com ensino médio (19,23\% das mulheres, $20 \%$ dos homens) e ensino superior $(11,54 \%$ das mulheres, $20 \%$ dos homens). Cerca da metade dos pesquisados ( $50 \%$ das mulheres, $53,33 \%$ dos homens) declarou-se casada. Predominou entre os pesquisados a situação de aposentado ( $30,77 \%$ das mulheres, $46,67 \%$ dos homens). A não demarcação do estoma previamente à cirurgia foi relatada por $88,46 \%$ das mulheres e $100 \%$ dos homens. Os tipos de estoma predominantes foram a colostomia ( $50 \%$ das mulheres, $33,33 \%$ dos homens) e a ileostomia $(42,31 \%$ das mulheres, $40 \%$ dos homens). Em $30,77 \%$ das mulheres e $13,33 \%$ dos homens a confecção do estoma apresentou localização inadequada. Houve relato de complicações do estoma por $92,31 \%$ das mulheres e $93,33 \%$ dos homens, predominando a dermatite periestomal (70\% das mulheres, $64,70 \%$ dos homens). Conclusão: A quase totalidade dos pesquisados apresentaram problemas relativos aos estomas, devidos em parte significativa à sua não demarcação e a localização inadequada. Estas são condições que podem ser evitadas ou minimizadas com a participação de profissional especializado durante 0 ato cirúrgico.
\end{abstract}

Keywords: Colostomia, Estoma Cirúrgico, Estomaterapia, lleostomia

\section{Referências Bibliográficas}

Carvalho DS. Tecnologia educacional para estomizados: construção de um guia de orientação para cuidados com a pele periestoma [dissertação]. Belém: Universidade do Estado do Pará, Escola de Enfermagem Magalhães Barata; 2014.

Esteves AMSD. Avaliação da qualidade de vida dos pacientes portadores de estomas intestinais [dissertação]. Alfenas: Unifenas; 2009. Oliveira MS. As complicações precoces e tardias e a demarcação de estoma intestinal [dissertação]. Ribeirão Preto: Universidade de São Paulo, Escola de Enfermagem de Ribeirão Preto; 2014. 


\title{
PROCESSO DE TRANSIÇÃO DA PESSOA ESTOMIZADA DA DEPÊNDENCIA DE CUIDADO AO AUTOCUIDADO: SUBSÍDIOS À ENFERMAGEM
}

\author{
Author(s): Marina Soares Mota ${ }^{1}$, Giovana Calcagno Gomes ${ }^{1}$, Prisciane Cardoso Silva ${ }^{1}$, Fabiane Lopes dos \\ Santos ${ }^{1}$, Bianca Dos Santos Blan ${ }^{1}$ \\ Institution(s) ${ }^{1}$ FURG - Universidade Federal do Rio Grande (R. Gen. Osório, 1-109 - Centro, Rio Grande - RS, \\ 96200-400)
}

\begin{abstract}
Submeter-se a cirurgia de estomização é um momento complexo na vida da pessoa e de sua família, que repercutir física e psicologicamente podendo levar a perda da autonomia e do autoconceito.1 Podem apresentar dependência de cuidados prejudicando sua qualidade de vida. Assim, o estudo objetivou conhecer como a pessoa com estomia vivência o processo de transição da dependência de cuidados ao autocuidado. Pesquisa qualitativa, descritiva e exploratória, realizada com 27 pessoas com estomias definitivas por câncer acompanhados em um Serviço de Estomaterapia no extremo sul do Brasil. Parecer número 0002/2014. Os dados foram coletados em 2014 por meio de entrevista semiestruturada e submetidos à Análise de Conteúdo à luz da Teoria das Transições de Afaf I. Meleis2. Verifica-se que a natureza da transição surge do processo tipo saúde/doença. A entrada/inicio do processo de transição surge na tomada de consciência de mudança desencadeada pelo diagnóstico de câncer e pela cirurgia de estomização. $O$ empenhamento ligado a retomada da autonomia surge na construção do conhecimento para o autocuidado frente às mudanças na sua vida e na sua nova relação com seu corpo, mudando a visão de si, do mundo e dos outros. Mostram-se fatores facilitadores do processo de transição para o autocuidado a construção do significado positivo à estomização, o preparo para a experiência ainda no pré-operatório, a estabilidade emocional, a fé, a religiosidade e a sensação de normalidade adquirida a partir de uma imagem próxima da anterior, o fornecimento gratuito pelo governo das bolsas coletoras, adjuvantes e ao atendimento da equipe multiprofissional. Verifica-se como inibidores do processo de transição a visão distorcida do corpo, o despreparo para viver com a estomia, a instabilidade emocional, a desmotivação com afastamento de atividades prazerosas, o cuidado excessivo e a superproteção da família, as complicações como hérnias e prolapsos, a falta de atitudes positivas quanto à vida, a negação da bolsa coletora, as tentativas frustradas de omitir o uso da bolsa coletora, a falta do domínio do manuseio dos equipamentos, o afastamento do trabalho, as dificuldades financeiras, o abandono das mulheres pelo parceiro, atitudes negativas e estigmatizantes por parte da família e a baixa qualidade dos materiais fornecidos pelo governo. Como indicadores de resultados, ou seja, que a transição se encaminha para o fim, estão na confiança para realizar atividades anteriores, aceitação de sua situação, visão positiva de sua vida e compartilhamento do seu cuidado com sua família. Identifica-se que a pessoa com estomia finalizou seu processo de transição da dependência para o autocuidado, ou seja, a saída da transição quando há domínio das competências para o cuidado físico, a readequando da imagem e do autoconceito. As transições são momentos de mudanças, representando a aquisição de estabilidade com o estado anterior, sendo visualizado pelo sentimento de bem-estar, bom desempenho nos papéis e nas relações2. Faz-se importante promover o autocuidado por esse ser o propulsor da qualidade de vida3. Concluiu-se que o processo de transição é complexo, mas o conhecimento sobre ele permite estabelecer ações terapêuticas que contribuem para a retomada do autocuidado.
\end{abstract}

Keywords: Marina Soares Mota, Giovana Calcagno Gomes, Prisciane Cardoso Silva , Fabiane Lopes dos Santos , Bianca Dos Santos Blan

\section{Referências Bibliográficas}

1.Mota MS, Gomes GC, Petuco VM. Repercussões no processo de viver da pessoa com estoma. Texto contexto - enferm. 2016; 25(1) p: e1260014. 2.Meleis Al. Transitons Theory: Middle-Range and Situation-Specific Theories in Nursing Research and practice. New York: Springer Publishing Company, 2010. 3. Mota M, Gomes G, Silva CD, Gomes VL, Pelzer M, Barros E. Autocuidado: uma estratégia para a qualidade de vida da pessoa com estomia. Investig Enferm. Imagen Desarr. 2016;18(1): 63-78. 


\title{
EFEITO DO PÒ DE HIDROCOLÓIDE NO TRATAMENTO DE PERILESÃO DE GASTROSTOMIA EM PACIENTES COM DOENÇA CRÔNICA HOSPITALIZADOS: SÉRIE DE CASOS
}

\author{
Author(s): Ana Cristina dos Santos Monteiro ${ }^{1}$, Maria Lucia Barbosa Maia dos Santos ${ }^{1}$, Juliana Caires de \\ Oliveira Achili Ferreira ${ }^{1}$ \\ Institution(s) ${ }^{1}$ ICr HCFMUSP - INSTITUTO DA CRIANÇA - HCFMUSP (Av. Dr. Enéas Carvalho Aguiar, \\ 647,São Paulo), ${ }^{2}$ ICr HCFMUSP - INSTITUTO DA CRIANÇA - HCFMUSP (Av. Dr. Enéas \\ Carvalho Aguiar, 647,São Paulo), ${ }^{3}$ ICr HCFMUSP - INSTITUTO DA CRIANÇA - HCFMUSP \\ (Av. Dr. Enéas Carvalho Aguiar, 647,São Paulo)
}

\begin{abstract}
Introdução: A gastrostomia é um procedimento indicado para crianças e adolescentes com doença crônica, como má absorção intestinal, distúrbios de deglutição, doenças neurológicas, entre outras. Pode evoluir com lesões periestoma devido necessidade de hospitalização por complicação da própria doença ou outras comorbidades, sendo necessário cuidado sistematizado e adequado dessas lesões para diminuir gastos com materiais, risco de infecção e desconforto do paciente. Objetivo: Apresentar uma série de casos de pacientes com gastrostomia e as condutas realizadas de maneira sistematizada para tratar as lesões de pele. Método: Série de casos, aprovada pela Comissão de Ética da Instituição, CAAE ํ16504619.1.0000.0068, consentimento informado assinado dos responsáveis pelos pacientes. Resultados: paciente de 1 ano e 10 meses, sexo feminino, com Amiotrofia Espinhal Tipo 1, foi submetida à gastrostomia aos 9 meses de idade, após 4 meses de internação; paciente de 2 anos, sexo masculino, com Síndrome de West, Ventriculites de repetição, Cardiopatia congênita, Prematuridade, gastrostomia desde 1 ano e 4 meses; paciente de 14 anos, sexo masculino, com Síndrome de Lennox Gastaut e Atraso de desenvolvimento neuropsicomotor, Deficiência de Alfa 1 Antitripsina, Pneumopatia Crônica e Broncopneumonias de repetição, Neoplasia Endócrina Múltipla tipo 1, Diarreia Crônica, Gastroparesia, Jejunostomia e Cistostomia, tem infecções de repetição e necessidade de hospitalização com certa frequência, e gastrostomia desde os 4 anos de idade; paciente de 12 anos, com Encefalopatia crônica não evolutiva, Anóxia neonatal, escoliose grave, traqueostomia, tem gastrostomia desde 8 anos de idade. Todos encontravam-se hospitalizados na Unidade de Terapia Intensiva Pediátrica quando apresentaram lesão periestoma, de característica traumática, não infecciosa, com alargamento do óstio e consequente vazamento de resíduo gástrico, sendo necessário intervenção local. Foram avaliados por uma enfermeira estomaterapeuta, que orientou limpeza local com solução fisiológica duas vezes ao dia e na presença de exsudato, seguida de aplicação de pó de hidrocolóide com função de barreira protetora, uma adaptação da Técnica de crosta nos quatro casos. O período de tratamento variou de 7 a 15 dias, com melhora das lesões observada após 48 horas de tratamento. Conclusão: Esta série de casos buscou evidenciar a importância do tratamento sistematizado para os pacientes que apresentam lesões periestoma durante hospitalização. Observou-se rápida melhora das lesões devido a utilização de tratamento padronizado, orientado por uma profissional estomaterapeuta, conforme é preconizado pelas associações nacionais e internacionais envolvidas no cuidado com a pele dos pacientes ostomizados, evidenciando a necessidade de um grupo de curativos e feridas em todo hospital pediátrico de alta complexidade. A avaliação precoce é fundamental no tratamento, pois gera rápida resolução da lesão, diminuição da dor e desconforto do paciente, propicia segurança ao familiar, e consequente redução de custos materiais, além de melhor dimensionamento das horas do cuidado e qualidade de vida durante a hospitalização.
\end{abstract}

Keywords: Estomaterapia, Lesão, Gastrostomia, Cuidados de enfermagem

\section{Referências Bibliográficas}

Correa JA et al. Resource utilization after gastrostomy tube placement: Defining áreas of improvement for future quality improvement projects. Journal of Pediatric Surgery 49 (2014) 1598-1601. http://dx.doi.org/10.1016/j.jpedsurg.2014.06.015 Park S, - Lee YJ, Oh DN, Kim J. Standardized Peristomal Skin Care in Prevention of Peristomal Skin Problems. J Korean Acad Nurs. 2011. 41(6):814-820. http://dx.doi.org/10.4040/jkan.2011.41.6.814 E. St-Louis et al. Gastrocutaneous fistulae in children - A systematic review and meta-analysis of epidemiology and treatment options. Journal of Pediatric Surgery 2018. 53:946-958. https://doi.org/10.1016/j.jpedsurg.2018.02.022 


\title{
CONSTRUÇÃO DE UM SIMULADOR PARA IRRIGAÇÃO DA COLOSTOMIA: INOVAÇÃO NO PROCESSO ENSINO APRENDIZAGEM
}

\author{
Author(s): \\ Josimare Aparecida Otoni Spira ${ }^{1}$, Eline Lima Borges ${ }^{1}$, Vera Lúcia de Araújo Nogueira Lima ${ }^{1}$, \\ Selme Silqueira de Matos ${ }^{1}$ \\ Institution(s) ${ }^{1}$ UFMG - Universidade Federal de Minas Gerais ( Av. Prof. Alfredo Balena, 190 - Santa Efigênia, \\ Belo Horizonte - MG, 30130-100)
}

\begin{abstract}
Introdução: a irrigação da colostomia é um método de regulação da atividade intestinal da pessoa colostomizada1. A técnica de irrigação deve ser ensinada por estomaterapeuta ou enfermeiro experiente2 e requer conhecimento técnico científico, o que exige do profissional competência e habilidades para sua execução. O número de pessoas com colostomia definitiva que se beneficia da técnica de irrigação é incipiente. Possivelmente decorrente do conhecimento deficiente por parte dos enfermeiros3, uma vez que, o conteúdo não é garantido na formação deste profissional. Também é fundamental dispor de recursos para a simulação realística para o ensino nessa área do conhecimento. Para inovar, propõe-se pensar em estratégias de ensino que possam garantir o processo de aprendizagem do enfermeiro sobre irrigação de pessoas com colostomia. Objetivo: construir um simulador para irrigação da colostomia. Material e método: trata-se de um estudo de metodologia ativa de ensino-aprendizagem. Esta proposta descontrói o modelo tradicional de ensino e fundamenta-se em uma pedagogia problematizadora, onde o educando é instigado a assumir uma postura ativa em seu processo de aprender e apreender o conhecimento, buscando a sua autonomia e a aprendizagem significativa4. $O$ estudo consistiu de três etapas. A primeira etapa foi o esboço de um manequim simulador para irrigação que permitisse a demonstração da técnica para os alunos do Curso de Estomaterapia. Na segunda etapa, o esboço se transformou na primeira proposta do simulador que foi avaliado por uma turma de 20 alunos de um Curso de Especialização em Estomaterapia, quando identificou-se possibilidades de avanço da tecnologia. Na terceira etapa, a proposta adquiriu novos contornos e avanços. As autoras fizeram parceria com um marceneiro que contribuiu para a construção do manequim que permite a realização do procedimento de irrigação semelhante ao que ocorre na prática clínica. O simulador foi testado pelos pesquisadores e os mesmos alunos. Resultado: o manequim mede $50 \mathrm{~cm}$ de altura, foi esculpido em madeira maciça no formato de humano, que inclui parte anterior do tórax, abdômen e terço superior da coxa, apoiado em uma base de madeira. No abdome, foi demarcado o local da colostomia onde o marceneiro fez o furo com $5 \mathrm{~cm}$ de diâmetro e sobre este, foi confeccionada a estomia, utilizando massa epóx. Na parte posterior do furo foi introduzida uma conexão de policloreto de vinila (PVC) que permite a passagem da água infundida na colostomia para um balão gigante (Número 350), acoplado na extremidade do PVC. A água do balão retorna para a colostomia, similar a descarga da irrigação. Ao término, as autoras realizaram a irrigação da colostomia obtendo êxito. Constatou-se a funcionalidade do manequim simulador e semelhança do procedimento realizado na prática clínica. Os resultados foram validados pelos alunos que participaram do processo de simulação realística e confirmaram a efetividade em relação à aprendizagem. Conclusão: o dispositivo construído é uma metodologia ativa de ensino-aprendizagem que contribuirá para o processo de educação do aluno do curso de estomaterapia, bem como do processo de reabilitação do paciente colostomizado, candidato a irrigação.
\end{abstract}

Keywords: Estomaterapia, Colostomia, Irrigação terapêutica, Educação

\section{Referências Bibliográficas}

1 Cesaretti IUR, Santos VLCG, Schiftan SS, Vianna LAC. Irrigação da colostomia: revisão acerca de alguns aspectos técnicos*. Acta Paul Enferm. 2008 [citado em 2019 Jun10];21(2):338-44. Disponível em:

http://www.scielo.br/pdf/ape/v21n2/pt_a17v21n2.pdf 2 Black P. Procedures for patients with a colostomy. Practice Nurse. 2011[cited 2019 Jun11];22(3):121-124. Available from:

https://www.magonlinelibrary.com/doi/abs/10.12968/pnur.2011.22.3.121 ?download=true\&journalCode=pnur 3 Clow T, Disley H, Greening L, Harker G. Professional guidance for teaching colostomy irrigation [online]. World Council of Enterostomal Therapists Journal. 2015 [cited 13 Jul 19];35(2):15-19. Available

from:https://search.informit.com.au/documentSummary;dn=304373715918428;res=IELHEA 4 Paiva MRF, Parente JRF, Brandão IR, Queiroz AHB. Metodologias ativas de ensino-aprendizagem: revisão integrativa. SANARE, Sobral, 2016 [citado em 2019 Jun10];15(02): 145-153. Disponível em: https://sanare.emnuvens.com.br/sanare/article/view/1049 


\title{
“OSTOMIA UMA FORMA DE VIVER”: A EXTENSÃO UNIVERSITÁRIA PROMOVENDO A CUIDADO ESPECIALIZADO
}

\author{
Author(s): Marina Soares Mota ${ }^{1}$, Andressa Fortes de Souza ${ }^{1}$, Giovana Calcagno Gomes ${ }^{1}$, Luana Daiane \\ Guimarães Lima ${ }^{1}$, Luana Pedroso Xavier ${ }^{1}$ \\ Institution(s) ${ }^{1}$ FURG - Universidade Federal do Rio Grande (Av. Itália, s/n - Km 8 - Carreiros, Rio Grande - RS, \\ Brasil)
}

\begin{abstract}
Introdução: Tornar-se pessoa com estomia se mostra um processo complexo no qual, normalmente, se experiência momentos de insatisfação com o corpo, baixa autoestima, sentimentos de autoexclusão, depressão e perda do desejo de retornar às atividades valorizadas e prazerosas.1 Para readquirir autonomia e retomar o autocuidado, as pessoas com estomias e suas famílias buscam os Serviço de Estomaterapia (SE) tendo acesso ao conhecimento acerca da doença que resultou a estomia, dos cuidados necessários e de como obter melhor qualidade de vida.2 Assim, o projeto de extensão, "Ostomia uma forma de viver" surgiu para prestar atendimento a pessoa com estomia intestinal e/ou urinária, fornecendo o conhecimento e os matérias para o autocuidado, além de desenvolver novos conhecimentos por meio da pesquisa e de fomentar no aluno de graduação o saber técnico-cientifico para o cuidado dessa população. Objetivo: Relatar a experiência de participar do projeto de extensão "Ostomia uma forma de viver". Material e método: O presente relato de experiência apresenta as atividades desenvolvida no projeto "Ostomia uma forma de viver" de 2009 a 2019, desenvolvido em um Hospital Universitário no extremo sul do Brasil. O relato se pauta nas experiências de uma ex-aluna do curso de enfermagem e bolsista no referido projeto. Resultados: O projeto "Ostomia uma forma de viver" foi construído com o intuito de prestar atendimento à pessoa com estomia e sua família com foco no autocuidado. Nesse projeto são desenvolvidas consultas de enfermagem e grupoterapias com as pessoas com estomias e sua família trabalhando assuntos como alimentação, atividade física, autoimagem, sexualidade, uso dos equipamentos, procurando a reinserção social e a promoção da autonomia. Na realização das ações de ensino se insere propiciando aos graduandos do curso de Enfermagem vivências singulares na área da Estomaterapia. Além disso, são realizadas pesquisas visualizando a qualificação do conhecimento com vista a melhoria do cuidado, as quais posteriormente são aplicadas ao SE com o propósito de melhoria no autocuidado para os pacientes com estomia. Sendo assim, o tripé Ensino, Pesquisa e Extensão se consolida de maneira eficiente. A promoção da qualidade de vida surge como um desafio para o Enfermeiro bem como para as graduandas integrantes do projeto, pois exige uma otimização e personalização das intervenções de enfermagem, ajustadas às necessidades específicas de cada pessoa com estomia, facilitando o processo de sua transição e capacitando-o para o autocuidado.3 Conclusões: O referido projeto não só transforma a vida das pessoas com estomias, mas também transforma a vida de quem participa do mesmo trazendo conhecimentos específicos, estimulando o trabalho em grupo, fomentando a Pesquisa assim como a educação em saúde. Esse se apresenta tanto como um espaço de cuidado, mas também de Pesquisa e de Ensino, sendo importante a inserção de projetos semelhantes nas universidades despertando mais enfermeiros para a área da Estomaterapia qualificando cada vez mais o cuidado.
\end{abstract}

Descritores: Estomaterapia; Enfermagem; Extensão Universitária.

Keywords: Estomaterapia, Enfermagem, Extensão Universitária

\section{Referências Bibliográficas}

1. Mota MS, Gomes GC, Silva CD, Gomes VL, Pelzer MT, Barros EJ. Autocuidado: uma estratégia para a qualidade de vida da pessoa com estomia. IEID [Internet]. 7 dec. 2015 [citado 12 jul. 2019];18(1):63-8. Available from:

https://revistas.javeriana.edu.co/index.php/imagenydesarrollo/article/view/12201 2. Mota MS, Reis TRVS, Gomes GC, Barros EJL, Nörnberg PKO, Chagas MCS. Stomized patients' perception of the stomatherapy service: a descriptive study. Online braz j nurs [internet] 2015 Sep [cited 2019 July 12]; 14 (3):238-47. Available from: http://

www.objnursing.uff.br/index.php/nursing/article/view/5085 3. Miranda LSG, Carvalho AAS, Paz EPA. Quality of life of ostomized person: relationship with the care provided in stomatherapy nursing consultation. Esc. Anna Nery [Internet]. 2018 [cited 2019 July 12]; 22(4):e20180075. Available from: http://www.scielo.br/scielo.php?script=sci_arttext\&pid=S141481452018000400216\&lng=en. Epub Oct 08, 2018. http://dx.doi.org/10.1590/2177-9465-ean-2018-0075. 


\title{
Adaptação cultural e validação do instrumento Ostomy Skin Tool para a língua portuguesa do Brasil
}

\author{
Author(s): Maristela Lopes Gonçalves Nunes ${ }^{1}$, Vera Lucia Conceição de Gouveia Santos ${ }^{2}$ \\ Institution(s) ${ }^{1}$ UTP - Faculdade Tuiuti do Paraná (Rua Sydnei Antonio Rangel Santos, 238 - Santo Inácio, \\ Curitiba - PR, 82010-330), ${ }^{2}$ EEUSP - Escola de Enfermagem da Universidade de São Paulo (Av. \\ Dr. Enéas Carvalho de Aguiar, 419 - Cerqueira César, São Paulo - SP, 05403-0)
}

\begin{abstract}
Introdução: Complicações da pele periestoma são problemas comuns para pessoas com estomas e podem ter um impacto negativo na qualidade de vida. $O$ uso de um instrumento para a avaliação dos distúrbios da pele periestoma auxilia os profissionais de saúde a avaliar o efeito de sua assistência no processo de cuidar. O Ostomy Skin Tool (OST) é um instrumento padronizado para avaliar a condição da pele periestoma. Inclui duas seções. A primeira, denominada DETßScore descreve a extensão e gravidade dos distúrbios da pele periestoma por meio de três aspectos: Descoloração, Erosão e Tecido com crescimento excessivo. A segunda seção refere-se ao AIM (Assessment, Intervention and Monitoring) Guide for Peristomal Skin Care e baseia-se na categorização dos distúrbios da pele periestoma de acordo com a sua causa. Objetivo: Adaptar e validar o instrumento Ostomy Skin Tool para a cultura brasileira. Método: O processo de adaptação cultural incluiu: tradução para o idioma português; avaliação e comparação das traduções com a versão original, por Comitê de Juízes, síntese das traduções em versão única em português do Brasil; retrotradução e submissão das versões retrotraduzidas a uma das autoras do instrumento original. A validade de conteúdo foi testada nessa fase, sendo analisada por meio do Índice de Validade de Conteúdo (IVC). Na segunda etapa, analisaram-se as propriedades psicométricas da versão adaptada: confiabilidade interobservadores (avaliação de fotos padronizadas e aplicação clínica), validade de construto convergente (correlacionando gravidade da complicação periestoma com dor) e validade de construto discriminante (segundo tipo de estoma, retração, tempo de cirurgia e demarcação do estoma). A confiabilidade interobservadores foi analisada por meio do teste Linear Weighting Kappa e Coeficiente de Correlação Intraclasse (CCI); a validade convergente, utilizando-se o Coeficiente de Correlação de Pearson e o Teste t-student para análise da validade de construto discriminante. O projeto foi aprovado pelo Comitê de Ética em Pesquisa da Escola de Enfermagem da USP (Processo $n^{0}$ 2.444.773/2017) e pelos serviços onde os dados foram coletados. Resultados: A amostra foi composta por 109 estomizados com complicações na pele periestoma, sendo 59(54,1\%) do sexo masculino, 48(44,0\%) aposentados, $58(53,2 \%)$ com colostomia, 65(59,6\%) com estomas retraídos e 79(72,5\%) com dermatite periestoma associada à umidade. Os IVC totais foram 0,83 para o DETBScore e 0,60 para o Guia AIM. Obtiveram-se confiabilidade leve (K=0,314) entre as observações dos enfermeiros na avaliação das complicações da pele periestoma usando fotografias padronizadas; e confiabilidade moderada a quase perfeita $(K=0,48-0,93$, segundo os domínios) quando avaliaram os pacientes na prática clínica. A correlação positiva entre o DET®Score e a intensidade de dor e diferenças estatisticamente significantes entre os escores DET® de pacientes com ileostomias e colostomias $(p=0,0344)$ atestaram, respectivamente, as validades convergente e discriminante do instrumento em sua versão adaptada. Conclusão: Este estudo confirmou o OST como o primeiro instrumento adaptado, confiável e válido para aplicação no Brasil. Ele fornecerá uma contribuição valiosa para a avaliação e intervenção da condição de pele periestoma realizada pelos profissionais de saúde em todos os contextos.
\end{abstract}

Keywords: Confiabilidade dos dados, Dermatite, Estomia, Estomaterapia, Estudos de validação

\section{Referências Bibliográficas}

1. Taneja $\mathrm{C}$ et al. Clinical and economic burden of peristomal skin complications in patients with recent ostomies. $\mathrm{J}$ Wound Ostomy Continence Nurs. 2017; 44 (4): p.1-8. 2. Maydick-Youngberg D. A descriptive study to explore the effect of peristomal skin complications on quality of life of adults with permanent ostomy. Ostomy Wound Management 2017; 63(5):10-23. 3. WCET International Ostomy Guideline Recommendations. WCET Journal. 2014; 34 (2): 26-28. 4. Jemec GB et al. Assessing peristomal skin changes in ostomy patients. Validation of the Ostomy Skin Tool. Br J Dermatol. 2011; 164(2): 330-35. 


\title{
Are We Ready? The Impact of Dementia on Stoma Care
}

\author{
Author(s): Michaela Ann Parker ${ }^{1}$ \\ Institution(s) ${ }^{1}$ Salts - Salts Healthcare (Richard Street Aston Birmingham UK)
}

\begin{abstract}
Introduction

Dementia is a broad term used to describe a range of progressive neurological disorders. Approximately 850,000 people live with this condition in the UK, with numbers predicted to rise to over 1 million by 2025 and 2 million by 2051 (1).

Dementia is now becoming a growing concern in Latin America and the Caribbean which has the highest rates worldwide

(2). It is now considered to be a 'public health priority', from a global perspective (3).

\section{Objective}

The aim of this presentation is to consider and explore the fact that even though public awareness and involvement is increasing, there still remain significant misunderstandings within both general society and healthcare settings, that create barriers to the appropriate management of this group of patients.
\end{abstract}

\section{Material}

Ostomists with dementia require diverse and creative support. Moving forward, Stoma care nurses should consider core health and social themes effected by this healthcare challenge and proactively seek to form key partnerships with specialists in dementia to enhance care provision. Training, development and any planning of care is vital and should involve clear strategies that reflect best practice. Given that the World Health Organisation now consider this health issue a priority, stoma care teams, both locally and globally should work together to strengthen consistency of care in preparation for the impact of this patient group on future stomatherapy services.

\section{Conclusion}

Stoma care nurses are in a key position to influence how the provision of stoma care services can be delivered in the future for someone with dementia, in order to enhance the quality of life for this patient group, their family members and carers. Stoma care nurses should feel empowered to take ownership of standards of care for this group and to advocate an individualised patient centred experience.

Keywords: stomatherapy, stoma care, dementia, public health priorities

\section{Referências Bibliográficas}

References: 1. Prince, M, Knapp, M, Guerchet, M, McCrone, P, Prina, M, Comas-Herrera, A, Wittenberg, R, Adelaja, B, Hu, B, King, D, Rehill, A and Salimkumar, D. Dementia UK: Update (second edition). Alzeihmer's Society. 2014. 2. Pan American Health Organisation. Health in the Americas: Mortality in the Americas. available from https//www.paho.org/saluden-las-americas-2017/?tag=dementia 3. World Health Organisation and Alzeihmer's Disease International. Dementia; a public health priority. World Health Organisation. 2012. 


\title{
Guia passo a passo para orientação do usuário na troca do dispositivo coletor em estomias: um relato de experiencia
}

\author{
Author(s): $\quad$ NILDETE VARGAS POZEBOM ${ }^{1}$, Giselda Quintana Marques ${ }^{1}$, Ivani Bueno de Almeida Freitas \\ ${ }^{1}$, Aldírio dos Santos Medeiros ${ }^{2}$ \\ Institution(s) ${ }^{1}$ SMS POA - Secretaria Municipal de Saúde de Porto Alegre (Avenida João Pessoa, 325 Porto \\ Alegre), ${ }^{2}$ Modulus - Modulus Equipamentos Médicos (R. Jacinto Gomes, 373 - Santana, Porto \\ Alegre - RS, 90040-270)
}

\begin{abstract}
Introdução: Com a criação de um estoma o paciente necessita de uma readaptação em sua rotina de cuidados e, aprendizado de habilidades não desenvolvidas.1 São muitos os fatores que influenciam o autocuidado do paciente, bem como a adesão, motivação para o tratamento e as intervenções propostas. Conhecer estes fatores possibilita compreensão dos desafios do processo de cuidar em estomaterapia.2 Sendo que um dos maiores desafios é melhorar a qualidade da assistência por meio da implementação de instrumentos que proporcionem um cuidado humanizado.3 A utilização de materiais educativos complementares à consulta tem sido descrita, por educadores, como a melhor forma de ensinar indivíduos adultos, pois possibilita que as pessoas retenham as informações explicadas.4 Diante do exposto, o Estomaterapeuta precisa encontrar alternativas de se fazer entender pelo paciente e seu cuidador e adaptar guias de orientação com informações individualizadas. Para tanto sugerimos o uso de um guia passo a passo de forma complementar à consulta. Objetivos: Relatar a experiência na utilização de guia passo a passo, personalizado, de orientação ao paciente e familiar para instalação do dispositivo coletor em estomas intestinais, e urinários em Serviço de Estomaterapia no município de Porto Alegre. Metodologia: Trata-se de um estudo descritivo, do tipo relato de experiência. Resultados: O guia passo a passo foi elaborado a partir da necessidade de fornecer ao paciente, por escrito as orientações transmitidas durante a capacitação para manuseio dos equipamentos para estomia, sua correta utilização e a sequência de aplicação pelo paciente e/ou cuidador. A descrição do passo a passo é feita de forma simples e esclarecedora, relembrando ao paciente e/ou cuidador as orientações recebidas durante a consulta com estomaterapeuta. Este guia foi elaborado pelos enfermeiros do serviço, em 2010, e foi sendo adaptado conforme as necessidades dos usuários e enfermeiros ao longo dos anos. Tem tido muito boa aceitação como complemento da consulta de enfermagem, medidos pela satisfação de usuários e cuidadores. Serve como um apoio às pessoas que estiveram presentes durante a orientação do cuidado da estomia e esclarece detalhes aos familiares e/ou cuidadores que não estiverem no momento da capacitação. Este instrumento considera as particularidades de cada paciente na medida em que sinaliza apenas os produtos que serão utilizados por este indivíduo ordenando e numerando sua aplicação. Possibilita a numeração dos frascos dos produtos de acordo com o guia escrito, facilitando o entendimento pelos usuários. Conclusão: Ao descrever a experiência no uso do guia passo a passo podemos concluir que, a complexidade do aprendizado do que é novo pelo usuário que não está preparado, a readaptação do seu estilo de vida diante de alterações corporais e sentimentos negativos necessitam de atitudes e instrumentos que desmistifiquem o novo e simplifiquem seu cotidiano.
\end{abstract}

Keywords: autocuidado, educação em saúde, estomaterapia, estomia

\section{Referências Bibliográficas}

1. Mota MS, Gomes GC. Mudanças no processo de viver do paciente estomizado após a cirurgia. Rev Enferm Univer Fed Pernam. on line. Recife. 2013; 7(esp): 7074-7081. 2. Santos VLCG. Representações do corpo e a ostomia: Estigma. In: Santos VLCG, Cesaretti IUR. Assistência em estomaterapia: cuidando do ostomizado. São Paulo: Atheneu; 2005. p. 89102. 3. Reveles AG, Takahashi RT. Educação em saúde ao ostomizado: um estudo bibliométrico. Rev Esc Enferm USP. São Paulo. 2007; 41(2): 245-250. www.ee.usp.br/reeusp/ 4. Ducci AJ, Pimenta CAM. Programas educativos e a dor oncológica Revista Brasileira de Cancerologia. Rio de Janeiro. 2003; 49(3): 185-192 


\title{
Portal educativo como estratégia para divulgar o cuidado ao estomizado
}

\author{
Author(s): $\quad$ Rudnei Prusch da Silva ${ }^{1}$, Sandra Maria Cesar Leal ${ }^{1}$, Karin Viegas ${ }^{1}$ \\ Institution(s) ${ }^{1}$ UNISINOS - Universidade do Vale do Rio dos Sinos (Porto Alegre)
}

\begin{abstract}
Este estudo foi desenvolvido no Programa de Pós-Graduação Mestrado Profissional em Enfermagem, da Universidade do Vale do Rio dos Sinos (UNISINOS). As motivações para a realização do mesmo advêm da minha formação como especialista em estomaterapia, o que me levou a valorizar a importância do cuidado de enfermagem das pessoas com estomias, principalmente, no que tange ao desenvolvimento desse tipo de trabalho para o cuidado ambulatorial. Em minha prática profissional, desempenho a função de enfermeiro estomaterapeuta e percebo a dificuldade dos enfermeiros em desenvolver suas habilidades e competências junto aos pacientes com estomias. Muitas dessas dificuldades estão relacionadas à falta de treinamentos específicos pertinentes ao tema. Outros fatos observados são a grande rotatividade desses profissionais, suas múltiplas atribuições e a falta da sistematização da assistência. Constantemente, recebo solicitações de orientação e visitas técnicas. Os pedidos de ajuda dos profissionais envolvidos com o cuidado de pessoas com estomia chegam por meio de mensagens, e-mails e telefone celular. A maioria das dúvidas relaciona-se aos cuidados e ao tratamento de lesões de pele periestomia e às decisões sobre qual dispositivo coletor utilizar. Este estudo teve o objetivo de elaborar um portal educativo para profissionais de enfermagem no atendimento a pessoas com estomia. A metodologia aplicada foi de desenvolvimento de recursos tecnológicos. A elaboração do Portal Educativo foi realizada a partir da atuação do pesquisador, na qualidade de enfermeiro Estomaterapeuta. Para a construção do design de navegação do portal educativo, seguiram-se as seguintes etapas: análise das necessidades; identificação dos usuários; organização do conteúdo; construção; manutenção. O referencial teórico foi subsidiado pela busca por estudos publicados nos últimos cinco anos. Foram utilizados recursos disponibilizados pela web, de forma que contribuam para o esclarecimento das dúvidas dos usuários que acessarem o portal educativo. Os produtos da pesquisa consistem no Portal Educativo de Apoio ao Cuidado a Pessoas com Estomia, está disponível no endereço eletrônico . Também, na construção do portal foi criada a marca "PEAPEE" que está em processo de registro. Os conteúdos elaborados para o Portal Educativo são: conceitos de estomias de eliminação intestinal e urinária; orientações para o cuidado com estomias de eliminação intestinal e urinária; orientações relativas à alimentação da pessoa com estomia; orientações para a manutenção da integridade da pele periestomia; orientações de uso dos dispositivos coletores; orientações de uso dos adjuvantes; complicações nas estomias e na região da pele periestomia; métodos de controle intestinal; sistema para fístulas; vídeos educativos; divulgação de livros, manuais e sites relacionados. Considera-se que o fácil acesso aos recursos digitais permite que profissionais de enfermagem e pacientes obtenham informações de maneira rápida, prática, eficiente e acessível a todos, podendo ser consultadas a partir de computadores ou celulares. Os benefícios do estudo estão pautados pela contribuição à qualificação dos profissionais de enfermagem para o cuidado da pessoa com estomia.
\end{abstract}

Keywords: Estomia, Estomaterapeuta, Ostoma, Pessoas com Estomia, Portal Educativo

\section{Referências Bibliográficas}

BURCH, Jennie. Choosing the correct accessory for each stoma type: an update. British Journal of Nursing, London, v. 22, n. 16, p. s10-s13, Sept. 2013a. Suppl. 10. Disponível em: . Acesso em: 15 out. 2017. NEIL, Nancy et al. A cost-utility model of care for peristomal skin complications. Journal of Wound, Ostomy, and Continence Nursing, St. Louis, v. 43, n. 1, p. 6268, 2016. doi:10.1097/WON.0000000000000194. SCHREIBER, M. L. Evidence-based practice. ostomies: nursing care and management. Medsurg Nursing, Pitman, v. 25, n. 2, p. 127-124, Mar. 2016. 


\title{
A COMPREENSÃO DE SENTIR-SE ESTOMIZADA: RELATO DE EXPERIÊNCIA SOB A ÓTICA DA FENOMENOLOGIA
}

\author{
Author(s): $\quad$ ROSANA FREITAS AZEVEDO ${ }^{1}$, ROSANA MARIA PEREIRA GARCIA ${ }^{1}$ \\ Institution(s) ${ }^{1}$ BAHIANA - Escola Bahiana de Medicina e Saúde Pública (R. Silveira Martins, 100 - Cabula, \\ Salvador - BA, 41150-100)
}

\begin{abstract}
Introdução: Para a população brasileira nos anos de 2018 e 2019, o Instituto Nacional do Câncer (INCA) estimou que o câncer colorretal ocuparia a terceira e a segunda posições entre os cânceres mais frequentes para homens e mulheres respectivamente. Uma das formas de tratamento para o câncer colorretal constitui-se na confecção da estomia, o que pode interferir significativamente na qualidade de vidas das pessoas. A realização de uma estomia poderá revelar-se como uma vivência traumatizante pelas limitações impostas ao corpo quanto pelas relações familiares, sociais e profissionais. Objetivo: Estudo qualitativo de abordagem fenomenológica na modalidade de relato de experiência que teve como objetivo descrever a compreensão de sentir-se estomizada durante uma atividade prática do componente curricular: Cuidados a pessoas com ostomia. Material e Método: Essa atividade foi realizada em um Curso de Especialização de Enfermagem em Estomaterapia de uma Instituição de Ensino Superior na Cidade de Salvador. A atividade realizada em duplas consistia em demarcar na região abdominal o local do estoma e após a demarcação deste, instalar o equipamento coletor correspondente. Ao realizarem a demarcação do estoma e instalação dos equipamentos coletores, as autoras descrevem a compreensão de se sentirem estomizadas, de utilizarem as bolsas coletoras, o que favoreceu a apreensão das práticas de cuidados especializados para essa clientela. Para análise deste relato de experiência foi utilizado o referencial teórico da fenomenologia. Esta abordagem compreensiva permite o desvelar do fenômeno tal como ele se mostra para quem o experiencia. A fenomenologia adota uma forma de reflexão que inclui a possibilidade de olhar as coisas como elas se manifestam, descrevendo o fenômeno sem intenção de explicá-lo. Resultados e Conclusões: A compreensão de sentir-se estomizada foi experienciada pela presença e implicações do uso da bolsa. Os resultados revelam-se com sentimentos como estranheza com o corpo, preocupação e dificuldades no manuseio e aceitação do equipamento durante todo período de permanência com a mesmo. O desenvolvimento da atividade conduziu as autoras à reflexão sobre a vivência com a estomia, fator determinante para a busca de estratégias de enfrentamento e adaptação às alterações da imagem corporal. Neste sentido, além dos sentimentos relatados, esse processo de aprendizagem propiciou a identificação das dificuldades advindas da adaptação da bolsa ao corpo possibilitando as autoras a compreenderem o momento vivido pela pessoa com estomia, no intuito de fornecer estratégias de cuidados de enfermagem mais eficazes.
\end{abstract}

Keywords: Enfermagem médico cirúrgica, Estomaterapia, Estomia, Cuidados de enfermagem

\section{Referências Bibliográficas}

1. Brasil. Ministério da Saúde. Instituto Nacional de Câncer José Alencar Gomes da Silva. Estimativas 2018: incidência de câncer no Brasil. Rio de Janeiro: INCA; 2017. 2. Cesaretti, IUR; SANTOS, VLC. Assistência em Estomaterapia: cuidando de pessoas com estomia. 2.ed.São Paulo: Atheneu; 2015. 3. HEIDEGGER, M. Ser e Tempo. 4.ed. Petrópolis (RJ): Vozes; 2006. 4. POKLADEK. DD. A fenomenologia do cuidar: prática dos horizontes vividos nas áreas de saúde, educacional e organizacional. 1. ed. São Paulo: Vetor; 2005. 


\title{
Desafios do cuidar: Como lidar com uma Esofagostomia cervical.
}

\author{
Author(s): Janaina Maria Felix Moraes ${ }^{1}$ \\ Institution(s) ${ }^{1}$ HIAE - Hospital Israelita Albert Einstein (Av Albert Einstein,627)
}

\begin{abstract}
Introdução: Este relato de experiência foi desenvolvido após observar a necessidades de maiores esclarecimentos a uma paciente submetida ao procedimento de Esofagostomia; Ao procurar orientações em livros e artigos, percebi que era praticamente nulo o conteúdo para educação; Assim logo despertei para suma importância de rever a anatomia do esôfago, descrever técnicas de cirurgia, indicações, cuidados com pós cirúrgico e dispositivos mais apropriados. Esofagostomia é a confecção de uma comunicação do esôfago com a pele, formando um "estoma". É feito na região cervical para derivar o trânsito de saliva ou alimentos deglutidos. Pode ser de "proteção", quando de uma esofagoplastia, a fim de evitar mediastinite ou fistula de anastomose, A cirurgia Esofagostomia é indicada em casos de neoplasias, corpos estranhos, perfurações, hérnia hiatal, fístulas, acalasia cricofaríngea, intussuscepção gastresofágica, megaesôfago e divertículos. Realizamos um trabalho de conscientização para a paciente e familiares que a ingesta de determinados alimentos via a cavidade oral seria somente para prazer e estimular paladar, que aporte nutricional realmente seria somente via gastrostomia, sendo feito uma parceria com o corpo de nutrição da instituição para adaptar melhor dieta/calorias/ necessárias. Os dispositivos para adaptar na Esofagostomia foi uns dos maiores desafios deste caso, pela disposição do local e por ter uma área que encontrava-se muito macerada e úmida.
\end{abstract}

Objetivo: Relatar a experiência vivenciada por um enfermeiro na CMC nos cuidados e desafios com uma Esofagostomia, bem como educar paciente/familiares a utilizar os melhores dispositivos para alcançar conforto ao paciente. Métodos: Treinos, adaptações, testes, orientações e registros. Resultados: Obter sucesso do entendimento do paciente/família aos melhores dispositivos. Conclusões: Orientação efetiva e conforto da paciente.

Palavras-chave: Esofagostomia ,Estomaterapia, Aderência,Saliva

Keywords: Aderência, Bolsa, Estoterapia, Pasta protetora, Saliva

\section{Referências Bibliográficas}

1. Cesaretti IUR,Paula MAB de,Paula PR.Estoterapia:Temas Basicos em estomas.Taubaté Sp:Cabral Editora e livraria Universtária;2006 2.Santos VLCG,Cesaretti IUR.Assistência em Estomaterapia:cuidando do ostomizado.São

Paulo:Atheneu,2000. 3.Ministerio da Saúde(BR),Secretaria de Atenção à Saúde.Portaria SAS/Ms n 400 de 16 de Novembro de 2009. 4. Estima-Revista da Associação Brasileira de Estomaterapia 


\title{
Atuação do enfermeiro generalista em demarcação de cirurgias geradoras de estomias: revisão integrativa da literatura.
}

\author{
Author(s): Maria carolina bernardi dos santos ${ }^{1}$, Aline de Oliveira Ramalho ${ }^{1}$, Júlia Drummond de Camargo ${ }^{1}$, \\ Daisy Cristina Zemke Barreiros Cristina Zemke Barreiros ${ }^{2}$, Ana Paula Guarnieri ${ }^{2}$ \\ Institution(s) ${ }^{1}$ HSL - Hospital Sírio -Libanês (Rua Dona Adma Jafet, 115), ${ }^{2}$ FM-ABC - Faculdade de Medicina \\ do ABC (São Paulo/Brasil )
}

\begin{abstract}
INTRODUÇÃO A demarcação de estomas consiste em delimitar a área ideal na parede abdominal para exteriorização da estomia, que é baseada em princípios científicos, é feita levando-se em consideração a estrutura do músculo retoabdominal e a distância das áreas críticas, que embora seja um procedimento considerado de simples execução necessita de um preparo prévio do enfermeiro, para que de fato auxilie na prevenção de complicações pós-operatórias e favoreça a qualidade de vida e reabilitação do paciente estomizado. Com um número ainda pequeno de enfermeiros especialistas na área, justifica-se a habilitação de enfermeiros generalistas engajados no cuidado ao paciente estomizado, que estejam aptos para execução deste procedimento.

OBJETIVO identificar na literatura os construtos existentes acerca da demarcação pré-operatória em cirurgias geradoras de estomias, bem como propor um protocolo de habilitação profissional no qual o profissional esteja apto a realizar a demarcação.

MATERIAL E MÉTODO Trata-se de uma revisão integrativa da literatura, que teve como questão norteadora: Qual a importância da demarcação pré-operatória em cirurgias geradoras de estomias e qual o papel no enfermeiro generalista neste contexto? Os critérios de inclusão foram materiais publicados entre os anos de 2008 a 2018, nos idiomas português, inglês e espanhol, disponíveis nas bases de dados MedLine/Pubmed, Scopus, LILACS, Scielo e BDENF. Os descritores utilizados foram "demarcação", "estomas cirúrgicos", "estomas", "enfermagem", "ileostomia", "colostomia" e "urostomias".. RESULTADOS : Após a pesquisa, 13 artigos preencheram os critérios de inclusão e exclusão, sendo estes inseridos no estudo. A leitura minuciosa dos artigos culminou em três categorias temáticas, sendo elas: Demarcação: Passo-a-Passo, Complicações e Qualidade de Vida. Conclusão: Os estudos reforçam a importância da demarcação pré-operatória como ferramenta para prevenção de complicações e reabilitação do estomizado em seu meio social, bem como auxiliaram na determinação de conceitos importantes para realização do procedimento.

CONCLUSÃO Ficou claro que o padrão ouro da demarcação é que esta seja realizada pelo enfermeiro estomaterapeuta ou pelo cirurgião, porém este levantamento forneceu conceitos importantes para preparo do enfermeiro generalista na execução do procedimento. Com apoio da literatura atual as autoras puderam propor um protocolo de habilitação do enfermeiro generalista, no qual o enfermeiro recebe treinamento teórico e prático, bem como realização da demarcação supervisionada pelo especialista, até que se encontre apto para a realização da demarcação, de forma segura ao paciente.
\end{abstract}

Keywords: demarcação, estomas cirúrgicos, estomas, enfermagem, estomaterapia

\section{Referências Bibliográficas}

Meirelles, C.A, Ferraz C.A. Estudo teórico da demarcação do estoma intestinal. R. Bras Enferm. 2001;54(3):500-501. Zimnicki , K.M. Preoperative Teaching and Stoma Marking in an Inpatient Population.A Quality Improvement Process. Using a FOCUS-Plan-DoCheck-Act Model. J Wound Ostomy Continence Nurs. 2015;42(2):165-169. Readding, L.A. Stoma siting: what the community nurse needs to know.British Journal of Community Nursing. 2003;11(8). 


\title{
SIGNIFICADO DO CATETER VESICAL DE DEMORA PARA O PACIENTE
}

\author{
Author(s): $\quad$ Adriana Pelegrini dos Santos Pereira ${ }^{1}$, ANA MARIA DIAS DE SOUZA MARCONI ${ }^{1}$ \\ Institution(s) ${ }^{1}$ FAMERP - FACULDADE DE MEDICINA DE SÃO JOSÉ DO RIO PRETO (RUA \\ BRIGADEIRO FARIA LIMA 5900)
}

\begin{abstract}
O cateterismo vesical de demora (CVD) é um procedimento invasivo no qual é introduzido um cateter até a bexiga com o objetivo de drenar a urina em pacientes impossibilitados de eliminação urinária e constitui um procedimento de enfermagem que permite a promoção á saúde do paciente. E estar com um cateter vesical, ocasiona desconforto tanto físico como psicologicamente, situações essas pouco valorizadas pelos profissionais de enfermagem(1). Frente a esta constatação objetiva-se com este trabalho: Identificar e compreender o significado de estar com um cateter vesical de demora pelos pacientes. Métodos: pesquisa de campo com abordagem qualitativa para compreender o significado de se ter um cateter vesical de demora inserido utilizando como referencial teórico-metodológico a Teoria das Representações Sociais (RS), pesquisa desenvolvida no ambulatório de urologia de um Hospital Escola no Município de São José do Rio Preto. A população constituiu-se de 14 pacientes submetidos ao CVD a mais de 72hs, ambos os gêneros, acima de 18; trabalho aprovado pelo CEP com o parecer de n 3.079.632. Utilizou-se para coleta de dados uma entrevista com 5 questões norteadoras sobre sua percepção de estar com um cateter vesical de demora. As falas foram gravadas e transcritas. A análise das entrevistas foi realizada em três etapas, fundamentada na análise de discurso(2). As representações encontradas foram discutidas com referências teóricas relativas a cada uma determinando o núcleo central e os periféricos de cada representação. Resultados e Discussão: Dentre as representações encontradas, emergiram três núcleos centrais com seus respectivos núcleos periféricos: Representações específicas do cotidiano de um paciente com cateter vesical de demora, referindo as alterações cotidianas existentes com o uso do cateter e alteração na vida sexual por estar com o cateter; Representações do significado de estar com um cateter vesical de demora, referindo-se as vantagens e desvantagens de seu uso verbalizando que estar com um cateter significa resolução do problema, ausência de dor, não usar mais fralda e as desvantagens é ser um problema, alterar a autoestima, Representações específicas do paciente frente à necessidade do uso do cateter, verbalizado ser necessário para a sobrevivência por permitir a eliminação urinária e esperança de um dia não necessitar mais do cateter. Conclusões: Dentre as representações encontradas, existem algumas que evidenciam a importância de sua adesão e outras para a rejeição a esse tratamento. Conhecendo as percepções e crenças positivas e negativas sobre esse tratamento, tornasse possível maior compreensão das atitudes tomadas pelos pacientes, das repercussões que esse tratamento tem na vida deles e, consequentemente, fornece-nos subsídios para uma atuação mais direcionada, pois os profissionais buscam minimizar as representações que levam à rejeição do tratamento, sejam elas objetivas ou subjetivas, e fortalecer aquelas que levam à adesão a ele.
\end{abstract}

Keywords: Cateteres de demora, Cateterismo urinário , Percepção, Estomaterapia

\section{Referências Bibliográficas}

1. Brunner LS, Suddarth DS. Tratamento de pacientes com disfunção do trato urinário superior ou inferior. In: Smeltzer SC, Bare BG, Hinkle JL, Cheever KH. Bunner e Suddarth Tratado de Enfermagem Médico-cirúrgico. 12ª ed. Rio de Janeiro: Guanabara Koogan, 2011. p. 1364-70. 2. Arruda A. Teoria das representações sociais e teorias de gênero. Cad Pesqui. 2002;(117):127-47. 3. Truzzi JC, Canalini EF, Prezotti JÁ, Resplande J. Recomendações SBU 2016. Cateterismo Vesical Intermitente [Internet]. São Paulo; 2016. 


\title{
RELATO DE EXPERIÊNCIA: Reflexão de uma Enfermeira estomaterapeuta após elaboração de plano de assistência focado na reabilitação de cirurgia de derivação urinária à Bricker, em um Serviço Ambulatorial Público de São Paulo
}

\author{
Author(s): Heloiza Ferreira Martins ${ }^{1}$ \\ Institution(s) ${ }^{1}$ PAM Várzea do Carmo - Estado de São Paulo (rua leopoldo miguez)
}

\begin{abstract}
Introdução

Estoma ou estomia são palavras de origem grega e se referem a abertura ou boca, feita para a exteriorização de um segmento de qualquer víscera oca do corpo1.

Segundo Paulo Rodrigues2, quando parte do trato urinário precisa ser removida, as derivações urinárias, como a técnica

Bricker podem ser um recurso valioso.

A necessidade de utilização de equipamento coletor é um dos maiores problemas, no que tange à Qualidade de vida, devido a perda da integridade física, da beleza e aceitação social estética3.

O Decreto no 5.296 de 2 de dezembro de 20044, respalda a pessoa com estomia como deficiente físico, o que lhe dá o direito à reabilitação.

Cesaretti et al.9, adverte prescrições indevidas acarretam impacto negativo na qualidade de vida, perda de tempo e recursos financeiros.
\end{abstract}

A partir dos achados da literatura, que vão ao encontro da experiência prática, a autora objetivou descrever a importância do enfermeiro e do serviço de estomaterapia no atendimento à pessoa com estomia, na prescrição individualizada e fornecimento de equipamentos coletores que promovam a reabilitação.

Metodologia

Trata-se de um relato de experiência.

Relato de Experiência

Esta experiência vivenciada pela autora, após elaboração de plano de assistência focado na reabilitação de cirurgia de derivação urinária à Bricker, gerou reflexão quanto a importância do enfermeiro e do Serviço, na prescrição individualizada de equipamentos que promovam a reabilitação.

Em 2017 um caso despertou atenção, uma paciente buscou o serviço com uma necessidade singular de equipamento de urostomia, com maior limite de recorte e o Serviço não pode disponibilizar a bolsa que atendesse esta necessidade.

A partir disso a adequação foi possível, apenas com um equipamento urinário de 2 peças da marca Alterna flange $60 \mathrm{~mm}$ e limite de recorte $55 \mathrm{~mm}$, fabricado e doado pela empresa Coloplast, o que possibilitou a contribuição no processo de reabilitação e minimizou riscos de complicações relacionadas a inadequação do equipamento, como vazamento, problemas de pele.

A autora destaca a importância de o Serviço ter disponibilidade de equipamentos e adjuvantes, que possam atender às especificidades. Além da importância do engajamento do enfermeiro, ao estabelecer plano de assistência.

A falta de equipamento e adjuvantes adequados, gera situações de stress entre o enfermeiro e o paciente, uma vez que este requer seus Direitos e o Serviço depende de investimento de verba pública para abastecimento dos insumos.

Para melhoria de padrões de cuidado em saúde, deve haver sinergia de ações e senso de responsabilidade entre profissionais de saúde e usuário.

Considerações Finais

É de extrema importância considerar, que ainda há muito o que se fazer para tornar mais fácil a vida das pessoas com estomia no Brasil. A reabilitação precisa ser garantida às pessoas portadoras de deficiência.

Tendo em vista a prática baseada em evidências, o objetivo deste estudo foi concluído e sugere novas reflexões

Keywords: derivação urinária , estomaterapia , prescrição , qualidade de vida , Reabilitação

\section{Referências Bibliográficas}

Referências 1. Santos VLCG, Cesaretti IUR. Evolução da Enfermagem em Estomaterapia no Decorrer de Sua História. In Santos VLCG, Cesaretti IUR. Assistência em Estomaterapia, Cuidando de Pessoas com Estomia. São Paulo: Atheneu; 2015. p.1. 2. Rodrigues P. Estomias Urinárias: Aspectos Conceituais e Técnicos. In Santos VLCG, Cesaretti IUR. Assistência em Estomaterapia, Cuidando de Pessoas com Estomia. São Paulo: Atheneu; 2015. p.47. 3. Feitosa EM. Influência da técnica da derivação urinária na qualidade de vida dos pacientes com câncer invasivo de bexiga submetidos à cistectomia radical. São Paulo. Dissertação [Mestrado em Urologia] _ Faculdade de Medicina da Universidade de São Paulo; 2012. 4. Brasil. Decreto n 5.296 de 2 de dezembro de 2004. Direito das pessoas com Deficiência. Diário Oficial da União 3 dez 2004; p.5. 


\title{
FATORES DE RISCO PARA DESENVOLVIMENTO DE DERMATITE PERIESTOMA: REVISÃO INTEGRATIVA DA LITERATURA.
}

\author{
Author(s): Diego Ferreira da Silva ${ }^{1}$, Leila Blanes Blanes ${ }^{1}$, Margarete Coelho Parra Miralia ${ }^{1}$, Adriano \\ Ferreira de Sousa ${ }^{1}$ \\ Institution(s) ${ }^{1}$ HIAE - Instituto Israelita de Ensino e Pesquisa Albert Einstein (Av. Albert Einstein, 627 - \\ Morumbi - São Paulo - SP - CEP: 05652-900 )
}

\begin{abstract}
Introdução: a formação de um estoma é uma parte essencial de muitas cirurgias abdominais eletivas e de emergências. Apesar da frequência com que essas cirurgias são realizadas o número de especialistas envolvidos no cuidado com o estoma, as complicações ainda são comuns. Método: estudo do tipo revisão integrativa da literatura, que descreviam por meio da revisão Integrativa, quais os fatores de riscos para o desenvolvimento de dermatite periestoma. Publicados entre 2014-2019, a busca foi realizada nas bases de dados LILACS e MEDLINE, foram analisados 24 artigos, identificando-se a causa, os fatores de riscos para o desenvolvimento de dermatite periestoma e os tipos de dermatites mais acometida. Resultados: a dermatite irritativa/úmida ou até mesmo encontrados em alguns artigos como irritativa por contato, foi encontrada com maior frequência, treze artigos (54,1\%), e o principal fator de risco era o vazamento de efluentes periestoma, seguida da dermatite alérgica quatro artigos (16,6\%), relacionado a alergia ao dispositivo/placa periestoma, entretanto também foram encontrados oito artigos (33,3\%), ao qual não classificava o tipo de dermatite, porém descrevia os fatores de riscos (vazamento de efluentes), que ao analisar criteriosamente se tratava de uma dermatite irritativa/úmida. Conclusões: As dermatites mais citadas, com maior frequência foram as dermatites irritativa/úmida seguida da dermatite alérgica. $\mathrm{E}$ os principais fatores de riscos encontrados decorrentes dessas dermatites foram vazamento de efluentes periestomal, relacionado a dermatite irritativa/úmida e hipersensibilidade ao material da placa coletora, em relação a dermatite alérgica. O plano terapêutico das dermatites periestomais inclui medidas de prevenção e tratamento. Para tanto o enfermeiro estomaterapeuta, é responsável por ajudar a prevenir e a tratar as dermatites periestomais, como também educar sobre outras complicações de lesões de pele após a confecção de um estoma, educando não só a equipe de saúde, mas principalmente o paciente sobre os fatores de riscos para dermatites periestomais.
\end{abstract}

Keywords: Dermatite AND Estoma, Dermatits AND Ostomy, Peristome AND Dermatitis

\section{Referências Bibliográficas}

Watson A.J, Nicol L, Donaldson S, Fraser C, Silversides A. Complications of stomas: their aetiology and management. Br J Community Nurs. 2013 Mar;18(3):111-2, 114, 116. Maydick-Youngberg D. A Descriptive Study to Explore the Effect of Peristomal Skin Complications on Quality of Life of Adults With a Permanent Ostomy. Ostomy Wound Manage. 2017 May;63(5):10-23. McGrath A. Stoma-associated problems: the important role of the specialist nurse. Br J Nurs. 2017 Mar 9;26(5):S30-S31 . 


\title{
RELATO DE EXPERIÊNCIA: ORIENTAÇÃO AO PACIENTE COM TRAQUEOSTOMIA DE URGÊNCIA BASEADA NA TEORIA DO DÉFICIT DO AUTOCUIDADO DE OREM
}

\author{
Author(s): Aline Araujo Villamor ${ }^{1}$, Ana Angélica de Souza Freitas ${ }^{1}$ \\ Institution(s) ${ }^{1}$ INCA - Instituto Nacional do Câncer (Praça da Cruz Vermelha, 23 - Centro - Rio de Janeiro - RJ )
}

\begin{abstract}
Intodução: A motivação para a descrição desse relato de experiência emergiu durante a prática de cuidado ao paciente com traqueostomia de urgência. Situação essa que acontece numa instituição de saúde especializada em tratamento oncológico clínico e cirúrgico ao paciente com neoplasias do trato aerodigestivo superior que englobam as regiões da boca, faringe e laringe. Sendo considerada como emergência oncológica a necessidade de realizar uma traqueostomia de urgência pela obstrução das vias áreas superiores causada pela neoplasia dessas regiões ou por complicação do tratamento. Encontram-se desafios nas orientações de cuidado ao paciente com traqueostomia recente, pois foram observados pontos importantes como: tempo curto de internação hospitalar de 24 horas; muitas informações para o autocuidado referentes à manipulação da cânula de traqueostomia associadas ao medo e negação da nova situação do estado de saúde; dificuldade de adaptação respiratória; dor no local onde foi inserida a cânula traqueal; e ausência de suporte emocional de familiares ou amigos. Objetivo: Descrever um relato de experiência da prática de cuidado ao paciente de pós-operatório de traqueostomia de urgência utilizando a Teoria do déficit do autocuidado de Orem. Método: As orientações são dadas aos pacientes com traqueostomia internado na enfermaria cirúrgica de cabeça e pescoço de um hospital público de oncologia. Para esse relato de experiência selecionamos pacientes com traqueostomia de urgência e os que não haviam sido traqueostomizados anteriormente. Observa-se na prática do cuidado que o paciente permanece internado por 24 horas, tornando-se um desafio para o paciente apreender as orientações dos cuidados de si e com a traqueostomia, nesse curto espaço de tempo. As orientações ao paciente com traqueostomia de urgência são preferencialmente realizadas na sala de curativo, considerada o espaço de cuidado de enfermagem, onde há um espelho grande na parede, cadeiras, material educativo impresso que é fornecido ao paciente no momento da internação hospitalar para consultá-lo em casos de dúvidas, cânulas de traqueostomia e um boneco com cânula de traqueostomia, considerado didático, para o paciente realizar um treinamento no mesmo antes de manipular sua traqueostomia. Resultados: Percebeuse a necessidade de fazer com que esse paciente tome ciência que mesmo com toda a mudança ele é a pessoa responsável pelo seu cuidado. É importante o fortalecimento do vínculo entre paciente e equipe de enfermagem. O paciente precisa confiar no profissional e em si mesmo, precisa saber que é capaz de cuidar de si próprio. Precisamos passar confiança ao paciente através do nosso preparo e através de uma linguagem clara, não-técnica. A enfermagem deverá identificar as necessidades dos pacientes e déficits nesse autocuidado, atentando para as características e limitações de cada cliente, avaliando a melhor ação assistencial e educativa. É importante deixar abertura para o paciente tirar as dúvidas. Empatia e paciência são fundamentais também. Conclusão: Ao usar a Teoria do déficit do autocuidado de Orem para guiar as ações assistenciais ao paciente com traqueostomia de urgência, observou-se que a aplicação da teoria contribui para a construção do autocuidado, tornando-o independente e com melhora da autoestima.
\end{abstract}

\section{Keywords: AUTOCUIDADO, ESTOMATERAPIA, TRAQUEOSTOMIA}

\section{Referências Bibliográficas}

Barbosa M M, Sá G M, Lima R A. Diagnóstico e tratamento dos tumores de cabeça e pescoço. São Paulo: Editora Atheneu, 2001. Matsubara M G S, Villela D L, Hashimoto S Y, Reis H C S, Saconato R A, Denardi U A, et al. Feridas e estomas em oncologia: Uma abordagem interdisciplinar. 1.ed. São Paulo: Lemar; 2012. Nogueira C S F. Instrumento CADEM adaptado: Subsídio para o autocuidado de pacientes cirúrgicos por câncer de cabeça e pescoço pela Enfermagem. Rio de Janeiro. Dissertação [Mestrado em Enfermagem] - Universidade Federal do Rio de Janeiro; 2017. Santos B, Ramos A, Fonseca C. Da formação à prática: Importância das Teorias do Autocuidado no Processo de Enfermagem para a melhoria dos cuidados. Journal of Aging and Invation 2017; 6 (1): 51-54. 


\title{
O PERFIL DE CRIANÇAS E ADOLESCENTES COM ESTOMA DA BAIXADA LITORÂNEA DO ESTADO DO RIO DE JANEIRO
}

\author{
Author(s): Viviane Cristina da Paz Torres ${ }^{2}$, Ariana Dias Ferreira ${ }^{1}$, Jennifer Souza Soares ${ }^{1}$, Luciana da Costa \\ Nogueira Cerqueira ${ }^{1}$, Gisele Barcelos Oliveira Koeppe ${ }^{1}$ \\ Institution(s) ${ }^{1}$ UVA CAMPUS CABO FRIO - UNIVERSIDADE VEIGA DE ALMEIDA (ESTRADA \\ PERINAS S-N), ${ }^{2}$ POLO I - POLO DA BAIXADA LITORÂNEA DO ESTADO DO RIO DE \\ JANEIRO (RUA GOVERNADOR VALADARES, CEP 28900-000, CABO FRIO-RJ)
}

\begin{abstract}
A construção de um estoma é considerada a cirurgia mais antiga feita no aparelho digestivo. Em países com um bom nível de assistência médica, há cerca de 1 estomizado para cada 1.000 habitantes, podendo ser bem superior esse número nos países menos desenvolvidos. Há no Brasil, uma crescente atenção ao portador de estomia, que é atestada por uma efetiva abordagem política que vem garantindo os direitos destas pessoas. Objetivo: levantar o perfil de crianças e adolescentes com estomia atendidos em um serviço de referência no município de Cabo Frio-RJ. Material e método: trata-se de um estudo transversal, descritivo, com abordagem quantitativa. O cenário do estudo foi um Serviço de Referência da baixada litorânea no atendimento de crianças e dolescentes com estomia. Os dados foram coletados nos prontuários de todas as crianças e adolescentes em atendimento no cenário do estudo. A coleta de dados foi realizada por meio de instrumento previamente elaborado para este estudo. Os dados coletados foram tabulados em uma planilha do software excel que proporcionou a construção de tabelas analíticas, possibilitando uma análise estatística descritiva. Resultados: o maior número da amostra atendida são lactentes, do sexo masculino, brancos, residentes de Cabo Frio, com uma renda familiar de até 1 salário mínimo, tendo a mãe como a principal responsável pelo cuidado. As estomias tem como principal etiologia as malformações, são de caráter temporário e apresentam a dermatite de contato como a principal complicação. Conclusão: Os dados da pesquisa corroboram com outras realizadas anteriormente, enriquecendo o conhecimento a partir do reforço das informações. Apesar da clientela pediátrica representar um número pequeno das pessoas portadoras de estomia, o reconhecimento desta realidade permite traçar estratégias precisas e efetivas para esta população nos polos de referência no atendimento do público infantil. Considera-se essencial a assistência do enfermeiro em todo esse contexto, sendo indispensável o papel desse profissional no processo de aceitação e incentivo ao autocuidado. Além disso, a necessidade de capacitação e ou especialização destes profissionais que atuam diretamente com esta clientela para elaboração de um plano de ações que atendam as crianças e adolescentes com estomia em sua totalidade.

Sugere-se que novos estudos sejam realizados com uma abordagem mais ampla em todos os tipos de estomias, enriquecendo o saber nesta área de atuação.
\end{abstract}

\section{Keywords: ESTOMATERAPIA, PDIATRIA, ENFERMAGEM}

\section{Referências Bibliográficas}

1- Brasil. Ministério da Saúde. Portaria n 400 de 16 de novembro de 2009. Diretrizes Nacionais para a Atenção à Saúde das Pessoas Ostomizadas. Brasília: Secretaria de Atenção à Saúde; 2009. 2- Monteiro SNC, Kamada I, Silva AL, Souza TCR. Perfil de crianças e adolescentes estomizados de um hospital público do Distrito Federal. ESTIMA, Braz. J.

Enterostomal Ther [Internet]. 2014 [acesso 03 mai 2018]; 12(3). Disponível em:

https://www.revistaestima.com.br/index.php/estima/article/view/93/0. 3- Freitas JPC, Borges EL, Bodevan EC.

Caracterização da clientela e avaliação de Serviço de atenção à saúde de pessoa com estoma de eliminação. ESTIMA, Braz. J. Enterostomal Ther [Internet]. 2018 [acesso 03 mai. 2018]; 16(e0918). Disponível em:

file://C:/Users/Asus/Downloads/402-1210-1-PB\%20(2).pdf. 4-Rosado SR, Dázio EMR, Fava SMCL, Maia PH, Filipini CB, Resck ZMR, et al. Experiência de Ser Mãe de Criança com Estomia. ESTIMA, Braz. J. Enterostomal Ther. 2014; 12(01): 1806-3144. 


\title{
PERFIL DA POPULAÇÃO COM ESTOMIA DA BAIXADA LITORÂNEA ASSISTIDA EM UM CENTRO DE REFERÊNCIA NO MUNICÍPIO DE CABO FRIO-RJ
}

\author{
Viviane Cristina da Paz Torres ${ }^{1}$, Sabrina Almeida Barreto Cacholi ${ }^{2}$, Viviane da Silva Nascimento \\ Author(s): $\quad{ }^{2}$, Gisele Barcelos Oliveira Koeppe ${ }^{2}$, Carlos Eduardo Peres Sampaio ${ }^{2}$, Luciana da Costa Nogueira \\ Cerqueira $^{2}$ \\ Institution(s) ${ }^{1}$ POLO I - POLO DA BAIXADA LITORÂNEA DO ESTADO DO RIO DE JANEIRO (RUA \\ GOVERNADOR VALADARES, CEP 28900-000, CABO FRIO-RJ), ${ }^{2}$ UVA CAMPUS CABO \\ FRIO - UNIVERSIDADE VEIGA DE ALMEIDA (ESTRADA DE PERINAS S-N ${ }^{\circ}$ CABO FRIO)
}

\begin{abstract}
Resumo

Objetivo: caracterizar o perfil sócio-clinico epidemiológico da população com estomia atendidas em um centro de referencia. Método: estudo transversal quantitativo realizado com 255 prontuários de paciente estomizado. Aprovado pelo comitê de ética com parecer N. 2.907.189. A coleta de dados ocorreu no Serviço de Atenção Básica à Pessoa Ostomizada (POLO I) no município de Cabo Frio no período de setembro a novembro de 2018. Realizado uma analise estatística descritiva. Resultados: Foi predominante o sexo masculino 138(54\%), idosos 75(29\%), brancos 128(50\%), casados 47(47\%), com até o ensino fundamental $151(59,2 \%)$, aposentados $88(35 \%)$ ou assegurados pelo INSS 58

(23\%). Prevaleceu os pacientes com colostomia $182(71 \%)$ por neoplasias 177 (68\%). Maior complicação foi dermatite 44 (17\%). Com tempo de permanecia temporária 86(6,7\%).

Conclusão: Foram obtidos dados importantes para uma melhor assistência de saúde, em destaque o enfermeiro, que se posiciona de forma direta e contínua com esses pacientes em relação ao acompanhamento e orientação dos pacientes e familiares. Nos dados sociais pode-se perceber que os pacientes atendidos no POLO tratam-se de sua maioria pacientes maiores de 60 anos, aposentados, casados e com o nível de escolaridade baixo, esses dados podem interferir diretamente na adesão, aceitação e continuidade ao tratamento adequado. Os estomas mais incidentes foram os intestinais, como causa as neoplasias e com tempo de permanência temporária e as maiorias das complicações como dermatite, prolapso, hérnia, retração, granuloma, sangramento, hiperemia, entre outros, podem estar associadas a continuidade e cuidados básicos com o estoma, o acompanhamento dos hábitos de vida e conscientização sobre o estoma pode interferir diretamente nestas questões. Esses dados são de grande importância para nortear a consulta fornecida a este paciente, com acompanhamento periódico do enfermeiro para esclarecer e orientar possíveis dúvidas, bem como se tornar um facilitador na aceitação e adesão ao tratamento de forma completa e adequada. Com o desenvolvimento deste estudo os pesquisadores também encontram algumas limitações, sendo uma delas a dificuldade de encontrar os dados sociais e clínicos do paciente, o que dificultou a realização de uma discussão mais coesa dos dados propostos. Sendo assim, entende-se a necessidade de uma restruturação no que tange aos registros multiprofissionais, além de uma padronização nos instrumentos de avaliação diária do paciente, o que auxilia diretamente no norteamento dos dados importantes a serem levantados.

Neste contexto, o presente estudo traz dados importantes sobre os pacientes estomizados da baixada litorânea atendidas no POLO I, que pode auxiliar na atualização do instrumento de coleta dos dados sociais e clínicos daqueles pacientes, o que contribui para melhoria da qualidade de assistência, gestão do cuidar e tomada de decisões.
\end{abstract}

Keywords: Estomia, Perfil de Saúde, Cuidados de Enfermagem

\section{Referências Bibliográficas}

1- MIRANDA, S. M.; LUZ, M. H. B. A.; SONOBE, H. M.; ANDRADE, E. M. L. R.; MOURA, E. C. C. Caracterização sociodemográfica e clínica de pessoas com estomia em Teresina. Revista Estima, v.14, n.1, p. 4, 2016. (https://www.revistaestima.com.br/index.php/estima/article/view/117/pdf). 2- NOGUEIRA, J. W. S.; KAMADA, I.; LINS, G. A. I. Readaptação funcional do estomizado: relato de experiências vividas. Revista Estima, v.14, n³, 2015. (https://www.revistaestima.com.br/index.php/estima/article/view/409/pdf). 3- CUNHA, R. R.; FERREIRA, A. B.; BACKES, V. M. S. Revisão- Características Sócio-Demográficas e Clínicas de Pessoas Estomizadas: Revisão de Literatura. Revista Estima, v.11, n², 2013. (https://www.revistaestima.com.br/index.php/estima/article/view/327) 


\title{
ELABORAÇÃO DE CARTILHA PARA ESTOMIZADOS: PROMOÇÃO DA QUALIDADE DE VIDA
}

Camila Barroso Martins ${ }^{1}$, Beatriz Moreira Alves Avelino ${ }^{1}$, Ingrid Caroline Uchôa Alexandre ${ }^{1}$, Lívia Cintia Maia Ferreira ${ }^{1}$, Karla Vanessa Pinto Vasconcelos ${ }^{1}$, Karine Rocha da Silva Abreu ${ }^{1}$, Débora Lira Correia ${ }^{1}$, Maíra Maria Leite de Freitas ${ }^{1}$, Kauane Matias Leite ${ }^{1}$, Caio Victor Fernandes de Oliveira ${ }^{1}$, Letícia Ellen Author(s): Vieira Rocha ${ }^{1}$, Andrezza Silvano Barreto ${ }^{1}$, Wanessa Pereira Cavalcante ${ }^{1}$, João Victor Mendonça Santana Cavalcante ${ }^{1}$, Geovana Monteiro de Oliveira 1, Thalia Alves Chagas Menezes ${ }^{1}$, Carla Beatriz da Pontes ${ }^{1}$, Viviane Mamede Vasconcelos Cavalcante ${ }^{1}$, Francisca Alexandra Araújo da Silva ${ }^{2}$, Solange Gurgel Alexandre $^{2}$

Institution(s) ${ }^{1}$ UFC - Universidade Federal do Ceará (Rua Alexandre Baraúna, no 1115 - Fortaleza -Ce), ${ }^{2}$ HU - Hospital Universitário Walter Cantídio (R. Pastor Samuel Munguba, 1290 - Rodolfo Teófilo, Fortaleza - CE)

\begin{abstract}
INTRODUÇÃO: Estomia é um procedimento cirúrgico caracterizado pela exteriorização de um órgão oco, mudando o seu trajeto comum 1 . Nesse contexto, a adoção de cuidados para com a estomia e a resolução de dúvidas dos pacientes se torna essencial². Além disso, a saúde física do indivíduo e seu estado psicológico, estão ligados a suas relações sociais, fatores ambientais e níveis de independência, tendo em vista as mudanças significativas que podem prejudicar sua qualidade de vida ${ }^{3}$. O enfermeiro contribui para a melhora da autoestima, auxiliando na compreensão das mudanças na imagem corporal e , fornecendo as orientações necessárias ao enfrentamento da nova condição. OBJETIVO: Descrever a construção de uma cartilha para pessoas com estomias. MATERIAIL E MÉTODO: Trata-se de estudo metodológico, realizado em três etapas, no período de Junho de 2017, sendo a $1^{\circ}$ etapa a organização do conteúdo/levantamento bibliográfico a partir de literatura pertinente ao tema, buscando as principais dúvidas, necessidades de orientações e alterações na qualidade de vida das pessoas com estomias; na $2^{\circ}$ etapa foi realizado o planejamento e escolha das ilustrações para o conteúdo e na $3^{\circ}$ etapa, a construção da cartilha propriamente dita. RESULTADOS: Constatou-se a presença de estudos válidos relacionados ao assunto e destinados ao público já referido, percebendo-se grande número de dúvidas e dificuldades no manuseio dos dispositivos de coleta. A cartilha contém 14 páginas; os temas abordados foram: explicação e classificação das estomias, cuidados necessários, manuseio dos dispositivos de coleta, cuidados com a pele e dicas de alimentação. A cartilha tem como foco permitir que a pessoa com estomia seja sujeito protagonista no processo de produção de saúde. Além disso, sua disponibilização é uma ferramenta relevante, que favorece a comunicação entre a equipe de saúde e o público-alvo, por meio do fornecimento de informações confiáveis e adequadas. CONCLUSÕES: O processo de construção demandou empenho, conhecimento e criatividade que juntos puderam contribuir para tornar esta tecnologia viável com o intuito de melhorar a qualidade de vida das pessoas com estomias. Foi evidenciada a importância da criação de material educativo bem elaborado, além de estimular novas tecnologias produzidas por enfermeiros, com vistas ao empoderamento dessas pessoas, autônomas em seus cuidados, com as ferramentas necessárias para a quebra de estigmas sociais.
\end{abstract}

Keywords: Estomaterapia, Estomia, Qualidade de vida

\section{Referências Bibliográficas}

1.DALMOLIN A, GIRARDON-PERLINI NMO, SIMON BS, COPPETI LC, MACHADO L. Familia conviviendo con una persona con estomía intestinal: un análisis documental. Cultura de los cuidados: Revista de enfermería y humanidades. Granada; 2019. 23(53). 2.MOTA MS, GOMES GC, SILVA CD, GOMES VLO, PELZER MT, BARROS EJL.Autocuidado: uma estratégia para a qualidade de vida da pessoa com estomia. Bogotá D.C: Investigacion en Enfermería, 2016. 18(1), 63-78. 3.RIBEIRO O, CUNHA M, DIAS A, ALBUQUERQUE C. Qualidade de vida dos ostomizados: perfil psicológico. Servir, Lisboa; 2016; 59(3); 40-43. 


\title{
ATUAÇÃO DO ENFERMEIRO NAS COMPLICAÇÕES EM ESTOMIAS DE ELIMINAÇÃO INTESTINAL: REVISÃO INTEGRATIVA
}

\author{
Author(s): Samantha Perissotto ${ }^{1}$, Jéssica da Silva Cunha Breder ${ }^{2}$, Luana Rosas Zulian ${ }^{3}$, Viviane Xavier de Oliveira ${ }^{4}$, \\ Néria Invernizzi da Silveira ${ }^{2}$, Neusa Maria Costa Alexandre ${ }^{2}$ \\ Institution(s) ${ }^{1} \mathrm{HC} / \mathrm{UNICAMP}$ - Hospital de Clínicas - UNICAMP (R. Vital Brasil, 251 - Cidade Universitária, Campinas - \\ SP, 13083-888), ${ }^{2}$ Fenf/UNICAMP - Faculdade de Enfermagem da Universidade Estadual de Campinas (R. \\ Tessália Vieira de Camargo, 126 - Cidade Universitária, Campinas - SP, 13083-), ${ }^{3}$ Hospital Samaritano - \\ Hospital Samaritano - São Paulo (R. Conselheiro Brotero, 1486 - Higienópolis, São Paulo - SP, 01232-010), \\ ${ }^{4}$ Prefeitura SP - Prefeitura Municipal de São Paulo (Rua Dr Lund, 41, Liberdade, São Paulo)
}

\section{Abstract \\ INTRODUÇÃO:}

Estudos demonstram alta incidência de complicações relacionadas a estomias de eliminação intestinal $(1,2)$. A atuação do enfermeiro, principalmente do estomaterapeuta, são essenciais no tratamento e na prevenção para a redução destas taxas $(3,4)$.

\section{OBJETIVOS}

O objetivo deste estudo foi identificar na literatura as principais ações de enfermagem para a prevenção e tratamento das complicações mais frequentes nas estomias de eliminação intestinal.

\begin{abstract}
MATERIAIS E MÉTODOS:
Revisão integrativa que seguiu as fases: identificação do tema e seleção da questão de pesquisa; estabelecimento de critérios para inclusão e exclusão de estudos; categorização dos estudos; avaliação dos estudos incluídos na revisão integrativa; interpretação dos resultados e síntese do conhecimento (5). O período foi de janeiro de 2007 a agosto de 2019, nas bases de dados e nos portais Medline, BVS, EMBASE, CINAHL e Scopus. Os descritores utilizados foram estomia, enfermagem e complicações pós-operatórias em inglês, português e espanhol.
\end{abstract}

\section{RESULTADOS:}

Dezessete artigos responderam à questão norteadora: "quais as ações de enfermagem podem ser utilizadas na prevenção e tratamento das complicações em estomias de eliminação intestinal?" A complicação mais abordada nos artigos foi a retração da estomia, seguida por hérnia paraestomal, estenose e separação mucocutânea. As ações de enfermagem mais citadas foram demarcação pré-operatória e acompanhamento com enfermeiro especialista no pré e pós-operatório. Quatro ensaios clínicos randomizados controlados associaram o acompanhamento contínuo pelo enfermeiro desde o período préoperatório, com o envolvimento da família, associado a visitas domiciliares ou seguimento por telefone após a alta com menores taxas de complicações.

\section{CONCLUSÃO:}

As ações realizadas pelo enfermeiro estomaterapeuta tem impacto na diminuição das taxas de complicações, com destaque para a demarcação pré-operatória. O acompanhamento contínuo pelo enfermeiro, desde o período pré-operatório até o seguimento após a alta também estão associados a menores taxas de complicações.

\section{Keywords: Complicações Pós-operatórias, Estomia, Enfermagem, Estomaterapia}

\section{Referências Bibliográficas}

1- Sung YH, Kwon I, Jo S, Park S. Factors affecting ostomy-related complications in Korea. J Wound, Ostomy Cont Nurs. 2010; 37(2):166-72. https://doi.org/10.1097/WON.0b013e3181cf7b76 2- Braumann C, Muller V, Knies M, Aufmesser B, Schwenk W, Koplin G. Complications After Ostomy Surgery: Emergencies and Obese Patients are at Risk-Data from the Berlin OStomy Study (BOSS). World J Surg. 2018. https://doi.org/10.1007/s00268-018-4846-9 3- Baykara ZG, Demir SG, Karadag A, Harputlu D, Kahraman A, Karadag S, et al. A multicenter, retrospective study to evaluate the effect of preoperative stoma site marking on stomal and peristomal complications. Ostomy Wound Manage. 2014; 60(5):16-26. 4- Xia L. The Effects of Continuous Care Model of Information-Based Hospital-Family Integration on Colostomy Patients: a Randomized Controlled Trial. Journal of Cancer Education. J Canc Educ. 2019. https://doi.org/10.1007/s13187-018-1465-y 5- Souza MT de, Silva MD da, Carvalho R de. Integrative review: what is it? How to do it? Einstein (São Paulo) 2010; 8(1):102-6. https://doi.org/10.1590/s1679-45082010rw1134 


\title{
Caracterização sociodemográfica e clínica de pessoas submetidas à reconstrução de trânsito intestinal
}

Janderson Cleiton Aguiar ${ }^{2,1}$, Tamiris Souza Rodrigues ${ }^{1}$, Natalia Sperli Geraldes Marin dos Santos

Author(s): $\quad$ Sasaki ${ }^{1}$, André Aparecido da Silva Teles ${ }^{2}$, Vanessa Damiana Menis Sasaki ${ }^{2}$, Helena Megumi Sonobe ${ }^{2}$

Institution(s) ${ }^{1}$ UNILAGO - União das faculdades dos grandes lagos (Rua Eduardo Nielsen, 960), ${ }^{2}$ EERP - USP - Escola de Enfermagem de Ribeirão Preto - USP (Avenida dos Bandeirantes 3900)

\begin{abstract}
Introdução: O Sistema Único de Saúde (SUS) garante a assistência a pessoas com estomas de eliminação através da Portaria 400. A presença do estoma e do equipamento coletor geram alterações fisiológicas, físicas e emocionais, que afetam a rotina de vida, relações interpessoais e autoestima. Ofertar a reconstrução do trânsito intestinal (RTI) às pessoas com estoma temporário é uma necessidade e um desafio para o SUS. Objetivo: Analisar a caracterização sociodemográfica e clínica das pessoas submetidas à Reconstrução de Trânsito Intestinal. Material e método: Estudo quantitativo, retrospectivo e descritivo, de levantamento de prontuários, no Serviço de Atenção ao Estomizado do Centro Especializado em Reabilitação em uma cidade do interior paulista. Projeto aprovado pelo Comitê de Ética em Pesquisa da Instituição proponente, sob parecer ํㅡ 2.831.709. Os critérios de inclusão foram: pessoas com 18 anos ou mais, residentes na microrregião e/ou no município sede do serviço; submetidos à cirurgia de Reconstrução de Trânsito Intestinal (RTI), no período entre 2010 a 2018; e o de exclusão: prontuários com dados incompletos. Os dados foram coletados em agosto de 2018, cujo instrumento de coleta de dados contemplou informações sociodemográficas e clínicas, digitados duplamente em banco de dados Excel, transferidos para o programa IBM SPSS, versão 22.0, com análise descritiva. A população foi constituída por 134 prontuários. Resultados: Do total de 134 prontuários de pessoas submetidas à RTI, houve predomínio do sexo masculino $78(58 \%), 122(91 \%)$ atendimentos exclusivamente pelo SUS; média de idade de 57,3 anos; diagnóstico oncológico em 63 (47\%); cirurgia de retossigmoidectomia 62 (46\%); além de 92 (69\%) de pessoas com colostomias e 88 $(66 \%)$ cirurgias de urgência. No período avaliado (2010 a 2018), prevaleceu doença oncológica como principal causa da construção de estoma intestinal, o que indica que as estratégias para prevenção e identificação precoce do câncer colorretal (CCR) ainda são insuficientes, refletindo na demora para o para a sua elucidação, o que gera estabelecimento do diagnóstico já em fase avançada da doença, resultando na necessidade de cirurgia de grande porte (retossigmoidectomia) e em caráter de urgência, quando estas pessoas já estão com quadro crítico e com complicações. Foram realizadas 134 RTI, um número pequeno, sendo em 2018, 480 estavam cadastrados neste programa, o que pode indicar que muitos não possuíam condições para a realização desta cirurgia ou que o SUS não tem conseguido ofertá-la, pois a prioridade é a realização de cirurgia para resolução do problema de saúde. Conclusão: Estes resultados apontam a necessidade de estratégias de prevenção e diagnóstico precoce de CCR e contribui para o planejamento da assistência especializada multiprofissional neste programa para o seguimento e preparo desta clientela para as mudanças na vida após RTI, bem como no gerenciamento da previsão e provisão de equipamentos coletores e adjuvantes.
\end{abstract}

Keywords: Assistência Prestada ao Paciente, Estomas Cirúrgicos, Estomaterapia, Perfil de Saúde

\section{Referências Bibliográficas}

Aguiar JC, Pereira APS, Galisteu KJ, Lourenção LG, Pinto MH. Clinical and sociodemographic aspects of people with a temporary intestinal stoma. Reme. 2017; 21 (1): 1-7. Brasil. Ministério da Saúde. Secretaria de Atenção à Saúde. Portaria no 400 de 16 de Novembro de 2009. Regulamenta a Atenção à Saúde das Pessoas Estomizadas. Brasília: MS [Internet]. 2009. [cited 2019 ago 11]. Disponível em: Zafar SN; Changoor NR, Williams K, Acosta RD, Greene WR, Fullum TM. et al. Race and socioeconomic disparities in national stoma reversal rates. The American Journal of Surgery [Internet]. 2016 [cited 2019 ago 11]; 211(4):710-15. Available from: http://www.sciencedirect.com/science/article/pii/S0002961016300010 Salomé GM, Almeida AS, Silveira MM. Quality of life and self-esteem of patients with intestinal stoma[Internet]. J. Coloproctol. 2014[cited 2019 ago 11]; 34(4):231-9. Available from: http://www.scielo.br/pdf/jcol/v34n4/2237-9363-jcol-34-04-0231.pdf 


\title{
PERFIL SOCIODEMOGRÁFICO E CLÍNICO DE PESSOAS DE UM MUNICIPÍO DO SUL DE MINAS GERAIS COM COMPLICAÇÕES DE ESTOMIA E DE PELE PERIESTOMA
}

Eliza Maria Rezende Dázio ${ }^{1}$, Marina Bavaresco ${ }^{1}$, Marina Cardoso Bueno ${ }^{2}$, Geruza Maria da Silva Author(s): Gonçalves Manfredini ${ }^{1}$, Larissa Oliveira de Carvalho ${ }^{1}$, Roberta Garcia Gomes ${ }^{1}$, Rogério Silva Lima $^{1}$, Silvana Maria Coelho Leite Fava ${ }^{1}$

Institution(s) ${ }^{1}$ UNIFAL-MG - Universidade Federal de Alfenas (Rua Gabriel Monteiro da Silva, 700 Alfenas MG CEP37130000), ${ }^{2}$ SMS - Prefeitura Municipal de Passos (Rua Lavras, 477 Muarama Passos 37902-314)

\begin{abstract}
INTRODUÇÃO: O aparecimento de complicações de estomia e de pele periestoma pode acarretar diversas alterações psicossociais e econômicas ${ }^{1}$. Estima-se que uma pessoa com estomia experimentará algum tipo de complicação na pele periestoma dentro de dois anos após a cirurgia, apesar dos avanços de técnicas cirúrgicas e dos cuidados no pré e pósoperatório2, 3. Para atender a demanda de cuidados especializados, assim como a previsão e provisão de equipamentos coletores e adjuvantes, considera-se importante conhecer as características sociodemográficas e clínicas dessa clientela. OBJETIVO: Descrever o perfil sociodemográfico e clínico de pessoas com estomia intestinal e que apresentam complicações de estomia e/ou pele periestoma. MÉTODO: Estudo descritivo realizado com pessoas maiores de 18 anos, com estomia intestinal definitiva ou temporária e complicações na estomia e/ou pele periestomal, cadastradas no serviço de referência de um município do sul de Minas Gerais. Os dados foram coletados em março de 2019, no domicílio, por meio de formulário de caracterização sociodemográfica e clínica. Para a análise dos dados utilizou-se a estatística descritiva. O estudo foi aprovado pelo Comitê de Ética em Pesquisa no 3.071.507. RESULTADOS: Dos dez participantes deste estudo, $70 \%$ eram do sexo feminino. A idade variou entre 52 anos e 74 anos, $50 \%$ eram casados, $60 \%$ tinham ensino fundamental incompleto, $20 \%$ ensino médio incompleto e $20 \%$ ensino superior. Apenas $10 \%$ declarou estar empregado, $60 \%$ eram aposentados e $30 \%$ recebiam benefício auxílio-doença. Quanto aos motivos que levaram a confecção da estomia $50 \%$ foi para tratamento de neoplasia colorretal; $70 \%$ das estomias eram do tipo colostomia e $50 \%$ em caráter definitivo, sendo que o tempo de estomia variou entre um mês e dez anos. Em relação às complicações de estomia e/ou pele periestoma, $60 \%$ dos participantes apresentaram mais de um tipo. Das complicações de estomia, a fístula foi encontrada em $10 \%$ dos participantes e $10 \%$ apresentava retração. Já em relação às complicações de pele periestoma, $50 \%$ apresentavam hérnia paraestomal e $90 \%$ dermatites, das quais $60 \%$ eram alérgicas, $30 \%$ irritativas e $10 \%$ fúngica. No que se refere ao tipo de equipamento coletor, $60 \%$ utilizavam de uma peça drenável. Quanto ao uso de adjuvantes, $70 \%$ faziam uso de um ou mais tipos de adjuvantes, entre eles o pó protetor, o cinto, a pasta e o lenço protetor. CONCLUSÃO: Constatou-se que o perfil da população era predominantemente do sexo feminino, aposentados, alfabetizados, com colostomia. As dermatites foram as complicações mais prevalentes e demandam cuidados de enfermagem no intuito de minimizar o seu aparecimento e/ou trata-las de forma adequada. Conhecer o perfil das pessoas com complicações de estomia contribui para o cuidado de enfermagem mais qualificado.
\end{abstract}

Keywords: Estomia, Eventos adveros, Complicações, Estomaterapia

\section{Referências Bibliográficas}

1.Vonk-Klaassen SM, Vocht HM, Ouden MEM, Eddes EH, Schuurmans MJ. Ostomy-related problems and their impact on quality of life of colorectal cancer ostomates: a systematic review. Quality of Life Research 25.1 (2016): 125-133. 2.Beitz JM, Colwell JC. Management approaches to stomal and peristomal complications. a narrative descriptive study. J Wound Ostomy Continence Nurs. 2016;43(3):263-8 3. Almutairi D, LeBlanc K, Alavi A. Peristomal skin complications: what dermatologists need to know. International Journal of Dermatology. 2017;57(3):257-64 


\title{
COMPLICAÇÕES DE ESTOMIA E DE PELE PERIESTOMA: REVISÃO INTEGRATIVA DE LITERATURA
}

\author{
Eliza Maria Rezende Dázio ${ }^{1}$, Marina Bavaresco ${ }^{1}$, Geruza Maria da Silva Gonçalves Manfredini ${ }^{1}$, \\ Author(s): Larissa Oliveira de Carvalho ${ }^{1}$, Camila de Mendonça Moraes ${ }^{1}$, Rogério Silva Lima ${ }^{1}$, Silvana \\ Maria Coelho Leite Fava ${ }^{1}$ \\ Institution(s) ${ }^{1}$ UNIFAL-MG - Universidade Federal de Alfenas (Rua Gabriel Monteiro da Silva, 700 Alfenas \\ MG CEP37130000)
}

\begin{abstract}
INTRODUÇÃO: A confecção de uma estomia altera a imagem corporal e pode produzir repercussões na multidimensionalidade do ser humano ${ }^{1}$. Apesar de ser um procedimento cirúrgico que salva vidas, estima-se que cerca de $80 \%$ das pessoas submetidas apresentam complicações². OBJETIVO: Identificar e analisar as evidências disponíveis na literatura sobre as complicações de estomia intestinal e de pele periestoma. MÉTODO: Trata-se de uma revisão integrativa da literatura, realizada em seis etapas ${ }^{3}$, com busca de estudos do tipo ensaio clínico randomizado, nas bases de dados National Library of Medicine (PUBMED), Literatura Latino-Americana e do Caribe em Ciências da Saúde (LILACS) e Web of Science (WOS), publicados nos idiomas inglês, espanhol e português, a partir da questão norteadora: Quais são as evidências disponíveis na literatura sobre as complicações de estomia intestinal e de pele periestoma em adultos nos últimos cinco anos? Foi realizada a busca por meio dos descritores controlados MeSH e DeCS e não controlados, de forma individual e por cruzamentos de dois em dois, entre todos os descritores. RESULTADOS: Identificou-se 13559 estudos, dos quais 12335 foram excluídos por duplicidade e por estarem fora do período anual estabelecido. Dos 30 estudos selecionados para a leitura na íntegra, 20 compuseram a amostra da presente revisão, dos quais, dez foram encontrados na Pubmed e dez na WOS. Os estudos foram agrupados em três categorias de análise, conforme a similaridade temática. A primeira categoria se refere às técnicas cirúrgicas no manejo de complicações de estomia e pele periestoma $(n=11)$, com técnicas cirúrgicas inovadoras acerca de tipos de suturas, de ressecção e de exteriorização de alça intestinal, além de reforços com malhas/telas para prevenção de hérnias paraestomais. Há formas de minimizar o risco do aparecimento de complicações, entretanto não há garantia de inexistência de complicações. A segunda categoria aborda a utilização de barreiras de pele e equipamentos coletores para o manejo de complicações de pele periestoma $(n=4)$. Apontaram principalmente as barreiras de pele para prevenção e tratamento da dermatite, que é a ocorrência mais comum de perda de integridade da pele. Os ensaios mostraram tipos de equipamentos coletores, composições e protetores de pele que podem ser usados, buscando reduzir o aparecimento de complicações de pele. A última categoria relaciona-se aos cuidados de saúde fornecidos para o manejo de complicações de estomia e de pele periestoma $(n=5)$. Reuniram estudos que abordaram o cuidado e os programas de acompanhamento, entre eles, visitas domiciliares, consultas e programas educativos. O cuidado e a educação às pessoas com estomia são fundamentais para que as pessoas se sintam confiantes em se cuidar. CONCLUSÃO: É essencial ampliar o conhecimento acerca das complicações de estomia e pele periestoma na tentativa de minimizá-las ou solucioná-las e, dessa forma, contribuir para a prática qualificada da assistência e para a melhoria na qualidade de vida das pessoas com estomia intestinal. Há lacunas do conhecimento em relação à demarcação da estomia.
\end{abstract}

Keywords: Estomia, Eventos adveros, Complicações, Estomaterapia

\section{Referências Bibliográficas}

1. Teles AAS, Eltink, CF, Martins LM, Lenza NFB, Sasaki VDM, Sonobe HM. Mudanças físicas, psicossociais e os sentimentos gerados pela estomia intestinal para o paciente: revisão integrativa. Rev. enferm. UFPE on line (2017): 10621072. 2. Pittman J, Bakas T, Ellett M, Sloan R, Rawl S. Psychometric evaluation of the ostomy complication severity index." Journal of Wound Ostomy \& Continence Nursing 41.2 (2014): 147-157. 3. Mendes KDS, Silveira RCCP, Galvão CM. Revisão integrativa: método de pesquisa para a incorporação de evidências na saúde e na enfermagem. Texto \& contexto enfermagem 17.4 (2008): 758-764. 


\title{
REVISÃO DA LITERATURA SOBE A REDE SOCIAL E O APOIO SOCIAL DE PESSOAS ESTOMIZADAS
}

\author{
Author(s): Cristiane Regina Soares ${ }^{1}$ \\ Institution(s) ${ }^{1}$ SBIBHAE-UVM - SBIB Hospital Albert Einstein - Vila Mariana (Rua Madre Cabrini, 462)
}

\begin{abstract}
Introdução: A rede social é uma característica estrutural das relações sociais; e o apoio social é a função que presta essa rede e o efeito sobre o bem-estar das pessoas. Diante disso, a rede social é um conjunto de pessoas e instituições presentes na vida de um indivíduo que podem ou não oferecer apoio social quando este se encontra em uma situação de vulnerabilidade, como diante de uma doença crônica ou deficiência. As repercussões sociais para o cliente estomizado e sua família iniciam no momento da necessidade da realização do estoma e na própria dificuldade do individuo de aceitar essa nova situação. O diagnóstico médico e a confecção do estoma de eliminação proporcionam impacto para a vida do paciente e daqueles com os quais se relacionam.(1-4) Objetivo: Identificar as principais contribuições da literatura cientifica em relação à rede social e o apoio social recebido pelas pessoas estomizadas. Método: Pesquisa realizada pelo método de revisão da literatura, da qual, a pergunta de pesquisa norteadora da revisão foi: Quais são as principais contribuições da literatura cientifica em relação à rede social e o apoio social de pessoas estomizadas?. A base de dados selecionada foi a Biblioteca Virtual em Saúde (BVS) e a busca foi realizada no mês de julho de 2019. Utilizou-se os descritores de assunto rede social, apoio social e estomia. Dessa maneira, foram encontrados 21 artigos, dos quais, após a leitura dos resumos foram selecionados sete artigos para a leitura na íntegra e análise dos resultados.(5) Resultados: A revisão da literatura demonstrou que a família possui a base para o enfrentamento da vida da pessoa com estomia com um novo olhar, um novo significado, possibilitando verificar a situação de maneira mais positiva e, consequentemente, tornando-se mais segura e confiante para a retomada das atividades cotidianas. As redes de amigos foram caracterizadas pela presença na nova rotina, preocupação, telefonemas ou palavra de conforto e de fé contribuindo para o bem-estar espiritual e a paz interior da pessoa estomizada, Em um dos estudos a tecnologia do uso do celular possibilitou a interação social, através de grupos e pelo uso da internet. A espiritualidade foi caracterizada como um suporte de sustentação emocional, possibilitando o paciente e a família seguirem em frente após a confecção de uma estomia. As associações de estomizados foram relatadas como um lugar seguro e comum a todos, tendo influência positiva na reabilitação. A maneira como os profissionais de saúde acolhiam, escutavam, o carinho, o respeito foram atitudes pontuadas em todas as entrevistas. O apoio social advindo dos aspectos materiais foi importante para a aquisição de equipamentos coletores e materiais adjuvantes necessários para o cuidado.(1-4) Conclusões: Portanto, os apoios sociais e as redes sociais da pessoa estomizada são considerados um importante suporte para minimizar o sofrimento e vivenciar os momentos da doença e a convivência com uma nova conformação de vida. Os profissionais de saúde devem estimular o contato com as redes de apoio para melhora da qualidade de vida e possibilitar bons resultados no enfretamento da nova condição.
\end{abstract}

Keywords: Rede social , Apoio Social, Estomaterapia , Estomia

\section{Referências Bibliográficas}

Referências 1. Coelho AR, Santos FS, Poggetto MTD. A estomia mudando a vida: enfrentar para viver. Rev Min Enferm. 2013;17(2):258-67. 2. Simon BS, Budó MLD, Schimith MD, Garcia RP, Gomes TF, Carvalho SORM. "Sempre ajudando em uma coisa ou outra": rede social da família da pessoa com estomia. Rev. Eletr. Enf. [Internet]. 2015 abr./jun.;17(2):370-8. 3. Oliveira GS, Bavaresco M, Filipini CB, Rosado SR, Dázio EMR, Fava SMCL. Vivências do cuidador familiar de uma pessoa com estomia intestinal por câncer colorretal. Rev Rene. 2014 jan-fev; 15(1):108-15. 4. Silva AL, Shimizu HE. A relevância da Rede de Apoio ao estomizado. Rev Bras Enferm. 2007 maio-jun; 60(3):307-11. 5. Mendes KDS, Silveira RCCP, Galvão CM. Revisão integrativa: método de pesquisa para a incorporação de evidências na saúde e na enfermagem. Texto \& contexto enferm. 2008 Out-Dez; 17(4): 758-64. 


\title{
EFEITO CICATRIZANTE DE UM PÓ FITOTERÁPICO NO TRATAMENTO DE DERMATITE NA PELE PERIESTOMAL.
}

\author{
Author(s): Ana Cristina da Silva ${ }^{1}$ \\ Institution(s) ${ }^{1}$ UNIVÁS - Universidade do Vale do Sapucaí (AV. Prefeito Tuany Toledo, 470 - Pouso Alegre)
}

\begin{abstract}
Introdução: Um estoma pode tornar-se um sério limitador da qualidade de vida, além de resultar num evento traumatizante, gerando alterações emocionais e orgânicas ${ }^{1}$. As complicações relacionadas ao estoma, podem ser prevenidas por meio da técnica cirúrgica apropriada e/ou pela adaptação do equipamento coletor adequado². Tais complicações podem perfazer de 20 a 70\% das pessoas com derivação intestinal ou urinária ${ }^{3}$. Dentre as diversas complicações destaca-se a dermatite periestomal, sendo o pó composto por hidrocolóides o tratamento preconizado pelo Estado. Partindo do pressuposto que a dermatite é a complicação mais frequente no ambulatório, local do estudo e que um produto na apresentação em pó, é capaz de cicatrizar a lesão sem prejudicar a adesividade da base do equipamento coletor, optou-se como produto de pesquisa do Mestrado Profissional da autora, desenvolver um pó fitoterápico, de baixo custo com intuito de comprovar sua eficácia no tratamento mencionado. Objetivo: Avaliar o efeito cicatrizante de um pó fitoterápico no tratamento da dermatite na pele periestomal. Material e Métodos: Foi desenvolvido e processado um pó fitoterápico no laboratório de botânica da Universidade do Vale do Sapucaí (UNIVÀS), para uso nas dermatites na pele periestomal dos pacientes atendidos com esta complicação. Tratou-se de um estudo clínico, analítico e longitudinal. Os sujeitos participantes da pesquisa eram homens e mulheres, maiores de 18 anos, com estomias intestinais, que apresentaram dermatite na pele periestomal e que não possuíam algum tipo de alergia ao produto, mediante concordância e assinatura do Termo de Consentimento Livre e Esclarecido (TCLE). Foram analisados dois grupos: o de estudo com o pó fitoterápico e o grupo controle com o pó industrializado padronizado. Essa pesquisa seguiu as determinações da RESOLUÇÃO № 466, DE 12 DE DEZEMBRO DE 2012, do Conselho Nacional de Saúde (CNS) que define os procedimentos éticos para a pesquisa em seres humanos, com parecer no 2.381.904. Resultados: O Grupo controle apresentou uma média de cicatrização da dermatite de 17 dias e o grupo de estudo, uma média de 13 dias, sem comprometimento na adesividade da base do equipamento coletor. Conclusões: O pó fitoterápico possui eficácia na cicatrização da dermatite periestomal sem comprometer a permanência do equipamento coletor.
\end{abstract}

Keywords: Ostomia, Medicamentos Fitoterápicos, Dermatite Irritante, Estomaterapia

\section{Referências Bibliográficas}

1- Fernandes RM, Miguir ELB, Danoso TV. Perfil da clientela estomizada residente no município de Ponte Nova, Minas Gerais. Rev Coloproct, 2011; 30 (4):385-392. 2- Meisner S, Lehur PA, Moran BM, Lima J, Gregor BE. Peristomal Skin complication are common, expensive and difficult to manage: A population based cost modeling study. Plos one, 2012. [acesso em 2019 mar 15]. Disponível em: https://doi.org/101271/journal.pone.0037813. 3- Steinhagen E, Colwell, J, Cannon LM. Intestinal Stomas - Postoperative Stoma Care and Peristomal Skin Complications. Clinics in Colon and Rectal Surgery, 2017; 30 (03), 184-192. [acesso em 2019 jun 15]. Disponível em: https://doi.org/10.1055/s-0037-1598159. 


\title{
CARACTERIZAÇÃO METODOLÓGICA DOS ESTUDOS DO CUIDADO DE ENFERMAGEM AO PACIENTE COM ESTOMIA DE ELIMINAÇÃO POR CÂNCER COLORRETAL
}

\author{
Jéssica Emanuela Mendes Morato ${ }^{1}$, Tarcísia Domingos de Araújo Sousa ${ }^{1}$, Fernanda da Mata \\ Author(s): Vasconcelos Silva ${ }^{1}$, Jabiael Carneiro da Silva Filho ${ }^{1}$, Betânia da Mata Ribeiro Gomes ${ }^{1}$, Isabel \\ Cristina Ramos Vieira Santos ${ }^{1}$ \\ Institution(s) ${ }^{1}$ UPE - Universidade de Pernambuco (R. Arnóbio Marquês, 310 - Santo Amaro, Recife - PE, \\ 50100-130), ${ }^{2}$ UPE - Universidade de Pernambuco (R. Arnóbio Marquês, 310 - Santo Amaro, \\ Recife - PE, 50100-130.), ${ }^{3}$ UPE - Universidade de Pernambuco (R. Arnóbio Marquês, 310 - Santo \\ Amaro, Recife - PE, 50100-130.), ${ }^{4}$ UPE - Universidade de Pernambuco (R. Arnóbio Marquês, 310 \\ - Santo Amaro, Recife - PE, 50100-130.), ${ }^{5}$ UPE - Universidade de Pernambuco (R. Arnóbio \\ Marquês, 310 - Santo Amaro, Recife - PE, 50100-130.), ${ }^{6}$ UPE - Universidade de Pernambuco (R. \\ Arnóbio Marquês, 310 - Santo Amaro, Recife - PE, 50100-130.)
}

\begin{abstract}
Introdução: Este trabalho investiga os estudos do cuidado de enfermagem a pessoa em situação de estomia de eliminação por câncer colorretal dada a importância deste câncer na realidade brasileira e a indicação da confecção de estomias como parte do manejo terapêutico. Espera-se 17.380 casos novos de câncer de cólon e reto nos homens e 18.980 em mulheres para cada ano do biênio 2018-2019, segundo o Instituto Nacional do Câncer - INCA. Estes valores correspondem a um risco de 16,83 casos novos a cada 100 mil, sendo o terceiro tipo de câncer mais frequente em homens e 17,90 casos para cada 100 mil mulheres, estimado como terceiro tipo mais frequente1. Objetivo: Caracterizar as abordagens metodológicas dos estudos no cuidado de enfermagem ao paciente com estomia de eliminação por câncer colorretal. Material e Método: Trata-se de revisão integrativa de literatura, tendo como meta preencher lacunas nos estudos do cuidar de enfermagem ao estomizado. Realizada busca de artigos nas bases de dados: BDENF, Lilacs, MedLine, Scopus e Cochrane. Resultados e Conclusão: Incluídos no estudo 04 artigos, de percurso metodológico variado e com pacientes predominantemente maiores de 18 anos. As variáveis qualitativas mais encontradas foram: sexo, escolaridade, religião e referentes ao estoma como: tempo de confecção, localização, caráter, complicações e mudanças de atividades2,3. As variáveis quantitativas relacionavam-se aos custos, escalas de qualidade de vida e de autoestima do estomizado4,5. Limitações encontradas nos estudos citavam o reduzido número de indivíduos participantes, destacando a necessidade de estudos longitudinais e que sejam realizados, de preferência, em grandes centros de atenção ao paciente em situação de estomia, com o objetivo de aumentar a representatividade epidemiológica. Descritores: Cuidados de Enfermagem; Estomia; Custos e Análise de Custo; Qualidade de vida.
\end{abstract}

Keywords: Cuidados de Enfermagem, Estomia, Custos e Análise de Custo, Qualidade de vida

\section{Referências Bibliográficas}

1. Instituto Nacional do Câncer (INCA): Estimativa 2018: incidência de câncer no Brasil//nstituto Nacional de Câncer José Alencar Gomes da Silva. Coordenação de Prevenção e Vigilância. - Rio de Janeiro, 2017. 2. Ferreira EC, Barbosa MH, Sonobe HM, Barichello E. Self-esteem and health-related quality of life in ostomized patients. Rev Bras Enferm [Internet]. 2017;70(2):271-8. DOI: http://dx.doi.org/ 10.1590/0034-7167-2016-0161 3. Sinha, Aditi et al. Quality of life of ostomates with the selected factors in a selected hospital of Delhi with a view to develop guidelines for the health professionals. Indian Journal Of Palliative Care, [s...], v. 15, n. 2, p.111-114, 2009. Medknow. http://dx.doi.org/10.4103/0973-1075.58455. 4. Hornbrook, Mark C. et al. Costs of an ostomy self-management training program for cancer survivors. Psycho-oncology, [s.l.], v. 27, n. 3, p.879-885, 7 dez. 2017. Wiley. http://dx.doi.org/10.1002/pon.4584. 5. Bohnenkamp, Susan Kay et al. Traditional Versus Telenursing Outpatient Management of Patients With Cancer With New Ostomies. Oncology Nursing Forum, [s.I.], v. 31, n. 5, p.1005-1010, 1 set. 2004. Oncology Nursing Society (ONS). http://dx.doi.org/10.1188/04.onf.10051010. 


\title{
CARACTERIZAÇÃO DE USUÁRIOS ESTOMIZADOS ATENDIDOS EM UM DEPARTAMENTO DE ÓRTESES E PRÓTESES DE UM MUNICÍPIO DO PARANÁ
}

\author{
Author(s): \\ Jacy Aurelia Vieira de Sousa ${ }^{1}$, RENATA PEDRÃO LEME MOTOMATSU ${ }^{2}$, Morgana Matias da \\ Rosa ${ }^{1}$ \\ Institution(s) ${ }^{1}$ UEPG - Universidade Estadual de Ponta Grossa (Av. General Carlos Cavalcanti, 4748, Ponta \\ Grossa/PR), ${ }^{2}$ UEL - Universidade Estadual de Londrina (Rodovia Celso Garcia Cid, PR 445 Km \\ 380, Londrina/PR)
}

\begin{abstract}
Introdução: Estomias de eliminações são desenvolvidas com a finalidade de exteriorização de um órgão interno na região da parede abdominal, resultando em um orifício. As causas que conduzem à construção de uma estomia são: traumas, neoplasias, doenças diverticulares, obstruções intestinais, fístulas, doenças inflamatórias e doenças congênitas. Considerando que o estomizado tem o direito de atenção integral a saúde, por meio de atendimentos especializados, desde a distribuição de equipamentos coletores e adjuvantes até prescrições de cuidados pelo enfermeiro estomaterapeuta, este serviço é fornecido pelo Sistema Único de Saúde e garantido pelas diretrizes nacionais para atenção à saúde de pessoas estomizadas da portaria no 400/2009. Quanto a isso, tem-se a seguinte questão norteadora: qual o perfil de usuários estomizados atendidos em um Departamento de Órteses e Próteses de um município do Paraná? Tal caracterização contribui para fundamentar a implementação de ações que possibilitem uma qualidade na atenção integral em saúde destes usuários. Objetivo: Caracterizar o perfil dos usuários estomizados atendidos em um Departamento de Órtese e Próteses da região dos Campos Gerais, no Paraná, quanto a aspectos sociodemográficos, clínicos e relacionados ao cuidado com a estomia. Material e método: Trata-se de um estudo quantitativo, retrospectivo, realizado em um Departamento de Órteses e Próteses no município de Ponta Grossa, localizado na região dos Campos Gerais, no Paraná, entre fevereiro e abril de 2019 por meio de coleta de dados de 246 prontuários. Os dados foram organizados em planilha no software Microsoft Excel 2013 e analisados por meio de estatística descritiva com apresentação de números absolutos, médias, números mínimos e máximos. A pesquisa foi avaliada pelo Comitê de Ética e Pesquisa da Universidade Estadual de Ponta Grossa, com parecer favorável no 3.274.437. Resultados: Houve predomínio do sexo masculino (133; 54,1\%), com média de idade de 62,44 anos (min.=04; máx.=97), casados(as) (138; 56,1\%), com um a quatro anos de estudo (103; $41,9 \%$ ), que residiam com cônjuge e filhos(as) $(72 ; 29,3 \%$ ) e aposentados (106; 43,1\%). Ademais, houve predomínio de colostomias $(164 ; 66,7 \%)$, permanentes $(59 ; 24,0 \%)$ e a principal causa foi o câncer $(155 ; 63,01 \%)$. A maioria dos usuários fazia uso de equipamento coletor de uma peça $(141 ; 57,3 \%)$, sem uso de adjuvantes $(112 ; 45,5 \%)$ e sem registro de complicações (218; 88,6\%). Entre as complicações apresentadas, destacaram-se a dermatite $(21 ; 8,5 \%)$ e a retração do estoma (03; $1,2 \%)$. Conclusões: O presente estudo permitiu a caracterização dos usuários estomizados do Departamento de Órteses e Próteses de Ponta Grossa-PR, sendo predominante o sexo masculino, idosos, casados, que viviam com cônjuge e filhos(as) e aposentados. A causa das estomias mais comum foi o câncer e a estomia de temporalidade permanente foi a que mais teve destaque. A pesquisa contribuiu para auxiliar o enfermeiro estomaterapeuta na melhoria da assistência aos usuários, bem como elaboração de mudanças voltadas ao atendimento das características e necessidades dessa clientela.
\end{abstract}

Keywords: Estomia, Estomaterapia, Enfermagem, Perfil de Saúde

\section{Referências Bibliográficas}

1. Brasil. Ministério da Saúde. Cuidados com estomias intestinais e urinárias. [internet] 2. ed. Rio de Janeiro: Ministério da Saúde; 2018. [acesso em 07 jul 2019]. Disponível em https://www.inca.gov.br/sites/ufu.sti.inca.local/files//media/document//ivro-cuidados-com-a-sua-estomia.pdf. 2. Miranda LSG, Carvalho AAS, Paz EPA. Qualidade de vida da pessoa estomizada: relação com os cuidados prestados na consulta de enfermagem de estomaterapia. Esc. Anna Nery [internet]. 2018 [acesso em 06 jul 2019]; 22(4):e20180075. Disponível em http://www.scielo.br/scielo.php?script=sci_arttext\&pid=S1414-81452018000400216\&lng=pt\&nrm=iso\&tlng=pt>. Doi: 10.1590/2177-9465-EAN-2018-0075. 3. Brasil, Ministério da Saúde. Portaria oㅡ 400, de 16 de novembro de 2009.

Estabelecer Diretrizes Nacionais para a Atenção a Saúde das Pessoas Ostomizadas. Diário Oficial [da] União. 2009 nov. 18; Seção 1.p 41-42. 


\title{
ATUAÇÃO DO ENFERMEIRO NA ASSISTÊNCIA AO PACIENTE COM COLOSTOMIA POR CÂNCER COLORRETAL
}

\author{
Author(s): Renata Tamara de Brito ${ }^{1}$, Rodrigo Borges ${ }^{1}$ \\ Institution(s) ${ }^{1}$ SCE - CENTRO UNIVERSITARIO sÃO CAMILO (RUA RAUL POMPEIA 144)
}

\begin{abstract}
Objetivo: Levantar na literatura o que têm sido produzido sobre a assistência de enfermagem junto às pessoas com câncer colorretal, e refletir sobre o papel do enfermeiro estomaterapeuta. Método: Trata-se de uma revisão do tipo narrativa. Resultados: Foram encontrados um total de sete estudos, cujo os resultados reforçam a importância da assistência de enfermagem junto as pessoas com estomias, não apenas em relação as questões técnicas para o manejo do equipamento coletor, mas sim uma assistência pautada no princípio da integralidade atendendo assim as reais necessidades dessas pessoas e de seus familiares, os resultados destacam também a necessidade de que esses profissionais tenham capacitação na área. Conclusão: Esses resultados nos fazem refletir sobre a assistência do enfermeiro estomaterapeuta junto ao paciente com estomia intestinal, ao revelar uma escassez de estudos na área e também uma certa invisibilidade desse profissional, visto que a maioria dos estudos trabalham com enfermeiros generalistas e os demais não deixa claro se os profissionais participantes possuem ou não a especialização em estomaterapia.

Sabemos que o enfermeiro generalista possui uma visão ampla do cuidado à pessoa com estomia intestinal e sua família, porém não podemos esquecer que se trata de uma questão complexa, fazendo necessário a capacitação e a atualização dos profissionais de enfermagem8.

Portanto, destacamos o fato de ser uma área que necessidade conhecimento especializado e habilidades específicas para o alcance de um cuidado de enfermagem eficiente e seguro. Esses resultados nos fazem refletir sobre a assistência do enfermeiro estomaterapeuta junto ao paciente com estomia intestinal, ao revelar uma escassez de estudos na área e também uma certa invisibilidade desse profissional, visto que a maioria dos estudos trabalham com enfermeiros generalista ou esclarecem qual a sua especialização.
\end{abstract}

\section{Keywords: CUIDADOS DE ENFERMAGEM, ESTOMIA , ESTOMATERAPIA}

\section{Referências Bibliográficas}

REFERÊNCIAS 1 Guyton AC, Hall JE. Princípios Gerais da Função Gastrointestinal-Motilidade, Controle Nervoso e Circulação Sanguínea. In: Guyton AC, Hall JE autores. Tratado de Fisiologia Médica. Rio De Janeiro: Elsevier; 2011. p. 795-804. 2 Santos CHM, Bezerra MM, Paraguassu BR. Perfil do paciente ostomizado e complicações relacionados ao estoma. Rev Bras Coloproct. 2007; 27(1):16-19. 3 Smeltzer SC, Bare BG, Hinkle JL, Cheever KH. Cuidados aos Pacientes com Disturbios Intestinais e Retais. In: Smeltzer SC, Bare BG, Hinkle JL, Cheever KH. Tratado de Enfermagem MédicoCirúrgica. Rio de Janeiro: Guanabara Koogan, 2009. p.1038-1079. 4 Matsubara MGS, Vilella DL, Hashimoto SY, Reis HC, Saconato RA, Denardi UA, Bandeira RC, Bozza VC. Feridas e estomas em Oncologia. São Paulo: Lemar, 2011. p.100 5 Rother ET. Revisão sistemática x revisão narrativa. Acta Paulista de Enfermagem. 2007; 20(2):v-vi. 6 Meirelles C; Ferraz C. Avaliação da qualidade do processo de demarcação do estoma intestinal e das intercorrências em pacientes ostomizados. Rev Latino-Americana de Enfermagem 2001; 9(5):32-08. 7 Sampaio FAA, Aquino PS, Araújo TL, Galvão MTG. Nursing care to an ostomy patient: application of the Orem's theory. Acta Paul Enferm 2008;21(1):94-100. 8 Ardigo FS, Amante LN. Conhecimento do profissional acerca do cuidado de enfermagem à pessoa com estomia intestinal e família. Texto Contexto Enferm, Florianópolis, 2013; 22(4): 1064-71. 9 Mauricio VC, Souza NVDO, Lisboa MTL. The nurse and her participation in the process of rehabilitation of the person with a stoma. Esc Anna Nery (impr.)2013; 17 (3):416 - 422. 10 Araújo JBGN, Alencar AMPG. Assistência de enfermagem ao portador de ostomia intestinal na atenção básica. Caderno de Cultura e Ciência, 2013; 12(2): 78-87. 11 Farias DLS, Nery RNB, Santana ME. O enfermeiro como educador em saúde da pessoa estomizada com câncer colorretal. Enferm. Foco 2018; 10 (1): 35-39 12 Gemelli LMG, Zago MMF. A interpretação do cuidado com o ostomizado na visão do enfermeiro: um estudo de caso. Rev Latino-am Enfermagem. 2002; 10(1):34-40. 13 Borges EL. A atuação do enfermeiro na estomaterapia e a legislação brasileira: avanços e crescimentos da área. $R$. Enferm. Cent. O. Min. 2016; 6(2): 1-2. 


\title{
INCIDÊNCIA DE COMPLICAÇÕES DE ESTOMA E PELEPERISETOMAL DE PACIENTES ONCOLÓGICOS SUBMETIDOS A ESTOMAS DE ELIMINAÇÃO.
}

\author{
Ana Gabriela Silva de Lima ${ }^{1}$, Diana Lima Villela de Castro ${ }^{2}$, Ayanne Sophia Brandão Duarte Sá ${ }^{1}$, \\ Author(s): Luiz Henrique de Andrade ${ }^{2}$, Andreza Rafaelle da Silva Oliveira ${ }^{1}$, Iranilda Sales Maia ${ }^{1}$, Renata \\ Ramos Menezes ${ }^{1}$ \\ Institution(s) ${ }^{1}$ HCP - Hospital de Câncer de Pernambuco ( Av. Cruz Cabugá, 1597 - Santo Amaro, Recife - PE), \\ 2 A.C.Camargo - A.C Camargo Cancer Center ( Rua Tamandaré, 753 - Liberdade, São Paulo - SP)
}

\begin{abstract}
Introdução: A confecção de uma estomia é um procedimento cirúrgico para exteriorização de órgãos ou vísceras para o meio externo. As estomias de eliminação podem ser classificadas como: ileostomia, colostomia, colostomia úmida e urostomia tipo bricker. Independente do tipo de estomia podem ter complicações relacionadas ao estoma e pele periestomal que associado a outros fatores que podem interferir na qualidade de vida e no processo adaptativo para a reabilitação. Objetivo: Identificar as complicações incidentes dos estomas de eliminação durante 180 dias de pósoperatório. Métodos e Metodologia: Trata-se de um estudo de coorte longitudinal com seguimento de 180 dias que foi realizado entre os anos de 2016 e 2017, nas enfermarias e ambulatórios de cirurgia oncológica, pelvica e urologia de um hospital de referência em oncologia em Pernambuco. Resultados: Foram acompanhados 27 pacientes.No pós-operatório imediato, as características clínicas do estoma foram obtidas através do exame físico relacionado ao estoma e levantamento de dados em prontuário. Os estomas predominantes foram colostomia $(51,8 \%)$ e ileostomia $(37,0 \%)$. Onze $(40,7 \%)$ são temporários, $06(22,2 \%)$ são definitivos e $10(37,1 \%)$ não tinham a informação em prontuário. Quanto às características do estoma, $14(51,8 \%)$ tem o tipo de exteriorização em alça; $21(77,8 \%)$ são protusos em relação ao nível da pele; $11(40,7 \%)$ estão localizados no quadrante inferior esquerdo (QIE); $12(44,4 \%)$ possuíam diâmetro menor ou igual a $39 \mathrm{~mm} ; 19(70,4 \%)$ não receberam informações, antes da cirurgia, da enfermeira ou cirurgião sobre a confecção do estoma e $25(92,6 \%)$ não tiveram estoma demarcado no pré-operatório. Durante o decorrer do estudo, a maioria dos voluntários apresentaram 1 ou mais complicações após a confecção do estoma, sendo $20(74,1 \%), 22(81,5 \%)$ e $12(44,4 \%)$, com 30 dias de PO, 90 dias de PO e 180 dias de PO, respectivamente. Das complicações apresentadas pelos voluntários, a dermatite de pele periestomal apresentou maior incidência em todas as avaliações da pesquisa $18(90 \%)$, 22(100\%) e 11 $(91,7 \%)$, com 30 dias de PO, 90 dias de $\mathrm{PO}$ e 180 dias de PO, respectivamente Conclusão: A complicação mais incidente relacionada ao estoma e pele periestomal foi à dermatite de pele periestomal visto que pacientes com câncer apresentam alterações tegumentares devido a progressão da doença, tratamento antineoplásico sistêmico, tratamento com radioterapia e uso de corticoides e imunossupressores. Estes fatores alteram o processo cicatricial acarretando maior vulnerabilidade de lesões na pele e mucosa.
\end{abstract}

Keywords: Complicações, Estomas, Oncologia

\section{Referências Bibliográficas}

Amaral AFS, Pulido KCS, Santos VLCG. Prevalência de lesões por fricção em pacientes hospitalizados com câncer. Rev Esc Enferm USP 2012; 46:44-50. Burch J. Preoperative care of patients undergoing stoma formation: what the nurse needs to know. Nurs Standard 2017; 31(36):40-3. Gulbiniene J, Markelis R, Tamelis A, Saladzinskas Z. The impact of preoperative stoma siting and stoma care education on patient's quality of life. Medicina 2004; 40(11):1045-53. 


\title{
MANEJO DA DERMATITE PERIESTOMA DE PACIENTE COM ILEOSTOMIA POR CÂNCER: RELATO DE CASO
}

\author{
Author(s): Júlia Casemiro Barioni ${ }^{1}$, André Aparecido da Silva Teles ${ }^{2}$, Vanessa Baldo Cozza ${ }^{3}$, Carolina \\ Mariottini Bonafim ${ }^{1}$, Helena Megumi Sonobe ${ }^{2}$ \\ Institution(s) ${ }^{1}$ HCFMRP-USP - Hospital das Clínicas (Av. Bandeirantes, 3900 - Vila Monte, Alegre Ribeirão \\ Preto), ${ }^{2}$ EERP-USP - Escola de Enfermagem de Ribeirão Preto (R. Prof. Hélio Lourenço, $3900-$ \\ Vila Monte Alegre, Ribeirão Preto), ${ }^{3}$ Coloplast A / S - COLOPLAST (São Paulo - Brasil)
}

\begin{abstract}
Introdução: No tratamento cirúrgico de um paciente com câncer colorretal pode ocorrer a necessidade de confecção de ileostomia temporária ou definitiva. A depender das condições clínicas e da evolução tumoral, mesmo que seja realizada a demarcação de estoma, o local e o estoma podem apresentar características que dificultam os cuidados específicos como dermatite de contato ou irritativa. A dermatite de contato constitui uma complicação muito comum em pacientes com ileostomia, principalmente quando o estoma é plano ou de baixo perfil, que causa infiltração do efluente e lesão de pele. Objetivo: relatar as condutas de manejo da equipe cirúrgica da dermatite irritativa periestoma por efluente ileal de uma paciente com ileostomia. Material e Método: Trata-se de um relato de caso de uma paciente submetida à estomização paliativa, internada na Enfermaria de Oncologia Cirúrgica de um hospital universitário do interior paulista, em maio de 2019. Projeto aprovado pela Instituição proponente (Parecer $n^{\circ}$ 134/2018). Paciente de 55 anos com diagnóstico médico de adenocarcinoma de cólon sigmoide, submetida à cirurgia de Colectomia total com anastomose ileorretal, em 2017, que durante o seguimento ambulatorial, em maio de 2019, foi diagnosticado com recidiva tumoral pélvica inoperável com fístula retovaginal, quando foi submetida à confecção de ileostomia (a $80 \mathrm{~cm}$ do Treitz - ângulo da junção duodenojejunal) para minimização de desconfortos gastrointestinais e de futuras complicações oncológicas. Apesar da demarcação préoperatória do estoma, não foi possível a confecção no local demarcado, sendo necessária sua fixação em região desfavorável à aplicação do equipamento coletor, em cuja avaliação clínica do paciente foram verificados estoma plano, abdome com pregas cutâneas, ferida operatória paralela ao estoma, grande volume de efluente ileal diário (3000ml/dia) e fadiga fisiológica por câncer e cirurgia. Resultados: Após insucesso de muitas tentativas de adaptação de equipamento coletor e uso de adjuvantes de proteção para pele periestoma, optou-se juntamente com a equipe médica pelo uso da Prótese de Enxerto de Dacron-Knitted, normalmente utilizado como prótese vascular, produzido por técnica de tricotagem (knitted) de fios de Dacron e impregnado com colágeno bovino e que, por ser resistente e flexível, foi suturada na pele periestoma, o que possibilitou direcionar o efluente para a bolsa coletora. Associou-se uso de adjuvantes (anel protetor moldável para pele periestoma) e equipamento coletor de duas peças de base convexa, além de cinto abdominal. Inicialmente houve a necessidade da troca do equipamento coletor diariamente, posteriormente a cada dois dias. A paciente evoluiu com resultados favoráveis e regressão total da dermatite irritativa, recebendo alta hospitalar em 15 dias. Conclusão: No caso desta paciente com condição clínica oncológica crítica, a abordagem da equipe multiprofissional, a utilização da Prótese de Dacron-Knitted, associada à avaliação diária do enfermeiro residente da Oncologia, à utilização de adjuvantes de proteção de pele periestoma e ao equipamento coletor de base convexa proporcionaram melhora efetiva, manejo da infiltração do efluente, manutenção da adesividade do equipamento, favoreceram a melhora clínica com minimização da fadiga oncológica e resolução da dermatite, com alta hospitalar do paciente em cuidados paliativos.
\end{abstract}

Keywords: Estomas Cirúrgicos. , Dermatite de contato, Complicações pós-operatórias. , Enfermagem perioperatória, Estomaterapia

\section{Referências Bibliográficas}

Martins LM, Sonobe HM, Vieira FS, Oliveira MS, Lenza NF, Teles AAS. Rehabilitation of individuals with intestinal ostomy. British Journal of Nursing. 2015 Dec 10; 24(22):S4-S11. Pinto IES, Queirós SMM, Queirós CDR, Silva CRR, Santos CSVB, Brito MAC. Fatores de risco associados ao desenvolvimento de complicações do estoma de eliminação e da pele periestomal. Rev. Enf. Ref. 2017 Dez; IV(15):155-66. Mauricio VC, Oliveira NVD, Lisboa MTL. O enfermeiro e sua participação no processo de reabilitacao da pessoa com estoma. Esc. Anna Nery. 2013 Ago 17(3):416-22. 


\title{
DEMARCAÇÃO DE ESTOMA INTESTINAL: CARACTERIZAÇÃO DE PACIENTES E EVOLUÇÃO PÓS-OPERATÓRIA MEDIATA
}

\author{
Author(s): Júlia Casemiro Barioni ${ }^{1}$, André Aparecido da Silva Teles ${ }^{2}$, Karen Martins ${ }^{2}$, Carolina Mariottini \\ Bonafim ${ }^{1}$, Helena Megumi Sonobe ${ }^{2}$ \\ Institution(s) ${ }^{1}$ HCFMRP-USP - Hospital das Clínicas (Av. Bandeirantes, 3900 - Vila Monte, Alegre Ribeirão \\ Preto), ${ }^{2}$ EERP-USP - Escola de Enfermagem de Ribeirão Preto (R. Prof. Hélio Lourenço, 3900 - \\ Vila Monte Alegre, Ribeirão Preto), ${ }^{3}$ Coloplast A / S - COLOPLAST (São Paulo - Brasil)
}

\begin{abstract}
Introdução: A assistência de enfermagem perioperatória à pessoa com doença colorretal candidata à confecção de estoma intestinal, inicia-se com a demarcação do local e ensino pré-operatório pelo estomaterapeuta ou enfermeiro capacitado, para prevenir ou minimizar o surgimento de complicações de estoma e pele periestoma. Na Instituição hospitalar do estudo, na Especialidade de Coloproctologia, a assistência a esta clientela é realizada por uma equipe interdisciplinar e, desde 1995, a demarcação de estoma tem sido realizada. Desde 2016, residentes do segundo ano Área de Enfermagem do programa multiprofissional em Oncologia, têm sido capacitados e realizam a demarcação de estoma no estágio clínico na Especialidade de Coloproctologia, sob a supervisão da coordenadora estomaterapeuta, em todos os pacientes que possuem a possibilidade de confecção de estoma intestinal. Objetivo: caracterizar os pacientes que realizaram a demarcação de estoma por doença colorretal e sua evolução no pós-operatório mediato, nos meses de junho e julho de 2019, em um hospital universitário do interior paulista. Material e Método: Estudo descritivo transversal prospectivo, aprovado pelo Comitê de Ética em Pesquisa da instituição proponente, sob Parecer $n^{\circ}$ 134/2018. Participaram 35 pacientes, cujos critérios de inclusão foram: terem recebido a comunicação do diagnóstico e da possibilidade de estomização pela equipe cirúrgica, realização de demarcação pré-operatória de estoma intestinal e submissão à cirurgia coloproctológica, nos meses de junho e julho de 2019. Os participantes passaram por uma avaliação clínica no préoperatório imediato, com ensino sobre a cirurgia e suas consequências, além de esclarecimentos de dúvidas e a demarcação de estoma era realizada ao final. Posteriormente, no pós-operatório, foram avaliados diariamente, com preparo dos pacientes e seus familiares em relação aos cuidados com estoma e equipamentos coletores, bem como a contrarreferência ao Programa de Ostomizados, com avaliação clínica e de estoma e a indicação de equipamentos, com participação da equipe multiprofissional. Resultados: Do total de 35 participantes, $62,9 \%$ eram do sexo masculino e $37,1 \%$ do feminino; procedentes da Divisão Regional de Saúde XIII de São Paulo (94,4\%) e de outras (8,6\%); 48,6\% com faixa etária até 59 anos e $51,4 \%$ com 60 anos ou mais; diagnósticos de câncer colorretal (62,5\%) e outros (37,1\%); com comorbidades $(65,7 \%)$ e sem comorbidades (34,3\%); $51,4 \%$ não necessitaram de estoma, $11,0 \%$ possuíam estoma intestinal prévio; e 3,0\% das cirurgias foram canceladas por falta de horário cirúrgico. Portanto, 12 tiveram confecção de estoma $(34,3 \%)$ e três $(9 \%)$ apresentaram complicações como prolapso e dermatite periestoma no pós-operatório mediato, durante a internação hospitalar. Realizado seguimento diário dos três pacientes, com gerenciamento do prolapso e a resolução da dermatite periestoma, mediante avaliação e indicação de adjuvantes/equipamentos coletores. A sistematização da assistência para estes pacientes, com demarcação de estoma, tem possibilitado assegurar a qualidade e a manutenção dos direitos de o paciente ter estoma demarcado e bem construído para favorecer o autocuidado e a utilização de equipamento coletor. Conclusões: Considerando o perfil clínico desta clientela nesta Instituição hospitalar, a demarcação e o seguimento perioperatório têm sido fundamentais, para assegurar a alta responsável, a reabilitação e a qualidade de vida do paciente.
\end{abstract}

Keywords: Estomaterapia., Enfermagem perioperatória, Estomas cirurgicos, Demarcação

\section{Referências Bibliográficas}

Cruz GMG, Constantino JRM, Chamone BC, Andrade MMA, Gomes DMBM. Complicações dos estomas em câncer colorretal: revisão de 21 complicações em 276 estomas realizados em 870 pacientes portadores de câncer colorretal. Rev bras. colo-proctol. 2008 Ago; 28(1): 50-61. Silva JC, Borsatto AZ, Teixeira ER, Umpiérrez AF. Demarcação abdominal por enfermeira estomoterapeuta. Enfermería. 2017 Jun; 6(1):12-8. Pinto IES, Queirós SMM, Queirós CDR, Silva CRR, Santos CSVB, Brito MAC. Fatores de risco associados ao desenvolvimento de complicações do estoma de eliminação e da pele periestomal. Rev. Enf. Ref. 2017 Dez; IV(15):155-66. 


\title{
SEXUALIDADE, ESTOMA E GÊNERO: REVISÃO INTEGRATIVA DA LITERATURA (2010 A 2017)
}

\author{
Author(s): Carla Teles de Carvalho Herdy Baptista ${ }^{1}$, Leoana Reis Marques ${ }^{1}$, Luciane Reis da Silva Conceição \\ ${ }^{1}$, Rosilane de Souza Assis Maia ${ }^{1}$, Sônia Dalva Bastos Machado ${ }^{1}$, Lúcia Helena Garcia Penna ${ }^{1}$
}

Institution(s) ${ }^{1}$ UERJ - UNIVERSIDADE ESTADUAL DO RIO DE JANEIRO (RIO DE JANEIRO)

\section{Abstract}

\section{RESUMO}

Esse estudo objetivou caracterizar as produções científicas nacionais sobre sexualidade, gênero e saúde e estomia no Brasil (de 2010 a 2017) e analisar a maneira como são abordadas tais temáticas. Trata-se de uma revisão integrativa de literatura, com abordagem qualitativa, onde teve-se como questão de pesquisa: De que maneira vem sendo abordada na literatura científica nacional a sexualidade da pessoa com Estomia no Brasil? Utilizou-se como bases de dados LILACS, BDENF e SCIELO. Foi realizada uma primeira leitura dos títulos e resumos dos artigos pesquisados para seleção da amostra final. Teve-se como critérios de inclusão os documentos disponíveis na íntegra online; recorte temporal de 2010 a 2017 e pesquisas realizadas no Brasil. Resultados: Foram selecionados 12 artigos que estavam de acordo com os critérios de inclusão. Em relação a temática apresentada, conseguimos obter resultados variados. Algumas temáticas presentes nas produções se destacam pelo número de vezes que foram abordados pelos autores, dentre elas estão a insegurança na retomada da sexualidade da mulher após estomia; o despreparo do Enfermeiro em lidar com a sexualidade das pessoas com estomia; Sexualidade prejudicada da pessoa com estomia; medo de rejeição; o ato sexual visto como secundário devido à readaptação sexual, dentre outros. Evidenciou-se a necessidade do aprofundamento no tema, com a reflexão do papel dos profissionais envolvidos no cuidado para a qualidade de vida dos pacientes com estoma, sendo necessário o trabalho interdisciplinar para esse enfretamento, com a importância inegável da contribuição da enfermagem nesse contexto.

Keywords: Estomaterapia, Estomia, Sexualidade, Gênero e Saúde

\section{Referências Bibliográficas}

1. Scott JW. Gênero: uma categoria útil de análise histórica. Educação e Realidade. 1990; 16(2), p.5. 2. Heilborn ML. Fronteiras simbólicas: gênero, corpo e sexualidade. Cadernos Cepia no 5. 2002; p.73-92. 3. Santos VLCG, Cesaretti IUR. Assistência em estomaterapia: cuidando do ostomizado. São Paulo: Atheneu, 2015. 4. Calcagno GG et al. Ser mulher estomizada: a percepção da sexualidade. Enferm Glob. 2012; 11 (27):22-33. Disponível em: http://scielo.isciii.es/pdf/ eg/v11n27/pt_clinica2.pdf 5. Weeks J. O corpo e a sexualidade. In: LOURO, Guacira Lopes (Org.). O corpo educado: pedagogias da sexualidade. Belo Horizonte: Autêntica, 2018. 6. Laqueur TW. Inventando o sexo: corpo e gênero dos gregos a Freud. Rio de Janeiro: Relume Dumará, 2001. 


\title{
ANSIEDADE, DEPRESSÃO E ESTRESSE PERCEBIDO NO PRÉ-OPERATÓRIO EM PACIENTES NA PRIMEIRA CIRURGIA POR CÂNCER COLORRETAL: RESULTADOS PARCIAIS
}

\author{
Author(s): André Aparecido da Silva Teles ${ }^{1}$, Karen Martins ${ }^{2}$, Vanessa Damiana Menis Sasaki ${ }^{1}$, Janderson \\ Cleiton Aguiar ${ }^{1}$, Tatiana Mara Silva Russo ${ }^{1}$, Júlia Casemiro Barioni ${ }^{2}$, Helena Megumi Sonobe ${ }^{1}$ \\ Institution(s) ${ }^{1}$ EERP-USP - Escola de Enfermagem de Ribeirão Preto (Av. Bandeirantes, 3900, Rib. Preto, SP.), \\ ${ }^{2}$ HC-FMRP - Hospital das Clínicas da Faculdade de Medicina de Ribeirão P (Av. Bandeirantes, \\ 3900, Rib. Preto, SP.)
}

\begin{abstract}
Introdução: A cirurgia é a principal terapêutica para o Câncer Colorretal (CCR), sendo o estoma, a consequência mais temida pelos pacientes e familiares. Além do estresse fisiológico, inerente ao procedimento anestésico-cirúrgico, os pacientes podem experimentar sentimentos de ansiedade, depressão e estresse, que constituem estressores adicionais, comprometendo a sua recuperação. Objetivo: Avaliar os escores de sintomas de ansiedade, depressão e estresse percebido em pacientes no pré-operatório da primeira cirurgia por Câncer Colorretal. Material e Método: Estudo descritivo, transversal e prospectivo, realizado no Serviço de Oncologia Cirúrgica com pacientes da Especialidade de Coloproctologia de um hospital universitário do interior paulista. A amostra, consecutiva e não probabilística, foi constituída por pacientes maiores de 18 anos, independentemente do sexo, com condições físicas e cognitivas para responder os questionários, no pré-operatório imediato da primeira cirurgia por CCR, nos meses de abril a agosto de 2019. Para a avaliação dos sintomas de ansiedade e depressão utilizou-se o instrumento Hospital Anxiety and Depression Scale(HADS) e o Perceived Stress Scale(PSS-10) para o estresse percebido, ambos adaptados e validados para o português, além de questionário sociodemográfico, clínico e terapêutico. O projeto foi aprovado pelo Comitê de Ética da instituição proponente (CEP - EERP 134/2018) e para a análise descritiva, utilizou-se o programa IBM SPSS, versão 22.0. Resultados: Participaram do estudo 32 pacientes, maioria do sexo masculino $(53,12 \%)$, média de idade de 62,06 anos ( $D P=14,16)$, procedentes de Ribeirão Preto/SP (46,87\%), casados (62,5\%), aposentados (50\%) e que possuíam, em média, 7,22 anos de estudo. Predominou câncer de reto $(37,5 \%)$, em estadiamento III $(37,5 \%)$ e o tipo histológico Adenocarcinoma moderadamente diferenciado $(71,87 \%)$; dois pacientes $(6,25 \%)$ realizaram tratamento neoadjuvante e a maioria $(65,52 \%)$ apresentou duas ou mais comorbidades associadas. Cinco pacientes utilizavam psicotrópicos, nove referiram dor de intensidade média de 4,3 na escala analógica no momento da entrevista e somente um relatou não ter sido informado pela equipe médica sobre a possibilidade de confecção de estoma; todos os pacientes foram demarcados. O escore médio dos sintomas de ansiedade foi 6,53 ( $\mathrm{DP}=4,38$; mediana=6), o de depressão foi 3,63 ( $\mathrm{DP}=3,49$; mediana=2) e o de estresse percebido foi 17,25 $(\mathrm{DP}=6,97$; mediana $=16,5)$. As mulheres apresentaram maiores escores de sintomas de ansiedade $(7,93 ; \mathrm{DP}=4,61)$, depressão $(3,93 ; \mathrm{DP}=3,63)$ e estresse percebido $(18,07 ; \mathrm{DP}=7,77)$ comparativamente aos homens. Os pacientes com idade igual ou superior a 60 anos apresentaram maiores escores médios de sintomas de depressão $(4,44 ; \mathrm{DP}=3,82)$ e estresse percebido $(17,83 ; \mathrm{DP}=7,11)$. Os pacientes com menos de 60 anos apresentaram maior escore de sintomas de ansiedade $(7,0 ; \mathrm{DP}=5,07)$ quando comparados aos pacientes com 60 anos ou mais. Conclusão: $O$ estabelecimento da linha de base dos sintomas de ansiedade, depressão e estresse percebido para os pacientes com CCR no pré-operatório e suas especificidades, contribuirá no planejamento da assistência especializada multiprofissional, com inclusão da família, para a sua minimização no preparo físico e emocional, ressaltando-se a realização da demarcação de estoma, o que favorecerá a sua recuperação e reabilitação.
\end{abstract}

Keywords: Ansiedade, Câncer Colorretal, Depressão, Estomaterapia, Estresse Percebido

\section{Referências Bibliográficas}

Botega NJ, Pondé MP, Medeiros P, Lima MG, Guerreiro CAM. Validação da escala hospitalar de ansiedade e depressão (HAD) em pacientes epiléticos ambulatoriais. Jornal Brasileiro de Psiquiatria. 1998 Jun.; 47 (6): 285-9. Hulley SB, Cummings SR, Newman TB. Delineando estudos transversais e de coorte. In: Hulley SB, Cummings SR, Browner WS, Grdy DG, Newman TB. Delineando a pesquisa clínica. 4.ed. Porto Alegre: Artmed; 2015. p. 90-102. Martins LM, Sonobe HM, Vieira FS, Oliveira MS, Lenza NFB, Teles AAS et al. Rehabilitation of individuals with intestinal ostomy. British Journal of Nursing. 2015; 24(Suppl 22): S4-S11. Reis, R.S., Hino, A.A., Anez, C.R. Perceived stress scale: reliability and validity study in Brazil. J Health Psychol. 2010; 15: 107-4. 


\title{
Orientações para o manejo do estoma cutâneo cateterizável para enema anterógrado do cólon (ACE): Relato de Casos
}

\author{
Author(s): $\quad$ LISANE TABARI $^{1}$ \\ Institution(s) ${ }^{1}$ Sarah - SARAH-BRASILIA (SMHS 501 BLOCO A BRASÍLIA - DF CEP: 70335-901)
}

\begin{abstract}
Introdução:

A Estomia Cutânea cateterizável para enema anterógrado do cólon (ACE) ou Malone Antegrade Continence Enema (MACE) é um conduto confeccionado com o apêndice e exteriorizado no abdômen para promoção da eliminação intestinal. Pode ser indicada para pessoas com alterações de controle e sensibilidade intestinal, refratárias aos tratamentos conservadores para constipação e incontinência fecal. A limpeza do cólon é feita a partir da introdução do clister ou enema (irrigação) pela estomia e permite a eliminação do conteúdo fecal pela região anal, em períodos regulares e controlados. Para o bom funcionamento da ACE é importante instruir o paciente quanto aos cuidados, antes e após a intervenção cirúrgica, sendo importante o acompanhamento ambulatorial pela equipe de enfermagem.

Objetivo: Descrever as orientações realizadas durante o acompanhamento ambulatorial de pacientes com estomia cutânea para enema anterógrado do cólon em relação ao manejo intestinal.

Métodos: estudo descritivo realizado com pacientes com ACE acompanhados no ambulatório de consulta de enfermagem estomaterapia em um hospital de reabilitação seguindo os preceitos éticos.

Resultados: A amostra foi composta por seis pacientes, quatro adultos e duas criança. Destes, quatro apresentavam diagnóstico médico de mielomeningocele, um caso com Síndrome de Vacter e um com lesão medular traumática. Os pacientes/acompanhantes foram acompanhados pelo enfermeiro estomaterapeuta em três momentos consecutivos quanto a realização da irrigação intestinal e os cuidados com o estoma e demonstraram independência, autocontrole, segurança e satisfação após as orientações quanto a continuidade do cuidado no domicílio.

Conclusão: Todos os paciente com proposta de ACE devem ser acompanhados antes e após o procedimento cirúrgico pelo enfermeiro para melhor adesão dos pacientes/cuidadores aos cuidados no domicílio. É importante a construção de um guia de orientação para a continuidade do cuidado no domicílio.
\end{abstract}

Keywords: Estomaterapia, enema, irrigação, Incontinência fecal, cuidado ambulatorial

\section{Referências Bibliográficas}

Gunnar A, Diseth TH, Helsth A, Edwin B,Stange M, Aafos G, et al. Appendicostomy for Antegrade Enema: Effects on Somatics and Psychosocial Functioning in Children with Myelomeningocele. Pediatrics 109;484-9;2002. Zee RS, Kern NG, Herndon CDA. Robotic-assisted laparoscopic MACE.Journal of Pediatric Urology Company,13,525-526, Elsevier Ltd;2017. Wilde P, Matson GG, Drott P, Mattsson S. Independence does not come with the method-treatment of neurogenic bowel dysfunction on children with myelomeningocele.Acta Paediatrica, 103, 2014. Santos VLCG, Cesaretti IUR, Assistência em Estomaterapia- Cuidando de Pessoas com Estomia. 2ํeição, São Paulo, ed Atheneu, 2015 


\title{
A PERSPECTIVA DA EQUIPE DE ENFERMAGEM SOBRE A ASSISTÊNCIA AOS PACIENTES COM ESTOMA INTESTINAL
}

Author(s): $\quad$ Isabella Fernandes Brianez ${ }^{1}$, André Aparecido da Silva Teles ${ }^{1}$, Lorena Alves Pantoni ${ }^{1}$, Tatiana Mara da Silva Russo ${ }^{1}$, Janderson Cleiton Aguiar ${ }^{1}$, Lívia Módolo Martins ${ }^{1}$, Vanessa Damiana Menis Sasaki ${ }^{1}$, Helena Megumi Sonobe ${ }^{1}$

Institution(s) ${ }^{1}$ EERP-USP - Escola de Enfermagem de Ribeirão Preto (Av. Bandeirantes, 3900, Rib. Preto, SP.), ${ }^{2}$ HC-FMRP - Hospital das Clínicas da Faculdade de Medicina de Ribeirão P (Av. Bandeirantes,3900, Rib. Preto, SP.)

\begin{abstract}
Introdução: A capacitação da equipe de enfermagem é fundamental para prestar assistência aos pacientes com doenças colorretais que resultam em estomização intestinal, por gerar repercussões físicas e psicossociais. Objetivos: analisar os incidentes críticos positivos e negativos relacionados à assistência de enfermagem pré e pós-operatória aos pacientes com estoma intestinal, na perspectiva da equipe de enfermagem; e analisar os aspectos fundamentais para a elaboração de educação permanente sobre assistência de enfermagem perioperatória para estes profissionais. O projeto foi aprovado pelo Comitê de Ética em Pesquisa da Instituição proponente sob Parecer 2.802.191. Material e método: Estudo quantitativo, descritivo e transversal, com participação de 13 profissionais da equipe de enfermagem, mediante critérios de inclusão, que relataram situações positivas e negativas relacionadas à assistência perioperatória aos pacientes com estoma intestinal, por meio da técnica de Incidentes Críticos. Realizou-se entrevistas, com gravação em áudio, transcrição de dados e análise de conteúdo dedutivo. Resultados: Do total de 77 incidentes críticos extraiu-se 46 situações negativas (16 no pré-operatório e 30 pós-operatório) e 31 positivas (13 no pré-operatório e 18 no pós-operatório), sendo que no préoperatório foram focalizados o preparo físico e psicoemocional do paciente e do familiar com possibilidade de estomização intestinal, participação dos familiares no contexto hospitalar e o preparo colônico. No pós-operatório evidenciou-se situações de complexidade clínica e psicoemocional destes pacientes, cuidados com estoma e equipamento coletor, reações dos pacientes e familiares à estomização e as complicações pós-operatórias. Em relação aos comportamentos estabeleceu-se 77, sendo 46 negativos e 31 positivos relacionados à condição clínica e psicossocial dos pacientes, capacitação profissional, participação dos familiares e demanda de cuidado especializado. Estabeleceu-se 110 consequências, sendo 70 negativas e 40 positivas, relacionadas à qualificação da assistência especializada, comprometimento clínico do paciente, desenvolvimento profissional e desafios para reabilitação. Os incidentes críticos negativos vinculados às consequências enfatizaram as dificuldades de cuidado às pessoas com doença oncológica em estadiamento avançado, o preparo colônico pré-operatório e a demora na recuperação pós-operatória, além da falta de conhecimento técnico-científico para lidar com os próprios sentimentos e os da clientela. Por outro lado, os incidentes críticos positivos foram relacionados ao acolhimento e estímulo com ações assertivas e otimistas e as consequências de enfrentamento da terapêutica com maior tranquilidade e confiança na recuperação pós-operatória. $A$ análise de todas as situações, comportamentos e consequências, relatados pela equipe de enfermagem, indicaram a necessidade de educação permanente destes profissionais em unidade de internação terciária, que deverá focalizar o ensino para o autocuidado, implementação de cuidados com o estoma, equipamento coletor e o manejo de complicações pós-operatórias com vistas à recuperação fisiológica e psicoemocional, além dos aspectos interacionais, com estimulação da autonomia desta clientela. O predomínio de incidentes negativos nas situações, comportamentos e consequências devem ser considerados no planejamento da capacitação profissional. Conclusão: A assistência perioperatória à pessoa com estoma intestinal e ao familiar pressupõe um planejamento integral, com competência técnica e interacional, para tanto torna-se necessária a educação permanente e condições de trabalho adequadas dos profissionais da enfermagem, considerando-se a perspectiva destes.
\end{abstract}

Keywords: Educação continuada, Enfermagem perioperatória, Estomas cirúrgicos, Estomaterapia

\section{Referências Bibliográficas}

Brianez IF (Escola de Enfermagem de Ribeirão Preto, Universidade de São Paulo, Ribeirão Preto). Assistência perioperatória aos pacientes com estoma intestinal: perspectiva da equipe de enfermagem. Trabalho de Conclusão de Curso. 2018. 32p. Dela Coleta JAA. técnica dos incidentes críticos: aplicação e resultados. Arq. Bras. Psic. Aplic.; 1974, 26(2): 35-58. Gemmill R, Kravits K, Ortiz M, Anderson C, Lai L, Grant M. What do surgical oncology staff nurses know about colorectal cancer ostomy care? J Contin Educ Nurs. 2011 Feb.; 42(2):81-8. Klemp JR, Frazier LM, Glennon C, Trunecek J, Irwin M. Improving cancer survivorship care: oncology nurses'educational needs and preferred methods of learning. J Canc Educ. 2011; 26: 234-42. 


\title{
AS DEMANDAS PSICOLÓGICAS DE PACIENTES EM TRATAMENTO CIRÚRGICO PARA A CONFECÇÃO DE ESTOMA INTESTINAL
}

\author{
Author(s): Natália Michelato Silva ${ }^{1}$, Sara Rodrigues Rosado ${ }^{1}$, Manoel Antônio dos Santos ${ }^{2}$, André \\ Aparecido da Silva Teles ${ }^{1}$, Helena Megumi Sonobe ${ }^{1}$ \\ Institution(s) ${ }^{1}$ EERP-USP - Escola de Enfermagem de Ribeirão Preto (Av. Bandeirantes, 3900, Rib. Preto, SP.), \\ ${ }^{2}$ FFCLRP-USP - Faculdade de Filosofia, Ciências e Letras de Ribeirão Preto (Av. Bandeirantes, \\ 3900, Rib. Preto, SP.)
}

\begin{abstract}
Introdução: O tratamento cirúrgico com possibilidade de confecção de estomia intestinal gera mudanças, tanto fisiológicas como psicológicas, com diversidade de emoções, sentimentos, dúvidas, incertezas e medos. Objetivo: Analisar as demandas de atendimento psicológico de pacientes no perioperatório por doenças colorretais. Material e método: Estudo de abordagem qualitativa com 46 participantes, cujos critérios de seleção foram: pessoas com doença colorretal em tratamento cirúrgico com possibilidade de confecção de estoma intestinal, acima de 18 anos, de ambos os sexos, internados em um hospital universitário do interior paulista. Foram estabelecidas duas questões norteadoras: "O que significou para o(a) $\mathrm{Sr}(a)$ internar para fazer a cirurgia com colostomia?"; "Como tem sido a sua experiência após esta cirurgia?". Além das entrevistas, foram utilizadas diferentes técnicas de coleta de dados como observação não participante e participante, diário de campo e informantes secundários, que compuseram o trabalho de campo. Para a análise e interpretação de dados utilizou-se a análise de conteúdo indutivo, segundo a proposta da Análise Temática, com etapas de identificação, análise e relato dos temas das demandas psicológicas. A interpretação foi subsidiada pelo referencial da Psicologia Hospitalar. O projeto foi aprovado pelo Comitê de ética em Pesquisa da instituição proponente, sob Parecer 316/2016. Resultados: As demandas de atendimento psicológico apresentadas pelos pacientes no pré-operatório foram vinculadas à necessidade de informações sobre diagnóstico, tratamento cirúrgico e equipamento coletor. Os pacientes ficavam apreensivos e angustiados com a possibilidade da confecção da estomia, independente do diagnóstico oncológico ou não, pois a possibilidade de mutilação e a mudança em seu próprio corpo eram estarrecedoras. No pós-operatório, estas demandas focalizaram as reações fisiológicas e psicológicas; em relação aos cuidados pós-operatórios houve uma diversidade de sentimentos e emoções decorrentes da concretização da estomização ou não. Pacientes estomizados apresentaram dualidade de sentimento, entre tristeza e alívio por ter conseguido sobreviver à cirurgia e a esperança de uma vida melhor. O equipamento coletor para estes pacientes gerou preocupações e dúvidas sobre a troca, cuidados e a manutenção de suas atividades cotidianas, além das informações sobre a acessibilidade aos equipamentos coletores/adjuvantes e aos benefícios sociais. Os pacientes não estomizados se mostraram bastante aliviados por não ter uma "bolsinha" em seu abdômen, trazendo esperança de uma vida melhor. Ainda, manifestaram dúvidas sobre as reações fisiológicas decorrentes da cirurgia e sobre o acompanhamento ambulatorial. As demandas de atendimento psicológico foram vinculadas à evolução clínica. Conclusão: A equipe interdisciplinar necessita ter conhecimentos sobre a doença, tratamentos, consequências e reações dos pacientes. O psicólogo, além de compreender o estigma da estomia intestinal, deve conhecer as consequências na vida do paciente e do familiar, pois são fundamentais para o seu atendimento. Este profissional poderá oferecer suporte emocional para auxiliar esta clientela no enfrentamento das incertezas da cirurgia e do adoecimento; e estar inserido na equipe interdisciplinar, pois cada profissional possui uma intervenção específica para o atendimento integral, melhorando a qualidade da assistência perioperatória.
\end{abstract}

Keywords: Equipe de Assistência ao Paciente, Estomaterapia, Estomia, Psicologia

\section{Referências Bibliográficas}

Bardin L. Análise de conteúdo. Lisboa: Edições 70, 2011. Silva NM, Gaspar KC. Ansiedade e pacientes oncológicos em início de tratamento radioterápico. In: Angerami-Camon VA, Gaspar KC (orgs.). Psicologia e Câncer. São Paulo: Casa do Psicólogo; 2013, p. 273-94. Silva NM, Santos MA, Rosado SR, Galvão CM, Sonobe HM. Aspectos psicológicos de pacientes estomizados intestinais: revisão integrativa. Revista Latino Americana de Enfermagem; 2017, 25: 1-11. 


\title{
PERFIL DOS BRASILEIROS COM ESTOMA DE ELIMINAÇÃO
}

Author(s): Amanda Ferreira de Almeida Colombi ${ }^{1,3}$, Eline Lima Borges ${ }^{2}$, Grazielly Santana de Paulo ${ }^{1}$, Vanessa Institution(s) ${ }^{1}$ FAESA - FAESA Centro Universitário (Av. Vitória, 2220 - Monte Belo, Vitória - ES, 29053-360), ${ }^{2}$ UFMG Universidade Federal de Minas Gerais (Av. Prof. Alfredo Balena, 110 - Santa Efigênia, Belo Horizonte - MG, 30130-100), ${ }^{3}$ UFES - Universidade Federal do Espírito Santo (Av. Mal. Campos, 1468 - Maruípe, Vitória ES, 29047-105)

\begin{abstract}
O Brasil possui uma grande extensão territorial, com diferenças culturais e sociais acentuadas, apresentando serviços de saúde que oferecem serviços de abrangência e qualidades distintas. Ainda não há um sistema de informação ou política de registro dos casos de estoma, uma análise acerca das características dos estomizados brasileiros pode contribuir para o atendimento de suas reais necessidades e para o direcionamento de políticas públicas e de saúde. O estudo teve o objetivo de identificar a prevalência e o perfil dos brasileiros com estoma de eliminação. Trata-se de revisão integrativa cuja busca de artigos publicados entre 2000 e 2018 ocorreu nas bases de dados LILACS, BDENF, MEDLINE, IBECS, além do site da Revista Estima por meio de descritores controlados, em português, inglês e espanhol de desenho descritivo, transversal e epidemiológico. $\mathrm{Na}$ amostra de artigos encontrados foi possível identificar que a maioria dos estomizados brasileiros era do sexo masculino, casados, com idade superior a 60 anos, aposentados, de baixa renda salarial, o estoma era colostomia definitiva decorrente de câncer colorretal. As complicações na pele periestoma foram as mais citadas. Os dispositivos quando avaliados eram geralmente inadequados. Muitos dados clínicos e sociodemográficos estavam ausentes em alguns estudos da amostra. Não foi possível identificar a prevalência de pessoas com estoma de eliminação no Brasil devido à apenas um estudo identificar a prevalência em um município no estado de Minas Gerais. Os resultados da revisão confirmam a necessidade dos gestores, responsáveis pelas políticas públicas do Brasil, criarem mecanismos que propiciem registro de dados que irão permitir a elaboração de estudos epidemiológicos futuros.
\end{abstract}

Keywords: Estomia, Perfil de Saúde, Cuidados de Enfermagem

\section{Referências Bibliográficas}

Caetano CM, Beuter M, Jacobi CS, Misrtura C, ROSA BVC, Seiffert MA. O cuidado à saúde de indivíduos com estomias. Revista Brasileira de Ciências da Saúde, v.12, n.39, p.59-65, 2014. Mendes, KDS, Silveira RCCP, GALVÃO CM. Revisão integrativa: método de pesquisa para a incorporação de evidências na saúde e na enfermagem. Texto e Contexto -

Enfermagem, Florianópolis, v. 17, n. 4, p. 758-764, 2008. Moraes JT, Amaral CFS, Borges EL, Ribeiro MS, Guimarães EAA. Serviços de atenção ao estomizado: análise diagnóstica no Estado de Minas Gerais, Brasil. Cad. Saúde Colet. v.22 n.1, p.101-8, 2014. 


\title{
CARACTERIZAÇÃO CLÍNICA E DE EQUIPAMENTOS COLETORES/ADJUVANTES DE ESTOMIZADOS DE TRÊS SERVIÇOS PÚBLICOS ESPECIALIZADOS
}

\author{
Author(s): Sara Rodrigues Rosado ${ }^{1}$, Natália Michelato Silva ${ }^{1}$, Eliza Maria Rezende Dázio ${ }^{2}$, Bráulio Roberto \\ Gonçalves Marinho Couto ${ }^{3}$, Helena Megumi Sonobe ${ }^{1}$ \\ Institution(s) ${ }^{1}$ EERP-USP - Escola de Enfermagem de Ribeirão Preto (Av. Bandeirantes, 3900, Rib. Preto, SP.), \\ ${ }^{2}$ Unifal - MG - Universidade Federal de Alfenas (Rua Gabriel Monteiro da Silva, 700, \\ Alfenas/MG), ${ }^{3}$ UniBh - Centro Universitário de Belo Horizonte (Av. Professor Mário Werneck, \\ 1685, Belo Horizonte/MG )
}

\begin{abstract}
Introdução: As demandas assistenciais do estomizado intestinal desafiam a implementação do Programa de Ostomizados em todo o território brasileiro pelo Sistema Único de Saúde (SUS), no que se refere à previsão e provisão de equipamentos coletores (EC) e adjuvantes adequados às reais necessidades desta clientela, que evoluíram historicamente, com ratificação dos seus direitos pela Portaria 400. Objetivo: Analisar a utilização dos equipamentos coletores (EC) e adjuvantes fornecidos às pessoas com estomia intestinal e presença de complicações de estoma e pele periestoma, em três serviços públicos especializados. Material e método: Estudo prospectivo, observacional, correlacional, de abordagem quantitativa, com participação de 204 estomizados intestinais, avaliados entre maio de 2017 a março de 2018, de três serviços públicos especializados, do estado de Minas Gerais. A amostra consecutiva e não probabilística foi selecionada mediante critérios de inclusão: pessoas com estomas intestinais, acima de 18 anos, de ambos os sexos, cadastradas e em seguimento no serviço especializado, que compareceram para avaliação clínica; e de exclusão: pessoas com instabilidade clínica. Utilizouse instrumento de coleta de dados, validado para este estudo, contemplando informações sociodemográficas, clínicas sobre estomia e pele periestoma e sobre EC/adjuvantes. O projeto foi aprovado pelo Comitê de Ética em Pesquisa da instituição proponente (Parecer 1.822.568). Para a análise descritiva, realizou-se dupla digitação em planilhas do aplicativo

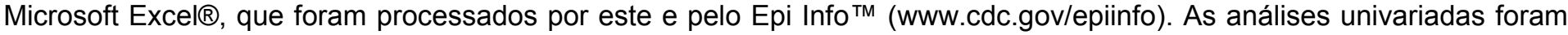
realizadas por meio de testes de hipóteses estatísticos bilaterais, considerando um nível de significância de $5 \%(\alpha=0,05)$. Resultados: Do total de 204 participantes, $66,7 \%$ eram colostomizados; $60,3 \%$ definitivos; $97,6 \%$ sem demarcação préoperatória de estoma. As complicações de estoma ocorreram em $66,7 \%$, sendo retração (39,7\%), prolapso (25,0\%), granuloma $(70,6 \%)$ e estenose $(4,4 \%) ; 52,0 \%$ apresentaram hérnia paraestomal e $86,8 \%$ apresentaram complicação de pele periestoma, sendo foliculite $(22,0 \%)$; dermatite alérgica $(8,5 \%)$; dermatite mecânica $(10,2 \%)$ e dermatite de contato $(41,2 \%)$. Utilizavam EC de uma peça (58,8\%), sem filtro antiodor de carvão $(63,2 \%)$; com base plana $(93,1 \%) ; 53,0 \%$ não utilizavam adjuvantes e dentre os $47,0 \%$ que faziam uso, eram utilizados pó de resina sintética $(56,3 \%)$, pasta protetora de pele $(55,2 \%)$, cinto $(22,9 \%)$ e spray $(5,2 \%) ; 87,8 \%$ apresentaram queixas no autocuidado como balonismo $(78,4 \%)$, liberação de odor $(25 \%)$ e descolamento do EC (23\%). Apenas $2 \%$ realizavam irrigação intestinal. Houve correlação estatisticamente significante entre o recorte maior da base e dermatite irritativa $(p=0,005)$; entre uso de pasta/pó de resina sintética e dermatite irritativa ( $p=0,001)$; e dermatite mecânica e o uso de EC de uma peça $(p=0,006)$. A acessibilidade destes pacientes aos EC/adjuvantes e mesmo a assistência ainda é um desafio na implementação deste programa especializado. Conclusão: $O$ fornecimento de EC/adjuvantes pelo serviço público não têm conseguido atender integralmente as necessidades de estomizados intestinais e para a melhoria desta assistência, serão necessários assegurar a avaliação clínica periódica, melhorar a previsão e provisão no gerenciamento de recursos públicos, educação permanente, além da demarcação de estomia pré-operatória no contexto hospitalar.
\end{abstract}

Keywords: Autocuidado, Equipamentos e Provisões, Estomas cirúrgicos, Estomaterapia, Reabilitação

\section{Referências Bibliográficas}

Rosado SR (Escola de Enfermagem de Ribeirão Preto, Universidade de São Paulo, Ribeirão Preto). Equipamentos coletores/adjuvantes de estomizados intestinais e a assistência especializada: a acessibilidade para o alcance da reabilitação. 2019. 227f. Tese (Doutorado). 2019. 227p Pittman J, Rawl SM, Schmidt CM, Grant M, Ko CY, Wendel C, et al. Demographic and clinical factors related to ostomy complications and quality of life in veterans with an ostomy. J Wound Ostomy Continence Nurs. 2008; 35(5): 493-503. Doi: 10.1097/01.WON.0000335961.68113.cb. Santos VLCG, Paula CAD, Secoli SR. Adult ostomy patients in the city of São Paulo: a study of specialized equipment costs. Rev Esc Enferm USP. 2008; 42(2): 249-55. Doi: 10.1590/S0080-62342008000200006. 


\title{
Relato de experiência: atuação do enfermeiro estomaterapeuta no tratamento de estomas com necrose parcial
}

\author{
Author(s): FERNANDA SOUZA BERNY ${ }^{2}$, Rosaura Paczec ${ }^{1}$ \\ Institution(s) ${ }^{1}$ PMPA - Prefeitura Municipal de Porto Alegre (Capitão Montanha, 27. Centro. Porto Alegre), ${ }^{2}$ \\ Fufamed - Fufamed (São Nicolau 1088 Porto Alegre)
}

\begin{abstract}
Introdução: A necrose estomal é considerada uma complicação precoce, geralmente aparecendo nos primeiros dias de pós operatório, e que ocorre por falta de aporte sanguíneo adequado no estoma podendo ser parcial ou total. Existem vários padrões morfológicos de necrose: de coagulação, liquefação, caseosa e gordurosa. É importante a utilização de bolsas transparentes no pós cirúrgico imediato para verificação do estado, funcionamento e coloração do estoma a fim de diagnosticar qualquer tipo de complicação precocemente e evitar danos maiores ao paciente. Objetivo: Relatar a conduta do enfermeiro estomaterapeuta em serviço especializado no tratamento de estomas com necrose parcial. Material e métodos: Estudo descritivo do tipo relato de experiência. Resultados: Durante a consulta, a enfermeira estomaterapeuta deve avaliar as condições da região periestomal e do estoma, seu funcionamento, localização, e identificando a necrose deve observar a quantidade de tecido necrosado, tipo de necrose e sua localização. Não havendo necrose total ou necrose que impeça o funcionamento do estoma, o enfermeiro estomaterapeuta é o profissional habilitado para realizar desbridamento instrumental conservador, autolítico, enzimático ou mecânico. Em outros casos o paciente deve ser encaminhado ao cirurgião responsável ou serviço hospitalar onde é acompanhado. Conclusão: É de extrema importância a detecção precoce de qualquer tipo de complicação estomal, especialmente as necroses, pois em muitos casos é necessário reparação cirúrgica imediata. Nas necroses parciais de estoma a atuação do enfermeiro estomaterapeuta é essencial para um tratamento eficaz evitando a ocorrência de outras complicações associadas, como a infecção, a retração, o descolamento mucocutâneo e as dermatites de contato ou irritativas.
\end{abstract}

Keywords: ESTOMATERAPIA, ESTOMIA, NECROSE

\section{Referências Bibliográficas}

Junqueira M. Complicações de Colostomia e os Cuidados de Enfermagem. 2010. p.18-22. Monografia de Graduação em Bacharel - Faculdade de Ciências da Saúde Archimedes Theodoro Faculdade de Enfermagem, Além Paraíba, 2010. Silva ES, Castro DS, Garcia TR, Romero WG, Primo CC. Tecnologia do cuidado à pessoa com colostomia: diagnósticos e intervenções de enfermagem. REME - Rev Min Enferm. 2016; [Citado em 19 de jul 2019 ]; 20:e931. Disponível em: DOI: 10.5935/1415-2762.20160001 Santos JS et al. Perfil clinico e epidemiológico dos pacientes submetidos a estomas intestinais.. In: Anais da VII Mostra de Pesquisa em Ciência e Tecnologia DeVry Brasil. Anais. BELÉM, CARUARU, FORTALEZA, JOÃO PESSOA, MANAUS, RECIFE, SALVADOR, SÃO LUÍS, SÃO PAULO, TERESINA: DEVRY BRASIL, 2016. Disponível em: https//www.even3.com.br/anais/viimostradevry/29849. 


\title{
PROTOCOLO DE ASSISTÊNCIA EM ENFERMAGEM PARA ALTA HOSPITALAR DO PACIENTE ESTOMIZADO
}

\author{
Author(s): Thays da Silva Gomes Lima ${ }^{1}$, DANIELA DA SILVA FERREIRA ${ }^{1}$ \\ Institution(s) ${ }^{1}$ INCA - INSTITUTO NACIONAL DE CÂNCER (Praça Cruz Vermelha, 23 - Centro, Rio de \\ Janeiro - RJ, 20230-130), ${ }^{2}$ INCA - INSTITUTO NACIONAL DE CÂNCER (Praça Cruz \\ Vermelha, 23 - Centro, Rio de Janeiro - RJ, 20230-130), ${ }^{3}$ INCA - INSTITUTO NACIONAL DE \\ CÂNCER (Praça Cruz Vermelha, 23 - Centro, Rio de Janeiro - RJ, 20230-130)
}

\begin{abstract}
Introdução: O câncer colorretal é uma das neoplasias mais frequentes nos adultos, em ambos os sexos, com aumento da incidência com o avanço da idade. A cirurgia é o método primário de tratamento para esta afecção, onde ocorre a ressecção cirúrgica do segmento intestinal comprometido com possibilidade de confecção de um estoma podendo acarretar mudanças dos hábitos de vida do paciente. Nesse cenário, é importante que enfermeiro e paciente desenvolvam diálogo acerca dos cuidados com o dispositivo coletor estoma e a pele periestomal o mais precocemente possível, para promover a autonomia e independência no desenvolvimento do autocuidado após a alta hospitalar. Objetivo: Descrever o Protocolo de assistência em enfermagem para alta hospitalar de pacientes adultos estomizados, internados em clínicas cirúrgicas do Instituto Nacional de Câncer - HC- I, elaborado em 2019, em fase de aprovação da Instituição. Métodos: Estudo descritivo que apresenta o conjunto de ações de cuidados de enfermagem contidas no Protocolo de Assistência de Enfermagem ao paciente estomizado, que foi elaborado no primeiro semestre de 2019, por Enfermeiras Estomaterapeutas deste hospital. Está baseado no conjunto de cuidados e medidas que visam atender as necessidades humanas Básicas, em uma condição de saúde específica, incluindo abordagem física, social e psicológica com vistas a reabilitação integral do indivíduo. Resultados: As condutas estabelecidas nesse protocolo foram baseadas em três pilares de assistência: Problematizar orientações referentes à troca do equipamento coletor (medição correta, como fazer o corte da placa, como colar novo coletor). Problematizar aspectos referentes aos sinais de complicações com a pele periestomal. Integrar aos cuidados com a pele e mucosas o aporte psicológico, social e espiritual do paciente. Dessa maneira, o agente da ação do cuidado é o Enfermeiro assistencial, que irá realizar orientações dialogadas no momento da alta hospitalar, abordando as condições do estoma quanto a coloração, protrusão e funcionamento; avaliação da integridade da pele ao redor do estoma e sinaliza sinais e sintomas de possíveis complicações na pele; Observação da presença de bastão de sustentação, informando ao paciente a importância deste e o momento ideal para retirada do mesmo; Avaliação do volume e aspecto do efluente drenado, orientando o paciente o que esperar após a alta, e como realizar o esvaziamento do coletor de maneira higiênica; Orientação quanto a colagem de novo coletor; retirada do dispositivo anterior de forma atraumática; como recortar a placa de forma ideal; como avaliar a necessidade de materiais adjuvantes e como utilizá-los; como proceder à manutenção diária do estoma. Orientação quanto a necessidade de seguir as instruções nutricionais, o acompanhamento ambulatorial médico. Encaminhamento a enfermeira estomaterapeuta no momento da alta hospitalar, e a outros profissionais se necessário. Conclusão: Esse protocolo é um guia de ações de enfermagem indispensável para garantir a adoção de medidas padronizadas em todas as unidades de internação, bem como o sucesso do tratamento e a reabilitação da pessoa com estoma intestinal visando qualidade de vida dessa clientela.
\end{abstract}

Keywords: Estomaterapia, estomias, alta hospitalar, protocolos

\section{Referências Bibliográficas}

Ministério da Saúde [homepage na Internet]. Portaria n 2.439/GM. Política Nacional de Atenção Oncológica. Ministério da Saúde; [acesso em: 8 agosto 2019].. Brasília. Disponível em http://dtr2001.saude.gov.br/sas/PORTARIAS/Port2005/GM/ GM-2439.htm. Hueso Montoro C, Bonill Bonill de las Nieves C, Celdrán Mañas M, Hernández Zambrano SM, Amezcua M, Morales Asencio JM. Experiences and coping with the altered body image in digestive stoma patients. Rev. Latino-Am. Enfermagem. 2016; 24:e2840. http:// dx.doi.org/10.1590/1518- 8345.1276.2840 Mareco, A. P. M., Pina, S. M., \& Farias, F. C. (2019). A importância do enfermeiro na assistência de pacientes com estomias intestinais. ReBIS-Revista Brasileira Interdisciplinar de Saúde, 2019; v. 1(n 2): 19- 23. 


\title{
EFETIVIDADE DAS ORIENTAÇÕES E CUIDADOS DE ENFERMAGEM AO PACIENTE ESTOMIZADO E SUA FAMÍLIA
}

\author{
Camila da Costa Chagas ${ }^{1}$, Patricia Pedroso da Silva ${ }^{1}$, Daiany Santos Fernades ${ }^{1}$, Anelissie Liza
}

Author(s): $\quad$ Hul $^{1}$, Katilene Wrezinski ${ }^{1}$, Adriana Fischborn ${ }^{1}$, Elisandra Leites Pinheiro ${ }^{1}$, Daniela Tenroller de Oliveira $^{1}$

Institution(s) ${ }^{1}$ HMV - Hospital Moinhos de Vento (Rua Ramiro Barcelos, 910)

\begin{abstract}
Introdução: A estomia é um procedimento cirúrgico, no qual é realizada uma abertura artificial entre o intestino e a parede abdominal.1 Pacientes submetidos a tal procedimento têm sua perspectiva de vida modificada, principalmente pela imagem corporal alterada devido à presença do estoma associado a bolsa coletora.2 Cabe ao enfermeiro, como profissional de saúde, desenvolver um plano de cuidados adequado ao preparo do paciente para o convívio com a estomia.3 Objetivos: Descrever a experiência da orientação ao paciente quanto ao seu autocuidado, na prevenção da qualidade e segurança da assistência prestada, na sua efetividade e continuidade, disponibilizando a atenção necessária e peculiar a cada paciente. Ressaltando a importância das orientações de enfermagem para o desenvolvimento do autocuidado do paciente estomizado. Método: Trata-se de um estudo transversal de caráter descritivo, que faz parte de um projeto guarda-chuva da instituição, como parecer CAAE: 57679316.9.0000.5330, que relata a vivência de enfermeiros na prática de um hospital privado de Porto Alegre, no período de 2016 a 2018, onde foi implementado um grupo de orientações e cuidados com estomias para pacientes e familiares, com divulgação nas unidades de internação para todos os pacientes estomizados. Resultados: A partir dos dados de 2016 a 2018, calcula-se 102 orientações realizadas ao ano. Dessas experiências, constatou-se maior adesão na participação dos pacientes e familiares no autocuidado, manipulação e independência. A percepção dos cuidados pela equipe de enfermagem realizada aos pacientes estomizados foi de maior aderência às orientações e manipulação dos dispositivos. Desta forma, o processo de informação e comunicação vivenciado pelo paciente estomizado durante sua internação, é de extrema importância para se garantir sua efetividade na assistência. Participando efetivamente do processo de orientações e cuidados, o grupo de referência em estomaterapia (Grest), realiza encontros semanalmente, com pacientes e familiares estomizados, sendo conduzido por uma enfermeira referência do grupo. Nestes encontros os pacientes são orientados e treinados quanto ao autocuidado, manipulação de troca de placa $e$ bolsa, produtos disponíveis no mercado, locais de compras, possíveis complicações, vida social, entre outras dúvidas. A relação entre o enfermeiro e o paciente estomizado baseada no diálogo e orientações, é visto de forma positiva, pelo fato de favorecer as ações educativas, que por sua vez são fundamentais para que o paciente assuma o cuidado integral tornando o indivíduo independente e autônomo. Conclusão: Percebe-se que quando o acompanhamento ao paciente estomizado é realizado de forma adequada, e o fornecimento de informações é conduzido com clareza, a recuperação física será mais rápida e menos penosa, permitindo inclusive uma reinserção social de forma mais natural e tranquila. Esse trabalho desenvolvido ainda no hospital, que desempenha esse papel de orientações e cuidados durante a internação, tem resultados satisfatórios, alcançando os objetivos propostos a partir da satisfação e minimização das dúvidas do paciente/familiar e cuidadores. Desta forma, diminuindo as possíveis complicações pós-alta e melhorando a adaptação à nova realidade. Esses resultados possibilitam e nos motivam a desenvolver atividades, que possam contribuir cada vez mais para o bem-estar do paciente.
\end{abstract}

Keywords: autocuidado, estomoterapia, orientação

\section{Referências Bibliográficas}

1. Cesaretti, IUR. Assistência em Estomaterapia: Cuidando de pessoas com Estomia. São Paulo, Editora Atheneu; 2015. 2. Nascimento, CMS et al. Vivência do paciente ostomizado: Uma contribuição para a assistência de enfermagem.

Florianópolis. Contexto Enfermagem. V,20, n.3, p. 557-564, 2011. 3. Nieves, CB et al. Percepção de pacientes ostomizado sobre os cuidados de saúde recebidos. Rev.Latino-Am. Enfermagem. V, 25, 2017. 


\title{
CONSTRUÇÃO DE TECNOLOGIA EDUCATIVA PARA O FAMILIAR CUIDADOR DE CRIANÇAS COM ESTOMIA INTESTINAL
}

\author{
Author(s): $\quad$ Luciana Evangelista Marrocos de Aragao ${ }^{1}$ \\ Institution(s) ${ }^{1}$ UNIFAMETRO - Faculdade Metropolitana da Grande Fortaleza (RUA CONSELHEIRO \\ ESTELITA BAIRRO JACARECANGA)
}

\begin{abstract}
INTRODUÇÃO: Estomia é um termo originário da Grécia que significa boca ou abertura e é empregado para denotar a exteriorização de qualquer órgão oco através da pele1. Sua nomenclatura varia e pode incidir em regiões distintas do corpo humano, recebendo uma denominação própria para cada uma delas, sendo estas de caráter temporário ou definitivo, podendo acometer adultos ou crianças. A confecção de uma estomia em uma criança acarreta mudanças na sua vida e de seus familiares, como complicações, alta hospitalar, volta ao lar, reinternações, tratamentos e convívio social, além do impacto da doença, o que requer alteração na dinâmica familiar2. Assim, o cuidado com a criança exige de sua família a adoção de novas medidas e decisões que contribuam na retomada das atividades cotidianas3. Nesse contexto, o familiar cuidador é apontado como aquela pessoa que presta assistência a pacientes com limitações físicas. Dessa maneira, reconhecendo a importância do uso de tecnologias educativas, com enfoque nos cuidados as crianças estomizadas, esse estudo tem como OBJETIVO: Construir tecnologia educativa para o familiar cuidador de crianças com estomia intestinal. MÉTODO: Trata-se de uma pesquisa metodológica4, do tipo desenvolvimento, realizada no mês de agosto a dezembro de 2018 em Fortaleza-Ceará-Brasil. Por se tratar da primeira etapa do estudo metodológico, não foi enviado para o Comitê de Ética e Pesquisa, pretende-se validar o conteúdo, a aparência e a clínica em estudo posterior. RESULTADOS: O estudo foi realizado em duas fases: 1) Embasamento científico e 2) Construção da cartilha educativa. Na primeira fase, foi realizado um levantamento do tipo "Revisão Narrativa", usando os Descritores em Ciências da Saúde (DeCS): "estomia intestinal", "criança", "família", "cuidados de enfermagem" e "educação em saúde", nas bases de dados National Library of Medicine (PUBMED/MEDLINE), Literatura Latino-Americana e do Caribe em Ciências da Saúde (LILACS) e na Biblioteca Eletrônica Scientific Electronic Library Online (SCIELO), além de pesquisas no livro "Assistência em Estomterapia: cuidando de pessoas com estomias", em consensos nacionais e internacionais. Na segunda fase, a cartilha foi construída em dois momentos: a) Seleção de ilustração (realizada por um design gráfico) e b) Montagem da cartilha. A cartilha educativa para familiar cuidador intitulada "Cuidando de crianças com estomia intestinal", contém 9 páginas, composta por elementos textuais (capa, apresentação), textuais (figuras e textos) e pós-textuais (referências bibliográficas). A cartilha traz uma abordagem simples e de fácil entendimento, numa linguagem clara e com ilustrações que visam proporcionar uma tecnologia educativa atrativa para fornecer aos leitores a veracidade da ferramenta produzida. Dentre dos conteúdos abordados, destaca-se o item "Cuidados com a pele da criança com estomia intestinal", no qual aborda os seguintes aspectos: higienização da bolsa e da pele periestoma, o uso dos produtos que não podem ser utilizados na pele, o esvaziamento a bolsa, troca da bolsa, os materiais necessários para a higiene que devem ser levados ao sair de casa, dentre outros cuidados. CONCLUSÃO: Acredita-se que a cartilha possa contribuir na melhoria de orientações para cuidadores, possibilitando explanação dos cuidados, fomentando o diálogo, esclarecimento de dúvidas e facilitando a pratica educativa do cuidado
\end{abstract}

Keywords: Enfermagem, Estomarerapia, Estomia, Criança, Cuidador

\section{Referências Bibliográficas}

1. Santos VLCG, Cesaretti IUR. Assistência em Estomaterapia: Cuidando de pessoas com estomia. São Paulo: Ed. Atheneu, 2015. 2. Rosado SR, Silva NM, Filipini CB et al. Viva bem com uma estomia: relato de experiência sobre a elaboração de uma cartilha. Rev enferm UFPE on line., Recife, 11(Supl. 5):2242-9, maio., 2017. 3. Coelho MAS, Oliveira CG, Bezerra STF, Almeida ANS, Cabral RL, Coelho MMF. Self care of patients with colostomy, periostomal skin and collecting bag. Rev enferm UFPE on line [Internet]. 2015. 4. Polit DF, Beck CT. Fundamentos de pesquisa em enfermagem: avaliação de evidências para a prática da enfermagem. 7. ed. Porto Alegre: Artmed; 2011. 669 p. 


\title{
INFLUÊNCIA DA ESTOMIA NA SEXUALIDADE E SUA INTERFACE SOBRE A QUALIDADE DE VIDA: UMA REVISÃO INTEGRATIVA.
}

\author{
Rejane Marins Silva Souza ${ }^{2}$, Joice Lopes Ramos ${ }^{1,1}$, Camila Matheus de Castro ${ }^{1,1}$, Vivian Alves \\ Author(s): Venancio Vieira ${ }^{1,1}$, Lucia Helena Garcia Penna ${ }^{1}$ \\ Institution(s) ${ }^{1}$ UERJ - Universidade Estadual do Rio de Janeiro (Boulevard 28 de Setembro, 157/ Vila Isabel, \\ RJ), ${ }^{2}$ UERJ - Universidade Estadual do Rio de Janeiro (Boulevard 28 de Setembro, 157/ Vila \\ Isabel, RJ), ${ }^{3}$ UERJ - Universidade Estadual do Rio de Janeiro (Boulevard 28 de Setembro, 157/ \\ Vila Isabel, RJ), ${ }^{4}$ UERJ - Universidade Estadual do Rio de Janeiro (Boulevard 28 de Setembro, \\ 157/ Vila Isabel, RJ)
}

\begin{abstract}
Introdução: Estomia é o procedimento cirúrgico em que ocorre a exteriorização de um órgão oco através da parede do corpo a fim de desviar temporariamente ou definitivamente o segmento habitual do mesmo e sua nomenclatura depende de sua localização. Diante da importância em se pensar a sexualidade como elemento fundamental na qualidade de vida, e compreender de que maneira vem sendo discutido em pesquisas, o objetivo deste estudo foi descrever a repercussão da estomia sobre a sexualidade e consequentemente sobre a qualidade de vida. Método: Revisão integrativa de literatura tendo como Bases de Dados da Biblioteca Virtual em Saúde (BVS).O levantamento e seleção das publicações foram de 2010 a 2017. Foram empregados os critérios de seleção, ou seja, artigos disponíveis no formato completo, nacionais, publicado no idioma português. Em seguida foi realizada a retirada dos trabalhos repetidos. Verificou-se um total de 40 publicações no formato de texto e resumos completos das quais 26 não apresentavam conexões com as palavras chaves.A análise das idéias principais deu-se através das técnicas de análises de conteúdo de Bardin. Resultados:Utilizou-se 14 artigos,organizados em ordem decrescente de publicação sendo três publicados em 2017, dois em 2016, três em 2015, três em 2013, um em 2012 e dois em 2011. Quanto ao local de origem os estudos foram desenvolvidos na região Nordeste, Sul, Sudeste e Norte, assim distribuídos por Estado: Pernambuco (três publicações), Piauí (duas publicações), Rio Grande do Norte (uma publicação), Rio Grande do Sul (duas publicações), Santa Catarina (uma publicação), e Rio de Janeiro (uma publicação), Minas Gerais (três publicações) e Pará (uma publicação). Os dados foram agrupados em duas categorias: Interferências do estoma sobre a sexualidade e a qualidade de vida, produzindo um total de 04 unidades temáticas (U.T): imagem corporal, autoestima, sexualidade e dimensão da qualidade de vida. $\mathrm{E}$ o cuidado à pessoa com estoma em busca da qualidade de vida, produzindo um resultado de 04 U.T: assistência de enfermagem, educação em saúde, restrição alimentar e rede de apoio/ resiliência.Conclusão: O conhecimento do enfermeiro ainda permeia por dificuldades quando se trata em promover a assistência à pessoa com estomas intestinais com o impacto em sua sexualidade, tornando esse tema relevante para pesquisas futuras.Foi possível perceber que a imagem corporal e a autoestima da pessoa com ostomia estão ligados a sentimentos de sofrimento, medo, insegurança e vergonha, os quais refletem diretamente na sua sexualidade, vida social e laboral, sendo identificadas ainda a adaptação e a aceitação da ostomia refletindo na qualidade de vida. Recomenda-se que a enfermagem se aprofunde nos conhecimentos sobre o estoma e tenha um olhar diferenciado, auxiliando as pessoas com estomias a encarar essa realidade e contribuindo para uma favorável adaptação e melhor qualidade de vida.
\end{abstract}

Keywords: Enfermagem, Estomaterapia, Estomia, Sexualidade

\section{Referências Bibliográficas}

1. Kimura CA; Kamada I; Fortes RC; Monteiro PS. Reflexões para os profissionais de saúde sobre a qualidade de vida de pacientes oncológicos estomizados. Comunicação, ciências, saúde. 2009, Out/ Dez; 20 (4): 333- 340. 2. Santos FS; Poggeto MTD; Rodrigues LR. A percepção da mulher portadora de estomia intestinal acerca de sua sexualidade. Revista mineira de enfermagem, v. 12, n. 3, p. 355-362, 2008. 3. Bardin L. Análise de conteúdo. 3. reimp. Lisboa: Edições, v. 70, 2011. 


\title{
MANEJO COM FÍSTULA ENTÉRICA: RELATO DE CASO
}

\author{
Author(s): Joseane Flor dos Santos Oliveira ${ }^{1}$, Maria Aparecida Da Silva Limeira ${ }^{1}$, Elizabeth Trajano Nóbrega \\ Guedes ${ }^{1}$, Jéssica Ferreira da Silva ${ }^{1}$, Vanessa Diniz de Castilho ${ }^{1}$, Elaine de Oliveira Guimarães ${ }^{1}$ \\ Institution(s) ${ }^{1}$ Unimed - Alberto Urquiza Wanderley (Av. Min. José Americo de Almeida)
}

\begin{abstract}
Introdução: As fístulas enterocutâneas são comunicações de determinados órgãos com outro e pode ser classificada como interna e externa1. As comunicações do trato intestinal com outros órgãos adjacentes, são as internas e as externas quando em contato direto com epiderme2. Dentre as causas pode-se destacar os procedimentos cirúrgicos, irradiação, doença inflamatória intestinal, diverticulites, apendicites, isquemia intestinal, perfuração de úlceras gástricas e neoplasias3,4. O diagnóstico além dos sintomas clínicos, é necessário exames como fistulografia, tomografia de abdômen e ultrassonografia de abdomen1. Objetivo: Divulgar o bom manejo com equipamentos adequados melhorando a qualidade de vida do paciente com fístula. Metódo: Trata-se de um estudo com revisão na literatura, onde foi incluso a leitura de 15 artigos científicos com tema pertinentes ao assuntos, e associado ao relato de caso. Resultados: Paciente I.N.S, mastectomizada bilateral, iternada dia 26 de novembro de 2018, para colonoscopia, em 29 do corrente mês e ano realiza retosigmoidectomia abdominal e ileostomia; Cinco dias após procedimento paciente presenta efluente em alta quantidade $e$ pequena deiscência de ferida operatória; Realizado fistulografia e comprovado presença de fístula entérica; Acoplado bolsa de colostomia porém sem sucesso; Em 15 de dezembro realizado primeiro atendimento pela equipe especializada, onde foi encontrado perilesão de ileostomia, cistostomia e fístula, com fissuras de grande diâmetro, sangrenta, hiperemia grave, edema e dor; Por motivo de consistência de efluente com alto débito em ileostomia e fístula as bolsas sofriam rápida infiltração chegando a ser necessária quatro trocas ao dia gerando um total de oito bolsas em doze horas . Iniciado tratamento com pó de hidrocoloide brava, spray protetor brava, anel moldável brava, fita moldável brava, limpador de pele coloplast, pasta protetora sem álcool brava, pasta protetora com álcool coloplast e kit fístula. A troca do primeiro kit fístula foi com 3 dias, sendo visível a recuperação da epiderme em perilesão de estomas. Na segunda troca paciente não apresentava mais dermatite severa fissuras cicatrizadas com apenas hiperemia leve. Conclusão: Com uso do dispositivo adequado e adjuvantes foi possível reduzir o número de trocas de bolsas onde chegou a ser utilizado por dia oito bolsas coletoras, após adaptação paciente chega até o quinto dia sem realizar trocas, tendo assim uma qualidade de vida hospitalar melhor, onde a mesma pode ir para cadeira de rodas sem correr o risco de sujidade em roupas, como também custo benefício para instituição e redução para tempo de enfermagem em beira leito. $\mathrm{O}$ olhar diferenciado do enfermeiro $\mathrm{e}$ toda equipe de cuidado é de grande relevância para o cuidado assertivo do paciente e sustentabilidade hospitalar.
\end{abstract}

Keywords: Kit Fístula, Adjuvantes, Dermatite

\section{Referências Bibliográficas}

1. Berry SM, Fischer JE. Fístulas Enterocut. Curr Probl Surg, 2007, 31: 474-567. 2. Meguid MM, Campos ACL. Manejo Nutricional de pacientes com fístulas gastrointestinais. Surg Clin North Am, 2009,76: 1035-1080. 3. Webster MW JR, Casey LC. Fistulas do trato Intestinal. Curr Probl Surg, 1976, 13: 1-65. 4.Fístula enterocutânea. Site do Centro Médico UCSF. Disponível em: http://www.ucsfhealth.org/conditions/enterocutaneous_fistula. Acessado em 23 de julho de 2019. 


\title{
PROTOCOLO DE USO DE SACO COLETOR EM ESTOMIAS INTESTINAIS COMO MEDIDA DE CONTROLE DE INFECÇÃO RELACIONADA À ASSISTÊNCIA EM UM HOSPITAL PÚBLICO
}

\author{
Samantha Perissotto ${ }^{1}$, Renata Bigatti Bellizzotti Pavan ${ }^{1}$, Aline Recco Luca Domingues ${ }^{1}$, Edson \\ Author(s): $\quad$ Fernando Fuim ${ }^{1}$, Ivan Rogério Antunes ${ }^{1}$, Eliane Molina Psaltikidis ${ }^{1}$, Gislaine Pinhelli ${ }^{1}$, Joaquim \\ Antonio Graciano ${ }^{1}$ \\ Institution(s) ${ }^{1}$ HC/UNICAMP - Hospital de Clínicas - UNICAMP (R. Vital Brasil, 251 - Cidade Universitária, \\ Campinas - SP, 13083-888)
}

\begin{abstract}
Introdução:

O aumento de condições que causam a internação de indivíduos cada vez mais graves e imunocomprometidos, somado ao surgimento de microrganismos resistentes a antimicrobianos, confere às infecções relacionadas à assistência em saúde (IRAS) especial relevância para a saúde pública (1). Dentre as bactérias multirresistentes, uma das que possuem maior importância epidemiológica e clínica está a Klebsiella pneumoniae produtora de carbapenemase (KPC) que causa infecções de alta letalidade e com poucas opções terapêuticas (2).
\end{abstract}

\section{Objetivo:}

Descrever a construção e implementação do protocolo de utilização de saco plástico no interior dos equipamentos coletores de estomias intestinais como medida de controle da infecção cruzada de microrganismos, durante higienização da bolsa coletora.

Materiais e Métodos:

Trata-se de um estudo descritivo, realizado em uma enfermaria de gastrocirurgia e gastroclínica de um hospital público e universitário do interior do estado de São Paulo. Diante de um surto de colonização por KPC que ocorreu na enfermaria foi implementada como uma das medidas de controle a revisão do protocolo de limpeza das estomias intestinais. A revisão da técnica foi feita pela equipe de enfermagem da unidade em conjunto com a Comissão de controle de Infecção Hospitalar e com o Núcleo de Estomaterapia da instituição.

\section{Resultados:}

$\mathrm{Na}$ análise de possíveis fontes de contaminação cruzada por KPC, surgiu a necessidade de revisar o protocolo de limpeza das bolsas coletoras, com intuito de diminuir a exposição aos microrganismos presentes nos efluentes do equipamento coletor. O processo de limpeza realizada, antes da revisão do protocolo, gerava contaminação de vários pontos de toques frequentes, tanto na unidade do paciente como no banheiro. A nova estratégia foi a colocação de um saco plástico descartável, no interior da bolsa coletora, e uma vez atingido um terço da sua capacidade, o saco é removido e desprezado no lixo comum. Após teste piloto e treinamento da equipe de enfermagem, o novo protocolo foi implementado e inserido no manual de técnicas de enfermagem do hospital e ampliado para outras enfermarias.

\section{Conclusão:}

Esse protocolo teve como finalidade reduzir a manipulação do efluente durante a higienização do equipamento coletor evitando assim a exposição de microrganismos presentes na flora intestinal, principalmente em pacientes colonizados por KPC, no ambiente hospitalar. Esse processo facilitou a higienização da bolsa coletora pela equipe de enfermagem, permitiu maior conforto do paciente, melhora do autocuidado e, principalmente, auxiliou no controle do surto KPC em conjunto com outras medidas que foram implementadas.

Keywords: Infecção Relacionada à Assistência à Saú, Estomia, Enfermagem, Estomaterapia

\section{Referências Bibliográficas}

1- Padoveze $M C$, Fortaleza $C M C B$. Infecções relacionadas à assistência à saúde: desafios para a saúde pública no Brasil. Rev Saúde Pública 2014;48(6):995-1001 2-Vera-Leiva Alejandra, Barría-Loaiza Carla, Carrasco-Anabalón Sergio, Lima Celia, Aguayo-Reyes Alejandro, Domínguez Mariana et al . KPC: Klebsiella pneumoniae carbapenemasa, principal carbapenemasa en enterobacterias. Rev. chil. infectol. 2017;34(5): 476-484. 


\title{
O SIGNIFICADO DO AUTOCUIDADO: PERSPECTIVA DA PESSOA COM ESTOMIA INTESTINAL, FAMILIARES E PROFISSIONAIS DO PROGRAMA ESPECIALIZADO
}

\author{
Author(s): Vanessa Damiana Menis Sasaki ${ }^{1}$, André Aparecido da Silva Teles ${ }^{1}$, Natália Michelato Silva ${ }^{1}$, \\ Janderson Cleiton Aguiar ${ }^{1}$, Lívia Modolo Martins ${ }^{1}$, Helena ; Megumi Sonobe ${ }^{1}$ \\ Institution(s) ${ }^{1}$ EERP-USP - ESCOLA DE ENFERMAGEM DE RIBEIRÃO PRETO (R. Prof. Hélio Lourenço, \\ 3900 - Vila Monte Alegre, Ribeirão Preto - SP)
}

\begin{abstract}
Introdução: O autocuidado com estomia intestinal e os equipamentos coletores tem constituído um desafio para as próprias pessoas, familiares e profissionais do programa especializado. Objetivo: analisar e construir o significado da experiência de autocuidado com a estomia intestinal, na perspectiva de pacientes, familiares e da equipe multidisciplinar do programa especializado no Sistema Único de Saúde. Material e método: Estudo exploratório, de abordagem qualitativa, desenvolvida por meio de entrevistas com a técnica do grupo focal, distintamente para os participantes estomizados, familiares e profissionais do Programa de Ostomizados; diário de campo, observação não participante e participante para a obtenção dos dados, com utilização da Análise Temática e do Modelo Social da Deficiência para a interpretação. Este Modelo considera a lesão como uma condição relacionada à deficiência e ao adoecimento, extrapolando a compreensão para além da dor física, sofrimento e limitações corporais, incluindo-se a necessidade da acessibilidade à assistência de saúde para assegurar a igualdade de direitos e a conquista de autonomia e reintegração social, mediante a remoção de barreiras sociais, que requer a adoção de um novo estilo de vida. O projeto foi aprovado pelo Comitê de Ética em Pesquisa da Instituição proponente sob Parecer ํㅜ 896.782. Resultados: Categorizou-se a experiência dos estomizados com tema "A experiência da necessidade do autocuidado após o processo de estomização intestinal", em dois núcleos temáticos "Assistência interdisciplinar necessária às pessoas estomizadas intestinais"; e "O autocuidado para a reabilitação da pessoa estomizada intestinal", evidenciando a necessidade de assistência especializada hospitalar e o suporte profissional interdisciplinar no seguimento ambulatorial. A experiência dos familiares foi discutida com o tema: "Desafios do familiar no convívio com a pessoa estomizada intestinal", cujas unidades temáticas foram "A sobrecarga da responsabilização pelo cuidado e o preconceito da estomia intestinal"; e "Nova dinâmica familiar para a reabilitação da pessoa estomizada intestinal", que enfatizou a importância da família no planejamento da assistência especializada e o suporte profissional para esta. Explorou-se a experiência dos profissionais com o tema "Desafios para a implementação do Programa de Ostomizados" e os núcleos temáticos "Em busca do trabalho em equipe no Programa de Ostomizados"; e "Demandas de assistência especializada para pessoas estomizadas intestinais", que indicou as expectativas destes sobre as necessidades de assistência especializada e o trabalho em equipe. Diante da consonância da análise interpretativa destas experiências, o significado construído para a experiência de necessidade de autocuidado com a estomia e equipamentos coletores foi "a luta cotidiana para adoção de um novo estilo de vida para além da estomia e dos equipamentos coletores, em busca de reabilitação". O autocuidado desta clientela é o início de sua reabilitação, mas pela sua complexidade, há necessidade da inclusão do conceito de deficiência física no preparo das pessoas e dos familiares, assim como na educação permanente dos profissionais de saúde para o enfrentamento do estigma, do preconceito social e do auto preconceito, além dos desafios cotidianos para o um novo estilo de vida, com seguimento especializado interdisciplinar. Descritores: Autocuidado. Estomia. Pessoas com Deficiência. Estomaterapia.
\end{abstract}

Keywords: Autocuidado, Estomia, Pessoas com Deficiência, Estomaterapia

\section{Referências Bibliográficas}

Sasaki VDM. (Escola de Enfermagem de Ribeirão Preto, Universidade de São Paulo, Ribeirão Preto). Autocuidado com a estomia intestinal e equipamentos coletores: perspectiva das pessoas estomizadas intestinais, familiares e equipe multidisciplinar do Programa de Ostomizados. Tese de Doutorado. 2018. 212 p. Finkelstein V. The Social Model of Disability repossessed. In: Oral paper Manchester Coalition of Disabled People, 2001. Disponível em: . Braun V, Clarke V. Using thematic analysis in psychology. Qual Res Psychol. 2006; 3(2): 77-101. Martins LM, Sonobe HM, Vieira FS, Oliveira MS, Lenza NFB, Teles AAS. Rehabilitation of individuals with intestinal ostomy. Br J Nurs. 2015 Dec.; 24(22):S4-S11. Disponível em: http://www.magonlinelibrary.com/doi/pdfplus/10.12968/bjon.2015.24.Sup22.S4 


\title{
CAPACITAÇÃO DE ENFERMEIROS NO PROCEDIMENTO DE IRRIGAÇÃO FAVORECENDO A CONSTRUÇÃO DE BOAS PRÁTICAS EM ATENÇÃO AOS COLOSTOMIZADOS: UM RELATO DE EXPERIÊNCIA
}

\author{
Author(s): $\quad$ OSCAR CASSAVILANI ${ }^{1}$, ANDREIA APARECIDA DE LUCCA MOORE BONELLO ${ }^{1}$ \\ Institution(s) ${ }^{1}$ FIEL - FACULDADES INTEGRADAS EINSTEIN DE LIMEIRA (R. JATOBÁ, 200, VILA \\ QUEIROZ, LIMEIRA - SP. CEP: 13485-023), ${ }^{2}$ FIEL - FACULDADES INTEGRADAS \\ EINSTEIN DE LIMEIRA (R. JATOBÁ, 200, VILA QUEIROZ, LIMEIRA - SP. CEP: 13485-023)
}

\begin{abstract}
Trata-se de um relato de experiência sobre um treinamento de capacitação desenvolvido com as enfermeiras de um Ambulatório de Feridas, Incontinência e Estomias e o estagiário da graduação de Enfermagem de uma instituição de ensino, ambos no município de Limeira. O objetivo da capacitação foi desenvolver a capacidade dos integrantes da equipe para desenvolverem, ensinarem e incentivarem os colostomizados a praticarem a técnica de irrigação da colostomia. $O$ trabalho englobou os aspectos técnicos inerentes ao procedimento de irrigação de colostomia. A irrigação de colostomia é um método de controle da eliminação intestinal podendo o colostomizado ficar até 72 horas sem possuir alguma excreção além da possibilidade de usar outros tipos de insumos para proteger o estoma, mais singelos e discretos do que a bolsa coletora de fezes, impactando positivamente a qualidade de vida dos colostomizados. Participaram da capacitação dois profissionais enfermeiros e um estagiário de enfermagem. O treinamento foi desenvolvido por uma enfermeira vinculada a empresa fabricante do dispositivo de irrigação - irrigador, sendo organizado em três dias consecutivos durante o mês de março de 2019. Para tanto utilizamos o cadastro dos portadores de colostomizados sendo selecionados três usuários que tinha indicação para o procedimento e interesse em realiza-lo colaborando com o treinamento em questão. Foi utilizado o enfoque de cunho reflexivo e participativo com perguntas acerca das questões anatômicas e fisiológicas humanas durante todo o decorrer do procedimento, enfatizando sempre as possíveis complicações caso a técnica não seja realizada corretamente. A experiência permitiu conhecer as particularidades de quem convive com um estoma diariamente e perceber que enfermeiros treinados, capacitados e habilitados podem influenciar positivamente a vida desses indivíduos, transformando suas rotinas diárias, alcançando assim a qualidade de vida almejada.
\end{abstract}

Keywords: CAPACITAÇÃO, ESTOMATERAPIA, IRRIGAÇÃO DA COLOSTOMIA

\section{Referências Bibliográficas}

Cesaretti IUR, Santos VLCG, Vianna LAC. Qualidade de vida de pessoas colostomizadas com e sem uso de métodos de controle intestinal. Rev Bras Enferm $2010 \mathrm{Jan} / \mathrm{Fev}$;63(1)16-21. Maruyama SAT, Barbosa CS, Bellato R, Pereira WR, Navarro JP. Auto-irrigação - estratégia facilitadora para a reinserção social de pessoas com colostomia. Rev Eletr Enf 2009 Set;11(3):665-673. Santos VLCG, Cesaretti IUR. Assistência em Estomaterapia: cuidando de pessoas com estomia. 2. ed. São Paulo: Atheneu,; 2015. 


\title{
CAPACITAÇÃO DA EQUIPE DE ENFERMAGEM x REDUÇÃO NAS COMPLICAÇÕES DECORRENTE DE ADESÃO INCORRETA DO KIT DE ILEOSTOMIA
}

\author{
Author(s): Mônica Rabelo Santos ${ }^{1}$, Priscilla Alcântara dos Santos ${ }^{1}$ \\ Institution(s) ${ }^{1}$ HUSE - Hospital de Urgência de Sergipe (Av. Tancredo Neves, Bairro Capucho, Aracaju-se)
}

\begin{abstract}
Introdução - A ileostomia é um procedimento cirúrgico de exteriorização do intestino delgado através da parede abdominal. Fica localizado no quadrante inferior direito e não há presença de um esfíncter que controle voluntariamente a evacuação, sendo necessário um kit coletor para armazenar o conteúdo. Dependendo da etiologia da doença, são classificados quanto ao tempo de permanência em definitivos ou temporários. Quanto as características da consistência são eliminações líquidas, com odor forte e em grande quantidade. A equipe de enfermagem precisa está consciente do tipo de ostomia, para assim, atuar minimizando complicações na manipulação do kit de ostomia. As ações educativas realizadas nas instituições faz com que haja uma boa qualidade no atendimento, refletindo em redução de tempo de permanência e gastos com insumos hospitalares. As capacitações tem melhorado muito a assistência e enfermagem ao paciente ostomizado e especificamente ao paciente portador de ileostomia. Complicações como dermatites são comuns em pacientes portadores de ileostomia. Isso porque, o efluente da eliminação é muito ácido, fazendo com que, a pele periostomal fique comprometido quando o kit não for bem adaptado no estoma. Quando os cuidados e as orientações à família são realizados de forma correta, observasse uma redução importante nas complicações de adesão do kit de ostomia. Sabe-se também que as ações educativas voltados para ostomias, faz a equipe de enfermagem entender cada estoma e assim atuar positivamente combatendo as complicações decorrentes na manipulação do kit. Objetivo - Mostrar que as capacitações da equipe de enfermagem sobre os cuidados com as ileostomia, e uma adequada adesão do kit, reduz as complicações na pele. Método - Trata-se de um estudo do tipo exploratório, com abordagem quantitativa, realizado nas planilhas de dados da Comissão de pele do hospital de urgência de Sergipe de janeiro a dezembro de e 2018 . As capacitações foram em todo o ano de 2018 . Resultado - No total de 51 pacientes ileostomizados, as complicações decorrentes de adesão do kit foram observados em 5 pacientes. Uma média muito boa para esse tipo de ostomia de acordo com as literaturas. Conclusão - Diante do exposto, fica evidente que as capacitações da equipe de enfermagem, voltado aos cuidados com as ostomias, e especificamente a ileostomia, foram de muita importância para a redução das complicações de adesão dos dispositivos de coleta. Ficou evidente que com as ações educativas na instituições voltadas para qualificação dos cuidados prestados aos pacientes ilesotomizados, melhorou a assistência voltada a esses pacientes.
\end{abstract}

Keywords: ESTOMATERAPIA, CUIDADOS DE ENFERMAGEM, ILEOSTOMIA, COMPLICAÇÕES DE ADESÃO DO KIT, CAPACITAÇÃO DA EQUIPE DE ENFERMAGEM

\section{Referências Bibliográficas}

1 - AGUIAR, E.S. S. et al. Complicações do Estoma e Pele Periestoma em Pacientes com Estomas Intestinais. Revista Estima. v.9, n.2, 2011. Disponível em:. Acesso em: 10 de agosto de 2016. 2 -BORGES,E.L.DOMANSKY,R.T. Manual para Prevenção de Lesões de Pele. Editora Rubio,Rio de Janeiro,2012. 3 - - GEOVANINI, T. Tratado de feridas e curativos: enfoque multiprofissional. São Paulo: Rideel, 2014. 4 - MALAGUTTI, W. Feridas; Conceito e Atualidades. Editora Martinari, São Paulo,2014. 5 - - SACONATO,R.A.et al.Feridas e Estomas: uma abordagem interdisciplinar. Editora Limar,São Paulo,2015. 


\title{
ANÁLISE DA PREVALÊNCIA DE CIRURGIAS REALIZADAS PARA A CONFECÇÃO DE ESTOMIAS DIGESTIVAS EM UM HOSPITAL PÚBLICO NO INTERIOR DA AMAZÔNIA
}

\author{
Author(s): INGRID DA SILVA LEITE ${ }^{1}$, Carla Sousa da Silva ${ }^{2}$, Douglas Eduardo Santos Avelar ${ }^{2}$, Júlya \\ Robert de Oliveira Azevedo ${ }^{2}$, Luan Gomes dos Santos ${ }^{2}$ \\ Institution(s) ${ }^{1}$ UNB - Universidade de Brasília (UnB - Faculdade de Ciências de Saúde - Asa Norte, Brasília - \\ DF, 70910-900), ${ }^{2}$ UNAMA - Unama Centro Universitário da Amazônia ( R. Rosa Vermelha, 335 - \\ Aeroporto Velho, Santarém - PA, 68010-200)
}

\begin{abstract}
INTRODUÇÃO: Estomia é a abertura de uma nova boca confeccionada a partir de procedimentos cirúrgicos, afim de exteriorizar vísceras ocas do corpo humano3. Os tratamentos cirúrgicos que resultam em estomias estão atrelados ao trato gastrointestinal e geniturinário, realizando atividades de desvio de excretas, descompressões e alimentação1. O auxílio terapêutico que os estomas proporcionam são muito consistentes, entretanto é possível que venham ocorrer complicações2. O profissional enfermeiro exerce papel primordial frente a necessidade do paciente estomizado, uma vez que este é um profissional facilitador do processo de transição de saúde-doença1. OBJETIVO: identificar e analisar a prevalência de cirurgias realizadas para a confecção de estomas digestivas em pacientes atendidos em um hospital público na Amazônia no ano de 2018. METÓDOS: Pesquisa documental com abordagem quantitativa, realizada no Hospital Regional do Baixo Amazonas entre janeiro a dezembro de 2018, a partir do fornecimento de dados públicos de indicadores de cirurgia pelo departamento de ensino e pesquisa. RESULTADOS: Verificou-se que no decorrer de todo o ano de 2018, foram realizados 61 procedimentos para a confecção de uma estomia digestiva, dos quais 29 (47,54\%) foram estomias digestivas de eliminação e $32(52,45 \%)$ foram estomias digestivas de alimentação. Em uma análise mensal, os meses de janeiro e março revelaram maior índice de confecção de estomias com 11 (18,03\%) procedimentos cada, sendo que em ambos houveram maiores registros de estomias digestivas para alimentação com 7 e 9 casos respectivamente. Quanto aos demais meses, fevereiro e abril tiveram $6(9,83 \%)$ cirurgias cada, sendo que no primeiro houve prevalência de estomias digestivas para alimentação com 4 casos, em contraposto ao segundo mês com prevalência de estomias digestivas para eliminação com 4 casos; em maio houveram 9 (14,75\%) procedimentos, 4 para eliminação e 5 para alimentação; em junho foram realizados $5(8,19 \%)$ procedimentos, com apenas 1 para eliminação; nos meses de julho, setembro, outubro, novembro e dezembro realizaram-se $2(3,27 \%)$ procedimento ao mês, sendo que todos foram exclusivamente para eliminação, e quanto ao mês de agosto, houveram $3(4,91 \%)$ procedimentos, sendo 2 para eliminação e 1 para alimentação. Do total, houve prevalência de pacientes do sexo masculino com $34(55,73 \%)$ casos, com faixa etária média de idade de 48 anos para esse público e 49 anos para o feminino. Dos procedimentos realizados, 34 (55,73\%) foram em pacientes oncológicos, seguido de $16(26,22 \%$ geral e $11(18,03)$ de cunho pediátrico. Os procedimentos para fins de eliminação, se deram exclusivamente por colostomias, já dentre as de alimentação, houveram 9 jejunostomias, e 23 gastrostomias. Conclusões: Constatou-se uma quantidade significativa de confecções de ostomias no ano de 2018, desta forma, verificou-se que houve maior incidência de procedimentos para realização de estomias digestivas para alimentação, com prevalência de indivíduos do sexo masculino. É fundamental que a equipe de saúde esteja devidamente preparada para atender os riscos cirúrgicos envolvidos no transoperatório, bem como apta para acompanhar e colaborar com o desenvolvimento da independência do autocuidado deste cliente.
\end{abstract}

Keywords: assistência integral à saúde, estomaterapia, procedimentos cirúrgicos operatórios

\section{Referências Bibliográficas}

1. OLIVEIRA, I. V. et al. Cuidados e saúde em pacientes estomizados. Revista Brasileira em Promoção da Saúde. Goiânia (GO). v. 31, n. 2 p. 01-09, abr. - jun., 2018. Disponível em: http://pesquisa.bvsalud.org/portal/resource/pt/biblio-906970. Acesso em: 15 de abril de 2019. 2. SILVA, C. R. R. et al. Competência para o autocuidado na fase pré-operatória da pessoa com estoma de eliminação intestinal. Revista de Enfermagem referência. Porto (PT). v. 4, n. 18, p. 39-50, jul. - set., 2018. Disponível em: https://doi.org/10.12707/RIV18026. Acesso em: 10 de fev. de 2019. 3. WALL, S.S.; SANTOS, C. P. Reinserção social da pessoa ostomizada. Revista da Mostra de Trabalhos de Conclusão de Curso. Bagé (RS). v. 1, n. 1, p. 14-15, jan., 2017. Disponível em: trabalhos.congrega.urcamp.edu.br. Acesso em: 10 de fev. de 2019. 


\title{
PERFIL DAS CIRURGIAS PARA CONFECÇÃO DE ESTOMIAS DIGESTIVAS DE ALIMENTAÇÃO REALIZADAS EM UM HOSPITAL DE ENSINO NO MUNICÍPIO DE SANTARÉM NO PARÁ
}

\author{
Author(s): INGRID DA SILVA LEITE ${ }^{1}$, Carla Sousa da Silva ${ }^{2}$, Douglas Eduardo Santos Avelar ${ }^{2}$, Júlya \\ Robert de Oliveira Azevedo ${ }^{2}$, Luan Gomes dos Santos ${ }^{2}$ \\ Institution(s) ${ }^{1}$ UNB - Universidade de Brasília (UnB - Faculdade de Ciências de Saúde - Asa Norte, Brasília - \\ DF, 70910-900), ${ }^{2}$ UNAMA - Unama Centro Universitário da Amazônia ( R. Rosa Vermelha, 335 - \\ Aeroporto Velho, Santarém - PA, 68010-200)
}

\begin{abstract}
INTRODUÇÃO: a estomia é conceituada como uma abertura de cunho cirúrgico com fins de eliminação ou comunicação, podendo ser uma estomia digestiva ou urinaria, cuja primeira pode ser, ainda, de eliminação ou alimentação1. Inúmeras são as patologias que impossibilitam o paciente de uma alimentação oral por tempo prolongado, portanto opta-se pela confecção de gastrostomias ou jejunostomias em bloco operário2. A enfermagem tem um papel fundamental no processo de cuidar, logo é imprescindível que está dispenda de conhecimentos especializados, garantindo um atendimento de qualidade e integral3. OBJETIVO: descrever o perfil das cirurgias realizadas para a confecção de uma estomia digestiva de alimentação no ano de 2018 em um hospital de ensino no Pará. METODOLOGIA: Pesquisa documental, de caráter exploratório e retrospectivo, com abordagem quantitativa, realizada no Hospital Regional do Baixo Amazonas - Santarém (Pará) no período de janeiro a dezembro de 2018, após autorização do departamento de ensino e pesquisa. RESULTADOS E DISCUSSÃO: No ano de 2018 foram realizadas, ao todo, 32 estomias digestivas de alimentação em bloco cirúrgico, sendo $7(21,87 \%)$ no mês de janeiro, $4(12,5 \%)$ no mês de fevereiro, $9(28,12 \%)$ no mês de março, $2(6,25 \%)$ no mês de abril, $5(15,62 \%)$ no mês de maio, $4(12,5 \%)$ no mês de junho e $1(3,12 \%)$ caso no mês de agosto, sem registros nos meses de julho, setembro, outubro, novembro e dezembro. Do total, houve prevalência de paciente do sexo masculino com 22 $(68,75 \%)$ casos, comparado ao do sexo feminino com $10(31,25 \%)$ casos. A faixa etária média se deu com 31 anos para mulheres e 47 anos para homens. Dos procedimentos realizados $23(71,87 \%)$ formam gastrostomias e $9(28,12 \%)$ jejunostomias; $10(31,25 \%)$ procedimentos se deram por urgência e $22(68,75 \%)$ de forma eletiva; 8 fizeram parte de especialidade oncológica, $14(43,75 \%)$ da geral e $10(31,25 \%)$ pediátricas. A respeito do potencial de contaminação, 15 $(46,87 \%)$ foram classificadas como potencialmente contaminadas e $17(53,12 \%)$ contaminadas, além de 29 (90,62\%) procedimento de médio porte e $3(9,37 \%)$ de grande porte. CONCLUSÃO: Constatou-se uma quantidade significativa de paciente submetidos a realização de estomias digestivas para alimentação, desta forma, verificou-se maior incidência de procedimento no mês de março com $9(28,12 \%)$ casos, comparado aos outros meses. Houve prevalência de pacientes do sexo masculino; de cirurgias do tipo gastrostomia com $23(71,87 \%)$ casos; procedimentos por via eletiva com $22(68,75 \%)$ casos; da especialidade geral com $14(43,75 \%)$ casos; contaminadas com $17(53,12 \%)$ e de médio porte com $29(90,62 \%)$.
\end{abstract}

Keywords: assistência integral à saúde, estomaterapia, jejunostomia

\section{Referências Bibliográficas}

1. ALÁRIO, J. B.; KAMADA, C. L. Infecções bacterianas mais frequentes em pacientes oncológicos após ostomia gastrointestinal. Revista Científica Multidisciplinar Núcleo do Conhecimento. Rio de Janeiro (RJ). v. 8, n. 13, p. 32-60, ago., 2018. Disponível em: https://www.nucleodoconhecimento.com.br/saude/infeccoes-bacterianas. Acesso em: 15 de fevereiro de 2019. 2. MEDEIROS, L. P.et al. Atividades da intervenção de enfermagem "cuidados com ostomia". Revista de Enfermagem UFPE On Line. Recife (PE). v. 11, n. 12, p. 5417-5426, dez., 2017. Disponível em: http://doi.org/10.5205/19818663-vlli12a22899p5417-5426-2017. Acesso em: 14 de fevereiro de 2019. 3. MIRANDA, L. S. G.; CARVALHO, A. A. S.; PAZ, E. P. A. Qualidade de vidada pessoa estomizada: relação com os cuidados prestados na consulta de enfermagem de estomaterapia. Escola Anna Nery. Rio de Janeiro (RJ). v. 22, n. 4, p. 1-9, jul., 2018. Disponível em: www.scielo.br/EAN. Acesso em: 14 de fevereiro de 2019. 


\title{
PERFIL SOCIODEMOGRÁFICO DE PACIENTES COM ESTOMIA DEFINITIVA POR CÂNCER COLORRETAL: INTERFERÊNCIA NA QUALIDADE DE VIDA
}

\author{
Author(s): Daniele Brito Valladão Maciel ${ }^{2}$, Mauro Leonardo Caldeira dos Santos ${ }^{2}$, Norma Valeria Dantas de \\ Oliveira Souza ${ }^{3}$, Patricia dos Santos Claro Fully ${ }^{2}$, Flavia Halasz ${ }^{2}$, Hayana Pereira Leal ${ }^{3}$ \\ Institution(s) ${ }^{2}$ UFF - Universidade Federal Fluminense (Rua Dr Celestino, 74 centro Niterói RJ), ${ }^{3}$ UERJ - \\ Universidade Estadual do Rio de Janeiro (Boulevard 28 de setembro, 157 Vila Isabel-RJ)
}

\begin{abstract}
O carcinoma colorretal é a terceira causa de neoplasia maligna mais frequente em homens e a segunda mais frequente em mulheres, perdendo apenas para o câncer de mama. No Brasil, esse é um dos tipos de neoplasias que mais aumentam na população e segundo o Instituto Nacional do Câncer José de Alencar (INCA) estimam-se 17.380 casos novos de câncer de cólon e reto em homens e 18.980 em mulheres para cada ano do biênio 2018-2019. Esses valores correspondem a um risco estimado de 16,83 casos novos a cada 100 mil homens e 17,90 para cada 100 mil mulheres 1 . É uma das causas principais de cirurgias para realização de estomias, em que consiste na ressecção cirúrgica do local afetado. $O$ acometimento de uma parte do intestino seja ele delgado ou grosso faz com que seja necessário desviar o trânsito normal das eliminações fisiológicas2. A realização de um estoma pode ser temporária ou definitiva, dependendo das características e extensão da doença que gerou a confecção da mesma. Porém, independente do tempo de permanência, o estoma é um procedimento extremamente invasivo, que pode trazer constrangimentos de ordem psicossociais, físicas e espirituais, repercutindo assim, em transtornos nas relações sociais e familiares3. Diante de tudo isso, acredita-se que a qualidade de vida seja alterada em decorrência da necessidade de um estoma, seja ele de caráter definitivo ou provisório e que essa qualidade de vida seja ainda pior quando se trata de um paciente portador de estoma por câncer colorretal, tendo em vista as dificuldades que os pacientes precisam enfrentar, não somente o diagnóstico de câncer, que traz consigo uma gama de sentimentos como dor, incertezas, insegurança quanto ao futuro, sofrimento, mitos relacionados a ele como a possibilidade de morte eminente. E ainda ter que conviver com um estoma e todas as repercussões advindas deste4. Estas mudanças tornam a confecção da estomia intestinal de eliminação um processo traumático e agressivo que reduz significativamente a qualidade de vida $(\mathrm{QV})$ da pessoa estomizada5.Objetivo: Este estudo teve como objetivo descrever o perfil sociodemográfico de pessoas com estomias definitivas acometidas pelo câncer colorretal de um Município do Rio de Janeiro e associá-lo à qualidade de vida. Método: Trata-se de um estudo descritivo, transversal, com abordagem quantitativa, realizado no período de janeiro a abril de 2018, no Pólo de Ostomizados I do Município de Itaboraí. Os dados foram coletados mediante questionário estruturado e a análise dos dados foi realizada com o software Minitab versão 18. A pesquisa foi aprovada pelo Comitê de Ética em Pesquisa do Hospital Universitário Antônio Pedro sob CAEE: 71086117.6.0000.5243. 2.413.516. Resultados: De 83 pessoas cadastradas, somente 35 participaram. Identificou-se a predominância do sexo masculino, casados, estomia do tipo colostomia, tempo de estomia de 1-3 anos, idade entre 50 e 69 anos. Conclusão: Esse trabalho possibilitou conhecermos a população de estomizados acometidos pelo câncer colorretal levando assim uma melhor compreensão sobre pessoas com estomias definitivas com o intuito de poder orientar para uma melhor assistência de enfermagem.
\end{abstract}

Keywords: Estomia, Perfil de saúde, Qualidade de vida, Estomaterapia

\section{Referências Bibliográficas}

1. Instituto Nacional de Câncer José Alencar Gomes da Silva. Coordenação de Prevenção e Vigilância. Estimativa 2018: incidência de câncer no Brasil. [Internet]. Rio de Janeiro: INCA; 2017 [acesso em 12 dez 2017]. Disponível em: http://www1.inca.gov.br/estimativa/2018/estimativa-2018.pdf 2. Vieira LM, Ribeiro BNO, Gatti MAN, Simeão, SFAP, Conti MHS, Vitta A. Câncer Colorretal: entre o sofrimento e o repensar da vida. Saúde em debate [Internet]. 2013 [acesso em 04 jan 2018]; 37(97):261-269. Disponível em: https://doi.org/10.1590/s0103-11042013000200008 3. Souza MJ. Qualidade de vida de pessoas ostomizadas [dissertação]. Bahia: Universidade Federal do Recôncavo da Bahia; 2015. 4. Cascais AFMV, Martini JG, Almeida PJS. O impacto da ostomia no processo de viver humano. Texto Contexto - Enferm. [Internet]. 2007 [acesso em 07 jan 2018]; 16(1):163-167. Disponível em: https://doi.org/10.1590/s0104-07072007000100021 5. Silva CRDT, Andrade EMLR, Luz MHBA, Andrade JX, Silva GRF. Qualidade de vida de pessoas com estomias intestinais de eliminação. Acta Paul. Enferm. [Internet]. 2017 [acesso em 07 jan 2018]; 30(2):144-151. Disponível em: https://doi.org/10.1590/19820194201700023 


\title{
CUIDADOS DE ENFERMAGEM À PESSOA COM FÍSTULAS ENTEROCUTÂNEAS: REVISÃO INTEGRATIVA
}

\author{
ANDRÉIA CAVALCANTE DE SOUZA ${ }^{1}$, DANIELA TINTI MOREIRA BORGES ${ }^{1}$, SILMARA \\ Author(s): JORGE GARCIA ${ }^{1}$, THUANY ARAUJO LEMES ${ }^{1}$, VANESSA TATIANE APPEL ${ }^{1}$, JOÃO \\ JÚNIOR GOMES ${ }^{1}$ \\ Institution(s) ${ }^{1}$ FAMERP - Faculdade de Medicina de São José do Rio Preto (Av. Brigadeiro Faria Lima, 5416 - \\ Vila São Pedro - 15090-000 São José do Rio Pre)
}

\begin{abstract}
INTRODUÇÃO: Fístulas enterocutâneas são definidas como comunicação anormal entre o trato gastrointestinal, vísceras ocas ou órgãos da cavidade abdominal e a superfície cutânea. Os fatores de risco para o desenvolvimento das fístulas incluem neoplasia maligna, imunodepressão, hipertensão arterial, diabetes mellitus, idade avançada, procedimento cirúrgico realizado durante processo infeccioso e doença inflamatória intestinal. O tratamento das fístulas enterocutâneas possui alto grau de complexidade, demandando cuidados de uma equipe multidisciplinar. Considerando o enfermeiro como membro desta equipe multidisciplinar, é de fundamental importância que suas ações garantam a qualidade do cuidado. OBJETIVO: Identificar as ações específicas realizadas pelo enfermeiro no cuidado com as fístulas enterocutâneas. MATERIAL E MÉTODOS: Trata-se de uma revisão integrativa da literatura, buscando responder à questão norteadora: "Quais são os cuidados de enfermagem à pessoa com fístula enterocutânea? " Foi realizada uma busca de literatura nas bases de dados PubMed, Scielo e LILACS no mês de abril de 2019 utilizando as palavras-chave: fístula intestinal e cuidados de enfermagem; idiomas português, inglês e espanhol; disponíveis na íntegra; publicados nos últimos 10 anos em adultos. Foram excluídos os estudos que não abordavam as fístulas enterocutâneas em adultos, estudos e trabalhos de conclusão de curso e artigos que não abordavam os cuidados de enfermagem. RESULTADOS: Foram selecionados 10 artigos, na análise destes, predominaram estudos internacionais com nível de evidencia 4 de modo que $10 \%$ dos estudos buscaram identificar o perfil do enfermeiro no atendimento às colostomias e suas complicações, entre elas a fístula enterocutânea, demonstrando que $50 \%$ dos enfermeiros estavam aptos para realizarem os cuidados destes pacientes; $10 \%$ descrevem o desenvolvimento de um guia para orientar enfermeiros quanto aos cuidados com fístulas enterocutâneas. $40 \%$ dos estudos encontrados abordam sobre o uso da pressão negativa para o tratamento e $40 \%$ dos estudos afirmam que são necessários conhecimentos e entendimentos dos profissionais de saúde, em especial enfermeiros, acerca dos princípios de tratamento das feridas, incluindo o gerenciamento da dor e irritação causados pelas fístulas enterocutâneas. Os estudos reforçam que o tratamento das fístulas enterocutâneas representam um desafio para toda a equipe de saúde. CONCLUSÃO: O estudo possibilitou identificar, entre as ações do enfermeiro, o uso da terapia por pressão negativa como uma das opções mais utilizadas; a importância do gerenciamento da dor e do conhecimento quanto aos princípios gerais no tratamento de feridas também foram identificadas. Ainda que apontadas em um percentual menor a necessidade de orientação e difusão do conhecimento também merecem destaque pela relevância na qualidade do cuidado.
\end{abstract}

\section{Keywords: CUIDADOS DE ENFERMAGEM, CICATRIZAÇÃO, ESTOMATERAPIA, FÍSTULA INTESTINAL}

\section{Referências Bibliográficas}

1 Gutiérrez UC, Jasso OS, Maza JM. Fístulas enterocutáneas: Actualidades sobre diagnóstico y tratamiento. Ver Mex da Digestive Surgery 2017; 6 (3): 120-126. 2 Wercka J, et al. Perfil epidemiológico, incidência e desfecho dos pacientes com fístula abdominal pós-operatória. Rev. Col. Bras. Cir. 2016, 43(2): 117-123. 3 Talé LF, Sinibaldi CR, Ortz I, et al. O. Guía de Manejo para las Fístulas Enterocutáneas. Rev Guatem Cir 2015, 19: 73-84. 4 Mcnaughton V, Brown J, Hoeflok J, et al. Summary of best practice recommendations for management of enterocutaneous fistulae from the Canadian Association for Enterostomal Therapy ECF Best Practice Recommendations Panel. J Wound Ostomy Continence Nurs 2010, 37(2): 84-173. 5 Reider KE. Fistula Isolation and the Use of Negative Pressure to Promote Wound Healing: A Case Study.J Wound Ostomy Continence Nurs 2017, 44(3): 293-298. 


\title{
Cuidados de enfermagem relacionados às complicações da pessoa com colostomia: revisão integrativa
}

\author{
Author(s): Daniele Brito Valladão Maciel ${ }^{1}$, Lidia Pignaton Soares ${ }^{1}$, Daniella Cristina Julio Lima ${ }^{1}$, Fernanda \\ Brito Bastos ${ }^{1}$, Magda dos Santos Reis Machado ${ }^{1}$ \\ Institution(s) ${ }^{1}$ UERJ - Universidade Estadual do Rio de Janeiro (Boulevard 28 de setembro, 157 Vila Isabel-RJ)
}

\begin{abstract}
A confecção de um estoma visa criar uma abertura na pele, através da qual será construído um novo trajeto que comunica um órgão interno oco a uma superfície do corpo. Dentre os tipos de estomas, há variações quanto à localização e finalidade, sendo os mais comuns de origem intestinal e urinária, com maior incidência as colostomias, uma vez que sua maioria está associada ao câncer colorretal1. Esta abordagem inclui um procedimento médico-cirúrgico, porém as atribuições da enfermagem no acompanhamento do paciente e sua família são de grande relevância. Este cuidado perpassa o período transoperatório, desde o preparo para a cirurgia, até o manejo e o cuidado com o estoma, de forma a evitar complicações preveníveis e favorecer a recuperação e a reabilitação da pessoa estomizada2. As complicações dos estomas apresentam uma incidência variável e podem ter vários fatores causadores, como: o posicionamento do estoma, inadaptação do sistema e irritação da pele periestomal 3,4,5. Estas complicações podem ser identificadas precocemente, desde o período intra-operatório ou pós-operatório imediato5. A colostomia gera naturalmente algumas restrições corporais e impacta em mudanças nos hábitos de vida, surgindo necessidades específicas ao paciente. Porém, também podem trazer grandes prejuízos em casos de complicações. Dessa forma, é imprescindível que a enfermeira tenha conhecimento de anatomia, fisiopatologia e técnica cirúrgica, para proporcionar o devido preparo físico e psicológico do paciente6. Objetivos: Identificar na literatura as publicações científicas de enfermeiros acerca do cuidado relacionados às complicações da pessoa com colostomia; e analisar os artigos obtidos sobre a temática para a discussão acerca do cuidado especializado em enfermagem em Estomaterapia. Método: Revisão integrativa da literatura incluindo artigos publicados por enfermeiros, no período de 2015 a 2018, em periódicos indexados na Biblioteca Virtual de Saúde e que respondam à seguinte questão norteadora: $O$ que tem sido produzido pela enfermagem acerca dos cuidados prestados às pessoas com colostomia, especificamente quanto ao manejo de complicações relacionadas? Estabeleceram-se como critérios de inclusão artigos em Português, Espanhol e Inglês, disponíveis na íntegra e gratuitamente. O operador booleano AND foi utilizado junto aos descritores "Colostomia", "Cuidados de Enfermagem", "Complicações PósOperatórias" e a palavra-chave "Estomaterapia", a partir do método integrado. Resultados: Doze artigos responderam à questão norteadora, e foram agrupados em 3 categorias: qualidade de vida e percepção do estomizado, perfil sociodemográfico e diagnósticos de Enfermagem. Conclusão: Os estudos destacaram a escassez de produções científicas sobre a temática, constituindo uma importante lacuna. Identificou-se a necessidade de explorar mais aspectos relacionados às complicações em colostomias, com o intuito de ampliar o conhecimento dos profissionais de enfermagem e facilitar a criação de estratégias eficazes para manejo das complicações apresentadas pela pessoa com colostomia.
\end{abstract}

Keywords: Colostomia, Cuidados de Enfermagem, Complicações Pós-Operatórias, Estomaterapia

\section{Referências Bibliográficas}

1. Campos MGCA, Sousa ATO, Vasconcelos JMB, Lucena SAP, Gomes SKA. Feridas complexas e estomias: Aspectos preventivos e manejo clínico. João Pessoa: Ideia, 2016. 398p. 2. 2. Cowell, J. C. and J. Beitz, Suevery of wound, ostomy and continence (WOC) nurse dinicians on stomal and peristomal complications: a content validation study. J Wound Ostomy Continence Nurs,2007.34(1):p.57-69. 3. 3. Shellito, P . C., Complications stoma surgery. Dis Colon Rectum, 1998. 41(12): p.1562-72. 4. 4. Shabbir, J. and D.C. Britton, Stoma Complications: A literature overview. Colorectal Dis,2009. 5. 5. Butler, D.L., Early post operative complications following ostomy surgery:a review. J Wound Ostomy Continence Nurs, 2009. 36(5): p 513-9;quiz 520-1. 6. Silva ES, Castro DS, Garcia TR, Romero WG, Primo CC. Tecnologia do cuidado à pessoa com colostomia: diagnósticos e intervenções de enfermagem. REME - Rev Min Enferm. 2016; [Citado em]; 20 : e931. 


\title{
CARACTERIZAÇÃO SOCIODEMOGRÁFICA E CLÍNICA DE INDIVÍDUOS COM QUEIXAS COLORRETAIS EM UNIDADE SAÚDE DA FAMÍLIA
}

\author{
Lívia Modolo Martins ${ }^{1}$, Vanessa Damiana Menis Sasaki ${ }^{1}$, André Aparecido da Silva Teles ${ }^{1}$, \\ Author(s): $\quad$ Tatiana Mara da Silva Russo ${ }^{1}$, Camila Maria Silva Paraizo Horvath ${ }^{1}$, Lorena Alves Pantoni ${ }^{1}$, \\ Janderson Cleiton Aguiar ${ }^{1}$, Helena Megumi Sonobe ${ }^{1}$ \\ Institution(s) ${ }^{1}$ EERP-USP - ESCOLA DE ENFERMAGEM DE RIBEIRÃO PRETO - EERP-USP (R. Prof. \\ Hélio Lourenço, 3900 - Vila Monte Alegre, Ribeirão Preto - SP)
}

\begin{abstract}
Introdução: Na Atenção Primária à Saúde (APS) torna-se fundamental a identificação de indivíduos que buscam assistência por queixas colorretais para a implementação de ações preventivas, pois estas podem indicar o desenvolvimento de doenças, que tem constituído um desafio epidemiológico. Objetivo: Caracterizar o perfil sociodemográfico e clínico de indivíduos em atendimento por queixas colorretais, em uma Unidade de Saúde da Família no interior paulista. Material e Método: Estudo descritivo quantitativo com participação de 55 indivíduos, acima de 18 anos, com queixas colorretais, atendidos entre 2017 e 2018, em uma Unidade de Saúde da Família do interior paulista. Elaborou-se instrumento de coleta de dados, mediante revisão de literatura, que contempla informações sociodemográficas, de hábitos de vida, clínicas e seguimento no sistema público de saúde. O projeto foi aprovado pelo Comitê de Ética da instituição proponente (CEP EERP 210/2018), com coleta de dados entre abril e julho de 2019, cuja análise descritiva foi realizada com o programa SPSS, versão 22.0. Resultados: Do total de 55 participantes, predominou sexo feminino (60\%), média de idade de 65,9 anos; cor branca $(81,8 \%)$ casada $(54,5 \%)$; média de 8,2 anos de estudo, aposentada $(38,2 \%)$; renda individual média de $R \$$ 1996,00; e renda familiar média de $\mathrm{R} \$ 3.282,42$. Identificou-se que $78,2 \%$ dos entrevistados estavam com índice de massa corporal (IMC) acima do considerado saudável, além de fatores de risco para o desenvolvimento de doenças crônicas intestinais como sedentarismo (70,9\%), tabagismo (47,3\%); etilismo (54,5\%); consumo de carne $(65,5 \%)$ e embutidos $(38,2 \%)$; além de $54,5 \%$ apresentarem alguma queixa colorretal ao buscarem assistência na APS. Houve encaminhamento para serviços secundários de Coloproctologia ou Colonoscopia, em $58,2 \%$ por demanda profissional da APS para rastreamento de doenças crônicas intestinais considerando-se a queixa colorretal ou exame de sangue oculto nas fezes positivo ou por se enquadrarem em critérios de rastreamento para doenças crônicas colorretais (Neoplasia colorretal, Doença de Crohn e Retocolite ulcerativa); $23,6 \%$ por sangramento e 9,1\% por demanda individual. Dentre as principais queixas colorretais dos participantes, verificou-se o sangramento nas fezes $(32,7 \%)$ e a constipação intestinal $(27,3 \%)$. Conclusões: A caracterização sociodemográfica e clínica dos participantes deste estudo, atendidos em uma Unidade de Saúde da Família retrata a demanda de necessidade de intervenções preventivas para a redução do adoecimento colorretal e de outras condições crônicas associadas ao estilo de vida. Especificamente, em relação às doenças colorretais, as intervenções na APS poderão favorecer a minimização de fatores de risco para o desenvolvimento de doenças como neoplasias colorretais ou doenças inflamatórias intestinais, que quando do seu diagnóstico, encontra-se em fase avançada, gerando estomia intestinal definitiva. Desta forma, é possível modificar a lógica hospitalocêntrica na assistência à saúde.
\end{abstract}

Keywords: Perfil de Saúde, Doenças não transmissíveis, Estilo de Vida, Prevenção primária., Estomaterapia

\section{Referências Bibliográficas}

Hines R, Markossian, T, Johnson, A. et al. Geographic residency status and census tract socioeconomic status as determinants of colorectal cancer outcomes. Am J Public Health. 2014; 104 (3): 63-71. Oliveira R C, Rêgo M A. Mortality risk of colorectal cancer in Brazil from 1980 to 2013. Arq. Gastroenterol. 2016; 53(2): 76-83. Brasil. Ministério da Saúde. Secretaria de Atenção à Saúde. Departamento de Atenção Básica. Rastreamento / Ministério da Saúde, Secretaria de Atenção à Saúde, Departamento de Atenção Básica. - Brasília: Ministério da Saúde. 2010: 95 p.: - (Série A. Normas e Manuais Técnicos) (Cadernos de Atenção Primária, n. 29). Brasil. Ministério da Saúde. Secretaria de Atenção à Saúde. Protocolos clínicos e diretrizes terapêuticas: volume 3 / Ministério da Saúde, Secretaria de Atenção à Saúde. Brasília: Ministério da Saúde. 2014: 604 p.: il. 


\title{
A importância do enfermeiro como mediador do cuidado a pacientes com estomias e seu familiar cuidador
}

\author{
Author(s): Fernanda Reis Rodrigues ${ }^{1}$ \\ Institution(s) ${ }^{1}$ ESAP - Institudo de Estudos Avançados e Pós Graduação (R. Quintino Bocaiúva, 812)
}

\begin{abstract}
As estomias tem origem grega a partir do étimo stoma, que expõe a ideia de "boca" e consiste em uma técnica de abertura de um órgão por meio de um ato cirúrgico, que passa a ter contato com o meio externo para eliminações de secreções. Objetiva-se a substituir as funções de drenar fluidos e gases do órgão que está afetado. Os pacientes estomizados se deparam com grandes mudanças na estética, dificuldade de aceitação e convívio, implicando psicologicamente e socialmente na vida deste indivíduo. Está incluso nesse contexto, também os familiares ou em especial os familiares cuidadores. Sendo assim, com esse trabalho buscou-se a importância da enfermagem no preparo e adaptação do paciente e familiar, que deve ter início na internação, por meio de um plano de alta ou por cartilhas, encorajando o autocuidado. Para tanto, foi realizado um estudo bibliográfico, do tipo revisão de literatura, através de um levantamento de dados na Biblioteca Científica Eletrônica Online (SCIELO), na Literatura Latino-americana e do Caribe em Ciências da Saúde (LILACS) e no Banco de Dados em Enfermagem (BDENF). Selecionados 7 artigos após leitura criteriosa do conteúdo. Verificando que o cuidado e auxílio dos profissionais enfermeiros aos pacientes e familiares, possibilita maior aceitação da estomia, diminui os medos e angústias e dificulta o retorno do paciente ao ambiente hospitalar ocasionado por complicações e falta de cuidados. Observa-se também a necessidade de novas e mais pesquisas com a temática, e nos faz concluir que o processo de cuidado domiciliar começa no ambiente hospitalar com o plano de alta.
\end{abstract}

Keywords: Cuidados de Enfermagem, Estomias, Estomaterapia, Enfermagem, Cuidado Domiciliar

\section{Referências Bibliográficas}

1. Brito LEÓ, Fé ÉM, Carvalho REFL de, Melo GAA, Pereira FGF. Plano de alta de enfermagem para estomizados intestinais. Rev enferm UFPE. 2019; 13: e239794. https://doi.org/10.5205/1981-8963.2019.239790. 2. Instituto Nacional de Câncer José Alencar Gomes da Silva -INCA. Cuidados com a sua estomia intestinais urinárias: orientações ao usuário [Cartilha elaborada pelo setor de Estomaterapia]. Rio de Janeiro: Inca; 2018. 20 p. 3. Moraes JT, Santos CF, Borges EL. Da formação à prática: a percepção de supervisores de enfermagem sobre os cuidados em estomias. Rev. Enferm UERJ, Rio de Janeiro, 2016; 24(2): e14733. 4. Nascentes CC, Moreira MC, Oliveira NVD de, Palasson RR, Ghelman LG, Souza MHN. Rede social no cuidado à pessoa estomizada por câncer colorretal. Rev. Enferm UFPE. 2019; 13: e239569. https://doi.org/10.5205/1981-8963.2019.239569. 5. Simon BS, Budó MD, Schimith MD, Garcia RP, Gomes TF, Carvalho SO. "Sempre ajudando em uma coisa ou outra": rede social da família da pessoa com estomia. Rev. Eletr. Enferm. 2015 abr./jun. 17(2): 370-8. 6. Souza JL, Gomes GC, Barros EJL. O cuidado à pessoa portadora de estomia: o papel do familiar cuidador. Rev. Enferm. UERJ, Rio de Janeiro, 2009 out/dez; 17(4): 550-5. 7. Souza JL, Gomes GC, Xavier DM, Alvarez SQ, Oliveira SM. O preparo do familiar para o cuidado à pessoa com estomia. Rev. Enferm. UFPE, Recife, 2019 mar; 7(1): 64956. 


\title{
CÂNCER COLORRETAL: EXPERIÊNCIA COM A ESTOMIA E O PROCESSO DE REABILITAÇÃO
}

\author{
Author(s): BRUNA RAFAELA LEITE DIAS ${ }^{2}$, ODENILCE VIEIRA PEREIRA ${ }^{2,1}$ \\ Institution(s) ${ }^{1}$ HUJBB - HOSPITAL JOÃO DE BARROS BARRETO (RUA DOS MUNDURUCUS, 4487 - \\ GUAMÁ), ${ }^{2}$ UFPA - UNIVERSIDADE FEDERAL DO PARÁ (RUA AUGUSTO CORREA Nº1 \\ - GUAMÁ)
}

\begin{abstract}
INTRODUÇÃO: O câncer colorretal abrange tumores que acometem um segmento do intestino grosso (o cólon) e o reto. Pode começar como um pólipo benigno na parede interna do intestino ou tornar-se maligno ao invadir os tecidos normais1. Nesse contexto, a cirurgia pode ser apontada como a principal escolha para o tratamento, havendo a remoção do tumor, do segmento comprometido do cólon ou do reto, e dos linfonodos adjacentes. Na maioria dos casos, os segmentos sadios podem ser interligados novamente. Na impossibilidade da anastomose, se faz necessária a confecção de uma estomia2. As pessoas submetidas à cirurgia para confecção de estomias intestinais enfrentam vários problemas de cunho físico, psicológico e social3. A adaptação dessas pessoas a uma nova forma de viver e a educação em saúde é fundamental para desenvolver a troca de saberes e práticas, estimulando a busca de soluções e evitando agravos e complicações não só quanto ao desenvolvimento das competências do indivíduo quanto ao autocuidado, como também às necessidades manifestadas4. OBJETIVO: Descrever experiências de pesșoas com câncer colorretal submetidas à estomia que influenciaram no processo de reabilitação. MATERIAL E MÉTODO: Recorte de Trabalho de Conclusão de Residência na área de oncologia, apresentado em fevereiro de 2019, para obtenção do título de especialista em oncologia. Trata-se de um estudo exploratório, descritivo, com abordagem qualitativa, desenvolvido nos meses de outubro e novembro de 2018, em um hospital universitário no município de Belém/PA. Os dados foram coletados por meio da técnica de entrevista semiestruturada e analisados por meio da análise de conteúdo proposta por Bardin. Foi conduzido de acordo com a Resolução 466/2012 do Conselho Nacional de Saúde (CNS), aprovado pelo CEP sob parecer no 2.876.150 HUJBB/UFPA. RESULTADOS: A maioria dos entrevistados vivenciou dificuldades ocasionadas talvez por desconhecimento e ou orientação inadequada, o que pode ter comprometido o processo de reabilitação. CONCLUSÕES: Concluiu-se ser primordial o preparo das pessoas com câncer colorretal diante da possibilidade de confecção da estomia, sendo necessário o envolvimento do enfermeiro como agente educador antes e após o procedimento cirúrgico, para reduzir as dificuldades dessas pessoas e facilitar a adaptação à sua nova condição de vida. PALAVRAS-CHAVE: Câncer colorretal. Estomaterapia. Reabilitação.
\end{abstract}

\section{Keywords: CANCER COLORRETAL, ESTOMATERAPIA, REABILITAÇÃO}

\section{Referências Bibliográficas}

REFERÊNCIAS 1. Brunner LS, Suddarth DS. Manual de enfermagem médico-cirúrgica. 13. ed. Rio de Janeiro: Guanabara Koogan; 2015. 2. Rolny P. The need for surgery after endoscopic treatment of colorectal neoplasms is the most important outcome criterion. Endoscopy. 2017;49(1):80-2. 3. Freire DA, Angelim RCM, Souza NR, Brandão BMGM, Torres KMS, Serrano SQ. Autoimagem e autocuidado na vivência de pacientes estomizados: o olhar da enfermagem. REME rev. min. enferm. 2017;21:1-7. 4. Wild CF, Favero NB, Salbego C, Vale MG, Silva JRP, Ramos TK. Educação em saúde com estomizados e seus familiares: possibilidade para melhor qualidade de vida. Rev Enferm UFSM. 2016;6(2):290-7. 


\title{
INVENTÁRIO DE ADAPTAÇÃO AO ESTOMA (OAI-23) : UMA APLICAÇÃO À REGIÃO NORTE DO BRASIL
}

\author{
Author(s): Regina Ribeiro Cunha ${ }^{1,2}$, Aloma Sena Soares ${ }^{2}$, Cassilene Oliveira da Silva ${ }^{2}$, Maria Samara Alves \\ da Silva ${ }^{1}$, Vera Lúcia Conceição de Gouveia Santos ${ }^{3}$, Edson Marcos Leal Soares Ramos ${ }^{1}$ \\ Institution(s) ${ }^{1}$ UFPA - Universidade Federal do Pará (Av. Augusto Corrêa,01. CEP 66075110. Belém, PA, \\ Brasil), ${ }^{2}$ UEPA - Universidade do Estado do Pará (Av. José Bonifácio, 1289. CEP 66065362. \\ Belém, PA, Brasil), ${ }^{3}$ EEUSP - Escola de Enfermagem da Universidade de São Paulo (Av. Dr. \\ Enéas Carvalho de Aguiar, 419. CEP 05403000. São Paulo,SP, Brasil)
}

\begin{abstract}
Introdução: A cirurgia geradora de estomia poderá levar a cura de um determinado agravo à saúde. Entretanto, para algumas pessoas poderá ser mais difícil aceitar a estomia, resultando em um processo de adaptação mais demorado, exigindo destas novas formas de autocuidado e enfrentamento de questões emocionais e físicas, devido a alteração da imagem corporal. Objetivo: Determinar o grau de adaptação a estomia de pessoas atendidas em um serviço de referência estadual na cidade de Belém, Pará, Brasil. Material e Método: Estudo descritivo-exploratório, transversal, realizado com pessoas com estomia de ambos os sexos, maiores de 18 anos, no período de junho de 2014 a fevereiro de 2016. A entrevista e a avaliação clínica dos participantes foram realizadas durante Consulta de Enfermagem em um serviço de referência especializado em Belém, PA, Brasil. Foi aplicado o Inventário de Adaptação ao Estoma (OAI-23). Os dados foram analisados de acordo com o cálculo do Ranking Médio (RM). O estudo atendeu as normas e aspectos éticos da pesquisa envolvendo seres humanos. Resultados: A pesquisa incluiu (135) pessoas com estomia, 63,7\% (86) são do sexo masculino e $36,3 \%$ (49) do sexo feminino e com $40 \%$ (54) com faixa etária entre 51 e 77 anos. A neoplasia foi a causa básica que gerou a estomia em 46,6\% (63). Quanto aos tipos de estomia, 37,1\% (50) eram ileostomia, 59,2\% (80) colostomia e 3,7\% (5) urostomia. Destes $97,0 \%$ (131) pessoas com estomia conseguiram responder o formulário OAI-23. A aceitação e a preocupação com a estomia foram reveladas entre os participantes deste estudo. A insegurança frente ao compromisso social e as dificuldades quanto a percepção da estomia, superação da doença e da cirurgia, contribuem para o sentimento de raiva por sua condição de saúde. Conclusão: Os resultados deste estudo permitem inferir que as pessoas com estomias apresentam grau moderado de adaptação ao revelarem aceitar sua estomia mesmo expressando preocupação, insegurança e raiva, questões que demandam orientações e acompanhamento durante o processo de adaptação à estomia e a sua condição de saúde.
\end{abstract}

Keywords: Adaptação, Ajustamento Social, Estomia , Estomaterapia

\section{Referências Bibliográficas}

1. Gautam S, Koirala S, Poudel A, Paudel D. Psychosocial adjustment among patients with ostomy; a survey in stoma clinics, Nepal. Nursing: Research and Reviews. 2016; 55(1):13-21. 2. Karadag A, Karabulut H, Baykara ZG, Harputlu D, Toyluk E, Ulusoy B et al. A prospective, multicentered study to assess social adjustment in patients with an intestinal stoma in Turkey. Ostomy Wound Manag. 2015; 61(10): 16-29. 3. Nascimento DCD, Chagas CC, Souza NVDDO, Marques GS, Rodrigues FR, Cunha CV et al. Experiência Cotidiana: a Visão da Pessoa com Estomia Intestinal. Revista Estima. 2016; 14(4). 


\title{
CRITÉRIOS DE AVALIAÇÃO DE ESTOMAS DE ELIMINAÇÃO EM UM AMBULATÓRIO DE FERIDAS E ESTOMIAS
}

\author{
Author(s): PAULO SÉRGIO GOMES DA SILVA ${ }^{1}$, Fabianny Torres de Oliveira ${ }^{1}$, Hilma Keylla de Amorim \\ ${ }^{1}$, Lázaro Betel Eustaquio da Silva ${ }^{2}$, Lucy Kelly Brito Bomfim Eustaquio ${ }^{1}$ \\ Institution(s) ${ }^{1}$ HUPAA - Hospital Universitário Professor Alberto Antunes (AV Lourival melo Mota, SN, \\ Cidade Universitária, Maceió/AL), ${ }^{2}$ HM Assist Domiciliar - Homedical Assistência Domiciliar \\ (Rua do Uruguai, 114, Jaraguá, Maceió/AL)
}

\begin{abstract}
Introdução: o paciente portador de estoma de eliminação necessita de uma atenção especial dos profissionais da saúde, destacando-se o cuidado de enfermagem como imprescindível no período pré e pós-operatório, uma vez que sua assistência é pautada na avaliação, realização do manejo do dispositivo coletor do efluente e orientação ao paciente e família quanto aos cuidados necessários. Dessa forma, é notório que avaliação do estoma e pele periestomal é uma das etapas fundamentais, visto que influenciará diretamente nas condutas do profissional frente ao processo de reabilitação. Objetivo: descrever os critérios de avaliação de estomas de eliminação e pele periestomal instituídos em um ambulatório de feridas e estomias. Método: Trata-se de um estudo descritivo e exploratório com abordagem qualitativa dos principais critérios de avaliação de estomas de eliminação realizados por enfermeiros durante assistência de enfermagem ao paciente admitido no Ambulatório de Pesquisa, Prevenção e Tratamento de Feridas e Estomias do Hospital Universitário Professor Alberto Antunes, na cidade de Maceió/AL. Resultados/Discussão: Os enfermeiros do ambulatório de feridas e estomias elaboraram uma ficha de Consulta de Enfermagem Admissional para os pacientes atendidos no serviço, na qual constam dados de identificação do paciente, história clínica e dados relacionados ao estoma e pele periestomal (tipo de estomia, localização no abdome, tempo de permanência, diâmetro e protusão do estoma, aspecto do estoma, tipo de efluente, condições da pele periestomal, complicações, conduta de enfermagem, dispositivo adaptado, orientações de enfermagem e se faz uso de irrigação intestinal. Nesta ficha também possui o campo para agendamento de retorno para reavaliação, bem como informações inerentes ao registro de óbito, transferência de cadastro e reversão do estoma. Dessa forma, é de extrema importância que o enfermeiro desempenhe sua assistência embasada nas evidências científicas, promovendo uma avaliação fundamentada que possibilite o processo de reabilitação do paciente estomizado. Conclusão: portanto, é perceptível que a implementação dos critérios de avaliação de estomas de eliminação adotados no ambulatório de feridas e estomias contribuam para que o enfermeiro desempenhe a sistematização da assistência de enfermagem, promova à uniformidade do cuidado prestado e contribua no tratamento adequado às condições clínicas do paciente. O conhecimento a respeito da avaliação de estomias de eliminação é fundamental para prestação do cuidado de enfermagem, pois possibilita uma assistência com mais rigor científico e resolutividade nas ações assistenciais.
\end{abstract}

Keywords: Assistência de Enfermagem, Estomas, Avaliação de Estomas, Paciente

\section{Referências Bibliográficas}

BRASIL. Ministério da Saúde. Portaria n 400 de atenção à saúde das pessoas com estoma. Brasília-DF, 2009. Disponível em: http://bvsms.saude.gov.br/bvs/saudelegis/sas/2009/prt0400_16_11_2009.html. Acesso em 20 de agosto de 2019. Manual de orientação aos serviços de atenção às pessoas ostomizadas. Disponível em: HTTPS://saude.es.gov.br?Media/sesa/Consulta\%20P\%C3\%BAblica/Ostomizado/MANUAL_OSTOMIZADOS_Consulta\%20 publica\%202017\%20(1).pdf. Acesso em: 20 de agosto de 2019. MAURícIO, Vanessa Cristina; SOUZA, Norma Valéria Dantas de Oliveira; LISBOA, Márcia Teresa Luz. O enfermeiro e sua participação no processo de reabilitação da pessoa com estoma. Escola Anna Nery Revista de Enfermagem, v. 17, n.3, p. 416-422, 2013. SOUSA, Clementina Fernandes de; SANTOS, Célia; GRAÇA, Luís Carlos Carvalho. "Construção e validação de uma escala de adaptação a estomia de eliminação". Revista de enfermagem (2015): 21-30 


\title{
TECNOLOGIA EDUCATIVA SOBRE CUIDADOS DOMICILIARES AO PACIENTE TRAQUEOSTOMIZADO
}

\author{
Débora de Araújo Moreira Varela ${ }^{1}$, Elayne Mara Almeida Ramos ${ }^{1}$, Francisca Camila Araújo da \\ Author(s): Silva ${ }^{1}$, Jacinta Paula Sousa ${ }^{1}$, Carla Daniele Mota Rêgo Viana ${ }^{1}$, Bruna Michelle Belém Leite \\ Brasil $^{1}$, Francismeire Brasileiro Magalhães ${ }^{1}$, Maria das Graças da Silva Guerreiro ${ }^{1}$ \\ Institution(s) ${ }^{1}$ ESTÁCIO/FIC - CENTRO UNIVERSITÁRIO ESTÁCIO DO CEARÁ (R. Eliseu Uchôa Beco, \\ 600 - Patriolino Ribeiro, Fortaleza - CE, 60810-270)
}

\begin{abstract}
Introdução: O termo traqueostomia (TQT) é atribuído ao procedimento por meio do qual se realiza a abertura e a exteriorização da luz traqueal, que tem por finalidade contornar um obstáculo mecânico das vias aéreas superiores, diminuindo a resistência respiratória, possibilitando a ventilação pulmonar por meio dessa via e, também, facilitando a remoção de secreções em excesso, provenientes da traqueia e dos brônquios. É, geralmente, realizada, em pacientes da Unidade de Terapia Intensiva (UTI), facilitando o desmame da ventilação mecânica (1). Mais de $30 \%$ dos pacientes que necessitam de VM por, pelo menos, 2 dias, permanecem dependente desta por longo tempo e, destes, 10\% serão traqueostomizados, procedimento este que permite a retirada do tubo traqueal e a diminuição da sedação durante a VM, possibilitando a redução do tempo de ventilação artificial, da incidência de pneumonia e do tempo de internação hospitalar(2). Desse, modo, a produção de tecnologias educativas que auxiliem no processo de auto-cuidado desses pacientes após a alta hospitalar propiciam uma excelente ferramenta para o enfermeiro, de modo que este possa ensinar e empreender cuidados de modo eficaz. Objetivo: Desenvolver uma tecnologia educativa de orientações sobre os cuidados domiciliares com a traqueostomia para pacientes, cuidadores e familiares. Material e Método: Pesquisa experimental, de desenvolvimento tecnológico, baseada na elaboração de um aplicativo. O desenvolvimento do conteúdo foi realizado em 2 passos: Revisão Integrativa da Literatura e Desenvolvimento Geral do Conteúdo. A Revisão Integrativa foi realizada conforme Mendes e Galvão (2008) a partir da qual a busca foi realizada nos meses de julho e agosto de 2018, nas bases de dados LILACS, SCIELO e MEDLINE da Biblioteca Virtual em Saúde MS (Ministério da Saúde). Resultados: o aplicativo foi construído utilizando uma plataforma online de criação de aplicativos, Fábrica de Aplicativos - o FabApp (3). A escolha baseou-se na possibilidade que a plataforma oferece de que usuários, sem domínio de programação, criem e publiquem suas próprias aplicações. Lançada em 2012, inicialmente chamada de Universo.Mobi, passou a ser chamada de Fábrica de Aplicativos após ter sido acelerada como negócio de impacto pela Artemísia, Din4mo e Instituto Quintessa, desenvolvendo uma plataforma que simplifica o desenvolvimento de aplicativos, gerenciamento e publicação de apps web, Android e iOS / iPhone(4). Conclusões: Esta tecnologia educativa buscou a colaboração da literatura atualizada na área, visto que, a traqueostomia trata-se de um procedimento que requer maior enriquecimento científico, a fim de que as informações repassadas fossem o mais fidedignas possível. Assim, esta tecnologia servirá como um suporte ao paciente bem como sua família e/ou cuidador e ao profissional de Enfermagem no sentido de garantir facilidade de acesso a informação em qualquer ambiente e localidade, utilizando um recurso amplamente comum no cotidiano da sociedade atual.
\end{abstract}

Keywords: Cuidados de Enfermagem, Tecnologia, Traqueostomia

\section{Referências Bibliográficas}

CASTRO, A. P. et al. Educação em Saúde na Atenção ao Paciente Traqueostomizado: Percepção de Profissionais de Enfermagem e Cuidadores. Revista Brasileira de Cancerologia 2014; 60(4): 305-313. Disponível em: Acesso em: 11 agos. 2018. MEHTA, A.B.; Syeda, S. N.; Bajpayee, L.; Cooke, C. R., Walkey, A. J.; Wiener, R. S. Trends in Tracheostomy for Mechanically Ventilated Patients in the United States, 1993-2012. Am J Respir Crit Care Med. 2015 Aug, vol.15, p.192. MENDES, F.; Ranea, P.; Oliveira, A. C. T. de. Protocolo de desmame e decanulação de traqueostomia. Revista UNILUS Ensino e Pesquisa, v. 10, n. 20, jul./set. 2013. Disponível em: Acesso em: 11 set 2018. FabApp@, [software na internet]. Brasil: Adobe Systems Inc; 2013 [cited 2018 Out 10]. Available from: https://fabricadeaplicativos.com.br/ 


\title{
CONSTRUÇÃO DE TECNOLOGIA EDUCATIVA PARA IRRIGAÇÃO DA COLOSTOMIA
}

\author{
Lidia stella Teixeira de Meneses ${ }^{1}$, Sherida Karanini paz Oliveira ${ }^{4}$, Roberta Meneses Oliveira ${ }^{3}$, Camila Lima \\ Author(s): dos Santos ${ }^{2}$, Luciana Catunda Gomes de Menezes ${ }^{5}$, Yara Lanne Santiago Galdino ${ }^{6}$
}

Institution(s) ${ }^{1}$ HUWC - Hospital Universitário Walter Cantídio (rua capitao francisco pedro 1290 Rodolfo Teófilo), ${ }^{2}$ HMK Hospital Monte Klinikum (rua republica do libano 747 ), ${ }^{3}$ UFC - Universidade Federal do Ceará (rua alexandre barauna ), ${ }^{4}$ UECE - Universidade Estadual do Ceará (av silas munguba), ${ }^{5}$ Fametro - Faculdade Metropolitana da Grande Fortaleza (Jacarecanga), ${ }^{6}$ SESA - Secretaria de Saude do Estado do Ceará (Av Historiador Raimundo Girão )

\begin{abstract}
Uma estomia intestinal é uma abertura, temporária ou permanente, criada cirurgicamente para a eliminação de fezes. Os tipos mais comuns são as ileostomias e as colostomias (WOCN, 2018). A confecção de um estoma intestinal causa a perda do controle da eliminação de fezes e gases, e isso constitui forte fator de impacto emocional para as pessoas com estomia. Para o controle da eliminação intestinal, tem-se a irrigação da colostomia (IC), que é a instilação de fluido no colón para a retirada de fezes. Reconhecendo a importância das tecnologias educativas na saúde, este estudo teve como objetivo a construção de um álbum seriado com orientações sobre IC. Trata-se de uma pesquisa metodológica do tipo desenvolvimento. $\mathrm{O}$ álbum seriado aborda informações sobre a IC: descreve o conceito de irrigação, qual as vantagens e desvantagens da realização do procedimento, quais os pacientes indicados e os contraindicados para a realização, quais os materiais necessários e qual a técnica utilizada para a realização do procedimento. Esse conteúdo foi obtido com base nas informações identificadas na revisão integrativa. O álbum possui 24 páginas e é composto por elementos pré-textuais (capa, apresentação); textuais (figuras e textos) e pós-textuais (referências bibliográficas). Na capa constam o título, e duas figuras, representando um paciente colostomizado e uma enfermeira. $\mathrm{Na}$ apresentação relata-se o objetivo do álbum e quando utilizá-lo. Os textos foram elaborados em língua portuguesa, no programa Adobe Illustrator CC 2018 com letra Gabriola, tamanho $14 \mathrm{~mm}$ para os textos e entrelinhas $16,8 \mathrm{~mm}$, para as figuras foi utilizada a paleta de cores: Candycolor. As ilustrações utilizadas foram elaboradas com a ajuda de um designer gráfico conforme as orientações selecionadas para o álbum. Ressalta-se que estas foram atrativas para facilitar a compreensão do texto. Todas estas ilustrações estão em colorido, pois a cor favorece a eficiência da comunicação Acredita-se que o álbum seriado com orientação da IC pode contribuir na melhoria das informações aos pacientes colostomizados, possibilitando explanação do procedimento, fomentando o diálogo, o esclarecimento de dúvidas e facilitando a prática educativa do enfermeiro.
\end{abstract}

Keywords: tecnologia educativa, colostomia, estomaterapia

\section{Referências Bibliográficas}

WOUND, OSTOMY AND CONTINENCE NURSES SOCIETY. Wocn society clinical guideline. Management of the adult patient with a fecal or urinary ostomy-an executive summary. J wound ostomy continence nurs. v. 45, n.1, p.50-58, 2018. 


\title{
A experiência do enfermeiro no cuidado ao diabético amputado com má adesão ao tratamento: uso de coberturas complexas e cicatrização
}

\author{
Author(s): JÉSSICA RODOLFO CAMPOS ${ }^{1}$ \\ Institution(s) ${ }^{1}$ CCR - SES - Secretaria do Estado de Santa Catarina (R. Rui Barbosa, 780 - Agronômica, Florianópolis - \\ SC, 88025-301)
}

\begin{abstract}
Introdução: Em todo o mundo o Diabetes Mellitus se apresenta como uma doença de grande incidência. A neuropatia diabética é uma das causas silenciosas de lesões nos pés destes pacientes onde o enfermeiro deve atuar não apenas como educador mas também usar seu conhecimento teórico prático para o tratamento destas lesões. Este relato mostra o diferencial na avaliação e reavaliação contínua do Enfermeiro nas lesões de amputação em diabéticos, assim como a necessidade de conhecimento teórico-prático para uma escolha de cobertura adequada a cada estágio cicatricial.

Objetivo: Relatar a experiência de cuidar de um paciente diabético com baixa adesão ao tratamento, no período pós operatório de amputação de hálux ocorrida por não aderência do paciente e da família às medidas preventivas. Além disso objetiva mostrar os desafios para o Enfermeiro de Saúde da Família na tomada de decisão de coberturas complexas na ferida operatória.

Material e método: Foi realizado o acompanhamento diário da lesão de amputação de Hálux E, do paciente P.C, 56 anos, diabético insulino dependente, não aderente ao tratamento. A Enfermeira acompannhou o mesmo no domicílio desde o período pós operatório imediato. A terapia tópica iniciou-se com Clorexidine $2 \%$ conforme prescrição do cirurgião, acrescida de pomada de hidrogel prescrita pela enfermeira. No $38^{\circ}$ dia de pós operatório a enfermeira optou por realizar troca da terapeutica visto estagnação na cicatrização vendo melhora na evolução cicatricial após esta medida. Após 80 dias da cirurgia foi inserido a cobertura Membracel. No $97^{\circ}$ a cobertura utilizada passou a ser o alginato + colágeno. Orientações sobre ingesta alimentar e hídrica foram realizadas e reforçadas durante todo o período do cuidado com o paciente, buscando sempre ve-lo como um todo e não apenas como uma ferida a ser cicatrizada.

Resultados e conclusões: Não foi possível realizar comparações mensurando a diferença de tempo de cicatrização de pacientes sujeitos ao uso de coberturas complexas e acompanhados pelo Enfermeiro, devido a falta de estudos na literatura. Essa experiência trás a reflexão sobre o quanto o Enfermeiro pode ter autonomia no campo de feridas e o quanto ainda é preciso avançar nos conhecimentos na área. É perceptível a diferença que um curativo diário com a avaliação e cobertura adequada tras no tempo de recuperação do paciente, porém não há parâmetros comparativos na literatura. Há necessidade de maiores estudos nesta área para se traçar comparações e mensurar a eficácia do uso das coberturas e acompanhamento do Enfermeiro.
\end{abstract}

\section{Palavras-chave: Amputação; Cobertura; Diabetes Mellitus; Estomaterapia;}

\section{Keywords: Amputação, Cobertura, Diabetes Mellitus, Estomaterapia}

\section{Referências Bibliográficas}

REFERÊNCIAS ${ }^{1}$ Brasil. Ministério da Saúde. Secretaria de Atenção à Saúde. Departamento de Atenção Básica. Estratégias para o cuidado da pessoa com doença crônica : diabetes mellitus / Ministério da Saúde, Secretaria de Atenção à Saúde, Departamento de Atenção Básica. - Brasília : Ministério da Saúde, 2013. ${ }^{2}$ BRASIL. Constituição (1988). Constituição da República Federativa do Brasil. Brasília, DF: Senado Federal, 1988. ${ }^{3}$ Di Pietro Carvalho, Renata, Di Pietro Carvalho, Carolina, Martins, Dulce Aparecida, APLICAÇÃO DOS CUIDADOS COM OS PÉS ENTRE PORTADORES DE DIABETES MELLITUS. Cogitare Enfermagem [en linea] 2010,15 (EneroMarzo) : [Fecha de consulta: 11 de mayo de 2018] Disponible en:ISSN 1414-8536 4 LIMA, M. H. M.; ARAUJO, E. P. D. Diabetes Mellitus e o processo de cicatrização cutânea. CogitareEnferm., v. 18, n. 1, p. 180-2, 2013. 5 PEREIRA, Jéssica da Silva et al. Efeito da quitosana e alginato na cicatrização de feridas: revisão integrativa. Enfermagem Atual, Rio de Janeiro, v. 1, n. 84, p.123-128, jan. 2018. Trimestral. 6 Santos Tavares, Darlene Mara dos, Dias, Flávia Aparecida, Rabelo Araújo, Luciana, Araújo Pereira, Gilberto, Perfil de clientes submetidos a amputações relacionadas ao diabetes mellitus. Revista Brasileira de Enfermagem [en linea] 2009,62 (NoviembreDiciembre) : [Fecha de consulta: 11 de mayo de 2018] Disponible en: 7 SILVA, ANA CATARINA DE OLIVEIRA et al. AS PRINCIPAIS COBERTURAS UTILIZADAS PELO ENFERMEIRO. REVISTA UNINGÁ, [S.I.], v. 53, n. 2, jan. 2018. ISSN 2318-0579. Disponível em: . 8 GOMES, Flávia Sampaio Latini; CARVALHO, Daclé Vilma; LIMA, Elenice Dias Ribeiro de Paula. Tratamento de feridas crônicas com coberturas oclusivas. Rev. Min. Enferm., Belo Horizonte, v. 1, n. 13, p.19-27, mar. 20099 DURANS, Nadja Helena Cordeiro; ROLIM, Isaura Letícia Tavares Palmeira; LIMA, Alice Bianca Santana. INTEGRIDADE DA PELE PREJUDICADA: EXEQUIBILIDADE DAS INTERVENÇÕES DE ENFERMAGEM. Revista UningÁ, São Luiz, v. 1, n. 53, p.25-32, maio 2017. 10 OLIVEIRA, Julia de Cassia et al. PÉ DIABÉTICO: PERFIL SOCIODEMOGRAFICO E CLÍNICO DE PACIENTES HOSPITALIZADOS.Revista Brasileira de CiÊncias da Saude, GoiÂnia, v. 1, n. 22, p.15-20, jan. 2018. 11 PEDROSA, H.C. (Org.). Grupo de Trabalho Internacional sobre o Pé Diabético. Consenso Internaciona sobre Pé Diabético. Brasília: Secretaria do Estado de Saúde do Distrito Federal, 2001. 126 p. 12 LOGATO, Maria Julia Spini; CAMPOS, Bernardo Almeida; NAVARRO, Tulio Pinho. PÉ DIABETICO: COMPLICAÇÃO EVITÁVEL - RELATO DE CASO. Revista Medica de Minas Gerais, Belo Horizonte, n. 27, p.90-92, mar. 2017. 


\title{
INCIDÊNCIA DE LESÕES POR PRESSÃO EM PACIENTES DE UM CENTRO DE TERAPIA INTENSIVA: UM ESTUDO RETROSPECTIVO
}

\author{
Author(s): ANA APARECIDA SAVIOLI ${ }^{1}$, Giovana de Paula Rezende Simino Simino ${ }^{2}$ \\ Institution(s) ${ }^{1}$ PUC Minas - Pontifícia Universidade Católica de Minas Gerais (savioliana@ yahoo.com.br), ${ }^{2}$ \\ UFMG - Universidade Federal de Minas Gerais (gsimino@ yahoo.com.br)
}

\begin{abstract}
Este estudo objetivou analisar a incidência de Lesão por Pressão (LP) nos pacientes internados em um Centro de Terapia Intensiva (CTI) de um hospital de grande porte em Belo Horizonte, Minas Gerais. Ademais, analisou as características clínicas e sociodemográficas destes com o surgimento destas lesões. Trata-se de um estudo observacional, quantitativo e descritivo, realizado no CTI adulto, no período de março de 2016 a setembro de 2018. Participaram 1.196 pacientes com idade de 18 a 92 anos, com prevalência de idosos e sexo masculino. A incidência foi de 84 pacientes (7,0\%), com prevalência de uma lesão por paciente. Dentre a localização das LP prevaleceu a região sacral, seguida da sacral e calcâneo e calcâneo por um período de internação que variou de 01 a 36 dias. Os escores da Escala de Braden avaliados no momento da admissão, no $5^{\circ}, 10^{\circ}$ e 20 dia variou de 06 a 23 pontos. Analisando a incidência de LP não houve relação estatisticamente significativa entre óbito e surgimento LP. Observou que o surgimento de LP foi menor nos pacientes quer já apresentavam uma lesão prévia, evidenciando que a prevenção para pacientes sem lesão prévia não teve o destaque merecido. Entende-se que houve cuidados quanto a prevenção, pela equipe com estes pacientes. Diante desta analise fica a dúvida se a equipe que atua no CTI está sendo mais curativa focando nos pacientes com LP e não olhando com tanto critério para os pacientes que necessitam de medidas preventivas. O estudo permitiu contribuir com o conhecimento de LP e fazer uma reflexão sobre o atendimento seguro e a qualidade da assistência prestada a estes pacientes, principalmente pela equipe de enfermagem.
\end{abstract}

Keywords: Centro de Terapia Intensiva, Estomaterapia, Incidência, Lesão por Pressão

\section{Referências Bibliográficas}

AGÊNCIA NACIONAL DE VIGILÂNCIA SANITÁRIA (ANVISA). Série Segurança do Paciente e Qualidade em Serviços de Saúde: Assistência Segura: Uma Reflexão Teórica Aplicada à Prática. Brasília, 2017. BORGHARDT A T. PRADO TN, BICUDO SDS et al., Ulcera de pressão em pacientes críticos : incidência e fatores associados, 2016. DOMANSKY, Rita de Cássia; BORGES, Eline Lima. Manual para prevenção de lesões de pele. Recomendações baseadas em evidências. $2^{\underline{a}}$ edição. Rubio, Rio de Janeiro, 2014. 


\title{
PREVENÇÃO DE LESÕES DE PELE EM RECÉM-NASCIDOS: EVIDÊNCIAS PARA A PRÁTICA DA ENFERMAGEM NEONATAL
}

\author{
Author(s): Simone Vidal Santos ${ }^{1}$, Flávia Regina Souza Ramos ${ }^{1}$, Roberta Costa ${ }^{1}$ \\ Institution(s) ${ }^{1}$ UFSC - Universidade Federal de Santa Catarina (Campus Reitor João David Ferreira Lima. \\ Trindade, Fpolis/SC - CEP: 88040-900)
}

\begin{abstract}
Introdução: a pele do recém-nascido apresenta particularidades anatômicas e fisiológicas que, aliadas à necessidade de procedimentos e uso de dispositivos para manutenção da vida, expõe esta população ao risco de lesões e infecção. Por esse motivo, uma das preocupações da equipe de enfermagem neonatal se relaciona ao cuidado com a pele do neonato ${ }^{1}$. Para minimizar os riscos, o enfermeiro precisa buscar subsídios que sustentem a sua prática. Neste sentido, surge a prática baseada em evidência (PBE) ${ }^{2}$. A necessidade de buscar evidências sobre cuidados de prevenção de lesões de pele em recém-nascidos respaldou a realização deste estudo. Objetivo: identificar evidências científicas sobre cuidados de prevenção de lesões de pele em recém-nascidos internados em Unidade Neonatal. Material e Método: revisão integrativa de literatura realizada em dois momentos de busca, nas bases de dados Cochrane, Medline, Lilacs e BDENF. Para o levantamento da amostra utilizou-se os operadores boleanos "OR" e "AND" e os descritores, que foram utilizados em português, inglês e espanhol: Recém-Nascido, Recém-Nascido Prematuro, Pele, Unidades de Terapia Intensiva Neonatal e Terapia Intensiva Neonatal. Foram incluídos artigos publicados entre 2013 e 2018, em periódicos nacionais e internacionais que abordassem a prevenção de lesões de pele em neonatos hospitalizados. Foram excluídos: editoriais, teses, dissertações, livros, resumos de congresso e estudos de revisão não sistematizados. O corpus de análise foi realizado por dois revisores, de forma simultânea e independente, através de um processo sequencial de leitura dos artigos, iniciando com a avalição do título, seguindo com os resumos e posteriormente com os estudos na íntegra. O nível de evidência seguiu a classificação da Oxford Centre for Evidence-based Medicine ${ }^{3}$. A amostra contou com 37 artigos. Os estudos foram organizados em planilha contendo: autor(es), ano de publicação, periódico, base de dados, amostra, delineamento, país de origem, tipo de cuidado de prevenção e nível de evidência. Os dados foram agrupados de acordo com temas semelhantes, subdivididos categorias e apresentados de forma descritiva. Resultados: as publicações ocorreram em sua maioria no ano de 2014, em revistas internacionais, idioma inglês, delineadas pelo Ensaio Clínico Randomizado Controlado e com nível de evidencia 2B. Dentre os cuidados, destacaram-se a termorregulação, seguida do uso de emolientes, antisséptico tópico, limpeza do coto umbilical, dispositivos para oxigenação e banho. O cuidado com acesso venoso, fototerapia, produtos de cuidado com a pele e dermatite de fralda apareceram em menor número. Dentre as práticas baseadas em evidência, destacam-se as que previnem o risco de hipotermia ao nascimento, como o uso de saco de polietileno e o contato pele-apele, bem como banho através do enrolamento e o uso de creme barreira à base de oxido de zinco para prevenir a dermatite da área de fraldas. Conclusão: existe escassez de evidências robustas para apoiar a prática do enfermeiro no cuidado da pele d recém-nascido hospitalizado. Observou-se ainda lacunas de conhecimento sobre gerenciamento da umidificação da incubadora, prevenção de lesão por pressão, fixação de dispositivos, administração de medicamentos e cateterismo umbilical, demonstrando que o cuidado com a pele é um tema que ainda demanda investimentos e mais pesquisas.
\end{abstract}

Keywords: Estomaterapia, Recém-Nascido, Pele, Cuidados de Enfermagem, Enfermagem Baseada em Evidências

\section{Referências Bibliográficas}

1 Visscher MO, Adam R, Brink S, Odio M. Newborn infant skin: physiology, development, and care. Clin Dermatol. 2015;33(3):271-80. DOI: http://dx.doi.org/10.1016/j.clindermatol.2014.12.003 2. Rumbo-Prieto JM, Romero-Martín M, Bellido-Guerrero D, Arantón-Areosa L, Raña-Lama CD, Palomar-Llatas F. Evaluación de las evidencias y calidad de las guías de práctica clínica sobre deterioro de la integridad cutánea: úlceras y heridas crónicas. Anales Sis San Navarra [Internet] 2016 [citado 2018 dec 25];39(3):405-15. Disponible en:

http://scielo.isciii.es/scielo.php?script=sci_arttext\&pid=S1137-66272016000300008\&lng=es 3 Phillips B, et al. Oxford Centre for Evidence-based Medicine. Levels of evidence [Internet]. Oxford: CEBM; 2009 [cited 2017 Jul 02]. Available from: https://www.cebm.net/2009/06/oxford-centre-evidence-based-medicine-levels-evidence-march-2009/ 


\title{
Assistência de Enfermagem ao paciente com Síndrome de Fournier
}

Author(s): anelvira de oliveira florentino ${ }^{2}$

Institution(s) ${ }^{2}$ HUI - Hospital Unimed Itapetininga (avenida wenceslau Braz ,2700 vila popular)

\begin{abstract}
Introdução:Síndrome de Fournier é uma doença grave, infecciosa, de rápida progressão, caracterizada por uma intensa destruição tissular, comprometendo a região genital e áreas adjacentes. Embora muito progresso tenha ocorrido desde a descrição original da Síndrome de Fournier, está debilitante doença ainda é responsável por altos índices de morbidade e mortalidade. Objetivo: Realizar uma pesquisa literária sobre a assistência de enfermagem ao paciente portador da Síndrome de Fournier. Método: Pesquisa de caráter descritivo e abordagem qualitativa, por meio de revisão literária nas bases de dados online Google Acadêmico e Biblioteca Virtual de Saúde. Resultado: A assistência de enfermagem pode ser implementada com a avaliação do paciente como o todo, buscando levantar e implementar condutas de cuidados integral que sane as necessidades do indivíduo. Na síndrome de fournier tratada com a (TPN) tem uma reconstrução precoce do leito da ferida reduzindo o desconforto dos pacientes uso de menos medicações e diminuição do tempo no hospital, proporcionando qualidade de vida desde sua inserção tornou-se uma bem estabelecida no tratamento de feridas complexas.. A enfermagem participa ativamente na avaliação do processo cicatricial tecidual, observa a evolução da ferida, também se faz necessária a interação com a equipe multidisciplinar. Esse trabalho em conjunto buscam uma melhor assistência qualificada e atenção ao paciente.Conclusão: Conclui que a Síndrome de Fournier, apesar de todos os avanços terapêuticos atuais, continua apresentando altos índices de mortalidade. O reconhecimento precoce da infecção associado a tratamento agressivo e invasivo são medidas essenciais para se tentar diminuir esses índices prognósticos. A enfermagem possui um papel indispensável durante a recuperação do cliente durante todo o tratamento, avaliando os sinais e sintomas das infecções, como, também na realização de curativos.
\end{abstract}

Keywords: Síndrome de fournier. , Enfermagem, Assistência

\section{Referências Bibliográficas}

1. Cardoso, J.B, Feres, O.F, Gangrena de Fournier, Cirurgia de Urgência e Trauma,40-4,493 Out, Dez 2007. 2. Dornelas M.T, et al. Sindrome de Fournier 10 de Avaliação, Rev.Bras. Cir.Plast 27,4,600-4 Out,2012. 3. Ebsehard T.D et al. Rev Saude, v.1, n.1, p57-68, Set 2014. 4. Siza,M.A.F. Intervenção de Enfermagem no Tratamento de Gangrena de Fournier Relato de Caso. 2009. 5. Cavalini.F, Moriya.T.M, Pelei.N.T.R, Sindrome de Fournier. A percepção do seu Portador, Rev.Esc. Enferm USP,36(2) 108-14 Set 2002. 6. Hoffman, A, L, Iglesias, L, F. Rothbarth, W.W. Arquivos Catarinense de Medicina - Volume 38 Suplemento 01-2009. 7. Lima, R.V.S, Coltro.P.S., Junior.A.F. Terapia por pressão no tratamento de feridas complexas.Rev.Col.Cir 2017,44(1) 08093. 8. Santos,E.J.F. Tratamento de feridas colonizadas infectadas com utilização de polihexanida .Rev de Enf III Serie n 4 Jul 2011. 


\title{
TERAPIA POR PRESSÃO NEGATIVA COM INSTILAÇÃO NO TRATAMENTO DE FERIDAS COMPLEXAS
}

\author{
Author(s): GISLEIDE DA SILVA CAMARGO ${ }^{1}$, Mônica Silva de Almeida ${ }^{1,1}$, Donata Maria de Souza \\ Pellegrino ${ }^{1,1,1}$ \\ Institution(s) ${ }^{1}$ Centro Universitário - Centro Universitário São Camilo (Av. Nazaré, 1501 - Ipiranga São Paulo - \\ SP)
}

\begin{abstract}
INTRODUÇÃO: Atualmente o tratamento de feridas tem sido considerado como um grave problema de saúde pública atingindo diversas camadas populacionais, tornando-se um grande desafio para os profissionais e para o sistema de saúde1. A Terapia por pressão negativa tem sido considerada como um grande avanço e uma das mais inovadoras tecnologias para simplificar a cobertura de feridas, a qual foi acrescida o processo de instilação passando a ser denominado de Terapia por pressão negativa com instilação, que pode ser usado como tratamento adjuvante para feridas infectadas, feridas com alto risco de infecção e / ou feridas que não responderam à terapia convencional2. OBJETIVO: levantar na literatura estudos que investigaram o uso da Terapia por pressão negativa com instilação no tratamento de feridas complexas. MÉTODO: Trata-se de uma revisão integrativa, realizada na base de dados Pubmed / Medline, utilizando os descritores associados "negative pressure wound therapy" and "wound" and "Instillation", foram selecionados 14 artigos para fazerem parte do estudo. RESULTADOS: Verificou-se que as pesquisas nessa temática ainda são incipientes, além dos estudo na sua maioria serem do tipo estudo de caso e apesar de suas importantes implicações seus resultados não podem ser generalizadas, mas oferecem oportunidades para realização de novos, principalmente frente aos resultados positivos encontrados. Os diversos benefícios dessa terapia que foram encontrados nos estudos levantados são: menos dias de tratamento, fechamento da ferida mais cedo, menor tempo de internação, aumento do tecido de granulação e diminuição significativa no número de operações de desbridamento. CONCLUSÃO: Recomenda-se a realização de novos estudos com maior nível de evidência, buscando substanciar os achados apresentados, como por exemplo a realização de agrupamento de grandes séries de casos explorando os benefícios dessa terapia promissora3. Os achados desse estudo ressaltam ainda que a Terapia por Pressão Negativa com Instilação se apresenta como uma opção promissora para o manejo de feridas complexas.
\end{abstract}

Keywords: Terapia por pressão negativa, Ferida, Instilação, Estomaterapia

\section{Referências Bibliográficas}

1 LEITÃO F, ELIAS M, TAVARES N. Terapia por pressão negativa: uma opção no tratamento do pé diabético. Journal of Aging \& Inovation. 2015;4(1):44-58. 2 BRINKERT D, et al. Negative pressure wound therapy with saline instillation: 131 patient case series. Int Wound J. 2013;10(1):56-60. 3 GUPTA S. Clinical recommendations and practical guide for negative pressure wound therapy with instillation. Int Wound J. 2016;13:159-174. 


\title{
ATUAÇÃO DO ENFERMEIRO ESTOMATERAPEUTA NA PREVENÇÃO DE LESÕES POR PRESSÃO OCASIONADAS POR DISPOSITIVOS MÉDICO-HOSPITALARES: UMA REVISÃO INTEGRATIVA
}

\author{
Author(s): Juliana Dias Medeiros Machado ${ }^{1}$, Paulo Sérgio da Silva ${ }^{2}$, Vanessa Ribeiro Pardauil ${ }^{3}$ \\ Institution(s) ${ }^{1}$ UERJ - Universidade do Estado do Rio de Janeiro (Boulevard 28 de Setembro, 157 - Vila Isabel, \\ Rio de Janeiro - RJ, 20551-030), ${ }^{2}$ UniRio - Universidade Federal do Estado do Rio de Janeiro (R. \\ Dr. Xavier Sigaud, 290 - Urca, Rio de Janeiro - RJ, 22290-180), ${ }^{3}$ HPA - Hospital Pan-Americano \\ (R. Moura Brito, 138 - Tijuca, Rio de Janeiro - RJ, 20520-060)
}

\begin{abstract}
Introdução: De saída, é oportuno contextualizar que as lesões por pressão (LPP) são acometimentos de saúde capazes de produzir o prolongamento das internações hospitalares. Trata-se de consequências comuns, resultantes de longa permanência em hospitais cuja incidência aumenta proporcionalmente à combinação dos fatores de riscos, dentre eles, destacam-se idade avançada e restrição ao leito1. Como de interesse nesse estudo, há que se considerar também como fator de risco a necessidade do cliente usar dispositivos médico-hospitalares. Considera-se que a formação destas lesões em regiões anatômicas atípicas, geralmente é ocasionada pelo uso de sondas e cateteres, sendo denominadas de lesões por pressão relacionadas a dispositivos médicos (LPP-RDM)2. Diante disso, coloca-se em relevo o protagonismo do enfermeiro estomaterapeuta na prevenção e tratamento desses tipos de lesões. Figura indispensável para implantação de práticas preventivas de cuidar relacionadas à LPP-RDM em uma lógica sistematizada de assistência. Objetivo: Frente ao exposto emerge o seguinte objetivo: identificar as ações preventivas de cuidar desenvolvidas por enfermeiros estomaterapeutas nas LPP-RDM. Material e Método: Trata-se de uma revisão integrativa. Os procedimentos metodológicos utilizados foram: I) Identificação da seguinte questão do estudo: Como o enfermeiro estomaterapeuta atua na prevenção das LPP-RDM? II) Estabelecimento dos critérios de seleção dos artigos: artigos que retratam o tema LPP-RDM, idioma português, recorte temporal de junho de 2014 até junho de 2019, cadastrados na Scientific Eletronic Library Online com os Descritores em Ciências da Saúde: "Lesão por Pressão", "Cuidados de Enfermagem" e "Enfermagem Baseada em Evidências". III) Extração de informações dos artigos incluídos sobre ações preventivas de cuidar para LPP-RDM realizadas por enfermeiros estomaterapeutas. IV) Avaliação dos artigos orientada pela análise de conteúdo disposta em Bardin. V) Interpretação dos resultados e apresentação da síntese do estudo compilada em uma categoria. Resultados: De 1265 artigos identificados foram incluídos após aplicação dos critérios 06 estudos. Os conteúdos analisados foram organizados na categoria, intitulada: "Atuação do enfermeiro estomaterapeuta na prevenção de LPP-RDM". Nos achados foi possível identificar as seguintes ações de cuidar realizadas por estomaterapeutas para prevenir LPP-RDM: identificar precocemente este tipo de lesão em grupos suscetíveis3. Destarte, a utilização de diretrizes e protocolos clínicos também tem sido apontada como melhor caminho para a prevenção4-5. Nesse tocante, as ações de cuidar identificadas foram: avaliação periódica da pele, reposicionamento dos dispositivos, e uso de curativos, principalmente o hidrocolóide, para diminuir a força de cisalhamento3. Conclusão: Com a certeza do inacabado, conclui-se que as ações de cuidar, na esfera preventiva, realizada por enfermeiros estomaterapeutas nas LPP-RDM estiveram associadas ao uso de protocolos assistenciais com ênfase para avaliação rigorosa da pele, monitoramento da posição dos dispositivos e diminuição de cisalhamentos. Assim, espera-se que esta síntese suscite a realização de pesquisas baseadas em evidências corroborando para produção de práticas de cuidar cada vez mais seguras e efetivas na prevenção de LPP-RDM.
\end{abstract}

Keywords: cuidados de enfermagem, dispositivos médicos, estomaterapia, lesão por pressão

\section{Referências Bibliográficas}

1- BRASIL. Ministério da Saúde; Anvisa; Fiocruz. Protocolo para prevenção de úlcera por pressão. Brasília, 2012. 2- Galetto SGS, Nascimento ERP, Hermida PMV, Malfussi LBH. Lesões por Pressão Relacionadas a Dispositivos Médicos: revisão integrativa da literatura. Rev Bras Enferm [Internet]. 2019;72(2):528-36. 3- Barbosa TP, Beccaria LM, Silva DC, Bastos AS. Associação entre sedação e eventos adversos em pacientes de terapia intensiva. Acta Paul Enferm. 2018;31(2):194-200. 4- Vasconcelos JMB, Caliri MHL. Ações de enfermagem antes e após um protocolo de prevenção de lesões por pressão em terapia intensiva. Esc Anna Nery 2017;21(1):e20170001 5- Mendonça PK, Loureiro MDR, Frota OP, Souza AS. Prevenção de lesão por pressão: ações prescritas por enfermeiros de centros de terapia intensiva. Texto Contexto Enferm, 2018; 27(4):e4610017 


\title{
RELATO DE EXPERIÊNCIA: ASSOCIAÇÃO DO HIDROGEL E A ESPUMA DE ALGINATO DE CÁLCIO E SÓDIO NA CICATRIZAÇÃO DE UMA LESÃO EM PÉ DIABÉTICO
}

\author{
Author(s): Flavia Cobuci Resende Rodrigues ${ }^{1}$, Vanise de Souza Pinto ${ }^{1}$ \\ Institution(s) ${ }^{1}$ UERJ - Universidade Estadual do Rio de Janeiro (Faculdade de Enfermagem - Boulevard 28 de \\ Setembro, 157 - Vila Isabel.)
}

\begin{abstract}
O Diabetes Mellitus é uma doença crônica degenerativa que vem se destacando como um importante problema de saúde pública com elevado índice de morbimortalidade. O pé diabético, uma de suas principais complicações, caracteriza-se por um conjunto de processos fisiopatológicos que comprometem células neurológicas e tecidos vasculares. O seu prognóstico quando diante de quadros infecciosos e ulcerações neuropáticas evolui para o alto número de amputações dos membros inferiores gerando um impacto psicossocial e econômico na vida dos pacientes e familiares por elas acometidos. ${ }^{1} \mathrm{O}$ cuidado de enfermagem destinado aos pacientes que possuem esse perfil engloba não só a compreensão da fisiologia da pele e seu processo de cicatrização mas também o conhecimento científico a cerca das diversas coberturas disponíveis no mercado que facilitam essa dinâmica. ${ }^{3} \mathrm{O}$ presente relato de experiência trata-se do cuidado de enfermagem a um paciente diabético após amputação não traumática de hálux em pé direito devido a ulceração neuropática. $O$ objetivo do estudo visou descrever a evolução cicatricial da lesão através do uso associado do Hidrogel e a espuma de Alginato de Cálcio e Sódio. Estudo descritivo e qualitativo, realizado de fevereiro a maio de 2019, por meio da aplicação do processo de enfermagem, registros escritos em prontuário e avaliação fotográfica periódica da lesão, respeitando-se os preceitos éticos. Os resultados foram alcançados em 12 semanas de acompanhamento após a implantação do processo de enfermagem, com diminuição de extensão da lesão, eliminação do esfacelo, e presença de tecido de granulação, com troca do curativo a cada cinco dias considerando os fatores extrínsecos associados. O estudo demonstrou, de maneira isolada, que através da implementação do processo de enfermagem e do acompanhamento de profissionais orientados, é possível acelerar o processo cicatricial da lesão ulcerativa em pé diabético proporcionando qualidade de vida ao paciente que será sempre a visão central da estomaterapia.
\end{abstract}

Keywords: Pé Diabético, Processo de Enfermagem, Hidrogel, Alginato de Cálcio e Sódio, Estomaterapia

\section{Referências Bibliográficas}

1. Andrade LL, Carvalho GCP, Valentim FAAA, Siqueira WA, Melo FMAB, Costa MML. Caracterização e tratamento de úlceras do pé diabético em um ambulatório. Rev Fun Care Online. 2019 jan/mar; 11(1):124-128. 2. Mendonça RJ, Netto JC. Aspectos celulares da cicatrização. An Bras Dermatol. 2009; 84(3):257-62. 3. Cavalcante BLL, Lima UTS. Relato de Experiência de uma estudante de Enfermagem em consultório especializado em tratamento de feridas. J Nurs Health. 2012 jan/jun; 1(2):94-103. 4. Ministério da Saúde (BR). Secretaria do Estado da Saúde do Distrito Federal. Grupo de Trabalho Internacional sobre Pé Diabético. Consenso Internacional sobre Pé Diabético. Brasília (DF):MS; 2001. 100p. 5. Pinheiro LS, Borges EL, Donoso MTV. Uso de hidrocolóide e alginato de cálcio no tratamento de lesões cutâneas. Rev Bras Enferm. 2013 set/out; 66(5):760-70. 


\title{
COMPARAÇÃO DE PROTOCOLOS DE PREVENÇÃO DE LESÃO POR PRESSÃO
}

\author{
Author(s): AUCELY CORREA FERNANDES CHAGAS ${ }^{1}$, RAFAELA SERRANO FUSQUINE ${ }^{1}$ \\ Institution(s) ${ }^{1}$ UCDB - UNIVERSIDADE CATÓLICA DOM BOSCO (Av. Tamandaré, 6000 - Jardim \\ seminário. Campo Grande - MS, 79117-010)
}

\begin{abstract}
Introdução: A lesão por pressão (LPP) é tida como um dos principais eventos adversos encontrados em serviços de saúde. Assim, a prevenção desse acometimento se diz respeito a uma ação criteriosa, sistemática e constante de qualidade, devendo ser prioridade no exercício do cuidado. Objetivo: Comparar protocolos preventivos de LPP do Brasil e dos Estados Unidos visando à detecção de alternativas de condutas. Materiais e método: Trata-se de um estudo de revisão, os quais foram utilizados como base a nota técnica no. 03/2017 da Agência Nacional de Vigilância Sanitária (ANVISA) e o NationalUlcerAdvisoryPanelde 2016. Resultados: Dentre as condutas em comum nos protocolos, cita-se: a avaliação inicial, contínua, do momento de admissão à alta, e diária da avaliação de riscos do indivíduo; a avaliação criteriosa da pele em, no mínimo, duas vezes por dia; a manutenção o paciente em posição confortável, evitando pressão sobre áreas de proeminência óssea e eritemas; a manutenção da pele hidratada e seca e do leito seco e protegido de líquidos por meio de barreiras; e a importância de avaliar as condições de nutrição e hidratação na avaliação geral do paciente. Dentre as exceções, ressalta-se que, dentro de suas particularidades, os protocolos possuem informações detalhadas sobre uma intervenção ou outra, dispondo de conselhos e referências científicas. Deve-se apontar que, no documento NationalUlcerAdvisoryPanelexiste recomendações sobre a importância de uma análise individualizada do paciente objetivando um julgamento clínico e excluindo a utilização de escalas de risco, dando como justificativa a limitação que este instrumento traz para o profissional ao limitar o paciente e suas condições em uma pontuação geral. Além desta, existem recomendações quanto à adesão de balanceador de pH após o banho para evitar ressecamento excessivo da pele e a não utilização de dimetilsufóxido como método de tratamento de LPPs, por não ser aprovado para uso no país. Na norma técnica da ANVISA, existe a recomendação da troca de decúbito a cada duas horas, critério não estipulado no documento oposto. Conclusão: Os protocolos analisados são semelhantes em sua maioria, porém ao analisar documentos de instituições, regiões ou países distintos deve-se atentar para a divergência cultural e de crenças que cada população possui sobre o cuidado. Com isso, esta análise se faz útil ao identificarmos e analisarmos diferentes condutas e, com isso, aprimorar nosso processo de cuidado baseando-nos em diferentes perspectivas.
\end{abstract}

Keywords: Lesão por pressão, Avaliação em enfermagem, Estomaterapia

\section{Referências Bibliográficas}

Wada A, Teixeira Neto N, Ferreira MC. Úlceras por pressão. Rev. med. Hosp. Univ. [internet]. 2010 jul/dez; 89(3/4):170-7. Disponível em: http://www.revistas.usp.br/revistadc/article/download/46293/49949 National Pressure Ulcer Advisory Panel. Pressure Ulcer Stages Revised. Washington, 2016; Disponível em: http://www.npuap.org/about-us/ Agência Nacional de Vigilância Sanitária. Nota técnica GVIMS/GGTES № 03/2017. Práticas seguras para prevenção de Lesão por Pressão em serviços de saúde. Brasília (DF): 2017. Disponível em: http://portal.anvisa.gov.br/documents/33852/271855/Nota+T\%C3\%A9cnica+ GVIMS-GGTES+n\%C2\%BA+032017/54ec39f6-84e0- 4cdb-a241-31491ac6e03e. Acesso em: 25. Jun. 2019 


\title{
CONHECIMENTO DOS ENFERMEIROS QUANTO À LESÃO POR FRICÇÃO
}

\author{
Author(s): $\quad$ Fabiana da Silva Augusto ${ }^{1}$, Gisele Cabral da Silva ${ }^{1}$, Celina Mayumi Morita Saito ${ }^{1}$, Leila Blanes ${ }^{1}$, \\ Lydia Masako Ferreira ${ }^{1}$ \\ Institution(s) ${ }^{1}$ UNIFESP - UNIVERSIDADE FEDERAL DE SÃO PAULO (R. BOTUCATU, 740, VILA \\ CLEMENTINO, SÃO PAULO-SP)
}

\begin{abstract}
Introdução: A lesão por fricção (LF) é uma ferida traumática que acomete pessoas com pele frágil e é encontrada com frequência no ambiente hospitalar. Os profissionais de saúde devem ter conhecimento atualizado sobre estas lesões para poder prevenir e tratar adequadamente. Objetivo: Identificar o conhecimento de enfermeiros sobre as LFs. Métodos: Estudo clínico descritivo e transversal, realizado em um hospital terciário de São Paulo. Participaram 110 enfermeiros, sendo 97 $(88,2 \%)$ mulheres, com idade média de 35,4 anos e $96(87,3 \%)$ com pelo menos uma especialização na área de enfermagem. Para a coleta de dados, foi utilizado instrumento com perguntas estruturadas sobre definição, localização mais frequente, sintomas, fatores de risco, medidas preventivas e tratamento das LFs. Foram utilizados os testes de Qui Quadrado, Mann-Whitney, Kolmogorov-Smirnov e t de Student. Resultados: Houve maior número de respostas corretas no que diz respeito a definição $(n=108 / 98,2 \%)$ e principais sintomas das LFs $(88 / 81,5 \%)$. Também observado acertos acima de $50 \%$ nas perguntas relativas a medidas preventivas $(n=89 / 83,9 \%)$, classificação $(n=79 / 87,7 \%)$ e tratamento das LFs $(n=100 / 92,6 \%)$, no entanto, houve menor número de acertos com relação aos locais mais acometidos $(n=51 / 46,4 \%)$ e os principais fatores de risco para LF $(n=57 / 53,3 \%)$. Os participantes realizaram algum curso sobre tratamento de feridas apresentaram melhor desempenho no que diz respeito à classificação destas lesões $(p=0,003)$. Conclusão: Foi verificado conhecimento adequado dos enfermeiros desta casuística quanto a definição, sintomas, medidas preventivas, classificação e tratamento das LFs. Os participantes que realizaram curso prévio sobre tratamento de feridas apresentaram melhor desempenho no item classificação destas lesões.
\end{abstract}

Keywords: Conhecimento , Enfermeiras e Enfermeiros, Ferimentos e Lesões, Lesão por Fricção, Prevenção de Doenças

\section{Referências Bibliográficas}

(1) Baranoski S, LeBlanc K, Gloeckner M. CE: Preventing, Assessing, and Managing Skin Tears: A Clinical Review. Am J Nurs. 2016;116(11):24-30. (2) LeBlanc K, Baranoski S; Skin Tear Consensus Panel Members. Skin tears: state of the science: consensus statements for the prevention, prediction, assessment, and treatment of skin tears. Adv Skin Wound Care. 2011;24(9 Suppl):2-15. (3) LeBlanc K, Baranoski S; International Skin Tear Advisory Panel, 2013. Skin tears: the forgotten wound. Nurs Manage. 2014; 45(12):36-46; quiz 46-7. (4) Pulido KCS, Santos VLCG, Carville K. Adaptação cultural, validade de conteúdo e confiabilidade interobservadores do "STAR Skin Tear Classification System". Rev LatinoAm Enfermagem. 2015;23(1):155-61. 


\title{
PREVALÊNCIA DE LESÃO POR PRESSÃO EM UNIDADE DE TERAPIA INTENSIVA
}

\author{
Silvia Angélica Jorge ${ }^{1}$, Angélica Olivetto de Almeida ${ }^{1}$, Vanessa Abreu da Silva ${ }^{1}$, Daniela \\ Author(s): Fernanda dos Santos Alves ${ }^{1}$, Ivan Rogério Antunes ${ }^{1}$, Juliany Lino Gomes Silva ${ }^{1}$, Mariana de \\ Jesus Meszaros ${ }^{1}$, Paula Cristina Nogueira ${ }^{1}$ \\ Institution(s) ${ }^{1} \mathrm{HC}$ - UNICAMP - Hospital de Clínicas Universidade Estadual Campinas (Rua Vital Brasil 261, \\ Cidade Universitária Zeferino Vaz, Campinas - SP)
}

\begin{abstract}
Introdução: A Política Nacional de Segurança do Paciente enfatiza o desenvolvimento de ações para a cultura de segurança, dentre elas o engajamento dos profissionais na prevenção de eventos adversos como lesões por pressão [1]. Os doentes internados em unidades de terapia intensiva estão em maior risco de desenvolver lesão por pressão, devido à sua condição física debilitada e à exposição a fatores de risco [2,3]. Objetivos: Avaliar a prevalência de lesão por pressão em pacientes adultos internados em terapia intensiva. Material e Método: Estudo descritivo, transversal, em hospital de ensino no interior do Estado de São Paulo, parte da pesquisa multicêntrica DecubICUs. A coleta dos dados foi realizada por estomaterapeutas e incluiu informações dos pacientes com idade igual ou superior a 18 anos e tempo de permanência maior que 24h. Os pacientes que não estavam na unidade ou que receberam alta antes da avaliação foram excluídos da análise. A ficha de coleta incluiu dados sociodemográficos, clínicos, avaliação do risco de lesão por pressão, medidas preventivas e características das lesões de acordo com as categorias propostas pela National Pressure Ulcer Advisory Panel, European Pressure Ulcer Advisory Panel e Pan Pacific Pressure Injury Alliance [5]. Os dados foram inseridos na plataforma REDCap e analisados no Microsoft Excel®. Todos os participantes assinaram o termo de consentimento livre e esclarecido. $\mathrm{Na}$ impossibilidade de consentir a participação, o consentimento foi obtido junto ao seu representante legal. $\mathrm{O}$ projeto foi aprovado pelo comitê de ética em pesquisa sob Parecer № 2.783.874. Resultados: A amostra foi composta por 32 pacientes, sexo masculino $(65,6 \%)$, internados na unidades de terapia intensiva geral $(50,0 \%)$, tempo de permanência de 8,72 dias, média de idade de 57,5 anos e IMC médio de $27,9 \mathrm{~kg} / \mathrm{cm}^{2}$. As principais causas de internação foram infarto agudo do miocárdio (12,5\%) e acidente vascular isquêmico ou hemorrágico (9,4\%). A hipertensão arterial $(34,4 \%)$ e o diabetes mellitus tipo $2(31,3 \%)$ foram as principais comorbidades. Durante a internação, 56,3\% dos pacientes foram submetidos a procedimentos cirúrgicos e $59,4 \%$ estavam sob ventilação mecânica na admissão. Quanto ao risco para desenvolver lesões por pressão, 9,4\% pacientes foram avaliados como sem risco, $25,0 \%$ baixo risco, $12,5 \%$ risco moderado, $21,9 \%$ alto risco e $31,2 \%$ muito alto risco. Em relação às lesões por pressão, oito pacientes (25,0\%) tinham 13 lesões: occipitais não classificáveis $(n=2)$, occipital estágio $3(n=1)$, pavilhão auricular $(n=3)$, mucosa oral $(n=1)$, ombro estágio $2(n=1)$, mucosa genital $(n=1)$, e região sacral $(n=4$, estágios 1 , 2 e 4). As medidas preventivas empregadas foram: reposicionamento do paciente $(87,5 \%)$, utilização de almofadas de espuma $(71,9 \%)$, hidratação da pele $(59,4 \%)$, reforço dos calcâneos $(28,1 \%)$ e utilização de colchões de pressão alternada $(21,9 \%)$. Conclusões: O estudo indicou a presença de lesão por pressão em um quarto dos pacientes avaliados, sendo que todos foram classificados como alto ou muito alto risco.
\end{abstract}

Keywords: Lesão por Pressão, Estomaterapia, Segurança do Paciente, Prevalência

\section{Referências Bibliográficas}

1- Brasil. Portaria oㅜ 529, de 1ํ de abril de 2013. Institui o Programa Nacional de Segurança do Paciente (PNSP). Diário Oficial da União, 2 abr 2013 2- Bennett G, Dealey C, Posnett J, (2004) The cost of pressure ulcers in the UK. Age Ageing 33: 230-235 3- Keller BP, Wille J, van Ramshorst B, van der Werken C, (2002) Pressure ulcers in intensive care patients: a review of risks and prevention. Intensive Care Med 28: 1379-1388 4- National Pressure Ulcer Advisory Panel, European Pressure Ulcer Advisory Panel and Pan Pacific Pressure Injury Alliance. Prevention and Treatment of Pressure Ulcers: Quick Reference Guide. Emily Haesler (Ed.). Cambridge Media: Osborne Park, Australia; 2014. 


\title{
Tecnologia na Estomaterapia - Relato de experiência em ferida complexa
}

\author{
Author(s): $\quad$ LUANA AIRES MEDEIROS DINIZ ${ }^{1}$, DANIELLE NERIS FERREIRA ${ }^{1}$ \\ Institution(s) ${ }^{1}$ HUMAP/EBSERH - HOSPITAL UNIVERVISTÁRIO MARIA APARECIDA PEDROSSIAN \\ (Av. Sen. Filinto Müler, 355 - Vila Ipiranga, Campo Grande - MS, 79080-190)
}

\begin{abstract}
Introdução: A lesão decorrente de síndrome compartimental associado a processo infeccioso demonstra uma preocupação por parte da equipe interdisciplinar, considerando o entorno de complicações que esse agravo pode ocasionar, seja nos aspectos referente ao local da lesão, quanto as repercussões sistêmicas. Diante disso, a tomada de decisões com intervenções imediatas é fundamental para o tratamento, o que garante também a sobrevida do paciente, e isso exige, um manejo clinico e cirúrgico apurado. O enfermeiro estomaterapeuta, como membro da equipe interdisciplinar, tem uma atuação sine qua non no tratamento de feridas, participando da avaliação e execução de procedimentos, elaboração de protocolos, seleção e indicação de novas tecnologias, seja nos aspectos preventivos ou de tratamento de pessoas com feridas,2. Objetivo: Relatar a experiência da assistência de enfermagem em estomaterapia ao paciente com ferida complexa e apresentar a sua evolução frente a terapêutica adotada, quanto ao curativo e a indicação de cobertura, como recurso tecnológico para a estomaterapia. Material e Método: Trata-se de um estudo retrospectivo, descritivo, do tipo relato de experiência, com coleta dos dados através da análise dos registros de prontuário de um paciente com ferida complexa que ficou internado em um hospital de ensino de Campo Grande-MS, no âmbito do Sistema Único de Saúde no período de janeiro-fevereiro de 2019. O paciente foi avaliado e assistido por enfermeiro estomaterapeuta durante o período de internação, a cada atendimento, realizava-se curativo da lesão e estabelecia-se sua avaliação nos seguintes aspectos: leito da lesão, dimensão, exsudato (característica e quantidade), margem, odor e dor. Após avaliação, estabelecia-se as condutas, no que se refere ao tipo de curativo, técnica de limpeza, cobertura primária e secundária, periodicidade de troca, necessidade de desbridamento dos fragmentos de tecido desvitalizado, em observância as orientações do protocolo institucionalizado. Resultado: O cuidado em estomaterapia engloba a aplicação de diversas tecnologias disponíveis, dentre elas encontra-se as coberturas utilizadas em curativos, elemento este fundamental para a evolução da lesão e consequentemente essencial num conjunto de intervenções a ser realizada para a recuperação do indivíduo3. Nesse relato, as coberturas indicadas sequencialmente para o tratamento da ferida foram: hidrofibra com prata, malha não aderente com petrolato e acidos graxos essenciais, cada qual no seu momento oportuno. Precedendo a aplicação de coberturas, realizouse a limpeza exaustiva com SF $0,9 \%$ e aplicação da solução Polihexametileno Biguanida $0,1 \%$ no leito da lesão, mantendoa por 15 minutos. Com esses recursos houve progressão significativa na evolução da lesão, principalmente pela formação de tecido de granulação, em que o leito esteve apto a enxertia em 20 dias de tratamento. Conclusão: A indicação de um recurso tecnológico inserido no contexto da prática do curativo precedeu de uma avaliação criteriosa, científica, e também humana, dessa forma a atuação de enfermeiros estomaterapeutas no corpo da equipe interdisciplinar foram fundamentais para a evolução da lesão e consequentemente na recuperação do paciente, demonstrando qualidade da assistência de enfermagem frente ao atendimento de um caso complexo.
\end{abstract}

Keywords: Ferimentos e Lesões, Tecnologia, Estomaterapia

\section{Referências Bibliográficas}

1 Cofen. Conselho Federal de Enfermagem. Resolução 567 de 29 de Janeiro de 2018. Regulamenta a atuação da equipe de enfermagem no cuidado aos pacientes com feridas. Brasília-DF, 2018. 2 Yamada, BFA.; Ferrola, EC; Azevedo, GR; Blanes, L., Rogenski, NMB; Santos, VLCG. Competências do enfermeiro estomaterapeuta (ET) ou do enfermeiro pósgraduado em estomaterapia (PGET). Rev Estima. 2008; 6(1). 3 Shoji, S.; Souza, NVDO.; Mauricio, VC; Costa, CCPC; Alves, FT. O cuidado de enfermagem em estomaterapia e o uso das tecnologias. Rev Estima, 2017; 15(3): 169-177. 


\title{
Avaliando o Índice Tornozelo-Braquial (ITB) e relacionado aos riscos de lesões de membros inferiores: relato de experiência de atividade de uma Liga Acadêmica
}

\author{
Juliana Balbinot Reis Girondi ${ }^{2}$, Scheila Monteiro Evaristo ${ }^{3}$, Amanda de Souza Vieira ${ }^{1}$, Lúcia
} Nazareth Amante ${ }^{1}$, Luciara Fabiane Sebold ${ }^{1}$, Cilene Fernandes Soares ${ }^{2}$, Eluze Luz Ouriques Neta Author(s): $\quad{ }^{1}$, Helena Sophia Strauss Mohr ${ }^{1}$, Eduarda Brito dos Santos ${ }^{1}$, Gabriela Beims i Gapsk ${ }^{1}$, Sibele Maria Schuantes Paim ${ }^{1}$, Suzana dos Santos da Rosa ${ }^{1}$, Maria Eduarda Hames ${ }^{1}$, Fernanda Lunardi ${ }^{1}$ Institution(s) ${ }^{1}$ UFSC - Universidade Federal de Santa Catarina (Campus Reitor João David Ferreira Lima, s/n Trindade. Depto Enfermagem), ${ }^{2}$ SMS Florianópolis - Secretaria Municipal de Saúde de Florianópolis (Avenida Professor Henrique da Silva Fontes, $n^{\circ}$ 6100. Trindade. Fpolis.), ${ }^{3}$ SMS São José - Secretaria Municipal Saúde São José (Av. Acioni Souza Filho, 403 - Centro, São José - SC, 88111-330)

\begin{abstract}
Introdução: Medida de grande significância para a avaliação no déficit cardiovascular é o Índice Tornozelo-Braquial (ITB), importante sinalizador da Doença Arterial Obstrutiva Periférica (DAOP) em sua fase assintomática. Considerando-se que o diabetes e a hipertensão são dois dos mais importantes fatores de risco para o desenvolvimento de DAOP e geralmente estão presentes em idosos, justifica-se a maior importância da realização do ITB nessa população. A DAOP leva à dificuldade da progressão do sangue, oxigênio e nutrientes para os tecidos dos membros como músculos, nervos, ossos e pele, aumentando o risco de lesões em membros inferiores. Objetivo: Avaliar o Índice Tornozelo-Braquial em idosos na comunidade e descrever características associadas. Material e Método: Relato de experiência de intervenção educativa desenvolvida por uma Liga Acadêmica de cuidado à pessoa com estomias e feridas durante a Semana de Enfermagem 2019, no sul do Brasil. A atividade foi desenvolvida em dois momentos e teve duração de quatro horas. No primeiro, os idosos foram divididos em seis grupos dispostos em círculos e encorajados a realizarem auto percepção da pele, observando sinais os quais conferem risco para manutenção de sua integridade, e, assim propor cuidados, com base em seus conhecimentos. Após, o representante de cada grupo apresentou em plenária o consenso da equipe e os mediadores fizeram articulação de cada eixo apresentado aos cuidados propostos pela literatura. A segunda parte consistiu na avaliação do ITB e aplicação do Questionário de Claudicação de Edimburgo. A oficina faz parte de um macroprojeto aprovado pelo Comitê de Ética sob no 74769317.5.1001.0121. Resultados: Participaram 24 idosos, com idade entre 60 a 75 anos, a maioria do sexo feminino. Entre as comorbidades autoreferidas identificou-se: hipotireoidismo, artrose, cirrose hepática, depressão, hipertensão arterial sistêmica, diabetes mellitus (tipo 1 e 2), fibromialgia. Do primeiro momento emergiram mediante consenso dos grupos, a partir da repetição dos conceitos, seis eixos relacionados aos cuidados com a pele a partir de seus saberes populares: uso de hidrantes diariamente, ingestão de líquidos para evitar ressecamento da pele, evitar uso de produtos agressivos sobre a pele tais quais os esfoliantes, utilizar protetor solar diariamente, evitar água quente durante o banho e utilizar sabonete neutro. Em relação ao segundo momento: os achados consistem em dor/desconforto nas pernas ao deambular (10 idosos); a dor começa quando está em pé parado ou sentado (7); presença da dor ao subir ladeira ou andar rápido (5); dor está presente quando caminha em ritmo normal ou plano (6); quando parados, a dor geralmente continua por mais de 10 minutos (5) ou geralmente desaparece em 10 minutos ou menos (5). A média de ITB foi de 1,01; um idoso apresentou ITB alterado, sendo orientado para consulta médica. Conclusão: Os valores de ITB e os sintomas pioram com o avanço da idade. O reconhecimento da DAOP como um marcador sensível de aterosclerose sistêmica, o aumento no risco de eventos cardiovasculares e de lesões em membros inferiores tornam-se fatores decisivos para a utilização do ITB e do Questionário de Claudicação de Edimburgo.
\end{abstract}

Keywords: Doença Arterial Periférica, Idoso, Estomaterapia, Claudicação Intermitente, Ferimentos e Lesões

\section{Referências Bibliográficas}

1. Lira ALB, Sá JD, Nogueira ILA, Medeiros MDC, Fernandes MICD, Vitor AF. Integridade da pele em idosos: revisão da literatura segundo as cartas de promoção da saúde. Cogitare Enferm. 2012; 17(4):767-74. 2. Mallmann DG, Galindo Neto NM, Sousa JC, Vasconcelos EMR. Educação em saúde como principal alternativa para promover a saúde do idoso. Ciênc. saúde coletiva. 2015; 20(6): 1763-72. 3. Oliveira RA. A pele em diferentes etapas da vida. In: Domansky RC. Manual de prevenção de lesões de pele: recomendações baseadas em evidências. 1.ed. Rio de Janeiro: Rubio; 2014. p. 9-40. 4. Costa RKS, Torres GV, Salvetti MG, Azevedo IC, Costa MAT. Validade de instrumentos sobre o cuidado de enfermagem à pessoa com lesão cutânea. Acta Paulista de Enfermagem. 2014; 27(5): 447-57. 5. Maggi DL, Quadros LRDP, Azzolin KO, Goldmeier S. Índice tornozelo-braquial: estratégia de enfermeiras na identificação dos fatores de risco para doença cardiovascular. Revista da Escola de Enfermagem da USP. 2014; 48(2): $223-27$. 


\title{
A UTILIZAÇ̃̃o DA PAPAÍNA COMO COBERTURA PARA LESÕES DE PELE: REVISÃo SISTEMÁTICA DE LITERATURA
}

\author{
Author(s): $\quad$ Douglas Alves do Amaral ${ }^{1}$ \\ Institution(s) ${ }^{1}$ HED - HOSPITAL DE ASSISTÊNCIA DOMICILIAR (Rua: Capitão Sampaio Xavier No 290 - \\ Cep: 52050-290 - Recife/PE)
}

\begin{abstract}
RESUMO

Trata-se de um estudo de revisão integrativa, analisando as pesquisas mais relevantes acerca do tema, e sintetizando o estado de conhecimento do assunto em questão. A prática baseada em evidências é uma abordagem que preconiza a utilização de resultados de pesquisas na prática clínica, sendo a revisão integrativa um de seus recursos. A presente investigação é uma revisão integrativa que teve como objetivo buscar e avaliar as evidências científicas disponíveis sobre a aplicabilidade da papaína em pacientes portadores de úlceras.

INTRODUÇÃO

A pele é um órgão composto por três camadas e tem função protetora, termorreguladora e captadora de estímulos táteis e dolorosos. A lesão da pele é caracterizada pela interrupção da continuidade do órgão e sua integridade, podendo se apresentar em variadas extensões, causadas por traumas ou desencadeado por afecção clínica, podendo se apresentar de forma aguda ou crônica. A remoção do tecido inviável através do desbridamento é benéfico por remover os tecidos, desvitalizados. Os tipos de desbridamento utilizados são: mecânico, autolítico, biológico e enzimático. O autolítico é realizado pela autólise natural que ocorre no tecido necrótico e surge da junção de três fatores: hidratação do leito da lesão, ação de enzimas endógenas e fibrinólise. Neste contesto surge a papaína, atuando como desbridante enzimático, promovendo remoção atraumática do tecido inviável, bem como promotor da granulação e epitelização.

OBJETIVOS

Analisar as evidências científicas disponíveis sobre a aplicabilidade da papaína em pacientes portadores de úlceras. METODOLOGIA

Trata-se de um estudo de revisão sistemática, analisando as pesquisas mais relevantes acerca do tema, e sintetizando o estado de conhecimento do assunto em questão. Para a estruturação do trabalho, foi realizado inicialmente uma identificação dos estudos através da Biblioteca Virtual em Saúde (BVS) e google acadêmico, utilizando os descritores "papaína", "lesões" e "estomaterapia".

RESULTADOS

Foi possível identificar que em todos os trabalhos houve reepitelização de tecidos com relação ao uso da papaína em diversas concentrações. Com relação à concentração da papaína, foram analisados estudos que utilizaram as concentrações de $2 \%$ e $4 \%$, 4 a $6 \%$ e $10 \%$. Onde a de $2 \%$ a $4 \%$ foram mais utilizadas para promover a granulação dos tecidos, $4 \%$ a $6 \%$ a fim de realizar desbridamento enzimático em esfacelos ou quando a lesão apresentar exsudato purulento. Por fim, a concentração a $10 \%$ foi utilizada como adjuvante para realizar desbridamento enzimático em necrose seca, bem como atuação bactericida e bacteriostática
\end{abstract}

\section{CONSIDERAÇÕES FINAIS}

As lesões de pele são consideradas um problema de saúde pública, impactam psicologicamente, social e economicamente para o indivíduo, além de ter custos elevados para o sistema de saúde. Com isso é necessária a utilização de coberturas especiais no processo de cicatrização. Este trabalho permitiu endossar a produção científica acerca da utilização da papaína, como potente produto seguro e efetivo de terapêutica desbridante e estimulante da regeneração de lesões das mais diversas etiologias, destacando-se pelo baixo custo e boa resolutividade, adequando-se à realidade financeira da massiva população brasileira, acredita-se ainda que este trabalho possa corroborar com o desenvolvimento de protocolos para a utilização da papaína.

\section{Keywords: PAPAÍNA , LESÕES , ESTOMATERAPIA}

\section{Referências Bibliográficas}

REFERÊNCIAS 1. LEITE, Andréa Pinto et al. Uso e efetividade da papaína no processo de cicatrização de feridas: uma revisão sistemática. Rev. Gaúcha Enferm., Porto Alegre, v. 33, n. 3, p. 198-207, setembro. 2012. 2 . PEREIRA, Ângela Lima; BACHION, Maria Márcia. Tratamento de feridas: análise da produção científica publicada na Revista Brasileira de Enfermagem de 1970-2003. Rev. bras. enferm. Brasília, v. 58, n. 2, p. 208-213, abr. 2005. 3. COUTINHO, V.L. Papaína Associada ao Silicato de Magnésio para Cicatrização de Feridas. PI0401713-7A. 07 maios 2004, 01 ago. 2006 


\title{
PREVALÊNCIA DE LESÕES DE PELE EM PACIENTES CRÍTICOS
}

\author{
Mariana de Jesus Meszaros ${ }^{1}$, Vanessa Abreu da Silva ${ }^{1}$, Angélica Olivetto de Almeida ${ }^{1}$, Daniela \\ Author(s): Fernanda dos Santos Alves ${ }^{1}$, Ivan Rogério Antunes ${ }^{1}$, Juliany Lino Gomes Silva ${ }^{1}$, Silvia Angélica \\ Jorge ${ }^{1}$, Paula Cristina Nogueira Nogueira ${ }^{2}$ \\ Institution(s) ${ }^{1}$ HC/UNICAMP - Hospital de Clínicas da Universidade Estadual de Campinas (R. Vital Brasil, \\ 251 - Cidade Universitária, Campinas - SP, 13083-888), ${ }^{2}$ EEUSP - Escola de Enfermagem da \\ Universidade de São Paulo ( Av. Dr. Enéas Carvalho de Aguiar, 419 - Cerqueira César, São Paulo - \\ SP, 05403-)
}

\begin{abstract}
Introdução: As lesões de pele em pacientes críticos representam desafio para os profissionais e instituições de saúdes, pois podem aumentar o tempo de internação e elevar os custos com o tratamento. Para o paciente, as lesões de pele podem causar sofrimento e impactar negativamente na sua qualidade de vida [1]. Objetivos: Identificar a prevalência de lesões de pele em pacientes críticos, internados em unidade de terapia intensiva. Material e Método: Estudo descritivo, transversal, conduzido em unidade de terapia intensiva de adultos, de um hospital universitário do interior do Estado de São Paulo, como parte do estudo multicêntrico DecublCUs. O local do estudo conta com 409 leitos para internação de pacientes adultos e pediátricos, dos quais 55 são leitos de terapia intensiva adulto. A amostra incluiu pacientes, com idade igual ou maior que 18 anos e tempo de internação superior a 24 horas. Foram excluídos os pacientes que estavam em exames ou procedimentos fora da unidade e aqueles que receberam alta da unidade antes de serem avaliados. A coleta de dados foi realizada por sete enfermeiros, estomaterapeutas, por meio de instrumento contendo variáveis sociodemográficas, antecedentes pessoais, diagnóstico principal, comorbidades e presença de lesões de pele - dermatite associada à incontinência, lesão associada a adesivos, lesão por fricção e lesões por pressão. Os pacientes foram avaliados uma única vez, de forma sistemática, todos no mesmo dia, quanto a presença de lesões de pele. Os dados foram digitados na Plataforma REDCap e exportados para o software Excel (Microsoft $\Theta$ ), onde foram analisados. O projeto foi aprovado pelo comitê de ética em pesquisa da instituição (Parecer no 2.783.874). Todos os participantes ou seus representantes legais assinaram o termo de consentimento livre e esclarecido. Resultados: A amostra foi composta por 32 pacientes, sendo a maioria do sexo masculino (65,6\%), com média de idade de 57,5 anos e de tempo de internação de 8,72 dias. 0 tipo de admissão foi urgência para $62,5 \%$ dos pacientes, procedentes do serviço de atendimento pré hospitalar $(53,1 \%)$. 0 diagnóstico principal foi infarto agudo do miocárdio (12,5\%) e, o secundário, hipertensão arterial sistêmica $(34,4 \%)$. O diabetes mellitus tipo 2 foi a comorbidade mais frequente $(31,3 \%)$ entre os pacientes avaliados. A lesão de pele mais frequente foi a lesão por pressão (25,0\%), sendo que 37,5\% delas estavam presentes no momento de admissão do paciente. As lesões de pele associadas à umidade estavam presentes em 6,25\% dos pacientes, sendo a dermatite associada à incontinência o evento predominante. Entre as lesões associadas a adesivos (15,6\%), as lesões causadas por fitas adesivas foram as mais frequentes $(80,0 \%)$. Cerca de $10 \%$ dos pacientes apresentavam lesões por fricção, sendo as categorias 1B $(n=1), 2 A(n=1)$ e $3(n=1)$ as classificações de gravidade. Conclusões: As lesões de pele estavam presentes em $40,6 \%$ dos pacientes, sendo que $15,6 \%$ apresentavam dois tipos de lesões e a lesão por pressão foi o tipo mais frequente.
\end{abstract}

Keywords: Estomaterapia, Ferimentos e Lesões, Prevalência, Cuidados Críticos

\section{Referências Bibliográficas}

1. Campanili TCGF, Santos VLCG, Strazzieri-Pulido KC, Thomaz PBM, Nogueira PC. Incidence of pressure ulcers in cardiopulmonary intensive care unit patients. Rev Esc Enferm USP. 2015; 49:7-14. 


\title{
TRATAMENTO DE LESÃO DE PELE E SUAS COMPLICAÇÕES CAUSADA POR ADMINISTRAÇÃO INTRAMUSCULAR DE SILICONE INDUSTRIAL: RELATO DE CASO
}

\author{
Author(s): Suelen Souza do Carmo ', Carolina de Mendonça Carvalho ', Nathalia Santos da Cruz ${ }^{1}$, Roselena Pechoto \\ de Oliveira ${ }^{1}$, Marina Akemi Higo ${ }^{1}$, Ana Karina de Souza Nardelli ${ }^{1}$, Elaine Cristina Freitas ${ }^{1}$ \\ Institution(s) ${ }^{1}$ HMMG - Hospital Municipal Dr Mário Gatti (Av. Pref. Faria Lima, 340 - Parque Italia, Campinas - SP, \\ 13036-902)
}

\begin{abstract}
Introdução

Silicone líquido industrial é utilizado frequentemente como material de preenchimento e alteração do contorno corporal com objetivo estético, clandestinamente. Há inúmeras complicações descritas na literatura como: processos inflamatórios localizados, formação de siliconomas, migração do material, inflamações sistêmicas graves associadas ou não a infecções. O tratamento poderá ser clinico ou cirúrgico, com a realização de desbridamentos e enxertos.

Atualmente, a terapia à vácuo tem sido a escolha para o preparo do leito da lesão para enxerto de pele. Dentre os benefícios relacionados estão: diminuição do edema local, colonização bacteriana e dor entre as trocas do curativo; manutenção do ambiente úmido; aumento da vascularização sanguínea; maior rapidez na evolução da lesão.

Objetivo

Relatar evolução da lesão ocasionada pela aplicação do silicone industrial, tratamento instituído, com enfoque no uso da terapia por pressão negativa, visando à cicatrização e preparo do leito para enxertia.

Material e Método

Trata-se de estudo descritivo, retrospectivo, do tipo: relato de experiência realizado com paciente de hospital-ensino público de Campinas /SP. Submetido ao CEP conforme Resolução 466/12, aprovação no 2.715.215.

Resultados

Sexo masculino, 19 anos, internou em 22/05/2017 devido à abscesso cutâneo causado por injeção de silicone industrial via intramuscular em glúteos.

Apresentando febre, dor intensa nos glúteos, deformidade local, lesões ulceradas, acometimento de epiderme, uso de antibióticos intravenoso. Realizado fasciotomia, sem efetividade. Em 28/05/2017 realizado desbridamento cirúrgico de tecido necrótico em glúteos, após, curativo com papaína 10\% gel. Evoluiu com piora clínica, aumento de necrose em região previamente íntegra de glúteos, ventilação mecânica, aporte nutricional via enteral e parenteral, uso de drogas vasoativas e sedativos, reposição de componentes sanguíneos. Realizado desbridamento cirúrgico em 30/05/2017, extenso,

abrangendo glúteo direito, esquerdo, face posterior de coxa direita e esquerda, exposição de tecido muscular e tendões, tecido pálido, grande quantidade de esfacelo, ocluído com sulfadiazina de prata $1 \%$ com troca diária, realizado colostomia protetora. Em 02/06/2017 instalado terapia à vácuo em toda área lesionada, suturando a espuma de poliuretano nas bordas da lesão, vedado por filme fino de poliuretano e instalado uma bomba de sucção à vácuo contínuo em $-125 \mathrm{mmHg}$ em cada lado do glúteo/coxa. Realizado 5 trocas de curativo associado a terapia à vácuo, observando continuamente o aumento do tecido de granulação de aspecto vermelho vívido e saudável. Término do uso da terapia a vácuo, introduzido curativo hidrofibra com prata e hidroalginato com prata. Leito preparado para enxertia. Realizado enxerto de pele total em malha expandido em 28/07/2017 em outro hospital. Alta hospitalar em 21/09/2017, seguimento ambulatorial com fisioterapia, cirurgia geral e estomaterapia. Recebeu alta ambulatorial em 31/01/2018 com lesão 100\% cicatrizada.

Conclusão

Observou-se que a literatura nacional e internacional é escassa quando se trata de investigações desta natureza, a maioria dos estudos é de anos anteriores a 2015, necessário aprofundamento sobre o assunto.

Recomenda-se o uso da terapia por pressão negativa em casos semelhantes devido à efetividade, trata-se de um caso que apresentou severas complicações sistêmicas, instituído tratamento com terapia à vácuo, obtido controle e manejo das complicações, assim como preparo do leito da lesão para cirurgia reconstrutiva.
\end{abstract}

Keywords: Estomaterapia, Silicone industrial, Terapia à vácuo, Lesão de pele, Cicatrização

\section{Referências Bibliográficas}

Referências MILCHESKI DA et al. Terapia por pressão negativa na ferida traumática complexa do períneo. Rev Col Bras Cir. 2013; 40(4): 312-317. MELLO DF et al. Complicações locais após a injeção de silicone líquido industrial- série de casos. Rev Col Bras Cir. 2013; 40(1): 037-043. OTHMAN D. Negative Pressure Wound Therapy Literature Review of Efficacy, Cost Effectiveness, and Impacto on Patients' Quality of Life in Chronic Wound Management and Its Implementation in the United Kingdom. Plastic Surgery International, Vol 2012. LIATAS FP. Evaluacion de la terapia con presion negativa tópica en la cicatrización de heridas agudas Y úlceras cutâneas tratadas en un hospital valenciono. Enferm Dermatol. 2015; 9(24). PINTO et al 2017, Silicone industrial para transformar o corpo: prevalência e fatores associados ao seu uso entre 
travestis e mulheres transexuais em São Paulo, Brasil. Cad. Saúde Pública 2017; 33(7).

\title{
Medidas não invasivas de prevenção da recidiva de úlcera venosa: revisão integrativa
}

\author{
Author(s): $\quad$ Sônia Regina Pérez Evangelista Dantas ${ }^{2}$, Francielle Janaina de Souza ${ }^{2}$, Juliana Fonseca Santos \\ Tomaz de Aquino ${ }^{2}$, Mirian Alves Guimarães Silva ${ }^{2}$, Míryam Ferreira de Oliveira ${ }^{2}$ \\ Institution(s) ${ }^{2}$ UNICAMP - UNIVERSIDADE ESTADUAL DE CAMPINAS (Cidade Universitária Zeferino \\ Vaz - Barão Geraldo - Campinas SP)
}

\begin{abstract}
Introdução: Úlceras por insuficiência venosa (UV) representam $75 \%$ das úlceras crônicas de membros inferiores e acometem aproximadamente $1 \%$ da população mundial, com aumento da prevalência para $2 \%$ na população com mais de 80 anos, caracterizando-se como problema de saúde pública mundial. O tratamento padrão da UV é muito bem estabelecido e consiste, essencialmente, da terapia compressiva do membro e terapia tópica para úlcera. O principal fator relacionado com as recidivas é a não adesão às medidas de prevenção relacionadas com mudanças no estilo de vida e uso de terapia compressiva, por desconhecimento e falta de orientações adequados ou negligência. Objetivo: Este estudo teve como objetivo identificar, na literatura, as medidas não invasivas de prevenção da recidiva de úlceras venosas. Método: Realizou-se revisão integrativa nas bases de dados da Biblioteca Virtual em Saúde (BVS), Public Medline (PubMed), Cumulative Index of Nursing and Allied Health Literature (CINAHL) e Excerpta Medica dataBASE (Embase) no período de 2015 a 2017. A busca bibliográfica foi realizada utilizando-se os descritores controlados "varicose ulcer" e "recurrence" e o operador booleano AND entre eles em todas as bases de dados descritas, em português, inglês e espanhol. Após as buscas, dois revisores realizaram a pré-seleção por títulos e resumo dos artigos seguida da leitura na íntegra dos estudos pré-selecionados. Resultado: Identificaram-se 210 estudos, sendo que 188 foram excluídos por não atenderem à questão norteadora. Dois revisores leram na íntegra os 22 artigos pré-selecionados e incluíram nesta revisão nove que fi zeram parte da discussão deste trabalho. Conclusão: Os estudos desta revisão sugerem que a adesão e o uso correto da terapia compressiva com meias associados a medidas de educação e autocuidado são efetivos para prevenção de recidiva da úlcera venosa. A associação de ácido acetilsalicílico com as medidas padrão de tratamento ainda carece de resultados conclusivos e sugerem-se novos estudos para comprovação da eficácia.
\end{abstract}

Keywords: Cuidados de enfermagem., Estomaterapia., Insuficiência venosa., Recidiva., Úlcera varicosa.

\section{Referências Bibliográficas}

1. Liberato SMD, Araújo RO, Souza AJG, Marconato AMP, Costa IKF, Torres GV. Adesão ao tratamento de pessoas com úlceras venosas atendidas na atenção primária à saúde. Aquichán. 2017;17(2):128-39. https://doi.org/10.5294/ aqui.2017.17.2.2 2. Nicolosi JT, Altran SC, Barragam JP, Carvalho VF, Isaac C. Terapias compressivas no tratamento de úlcera venosa: estudo bibliométrico. Aquichán. 2015;15(2);283-95. https:// doi.org/10.5294/aqui.2015.15.2.11 3. Borges EL, Ferraz AF, Carvalho DV, Matos SS, Lima VLAN. Prevenção de recidiva de úlcera varicosa: um estudo de coorte. Acta Paul Enferm. 2016;29(1):9-16. https://doi. org/10.1590/1982-0194201600003 4. Sociedade Brasileira de Angiologia e de Cirurgia Vascular. Projeto diretrizes SBACV: insufi ciência venosa crônica - Diagnóstico e tratamento [Internet]. Rio de Janeiro: SBACV; 2015 [citado $10 \mathrm{Fev}$ 2018]. Disponível em: http://www.sbacv.org.br/lib/media/ pdf/diretrizes/insufi ciencia-venosacronica.pdf 5. Harding K, Dowsett C, Fias L, Jelnes R, Mosti R, Õiem R, et al. Simplifying venous leg ulcer management. Consensus recommendations [Internet]. London: Wounds International; 2015 [citado 10 Fev 2018]. Disponível em: http://www.3mlearning. co.uk/media/1072/3m_14_4_consensus_web.pdf 


\title{
CONSTRUÇÃO E VALIDAÇÃO DE CARTILHA DE AUTOCUIDADO PARA PREVENÇÃO DE LESÃO POR PRESSÃO
}

\author{
Author(s): Daniel Nogueira Nogueira Cortez ${ }^{1}$, Isabela Ferreira Rodrigues ${ }^{1}$, Laysla Luiza Santos ${ }^{1}$, Juliano \\ Teixeira Moraes ${ }^{1}$ \\ Institution(s) ${ }^{1}$ UFSJ/CCO - Universidade Federal de São João del-Rei/Campus Divinópolis (R Sebastião \\ Gonçalves Coelho, 400 - B. Chanadour. Divinópolis/MG. CEP:35.501-296)
}

\begin{abstract}
Introdução: A prevenção e o tratamento da Lesão por Pressão é multidisciplinar e envolve ações terapêuticas e educativas, pois visa corrigir fatores de risco para o desenvolvimento da lesão, assim como realizar a sua cicatrização. Em relação às ações educativas, o sucesso na prevenção e tratamento da Lesão por Pressão envolve a participação do paciente, dos seus familiares/cuidadores e dos profissionais de saúde. Neste contexto, existem diversas tecnologias e formatos de instrumentos educativos, como folhetos, manuais, folders, livretos, álbum seriado e cartilhas que podem se apresentar impressos ou de forma virtual para o uso em aplicativos, mas que ainda não foram produzidos e validados cientificamente. Objetivo: Descrever o processo de construção e validação de uma cartilha de autocuidado para prevenção de Lesão por Pressão. Material e Método: Trata-se de uma pesquisa metodológica, com abordagem quantitativa, que construiu uma cartilha de autocuidado para prevenção de pacientes com risco para desenvolver Lesão por Pressão. A pesquisa foi desenvolvida em 4 etapas: levantamento bibliográfico; construção do material educativo (ilustração, layout, design e textos), cálculo do índice de Facilidade de Leitura de Flesch e validação do material por experts da área. Aprovado pelo comitê de ética com parecer de número 2.854.58. Resultados: A cartilha foi composta por capa, 5 páginas e 19 imagens, sendo que cada página contou com uma média de 4 imagens. A cartilha foi validada quanto ao conteúdo e aparência por 11 experts, com o Índice de Validade de Conteúdo de $0,93 \%$. Os textos da cartilha foram avaliados como de leitura razoavelmente fácil, com Índice de Facilidade de Leitura de Flesch de 71\%. Conclusão: A cartilha foi validada quanto ao conteúdo e aparência, podendo ser usada como material educativo aos pacientes que apresentam risco de desenvolver Lesão por Pressão.
\end{abstract}

Keywords: Lesão por Pressão, Autocuidado, Folheto, Estomaterapia

\section{Referências Bibliográficas}

1. Boyko T V, Longaker MT, Yang GP. Review of the Current Management of Pressure Ulcers. Adv wound care [Internet]. 2018 Feb 1 [cited 2019 May 15];7(2):57-67. Available from: http://www.ncbi.nlm.nih.gov/pubmed/29392094 2. National Pressure Ulcer Advisory Panel-NPUAP. Pressure Ulcer Stages Revised [Internet]. Washington. 2016 [cited 2019 May 18]. Available from: http://www.npuap.org/about-us/ 3. Smith IL, Nixon J, Brown S, Wilson L, Coleman S. Pressure ulcer and wounds reporting in NHS hospitals in England part 1: Audit of monitoring systems. J Tissue Viability [Internet]. 2016 Feb [cited 2019 May 23];25(1):3-15. Available from: https://linkinghub.elsevier.com/retrieve/pii/S0965206X15000935 4. Soares CF, Heidemann BSI. Promoção da saúde e prevenção da lesão por pressão: expectativas do enfermeiro da atenção primária. Texto Context Enferm [Internet]. 2018 [cited 2019 May 15];27(2). Available from: http://dx.doi.org/10.1590/0104-070720180001630016 


\title{
FATORES DE RISCO PARA LESÕES EM MEMBROS INFERIORES DE PESSOAS COM DIABETES TIPO 2
}

\author{
Author(s): Fátima Tereza Praia Lima ${ }^{1}$, Eliana Marques Gomes da Silva ${ }^{1}$, Hanna Beatriz de Souza Carvalho ${ }^{1}$, \\ Rogério Nunes de Aguiar ${ }^{1}$ \\ Institution(s) ${ }^{1}$ UEA - Universidade do Estado do Amazonas (Avenida Djalma Batista, 3578 - Chapada CEP \\ 69050-030 Manaus AM)
}

\begin{abstract}
Introdução - O diabetes (DM) sobressai entre as doenças crônicas não transmissíveis e possui aumento significativo nos índices de morbidade e mortalidade. Dentre complicações do $\mathrm{DM}$, as úlceras diabéticas têm projeções crescentes, representando grave problema de saúde pública, com elevados custos com internação hospitalar ou tratamento ambulatorial. Em virtude da complexidade e cronicidade do DM e seu potencial agravante de danos, este estudo almeja contribuir com aspectos relacionados à identificação dos fatores de riscos de lesões cutâneas na avaliação dos membros inferiores de pessoas com DM tipo 2. Objetivo - Identificar os fatores de risco para lesões em membros inferiores de pessoas com diabetes tipo 2, através de um instrumento de coleta de dados. Metodologia - Estudo descritivo, exploratório com abordagem quantitativa. O Estudo faz parte do projeto titulado Efeito de Promoção de Saúde e Resiliência em pessoas com DM tipo 2, aprovado pelo CEP da Universidade do Estado do Amazonas (UEA). A coleta de dados ocorreu no período de 04 a 08 de junho de 2018 no Laboratório de Pesquisa em Estomaterapia da UEA. A população amostra foi 28 pessoas diagnosticadas com DM tipo 2. Resultados - O perfil dos pacientes: A maioria do sexo feminino (64\%), com idade acima de 60 anos (61\%); desempregado ou aposentado (57\%); sem renda individual até menos de salário mínimo $(60 \%)$; Tempo de diagnóstico há mais de 05 anos (61\%); hipertensão associada (64\%); sedentarismo (53\%). Aspectos identificados ao exame de membros inferiores: coxas e pernas com rachaduras $(53 \%)$; xerodermia (89\%); fina (71\%); pêlos rarefeitos ou ausentes $(67 \%)$, vasos dilatados $(61 \%)$. Aspectos dos pés: xerodermia $(89 \%)$; pele descamativas $(54 \%)$; fina $(71 \%)$; préulceração (57\%); dor (57\%); dor ao caminhar (68\%), intensidade da dor moderada e intensa (50\%), fadiga e câimbras (78\%); acorda a noite com os sintomas (84\%). Aspectos das unhas: corte não adequado (75\%); hiperidrose (93\%); tíneas pedis (61\%); quebradiças (71\%). Classificação de risco de lesão; baixo risco (61\%); moderado risco (36\%) e alto risco (3\%). Conclusão - As características encontradas como sinais e sintomas na avaliação dos membros inferiores, principalmente na região coxa, perna e pé são indicadores de riscos de lesões cutâneas. Entretanto, faz-se necessário realizar novas pesquisas devido ao tamanho da amostra e validar o instrumento elaborado para este estudo que aborda avaliação de todas as regiões dos membros inferiores, visto que os instrumentos existentes dão apenas ênfase aos pés.
\end{abstract}

\section{Keywords: FATORES DE RISCO, LESÕES , MEMBROS INFERIORES, PESSOAS DIABETES , TIPO 2}

\section{Referências Bibliográficas}

Referência Bibliográfica; 1. Malta DC, Bernal RTI, Lima MG, Araújo SSC, Silva. Doenças não crônicas não transmissíveis e a utilização de serviços de saúde: análise da Pesquisa Nacional de Saúde no Brasil. Rev Saude Publica. 2017; 51 Supl 1:4s. 2. (Bio-Manguinhos/Fiocruz), Isabela Pimentel. Portal Fiocruz (https://portal.fiocruz.br).

https://portal.fiocruz.br/noticia/taxa-de-incidencia-de-diabetes-cresceu-618-nos-ultimos-10-anos. FIOCRUZ. 2018. 02.02. 3. Association, American Diabetes. Diagnosis and Classification of. Revista Diabetes Care. 2014. Pagina 81. Volume 37.

Edição 1. 4. Faria Maraschin Jorge de; Nádia, Murussi; Vanessa, Witter; Pinho, Silveiro Sandra. Classificação do Diabetes Melito. Arquivos Brasileiros de Cardiologia. 2010. Pagina 34. Volume 95. Edição 2. 5. Federação Internacional de Diabetes. Recomendação prática clínica no Pé Diabético: Um guia para profissionais de saúde. 2017. Bruxelas. Bélgica. 6. PACE, A.E.; FOSS, M.C.; VIGO, K.O.; HAYASHIDA, M. Fatores De Risco Para Complicações Em Extremidades Inferiores De Pessoas Com Diabetes Mellitus. Revista Brasileira Enfermagem. 2002. Pagina 514-521. Volume 55. Edição 5. 7. Casaccia, Bertoluci Marcello. Capítulo 07 - Complicações macrovasculares do Diabetes. eBook 2.0 SBD Diabetes. 2014. 8. Israel, Crispim Daisy.Canani Luís H. Gross Jorge L. Tschiedel Balduíno. Souto Kátia E.P. Roisenberg. Familial History of Type 2 Diabetes in Patients from Southern Brazil and its Influence on the Clinical Characteristics of this Disease. Arq Bras Endocrinol Metab. 2006.Pagina 862-868. Volume 50 №. 05. 9. Ortiz MCA, Zanetti ML. Levantamento dos fatores de risco para diabetes mellitus tipo 2 em uma instituição de ensino superior. Revista Latino Americana de Enfermagem. 2001. Pagina 58-63. Volume 9. Edição 3. 10. Maneck, Hocayen Palloma de Almeida Soares. Malfatti Carlos Ricardo. Tabagismo em pacientes diabéticos: Predisposição as doenças crônico-degenerativas e neoplasia. Revista Cinergis. 2010. Pagina 1925. Volume 11. Edição 2. 11. Básica. Brasil. Ministério da Saúde. Secretaria de Atenção à Saúde. Departamento de Atenção. Estratégias para o cuidado da pessoa com doença crônica: diabetes mellitus. 2013. Cidade - Brasília. Editora MSOS 2013/0359. 


\title{
RELATO DE EXPERIÊNCIA DO USO DE EXUFIBER AG EM LESÃO TRAUMÁTICA EM PACIENTE PEDIÁTRICO
}

\author{
Author(s): Gláucia Oliveira ${ }^{1}$, Suellen Alves ${ }^{1}$, Maria Beatriz Fernandes ${ }^{1}$ \\ Institution(s) ${ }^{1}$ HRB-JA - HOSPITAL REGIONAL DE BARBACENA DR. JOSÉ AMÉRICO (Avenida 14 de \\ agosto, s/n, Bairro Floresta, Barbacena - MG, CEP 36202-630)
}

\begin{abstract}
INTRODUÇÃO:

As feridas traumáticas são causadas por trauma grave, resultando em lesões com extensa perda cutânea e com prejuízo na viabilidade tecidual, como ferimentos descolantes nos membros inferiores, amputações de membros e de dedos, além de contusões, lacerações e grandes esmagamentos, com exposição de tecidos nobres. (Dealey C. 2008)
\end{abstract}

OBJETIVO:

O presente estudo visa relatar um caso clínico de lesão traumática em paciente pediátrico tratado com o curativo a base de hidrofibra com prata, Exufiber Ag.

MATERIAL E MÉTODOS:

Trata-se de um estudo descritivo, tipo relato de experiência, realizado em uma unidade de internação de clínica cirúrgica do Hospital Regional de Barbacena, Rede FHEMIG.

RESULTADOS:

J.O.P, sexo masculino, 13 anos, vítima de atropelamento, portando lesão traumática extensa em pé esquerdo com exposição das articulações tarsometatarsais e matatarsofalangeanas, luxação exposta do $2^{\circ}$ dedo, ruptura de todos os tendões extensores curtos e longos, abrasões ósseas com perda total de substância sem condições de tenorrafia. Área total da lesão medindo $252 \mathrm{~cm} 2$.

Devido a sua gravidade, potencial de risco de infecção e dor nas trocas de curativos foi instituído como cobertura primária o curativo Exufiber Ag, a base de hidrofibra com prata e limpeza com solução a base de PHMB.

As trocas ocorriam a cada 3 dias na enfermaria. Na primeira troca pôde-se observar controle da hemostasia com formação de fibrina em toda a extensão da lesão. Também foi observado um desbridamento autolítico significativo além de promover a granulação da lesão. Após 5 trocas de curativos a lesão apresentou melhora significativa medindo $108 \mathrm{~cm} 2$ de área total. Paciente então foi encaminhado para procedimento de enxertia contribuindo para sua desospitalização precoce.

CONCLUSÃO:

Conclui-se que o uso da hidrofibra com prata, Exufiber Ag, no paciente pediátrico alcançou resultado satisfatório sem nenhuma complicação em um curto espaço de tempo, além de contribuir para: prevenção de infecção, desbridamento autolítico, controle de exsudato, granulação da lesão e proteção das bordas e pele peri-lesão. Ao final do tratamento paciente referia redução significativa da dor.

\section{Keywords: LESÃO TRAUMÁTICA, CURATIVO, HIDROFIBRA COM PRATA, PEDIATRIA, ESTOMATERAPIA}

\section{Referências Bibliográficas}

1. Dealey C., Cuidando de feridas: um guia para as enfermeiras. $3^{\text {a }}$ ed. São Paulo: Atheneu; p. 194, 2008. 2. Campos, M., Sousa A.,et al. Feridas complexas e estomias.1 ${ }^{\text {a }}$ ed. João Pessoa: Ideia; p. 323, 2016. 3. Ramalho A., Trombeta J., Relato de experiência do uso de hidrofibra com prata em deiscência peri-gastrostomia convencional.disponível em http://sobest.org.br/trabalhos/13 . 4. Salomé G., Estudo clínico: Hidrofibra com prata e hidrogel com alginato na cicatrização de ferida em pacientes com diabetes mellitus. Rv. Estima. São Paulo. 2008, Vol 6, №4. 


\title{
LETRAMENTO FUNCIONAL EM SAÚDE E A PREVENÇÃO DE COMPLICAÇÕES COM OS PÉS EM PESSOAS COM DIABETES
}

\author{
GIVANEIDE OLIVEIRA DE ANDRADE LUZ ${ }^{1}$, Hysadora Karolinne da Silva Costa ${ }^{1}$, Dayanne \\ Daphyne de Aguiar Alves ${ }^{1}$, Ana Conceição Fernandes de Oliveira ${ }^{1}$, Juliana Victória Mendes da \\ Author(s): $\quad$ Luz $^{1}$, Maria Natália Moreira da Silva ${ }^{1}$, Giovana Ferreira Lima ${ }^{1}$, Priscila Farias Stratmann ${ }^{1}$, Isabel \\ Cristina Ramos Vieira Santos ${ }^{1}$
}

Institution(s) ${ }^{1}$ FENSG - Faculdade de Enfermagem Nossa Senhora das Graças (Rua. Dr. Otávio Coutinho Santo Amaro, Recife - PE, 52171-011)

\begin{abstract}
Introdução. A prevenção do pé diabético envolve conhecimento e tomada de decisão para a execução de tarefas de autocuidado por parte do paciente, tais como: monitoramento do índice glicêmico, adequação da alimentação, uso de medicamentos e cuidados com os pés. Isso deveria ocorrer quando o paciente estivesse de posse da informação e com o letramento para este fim. Segundo a Organização Mundial de Saúde o Letramento Funcional em Saúde consiste na "capacidade de obter, processar e compreender as informações em saúde, no intuito de tomar decisões apropriadas para a gestão do autocuidado". Objetivo. Descrever o nível de Letramento Funcional em Saúde e o autocuidado com os pés em pessoas com diabetes mellitus. Material e Método. Estudo transversal, descritivo de abordagem quantitativa. Amostra por conveniência de 97 pacientes entre o período de fevereiro a junho de 2018. Foram utilizados os instrumentos: Brief Test of Functional Health Literacy in Adults (B-TOFHLA) e o Questionário de atividades de autocuidado com o diabetes (QAD), ambos validados para uso no Brasil. O projeto foi aprovado pelo Comitê de Ética em Pesquisa com Parecer № 2.681.288. Resultados. O perfil do grupo estudado apresentou-se com idades equilibradas entre os maiores $(50,0 \%)$ e menores $(48,5 \%)$ de 60 anos; sexo feminino; casados; autodeclarados pardos; escolaridade entre cinco e onze anos de estudo $(76,3 \%)$; economicamente ativos $(77,3 \%)$ com renda familiar entre dois e três salários mínimos $(41,2 \%)$. Para esse estudo foi considerado Letramento Funcional em Saúde inadequado e marginal, inadequados, onde foi encontrado $70 \%$ inadequado e $30 \%$ adequado. Quanto aos cuidados diários com os pés nos últimos sete dias a média foi de: 4,02 dias para exame dos pés; 3,88 dias para examina dentro dos sapatos antes de calçá-los e 5,07 dias para seca os espaços entre os dedos dos pés depois de lavá-los; valores insuficientes para prevenção de complicações nos pés. Tendo em vista que são atividades de fácil execução e de baixo custo. Conclusões. Contudo, é possível hipotetizar que o Letramento Funcional em Saúde esteja relacionado a baixa adesão do autocuidado com os pés, neste grupo, dificultando a tomada de decisão e prática de atividades de prevenção desta complicação, visto que a escolaridade se apresentou de forma adequada para busca e compreensão de informações. Faz-se necessário maiores investimentos no Letramento Funcional em Saúde nas práticas de educação em saúde para o autocuidado.

Descritores: Pé Diabético, Autocuidado, Alfabetização em Saúde, Enfermagem, Estomaterapia.
\end{abstract}

Keywords: Pé Diabético, Autocuidado, Alfabetização em Saúde, Enfermagem, Estomaterapia

\section{Referências Bibliográficas}

Referências. 1. Ministério da Saúde (BR). Secretaria de Atenção à Saúde. Departamento de Atencão Básica. Estratégias para o cuidado da pessoa com doença crônica: Diabetes Mellitus. Caderno de atenção básica n. 36 [Internet] Brasília: Ministério da Saúde; 2014 [acesso em 04 mar 2018]. Disponível:

http://bvsms.saude.gov.br/bvs/publicacoes/estrategias_cuidado_pessoa_diabetes_mellitus_cab36.pdf. 2. World Health Organization (WHO). Health Promotion Glossary. [Internet] Geneva: WHO; 1998 [acesso em 04 mar 2018]. Disponível: http://www.who.int/healthpromotion/about/HPR\%20Glossary\%201998.pdf. 3. Santos MIPO, Portella MR. Condições do letramento funcional em saúde de um grupo de idosos diabéticos. Rev Bras Enferm [Internet] 2016;69(1) [acesso em 04 mar 2018]. Disponível: http://www.scielo.br/pdf/reben/v69n1/0034-7167-reben-69-01-0156.pdf 4. Carthery-Goulart MT, Anghinah R, Areza-Fegyveres R, Bahia VS, Brucki SMD, Damin A,et al. Performance of a Brazilian population on the test of functional health literacy in adults. Rev Saúde Pública [Internet] 2009;43(4) [acesso em 04 mar 2018]. Disponível: http://www.scielo.br/pdf/rsp/v43n4/124.pdf 5. Michels MJ, Coral MHC, Sakae TM, Damas TB, Furlanetto LM. Questionário de Atividades de Autocuidado com o Diabetes: tradução, adaptação e avaliação das propriedades psicométricas. Arq Bras Endocrinol Metab [Internet] 2010;54(7) [acesso em 04 mar 2018]. Disponível: http://www.scielo.br/pdf/abem/v54n7/09.pdf 


\title{
O AUTOCUIDADO COM OS PÉS E O LETRAMENTO FUNCIONAL EM SAÚDE INADEQUADO EM PESSOAS COM DIABETES
}

\author{
Author(s): Aguiar Alves ${ }^{1}$, Jabiael Carneiro da Silva Filho ${ }^{1}$, Marcos Antonio de Oliveira Souza ${ }^{1}$, Clara lasmim Carvalho \\ da Silva ${ }^{1}$, Ana Conceição Fernandes de Oliveira ${ }^{1}$, Marta Regina Chaves Camilo Fernandes ${ }^{1}$, Isabel \\ Cristina Ramos Vieira Santos ${ }^{1}$ \\ Institution(s) ${ }^{1}$ FENSG - Faculdade de Enfermagem Nossa Senhora das Graças (Rua. Dr. Otávio Coutinho - Santo \\ Amaro, Recife - PE, 52171-011)
}

\begin{abstract}
Introdução. O autocuidado é condição sine qua non no controle do diabetes mellitus e prevenção de suas complicações. A baixa adesão às atividades de autocuidado é inquietante e tem sido relacionada a fatores pessoais, econômicos e socioculturais, além dos relacionados à própria patologia, ao sistema de saúde e à equipe multiprofissional. O Letramento Funcional em Saúde pode servir um instrumento para dirimir esses fatores, facilitando o processo de comunicação e apropriação de informações. De acordo com a Organização Mundial de Saúde o Letramento Funcional em Saúde consiste na "capacidade de obter, processar e compreender as informações em saúde, no intuito de tomar decisões apropriadas para a gestão do autocuidado". Objetivo. Verificar associação entre atividades de autocuidado com o pé e o e letramento funcional inadequado em pessoas com diabetes mellitus. Material e Método. Estudo transversal, descritivo de abordagem quantitativa. Amostra por conveniência de 97 pacientes entre o período de fevereiro a junho de 2018. Foram utilizados os instrumentos: Brief Test of Functional Health Literacy in Adults (B-TOFHLA) e o Questionário de atividades de autocuidado com o diabetes (QAD), ambos validados para uso no Brasil. O projeto foi aprovado pelo Comitê de Ética em Pesquisa com Parecer № 2.681.288. Resultados. O perfil do grupo estudado apresentou-se com idades equilibradas entre os maiores $(50,0 \%)$ e menores $(48,5 \%)$ de 60 anos; sexo feminino; casados; autodeclarados pardos; escolaridade entre cinco e onze anos de estudo (76,3\%); economicamente ativos $(77,3 \%)$ com renda familiar entre dois e três salários mínimos $(41,2 \%)$. 0 Letramento Funcional em Saúde inadequado esteve presente em $43 \%$ dos participantes de pesquisa, e apesar de, quando analisado com as atividades relacionadas ao autocuidado com os pés não terem apresentado relevância estatística (exame dos pés, $p=0,36$; examina dentro dos sapatos antes de calçá-los, $p=0,14$ e seca os espaços entre os dedos dos pés depois de lavá-los, $p=0,95)$, foi possível encontrar valores estatisticamente relevantes para atividades de autocuidado que são fatores de risco para desenvolvimento de pé diabético, como: não seguir a dieta recomendada $(p=0,00)$, ingerir doces $(p=0,00)$, avaliar a glicemia sanguínea em intervalos também recomendados por profissionais de saúde $(p=0,00)$. Conclusões. Portanto, é perceptível que, apesar de o Letramento Funcional em Saúde Inadequado não ter sido associado ao autocuidado com o pé diabético, neste grupo, existe uma relação indireta do mesmo com a baixa adesão do autocuidado com o diabetes mellitus a qual poderá reverberar em complicações microvasculares nos pés. É possível ainda que o Letramento Funcional em Saúde Inadequado possa estar dificultando a tomada de decisão e prática de atividades de prevenção desta complicação, tendo em vista que a escolaridade se apresentou de forma adequada para busca de informações.

Descritores: Pé Diabético, Autocuidado, Alfabetização em Saúde, Enfermagem, Estomaterapia.
\end{abstract}

Keywords: Pé Diabético, Autocuidado, Alfabetização em Saúde, Enfermagem, Estomaterapia

\section{Referências Bibliográficas}

Referências. 1. Ministério da Saúde (BR). Secretaria de Atenção à Saúde. Departamento de Atencão Básica. Estratégias para o cuidado da pessoa com doença crônica: Diabetes Mellitus. Caderno de atenção básica n. 36 [Internet] Brasília: Ministério da Saúde; 2014 [acesso em 04 mar 2018]. Disponível:

http://bvsms.saude.gov.br/bvs/publicacoes/estrategias_cuidado_pessoa_diabetes_mellitus_cab36.pdf. 2. Sampaio HAC, Carioca AAF, Sabry MOD, Santos PM, Santos MAMS, Passamai MPB. Letramento em saúde de diabéticos tipo 2:fatores associados e controle glicêmico. Ciência \& Saúde Coletiva [Internet] 2015; 20(3) [acesso em 04 mai 2018]. Disponível: http://www.scielo.br/pdf/csc/v20n3/1413-8123-csc-20-03-00865.pdf 3. World Health Organization (WHO). Health Promotion Glossary. [Internet] Geneva: WHO; 1998 [acesso em 04 mar 2018]. Disponível:

http://www.who.int/healthpromotion/about/HPR\%20Glossary\%201998.pdf. 4. Carthery-Goulart MT, Anghinah R, ArezaFegyveres R, Bahia VS, Brucki SMD, Damin A,et al. Performance of a Brazilian population on the test of functional health literacy in adults. Rev Saúde Pública [Internet] 2009;43(4) [acesso em 04 mar 2018]. Disponível:

http://www.scielo.br/pdf/rsp/v43n4/124.pdf 5. Michels MJ, Coral MHC, Sakae TM, Damas TB, Furlanetto LM. Questionário de Atividades de Autocuidado com o Diabetes: tradução, adaptação e avaliação das propriedades psicométricas. Arq Bras Endocrinol Metab [Internet] 2010;54(7) [acesso em 04 mar 2018]. Disponível: http://www.scielo.br/pdf/abem/v54n7/09.pdf 


\title{
USO DE TERAPIA POR PRESSÃO NEGATIVA AVELLE ${ }^{\text {TM }}$ PARA SÍNTESE DE DEISCÊNCIA EM REGIÃO DE TORNOZELO
}

\author{
Author(s): $\quad$ Monique de Grande Xavier ${ }^{1}$, Daniela Vilas Boas Silva ${ }^{1}$ \\ Institution(s) ${ }^{1}$ FAMERP - Faculdade de Medicina de São José Rio Preto (Avenida Brigadeiro Faria Lima)
}

\begin{abstract}
Introdução

A associação de infecção com a perda de partes moles, complicação das mais complexas nas cirurgias de extremidade, leva a problemas de difícil solução, como exposição de material de síntese e estruturas nobres, como tendão, nervo e osso. 1,2 Um método de opção terapêutica, o sistema de terapia por pressão negativa (TPN), traz como benefícios: o controle de drenagem de exsudados, a redução do edema local, a redução da carga bacteriana e o desenvolvimento precoce de um tecido de granulação pela estimulação angiogênica. 3,4 Os prejuízos causados pelo aumento do tempo de permanência hospitalar de um paciente devido ao retardo na cicatrização de lesões de pele ou infecção de uma ferida operatória (FO) têm sido foco de preocupação em diferentes contextos das práticas de saúde.

O Avelle ${ }^{\mathrm{TM}}$ (ConvaTec) é um dispositivo portátil de terapia por pressão negativa (80 $\mathrm{mmHg}$ ) associada a tecnologia Hydrofiber $₫$ (que propicia desbridamento autolítico e promove controle da umidade do ambiente da ferida), pode ser usado por até 30 dias em incisões cirúrgicas.

Objetivo

Demostrar a importância do curativo de terapia por pressão negativa Avelle ${ }^{\mathrm{TM}}$ para aceleração da cicatrização de deiscência pós-complicação de remoção de placa cirúrgica infectada em região de tornozelo.

Relato de Caso

Paciente F.M. M, 42 anos no dia 28 de abril de 2017 sofreu uma fratura de tornozelo jogando futebol, recebeu primeira avaliação no Pronto Atendimento do Hospital Unimed Rio Claro. Foi orientado quanto à imobilização com tala gessada por quatro meses. Após esse período foi retirado a imobilização, voltando às atividades normalmente.

Após dois meses, começou a apresentar dores e edema no local. Passou por vários médicos e realizou vários exames o qual foi diagnosticado com artrose. Em 30 janeiro de 2018 passou por procedimento cirúrgico para alongamento de fíbula e reposição de pinça, colocado placa com 9 parafusos. Em 21 de agosto de 2018 foi realizado retirada de dois parafusos da sindesmose com finalidade de aliviar dores, sem sucesso. As dores e o edema não cessaram após este procedimento. Em dezembro de 2018 após ficar dois dias consecutivos na piscina apresentou deiscência em incisão cirúrgica, o que levou a realizar curativos no local, realizados no Ambulatório de Curativos. Foi então realizado novo procedimento cirúrgico em 29 de março de 2019 para limpeza do local e retirada de placas. Foi admitido pelo atendimento domiciliar após esse procedimento, por osteomielite de fíbula esquerda. Ferida Operatóra com presença de sutura aproximando as bordas, aproximadamente $15 \mathrm{~cm}$ de comprimento, com hiperemia e secreção serosanguinolenta em pequena quantidade. Após a retirada de pontos conforme prescrição médica, apresentou desicência. Utilizado Avelle por 14 dias (2 trocas) e obtendo um resultado de $100 \%$ de epitelização, após foi utilizado Aquacel Foam Adhesive para proteção do local.

Discussão

O uso tópico da terapia por pressão negativa tem sido amplamente estudado na literatura mundial nos últimos 20 anos a efetividade dessa terapêutica no tratamento de ferimentos superficiais.6,7,8 Os benefícios de tal terapêutica em feridas complexas graves, com extensas perdas de partes moles associadas a infecções locais, têm sido relatados nos últimos anos.
\end{abstract}

Keywords: Avelle, Curativo , Terapia por pressão negativo

\section{Referências Bibliográficas}

1. Bihariesingh VJ, Stolarczyk EM, Karim RB, van Kooten EO. Plastic solutions for orthopaedic problems. Arch Orthop Trauma Surg. 2004;124(2):73-6. 2. Kramhøft M, Bødtker S, Carlsen A. Outcome of infected total knee arthroplasty. J Arthroplasty. 1994;9(6):617-21 3. Strecker W, Fleischmann W. Nécroses cutanées traumatiques et non traumatiques. Pansements sous vide. Appareil Locomoteur. 2007:1-5, http://dx.doi.org/10.1016/ S0246-0521(07)43187-4 [Article 15-068A-10]. 4. Leininger BE, Rasmussen TE, Smith DL, Jenkins DH, Coppola C. Experience with wound VAC and delayed primary closure of contaminated soft tissue injuries in Iraq. J Trauma. 2006;61(5):1207-11 5. Morykwas MJ, Argenta LC, Shelton-Brown EI, McGuirt W. Vacuum-assisted closure: a new method for wound control and treatment: animal studies and basic foundation. Ann Plast Surg. 1997;38(6):553-62 6. Scherer SS, Pietramaggiori G, Mathews JC, Prsa MJ, Huang S, Orgill DP. The mechanism of action of the vacuum-assisted closure device. Plast Reconstr Surg. 2008;122(3):786-97. 7. Argenta LC, Morykwas MJ, Marks MW, DeFranzo AJ, Molnar JA, David LR. Vacuum-assisted closure: state of clinic art. Plast Reconstr Surg. 2006; 1177 Suppl:127S-42S. 8. Joseph E, Hamori CA, Bergman S, Roaf E, Swann NF, Anastasi GW. A prospective, randomized trial of vacuumassistedclosure versus standard therapy of chronic nonhealing wounds. Wounds. 


\title{
VIVENDO COM A FERIDA CRÔNICA: SABERES E PRÁTICAS DE PACIENTES COM ÚLCERA VENOSA
}

\author{
Author(s): Isabelly Christina Gomes Vieira ${ }^{1}$, Mariana André Honorato Franzoi ${ }^{2}$ \\ Institution(s) ${ }^{1}$ UnB - Universidade de Brasília, Faculdade de Ciências da Saúde (Campus Universitário Darcy Ribeiro, \\ Brasília - DF ), ${ }^{2}$ UnB - Universidade de Brasília, Faculdade de Ciências da Saúde (Campus Universitário \\ Darcy Ribeiro, Brasília - DF)
}

\begin{abstract}
Introdução: A úlcera venosa é uma complicação tardia da insuficiência venosa crônica. As úlceras venosas merecem atenção por apresentarem elevada taxa de recidiva, exigirem longo período de tratamento, afetarem negativamente a qualidade de vida dos pacientes e implicarem em importante ônus financeiro aos serviços de saúde $(1,2)$. A dificuldade no reparo tecidual e as altas taxas de recidivas estão relacionados principalmente à falta de conhecimento do paciente sobre sua doença e ao processo terapêutico(3,4). Objetivo: Descrever os saberes e práticas adotados por pacientes com úlcera venosa durante o tratamento da lesão. Material e Método: Estudo descritivo, de abordagem qualitativa, realizado com onze pacientes em tratamento de úlcera venosa em um Serviço Ambulatorial de Estomaterapia em Brasília, Distrito Federal. Trata-se da primeira etapa de um estudo metodológico para direcionar o desenvolvimento de tecnologia educativa voltada aos usuários desse serviço. A coleta de dados foi realizada em abril de 2019 por meio de entrevistas semiestruturadas, que foram gravadas e posteriormente transcritas na íntegra. Os dados foram submetidos à análise de conteúdo temática. A pesquisa foi aprovada pelo Comitê de Ética em Pesquisa da instituição sob número de parecer 3.269.869. Resultados: A maioria era do sexo feminino e com mais de sessenta anos. Três categorias emergiram a partir da análise de conteúdo das entrevistas: práticas e saberes gerais no autocuidado da úlcera; mitos e crenças que perpassam o autocuidado; e dificuldades vivenciadas durante o cuidado com a úlcera. Os pacientes referiram o uso da meia de compressão, a realização de repouso, automedicação e a hidratação da pele como cuidados diários que realizam em seus domicílios para tratamento e prevenção de recidivas da úlcera venosa. Além disso, revelaram mitos e crenças relacionados à etiologia da úlcera venosa, por exemplo, o contato com água suja, e aos tipos de alimentos que acreditam serem prejudiciais ao processo de cicatrização da úlcera, a exemplo da pimenta e outros condimentos, carne de porco, frutas cítricas e alguns tipos de peixe. Sobre as dificuldades vivenciadas no cuidado da úlcera, os pacientes relataram impasses para realizarem de maneira confortável a própria higiene corporal, restrições com o vestuário por insatisfação com autoimagem corporal, além dos custos elevados com as meias de compressão e materiais para tratamento da ferida. Conclusão: Este estudo desvelou saberes, crenças e práticas que os pacientes com úlcera venosa apresentam a respeito da doença vascular e ao processo de cicatrização da lesão, essenciais para direcionar o planejamento e desenvolvimento de uma tecnologia educativa em saúde voltada às necessidades dos usuários do ambulatório de forma a potencializar o autocuidado. A abordagem à pessoa com úlcera venosa requer uma terapêutica multidisciplinar que inclui o enfermeiro estomaterapeuta. Desta forma, é imprescindível que este profissional identifique os conhecimentos e as dificuldades de seus pacientes, bem como elabore ações educativas que visem a superação de tais carências.
\end{abstract}

Keywords: Estomaterapia, Úlcera Venosa, Cuidados de Enfermagem

\section{Referências Bibliográficas}

1. Borges EL. Feridas: úlceras dos membros inferiores. Rio de Janeiro: Gua Koogan, 2011. 203p. 2. Costa IKF, Dantas DV, Melo GSM, Tibúrcio MP, Medeiros LP, Torres GV. Protocolo de assistência a pessoas com úlcera ven atenção primária: revisão integrativa da literatura. Revista de Pesquisa Cui Fundamental Online. 2017; 9(2):566-574. 3. Brown A. Self-care strategies to prevent venous leg ulceration recurrence. Pract Nurs. 2018;29(4):152-8. 4. Santos SF, Camacho AC, Oliveira BR, Nogueira GA, Joaquim FL. Influence of venous ulcer in patients' quality of life: an integrative review. J Nursing UFPE Online. 2015;9(3):7710-22. 


\title{
Validação de conteúdo de um instrumento de auditoria relacionado a prevenção de lesão por pressão
}

Vanessa Abreu da Silva ${ }^{1}$, Maria Carolina Martins ${ }^{1}$, Renata Cristina Gasparino ${ }^{1}$, Ivan Rogério Author(s): Antunes ${ }^{1}$, Angélica Olivetto de Almeida ${ }^{1}$, Bruna Bueno Soares ${ }^{1}$, Renata Bigatti Pavan ${ }^{1}$, Ana Paula Bordin ${ }^{1}$, Elenita de Castro Recco ${ }^{1}$, Luciana Alves Zapparoli ${ }^{1}$, Alessandra N C P Roscani ${ }^{1}$

Institution(s) ${ }^{1}$ HC-UNICAMP - Hospital das Clínicas - Unicamp (R. Vital Brasil, 251 - Cidade Universitária, Campinas - SP, 13083-888), ${ }^{2}$ HC-UNICAMP - Hospital das Clínicas - Unicamp (R. Vital Brasil, 251 - Cidade Universitária, Campinas - SP, 13083-888)

\begin{abstract}
Introdução: A lesão por pressão (LP) é um dos eventos adversos de maior notificação entre os anos de 2014 e 2019 no Brasil'. Sabe-se que a ocorrência de LP pode ser evitada por meio da implementação de estratégias de prevenção para todos os pacientes previamente identificados como de risco². Nesse contexto, a utilização da auditoria representa uma estratégia para avaliar se essas medidas de prevenção estão, realmente, sendo implementadas assegurando, assim, a qualidade da assistência e a segurança do paciente ${ }^{3}$. Objetivo: Revisar e validar o conteúdo de um instrumento para verificação da implementação, pela equipe de enfermagem, das medidas de prevenção de LP. Método: Trata-se de um estudo metodológico desenvolvido em duas etapas: na primeira, foi realizada a revisão do instrumento de auditoria de prevenção de LP elaborado previamente pela equipe de enfermeiros, do Núcleo de Estomaterapia, de um Hospital Universitário do interior de São Paulo. A revisão foi baseada no protocolo institucional e no consenso da National Pressure Ulcer Advisory Panel, European Pressure Ulcer Advisory Panel e Pan Pacific Pressure Injury Alliance para prevenção de LP4. Na segunda etapa, foram avaliadas a relevância e a representatividade de cada um dos itens do instrumento por um grupo de seis juízes com reconhecido saber e publicações na área do estudo5. A concordância entre os juízes foi mensurada por meio do Índice de Validade de Conteúdo e valores acima de 0,9 foram considerados satisfatórios5. 0 projeto foi aprovado pelo Comitê de Ética em Pesquisa, sob parecer no 3.045.941. Resultados: Após a revisão e reelaboração do instrumento de auditoria, pelas pesquisadoras, o mesmo foi submetido à avaliação do comitê de juízes. Foram necessárias duas rodadas para que todos os itens atingissem Índice de Validade de Conteúdo maior que 0,9. Na primeira, foram feitas sugestões que alteraram substancialmente cinco itens do instrumento, que foram novamente avaliados na segunda rodada, atingindo uma concordância de $100 \%$. A versão final do instrumento, composta por 26 itens distribuídos em quatro partes: 1) Avaliação de risco de desenvolver LP; 2) Avaliação nutricional; 3) Alívio e Redução de pressão local e 4) Avaliação e cuidados com a pele. Conclusão: O instrumento denominado "Auditoria de prevenção de lesão por pressão" foi revisado e teve o seu conteúdo validado com sucesso.
\end{abstract}

Keywords: Estudos de Validação, Auditoria em Enfermagem, Lesão por Pressão, Segurança do Paciente, Estomaterapia

\section{Referências Bibliográficas}

Brasil. Agência Nacional de Vigilância Sanitária (Anvisa). Relatórios de Eventos adversos notificados à Anvisa. Publicações [internet]. 2019. Wound, Ostomy and Continence Nurses Society (WOCN). Guideline for prevention and management of pressure ulcers (injuries). Agency for Health care Research and Quality; 2016; Available from:

https://www.guideline.gov/summaries/summary/50473/guideline-for-prevention-and-management-of-pressure-ulcersinjuries?q=pressure\# Brasil. Agência Nacional de Vigilância Sanitária (Anvisa). Boletins Informativo - Segurança do paciente e qualidade em serviços de saúde. [internet]. 2013. National Pressure Ulcer Advisory Panel, European Pressure Ulcer Advisory Panel and Pan Pacific Pressure Injury Alliance. Prevention and Treatment of Pressure Ulcers: Quick Reference Guide. Emily Haesler (Ed.). Cambridge Media: Osborne Park, Western Australia; 2014. Coluci MZO, Alexandre NMC, Milani D. Construção de instrumentos de medida na área da saúde. Ciênc. saúde coletiva [Internet]. 2015;20(3):92536. Available from: http://www.scielo.br/scielo.php?script=sci_arttext\&pid=S1413-

81232015000300925\&lng=en.\%20http://dx.doi.org/10.1590/1413-81232015203.04332013 


\title{
TRATAMENTO DE BIOFILME EM FERIDAS: REVISÃO INTEGRATIVA
}

\author{
Author(s): \\ Eliane Santa Cruz Santos ${ }^{1}$, Manuela Perdigão Silva da Costa ${ }^{1}$, Nathalia Santos da Cruz Peluque ${ }^{1}$, \\ Sônia Regina Pérez Evangelista Dantas ${ }^{1}$ \\ Institution(s) ${ }^{1}$ Unicamp - UNIVERSIDADE ESTADUAL DE CAMPINAS (Cidade Universitária Zeferino Vaz - \\ Barão Geraldo - Campinas SP)
}

\begin{abstract}
INTRODUÇÃO: As bactérias ao invadirem uma espécie, como a do ser humano, formam os biofilmes por meio da fixação a um substrato, produção de uma matriz e formação de microcolônias. Este substrato pode ser biótico ou abiótico e está envolvido numa matriz de substâncias poliméricas extracelulares, conhecida na sigla em inglês EPS (extracelular polymeric substance), garantindo a sobrevivência bacteriana. Todas as feridas são susceptíveis à formação de biofilmes por fornecerem um ambiente propício com água e nutrientes. Porém, sua maior incidência está nas feridas crônicas, devido ao tempo prolongado de evolução, uma vez que estas permanecem estagnadas no estado de inflamação, com contínua destruição dos tecidos e limitação da cicatrização. A presença de biofilmes em feridas prejudica o processo de reparação tecidual e aumenta o risco de infecção. OBJETIVO: Identificar na literatura tecnologias para o tratamento de biofilmes em feridas. MÉTODO: Realizou-se uma revisão integrativa nas bases de dados da Biblioteca Virtual em Saúde (BVS), do Public Medline (PUBMED), Cumulative Index of Nursing and Allied Health Literature (CINAHL), SCOPUS e Web of Science. A busca bibliográfica foi realizada utilizando os descritores controlados: biofilmes, terapêutica, cicatrização e curativos oclusivos, em inglês, português e espanhol, utilizando o operador booleano AND entre eles. Foram incluídos ensaios clínicos randomizados e não randomizados, coorte, caso controle e revisões de literatura, publicados de 2012 a 2017. Após as buscas, dois revisores realizaram uma pré-seleção por títulos e resumo dos artigos, seguido da leitura na íntegra dos estudos pré-selecionados. RESULTADO: Foram identificados 169 artigos e excluídos 155 por não atenderem à questão norteadora. Dois revisores leram na íntegra 14 estudos que foram incluídos nessa revisão. Os produtos com ação antisséptica em biofilmes avaliados nos artigos dessa revisão foram os sais de benzalconio, dicloridrato de octenidina, compostos iodóforos, gluconato de clorexidina, liberadores de prata, surfactante com sulfadiazina de prata a 1\%, ácido etileno diamina tetra acético e polihexametileno biguanida, entretanto, há escassez de ensaios clínicos randomizados e bem conduzidos que mostrem evidências no tratamento tópico do biofilme e maioria dos estudos não cita os protocolos de uso. CONCLUSÃO: A análise dos artigos dessa revisão mostrou consenso de que o desbridamento associado ao uso de um produto antisséptico tópico é efetivo para o tratamento do biofilme e prevenção de sua reestruturação, entretanto, não há consenso sobre a melhor tecnologia.
\end{abstract}

Keywords: Biofilmes , Terapeutica, Cicatrização, Curativos oclusivos, Estomaterapia

\section{Referências Bibliográficas}

1) Leaper D, Assadian O, Edmiston CE. Approach to chronic wound infections. Br J Dermatol. 2015 Aug;173(2):351-8. 2) Zölß C, Cech JD. Efficacy of a new multifunctional surfactant-based biomaterial dressing with $1 \%$ silver sulphadiazine in chronic wounds.. Int Wound J. 2016 Oct;13(5):738-43. 3) Percival SL, Donelli G, Vuotto C, Rimmer S, Lipsky BA. Antiseptics for treating infected wounds: Efficacy on biofilms and effect of pH. , Crit Ver Microbiol.2016; 42(2):293-309. 4) Wolcott, R. Disrupting the biofilm matrix improves wound healing outcomes. J Wound Care; 24(8): 366-71, 2015 Aug. 5) Finnegan S, Percival SL. Clinical and Antibiofilm Efficacy of Antimicrobial Hydrogels. Adv Wound Care (New Rochelle). 2015 Jul 1;4(7):398-406. 


\title{
CARACTERIZAÇÃO DOS PRIVADOS DE LIBERDADE COM DERMATOSES EM UMA UNIDADE PRISIONAL DO ESTADO DE SÃO PAULO
}

\author{
Author(s): Daniela Tinti Moreira Borges ${ }^{1,2}$, Silmara Jorge Garcia ${ }^{1,2}$, Flavia Carla Takaki Cavichioli ${ }^{1,2}$, Leila \\ Blanes ${ }^{1}$, Lydia Masako Ferreira ${ }^{1}$ \\ Institution(s) ${ }^{1}$ UNIFESP - Universidade Federal de São Paulo (Rua Botucatu, 740, 2. andar. Vila Clementino, \\ São Paulo), ${ }^{2}$ SAP - Secretaria da Administração Penitenciária (Rua Libero Badaro, 600. São \\ Paulo/SP)
}

\begin{abstract}
Introdução: Estudos sobre as condições de saúde em unidades prisionais descrevem falta de tratamento adequado e poucas oportunidades de prevenção de doenças 1,2. Dentre os problemas de saúde que afetam a população carcerária encontram-se doenças infectocontagiosas, incluindo dermatoses infecciosas3-5. Pesquisas em ambiente prisional no Canadá, Suíça e Nigéria apontam a presença de micoses, foliculites, furunculoses, pediculoses, escabioses4, infecções da pele e tecido subcutâneo, dermatite, eczema e doenças papuloescamosas5. Destaca-se a presença de infecções fúngicas relacionadas ao clima quente e úmido, locais superpopulosos e higiene precária3. Objetivo: Caracterizar os privados de liberdade com dermatoses em uma unidade prisional no interior do Estado de São Paulo. Método: estudo retrospectivo e descritivo, aprovado pelo CEP Unifesp (Parecer n. 2.351.279) e CEP SAP (Parecer n. 2.462.054). O estudo ocorreu na Penitenciária "Nestor Canoa" de Mirandópolis, localizada no interior do estado de São Paulo. A população prisional nesta unidade é exclusivamente masculina e durante o estudo a população prisional era de 2.065 pessoas. Os dados foram coletados em prontuários de saúde dos privados de liberdade que apresentaram dermatoses entre janeiro de 2016 a janeiro 2017. Resultados: 71 privados de liberdade receberam diagnóstico médico de dermatoses durante o período do estudo. Observou-se faixa etária de 20 a 54 anos, a média de idade foi de 37,67 anos; a cor da pele predominante foi a branca (49,30\%). Quanto ao estado civil, 76,06\% possuía união estável ou estavam casados e em relação à escolaridade $50,70 \%$ possuía ensino fundamental incompleto. As dermatoses encontradas foram: micoses superficiais da pele $(31,71 \%)$, onicomicoses $(17.07 \%)$, furunculose $(14,63 \%)$, pruridos $(14,63 \%)$, dermatite não especificada $(9,76 \%)$. Piodermite, acne, carcinoma basocelular, eritema, escabiose, foliculite e xerodermia somaram $12.2 \%$. Destaca-se que cinco pacientes apresentavam mais de uma doença de pele. Conclusões: A partir deste estudo foi possível caracterizar os privados de liberdade com dermatoses em uma unidade prisional, de modo que foram observadas especialmente infecções fúngicas e bacterianas, representadas pelas micoses superficiais da pele, onicomicoses e furunculose, as quais somam $63,41 \%$ das dermatoses encontradas.
\end{abstract}

\section{Keywords: DERMATOPATIAS, ESTOMATERAPIA, FERIMENTOS E LESÕES, MICOSES, PRISÕES}

\section{Referências Bibliográficas}

1. Minayo MCS, Ribeiro AP. Health conditions of prisoners in the state of Rio de Janeiro, Brazil. CienSaude Colet. 2016 Jun;21 (7):2031-40.doi: 10.1590/1413-81232015217.08552016 2. Rodrigues B, Puntel MA, Becker D, Barbosa M, Hermes V, Possuelo LG. Prevalência de doenças infecciosas na população masculina recolhida no presídio regional de Santa Cruz do Sul. III Salão de Ensino e Extensão. 2012 Out 22-26, Santa Cruz do Sul, RS Universidade de Santa Cruz do Sul; 2012. 3. Oyeka CA, Eze II. Fungal skin infections among prison inmates in Abakaliki, Nigeria. Mycoses. Jan 2008;51:50-4.

Doihttps://doi.org/10.1111/j.1439-0507.2007.01408.x 4. Wolff H, Sebo P, Haller DM, Eytan A, Niveau G, Bertrand D, Gétaz L, Cerutti B. Health problems among detainees in Switzerland: a study using the ICPC-2 classification. BMC Public Health. Abr2011;11:245.doi: 10.1186/1471-2458-11-245. 5. Gavigan G, McEvoy A, Walker J. Patters of skin disease in a sample of the federal prison population: a retrospective chart review. CMAJ. 2016; 4(2): 326-30. 


\title{
CURSO DE EDUCAÇÃO PERMANENTE ON-LINE SOBRE TRATAMENTO DE FERIDAS PARA PROFISSIONAIS DE SAÚDE DO SISTEMA PRISIONAL DO ESTADO DE SÃO PAULO
}

\author{
Author(s): Flavia Carla Takaki Cavichioli ${ }^{1,2}$, Daniela Tinti Moreira Borges ${ }^{1,2}$, Gisele Grinevicius Garbe ${ }^{1}$, \\ Leila Blanes ${ }^{1}$, Denise Nicodemo ${ }^{1}$, Lydia Masako Ferreira ${ }^{1}$ \\ Institution(s) ${ }^{1}$ UNIFESP - Universidade Federal de São Paulo (Rua Botucatu, 740 - Vila Clementino - São \\ Paulo/SP), ${ }^{2}$ SAP - Secretaria da Administração Penitenciária (Av. Libero Badaro, 600. São \\ Paulo/SP)
}

\begin{abstract}
Introdução: A EAD é um recurso educacional relevante na capacitação permanente para profissionais que trabalham em instituições de saúde1. A utilização de ferramentas tecnológicas permite atingir maior número de profissionais, proporciona flexibilidade de estudo e permite o estudante a construir seu próprio conhecimento2,3. 0 cuidado de pacientes com feridas é um desafio para os profissionais, a falta de habilitação dos profissionais acarreta em dificuldades no cuidado integral do paciente4. Dentre as instituições destacam-se as prisões em que a população carcerária enfrenta problemas como superlotação e condições insalubres que favorecem a ocorrência de lesões de pele5. Objetivos: Desenvolver e validar o curso de Educação Permanente on-line sobre Tratamento de Feridas para profissionais de saúde do Sistema Prisional do Estado de São Paulo. Método: Estudo descritivo sobre o desenvolvimento, configuração e validação do curso a partir do protocolo de feridas desenvolvida na SAP. Estudo aprovado pelo Comitê de Ética em Pesquisa da UNIFESP (certificado CAAE 91270218.3.0000.5505) e da SAP (certificado CAAE 91270218.3.3001.5563). O desenvolvimento do curso foi dividido em etapas: a primeira fase com a busca de anterioridade; e a elaboração do conteúdo do curso, baseado no Protocolo de Tratamento para o Sistema Penitenciário e artigos encontrados nas bases de dados BVS, Lilacs, Pubmed e ERIC. A configuração do curso na plataforma Moodle na segunda fase e, terceira etapa, a validação pela Técnica Delphi com consulta aos especialistas e adequação do curso de acordo com a recomendação dos juízes. Resultados: O curso possui seis módulos com arquivos de conteúdo, seis exercícios de fixação e uma avaliação de aprendizagem. Para a validação, foram realizadas duas rodadas de avaliação dos juízes especialistas, com resultados de IVC $=0,83$ (Delphi 1) e IVC= 0,98 (Delphi 2). O curso foi configurado na plataforma na Moodle, em instalação provisória, para posterior implementação na EAP. Conclusão: Foi desenvolvido e validado o Curso de Educação Permanente on-line sobre Tratamento de Feridas para profissionais de saúde do Sistema Prisional do Estado de São Paulo.
\end{abstract}

\section{Keywords: CAPACITAÇÃO PROFISSIONAL, EDUCAÇÃO A DISTÂNCIA, EDUCAÇÃO EM ENFERMAGEM, ESTOMATERAPIA, PRISÕES}

\section{Referências Bibliográficas}

1. Ortega J, Hooshmand M, Foronda C, Padron M, Simon D, Waters M, et al. Developing nurse leaders across the Americas: evaluation of an online nursing leadership course. Rev Panam Salud Publica. 2018; 42(152): 1-8. 2. Aroldi JBC, Peres HHC, Mira VL. Percepção do impacto no trabalho de um treinamento on-line sobre prevenção de lesão por pressão. Texto Contexto Enferm, 2018; 27(3): 1-12. 3. Avelino CCV, Costa LCS, Buchhorn SMM, Nogueira DA, Goyatá SLT. Avaliação do ensino-aprendizagem sobre a CIPE® utilizando o Ambiente Virtual de Aprendizagem. Rev Bras Enfermagem. 2017; Mai-jun; 70 (3): 630-7. 4. Redmond C, Davies C, Cornally D, Fegan M, O'Toole M. Teaching and learning in the Biosciences: the development of na educational programme to assist student nurses in their assessment and management of patients with wounds. Journal of Clinical Nursing. 2015; Jun; 25:2706-12. 5. Garcia SJ, Borges DTM, Blanes L, Ferreira LM. Evaluación clínica y epidemiológica de pacientes com heridas en una unidad penitenciaria del estado de São Paulo.

Rev. Avances en Enfermería. 2019; 37(1): 1-8. 


\title{
AVALIAÇÃO DA SENSIBILIDADE TÁTIL PODAL DE PORTADORES DE DIABETES MELLITUS TIPO II
}

\author{
Author(s): Fábio Braga Teixeira ${ }^{1}$, Maria Eduarda Gomes Vieira ${ }^{1}$, Junia Leonne Dourado de Almeida Lima ${ }^{1}$ \\ Institution(s) ${ }^{1}$ FADIP - Faculdade Dinâmica de Ponte Nova (Rua G, 205 - Bairro Paraíso - Ponte Nova - MG - \\ Cep: 35430-302)
}

\begin{abstract}
Introdução: $O$ pé diabético é uma síndrome temida em portadores de diabetes mellitus, caracterizada pela perda da sensibilidade motora e angiopatologias, que com frequência evoluem para feridas de difícil cicatrização e amputações. A descoberta precoce desta condição somado a orientações de autocuidado tem sido documentada como medidas eficazes na prevenção das complicações do pé diabético. Objetivo geral: Avaliar a sensibilidade tátil podal de portadores de diabetes mellitus tipo 2 (DM2) utilizando o monofilamento de Semmes-Weisnstein. Materiais e Métodos: Estudo descritivo transversal com abordagem quantitativa. A amostra foi do tipo não probabilística, formada por 35 portadores de DM2, com cognição preservada certificada pelo teste do Mini Exame do Estado Mental de Folstein et al., adaptado por Brucki et al.1 Participaram indivíduos de ambos os sexos, com idade entre 30 a 70 anos, sem diagnóstico de neuropatia periférica e amputações prévias, vinculados a Unidade de Saúde da Família Dr. Abdala Felício (USF) na cidade de Ponte Nova em Minas Gerais. A coleta de dados ocorreu no mês de julho de 2018 na sede da USF ou no domicílio dos investigados que após responderem um questionário sócio epidemiológico, tiveram à sensibilidade de seus pés testada com auxilio de um monofilamento de Semmes-Weinstein, com carga de 10 gramas, em quatro locais: 1o pododáctilo (superfície plantar da falange distal) e as $1^{a}, 3^{\underline{a}}$ e $5^{\underline{a}}$ quinta cabeças dos metatarsos de cada pé, conforme técnica recomendada pelo Ministério da Saúde2. Os resultados encontrados receberam tratamento estatístico por meio do programa GraphPad Prism ${ }^{\circledR}$ para Windows versão 6.0 (GraphPad Software Inc., San Diego, CA, EUA), com o nível de significância p=0,05. Este estudo foi autorizado pelo Comitê de Ética em pesquisa com seres humanos da Faculdade Dinâmica de Ponte Nova e recebeu o número 2.702.345. Resultados: Dentre os investigados, $94 \%(n=30)$ eram mulheres e a idade média foi de $57 \pm 9,4$ anos, $63 \%(n=20)$ afirmaram ter o ensino fundamental incompleto e $56 \%(n=18)$ alegaram estar casados. Quanto ao comportamento, $25 \%(n=16)$ afirmaram serem tabagistas, $91 \%(n=24)$ sedentários e $84 \%$ estavam com IMC acima do desejado, sendo identificados $22 \%(n=7)$ com sobrepeso, $37 \%(n=12)$ com obesidade tipo I e $28 \%(n=8)$ com obesidade tipo II. A média de tempo de diagnóstico de DM2 foi de $5 \pm 7$ anos e $25 \%(n=8)$ relataram ser insulino-dependentes. No teste de sensibilidade foram detectados que $41 \%(n=13)$ dos investigados possuíam neuropatia periférica com insensibilidade detectada. $\mathrm{Na}$ análise estatística da influencia das variáveis com o resultado do teste de sensibilidade, não foram encontrados correlações significativas. Conclusão: $O$ teste foi de fácil execução e provou ser uma importante ferramenta para a identificação precoce do pé diabético, revelando um percentual de portadores de neuropatia periférica, próximo do que prevê a literatura consultada, cerca de $50 \%$ dos portadores de DM com mais 60 anos.3,4
\end{abstract}

Keywords: Pé diabético, Neuropatias diabéticas, Estomaterapia, Rastreio

\section{Referências Bibliográficas}

1- Brucki, Sonia M.D. et al. Sugestões para o uso do mini-exame do estado mental no Brasil. Arq. Neuro-Psiquiatr. [online]. 2003, vol.61, n.3B, pp.777-781. Disponível em: http://www.scielo.br/scielo.php?pid=S0004-

282X2003000500014\&script=sci_abstract\&tIng=pt. Acesso em 28/05/18. 2 - Brasil. Ministério da Saúde. Manual do Pé Diabético: estratégias para o cuidado da pessoa com doença crônica.- Brasília: Ministério da Saúde, 2016. Disponível em: dab.saude.gov.br/portaldab/biblioteca.php?conteúdo.../manual_do_pe_diabetico. Acesso em 28/05/2018. 3 - Caifá, JS et al. Atenção integral ao portador de Pé Diabético. J Vasc Bras 2011; 10(4): 1-25. Disponível em:

http://www.scielo.br/scielo.php?script=sci_arttext\&pid=S1677-54492011000600001. Acesso em 28/05/2018 4 - Santos

GILS, Capirunga JBM, Almeida OSC. Pé Diabético: Condutas do Enfermeiro. Rev. Enfermagem Contemporânea. 2013; 2(1): 225-41. Disponível em: https://www5.bahiana.edu.br/index.php/enfermagem/article/view/303. Acesso em 28/05/2018. 


\title{
MELHORES COBERTURAS PARA O TRATAMENTO DE LESÃO POR FRICÇÃO: REVISÃO INTEGRATIVA
}

\author{
Author(s): Ana Cristina dos Santos Monteiro ${ }^{2,1}$, Mariana Côrtes Pellisari Tanaka ${ }^{2}$, Ednalda Maria Franck ${ }^{2}$, \\ Maria Angela Boccara de Paula ${ }^{2}$ \\ Institution(s) ${ }^{1}$ ICr HCFMUSP - INSTITUTO DA CRIANÇA - HCFMUSP (Av. Dr. Enéas Carvalho Aguiar, \\ 647,São Paulo), ${ }^{2}$ UNITAU - Universidade de Taubaté (Endereço: Av. Tiradentes, 500, Bom \\ Conselho, Taubaté-SP CEP: 12030-180 ), ${ }^{3}$ UNITAU - Universidade de Taubaté (Endereço: Av. \\ Tiradentes, 500, Bom Conselho, Taubaté-SP CEP: 12030-180 ), ${ }^{4}$ UNITAU - Universidade de \\ Taubaté (Endereço: Av. Tiradentes, 500, Bom Conselho, Taubaté-SP CEP: 12030-180 )
}

\begin{abstract}
Introdução: Lesão por fricção (LF) pode ser definida como o resultado de cisalha-mento, fricção ou trauma que ocasionam a separação das camadas da pele. Estão associadas à fragilidade da pele e ocorrem frequentemente nos extremos da idade (neonatos e idosos) e podem ser encontradas em todas as áreas do corpo, porém, as extremidades são as áreas mais comumente afetadas. Objetivo: Identificar as melhores coberturas para o tratamento de lesão por fricção e o nível de evidência dos estudos. Método: Revisão integrativa da literatura realizada nas bases de da-dos Literatura Latino-Americana e do Caribe em Ciências da Saúde (LILACS), OVID, National Library of Medicine (PUBMED) e nas bibliotecas eletrônicas Scien-tific Eletronic Library Online (SciELO) e Biblioteca Virtual da Saúde (BVS) e no Go-ogle Acadêmico de 2000 a 2018, nos idiomas português, inglês e espanhol. Resul-tados: 45 artigos foram incluídos nessa revisão, espuma absorvente e silicone fo-ram as coberturas mais utilizadas para tratar as lesões por fricção, dentre outras. Quanto aos países que mais publicaram, os EUA publicou 18 artigos, seguido do Reino Unido 09, Austrália 07, Canada 03 e Brasil com 03. Segundo nível de evidência dos artigos que foram inclusos na pesquisa, 17 artigos foram classificados com nível 5 (revisão sistemática de estudos descritivos e qualitativos), 15 nível 7 (opinião de autoridades e/ou relatório de comitês de especialistas) e 10 nível 6 (único estudo descritivo ou qualitativo). Conclusão: as melhores coberturas para o tratamento das lesões por fricção são as coberturas não aderentes e as mais utilizadas, segundo os artigos analisados nesta pesquisa foram o silicone e a espuma absorvente (24/53\%, cada), hidrogel (18/40\%), e malhas não aderentes e alginato (17/ $38 \%$, cada). O nível de evidência dos estudos é considerada baixa, pois baseiam-se em revisão de estudos descritivos (quantitativos ou qualitativos), estudos descritivos ou opinião de especialistas (individual ou comitê).
\end{abstract}

Keywords: Lesão por fricção, Skin Tears, Ferimentos e lesões, Tratamento, Estomaterapia

\section{Referências Bibliográficas}

1. Pulido KCS, Peres GRP, Campanili TCGF, Santos VLCG. Prevalência de le-são por fricção e fatores associados: revisão sistemática. Rev Esc Enferm USP. 2015; 4: 674-680 2. Leblanc K., Christensen D, Orsted H, Keast D. Prevention and treatment of skin tears. Wound Care Canada. 2008; 1: 14-30. 3. Pulido, KCS. Adaptação cultural e validação do instrumento "Star Skin tear classification system" para língua portuguesa no Brasil. [Tese de mestrado]. São Paulo: Universidade de São Paulo, Escola de Enfermagem, 2010. 189p. 


\title{
FOTOBIOMODULAÇÃO COM LASER DE BAIXA INTENSIDADE NO TRATAMENTO DE ÚLCERAS NEUROPÁTICAS POR DIABETES: REVISÃO INTEGRATIVA
}

\author{
Author(s): Valéria Masson ${ }^{1}$, Grosseli Aniele ${ }^{1}$, Lilian Nogueira da Silva ${ }^{1}$, Sônia Regina Pérez Evangelista \\ Dantas ${ }^{1}$ \\ Institution(s) ${ }^{1}$ UNICAMP - UNIVERSIDADE ESTADUAL DE CAMPINAS (Cidade Universitária Zeferino \\ Vaz - Barão Geraldo - Campinas SP)
}

\begin{abstract}
INTRODUÇÃO: A fotobiomodulação por laser de baixa intensidade (LBI) envolve a aplicação de luz de um comprimento de onda específico para estimular os processos celulares. Os efeitos da fototerapia são químicos e as respostas celulares acontecem como resultado de mudanças nas moléculas receptoras, os cromóforos. A energia absorvida pelos fotoreceptores estimula o metabolismo celular e pode ser transferida para outras moléculas, causando reações químicas no tecido e atuando como um bioestimulador para o reparo tecidual, aumentando a circulação local, a proliferação celular e a síntese de colágeno. A teoria do citocromo-c oxidase, enzima terminal na cadeia respiratória mitocondrial eucariótica, tem sido a mais estudada para explicar o mecanismo de ação do laser. O citocromo-c oxidase facilita a transferência de elétrons para o oxigênio molecular e o produto final deste complexo é a produção de ATP (trifosfato de adenosina). Os efeitos terapêuticos do laser sobre os diferentes tecidos biológicos são amplos e, entre eles, destacam-se os efeitos tróficoregenerativos, anti-inflamatórios e analgésicos. OBJETIVO: Avaliar o uso da fotobiomodulação com laser de baixa intensidade como terapia adjuvante na cicatrização de úlceras neuropáticas por diabetes. MÉTODO: As etapas que conduziram esta revisão foram: identificação do tema e questão norteadora, busca na literatura com estabelecimento de critérios para inclusão e exclusão de estudos, definição das informações a serem extraídas dos estudos selecionados, avaliação dos estudos incluídos na revisão integrativa, interpretação dos resultados, apresentação da revisão/síntese do conhecimento. Realizou-se uma revisão integrativa nas bases de dados SCOPUS, MEDLINE, Web of Science, CINAHL, no período de 2012 a 2018. Os artigos foram selecionados de forma independente por dois pesquisadores. Foram encontrados 23 artigos, após a leitura do conteúdo e consenso entre os pesquisadores, foram excluídos dez artigos, totalizando 13 artigos na amostra final. RESULTADO: Os estudos mostraram eficácia do laser de baixa intensidade como tratamento adjuvante na cicatrização da úlcera, na qualidade da reparação tecidual, no tempo de cicatrização da lesão e na redução da dor. Estudos de revisão sistemática evidenciaram ausência de protocolos padronizados na utilização do LBI e consideraram como fator limitante dessa tecnologia, pois a eficácia terapêutica depende de parâmetros precisos e específicos. CONCLUSÃO: Os resultados desse estudo mostraram que a LBI é efetiva como tratamento adjuvante da úlcera neuropática por diabetes, pois acelera o processo de reparação tecidual, com bons resultados com relação a qualidade e tempo total de cicatrização, controle da carga microbiana e melhora na dor.
\end{abstract}

Keywords: pé diabético, terapia com luz de baixa intensidade, cicatrização, Estomaterapia

\section{Referências Bibliográficas}

1. Tchanque-Fossuo CN, Ho D, Dahle SE, Koo E, Li C, Isseroff RR, Jagdeo J. A systematic review of low-level light therapy for treatment of diabetic foot ulcer. Wound Rep and Reg.2016; 24: 418-426. doi:10.1111/wrr.12399 2. Mathur RK, Sahu, K, Saraf S. et al. Low-level laser therapy as an adjunct to conventional therapy in the treatment of diabetic foot ulcers. Lasers Med Sci. 2017; 32: 275. https://doi.org/10.1007/s10103-016-2109-2 3. Houreld NN. Shedding Light on a New Treatment for Diabetic Wound Healing: A Review on Phototherapy. The Scientific World Journal. 2014 Jan 6. doi: 10.1155/2014/398412 4. Smith KC. Laser (and LED) therapy is phototherapy. Photomed Laser Surg. 2005; 23(1):78-80, Disponível em: < http://dx.doi.org/10.1089/pho.2005.23.78 > . 5. Lins RDAU. et al. Biostimulation effects of low-power laser in the repair process. An. Bras. Dermatol. 2010; 85(6): 849-855. Disponível em: < http://www.scielo.br/scielo.php?script=sci_abstract\&pid=S0365-05962010000600011\&lng=en\&nrm=iso\&tlng=pt >. 


\title{
Avaliação clínica da pele de recém-nascidos a termo após o uso de sabonete líquido ou barra: relato de dois casos
}

\author{
Author(s): $\quad \begin{aligned} & \text { Mily Constanza Moreno Ramos } \\ & \text { Velasco }\end{aligned}$ \\ Institution(s) ${ }^{1}$ EEUSP - Escola de Enfermagem da Universidade de São Paulo (Av. Dr. Enéas de Carvalho \\ Aguiar, 419), ${ }^{2}$ FCFUSP - Faculdade de Ciências Farmacêuticas da USP (Av. Prof. Lineu Prestes, \\ 580)
}

\begin{abstract}
Introdução: A pele do recém-nascido $(\mathrm{RN})$ enfrenta um processo de maturação ao longo do primeiro ano de vida. Cuidados específicos podem prevenir a fragilização da pele, doenças dermatológicas como a dermatite atópica e, lesões de pele. Dentre os cuidados, encontra-se o banho que muitas vezes é realizado utilizando sabonetes líquidos e em barra, que, muitas vezes, não preservam o estado fisiológico da pele do RN. Objetivos: descrever os parâmetros biométricos e integridade da pele de dois RN a termo saudáveis que utilizaram sabonete líquido e sabonete em barra. Material e Métodos: estudo descritivo, tipo relato de caso, aprovado pelo Comitê de Ética do Hospital Universitário da Universidade de São Paulo (HU/USP). O estudo foi realizado no alojamento conjunto do HU/USP com dois RN saudáveis que utilizaram sabonete líquido $(A)$ e sabonete em barra $(B)$ durante o primeiro mês de vida em três momentos: às 48 horas de vida, 14 ㅇ dia, e 28으 dia de vida. Como parâmetros biométricos da pele foram mensurados em quatro regiões do corpo: o pH e a corneometría (nível de hidratação superficial em Unidades Arbitrárias/UA), com o aparelho Multi Probe Adapter- MPA5 e as sondas Skin-pH-Meter ${ }^{\circledR}$ e Corneometer CM820® (Courage + Khazaka electronic GmbH, Cologne, Germany); e a integridade da pele foi avaliada por meio da Escala de Condição da Pele do Recém-Nascido. Resultados: Na avaliação realizada às 48 horas, ambos os $\mathrm{RN}$ tiveram em média um $\mathrm{pH}$ levemente ácido $(A=4,56$ e $B=5,05)$, porém apresentou um aumento no $14^{\circ}$ dia $(A=5,95$ e $B=6,55)$ retornando à normalidade no $28^{\circ}$ dia. $A$ pele apresentou menor hidratação na primeira avaliação $(A=21,91 \cup A$ e $B=23,48 \cup A)$ que evidenciou aumento aos 14 dias $(A=33,59 \cup A$ e $B=32,96$ UA) e 28 dias $(A=72,75$ UA e $B=55,84 \cup A)$. Na avaliação da condição da pele às 48 horas, $(A)$ evidenciou ressecamento na pele (2 pontos vs. 1 ponto), aos 14 dias ambos RN estavam com a pele seca (2 pontos), voltando à normalidade aos 28 dias de vida (1 ponto). Conclusão: Ao longo do estudo foram observadas características da pele similares entre os RN, exceto a hidratação superficial da pele que no inicio mostrou valores muito baixos e teve um aumento progressivo em ambos RN após os 14 dias de vida sendo maior no RN que usou sabonete líquido o que pode sugerir ser mais benéfico para a hidratação da pele.
\end{abstract}

Keywords: Recém-nascido, Pele, Sabonete, Estomaterapia

\section{Referências Bibliográficas}

Bartels NG, Scheufele R, Sc M, Prosch F, Schink T, Ph D, et al. Effect of Standardized Skin Care Regimens on Neonatal Skin Barrier Function in Different Body Areas. Pediatr Dermatol. 2010;27(1):1-9 Blume-Peytavi U, Lavender T, Jenerowicz D, Ryumina I, Stalder J, Torrelo A, et al. Recommendations from a European Roundtable Meeting on Best Practice Healthy Infant Skin Care. Pediatr Dermatol. 2016;33(3):311-21. Fluhr JW, Darlenski R, Taieb A, Hachem J, Baudouin C, Msika P, et al. Functional skin adaptation in infancy - almost complete but not fully competent. Exp Dermatol. 2010;19:483-92.

Lavender T, Bedwell C, Roberts SA, Hart A, Turner MA, Carter L, et al. Randomized, Controlled Trial Evaluating a Baby Wash Product on skin barrier function in healthy, term neonates. JOGNN. 2013;42:203-14 Mendes B, Midori Shimabukuro D, Uber M, Taniguchi K. Avaliação crítica do pH dos sabonetes infantis. J Pediatr (Rio J). 2016;92(3):290-5. 


\title{
CARACTERÍSTICAS DAS LESÕES DE PACIENTES ATENDIDOS POR UMA COMISSÃO DE CURATIVOS.
}

\author{
Author(s): $\quad$ Tarcisio Vitor Augusto Lordani ${ }^{1}$, Ariana Rodrigues da Silva Carvalho ${ }^{1}$, Julia Ampessan ${ }^{1}$ \\ Institution(s) ${ }^{1}$ Unioeste - Universidade Estadual do Oeste do Paraná (Rua universitaria, 1619)
}

\begin{abstract}
Introdução: A ferida constitui uma ruptura da integridade da pele, por sua vez, a pele é capaz de reconstituir-se quando necessário, afim de promover a manutenção da homeostase. Para garantir a segurança do paciente acometido por lesões na pele, é necessário que os profissionais de enfermagem tenham conhecimento sobre a pele, fatores que a possam comprometer e sua fisiologia, além de manterem-se atualizados quanto a produtos e condutas. A implementação de uma comissão de curativos facilita o cuidado a ser prestado ao indivíduo, pois além de envolver a equipe de enfermagem no tratamento de lesões complexas e orientações quanto a condutas, envolve o trabalho multiprofissional afim de proporcionar um tratamento adequado voltado ao indivíduo. Objetivo: Descrever as características das lesões dos pacientes atendidos por uma comissão de curativos. Material e Método: Trata-se de um estudo retrospectivo, secundário, realizado em um Hospital Universitário localizado na cidade de Cascavel - Pr. O presente estudo faz parte dos objetivos de um grande projeto intitulado "Avaliação e acompanhamento multiprofissional de pacientes portadores de lesões cutâneas assistidos em uma instituição hospitalar pública de ensino", com parecer de aprovação no CEP número: 2.989.411. A coleta dos dados foi realizada nos arquivos da Comissão de Curativos entre os meses de junho a setembro de 2018. Neste período, foram avaliados 57 pacientes, os dados coletados foram referentes a localização das lesões, tipo de lesões, características, condutas, produtos e coberturas utilizadas no início e no final do tratamento, média do tempo de acompanhamento e média do número de avaliações recebidas. Os dados foram submetidos a análise estatística simples. Resultados: Durante o período analisado foram identificadas 94 lesões (100\%), destas, os MMII foram os locais com maior predominância, 39 lesões $(41,49 \%)$. Quanto ao tipo de lesão, $32(34,04 \%)$ foram classificadas como LPP. Quanto ao tipo de tecido presente nas lesões, 51 (54\%) apresentou em sua superfície tecido desvitalizado. Dentre as condutas, produtos e coberturas utilizados pelos profissionais no início do tratamento, evidenciou o predomínio do uso de ácidos graxos essenciais - AGE, em 51 lesões (54\%), o mesmo predomínio se manteve no final do tratamento, onde o uso de AGE foi utilizado em 46 lesões (49\%). Conclusões: Através da análise dos dados, foi possível conhecer as características das lesões apresentadas pelos pacientes em acompanhamento, proporcionando conhecimento e fundamentando o planejamento e organização das ações que serão realizadas pela equipe.
\end{abstract}

Keywords: Estomaterapia, Ferimentos e lesões, Cicatrização de feridas, Comissão de curativos

\section{Referências Bibliográficas}

1. Laureano, A, Rodrigues, AM. Cicatrização de Feridas. Portugal: Revista da SPDV. 2011. 2. Krause TCC, Assis GM, Danski MTR. Implantação de uma Comissão de Cuidados com a Pele em um Hospital de Ensino. Estima; 2016. 3, Potter PA, Perry AG. Fundamentos de enfermagem. 7 ed. São Paulo: Elsvier; 2009. 


\title{
PERFIL DOS PACIENTES ATENDIDOS POR UMA COMISSÃO DE CURATIVOS
}

\author{
Author(s): $\quad$ Tarcisio Vitor Augusto Lordani ${ }^{1}$, Julia Ampessan ${ }^{1}$, Ariana Rodrigues da Silva Carvalho ${ }^{1}$ \\ Institution(s) ${ }^{1}$ Unioeste - Universidade Estadual do Oeste do Paraná (Rua universitaria, 1619)
}

\begin{abstract}
Introdução: A ruptura da integridade da pele constitui uma vulnerabilidade do indivíduo a riscos biológicos e traz um impacto negativo a sua qualidade de vida. O tratamento de lesões é realizado pelo profissional de enfermagem, e este, por sua vez, necessita apresentar conhecimento técnico-científico para a realização do cuidado adequado. A presença de uma comissão de curativos na instituição permite que ocorra o acompanhamento de lesões complexas e também a orientação sobre as condutas a serem realizadas. Objetivo: Caracterizar o perfil dos pacientes atendidos por uma comissão de curativos. Material e Método: Trata-se de um estudo retrospectivo, secundário, realizado em um Hospital Universitário localizado na cidade de Cascavel-Pr. O presente estudo faz parte dos objetivos de um grande projeto intitulado "Avaliação e acompanhamento multiprofissional de pacientes portadores de lesões cutâneas assistidos em uma instituição hospitalar pública de ensino", com parecer de aprovação no CEP/ UNIOESTE número: 2.989.411. Para a coleta de dados buscou-se os arquivos da comissão de curativos - COC entre os meses de junho a setembro de 2018. Neste período, foram avaliados dados referentes a sexo, idade, motivo da internação e tempo de internação de 57 pacientes atendidos pela COC. Os dados foram submetidos a análise estatística simples. Resultados: A predominância dos pacientes foram do sexo masculino $38(66 \%)$, com idade média de $(55,34 \pm 16,45)$. Quanto ao local de internação, mostrou-se predominante a unidade de clínica médica e cirúrgica, onde apresentavam-se $17(36 \%)$ pacientes. Conclusões: Através da análise dos dados, é possível identificar o perfil dos pacientes para poder intensificar as medidas preventivas direcionando-as de acordo com as características de cada grupo.
\end{abstract}

Keywords: Perfil epidemiológico, Ferimentos e lesões, Cicatrização de feridas, Comissão de curativos

\section{Referências Bibliográficas}

1. Krause TCC, Assis GM, Danski MTR. Implantação de uma Comissão de Cuidados com a Pele em um Hospital de Ensino. Estima; 2016. 2. Potter PA, Perry AG. Fundamentos de enfermagem. 7 ed. São Paulo: Elsvier; 2009. 3. Silva FAA, Freitas CHA de, Jorge MSB, Moreira TMM, Alcântara MCM de. Enfermagem em estomaterapia: cuidados clínicos ao portador de úlcera venosa. Brasília: Revista Brasileira de Enfermagem; 2009. 


\title{
A ATIVIDADE CICATRIZANTE DO EXTRATO DE CALOPHYLLUM BRASILIENSE CAMBES EM FERIDAS CUTÂNEAS INDUZIDAS EM RATOS
}

\author{
Author(s): $\quad$ Tarcisio Vitor Augusto Lordani ${ }^{1}$ \\ Institution(s) ${ }^{1}$ Unioeste - Universidade Estadual do Oeste do Paraná (Rua universitaria, 1619)
}

\begin{abstract}
Introdução: Desde a antiguidade, as feridas cutâneas constituem um sério problema de saúde, pois estão associadas à dor, imobilidade, incapacidade, diminuição da qualidade de vida originadas por hospitalizações e afastamento do convívio social. Na tentativa de minimizar esse problema, diversas substâncias extraídas de plantas medicinais têm sido estudadas demonstrando resultados benéficos no auxílio da cicatrização. O Calophyllum brasiliense Cambess tem sido usado na medicina popular para tratar a dor, infecções, inflamação e úlceras. Estudos confirmaram que extratos e óleos do gênero Calophyllum possuem atividade antimicrobiana, antifúngica e cicatrizante. Objetivo: Avaliar a atividade cicatrizante do extrato bruto de C. brasiliense em feridas cutâneas induzidas em ratos. Método: A amostra foi composta por 30 ratos Wistar, com peso médio de $250 \pm 30 \mathrm{~g}$. Após a indução da ferida cutânea, os animais foram divididos aleatoriamente em grupos e tratados diariamente com Hidrogel contendo o extrato bruto de Callophylum brasiliense Cambess a $2 \%$, Hidrogel base e Solução salina $0,9 \%$. As análises morfométricas e morfológicas foram realizadas após 7 e 14 dias de tratamento. $O$ protocolo de pesquisa foi aprovado pelo Comitê de Ética no Uso de Animais (CEUA) da Universidade Estadual do Oeste do Paraná (Unioeste). Resultados: Os resultados demonstraram que os animais tratados com Hidrogel contendo o extrato bruto de C. brasiliense a $2 \%$ apresentaram diferença estatística em relação aos demais grupos quanto ao percentual de fechamento das feridas, neovascularização e quanto ao percentual de colágeno tipo I e III. Também, demonstrou evidências clínicas benéficas em várias fases do processo de cicatrização. Conclusão: O Hidrogel contendo o extrato bruto de C. brasiliense a $2 \%$ promoveu a aceleração da cicatrização de feridas em ratos e maior permeação cutânea. Este extrato pode ser um medicamento promissor para cicatrização de feridas, para isso, novos estudos testando diferentes doses, veículos e tempo de tratamento são necessários para entender melhor o mecanismo completo da cicatrização e os efeitos deste extrato em humanos.
\end{abstract}

Keywords: Calophyllum brasiliense Cambes, Cicatrização de feridas, Plantas medicinais

\section{Referências Bibliográficas}

1. Mandelbaum SH, Di Santis ÉP, Mandelbaum MHS. Cicatrização: conceitos atuais e recursos auxiliares-Parte I Cicatrization: current concepts and auxiliary resources-Part I. An Bras Dermatologia. 2003;78(4):393-410. 2. Lordani TVA, Lara CE, Ferreira FBP, Monich MST, Silva CM, Lordani CRF, Bueno FG, Teixeira JJV LM. Therapeutic Effects of Medicinal Plants on Cutaneous Wound Healing in Humans: A Systematic Review. Mediators Inflamm. 2018; 3. Lordani TVA, Brenzan MA, Cortez LER, Lordani CRF, Honda PA, Lonardoni MVC, et al. Effect of a topical formulation containing Calophyllum brasiliense Camb. extract on cutaneous wound healing in rats. Nat Prod Res. 2016;29(10). 


\title{
CUIDADO DOMICILIAR DE ENFERMAGEM AO IDOSO COM FERIDAS NA ÓTICA DO CUIDADOR FAMILIAR
}

\author{
Author(s): \\ Fernanda Vieira Nicolato $^{2}$, Edna Aparecida Barbosa de Castro ${ }^{2}$, Anadelle de Souza Teixeira Lima \\ Institution(s) ${ }^{1}$ HUUFJF - Hospital Universitário de Juiz de Fora (Av. Eugênio do Nascimento, s/n - Dom Bosco, \\ Juiz de Fora - MG, 36038-330), ${ }^{2}$ UFJF - Universidade Federal de Juiz de Fora (Campus \\ Universitário, Rua José Lourenço Kelmer, s/n - São Pedro, MG, 36036-900)
}

\begin{abstract}
As mudanças, sócio demográficas e epidemiológicas, na população brasileira sinalizam para o desenvolvimento de estratégias integradoras na atenção à saúde ao idoso em domicílio1, o que propõe a Política Nacional de Atenção Domiciliar no Brasil2. Na prevenção e tratamento de lesões crônicas em idosos pelo enfermeiro, destacam-se a aplicação do Processo de Enfermagem3 sistematizado conforme teorias, normas, rotinas, protocolos validados e revisados. Objetivo: desenvolver uma teoria substantiva sobre os custos da família com o cuidado de idosos com feridas no contexto da Atenção Domiciliar no SUS. Material e Método: resulta de uma dissertação de mestrado, com o método da Teoria Fundamentada nos Dados4. Os dados foram coletados em visitas domiciliares, por meio de entrevistas abertas e observação direta. Para isso, agendou-se com os 10 cuidadores familiares. A pesquisa teve aprovação do Comitê de Ética, de número 1.480.500. A análise ocorreu pela codificação: aberta, axial e seletiva4 obtendo-se a compreensão do fenômeno no processo de cuidar pela família de idosos com ferida no contexto domiciliar. Resultados: O modelo teórico substantivo foi construído a partir da conexão e interconexão entre os fenômenos apresentados. Tendo como fenômeno central, que representa o tema principal da pesquisa: Assumindo os custos do cuidado domiciliar de um idoso com ferida. Sendo analisados os custos diretos, indiretos e intangíveis. A partir disso, os pressupostos teóricos foram obtidos: a equipe de enfermagem foi mencionada pelos cuidadores familiares de idosos com feridas em atenção domiciliar, como sendo essencial no tratamento e na prevenção das feridas; o enfermeiro foi reconhecido como o profissional que gerencia, orienta e que prescreve o cuidado em visitas semanais e os técnicos de enfermagem como os que realizam o procedimento; a ferida demanda um cuidado contínuo por equipe de enfermagem, porém o curativo diário na ferida do idoso é assumido e realizado pelo cuidador familiar, com o suporte da equipe de enfermagem em visitas para ensino do procedimento; o cuidado com a ferida é o mais crítico e desafiador para o cuidador, que busca estratégias para a superação das reações iniciais de repulsa e de alívio de sentimentos de medo causados com a nova realidade; com o fato de ter que fazer o curativo, os cuidadores tiveram que aprender a fazê-lo, expondo aspectos tanto da corresponsabilização da família como da transferência de domínios técnicos ao familiar. Conclusões: Compete ao enfermeiro, avaliar as lesões, propor cuidados, realizar curativos, coordenar e supervisionar a equipe de enfermagem na prevenção e no tratamento das feridas, 3 avaliar o papel assumido pelo cuidador, educar e orientar por meio de medidas sistemáticas de apoio e suporte, evitando que o cuidador familiar assuma um papel que não the compete. Os cuidadores familiares de idosos com feridas devem ser alvo das ações de enfermagem e, também, das políticas públicas em âmbito domiciliar, visto que necessitam, além de apoio de profissionais especializados no tratamento de ferida, do acesso a materiais, que é de alto custo. Recomenda-se a atuação do enfermeiro estomaterapeuta na assistência domiciliar ao idoso com ferida, considerando a complexidade que envolve a assistência domiciliar.
\end{abstract}

Keywords: Assistência Domiciliar, Cuidador, Estomaterapia, Ferimentos e Lesões

\section{Referências Bibliográficas}

1. Brito MCC. Freitas CASL, Mesquita KO, Lima GK. Envelhecimento Populacional e os Desafios para a Saúde Pública: Análise da Produção Científica. Revista Kairós Gerontologia, 2013; 16:161-178. 2. Ministério da Saúde. Portaria GM/MS no 825, de 25 de abril de 2016. Redefine a Atenção Domiciliar no âmbito do Sistema Único de Saúde (SUS) e atualiza as equipes habilitadas. Diário Oficial da União, 2016. 3. Conselho Federal de Enfermagem. Resolução oㅡ 0501, de 9 de dezembro de 2015. Regulamenta a competência da equipe de enfermagem no cuidado às feridas e dá outras providências. COFEN, 2015. 4. Strauss A, Corbin J. Pesquisa qualitativa: técnicas e procedimentos para o desenvolvimento de teoria fundamentada. 2. ed. Porto Alegre: Artmed; 2008. 


\title{
PREVENÇÃO DA RADIODERMITE EM CÂNCER DE MAMA: UMA REVISÃO INTEGRATIVA.
}

Author(s): MARLIZE BRANDAO RIBEIRO CARDOSO ${ }^{1}$, kelly silva oliveira ${ }^{1,2}$, cristiane costa reis silva $^{1,3}$ Institution(s) ${ }^{1}$ EBMSP - Escola Bahiana de Medicina de Saúde publica (Avenida D João VI, 275), ${ }^{2}$ EBMSP Escola Bahiana de Medicina de Saúde publica (Avenida D João VI, 275), ${ }^{3}$ EBMSP - Escola Bahiana de Medicina de Saúde publica (Avenida D João VI, 275), ${ }^{4}$ EBMSP - Escola Bahiana de Medicina de Saúde publica (Avenida D João VI, 275)

\begin{abstract}
O câncer de mama continua sendo uma importante causa de morte em mulheres. Estimam-se 59.700 casos novos de câncer de mama, para cada ano do biênio 2018-2019, para o Brasil, com um risco estimado de 56,33 casos para cada 100 mil mulheres, permanecendo a neoplasia maligna de maior incidência feminina (1). Este estudo teve como objetivo identificar o melhor tratamento para radiodermite na mama, reunindo medidas de prevenção e tratamento. Trata-se de uma pesquisa bibliográfica integrativa, que utilizou as bases de dados: BVS, Scielo, Lilacs e Medline. A coleta de dados foi entre 2013 e 2018. Foram pré-selecionados 19 referências, sendo que 12 e atendiam os critérios de inclusão e contemplavam a pergunta norteadora compondo assim a amostra final. Os estudos incluídos tinham nível de evidência entre I e IV nos três idiomas: português, inglês e espanhol. De acordo com os estudos analisados, observou-se que na prevenção da radiodermite se dá através do autocuidado principalmente, com a hidratação da pele. A eficácia contra a toxidade com o uso de corticosteroides na profilaxia como também no tratamento, foi bem evidenciado nos estudos. A utilização de ferramenta como escalas de avaliação do grau da radiodermite é relevante nas instituições para uma melhor definição da toxidade.

O tratamento nos estudos esteve atrelado à prevenção, que trouxeram significância no uso de costicosteróides para o tratamento e uso de Fotobiomodulação de baixa intensidade na prevenção e preservação da pele contra radiodermite. A necessidade de mais pesquisas tecnológicas com evidências nessa temática ficou evidente nesse estudo.
\end{abstract}

Keywords: Lesão por radiação,, Radiodermite, Câncer de mama, Radioterapia, Estomaterapia

\section{Referências Bibliográficas}

1. BRASIL. Ministério da Saúde (BR). Instituto Nacional de Câncer (INCA). Estimativa 2016: incidência de câncer no Brasil. [Internet]. Rio de Janeiro: INCA, 2016. Disponível: Acesso em 25 outubro 2018. 2. BRASIL. Instituto Nacional de Câncer José Alencar Gomes da Silva. Estimativa 2012: incidência de câncer no Brasil. Rio de Janeiro: INCA; $2011.118 p .3$.

Schneider F, Petrolo E, Lind J, Schwanke A, Danski M. (2013) Prevenção e Tratamento de Radiodermatite: Uma revisão integrativa. Curitiba: Cogitare Enferm. jul/set;18(3):579-86. 4. Calvo, F. Oncologia Radioterápica - princípios, métodos, gestión y prática clinica. Copyrigth Spain: Arán Editores, S.L., 2010. ISBN 978-84-92977-05-5. Cap. 6.3. 3 Cuidados de la piel. 5. Veríssimo, Margarida [et. al] - Radioterapia em Utentes de ORL - Ação de Enfermagem. In: Sinais Vitais. N.ํㅜ 52, Janeiro de 2004, p. 25-30. 


\title{
IMPACTO NOS CUSTOS HOSPITALARES DA IMPLANTAÇÃO DE UM CARE BUNDLE PARA PREVENÇÃO DE LESÃO POR PRESSÃO
}

\author{
Author(s): \\ Aline de Oliveira Ramalho ${ }^{1}$, Eliane Mazocoli ${ }^{1}$, Karoline Razimaviscius ${ }^{1}$, Natalia Balestra ${ }^{1}$, Nilda \\ Rosa Prado ${ }^{1}$
}

Institution(s) ${ }^{1}$ HSL - Hospital Sírio Libanês (Rua Adma Jafet, 91)

\begin{abstract}
As lesões por pressão (LP) são problemas de saúde pública mundial, com alta taxa de morbimortalidade, possuindo alto impacto nos custos dos serviços de saúde.

Objetivo: Avaliar a relação custo-benefício relacionada a prevenção e tratamento de lesões por pressão, nos pacientes internados em uma UTI cardiológica.

Metodologia: Estudo descritivo com abordagem quantitativa, envolvendo dados de consumo de produtos tópicos para prevenção e tratamento de lesões, antes e após a implantação de um projeto de redução de lesões por pressão utilizando a ciência da melhoria. O projeto foi realizado em uma unidade de terapia intensiva cardiológica de um hospital brasileiro de grande porte. Para análise considerou-se os meses de setembro/2017 a fevereiro/2018 como pré-intervenção e março/2018 a agosto 2018 como pós intervenção.

Resultados: Nos meses que antecederam o início do projeto de redução de lesão por pressão, a mediana de custo mensais com materiais para tratamento de LP foi de $R \$ 40.516,66$ e de materiais para prevenção de lesões foi $R \$ 6.975,24$. Durante a realização do projeto, foram elaboradas diversas ações, valendo destacar elaboração e implantação de um care bundle, com intervenções baseadas em evidencias, aplicação de cobertura cinco camadas com silicone e borda na região sacral em pacientes de risco, engajamento da equipe multiprofissional e envolvimento do paciente e família no cuidado, através da elaboração em conjunto de um folder de orientação. Neste período de desenvolvimento do projeto a mediana de custos mensais relacionados com o tratamento reduziu para $R \$ 15.546,42$, (redução de $61,63 \%$ ) e uma redução acumulada no decorrer dos seis meses de $R \$ 122.488,62$. Com relação aos custos dos cuidados tópicos com prevenção, a mediana se manteve similar durante todo o levantamento, não havendo maiores custos com a prevenção, quando comparado ao período anterior ao início do projeto.

Conclusão: A realização de um projeto de prevenção de lesão por pressão, pautado na ciência da melhoria, se mostrou eficaz na redução dos custos com o tratamento de lesões, valendo destacar que durante o projeto, não houve aumento do consumo de materiais utilizados para prevenção, e sim a revisão e alinhamento dos processos, onde foi possível aumentar a efetividade da utilização de recursos já existentes.
\end{abstract}

Keywords: Custos, Estomaterapia, Lesão por Pressão, PREVENÇÃO

\section{Referências Bibliográficas}

Précoma HF, Caudouro, FLF. Eventos adversos notificados em unidade de terapia intensiva: análise documental. Anais do EVINCI-UniBrasil, v. 1, n. 4, p. 1527-1539, 2016. 2- Campanili TCGF, Santos VLCG, Strazzieri-Pulido KC, Thomaz PBM, Nogueira PC. Incidence of pressure ulcers in cardiopulmonary intensive care unit patients. Rev. esc. enferm. USP [Internet]. 2015 Dec. 3 - Annette Richardson, Joanna Peart, Stephen E. Wright, lain J. McCullagh; Reducing the incidence of pressure ulcers in critical care units: a 4-year quality improvement, International Journal for Quality in Health Care, Volume 29, Issue 3, 1 June 2017, Pages 433-439 


\title{
Desenvolvimento de um aplicativo móvel para avaliação e ensino sobre Skin Tears.
}

Author(s): Edson Maruyama Diniz ${ }^{1}$, Maria Angela Boccara de Paula ${ }^{2}$

Institution(s) ${ }^{1}$ PMSP - Prefeitura Municipal de São Paulo (R. General Jardim, 36 - Vila Buarque. São Paulo SP), ${ }^{2}$ UNITAU - Universidade de Taubaté (R. Quatro de Março, 432 - Centro, Taubaté - SP)

\begin{abstract}
Introdução: Segundo a International Skin Tear Advisory Panel (ISTAP) as "Skin Tears" são feridas traumáticas, causadas por forças mecânicas, incluindo a remoção de adesivos médicos. Também conhecidas como lesão por fricção ou lacerações, são lesões traumáticas causadas por contusão, fricção ou laceração, resultando na separação das camadas da pele. Essa separação pode ser parcial, quando a epiderme é separada da derme ou total, quando além destas, as estruturas da hipoderme também estão envolvidas. A primeira tentativa de classificação das "Skin Tears" foi realizada em 1990 por Payne e Martin, sendo redesenhada a luz da prática baseada em evidências por Carville em 2007, resultando no sistema STAR - Skin Tear Classification System. Tal sistema de classificação já foi adaptado para a língua portuguesa no Brasil, confirmando também sua validade de conteúdo. Assim como o sistema de classificação representa uma evolução, novas tecnologias surgem constantemente, sendo que várias tem sido incorporada à área da saúde. Dentre elas, uma que se destaca é o uso de dispositivos móveis. Dessa forma, desenvolver soluções computacionais em aplicativos móveis é uma forma eficaz de disponibilizar a ferramenta, atingir e auxiliar o público alvo. Objetivo: idealizar e desenvolver um aplicativo móvel para ensino e classificação das Skin Tears por meio do Sistema STAR, com interface amigável, rápida e segura. Método: Estudo descritivo realizado na modalidade de produção tecnológica. Para desenvolvimento do aplicativo foi utilizado o Design Instrucional Contextualizado. O aplicativo móvel foi desenvolvido em três etapas: análise, design e desenvolvimento. Resultados: foi utilizado a ferramenta online easyeasyapps.net para desenvolvimento do aplicativo. Foram criados fluxogramas das funções estáticas e dinâmicas do aplicativo. O aplicativo móvel tem seis ícones: O que é?; Sistema Star; Classificar; Intervenções; Bibliografia e Sobre o app. O sistema de classificação foi desenvolvido baseado em um fluxograma para tomada de decisão, resultando na classificação da lesão, assim como exibição de fotografias sugestivas do grau da lesão, facilitando o processo de tomada de decisão pelo profissional da saúde. Conclusões: esperase que o aplicativo possa auxiliar os profissionais da saúde na classificação das Skin Tears, na escolha da terapia mais adequada, bem como no registro correto, além de servir como instrumento de educação permanente.
\end{abstract}

Keywords: FERIDAS, ESTOMATERAPIA, TELESSAÚDE, MSAÚDE

\section{Referências Bibliográficas}

Silva CVB; Campanili TCGF; LeBlanc K; Baranoski S; Santos VLCG. Cultural adaptation and content validity of ISTAP Skin Tear Classification for Portuguese in Brazil. ESTIMA, Braz. J. Enterostomal Ther., São Paulo, v16, e2618, 2018. StrazzieriPulido, KC. Adaptação cultural e validação do instrumento "Star Skin Tear Classification System", para a língua portuguesa no Brasil [dissertação]. São Paulo: Universidade de São Paulo, Escola de Enfermagem; 2010 [citado 2019-07-17].

doi:10.11606/D.7.2010.tde-23122010-103305. Pinheiro ALS, Andrade KTS, Silva DO, Zacharias FCM, Gomide MFS, Pinto IC. Gestão da Saúde: o uso dos sistemas de informação e o compartilhamento de conhecimento para a tomada de decisão. Texto contexto - enferm. [Internet]. 2016 [cited 2019 July 26] ; 25( 3 ): e3440015. 


\title{
AUTOCUIDADO COM OS PÉS: AVALIAÇÃO DE PACIENTES DIABÉTICOS ACOMPANHADOS NA LINHA DE CUIDADO
}

\author{
Samila Torquato Araújo ${ }^{1}$, Lívia Dantas Lopes ${ }^{3}$, Marília Araripe Ferreira ${ }^{3}$, Tatiana Rebouças \\ Author(s): $\quad$ Moreira $^{2}$, Synara Cavalcante Lopes ${ }^{2}$, Bruna Michelle Belém Leite Brasil ${ }^{1}$, RAELLY RAMOS \\ CAMPOS XIMENES ${ }^{2}$, Renan Magalhães Montenegro Junior ${ }^{2}$ \\ Institution(s) ${ }^{1}$ ESTÁCIO - Centro Universitário Estácio do Ceará (R. Eliseu Uchôa Beco, 600), ${ }^{2}$ HUWC - \\ HOSPITAL UNIVERSITÁRIO WALTER CANTÍDIO (RUA CAPITÃO FRANCISCO PEDRO, \\ 1290), ${ }^{3}$ UFC - UNIVERSIDADE FEDERAL DO CEARÁ ( R. Alexandre Baraúna, 1115)
}

\begin{abstract}
Introdução: diabetes mellitus (DM) pode ser definido como um grupo heterogêneo de desequilíbrios metabólicos cujo denominador comum é a hiperglicemia e seus possíveis desfechos associados, causada por fatores genéticos, epigenéticos e ambientais, que levam a defeitos na secreção de insulina, ação da insulina ou em ambos ${ }^{1}$. Sendo o autocuidado um manejo que inclui adesão a uma alimentação saudável, à atividade física, ao monitoramento periódico da glicemia, à ingestão correta de medicamentos prescritos e ao cuidado adequado com os pés²-3. Objetivo: avaliar o autocuidado com os pés dos pacientes acompanhados no ambulatório da Linha de Cuidado de Diabetes. Material e Método: trata-se de um estudo descritivo com abordagem quantitativa, realizado em um hospital de Fortaleza-Ceará, no ambulatório de Linha de Cuidado de Diabetes, no período de setembro a dezembro de 2016. A amostra foi de 75 pacientes, os quais responderam um questionário sobre os dados sócio demográficos e Questionário de Avaliação da Adesão ao Autocuidado com os Pés para Diabéticos (QPED). Os dados coletados foram analisados no programa estatístico EPI INFO, versão 3.5. Os aspectos éticos e legais de pesquisa com seres humanos foram respeitados, sendo aprovado sob o número 1.207.541. Resultados: o autocuidado com os pés foi avaliado de forma detalhada e resultados estatisticamente significantes mostraram-se quando $74,2 \%$ das mulheres tinham o hábito de utilizar hidratante nos pés e $69,2 \%$ dos homens nunca haviam realizado tal cuidado $(p=0,004)$. Quanto à utilização de soluções caseiras ou outros produtos em curativos realizados em casa, $45,7 \%$ dos homens fizeram uso dessas substâncias enquanto $77,5 \%$ das mulheres afirmaram não utilizar $(p=0,030)$. Homens apresentaram baixa adesão ao autocuidado com os pés. Conclusão: portanto, observa-se a importância de considerar as diferenças de gênero no autocuidado com os pés permitindo à equipe multiprofissional, em especial o enfermeiro, direcionar atividades educacionais sobre autocuidado e intervenções nos fatores de risco para complicações no pé diabético.
\end{abstract}

Keywords: Diabetes Mellitus, Pé Diabético, Educação em saúde, Estomaterapia

\section{Referências Bibliográficas}

1. Kozakova M, Palombo C. Diabetes Mellitus, Arterial Wall, and Cardiovascular Risk Assessment. Int J Environ Res Public Health [Internet]. 2016; 13(2):201. 2. American Diabetes Association. Standards of medical care in diabetes-2017. Diabetes care [Internet]. 2017; 40(Suppl. 1):S1-2. 3. Menezes LCG de, Moura NS, Vieira LA et al. Pesquisa ação: práticas de autocuidado das pessoas com pé diabético. Rev enferm UFPE on line. 2017; 11(Supl. 9):3558-66. 


\title{
Validação linguística do Diabetic Foot Ulcer Scale -Short Form (DFS-SF) para o Brasil
}

\author{
Uiara Aline de Oliveira Kaizer ${ }^{1}$, Elaine Aparecida Rocha Domingues ${ }^{1}$, Ana Claudia Honório \\ Author(s): $\quad$ Barbosa ${ }^{1}$, Roberta Cunha Matheus Rodrigues ${ }^{1}$, Marilia Estevam Cornélio ${ }^{1}$, Thaís Moreira São \\ João ${ }^{1}$ \\ Institution(s) ${ }^{1}$ Unicamp - Universidade Estadual de Campinas (R. Tessália Vieira de Camargo, 126)
}

\begin{abstract}
Introdução: A ulceração nas extremidades é a complicação mais frequente em pessoas com diabetes mellitus (DM) e representa um grave problema de saúde. Há evidências de que a qualidade de vida relacionada à saúde (QVRS), por sua vez, se agrava conforme os pacientes apresentam maiores complicações nos pés. A QVRS desses pacientes pode ser avaliada por meio de instrumentos de medida, os quais são escassos na população brasileira.

Objetivo: disponibilizar a versão brasileira do instrumento Diabetic foot ulcer scale- short form (DFS-SF), um instrumento que avalia a QV de pessoas com pé diabético e avaliar a sua validade de conteúdo.

Método: estudo metodológico, composto pelas etapas: 1) validação linguística: composta por tradução, retrotradução, avaliação pelo comitê de especialistas e pré-testagem junto aos pacientes-alvos; e 2) avaliação da validade de conteúdo, praticabilidade e aceitabilidade. O estudo foi realizado em um Ambulatório de Pé Diabético do interior do estado de São Paulo. Foi utilizado um instrumento previamente testado de caracterização sociodemográfica e a versão brasileira do DFSSF. O estudo foi aprovado sob o CAAE no 66816717.1 .0000 .5404

Resultados: a amostra $(n=30)$ foi composta por homens $(76,7 \%)$, com 57,4 anos, brancos $(86,7 \%)$; a maioria $(56,7 \%)$ possuía mais de oito anos de estudo e era aposentada $(56,7 \%)$. A maior parte $(53,3 \%)$ apresentava diagnóstico de DM há mais de 19 anos; Classificação de Wagner 2 (46,7\%); úlcera neuropática $(76,7 \%)$ e relataram ter úlcera no pé por mais de 3 meses $(73,3 \%)$. As equivalências semântica, idiomática, cultural e conceitual entre a versão traduzida e a versão original foram obtidas. O DFS-SF foi bem aceito e de fácil entendimento.

Considerações Finais: A versão brasileira do DFS-SF parece ser compreensível e de fácil aplicação. Outros estudos estão sendo desenvolvidos para avaliar sua estrutura fatorial, confiabilidade e validade interna e permitir sua utilização na prática clínica.
\end{abstract}

Keywords: diabetes mellitus, questionários, qualidade de vida, estomaterapia

\section{Referências Bibliográficas}




\title{
PROTOCOLO DE TRATAMENTO DE FERIDAS PARA O SISTEMA PENITENCIÁRIO DO ESTADO DE SÃO PAULO
}

\author{
Author(s): SILMARA JORGE GARCIA ${ }^{1,2}$, LEILA BLANES ${ }^{1}$, HEITOR FRANCISCO DE CARVALHO \\ GOMES ${ }^{1}$, LYDIA MASAKO FERREIRA ${ }^{1}$ \\ Institution(s) ${ }^{1}$ UNIFESP - Universidade Federal de São Paulo (R. Botucatu, 740 - Vila Clementino, São Paulo - \\ SP, 04023-062), ${ }^{2}$ SAP - SECRETARIA DE ADMINISTRAÇÃO PENITENCIÁRIA - SP (R. \\ Líbero badaró, $\mathrm{n}^{\circ}$ 600, $5^{\circ}$ andar - centro São Paulo, CEP 01008-000)
}

\begin{abstract}
Resumo

Introdução: As feridas são frequentes nos serviços de saúde e podem interferir na qualidade de vida das pessoas. Diversos serviços de saúde necessitam de direcionamento no tratamento dessas lesões, inclusive os ambulatórios de saúde do sistema penitenciário. 1, 2,3

Objetivo: Elaborar e implementar um protocolo de tratamento de feridas para o sistema penitenciário do Estado de São Paulo.

Materiais e Método: O estudo foi aprovado pelo Comitê de Ética em Pesquisa da Unifesp (CAAE 59996916.0.0000.5505) e da Secretaria de Administração Penitenciária (SAP) (CAAE 59996916.0.3001.5563). Trata-se de um estudo de desenvolvimento de protocolo realizado em etapas: iniciou-se com a busca de anterioridade, perfil epidemiológico, revisão da literatura, elaboração do conteúdo e a validação utilizando a técnica de Delphi. Para medir a concordância das respostas obtidas foi utilizado o Índice de Validade de Conteúdo (IVC). Na segunda rodada, o IVC global do protocolo foi de 1, acima do mínimo exigido de 0,90 ou mais, alcançando o nível de maior concordância.

Resultados: O Protocolo de tratamento de feridas foi desenvolvido com base na literatura e nas características da instituição. Em sua versão final, após a validação, foi composto por 70 páginas e 15 ilustrações com os seguintes itens: Introdução, objetivo, atribuições de equipe de saúde, operacionalização, considerações sobre as feridas e cicatrização, avaliação das condições gerais do paciente, avaliação das feridas, tratamento, orientações assistenciais, considerações sobre a terapia tópica e ilustrações.

Conclusão: Foi desenvolvido um protocolo para o tratamento de feridas para o Sistema Penitenciário do Estado de São Paulo e implementado na unidade Penitenciária "Nestor Canoa" de Mirandópolis.
\end{abstract}

Keywords: ESTOMATERAPIA, ESTUDOS DE VALIDAÇÃO, FERIMENTOS E LESÕES, PRISÕES, PROTOCOLOS

\section{Referências Bibliográficas}

1.Costa RKS, et al. Instrument for evaluating care givenby undergraduate nursing students to people with wounds. Rev. esc. enferm. USP [online]. 2015; 49(2): 317-25. 2.Morais GFC, Oliveira SHS, Soares MJGO. Avaliação de feridas pelos enfermeiros de instituições hospitalares da rede pública, Texto Contexto Enferm, Florianópolis, 2008; 17(1): 98-105. 3.Waidman MAP, et al. La vida diaria de la persona con heridas crónicas y su salud mental. Texto contexto - enferm. [online]. 2011, vol.20, n.4, 691-99. 


\title{
EFEITO DAS ESTRATÉGIAS DE UM PROGRAMA DE ORIENTAÇÃO DO ESTILO DE VIDA E O PROCESSO DE CICATRIZAÇÃO EM PACIENTES COM ÚLCERA VENOSA: ENSAIO CLÍNICO RANDOMIZADO
}

\author{
Author(s): \\ Uiara Aline de Oliveira Kaizer ${ }^{1}$, Elaine Aparecida Rocha Domingues ${ }^{1}$, Maria Helena de Melo \\ Lima $^{1}$ \\ Institution(s) ${ }^{1}$ Unicamp - Universidade Estadual de Campinas (Rua Tessália Vieira de Camargo - Cidade \\ Universitária)
}

\begin{abstract}
Introdução: A gestão da úlcera de etiologia venosa consiste na aplicação da terapia de compressão associada às recomendações que envolvem mudanças do estilo de vida. As orientações são essenciais na redução de morbidades e fatores de riscos presentes nos pacientes, favorecendo o processo cicatricial e melhora da qualidade de vida. Objetivo: avaliar o efeito das estratégias de um programa de orientação do estilo de vida para pacientes com úlcera venosa. Método: Trata-se de um estudo experimental randomizado, controlado e unicego. Como desfecho primário foi realizado a análise da evolução da ferida no que se refere a redução da área em $\mathrm{cm} 2$ e suas características (aparência do leito e quantidade do exsudato) e, a avaliação da intensidade da dor e qualidade de vida, como desfecho secundário. Participaram do estudo 71 pacientes com úlcera de etiologia venosa aleatorizados em dois grupos: grupo controle e grupo intervenção com seguimento de 12 semanas. O grupo controle recebeu as orientações de rotina dos serviços de saúde. Enquanto o grupo intervenção recebeu orientações a cerca do estilo de vida, no que concerne a fisiopatologia da úlcera venosa, importância da terapia de compressão, prática de exercício físico e repouso, em quatro momentos presenciais e dois por contato telefônico. Resultados: Nos domínios de avaliação da qualidade de vida dentro e entre os grupos, houve diferença significante no domínio satisfação da qualidade de vida $(p=0,0300)$ para o grupo intervenção ao final do seguimento. Na avaliação da área da ferida, o grupo intervenção apresentou contração da área significante nos dias 30, 60 e 90 dias de seguimento em comparação ao controle $(p=0,0197 p=0,0472$ e $p=0,0116)$, respectivamente. Para as comparações ao longo do seguimento entre os grupos, ocorreu melhora significante entre os tempos de ambos os grupos $(p$
\end{abstract}

Keywords: úlcera varicosa, úlcera da perna, estilo de vida, ensaio clínico, estomaterapia

\section{Referências Bibliográficas}

Harding K, Dowsett C, Fias L, Jelnes R, Mosti G, Öien R, et al. Simplifying venous leg ulcer management: consensus recommendations. 2015.Disponível em: http://www.woundsinternational.com/consensus-documents/view/simplifyingvenous-leg-ulcer-management; 2015 Meaume, S. et al. Quality of life in patients with leg ulcers: results from CHALLENGE, a double-blind randomised controlled trial. L Wound care. 2017 jul2; 26(7): 268-379 Latz CA, Brown KR, Bush RI.

Compression therapies for chronic venous leg ulcers: interventions and adherence. Chronic Wound Care Management and Research. 2015; 12: 11-21. O'Brien J, Finlayson K, Kerr G, Edwards H. Evaluating the effectiveness of a self-management exercise intervention on wound healing, functional ABPllity and health-related quality of life outcomes in adults with venous leg ulcers: a randomised controlled trial. Int Wound J. 2017; 14:130-137 


\title{
RELATO DE EXPERIÊNCIA: OS DESAFIOS NO MANEJO DE LESÕES SEM ETIOLOGIA ESPECÍFICA EM PEDIATRIA
}

\author{
Author(s): Elaine Simone de Barros ${ }^{3}$ \\ Institution(s) ${ }^{2}$ HSPE - INSTITUTO DE ASSISTÊNCIA MÉDICA AO SERVIDOR PÚBLICO ESTADUAL \\ (RUA PEDRO DE TOLEDO, 1800, $14^{\circ}$ ANDAR)
}

\begin{abstract}
Introdução: O tratamento de lesões em pediatria vem sendo discutido por toda a equipe interdisciplinar em saúde como sendo um desafio contínuo, podendo comprometer aspectos físicos, emocionais, sociais e psicológicos tanto da criança como de seus familiares. O objetivo deste estudo foi relatar a experiência no manejo de lesão sem etiologia específica em paciente pediátrico tratada com cobertura de carboximetilcelulose sódica com prata iônica (Aquacel Ag®) e papaína gel a $6 \%$, onde relata a experiência de situação vivenciada em 2013, em uma unidade de Pediatria onde paciente sob cuidados da equipe de saúde evoluiu com sepse por lesões sem etiologia específica. Material e Método: Estudo retrospectivo de relato de experiência com coleta de dados através de prontuário da SAE - Sistematização da Assistência de Enfermagem, com validação do Histórico para levantamento de história de alergia, exame físico e anotação da equipe de enfermagem diários, somados a registros fotográficos seriados, realizado na Unidade de Pediatria do Hospital do HSPE, hospital este que atende a servidores públicos do Estado de São Paulo e seus dependentes, onde foi utilizado terapia tópica com cobertura à base de carboximetilcelulose sódica com prata iônica (Aquacel Ag®) e papaína gel a 6\%. Tiveram como instrumento de avaliação das lesões a ferramenta Time, registros fotográficos em dias alternados e mensuração semanal. A pesquisa foi submetida ao Comitê de Ética da instituição sob o CAAE: 14892619.8.0000.5463 em 02/06/2019. A paciente foi selecionada por apresentar evolução no processo de cicatrização durante o período de internação, apesar do diagnóstico inicial até a alta hospitalar de etiologia indefinida, a hipótese diagnóstica foi de Infecção por Citomegalovirose $(\mathrm{CMV})+$ Sepse grave por Gram negativo (secundária a infecção de pele), evidenciando o desafio constante nos cuidados da enfermagem pediátrica. Resultados: Os resultados foram importantes, pois mostrou que lesões em pediatria podem ter seu manejo seguro com coberturas tecnológicas, tendo controle de infecção, do odor, do exsudato e a diminuição do risco de trauma no leito da ferida, com diminuição da dor local às trocas favorecendo o processo de cicatrização. A assistência de enfermagem foi baseada na complexidade assistencial indicada, tendo como fator agravante a localização das lesões (região perianal, perineal e língua), o manejo da incontinência urinária e a presença de diarréia. A criança permaneceu internada por 49 dias, tendo $90 \%$ das lesões com tecido de epitelização até o dia da alta hospitalar. Os produtos utilizados estão devidamente em consonância com a Agência Nacional de Vigilância Sanitária (ANVISA). Conclusão: Este relato proporcionou aprendizado no cuidado sistematizado em paciente pediátrico portador de lesões sem etiologia específica, grave, complexa e de difícil resolução, possibilitando a necessidade em assistí-la integralmente, percebendo-a além das lesões. Também foi possível detectar que a escassez de literatura e consensos no manejo de lesões em pediatria contribuiu para o atraso no possível diagnóstico clínico e salienta a importância do conhecimento dessas manifestações cutâneas nessa população e do uso de tecnologias em coberturas para manejo de feridas.
\end{abstract}

Keywords: ESTOMATERAPIA, FERIDAS, FERIDAS EM PEDIATRIA, PEDIATRIA

\section{Referências Bibliográficas}

1) King A, Stellar JJ, Blevins A, Shah KN. Dressings and Products in Pediatric Wound Care -Adv Wound Care (New Rochelle). 2014 Apr 1; 3(4): 324-334. 2) Mehl A, Feridas na clínica pediátrica: diagnóstico e tratamento - Rev. Pediatria Moderna, Vol.48 no 11 - Nov 2012, p. 436 à 450- Disponível em http://www.moreirajr.com.br/revistas.asp?id_materia=5222\&fase=imprime [Consultado em 12/08/18] 3) Stamatas GN, et al. Infant Skin Microstructure Assessed In Vivo Differs from Adult Skin in Organization and the Cellular Level, First published: 21 April 2010- https://doi.org/10.1111/j.1525-1470.2009.00973.x 


\title{
ANÁLISE DO PH (POTENCIAL HIDROGENIÔNICO) DE SABONETES EMPREGADOS NA HIGIENE DA PELE DE RECÉM-NASCIDOS E CRIANÇAS
}

\author{
Author(s): $\quad \begin{aligned} & \text { Mily Constanza Moreno Ramos } \\ & \text { Velasco }\end{aligned}$ \\ Institution(s) ${ }^{1}$ EEUSP - Escola de Enfermagem da Universidade de São Paulo (Av. Dr. Enéas Carvalho de \\ Aguiar, 419), ${ }^{2}$ FCFUSP - Faculdade de Ciências Farmacêuticas da USP (Av. Prof. Lineu Prestes, \\ 580)
}

\begin{abstract}
Introdução: A pele do recém-nascido (RN) enfrenta um processo de maturação ao longo do primeiro ano de vida. $\mathrm{O} \mathrm{pH}$ da pele após o nascimento varia entre neutro a levemente alcalino $(6,0$ até 7,5$)$, tornam-se ácido entre o $3^{\circ}$ e o $4^{\circ}$ dia de vida e se torna mais estável no primeiro mês de vida, com valores ao redor de 5 . O manto ácido da pele $(\mathrm{pH}=4,5-5,5)$ é fundamental na resistência contra micro-organismos patógenos, na maturação da barreira epidérmica, nos processos de reparação tecidual e renovação celular. A utilização de sabonetes líquidos e em barra com valores de $\mathrm{pH}$ diferentes ao fisiológico podem fragilizar a barreira cutânea ocasionando reações como ressecamento, irritação, colonização por microorganismos patógenos oportunistas e aparecimento de lesões de pele. Objetivos: Analisar o valor de pH de sabonetes destinados à higiene de recém-nascidos e crianças disponíveis no mercado e estimar o impacto que causaria na pele dos recém-nascidos e crianças. Material e Métodos: estudo quantitativo, experimental e descritivo, que analisou 17 sabonetes (8 em barra e 9 líquidos) que foram comprados em uma farmácia de São Paulo, Capital e analisados no laboratório de Cosmetologia da Faculdade de Ciências Farmacêuticas da USP. Para a análise do pH dos sabonetes foi utilizado o pHmetro digital de bancada (DM-22®), calibrado. Para os sabonetes líquidos foram utilizados $40 \mathrm{~mL}$ de cada sabonete em béquer de $50 \mathrm{~mL}$ e imergido o eletrodo do pHmetro para a leitura. No caso dos sabonetes em barra foi pesado cerca de $1,0 \mathrm{~g}$ e dispersou-se em $100 \mathrm{~mL}$ de água destilada, aqueceu-se em chapa aquecedora (IKA® C-MAG HS 7 ) a $37,0^{\circ} \mathrm{C}$ e agitador magnético até completar a dispersão da amostra. A preparação foi resfriada e submetida à leitura do $\mathrm{pH}$. Resultados: o pH dos sabonetes líquidos e em barra variou de 5 até 10,14 . Seis $(35,2 \%)$ tinham pH entre 4,5 e 6,9. E, 10 $(58,8 \%)$ tinham $\mathrm{pH}$ maior a 7 . $\mathrm{Na}$ média, o $\mathrm{pH}$ dos sabonetes em barra foi de $8,82 \pm 1,82$ sendo que oito (88,8\%) apresentaram $\mathrm{pH}$ maior a $7 \mathrm{e}$, apenas um $(11,1 \%) \mathrm{pH}$ menor a 5 . No entanto, nos sabonetes líquidos o valor médio de $\mathrm{pH}$ foi de $6,02 \pm 1,11$ sendo que cinco (37,5\%) entre 4,5 e 6,9 e três $(37,5 \%) \quad \mathrm{pH}>7$. Conclusão: os sabonetes líquidos apresentaram valores mais próximos ao $\mathrm{pH}$ fisiológico da pele, sendo mais compatíveis e recomendados para a higiene da pele do $\mathrm{RN}$ e da criança.
\end{abstract}

Keywords: Recém-nascido, sabonete, pele, pH, Estomaterapia

\section{Referências Bibliográficas}

Ali SM, Yosipovitch G. Skin pH: From basic science to basic skin care. Acta Dermato-Venereologica. 2013. p. 261-7. Blume-Peytavi U, Lavender T, Jenerowicz D, Ryumina I, Stalder J, Torrelo A, et al. Recommendations from a European Roundtable Meeting on Best Practice Healthy Infant Skin Care. Pediatr Dermatol. 2016;33(3):311-21. Fluhr JW, Darlenski R, Taieb A, Hachem J, Baudouin C, Msika P, et al. Functional skin adaptation in infancy - almost complete but not fully competent. Exp Dermatol. 2010;19:483-92. Mendes B, Midori Shimabukuro D, Uber M, Taniguchi K. Avaliação crítica do pH dos sabonetes infantis. J Pediatr (Rio J). 2016;92(3):290-5. Telofski L, Morello P, Correa MCM, Stamatas G. The Infant Skin Barrier: Can We Preserve, Protect, and Enhance the Barrier? Dermatol Res Pract. 2012;2012:1-18. 


\title{
TRATAMENTO DE LESÃO POR EXTRAVASAMENTO EM LACTENTE HOSPITALIZADO EM UNIDADE DE TERAPIA INTENSIVA
}

\author{
Author(s): Ana Cristina dos Santos Monteiro ${ }^{1}$, Maria Lúcia Barbosa Maia dos Santos ${ }^{1}$, Juliana Caires de \\ Oliveira Archili Ferreira ${ }^{1}$ \\ Institution(s) ${ }^{1}$ ICr-HCFMUSP - Instituto da Criança do HCFMUSP (Av. Dr. Enéas Carvalho Aguiar, 647, \\ Cerqueira Cesar, São Paulo/SP)
}

\begin{abstract}
Introdução: A rede venosa periférica dos pacientes pediátricos é muito débil, e os dispositivos invasivos colocados particularmente em lactentes e recém-nascidos, podem ocasionar eventos graves como infecção, inflamação ou destruição da parede do vaso sanguíneo, quando não inseridos ou avaliados corretamente. Nestes casos, é de suma importância o reconhecimento do tipo de complicação para realização de medidas específicas voltadas à cicatrização. Método: Trata-se de um estudo descritivo do tipo relato de caso, realizado no Unidade de Terapia Intensiva Pediátrica (CTIP) em hospital público de alta complexidade na cidade de São Paulo. Resultado: paciente prematuro, POT de Atresia de esôfago e fístula traqueoesofágica, transferido de outra instituição com infiltração de solução com bicarbonato de sódio $8.4 \%$ em acesso venoso na região posterior do antebraço direito, que evoluiu com lesão necrótica extensa. $O$ tratamento local compreendeu curativo realizado a cada 48 horas com utilização de solução fisiológica morna, aplicação de cobertura primária estéril, não aderente e não oclusiva, constituída por uma rede $100 \%$ de poliéster, impregnada com matriz cicatrizante TLC-Ag, e creme barreira protetora nas bordas, seguida de oclusão com membrana polimérica (polymem) e enfaixamento do membro acometido com malha tubular. O período de tratamento na unidade foi de 33 dias. Conclusão: A avaliação da lesão por um profissional especialista, bem como o emprego dos materiais específicos para o tratamento propiciou resolução da mesma, e corroborou com a importância da utilização de protocolos de tratamento de lesões em unidades de terapia intensiva pediátrica e nos setores de internação, associada a atualização periódica dos profissionais quanto a compatibilidade medicamentosa e manutenção de dispositivos intravenosos.
\end{abstract}

Keywords: Extravasamento, Lesão, Estomaterapia, Tratamento, Unidade de Terapia Intensiva Pediátrica

\section{Referências Bibliográficas}

1. Corbett et al. Treating extravasation injuries in infants and young children: a scoping review and survey of UK NHS practice. BMC Pediatrics (2019) 19:6. 2. Kloc, M., Ghobrial, R. M., Wosik, J., Lewicka, A., Lewicki, S., \& Kubiak, J. Z. (2019). Macrophage functions in wound healing. Journal of tissue engineering and regenerative medicine, 13(1), 99-109. 3. Sgonc R, Gruber J: Age-Related Aspects of Cutaneous Wound Healing: A Mini-Review. Gerontology 2013;59:159-164. doi: 10.1159/000342344 4. Murphy et al. Extravasation injury in a paediatric population. ANZ J Surg 89 (2019) E122-E126. 5. Goutos I, Cogswell LK, Giele H. Extravasation injuries: a review. J. Hand Surg. Eur. Vol.2014;39: 808-18.2. 6. Garland JS, Dunne WM, Havens Pet al. Peripheral intravenous catheter complications in critically ill children: a prospective study.Pediatrics1992;89: 1145-50. 7. López JLG et al. Indwell times, complications and costs of open vs closed safety peripheral intravenous catheters: a randomized study. Journal of Hospital Infection 86 (2014) 117-126. 


\title{
A EDUCAÇÃO EM SAÚDE PARA O CUIDADO DOMICILIAR DE FERIDAS POR CUIDADORES FAMILIARES: ANÁLISE REFLEXIVA
}

\author{
Author(s): Anadelle de Souza Teixeira Lima ${ }^{1}$, Fernanda Vieira Nicolato ${ }^{2}$ \\ Institution(s) ${ }^{1}$ HUUFJF - Hospital Universitário de Juiz de Fora (Av. Eugênio do Nascimento, s/n - Dom Bosco, \\ Juiz de Fora - MG, 36038-330), ${ }^{2}$ UFJF - Universidade federal de Juiz de Fora (Campus \\ Universitário, Rua José Lourenço Kelmer, s/n - São Pedro, MG,)
}

\begin{abstract}
As mudanças contemporâneas nos perfis demográficos e epidemiológicos das populações são discutidas como sendo um dos principais fatores responsáveis pela demanda por cuidados no domicílio ${ }^{1}$. O envelhecimento constitui um fator de risco para o desenvolvimento de alterações na pele, dessa forma, a pele do idoso necessita de um cuidado especial, visto que o risco de lesão nesta faixa etária aumenta ${ }^{2}$. A educação em saúde é considerada de baixo custo para os serviços de saúde, pois favorece a identificação precoce das lesões de pele, melhores condições para o tratamento, recuperação precoce das lesões e qualidade de vida dos idosos ${ }^{3}$. Objetivo: Refletir sobre a educação em saúde para cuidadores familiares para a realização do cuidado domiciliar de idosos com feridas. Método: Trata-se de análise reflexiva fundamentada em revisão bibliográfica, realizada em artigos científicos indexados, nas bases de dados da Lilacs, BDENF e Scielo. Essa reflexão foi realizada a partir da seguinte questão norteadora: como é realizada a educação em saúde para que os cuidadores familiares possam cuidar de uma ferida no domicílio? Resultados: Na transferência do cuidado hospitalar para o domicílio, é uma oportunidade de comunicação entre os cuidadores e a equipe profissional, de modo a realizar informações antecipadas que, provavelmente, melhorarão o processo de transição do paciente e do cuidador4. Para Guimarães e colaboradores5, a maioria dos cuidadores de pessoas hospitalizadas com feridas, tem interesse e participam de algum modo, na realização do curativo. O curativo expõe a lesão, odores e exsudatos que podem causar repulsa por parte de leigos que assistem o procedimento, no entanto, a permanência dos cuidadores neste momento pode indicar interesse em aprender e acompanhar a evolução da ferida do familiar. A equipe de enfermagem pode aproveitar tais momentos para orientar o cuidador e prepará-lo para os cuidados no domicílio. O ensino para o cuidado com feridas, percebe-se que ele é ministrado pela enfermagem, que tem um papel bastante importante na educação em saúde. Mas, a legislação não descreve detalhadamente o que pode ou não ser ensinado, sabe-se que existe o dever de ensinar, porém, não se tem a convicção de suas fronteiras. No entanto, o enfermeiro não tem respaldo para delegar ao cuidador as atividades inerentes ao cargo de enfermeiro ou técnico de enfermagem6. Conclusões: Conclui-se que ações educativas para a prevenção e cuidados com as lesões precisam ser realizadas, já que no cuidado domiciliar de idosos com feridas, os cuidadores tem mostrado a necessidade de aprendizado para esse cuidado especificamente. Deve-se levar em conta a capacidade de aprender sobre o processo de cuidado do cuidador, para que desenvolvam atividades educativas de acordo com as reais necessidades de cada pessoa. No entanto, torna-se necessária a regulamentação das atividades que possam ser desempenhadas por cuidadores, para que os profissionais sintam-se respaldados. No que se refere ao cuidado desempenhado no domicílio, os enfermeiros precisam estar atualizados com as disponibilidades de novas tecnologias para o tratamento de feridas e seu uso no dia-a-dia precisa ser monitorado por um profissional capacitado, sendo, neste caso, o enfermeiro estomaterapeuta.
\end{abstract}

Keywords: Assistência Domiciliar, Estomaterapia, Ferimentos e Lesões, Saúde do Idoso

\section{Referências Bibliográficas}

1- Braga PP et al. Oferta e demanda na atenção domiciliar em saúde. Ciência \& Saúde Coletiva, 2016. 21(3): 903-912. Disponível em: http://www.scielo.br/pdf/csc/v21n3/1413-8123-csc-21-03-0903.pdf 2- Lira ALBC et al. Integridade da pele em idosos: revisão da literatura segundo as cartas de promoção da saúde. Cogitare Enfer, 2012. 17(4):767-74. Disponível em: file:///C:/Users/Acer/Downloads/30389111572-2-PB\%20(1).pdf 3- Coelho ND et al. Conhecimento de cuidadores acerca de lesões de pele em idosos. Revista cuidado é fundamental, 2017.9(1): 247-252, 2017. Disponível em: file://C:/Users/Acer/Downloads/5401-30696-1-PB\%20(2).pdf 4 -Moro JV, Caliri MHL. Úlcera por pressão após a alta hospitalar e o cuidado em domicílio. Esc. Anna Nery, Rio de Janeiro ,2016. 20(3):16-58 . Disponível em: http://www.scielo.br/scielo.php?script=sci_arttext\&pid=S1414-81452016000300203\&lang=pt 5 -Guimarães TK. Caracterização do comportamento de cuidadores informais de pacientes com feridas no âmbito hospitalar. Rev. Eletr. Enf., 2017. 19(2). Disponível em: file:///C:/Users/Acer/Downloads/39588-194779-1-PB.pdf 6 -Przenyczka RA, Lacerda MR. Dilemas éticos no ensino do cuidado domiciliar de enfermagem. Cienc Cuid Saude, 2009. 8(4):586-593. Disponível em: file:///C:/Users/Acer/Downloads/6564-34650-1-PB\%20(2).pdf 


\title{
BUNDLE DE CUIDADOS ASSOCIADOS A LESÃO POR PRESSÃO RELACIONADA À DISPOSITIVOS MÉDICOS NO AMBIENTE HOSPITALAR
}

\author{
Author(s): $\quad$ CILENE FERNANDES SOARES ${ }_{1}^{1}$, Juliana Balbinot Reis Girondi ${ }^{1}$, Daniela Soldera ${ }^{1}$, Amanda de Souza \\ Vieira ${ }^{1}$, Lúcia Nazareth Amante ${ }^{1}$, Luciara Fabiane Sebold ${ }^{1}$ \\ Institution(s) ${ }^{1}$ UFSC - UNIVERSIDADE FEDERAL DE SANTA CATARINA (CAMPUS UNIVERSITÁRIO, TRINDADE, \\ FLORIANÓPOLIS, SC ), ${ }^{2}$ UFSC - UNIVERSIDADE FEDERAL DE SANTA CATARINA (CAMPUS \\ UNIVERSITÁRIO, TRINDADE, FLORIANÓPOLIS, SC ), ${ }^{3}$ UFSC - UNIVERSIDADE FEDERAL DE SANTA \\ CATARINA (CAMPUS UNIVERSITÁRIO, TRINDADE, FLORIANÓPOLIS, SC ), ${ }^{4}$ UFSC - UNIVERSIDADE \\ FEDERAL DE SANTA CATARINA (CAMPUS UNIVERSITÁRIO, TRINDADE, FLORIANÓPOLIS, SC ), ${ }^{5}$ \\ UFSC - UNIVERSIDADE FEDERAL DE SANTA CATARINA (CAMPUS UNIVERSITÁRIO, TRINDADE, \\ FLORIANÓPOLIS, SC ), ${ }^{6}$ UFSC - UNIVERSIDADE FEDERAL DE SANTA CATARINA (CAMPUS \\ UNIVERSITÁRIO, TRINDADE, FLORIANÓPOLIS, SC )
}

\begin{abstract}
Introdução: A Lesão por Pressão, embora reconhecida como um problema de saúde pública, mundialmente ainda permanecem com taxas elevadas. No Brasil a incidência é dimensionada entre 19,1\% a 39,8\%, independente do ambiente de cuidado. O enfermeiro é o gestor do cuidado em relação às Lesões por Pressão relacionadas a Dispositivos Médicos, as quais podem surgir em decorrência do desconhecimento da equipe cuidadora, em relação aos riscos que estes dispositivos podem provocar e carência nos cuidados preventivos que podem e devem ser implementados. Objetivo: construir e validar um Bundle para prevenção, diagnóstico e tratamento de Lesões por Pressão relacionadas a Dispositivos Médicos. Material e Método: Estudo metodológico realizado em três etapas: Revisão de literatura para construção do instrumento; investigação da experiência de enfermeiros assistenciais, por conseguinte, validação de conteúdo constituído pelas etapas de ajuizamento e elaboração da versão final do Bundle. A etapa de construção do instrumento ocorreu entre janeiro e fevereiro de 2019, com base na revisão integrativa, sendo composto por três partes: diagnósticos de enfermagem (contendo 3 diagnósticos de enfermagem com 17 características definidoras) a segunda e a terceira com cuidados voltados à prevenção e tratamento deste tipo de lesão (contendo 51 tópicos de cuidados). Para validação do instrumento foram convidados a participar enfermeiros experts na área, que desenvolvem atividades assistenciais, de ensino e/ou pesquisa com título de Estomaterapeuta certificado pela Associação Brasileira de Estomaterapia (SOBEST). Quanto ao critério de exclusão, consistiu em não respeitar o prazo de 10 dias de retorno do instrumento de coleta de dados preenchido. Essa etapa ocorreu de abril a maio de 2019. A operacionalização da técnica Delphi ocorreu no período de abril e maio de 2019, por meio de duas rodadas via e-mail, pelo sistema Google Docs ${ }^{\circledR}$. Considerou-se válido o consenso de $80 \%(0,8)$ ou mais entre as avaliações dos juízes. O estudo está vinculado ao macroprojeto financiado pelo CNPq: "Estratificação de risco e intervenções de enfermagem no diagnóstico, prevenção e tratamento de skin tears e úlcera por pressão em idosos", aprovado pelo Comitê de Ética da Universidade Federal de Santa Catarina por meio do parecer consubstanciado CAAE no 74769317.5.1001.0121. Resultados: Foram convidados 134 juízes, selecionados a partir dos que possuíam as características definidoras previamente determinadas e possíveis de contatar. Participaram 20 juízes, e a representatividade dos itens do conteúdo abordado foi mensurada por meio do índice de validade de conteúdo (IVC). Foram realizadas as readequações do instrumento em concordância com as contribuições dos avaliadores. $O$ instrumento elaborado em sua versão final apresenta 40 itens: voltados para Prevenção, Diagnóstico e Tratamento de Lesões por Pressão relacionadas a Dispositivos Médicos. Conclusão: Espera-se que este Bundle possa contribuir para redução da ocorrência do agravo através da qualificação da assistência de Enfermagem prestada, vislumbrando a segurança do paciente.
\end{abstract}

\section{Keywords: CUIDADO, ESTOMATERAPIA, LESÃO POR PRESSÃO}

\section{Referências Bibliográficas}

Stuque AG, et al. Protocolo para prevenção de úlcera por pressão. RevRene. 2017;18(2):272-282. doi: https://doi.org./10.15253/2175-6783.2017000200018 Johnson BM, et al. Medical device-related pressure injuries: An exploratory descriptive study in an acute tertiary hospital in Australia. Journal of Tissue Viability. 2017;26(4): 246-253. doi: https://doi.org/10.1016/j.jtv.2017.09.008 Karadag A, Hanonu S, Eyikara Evrim. A Prospective, Descriptive Study to Assess Nursing Staff Perceptions of and Interventions to Prevent Medical Device-related Pressure Injury. Ostomy Wound Manage. 2017;63(10):34-41. doi: https://doi.org./10.25270 / owm.2017.10.3441. Makic MBF. Pressure ulcers related to medical devices and intensive care patients. J Perianesth Nurs. 2015;30(4):336-337. doi:

https://doi.org/10.1016/j.jopan.2015.05.004 


\title{
COBERTURAS PARA ÁREAS DOADORA DE ENXERTO DE PELE: REVISÃO INTEGRATIVA DA LITERATURA
}

\author{
Author(s): fernanda silva dos santos ${ }^{2,1}$, silvana janning prazeres ${ }^{1}$, sandra maria cezar leal ${ }^{1}$ \\ Institution(s) ${ }^{1}$ UNISINOS - Universidade do Vale do Rio dos Sinos (Av. Unisinos, 950 Bairro Cristo Rei São \\ Leopoldo/RS CEP: 93.022-750), ${ }^{2}$ HPS-POA - Hospital de Pronto Socorro de Porto Alegre (Largo \\ Teodoro Herzl s/n - Cidade Baixa, Porto Alegre - RS, 90040-192)
}

\begin{abstract}
INTRODUÇÃO: queimaduras se destacam, entre os diversos mecanismos de trauma, como os de maior gravidade e mortalidade. A otimização do tratamento reduz dor, tempo de hospitalização, sequelas funcionais e estéticas1. As queimaduras de segundo grau profundo e terceiro, principalmente as de grande extensão necessitam excisão e enxertia precoce, conduta que além de acelerar o processo cicatricial, reduz taxas de infecção e mortalidade. Neste contexto o autoenxerto constitui o método de escolha, culminando no surgimento de uma nova ferida, a área doadora. A busca pelo curativo ideal para o tratamento das áreas doadoras de enxerto de pele parcial tem se intensificado nos últimos anos, mas ainda é um assunto controverso2. OBJETIVOS: investigar o que está sendo publicado sobre o uso coberturas para áreas doadoras de enxerto de pele parcial. MÉTODO: revisão integrativa da literatura. A busca foi realizada na Biblioteca Virtual de Saúde, nas bases de dados: Medical Literature Analysis and Retrieval System Online (MEDLINE), Literatura Latinoamericana e do Caribe em Ciências da Saúde (LILACS) e Base de Dados de Enfermagem (BDENF), incluindo publicações do período de 2005 a 2018 nos idiomas inglês, espanhol e português. Foram utilizados descritores "sítio doador de transplante/transplant donor site", "queimaduras/burns" e "curativos /bandages/dressings" combinados pelo operador booleano AND. Seguiu-se a legislação de direitos autorais, Lei № 9.279/19963 e Lei 12.853/20134. RESULTADOS: inicialmente foram localizados 92 estudos, 69 foram excluídos após a leitura dos títulos e resumos totalizando 23 estudos selecionados, os quais foram lidos na íntegra e incluídos na pesquisa. Desses, a maioria (39\%) foram publicados nos Estados Unidos e não foram encontrados estudos brasileiros. As profissões do primeiro autor mais frequentes foram médico $(65,2 \%)$ e enfermeiro (8,7\%). Quanto ao delineamento, 91,3\% foi de ensaios clínicos controlados dos quais 39\% tinham limitações quanto a tamanho da amostra, método de randomização e avaliação dos desfechos estudados. Em relação aos desfechos, epitelização e dor foram os mais avaliados por $87 \%$ e $82 \%$ dos estudos respectivamente. Identificou-se o uso de várias tecnologias, num total 19 avaliadas, as mais frequentes foram gazes impregnadas com petrolato (39\%), os substitutos de pele (26\%) e a hidrofibra de carboximetilcelulose com prata (26\%). CONCLUSÕES: alguns fatores dificultaram resultados conclusivos, dentre os quais destacam-se: ampla variedades de coberturas avaliadas, limitações metodológicas e resultados heterogêneos. Assim, as evidências reunidas não permitiram determinar a cobertura mais indicada para o tratamento das áreas doadoras de enxerto de pele parcial em pacientes queimados. Entretanto, foi possível identificar a contra-indicação do uso de gazes de algodão, as quais apresentaram maior tempo de epitelização e níveis de dor. Conclui-se que são necessários novos estudos, principalmente no Brasil, enfatizando coberturas disponíveis no país. Acrescente-se que a inserção da Estomaterapia neste contexto, poderá contribuir para a criação evidências e qualificação do cuidado de enfermagem ao paciente
\end{abstract}

Descritores: queimaduras, curativos oclusivos, sítio doador de transplante, estomaterapia

Keywords: curativos oclusivos, estomaterapia, queimaduras, sítio doador de transplante

\section{Referências Bibliográficas}

1 Voineskos SH, Ayeni OA, McKnight L, Thoma A. Systematic review of skin graft donor-site dressings. Plast Reconstr Surg 2009 Jul;124(1):298-306. 2 Serebrakian AT, Pickrell BB, Varon DE, Mohamadi A, MD, Grinstaff MW, Rodriguez EK et al. Meta-analysis and Systematic Review of Skin Graft Donor-site Dressings with Future Guidelines. Plast Reconstr Surg Glob Open 2018 Sep 24;6(9):e1928. 3 Brasil. Lei no 9.279 de 14 de maio de 1996. Regula direitos e obrigações relativos à propriedade industrial. Diário Oficial [da] República Federativa do Brasil, Brasília, DF, 15 mai. 1996. Disponível em: . Acesso em: 06/08/2019. 4 Brasil. Lei 12.853, de 14 de agosto de 2013. Altera os arts. 5o, 68, 97, 98, 99 e 100, acrescenta arts. 98-A, 98-B, 98-C, 99-A, 99-B, 100-A, 100-B e 109-A e revoga o art. 94 da Lei 9.610, de 19 de fevereiro de 1998, para dispor sobre a gestão coletiva de direitos autorais, e dá outras providências. 15/08/2013. Disponível em: . Acesso em: 06/08/2019. 


\title{
PERFIL CLÍNICO-LABORATORIAL DE PACIENTES ADULTOS ACOMETIDOS POR LESÃO POR PRESSÃO EM AMBIENTE HOSPITALAR.
}

\author{
Marcela Gama Santana Moreira ${ }^{1,2}$, Silvia de Magalhães Simões ${ }^{1}$, Caíque Jordan Nunes Ribeiro ${ }^{1}$, \\ Author(s): $\quad$ Patrícia Gouveia do Couto Nascimento ${ }^{2}$, Camila Alves Moreira ${ }^{2}$, Isabela Maia dos Anjos ${ }^{2}$ \\ Institution(s) ${ }^{1}$ UFS - Universidade Federal de Sergipe (Rua Claudio Batista, s/n. Bairro Sanatório. 49.060-110. \\ Aracaju, Sergipe.), ${ }^{2}$ CENUT - Centro Especializado de Nutrição (Rua Tênisson Ribeiro,126. \\ Salgado Filho. Aracaju, Sergipe.)
}

\begin{abstract}
Introdução: As lesões por pressão (LP) representam um problema significativo em todo o mundo por conta da alta prevalência e por resultarem em inúmeros desfechos negativos. O portador de LP pode ser qualquer pessoa que sofra fortes pressões sobre a pele que sejam suficientes para causar isquemia tecidual. Objetivo: Caracterizar o perfil clínico e laboratorial de pacientes adultos acometidos por LP durante internação hospitalar. Material e Método: Estudo descritivo e retrospectivo, com abordagem quantitativa de dados secundários por meio de pesquisa documental. Os dados foram coletados por meio de relatórios de notificação de LP da comissão de pele de um hospital privado em Aracaju, Sergipe, no período de junho de 2017 a junho de 2018. Foram excluídos os casos de lesão por dispositivo médico. Esse estudo seguiu as recomendações da Resolução 466/2012 do Conselho Nacional de Saúde (CNS) e foi aprovado pelo Comitê de Ética em Pesquisa da Universidade Federal de Sergipe (número do parecer: 2.769.672). Resultados: A amostra foi constituída por 95 pacientes. O sexo feminino prevaleceu, correspondendo a $52,6 \%$ dos participantes. A média de idade foi 74,8 anos $( \pm 14)$, 76 pacientes $(80 \%)$ passaram pela Unidade de terapia intensiva (UTI), $23(24,2 \%)$ eram portadores de doença oncológica, $15(15,8 \%)$ estavam em cuidados paliativos e 52 (54,7\%) evoluíram a óbito. Quantos às alterações nos exames laboratoriais, 76 pacientes (84,4\%) apresentavam anemia, $58(64,4 \%)$ com leucocitose, $71(78,9 \%)$ com ureia elevada e 71 $(97,3 \%)$ com hipoalbuminemia. 28 pacientes $(30,4 \%)$ estavam com algum grau de desnutrição energético-proteica. Quanto às medicações, 54 pacientes $(56,8 \%)$ fizeram uso de drogas vasoativas, $47(49,5 \%)$ de sedativos, $65(68,4 \%)$ de corticoide e $85(86,3 \%)$ de antibióticos. Quanto aos suportes salva-vidas, 57 pacientes $(60 \%)$ necessitaram de ventilador mecânico e $36(37,9 \%)$ de hemodiálise. A média do escore pela escala de Braden foi de $10,5( \pm 2,5)$, conferindo classificação de alto risco. Conclusões: O conhecimento da população susceptível às LP pela equipe multiprofissional, especialmente pela enfermagem, é fundamental para o planejamento de ações preventivas individualizadas e eficazes.
\end{abstract}

Keywords: Estomaterapia, Hospitalização, Lesão por pressão

\section{Referências Bibliográficas}

Ascarruz-Vargas C, Tapia-Estrada D, Tito-Pacheco E, Vaiz-Bonifaz R. Valoración del riesgo de ulcera por presión según la escala de Braden en el paciente neurológico. Rev enferm Herediana 2014; 7(1), 10-6. Borghardt AT, Prado TN, Bicudo SDS, Castro DS, Bringuente MEO. Ulcera por pressão em pacientes críticos: incidência e fatores associados. Rev Bras Enferm 2016; 69(3), 431-8. Lima AFC, Castilho V, Baptista CMC, Rogenski NMB, Rogenski KE. Custo direto dos curativos de úlceras por pressão em pacientes hospitalizados. Revista Brasileira de Enfermagem 2016; 69(2), 290-7. Smit I, Harrison L, Letzkus L, Quatrara B. What Factors Are Associated With the Development of Pressure Ulcers in a Medical Intensive Care Unit? Dimensions of Critical Care Nursing 2016; 35(1), 37-41. 


\title{
MODELO DE PREDIÇÃO DE RISCO DE SKIN TEARS ENTRE PACIENTES DE UM HOSPITAL DE GRANDE PORTE
}

\author{
Author(s): $\quad$ FERNANDA ELISA PEREIRA ${ }^{1}$, ELINE BORGES ${ }^{1}$, MERY ABREU $^{1}$ \\ Institution(s) ${ }^{1}$ UFMG - UNIVERSIDADE FEDERAL DE MINAS GERAIS (AVENIDA PROFESSOR \\ ALFREDO BALENA,190, SANTA EFIGÊNIA, BH - MG)
}

\begin{abstract}
Introdução: a ocorrência de lesão cutânea é uma causa comum relacionado ao aumento do tempo de internação, e há menos de 25 anos começou-se a monitorar a epidemiologia da Skin tears (ST). Esse procedimento visa buscar evidências capazes de revelar a dimensão desse problema, além de subsidiar a elaboração de instrumentos de classificação e avaliação desse tipo de lesão. Objetivo: estabelecer um modelo de predição de risco das skin tears. Método: trata-se de uma coorte concorrente, envolvendo pacientes internados em um hospital privado de grande porte de Belo Horizonte, no estado de Minas Gerais. O desfecho clínico avaliado foi a presença de ST. A amostra foi formada por 129 pacientes que atenderam aos critérios de inclusão. A variável dependente (principal) foi a presença de ST e as variáveis independentes do paciente incluíram características sociodemográficas, comportamentais e clínicas durante o tempo de aproximadamente 4 meses. $\mathrm{Na}$ análise de sobrevivência foi utilizado o modelo de Regressão de Cox tanto uni quanto multivariado. Foram estimados os valores de Hazard Ratio (HR) com respectivos intervalos de confiança de $95 \%$, além de calculados os valores de significância para cada fator analisado. Para ilustrar os resultados significativos na análise multivariada, foram utilizados os gráficos de sobrevida por meio do método de Kaplan-Meier. Resultados: a incidência de ST foi de19,4\%. As lesões ocorreram principalmente da seguinte maneira: $14(56,0 \%)$ no braço, $9(36,0 \%)$ na perna e 1(4,0\%) na mão e $1(4 \%)$ no pé. $\mathrm{Na}$ análise multivariada, as variáveis que permaneceram associadas a um maior risco de ST foram doenças do aparelho circulatório; doenças infecciosas como causas da internação e insuficiência renal crônica como doença associada; uso prolongado de corticoide; presença de púrpura senil. $O$ aumento dos escores das subescalas percepção sensorial e nutrição dentro da Escala de Braden se mostrou associado a um menor risco de lesão. Conclusão: o estudo contribuiu para elucidar a epidemiologia relacionada às ST em pacientes de hospital geral de grande porte, sendo que os resultados obtidos poderão favorecer a elaboração de protocolos específicos de prevenção desse tipo de lesão.
\end{abstract}

Keywords: ESTUDOS EPIDEMIOLÓGICOS, FERIMENTOS E LESÕES, FRICÇÃO, FATORES DE RISCO, FATORES DE PROTEÇÃO

\section{Referências Bibliográficas}

BARANOSKI, S.; LEBLANC, K.; GLOECKNER, M. CE: Preventing, Assessing, and Managing Skin Tears: a clinical review. American Journal of Nursing, Philadelphia, v. 116, n. 11, p. 24-30, 2016. BARANOSKI, S.; LEBLANC, K.; GLOECKNER, M. Preventing, Assessing, and Managing Skin Tears: a clinical review. Am J Nurs., New York, v. 116, n. 11, p. 24-30, 2016 LEBLANC, K. et al. Best Practice Recommendations for Prevention and Management of Skin Tears in Aged Skin: An Overview. J Wound Ostomy Continence Nurs., St. Louis, v. 45, n. 6, p. 540-542, Nov./Dec. 2018. 


\title{
MANEJO DA ÚLCERA VENOSA CRÔNICA COM POLIHEXAMETILENO-BIGUANIDA (PHMB) GEL 0,2\% E PAPAÍNA EM PÓ 10\%: UM RELATO DE CASO
}

\author{
Author(s): SUZY RAMOS ROCHA ${ }^{1}$, RENATA PENHA FARIA ${ }^{1}$, DAYSE CARVALHO DO \\ NASCIMENTO $^{2}$, ANDRESSA DE SOUZA TAVARES ${ }^{2}$, GRACIETE SARAIVA MARQUES ${ }^{2}$ \\ Institution(s) ${ }^{1}$ INCA - Instituto Nacional de Câncer (Praça da cruz vermelha, centro, Rio de Janeiro ), ${ }^{2}$ HUPE - \\ Hospital Universitário Pedro Ernesto (Boulevard 28 de setembro, n.77 - Vila Isabel)
}

\begin{abstract}
Introdução: A úlcera venosa é decorrente da hipertensão venosa ocasionada pela insuficiência crônica dos vasos, resultante da anormalidade do funcionamento do sistema venoso e incompetência valvular, associada ou não à obstrução do fluxo venoso. É considerada um problema de saúde pública, correspondendo a cerca de $80 \%$ dos casos de úlcera de perna. O tratamento é de difícil manejo com processo de cicatrização lentificado acompanhado de baixa adesão e fidelização do paciente. Cabe ressaltar ainda, alta incidência e índices elevados de morbi-mortalidade1,2. Objetivos: Discorrer sobre as intervenções do estomaterapeuta na úlcera venosa crônica e analisar a resposta da associação PHMB gel $0,2 \%$ e papaína em pó no manejo da úlcera venosa crônica. Material e Método: Relato de caso de uma paciente assistida no ambulatório de curativo de um hospital universitário, localizado no Rio de Janeiro: Mulher, 62 anos, hipertensa, diabética, com história prévia de hanseníase multibacilar tratada e insuficiência venosa crônica. A avaliação e evolução foram realizadas através de exame clínico e registro fotográfico, utilizando termo de consentimento livre e esclarecido, com autorização para a realização e publicação do estudo (CEP: 2.013.490): lesões em maléolo D externo, 15x16cm e maléolo $\mathrm{D}$ interno, $14 \times 5 \mathrm{~cm}$, ambas com exsudato purulento moderado, bordas irregulares e maceradas, com hiperqueratose, esfacelo moderado e odor fétido. Após avaliação foi realizado curativo com PHMB gel $0,2 \%$ (ação antisséptica em bactérias gram negativas e positivas, anaeróbias e formação de placas e biofilmes) 4 em associação com papaína em pó 10\% (ação desbridante, antiinflamatória e auxilia na contração e junção de bordas de feridas)5, com troca diária. Após melhora do quadro infeccioso, a partir da segunda semana, manteve-se as coberturas utilizadas anteriormente associadas a terapia contensiva, com troca a cada 7dias. Resultados: Paciente apresentou lesões com contração de bordas, redução do exsudato e ausência de odor remetendo escolha correta das coberturas utilizadas. Conclusões: A úlcera venosa é uma lesão de difícil manejo, uma vez que seu processo de cicatrização sofre influência de fatores extrínsecos e intrínsecos do indivíduo. Conclui-se que o uso da papaína 10\% apresentou boa resposta na redução do tecido desvitalizado e promoção do tecido de granulação, bem como o PHMB gel $0,2 \%$ proporcionou o controle da proliferação bacteriana, observada também pela ausência de odor. Contudo, cabe reforçar que se faz necessário a associação da terapia contensiva, como padrão ouro no tratamento, e a orientação de autocuidado ao paciente para um resultado mais efetivo.
\end{abstract}

Keywords: Estomaterapia, Úlcera Venosa, Papaína

\section{Referências Bibliográficas}

1.Teixeira AKS, Silva LF, Marques AD, Soares CRS. Caracterização de pacientes com úlcera venosa assistidos em ambulatório de estomaterapia de hospital público. ESTIMA, Braz. J. Enterostomal Ther., 16: e0318. doi:

10.30886/estima.v16.346_PT. Disponível em <

https://www.revistaestima.com.br/index.php/estima/article/download/346/pdf_1> Acessado em 06/08/2019 2.Cruz CC, Caliri MHL, Bernardes RM. Características epidemiológicas e clínicas de pessoas com úlcera venosa atendidas em unidades municipais de saúde. ESTIMA, Braz. J. Enterostomal Ther., 16:e1218. doi: 10.30886/estima.v16.496_PT. Disponível em < https://www.revistaestima.com.br/index.php/estima/article/download/496/pdf_1> Acessado em 06/08/2019 3. Sant'ana SMSC, Bachion MM, Santos QR,Nunes CAB, Malaquias SG, Oliveira BGRB. Úlceras venosas: caracterização clínica e tratamento em usuários atendidos em rede ambulatorial. REBEn. [periódicos na internet]. 2012, Jul; 65(4): 637-44. Disponível em Acessado em 29/07/2019 4.Santos MC. Efetividade do polihexametileno-biguanida (phmb) na redução do biofilme em feridas crônicas: revisão sistemática. Universidade federal do paraná. Curitiba 2017 . Disponível em Acessado em 29/07/2019 5. Leite AP, Oliveira BGRB, Soares MF, Barrocas DLR. Uso e efetividade da papaína no processo de cicatrização de feridas: uma revisão sistemática. Rev Gaúcha de Enferm.[periódicos na internet]. 2012 Set;33(3):198-207. Disponível em < http://www.scielo.br/scielo.php?script=sci_arttext\&pid=S1983-14472012000300026> Acessado em $29 / 07 / 2019$ 


\title{
Prevalência de lesões de pele em crianças e adolescentes internados em um hospital pediátrico privado do município de São Paulo
}

\author{
Author(s): $\quad$ Lilian Sayuri Onaga ${ }^{1}$ \\ Institution(s) ${ }^{1}$ FJLES - Fundação José Luiz Egydio Setubal (Av. Angélica, 1987 - $17^{\circ}$ andar. São Paulo, SP CEP \\ 01228-200)
}

\begin{abstract}
TÍTULO: Prevalência de lesões de pele em crianças e adolescentes internados em um hospital pediátrico privado do município de São Paulo

INTRODUÇÃO: A pele da criança caracteriza-se por ser imatura, fina, sensível, frágil e facilmente irritável, o que a torna mais vulnerável a agressores externos.(1) Por isso, ao ser hospitalizada, a criança apresenta maior predisposição para o desenvolvimento de lesões de pele.

OBJETIVOS: Analisar a prevalência de lesões de pele (dermatite associada a incontinência, lesão de pele relacionada a adesivo médico, lesão por pressão e infecção de sítio cirúrgico) em um hospital pediátrico privado de São Paulo. MATERIAL E MÉTODO: Estudo epidemiológico, observacional, transversal, descritivo e correlacional realizado nas unidades de internação e de terapia intensiva de um Hospital Pediátrico após aprovação do comitê de ética. A coleta de dados foi realizada através de exames físico e análise de prontuário de todas as crianças internadas (0 a 18 anos) entre julho e agosto de 2018.

RESULTADOS: A amostra foi composta por 117 pacientes. Constatou-se uma prevalência de 29,9\% de lesões de pele: 13,6\% DAI; 9,4\% MARSI; 2,5\% LP, 0,8\% infecção de sítio cirúrgico e os outros 6,8\% apresentavam outros tipos de lesão. São escassas as publicações acerca da prevalência de lesões em crianças hospitalizadas. A prevalência encontrada está abaixo da literatura: DAI de 15 a 25\% no Brasil e 3 a 8\% em estudo internacional (2, 3); MARSI de 23,53 a 54,17\%; LP varia entre 0,29 a 27\% internacionalmente e $80,6 \%$ nacionalmente (4) e a infecção relacionada ao sítio cirúrgico representa $17 \%$ em pacientes pediátricos (5).

CONCLUSÃO: Esse estudo contribui para o conhecimento sobre a prevalência de lesões em crianças hospitalizadas, possibilitando a implementação de medidas preventivas.
\end{abstract}

Keywords: Ferimentos e lesões, Estomaterapia, Pediatria

\section{Referências Bibliográficas}

REFERÊNCIAS: (1) Pellegrino DMS, Chacon JMF, Blanes L, Ferreira LM. Úlcera por pressão na criança. In: Blanes L, Ferreira LM. Prevenção e tratamento de úlcera por pressão. 1 Ed. São Paulo: Atheneu, 2014, p. 33-44. (2) Faria TF, Kamada I. Dermatite associada à incontinência em recém-nascidos internados em uma unidade de terapia intensiva neonatal. In: Simpósio Centro-Oeste de Estomaterapia; 15-18 setembro; Centro de Eventos Brasil 21. Brasilia. SOBEST; 2016. (3) Acevedo GP, Acaraz AB, Mata CA, Canillas MLM, Bou JET. Prevalencia de lesiones por presión, incontinência, dermatites asociada a la incontinência y factores de riesgo para el desarollo de lesiones por presión en um hospital materno-infantil de tecer nível. Gerokom. 2018; 29(2): 83-91. (4) Chimentão DMN, Domansky RC. Prevenção de lesões de pele associadas à umidade. In: Domansky RC, Borges E. Prevenção de lesões de pele. 2ª Ed. Rio de Janeiro: Rubio, 2014, p93-150. (5) Martins MA, Goulart EMA, França E, Alberti LR. Infecções de sítio cirúrgico na criança e no adolescente. Rev Med Minas Gerais. 2012; 22(3): 308-14. 


\title{
FERIDAS E O TRANSTORNO DEPRESSIVO: UM PARADIGMA PARA O PROFISSIONAL ENFERMEIRO
}

\author{
Author(s): Gabriel Angelo de Aquino ${ }^{1}$, Camila Barroso Martins ${ }^{1}$, Joyce da Silva Costa ${ }^{1}$, Kátia Leite \\ Rodrigues Januário ${ }^{2}$ \\ Institution(s) ${ }^{1}$ UFC - Universidade Federal do Ceará (Rua Alexandre Baraúna, 1115 - Rodolfo Teófilo, Fortaleza \\ - CE, 60430-160), ${ }^{2}$ HUWC - Hospital Universitário Walter Cantídio (Rua Capitão Francisco \\ Pedro, 1.290 -Rodolfo Teófilo, Fortaleza-CE; 60430-370)
}

\begin{abstract}
INTRODUÇÃO: A depressão é caracterizada pela tristeza profunda, perda de interesse ou prazer, sentimento de culpa ou baixa autoestima, distúrbios de sono ou apetite, sentimento de cansaço e baixa concentração. É considerada uma das 10 principais causas de incapacitação no mundo, o que acaba levando a limitação de atividades físicas, pessoais e sociais, que podem se manifestar em qualquer pessoa, a qualquer hora e em qualquer idade1,2. A relação de depressão e as feridas crônicas, estabelece essas lesões como fatores geradores de sofrimento, tanto físico como emocional nas pessoas, sendo uma condição que gera um desgaste multifatorial, interferindo na autoestima, tem influência negativa na autoimagem e na qualidade de vida, situação que pode estar diretamente relacionada com a depressão3. OBJETIVO: Identificar os principais fatores relacionados com o desenvolvimento de transtornos depressivos em pessoas com feridas crônicas. MATERIAL E MÉTODOS: Trata-se de uma pesquisa de revisão bibliográfica, com caráter exploratório, descritivo e analítico sobre feridas crônicas e sua correlação com quadros depressivos. A coleta de dados ocorreu por levantamento das produções científicas a partir das bases de dados eletrônicos da Literatura Latino-Americana e do Caribe em Ciências da Saúde (LILACS) e Literatura Internacional em Ciências da Saúde (MEDLINE) consultadas através do site da Biblioteca Virtual em Saúde (BVS) utilizando-se das palavras-chave feridas crônicas e depressão. A seleção dos artigos aconteceu pelos seguintes critérios: publicados entre os anos de 2010-2019, disponível no idioma português ou inglês e acesso ao texto completo. RESULTADOS: Foram encontrados 35 artigos dos quais, permaneceram apenas 5 , sendo 2 em português e $3 \mathrm{em}$ inglês. Os principais fatores relacionados com o desenvolvimento de quadros depressivos em pessoas com feridas crônicas que convergiram nos artigos selecionados foram: Odor; mobilidade reduzida; dor; autonomia prejudicada; distúrbios de autoimagem; baixa autoestima e isolamento social. Além dos fatores que convergiram, outros foram vistos como predisponentes, mas que só foram citados apenas em 2 artigos, como: Habituação com as trocas diárias de curativos; presença de exsudato; abstenções alimentares e o uso de medicamentos contínuos. Essas mudanças ou fatores acabam promovendo a desmotivação e a incapacidade para o autocuidado, e para as atividades de vida e de convívio social. CONCLUSÃO: As feridas crônicas causam um impacto significativo na qualidade de vida das pessoas que as possuem, devido à sucessão de mudanças nos aspectos biopsicossocial na vida do indivíduo. A identificação de fatores relacionados com o desenvolvimento de quadros depressivos em pessoas com feridas crônicas permite ao enfermeiro traçar planos de intervenção para a prevenção e tratamento, contribuindo para melhorar a qualidade de vida dessas pessoas.
\end{abstract}

Keywords: Depressão, Enfermagem, Estomaterapia, Feridas

\section{Referências Bibliográficas}

1. World Health Organization (WHO). Depression and Other Common Mental Disorders: Global Health Estimates. Geneva: World Health Organization; 2017. 2. American Psychiatric Association. Diagnostic and statistical manual of mental disorders (DSM-V). 5. ed. London: [s.n.], 2014. 3. Almeida SA et al. Depressão em indivíduos com lesão traumática de medula espinhal com úlcera por pressão. Rev. Bras. Cir. Plást. 2013 Jun; 28 (2): 282-288. 


\title{
ENFERMAGEM E O CUIDADO PÓS-OPERATÓRIO DE UMA PARATIREOIDECTOMIA: ESTUDO DE CASO
}

\author{
Author(s): Gabriel Angelo de Aquino ${ }^{1}$, Joyce da Silva Costa ${ }^{1}$, Camila Barroso Martins ${ }^{1}$, Francisca \\ Alexandra Araújo da Silva ${ }^{2}$, Janaína Fonseca Victor Fonseca ${ }^{1}$ \\ Institution(s) ${ }^{1}$ UFC - Universidade Federal do Ceará (Rua Alexandre Baraúna, 1115 - Rodolfo Teófilo, Fortaleza \\ - CE, 60430-160), ${ }^{2}$ HUWC - Hospital Universitário Walter Cantídio (Rua Capitão Francisco \\ Pedro, 1.290 -Rodolfo Teófilo, Fortaleza-CE; 60430-370)
}

\begin{abstract}
INTRODUÇÃO: Dentro as neoplasias de cabeça e pescoço os tumores das glândulas salivares são pouco frequentes, corresponde ente 3 a $5 \%$ dos tumores nesta localização, onde $70 \%$ surgem na parótida, sendo $25 \%$ neoplasias malignas 1 . Os tumores originados a partir das glândulas salivares são provavelmente os mais complexos das neoplasias humanas, haja vista o seu amplo espectro histológico2. O tratamento é normalmente cirúrgico e a enfermagem tem um papel essencial na assistência prestada no pós-operatório, tendo em vista que é um período de reabilitação, sendo necessário uma assistência adequada e eficaz para a completa recuperação do paciente3. OBJETIVO: Descrever os cuidados prestados a um paciente no pós-operatório de paratireoidectomia de carcinoma de parótida. MATERIAL E MÉTODO: estudo de caso realizado em um Hospital Terciário de Fortaleza-Ceará, no período de agosto a outubro de 2018. Utilizou-se de entrevista, exame físico e leitura do prontuário do paciente. A lesão foi registrada e fotografada para acompanhamento mais fidedigno de sua evolução. Foi assegurado o cumprimento das normas para pesquisas com seres humanos presentes na Resolução 466/12 do Conselho Nacional de Saúde do Brasil. Estudo aprovado pelo comitê de ética sob o parecer de número 2.699.599 do Hospital Universitário Walter Cantídio. RESULTADOS: Foi realizada cirurgia extensa de parotidectomia em 31 de agosto de 2018 e logo após utilizou-se como cobertura a tela hidrodesbridante com prata e hidrogel com PHMB. A partir do dia 25 de setembro até o momento de sua alta hospitalar, em 16 de outubro, utilizou-se membrana de poliuretano obtida pela adição superficial de monômeros de poliamida e de hidroximetilmetacrilato e uso de espuma de transferência de exsudato com troca a cada 72 horas. O acompanhamento da lesão foi realizado e registrado. CONCLUSÃO: Observou-se uma melhora importante nos parâmetros importantes de cicatrização, reafirmando o importante papel do enfermeiro na aplicação de tecnologias para o tratamento e cuidado de pessoas com feridas.
\end{abstract}

Keywords: Enfermagem, Estomaterapia, Neoplasias

\section{Referências Bibliográficas}

1. Halperin EC, Wazer DE, Perez CA, Brady LW. Perez and Brady's principles and practice of radiation oncology. 6. Ed. Lippincott Williams and Wilkins, 2013. 2. Lima SS, Soares AF, Amorim RFB, Freitas RA. Perfil epidemiológico das neoplasias de glândulas salivares: análise de 245 casos. Rev. Bras. Otorrinolaringol. 2005 Jun; 71( 3 ): 335-340. 3. Rocha DR, Ivo OP. Assistência de enfermagem no pré-operatório e sua influência no pós-operatório. Rev. Enferm. Contemp. 2015 Jul./Dez.; 4(2):170-178. 


\title{
Custo-efetividade da bota de Unna e terapia de compressão de multicomponentes no tratamento da úlcera venosa
}

\author{
Author(s): $\begin{aligned} & \text { Eline Lima Borges }{ }^{2} \text {, Josimare Aparecida Otoni Spira }{ }^{2} \text {, Jairo da Cruz Santos }{ }^{2} \text {, Juliano Teixeira } \\ & \text { Moraes }{ }^{3}\end{aligned}$ \\ Institution(s) ${ }^{2}$ UFMG - Universidade Federal as Gerais (Av. Antônio Carlos, 6627, Pampulha - Belo Horizonte - \\ MG - CEP 31270-901), ${ }^{3}$ UFSJ - Universidade Federal de São João del-Rei (Praça Frei Orlando, \\ 170, Centro, São João del-Rei, Minas Gerais, CEP: 36307-352)
}

\begin{abstract}
Introdução: O custo anual estimado do tratamento de úlcera venosa varia de $\$ 10.000$ a $\$ 20.000(1)$. A terapia de compressão faz parte do tratamento destas úlceras porque reduz a pressão do sistema venoso, promovendo a cicatrização(2). Os sistemas elásticos de multicomponentes de alta compressão $(40 \mathrm{mmHg}$ ) são mais eficazes do que os componentes não elásticos (contensão), como por exemplo a bota de Unna(3). No Brasil persiste a cultura que o sistema de multicomponentes é oneroso o que mantém a bota de Unna como a primeira escolha de tratamento. Objetivo: comparar o custo-efetividade da terapia de compressão elástica de multicomponentes de alta compressão e bota de Unna. Método: estudo clínico comparativo não aleatorizado, de avaliação econômica do custo-efetividade de duas terapias de compressão, realizado em um serviço ambulatorial. A amostra (n) foi composta por 32 úlceras venosas alocadas nos grupos terapia de compressão elástica de multicomponentes (terapia elástica $n=16$ ) e terapia de compressão não elástica (bota de Unna $n=16$ ). O tempo de seguimento médio foi de 33 dias em ambos os grupos que apresentavam úlceras com áreas semelhantes. Os dados foram extraídos dos prontuários. As variáveis do estudo foram edema, área da úlcera, tipo de terapia de compressão e número de trocas. Foram considerados exclusivamente os custos relacionados às terapias de compressão. Os dados foram submetidos a análise estatística descritiva. A pesquisa foi aprovada pelo Comitê de Ética em Pesquisa da Universidade Federal de Minas Gerais (número 1.921.560). Resultados: a média de trocas de terapia por úlcera e redução média da área nos grupos terapia elástica e bota de Unna foram 5,9 trocas e 15,28 cm2 e 8,6 trocas e 7,4 $\mathrm{cm} 2$, respectivamente. A redução média das medidas das circunferências da panturrilha e do tornozelo foi, respectivamente, de $1,6 \mathrm{~cm}$ e $1,2 \mathrm{~cm}$ com a terapia elástica e $0,81 \mathrm{~cm}$ e $0,78 \mathrm{~cm}$ com bota de Unna. $O$ custo-efetividade da terapia elástica em relação à bota de Unna foi 2,07 vezes mais efetiva para a redução da área. $O$ custo médio da terapia elástica para reduzir $1 \mathrm{~cm} 2$ foi 2,37 vezes maior comparada a bota de Unna. O custo-efetividade da terapia elástica em relação à bota de Unna foi 1,76 vezes mais efetiva na redução do edema. $O$ custo médio para reduzir $1 \mathrm{~cm}$ de edema foi 2,80 vezes maior do que na terapia de bota de Unna. Conclusão: a terapia elástica foi superior a bota de Unna na redução da área da úlcera e do edema da perna, além de requerer um número menor de trocas com custo superior ao da bota de Unna.
\end{abstract}

Keywords: Estomaterapia, custo efetividade, úlcera venosa, terapia de compressão

\section{Referências Bibliográficas}

1 Lal BK. Venous ulcers of the lower extremity: definition, epidemiology, and economic and social burdens. Seminars in Vascular Surgery. 2015;28(1):3-5. 2 Wound Ostomy and Continence Nurses Society (WOCN). Guideline for management of wounds in patients with lower-extremity venous disease. Mount Laurel: WOCN, 2011. 3 O'Meara S, Cullum N, Nelson EA, Dumville JC. Compression for venous leg ulcers. Cochrane Database of Systematic Reviews 2012, Issue 11. DOI:

10.1002/14651858.CD000265.pub3 


\title{
AVALIAÇÃO DA ASSOCIAÇÃO ENTRE ALTERAÇÕES NOS PÉS E O RISCO DE PÉ DIABÉTICO NO MUNICÍPIO DE FORTALEZA/CE
}

\author{
Author(s): $\quad$ Georgea Bezerra CarvalhoG ${ }^{1}$, KATHARINA SHIRLEY AMÂNCIO JUSTO SOARES ${ }^{1}$, Patrícia \\ Freire de Vasconcelos. ${ }^{1}$, Solange Gurgel Alexandre ${ }^{1}$, Vanessa Emille Carvalho de Sousa Freire ${ }^{1}$ \\ Institution(s) ${ }^{1}$ UECE - Universidade Estadual do Ceará (Av Dr Silas Munguba, 1700, Campus Itapepy.)
}

\begin{abstract}
Diabetes Mellitus (DM) é uma das doenças não-transmissíveis mais comuns do mundo. Quando não controlada nem diagnosticada precocemente, traz como grave consequência o Pé Diabético, relevante complicação crônica, mutilante e onerosa para o indivíduo e para o sistema de saúde, sendo definido como "infecção, ulceração e/ou destruição de tecidos moles associadas a alterações neurológicas e vários graus de doença arterial periférica (DAP) nos membros inferiores" 2 . Nesse contexto, medidas de prevenção poderiam evitar de $44 \%$ a $85 \%$ das amputações, um de seus desfechos mais recorrentes, reduzindo o ônus gerado pela doença e elevando a qualidade de vida desses pacientes 3 . A compreensão deve fenômeno passa pela identificação dos fatores de risco como por exemplo as alterações nos pés. OBJETIVO: Avaliar a associação entre as alterações nos pés e o risco para desenvolver o Pé Diabético. MATERIAL E MÉTODO: Estudo analítico, quantitativo do tipo transversal, realizado em Unidade de Atenção Primária à Saúde (UAPS), no município de Fortaleza/CE. A população do estudo foi de 836 pessoas, com uma amostra de 263 pacientes. Foram incluídos os pacientes com DM tipo 2, com condições mentais de participar, validadas com a aplicação do mini exame mental. Os dados foram coletados por meio de um formulário estruturado e do exame físico do pé. Foram observados os princípios bioéticos preconizados pelo Conselho Nacional de Saúde MS (Resolução 466/12), com aprovação do CEP sob Parecer $n^{\circ}$ 3.069.313/CAAE 99840718.8.0000.5534. RESULTADOS: As alterações dermatológicas nos pés, corte de unhas, unhas espessas, calosidades e micoses interdigitais tiveram associações significativas com o risco de Pé Diabético, indicando que o autocuidado pode contribuir para a prevenção de lesões nos pés. Quanto à presença de lesões pré-ulcerativas houve significância entre as variáveis calosidades $(p=0,001)$ e micose interdigital $(p=0,022)$. As dermatopatias foram observadas na maioria dos participantes, sendo importante ressaltar que são alterações corriqueiras às quais não é dada a devida importância, podendo se agravar e causar infecções. Sobre a avaliação da presença de deformidades, houve associação positiva entre todas as variáveis relacionadas às deformidades como dedos em garra $(p=0,023)$, dedos em martelo $(p$
\end{abstract}

Keywords: Diabetes Mellitus, Pé Diabético, Risco

\section{Referências Bibliográficas}

1 ORGANIZAÇÃO MUNDIAL DA SAÚDE. OMS diz que mais de 16 milhões de brasileiros sofrem de diabetes. Genebra, 2016. Disponível em: . 2 INTERNATIONAL WORKING GROUP ON THE DIABETIC FOOT. Guidance documents on prevention and management of foot problems in diabetes: development of an evidence-based global consensus [Internet]. [S.I.]: International Working Group on the Diabetic Foot, 2015. Disponível em: < http://www.iwgdf.org/files/2015/website_development.pdf> Acesso em 16 de março de 2018. 3 TAVARES, D. M. S.; DIAZ, F. A.; ARAÚJO, L. R.; PEREIRA, G. A. Perfil de clientes submetidos a amputações relacionados ao diabetes mellitus. Rev. Bras. Enferm., Brasília, v. 62, n. 6, p. 825-830, nov./dez. 2009. 


\title{
Wound Evolution: aplicativo e base de dados para coleta, armazenamento e consulta de dados de pessoas com feridas
}

\author{
Author(s): Josimare Aparecida Otoni Spira ${ }^{1}$, Eline Lima Borges ${ }^{1}$, Paulo Roberto Ribeiro Dayrell ${ }^{2}$ \\ Institution(s) ${ }^{1}$ UFMG - Universidade Federal de Minas Gerais (Av. Antônio Carlos, 6627, Pampulha - Belo \\ Horizonte - MG - CEP 31270-901), ${ }^{2}$ UFF - Universidade Federal Fluminense (Rua Miguel de \\ Frias, 9 Icaraí Niterói - RJ 24220-900)
}

\begin{abstract}
Introdução: feridas crônicas representam um grande desafio para equipes de saúde, em especial enfermeiros que são os profissionais responsáveis pelo tratamento e acompanhamento dos pacientes que apresentam feridas. Frente aos avanços nas terapias de tratamento, percebe-se também a necessidade de repensar a forma de documentar os dados do paciente e de sua ferida, de forma a subsidiar o raciocínio clínico do profissional, orientar a tomada de decisão na indicação do tratamento tópico e o acompanhamento do processo de cicatrização, bem como servir como base de dados para pesquisa. Objetivo: construir um sistema para documentar e armazenar os dados do paciente e de sua(s) ferida(s). Material e método: trata-se de um estudo metodológico. É considerado uma estratégia que utiliza de maneira sistemática os conhecimentos existentes para elaboração de uma nova intervenção ou melhora significativa de uma intervenção existente, ou ainda, elabora ou melhora um instrumento, um dispositivo ou um método de mediação(1). Desse modo o pesquisador tem como meta a elaboração de um instrumento confiável, preciso e utilizável que possa ser empregado por outros pesquisadores/pessoas(2). A construção do sistema contemplou quatro fases(3). A primeira contemplou a definição do produto a ser construído e foi fundamentada no conteúdo de formulários físicos já utilizados em um serviço ambulatorial de atendimento de pessoas com feridas de diversas etiologias. A segunda consistiu no design/desenvolvimento do sistema, com a criação de um banco de dados relacional e posterior desenvolvimento de um aplicativo utilizando o framework IONIC 4(4), cuja comunicação com o sistema gerenciador de banco de dados é estabelecida através de rede. Na terceira e na quarta etapas foram realizadas, respectivamente, a implementação e avaliação do sistema no referido serviço. A realização do estudo não envolveu a participação de seres vivos, por isto, não demandou aprovação por um Comitê de Ética. Resultados: o sistema Wound Evolution permite o armazenamento de dados referentes à avaliação clínica do paciente $\mathrm{e}$ ferida, incluindo o registro fotográfico da mesma e o tratamento tópico implementado. Além disto, permite a inserção dos diagnósticos de enfermagem, auxiliando o enfermeiro na tomada de decisão clínica. O sistema estará disponível para o profissional de saúde nas plataformas Android, iOS e Web e o banco de dados no repositório do github disponível no link https://github.com/observatorioestomoterapia/Wound-Evolution. O sistema é open source, o que permite ao usuário customizar o software de acordo com as necessidades do serviço. Conclusão: A solução tecnológica desenvolvida facilita o processo de trabalho dos enfermeiros na prática clínica, permite o rápido acesso aos dados do paciente e agiliza o processo de pesquisa nessa área da Estomaterapia.
\end{abstract}

Keywords: Estomaterapia, Dispositivos Móveis, Ferimentos e Lesões, Base de dados, Documentação

\section{Referências Bibliográficas}

1 Contradiopoulos AP, Champagne F, Louise DJ, Potvin LD. Saber preparar uma pesquisa. São Paulo: hucitec, 19972 Polit DF, Beck CT. Fundamentos da pesquisa em enfermagem: avaliação de evidências para a prática de enfermagem. $7^{\underline{a}}$ ed. Porto Alegre: ArtMed; 20113 Dick W, Carey L, Carey JO. The Systematic Design of Instruction. Educational Technology Research and Development. 2006 [cited 2019 jul 30]; 54(4):417-20. Available from:

https://link.springer.com/article/10.1007/s11423-006-9606-0 4 Zhen-An Liu . Proceedings of International Conference on Technology and Instrumentation in Particle Physics 2017. Springer Proc.Phys. 2018 [cited 2019 jul 30]. DOI: 10.1007/978981-13-1316-5 


\title{
Educação em Saúde uma Ferramenta Importante no Auxílio ao Tratamento de Lesões: Relato De Experiência
}

\author{
Author(s): $\quad$ Priscila Paranhos Lebeis ${ }^{1}$, Rita de Jesus Grijó e Silva ${ }^{1}$, Cíntia Machado Lima ${ }^{1}$, Christiany \\ Christiany Moçali Gonzalez ${ }^{1}$ \\ Institution(s) ${ }^{1}$ HMLJ - Hospital municipal lourenço jorge (Av Ayrton senna 2000)
}

\begin{abstract}
Introdução: É sabido que existem diversos fatores que dificultam a cicatrização de feridas tais como a sua extensão, infecção, uso de agentes tópicos inadequados, técnica inadequada de curativos, idade, aporte nutricional inadequado, entre outros $^{1}$. Nesse cenário, se faz necessário que o tratamento da lesão seja realizado de forma holística, considerando a realidade em que o paciente está inserido e seu entendimento a cerca do que acontece com ele, uma vez que será ele o responsável pelo seu próprio cuidado. Para atender essa demanda, a educação em saúde surge com uma estratégia importante no tratamento das feridas no âmbito ambulatorial. Segundo a OMS (Organização Mundial de Saúde) a educação em saúde é entendida como uma combinação de ações e experiências de aprendizado planejado com o intuito de habilitar as pessoas a obterem controle sobre fatores determinantes e comportamentos de saúde ${ }^{2}$. Considerada uma prática social, contribui para a formação da consciência crítica das pessoas a respeito de seus problemas de saúde, a partir da sua realidade, e estimula a busca de soluções e organização para a ação individual e coletiva ${ }^{3}$. Objetivo: Relatar a experiência da inserção da educação em saúde como instrumento do cuidado no acompanhamento e auxilio no processo de cicatrização de uma lesão. Método: Trata-se de um relato de experiência desenvolvido em um hospital da Zona Oeste do Rio de Janeiro/RJ, oportunizado pelo acompanhamento ambulatorial do paciente no período de 10/06/2019 a 02/07/2019. A experiência partiu da realização do curativo no ambulatório e a utilização da educação em saúde como estratégia do cuidado no tratamento domiciliar da lesão, onde o foco foi a transformação da consciência ingênua construída a partir do conhecimento proveniente do senso comum, em uma consciência crítica construída com o intercâmbio dos saberes e práticas entre os profissionais de saúde envolvidos no cuidado da lesão e a paciente, como também sua cuidadora, onde objetivou-se transformar a realidade existente. Resultados: Lesão traumática superficial em MIE (imobilizado) com 27 dias de evolução, sendo tratada por familiar (mãe) utilizando-se agentes tópicos de forma inadequados (aroeira, hidrogel e álcool $70 \%$ na lesão). Realizado educação em saúde, através do diálogo, onde a relação estabelecida com a paciente e familiar possibilitou que houvesse a construção do cuidado de forma horizontal e não de forma prescritiva e hierarquizada. Se considerou a realidade, os conhecimentos, as crenças e a realidade na qual a paciente e a familiar estavam inseridas, fazendo com que a prática do cuidado domiciliar da lesão tivesse alta adesão e técnica utilizada no curativo, como também a forma correta da utilização de agente tópicos, fossem alterados pelo despertar da consciência crítica. Conclusão: A educação é um processo dinâmico, sendo fundamental a participação e envolvimento do familiar. Observou-se considerável melhora no aspecto da lesão já no primeiro retorno. Consideramos uma boa resposta a partir do entendimento do cuidador na forma de realizar o curativo e na utilização correta de agentes tópicos. O comprometimento dos profissionais a parceria e o aprendizado do cuidador contribuíram para uma boa evolução na cicatrização da lesão.
\end{abstract}

\section{Keywords: CICATRIZAÇÃO, EDUCAÇÃO EM SAÚDE, ESTOMATERAPIA}

\section{Referências Bibliográficas}

Brasil. Ministério da Saúde. Secretaria de Políticas de Saúde. Departamento de Atenção Básica. Manual de condutas para úlceras neurotróficas e traumáticas / Ministério da Saúde, Secretaria de Políticas de Saúde, Departamento de Atenção Básica. - Brasília: Ministério da Saúde, 2002. [acesso: 15 jun 2019]. Disponível em:

http://bvsms.saude.gov.br/bvs/publicacoes/manual_feridas_final.pdf Brasil. Fundação Nacional de Saúde. Diretrizes de educação em saúde visando à promoção da saúde: documento base - documento l/Fundação Nacional de Saúde -Brasília: Funasa, 2007.70 p.:il. [acesso em 15 jun 2019]. Disponível em: http://www.funasa.gov.br/site/wp-

content/files_mf/dir_ed_sau.pdf Brasil. Ministério da Saúde (MS). Secretaria de Gestão do Trabalho e da Educação na Saúde. Departamento de Gestão e da Regulação do Trabalho em Saúde . Câmara de Regulação do Trabalho em Saúde. Brasília: MS; 2006. [acesso: 15 jun 2019] disponível em: http://bvsms.saude.gov.br/bvs/publicacoes/glossario_gestao_trabalho_2ed.pdf 


\title{
LESÃO POR EXTRAVASAMENTO DE TRASTUZUMABE ENTANSINA: MANEJO EM PACIENTE ONCOLÓGICO
}

\author{
Renata Ramos Menezes ${ }^{1,2}$, Simone Yuriko Kameo ${ }^{2}$, Giliane Leite Hardman ${ }^{3}$, Glebson Moura Silva ${ }^{2}$, \\ Author(s): Nivaldo Farias Vieira ${ }^{3}$, Bruno Ferreira Amorim ${ }^{2}$, Jéssica dos Santos Costa ${ }^{2}$, Maria Júlia Oliveira Ramos ${ }^{2}$, \\ Ayanne Sophia Brandão Duarte Sá ${ }^{1}$, Andreza Rafaelle da Silva Oliveira ${ }^{1}$ \\ Institution(s) ${ }^{1}$ HCP - Hospital de Câncer de Pernambuco (Avenida Cruz Cabugá, $n^{\circ}$ 1597), ${ }^{2}$ UFS - Universidade Federal \\ de Sergipe (Avenida Governador Marcelo Déda, $\left.n^{\circ} 13\right),{ }^{3}$ Onco Hematos - Clínica Onco Hematos (Rua \\ Itabaiana, $\left.n^{\circ} 945\right)$
}

\begin{abstract}
INTRODUÇÃO: Trastuzumabe Entansina é um dos agentes antineoplásicos indicados em monoterapia para tratamento de pacientes com câncer de mama metastático ou localmente avançado não ressecável. É conjugado de anticorpomedicamento, que tem HER2 (receptor-2 do fator de crescimento epidérmico humano) como alvo, e contém a lgG1 antiHER2 humanizada, trastuzumabe, ligada de forma covalente com a droga inibitória de microtúbulo DM1 (um derivado de maitansina) por meio do ligante tioéter estável MCC (4-[N-maleimidometil] ciclohexano-1-carboxilato). OBJETIVO: Descrever um relato de caso de extravasamento de Trastuzumabe Entansina em paciente com carcinoma ductal invasivo (CDI) de mama. MATERIAL E MÉTODO: Trata-se de um relato de caso clínico, descritivo, a partir da vivência da equipe assistencial, que atua em um ambulatório de tratamento oncológico na cidade de Aracaju, Sergipe. Os dados foram coletados através de informações no prontuário, e as imagens foram feitas pela equipe multiprofissional do referido ambulatório. O trabalho foi aprovado pelo Comitê de Ética em Pesquisa da Universidade Federal de Sergipe $\left(\mathrm{n}^{\circ}\right.$ parecer: 2.244.176), sendo respeitadas as informações contidas na Resolução 510/16 do Conselho Nacional de Saúde. RESULTADOS: O.R.S, feminino, 72 anos, casada, natural de Paripiranga, Bahia. Diagnosticada em outubro de 2014 com $\mathrm{CDI}$ em mama direita com metástase hepática, T4NxM1 ( $\mathrm{T}=$ tumor primário; $\mathrm{N}=$ linfonodos das cadeias de drenagem linfática do órgão em que o tumor se localiza; $M$ = presença ou ausência de metástases à distância). Realizou protocolo quimioterápico CLEOPATRA, seguido de cirurgia e radioterapia. Ficou quatro anos sem acompanhamento clínico por opção, quando apresentou tumoração em mama direita. Administrado Trastuzumabe Entansina por cateter venoso central totalmente implantado (CVC-TI). Após a infusão, apresentou desconforto em região do CVC-TI, na inserção da agulha, sendo evidenciado extravasamento, com presença de edema e eritema. Realizados aspiração do conteúdo, dexametasona tópica e compressa morna. Houve piora da ferida, com pele hiperemiada, presença de flictenas, dor e calor. Administrados antibiótico e anti-inflamatório oral. Posteriormente, apresentou melhora das feridas, porém havia progressão de doença pulmonar expressiva, e foi a óbito em 05 de maio de 2017. DISCUSSÃO: A toxicidade dermatológica local decorrente do extravasamento deste tipo de droga, embora seja considerada uma ocorrência rara em se tratando de Trastuzumabe Entansina, é um dos principais efeitos adversos da terapia antineoplásica, sendo classificada como uma emergência oncológica. Em estudos clínicos com esse quimioterápico, foram observadas reações semelhantes ao caso descrito, mais frequentemente dentro de 24 horas de infusão. O tratamento específico para extravasamento de Trastuzumabe Entansina não é conhecido até o momento. O local de infusão deve ser cuidadosamente monitorado, para verificar possível infiltração subcutânea durante a administração da droga. CONCLUSÕES: A prevenção do extravasamento é uma preocupação constante na prática clínica, e torna-se importante o aperfeiçoamento e elaboração de diretrizes clínicas, para que os profissionais identifiquem os pacientes com maior risco de extravasamento, e assim, evitá-lo. Especialmente o enfermeiro, que atua na assistência oncológica deve ter conhecimento sobre prevenção e intervenção para extravasamento por drogas antineoplásicas. O acompanhamento rigoroso da lesão causada pelo extravasamento deve ser realizado por equipe assistencial, a fim de diminuir transtornos e toxicidades do tratamento.
\end{abstract}

Keywords: Antineoplásicos, Cuidados de Enfermagem, Estomaterapia, Relatos de Casos

\section{Referências Bibliográficas}

Instituto Nacional de Câncer José Alencar Gomes da Silva (BR). ABC do câncer: abordagens básicas para o controle do câncer. Rio de Janeiro: Instituto Nacional de Câncer José Alencar Gomes da Silva; 2019 [acesso em 2019 ago 19]. Disponível em:

https://www.inca.gov.br/sites/ufu.sti.inca.local/files//media/document//ivro-abc-4-edicao.pdf. Produtos Roche Químicos e Farmacêuticos S.A. (BR). Kadcyla® (trastuzumabe entansina). Rio de Janeiro: Produtos Roche Químicos e Farmacêuticos S.A; 2014 [acesso em 2019 ago 19]. Disponível em:

http://www.anvisa.gov.br/datavisa/fila_bula/frmVisualizarBula.asp?pNuTransacao=3390712014\&pldAnexo=2038058. Schneider F Pedrolo E. Extravasamento de drogas antineoplásicas: avaliação do conhecimento da equipe de enfermagem. Rev. Min. Enferm. [Internet]. 2011 [acesso em 2019 ago 19]; 15(4): 522-529. Disponível em: www.reme.org.br/exportar-pdf/66/v15n4a08.pdf. Souza NR de, Bushatsky M, Figueiredo EG de, Melo JT da S, Freire D de A, Santos ICRV. Emergência oncológica: atuação dos enfermeiros no extravasamento de drogas quimioterápicas antineoplásicas. Esc. Anna Nery [Internet]. 2017 [acesso em 2019 ago 19]; 21 (1): e20170009. Disponível em: http://www.scielo.br/scielo.php?script=sci_arttext\&pid=S1414-81452017000100209\&lng=en. 


\title{
TECNOLOGIAS ASSISTENCIAIS EFICAZES PARA A PREVENÇÃO DE LESÃO POR PRESSÃO: UMA CONTRIBUIÇÃO PARA A ESTOMATERAPIA
}

\author{
Author(s): jennifer ferreira figueiredo cabral ${ }^{1}$, Luis Rafael Leite Sampaio ${ }^{2}$, Francisco Antonio da Cruz \\ Mendonça ${ }^{4}$, Fernanda Jorge Magalhães ${ }^{3}$, Fernanda Maria Silva ${ }^{2}$ \\ Institution(s) ${ }^{1}$ UNIFOR - Universidade de Fortaleza (Av. Washigton Soares), ${ }^{2}$ URCA - UNIVERSIDADE \\ REGIONAL DO CARIRI (CAMPUS PIMENTA), ${ }^{3}$ FAMETRO - FACULDADE \\ METROPOLITANA DE FORTALEZA (Fortaleza/CE), ${ }^{4}$ FIC - CENTRO UNIVERSITÁRIO \\ ESTÁCIO DO CEARÁ (Fortaleza/CE), ${ }^{5}$ URCA - UNIVERSIDADE REGIONAL DO CARIRI \\ (CAMPUS PIMENTA)
}

\begin{abstract}
INTRODUÇÃO: A segurança do paciente objetiva mitigar os eventos adversos que elevam a morbimortalidade, os custos em saúde e riscos advindos da assistência em saúde. Neste sentido, a incidência de lesão por pressão (LP) compreendida como principal evento adverso resultante do dano à pele e tecidos subjacentes decorrente de forças de pressão, cisalhamento e fricção passou a ser indicador da qualidade da assistência de enfermagem, sendo primordial ao estomaterapeuta ter conhecimento das tecnologias assistenciais para o cuidado voltado à prevenção de LP. OBJETIVO: Identificar as tecnologias assistenciais eficazes para prevenção de lesão por pressão. MÉTODOS: Este estudo tratou-se de uma revisão integrativa realizada nas bases de dados: LILACS, BDENF, MEDLINE, COCHRANE, CINAHL e WEB OF SCIENCE, utilizando a estratégia de cruzamento dos descritores MESH: pressure ulcer, prevention and control, adotando o boleano AND. Como critério de inclusão ensaios clínicos randomizados controlados ou não controlados, publicados nos últimos dez anos, nos idiomas inglês, português, espanhol e texto completo disponível e que tivesse como intervenção uma tecnologia do tipo assistencial. RESULTADOS E DISCUSSÃO: 14 tecnologias responderam ao nosso objetivo após aplicação dos critérios de elegibilidade, sendo elas o curativo de silicone, a superfície de pele de carneiro, a bota de dispositivo de suspensão de calcanhar, o dispositivo contínuo de mapeamento de pressão à beira do leito, a bota de suspensão para redistribuição de pressão, o protetor de calcanhar, a espuma de poliuretano, o colchão com alternância de ar de baixa pressão, o lençol de seda, o curativo de espuma de silicone, as almofadas de proteção para cadeira de roda, o filme transparente de poliuretano e o reposicionamento no ângulo de $30 \circ$ a cada duas horas. Duas tecnologias tiveram maior frequência: as coberturas de silicone e os protetores de calcâneos. Após análise dos achados, surgiu a categoria: Eficácia das tecnologias para prevenção da lesão por pressão nas práticas assistenciais em enfermagem. Estes achados evidenciam a importância dos artefatos tecnológicos para a gestão da fricção e da pressão deletéria ao tecido, ao referir no mercado existem diversos dispositivos e superfícies de apoio, cuja configuração física e/ou estrutural permite a redistribuição da pressão e também outras funções terapêuticas acrescentadas para a gestão das cargas tissulares, da fricção, cisalhamento e microclima. CONCLUSẨO: As tecnologias asssistenciais identificadas nos permitem concluir que prevenção de lesões por pressão está intimamente relacionada ao uso destas tecnologias, sendo notório que a prevenção é o melhor tratamento para a LP e que o atual nível de conhecimento coloca os estomaterapeutas em condições de prevenir, necessitando que se empoderem deste conhecimento para subsidiar as tomadas de decisões na sua prática em estomaterapia.
\end{abstract}

Keywords: Estomaterapia, Lesão por pressão, Tecnologia

\section{Referências Bibliográficas}

Anvisa. Práticas seguras para a prevenção de lesão por pressão em serviços de saúde. NOTA TÉCNICA GVIMS/GGTES № 03/2017. Disponível em: . Acesso em: 15 abr. 2018. Merhy E E; Onocko R. Agir em saúde: um desafio para o público. São Paulo: Hucitec, 2002. p. 71-112. Shannon R J, Brown L, Chakravarthy, D. Pressure Ulcer Prevention Program Study: A Randomized, Controlled Prospective Comparative Value Evaluation of 2 Pressure Ulcer Prevention Strategies in Nursing and Rehabilitation Centers. Advances in Skin \& Wound Care: October 2012 - Volume 25 - Issue 10 - p 450-464. Disponível em:

https://journals.Iww.com/aswcjournal/Abstract/2012/10000/Pressure_Ulcer_Prevention_Program_Study__A.8.aspx. Acesso em 2 de maio de 2018. Santamaria et al. A randomised controlled trial of the effectiveness of soft silicone multi-layered foam dressings in the prevention of sacral and heel pressure ulcers in trauma and critically ill patients: the border trial. Int Wound J. 2015 Jun;12(3):302-8. Disponível em: https://www.ncbi.nlm.nih.gov/pubmed/23711244. Acesso em 2 de maio de 2018. Mistiaen P et al. The effectiveness of the Australian Medical Sheepskin for the prevention of pressure ulcers in somatic nursing home patients: a prospective multicentre randomised controlled Trial. Wound Repair and Regeneration: 2010, 18(6), 572-579. Disponível em: . Acesso em 2 de maio de 2018. 


\title{
IMPORTÂNCIA DA NUTRIÇÃO NA CICATRIZAÇÃO DAS FERIDAS
}

\author{
Author(s): Yara Cordeiro Guimarães ${ }^{1}$, Arian Santos de Jesus ${ }^{1}$, Josefa Edilma Jesus dos Anjos ${ }^{1}$, Patricia \\ Sampaio Farias Oliveira ${ }^{1}$, Cristiane Costa Reis da Silva ${ }^{1}$ \\ Institution(s) ${ }^{1}$ UNIFACS - Universidade Salvador (Av. Luís Viana Filho no 3146 / 3100 Pituaçu, Salvador - \\ Bahia. CEP. 41.720-200)
}

\begin{abstract}
Introdução: A pele é um órgão que se encontra sempre exposto a frequentes agressões, e por isso possui uma capacidade de reparação tecidual considerada importante para a sobrevivência, além de agir como barreira contra agentes externos. Ferida consiste em qualquer tipo de lesão na qual ocorre o interrompimento da solução de continuidade da pele. As feridas podem ser classificadas através de vários aspectos, dentre eles, a formação, origem da lesão, grau de contaminação, evolução cicatricial, aspectos do leito e tipo de exsudato. O processo de cicatrização consiste na substituição de um tecido lesado por um tecido conjuntivo vascularizado de forma sistêmica, dinâmica e complexa, mantendo a homeostase do processo para que ocorra a recuperação do tecido lesionado. A nutrição possui participação ativa e primordial nesse processo. Objetivos: Descrever a importância da nutrição na cicatrização das feridas; Identificar os nutrientes importantes na cicatrização das feridas; Apontar a necessidade de uma boa nutrição aos pacientes com feridas. Metodologia: $O$ presente estudo consiste em uma pesquisa bibliográfica qualitativa de caráter exploratório. Utilizando a pergunta norteadora: De que maneira a nutrição influencia na cicatrização das feridas? A extração de dados foi realizada nas bases de dados da Biblioteca Virtual em Saúde (BVS), por meio das bases de dados LILACS- Literatura Latino-Americana e do Caribe em Ciências da Saúde, SciELO- Scientific Electronic Library Online, MEDLINE- Medical Literature Analysis and Retrieval System Online, BDENF- Base de dados de enfermagem, Coleciona SUS- Coleção Nacional das Fontes de Informação do SUS, IBECS - Índice Bibliográfico Español en Ciencias de la Salud. Foram incluídos estudos completos disponíveis online na íntegra no idioma português, inglês e espanhol, com recorte temporal entre 2011 e 2017. Resultados: Foram identificados 41 artigos compatíveis com os critérios de inclusão, após a leitura destes artigos foram selecionados 15 publicações que estavam diretamente relacionadas à temática. Os Resultados emergiram para 2 categorias temáticas: $\mathrm{A}$ nutrição como fator primordial na cicatrização; Nutrientes que auxiliam na cicatrização. Conclusão: A intervenção nutricional é considerada como uma ferramenta duradoura neste processo, identificando o estado nutricional e executando um equilíbrio na dieta, revertendo as deficiências nutricionais que podem impedir a sequência da cicatrização e colaborar no aparecimento de novas lesões. Os nutrientes que obtiveram destaque foram as proteínas, carboidratos, lípidos, alguns aminoácidos, vitamina A, B C, E, zinco, cobre, ferro e água. Conclusão: Desta forma, conclui-se que a nutrição é fundamental no processo de cicatrização e que a deficiência de alguns nutrientes interfere diretamente no processo, retardando, dificultando e até impedindo a cura. Portanto, é fundamental que o profissional de saúde ofereça um cuidado integral ao paciente com feridas, realizando todas as intervenções precisas e evidenciando a atenção ao estado nutricional durante todo tratamento, uma vez que a nutrição é considerada como um tratamento eficaz na prevenção e no tratamento das lesões.
\end{abstract}

Keywords: Cicatrização, Estado Nutricional, Estomaterapia, Feridas

\section{Referências Bibliográficas}

Bottoni A, Bottoni A, Rodrigues RC, Celano RMG. Papel da Nutrição na Cicatrização Revista Ciências em Saúde. 2011 abr; Vol.1, N 1. [acesso em 20 de abril 2018]. Disponível em: http://200.216.240.50:8484/rcsfmit/ojs-2.3.3-

3/index.php/rcsfmit_zero/article/view/31 Diniz AG. Relevância da nutrição no processo de cicatrização de feridas. Trabalho de conclusão de curso; Curso de especialização em atenção básica em saúde da família; Lagoa Santa/ MG; Universidade Federal de Minas Gerais, 2013, 53 p. [acesso em 20 de abril 2018]. Disponível em: https://www.nescon.medicina.ufmg.br/biblioteca/registro/Relevancia_da_nutricao_no_proces so_de_cicatrizacao_de_feridas_/461 Eberhardt TD, Dias CFC, Fonseca GGOF, Kessler M, Soares RSAS, Lima SBS. Cicatrização de feridas: Análise das tendências em teses e dissertações. Rev Enferm UFSM 2015 Abr/Jun;5(2): 387-395. [acesso em 21 setembro 2017]. Disponível em: https://periodicos.ufsm.br/reufsm/article/view/15259/pdf 


\title{
USO DE REDE NEURAL ARTIFICIAL NA TRIAGEM DE PESSOAS EM ALTO RISCO DE PÉ DIABÉTICO
}

\author{
Author(s): Ana Cláudia Barbosa Honório Ferreira ${ }^{1}$, Danton Diego Ferreira ${ }^{3}$, Uiara Aline de Oliveira Kaizer ${ }^{1}$, \\ Henrique Ceretta Oliveira ${ }^{1}$, Maria Helena Baena de Moraes Lopes ${ }^{1}$ \\ Institution(s) ${ }^{1}$ Unicamp - Universidade Estadual de Campinas (Cidade Universitária Zeferino Vaz - Barão \\ Geraldo, Campinas - SP, 13083-970), ${ }^{2}$ Unilavras - Centro Universitário de Lavras (Rua Padre José \\ Poggel, 506 - Centenario, Lavras - MG, 37200-000), ${ }^{3}$ UFLA - Universidade Federal de Lavras \\ (Aquenta Sol, Lavras - MG, 37200-000)
}

\begin{abstract}
Introdução: O Diabetes Mellitus configura-se como uma epidemia mundial, traduzindo-se em um grande desafio para os sistemas de saúde de todo o mundo. Um grande impacto econômico ocorre nos serviços de saúde como consequência dos crescentes custos do tratamento dessa doença e, sobretudo, de suas complicações. Dentre elas destaca-se o pé diabético, considerada uma complicação grave, que afeta os membros inferiores, podendo levar a ulcerações e até mesmo a amputações. Objetivo: Avaliar o desempenho de uma Rede Neural Competitiva na identificação de pessoas com diabetes mellitus que apresentam alto risco de desenvolver o pé diabético. Material e método: Pesquisa de teste diagnóstico, em que foi utilizado um banco de dados composto por 54 fatores de risco para o pé diabético, investigados em 250 pessoas com diabetes. As informações foram coletadas em uma Associação de Diabéticos, e o instrumento de coleta de dados continha perguntas a respeito das condições socioeconômicas, hábitos e atitudes relacionados à cuidados com a saúde e com os pés, baseando-se apenas no relato dos participantes, sem a realização de exame físico. Através do uso de uma Rede Neural Competitiva foi construído um modelo neural capaz de dividir o banco de dados em dois grupos, denominados $A$ e B, a partir das similaridades entre as informações dos participantes. Aprovação no comitê de ética em pesquisa: Esta pesquisa foi aprovada pelo Comitê de Ética e Pesquisa com seres humanos, CAAE 66815617.3.00005404. Resultados: Verificou-se que o grupo B foi composto por pessoas com maior risco de desenvolver o pé diabético, por possuírem maior frequência de variáveis de risco para esta complicação, além disso, os testes estatísticos (teste $t$ de Student, teste $U$ de mann-Whitney, teste qui-quadrado e exato de Fisher) comprovaram diferença significativa entre os grupos (95\% de certeza). As variáveis que mais discriminaram os dois grupos estão de acordo com os achados de outros estudos, sendo estas fundamentais para detecção de risco para o pé diabético. Os dados foram também validados por duas enfermeiras, com experiência em pé diabético, que analisaram as informações de 50 pessoas escolhidas aleatoriamente a partir do banco de dados de 250 participantes. O modelo proposto encontrou 23 resultados verdadeiros positivos, 2 falsos positivos, 15 verdadeiros negativos e 9 falsos negativos, alcançando sensibilidade de $71,9 \%$, especificidade de $88,2 \%$ e acurácia de $92,0 \%$. Os grupos A e B diferiram quanto a frequência das seguintes variáveis: sentir formigamento, dormência, queimação, choque e dor em pés, apresentar unhas encravadas e calos nos pés e uso de bolsa de água quente para aquecer os pés. Conclusão: O sistema pode otimizar o trabalho da equipe de saúde, principalmente da enfermagem, pois realiza triagem de pessoas com diabetes mellitus, indicando aqueles com alto risco de desenvolver o pé diabético e que necessitam de acompanhamento prioritário, com realização de exames de avaliação dos pés, em busca da prevenção desta complicação.
\end{abstract}

Keywords: Diabetes mellitus, Pé diabético, Estomaterapia, Redes Neurais Artificiais

\section{Referências Bibliográficas}

Brasil. Ministério da Saúde. Diabetes Mellitus. Cadernos de Atenção Básica n.ำ16, Série A. Normas e Manuais Técnicos. Brasília, DF, 2006. International Working Group on the Diabetic Foot. International Consensus on the Diabetic Foot. M Wijnandts, Department of Internal Medicine, Academic Hospital Maastricht, Netherlands, fl3, 2001. International Diabetes Federation. Diabetes Atlas, 8th ed [Internet]. Brussels: Belgium.; 2017. Available from: http://www.diabetesatlas.org/. HAYKIN, S. Neural networks and Learning Machines, 3 ed., Prentice Hall, 2008. 


\title{
PROTOCOLO DE PREVENÇÃO E TRATAMENTO DA LESÃO POR FRICÇÃO.
}

Author(s): Fabiana da Silva Augusto ${ }^{1}$, Celina Mayumi Morita Saito ${ }^{1}$, Leila Blanes ${ }^{1}$, Lydia Masako Ferreira ${ }^{1}$ Institution(s) ${ }^{1}$ UNIFESP - UNIVERSIDADE FEDERAL DE SÃO PAULO (R. BOTUCATU, 740 - VILA CLEMENTINO - SÃO PAULO - SP)

\begin{abstract}
Introdução: A lesão por friç̧ão é uma ferida traumática provocada por fricção isolada ou acompanhada de cisalhamento, levando à separação parcial ou total da derme e epiderme. Acomete principalmente pessoas nos extremos de idade, como neonatos e idosos. Os profissionais de saúde devem ter conhecimento sobre lesões por fricção para realizar a prevenção e tratamento adequados. Objetivo: Desenvolver e implementar um protocolo de prevenção e tratamento de lesões por fricção no Hospital São Paulo (HSP). Métodos: Estudo transversal de desenvolvimento de protocolo de prevenção e tratamento de lesão por fricção para implementação no HSP. Para o desenvolvimento do conteúdo do protocolo, foram coletadas informações de artigos selecionados em busca realizada nas bases MEDLINE e SciELO no período de setembro de 2016 a novembro de 2016. A validação do protocolo foi realizada através da técnica Delphi, com especialistas em prevenção e tratamento de feridas. Foi realizado o treinamento presencial de profissionais de enfermagem e desenvolvido um módulo no Programa de Educação Permanente online do hospital. Resultados: O protocolo e material educativo foram disponibilizados no formato impresso e online. O protocolo desenvolvido foi implementado no HSP e 636 profissionais da área de saúde participaram do treinamento. O protocolo foi divulgado online e distribuído em formato impresso nos setores do hospital. Um cartaz simplificado do protocolo foi desenvolvido e afixado em murais das unidades. Em continuidade ao processo de implementação, foi desenvolvido um módulo no Programa de Educação Permanente online para profissionais de enfermagem do HSP. Conclusão: O protocolo de prevenção e tratamento de lesão por fricção foi desenvolvido e implementado no HSP.
\end{abstract}

Keywords: ferimentos e lesões, lesão por fricção, prevenção, protocolo, tratamento

\section{Referências Bibliográficas}

(1) LeBlanc K, Baranoski S. Skin tears: state of the science: consensus statements for the prevention, prediction,

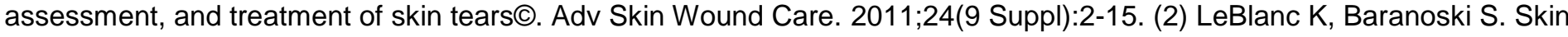
tears: The forgotten wound. Nurs Manage. 2014;45(12);36-46. (3) LeBlanc K, Baranoski S, Christensen D, Langemo D, Edwards K, Holloway S, Glockner M, Williams A, Campbell K, Alam T, Woo KY. The art of dressing selection: a consensus statement on skin tears and best practice. Adv Skin Wound Care. 2016;29(1): 32-46. (4) Strazzieri-Pulido KC. Adaptação cultural e validação do instrumento STAR Skin Tear Classification System para a língua portuguesa no Brasil [dissertação]. São Paulo: Escola de Enfermagem, USP; 2010. 


\title{
ATUAÇÃO DE ENFERMEIROS DE HOME CARE NA PREVENÇÃO DE LESÕES POR PRESSÃo ATRAV̉ÉS DA IMPLANTAÇÃO DE UMA COMISSÃO DE CUIDẢDOS COM A PELE
}

\author{
Author(s): GISLAINE MELO MEIRA ${ }^{1}$ \\ Institution(s) ${ }^{1}$ Lar e Saúde - Lar e Saúde - Assistência Domiciliar (Sete de Setembro 6216 Seminário Curitiba)
}

\begin{abstract}
Introdução: O bem estar dos pacientes é uma das características do Home Care, uma vez que este paciente encontra-se em ambiente familiar, natural seu, e que proporciona-lhe mais conforto durante a execução de seu tratamento de saúde. $O$ enfermeiro de Home Care é figura chave para o sucesso do tratamento do paciente, já que neste ambiente diferente do hospitalar, as relações pessoais tornam-se maiores, e por consequência o nível de confiabilidade do paciente neste profissional torna-se maior, sendo a este confiado a execução de atividades profiláticas. A necessidade de uma assistência sistematizada para os pacientes com lesões na pele levou a Criação e implantação de uma Comissão de cuidados com a Pele (CCP) coordenada por uma Enfermeira Estomaterapeuta em um serviço de Home Care. Objetivo: Relatar a experiência de implantação da Comissão de Cuidados com a Pele (CCP) em um serviço de Home Care. Material e Métodos: Trata-se de um estudo descritivo, do tipo relato de experiência, realizado a partir da vivência da autora enquanto enfermeira da Comissão de Cuidados com a Pele (CCP) de um serviço de Home Care. Resultados: Diante do aumento da demanda e da necessidade de reforçar as ações relacionadas à segurança do paciente, com o objetivo de melhorar a assistência, principalmente no que tange à prevenção das lesões por pressão (LPP), foi criada então a Comissão de Cuidados com a Pele (CCP) em 2018. Esta Comissão é composta por uma equipe multidisciplinar (médico, nutricionista, assistente social, farmacêutica, fisioterapeuta, analista de auditoria, e enfermeiros) que atuam realizando reunião mensais para discussão dos casos e elaboração de protocolos embasados em evidências científicas atualizadas. Diante disso, a equipe da CCP criou um regimento, em conjunto com a Gerência de Enfermagem a partir do modelo de outros regimentos da instituição, e regulamenta as finalidades, composição da CCP e atribuições de seus membros. Os enfermeiros supervisores são capacitados sobre as ações tanto de prevenção como de tratamento de Lesões por Pressão e assim disseminam as informações no domicílio do pacientes aos profissionais de saúde, cuidadores e familiares com intuito de padronizar as ações e diminuir a incidência de LPP nos pacientes assistidos pelo Home Care. A implantação de uma Comissão de Cuidados com a Pele demonstrou sua efetividade através do impacto positivo constatado pela evolução favorável das lesões, utilização adequada da tecnologia disponível e pelo envolvimento multidisciplinar na campanha de prevenção de lesões por pressão. Destaca-se como ganho institucional a construção de protocolos que orientam condutas padronizadas, com o uso racional e adequado da tecnologia disponível, diminuindo gastos e minimizando riscos aos pacientes. Além do citado, o enfoque em prevenção de lesões por pressão e a utilização adequada de tecnologias estão em consonância com o movimento mundial de segurança do paciente.
\end{abstract}

Keywords: Lesão por Pressão, Promoção da Saúde, Home Care

\section{Referências Bibliográficas}

BRUM, M. L. B. et al. Protocolo de assistência de enfermagem a pessoas com feridas como instrumento para autonomia profissional. Rev Enferm UFSM, v. 5, n.1, p. 50-57, 2015.Disponível em: Acesso em 10 jul. 2019. CAUDURO, F.P. et al. ATUAÇÃO DOS ENFERMEIROS NO CUIDADO DAS LESÕES DE PELE. Rev enferm UFPE on line., Recife, 12(10):262834, out., 2018. Disponível em: Acesso em 10 jul. 2019. KRAUSE,T. C.C; ASSIS, G.M.; DANSKI, M.T.R. Implantação de uma Comissão de Cuidados com a Pele em um Hospital de Ensino. ESTIMA, v.14 n.1, p. 13-20, 2016. Disponível em: Acesso em 10 jul. 2019. 


\title{
Estado d arte sobre a utilização de ozonioterapia em tratamento de feridas.
}

\author{
Author(s): $\quad$ LIVIA DE SA ANDRADE ${ }^{1}$, Celia Maria de Oliveira ${ }^{1}$ \\ Institution(s) ${ }^{1}$ EEUFMG - FACULDADE DE ENFERMAGEM UFMG (AV. ALFREDO BALENA, 190, \\ SANTA EFIGENIA, BELO HORIZONTE)
}

\begin{abstract}
Introdução: avaliar uma ferida significa atribuir a ela especificidades que permitam estabelecer planos de tratamentos a fim de promover sua cicatrização. ${ }^{1} \mathrm{O}$ enfermeiro estomaterapeuta tem conhecimento para trabalhar com pessoas com feridas, estomizadas e com incontinência. ${ }^{2}$ É capaz de avaliar a pessoa com ferida de forma criteriosa e objetiva, com embasamento científico para implementar terapias. Visando favorecer a cicatrização utiliza medicamentos e coberturas selecionadas de acordo com a lesão existente. ${ }^{1}$ Neste cenário, o ozônio se apresenta como uma proposta inovadora para tratamento de feridas. 3 O ozônio medicinal está misturado ao oxigênio e sua porção atinge no máximo $5 \%$ do total da mistura. Entre as principais ações do ozônio está a germicida.4 É um potente agente antioxidante contra vírus, bactérias e fungos.4 Sua apresentação pode ser na forma de água, óleo ou gás e será aplicado na ferida de acordo com a avaliação realizada pelo profissional.5 Objetivo: identificar na literatura o uso do ozônio no tratamento de feridas. Método: revisão de literatura sobre a utilização de ozonioterapia em tratamento de feridas. Foi realizada busca na Biblioteca Virtual em Saúde, sendo utilizados os descritores: Estomaterapia; Ozonio; Feridas; Lesões; Enfermagem. Resultados: foram encontrados 92 artigos nas bases de dados, 50 apresentaram texto completo disponível gratuitamente, 14 artigos estavam de acordo com o tema proposto, seis eram estudos primários e compuseram a amostra. Discussão: a utilização do ozônio é ainda controversa. 6 Entretanto, sua ação bactericida foi descrita em todos os estudos quando utilizado em concentrações altas. 6 Considerações finais: Diante da comprovada ação bactericida do ozônio e da crescente incidência de contaminação de feridas por bactérias multirresistentes, mostra-se relevante a investigação sobre os efeitos do ozônio na cicatrização de feridas. Neste sentido, é necessário o desenvolvimento de estudos primários sobre a utilização do ozônio como modalidade terapêutica.
\end{abstract}

DECS: ESTOMATERAPIA; OZONIO; FERIDAS; LESOES; ENFERMAGEM.

Keywords: feridas, ozonio, estomaterapia, lesões, enfermagem

\section{Referências Bibliográficas}

REFERENCIAS 1. Borges EL et al. Feridas: como tratar. 2.ed. Belo Horizonte: Coopmed,2008. 2. Santos VLCG, Cesaretti IUR. Assistencia em estomaterapia: cuidando de pessoas com estomia. 2. ed. São Paulo: Editora Atheneu, 2008 3. BieringSorensen F, Thomsen C. Medical social and oc-cupational history as risk indications for low-back trouble in a general population. Spine. 1986;11(7):720-5 Disponivel em https://www.ncbi.nlm.nih.gov/pubmed/2947336 ; visualizado em 25/07/209 4. Marx J. Immunology. Antibodies kill by producing ozone. Science. 2002;298(5597):1319.11. Pereira MMS, Navarini A, Mimica LMJ, et al. Efeito de diferentes gases sobre o crescimento bacteriano: estudo expe-rimental "in vitro" Rev Bras Col Bras Cir. 2005;32(1):12-4. 5. Biering-Sorensen F, Thomsen C. Medical social and oc-cupational history as risk indications for low-back trouble in a general population. Spine. 1986;11(7):720-5. Disponivel em:

http://www.scielo.br/scielo.php?script=sci_arttext\&pid=S0100-69912005000100004; visualizado em25/07/2019. 6. .Tormin SC, et al. Análise do efeito bactericida do ozônio sobre bactérias multirresistentes. Arq. Med. Hosp. Fac Cien. Med Santa Casa São Paulo. 2016. Disponível em: http://arquivosmedicos.fcmsantacasasp.edu.br/index.php/AMSCSP/article/view/107, visualizado em 21/06/2019. 


\title{
ESCALAS DE AVALIAÇÃO DE ODOR EM FERIDAS NEOPLÁSICAS:UMA REVISÃo INTEGRATIVA
}

\author{
Marcos Antonio de Oliveira Souza ${ }^{2}$, Nauã Rodrigues de Souza ${ }^{2}$, Jessica Thamires da Silva Melo ${ }^{3}$ \\ Author(s): Maria Alessandra Campos Absalão Xavier ${ }^{4}$, Gabriela Lopes de Almeida ${ }^{2}$, Isabel Cristina Ramos \\ Vieira Santos ${ }^{2}$, Ayanne Sophia Brandão Duarte Sá ${ }^{5}$, Andreza Rafaelle da Silva Oliveira ${ }^{5,2}$, Renata \\ Ramos Menezes ${ }^{5}$ \\ Institution(s) ${ }^{2}$ UPE - Universidade de Pernambuco, FENSG (R. Dr. Otávio Coutinho - Santo Amaro, Recife ), ${ }^{3}$ \\ HGV - Hospital Getúlio Vargas (Av. Gen. San Martin, s/n - Cordeiro, Recife - PE), ${ }^{4}$ HUOC - \\ Hospital Universitário Oswaldo Cruz (R. Arnóbio Marquês, 310 - Santo Amaro, Recife - PE), ${ }^{5}$ \\ HCP - Hospital de Câncer de Pernambuco (Av. Cruz Cabugá, 1597 - Santo Amaro, Recife - PE)
}

\begin{abstract}
Introdução: O câncer constitui um problema de saúde publica, e nesse sentido, a Organização Mundial de Saúde (OMS) estima que seu impacto na população correspondera a mais de 20 milhões de casos novos para 2025 . Entre os pacientes com neoplasias, 5 a 10\% desenvolverão feridas relacionadas à doença, seja por consequência de um tumor primário ou por um processo de metástase das células malignas. O odor e a sintomatologia constante no dia a dia do paciente com ferida neoplásica, provocando náuseas e desencadeando o agravamento progressivo de seu estado nutricional, além de afligir as pessoas com quem se relaciona ou mesmo os profissionais de saúde e contato direto. Objetivo: Verificar a existência de instrumentos de avaliação do odor em feridas neoplásicas. Material e Método: Trata-se de uma revisão integrativa da literatura, construída por meio de análise sistemática e ampla dos estudos disponíveis no meio científico. O levantamento bibliográfico foi realizado entre setembro e outubro de 2016 nas bases de dados Lilacs, SCiELO, Ibecs e MedLine, incluindo publicações nacionais e internacionais. Resultados: Quanto aos tipos de estudo encontrados, verifica-se que a maioria foi de revisão (47\%), com maior frequência de revisões de especificação narrativa (33\%). Em relação à autoria, mais da metade dos artigos foi elaborada apenas por enfermeiros (53\%). Os anos de 2009 e 2014 apresentam maior quantitativo de publicações quando comparados aos demais. Quanto às bases de dados, a MedLine apresentou maior número de artigos $(n=12)$, seguido pela Lilacs $(n=2)$ e a lbecs $(n=1)$. Foram encontradas nove escalas, que apresentaram uma variação de pontuação de três a dez graus. Dentre estas, a maior frequência foi constituída por escalas de quatro graus (33\%). Das escalas encontradas, sete são direcionadas a avaliar especificamente a intensidade do odor e apenas duas avaliam a distância entre a fonte e o observador. Quanto à autoria, a maior parte delas não apresentava autor declarado (56\%), e a mais usada dentre elas foi o Guia de avaliação do odor (33\%), de natureza quali-quantitativa, que pontua o sintoma em quatro níveis. Das nove escalas encontradas, apenas uma é validada, a escala de Teler. Discussão: O manejo das feridas neoplásicas com mau odor representa um dos problemas mais difíceis para os enfermeiros no ambiente hospitalar e comunitário. Esse profissional necessita não só da habilidade de avaliação, mas de estar munido de instrumentos válidos e confiáveis para padronizar a comunicação interdisciplinar e, desta forma, utilizar produtos adequados para tratar o sintoma, assegurando aos pacientes uma melhor qualidade de vida. Conclusões: Os resultados deste estudo demonstraram que até o momento só existe uma escala de avaliação do odor em feridas neoplásicas validada, apontando para necessidade de desenvolvimento de novas ferramentas que incorporem na pratica clínica instrumentos validados e confiáveis.
\end{abstract}

Keywords: Escalas, Estomaterapia, Ferimentos e lesões, Odor

\section{Referências Bibliográficas}

Instituto Nacional de Cancer Jose Alencar Gomes da Silva. Estimativa 2016: incidencia de cancer no Brasil.[acesso em 8 jan 2017]. Disponível em: http://www.inca.gov.br/bvscontrolecancer/publicacoes/edicao/Estimativa_2016.pdf Matsubara MGS, Villela DL, Hashimoto SY, Reis HCS, Saconato RA, Denardi UA, et al. Feridas e estomas em oncologia: uma abordagem interdisciplinar. 1a edição São Paulo: Lemar; 2011. Gomes IP, Camargo TC.Tumoral skin lesions and nursing care: in search of evidences on symptoms management. Rev Enferm UERJ[Internet]. 2004[acesso em 2017 Jan 8];12(2):211-16. Disponível em: //www.facenf.uerj.br/v12n2/v12n2a14.pdf Portuguese 


\title{
REVISÃO DA LITERATURA SOBRE AS PRINCIPAIS CARACTERÍSTICAS DE LESÕES POR PRESSÃO EM IDOSOS
}

\author{
Author(s): Cristiane Regina Soares ${ }^{1}$ \\ Institution(s) ${ }^{1}$ SBIBHAE - UVM - SBIB Hospital Albert Einstein - Vila Mariana (Rua Madre Cabrini, 463)
}

\begin{abstract}
Introdução: O elevado crescimento da população idosa está relacionado às mudanças demográficas e epidemiológicas, diante disso observa-se a necessidade de se realizar pesquisas com foco nessa população e, consequentemente aos problemas a que estão expostas como, por exemplo, a ocorrência de lesões por pressão (LPs). A própria fisiologia do envelhecimento abarca uma diminuição na reserva funcional. Sendo assim, o idoso reduz a sua mobilidade, às vezes permanece acamado, com um alto risco de desenvolver lesões, devido, a pressão constante em áreas de proeminências ósseas. Essa pressão pode ocasionar hipóxia e redução dos nutrientes no tecido da região exposta à pressão e resultar em morte celular, pois, ocorre uma considerável interferência na circulação sanguínea. Sendo assim, a proposta dessa revisão é reunir estudos que possibilitem subsidiar a assistência de enfermagem, vislumbrando o aumento da população idosa ao longo dos anos, juntamente com as próprias características do envelhecimento e a importância no manejo das LPs.(1-4) Objetivo: Identificar as principais contribuições da literatura cientifica em relação às características das LPs em idosos. Método: Pesquisa realizada pelo método de revisão da literatura, da qual, a pergunta de pesquisa norteadora da revisão foi: Quais são as principais contribuições da literatura cientifica em relação às características das lesões por pressão em idosos?. A base de dados selecionada foi a Biblioteca Virtual em Saúde (BVS) e a busca foi realizada no mês de julho de 2019. Utilizaram-se os descritores de assunto lesão por pressão e idoso. Os critérios de inclusão foram artigos científicos disponíveis na íntegra, somente no idioma em português e estudos publicados nos últimos cinco anos (2015 a 2019). Dessa maneira, foram encontrados 35 artigos, dos quais, após a leitura dos resumos foram selecionados quatro artigos para a leitura na íntegra e análise dos resultados.(5) Resultados: O total de LPs avaliadas nos quatro estudos foram aproximadamente 150 feridas. A região de maior acometimento das lesões é na região sacral em três estudos, enquanto que em uma pesquisa a região de maior incidência das feridas foi nos calcâneos, seguida da região sacral. Quanto ao estágio, a maioria dos estudos apontaram o estágio 1 ou 3 nas LPs. O principal local de desenvolvimento das LPs foi ao momento da hospitalização. Os estudos demonstraram uma forte relação entre o tempo de dias de internação e a mobilidade reduzida, seja para as atividades de vida diárias ou mobilidade no leito, com o desenvolvimento de LPs.(1-4) Conclusões: As LPs são um evento de ocorrência expressiva entre os idosos, causando sofrimento físico e emocional, indicando que medidas preventivas devem ser incluídas na atuação das equipes de enfermagem.
\end{abstract}

Keywords: Lesão por pressão , Idoso, Estomaterapia

\section{Referências Bibliográficas}

1. Alves CTRR, Junqueira EMD, Cançado FB, Fonseca ALS, Gil LF, Sanches FG, Couto MA. Acompanhamento de lesões por pressão em uma unidade de internação. Cuid Arte Enfermagem. 2018; Jan.-Jun;12(1):45-51. 2. Vieira CPB, Furtado AS, Almeida PCD, Luz MHBA, Pereira AFM. Prevalência e caracterização de feridas crônicas em idosos assistidos na atenção básica. Rev baiana enferm. 2017; 31(3):e17397. 3. Queiroz ACCM, Mota DDCF, Bachion MM, Ferreira ACM. Úlceras por pressão em pacientes em cuidados paliativos domiciliares: prevalência e características. Rev Esc Enferm USP. 2014; 48(2):264-71. 4. Petz FFC, Crozeta K, Meier MJ; Lenhani BE, Kalinke LP, Pott FS. Úlcera por pressão em unidade de terapia intensiva: estudo epidemiológico. Rev enferm UFPE on line., 2017 Jan; 11(Supl. 1):287-95. 5. Mendes KDS, Silveira RCCP, Galvão CM. Revisão integrativa: método de pesquisa para a incorporação de evidências na saúde e na enfermagem. Texto \& contexto enferm. 2008 Out-Dez; 17(4):758-64. 


\title{
ABORDAGEM MULTIDISCIPLINAR NO MANEJO DE LESÕES PERIANAIS POR DOENÇA DE CROHN FISTULIZANTE COM NOVASOURCE PROLINE $®$ E COBERTURA DE HIDROFIBRA ALGINATO AG®
}

\author{
Author(s): Silvia Alves da Silva Carvalho ${ }^{1}$, Fábio Correa Bento ${ }^{1}$, Maria da Glória Silva ${ }^{1}$ \\ Institution(s) ${ }^{1}$ CHPBG - COMPLEXO HOSPITALAR PADRE BENTO DE GUARULHOS (Av. Emílio Ribas, \\ 1819 - Gopouva, Guarulhos - SP, 07051-000)
}

\begin{abstract}
A Doença de Crohn (DC) é um processo inflamatório crônico de etiologia desconhecida, não curável por tratamento clínico ou cirúrgico, acomete o trato gastrointestinal de forma uni ou multifocal com intensidade variável e transmural. ${ }^{1}$ No intestino delgado e intestino grosso podem ocorrer manifestações perianais. As fítulas perianais compreendem uma doença comum e desabilitadora da doença de crohn e acomete cerca de $20 \%$ a $43 \%$ dos pacientes, associada a dor, isolamento social e redução da qualidade de vida. ${ }^{3}$ As manifestações clínicas mais frequentes são de natureza inflamatória, obstrutiva, etenosante e/ou fistulizante. ${ }^{4}$

R.P.S. M, 21 anos, sexo masculino, solteiro, natural e procedente de São Paulo,com diagnóstico de Doença de Crohn/há 10 anos, em tratamento com terapia imunobiológica, estomizado há 01 ano e 04 meses, nega queixas gástricas com fístula perianal, apresentando abscessos em glúteos (drenados). Ao exame MEG, A2, L2, B2= 5, IAHB = 6 leve, IADC= 7 leve evolui desnutrido, desidratado, emagrecido com IMC 14,72 com dor de intensidade 4 score de 0 a 5 . Lesão em região peri fístula perianal com perda tecidual, bordas irregulares, maceradas, leito com tecido inviável desvitalizado, infectada e com características de biofilme presente medindo longitudinal 5,5mm X 3, 2mm transversal e apresenta descolamento muco cutâneo, com trajeto fistuloso medindo $6,5 \mathrm{~mm}$ às $3 \mathrm{~h}$. Relata episódios de hipertermia vespertina $38^{\circ} \mathrm{C}$, exsudato espesso purulento de odor fétido de coloração marrom.

CONDUTA ESTOMATERAPEUTA

Geral: Solicitado todos os exames de controle (tabela) e sorologias (HIV, HEPATITES) a procura de resultados que interfiram na cicatrização, houve diminuição dos seguintes exames: Hematócrito, Plaquetas, Hemoglobina, Albumina, transferrina, magnésio,ferretina,cálcio total,vitamina D, Vitamina A, Zinco sérico. Discutido caso com o coloproctologista assistente e solicitado também exames de imagem EDA/RNM. (correção do Hb e Ht com ferro oral).

Especifico: Preparo do leito da ferida, retirada do tecido desvitalizado e biofilme com desbridamento mecânico e autolítico, aplicado creme barreira em pele peri lesão.

SUPORTE NUTRICIONAL

- Dieta VO, consistência normal, Hipercalórica/Hiperproteica

- Valor calórico total da dieta ( VO + SNO) : $2.526 \mathrm{Kcal} / \mathrm{dia}$

- Valor protéico total da dieta : 167,8 g/dia = 4,4 g/kg/PA/dia

SUPLEMENTAÇÃO

Enriquecida com prolina e arginina, zinco, selênio, Vitaminas A, C e E, sem sacarose, hiperproteica (Proline $\left.{ }^{\circledR}\right)$.

Indicação: cicatrização das lesões por pressão e outras afecções teciduais.

Posologia: 03 unidades/dia

Resultados: O manejo da lesão peri fístula com hidrofibra de alginato com prata iônica e terapia nutricional, demonstrou efetividade no processo cicatricial, com sua ação antimicrobiana, favorecendo a a granulação tecidual através do controle do meio úmido e liberação sustentado de prata iônica em meio potencialmente contaminado. A abordagem multidisciplinar associada a introdução de Proline $\AA$ acelerou o processo contribuindo para um percentual granulação significativo ( $69 \%$ a $97 \%$ ), controle dos sintomas e melhoria da satisfação do paciente. (Registros em gráficos de evolução cicatricial.
\end{abstract}

Keywords: Feridas, Estomaterapia, Enfermagem DII, Doença Inflamatória Intestinal, Nutrição Clínica,

\section{Referências Bibliográficas}

1. Habr-Gama A. et al. Doença de Crohn intestinal. Rev Assoc Med Bras. 2011;57(1):10-13. 2. Cardozo WS, Sobrado CW. Doença inflamatória intestinal. 2. ed. - Ed. Manole -SP, 2015. 3. Kotze PG, Shen B,Lightner A, et al. Modern management of perianal fistulas in Crohn's disease: future directions Gut Epubahead of print: [pleaseinclude Day Month Year].doi:10.1136/gutjnl-2017-314918. 4. Cesaretti UR, Santos VLCG. Assistência em Estomaterapia. Cuidando de Pessoas com Estomia. Ed. Atheneu,2015; 14: 190. 1 Enf. Estomaterapeuta Complexo Hospitalar Padre Bento - SP 2 Enf. Estomaterapeuta ICESP - SP. 5. Montreal, 2005. Escala de classificação de Montreal. 6. Harvey RF, Bradshaw, Lancet, 1980:I:514. Escala Indice de Atividade Inflamatória Harvey e Bradshaw. 7. Best WR, et AL, 1976. Escala IADC Indice de Atividade Inflamatória Crohn- Crohn`s Disease Index 8. MS, Circular Normativa n 9/DGCG de 14/6/2003- Escala de Dor (faces e numérica). 


\title{
BIOFILME E SUAS CARACTERÍSTICAS EM ÚLCERAS VARICOSAS
}

\author{
Susiane Sucasas Frison Frison ${ }^{1}$, Eline Lima Borges ${ }^{1}$, Kinulpe Honorato-Sampaio Honorato- \\ Sampaio $^{2}$, Antônio Carlos Martins Guedes Guedes ${ }^{1}$ \\ Author(s): \\ Institution(s) ${ }^{1}$ UFMG - Universidade Federal de Minas Gerais (Av. Professor Alfredo Balena. 190. Santa
Efigênia. Belo Horizonte. MG.), ${ }^{2}$ UFGJM - Universidade Federal dos Vales do Jequitinhonha e \\ Mucuri (Rua da Glória, nº 187, Centro, Diamantina - MG)
}

\begin{abstract}
Introdução: a maior parte do conhecimento a respeito dos biofilmes é proveniente de estudos com Pseudomonas aeruginosa e Staphylococcus aureus. Diferem das bactérias planctônicas em sua estrutura, expressão gênica, resistência aos antibióticos e interação com o hospedeiro. As células microbianas que residem em substâncias poliméricas extracelulares normalmente ocupam $5 \%$ a $30 \%$ do volume do biofilme(1). As úlceras venosas são colonizadas por bactérias que podem ser capazes de garantir a sua sobrevivência e evolução por meio da formação de biofilmes, que apresentam múltiplos mecanismos de defesa e sobrevivência a ataques virais, a desidratação, a tensão de cisalhamento, a agentes antimicrobianos, a ação de antibióticos e a imunidade do hospedeiro(2). Estudos que descrevam as características dos biofilmes em úlceras venosas são escassos(2-3). Objetivos: analisar as características do biofilme de úlceras venosas, identificar a sua localização, caracterizar a sua formação e relacionar a presença do mesmo com os dados da úlcera referentes ao seu tempo de existência, área lesada e tecido necrótico. Material e Método: trata-se de um estudo descritivo envolvendo 44 pacientes com úlcera venosa de onde foram coletados dois fragmentos por meio de biópsia com punch $3 \mathrm{~mm}$ sob técnica asséptica, perfazendo 88 amostras. Os fragmentos que apresentaram ausência de bactérias à análise por meio da bacteriologia foram eliminados do estudo, resultando em 42 fragmentos, correspondendo a úlcera de 21 pacientes, que passaram por análise da microscopia eletrônica de transmissão (MET). As úlceras foram fotografadas, classificadas quanto ao tempo de existência, a área lesada e o tecido necrótico foram mensurados. A pesquisa respeitou os preceitos da resolução $n^{\circ} 4.66$ e foi aprovada pelo Comitê de Ética em Pesquisa da Universidade Federal de Minas Gerais, protocolo no ETIC 112/09. Resultados: dos 42 fragmentos de úlceras venosas analisados, três (7\%) apresentaram biofilmes bacterianos, correspondendo a três participantes (14\%). Verificou-se que os biofilmes em úlceras venosas podem ser mono ou polimocrobianos. A Pseudomonas aeruginosa foi a bactéria encontrada com maior frequencia nos biofilmes detectados. $O$ biofilme não estava presente na superfície, mas sim em camada um pouco mais abaixo. A detecção de biofilmes em lesões crônicas não teve relação direta com o tempo de existência da mesma. Não foi possível estabelecer uma correlação entre o tamanho da lesão e a presença desses microrganismos pelo pequeno tamanho amostral (três). A presença de neutrófilos em pacientes com e sem biofilmes foi observada, indicando a persistência do estado inflamatório das úlceras venosas, provavelmente causado por esses microrganismos. Conclusão: achados indicam que a detecção do biofilme em úlcera venosa não é usual. Há necessidade de desenvolvimento de pesquisas que possam contribuir para a detecção do biofilme na prática clínica.
\end{abstract}

Keywords: Biofilmes Bacterianos, Úlcera varicosa, Cuidado de Enfermagem

\section{Referências Bibliográficas}

1-Zhao G, Usui ML, Lippman SI, James GA, Stewart PS, Fleckman P, et al. Biofilms and Inflammation in Chronic Wounds. Advances in wound care. 2013 Sep;2(7):389-399. 2-Bianchi T, Wolcott RD, Peghetti A, Leaper D, Cutting K, Polignano R. et al. Recommendations for the management of biofilm: a consensus document. J Wound Care. 2016 Jun;25(6):305-17. doi: 10.12968/jowc.2016.25.6.305. 3-Pugliese DJ. Infection in Venous Leg Ulcers: Considerations for Optimal Management in the Elderly. Drugs Aging, 2016 Feb.;33(2):87-96. 


\title{
AVALIAÇÃO DA EFICÁCIA DE UM TREINAMENTO RELACIONADO À PREVENÇÃO DE LESÃO POR PRESSÃO
}

\author{
Author(s): Maria Carolina Pinto Martins ${ }^{1}$, Vanessa Abreu da Silva ${ }^{2}$, Angélica Olivetto de Almeida ${ }^{2}$, Ivan \\ Rogério Antunes ${ }^{2}$, Alessandra Nazareth Cainé Pereira Roscani ${ }^{2}$, Renata Cristina Gasparino ${ }^{1}$ \\ Institution(s) ${ }^{1}$ Fenf-UNICAMP - Faculdade de Enfermagem da Universidade Estadual de Campinas \\ (Universidade Estadual de Campinas - Unicamp Rua Tessália Vieira de Camargo, 126), ${ }^{2} \mathrm{HC}$ - \\ UNICAMP - Hospital de Clínicas da Universidade Estadual de Campinas (Hospital de Clínicas da \\ UNICAMP | Rua Vital Brasil, 251 - Cidade Universitária ")
}

\begin{abstract}
Introdução: A Lesão por Pressão (LP) tem sido um dos eventos adversos mais notificado no Brasil nos últimos anos. A literatura tem mostrado um conhecimento insatisfatório dos profissionais de enfermagem sobre a prevenção de LP, o que torna fundamental capacitações para qualificar a assistência e garantir a segurança do paciente. Objetivo: Validar um instrumento de auditoria e avaliar a eficácia de um treinamento para implementação de medidas de prevenção de LP. Método: Estudo quase-experimental, conduzido em cinco enfermarias de um hospital universitário, em Campinas. O estudo foi desenvolvido em quatro etapas: 1) validação de conteúdo do instrumento de auditoria de prevenção de LP, por seis juízes. A concordância entre os juízes foi mensurada por meio do Índice de Validade de Conteúdo e valores acima de 0,9 foram considerados satisfatórios; 2) auditoria para avaliar se as medidas de prevenção de LP, descritas no protocolo institucional, estavam sendo implementadas pela equipe de enfermagem; 3) capacitação da equipe de profissionais de enfermagem, por meio da simulação clínica, com aplicação de pré e pós teste. As notas dos participantes, nesses testes, poderia variar entre zero (nenhum conhecimento) e dez (total conhecimento) e a comparação das notas no pré e pós-teste foi avaliada por meio do teste de Mann Whitney; 4) auditoria para avaliar a implementação das medidas de prevenção de LP, após intervenção educativa. Resultados: $O$ instrumento de auditoria, após duas rodadas, foi validado pelos juízes com um Índice de Validação de Conteúdo superior a 0,9. A versão final possui 33 itens divididos em quatro subtítulos. Na primeira auditoria, participaram 28 pacientes e a taxa de conformidade da implementação das medidas de prevenção de LP foi de $71,6 \%$. Na capacitação, participaram 127 profissionais de enfermagem (72\% do total) e a média de acertos no pré e pós-teste respectivamente, por grupo profissional, foi de 7,9 ( $\mathrm{DP}=1,3)$ e $8,4 \quad(\mathrm{DP}=1,2)(\mathrm{p}=0,0007)$ para os técnicos de enfermagem e 8,3 $(\mathrm{DP}=0,7)$ e 8,6 ( $\mathrm{DP}=0,8)$ para os enfermeiros $(p=0,0299)$. Na auditoria, realizada dois meses após a capacitação, em 28 pacientes, a taxa de conformidade foi $63,8 \%$. Conclusão: $O$ instrumento para auditoria de prevenção de LP foi validado. Na simulação clínica, médias superiores foram encontradas no pós-teste o que demonstra a aquisição do conhecimento. No entanto, quando avaliou-se o terceiro nível de aprendizagem, mudança de comportamento ou aplicação, não obteve-se o resultado esperado, demonstrando que outros fatores interferem na mudança de comportamento, considerando que apesar da equipe ter agregado conhecimento com a capacitação, as atitudes ainda não foram alteradas na prática clínica.
\end{abstract}

Keywords: Capacitação em serviço, Enfermagem, Estomaterapia, Lesão por Pressão, Segurança do Paciente

\section{Referências Bibliográficas}

1. Brasil. Agência Nacional de Vigilância Sanitária (Anvisa). Relatórios de Eventos adversos notificados à Anvisa. Publicações [internet]. 2019. Disponível em:

https://www20.anvisa.gov.br/segurancadopaciente/index.php/publicacoes/category/relatorios-dos-estados 2. Galvão NS, Serique MAB, Santos VLCG, Nogueira PC. Knowledge of the nursing team on pressure ulcer prevention. Rev Bras Enferm [Internet]. 2017;70(2):294-300. Disponível em: http://www.scielo.br/scielo.php?script=sci_arttext\&pid=S0034-

71672017000200294 3. Coluci MZO, Alexandre NMC, Milani D. Construção de instrumentos de medida na área da saúde. Ciênc. saúde coletiva [Internet]. 2015;20(3):925-36. Disponível em: http://www.scielo.br/scielo.php?pid=S1413$81232015000300925 \&$ script=sci_abstract\&tlng=pt 


\title{
DESENVOLVIMENTO DE MANUAL PARA ENFERMEIROS COM FOCO NA PREVENÇÃO DE SKIN TEARS EM IDOSOS
}

Yara Lanne Santiago Galdino ${ }^{1}$, Bárbara Dirce da Silva Holanda ${ }^{2}$, Lidiana Lacerda de Lima ${ }^{2}$, Ana Author(s): Carolina de Oliveira e Silva ${ }^{2}$, Petra Kelly Rabelo de Sousa ${ }^{2}$, Geórgia Catunda Gomes ${ }^{2}$, Luciana Catunda Gomes de Menezes ${ }^{2}$

Institution(s) ${ }^{1}$ CSM - CENTRO DE SAÚDE MEIRELES (Av. Antonio Justa 3113. Meireles. Fortaleza- Ceará), ${ }^{2}$ FAMETRO - FAMETRO (Rua Conselheiro Estelita No 500 - Centro. Fortaleza-Ceará)

\begin{abstract}
INTRODUÇÃO: A lesão por fricção ou skin tears (ST) é uma lesão rasa, limitada à derme e que tem como característica principal a presença de um retalho de pele1. Apresenta diversos fatores contribuintes, dentro deles, destaca-se a idade2, além também de existir pouco conhecimento dos enfermeiros com relação ao direcionamento de sua conduta prática para o manejo de ações preventivas e de tratamento. Diante dessa condição e reconhecendo a importância da construção de novas estratégias educativas por meio de manuais, esse estudo teve como OBJETIVO: Desenvolver um manual para enfermeiros com foco na prevenção de skin tears em idosos. MÉTODO: Trata-se de uma pesquisa metodológica3, do tipo desenvolvimento, realizada no mês de março a junho de 2019 em Fortaleza-Ceará-Brasil. Por se tratar da primeira etapa do estudo metodológico, não foi enviado para o Comitê de Ética e Pesquisa, pretende-se validar o conteúdo, a aparência e a clínica em estudo posterior. RESULTADOS: A etapa da construção do manual ocorreu em duas fases: 1) Levantamento bibliográfico e 2) Construção do manual educativo. Na primeira fase, foi realizado um levantamento do tipo Revisão Narrativa, usando os Descritores em Ciências da Saúde (DeCS): "Ferimentos e Lesões"; "Prevenção"; "Educação em Saúde" e "Idoso", nos idiomas português, inglês e espanhol, em duas bases de dados: National Library of Medicine (PUBMED/MEDLINE), Literatura Latino-Americana e do Caribe em Ciências da Saúde (LILACS), na Biblioteca Eletrônica Scientific Electronic Library Online (SCIELO), além da consulta na dissertação de Strazzieri-Pulido4, em livros e em manuais para compor a amostra dos conteúdos científicos. Na segunda fase, o manual foi construído em dois momentos: a) Seleção de ilustração (realizada por um design gráfico e por imagens retiradas da internet) e b) Montagem do Manual. $O$ manual educativo para enfermeiros intitulado "Skin Tears: Conhecendo Para Prevenir", contém 36 páginas e é composto por elementos pré-textuais (capa, contracapa, apresentação e sumário); textuais (figuras e textos) e pós-textuais (referências bibliográficas). Os assuntos abordados no manual foram: Camadas da pele, Definição das Skins Tears, Classificação seguindo as recomendações do "STAR Skin Tear Classification System4, Fatores intrínsecos e extrínsecos associados ao desenvolvimento das Skins Tears e Topografias corporais mais atingidas. Em relação as medidas preventivas, esse foi o maior conteúdo, e subdividido em: Cuidados com a pele (Proteger áreas frágeis e delgadas; Mobilizar os indivíduos de acordo com as técnicas preconizadas; Evitar o uso de fitas e curativos adesivos; Evitar o uso de sabão, detergentes e perfumes; Evitar banhos quentes e prolongados; Hidratar a pele; Evitar massagear a pele; Manter as unhas aparadas e lixadas, dentre outros); Promoção de nutrição e hidratação adequada; Promoção de um ambiente seguro e algumas outras dicas para prevenir as skins tears. Pra registrar as dúvidas que possam surgir, o manual finaliza com uma página contendo "Dúvidas? Anote aqui!" Nos elementos pós-textuais, encontra-se as referências, na qual destaca-se a dissertação de Strazzieri-Pulido4. Espera-se que este manual educativo possa contribuir na melhoria da assistência a pacientes idosos e sirva como orientação para a prática clínica de enfermeiros.
\end{abstract}

Keywords: Enfermagem, Ferimentos e Lesões, Prevenção, Manuais, Tecnologia educativa

\section{Referências Bibliográficas}

1. Sanada $\mathrm{H}$. et al. Incidence of skin tears in the extremities among elderly patients at a long term medical facility in Japan: A prospective cohort study. Geriatrics \& gerontology international, 2015, v. 15, n. 8, p. 1058-1063. 2. Strazzieri-Pulido KC, Santos VLC de G, Carville K. Adaptação cultural, validade de conteúdo e confiabilidade interobservadores do" STAR Skin Tear Classification System". Revista Latino-Americana de Enfermagem, 2015, v. 23, n. 1, p. 155-161. 3. Polit DF, Beck CT. Fundamentos de pesquisa em enfermagem: avaliação de evidências para a prática da enfermagem. 7. ed. Porto Alegre: Artmed; 2011. 669 p. 4. Strazzieri-Pulido KC. Adaptação cultural e validação do instrumento "Star Skin Tear Classification System, para a língua portuguesa no Brasil, apresentada à Escola de Enfermagem, Universidade de São Paulo, São Paulo, SP, Brasil; 2010. 


\title{
O Papel do Enfermeiro no Tratamento de Lesões no que Transcende a Qualidade de Vida do Paciente: Um Relato de Caso
}

\author{
Author(s): $\quad$ PRISCILA RAIBOLT PAZINATTO PINTO ', ANA CRISTINA BARBOSA KRUCHAK ${ }^{1}$ \\ Institution(s) ${ }^{1}$ HGeRJ - HOSPITAL GERAL DO RIO DE JANEIRO (Av. Duque de Caxias, 1551 - Deodoro, Rio de Janeiro - \\ RJ, 21615-220)
}

\begin{abstract}
INTRODUÇÃO

A celulite infecciosa caracteriza-se pela infecção da pele e tecidos moles (IPTMs), pode ser desencadeada pela entrada de bactérias através da barreira da pele. Apresentam inflamação aguda, difusa, edematosa, supurativa com bordas mal delimitadas que estendem-se atingindo derme e tecido subcutâneo. Os agentes mais prevalentes são o S. Aureus e o estreptococos do grupo A. As IPTMs estão entre as principais causas de comparecimento ao Pronto Socorro e se não tratadas adequadamente podem evoluir com complicações. Neste cenário a Enfermagem, através da Estomaterapia, apresenta-se como grande aliada no tratamento de feridas de difícil cicatrização. Estudos apontam que lesões de significativa necrose tecidual podem não apresentar resposta efetiva ao tratamento isolado com antimicrobianos, necessitando desbridamento.

OBJETIVO Relatar a experiência dos cuidados de Enfermagem a paciente com celulite infecciosa, com uso de cobertura Tecnologia Lípido Coloide - carboximetilcelulose e partículas lipofílicas composta por fibras poliabsorventes impregnada com prata (TCL-Ag).

MATERIAL E MÉTODO Estudo descritivo tipo relato de experiência ocorrido em Hospital de grande porte do RJ, no período de maio a agosto de 2019. Pesquisa autorizada pela instituição e contemplando os princípios éticos e legais da Resolução do Conselho Nacional de Saúde (CNS) ํ 466/12. Utilizado pesquisa ao prontuário, avaliação da evolução da lesão acompanhada por exame físico e registro fotográfico por enfermeiros, e busca teórica na base de dados SCIELO.

RESULTADOS Paciente, sexo feminino, 78 anos, queda de própria altura sete dias antes da entrada hospitalar, apresenta lesão em antebraço esquerdo medindo $16 \times 10 \mathrm{~cm}$, aspecto bolhoso, hiperemiada, edemaciada e dolorosa, diagnóstico médico celulite infecciosa, indicado internação. Realizado antibióticoterapia endovenosa, desbridamento cirúrgico, hemotransfusão e uso de terapias tópicas (hidrofibra com prata e papaína 10\%) sem melhora significativa. Evolução para categoria 3 , extensa necrose e esfacelo medindo $15 \times 9 \mathrm{~cm}$ e $6 \times 3 \mathrm{~cm}$, exsudativa, bordas hiperemiada, mal delimitadas. Ao décimo oitavo de internação realizado novo desbridamento cirúrgico e iniciado terapia tópica TLC-Ag. Trocas com intervalo de $96 \mathrm{~h}$. Após a primeira semana apresentou redução para $10 \times 7 \mathrm{~cm}$ e $3 \times 2 \mathrm{~cm}$, diminuição do esfacelo em substituição ao tecido vitalizado. Indicado alta hospitalar com trocas programadas para sete dias. Após a quinta troca a lesão menor apresentou-se praticamente cicatrizada, e a maior redução satisfatória para 7x2cm, baixa exsudação, tecido granulação prevalente, ausência de dor, bordas e pele perilesão íntegra. Sétima troca, lesão $5 \times 1,5 \mathrm{~cm}$, totalmente granulada, substituído uso para cobertura sem Prata. Paciente liberada na nona semana com lesão cicatrizada.

CONCLUSÕES A eleição da cobertura é uma tarefa desafiadora, exige capacidade técnica, acompanhamento da lesão e conhecimento das tecnologias disponíveis. O uso do curativo TCL-Ag foi uma ótima escolha para o tratamento deste caso, sua ação autolítica e antimicrobiana, combinado a absorção do exsudato residual manteve a umidade ideal, favorecendo a cicatrização, promovendo conforto e qualidade de vida ao paciente, reduzindo custos de uma internação prolongada. A presença do enfermeiro, dotado de expertise no tratamento de lesões é primordial, suas ações devem abranger não apenas o tratamento restaurador, mas também ações preventivas, e controladoras de agravos, meta do planejamento assistencial de Enfermagem na promoção da qualidade, no cuidado e na segurança do paciente.
\end{abstract}

Keywords: ESTOMATERAPIA, ENFERMAGEM, CELULITE, LESÃO

\section{Referências Bibliográficas}

Souza C. INFECÇÕES DE TECIDOS MOLES: ERISIPELA. CELULITE. SÍNDROMES INFECCIOSAS MEDIADAS POR TOXINAS. RMRP [Internet]. 30dez.2003 [citado 10ago.2019];36(2/4):351-6. Available from: http://www.revistas.usp.br/rmrp/article/view/733 Malheiro LF, Magano R, Ferreira A, Sarmento A, Santos L. Infecções da pele e de tecidos moles na unidade de terapia intensiva: estudo retrospectivo em um centro terciário. Rev. bras. ter. intensiva [Internet]. 2017 June [cited 2019 Aug 10] ; 29( 2): 195-205. Available from: http://www.scielo.br/scielo.php?script=sci_arttext\&pid=S0103-507X2017000200195\&Ing=en. Epub June 12, 2017.

http://dx.doi.org/10.5935/0103-507x.20170019 Valiati, LS, Corrêa, NC, Geist, JGB, Campos, LEC. ERISIPELA E CELULITE. Acta med. (Porot Alegre); 33(1): [6], 21 dez. 2012. Gonçalves MBB, Rabeh SAN, Nogueira PC. Revisão - Terapia Tópica para Ferida Crônica: Recomendações para a Prática Baseada em Evidências. Rev Estima. 2014; 12 (1): 42 - 49. Disponível em: https://www.revistaestima.com.br/index.php/estima/article/view/337 Mendonça PK, Loureiro MDR, Frota OP, Souza AS. PREVENÇÃO DE LESÃO POR PRESSÃO: AÇÕES PRESCRITAS POR ENFERMEIROS DE CENTROS DE TERAPIA INTENSIVA. Texto contexto enferm. [Internet]. 2018 [citado 10ago.2019]; 27(4): e4610017. Available from: http://www.scielo.br/scielo.php?script=sci_arttext\&pid=S0104-07072018000400310\&Ing=en. Epub Nov 01, 2018. http://dx.doi.org/10.1590/0104-07072018004610017 


\title{
PREVALÊNCIA DE LESÃO DE PELE RELACIONADA A INSUMOS ADESIVOS E FATORES ASSOCIADOS EM UNIDADES CRÍTICAS CARDIOLÓGICAS
}

\author{
Author(s): Caroline Maria Pereira Alcântara ${ }^{1}$, Paula Cristina Nogueira ${ }^{1}$, Evellyn Lima da Silva Oliveira ${ }^{1}$, \\ Vera Lúcia Conceição de Gouveia Santos ${ }^{1}$, Ticiane Faustino Campanili ${ }^{1}$ \\ Institution(s) ${ }^{1}$ EEUSP - Escola de Enfermagem da USP (Av. Dr. Enéas Carvalho de Aguiar, 419)
}

\begin{abstract}
Introdução: A manutenção da integridade da pele é um indicador da qualidade da assistência de enfermagem. Nos serviços de saúde, as Lesões de Pele Relacionadas a Insumos Adesivos (LPRIA) são significativas, mas subvalorizadas, e tem potencial impacto nos resultados, satisfação e segurança dos pacientes.Os insumos adesivos, definição por tradução livre proposta por um grupo de especialistas que discutem o tema no Brasil, são comumente utilizados nos serviços de saúde. Compõem uma variedade de produtos que incluem: fitas, curativos, eletrodos, barreiras de estomas, entre outros. Se a técnica para remoção de adesivo não for utilizada de forma adequada, camadas da pele são removidas, o que não só afeta a integridade da pele, mas também causa dor, risco de infecção, retarda a cicatrização e, além disso, aumenta o tempo de internação hospitalar e consequentemente os custos para as Instituições. Objetivo: identificar e analisar a prevalência pontual de lesão de pele relacionada a insumos adesivos em pacientes internados em Unidades de Terapia Intensiva cardiológicas e os fatores demográficos e clínicos associados à sua ocorrência, com foco na qualidade da assistência e segurança do paciente. Método: Estudo observacional, epidemiológico, transversal e quantitativo conduzido nas Unidades de Terapia Intensiva de dois hospitais públicos, referência em cardiologia, localizados no município de São Paulo. A população do estudo foi constituída por todos os pacientes adultos e idosos internados nas UTI dos dois hospitais e a amostra foi constituída daqueles com idade maior ou igual a 18 anos e foram excluídos os pacientes que não estavam presentes na unidade no período de coleta de dados. A coleta dos dados foi realizada em um único dia por enfermeiros estomaterapeutas e enfermeiros especialistas em cardiologia que atuam com lesões de pele.Foram coletados dados demográficos e clínicos dos prontuários dos pacientes e as lesões foram identificadas por meio de inspeção da pele. Os dados foram analisados por meio de estatística descritiva, análises bivariada e multivariada. $\mathrm{O}$ estudo foi aprovado pelo Comitê de Ética em Pesquisa da Escola de Enfermagem da Universidade de São Paulo (№ parecer: 2.830.965). Resultados: 28 pacientes apresentaram lesão, perfazendo prevalência de 22,7\%. O principal agente causador foi o filme de poliuretano transparente $(46,9 \%)$ e a região mais acometida foi a cervical $(25,1 \%)$. Presença de uréia sérica maior ou igual a $48.5 \mathrm{mg} / \mathrm{dL}$, com plaquetas menores que $193.500 \mathrm{~mm} 3$ ou plaquetas maiores que $193.500 \mathrm{~mm} 3$ e pressão arterial sistólica maior que $122 \mathrm{mmHg}$, mostraram-se como fatores associados à ocorrência dessas lesões. Conclusão: $\mathrm{O}$ estudo contribuiu para os conhecimentos relacionados à epidemiologia desse tipo de lesão, favorecendo o planejamento de cuidados preventivos.
\end{abstract}

Keywords: Estomaterapia, Ferimentos e lesões, Adesivos teciduais, Unidades de terapia intensiva, Prevalência

\section{Referências Bibliográficas}

1. Zhao H, He Y, Wei Q, Ying Y. Medical adhesive-related skin injury prevalence at the peripherally inserted central catheter insertion site: a cross-sectional, multiple-center study. J Wound Ostomy Continence Nurs. 2018;45(1):22-25. DOI:

http://dx.doi.org/10.1097/WON.0000000000000394 2. McNichol L, Lund C, Rosen T, Gray M. Medical adhesives and patient safety: state of the science: consensus statements for the assessment, prevention, and treatment of adhesive-related skin injuries. J Wound Ostomy Continence Nurs. 2013;40(4):365-80. DOI: http://dx.doi.org/10.1097/WON.0b013e3182995516 3. McNichol L, Bianchi J. Medical adhesive-related skin injuries (MARSI) - made easy. Wounds UK [Internet]. 2016 [cited 2019 Feb 28];12(4):1-4. Available from: https://www.wounds-uk.com/download/resource/1334 4. Konya C, Sanada H, Sugama J, Okuwa M, Kamatani Y, Nakagami G, et al. Skin injuries caused by medical adhesive tape in older people and associated factors. J Clin Nurs. 2010; 19(9-10):1236-42. DOI: https://doi.org/10.1111/j.1365-2702.2009.03168.x 


\title{
PERCEPÇÃO DE ENFERMEIROS RECÉM-FORMADOS SOBRE O CUIDADO DE ESTOMATERAPIA A PESSOAS COM DM 2 E ÚLCERAS PLANTARES EM TRATAMENTO COM UMA BIOMEMBRANA VEGETAL
}

\author{
Author(s): Yara Lanne Santiago Galdino ${ }^{1}$, Larissa Emília Magalhães Oliveira ${ }^{2}$, Leonardo Cardoso de Sousa ${ }^{2}$, \\ Ana Kare Lessa Sampaio ${ }^{2}$, Flavia Karolyne Sousa Alves ${ }^{2}$, Luciana Catunda Gomes de Menezes ${ }^{2}$ \\ Institution(s) ${ }^{1}$ CSM - CENTRO DE SAÚDE MEIRELES (AV. Antônio Justa 3113, Meireles. Fortaleza-CE), ${ }^{2}$ \\ FAMETRO - FAMETRO (Rua Conselheiro Estelita, 500 - Centro, Fortaleza - CE)
}

\begin{abstract}
INTRODUÇÃO: O diabetes mellitus tipo 2 (DM 2) e mais especificamente as úlceras neuropáticas representam problema de saúde pública1 que se configuram como complicação complexa, comum, incapacitante e de alto custo. Existem no mercado diversas estratégias de prevenção e tratamento eficazes para os cuidados com as úlceras plantares afim de evitar amputação, destaca-se nessa pesquisa o uso de uma biomembrana vegetal do látex da Calotropis Procera, esta chamada de "algodão-de-seda" da família Asclepiadaceae, originária da Índia e África Tropical, podendo ser encontrada em quase todas as regiões tropicais semiáridas da América, incluindo o Brasil onde é amplamente encontrada no Estado do Ceará2. Para fazer uso desse tratamento, torna-se necessário um cuidado especializado de Enfermagem. O recém-formado é considerado novato em um determinado campo de atuação, isto é, não tem experiência e/ou domínio do cuidado3. Logo, para o tratamento com o uso de uma biomembrana vegetal, faz-se necessário um treinamento do enfermeiro Estomaterapeuta para que os cuidados de Estomaterapia as pessoas com DM e úlceras plantares prestados pelos recémformados possam repercutir na segurança do paciente e epitelização da úlcera. OBJETIVO: Compreender a percepção de enfermeiros recém-formados sobre o cuidado de Estomaterapia a pessoas com DM 2 e úlceras plantares em tratamento com uma biomembrana vegetal. MÉTODO: Pesquisa qualitativa e descritiva realizada em uma Clínica Escola Integrada de uma universidade privada de Fortaleza-Ceará-Brasil nos meses de março a julho de 2019. Foram incluídos quatro enfermeiros participantes de um programa de capacitação teórico-prático que foram entrevistadas e os dados obtidos foram analisados por meio da Técnica de Análise de Conteúdo de Bradin4. O estudo foi aprovado pelo Comitê de Ética e Pesquisa da Unifametro sob CAAE 08284019.4.0000.5618. RESULTADOS: O perfil dos participantes quanto aos dados pessoais é caracterizado por: $75 \%$ do sexo feminino; $50 \%$ solteiros; $100 \%$ na faixa etária de 20 a 30 anos. Quanto às características profissionais, $100 \%$ fizeram estágio extracurricular em um ambulatório para o tratamento de pessoas com DM e úlceras plantares, todos participaram de cursos ou eventos sobre os cuidados em Estomaterapia e $100 \%$ não estavam trabalhando. Diante das percepções, foram construídas duas categorias temáticas: 1) Aspectos favoráveis ao cuidado de Estomaterapia e 2) Aspectos desfavoráveis ao cuidado de Estomaterapia. Na categoria 1, os discursos mostraram que a assistência com um Enfermeiro Estomaterapeuta que possuem formação prévia e experiência com o uso de uma biomembrana vegetal traz menores dificuldades e mais segurança na atuação dos recém-formados. Já na categoria 2, o cuidado é percebido como complexo e especializado, exigindo formação pós-graduada em Estomaterapia. Portanto, a formação no curso de graduação foi considerada insuficiente para a prestação desse tipo de cuidado, gerando medo e insegurança nos recém-formados. CONCLUSÃO: O cuidado de Estomaterapia confronta o recém-formado aflorando sentimentos de despreparo para cuidar, mas o mobiliza a ampliar os conhecimentos para exercer o cuidado. Evidencia-se dicotomia teoria-prática e fragilidades nas experiências de ensino-aprendizagem na formação graduada.
\end{abstract}

Keywords: Enfermagem, Prática Profissional, Diabetes mellitus, Pé diabético

\section{Referências Bibliográficas}

1. Caiafa JS, Castro AA, Didelis C, Santos VP, Silva ES da, Sitrângulo JRCJ. Atenção integral ao portador de pé diabético. J. Vasc. Bras., 2011, v. 10, n. 4, p. 1-32, Suplemento 1. 2. Lima Filho, J.V. et al. Proteins from latex of Calotropis procera prevent septic shock due to lethal infection by Salmonella enterica serovar Typhimurium. Journal of Ethnopharmacology, 2010. 3. Almeida RO, Oliveira FT, Ferreira MA, Silva RC. Enfermeiros recém-formados e o cuidado intensivo em unidades de pacientes não-críticos. Rev Bras Enferm [Internet]. 2019;72(Suppl 1):254-62. 4. Bardin L. Análise de Conteúdo. Lisboa: Edições 8a, 2010. 


\title{
APLICATIVO MÓVEL PARA AUXÍLIO NO ATENDIMENTO DAS VÍTIMAS DE QUEIMADURAS
}

\author{
Author(s): Hélio Martins do Nascimento Filho ${ }^{1}$, Hudson Alex Lázaro ${ }^{1}$, Leila Blanes ${ }^{1}$, Alessandra Haddad ${ }^{1}$, \\ Christiane Steponavicius Sobral ${ }^{1}$, Lydia Masako Ferreira ${ }^{1}$ \\ Institution(s) ${ }^{1}$ UNIFESP - Universidade Federal de São Paulo UNIFESP (Rua Botucatu, 740 - $2^{\circ}$ andar - Vila \\ Clementino, CEP:04023-062 - SP/SP)
}

\begin{abstract}
Introdução:

No Brasil, estima-se que dois milhões de pessoas ao ano sofrem queimaduras. Muitos desses pacientes queimados são atendidos por médicos não especialistas que necessitam de informação sobre o tratamento de queimaduras. $\mathrm{O}$ uso dos smartphones constitui-se numa solução para disseminar informações específicas para profissionais da área da Saúde, por meio de aplicativos médicos. Espera-se que a criação de um aplicativo para tratamento de queimaduras contribua para a diminuição da morbimortalidade das vítimas, conseqüentemente causando um grande impacto social e econômico para a saúde pública.

Objetivo:

Desenvolver um aplicativo para smartphones que auxiliará os profissionais de Saúde no tratamento das vítimas de queimaduras.

Material e Método:

Foram utilizadas a metodologia Design Thinking e o Projeto Canvas para definição do conteúdo do aplicativo. Foi utilizada a ferramenta de desenvolvimento Android StudioTM para a elaboração do mesmo.

Resultados:

O conteúdo foi baseado nos principais tópicos que devem ser de conhecimento do profissional de saúde que fará o atendimento básico do paciente queimado. O aplicativo apresenta também uma ferramenta bidimensional onde é realizado o cálculo da superfície corporal queimada do paciente e da correção hídrica necessária nas primeiras 24 horas de atendimento e já se encontra disponível na loja de aplicativos Google PlayTM

Conclusões:

O aplicativo desenvolvido SOS BURNS apresenta-se como uma ferramenta de auxílio para os profissionais de Saúde que lidam com o atendimento de vítimas de queimadura.
\end{abstract}

Referências bibliográficas:

Badwan B, Bothara R, Latijnhouwers M, Smithies A, Sandars J. The importance of design thinking in medical education. Medical Teach. 2017 Nov;10:1-2.

Ferreira FK, Song EH, Gomes H, Garcia EB, Ferreira LM. New mindset in scientific method in the health field: design thinking. Clinics 2015 Dec; 70(12):770-2.

Goldberg H, Klaff J, Spjut A, Milner S. A mobile app for measuring the surface area of a burn in three dimensions: comparison to the lund and browder assesment. J Burn Care Res. 2014 Nov/Dec;35(6):480-83.

Lázaro HA, Leão CEG. Uso de aplicativos móveis para auxílio no atendimento das vítimas de queimaduras. Rev Bras Queimaduras $2013 \mathrm{dez} ; 12(4): 286-88$.

Morris R, Javed M, Bodger O, Gorse S H, Williams D. A comparison of two smartphone applications and the validation of smartphone applications as tools for fluid calculation for burns resuscitation. Burns 2014 Aug;40(5):826-34.

Keywords: Internet, Smartphone, Queimaduras, Estomaterapia, Aplicativos móveis

\section{Referências Bibliográficas}

Badwan B, Bothara R, Latijnhouwers M, Smithies A, Sandars J. The importance of design thinking in medical education. Medical Teach. 2017 Nov;10:1-2. Ferreira FK, Song EH, Gomes H, Garcia EB, Ferreira LM. New mindset in scientific method in the health field: design thinking. Clinics 2015 Dec; 70(12):770-2. Goldberg H, Klaff J, Spjut A, Milner S. A mobile app for measuring the surface area of a burn in three dimensions: comparison to the lund and browder assesment. $J$ Burn Care Res. 2014 Nov/Dec;35(6):480-83. Lázaro HA, Leão CEG. Uso de aplicativos móveis para auxílio no atendimento das vítimas de queimaduras. Rev Bras Queimaduras 2013 dez;12(4):286-88. Morris R, Javed M, Bodger O, Gorse S H, Williams D. A comparison of two smartphone applications and the validation of smartphone applications as tools for fluid calculation for burns resuscitation. Burns 2014 Aug;40(5):826-34. 


\title{
INCIDÊNCIA E FATORES ASSOCIADOS AO SURGIMENTO DE COMPLICAÇÕES NO SÍTIO CIRÚRGICO DE PACIENTES ONCOLÓGICOS: ESTUDO OBSERVACIONAL CASO-CONTROLE
}

\author{
GILLENE APARECIDA DE SENA ${ }^{2}$, ELINE LIMA BORGES ${ }^{1}$, JOSIMARE OTONI SPIRA ${ }^{1}$, PATRICIA \\ APARECIDA BARBOSA SILVA ${ }^{1}$, MERY NATALIA SILVA ABREU ${ }^{1}$ \\ Institution(s) ${ }^{1}$ FHEMIG - FUNDAÇÃO HOSPITALAR DE MINAS GERAIS (Alameda Vereador Álvaro Celso, 100 - Santa \\ Efigênia, Belo Horizonte ), ${ }^{2}$ UFMG - UNIVERSIDADE FEDERAL DE MINAS GERAIS (Av. Prof. Alfredo \\ Balena, 190 - Santa Efigênia, Belo Horizonte )
}

\begin{abstract}
A cirurgia é essencial para os cuidados do paciente com câncer, preenche papéis na prevenção, diagnóstico, tratamento curativo, paliativo e reconstruções(1). Em relação ao tratamento, os melhores resultados são alcançados quando se consegue a redução da carga tumoral. Porém, o tumor quanto tratamentos complementares comprometem a resposta imune do organismo(2) e consequentemente afetam o processo de cicatrização da ferida cirúrgica.

Estima-se para 2030 21,6 milhões de novos casos de câncer no mundo, destes, 17,3 milhões de pacientes precisarão de alguma cirurgia (3).

Objetivos: identificar a incidência de pacientes oncológicos com ferida cirúrgica complexa em regiões de pelve e abdome; determinar fatores preditivos para o surgimento de complicações no sítio cirúrgico em regiões de abdome e pelve em pacientes oncológicos. Material e Método: estudo observacional do tipo caso-controle, com amostra de 124 pacientes submetidos à cirurgia de pelve ou abdome, sendo 33 indivíduos com complicações no sítio cirúrgico (caso) e 91 pacientes com ferida cirúrgica simples (controle), na proporção 1:3. A variável dependente foi ferida cirúrgica complexa (FCC) e as variáveis independentes incluíram sociodemográficas; comportamentais; doenças associadas; polifarmácia; medicamentos; estado nutricional; biomarcadores séricos; tratamento neoadjuvante; topografia do sítio cirúrgico e tipo intervenção cirúrgica. Os dados foram obtidos por meio de consulta dos prontuários eletrônico do paciente. A análise foi realizada no programa Statistical Package for Social Sciences e foi utilizado o modelo de regressão logística binária considerando nível de significância de 5\%. A realização do estudo foi aprovada pelos Comitês de Ética em Pesquisa sob o parecer $\mathrm{n}$. 63632417.5.0000.5149, e pareceres consubstanciados de n. 1.959.911 e n. 2.058.901. Resultados: a incidência encontrada em pacientes oncológicos com FCC foi de 26,61\% (IC 95\%: 18,73-34,50). As variáveis independentes que apresentaram maior chance para complicações da ferida cirúrgica $(p<0,05)$ na análise univariada foram uso de cinco ou mais medicamentos $(\mathrm{OR}=13,95$; IC 95\% = 3,97-49,06), antibiótico $(\mathrm{OR}=18,22 ; \mathrm{IC} 95 \%=6,71-49,47)$, anticoagulante $(\mathrm{OR}=$ $4,77$; IC $95 \%=1,98-11,49)$, antipsicótico $(O R=5,31$; IC $95 \%=1,72-16,41)$, não eutrófico $(O R=8,96$; IC $95 \%=2,60$ $30,86)$, albumina sérica $<12 \mathrm{~g} / \mathrm{dL}$ e masculino
\end{abstract}

Keywords: Deiscência de Ferida Operatória, Estomaterapia, Fatores de Risco, Fatores de Proteção, Oncologia

\section{Referências Bibliográficas}

1. Silva LASR. Oncologic surgery: a great challenge. Rev Col Bras Cir [Internet]. 2016 [cited 2017 Jan 7];43(3):139-40. Available from: http://www.scielo.br/pdf/rcbc/v43n3/pt_0100-6991-rcbc-43-03-00139.pdf 2. Garritano CRO, Nubila FD, Couto RM, Fiorelli RKA, Aun LB. Use of transfer fator in immunosuppressed surgical patients. Rev Col Bras Cir [Internet]. 2017 [cited 2018 Jan 9];44(5):452-56. Available from: http://www.scielo.br/pdf/rcbc/v44n5/1809-4546-rcbc-44-05-00452.pdf 3. Sullivan R, Alatise OI, Anderson BO, Audisio R, Autier P, Aggarwal A et al. Global câncer surgery: delivering safe, affordable, and timely câncer surgery. Lancet Oncol [Internet]. 2015 [cited 2018 Mar 07];16(11):1193-224. Available from: https://www.thelancet.com/journals/lanonc/article/PIIS1470-2045(15)00223-5/fulltext 


\title{
HIDROFIBRA COM PRATA NO TRATAMENTO DA LESÃO FÚNGICA:RELATO DE EXPERIÊNCIA
}

\author{
Author(s): $\quad$ Lisabel Tabari ${ }^{1}$, Ana America Gonçalves SILVA ${ }^{1}$, Janaina Barbosa SILVA ${ }^{1}$ \\ Institution(s) ${ }^{1}$ SARAH - Associação das Pioneiras Sociais (SMHS 501 BLOCO A BRASÍLIA - DF), ${ }^{2}$ SARAH \\ - Associação das pioneiras sociais (SMHS 501 BLOCO A BRASÍLIA - DF CEP: 70335-901)
}

\begin{abstract}
HIDROFIBRA COM PRATA NO TRATAMENTO DA LESÃO FÚNGICA:RELATO DE EXPERIÊNCIA

Resumo

Introdução: A maioria das infecções na pele causadas por fungos ocorre quando existem condições ideais de calor e umidade, muitas vezes associados a friç̧ão, maceração, ausência de luminosidade e a presença de queratina. $O$ estresse de cisalhamento pode favorecer a hiperceratose que obstrui a saída do folículo e pode servir como alimento para os fungos. Objetivo: Descrever o tratamento conservador alternativo a ressecção cirúrgica na cicatrização de uma lesão por pressão associada a lesão cutânea por fungos na região sacral.Material e Método: Trata-se de um relato de caso realizado no período de março a julho de 2019, com uma paciente de 39 anos, diagnóstico de lesão medular traumática, lesão de pele em região sacrococcígea com hiperplasia pseudoepiteliomatosa associada a estruturas morfologicamente compatíveis com fungo e indicação de ressecção cirúrgica. O estudo relata a evolução no tratamento da lesão fúngica com o uso de terapia tópica com polihexanida $0,1 \%$ e hidrofibra com prata. Os dados evolutivos foram obtidos por meio de registros fotográficos periódicos da ferida e registros avaliativos em prontuário eletrônico, respeitando-se os preceitos éticos. Resultados: $O$ alcance dos resultados foi obtido com 12 semanas de tratamento conservador, com cicatrização completa das lesões, melhora do aspecto da pele e crescimento de pelos na região. Conclusão: Os cuidados com o posicionamento, alívio da pressão, redução das forças de cisalhamento e o uso de produtos compropriedades antifúngicas contribuíram para promoção de alterações na microbiota e a cicatrização da lesão, evitando a intervenção cirúrgica da lesão.Novos estudos são necessários para identificar a influência das forças depressão e cisalhamento na produção de hiperceratose e colonização fúngica em lesões crônicas de pele em pessoas com lesão medular.

Descritores: Micoses, lesão por pressão, estomaterapia, curativos
\end{abstract}

Keywords: Micoses, lesão por pressão, estomaterapia , curativos

\section{Referências Bibliográficas}

Tomaz, D. Será fungo? Revista Portuguesa de Clínica Geral, v. 27, n. 1. p. 96-108, 2011. BRASIL. Agencia Nacional de Vigilância Sanitária2004). http://www.anvisa.gov.br/servicosaude/microbiologia/mod_7_2004.pdf Abd Elmegeed Al Shimaa M., Ouf S.A., Moussa Tarek A.A., Eltahlawi S.M.R..Dermatophytes and other associated fungi in patients attending to somehospitals in Egypt. Braz. J. Microbiol. [Internet]. 2015 Sep [cited 2019 Aug11];46(3):799-805. Available from: http://www.scielo.br/scielo.php?script=sci_arttext\&pid=S1517-

83822015000300799\&lng=en.http://dx.doi.org/10.1590/S1517-838246320140615 


\title{
PRODUÇÃO DE UMA TECNOLOGIA EDUCATIVA COMO FERRAMENTA DE AUTOCUIDADO AOS PACIENTES COM PÉ DIABÉTICO ATENDIDOS EM UMA
}

\author{
Author(s): DEIVID DOS SANTOS DIAS ${ }^{1}$, Flavia Karolyne Sousa Alves ${ }^{1}$, Ana Kare Lessa Sampaio ${ }^{1}$, Bruna \\ Negreiros de Sá ${ }^{1}$, Mirian Ferreira Coelho Castelo Branco ${ }^{1}$, Lucina Catunda Gomes de Menezes ${ }^{1}$ \\ Institution(s) ${ }^{1}$ Unifametro - Centro Universitário Fametro (Rua Conselheiro Estelita $N^{\circ} 500$ - Centro, Fortaleza- \\ $\mathrm{Ce})$
}

\begin{abstract}
INTRODUÇÃO: As pessoas com Diabetes Mellitus podem vir sofrer diversos tipos de problemas e se não houver o cuidado necessário pode haver complicações. Estas são as principais responsáveis pela morbimortalidade das pessoas com diabetes. Nas complicações crônicas, a neuropatia diabética consta como a mais prevalente, pois corresponde a 40\% dos pacientes ${ }^{1}$. Esta aumenta para $60 \%$ nos pacientes com idade acima de 60 anos $^{2}$. Na área da Enfermagem, existem distintas tecnologias que promovem a emancipação das pessoas envolvidas no processo de cuidar. Na classificação das tecnologias, destacamos a tecnologia educativa, a qual consiste num conjunto sistemático de conhecimentos científicos que tornem possível o planejamento, a execução, o controle e o acompanhamento envolvendo todo o processo educacional formal e informal ${ }^{2}$. Logo, no que se refere a ações preventivas, é fundamental que um plano de cuidado seja pactuado com a pessoa para que além de orientações de uso inclua as mudanças de estilo de vida. OBJETIVO: Desenvolver folheto educativo que facilite o processo de ensino-aprendizagem sobre a importância da prática de cuidados com os pés, alimentação e o uso adequado das medicações para alterações no perfil de risco da pessoa com diabetes. METODOLOGIA: Trata-se de um estudo descritivo do tipo metodológico, onde se enfocou a construção da tecnologia que atendessem a demanda da pesquisa clínica de enfermagem para tratamento do pé diabético atendidas em um ambulatório de estomaterapia implantado na Clínica Integrada de um centro universitário privado. Foram considerados os preceitos éticos e legais que envolvem a pesquisa com seres humanos, conforme a Resolução 466/2012 do Ministério da Saúde ${ }^{3}$. O estudo foi aprovado pelo Comitê de Ética e Pesquisa da Área da Saúde (CAAE) 08284019.4.0000.5618 e o número do parecer 3.164.340. RESULTADOS: A etapa de desenvolvimento do folder ocorreu em duas fases: (1) Embasamento científico para fundamentar o folder e (2) Construção do folder. Na primeira fase, foi realizado uma revisão bibliográfica, do tipo narrativa, em duas bases de dados: Literatura Latino-Americana e do Caribe em Ciências da Saúde (LILACS), na Biblioteca Eletrônica Scientific Electronic Library Online (SCIELO). A partir da vivência no ambulatório de estomaterapia, somada ao aprofundamento sobre a temática, desenvolveu-se um folheto educativo que venha auxiliar o profissional de enfermagem na assistência qualificada de pacientes com pé diabético. A segunda fase, ocorreu em dois momentos: Composição das ilustrações e Construção do folder. O folder educativo intitulado como "O cuidado com o paciente com pé diabético" contém 3 páginas e é composto por elementos pré-textuais (capa e apresentação); textuais (figuras e textos) e pós-textuais (referências bibliográficas). Buscando atender os objetivos propostos, a elaboração textual do folder: 1 . Acompanhamento de glicemia e PA 2. Atenção na alimentação 3. Atenção no uso da medicação 4. Cuidados com os pés 5. Orientações sobre o curativo do paciente com pé diabético 6. Observações. CONCLUSÃO: As tecnologias educacionais aparecem para facilitar o processo de trabalho do enfermeiro, transforma as práticas profissionais e da própria organização do trabalho, tomando como referência as necessidades de saúde das pessoas e das populações, empoderando os usuários em seu autocuidad
\end{abstract}

Keywords: Estomaterapia, Enfermagem, Tecnológia Educacional, Pé Diabético

\section{Referências Bibliográficas}

1 Santos, H.C, et al. Escores de neuropatia periférica em diabéticos. Rev Soc Bras Clin Med. v.13, n.1. 2015. Disponível em < http://files.bvs.br/upload/S/1679-1010/2015/v13n1/a4768.pdf>. Acesso em 01 maio. 2019. 2 Menezes, L.C.G, et al.

Estratégias educativas para pessoas diabéticas com pé em risco neuropático: síntese de boas evidências. Disponível em < https://revistas.ufg.br/fen/article/view/40281> Rev. Eletr. 2016. Acesso em 01 maio. 2019. 3 Brasil. Conselho Nacional de Saúde. Diretrizes e normas regulamentadoras de pesquisa em seres humanos. Resolução no 466, de 12 de dezembro de 2012. 


\title{
PREVALÊNCIA DE LESÕES DE PELE EM PACIENTES INTERNADOS EM UM HOSPITAL ONCOLÓGICO DO SUL DO BRASIL
}

\author{
Author(s): ROSELI FILLUS ${ }^{2}$ \\ Institution(s) ${ }^{1}$ HEG - LIGA PARANAENSE DE COMBATE AO CANCER (Rua Dr. Ovande do Amaral 201 \\ Jardim das Américas CURITIBA PR), ${ }^{2}$ HEG - LIGA PARANAENSE DE COMBATE AO \\ CANCER (Rua Dr. Ovande do Amaral 201 Jardim das Américas CURITIBA PR)
}

\begin{abstract}
Introdução:O desenvolvimento de lesões de pele pode ser influenciado por fatores intrínsecos como: idade, cor, $\mathrm{pH}$ e condições da pele, estado nutricional e peso do paciente, nível de consciência, grau de mobilidade, edema, doenças como Diabetes Mellitus, Hipertensão Arterial, Anemia, alterações da função renal entre outras. O câncer é uma doença grave, afeta todas as faixas etárias, não respeitando cor, raça, idade, classe social, causando dor, angústia e sofrimento para o paciente e todos os envolvidos com o mesmo1. Pacientes com câncer, em geral apresentam debilidade física e diminuição da imunidade em decorrência da doença e dos tratamentos utilizados tornando estes indivíduos mais susceptíveis as alterações Objetivo Geral: Determinar a prevalência de lesões de pele em pacientes internados em um hospital oncológico do Sul do Brasil. Objetivo Específico: Identificar o perfil sociodemográfico e epidemiológico dos pacientes que apresentam lesões de pele. Método: Estudoepidemiológico, observacional, transversal, exploratório, descritivo, com abordagem quantitativa realizado com pacientes internados pelo SUS, nas unidades de internação e de terapia intensiva adulto e pediátrica de um hospital oncológico do Sul do Brasil. A coleta de dados foi realizada num único dia, mediante entrevista com o paciente e/ou acompanhante e exame físico com inspeção da pele para identificação das lesões. $O$ projeto foi aprovado pelo CEP do hospital Parecer no Parecer no 2602 de 28/07/2017. Resultados e Discussão:No dia da coleta de dados 74 pacientes preenchiam os critérios de inclusão, 09 (12\%) não puderam participar, desta forma, a amostra foi constituída por 65 pacientes, $88 \%$ dos elegíveis. Do total de participantes 56\% eram mulheres, $65 \%$ brancos, $54 \%$ tinha diagnóstico de câncer há menos de um ano. A idade variou entre 3 e 85 anos, sendo que 64,6\%eram maiores de50 anos. $\mathrm{Na}$ avaliação da pele identificou-se que30 (46\%) dos pacientesapresentavam lesões, destes, 07(10,8\%) apresentavam mais de uma lesão, totalizando 38 lesões, obtendo-se uma prevalência de 58,4\% para todos os tipos de lesão. Em relação ao local de ocorrência, 20 (52,6\%) surgiram no hospital, 06 (15\%) vieram do domicílio com lesão e 12 (31\%) não tinham esta informação. Sobre o tipo de lesão, 25 (38,5\%) foram caracterizadas como LPP, destas, 12 (48\%) classificadas como lesão por dispositivo médico. As lesões por umidade ficaram em segundo lugar com prevalência de 7,7\%; as lesões oncológicas com $6,2 \%$, extravasamento $3 \% ; 1,5 \%$ nas lesões por adesivo e 1,5\% de lesões por fricção. Considerações Finais: Observou-se que a LPP foi a mais prevalente entre as lesões encontradas, chama a atenção para as lesões por dispositivos médicos que até recentemente não apareciam na maioria dos estudos nacionais. Houve diferença entre os setores do hospital, devido às características e condições dos pacientes internados. Entre as limitações deste estudo, pode-se citar o número de pacientes e a dificuldade de se encontrar estudos semelhantes para comparação. Acredita-se que o estudo poderá contribuir para o conhecimento dos profissionais sobre o risco e a necessidade de implementação de medidas de prevenção
\end{abstract}

Descritores: ferida; enfermagem oncologica, estomaterapia; prevenção

Keywords: ferida, enfermagem, oncologia, estomaterapia, prevenção

\section{Referências Bibliográficas}

AZEVEDO, I, C, et al .Tratamento de feridas: A especificidade das lesões oncologias. Revista saúde e pesquisa, v.7, n. 2, p. 303-313, maio 2014.Disponivel em:http://periodicos.unicesumar.edu.br/index.php/saudpesq/article/view/3306 AMARAL, Ana Flávia dos Santos; PULIDO, Kelly Cristina Strazzieri; SANTOS, Vera Lucia Conceição de Gouveia. Prevalência de lesões por fricção em pacientes hospitalizados com câncer. Rev. esc. enferm. USP, São Paulo , v. 46, n. spe, p. 44-50, Oct. 2012. Availablefrom. accesson 12 Aug. 2019. http://dx.doi.org/10.1590/S0080-62342012000700007. SCHMIDT, Fernanda Mateus Queiroz; VILELA; SANTOS, Vera lúcia Conceição de Gouveia; BANDEIRA, Mariana Alves et al. Prevalência de lesões por friç̧ão e fatores associados em pacientes hospitalizados com câncer. In: ANAIS DO SEMINáRIO INTERNACIONAL EM SAúDE DO ADULTO, 2017, . Anais eletrônicos... Campinas, GALOÁ, 2018. Disponível em: Acesso em: 12 ago. 2019. 


\title{
ANÁLISE DE CASOS MÚLTIPLOS DE PESSOAS COM DIABETES MELLITUS TIPO 2 EM USO DE UMA BIOMEMBRANA VEGETAL E HIDROCOLÓIDE PÓ PARA TRATAMENTO DE ÚLCERAS PLANTARES
}

\author{
LUCIANA CATUNDA GOMES DE MENEZES ${ }^{1}$, Ana Kare Lessa Sampaio ${ }^{1}$, Flavia Karolyne Sousa Alves ${ }^{1}$, \\ Author(s): Lígia Silva Nunes Cavalcante ${ }^{1}$, Mirian Ferreira Coelho Castelo Branco ${ }^{1}$, MARIA REGINA CHAVES \\ RIBEIRO ${ }^{1}$, Karla Mirelle Campelo Martins ${ }^{1}$ \\ Institution(s) ${ }^{1}$ UNIFAMETRO - CENTRO UNIVERSITÁRIO FAMETRO (RUA CONSELHEIRO ESTELITA BAIRRO \\ JACARECANGA), ${ }^{2}$ UFC - UNIVERSIDADE FEDERAL DO CEARÁ (Av. da Universidade, 2853 - Benfica, \\ Fortaleza - CE, 60020-181)
}

\begin{abstract}
INTRODUÇÃO: A úlcera neuropática é a complicação crônica mais comum da pessoa com diabetes mellitus (DM), além de complexa, incapacitante e de alto custo, representando um problema de saúde pública em crescente ascensão, que muitas vezes, se não for tratada precocemente e adequadamente, evoluem para amputações1. Essas ulcerações causam destruições dos tecidos moles, que ocorrem concomitantemente com alterações neurológicas de diversos graus, devido à doença arterial periférica (DAP) localizada nos membros inferiores2. Para tanto, torna-se necessário tratá-la de maneira adequada. A biomembrana do látex da Calotropis procera (BioMem CpLP) é um produto biotecnológico composto pela fração isolada obtida do látex da Calotropis procera que tem demonstrado potencial cicatrizante por estimular a fase inflamatória da cicatrização estimulando a liberação de citocinas pró inflamatórias acarretando em uma notável melhora das fases subsequentes do processo de cicatrização3. Reconhecendo a importância do tratamento do pé diabético para evitar amputação, essa pesquisa tem como OBJETIVO: Analisar cinco casos múltiplos de pessoas com diabetes mellitus tipo 2 em uso de uma biomembrana vegetal (BioMem CpLP) e hidrocolóide pó para tratamento de úlceras plantares. MÉTODO: Trata-se de estudo descritivo, com abordagem qualitativa, do tipo Estudo de Caso Múltiplos realizado com cinco pacientes atendidos em uma Clínica Escola Integrada de uma universidade privada em Fortaleza-Ceará-Brasil nos meses de março a julho de 2019. A pesquisa foi aprovada pelo Comitê de Ética e Pesquisa da Unifametro sob CAAE 08284019.4.0000.5618. Os dados foram coletados por meio de um instrumento que abordou os seguintes dados: sociodemográficos; clínicos sobre o DM e sobre os aspectos da úlcera plantar. RESULTADOS: No tocante aos Dados sociodemográficos, os resultados apontaram: prevalência de pessoas do sexo masculino com $80 \%$, idade média de 55 anos, casados, com 1 a 5 anos de estudo, renda individual e familiar variando de 1 a 2 salários mínimos. Nos Dados Clínicos sobre o DM, a média do tempo de diagnóstico dos participantes foi de 9,56 anos, a hipertensão arterial sistêmica foi à comorbidade mais prevalente, $93,3 \%$ faziam uso de antidiabético oral, $64 \%$ utilizavam insulina, $65,3 \%$ são sedentários e $50,3 \%$ possuem comprometimento da acuidade visual para perto. Os Dados sobre os aspectos da úlcera plantar mostram que: o uso da BioMem CpLP foi capaz de desbridar o tecido desvitalizado em $85,7 \%$ dos pacientes e apresentou aumento na formação do tecido cicatricial em quase $86 \%$ das úlceras, enquanto que nas úlceras tratadas com hidrocolóide pó o aumento foi de $70 \%$. CONCLUSÃO: Conclui-se que os estudos de casos podem ser métodos de pesquisa utilizados em pessoas com diabetes mellitus tipo 2 para acompanhamento e tratamento de úlceras plantares com a BioMem CpLP, além de ter contribuído para o conhecimento dessas pessoas acerca do adoecimento e dos cuidados com os pés.
\end{abstract}

Keywords: Enfermagem, Estudos de casos múltiplos, Cicatrização de feridas, Pé diabético, Calotropsi procera

\section{Referências Bibliográficas}

1. Armstrong DG, Cohen K, Courric S, Bharara M, Marston W. Diabetic foot ulcers and vascular insufficiency: our population has changed, but our methods have not. J Diabetes Sci Tech. 2011, v. 5, n. 6, p.:1591-1595. 2. International Working Group on the Diabetic Foot. International consensus on the diabetic foot and practical guidelines on the management and the prevention of the diabetic foot, 2015. 3. Lima Filho, J.V. et al. Proteins from latex of Calotropis procera prevent septic shock due to lethal infection by Salmonella enterica serovar Typhimurium. Journal of Ethnopharmacology, 2010. 


\title{
PERFIL DOS PACIENTES COM SÍNDROME DE FOURNIER
}

\author{
Author(s): Cintia Moraes Colombo ${ }^{1}$, Denize Pereira Silva ${ }^{1}$, Ursulla Vilella Andrade ${ }^{1}$, Karla Toleto Candido \\ Muller $^{1}$, AUCELY CORREA FERNANDES CHAGAS ${ }^{1}$ \\ Institution(s) ${ }^{1}$ UCDB - UNIVERSIDADE CATÓLICA DOM BOSCO (AV. Tamandaré 6000), ${ }^{2}$ UCDB - \\ UNIVERSIDADE CATÓLICA DOM BOSCO (AV. Tamandaré 6000)
}

\begin{abstract}
Introdução: a Síndrome de Fournier é uma doença infecciosa, de rápida evolução, que pode acometer região genital e áreas adjacentes. Descrita por destruição tissular envolvendo o tecido subcutâneo e a fáscia. Tem origem no escroto e pênis no homem, e em mulheres na vulva e virilha, podendo afetar a parede abdominal. Objetivos: Conhecer o perfil dos pacientes com Síndrome de Fournier e descrever qual foi a melhor conduta para um tratamento adequado, de acordo com a evolução. População e Método: trata-se de um estudo documental transversal e retrospectivo de análise quantitativa realizado em Campo Grande, Mato Grosso do Sul no ano de 2019, realizado no Hospital Universitário Maria Aparecida Pedrossian - HUMAP. Resultados: foram estudados 15 pacientes com Síndrome de Fournier no período de janeiro de 2007 a maio de 2019. A maioria dos pacientes foi do sexo masculino (93,33\%). Sendo a faixa etária predominante de 41 a 60 anos, com um porcentual de $46,67 \%$. Quanto ao tempo de internação, 33,33\% dos pacientes ficaram internados por um período de tempo maior que 15 dias. Todos os pacientes apresentaram comorbidades associadas a doença. 46,67\% utilizavam como a Sulfadiazina de prata e $26,67 \%$ usavam Kollagenase. Foram identificados outros produtos, comoProntosan gel em $13,33 \%$ e $6,67 \%$ adaptavam Placa de carvão ativado e Placa Alginato de Cálcio. O uso de antibioticoterapia e os cuidados com a ferida é de suma importância para a evolução clínica. Conclusão: a equipe médica e da enfermagem, devem ter pleno conhecimento da síndrome para ter um diagnóstico e tratamento rápido e preciso
\end{abstract}

Keywords: Fasciíte necrosante, Gangrena de Fournier, Enfermagem

\section{Referências Bibliográficas}

1. Dornelas MT, Correa MPD, Barra FML, Corrêa LD, Silva EC, Dornelas GV, et al. Síndrome de Fournier: 10 anos de avaliação. RevBrasCirPlást. 2012;27(4):600-4 2. Cordeiro TMSC, Freitas GB, Braga VS, Reis TS, Castro TVB.Síndrome de Fournier: diagnósticos de enfermagem segundo a nanda. RevEpidemiolControllnfect. 2014;4(4):262-263 3. Azevedo CCSF, Araujo APL, Marin CV, Baldi D, Alves JPF. Síndrome de Fournier: um artigo de revisão. CONNECTION LINE, 2016 4. Abreu RAA, Filho JMML, Corrêa M, Coimbra RAA, Figueira ALM, Speranzini MB. Síndrome de Fournier: estudo de 32 pacientes: do diagnostico a reconstrução. GED gastroenterol. endosc. dig. 2014:33(2):45-51 5. Eberhardt TD, KesslerM , Soares RSA, Dias CFC , Fonseca GGP , Muller LA, et al. Assistência de Enfermagem ao Portador de Síndrome de Fournier: Revisão da Literatura. Rev. Saúde. AJES, 2014; 1(1), 57-68. 6. Lamberty C, Vetoratto ES. Gangrena de Fournier. Relato de experiência Evento: XVI Jornada de Extensão, salão do conhecimento Unijuí 2015. 7. Santos DR, Roman ULT, Westphalen AP, Lovison K, Neto FACS.Perfil dos pacientes com gangrena de Fournier e sua evolução clínica. Revista do Colégio Brasileiro de Cirurgiões, 2018; 45(1). 8. Cavalina F, Moriya TM, Pela NTR. Síndrome de Fournier: a percepção do seu portador. Revista da Escola de Enfermagem da USP, 2002; 36(2), 108-114. 9. Silva LCP, Soares FV, Sales PRS, Barbosa PMK, Salvi JA. Fatores que interferem na utilização do prontuário do paciente em suporte de papel. Rev. adm. saúde, 2011; 53-59. 10. BRASIL. Conselho Federal de Medicina. Resolução n¹638, de agosto de 2002. Define prontuário médico e torna obrigatória a criação da Comissão de Revisão de Prontuários nas instituições de saúde. 11. Santos DMD, Silva IC. (2018). Conhecimento dos enfermeiros sobre a SAE em um hospital privado conveniado ao SUS no município de neropolis-GO. 12. BRASIL. Conselho Federal de Enfermagem. Resolução $n^{\circ} 0514$, de mio de 2016. Aprova o guia de recomendações para os registros de enfermagem no prontuário do paciente com a finalidade de nortear os profissionais de enfermagem. 13. Lima MHM, Araujo EP. Diabetes mellitus eo processo de cicatrização cutânea. Cogitare Enfermagem, 2013; 18(1), 170-172 14. Squizatto RH, Braz RM, Lopes AO, Rafaldini BP, Almeida DB, Poletti NAA. Perfil dos usuários atendidos em ambulatório de cuidado com feridas. CogitareEnferm, v.22, n. 1, p. 1-9, 2017. 15. Simoes MLPB, AlcantraEM,Dallagnol JC, Yoshizumi KO, Torres LFB, Borsato KS. Cicatrização de feridas: estudo comparativo em ratos hipertensos não tratados e tratados com inibidor da enzima conversora da angiotensina. RevColBrasCir, 2006; 33(2), 74-8. 16. Candelaria PAP, Klug WA, Capelhuchnk P, Fang CB. Síndrome de Fournier: análise dos fatores de mortalidade. RevBrasColoproctol, 2009; 29(2), 197-202. 17. Mehl AA, Filho DCN, Mantovani LM, Grippa MM, Berger R, Krauss D, Ribas D. Manejo da gangrena de Fournier: experiência de um hospital universitário de Curitiba. RevColBrasCir, 2010; 37(6), 435-41. 18. Santos E, Queirós P, Cardoso D, Cunha M, Apóstolo J. A eficácia das soluções de limpeza para o tratamento de feridas: uma revisão sistêmica. Revista de Enfermagem, n.9, p. 133-144, 2016. 19. Silva HYW, Moura TR, Lopes MR, Neto FC, Damata FR, Barboza GP, et al. Relato de caso: Síndrome de Fournier após implantação de slingtransobturatório. Comun. ciênc. saúde, 2013 24(1), 77-84. 20. Cruz RAO, Andrade LL, Arruda AJCG. Produção científica sobre gangrena de Fournier e os cuidados de enfermagem: revisão integrativa. Rev. enferm. UFPE online, 2016; 10(5), 4329-4335. 21. Cardoso JB, Feres O. Gangrena de Fournier. Medicina (Ribeirao Preto. Online), 2007; 40(4), 493-499. 22. Blanes, L. Tratamento de feridas. Cirurgia vascular: guia ilustrado. 2004 ; São Paulo. 23. Carneiro CM, Souza FB, Gama FN. Tratamento de feridas: assistência de enfermagem nas unidades de atenção primária à saúde. RevEnferm Integrada, 2010; 3(2), 494-505. 


\title{
O USO DE CREME NÃO IÔNICO COM PHMB NO TRATAMENTO DE QUEIMADURA: RELATO DE CASO
}

\author{
Author(s): Rafaela Butinholi Antonucci ${ }^{1}$, Milene Mendonça ${ }^{1}$ \\ Institution(s) ${ }^{1}$ Lucy Montoro SJRP - Centro de Reabilitação Lucy Montoro de São José do Rio Preto (Avenida Jamil \\ Ferez Kfouri, $n^{\circ} 40$ )
}

\begin{abstract}
Introdução: A queimadura é uma lesão que compromete a pele, o maior órgão do corpo humano, cujas funções são vitais para preservar a homeostasia corporal e manutenção da temperatura corpórea, além de desempenhar função antimicrobiana, servindo de barreira de microrganismos. A queimadura é avaliada em graus conforme o trauma o trauma tecidual. Estima-se que ocorram no Brasil cerca de 1 milhão de acidentes com queimaduras por ano; destes, 100 mil procurarão atendimento hospitalar e cerca de 2.500 irão a óbito. Sabe-se que a queimadura é um trauma complexo, de difícil prognóstico, com alta taxa de morbimortalidade e que o enfermeiro desempenha um importante papel na reabilitação desses pacientes. O PHMB (Polihexametileno-Biguanida) é um antisséptico do mesmo grupo da clorexedina que atua em bactéricas gram positivas e gram negativas, e em anaeróbios que são responsáveis pelo odor. O PHMB também é considerado um antimicrobiano, que favorece o controle de microorganismos presente em feridas infectadas, visto que as moléculas deste produto exercem seu efeito bactericida por meio de mecanismos de agregação, mediada pelos seus núcleos catiônicos de biguanida. Também atua na modificação da permeabilidade da membrana citoplasmática microbiana, que leva a perda de componentes fundamentais e morte celular. Objetivo: Descrever um estudo de caso no qual foi utilizado creme dermatológico não iônico com PHMB para tratamento de queimadura no Ambulatório de Tratamento de Feridas em um Centro de Reabilitação no interior do estado de São Paulo. Metodologia: Estudo de caso descritivo, iniciado após a autorização da paciente e de seu responsável através do Termo de Consentimento Livre e Esclarecido para o registo das imagens e descrição do caso no período de 30 dias. Resultados: Iniciado tratamento da lesão aplicando o creme de PHMB em toda extensão da lesão, sendo a mesma ocluída com gaze, e faixa crepe, realizndo troca do curativo diário após a limpeza por irrigação com soro fisiológico 0,9\%. Ferida com tecido de necrótico em toda sua extensão, realizada escarificação da necrose no primeiro atendimento e desbridamentos com Lâmina de bisturi no 23 conforme retorno semanal do paciente. Em 15 dias apresentando-se com tecido de granulação vermelho vivo brilhante, bordas regulares, com ilhas de epitélio e com tecido de epitelização, com diminuição siginificativa de suas margens. Foram realizados 4 retornos de acompanhamento do paciente, apresentando completa epitelização em 30 dias. Conclusão: $O$ uso do creme dermatológico não iônico de PHMB acelerou o processo de cicatrização, reduziu o risco de infecção e controlou a carga microbiana na lesão, auxiliou no desbridamento autolítico, favorecendo a cicatrização e diminuindo os riscos de complicações como infecção e possível amputação do membro. O resultado obtido com o tratamento comparando com a literatura dos tratamentos com produtos convencionais comprova que o uso do creme com PHMB controla a ação microbiana, devido à ação antimicrobiana do PHMB, mantendo o meio úmido, favorecendo o desbridamento autolítico e estimulando a formação de tecido de granulação e epitelização da lesão precoce, evitando complicações e desconforto ao paciente, trazendo segurança aos profissionais e ao paciente.
\end{abstract}

Keywords: feridas, queimadura, tratamento, cicatrização

\section{Referências Bibliográficas}

ALMEIDA, Wylker Farias; SANTOS, Joyce Nunes dos. Assistência de enfermagem em grupos de riscos a queimadura. Revista Brasileira de Queimaduras, Florianópolis, v. 12, n. 2, Junho 2013. KIRKER, K. R.; FISHER, S. T.; JAMES, G. A.; MCGHEE, D.; SHAH, C. B. Efficacy of polyhexamethylene biguanidecontaining antimicrobial foam dressing against MRSA relative to standard foam dressing. WOUNDS, v. 9, n. 3, p. 229-233, 2009. TIMMONS, J.; LEAK, K PHMB: Utilización del apósito de espuma antimicrobiana (AMD) KendallTM (PHMB 0,5\%) en el tratamiento de las heridas crónicas. Gerokomos, v. 21 , n. 1 , p. $37-43,2010$. 


\title{
UTILIZAÇÃO DO CREME DE PHMB NO TRATAMENTO DE QUEIMADOS: RELATO DE CASO
}

\author{
Author(s): Franciele Brunelli Cassiano ${ }^{1}$, Milene Mendonça ${ }^{1}$ \\ Institution(s) ${ }^{1}$ HPA - Hospital Padre Albino (Rua: Belém, 519 - Centro, Catanduva -sp)
}

\section{Abstract}

Introdução: As queimaduras são consideradas traumas de pele, graves e agressivas, pois causam alterações não só físicas, mas também psicológicas. Queimaduras são caracterizadas pela ação direta ou indireta do calor sobre o corpo humano, quando o mesmo encontra-se em contato com chamas, líquido aquecido, frio extremo, substâncias químicas e radiação, e são classificadas de acordo o grau de extensão e sua profundidade, queimaduras de primeiro, segundo e terceiro grau. O PHMB (Polihexametileno-Biguanida) é um antisséptico do mesmo grupo da clorexedina que atua em bactérias gram positivas e gram negativas, tendo ação direta e comprovada em BIOFILME. Ele também é considerado um antimicrobiano, que favorece o controle de microorganismos presente em feridas infectadas, visto que as moléculas deste produto exercem seu efeito bactericida por meio de mecanismos de agregação, mediada pelos seus núcleos catiônicos de biguanida. Objetivo: Comprovar a eficácia do creme não iônico PHMB em pacientes que apresentem queimaduras de quaisquer etiologias e SCQ, observando a evolução de tecidos e maior custo benefício para a instituição, em forma de relato de caso, durante o período de hospitalização. Metodologia: Abordagem descritiva, com acompanhamento fotográfico periódico durante a troca dos curativos, após o esclarecimento de duvidas pertinente e autorização do paciente através do termo de Consentimento Livre e Esclarecido, para o registro de imagens e descrição do caso. Resultados: Realizado tratamento com o uso do tópico de creme não iônico de PHMB, em paciente vítima de queimadura por chamada direta SCQ $45 \% 2^{\circ}$ superficial e $2^{\circ}$ profundo, o mesmo foi submetido ao procedimento de balneoterapia sob anestesia para realização de desbridamento mecânico. Aplicado creme de PHMB em toda SCQ, sendo a mesma ocluída com atadura rayon embebida por AGE, sobre posto chumaço, e envolto por atadura crepe, sendo trocado a cada 72 horas. A queimadura apresentava tecidos desvitalizados como necrose de liquefação, e áreas de granulação, com o uso de PHMB, foi possível observar sua ação autolítica associada á cobertura antimicrobiana com ação de 72 horas no leito da lesão, exsudato seroso em moderada quantidade e sem odor. Em 10 dias apresentando-se com tecido de granulação vermelho vivo brilhante, bordas regulares, ilhas de epitélio e em algumas partes onde se localizava SCQ de $2^{\circ}$ superficial, houve cicatrização total, contração de bordas e epitelização da mesma. Em áreas de $2^{\circ}$ profundo, optou-se pela realização de enxertia de pele autóloga, para que o paciente pudesse obter alta precoce e qualidade na cicatrização Foram realizadas 7 trocas do curativo com o creme de PHMB, e enxertia de pele em áreas mais profundas, após alta e acompanhamento ambulatorial, apresentando completa epitelização em 30 dias. Conclusão: Com o uso do creme dermatológico não iônico de PHMB pode-se obsevar que houve aumento no processo cicatricial, curativos menos traumáticos durante o período de hospitalização. Mostrou custo beneficio positivo quando comparado com outras coberturas de troca diária, reduziu o risco de infecção e controlou a carga microbiana comprovados com resultado de punch cutâneo no inicio e término do tratamento com PHMB, propiciando a cicatrização, controle de carga microbiana.

\section{Keywords: FERIDAS, CICATRIZAÇÃO, QUEIMADURAS, TRATAMENTO}

\section{Referências Bibliográficas}

SERRA, Maria Cristina do Valle Freitas.; GOMES, Dino Roberto.; CRISOSTOMO, Márcio R. Fisiologia e fisiopatologia.In: LIMA JR,Edmar Maciel.Tratado de queimaduras.São Paulo: Ateneu,2006. p. 37. LIMA JR, Edmar Maciel, BAPTISTA, Ricardo José. Campanha de prevenção de queimaduras. In: LIMA JR, Edmar Maciel et al. Tratado de Queimaduras no Paciente Agudo. ed.2. São Paulo: Atheneu, 2008. p. 540. ALMEIDA, Wylker Farias; SANTOS, Joyce Nunes dos.

Assistência de enfermagem em grupos de riscos a queimadura. Revista Brasileira de Queimaduras, Florianópolis, v. 12, n. 2, Junho 2013. KIRKER, K. R.; FISHER, S. T.; JAMES, G. A.; MCGHEE, D.; SHAH, C. B. Efficacy of polyhexamethylene biguanidecontaining antimicrobial foam dressing against MRSA relative to standard foam dressing. WOUNDS, v. 9, n. 3, p. 229-233, 2009. TIMMONS, J.; LEAK, K PHMB: Utilización del apósito de espuma antimicrobiana (AMD) KendallTM (PHMB $0,5 \%$ ) en el tratamiento de las heridas crónicas. Gerokomos, v. 21, n. 1, p. 37-43, 2010. 


\title{
CONSULTA DE ENFERMAGEM COM ENFOQUE NA PREVENÇÃO DE ÚLCERAS DIABÉTICAS
}

\author{
Luciane Resende da Silva Leonel ${ }^{1}$, Luana Silva de Sousa ${ }^{1}$, Jéssyca Fernanda Pereira Brito ${ }^{1}$, \\ Author(s): Amanda Karoliny Meneses Resende ${ }^{1}$, Verônica Elis Araújo Rezende ${ }^{1}$, Marcelane Macêdo dos \\ Santos $^{2}$, Rosa Sousa Silva ${ }^{2}$, Kellen Larissa dos Santos Sousa ${ }^{2}$, Ana Karolina Belfort de Sousa ${ }^{2}$, \\ Sandra Marina Gonçalves Bezerra ${ }^{3,1}$ \\ Institution(s) ${ }^{1}$ UESPI - Universidade Estadual do Piauí (R.Lucídio Freitas,2791- Matinha, Teresina- \\ PI,64003120), ${ }^{2}$ Aliança - Faculdade Uninassau Aliança (R.São Pedro, 957-Centro (Sul), Teresina- \\ PI, 64001-260), ${ }^{3}$ UFPI - Universidade Federal do Piauí (Campus Universitário Ministro Petrônio \\ Portella,Bairro-Ininga,Teresina-PI)
}

\begin{abstract}
INTRODUÇÃO: É recomendado que pacientes com Diabetes Mellitus (DM) sejam avaliados anualmente quanto a sensibilidade e integridade dos pés medida importante para se identificar fatores de risco para desenvolvimento de ulcera nos pés e futuras amputações. OBJETIVO: Relatar a consulta de enfermagem na avaliação dos pés de pacientes com Diabetes Mellitus com enfoque na prevenção de úlcera diabética. METODOLOGIA: Trata-se de um estudo qualitativo do tipo relato de experiência de acadêmicas de enfermagem durante atendimento aos pacientes portadores de DM na consulta de enfermagem as atividades ocorreram no período de setembro a novembro de 2018 em uma Unidade Básica de Saúde (UBS) do município de Teresina, Piauí. Foram atendidas30 pessoas com diagnóstico de DM. Durante a consulta de enfermagem eram realizado o exame físico, avaliação neurosensitiva mediante a utilização de microfilamento de 10 miligramas e diapazan de $128 \mathrm{hz}$, avaliação dos calçados além de repassados orientações sobre cuidados diários.A pesquisa partiu de um projeto desenvolvido em pacientes com diabetes e comorbidades e foi submetido ao comitê de ética da Universidade Estadual do Piauí sob parecer número 3.479.211, respeitado os aspectos éticos segundo a resolução 466/2012. RESULTADO E DISCUSSÃO: Os atendimentos aos pacientes diabéticos ocorriam nos dias pré-agendados do programa Hiperdia. No primeiro momento da consulta de enfermagem realizamos a coleta de dados para investigação do histórico de saúde do paciente, em seguida realizamos exame físico, com dados antropométricos, pressão arterial, níveis glicêmicos.Posteriormente, eram realizados avaliação e inspeção minuciosa dos pés examinado a pele, as unhas, pulsos, presença de lesão ou micoses, temperatura das extremidades inferiores e avaliação da sensibilidade mediante a utilização do microfilamento e teste da sensibilidade vibratória com o uso do diapazan conforme orientações do Ministério da Saúde. Também eram repassadas orientações sobre cuidados para prevenção de úlcera diabética, além da distribuição de panfleto informativo sobre os principais cuidados com os pés. Observamos que a maioria dos pacientes não sabiam sobre os cuidados para prevenção de lesões.Na avaliação do calçado somente seis pacientes $(20 \%)$ apresentavam calçados adequados; dezoito $(60 \%)$ apresentaram alterações de sensibilidade com teste com microfilamento e sete $(23,3 \%)$ apresentaram alterações na sensibilidade vibratória, vinte (66,7\%) apresentaram corte inadequado das unhas, seis (20\%) pacientes apresentaram onicomicose, cinco $(16,7 \%)$ dos paciente relataram já ter desenvolvido úlcera diabética.CONCLUSÃO:Observamos que alterações da sensibilidade e fatores de risco para desenvolvimento de úlcera diabética foram presentes na população avaliada. O estimulo ao autocuidado é uma importante estratégia para prevenção das ulceras nos pés, o enfermeiro tem papel fundamental neste processo de promoção e prevenção de saúde nos cuidados ao paciente com DM.
\end{abstract}

Keywords: Estomaterapia, Diabetes Mellitus, Pé Diabético, Enfermagem

\section{Referências Bibliográficas}

Brasil. Ministério da Saúde. Manual do pé diabético: estratégias para o cuidado da pessoa com doença crônica. Ministério da Saúde, Secretaria de Atenção à Saúde, Departamento de Atenção Básica. Brasília, 2016. BezerraGC, SantosICRV, Lima JC, Souza MAO. Avaliação do risco para desenvolver pé diabético na atenção básica. Estima. 2015; 13(3). Salci MA, Meirelles BHS, Silva DMGV. Educação em saúde para prevenção das complicações crônicas do diabetes mellitus na atenção primária. Esc Anna Nery. 2018; 22(1). 


\title{
Prevalência de Lesão por Pressão (LP) em pacientes críticos: a realidade de um hospital privado da cidade de São Paulo
}

Amanda Cristina Maria Aparecida Gonçalves Brandão ${ }^{1}$, Mariana Fernandes Cremasco ${ }^{1}$, Bianca Author(s): $\quad$ Reyez Murano Amaro ${ }^{1}$, Maria Emilia Gaspar Ferreira Del Cistia ${ }^{1}$, Luana Gentil ${ }^{1}$, Marcele Liliane Pesavento ${ }^{1}$

Institution(s) ${ }^{1}$ HIAE - Hospital Israelita Albert Einstein (São Paulo, SP, Brasil)

\begin{abstract}
Introdução: O desenvolvimento de LP adquiridas em centros hospitalares traz uma grande preocupação para os profissionais da saúde, geram altos custos para o tratamento, comprometimento emocional e doloroso para o paciente e cuidadores envolvidos, além do aumento da demanda de trabalho da enfermagem. Há uma escassez de estudos que abordem a LP em pacientes críticos, resultando em lacunas importantes para a compreensão da epidemiologia, etiologia, fatores de risco e do manejo. A experiência clínica dá indícios, a partir da observação empírica, de que esta é uma condição com relevância clínica e prevalente principalmente na Unidade de Terapia Intensiva (UTI). Objetivo: Identificar a prevalência de LP em pacientes adultos internados na UTI. Material e método: Trata-se de um estudo transversal, retrospectivo, descritivo, com abordagem quantitativa. A pesquisa será realizada em uma instituição privada de nível terciário na capital do Estado de São Paulo A amostra deste estudo constitui-se de pacientes internados no dia da coleta de dados trimestral na UTI adulto dos anos 2017 e 2018. O projeto de pesquisa foi encaminhado e aprovado pelo Comitê de Ética em Pesquisa (CEP) do Hospital Israelita Albert Einstein, por meio da Plataforma Brasil - CAAE: 85659218.6.0000.0071, parecer: 3.415.439. Resultados: O estudo foi composto por 167 pacientes. A prevalência da LP foi de 14,3\% (24). A idade média dos pacientes com LP foi de 67,4 anos. Houve uma predominância da LP em pacientes do sexo masculino $(19 ; 21,6 \%)$ com diferença estatística significante $(p), 005)$ quando comparada com o sexo feminino (5; $6,3 \%$ ). Conclusões: Os resultados encontrados contribuem para o diagnóstico situacional da ocorrência da LP. Este estudo poderá contribuir para a sistematização das práticas clínicas e adoção de protocolos assistenciais visando a qualidade e segurança do paciente.
\end{abstract}

Keywords: Lesão por Pressão, Unidades de Terapia Intensiva, Estudos Transversais, Estomaterapia

\section{Referências Bibliográficas}

1. National Pressure Ulcer Advisory Panel, European Pressure Ulcer Advisory Panel, Pan Pacific Pressure Injury Aliance.

Prevention and treatment of pressure ulcers: clinical practice guideline. Washington, DC: NPUAP/EPAUAP/PPPIA; 2014. 2. Borghardt AT, Prado TN, Bicudo SDS, Castro DS, Bringuente MEO. Úlcera por pressão em pacientes críticos: incidência e fatores associados. Rev Bras Enferm. 2016 mai-jun;69(3):460-7. 3. International Guidelines. Pressure ulcer prevention: prevalence and incidence in context. A consensus document. London: MEP; 2009. 


\title{
Redução de lesão por pressão em paciente crítico utilizando a ciencia da melhoria
}

\author{
Author(s): Aline de Oliveira Ramalho ${ }^{1}$, Eliane Mazócoli ${ }^{1}$, Karoline Razimavicius Barbado Vilalva ${ }^{1}$, Natalia \\ Balestra ${ }^{1}$, Nilda Rosa de Oliveira Prado ${ }^{1}$ \\ Institution(s) ${ }^{1}$ HSL - Hospital Sírio Libanês (Rua Adma Jafet, 91)
}

\begin{abstract}
As lesões por pressão (LP) são considerados eventos adversos graves que podem ocorrer durante uma internação hospitalar, sendo associadas com aumento do tempo de internação, sepse e morbi-mortalidade. O acompanhamento dos indicadores de LP está relacionado a qualidade assistencial e é uma das metas de segurança do paciente. Durante a análise da prevalência de lesão por pressão institucional, foi identificada uma oportunidade de melhoria na UTI cardiológica, que apresentava nesta data alta prevalência, com uma mediana de 50\% entre setembro de 2017 a fevereiro de 2018.
\end{abstract}

Objetivo: Relatar as intervenções implementadas para redução da prevalência de lesão por pressão na UTI cardiológica, utilizando a ciência da melhora.

Metodologia: Estudo descritivo realizado através da análise dos indicadores de qualidade em uma UTI de um hospital de grande porte, antes de depois de intervenções para redução das lesões por pressão. Como proposta de melhoria foi elaborado em conjunto com a equipe local um diagrama direcionador contendo quatro pilares de mudança: 1) Levantamento das melhores práticas relacionadas a prevenção de LP; 2) Criação de um care bundle de prevenção; 3 ) Engajamento da equipe multiprofissional; 4) Envolvimento do paciente e familiares no cuidado. A partir disso, as idéias de mudança foram estabelecidas e testadas através da ferramenta PDSA, com testes rápidos e em pequena escala, afim de avaliar a viabilidade das ideias propostas. Entre as ações desenvolvidas e implementadas, temos: care bundle de prevenção associado à utilização de espuma multicamadas com bordas de silicone em pacientes de alto risco; uso de uma almofada de gel na região sacral/glútea em pacientes submetidos a hipotermia induzida, elaboração de uma diretriz específica para a prevenção de lesões de pele no paciente de alta criticidade e instabilidade hemodinâmica e oficinas educativas para consolidar os novos processos com toda equipe multiprofissional.

Resultados: A prevalência de lesão por pressão foi reduzida de 50\% para 10\% em 6 meses (81\% de redução), com $83 \%$ de adesão ao care bundle de prevenção. Foi definido como indicador de equilíbrio o tempo de permanência do paciente nesta unidade. Notamos uma diminuição de $20 \%$ no tempo de permanência do paciente em unidade de terapia intensiva, durante este período (de 5,48 dias a 4,27 dias).

Conclusões: A implementação de um projeto focado nas necessidades setoriais utilizando a ciência da melhoria, proporcionou uma diminuição importante na prevalência de lesão por pressão em pacientes altamente críticos. É importante ressaltar que, além de uma metodologia inovadora, estão ligados a esse resultado positivo também o engajamento da equipe, o envolvimento da equipe multiprofissional e inclusão dos pacientes e familiares no cuidado.

Keywords: Lesão por Pressão, Prevenção, Estomaterapia

\section{Referências Bibliográficas}

1-Précoma HF, Caudouro, FLF. Adverse events reported in intensive care: documentary analysis. Anais do EVINCIUniBrasil, v. 1, n. 4, p. 1527-1539, 2016. 2- Campanili TCGF, Santos VLCG, Strazzieri-Pulido KC, Thomaz PBM, Nogueira PC. Incidence of pressure ulcers in cardiopulmonary intensive care unit patients. Rev. esc. enferm. USP [Internet]. 2015 Dec. 3 - Annette Richardson, Joanna Peart, Stephen E. Wright, lain J. McCullagh; Reducing the incidence of pressure ulcers in critical care units: a 4-year quality improvement, International Journal for Quality in Health Care, Volume 29, Issue 3, 1 June 2017, Pages 433-439 


\title{
AVALIAÇÃO CLÍNICA DA PREVALÊNCIA DE BACTÉRIAS EM PACIENTES DIABÉTICOS COM FERIDAS CRÔNICAS INESPECÍFICAS NO SERTÃO DA PARAÍBA:ESTUDO EXPERIMENTAL.
}

\author{
Author(s): PASCALLE DE SOUSA ROCHA ${ }^{1}$, Luis Rafael Leite Sampaio ${ }^{2}$, FERNANDO FONSECA ${ }^{3}$, YTERFANIA SOARES \\ Institution(s) ${ }^{1}$ IFPB - INSTITUTO FEDERAL DA PARAÍBA (R. Pres. Tancredo Neves, s/n - Jardim Sorrilandia, Sousa - PB, 58805- \\ 345), ${ }^{2}$ URCA - UNIVERSIDADE REGIONAL DO CARIRI ( Rua Cel. Antônio Luis, 1161 - 63105-000 - Pimenta - \\ Crato/CE), ${ }^{3}$ FMABC - FACULDADE DE MEDICINA DO ABC (Av. Lauro Gomes, 2000 - Vila Sacadura Cabral, Santo \\ André - SP, 09060-870)
}

\begin{abstract}
Introdução: A Diabetes Mellitus por ser uma doença crônica que pode acarretar várias outras complicações como a retinopatia, nefropatias, cetoacidose e pode-se destacar o Pé Diabético, que em 2014 foi responsável por 1863 admissões no hospital e a 1385 amputações. ${ }^{1}$ O pé diabético é decorrente de uma infecção, ulceração e ou destruição dos tecidos profundos, relacionados a anormalidades neurológicas e a vários graus da doença vascular periférica nos MMII3. Considera-se causa simples de invalidez, já que por circunstância da provável amputação do membro acometido induz a baixa da melhoria de vida do portador de diabetes. A úlcera aparece no dorso, dedos ou bordas do pé e, normalmente, está relacionada à utilização de calçados inapropriados, e é mais prevalente nos homens por causa do mau controle das complicações crônicas ${ }^{2}$. Objetivo: Analisar e identificar os tipo de bactérias prevalentes nos pacientes diabéticos com feridas crônicas inespecíficas. Material e Método: Trata-se de uma pesquisa experimental, de caráter descritivo e exploratório com abordagem quantitativa, realizada na faculdade Santa Maria, no Alto Sertão do Estado da Paraíba, durante o período de março a outubro de 2018, após a aprovação do Comitê de Ética em Pesquisa da (FSM), com CAAE 64526217.9.0000.5180 Numero do parecer: 2.016.083, de forma a garantir o sigilo das informações pessoais sendo o público-alvo pacientes com feridas crônicas de diferentes etiologias, maiores de 18 anos tais, de ambos os sexos e faixas etárias. Resultados: Foram analisados Swab de 21 pacientes que eram diagnosticados com Diabetes Mellitus, mediante confirmação com glicemia de jejum, onde a maioria foi do sexo feminino com 11 (52\%). Observou-se que com relação à escolaridade, obteve-se um alto nível de analfabetos com 10 (48\%). Quanto à faixa etária, predominou de 70 à 90 anos com 10 (48\%). Sobre o tempo de lesão, teve prevalência de 1 ano à 3 anos com 7 (33\%). Em consideração ao grau da ferida, foi observado que 8 (38\%) tinham o grau 02. A localização da ferida mais encontrada foi no dorso do pé - 3 (14\%), e região Sacral/Trocânter - 3(14\%). A bactéria que mais prevaleceu foi a Pseudômonas aeruginosa com 5 (24\%) das culturas positivas. Conclusão: O presente estudo originou o perfil bacteriológico de pacientes diabéticos portadores de feridas inespecíficas, e os resultados mostram a necessidade de se fazer exames para saber diagnósticos específicos e assim, eliminar ou diminuir microrganismos antes que causem complicações maiores e comprometam partes do corpo do paciente. Além disso, visando a prevenção e o controle de infecções relacionadas à assistência à saúde, para aprimorar a qualidade da assistência e a segurança do paciente.
\end{abstract}

\section{Keywords: ESTOMATERAPIA, DIABETES MELLITUS, INFECÇÃO DE FERIMENTOS, BACTÉRIAS}

\section{Referências Bibliográficas}

1. Cubas, M.R.; Santos, O.M.; Retzlaff, E.M.A.; Telma, H.L.C.; Andrade, I.P.S.; Moser, A.D.L.; Erzinger, A.R. Pé diabético: orientações e conhecimento sobre cuidados preventivos, Fisioter. Mov., Curitiba, jul./set 2013.v. 26, n. 3, p. 647-655. 2. Oliveira, de A.F; Filho, $\mathrm{H}$ de O. Perfil microbiológico e de resistência antimicrobiana no pé diabético infectado. J Vasc Bras ,Lages- SC,, Out.-Dez 2014.Vol. 13(4):289-293. 3. Pessoa, V.S. Pseudomonas aeruginosa: Epidemiologia e resistência a antimicrobianos em Hospital Universitário do Sudeste do Brasil, [Dissertação em Ciências da Saúde] Faculdade de Medicina da Universidade Federal de Uberlêndia, 2013. 


\title{
FERIDAS NEOPLÁSICAS: EVIDÊNCIAS CIENTÍFICAS PARA A ASSISTÊNCIA DE ENFERMAGEM HOSPITALAR
}

\author{
Lorena Alves Pantoni ${ }^{1}$, André Aparecido da Silva Teles ${ }^{1}$, Lívia Modolo Martins ${ }^{1}$, Vanessa \\ Author(s): Damiana Menis Sasaki ${ }^{1}$, Janderson Cleiton Aguiar ${ }^{1}$, Camila Maria Silva Paraizo Horvath ${ }^{1}$, \\ Helena Megumi Sonobe ${ }^{1}$ \\ Institution(s) ${ }^{1}$ EERP-USP - ESCOLA DE ENFERMAGEM DE RIBEIRÃO PRETO - EERP - USP (R. Prof. \\ Hélio Lourenço, 3900 - Vila Monte Alegre, Ribeirão Preto - SP, )
}

\begin{abstract}
Introdução: Para a assistência de enfermagem aos pacientes com feridas neoplásicas é fundamental um protocolo de curativo no contexto hospitalar, para o manejo dos desconfortos físicos e psicossociais, com base em evidências científicas. Objetivo: analisar as evidências científicas sobre o manejo de feridas neoplásicas em pacientes para estabelecer as recomendações para a elaboração de protocolo de curativo no contexto hospitalar. Material e método: Revisão Integrativa, fundamentada na Prática Baseada em Evidências, em seis etapas: identificação do tema e seleção da questão de pesquisa; estabelecimento de critérios para inclusão e exclusão de estudos; categorização dos estudos; avaliação dos estudos incluídos na revisão integrativa; interpretação dos resultados e síntese do conhecimento dos principais resultados evidenciados na análise dos artigos incluídos, mediante a questão de pesquisa: "Quais as evidências científicas sobre curativos de pacientes com feridas neoplásicas para estabelecer as recomendações no contexto hospitalar?". As buscas foram realizadas com descritores controlados e não controlados "neoplastic wounds"; "tumor wounds"; "malignant wounds", utilizando-se o operador booleano "OR", nas bases de dados Literatura Latino-Americana e do Caribe de Informações em Ciências da Saúde (Lilacs), Cumulative Index to Nursing and Allied Health Literature (CINAHL), Web of Science (WOS) e National Library of Medicine National Institutes of Health (PUBMED), resultando em 211 artigos científicos, mediante critérios de inclusão e exclusão, a amostra final foi de 17 artigos científicos. Utilizou-se instrumento de coleta de dados para a extração de informações como identificação, características metodológicas e avaliação do rigor metodológico da amostra, com análise descritiva. Resultados: Do total de 17 artigos, identificou-se 10 artigos com nível de evidência VI, dois com nível II, dois com nível I, dois com nível IV e um com nível V. Dez artigos foram categorizadas em "Intervenções para o manejo de pacientes com feridas neoplásicas", destacando-se utilização de protocolos e de instrumentos, para avaliação da ferida e de outras dimensões do paciente, além da necessidade do envolvimento do próprio paciente, familiares e profissionais para propiciar conforto e bem estar, sendo que sete artigos constituíram a categoria "Eficácia de coberturas no manejo das feridas neoplásicas", e refinamento da avaliação clínica para estabelecer fatores preditores da condição clínica do paciente e da evolução da ferida neoplásica, principalmente da dor, sangramento, odor e necrose, além da avaliação da eficácia das coberturas. Conclusão: As recomendações para a elaboração do protocolo de assistência de enfermagem aos pacientes com feridas neoplásicas envolvem aspectos de recursos materiais, ensino de pacientes e familiares, educação permanente de profissionais em relação aos conhecimentos especializados sobre avaliação da ferida e do paciente, gerenciamento de recursos e apoio institucional para assegurar a sua implementação. Há escassez de produção sobre feridas neoplásicas, com estudos com níveis de evidências pouco fortes e no contexto brasileiro somente obtivemos três produções.
\end{abstract} Descritores: Feridas neoplásicas. Assistência de enfermagem. Protocolos Clínicos. Estomaterapia.

Keywords: Feridas neoplásicas, Assistência de enfermagem, Protocolos Clínicos, Estomaterapia

\section{Referências Bibliográficas}

Referências Stillwell SB, Fineout-Overholt E, Melnyk BM, Williamson KM. Searching for the evidence: strategies to help you conduct a successful search. Am J Nurs. 2010; 110(5):41-7. Liberati A, Altman DG, Tetzlaff J, Mulrow C, Gotzche PC, Ioannidis JPA, et al. The PRISMA statement for reporting systematic reviews and meta-analyses of studies that evaluate health care interventions: explanation and elaboration. BMJ. 2009; 339:2700. Kelechi T J, Prentice M, Madisetti M, Brunette G, Mueller M. Palliative Care in the management of pain, odor, and exudate in chronic wounds at the end of life: a cohort study. Journal of Hospice \& Palliative Nursing. 2017; 19(1): 17-25. Seaman, S. Management of malignant fungating wounds in advanced cancer. Semin Oncol Nurs. 2006 Aug; 22(3):185-93. Maida V, Peck J, Ennis M, Brar N, Maida AR. Preferences for active and aggressive intervention among patients with advanced cancer. BMC Cancer. 2010 Oct 28; 10:592. 


\title{
Perfil Clínico dos pés e de bioimpedância de indivíduos com Diabetes tipo 2
}

\author{
Ana Paula Hey ${ }^{1}$, DEBORA HERNANDES DOMINGUES ${ }^{3}$, Pryscilla Velasco ${ }^{3}$, WILLIAN \\ Author(s): SALLES $^{2}$, CRISTIANO CAVEIÃO ${ }^{2}$ \\ Institution(s) ${ }^{1}$ UTP - UNIVERSIDADE TUIUTI DO PARANÁ (Rua Sydnei Antonio Rangel Santos, 238 - \\ cURITIBA PR), ${ }^{2}$ UNINTER - CENTRO UNIVERSITÁRIO INTERNACIONAL UNINTER (Rua \\ Luiz Xavier, 103 - Centro, Curitiba - PR), ${ }^{3}$ UNIBRASIL - ENFERMEIRA FORMADA PELO \\ CENTRO UNIVERSITÁRIO UNIBRASIL (R. Konrad Adenauer, 442 - Tarumã, Curitiba - PR), ${ }^{4}$ \\ UNIBRASIL - ENFERMEIRA FORMADA PELO CENTRO UNIVERSITÁRIO UNIBRASIL (R. \\ Konrad Adenauer, 442 - Tarumã, Curitiba - PR)
}

\begin{abstract}
Introdução: O pé diabético é conceituado como uma infecção, ulceração e ou destruição dos tecidos profundos associadas a anormalidades neurológicas e vários graus de doença vascular periférica nos membros inferiores. Já a biuoimpedância elétrica pode ser importante na avaliação da pessoa com diabetes, pois pode auxiliar na avaliação da composição corporal, do estado nutricional e das alterações metabólicas do indivíduo, permitindo um melhor manejo da doença e de suas complicações. Elevando a qualidade do diagnóstico e reduzindo a incidência de feridas e amputações. Objetivo: descrever o perfil clínico dos pés e de bioimpedância de indivíduos com Diabetes Tipo 2. Método: Trata-se de estudo quantitativo prospectivo descritivo, realizado em um programa de prevenção terciária para doentes crônicos de uma operadora de saúde privada, localizado em Curitiba-PR, entre abril à maio de 2019. Foi aprovado pelo CEP sob o número 3.245.092. Este estudo contou com a participação de indivíduos com Diabéticos tipo 2, que se enquadraram nos critérios de inclusão por terem mais de 18 anos e serem Diabéticos há mais de 5 anos. A coleta de dados foi realizada por meio de um Instrumento de exames dos pés e pelo exame de Bioimpedância Elétrica (Aparelho InBody120). Resultados: Foram incluídos no estudo 15 participantes, sendo 60\% (9) do sexo masculino e $40 \%$ (6) do sexo feminino; na faixa etária de 35 a 77 anos, sendo estabelecido uma média de idade de 60,1. Os resultados obtidos do exame de bioimpedância demonstram que $80 \%$ (12) participantes encontram-se em desequilíbrio entre a relação massa magra-gordura, porem $20 \%$ (3) dos participantes que apresentaram resultados dentro dos padrões de normalidade, houve maior prevalência de alterações no exame clínico dos pés. No exame clínico dos pés, a maior parte dos participantes foi classificada como baixo risco para desenvolvimento de pé diabético. Destaca-se que as variáveis com significância estatística: teste de sensibilidade térmica; micose e onicocriptose. Conclusões: a bioimpedância, aliada ao exame clínico dos pés, pode ser um valioso instrumento para mensuração da composição corporal de pacientes Diabéticos, pois monitorar as alterações na composição corporal do Diabéticos pode contribuir para redução de complicações futuras, relacionas ao desequilíbrio entre massa magra-gordura e alterações dos pés.
\end{abstract}

Keywords: ESTOMATERAPIA, enfermagem, pé diabético, bioimpedância

\section{Referências Bibliográficas}

1.American Diabetes Association. Diagnosis and classification of diabetes mellitus. Diabetes Care. 2014;37(SUPPL.1):81-9. 2. Darokar AG, Phatak MS, Ali Thobani B, Kumar Patel A. Assessment of Body Composition by Bioelectrical Impedance Analysis in Type 2 Diabetes Mellitus Women of Central India. Int J Life Sci Sci Res [Internet]. 2016;2(4):457-61. 3. Dittmar M, Reber H, Kahaly GJ. Bioimpedance phase angle indicates catabolism in Type 2 diabetes. Diabet Med. 2015 


\title{
ASSISTÊNCIA DE ENFERMAGEM NA TERAPIA POR PRESSÃO NEGATIVA (TPN) EM PÉ DIABÉTICO: RELATO DE EXPERIÊNCIA
}

\author{
Patricia Herbster P. Lerma ${ }^{1}$, Susana Beatriz de Souza Pena ${ }^{2,3}$, Siena do Amaral Sampaio ${ }^{1}$, Ana \\ Author(s): Paula Brandão da Silva Farias ${ }^{2}$, Ariadne Freire de Aguiar Martins ${ }^{2}$, Silvestre Péricles Cavalcante \\ Sampaio Filho ${ }^{2,3}$, Rita Mônica Borges Studart ${ }^{3}$ \\ Institution(s) ${ }^{1}$ Unifametro - Centro Universitário Fametro (Rua Conselheiro Estelita, 500 - Centro, Fortaleza - \\ CE, 60010-260), ${ }^{2}$ NAPEN-COREN/CE - Núcleo de Aperfeiçoamento dos Profissionais de \\ Enfermagem (R. Mario Mamede, 609 - Fátima, Fortaleza - CE, 60415-000), ${ }^{3}$ UNIFOR - \\ Universidade de Fortaleza (Av. Washington Soares, 1321 (BLOCO B) - Edson Queiroz, Fortaleza - \\ CE, 60811-025)
}

\begin{abstract}
Introdução: Os pacientes acometidos por de Diabetes Mellitus possuem riscos de desenvolver lesões nos membros inferiores que podem vir acompanhados de infecçõess, dificuldades de ambulação, e até mesmo corroborar na amputação'. A mortalidade relacionada à amputação imediata é estimada em $19 \%$, e a sobrevida é de $65 \%$ em três anos, e $41 \%$ em cinco anos. Além disso, ocupa os primeiros lugares entre os principais problemas de saúde, afligindo vários países do mundo e causando grande impacto sócio econômico ${ }^{2},{ }^{3}$. A enfermagem tem se destacado em nosso país com o tratamento de lesões e feridas, bem como o resgate da auto estima dos pacientes. Um método de opção terapêutica é o sistema de terapia por pressão negativa (TPN), conhecido também como curativo a vácuo (VAC), traz como benefícios: o controle de drenagem das secreções, a redução do edema local, a redução da carga bacteriana e o desenvolvimento precoce de um tecido de granulação pela estimulação angiogênica (crescimento de novos vasos sanguíneos a partir dos já existentes)4,5. Objetivo: Relatar a experiência da acadêmica de enfermagem a respeito da assistência na TPN em pé diabético Material e Método: Relato de experiência da assistência de enfermagem em hospital de referência de nível secundário, no internato da faculdade, último semestre. Durante fereveiro à junho de 2019, fora analisado o caso de um paciente com pé diabético em pós-operatório de $1^{\circ}, 2^{\circ}$ e e $3^{\circ}$ pododáctilo, com reflexão sobre a atuação da enfermagem diante da TPN. Respeitado o anonimato do paciente. Resultados: Foi observado que sistema de terapia negativa consiste de um tubo de aspiração, um reservatório, uma bomba de vácuo e uma esponja multiporosa de poliuretano. O enfermeiro colocou a esponja recortada na extensão da ferida, e selou com um filme aderente transparente e permeável ao vapor. Esse conjunto foi conectado ao reservatório da bomba por um tubo aspirativo, o que permitiu o controle da quantidade de secreção aspirada e uma pressão local negativa em modo contínuo na ordem de 100 a $125 \mathrm{mmHg}$. O sistema de TPN foi trocado em 7 dias. $O$ uso do curativo foi descontinuado depois de se confirmar a formação de tecido de granulação saudável. Percebeu-se melhora na cicatrização, pois a lesão inicial apresentava exsudato aumentado, odor fétido e esfacelos na base. O tratamento corroborou em melhora da infecção local e menor tempo de internação hospitalar. Conclusão: Foi observado que atuar com a terapia por pressão negativa exige do enfermeiro conhecimentos sobre o leito da ferida, bem como sobre o sistema da terapia por pressão negativa. Tem se apresentado como tratamento eficaz e notório nas lesões e feridas. Além disso é área de especialidade e autonomia na enfermagem.
\end{abstract}

Keywords: Enfermagem, Estomaterapia, Tratamento de Ferimentos com Pressão Neg, Cicatrização

\section{Referências Bibliográficas}

1. Costa AWS, Azevedo AP, Costa FWS. A importância do profissional de enfermagem aos cuidados com o pé diabético. Revista Uningá. 2019; 56(S2): 1-13. 2. Oliveira JS. Complicações do Diabetes: Pé Diabético. São Paulo: Universidade Federal de São Paulo. Universidade Aberta do SUS, 2017. Trabalho de Conclusão de Curso em Enfermagem. 3.

Sociedade Brasileira de Diabetes. [homepage na internet]. O alto custo do pé diabético no Brasil. [acesso em 10 jun 2019]. Disponível em: http: https://www.diabetes.org.br/publico/ultimas/1609-o-alto-custo-do-pe-diabetico-no-brasil 4. Jones DA, Neves Filho WV, Guimarães JS, Castro DA., Ferracini, AM. Aplicação da terapia por pressão negativa no tratamento de feridas infectadas. Estudo de casos. Revista Brasileira de Ortopedia. 2016. 51(6): 646-651. 5. Abreu RLD, Gomes SKC, Silva AA, Brum CF, Azevedo MB. Assistência de enfermagem no tratamento de feridas por terapia de pressão subatmosferica (VAC) na UTI. Revista Rede de Cuidados em Saúde. 2016. 10(2):1-4. 


\title{
O CONTROLE DA DOR EM PACIENTES COM LESÃO POR PRESSÃO OU FERIDAS OPERATÓRIAS DURANTE SEUS MANUSEIOS/ABORDAGENS
}

\author{
Daiany Santos Fernandes ${ }^{1}$, Patricia Pedroso da Silva ${ }^{1}$, Bruno Pigatto ${ }^{1}$, Daniela Tenroller de \\ Author(s): $\quad$ Oliveira ${ }^{1}$, Elisandra Leites Pinheiro ${ }^{1}$, Elisangela Melo ${ }^{1}$, Fernanda Crossetti Cunha ${ }^{1}$, Poliana \\ Rodrigues da Silva ${ }^{1}$ \\ Institution(s) ${ }^{1}$ HMV - hospital moinhos de vento (Rua Ramiro Barcelos, 910)
}

\begin{abstract}
Introdução: A dor é considerada o $5^{\circ}$ sinal vital, a mesma não é uma doença, mas um sintoma, e um sinal de que algo não está certo em nosso corpo ${ }^{1}$. A associação internacional dos estudos da dor define essa sensação como uma experiência física e emocional desagradável, que também pode estar associada ou relacionada à lesão por pressão/ferida²: Lesão localizada na pele e/ou tecidos moles subjacentes, geralmente sobre uma proeminência óssea, ou relacionada a dispositivos médicos, podendo se apresentar em pele íntegra ou como úlcera aberta e dolorosa. ${ }^{3} \mathrm{O}$ fato de que, o envelhecimento e a institucionalização aumentam o risco da integridade da pele prejudicada, torna ainda mais necessário que os enfermeiros façam um diagnóstico precoce com vistas a implementação de ações no controle da dor e contribuam para a melhoria do cuidado.4 Objetivo: Avaliar registros de medidas para controle da dor antes e após a prestação dos cuidados assistenciais no manuseio das lesões por pressão ou feridas operatórias. Método: Trata-se de um estudo transversal de caráter observacional e descritivo, que faz parte de um projeto guarda-chuva da instituição, como parecer CAAE: 57679316.9.0000.5330. Foi realizada uma busca ativa nos prontuários de pacientes internados em unidades de internação, através dos registros de controles assistenciais juntamente com a prescrição médica, a administração ou não de analgesia, e pré ou pós-realização dos curativos. No estudo foram avaliados 12 prontuários de pacientes portadores de lesões e feridas operatórias no período de 01/04/2019 há 15/04/2019. Resultados: Na análise dos controles assistenciais avaliados, oito pacientes que possuem lesões por pressão ou feridas operatórias fizeram uso de analgésicos pósabordagens das lesões, entendendo-se que, houve sim necessidade do controle da dor, sendo que estes pacientes poderiam ter sido medicados previamente para evitar ou diminuir a dor durante o procedimento. $O$ controle $e$ gerenciamento da dor deve ser uma prioridade pela equipe assistencial, antes da prestação dos cuidados nas lesões ou feridas operatórias, onde se faz necessário um processo interativo, em que o profissional aplica, além da sua habilidade técnica, conhecimentos, intuição e sobretudo muita sensibilidade para com o paciente. Conclusão: O papel do enfermeiro e da sua equipe na identificação a necessidade do controle da dor antes de realizar qualquer tipo de abordagem a lesão/ferida é essencial, considerando que esses profissionais tenham as ferramentas corretas para identificação do nível de dor do paciente e um protocolo de analgesia padrão na instituição. Sabe-se que a importância da aplicação de meios medicamentosos antes da prestação de cuidados nestas lesões, ou feridas, previne a sensação desagradável da dor, proporcionando um atendimento mais humanizado e menos traumatizante ao paciente.
\end{abstract}

Keywords: Analgesia, Dor, Estomaterapia, Lesão por Pressão

\section{Referências Bibliográficas}

REFERÊNCIAS: 1. ANCP: Manual de cuidados Paliativos ANCP. 2 ed. Rio de Janeiro: Diagraphic, 2012. 2. SOUSA. Dor: 0 quinto sinal vital. revista latino-am Enfermagem, 2002. 3. POTTER; PERRY. Fundamentos de Enfermagem. 7. Ed. Rio de Janeiro: Elsevier. 4. National Pressure Ulcer Advisory Panel, European Pressure Ulcer Advisory Panel and Pan Pacific Pressure Injury Alliance. Prevention and Treatment of Pressure Ulcers: Clinical Practice Guideline. Emily Haesler (Ed.). Cambridge Media: Osborne Park, Austrália Ocidental; 2014. 


\section{Evolução da lesão em atendimento domiciliar}

Natalia Kato de Oliveira Ramalho ${ }^{1}$, Natalia Kato de Oliveira Ramalho ${ }^{1,1}$, roni de Paiva Santos Author(s): $\quad$ 1,1,1,1, Esther dos Santos Morais dos Santos Morais ${ }^{1,1,1,1}$, Sylvia Aparecida Vicentino ${ }^{1,1,1,1}$, Thaise Dantas Vieira Veiga ${ }^{1,1,1,1}$

Institution(s) ${ }^{1}$ Pronep SP - Pronep Home Care Medicina Domiciliar (Rua Bagé, 112)

\section{Abstract \\ Evolução da lesão em atendimento domiciliar}

A assistência domiciliar é um tema que atualmente traz muita discussão entre profissionais da área da saúde, por se tratar de uma modalidade que permite cuidados e realizações de alguns procedimentos realizados no domicílio.

Em virtude da doença crônica, temos uma doença hereditária, doença de Niemann-Pick (DNP), de caráter autossômico recessivo e rara, caracterizada pela deficiência da enzima que catalisa a hidrólise de esfingomielina a ceramida, principalmente nos tecidos do sistema reticuloendotelial. Os sintomas devem-se ao acúmulo de macrófagos repletos de lipídios e vacuolizados, denominados células de Niemann-Pick, em vários órgãos, como fígado, baço, medula óssea, pulmão e sistema nervoso central. Esta doença apresenta atualmente seis subtipos, dependendo da gravidade da deficiência enzimática: subtipo $A$, com forma neuropática aguda; subtipo $B$, a forma visceral; subtipo $C$, forma neuropática crônica; subtipo $D$, variante nova escocesa; subtipo $E$, forma adulta; e subtipo $F$, doença do histiócito azul-mar. Não há tratamento específico ou eficaz para a doença de Niemann-Pick.

No atendimento domiciliar nos deparamos com um caso de uma jovem de 17 anos de idade, levava uma vida comum até seus 03 anos de idade e começou a desenvolver alguns sintomas desta doença, como distrofia muscular, sendo encaminhada ao Hospital das Clínicas, onde foi submetida a exames laboratoriais que evidenciou: Síndrome de Nieamann Pick, desde então ficou com a musculatura atrofiada evoluindo com gastrostomia (GTM), traqueostomia (TQT) com uso de ventilação mecânica (VM), onde desenvolveu uma lesão eritematosa peri TQT.

O objetivo deste estudo foi analisar a cobertura de espuma de poliuretano multi camadas, composta por silicone, transferência do exsudato, dispersão, armazenamento e filme, em uma jovem com lesão Eritematosa, embasado no protocolo institucional.

Como método trata-se de uma revisão sistemática retrospectiva, efetuado levantamento e análise dos dados clínicos da paciente, acompanhamento evolutivo através de avaliação presencial, registros dos dados e fotográficos, respeitando os preceitos éticos.

Como resultado foi analisado efeito positivo em relação ao processo de cicatrização, como tempo de cicatrização e otimização dos processos, com a utilização de curativo multi camadas, considerado alta tecnologia, paciente mantinha atendimento prolongado com outros tipos de coberturas.

Conclui-se neste estudo a efetividade de protocolos institucionais que embasam o atendimento a paciente com feridas, compreendendo padronização dos produtos, orientação quanto a indicação e aplicação.

Keywords: Home care, Protocolos, Lesão, Cobertura

\section{Referências Bibliográficas}

1- DAL BEN, LW. Dimensionamento do pessoal de enfermagem em assistência domiciliária: percepção de gerentes e enfermeiras. São Paulo, 2005. 169p. Tese (Doutorado) Escola de Enfermagem, Universidade de São Paulo. 2- Doença de Niemann-Pick tipo B: avaliação do comprometimento pulmonar por TCAR Heloisa Maria Pereira Freitas1, Alexandre Dias Mançano2, Rosana Souza Rodrigues1,3, Bruno Hochhegger4, Pedro Paulo Teixeira e Silva Torres5, Dante Escuissato6 , Cesar Augusto Araujo Neto7, Edson Marchiori1 http://www.scielo.br/pdf/jbpneu/v43n6/pt_1806-3713-jbpneu-43-0600451.pdf em 29/05 4- Yamada B. Portal da Enfermagem - Estomaterapia: especialidade em ascensão [internet] 2011 [citado 2011 Agosto 16]. Disponível em http://www.portaldaenfermagem.com.br 5- Construção de tecnologia educacional para estomizados: enfoque no cuidado da pele periestoma - Rev. Bras. Enferm. Vol.72 no.2 Brasília Mar./Apr. 2019 Epub Apr18, 2019 - Dione Seabra de Carvalho; Ana Gracinda Ignácio da Silva; Sandra Regina Monteiro Ferreira; Levindo Cardoso Braga 


\title{
Suplementação oral especializada na cicatrização de Lesão Por Pressão em ambiente domiciliar: Relato de 2 casos.
}

\author{
Author(s): $\quad$ Katucha Maia Ayres Maria ${ }^{1}$, Gabriella Derestte ${ }^{1}$, Heloisa Gaspar ${ }^{1}$, Claudio Flauzino ${ }^{1}$ \\ Institution(s) ${ }^{1}$ Home Doctor - Home Doctor - Empresa de Atenção Domiciliar (Rua Capitão Francisco Teixeira \\ Nogueira, 154 Água Branca São Paulo SP 05037030)
}

\begin{abstract}
Introdução: O tratamento de lesão por pressão (LPP) é assunto de grande relevância para atenção domiciliar (AD), que rotineiramente é responsável pela continuidade do tratamento de lesões desenvolvidas em ambiente hospitalar e que geram impacto social e econômico. A terapia nutricional especializada com aporte proteico contendo aminoácidos específicos como arginina e prolina, além de diferenciado aporte calórico, de zinco, selênio e vitaminas vem sendo proposto com este objetivo, porém o seu uso em domicílio é pouco estudado1-3.
\end{abstract}

Objetivos: Avaliar os efeitos de uma suplementação oral especializada em ambiente domiciliar com fórmula modificada contendo prolina (Novasource Proline®) no processo cicatricial de 2 pacientes com lesão por pressão sacral grau III e IV refratárias ao tratamento habitual.

Metodologia: Dois pacientes com feridas crônicas refratárias foram selecionados. Ambos receberam $200 \mathrm{ml} 2 \mathrm{x} / \mathrm{dia}$ de fórmula modificada para nutrição enteral e oral 1,4 Kcal/ml (Novasource Proline®) por 90 dias e foram acompanhados semanalmente durante este período, com documentação fotográfica da lesão.

Resultados: Paciente 1, J.C.S, 35 anos, feminino, com diagnóstico de Tetraplegia causada por arma de fogo + bexiga neurogênica, LPP sacral há 2 anos refratária ao tratamento. No início do estudo apresentava lesão em estágio IV medindo $1,5 \times 1,5 \mathrm{~cm}$ de extensão e 1,8cm de profundidade, bordas lisas e regulares com tecido de granulação ao leito da lesão, recebendo suplemento nutricional hipercalórico e hiperproteico $200 \mathrm{ml}$ 2x/dia + modulo proteico $20 \mathrm{~g} 2 x / \mathrm{dia}$ via oral totalizando em média $58 \mathrm{~g} / \mathrm{Kg}$ de proteína ao dia. Foi realizada a substituição deste suplemento pela formula modificada durante o período do estudo.

Paciente 2, O.S.T, 80 anos, feminino, com diagnóstico de doença de Alzheimer avançada com alimentação enteral por gastrostomia. LPP há 4 anos de difícil cicatrização, em estagio III medindo $5 \times 1 \mathrm{~cm}$ de diâmetro e $5,5 \mathrm{~cm}$ de profundidade, com túnel lateralizado de $5 \mathrm{~cm}$ com bordas preservadas e regulares, com $95 \%$ do tecido de granulação e $5 \%$ de necrose de liquefação bem aderida ao leito, exsudato sanguinolento, com odor fétido, recebendo dieta por via enteral industrializada hipercalórica e normoproteica no volume de $800 \mathrm{ml} /$ dia, totalizando $55 \mathrm{~g} / \mathrm{Kg}$ de proteína ao dia. Foi complementada a dieta enteral com a formula modificada durante o período do estudo.

No período de estudo observou-se evolução favorável da lesão em ambos os casos. A lesão da paciente 1 apresentou cicatrização completa. A lesão da paciente 2 apresentou melhora na borda e profundidade da lesão, com extensão $5 X 1$ cm e profundidade $5,5 \mathrm{~cm}$ no início e extensão de $4 \times 1 \mathrm{~cm}$, profundidade de $4 \mathrm{~cm}$ com exsudato moderado translúcido e sem odor ao termino do estudo. Não existiram efeitos adversos ou intolerância durante o uso do suplemento oral.

Conclusão: O uso de fórmula nutricional especializada parece ser uma opção como adjuvante no tratamento de feridas crônicas, com uma evolução mais rápida e favorável quando comparado com uma fórmula não especializada.

Keywords: Estomaterapia, Lesão por Pressão, Nutrição, Terapia Nutricional

\section{Referências Bibliográficas}

Referências: 1. Molnar JA, Vlad LG, Gumus T. Nutrition and Chronic Wounds: Improving Clinical Outcomes. Plast Reconstr Surg. 2016 Sep;138(3 Suppl):71S-81S. 2. Thomas DR. Improving outcome of pressure ulcers with nutritional interventions: a review of the evidence. Nutrition. 2001 Feb;17(2):121-5. 3. Langemo D, Anderson J, Hanson D, et al. Nutritional considerations in wound care. Adv Skin Wound Care. 2006 Jul-Aug;19(6):297-8, 300, 303. 


\title{
Eficácia no uso de laser de baixa potência no tratamento de dermatite associada à incontinência
}

\author{
Author(s): $\quad$ Laís Del Moro Cespedes Wojastyk ${ }^{1}$, Wilka Medeiros Silva de Queiroz ${ }^{1}$ \\ Institution(s) ${ }^{1}$ BP Mirante - Real e Benemérita Associação Portuguesa de São Paulo (Rua Martiniano de \\ Carvalho, 965)
}

\begin{abstract}
A incontinência, definida como perda involuntária de urina e/ou fezes atinge parte dos idosos e pacientes críticos em todo mundo. Conforme demonstrado em estudo com pacientes críticos no Brasil, a incidência desse tipo de evento pode chegar a $40 \%$ e $65 \%$, para urina e fezes, respectivamente. A dermatite associada à incontinência (DAl) é definida como edema e eritema na superfície da pele, por vezes acompanhada por erupção e infecções secundárias. A principal causa da DAl é a exposição da pele à urina e/ou fezes. O tratamento e a prevenção desse tipo de complicação, convencionalmente, acontece com a utilização de produtos como cremes e filmes barreiras, pomadas, pastas, além de antibióticos e antifúngicos tópicos. A utilização de laserterapia de baixa potência no tratamento de feridas é considerado um recurso valioso, pela sua capacidade de cicatrização e por atuar no edema e dor no local da ferida. O objetivo deste estudo foi analisar a inclusão da utilização do laser de baixa potência ao tratamento convencional da DAl em um Hospital privado da cidade de São Paulo-SP. A metodologia do estudo é caracterizada como descritiva, retrospectiva de abordagem quantitativa. Identificamos os pacientes com DAl a partir da relação dos atendimentos de avaliação da Enfermeira Estomaterapeuta, excluímos os pacientes que tiveram alta hospitalar antes da finalização do tratamento ou óbito. Verificamos os prontuários de 14 pacientes, 6 pacientes receberam tratamento convencional conforme protocolo institucional e, 8 pacientes, após a implementação de laserterapia na Instituição, receberam além do tratamento convencional a utilização do laser de baixa potência para o tratamento da DAI. Em relação aos resultados, verificamos que 6 pacientes eram do sexo feminino e 8 do sexo masculino, todos os pacientes apresentavam incontinência, sendo 5 pacientes com incontinência fecal e 9 pacientes com incontinência mista. Em relação ao tempo de tratamento, nos pacientes que receberam tratamento convencional a média de dias de tratamento foi 32 dias, já nos pacientes que receberam o tratamento adjuvante com laserterapia a média de dias de tratamento foi de 6,5 dias. A utilização de laserterapia para esse tipo de lesão demonstrou uma eficácia ao tratamento com a diminuição do tempo, além da melhora em relação à dor e edema, percebido na prática clínica. Faz se necessário uma pesquisa mais robusta, com uma amostra maior para evidenciarmos os benefícios da utilização da laserterapia de baixa potência nesse tipo de lesão.
\end{abstract}

Keywords: Dermatite das fraldas, Estomaterapia, Ferimentos e Lesões

\section{Referências Bibliográficas}

Gonçalves PC. Dermatite associada à incontinência: estudo de coorte em pacientes críticos. Belo Horizonte. Dissertação [Mestrado em Saúde e Enfermagem] - Universidade Federal de Minas Gerais; 2016. Cochrane Database os Systematic Reviews. Beckman D, Van Damme N, Schoonhoven L, Van Lanche A, Kottner J, Beele H, et al. Interventions for preventing and treating incontinence -associated dermatitis in adults [acesso em 10 ago 2019]. Disponível em:

https://www.cochranelibrary.com/cdsr/doi/10.1002/14651858.CD011627.pub2/epdf/full Massahud Jr MR, Salomé GM, Ferreira LM. Laser de baixa intensidade e microcorrente na cicatrização em feridas cutâneas em ratos. Rev enferm UFPE on line set 2017 [acesso em 10 de ago 2019] 11(supl9): 3567-3573. Disponível em:

https://periodicos.ufpe.br/revistas/revistaenfermagem/article/view/234487/27683 


\title{
USO DE TERAPIA POR PRESSÃO NEGATIVA COM INSTILAÇÃO, APÓS REJEIÇÃO DE PRÓTESE FEMORAL: RELATO DE EXPERIÊNCIA
}

\author{
Cleocina Oliveira de Souza ${ }^{1}$, ISABELLE CRISTINE SANTANA DE OLIVEIRA ${ }^{2}$, SILVIA \\ Author(s): KARLA SILVA CAVALCANTE ${ }^{2}$, OLGA VIEIRA SILVA ${ }^{1}$, HILTON JOSÉ MELO BARROS ${ }^{2}$, \\ CAMILA FERNANDA FERRO ACCIOLY LINS ${ }^{1}$, BEATRIZ NAKASHIMA ${ }^{1}$ \\ Institution(s) ${ }^{1}$ ALAGOAS MEDICAL - ALAGOAS MEDICAL (RUA DOUTOR ANTONIO CANSANÇÃO), \\ ${ }^{2}$ SANTA CASA - SANTA CASA DE MISERICÓRDIA DE MACEIÓ (RUA BARÃO DE \\ MACEIÓ)
}

\begin{abstract}
Introdução: As fraturas de fêmur são fraturas graves e geralmente resultam de um trauma externo direto, porém também pode ocorrer em conseqüência de alguma deformidade óssea ou patologias. $1 \mathrm{~A}$ fratura no colo do fêmur é encontrada frequentemente na população acima de 60 anos de idade e ocorre, na maioria das vezes, por trauma de baixa energia, especialmente em queda da própria altura. 2 Infecções associadas a implantes ortopédicos continuam sendo uma grave complicação.3Objetivo: Relatar o uso da Terapia por Pressão Negativa com Instilação, após rejeição de prótese femoral. Materiais e Métodos: Relato de experiência em um hospital filantrópico da cidade de Maceió-AL, de paciente idoso, 75 anos, acometido por fratura de fêmur, após queda da própria altura. Realizada cirurgia com implante de prótese femoral. Após 5 meses, paciente dá entrada na emergência, apresentando sinais de infecção sistêmica e local. Iniciada antibioticoterapia, sem resposta satisfatória. Diagnóstico clínico de Osteomielite progressiva, com trocas de curativo diário. Então, equipe médica optou por manter a prótese, realizando lavagem da ferida com uma frequência maior, como tentativa de controlar o quadro infeccioso. Com dois meses de internação, paciente permaneceu aos cuidados da UTI por apresentar instabilidade hemodinâmica. A equipe multidisciplinar reuniu-se e decidiu como terapêutica, para gerenciamento de lesão aberta, a Terapia por Pressão Negativa com instilação de Solução Fisiológica a 0,9\%. Ao total foram realizadas 3 trocas de curativo com espuma reticular de poliuretano, com intervalos de 4 dias entre as trocas. Podendo assim, realizar procedimento de sutura da lesão. Para garantia de não haver novo ciclo infeccioso, deu-se continuidade a curativo com espuma reticular de poliuretano recortável por mais 3 ciclos, com intervalos de troca também de 4 dias. Resultados: Observou-se que após início do tratamento, o paciente também teve uma melhora sistêmica do seu quadro. Evidenciou-se que o tratamento com a Terapia por Pressão Negativa mais o método de instilação, propiciou uma melhora bastante significativa. Favorecendo, considerando seu estado geral, a rápida recuperação e desospitalização do cliente, devolvendo sua autonomia e bem estar físico, social e familiar. Conclusão: Este relato ressalta a importância da fratura no colo do fêmur em idosos devido à alta incidência e taxas de complicações pré e pós-operatórias relacionadas. Concluímos que a enfermagem tem um papel importante em todos os períodos do tratamento pois o enfermeiro é o profissional que está mais próximo do cliente.
\end{abstract}

Descritores: Fratura do fêmur, Enfermagem, Estomaterapia

Keywords: FRATURA DO FÊMUR, ENFERMAGEM, ESTOMATERAPIA

\section{Referências Bibliográficas}

Referências: Smeltzer SC, Bare BG, BRUNNER \& SUDDARTH - Tratado de Enfermagem Médico-Cirúrgica. 10ํecição, Rio de Janeiro: Editora Guanabara Koogan; 2005.1 Guimarães JM, Vaz M, Ono NK, et al. Fratura do Colo Femoral no idoso: osteossíntese e artroplastia - Projeto Diretrizes. novembro 2007. São Paulo: Sociedade Brasileira de Ortopedia e Traumatologia e Colégio Brasileiro de Radiologia; 2007.2 Lehner B. Wim F. Becker R. Jukema G,N. Primeiras experiências com Terapia por Pressão Negativa e instilação no tratamento de implantes ortopédicos infectados: Um estudo observacional clínico. Ortopedia Internacional 35 (9),1415,2011. 


\title{
MANEJO DO ODOR EM FERIDAS ONCOLÓGICAS: UM RELATO DE CASO
}

\author{
Author(s): Nadja Helena Cordeiro Durans ${ }^{1}$, Olinda da Silva Oliveira Neta ${ }^{1}$, Adrieli Quaresma ${ }^{1}$ \\ Institution(s) ${ }^{1}$ HUFURG - Hospital Universitário Dr. Miguel Riet Correa Jr. (R. Visc.de Paranaguá,102- \\ centro,Rio Grande-RS,96200-190)
}

\begin{abstract}
Introdução: A integridade da pele é um importante aspecto a ser avaliado e tratado em pacientes com diferentes diagnósticos, em especial àqueles com câncer, que muitas vezes têm um risco aumentado de desenvolver complicações de feridas que não cicatrizam (1). A ferida oncológica é um angustiante problema para um número significante de pacientes com câncer. As lesões oncológicas ocorrem devido a quebra da integridade da pele decorrente da proliferação celular descontrolada com consequente infiltração de células malignas nas estruturas da pele (2). Normalmente se desenvolvem durante os seis últimos meses de vida, em decorrência do tumor primário ou metastático (3). Em relação aos sintomas decorrentes das lesões oncológicas o odor fétido é considerado o mais desafiador em decorrência da sensação de constrangimento do paciente. O odor está associado à infecção ou colonização de bactérias anaeróbicas no tecido necrótico da lesão. O uso do metronidazol tem sido utilizado para controlar o odor. É possível observar que o paciente com feridas neoplásicas representa um desafio para o enfermeiro no que concerne ao manejo dos sinais e sintomas físicos e psicológicos que essas feridas impõem (4). Objetivo: Descrever o uso do metronidazol em ferida oncológica a partir de uma experiência assistêncial. Material e Método: Trata-se de um relato de caso de uma paciente, M.F.C, sexo feminino, 49 anos com diagnóstico de adenocarcinoma uterino invasor apresentando odor grau III. Resultado: Paciente foi admitida em um Hospital Universitário do Estado do Rio Grande do Sul no dia 17/07/2019 com câncer uterino avançado, colostomizada há seis anos evoluindo com necrose e descolamento de pele periestoma e fístula abdominal, drenagem de secreção purulenta, odor fétido decorrente das complicações por radioterapias e metástase. Os curativos eram realizados pelos enfermeiros da unidade. Iniciava-se pela limpeza da lesão com soro fisiológico $0,9 \%(\mathrm{SF} 0,9 \%) \mathrm{com}$ temperatura a $37^{\circ} \mathrm{C}$ usava-se uma seringa 40x12 no frasco do soro, e depois eram utilizados 03 comprimidos de metronidazol $250 \mathrm{mg}$ diluídos em 50ml de S,F 0,9\%, o curativo era realizado 3x ao dia. Não havia indicação de terapia endovenosa com a solução do metronidazol devido o estágio avançado da doença. Observou-se que após 7 dias de tratamento houve redução do odor para grau II de forma significativa. Conclusão: Observou-se que o uso do metronidazol tópico sobre o leito da ferida reduziu consideravelmente o odor fétido ocasionado pela lesão
\end{abstract}

Keywords: Estomaterapia, Metronidazol, Neutralizadores de odor, Úlcera

\section{Referências Bibliográficas}

1. Baglioni E, Trovato L, Marcarelli M, Frenello A, Bocchiotti MA. Treatment of oncological post-surgical wound dehiscence with autologous skin micrografts. Anticancer Res. 2016; 36(3): 975-9. 2. Instituto Nacional do Câncer (INCA). Tratamento e controle de feridas tumorais e úlceras por pressão no câncer avançado. Rio de Janeiro: MS; 2009. 3. Firmino F. Pacientes portadores de feridas neoplásicas em serviços de cuidados paliativos: contribuições para a elaboração de protocolos de intervenções de enfermagem. Rev Brasileira de Cancerologia. 2005; 51(4): 347-59. 4. Academia Nacional de Cuidados Paliativos. Manual de cuidados paliativos. Rio de Janeiro: Diagraphic; 2009. 


\title{
PERFIL DE IDOSOS DIABÉtICOS DE UM PROGRAMA DE PREVENÇÃo TERCIÁRIA DE UMA OPERADORA DE SAÚDE
}

\author{
Ana Paula Hey ${ }^{1}$, CRISTIANO CAVEIÃO ${ }^{2}$, WILLIAN SALES ${ }^{2}$, ROSILDA LUZIA NUNES ${ }^{3}$, \\ Author(s): $\quad$ DENISE LORENCINI ${ }^{3}$, IZABELE CRISTINA GARCIA RODRIGUES ${ }^{2}$, RODRIGO BERTÉ ${ }^{2}$ \\ Institution(s) ${ }^{1}$ UTP - UNIVERSIDADE TUIUTI DO PARANÁ (Rua Sydnei Antonio Rangel Santos, 238 - \\ cURITIBA PR), ${ }^{2}$ UNINTER - CENTRO UNIVERSITÁRIO INTERNACIONAL UNINTER (Rua \\ Luiz Xavier, 103 - Centro, Curitiba - PR), ${ }^{3}$ FUNDAÇÃO COPEL - FUNDAÇÃO COPEL (R. \\ Treze de Maio, 616 - São Francisco, Curitiba - PR,)
}

\begin{abstract}
Introdução: aspectos relacionados ao tipo e tempo de diagnóstico do diabetes melittus; controle metabólico inadequado; tabagismo; etilismo; obesidade; hipertensão arterial; falta de bons hábitos higiênicos no cuidado com os pés; histórico de amputações; histórico de úlceras no membro inferior; presença de úlcera; pressão anormal; uso de calçado inadequado; caminhar descalço; ausência de educação terapêutica prévia; isolamento social e; falta de acesso ao sistema de saúde, pode favorecer o desenvolvimento de complicações futuras. Objetivo: descrever o perfil de idosos diabéticos que frequentam um programa de prevenção terciária. Método: estudo quantitativo realizado em um programa de prevenção terciária de uma operadora de saúde, com 101 idosos. Os dados foram coletados em instrumento elaborado pelos pesquisadores, onde contém dados clínicos do paciente. Os resultados analisados por meio da estatística descritiva. Os dados foram coletados após a aprovação do projeto de pesquisa pelo Comitê de Ética sob parecer número 3.245.092. Resultado: 59,4\% eram do sexo masculino, com média de idade de 67,95 anos, 81,2\% com histórico familiar para doenças cardiovasculares, $85,1 \%$ diabetes tipo I com tempo médio de diagnóstico de 10,96 anos. Para o controle da diabetes, o tratamento é realizado por $65,3 \%$ dos pacientes com mais de 2 medicamentos. Associado ao diabetes, $53,5 \%$ é hipertenso e 4,9\% já sofreu infarto agudo do miocárdio e 3,9\% possui doença renal. Em relação ao tabagismo, 7,9\% são tabagistas e $10,9 \%$ são ex-tabagistas há 22,54 anos. Sobre a atividade física, $71,3 \%$ não realiza nenhuma e os que praticam $41,6 \%$ predomina a caminhada. O aumento do peso está entre $42,6 \%$ dos participantes, sendo $29,7 \%$ de sobrepeso. No acompanhamento de possíveis lesões de órgãos alvo, 77,2\% realizou exame de fundo de olho nos últimos 12 meses e $67,3 \%$ frequentam o dentista entre um a seis meses. Quando perguntado sobre o apoio familiar para o tratamento da diabetes, $89,1 \%$ afirmou receber e $57,4 \%$ classificam sua saúde atual como boa. Conclusão: denota-se entre os entrevistados a prevalência de diabetes do tipo I, e baixa adesão a realização de atividade física com predominância do sobrepeso. Dessa forma, intensificar ações preventivas para que o paciente desperte a necessidade do autocuidado e possa assumir esse controle, é fundamental para prevenção de agravos futuros.
\end{abstract}

Keywords: diabetes mellitus, estomaterapia, prevenção terciária, serviços de saúde para idosos

\section{Referências Bibliográficas}

Brasil. Ministério da Saúde. Secretaria de Atenção à Saúde. Departamento de Atenção Básica. Manual do pé diabético: estratégias para o cuidado da pessoa com doença crônica. Brasília: Ministério da Saúde, 2016. Boell JEW, Ribeiro RM, Silva DMGV da. Fatores de risco para o desencadeamento do pé diabético. Rev Eletrônica Enferm [Internet].

2014;16(2):386-93. Recuperado de: http://revistas.ufg.br/index.php/fen/article/view/20460 International Consensus on the Diabetic Foot. Consenso Internacional sobre Pé Diabético. 50 ed. Pedrosa HC tradução A de AC, organizador. Vol. 53, Secretaria de Estado de Saúde do Distrito Federal. Distrito Federal: Grupo de Trabalho Internacional sobre Pé Diabético; 2001. 1689-1699 p. 


\title{
SISTEMATIZAÇÃO DA ASSISTÊNCIA DE ENFERMAGEM A PESSOA COM ÚLCERA NEUROPÁTICA ACOMPANHADA EM UMA CLINICA ESCOLA INTEGRADA: UM ESTUDO DE CASO
}

\author{
Author(s): DEIVID DOS SANTOS DIAS ${ }^{1}$, Ana Kare Lessa Sampaio ${ }^{1}$, Flavia Karolyne Sousa Alves ${ }^{1}$, Bruna \\ Negreiros de Sá ${ }^{1}$, Mirian Ferreira Coelho Castelo Branco ${ }^{1}$, Lucina Catunda Gomes de Menezes ${ }^{1}$ \\ Institution(s) ${ }^{1}$ Unifametro - Centro Universitário Fametro (Rua Conselheiro Estelita No 500 - Centro, Fortaleza- \\ $\mathrm{Ce})$
}

\begin{abstract}
INTRODUÇÃO: As úlceras neuropáticas são lesões complexas, incapacitantes e de alto custo, gerando um grave problema de saúde pública enfrentados por pessoas com diabetes mellitus (DM) 1 ,2. Diante do exposto, torna-se fundamental o conhecimento e o uso do raciocínio clínico do Enfermeiro e estudantes de Enfermagem frente aos cuidados prestados aos pacientes com DM e úlceras neuropáticas. OBJETIVO: Estudo de caso realizado a uma pessoa com úlcera neuropática acompanhada em uma clínica escola integrada. MÉTODO: Trata-se de um estudo de caso, utilizando-se do Processo de Enfermagem, seguindo as classificações internacionais (NANDA-I, NIC e NOC) ${ }^{3}$, executado a partir da vivência das pesquisadoras em um ambulatório de estomaterapia localizado na clínica escola integrada de um Centro Universitário privado em Fortaleza-Ceará-Brasil, no mês de março de 2019. O estudo foi aprovado pelo Comitê de Ética e Pesquisa da Área da Saúde (CAAE) 08284019.4.0000.5618 e o número do parecer 3.164.340. Os dados foram coletados por meio de um instrumento que abordou os seguintes dados: sociodemográficos; clínicos e sobre os aspectos da úlcera neuropática. RESULTADOS: Dados sociodemográficos: M.I.R.S, 54 anos, feminina, viúva, ensino fundamental incompleto, autônoma, natural e residente de Fortaleza - CE. Dados Clínicos sobre o DM: Apresenta os seguintes diagnósticos médicos: Hipertensão Arterial e diabetes mellitus há 10 anos. Faz uso diariamente dos medicamentos: Losartana, Hidroclorotiazida, Metformina e insulina. Dados sobre os aspectos das úlceras neuropáticas: Realizou-se avaliação inicial das úlceras no dia 20/03/2019 que apresentava as seguintes características: lesão no hálux do membro inferior esquerdo com comprometimento da derme e epiderme medindo $1,4 \mathrm{~cm}^{2}$, presença de exsudato seroso moderado, biofilme, hiperqueratose, e tecido de granulação vermelho vivo no leito da lesão. Enquanto que na lesão do hálux do membro inferior direito, apresentava-se: comprometimento da derme e epiderme, medindo $1,5 \mathrm{~cm}^{2}$, com presença de biofilme, tecido de granulação hipocorado, hiperqueratose e edema em região dorsal do hálux. A partir da avaliação, estabeleceu-se a seguinte conduta: desbridamento instrumental conservador e limpeza com SF 0,9\%, em seguida instalado a cobertura biomembrana vegetal com curativo secundário gaze e faixa crepe. Após a $2^{a}$ semana, já percebia melhora significativa nas úlceras. Um mês após o início do tratamento, no dia 24/04/2019, pôde-se observar evolução com presença de tecido de granulação vermelho vivo e menor quantidade de tecido desvitalizado, de biofilme e de hiperqueratose. Durante o acompanhamento, destaca-se os seguintes diagnósticos de Enfermagem: "Integridade da pele prejudicada", relacionada à úlcera neuropática e "Ansiedade", relacionada à ameaça ao estado de saúde. As intervenções foram: cuidados com as úlceras, atividades de educação em saúde sobre o diabetes e as úlceras, supervisão da glicemia, monitoração nutricional, uso correto das medicações, dentre outros cuidados. Espera-se que: realize o controle nutricional e glicêmico, o autocuidado com os pés e a cicatrização das úlceras. CONCLUSÃO:Os cuidados prestados incluíram saberes e práticas dos discentes, ressaltando-se a importância da aplicação do processo de enfermagem como foco do trabalho do Enfermeiro, favorecendo um cuidado de qualidade nas pessoas com DM e úlceras neuropáticas, com respaldo científico e proporcionando retorno da paciente ao contexto social de maneira precoce
\end{abstract}

Keywords: Estomaterapia, Enfermagem, Úlcera Plantar, Diabetes Mellitus

\section{Referências Bibliográficas}

1, Brasil, Cadernos de Atenção Básica: Estratégia para o cuidado da pessoa com doença crônica/ Diabetes Mellitus. Ministério da Saúde. Secretaria de Atenção à Saúde. Departamento de Atenção Básica. Saúde na escola / Ministério da Saúde, Secretaria de Atenção à Saúde, Departamento de Atenção Básica. - Brasília: Ministério da Saúde, 2013. 2 , Armstrong, D.G.; Cohen, K.; Courric, S.; Bharara, M.; Marston, W. Diabetic foot ulcers and vascular insufficiency: our population has changed, but our methods have not. J Diabetes Sci Tech. v. 5, n. 6, p.:1591-1595, 2011.

http://dx.doi.org/10.1177/193229681100500636. PMid:22226282 3, Johnson. M. et al. Ligações NANDA - NIC - NOC: condições clínicas: suporte ao raciocínio e assistência de qualidade. $3^{\circ}$ ed. Rio de Janeiro: Elsevier. 2012 


\title{
CONVERSANDO SOBRE ÚLCERAS DE PERNA: ESTRATÉGIA DE DISSEMINAÇÃO E INTERMEDIAÇÃO DE CONHECIMENTO
}

\author{
Author(s): $\quad \begin{aligned} & \text { Solange Gurgel Alexandre }{ }^{1} \text {, Saionara Leal Ferreira }{ }^{1} \text {, Maria José Aguiar de Oliveira }{ }^{1} \text {, Francisca Alexandra Araújo da } \\ & \text { Silva }{ }^{1}, \text { Kauane Matias Leite }{ }^{2} \text {, João Victor Mendonça Santana Cavalcante }{ }^{2} \text {, Thalia Alves Chagas Menezes }{ }^{2} \text {, Lívia }\end{aligned}$ \\ Cintia Maia Ferreira ${ }^{2}$, Wanessa Pereira Cavalcante ${ }^{2}$, Karine Rocha da Silva Abreu ${ }^{2}$ \\ Institution(s) ${ }^{1}$ HUWC - HOSPITAL UNIVERSITÁRIO WALTER CANTÍDIO (R. Pastor Samuel Munguba, 1290 - Rodolfo Teófilo, \\ Fortaleza - CE, 60430-372), ${ }^{2}$ UFC - Universidade Federal do Ceará (R. Alexandre Baraúna, 1115 - Rodolfo Teófilo, \\ Fortaleza - CE, 60430-160)
}

\begin{abstract}
INTRODUÇÃO: Em algum momento da vida, pessoas com determinadas condições de saúde, irão desenvolver feridas, cuja grande maioria evolui de forma rápida e apresentam processo de cura demorado. Corroborando essa assertiva, estima-se que cerca de $1 \%$ a $2 \%$ da população mundial, irá desenvolver feridas crônicas, como as úlceras de perna ${ }^{1}$. As úlceras de perna, são feridas crônicas e abertas, relacionadas ao sistema vascular arterial e venoso. Segundo a Conferência Nacional de Consenso sobre Úlceras de Perna da Extremidade Inferior, as úlceras de perna acometem cerca de 2 a 5 pessoas em cada 10002. Nesse contexto, o enfermeiro enfrenta desafios cada vez maiores em sua prática de cuidado de feridas como resultado do aumento da expectativa média de vida e do aumento da prevalência de doenças crônicas3. Considerando a especificidade da especialização, o enfermeiro estomaterapeuta tem um papel fundamental no processo de cuidado das pessoas com úlceras de perna, durante todas as etapas de cicatrização. OBJETIVO: Descrever uma atividade educativa sobre úlceras de perna, voltada para as pessoas com o agravo e seus familiares e/ou cuidadores. MATERIAL E MÉTODO: Trata-se de estudo descritivo, do tipo relato de experiência, realizado em julho de 2019, durante uma palestra ministrada para 50 pessoas com úlceras de perna, atendidas em ambulatório especializado de um hospital universitário da cidade de Fortaleza/CE, e seus familiares e/ou cuidadores. No primeiro momento da palestra, os participantes foram estimulados a se colocar sobre o tema em questão, com o intuito de revelar a base de conhecimentos já existente. No segundo momento, o tema foi exposto por meio de slides pré-elaborados, utilizando aparelhos de multimídias, tendo como facilitadoras, duas enfermeiras estomaterapeutas que atuam no serviço. Os pontos abordados foram: definição e classificação das úlceras de perna, fisiopatologia, fatores de risco, ações de prevenção e tratamento, técnicas para curativos realizados no domicílio e seus insumos e ações de autocuidado. $O$ último momento voltou-se para a partilha de experiências entre os participantes. RESULTADOS: Os participantes se mostraram bastante interessados no tema, sendo claramente perceptível o desconhecimento acerca do mesmo, principalmente no que diz respeito à doença e sua fisiopatologia, apesar de muitos estarem em tratamentos há muitos anos. O entusiasmo foi evidente, com interação durante toda a palestra, esclarecimento de dúvidas e compartilhamento de experiências vividas no decorrer da convivência com a condição de pessoa com úlcera de perna. O ponto mais impactante teve relação direta com a comprovação da deficiência de conhecimento acerca de ações básicas adequadas de autocuidado. CONCLUSÃO: A atividade foi enriquecedora, tanto para a equipe organizadora quanto para os participantes. Acredita-se na importância de novas estratégias educativas que permitam a troca de informações e vivências, oportunizando a fala e o esclarecimento de dúvidas e considera-se esse tipo de atividade relevante para a criação de vínculo entre profissionais e público-alvo, aproximando-os e tornando mais fácil a sensibilização sobre as necessidades relacionadas ao tratamento e à cura, subsidiando a promoção da autonomia no processo de saúde/doença.
\end{abstract}

Keywords: Enfermagem, Estomaterapia, Feridas e Lesões , Úlceras da perna

\section{Referências Bibliográficas}

1. Oliveira, Fernanda Pessanha de; Oliveira, Beatriz Guitton Renaud Baptista de; Santana, Rosimere Ferreira; Silva, Bruna de Paula; Candido, Jessica de Souza Carvalho. Classificações de intervenções e resultados de enfermagem em pacientes com feridas: mapeamento cruzado. Rev. Gaúcha Enferm. [Internet]. 2016 [cited 2019 Jul 22] ; 37( 2 ): e55033. Available from: http://www.scielo.br/scielo.php?script=sci_arttext\&pid=S1983-14472016000200410\&lng=en. Epub May 31, 2016. http://dx.doi.org/10.1590/1983-1447.2016.02.55033. 2. Roura, Josep Marinel.lo; Soriano, José Verdú (Coord.). Conferencia nacional de consenso sobre las úlceras de la extremidad inferior (C.O.N.U.E.I.). Documento de consenso 2018. 2 ed. Madrid: Ergon; 2018. Disponível em: < https://www.ulceras.net/publicaciones/conuei2018aeevh.pdf > 3. Monte, Brenda Kelly da Silva; Moura, Elaine Cristina Carvalho; Costa, Jéssica Pereira; Silva, Grazielle Roberta Freitas da; Lopes, Vanessa Caminha Aguiar. Qualidade de vida de pacientes com úlceras vasculogênicas em tratamento ambulatorial. Revista RENE. [Internet]. 2018 [cited 2019 Jul 22]; 19(1): e3286. Avaiable from: http://periodicos.ufc.br/rene/article/view/32551/pdf. 


\title{
IMPLANTAÇÃO DO LABORATÓRIO DE ENFERMAGEM E FERIDAS EM UM INSTITUTO FEDERAL DE EDUCAÇÃO: UM RELATO DE EXPERIÊNCIA
}

\author{
Author(s): Elaine Carininy Lopes da Costa ${ }^{1}$, ALINE COSTA DE OLIVEIRA ${ }^{2}$, SANDRA MARINA \\ GONÇALVES BEZERRA ${ }^{2}$, Cliciane Furtado Rodrigues ${ }^{2}$, Thalita de Moraes Lima ${ }^{2}$ \\ Institution(s) ${ }^{1}$ IFPI - Instituto Federal de Educação do Piauí (Rua projetada S/N Bairro Uberaba II Oeiras PI), ${ }^{2}$ \\ FACIME - FACULDADE DE CIÊNCIAS MÉDICAS (RUA OLAVAO BILAC 2335 CENTRO \\ TERESINA PI)
}

\begin{abstract}
INTRODUÇÃO. O indivíduo com ferida seja aguda ou crônica necessita de assistência de enfermagem de boa qualidade, especializada e voltada para a sua necessidade. Considerando que a ocorrência de ferida pode interferir negativamente na qualidade de vida dos indivíduos gerando dor, infecções graves e que a assistência de enfermagem quando bem conduzida pode reduzir a cronicidade e os gastos, foi proposta a criação do LABENF (Laboratório de Enfermagem e Feridas) que possui caráter inovador por ser o primeiro em um Instituto Federal de Educação a prestar por meio de ações de extensão, atendimento especializado ao indivíduo com feridas agudas e crônicas, além da capacitação de profissionais de enfermagem. OBJETIVO: Relatar a experiência de implantação do Laboratório de Enfermagem e Feridas - LABENF em um Instituto Federal de Educação. METODOLOGIA: Trata-se de um estudo descritivo do tipo relato de experiência. O LABENF funciona no IFPI da cidade de Oeiras Piauí e foi implantado mediante a aprovação do seu projeto no edital de № 119 PROAGRUPAR/IFPI- 2018 (Edital de implantação e estruturação de Laboratórios no Instituto Federal do Piauí) possibilitando a aquisição de recursos financeiros para a compra de produtos como: PHMB, bota de una, alginato de cálcio, alginato de prata, espuma com PHMB, gaze com PHMB, gaze de Ryon e hidrogel, bem como equipamentos para teste de sensibilidade para os pés como os monofilamentos de Semmes-Weinstein e diapasão. Os pacientes atendidos são alunos da instituição com algum tipo de ferida e indivíduos da comunidade com feridas crônicas que foram encaminhados para 0 LABENF pela Estratégia Saúde da Família do município. Todos os pacientes atendidos no laboratório assinam um termo se comprometendo de seguir as orientações do tratamento. $O$ atendimento é realizado por uma enfermeira concludente da especialização em Estomaterapia. Além do atendimento a pessoas com feridas, é desenvolvido trabalho de atualização dos profissionais de enfermagem do município sobre tratamento de feridas. RESULTADOS: Ao todo foram atendidos 15 pacientes com feridas agudas e crônicas (queimaduras, feridas traumáticas e úlceras venosas). Foram realizadas consultas de enfermagem, bem como a análise e registro dos atendimentos com informações sobre o tipo de feridas, avaliação e escolha da melhor cobertura para cada caso. Em relação a capacitação dos profissionais de enfermagem, foram oferecidos minicursos sobre avaliação e preparo do leito de feridas, indicação das coberturas especiais bem como o manejo de úlceras de membros inferiores. Aos participantes que cumpriram a carga horária mínima foram entregues certificados expedidos pela coordenação de extensão do campus. CONCLUSÃO: Após a implantação do LABENF foi possível realizar assistência de enfermagem e o uso de novas tecnologias no tratamento do indivíduo com feridas agudas e crônicas, por meio de coberturas especiais e aplicação do laser, possibilitando a alta por cura de alguns de pacientes com feridas complexas em torno de 4 meses de tratamento. Além disso, o laboratório contribuiu para o aperfeiçoamento técnico e científico dos profissionais de enfermagem do município sobre tratamento de feridas promovendo informação e atualização científica em relação a temática por meio de minicursos.
\end{abstract}

Keywords: Estomaterapia, Extensão, Feridas

\section{Referências Bibliográficas}

ALMEIDA, W. A.; et al. Fatores associados à qualidade de vida de pessoas com feridas complexas crônicas. J. Res. Fundam. Care. Online, v. 10, n. 1, p. 9-16, 2018. Disponível em: DOI: 10.9789/2175-5361.2018.v10i1.9-16. Avesso em 11 de Agosto de 2018. BEZERRA, S, M. G. Feridas: efeito da intervenção educativa em relação ao conhecimento dos enfermeiros sobre avaliação, tratamento e custo. 184 f. 2016. Tese (Doutorado) - Universidade Federal do Piauí, Programa de Pós-graduação em Enfermagem. Teresina. 2016 MALAGUTTI, W.; KAKIHARA, C. T. Curativos, estomias e dermatologia: uma Abordagem Multiprofissional. 3 ed. São Paulo. Editora Martinari. 2014. 


\title{
PERFIL DOS PÉS DE IDOSOS DIABÉTICOS: PREVENÇÃO TERCIÁRIA EM UMA OPERADORA DE SAÚDE
}

\author{
Ana Paula Hey ${ }^{1}$, ANA CAROLINA GUARIPUNA ${ }^{1}$, CRISTIANO CAVEIÃO ${ }^{2}$, WILLIAN \\ Author(s): $\quad$ SALES $^{2}$, DENISE LORENCINI ${ }^{3}$, ROSILDA LUZIA NUNES ${ }^{3}$, RODRIGO BERTÉ $^{2}$, IZABELE \\ CRISTINA GARCIA RODRIGUES ${ }^{2}$ \\ Institution(s) ${ }^{1}$ UTP - UNIVERSIDADE TUIUTI DO PARANÁ (Rua Sydnei Antonio Rangel Santos, 238 - \\ cURITIBA PR), ${ }^{2}$ UNINTER - CENTRO UNIVERSITÁRIO INTERNACIONAL UNINTER (Rua \\ Luiz Xavier, 103 - Centro, Curitiba - PR), ${ }^{3}$ FUNDAÇÃO COPEL - FUNDAÇÃO COPEL (R. \\ Treze de Maio, 616 - São Francisco, Curitiba - PR,)
}

\begin{abstract}
Introdução: o pé diabético é conceituado como uma infecção, ulceração e ou destruição dos tecidos profundos associadas a anormalidades neurológicas e vários graus de doença vascular periférica nos membros inferiores. Indivíduos com risco para pé diabético, necessitam de uma avaliação precisa e minuciosa. A estratificação de risco pode identificar os indivíduos com pré-disposição para o pé diabético e reduzir sua incidência. A avaliação dos pés precisa ser realizada pelo menos uma vez ao ano. Objetivo: descrever o perfil clinico dos pés de idosos diabéticos de um programa de prevenção terciária. Método: estudo quantitativo realizado em um programa de prevenção terciária de uma operadora de saúde, com 101 idosos. Durante a avaliação clínica coletou-se a história clínica e procedeu-se a inspeção dos pés e calçados. Os dados foram coletados em instrumento elaborado pelos pesquisadores, baseado no Manual do Pé Diabético: estratégias para o cuidado da pessoa com doença crônica do Ministério da Saúde (2016). Os resultados analisados por meio da estatística descritiva. Os dados foram coletados após a aprovação do projeto de pesquisa pelo Comitê de Ética sob parecer número 3.245.092. Resultados: ao exame dos pés, $6 \%$ relataram dor noturna e 3\% apresenta melhora quando caminha, $6 \%$ fraqueza muscular. Sintomas ou sinais apresentados nos pés: $3 \%$ pontada, $7 \%$ agulhada, $14,9 \%$ formigamento, $10,9 \%$ dormência, $18,8 \%$ câimbras e $11,9 \%$ dor ao caminhar. Sobre avaliação dos pés, $84,2 \%$ nunca foi avaliado e $57,4 \%$ nunca recebeu orientações sobre cuidados com os pés. Quando ao uso do sapato, $13,9 \%$ faz utilização inadequada e $24,8 \%$ tem hábitos de caminhar descalço. Na avaliação dos pés, 17,8\% apresenta área de risco para ulceração, sendo o principal motivo os dedos em garra com $8,9 \%$. Sobre patologias nos pés, $57,4 \%$ possui uma ou mais, sendo: $5 \%$ hálux valgo, $11,9 \%$ tínea pedis e $25,7 \%$ hiperqueratose. Já as patologias em unhas, foi evidenciada em $27,7 \%$, sendo elas: $2 \%$ onicocriptose, $9 \%$ onicogrifose e $15,8 \%$ onicomicose. Apresentaram falta de hidratação nos pés $64,4 \%$ dos participantes. Conclusão: a avaliação clínica dos pés de idosos diabéticos é de extrema importância, pois é possível detectar precocemente alterações que possam ocasionar comorbidades futuras, além de proporcionar ação imediata ao detectar tínea pedis e hiperqueratose, patologias que podem ser prevenidas com educação em saúde.
\end{abstract}

Keywords: ESTOMATERAPIA, diabetes mellitus, pé diabético, PREVENÇÃO TERCIPARIA

\section{Referências Bibliográficas}

Brasil. Ministério da Saúde. Secretaria de Atenção à Saúde. Departamento de Atenção Básica. Manual do pé diabético: estratégias para o cuidado da pessoa com doença crônica. Brasília: Ministério da Saúde, 2016. International Consensus on the Diabetic Foot. Consenso Internacional sobre Pé Diabético. 50 ed. Pedrosa HC tradução A de AC, organizador. Vol. 53, Secretaria de Estado de Saúde do Distrito Federal. Distrito Federal: Grupo de Trabalho Internacional sobre Pé Diabético; 2001. 1689-1699 p. Boell JEW, Ribeiro RM, Silva DMGV da. Fatores de risco para o desencadeamento do pé diabético. Rev Eletrônica Enferm [Internet]. 2014;16(2):386-93. Recuperado de: http://revistas.ufg.br/index.php/fen/article/view/20460 


\title{
A ESTOMATERAPIA NO TRATAMENTO DE LESÕES CRÔNICAS RELACIONADAS AO DIABETES E ANEMIA FALCIFORME: UM RELATO DE CASO
}

\author{
Luciane Resende da Silva Leonel ${ }^{1}$, Jéssyca Fernanda Pereira Brito ${ }^{1}$, Luana Silva de Sousa ${ }^{1}$, \\ Author(s): Verônica Elis Araújo Rezende ${ }^{1}$, Yara Maria Rêgo Leite ${ }^{1}$, Roxana Mesquita de Oliveira Teixeira \\ ${ }_{2,1}$ Siqueira ${ }^{1}$, Aline Costa de Oliveira ${ }^{2}$, Juliana Oliveira de Sousa ${ }^{1}$, Sandra Marina Gonçalves Bezerra
}

Institution(s) ${ }^{1}$ UESPI - Universidade Estadual do Piauí (R.Lucídio Freitas,2791- Matinha, TeresinaPI,64003120), ${ }^{2}$ UFPI - Universidade Federal do Piauí (Campus Universitário Ministro Petrônio Portella,Bairro-Ininga,Teresina-PI)

\begin{abstract}
INTRODUÇÃO: Uma das complicações da Anemia Falciforme é ulceração nos membros inferiores sendo o tratamento difícil devido á fisiopatologia da doença, obstrução microvascular, hipercoagulabilidade, insuficiência venosa e hemólise1. Tais complicações associadas ao Diabetes Mellitus dificultam ainda mais a qualidade de vida da pessoa que as possuem, além dos custos financeiros, dor considerável e com impacto significativo na mortalidade, uma vez que tal doença retarda a cicatrização2,3.OBJETIVO: relatar experiência de profissionais frente ao tratamento de um paciente com úlceras crônica em membros inferiores decorrente de anemia falciforme e diabetes mellitus. MATERIAL E METODOS: Trata-se de um relato de caso desenvolvido em um ambulatório de feridas especializadas em pé diabético, em Teresina, no período de abril a junho de 2018, sendo realizados os encontros uma vez por semana. A evolução da lesão foi observada devido a mensuração e registro fotográfico a cada encontro, além de realizar orientações ao paciente quando aos cuidados diários com a lesão e repouso.A pesquisa partiu de um projeto desenvolvido em pacientes com diabetes e comorbidades e foi submetido ao comitê de ética da Universidade Estadual do Piauí sob parecer número 3.479.211 e respeitado os aspectos éticos segundo a resolução 466/2012. RESULTADOS: o paciente possuía quatro lesões em ambos os membros: duas no maléolo lateral e duas no maléolo medial. A princípio e de acordo com o acrônimo TIME o leito apresentava esfacelo, presença de sinais de infecção, exsudato em grande quantidade e seroso, odor fétido, excesso de umidade e bordas estagnadas sem sinais de avanço, além da presença de edema nos membros. Usou-se papaína em pó a 100\% diluída em $10 \mathrm{ml}$ de água destilada visando a retirada do tecido desvitalizado do leito. Quanto a mensuração, a lesão do maléolo lateral direito e esquerdo mediam 30,5 e $21,6 \mathrm{~cm} 2 \mathrm{e}$ o medial direito e esquerdo 58,5 e $77,05 \mathrm{~cm} 2$, respectivamente. No último encontro, a lesão apresentava-se com redução do esfacelo, odor e exsudato e bordas convergentes, realizou-se a mensuração observando os mesmos parâmetros da primeira com redução de 1,25 e 0,45 cm2 no maléolo lateral direito, 3,3 cm2 no maléolo medial esquerdo. Ocorreu o aumento na extensão da lesão em $9,05 \mathrm{~cm} 2$ no maléolo medial esquerdo tanto no comprimento quanto largura. CONCLUSÃO: No tratamento das vasculopatias cutâneas por anemia falciforme associada ao diabetes, o uso do conhecimento do estomaterapeuta otimiza o tratamento, acelerando o processo cicatricial e melhora a condição clínica do paciente. O uso da papaína em pó auxiliou na redução do esfacelo, contribuindo com a evolução da lesão.
\end{abstract}

Keywords: Estomaterapia, Anemia Falciforme, Diabetes Mellitus., Ferimentos, Lesões

\section{Referências Bibliográficas}

1 Connor JL Jr, Minniti CP, Tisdale JF, Hsieh MM. Sickle Cell Anemia and Comorbid Leg Ulcer Treated With Curative Peripheral Blood Stem Cell Transplantation. Int J Low Extrem Wounds. 2017;16(1):56-59. 2 Kim J, Chun DI, Kim S, Yang HJ, Kim JH, Cho JH, Yi Y, Kim WJ, Won SH. Trends in Lower Limb Amputation in Patients with Diabetic Foot Based on Vascular Intervention of Peripheral Arterial Disease in Korea: a Population-based Nationwide Study. J Korean MedSci. 2019; 34(26):e178. 3 Shanmugam VK, Angra D., Rahimi H, McNish S. Vasculitic e feridas autoimunes. J VascSurg Transtorno de Lymphat Venoso. 2017; 5 (2): 280-292. 


\title{
A incidência de lesões por pressão em pacientes da atenção domiciliar
}

\author{
Author(s): $\quad$ Caroline Batisteli Menezes ${ }^{1}$, Adriana Teófilo Pereira Quirino ${ }^{1}$, Heloisa Gaspar ${ }^{1}$, Claudio Flauzino \\ Institution(s) ${ }^{1}$ Home Doctor - Home Doctor - Empresa de Atenção Domiciliar (Rua Capitão Francisco Teixeira \\ Nogueira, 154 Água Branca São Paulo SP 05037030)
}

\begin{abstract}
Introdução: A Atenção Domiciliar (AD) é uma modalidade de atenção à saúde oferecida ao paciente no ambiente domiciliar, que engloba promoção à saúde, prevenção e tratamento de doenças, além de reabilitação garantindo ampla continuidade do cuidado ao paciente. Uma empresa privada de AD, é responsável pelo cuidado de aproximadamente 1600 pacientes e tem como uma de suas premissas além do tratamento e reabilitação, a promoção da saúde.

Lesão por pressão (LPP) é um dano localizado na pele e/ou tecidos moles subjacentes, geralmente sobre uma proeminência óssea ou relacionada ao uso de dispositivo médico. A lesão pode se apresentar como pele íntegra ou como úlcera aberta e pode ser dolorosa (NPUAP, 2016).

A LPP é um grande problema no ambiente hospitalar e também deve ser uma preocupação na AD, pois quando instalada ocasiona impacto clínico, social e financeiro a todos os envolvidos no cuidado (paciente, cuidador, familiar, prestador de AD e operadora de saúde).

Os pacientes na AD têm muitos fatores de risco para o surgimento de LPP: mobilidade reduzida, alterações na percepção sensorial e na circulação periférica, nível de consciência alterado, incontinência urinária e fecal. É fundamental que o enfermeiro enquanto gestor do cuidado realize uma abordagem apropriada para identificar o risco, realizar a prevenção de LPP e o tratamento.
\end{abstract}

Objetivo: Avaliar a incidência de lesões por pressão nos pacientes em Internação domiciliar.

Método: Estudo descritivo de prevalência realizado no período de janeiro a junho de 2019, incluindo todos os casos novos de LPP em pacientes de Internação Domiciliar. Foi realizada busca de casos de LPP através de relatos em canais oficiais de notificação, formulário institucional específico, leitura de e-mail do atendimento de urgência, análise em comitês e avaliação de prontuários físico e eletrônico.

Resultados: Foram avaliados 680 pacientes no período. A incidência de LPP foi de 2,9\% (20 casos). A faixa etária mais acometida foi de idosos ( 16 casos; $80 \%$ ), seguida de adultos ( 3 casos; $15 \%$ ) e um caso em pediatria ( $5 \%$ ). A média de idade dos pacientes com LPP foi de 85,8 anos. Dos 20 casos, $56 \%$ foram do sexo masculino e $44 \%$ feminino. Quando analisamos a representação da LPP dentro dos eventos adversos, encontramos que do total de eventos adversos avaliados apenas 3,64\% corresponderam a LPP.

Conclusão: Apesar dos diversos fatores de risco presente na grande parte dos pacientes em internação domiciliar o presente estudo demonstrou baixa incidência de LPP. A realização de cuidados integrais de forma individualizada e a atuação de enfermeiros especialistas nos cuidados com a pele, associada a treinamento e capacitação de toda equipe multidisciplinar e famíliares sobre a importância de medidas de prevenção de LPP corroboram com uma assistência mais segura e de qualidade.

Keywords: Estomaterapia, Lesão por Pressão, Serviço de Assistencia Domiciliar

\section{Referências Bibliográficas}

Referencias: 1. Ellis, M. Pressure ulcer prevention in care home settings. Nurs Older People. 2017 Mar 31;29(3):29-37. doi: 10.7748/nop.2017.e906. 2. Associação Brasileira de Estomaterapia. Classificação das lesões por pressão - Consenso NPUAP 2016 - adaptada culturalmente para o Brasil. São Paulo: SOBEST, 2016. [Acesso em: 09/08/2019] Disponível em:http://www.sobest.org.br/textod/35. 3. Andrade, SR. Fatores de Risco e condições predisponentes para úlcera por pressão: interfaces com o cuidado de enfermagem. Porto Alegre; sn 2016, 19p. 4. Law, J. Pressure ulcer prevention: education for nursing home staff. Br J Nurs. 2003 May 8-21;12 (9): 566-9 


\title{
PÉ DIABÉTICO: ESTRATIFICAÇÃO DE RISCO EM PROGRAMA DE PREVENÇÃO TERCIÁRIA DE UMA OPERADORA DE SAÚDE
}

\author{
CAMILA CORADASSI ${ }^{1}$, Ana Paula Hey ${ }^{1}$, CRISTIANO CAVEIÃO ${ }^{2}$, WILLIAN SALES ${ }^{2}$, \\ Author(s): DENISE LORENCINI ${ }^{3}$, ROSILDA LUZIA NUNES ${ }^{3}$, IZABELE CRISTINA GARCIA \\ RODRIGUES $^{2}$, RODRIGO BERTÉ ${ }^{2}$ \\ Institution(s) ${ }^{1}$ UTP - UNIVERSIDADE TUIUTI DO PARANÁ (Rua Sydnei Antonio Rangel Santos, 238 - \\ cURITIBA PR), ${ }^{2}$ UNINTER - CENTRO UNIVERSITÁRIO INTERNACIONAL UNINTER (Rua \\ Luiz Xavier, 103 - Centro, Curitiba - PR), ${ }^{3}$ FUNDAÇÃO COPEL - FUNDAÇÃO COPEL (R. \\ Treze de Maio, 616 - São Francisco, Curitiba - PR,)
}

\begin{abstract}
Introdução: a estratificação de risco para o desenvolvimento do pé diabético é composta por: existência da neuropatia periférica; presença da insuficiência vascular; ausência dos pulsos dos pés; palidez à elevação; rubor postural; alterações na pele dos membros inferiores; predisposição à infecção; presença de patologia ungueal; cortes incorretos das unhas e calos; anidrose; rachaduras; maceração interdigital; deformidades ósseas e articulares. Após o exame clínico, o paciente deve ser classificado de acordo com o sistema de estratificação de risco, onde zero classifica o paciente com neuropatia ausente; 1 com neuropatia presente; 2 neuropatia presente, sinais de doença vascular periférica e/ou deformidades nos pés; 3 classifica amputação /úlcera previa. Objetivo: descrever a avaliação clínica e estratificação de risco dos pés de idosos diabéticos de um programa de prevenção terciária. Método: estudo quantitativo realizado em um programa de prevenção terciária de uma operadora de saúde, com 101 idosos. Durante a avaliação clínica foram realizados os testes neurológicos para sensibilidade (superficial, profunda e térmica), motores, força e motilidade muscular e vasculares. Os dados foram coletados em instrumento elaborado pelos pesquisadores, baseado no Manual do Pé Diabético: estratégias para o cuidado da pessoa com doença crônica do Ministério da Saúde (2016). Os resultados analisados por meio da estatística descritiva. Os dados foram coletados após a aprovação do projeto de pesquisa pelo Comitê de Ética sob parecer número 3.245.092. Resultados: aos testes de sensibilidade: monofilamento 10G, 6\% apresentaram ausência e 12,9\% diminuída; $3 \%$ redução da sensibilidade dolorosa; $13,9 \%$ diminuição da vibratória e 4\% ausência; $2 \%$ diminuição da sensibilidade térmica e $3 \%$ ausência. O reflexo de aquileu estava diminuído em $5 \%$. A força muscular (panturrilha e tibial anterior) estavam diminuídas respectivamente em $5 \%$ dos participantes. As limitações da motilidade articular em grau 1 estava presente em $18,8 \%$. Nos testes vasculares, $2 \%$ apresentaram o pulso dorsal diminuído e $3 \%$ o tibial diminuído. A realização do índice tornozelo braço apresentou a média de 1,08. Classificaram-se 20,8\% com risco 1. Conclusão: realizar a estratificação de risco em idosos diabéticos proporciona subsídios para ações em relação ao período de avaliação clínica dos pés. Ainda é possível detectar precocemente o aparecimento de patologias para prevenção ou redução do dano que poderá ser causado.
\end{abstract}

Keywords: ESTOMATERAPIA, diabetes mellitus, pé diabético, serviços de saúde para idosos

\section{Referências Bibliográficas}

Brasil. Ministério da Saúde. Secretaria de Atenção à Saúde. Departamento de Atenção Básica. Manual do pé diabético: estratégias para o cuidado da pessoa com doença crônica. Brasília: Ministério da Saúde, 2016. Boell JEW, Ribeiro RM, Silva DMGV da. Fatores de risco para o desencadeamento do pé diabético. Rev Eletrônica Enferm [Internet]. 2014;16(2):386-93. Recuperado de: http://revistas.ufg.br/index.php/fen/article/view/20460 Kalyani RR, Corriere M, Ferrucci L. Age-related and disease-related muscle loss: the effect of diabetes, obesity, and other diseases. Lancet Diabetes Endocrinol. 2014;257:24. International Consensus on the Diabetic Foot. Consenso Internacional sobre Pé Diabético. 50 ed. Pedrosa HC tradução A de AC, organizador. Vol. 53, Secretaria de Estado de Saúde do Distrito Federal. Distrito Federal: Grupo de Trabalho Internacional sobre Pé Diabético; 2001. 1689-1699 p. 


\title{
EFETIVIDADE DO ÁCIDO HIALURÔNICO PARA A CICATRIZAÇÃO DE FERIDAS CRÔNICAS: REVISÃO SISTEMÁTICA
}

\author{
Author(s): $\quad$ Franciele Soares Pott ${ }^{1}$, Hellen Roehrs ${ }^{2}$, Janislei Stocco ${ }^{2}$, Marineli Joaquim Meier ${ }^{2}$, Fernando \\ Augusto Lavezzo Dias ${ }^{2}$ \\ Institution(s) ${ }^{1}$ HPM/PR - Hospital da Policia Militar do Paraná (Av. Pref. Omar Sabbag, 894), ${ }^{2}$ UPPR - \\ Universidade Federal do Paraná (Av. Pref. Lothário Meissner, 632)
}

\begin{abstract}
INTRODUÇÃO: As feridas crônicas são uma descontinuidade na pele. Incluem lesão por pressão (UP), úlceras venosas, arteriais ou mistas (UV) e úlcera de pé diabético e podem levar mais de 8 semanas para cicatrizar. Diferentes tecnologias foram desenvolvidas a fim de acelerar o processo de cicatrização, como as coberturas e agentes tópicos contendo ácido hialurônico $(\mathrm{AH})$, que retém a umidade e auxilia na resposta celular. OBJETIVO: Avaliar os efeitos do ácido hialurônico (e seus derivados, como o hialuronato de sódio) na cicatrização de feridas crônicas. MATERIAL E MÉTODO: Revisão sistemática, com protocolo publicado na Cochrane. Critérios de inclusão: ensaios clínicos randomizados sobre o uso do $\mathrm{AH}$ para a cicatrização de feridas crônicas, comparado a outras coberturas. Os desfechos foram: cicatrização completa, tempo para completar a cicatrização, efeitos adversos, qualidade de vida, dor, taxa de recorrência e alteração do tamanho da ferida. As bases dados consultadas foram: The Cochrane Wounds Group Specialized Register; CENTRAL; MEDLINE, EMBASE; EBSCO CINAHL, além de buscas manuais em listas de referências e sites de registro de ECR. RESULTADOS: Um total de 144 estudos foram identificados, sendo 10 ensaios (11 artigos) incluídos em sínteses qualitativas e dois agrupados em metanálise. No total, 772 participantes apresentando 165 úlceras de pressão, 54 úlceras do pé diabético e 553 úlceras venosas. Os estudos compararam HA (0,2\%, 0,5\%, 80\% em concentração) com colágeno, hidrocoloide, dextranômero, parafina, veículo neutro e colágeno liofilizado $(\mathrm{CL})$. Sete estudos relataram o resultado da cicatrização completa da úlcera em diferentes momentos. Entretanto a avaliação GRADE sugere que a qualidade da evidência é de muito baixa certeza para todas as comparações analisadas. É incerto se existe uma diferença na cicatrização completa da ferida crônica quando o AH é usado em comparação com outras coberturas/agentes tópicos. Um estudo demonstrou redução do tempo para completar a cicatrização em CL em comparação com HA em pessoas com úlceras do pé diabético (MD 16,60, 95\% Cl 7,95-25,25, 20 pacientes) no entanto, a certeza da evidência é muito baixa. Para os desfechos efeitos adversos e dor, não foi possível concluir se há influência do positiva ou negativa do HA pois a certeza da evidência é muito baixa. Nenhum dos estudos relatou qualidade de vida ou recorrência da ferida. Para o desfecho alteração do tamanho da ferida, quando o $\mathrm{AH}$ é usado em comparação com veículo neutro em úlceras de perna, o agrupamento de dois estudos em metanálise não mostrou diferenças entre as tecnologias analisadas (MD 30,44, IC 95\% 15,57 a 45,31, 190 pacientes), com certeza de evidência muito baixa. CONCLUSÕES: As evidências são insuficientes para determinar se o ácido hialurônico melhora a probabilidade de cura de úlceras crônicas. Para melhorar a qualidade das evidências, pesquisas futuras sobre os efeitos do AH na cicatrização dessas feridas devem considerar um tamanho maior de amostra e o cegamento, a fim de minimizar possíveis viéses.
\end{abstract}

Keywords: Enfermagem, Estomaterapía, Feridas Crônicas, Cicatrização, Revisão Sistemática

\section{Referências Bibliográficas}

1.Dicker KT, Gurski LA, Pradhan-Bhatt S, Witt RL, Farach-Carson MC, Jia X. Hyaluronan: a simple polysaccharide with diverse biological functions. Acta Biomaterialia 2014;10(4):1558-70. 2.Kirketerp-Møller K, Zulkowski K, James C. Chronic wound colonization, infection, and biofilms. In: Bjarnsholt T, Jensen PØ, Moser C, Høiby N editor(s). Biofilm Infections. 1st Edition. New 3.Higgins JPT, Green S (editors). Cochrane Handbook for Systematic Reviews of Interventions Version 5.0.1 [updated March 2011]. The Cochrane Collaboration, 2011. Available from www.cochrane-handbook.org. 


\title{
DA PROCURA A NECESSIDADE DA ESTRUTURAÇÃO DE UM SERVIÇO ESPECIALIZADO NO ATENDIMENTO DE LESÕES CRÔNICAS DE PELE EM UM MUNICÍPIO DA REGIÃO METROPOLITANA DE CURITIBA.
}

\author{
Author(s): Dayane Cristine Laskowski Schier ${ }^{1}$, Janete Laskowski ${ }^{1,1}$, Caroline Luize Coraiola ${ }^{1}$, Adriana \\ Author(s): $\quad$ Pereira $^{1}$, Tathiane Vieira ${ }^{1}$, Fernanda Cassanho ${ }^{1}$ \\ Institution(s) ${ }^{1}$ SMS Colombo - Prefeitura Municipal de Colombo ( R. XV de Novembro, 105 - Centro, Colombo \\ - PR, 83414-000)
}

\begin{abstract}
O termo "ferida" significa a perda da solução de continuidade do tegumento, evidenciada pela ruptura das camadas da pele ou de estruturas mais profundas. ${ }^{2}$ As feridas crônicas englobam uma grande variedade de lesões, sendo as mais comuns úlceras de perna em suas variadas etiologias, pés diabéticos, lesões por pressão e úlceras atípicas. ${ }^{3}$ No Brasil e no mundo estas lesões são consideradas um problema de saúde pública devido ao elevado e crescente custo para o sistema de saúde. ${ }^{1}$ As pesquisas sobre sua prevalência ainda são incipientes no Brasil, mas de acordo com estudos desenvolvidos nos Estados Unidos da América, estima-se que na população mundial 14\% das pessoas apresentam algum tipo de lesão durante suas vidas. ${ }^{1} \mathrm{O}$ objetivo deste estudo foi estruturar um serviço especializado no atendimento de lesões crônicas de pele, desenvolvendo um protocolo para atendimento e criando fluxos de direcionamento dos pacientes que pertencem a um município da região metropolitana de Curitiba. Material e Método: Trata-se de um relato de experiência no qual buscamos pontuar o caminho percorrido durante a estruturação dos fluxos e processos para a implantação do serviço. Este estudo foi realizado em um Município da região metropolita de Curitiba, durante os meses de abril a agosto de 2019. A escolha do local ocorreu a partir da grande demanda de pacientes com lesões de pele que procuravam as Unidades Básicas de Saúde do Município, a partir disto a Secretaria Municipal de Saúde percebeu a necessidade da organização de um serviço estruturado visando a melhor assistência destes usuários e por possuir em seu quadro funcional 3 enfermeiros estomaterapeutas a necessidade deste processo tornou-se primordial. Resultados: A estrutura criada visa que o primeiro atendimento dos pacientes com lesões crônicas seja centralizamos nestes profissionais estomaterapeutas e a eles será dada a responsabilidade por capacitar os demais enfermeiros das unidades básicas de saúde ou estratégia de saúde da família, para que possam oferecer a sequência no tratamento e ou realizar os cuidados simples aos pacientes que não se enquadrarem nos critérios de inclusão para o serviço especializado. Além disto, os novos processos irão oferecer autonomia ao Estomaterapeuta na solicitação de exames laboratoriais acelerando o processo de encaminhamento, quando necessário, a outros profissionais da equipe multiprofissional. Conclusão: Acreditamos que a partir deste serviço o Município irá oferecer aos usuários celeridade de acesso ao atendimento especializado em estomaterapia, maior resolutividade no tratamento das lesões crônicas de pele, diminuição de custos e maior qualidade de vida a população.
\end{abstract}

Keywords: Ambulatório de Feridas, Estomaterapia, Feridas Crônicas

\section{Referências Bibliográficas}

1. Borges EL, Filho HMN, Junior JFP. Prevalência de lesões crônicas de município da zona da mata mineira. Rev Min Enferm. 2018;22;e-1143. 2. Dealey C. Cuidando de feridas: um guia para as enfermeiras. São Paulo: Editora Atheneu, 2008. 3. Jeong HS, et al. Negative pressure wound therapy of chronically infected wounds using $1 \%$ acetic acid irrigation. Coreia, 2014. 


\title{
CARACTERIZAÇÃO DOS PACIENTES COM PÉ DIABÉTICO DE UM AMBULATÓRIO DE AVALIAÇÃO E TRATAMENTO DE LESÕES DE PELE
}

\author{
Author(s): GLAÍS PALUMBO ROLIM RIBEIRO ${ }^{1}$, TATIANA QUEIROZ RIBEIRO DE ALMEIDA ${ }^{2}$ \\ Institution(s) ${ }^{1}$ PSJP - PREFEITURA DE SÃO JOSÉ DOS PINHAIS (Rua Brigadeiro Arthur Carlos \\ Peralta,137), ${ }^{2}$ UFPR - UNIVERSIDADE FEDERAL DO PARANÁ (Av. Prefeito Lothário \\ Meissner, 632 - Jardim Botânico, Curitiba - PR, 80210-170)
}

\begin{abstract}
Introdução: As feridas crônicas, também conhecidas como feridas complexas são consideradas lesões graves e de difícil cicatrização, causando sérios problemas, impactando na qualidade de vida do paciente1. Pessoas com diabetes estão em risco de desenvolver úlceras nos pés. Essas feridas acarretam desconforto e muitas vezes tornam-se infectadas, dificultando a cicatrização. As úlceras do pé diabético que não cicatrizam podem resultar em amputação de parte ou de todo o pé ou mesmo da parte inferior da perna2. O impacto do pé diabético sobre o indivíduo pode se estender além da ulceração, pois as limitações que a doença e o tratamento impõem, tendem a prejudicar as atividades de vida diária, uma vez que comumente geram diferentes graus de incapacidade. O estigma e o medo associados às lesões nos pés e amputações podem provocar prejuízos emocionais e favorecer quadros depressivos3. O profissional de enfermagem necessita estar preparado para tomada de decisão e a partir daí, selecionar intervenções mais adequadas para situações específicas de cuidado. Devido a necessidade de diminuir a lacuna entre os avanços científicos e a prática clínica surge a necessidade de implantar a Prática Baseada em Evidência. Objetivos: Caracterizar os indivíduos com úlcera diabética que frequentam um ambulatório especializado no tratamento de feridas da região metropolitana de Curitiba. Metodologia: Pesquisa prospectiva, exploratória, descritiva com abordagem quantitativa. O projeto foi aprovado pelo CEP parecer 1.824.666. A coleta de dados foi realizada nos meses de novembro e dezembro de 2016. Resultados: A amostra foi constituída por 12 indivíduos com úlcera diabética, sendo 58,3\% masculino, $75 \%$, brancos e $58 \%$. A idade variou entre 38 a 78 anos, predominando a faixa etária entre 52 a 57 anos (41,6\%). Quanto as doenças de base: $75 \%$ são hipertensos. Do total dos participantes, $50 \%$ apresentam histórico de lesões anteriores, O tempo de lesão variou de 15 dias até 1 ano, com localização predominante do quarto quirodáctilo (25\%). Conclusões: Os resultados obtidos demonstram a importância no investimento em tecnologias para a cicatrização de feridas, mas principalmente em recursos humanos especializados e na organização de serviços públicos visando atender de forma equânime a população que dele necessita. Acredita-se que o conhecimento sobre os usuários do ambulatório poderá contribuir no planejamento e implementação de ações para a melhoria do serviço.
\end{abstract}

\section{Keywords: ESTOMATERAPIA, PÉ DIABÉTICO, ENFERMAGEM BASEADAS EM EVIDÊNCIAS, ENFERMAGEM}

\section{Referências Bibliográficas}

1. SOUZA, H. F.; ARAÚJO, A. M.; NELSON, I. C. A. S. R.; SILVA, K. R. F. O enfermeiro no manejo clínico de pacientes com úlcera venosa: revisão integrativa de literatura. Revista humano ser, Natal. v. 1, n. 1. 2015. Disponível em:

https://periodicos.unifacex.com.br/humanoser/article/view/623. Acesso em: 10 jul 2019. 2. DUMVILLE, J.C.; LIPSKY, B.Z.; HOEY, C.; CRUCIANI, M.; FISCON, M.; XIA, J. Topical antimicrobial agents for treating foot ulcers in people with diabetes Cochrane Systematic Review - Intervention Version published: 14 June 2017. Disponível em:

https://doi.org/10.1002/14651858.CD011038.pub2. Acesso em: 10 ago 2019. 3. OLIVEIRA,A.F; MARCHI, A.C.B, et al, 2014 .Estimativa de custo de tratar o pé diabético, como prevenir e economizar recursos. Ciênc. saúde coletiva [online]. 2014, vol.19, n.6, pp.1663-1671. ISSN 1413-8123.Disponível em: http://dx.doi.org/10.1590/1413-81232014196.09912013. Acesso em: 13 maio 2019. 


\title{
PERFIL EPIDEMIOLÓGICO DE PACIENTES COM LESÃO POR PRESSÃO ESTÁGIOS III E IV
}

\author{
SANTANA DE MARIA ALVES DE SOUSA ${ }^{1}$, Ana Carolina Morais dos Santos ${ }^{1}$, Antônio \\ Author(s): Ericeira Pinto Neto ${ }^{1}$, Camila Evangelista Carnib Nascimento ${ }^{1}$, Ingrid de Campos Albuquerque ${ }^{1}$, \\ Patricia Lima Queiroz ${ }^{1}$, Rosilda Silva Dias ${ }^{1}$ \\ Institution(s) ${ }^{1}$ UFMA - UNIVERSIDADE FEDERAL DO MARANHÃO (Cidade Univeritária, Campus do \\ Bacanga, São Luís - MA )
}

\begin{abstract}
Introdução: A lesão por pressão é uma lesão, localizada na pele e/ou tecido subjacente, normalmente sobre uma proeminência óssea, causada pela pressão ou pela pressão combinada com fricção e cisalhamento. Classifica-se em estágios I, II, III e IV, lesão por pressão não classificável, lesão por pressão tissular profunda; além das definições adicionais: lesão por pressão relacionada a dispositivo médico e lesão por pressão em membranas mucosas. Objetivo: analisar o perfil epidemiológico de pacientes com lesão por pressão estágios III e IV. Método: trata-se de um estudo descritivo de caráter quantitativo, realizado em quatro hospitais públicos de São Luís - MA. A população foi formada por 70 pacientes, de ambos os sexos, com idade igual ou superior a 18 anos, que assinaram o Termo de Consentimento Livre e Esclarecido. A pesquisa foi aprovada pelo Comitê de Ética em Pesquisa do HU-UFMA, parecer CEP 002600/2010. Os dados foram analisados após consulta do banco de dados do estudo "Úlcera por pressão: tratamento e custos sociais". Resultados: do total de 70 pacientes, verificou-se que 39 (55,71\%) eram do sexo masculino, 40 (57,14\%) possuíam mais de 60 anos, $38(54,28 \%)$ possuíam apenas ensino fundamental incompleto, $21(30 \%)$ eram aposentados, $15(21,42 \%)$ de outras profissões, $38(54,28 \%)$ são católicos, $37(52,85 \%)$ solteiros, $38(54,28 \%)$ tinham como origem da lesão por pressão, outra instituição hospitalar. A Disfunção Neurológica predominou em 24 pacientes (34,28\%). Foram identificados 40 pacientes $(57,14 \%)$ com Diabetes Melittus, Hipertensão Arterial Sistêmica ou outras doenças de base. A variável mobilidade obteve maior índice em pacientes restritos ao leito, totalizando em 65 (92,85\%). Quanto ao setor de internação 36 pacientes (51,42\%) encontravam-se na Clínica Médica. Ao final, 49 pacientes $(70 \%)$ tiveram alta. A maior parte dos pacientes internados, $36(51,42 \%)$ ficaram por um período menor que 50 dias, com um tempo médio de 105 dias e uma variação entre 11 a 376 dias. Dentre os 70 pacientes, foram registradas 123 lesões por pressão, média de 1,75 lesão por paciente, predominando o estágio IV, com 69 lesões (56,09\%). A região de maior incidência foi a sacra com 66 lesões $(53,65 \%)$. Conclusão: percebe-se que os perfis epidemiológicos são necessários para se estabelecer dados referentes ao problema do desenvolvimento dessas lesões. Acredita-se que este estudo possa colaborar significativamente com os dados acerca das lesões por pressão. Fica evidente a importância da implementação de um protocolo preventivo específico para lesão por pressão, além de conscientizar os profissionais sobre a existência desse problema e do alto risco para pacientes críticos e para os que estão sob cuidados básicos e intermediários.
\end{abstract}

Keywords: Lesão por Pressão, Perfil de Saúde, Enfermagem

\section{Referências Bibliográficas}

Agência Nacional de Vigilância Sanitária. Práticas seguras para prevenção de Lesão por Pressão em serviços de saúde. Nota Técnica GVIMS/GGTES no 03/2017. 2017. Blanes L, Ferreira LM. Prevenção e Tratamento de Úlcera por Pressão. São Paulo. Editora: Atheneu, 2014. p. 4-5. Costa M P et al. Epidemiologia e tratamento das úlceras de pressão: experiência de 77 casos. ACTA Ortopedia Brasileira. v. 13, n. 3, p. 124-133, São Paulo, Maio, 2015. NPUAP. National Pressure Ulcer Advisory Panel. NPUAP announces a change in terminology from pressure ulcer to pressure injury and updates the stages of pressure injury. April 13, 2016. Disponível em: . Acesso em: 27/10/2017 


\title{
Elaboração e Implementação de um Programa de Gerenciamento de Risco de Lesão por Pressão na Atenção Domiciliar na Saúde Suplementar
}

\author{
Author(s): Amanda de Castro Bonato Ferreira ${ }^{1}$ \\ Institution(s) ${ }^{1}$ Unimed Curitiba - Unimed Curitiba (Rua Padre germano Mayer, 840. cristo rei curitiba PR)
}

\begin{abstract}
Introdução: O surgimento de Lesões por Pressão (LPP) é considerado evento adverso ou seja, uma lesão ou dano não intencional que resulta em incapacidade ou disfunção, temporária ou permanente, e/ou prolongamento do tempo de permanência ou morte como consequência do cuidado de saúde prestado (1). No Brasil, a prevalência de LPP nos hospitais variou entre $35,2 \%$ a $63,6 \%$ e a incidência entre $11,1 \%$ e $64,3 \%$ dentre os pacientes graves, já na modalidade Atenção Domiciliar (AD) as taxas de prevalência variam entre $0 \%$ e $29 \%$ e as de incidência variam entre $0 \%$ e $17 \%$ (2). A prevenção de LPP consta em segundo lugar nos Protocolos Básicos de Segurança do Paciente do Ministério da Saúde (3), o esclarecimento e prestação de informações sobre riscos decorrentes do estado de saúde do indivíduo e a prevenção e controle de danos durante a assistência de Enfermagem constam na Lei do exercício profissional (4) e código de ética de Enfermagem. AD é considerada uma forma mais ampla de cuidados em domicílio envolvendo todas as ações neste campo e podendo ser classificada como: assistência domiciliar o qual abrange ações de caráter ambulatorial ou internação domiciliar (ID) onde cuidados intensivos são prestados. Independentemente da condição socioeconômica, muitas famílias buscam transferir a responsabilidade dos cuidados necessários com seus familiares para os profissionais/instituição de saúde levando à redução de cooperação entre cuidadores informais (familiares) e profissionais. Objetivo: Elaborar/ implementar plano de ação visando gerenciamento do risco de desenvolvimento LPP em beneficiários acompanhados pelo serviço de $A D$ da saúde suplementar. Material e Método: Estudo longitudinal prospectivo tecnológico. Resultados: $O$ diagnóstico situacional do serviço mostrou taxas de incidência e prevalência de LPP de $13,5 \%$ e $50 \%$ na modalidade ID e de $20,7 \%$ e $32 \%$ na modalidade assistência domiciliar respectivamente. O serviço aplica a Escala de Braden a todos os beneficiários avaliados para entrada no programa de $A D$ e mensalmente a cada visita de seu enfermeiro gestor (ou conforme necessidade/alteração do quadro clínico do beneficiário). Todos os indivíduos admitidos no programa de AD com escore de Braden $\leq 16$ são visitados por enfermeiro o qual orienta cuidador para prevenção de LPP. Tais instruções constam em formulário específico em forma de Check List o qual é preenchido via Tablet e incluído no prontuário (Figura 1). Informativo impresso contendo informações é entregue aos beneficiários (Figura 2) e sempre que surgir nova LPP o profissional que constatar deve registrar Evento adverso no prontuário eletrônico.Conclusões: $O$ treinamento da equipe multidisciplinar possibilitou o nivelamento de conhecimento sobre avaliação da pele e uso correto da escala de Braden. A confecção do formulário para orientações do cuidador possibilita a responsabilização do mesmo e documentação do trabalho de educação em saúde. Em um segundo momento serão coletados dados para estudo de custo evitado para seguir com padronização de novas tecnologias (posicionadores, coberturas multicamadas e superfícies de apoio diferenciadas), elaboração de aplicativo para celular que solicite a mudança de decúbito mostre imagens sugerindo o posicionamento solicitando uma fotografia do cliente para um reconhecimento facial e alerta de pontos de pressão.
\end{abstract}

Keywords: Estomaterapia, Lesão Por Pressão, Gestão de Riscos , Segurança do Paciente

\section{Referências Bibliográficas}

1. Mendes W, Travassos C, Martins M, Noronha JC. Revisão dos estudos de avaliação da ocorrência de eventos adversos em hospitais. Rev Bras Epidemiol 2005; 8(4): 393-406. 2. Cuddigan J, Ayello EA, Sussman, C. Pressure ulcers in America: Prevalence, incidence, and implications for the future. Advances in Skin \& Wound Care 2001; 14(4): 208-215. 3. Ministério da Saúde. Anexo 02: Protocolo Para Prevenção De Úlcera Por Pressão. 2013/07/09; 1-20. 4. Brasil. Presidência da República, Casa Civil, Subchefia para Assuntos Jurídicos. Lei no 7498 de 25 de Junho de 1986. Dispõe sobre a regulamentação do exercício da enfermagem, e dá outras providências [Internet]. Brasília, DF; 1986 [acesso em 2019 jul. 20]. Disponível em: http://www.planalto.gov.br/ccivil_03/leis/17498.htm 


\title{
PERFIL EPIDEMIOLÓGICO DAS LESÕES DE PELE OCORRIDAS EM PESSOAS COM LESÃO MEDULAR EM UM HOSPITAL DE REABILITAÇÃO.
}

\author{
Author(s): Janaina Barbosa da Silva ${ }^{1}$, Lisabel Tabari ${ }^{1}$ \\ Institution(s) ${ }^{1}$ APS - Rede Sarah de Hospitais de Reabilitação (SMHS 501 BLOCO A BRASÍLIA - DF CEP: 70335-901)
}

\begin{abstract}
Introdução. A Lesão medular (LM) ocasiona alterações motoras, sensoriais e autonômicas que tornam as pessoas acometidas, susceptíveis ao desenvolvimento de complicações cutâneas, como lesão por pressão, dermatites e infecções fungicas 1,2. Estas complicações são decorrentes das alterações neurológicas, que podem provocar a diminuição do fluxo sanguíneo e alterações nas respostas inflamatórias da pele 2. As lesões por pressão (LP) correspondem a segunda complicação prevalente nesta população,3,4,5 e estão entre os principais eventos adversos relacionados à assistência em saúde, notificados pelos Núcleos de Segurança aos Pacientes do País 6. Devido ao impacto negativo das complicações cutâneas nos indivíduos com Lesão Medular, o objetivo deste estudo é identificar o perfil das principais complicações cutâneas ocorridas em pacientes adultos admitidos no Programa de Neurorreabiliação em Lesão Medular, em um Hospital de Reabilitação. Metodologia. Estudo retrospectivo e quantitativo das lesões de pele ocorridas em pessoas admitidas no programa de Neurorreabilitação em Lesão Medular de um Hospital de Reabilitação, no período de janeiro de 2016 a dezembro de 2018. Os dados foram obtidos junto ao Controle de Qualidade da Unidade Sarah Centro e correspondem às lesões de pele notificadas ao Núcleo de Segurança do Paciente (NSP) Unidade Brasília. Resultados. Durante o triênio de 2016 a 2018 foram notificadas 118 lesões de pele, com aumento das notificações no ano de 2018. A maioria da amostra (88\%) era do gênero masculino, e a principal etiologia das lesões de pele notificadas ao NSP envolviam o grupo denominado Outras Lesões (54\%), composto por lesões traumáticas, lesões por adesivos, queimaduras, lesões peri incisionais, e outras lesões não especificadas. As Lesões Traumáticas seguidas pelas Lesões por Adesivo foram as mais frequentes e a maioria apresentou a ruptura da pele (87\%). As lesões por adesivo ocorridas no ano de 2018 ocorreram principalmente no contexto de fixação de curativo (80\%) e o comprometimento tissular predominante foi o flictena $(47 \%)$. As Lesões por Pressão (LP) corresponderam ao segundo grupo de complicações cutâneas ocorridas no triênio (33,8\%), sendo o Estágio 2 o comprometimento tissular mais frequente em todo o período. Apesar do grupo classificado como Outras Lesões ter sido o principal grupo notificado no período, o mesmo era composto de diversas etiologias. Deste modo, podemos inferir que a Lesão por Pressão representa o principal grupo de complicação cutâneas notificado no período, o que vêm de encontro aos dados disponíveis na literatura 3,4,5. Em relação às lesões de pele por umidade observa-se que no triênio houve o predomínio da Dermatite Intertriginosa Conclusão: A notificação de eventos adversos é uma importante ferramenta para melhoria da qualidade da assistência a saúde, porém, devemos considerar a existência de possíveis subnotificações e divergências diagnósticas durante a classificação das lesões. A prevenção das complicações cutâneas,que estão sujeitos os pacientes com LM, representam um desafio para equipe de enfermagem. A identificação do perfil das lesões ocorridas no Programa de LM permite o desenvolvimento de estratégias para a implementação de medidas preventivas para evitar ou diminuir o dano à pele.
\end{abstract}

Keywords: Dermatite, Epidemiologia, Estomaterapia, Medula Espinhal, Úlcera

\footnotetext{
Referências Bibliográficas

1- BRASIL, Ministério da Saúde. Secretaria de Atenção À Saúde. Departamento de Ações Programáticas Estratégicas. Diretrizes de Atenção à Pessoa com Lesão Medular. Brasília: Ministério da Saúde, 2013. Disponível em;

http://bvsms.saude.gov.br/bvs/publicacoes/diretrizes_atencao_pessoa_lesao_medular.pdf. Acesso em 15/10/2018. 2 - MARBOURG, J.M; et al. Spinal Cord Injury Suppresses Cutaneous Inflammation: Implications for Peripheral Wound Healing. Journal of Neurotrauma (34), p.1149-1155, mar.2017. Disponível em doi: 10.1089/neu.2016.4611. Acesso em 23/02/2017. 3 - LALA. D.; et al. Impact of Pressure Ulcers on Individuals Living with a Spinal Cord Injuri. Archives of Physical Medicine and Rehabilitation, v. 95, n.12, p.2312-2319, dez. 2014. Disponível em: www.archirves-pmr.og. Acesso em: 23/02/2017. 4 - CHOPRA, T. et al. Risk factors and acute in-hospital costs for infected pressure ulcers among gunshot-spinal cord injury victims in southeastern Michigan. American journal of infection control. v. 44, n. 3, p. 15-319, mar 2015. Disponível em: https://doi.org/10.1015/j.ajic.2015.10.002. Acesso em: 24 fev. 2017. 5 - WIELEN, H. V. et al. Hospital-acquired pressure ulcers in spinal cord injured patients: time to occur, time until closure and risk factors. Spinal Cord, v.54, n.9, p.725-731, jan.2016. Disponível em: www.nature.com /sc. Acesso em: 13/02/2018. 6 - AGÊNCIA NACIONAL DE VIGILÂNCIA SANITÁRIA. Gerência de Vigilância e Monitoramento dos Serviços de Saúde (GVIMS). Gerência Geral de Tecnologia em Serviços de Saúde. Nota técnica $n^{\circ} 3$. Práticas seguras para prevenção de Lesão por Pressão em serviços de saúde. Brasília, 2017. Disponível em: http://portal.anvisa.gov.br/documents/33852/271855/. Acesso em: fev/2017. 7- BARNES, M.P. Principles of neurological rehabilitation. Journal of Neurology, e.Neurosurgery \& Psychiatry, v. Manual de Prevenção e Tratamento de Lesões por Fricção 2003. supl. IV. Disponível em: https://www.ncbi.nlm.nih.gov/pmc/articles/PMC1765644/pdf/v074p00iv3.pdf. Acesso em: 15/10/2018 . 8- WORLD HEALTH ORGANIZATION. International Perspectives on Spinal Cord Injuri. 2013. Disponível em: http://apps.who.int/iris/bitstream/handle. Acesso em: 23/09/2018. T 9- TORRES, F., et al. Manual de Prevenção e Tratamento de Lesões por Fricção.1ํㅡㄹㅗão, São Paulo, 32p.2016. Disponível em https://proqualis.net/sites/proqualis.net/files/ManualJ\%2804_11_2016\%29_abril.pdf. Acesso em 10/08/2018. 10 - FERREIRA, D.H.; TEIXEIRA, M. L.O; BRANCO, E. M. S. C. Cuidados de Enfermagem para a Prevenção de Lesão de Pele por adesivos em feridas cirúrgicas. Cienc Cuid Saude, 16(2), abrjun, 2017. Disponível em DOI: 10.4025. Acesso em 05/08/2018. 11 - Vakharia P., James D.W. Intertrigo. Drugs\&Diseases, jun. 2018.
} 


\title{
QUALIDADE DE VIDA DE PACIENTES COM FERIDAS COMPLEXAS DE UM AMBULATÓRIO DE ENFERMAGEM
}

\author{
Author(s): \\ Ana Carolina Floriano de Moura ${ }^{1}$, Nazaré de Maria Silva Mendes ${ }^{1}$, Grazielle Roberta Freitas da \\ Silva ${ }^{1}$, Átila Sâmia Oliveira Rodrigues ${ }^{1}$, Sabrina de Paula Alves de Morais ${ }^{1}$ \\ Institution(s) ${ }^{1}$ UFPI - Universidade Federal do Piauí (Campus Universitário Ministro Petrônio Portella, Bairro \\ Ininga, Teresina/Piauí)
}

\begin{abstract}
Introdução: As feridas estão presentes em todo o mundo e, segundo estatísticas norte-americanas, $14 \%$ da população mundial é acometida por elas 1 . Nos casos de feridas complexas, o processo de cicatrização sofre interrupções, resultando na cronicidade da lesão, interferindo no tratamento clínico e na vida do paciente2. Portanto, os profissionais da equipe de enfermagem necessitam compreender e avaliar o impacto da ferida e de suas características clínicas na qualidade de vida (QV) da pessoa acometida e elaborar estratégias de enfrentamento às mudanças ocorridas3. Objetivo: analisar a qualidade de vida de pacientes com feridas complexas atendidos em um ambulatório de enfermagem. Material e Método: estudo analítico e transversal desenvolvido com 25 pacientes atendidos em um ambulatório de enfermagem, especializado em feridas complexas, de um hospital universitário, sendo a amostra não probabilística, por conveniência. A coleta de dados ocorreu no período de janeiro a fevereiro de 2019 durante consultas de enfermagem. Foi aplicada a versão abreviada do Freiburg Life Quality Assessment-Wound (FLQA-wk)4, 5 a cada sete dias nos pacientes avaliados. A relação entre as variáveis deu-se pela correlação de Spearman e o nível de significância foi de $p=0,05$. Este estudo foi aprovado pelo Comitê de Ética e Pesquisa da Universidade Federal do Piauí sob o parecer de número 3.026.373/2018. Resultados: foram realizadas 88 avaliações de um total de 51 feridas. Tanto no sexo masculino quanto no feminino, as maiores médias foram no domínio satisfação, sendo 3,46 e 3,22, respectivamente. A maior média por faixa etária foi do domínio satisfação $(3,67)$ no intervalo de $>72$ anos. O domínio com maior média por duração da cicatrização foi o vida diária $(3,51)$ na duração de um a cinco anos. Observaram-se correlações entre os domínios vida diária e físico $(p=0,45)$, vida social e vida diária $(p=$ $0,62)$, psicológico e físico $(p=0,63)$, psicológico e vida diária $(p=0,47)$, psicológico e vida social $(p=0,55)$, tratamento e vida diária $(p=0,52)$ e tratamento e vida social $(p=0,76)$. Conclusão: o registro e a avaliação da evolução da lesão devem ser criteriosos e periódicos, baseados em instrumentos validados para tal, para garantir uma assistência efetiva e permitir a avaliação do impacto da ferida e de suas características clínicas no dia-a-dia, facilitando a comunicação entre profissional e paciente, principalmente por tratarem-se de lesões complexas cujo tratamento é ambulatorial.
\end{abstract}

Keywords: Cuidados de Enfermagem, Estomaterapia, Qualidade de Vida

\section{Referências Bibliográficas}

1. Waidman MAP, Rocha SC, Correa JL, Brischiliari A, Marcon SS. O cotidiano do indivíduo com ferida crônica e sua saúde mental. Texto contexto - enferm. 2011; 20(4): 691-699. 2. Almeida WA, Ferreira AM, Ivo ML, Rigotti MA, Barcelos LS, Silva ALNV. Fatores associados à qualidade de vida de pessoas com feridas complexas crônicas. Rev. Pesqui. Cuid. Fundam. 2018; 10(1): 9-16. 3. Bedin LF, Busanello J, Sehnem GD, Silva FM, Poll MA. Estratégias de promoção da autoestima, autonomia e autocuidado das pessoas com feridas crônicas. Rev. Gaúcha Enferm. 2014; 35(3): 61-67. 4. Augustin M, Herberger K, Rustenbach SJ, Schäfer I, Zschocke I, Blome C. Quality of life evaluation in wounds: validation of the Freiburg Life Quality Assessment-Wound module, a disease-specific instrument. Int. Wound J. 2010; 7(6): 493-501. 5. Domingues EAR, Alexandre NMC, da Silva JV. Adaptação cultural e validação do Freiburg Life Quality Assessment - Wound para a língua portuguesa do Brasil. Rev. Latino-Am. Enfermagem. 2016; 24(1): 1-8. 


\title{
Atuação do enfermeiro na prevenção de infecção de sítio cirúrgico em cirurgia plástica de mastopexia com próteses através do uso de terapia por pressão negativa portátil e sem reservatório com interface de carboximetilcelulose sódica
}

\author{
Author(s): $\quad$ Fernanda Berny ${ }^{1}$, Rosaura Paczec ${ }^{2}$, Amanda Paris ${ }^{1}$, Viviane Paz ${ }^{1}$ \\ Institution(s) ${ }^{1}$ FUFAMED - Fufamed (R. São Nicolau 1088 Porto Alegre), ${ }^{2}$ PMPA - Prefeitura Municipal de \\ Porto Alegre (R.Capitão Montanha 27 Porto Alegre)
}

\begin{abstract}
Introdução: A infecção de sítio cirúrgico é aquela que ocorre como complicação de uma cirurgia sendo diagnosticada em até 30 dias se não houver implante protético e até 1 ano no caso de uso de implantes. É recomendado pela Organização Mundial da Saúde o uso de terapia por pressão negativa profilaticamente em pacientes adultos em incisões cirúrgicas com fechamento primário e com risco de infecção, para prevenção de ISC, e o uso de qualquer tipo de implante já caracteriza risco. A terapia por pressão negativa portátil e sem reservatório exerce $80 \mathrm{mmHg}$ de pressão, aproximando os bordos, reduzindo a tensão na ferida operatória, absorvendo exsudato, e por possuir interface exclusiva em carboximetilcelulose sódica retém qualquer tipo de microorganismo e não agride a pele adjacente. Deve ser aplicada após a sutura e pode permanecer por no máximo 7 dias. Objetivo: Relatar a conduta do enfermeiro na avaliação e instalação de terapia por pressão negativa portátil e sem reservatório em feridas operatórias. Material e métodos: Estudo descritivo do tipo relato de experiência. Resultados: As cirurgias de remodelagem de mamas com prótese de silicone normalmente requerem cicatrizes extensas, em formato de T, com reposicionamento de mamilo, e em muitos casos são associadas à colocação de próteses de silicone. A instalação da terapia por pressão negativa visa reduzir as chances de infecção, de necrose (por aumento do fluxo sanguíneo local), e contribui para um melhor resultado cicatricial já que aproxima mais as bordas permitindo uma melhor vedação e menor espaço para crescimento de tecido de granulação reduzindo complicações como cicatrizes hipertróficas e queloides. A instalação deve ser feita ao final da cirurgia e o enfermeiro deve observar o tamanho e a localização das incisões para a escolha do tamanho mais adequado de curativo. O paciente é orientado em relação ao funcionamento do equipamento (que possui vida útil de 30 dias) e o retorno para retirada do curativo deve ser marcado para 7 dias. Dentro deste prazo, é esperada cicatrização total da incisão e pontos de sutura prontos para a retirada. Conclusão: O uso da terapia por pressão negativa portátil, sem reservatório, com interface de carboximetilcelulose sódica é extremamente importante para redução das chances de infecção em pacientes submetidos a cirurgias de risco ou que envolvam a colocação de próteses. No caso das cirurgias plásticas os pacientes também obtêm o benefício estético garantindo uma cicatrização uniforme, sem hipertrofias ou queloides, com menor chance de deiscências ou necroses e resultados estéticos insatisfatórios.
\end{abstract}

Keywords: curativos oclusivos, estomaterapia, ferida cirúrgica

\section{Referências Bibliográficas}

Jeffery S, Leaper D, Armstrong D, Lantis J. Using negative pressure wound therapy to prevent surgical site infection. J Wound Care. 2018 Mar 1;27(Sup3):S5-S13. World Union of Wound Healing Societies (WUWHS) Consensus Document. Closed surgical incision management: understanding the role of NPWT. Wounds International, 2016. Disponível em: https://www.woundsinternational.com/uploads/resources/e1f19ed6450ae3053b58fb0fd137de86.pdf World Health Organization. Global Guidelines for the Prevention of Surgical Site Infection. World Health Organization 2018. Disponível em: https://apps.who.int/iris/bitstream/handle/10665/277399/9789241550475-eng.pdf?ua=1 


\title{
REDUÇÃO DE INCIDÊNCIA DE LESÃO POR PRESSÃO POR MEIO DE VISITA MULTIPROFISSIONAL AO PACIENTE CRÍTICO
}

\author{
Ana Carolina Floriano de Moura ${ }^{1}$, Grazielle Roberta Freitas da Silva ${ }^{1}$, Átila Sâmia Oliveira \\ Author(s): $\quad$ Rodrigues ${ }^{1}$, Anna Larissa de Castro Rego ${ }^{1}$ \\ Institution(s) ${ }^{1}$ UFPI - Universidade Federal do Piauí (Campus Universitário Ministro Petrônio Portella, Bairro \\ Ininga, Teresina/Piauí)
}

\begin{abstract}
Introdução: Os pacientes críticos estão sujeitos a uma maior quantidade de eventos adversos devido a gravidade de seu estado de saúde e frequência de intervenções invasivas repetidas por profissionais diferentes. Além disso, o processo de troca de informação entre a equipe multidisciplinar sofre interferências por barreiras que prejudicam o cuidado seguro. No entanto, discussões multiprofissionais a beira leito com uso de listas de verificações realizados por intensivistas podem melhorar os desfechos clínicos.1 Objetivo: analisar a efetividade da visita multiprofissional guiada por lista de verificação (LV) para melhoria de indicador de segurança do paciente crítico: incidência de lesão por pressão. Material e Método: Trata-se de um estudo quase experimental, do tipo antes e depois com grupo controle não equilavente. $O$ estudo foi realizado em uma UTI (Unidade de Terapia Intensiva) de um hospital universitário, constituinte de 15 leitos. A população foi composta de pacientes $(\mathrm{N}=367)$, internados entre julho e dezembro 2018, com amostra não probabilística e intencional $(\mathrm{N}=233)$, tendo incluídos, pacientes de 18 anos ou mais de ambos os sexos, e internação superior a 24 horas e excluídos internados em estado terminal. Os dados foram colhidos entre outubro e dezembro 2018, mediante a coleta dos dados clínicos, sociodemográficos e desenvolvimento de lesão por pressão (LP) durante internação de pacientes do grupo comparação (GC), internados entre julho e setembro 2018, em que não foram submetidos a visitas multiprofissionais diárias e grupo intervenção (GI), internados entre outubro e dezembro de 2018, incluídos na visitas multiprofissionais diárias, por meio de uma LV, a qual aborda entre os itens, a prevenção e atenção com LP. A variável dependente foi o indicador de segurança incidência de lesão por pressão (LPP).2 Os dados foram analisados por meio do software Statistical Package for the Social Sciences com análise descritiva. O projeto foi aprovado pelo Comitê de Ética em Pesquisa da Universidade Federal do Piauí com certificado de apresentação para apreciação ética número 3.000 .763 . Resultados: 125 pacientes $(53,65 \%)$ representaram o grupo comparação e $108(46,35 \%)$ o grupo intervenção. A maioria do sexo masculino, com idade superior a 60 anos, procedente do centro cirúrgico. A mediana de tempo de internação nos dois grupos foi de 4 dias. O GI houve menor porcentagem no desenvolvimento de LP, bem como a incidência de LP foi menor no GI $(7,7)$ comparado ao GC, no qual foi de 10,1. As inclusões de indicadores de segurança nas práticas de monitoramento da qualidade representam uma estratégia essencial para nortear melhorias, uma vez que, permitem a mensurar o nível de segurança em hospitais e apontam de forma direta problemas prioritários.3 Por outro lado, o uso de LV em discussões multiprofissionais tem sido relatado positivamente na melhora da eficácia e continuidade dos cuidados. Além de que têm sido relatadas redução no tempo de ventilação mecânica e frequência de infecção de foco pulmonar após visitas multiprofissionais com uso de LV. Conclusões: A diminuição da incidência de LP sugere o aumento de medidas profiláticas a prática de visitas multiprofissionais no cenário da UTI.
\end{abstract}

Keywords: Estomaterapia, Segurança do Paciente, Lista de Checagem, Comunicação

\section{Referências Bibliográficas}

1 D'empaire PP, Amaral AC. O que todo intensivista deveria saber sobre a passagem de plantão na unidade de terapia intensiva. Rev. Bras. Ter. Inten. 2017; 29 (2): 121-123. 2 Gouvea CSD. Desenvolvimento de indicadores de segurança para o monitoramento de cuidado em hospitais brasileiros de pacientes agudos. Carla Gouveia. - Rio de Janeiro, 2015. 39 p.(Relatório Proqualis). 3 Use of a standardized care communication checklist during multidisciplinary rounds in pediatric cardiac intensive care. JBI Database of Systematic Reviews and Implementation Reports. 2018; 16(2): 548-564.

DOI:10.11124/jbisrir-2017-003350 


\title{
CONSTRUÇÃO DE TECNOLOGIA EDUCATIVA SOBRE CUIDADOS COM OS PÉS: PREVENÇÃO DE COMPLICAÇÕES DO PÉ DIABÉTICO
}

Solange Gurgel Alexandre ${ }^{1}$, Viviane Mamede Vasconcelos Cavalcante ${ }^{2}$, Karla Vanessa Pinto Author(s): Vasconcelos ${ }^{2}$, Maíra Maria Leite de Freitas ${ }^{2}$, Caio Victor Fernandes de Oliveira ${ }^{2}$, Andrezza Silvano Barreto $^{2}$, Geovana Monteiro de Oliveira ${ }^{2}$, Carla Beatriz da Pontes Aguiar ${ }^{2}$ Institution(s) ${ }^{1}$ HUWC - HOSPITAL UNIVERSITÁRIO WALTER CANTÍDIO (R. Pastor Samuel Munguba, 1290 - Rodolfo Teófilo, Fortaleza - CE, 60430-372), ${ }^{2}$ UFC - Universidade Federal do Ceará (R. Alexandre Baraúna, 1115 - Rodolfo Teófilo, Fortaleza - CE, 60430-160)

\begin{abstract}
INTRODUÇÃO: Diabetes Mellitus (DM) é um conjunto de diversos distúrbios metabólicos, cuja principal característica é a hiplerglicemia decorrente de uma insuficiência na ação da insulina ou na liberação na secreção. No Brasil, avalia-se que $9,4 \%$ da população, cerca de 19 milhões de pessoas, possuem diabetes ${ }^{1}$. O pé diabético é uma de suas principais complicações. Segundo o Consenso Internacional de Pé Diabético, traduzido em 2001, o Pé Diabético é definido como infecção, ulceração e/ou destruição de tecidos moles, associados a alterações neurológicas e vários graus de doença arterial periférica (DAP) nos membros inferiores ${ }^{2}$. Os cuidados com os pés são essenciais à pessoa que possui tal patologia, tendo em vista que se perde a sensibilidade dos membros, o que pode ser importante para o desenvolvimento de feridas ${ }^{3}$. Considerando a necessidade de prevenção nesse contexto, o enfermeiro tem papel de destaque no planejamento e criação de tecnologias educativas voltadas para a orientação nos diferentes cenários de cuidado, trabalhando assim a prevenção de agravos e a promoção da saúde. OBJETIVO: Descrever a construção de material educativo sobre cuidados para prevenir o pé diabético. MATERIAL E MÉTODO: Estudo do tipo metodológico sobre a elaboração de um folder educativo para o cuidado domiciliar dos pés de pessoas diabetes, realizado em maio de 2019. A construção da tecnologia teve como base a literatura científica atualizada, sendo executado no software Microsoft Office 2013®. RESULTADOS: A construção do folder foi feita em etapas, sendo a primeira, voltada para a delimitação do assunto no tema "Pé diabético" que versou sobre os cuidados necessários com os pés da pessoa com diabetes, entre eles: higiene, hidratação, secagem, corte das unhas, calçados, meias, calos, calosidades e complicações. No segundo momento, foram reunidos materiais sobre o assunto, entre eles, manuais, cartilhas e artigos científicos, além de informações necessárias disponibilizadas pela Sociedade Brasileira de Diabetes. A última etapa constituiu-se da construção do folder, com figuras e elementos textuais. $\mathrm{O}$ material foi utilizado em uma capacitação interna de uma liga de enfermagem em Estomaterapia, na cidade de Fortaleza/CE, com vistas a dar as informações sobre o tema com recursos visuais que auxiliassem na apreensão do conteúdo. CONCLUSÃO: O processo de construção do folder se tornou relevante, na medida em que reuniu informações importantes sobre o tema, compilando o conhecimento e estimulando a construção de novas tecnologias educativas de fácil acesso e compreensão, com referências especificas para o público em questão. Além disso, trata-se de uma atividade que alia o processo criativo ao processo de educação em saúde, evidenciando a importância desse tipo de produção com bases científicas.
\end{abstract}

Keywords: Enfermagem, Estomaterapia, Pé Diabético, Feridas e lesões

\section{Referências Bibliográficas}

1. Sociedade Brasileira de Diabetes. Diretrizes da Sociedade Brasileira de Diabetes: 2015-2016. São Paulo (Brasil): AC Farmacêutica; 2016. Diagnóstico precoce do pé diabético: pp 137 -149. 2. Caiafa Jackson Silveira, Castro Aldemar Araujo, Fidelis Cícero, Santos Vanessa Prado, Silva Erasmo Simão da, Sitrângulo Jr. Cid J.. Atenção integral ao portador de pé diabético. J. vasc. bras. [Internet]. 2011 [cited 2019 Jul 29] ; 10 ( 4 Suppl 2 ): 1-32. Available from:

http://www.scielo.br/scielo.php?script=sci_arttext\&pid=S1677-54492011000600001\&lng=en.

http://dx.doi.org/10.1590/S1677-54492011000600001. 3. Feitosa, Maria Nivania Livramento; Feijão, Gerlana Sales; Silva Paula Lima da; Oliveira, Ana Camila Sousa; Brito, Maria Aparecida Correia. Assistência de enfermagem na atenção primária ao paciente com risco potencial de desenvolver pé diabético: uma revisão bibliográfica. Revista Uningá. [Internet]. 2017 [cited 2019 Jul 29] ; 54(1):185-196. Available from: http://revista.uninga.br/index.php/uninga/article/view/23/469. 


\title{
FOTOGRAFIA CLÍNICA PARA A GESTÃO DO REPARO TECIDUAL EM FERIDAS: PROJETO DE IMPLEMENTAÇÃO DESENVOLVIDO POR ENFERMEIROS TRAINEE
}

\author{
Author(s): \\ Gustavo Lopes Soares ${ }^{1}$, Raphaella da Silva Fernandes ${ }^{1}$, Milena Amorim Zuchetto ${ }^{1}$, Luciane \\ Buchner $^{1}$ \\ Institution(s) ${ }^{1}$ HOSPITAL BAÍA SUL - HOSPITAL BAÍA SUL (FLORIANÓPOLIS)
}

\begin{abstract}
Introdução: A enfermagem é uma profissão de perfil empreendedor e proativo, requerendo ações criativas e tecnológicas para melhorar a qualidade de vida das pessoas. Na atualidade, os programas trainee tem surgido como uma forma de ampliar o julgamento clínico reflexivo, visando o desenvolvimento de competências técnico-profissional para a formação, valorizando a inovação e responsabilidade com as exigências da realidade clínica. Desta forma, a vasta dinamicidade do cuidado avançado em feridas na assistência hospitalar requer uma abordagem multimodal e desafiadora, onde o gerenciamento de enfermagem se depara com a descontinuidade da assistência e fragilidades na descrição precisa dessas lesões cutâneas. Diante disso, emerge a necessidade de evidências objetivas que suplementem a tomada de decisão clínica, por meio de tecnologias inovadoras que sistematizem, tragam consistência e continuidade para a assistência. Em meio à essa problemática, o registro fotográfico surge como um instrumento promotor de informações precisas na incorporação da técnica clínica pautada em evidência. Objetivo: Descrever o processo de planejamento para implementação da fotografia clínica como tecnologia da gestão de feridas, por um programa trainee de enfermagem em assistência hospitalar. Metodologia: Trata-se da descrição de um desenho de projeto, relacionado com um macro-estudo de abordagem qualitativa pautado no método da Pesquisa-Ação. O cenário de investigação descrito envolve um hospital privado no Sul do Brasil e os participantes incluídos nesta projeção são enfermeiros assistenciais lotados na instituição, bem como enfermeiros implicados no programa trainee. Resultados: O processo metodológico de coleta de dados planejado envolve seis etapas para a implementação da fotografia clínica para a gestão de feridas, sendo essas: o reconhecimento do problema através de entrevistas individuais com roteiro estruturado aplicado em enfermeiros assistenciais, além de diários de campo acerca das experiências vivenciadas pelos enfermeiros trainee. Estas narrativas constroem o problema a ser desenvolvido, a partir disso são colhidas informações sobre recursos que sustentam a implantação do projeto, compreendendo uma revisão narrativa da literatura e análise da ferramenta de sistema de informação e comunicação utilizada na instituição. Essas duas etapas supracitadas darão origem ao Detalhamento Operacional de Enfermagem, sistematizando o processo de implementação da fotografia clínica. Esse documento será debatido em grupo focal envolvendo os enfermeiros entrevistados no primeiro momento da coleta para validar e aperfeiçoar o instrumento. A partir disso, será instituído um grupo piloto na unidade de internação de maior complexidade do hospital, com participação de duas enfermeiras assistenciais lotadas na unidade e um enfermeiro trainee, objetivando o teste e validação da implementação do projeto. O teste-piloto projetado terá duração de quatro semanas, em que serão registradas notas de observação acerca da experiência, registros de acompanhamentos em prontuários eletrônico e diálogo para lapidar a ideação projetada. Ao final, será desenvolvida a ação em formato de capacitação, visando instrumentalizar, tecnicamente, a captação de imagem para avaliação de alterações morfológicas, demonstração e análise do progresso terapêutico. Conclusões: Espera-se que a intersetorialidade do programa trainee de enfermagem permita a aplicação deste desenho de projeto em sua prática, de modo a ampliar as possibilidades para uma assistência hospitalar qualificada quanto ao gerenciamento de feridas.
\end{abstract}

Keywords: Fotografia, Feridas, Estomaterapia, Tecnologias Biomédicas, Pesquisa em Enfermagem Clínica

\section{Referências Bibliográficas}

SCHOLZE, G, FREITAS MBD, ZANONI PK, ANDRADE RPD, SILVA MAG. Os programas de trainee como processo de desenvolvimento de pessoas na organização: um estudo de caso. FAE Centro Universitário, 2017; 1(3). Disponível em: http://memorialtcccadernograduacao.fae.edu JONES RE, FOSTER DS, LONGAKER MT. Management of chronic wounds. American Medical Association (AMA), 2018; 14(320). Disponível em: http://dx.doi.org/10.1001/jama.2018.12426 THIOLLENT, M. Metodologia da pesquisa-ação. 4. ed. São Paulo: Brasiliense; 1998. CARVILLE K, SCOTT J, HAESLER E. Standard for wound prevention and management. Australian Nursing and Midwifery, 2017; 24(8). Disponível em: http://search.proquest.com/openview/.d8b11a569c2fc05a7f3acd0e7e07df44/1?pq-origsite 


\title{
ESTUDO DA RESISTÊNCIA CICATRICIAL CUTÂNEA EM Rattus norvegicus UTILIZANDO $O$ LASER DE BAIXA INTENSIDADE
}

\author{
Elaine Carininy Lopes da Costa ${ }^{1}$, Cliciane Furtado Rodrigues ${ }^{1}$, Antonio Luís Martins Maia Filho \\ Author(s): ${ }^{1}$, SANDRA MARINA GONÇALVES BEZERRA ${ }^{1}$, Thalita de Moraes Lima \\ Institution(s) ${ }^{1}$ FACIME - FACULDADE DE CIÊNCIAS MÉDICAS (RUA OLAVAO BILAC 2335 CENTRO \\ TERESINA PI), ${ }^{2}$ IFPI - Instituto Federal de Educação do Piauí (Rua projetada S/N Bairro Uberaba \\ II Oeiras PI)
}

\begin{abstract}
INTRODUÇÃO. A terapia com laser de baixa intensidade no tratamento de feridas apresenta-se como uma abordagem promissora livre de drogas e efeitos colaterais, promove a cicatrização de feridas, redução da inflamação, da dor e restauração das funções. O laser atua no aumento da proliferação de fibroblastos, osteoblastos e células epiteliais, bem como na síntese do colágeno, que é fundamental para uma boa cicatrização. OBJETIVOS: Comparar a resistência cicatricial de feridas tratadas com o laser de baixa intensidade e solução oleosa à base de ácidos graxos essenciais. MATERIAL E MÉTODOS: Trata-se de um estudo experimental do tipo caso controle e foi aprovado pela Comissão de Ética em Pesquisa CEUA/FACIME. Foram estudados 60 ratos (Rattus norvegicus) divididos em 4 grupos e analisados conforme o tempo experimental aos 7, 14 e 21 dias após os procedimentos cirúrgicos. Os animais foram distribuídos aleatoriamente em caixas específicas para ratos. Os grupos foram: Grupo C (Controle negativo: sem laser, sem AGE), Grupo AGE (AGE sem laser) Grupo LASER (Laser sem AGE), Grupo AGE+LASER (AGE e LASER). Sendo 5 o número de animais em cada grupo. Foi utilizado a solução "AGE-ÓLEO DE GIRASSOL" e o aparelho de laser vermelho, comprimento de onda 660 nm, potência útil $100 \mathrm{~mW}$. Após a anestesia, foi realizado a incisão cirúrgica da pele na região dorsolateral dos ratos de forma padronizada, com área e profundidade iguais para todos os animais. Transcorrido 24 horas do procedimento cirúrgico deuse início às aplicações dos agentes específicos de cada grupo, sendo realizada uma vez ao dia sempre no mesmo horário, no caso dos grupos LASER e LASER+AGE foram submetidos à irradiação por laser na faixa espectral de 660 nm, com dose de 0,5 J por ponto, com sessões a cada 48 horas. A análise estatística dos dados coletados foi realizada de maneira descritiva, através das medias mais ou menos desvio padrão e inferencial, através do teste ANOVA para comparação entre grupos. No grupo AGE RESULTADOS: A análise tensiométrica foi feita com todos os retalhos cutâneos dos animais em estudo e todos romperam no local da sutura. $\mathrm{Na}$ análise da tensão cicatricial média dos retalhos cutâneos nos tempos experimentais de 07, 14 e 21 dias de tratamento, observou- se força de ruptura superior, com diferença significativa em todos os grupos tratados em relação ao grupo controle, $p$
\end{abstract}

Keywords: Estomaterapia, Laser de baixa intensidade, Feridas

\section{Referências Bibliográficas}

ANDRADE FSSD, CLARK RMO, FERREIRA ML. Efeitos da Laserterapia de baixa potência na cicatrização de feridas cutâneas. Ver. Col. Bras. Cir., 41(2): 129-133, 2014. FERREIRA AM, SOUZA BMV, RIGOTTI MA, LOUREIRO MRD. Utilização dos ácidos graxos no tratamento de feridas: uma revisão integrativa da literatura nacional. Rev Esc Enferm USP, 46(3): 752-60, 2012. SOUSA RG, BATISTA KNM. Laserterapia na cicatrização de feridas associada ao diabetes mellitus Revisão. Um Bras Dermatol, 91 (4): 489-493, jul-ago 2016 


\title{
CUSTO DIRETO DO TRATAMENTO DE LESÃO POR PRESSÃO ESTÁGIOS III E IV EM PACIENTES DE UM HOSPITAL PÚBLICO ESTADUAL EM SÃO LUÍS - MA
}

\author{
SANTANA DE MARIA ALVES DE SOUSA ${ }^{1}$, Antônio Ericeira Pinto Neto ${ }^{1}$, Ana Carolina \\ Author(s): Morais dos Santos ${ }^{1}$, Poliana Pereira Costa Rabêlo ${ }^{1}$, Patricia Ribeiro Azevedo ${ }^{1}$, Ana Caroline \\ Silva Caldas ${ }^{2}$, Florene Vale dos Anjos ${ }^{3}$ \\ Institution(s) ${ }^{1}$ UFMA - UNIVERSIDADE FEDERAL DO MARANHÃO (Cidade Univeritária, Campus do \\ Bacanga, São Luís - MA ), ${ }^{2}$ COLUN - COLÉGIO UNIVERSITÁRIO - UFMA (Cidade \\ Univeritária, Campus do Bacanga, São Luís - MA ), ${ }^{3}$ HU UFMA - HOSPITAL UNIVERSITÁRIO \\ - UFMA (Rua Barão de Itapary, Centro, São Luís - Ma )
}

\begin{abstract}
INTRODUÇÃO: A lesão por pressão é considerada uma ferida crônica pela longa duração, reincidência frequente, e difícil cicatrização. Seu tratamento tem impacto econômico significativo para instituição de saúde, pelo aumento dos gastos de seu tratamento clínico. Desta forma, o enfermeiro deve adotar uma abordagem de melhor eficiência, levando em consideração o menor custo para o paciente e para a instituição hospitalar. OBJETIVO: Estabelecer o custo direto do tratamento da lesão po $r$ pressão estágios III e IV em pacientes de um Hospital da Rede Estadual em São Luís - MA. MATERIAL E MÉTODO: Trata-se de um estudo descritivo, de corte transversal desenvolvido com pacientes que desenvolveram lesão por pressão estágios III e IV. A coleta de dados foi realizada no período de março a junho de 2016, após autorização do Termo de Consentimento Livre e Esclarecido pelo participante da pesquisa ou familiar. Foi realizado entrevista com paciente e familiar para coleta dos dados sociodemográficos e clínicos. Após entrevista o paciente foi acompanhado diariamente para conferência do material utilizado no tratamento da lesão por pressão. Os gastos foram contabilizados a partir das notas de compras da instituição. Este estudo faz parte da pesquisa "Úlcera por pressão: tratamento e custos sociais", aprovado pelo Comitê de Ética em Pesquisa do HU-UFMA, sob parecer CEP 325/2010. RESULTADOS: Foram acompanhados 10 pacientes, a análise dos resultados nos permitiu concluir que a maioria dos pacientes foi do sexo masculino (70\%), com faixa etária prevalente $>70$ anos (50\%), procedentes da Capital (70\%), quanto ao diagnostico médico $60 \%$ eram neoplasia e $40 \%$ fratura de fêmur. Em relação ao consumo total de materiais e gastos com realização dos procedimentos para tratamento da lesão por pressão, foi contabilizado um gasto total de $R \$ 6.652,27$ (seis mil, seiscentos e cinquenta e dois reais e vinte e sete centavos), entre materiais de consumo, coberturas e tratamento cirúrgico (debridamento), correspondente a realização de 104 procedimentos. CONCLUSÃO: Desta forma acreditamos que os resultados obtidos nesta pesquisa poderão sensibilizar os profissionais de saúde e a equipe de enfermagem, para adotar medidas preventivas evitando o surgimento de lesão por pressão, pensando na qualidade da assistência prestada aos pacientes e na redução dos custos do tratamento da lesão por pressão.
\end{abstract}

Keywords: Lesão por Pressão, Custos, Enfermagem, Estomaterapia

\section{Referências Bibliográficas}

Araújo TM, Araújo MFM, Caetano JA. Comparação de escalas de avaliação de risco para úlcera por pressão em pacientes em estado crítico. Acta Paul. Enferm, v. 5, n. 24, p 695-700,2011. Baron MV, Pavani RM, Forgiarini Junior LAF. Inovações e tecnologias para prevenção da úlcera por pressão em calcâneo. Revista de Epidemiologia e Controle de Infecções, Santa Cruz do Sul, v. 7, n. 2. p. 122-131. 2017. Seveganani PO, Bruim SFF, Filus Wa. Custo direto de curativos em úlcera por pressão: estudo de caso. Boletim de Enfermagem Ano I. Paraná, 2007. Sobest, Associação Brasileira de Estomaterapia. Classificação das Lesões por Pressão - Consenso NPUAP 2016 - Adaptada Culturalmente para o Brasil. 2016. Disponível em < http://www.sobest.org.br/textod/35>. Acesso em 20/10/2017. 


\title{
APLICAÇÃO DE UMA FERRAMENTA PARA PREVENÇÃO DE LESÃO POR ADESIVOS MÉDICOS EM UM HOSPITAL PRIVADO
}

\author{
Author(s): Patricia Pedroso da Silva ${ }^{1}$, Daiany Santos Fernandes ${ }^{1}$, Camila de Freitas Gambim ${ }^{1}$, Elizandra \\ Cunn ${ }^{1}$, Elisandra Leites Pinheiro ${ }^{1}$, Daniela Tenroller de Oliveira ${ }^{1}$ \\ Institution(s) ${ }^{1}$ HMV - Hospital Moinhos de Vento (Ramiro Barcellos, 910)
}

\begin{abstract}
Introdução: As lesões de pele relacionadas a adesivos médicos (MARSI) são alterações cutâneas previsíveis, ocasionadas pela remoção ou escolha inadequada da fita ou outro dispositivo médico.1 Raramente um paciente que necessita de cuidados dentro de uma instituição hospitalar não irá fazer uso de algum tipo de adesivo.2 Um fator de discussão dentro das instituições hospitalares são lesões de pele, pois estão diretamente relacionadas a segurança do paciente. 3 No intuito de facilitar a identificação dos fatores que estão relacionados com lesão de pele por adesivos médicos e reconhecer critérios fundamentais para a prevenção das lesões, foi elaborado por uma empresa multinacional americana uma metodologia chamada "Visar", e implementada no hospital durante um processo de certificação de pele feito pela mesma. Essa metodologia tem como objetivo nortear o profissional da saúde no momento da avaliação da pele, melhorando a experiencia do paciente. Na ferramenta VISAR cada letra traz um conceito: Visualizar: está relacionada as condições de saúde e da pele do paciente. Inspecionar: inspecionar as condições da pele subjacente. Selecionar: escolha da fita mais apropriada às condições do paciente e os dispositivos a serem fixados. Aplicar: este se refere a aplicar o produto adesivo adequadamente, utilizando as técnicas corretas para cada tipo. Remover: sempre de forma correta e cuidadosa qualquer adesivo. Objetivo: Implementar a ferramenta VISAR no cuidado relacionado a adesivos médicos e orientar a equipe sobre as intervenções de enfermagem dirigidas à prevenção e analisar a sua eficácia. Método: Trata-se de um estudo transversal que faz parte de um projeto guarda-chuva da instituição, como parecer CAAE: 57679316.9.0000.5330, que relata a experiência de um processo de certificação de pele onde foi implementada a metodologia VISAR em uma instituição hospitalar privada de Porto Alegre. A certificação aconteceu em três etapas de avaliação presencial, com uma avaliadora especialista para assuntos científicos e educacionais de uma empresa fornecedora de dispositivos médicos. Foi analisado o protocolo de prevenção e tratamento de lesões de pele da instituição, avaliado os pacientes com alto risco de lesão por pressão conforme escala de braden e a prescrição de enfermagem. Resultados: Os resultados foram observados ao longo do processo de certificação. Na primeira avaliação foram vistos nas unidades de internação adulto 12 (doze) pacientes, onde foram encontrados 83 (oitenta e três) não conformidades no módulo de prevenção de lesão de pele relacionadas à adesivos médicos. Na segunda avaliação do mesmo pilar, foram avaliados 9 (nove) pacientes e encontradas 15 (quinze) não conformidades. Na terceira avaliação foram avaliados 4 (quatro) pacientes e nenhuma inconformidade foi encontrada. Recebemos um retorno positivo da empresa, conseguindo assim, a certificação de pele, além de melhorar as boas práticas na instituição. Conclusão: Os benefícios obtidos com a aplicação desta ferramenta envolvem a criação de uma nova rotina no âmbito hospitalar, aumentando a qualidade do serviço prestado. O enfermeiro e sua equipe tornam-se protagonistas nestes casos, criando possibilidades de transformação dessa prática. Dessa maneira, torna-se cada vez mais relevante a promoção de um espaço para a reflexão e discussão sobre a prevenção dos danos ocasionados por adesivos médicos
\end{abstract}

Keywords: Adesivos, Estomoterapia, Úlcera Cutânea

\section{Referências Bibliográficas}

REFERÊNCIAS: 1. sive-related skin injuries . J Wound Ostomy Continence Nurs. $2013 ; 40$ ( 4 ): 365-380 . 2. DOMANSKY, R. C.; BORGES, E. L. Manual para Prevenção de Lesões de Pele: recomendações McNichol L, Lund C , Rosen T , Gray M . Medical adhesives and patient safety: state of the science: consensus statements for the assessment, prevention, and treatment of adhebaseadas em evidências. Rio de Janeiro: Editora Rubio, 270 p., 2012. 3. Bavaresco T, Medeiros RH, Lucena A de F. Implantação da Escala de Braden em uma unidade de terapia intensiva de um hospital universitário. Rev. Gaúcha Enferm. 2013; 32 (4): 702-10. 


\title{
Protocolo Assistencial de curativos em ECMO em UTI Cardiopediátrica
}

\author{
CLARIANA ALVES MAJADO DE OLIVEIRA ${ }^{1}$, Erica de Oliveira Paes ${ }^{1,1,1,1}$, Adriana da Silva
} Author(s): $\quad$ Magalhães ${ }^{1}$, Giovana Broccoli ${ }^{1}$, Ana Lúcia Capucho Lorena Abrahão ${ }^{1}$, Maria do Carmo Martins Jatobá $^{1}$

Institution(s) ${ }^{1}$ HCor - Associação Beneficente Síria - Hospital do Coração (Rua Desembargador Eliseu Guilherme, 147)

\begin{abstract}
INTRODUÇÃO: Oxigenação por Membrana Extracorpórea (ECMO) é utilizada como terapia de suporte para estabilidade de pacientes com cardiopatias congênitas e adquiridas, que não responderam ao tratamento clínico convencional. Esta terapia serve como ponte para recuperação do paciente, dispositivos de longa permanência ou transplante. Na UTI Cardiopediátrica temos uma variação de 5 a 12 casos ano de ECMO veno-arterial, 94,3\% com canulação central mantendo esterno aberto, o qual é protegido por um tecido de látex suturado à pele. Distúrbios hemorrágicos são as complicações mais frequentes, pelo contato do sangue ao circuito e uso contínuo de heparina. Alterações cutâneas como pele friável e úmida podem ocorrer em resultado ao uso da terapia. Preparar a ferida operatória para futuro restabelecimento e atuar na prevenção do desenvolvimento de MARSI (medical adhesive related skin injury) é necessário pela implantação de um protocolo específico nesta terapia.Objetivo: Descrever protocolo assistencial em curativos em uma Unidade de terapia intensiva (UTI) Cardiopediátrica, em pacientes em ECMO com canulação central e esterno aberto. Material e Método: O leito da ferida úmido pelo sangramento e troca frequente do curativo, aplicou-se protocolo institucional assistencial de curativos pós-cirurgia cardíaca adaptado a população pediátrica em ECMO, através da reunião do time de ECMO pediátrico e o Grupo de Pele institucional escolhendo apropriadamente a terapia baseada no objetivo, local de aplicação e condição do paciente. O curativo é executado de forma estéril, com antissepsia local. Ao redor da incisão, pescoço, cânulas e drenos, é aplicado uma solução de polímero em haste para formação de película protetora. Peri dispositivos e canulações é fixado uma placa de silicone formando uma moldura, diminuindo área de tensão, aderindo à estrutura da pele ilesa e para fixação do curativo secundário, permitindo que o sangramento passe para a cobertura absorvente. Aplica-se gaze estéril ao redor da placa de látex para absorção do sangramento e visualização esternal em situações de tamponamento cardíaco e abaulamento da placa. Sobre a ferida operatória aplica-se filme transparente permeável aos vapores de água, adaptável ao local evitando a maceração das bordas. A troca em $72 \mathrm{~h}$ e conforme necessidade. Resultados: A preservação da integridade da pele próxima ao local do trauma estabelecido pela ECMO e altas doses de heparina, além da prevenção de MARSI é resultado da associação adequada de curativos e uso de materiais tecnológicos. O cuidado com a pele durante a ECMO minimiza a relação de lesões de pele, na prevenção de contaminação bacteriana local e preparo do leito da ferida para recuperação pós retirada de ECMO. Melhores práticas aplicam estratégias preventivas de cuidado, combinação adequada de curativos, técnicas de remoção de adesivos, avaliação e tratamento das lesões. O gerenciamento do protocolo evidencia a diminuição da carga de trabalho do enfermeiro, redução de quadros infecciosos cutâneos, redução do tempo de internação e custos, mudanças não planejadas no tratamento, além do conforto ao paciente. Conclusão: A união do time de ECMO e Grupo de Pele trouxeram resultados positivos à assistência de enfermagem na adaptação de um protocolo já existente.
\end{abstract}

Keywords: Oxigenação por Membrana Extracorpórea, Critical care nursing, Estomaterapia, Postoperative care, MARSI

\section{Referências Bibliográficas}

1. Cardiologia. Arq Bras Cardiol. 2016; 107(2Supl.2):1-33. 2. Global Guidelines for the Prevention of Surgical Site Infection .All rights reserved. Publications of the World Helath Organization are avaiable on the WHO website nov.2016. ( http//www.who.int ) . 3. Oliveira, A.C. de, Silva, M.V. Terapia e prática na prenvencao de infecção de sitio cirúrgico. Barueri. SP. Manole,2015. 4. McNichol L, Lund C, Rosen T, Gray M. Medical adhesives and patient safety: state of the science: consensus statements for the assessment, prevention, and treatment of adhesive-related skin injuries. Orthop Nurs. 2013 Sep-Oct;32(5):267-81. 5. Ferreira, D.H, Teixeira ,M.L.O , Branco, E.M.S.C. Cuidados de enfermagem para a prevenção de lesão de pele por adesivos em feridas cirúrgicas. Cienc Cuid Saude 2017 Abr-Jun; 16(2). 6. Ousey,K, Wasek,S. Clinician perspectives on medical adhesive-related skin injuries. Wounds UK, 2016 12(4) 42-46. 


\title{
ADAPTAÇÃO E VALIDAÇÃO DO SISTEMA DE CLASSIFICAÇÃO - ISTAP PARA LESÕES POR FRICÇÃO
}

Cinthia Viana Bandeira da Silva ${ }^{1}$, Ticiane Carolina Gonçalves Faustino Campanili ${ }^{2}$, Noélle de Author(s): $\quad$ Oliveira Freitas ${ }^{1}$, Kimberly LeBlanc ${ }^{3}$, Sharon Baranoski ${ }^{3}$, Vera Lúcia Conceição de Gouveia Santos ${ }^{1}$

Institution(s) ${ }^{1}$ EEUSP - ESCOLA DE ENFERMAGEM USP (Av. Dr. Enéas Carvalho de Aguiar, 419Cerqueira César, São Paulo - SP, 05403-00), ${ }^{2}$ INCOR - INSTITUTO DO CORAÇÃO HCFMUSP (Av. Dr. Enéas Carvalho de Aguiar, 44 - Cerqueira César, São Paulo - SP, 05403-90), ${ }^{3}$ ISTAP International Skin Tear Advisory Panel (99 University Ave, Kingston, ON K7L 3N6, Canadá)

\begin{abstract}
Introdução: Lesões por fricção-LF são cada vez mais prevalentes, principalmente entre pacientes idosos. Padronizar a linguagem sobre elas possibilita uma melhor comparação da sua epidemiologia entre diversas culturas, além de permitir uma busca por melhoria na prevenção e tratamento. Objetivo: Adaptar culturalmente o ISTAP Skin Tear Classification para a língua portuguesa no Brasil e avaliar a validade de conteúdo, a confiabilidade interobservadores e a validade de critério concorrente. Material e Método: Estudo metodológico realizado em um Hospital Universitário na cidade de São Paulo, estado de São Paulo, Brasil. O projeto foi aprovado pelo Comitê de Ética em Pesquisa da Escola de Enfermagem da USP (processo no 66513517.7.0000.5392/2017/CEPEEUSP). A adaptação cultural foi realizada de acordo com as etapas sugeridas pela literatura: tradução, avaliação por comitê de juízes (validade de conteúdo) e retrotradução. Na etapa de validação, para a avaliação da confiabilidade interobservadores foi utilizada uma base de dados de fotografias, 36 enfermeiros classificaram $30 \mathrm{LF}$, em três grupos, de acordo com a versão adaptada do ISTAP. Para a avaliação clínica, 23 enfermeiros classificaram 12 LF em oito pacientes. Concomitante a aplicação clínica, uma enfermeira estomaterapeuta classificou as LF encontradas utilizando simultaneamente a versão adaptada do ISTAP e o Sistema de Classificação STAR, para testar a validade de critério concorrente. A análise estatística foi realizada pelo pacote estatístico $R$ para análise das medidas de tendência central (frequência simples, média e mediana), de variabilidade (desvio-padrão, máximo, mínimo) e as análises psicométricas. Os dados da etapa de fotografias foram analisados por meio do Kappa Fleiss e a análise da validade de critério concorrente meio de correlação de Pearson. Resultados: Na etapa de tradução foram obtidas duas versões em português do instrumento tradução que posteriormente foram e analisadas pelo comitê de juízes. Foram identificadas discordâncias em termos específicos da área que obtiveram um baixo valor de índice de validade de conteúdo No entanto, a validade de conteúdo foi confirmada após discussão das discrepâncias entre as autoras e os membros do comitê de juízes. A versão oriunda da etapa do comitê de juízes foi retrotraduzida e enviada para a autora do instrumento original avaliar a qual aprovou a versão. A média de 17.83 acertos ( $\mathrm{DP}=5.03$ ) resultaram de 1080 observações de fotografias, com Kappa Fleiss=0.279 (nível razoável de concordância). A confiabilidade interobservadores por meio de aplicação clínica obteve taxa global de acerto de $76.7 \%$ em 85 observações. A validade de critério concorrente obteve correlação total $(r=1)$ entre o ISTAP e o STAR. Conclusões: Considera-se que a Classificação ISTAP para LF é um instrumento confiável e válido também no Brasil, tornando-se uma opção para uso na prática clínica da estomaterapia.
\end{abstract}

Keywords: Estomaterapia , Estudos de validação, Ferimentos e lesões, Pesquisa metodológica em enfermagem, Prática avançada de enfermagem

\section{Referências Bibliográficas}

1. LeBlanc K, Baranoski S. Skin tears: state of the science: consensus statements for the prevention, prediction, assessment, and treatment of skin tears@. Adv Skin Wound Care. 2011;24(9):2-15. doi:

https://doi.org/10.1097/01.ASW.0000405316.99011.95. 2. Silva CVB; Campanili TCGF; LeBlanc K; Baranoski S; Santos VLCG. Adaptação cultural e validade de conteúdo do ISTAP Skin Tear Classification para o português no Brasil. ESTIMA, Braz. J. Enterostomal Ther., 16: e2618. doi: 10.30886/estima.v16.590_PT 3. LeBlanc K, Baranoski S, Holloway S, Langemo D. Validation of a new classification system for skin tears. Adv Ski Wound Care. 2013;26(6):263-5. 4. Polit DF, Beck CT, editores. Fundamentos de pesquisa em enfermagem. $7^{\underline{a}}$ ed. Porto Alegre: Artes Médicas; 2011. 5. Serra R, lelapi N, Barbetta A, de Franciscis S. Skin tears and risk factors assessment: a systematic review on evidence-based medicine. Int Wound J. 2018;15(1):38-42. 


\title{
CARACTERIZAÇÃO DE PACIENTES COM PERITONEOSTOMIA EM USO DE TERAPIA POR PRESSÃO NEGATIVA INTERNADOS EM UTI
}

\author{
Author(s): Patrícia Regiane da Silva ${ }^{1}$, Mariana Martins Pinto ${ }^{1}$, Alice Naomi Nakaoshi ${ }^{1}$, Lígia Maria Dal \\ Secco ${ }^{1}$ \\ Institution(s) ${ }^{1}$ HCFMUSP - Hospital das Clínicas - Faculdade de Medicina da USP (Av. Dr. Enéas de Carvalho \\ Aguiar, 255)
}

\begin{abstract}
INTRODUÇÃO: a Unidade de Terapia Intensiva (UTI) é uma unidade hospitalar que concentra condutas e cuidados aos pacientes críticos. Neste cenário, encontram-se pacientes pós-cirúrgicos de abdômen que utilizam a técnica de peritoneostomia com indicações para traumas com incapacidade de fechar a cavidade abdominal, hipertensão intraabdominal, síndrome do compartimento abdominal e peritonites difusas, que requerem um plano de cuidados de enfermagem. A peritoneostomia é definida como procedimento cirúrgico realizado por laparotomia no qual mantém a cavidade abdominal aberta e com cobertura provisória por diferentes materiais, sendo uma delas a terapia por pressão negativa. OBJETIVO: Caracterizar os pacientes com peritoneostomias em uso de terapia por pressão negativa. METODO: Trata-se de um estudo exploratório, retrospectivo, descritivo, com abordagem quantitativa, realizado no Instituto Central do Hospital das Clínicas da Faculdade de Medicina da Universidade de São Paulo (HCFMUSP), na UTI de Emergência Cirúrgica, sob a liberação do CAAE: 76722817.5.0000.0068. Foram analisados os prontuários dos pacientes adultos maiores de 18 anos admitidos na unidade que realizaram como tratamento cirúrgico a técnica de peritoneostomia sob o uso de terapia por pressão negativa, no período de 01/01/2015 à 31/12/2016. RESULTADOS: O estudo demonstrou que 15 pacientes com peritoneostomia em uso de terapia por pressão negativa foram maioria homens na faixa etária de 20 a 40 anos. A terapia mais utilizada foi a de técnica de Barker, seguida da técnica de VAC. Ambos os pacientes tanto os com diagnósticos primários relacionados a trauma como os de emergências clínicas com tratamento cirúrgico se beneficiaram da técnica. CONCLUSÃO: Diante da escassez de artigos e dados da pesquisa necessita-se de maiores estudos relacionados aos cuidados do paciente com peritoneostomia em uso de terapia de pressão negativa para promover um melhor qualidade na Sistematização da Assistência de Enfermagem (SAE).
\end{abstract}

Keywords: Peritoneostomia, Terapia a vácuo, Estomaterapia, Assistência de Enfermagem, Terapia por pressão negativa

\section{Referências Bibliográficas}

1. Barros, E. A., Carvalho, S., Nascimento, V. P., Cruvinel Neto, J. O. S. É., \& FONSECA, A. Z. (2016). Comparative study of abdominal cavity temporary closure techniques for damage control. Revista do Colégio Brasileiro de Cirurgiões, 43(5), 368-373. 2. Junior, A. C. R., Novo, F. D. C. F., Arouca, R. D. C. S., Silva, F. D. S. C., Montero, E. F. D. S., \& Utiyama, E. M. (2014). Abdômen aberto: experiência em uma única instituição. Rev. Col. Bras. Cir, 42(2), 93-6. 3. Batacchi S, Matano S, Nella A, et al. Vacuum-assisted closure device enhances recovery of critically ill patientes following emergency surgical procedures. Critical Care. [Internet] 2009 13(6). 4. de Abreu, R. L. D., da Costa Gomes, S. K., Silva, A. A., Brum, C. F., \& de Azevedo, M. B. (2016). Assistência De Enfermagem No Tratamento De Feridas Por Terapia De Pressão Subatmosférica (Vac) Na Uti. Revista Rede de Cuidados em Saúde,10(2). 5. Lewis SL, Dirksen SR, Heitkemper MM, et al. Tratado de enfermagem médico- cirúrgica: avaliação e assistência dos problemas clínicos. 8ª ed. Rio de Janeiro: Elsevier; 2013. $1802 p$. 


\title{
NOTIFICAÇÕES DE LESÕES DE PELE EM UM HOSPITAL PÚBLICO EM FORTALEZA- CEARÁ
}

\author{
RAELLY RAMOS CAMPOS XIMENES ${ }^{1}$, Solange Gurgel Alexandre ${ }^{1}$, Francisca Alexandra \\ Author(s): Araújo da Silva ${ }^{1}$, Rhanna Emanuela Fontenele Lima de Carvalho ${ }^{2}$, Andreina Fontenele Teixeira ${ }^{1}$, \\ Mona Lisa Menezes Bruno ${ }^{1}$ \\ Institution(s) ${ }^{1}$ HUWC - HOSPITAL UNIVERSITÁRIO WALTER CANTÍDIO (RUA CAPITÃO FRANCISCO \\ PEDRO, 1290), ${ }^{2}$ UECE - UNIVERSIDADE ESTADUAL DO CEARÁ (Av. Dr. Silas Munguba, \\ 1700)
}

\begin{abstract}
Introdução: a notificação de incidentes permite a abordagem da situação e a identificação de erros no processo de cuidado, e que por meio destas podem ser realizadas ações com vistas a mudança de atitudes para a redução de danos ${ }^{1}$. É fundamental que seja criada uma cultura de notificação, por meio da qual os profissionais se conscientizem da importância da notificação e desmitifiquem que o ato de notificar gera punição². Destaca- se, portanto, a necessidade de envolvimento dos profissionais de saúde no estabelecimento da cultura de segurança do paciente nas instituições de saúde, em especial no que concerne à notificação de lesão de pele. Dessa forma, este fato requer das instituições hospitalares estrutura física e ambiental, número de profissionais de saúde adequado e recursos materiais auxiliares para garantir uma assistência de qualidade3. Objetivo: caracterizar os casos notificados de pacientes com lesões de pele em um hospital público de Fortaleza- Ceará. Material e método: trata-se de estudo epidemiológico-descritivo, transversal, retrospectivo, com abordagem quantitativa. O cenário do estudo foi um hospital público, localizado na cidade de Fortaleza- Ceará. Sendo realizado a pesquisa no setor de gerência de risco, onde faz monitoramento de notificações mediante o aplicativo Vigilância em Saúde e Gestão de Riscos Assistenciais Hospitalares. A população foi constituída de pessoas hospitalizadas, que tiveram motivo de notificação lesão de pele, no período de 01 de janeiro de 2018 à 31 de dezembro de 2018, totalizando 225 notificações. Foram excluídos todos os casos que tiveram notificação com registro duplo, constituindo oito. Sendo, portanto, tabuladas 217 notificações. Os achados foram digitados em um banco de dados realizado no Excell®. Os aspectos éticos foram respeitados em todas as etapas do estudo, com número do parecer 2.699.599. Resultados: segundo estas notificações, $130(60 \%)$ foi por lesão por pressão (LP) que ocorreram durante internação no referido hospital; 28 $(12,9 \%)$ notificações foram LP que não ocorreu durante internação hospitalar, sendo registrada que $5(2,3 \%)$ foi proveniente do domicílio, $13(6 \%)$ pessoas veio admitido com LP de outro hospital e $10(4,6 \%)$ registros não foi informado o local que o paciente adquiriu a LP; $13(6 \%)$ foi lesão ocasionada por dispositivo médico; e 46 (21,1\%) envolveram notificações de outros tipos de lesões de pele: úlcera arterial, úlcera venosa, úlcera de pé diabético, dermatite associada à incontinência, dentre outras. Conclusões: a notificação de lesão de pele por profissionais de saúde, favorece a elaboração de um banco de dados com as principais lesões de pele em uma instituição hospitalar. Salienta-se, portanto, a necessidade do estímulo à cultura de segurança do paciente no tocante a notificação, pois permitirá que os gestores junto aos profissionais de saúde, possam fundamentar ações para o (re)planejamento do cuidado, visando o atendimento seguro ao paciente, bem como traçar estratégias de prevenção a LP, assim como cuidados adequados a outros tipos de lesões de pele. Para tal, faz-se necessária a realização de campanhas educativas e treinamentos contínuos para estímulo às notificações.
\end{abstract}

Keywords: Lesão por pressão, Segurança do Paciente, Notificação, Estomaterapia

\section{Referências Bibliográficas}

1. BRASIL. Ministério da Educação. Diretriz EBSERH para Ações em Segurança do Paciente e Vigilância em Saúde: Manual Básico. Série "Diretrizes Ebserh sobre Segurança do Paciente". v.2. $1^{\circ}$ ed. Brasília-DF; 2016. 2. Barcellos RA, Toscan M, Báo ACP, Amestoy SC. Efetividade do gerenciamento de riscos clínicos na terapia intensiva. Cogitare Enferm. 2016; 21, esp: 01-09. 3. Tonole R, Brandão ES. Recursos humanos e materiais para a prevenção de lesão por pressão. Rev enferm UFPE on line. 2018; 12(8):2170-80. 


\title{
EXPERIÊNCIA NO USO DE TERAPIA POR PRESSÃO NEGATIVA EM DESCÊNCIA DE ESTERNORRAFIA
}

Juliana Oliveira Sousa ${ }^{3}$, Elaine Carininy Lopes da Costa ${ }^{2}$, Cliciane Furtado Rodrigues ${ }^{3}$, Thalita de Author(s): $\quad$ Moraes Lima ${ }^{3}$, Luciane Resende da Silva Leonel ${ }^{3}$, Lailda de Assis Santos ${ }^{3}$, Yara Maria Rêgo Leite $^{3}$, Naiana Lustosa de Araújo Sousa ${ }^{3}$

Institution(s) ${ }^{2}$ IFPI - Instituto Federal de Educação do Piauí (Rua projetada S/N Bairro Uberaba II Oeiras PI), ${ }^{3}$ FACIME - FACULDADE DE CIÊNCIAS MÉDICAS (RUA OLAVAO BILAC 2335 CENTRO TERESINA PI)

\begin{abstract}
INTRODUÇÃO: O desenvolvimento de uma ferida de difícil tratamento aumenta o tempo de hospitalização, eleva os custos e acarreta maiores taxas de morbi-mortalidade. O método de utilizar a pressão negativa sobre o leito da ferida através de esponja de poliuretano, popularizado como terapia a vácuo, foi introduzido por Argenta há cerca de 15 anos, atribuindo seu sucesso ao controle do edema, redução do número de colônias de bactérias e aumento do fluxo sangüíneo local,com conseqüente melhoria do tecido de granulação. Com o uso do vácuo, observa-se a formação mais precoce do tecido de granulação, o que possibilitou enxertia também mais precoce e fechamento mais rápido dessas feridas quando comparados com os longos tempos antes observados. Os resultados obtidos até o momento revelam que a terapia a vácuo é de grande auxilio também nas feridas agudas traumáticas, no tratamento de lesão cirúrgica infectada no esterno e no abdômen complicado e na integração de enxertos de pele. OBJETIVO: Relatar a experiência da eficácia do uso de Terapia por Pressão Negativa em deiscência de esternorrafia. METODOS: O Hospital Universitário do Piauí conta com cirurgias cardíacas desde março de 2015,desde então temos acompanhado diversos métodos de cicatrização de esternorrafia. Este trabalho trata-se de um relato de experiência vivenciados por integrantes do Grupo de Estudos da Pele (GEPe) do HUUFPI, observando-se em específico um caso onde a paciente é portadora de diabetes mellitus, testemunha de jeová (não permite ser hemotransfundida), que evoluiu com infecção tendo passado por três desbridamentos cirúrgicos introduziu-se a terapia a vácuo, na segunda aplicação observou-se considerável granulação no leito da ferida. RESULTADOS: Foram realizadas duas trocas de curativo com Terapia por Pressão Negativa ,sendo as trocas realizadas no Centro Cirúrgico. As trocas foram feitas por uma enfermeira e um cirurgião cardíaco. CONCLUSÃO. A utilização da Terapia por Pressão Negativa em deiscência de esternorrafia, com apenas duas trocas ,permitiu uma satisfatória granulação no leito da ferida, aproximação de bordas, redução da colonização bacteriana e preparação da lesão para possível enxerto ou síntese através de fio cirugico.
\end{abstract}

Keywords: Estomaterapia, feridas, terapia por pressão negativa

\section{Referências Bibliográficas}

GEOVANINI, T. Tratado de feridas e curativos: Enfoque multiprofissional. São Paulo. Editora Rideel. 2014 MALAGUTTI, W; KAKIHARA, C. T. Curativos, estomias e dermatologia: uma Abordagem Multiprofissional. 3 ed. São Paulo. Editora Martinari. 2014. OLIVEIRA, R.A.; A pele nos diferentes ciclos da vida: IN: DOMANSKY, E.C.; BORGES, E. L. Manual de prevenção de lesões de pele: recomendações baseadas em evidências. Rio de Janeiro. Editora Rubio. 2012 


\title{
DESAFIOS PARA IMPLANTAÇÃO DO PROGRAMA DE FERIDAS NO INTERIOR DE PERNAMBUCO
}

\author{
Author(s): Ana Paula dos Santos Albuquerque ${ }^{1}$ \\ Institution(s) ${ }^{1}$ SMS - Secretaria de Saúde do Município de Caruaru (Caruaru - PE)
}

\begin{abstract}
Introdução: As lesões de pele constituem um grave problema de saúde pública e gera um grande impacto na qualidade de vida dos pacientes, no tempo destinado para a assistência de enfermagem e no custo dos recursos materiais utilizados para a prevenção e tratamento dessas lesões. O tratamento do paciente com ferida deve ser dinâmico e precisa acompanhar a evolução científica e tecnológica visando à avaliação do paciente, indicação do tratamento, organização e sistematização da assistência. Dessa forma, faz-se necessário para o profissional de enfermagem que trabalha com prevenção e tratamento de feridas o conhecimento da fisiologia da pele, da cicatrização, dos fatores de risco, assim como o conhecimento dos produtos disponíveis no mercado e sua correta indicação. No município de Caruaru, interior de PE, existia duas unidades básicas de saúde que oferecia atendimento a pacientes portadores de lesões, porém sem nenhum tipo de sistematização, não existia enfermeiro responsável, sendo a assistência, prescrição e acompanhamento das lesões, feito apenas por técnicos de enfermagem. Objetivo:Avaliar o impacto da implantação do programa de feridas no município de Caruaru - PE, utilizando recursos do SUS. Material e Método: Trata-se de uma pesquisa descritiva documental, realizada no município de Caruaru, localizado no interior do Estado de PE, com implantação em 2014 e avaliação da implantação após 5 anos, 2019. Resultados: A idéia da implantação do programa de feridas nasceu de uma inquietação sobre a qualidade da assistência prestada aos pacientes portadores de lesões no ano de 2014. O primeiro passo foi o reconhecimento da situação atual, com diagnóstico das dificuldades e potencialidades. Foram elencados como dificuldades: ausência do profissional enfermeiro e equipe multidisciplinar, pouca diversificação de coberturas especiais, prescrição das coberturas existentes por técnicos de enfermagem, assistência não holística, com foco apenas na lesão. Como potencialidades: necessidade de mudança do padrão atual. Conclusões: O programa foi implantado em $2014 \mathrm{com}$ a inclusão de um enfermeiro responsável pelo cadastro e atendimento ao paciente de forma holística. Foram desenvolvidos procedimentos operacionais padrão e fluxograma de atendimento, formulário de cadastro e acompanhamento das lesões, estabelecimento de cronograma de treinamento para a equipe de enfermagem das UBS, padronização das coberturas mais indicadas para o perfil das lesões. Agora, no ano de 2019, o maior desafio é a integração entre o serviço ambulatorial e as UBS, bem como estabelecimento do fluxograma entre a gerência farmacêutica e toda a rede de cuidados. Pode-se destacar como ganho institucional a elaboração do protocolo que orienta condutas padronizadas, com o uso racional e adequado das coberturas especias disponíveis, evitando gastos desnecessários e riscos aos pacientes. Além disso, o foco nos treinamentos está na prevenção de lesões evitáveis e a utilização adequada das coberturas.
\end{abstract}

Keywords: Estomaterapia, Saúde Pública, Atenção Primária a Saúde, Enfermagem, Ferimentos e lesões

\section{Referências Bibliográficas}

1. Caveião C, Hey AP, Sales WB, Tavares ELP, de Souza E, da Silva MMBG. Conhecimento do enfermeiro da atenção primária à saúde sobre a indicação de coberturas especiais. ESTIMA, Braz. J. Enterostomal Ther. 2018; 16:e3118. 2. Krause TCC, Assis GM, Danski MTR. Implantação de uma Comissão de Cuidados com a Pele em um Hospital de Ensino. ESTIMA, Braz. J. Enterostomal Therm., 2016; 14(1): 13-20. 3. Ministério da Saúde. Secretaria de Atenção à Saúde. Departamento de Atenção Básica (BR). Normas e Manuais Técnicos. Cadernos de Atenção Primária, n. 29. Brasília: MS; 2010 [citado $11 \mathrm{dez}$ 2017]. Disponível em: http:// bvsms.saude.gov.br/bvs/publicacoes/caderno_atencao_ primaria_29_rastreamento.pdf. 4. Teixeira AKS, Menezes LCG, Oliveira RM. Serviço de estomaterapia na perspectiva dos gerentes de enfermagem em hospital público de referência. ESTIMA, Braz J Enterostomal Ther. 2016;14(1):3-12. 5. World Health Organization. World Alliance for Patient Safety, Taxonomy. The conceptual framework for the international classification for patient safety. Version 1.1. Final Technical Report. WHO: Geneva; 2009. 


\title{
Perfil epidemiológico das lesões de pele ocorridas em pessoas com lesão medular em um Hospital de Reabilitação.
}

\author{
Author(s): $\quad$ JANAINA BARBOSA SILVA ${ }^{1}$, Lisabel Tabari ${ }^{1}$ \\ Institution(s) ${ }^{1}$ SARAH - Associação das pioneiras sociais (SMHS 501 BLOCO A BRASÍLIA - DF CEP: 70335- \\ 901)
}

\begin{abstract}
Introdução. A Lesão medular (LM) ocasiona alterações motoras, sensoriais e autonômicas que tornam as pessoas acometidas, susceptíveis ao desenvolvimento de complicações cutâneas, como lesão por pressão, dermatites e infecções fungicas 1,2. Estas complicações são decorrentes das alterações neurológicas, que podem provocar a diminuição do fluxo sanguíneo e alterações nas respostas inflamatórias da pele 2. As (LP) estão entre os principais eventos adversos relacionados à assistência em saúde.

Metodologia. Estudo retrospectivo e quantitativo das lesões de pele ocorridas em pessoas admitidas no programa de Neurorreabilitação em Lesão Medular de um Hospital de Reabilitação, no período de janeiro de 2016 a dezembro de 2018. Os dados foram obtidos junto ao Controle de Qualidade da Unidade Sarah Centro e correspondem às lesões de pele notificadas ao Núcleo de Segurança do Paciente (NSP) Unidade Brasília.

Resultados. Durante o triênio de 2016 a 2018 foram notificadas 118 lesões de pele, com aumento das notificações no ano de 2018. A maioria da amostra (88\%) era do gênero masculino, e a principal etiologia das lesões de pele notificadas ao NSP envolviam um grupo composto por lesões por adesivos, queimaduras, peri incisionais, e outras lesões não especificadas. As Lesões Traumáticas seguidas pelas Lesões por Adesivo foram as mais frequentes e a maioria apresentou a ruptura da pele (87\%). As lesões por adesivo ocorridas no ano de 2018 ocorreram principalmente no contexto de fixação de curativo (80\%) e o comprometimento tissular predominante foi o flictena (47\%). As Lesões por Pressão (LP) corresponderam ao segundo grupo de complicações cutâneas ocorridas no triênio, com predomínio da LP relacionada à dispositivos médicos (51\%) e da LP em membrana mucosa (48\%). O uso de cateter vesical de demora e o gesso foram os principais fatores predisponentes à lesão por pressão por dispositivo médico, sendo o Estágio 2 o comprometimento tissular mais frequente em todo o período. O uso do dispositivo urinário masculino foi o fator predisponente à lesão por membrana mucosa (48\%). Apesar do grupo classificado como Outras Lesões ter sido o principal grupo notificado no período, o mesmo era composto de diversas etiologias. Deste modo, podemos inferir que Lesão por Pressão representa o principal grupo de complicação cutâneas notificado no período, o que vêm de encontro aos dados disponíveis na literatura. Em relação às lesões de pele por umidade observa-se que no triênio houve o predomínio da Dermatite Intertriginosa (69\%). Conclusão A notificação de eventos adversos é uma importante ferramenta para melhoria da qualidade da assistência a saúde, porém, devemos considerar que podem existir possíveis subnotificações dos dados e divergências diagnósticas durante a classificação das lesões. As complicações cutâneas representa um desafio para equipe de enfermagem, que precisa desenvolver estratégias preventivas. A identificação do perfil das lesões ocorridas no Programa de Lesão Medular permite o desenvolvimento de diferentes estratégias e a implementação de medidas preventivas para evitar ou diminuir os danos na pele.
\end{abstract}

Keywords: Estomaterapia, Dermatite, Úlcera, Epidemiologia

\section{Referências Bibliográficas}

1. BRASIL, Ministério da Saúde. Secretaria de Atenção À Saúde. Departamento de Ações Programáticas Estratégicas. Diretrizes de Atenção à Pessoa com Lesão Medular. Brasília: Ministério da Saúde, 2013. Disponível em; http://bvsms.saude.gov.br/bvs/publicacoes/diretrizes_atencao_pessoa_lesao_medular.pdf. Acesso em 15/10/2018. 2 Implications for Peripheral Wound Healing JOURNAL OF NEUROTRAUMA 34:1149-1155 (Mairch 15, 2017); 2 . Paiva M.C.M. S., et al. Motivos da equipe de enfermagem para a notificação de eventos adversos. Rev. Latino-Am. Enfermagem Artigo Original set.-out. 2014;22(5):747-54 DOI: 10.1590/0104-1169.3556.2476 www.eerp.usp.br/rlae 3 - Vakharia P., James D.W. Intertrigo. Drugs\&Diseases, jun. 2018. Disponível em https://emedicine.medscape.com/article/108769. Acesso em 11/08/2018. 


\title{
Úlcera Terminal de Kennedy: Conhecimento da enfermagem em relação à lesão de pele em fase final de vida
}

\author{
Author(s): $\quad$ Daniele Tavares da Silva ${ }^{1}$, Aline Chaves Neri ${ }^{1}$ \\ Institution(s) ${ }^{1}$ HSP - Hospital Santa Paula (Av. Santo Amaro, 2468)
}

\begin{abstract}
A terminalidade de vida é quando ocorrem falhas de muitos órgãos, e dentro deste contexto precisamos nos atentar para o maior órgão do corpo humano: a pele. A disfunção da pele no final da vida pode acontecer no tecido, na célula ou em nível molecular e está relacionada à diminuição da perfusão cutânea, levando a um estado de hipóxia localizada e com isso ocorre a redução da capacidade para utilizar os nutrientes vitais e outros fatores necessários para manter a função normal da pele. (SANTOS, VERA, 2009) Entretanto, se algumas feridas são do conhecimento do enfermeiro, como as Lesões por Pressão (LP), outras são desconhecidas, tais como as Úlceras Terminais de Kennedy (UTK), cuja etiologia tem vindo a ser associada a doente em fim de vida. (KENNEDY, KL, 1989) Esse tipo de lesão foi descrita pela primeira vez na literatura pela enfermeira Karen Kennedy, no ano de 1989, nos Estados Unidos, no hospital Byron Health Center, em uma unidade de cuidados intermediários. (ATOS et al, 2015) As UTK são consideradas LP que apresentam margens irregulares, e com formatos como borboleta, pera ou ferradura. Tem um início súbito, normalmente a piora é drástica, e ocorre em 48hs. Sua coloração pode ser vermelha, amarela, púrpura ou preta. E após o surgimento a sobrevida do paciente portador da UTK foi de até seis semanas de vida. (SCHANK, 2009) O conceito "abordagem paliativa nas feridas" é relativamente novo no meio científico, porém é importante que a família seja esclarecida sobre a UTK essencialmente pelo fato desta úlcera ocorrer subitamente e estar relacionada à terminalidade de vida e não por negligencia de cuidados da equipe de enfermagem. (ARIZONA, 2014 e KENNEDY, KL, 1989) O objetivo do estudo foi identificar o que a literatura aborda sobre a UTK sobre o conhecimento dos profissionais de enfermagem em relação à lesão de pele em fase final de vida. Realizado uma revisão não sistemática da literatura, com foco no levantamento de pesquisa sobre o conhecimento da enfermagem em relação à UTK. A pesquisa bibliográfica manifesta pouca evidência com estudos baseados na prática clínica onde descreve que os profissionais da saúde não conseguem diferenciar as Úlceras Terminais de Kennedy das restantes Lesões Por Pressão. Conclui - se que as modificações da pele em fase final de vida vão para além do desenvolvimento de UTK, sendo muitas vezes inevitáveis e exigindo a adequação dos cuidados de enfermagem. Devido à escassez de estudos sobre a UTK podese pensar que muitos enfermeiros têm pouco ou nenhum conhecimento sobre este tipo de úlcera, o que gera um déficit de saber no cuidado, comprometendo a assistência. Com isso mostra-se a importância de realizar novas pesquisas sobre o tema.
\end{abstract}

Keywords: ulcera terminal de kennedy, lesão por pressão, paliativos, enfermagem

\section{Referências Bibliográficas}

Kennedy terminal ulcer. Arizona; 2014. [atualizado 2014;citado2016 ago,16]. Disponível em :

http://www.kennedyterminalulcer.com/. Fernanda Lucia da Silva, FLS; Maria Teresa Silva Souza, MTSS; Paulo Ricardo da Fonseca, PRF; Alana Tamar Oliveira de Sousa, ATOS. Úlcera terminal de kennedy conhecimentos e implicações para a enfermagem. CONBRACIS 2 edição. Kennedy KI. The prevalence of pressure ulcers in na intermediate care facility.

Decubitus. 1989;2(2):44-5 Santos, Vera. SCALE - Modificações da Pele no final de vida. Revista Estima. 2009 ; 7 (3); p. 42 -

44 Schank JE. Kennedy terminal ulcer: the "ah-ha!" moment and diagnosis. Ostomy Wound Manage. 2009 Sep 15;55(9):404. 


\title{
APLICATIVO MÓVEL PARA SUBSÍDIO À TOMADA DE DECISÃO NO CUIDADO DA ÚLCERA DO PÉ DIABÉTICO
}

\author{
Author(s): $\quad$ Rafael Colodettil ${ }^{1}$, Sheilla Diniz Silveira Bicudo ${ }^{1}$, Thiago Nascimento do Prado ${ }^{1}$, Paula Cristina \\ de Andrade Pires Olympio ${ }^{1}$, Maria Edla de Oliveira Bringuente ${ }^{1}$, Roseane Vargas Rohr ${ }^{1}$ \\ Institution(s) ${ }^{1}$ UFES - UNIVERSIDADE FEDERAL DO ESPÍRITO SANTO (Av. Marechal Campos, 1468, \\ Maruípe, Vitória, Dep. Enf., CEP 29.043-900)
}

\begin{abstract}
Introdução: Mundialmente, estima-se que um membro inferior é perdido a cada 20 segundos, por causa das úlceras do pé diabético, não só afetando seriamente a qualidade de vida do paciente, mas também, aumentando o risco de amputação contralateral. Logo, o processo de decisão envolvido no manuseio tópico dessas lesões deve visar à obtenção da cicatrização primária, ou seja, o melhor desfecho possível para o paciente, em termos de função e bem-estar. Uma intervenção de enfermagem bem conduzida e no momento adequado, propicia uma janela de oportunidade, crucial para alterar a cadeia de eventos da ferida e a evolução para amputação. Objetivos: Desenvolver e validar um aplicativo para dispositivos móveis que auxilie enfermeiros no processo de tomada de decisão do tratamento tópico na úlcera do pé diabético. Material e Método: Trata-se de um estudo metodológico aprovado pelo Comitê de Ética em Pesquisa do Centro de Ciências da Saúde - CCS da Universidade Federal do Espírito Santo, sob CAAE no 66019217.5.0000.5060. A pesquisa foi realizada em quatro passos: 1) Definição de requisitos e elaboração do mapa conceitual do aplicativo; 2) Geração das alternativas de implementação e prototipagem; 3) Testes; 4) Implementação. Para desenvolvimento do aplicativo utilizou-se software Nativescript para plataforma Android. Testes de usabilidade com 18 participantes, considerando as heurísticas de Nielsen e adaptações das heurísticas de usabilidade para dispositivos móveis. Resultados: o aplicativo oferece informações atuais sobre a lesão do pé diabético, como conceito, avaliação da úlcera, princípios do tratamento, recomendações clínicas para melhor cicatrização e os curativos para o tratamento tópico. Conclusões: Os métodos estabelecidos para o desenvolvimento e validação, revelaram-se adequados para atingir os objetivos propostos. Com a oferta dessa ferramenta tecnológica espera-se contribuir para o melhor cuidado da ferida do pé diabético, contribuindo para uma prática de enfermagem baseada em evidência, além de divulgar a Estomaterapia nacional como precursora de boas práticas para a segurança do paciente.
\end{abstract}

Keywords: Aplicativos móveis, Estomaterapia, Informática em Enfermagem, Pé diabético, Tecnologia da Informação

\section{Referências Bibliográficas}

1. Bakker K, Apelqvist J, Lipsky BA, Van Netten JJ, Schaper NC. Internacional Working Group on the Diabetic Foot. International consensus on the diabetic foot and practical guidelines on the management and the prevention of the diabetic foot [Internet]. IWGDF Editorial Board; 2015. [Acesso 11 jun 2017]. Disponível em: http://iwgdf.org/guidelines/developmentof-the-iwgdf-guidance-documents-2015. 2. Dumville JC, Lipsky BA, Hoey C, Cruciani M, Fiscon M, Xia J. Topical antimicrobial agents for treating foot ulcers in people with diabetes. Cochrane Database of Systematic Reviews. 2017; 6. doi: 10.1002/14651858.CD011038.pub2. 3. Game FL, Apelqvist J, Attinger C, Hartemann A, Hinchliffe RJ, Londahl M et al. Effectiveness of interventions to enhance healing of chronic ulcers of the foot in diabetes: a systematic review. Diabetes Metab Res Rev. 2016; 32 Sup:1. doi: 10.1002/dmrr.2707. 4. International Diabetes Federation. IDF Diabetes Atlas [Internet]. 8th ed. Bruxelas (Bélgica); 2017. [Acesso $10 \mathrm{mar}$ 2017]. Disponível em: http://diabetesatlas.org/resources/2017-atlas.html. 5. Oliveira RM, Duarte AF, Alves D, Furegato, AR. Desenvolvimento do aplicativo TabacoQuest para informatização de coleta de dados sobre tabagismo na enfermagem psiquiátrica. Rev Latino-Am Enfermagem [Internet]. 2016; 24(e2726). doi: $10.1590 / 1518-8345.0661 .2726$. 


\title{
TRATAMENTO DE BIOFILME EM LESÃO CRÔNICA COM AQUACEL AG+
}

\author{
Author(s): Priscilla Alcântara dos Santos ${ }^{1}$, Mônica Rabelo Santos ${ }^{1}$ \\ Institution(s) ${ }^{1}$ HUSE - Hospital de Urgência de Sergipe (Av:Tancredo Neves. Bairro Capucho, Aracaju-se)
}

\begin{abstract}
Introdução- A pele tem como função primaria a proteção do meio externo. Quando ocorre uma ferida, inicia um reparo tecidual, um processo complexo e que envolve várias fases (proliferação celular, migração e remodelamento), com o objetivo de criar uma nova proteção e retomar a função primaria. A falha no processo de cicatrização de uma ferida pode prolongar o tempo de reparo e conduzir a complicações, tais como infecção, dor crônica, amputações, maiores taxas de mortalidade e aumenta o tempo de internação.O biofilme é o crescimento microbiano de microcolônias organizadas e especies bacterianas que se aderem em comunidades.As feridas crônicas são um desafio frequente em ambientes hospitalares, pois encontramos pacientes manipulados por vários tipos de antibióticos potentes e com pouca resposta terapêutica.O biofilme é difícil de ser removido completamente, mesmo com desbridamentos pois ele se modifica rapidamente. A reposta inflamatória é completamente prejudicada, assim como a formação de tecido de granulação e epitelização. O Aquacel Ag+ Extra contém prata, ácido etilenodiamino tetra-acético( EDTA)e cloreto de benzetônico(BEC). A associação do quelante ( EDTA), surfactante(BEC) e a prata iônica . A fibra de celulose $100 \%$ contribui para absorção de maior quantidade de exsudato criando um gel coeso que facilita a remoção das bactérias do biofilme. Objetivo-Tratar as feridas crônica com biofilme com o uso de aquacel Ag+ extra no hospital público do estado de Sergipe. Material ou MétodoFoi utilizado coleta de dados em planilha da comissão de pele realizado de janeiro a julho de 2019.Resultado- Os dados mostraram que as feridas crônicas tratadas com o Aquacel Ag+ extra evoluíram com resultados de cicatrização em $90 \%$ dos casos. Com outras coberturas de prata esse resultado caiu para 50\%.Conclusão- Com base nos resultados da coleta de dados, a instituição colocou no protocolo a utilização do Aquacel Ag+ extra como conduta padrão nas feridas crônicas. Com essa medida adotada houve redução de insumos hospitalares e tempo de permanência do paciente.
\end{abstract}

Keywords: BIOFILME, LESÃO CRÔNICA, AQUACEL AG+

\section{Referências Bibliográficas}

1-PARSONS.D,BOWLER.PG,MYLER.V.Pensos antimicrobianos de prata no tratamento de feridas:uma comparação de características antimicrobiana,física e química, 2005 2-MALAGUTTI,W. Feridas; conceitos e atualidades.Editora Martinari,São paulo,2014. 3-GEOVANINI,T. Tratado de Feridas e curativos: Enfoque Multiprofissional. Editora Rideel, São paulo,2014. 4-BORGES,E.L.DOMANSKY,R.T. Manual para Prevenção de Lesões de Pele. Editora Rubio,Rio de Janeiro,2012. 


\title{
Prevalência de lesão de pele relacionada a insumos adesivos em pacientes críticos
}

\author{
Author(s): Evellyn Lima da Silva Oliveira ${ }^{1}$, Rayanne Suélly da Costa Silva Santos ${ }^{1}$, Vera Lúcia Conceição de \\ Gouveia Santos ${ }^{1}$, Caroline Maria Pereira Alcântara ${ }^{1}$, Paula Cristina Nogueira ${ }^{1}$ \\ Institution(s) ${ }^{1}$ EEUSP - Escola de Enfermagem da Universidade de São Paulo (Av Dr. Enéas Carvalho de \\ Aguiar, 419 - Cerqueira César)
}

\begin{abstract}
Introdução: A lesão de pele relacionada a insumos adesivos (LPRIA) é definida como um eritema, incluindo, mas não se limitando a vesículas, bolhas, erosão ou ruptura da pele que persiste 30 minutos ou mais após a remoção do adesivo1. São divididas em cinco tipos: dermatites irritativa, alérgica, foliculite, maceração e trauma mecânico, e este subdivide-se em lesão por fricção, remoção da epiderme e lesão por tensão1,2. Apesar de todos os pacientes em uso de adesivos estarem suscetíveis à ocorrência de lesões, há fatores que predispõem ao risco para o seu desenvolvimento, como: extremos de idade, umidade, desnutrição, desidratação, condições clínicas e dermatológicas e uso prévio de produtos adesivos. Além disso, é preciso levar em consideração que as propriedades dos produtos também influenciam o risco3. Objetivo: Identificar e analisar a prevalência pontual de LPRIA em pacientes internados em unidade de terapia intensiva (UTI). Método: Trata-se de um estudo transversal realizado em nove hospitais localizados em São Paulo, Brasil. A população do estudo foi composta por todos os pacientes internados nas UTIs na data de coleta de dados com idade maior ou igual a 18 anos. Os dados foram coletados por inspeção da pele dos pacientes e consulta em prontuários. Ao ser identificada qualquer LPRIA, esta foi examinada quanto à classificação1, agentes causadores e localização anatômica. O estudo foi avaliado e aprovado pelo comitê de ética de todos os hospitais participantes. Os dados foram inseridos na plataforma RedCap, que foi construída baseada no instrumento da coleta de dados e após, transferidos para uma planilha do programa Microsoft Excel e analisados por meio do Programa Statistical Package for the Social Science - SPSS. Os dados foram analisados por meio de estatística descritiva, teste exato de Fisher, teste Qui-quadrado de Pearson, teste T e teste de Wilcoxon-MannWhitney. Resultados: A maioria dos pacientes eram do sexo masculino $(52,8 \%)$, com idade média de 62,7 anos (DP = 17,2). As LPRIA estavam presentes em 61 pacientes, perfazendo uma prevalência de $16,2 \%$, sendo que seis pacientes tiveram mais de um tipo de lesão, totalizando 67 casos. O tipo mais predominante foi a remoção da epiderme $(46,3 \%)$. 0 principal agente causador foi o filme de poliuretano transparente $(44,7 \%)$ e a região mais acometida foi o tórax $(23,9 \%)$. Todas as UTIs apresentavam protocolos para prevenção de lesão de pele no geral, mas nenhuma específica para LPRIA. Conclusão: O estudo contribuiu para os conhecimentos relacionados à epidemiologia de tais lesões, favorecendo o planejamento de cuidados preventivos, mas reforça a necessidade de novos estudos.
\end{abstract}

Keywords: adesivos teciduais, estomaterapia, Ferimentos e lesões, prevalência, unidades de terapia intensiva

\section{Referências Bibliográficas}

1. McNichol L, Lund C, Rosen T, Gray M. Medical Adhesives and Patient Safety: state of the Science. Wound, Ostomy Cont Nurses Soc.2013;32(5). 2. Mcnichol L, Bianchi J. Medical adhesive-related skin injuries (MARSI) - made easy. Wounds UK. 2016;12(4):1-4. 3. Hitchcock J, Savine L. Medical adhesive-related skin injuries associated with vascular access. Br J Nurs. 2017;26(8):4-12. 


\title{
COBERTURAS ESPECIAIS NO TRATAMENTO DE LESÕES DE PACIENTES COM LEISHMANIOSE TEGUMENTAR AMERICANA
}

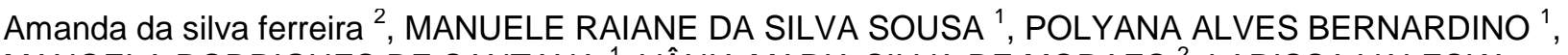
MANOELA RODRIGUES DE SANTANA ${ }^{1}$, VÂNIA MARIA SILVA DE MORAES ${ }^{2}$, LARISSA VALESKA MARIA DA SILVA BRITO ${ }^{2}$, BIANCA LEÃO BARRETO ${ }^{2}$, TACIANA DA SILVA GONÇALVES ${ }^{2}$,

Author(s): CHRISLAINY LOPES DE AGUIAR ${ }^{2}$, CLÁUDIA GONCCALVES LOBO ${ }^{2}$, FABIANA SANTOS DA SILVA OLIVEIRA ${ }^{2}$, JANICLER CORREIA DA SILVA ${ }^{2}$, RHAYANA MARQUES DOS SANTOS ${ }^{2}$, SOPHIA MARIA DANTAS ${ }^{3}$, LUIZ CARLOS ALVES ${ }^{3,4}$

Institution(s) ${ }^{1}$ UNICAP - UNIVERSIDADE CATÓLICA DE PERNAMBUCO (R. do Príncipe, № 526 - Boa Vista, Recife PE, 50050-900), ${ }^{2}$ FACHO - FACULDADE DE CIÊNCIAS HUMANAS DE OLINDA (Rod. PE-015 KM 3, 6 Santa Tereza, Olinda - PE, 53330-740), ${ }^{3}$ FIOCRUZ - FUNDAÇÃO OSWALDO CRUZ - INSTITUTO AGGEU MAGALHÃES (Campus da UFPE - Av. Prof. Moraes Rego, $s / n$ - Cidade Universitária, Recife - PE), ${ }^{4}$ LIKA LABORATÓRIO DE IMUNOPATOLOGIA KEIZO ASAMI (Av. Prof. Moraes Rego - Cidade Universitária, Recife - PE, 52171-011)

\begin{abstract}
INTRODUÇÃO: A Leishmaniose Tegumentar Americana (LTA) é um grave problema de saúde pública, sendo uma infecção causada pela L.(V.)braziliensis. Apresenta diversas formas clínicas, assintomática até cutâneas e mucocutâneas. A forma cutânea é a manifestação mais corriqueira com poucas ulcerações de bordas elevadas, variando em tamanho, em áreas expostas do corpo, pernas e braços. Além do tratamento convencional com antimoniato pentavalente, o cuidado com a lesão auxilia na evolução e o uso das coberturas, que são curativos bem definidos, garante princípios ideais de cicatrização. As características do tecido presente no leito das lesões desempenham ação na evolução do processo de cicatrização. A cobertura pode aumentar o odor, crescimento bacteriano e vazamento, ocasionando, por vezes, laceração das bordas da lesão, sendo necessário proteger a pele com um creme de barreira. O desbridamento autolítico, associado ao instrumental, facilita a retirada dos tecidos inviáveis. OBJETIVO: Avaliar coberturas especiais no tratamento de lesões de pacientes com Leishmaniose Tegumentar Americana. MÉTODO: Recorte do projeto do programa de pesquisa para o SUS (PPSUS - Pernambuco). Estudo de caso prospectivo, no período de março a julho 2019. CAAE 59093316.0.000.5190. A população composta pelos pacientes cadastrados no projeto caracterização da Leishmaniose Tegumentar Americana do município de Timbaúba, Pernambuco. Demanda espontânea, classificados em grupos de acordo com o histórico de tratamento com glucantime. Os registros da evolução das lesões foram por fotografias, consentidas após assinatura do TCLE. RESULTADOS: Portadores foram informados para fazerem seus curativos diários, troca das coberturas especiais a cada dois dias e semanalmente estiveram avaliadas pela enfermeira do grupo. Concretizadas características do leito da lesão quanto ao número, categoria, diâmetro, conteúdo bacteriano, odor, exsudato e cobertura instituída. Realizado técnica de Scare com agulha hipodérmica, desbridamento autolítico e mecânico. Curativos realizados com soro fisiológico $0,9 \%$, e as coberturas sobrepostas para cada característica da lesão. Indicamos hidrogel, carvão ativado com prata, ácidos graxos essenciais e creme de barreira. Destacando melhoras no leito da lesão. CONCLUSÃO: O tratamento das lesões abrange avaliações locais e sistêmicas, consisti em complexas e infecções secundárias. Necessária avaliação dos aspectos socioeconômicos, adesão ao tratamento, e autocuidado. O acompanhamento e tratamento apropriou evolução na cicatrização constatando eficácia das coberturas especiais. O manejo apropriado levou a redução das lesões. Respeitável o uso de coberturas concomitante com o tratamento quimioterápico.
\end{abstract}

Keywords: Leishmaniose tegumentar, Lesão, Estomoterapia.

\section{Referências Bibliográficas}

Referências: 1. Carvalho LP et al. Protective and pathologic immune responses in human tegumentary leishmaniasis. Frontiers in Immunology. v.2, p. 301; 2012. 2. Thuler SR, Boccara MAP. Guia de boas práticas [SOBEST] preparo do leito da lesão: desbridamento. São Paulo; 2017. 3. Yamada BFA. Limpeza e Desbridamento no Tratamento da Ulcera por Pressão, in Blanes L, Ferreira LM,Prevenção e Tratamento de Ulcera por Pressão, São Paulo; Ed. Atheneu; 2014. 4. Franco D, Gonçalves LF. Feridas cutâneas: a escolha do curativo adequado. Rev Col Bras Cir; [periódico na Internet] 2008; 35(3). Disponível em URL: http://www.scielo.br/rcbc. 5. Santos et al. Avaliação e tratamento de feridas: Orientação aos profissionais de enfermagem. Hospital de Clínicas. Porto Alegre- RS; 2009. Descritores: Leishmaniose tegumentar; Lesão; Estomoterapia. 


\title{
EFICÁCIA DO METRONIDAZOL NO CONTROLE DO ODOR ASSOCIADO À INFECÇÃO EM FERIDAS NEOPLÁSICAS
}

\author{
Rayne Raissa Correia de Carvalho ${ }^{1}$, Nauã Rodrigues de Souza ${ }^{2}$, Isabel Cristina Ramos Vieira \\ Author(s): $\quad$ Santos ${ }^{2,1}$, Marcos Antonio de Oliveira Souza ${ }^{2}$, Aurenice Gomes Silva ${ }^{1}$ \\ Institution(s) ${ }^{1}$ UNICAP - Universidade Católica de Pernambuco (Rua do Principe, 526 Boa Vista - Recife, PE - \\ Cep: 50050-900), ${ }^{2}$ UPE - Universidade de Pernambuco ( Av. Gov. Agamenon Magalhães - Santo \\ Amaro, Recife - PE, 50100-010)
}

\begin{abstract}
Introdução: O uso de drogas com ação bactericida tem sido recomendado pela literatura para controlar as infecções e, consequentemente o mau odor resultante em feridas neoplásicas e, dentre estas, se destaca o metronidazol, comumente indicado para os microorganismos anaeróbios, entretanto, a flora microbiológica presente na ferida neoplásica é frequetemente polimicrobiana, como por exemplo, os aeróbios que também podem causar o mau odor dessas feridas. Objetivos: identificar os estudos clínicos disponíveis na literatura sobre a efetividade do metronidazol no controle do odor associado às infecções em feridas neoplásicas. Material e Métodos: trata-se de uma revisão integrativa realizada nas bases de dados LILACS, SCIELO, MEDLINE e BDENF, no período de agosto a setembro de 2017, que culminou com a seleção de 4 artigos científicos sobre a temática. Resultados: As evidências apóiam o uso de metronidazol tópico para a redução de odor resultante da presença de organismos anaeróbicos. No entanto, os achados dos estudos analisados registraram a presença de flora polimicrobiana composta por bactérias aeróbicas, anaeróbicas e facultativas, e atestam para eliminação ou redução exclusiva de anaeróbios enquanto as bactérias aeróbicas e facultativas permaneceram inalteradas. Encontrada também controvérsias sobre os melhores métodos de aplicação e a duração ótima do tratamento, falta de consenso quanto a quantidade ou a frequência de uso do metronidazol necessário para reduzir a carga bacteriana ou diminuir o odor. Conclusões: No que pese a ampla utilização do metronidazol, as evidências apresentadas nos estudos aqui analisados demonstram efetividade apenas para bactérias anaeróbias. Estes fatores devem ser considerados por profissionais de saúde, especificamente por enfermeiros, por serem estes diretamente relacionados à sua aplicação.
\end{abstract}

Keywords: Oncologia, Infecção de feridas, Metronidazol, Desodorização, Efetividade

\section{Referências Bibliográficas}

1. MAIDA, V. Malignant wound management. Public Health Emerg. China, v. 1, n. 12, [cerca de 14 p.], jun.2016.Disponível em: Acesso em: 20 mai. 2016. 2. Watanabe K, Shimo A, Tsugawa K, Tokuda Y, Yamauchi H, Miyai, et al. Safe and effective deodorization of malodorous fungating tumors using topical metronidazole $0.75 \%$ gel (GK567): a multicenter, open-label, phase III study (RDT. 07. SRE. 27013). Supportive Care in Cancer, 2016; 24(6), 2583-90. 3. Adderley UJ, Holt IGS. Topical agents and dressings for fungating wounds. Cochrane Database Syst Rev. England, v. 15, n. 5, p. 01-26, may. 2014. Disponível em: <http://onlinelibrary.wiley.com/doi/10.1002/14651858.CD003948.pub3/epdf> 


\title{
Tratamento tópico de feridas em pacientes com Leishmaniose Cutânea: uma revisão integrativa
}

\author{
Author(s): $\quad$ Vera Lucia de Oliveira Melhorini ${ }^{1}$, Jacy Aurelia Vieira de Souza ${ }^{1}$, Juliane Heloise de Oliveira ${ }^{1}$, \\ Werydiane Matuswski da Silva ${ }^{1}$, Adriele Aparecida Simões Lima ${ }^{1}$ \\ Institution(s) ${ }^{1}$ PUC -PR - Pontifícia Universidade Católica de Curitiba (R. Imac. Conceição, 1155 - Prado Velho, \\ Curitiba - PR)
}

\begin{abstract}
Introdução: A Leishmaniose cutânea (LC) é considerada uma das doenças mais negligenciadas do mundo e afeta predominantemente países mais pobres ou em desenvolvimento, como o Brasil. As lesões provenientes da LC, em geral, são ulceradas, indolores, presentes em locais expostos da pele, como nariz, braços e pernas, com bordas delimitadas e elevadas e base eritematosa.Objetivo: Analisar as evidências científicas nacionais e internacionais relacionadas ao tratamento tópico de feridas em pacientes com Leishmaniose cutânea (LC). Material e método: Revisão integrativa da literatura, com coleta dos dados em outubro de 2018, por meio dos descritores: Leishmaniose e Leishmaniose cutânea, entrecruzados com o descritor Ferida. Foram incluídos todos os artigos relacionados ao tema Leishmaniose cutânea, publicados de 2008 a 2018, em inglês, português ou espanhol, disponíveis gratuitamente e na íntegra. Foram excluídos aqueles não relacionados ao tratamento tópico de feridas, não realizados com seres humanos e que se apresentavam em mais de uma base (duplicada). Resultados: A amostra final desta revisão foi constituída por dezesseis artigos científicos que versavam sobre perspectivas de tratamento tópico de feridas em pacientes com Leishmaniose cutânea, com publicação nos anos de 2010, 2011, 2013, 2014, 2015, 2016 e 2017. Os estudos foram publicados em periódicos internacionais e o número de autores por estudo variou de um a dezenove, totalizando 118 autores. Abordagens tópicas ao tratamento de feridas provenientes da Leishmaniose cutânea tem sido testadas, devido à baixa toxicidade, melhor aceitação e por, de modo satisfatório, constituírem-se como coadjuvantes no tratamento, posto que nenhum método único tem o potencial de erradicar esta infecção. As terapias tópicas incluem o calor, crioterapia, pomadas, cremes e injeções intralesões de compostos de antimônios pentavalentes, terapia fotodinâmica, laser, dentre outros. Estas que envolvem antimoniais são consideradas mais dolorosas, caras e, frequentemente, toxicas, o que tem fomentado o desenvolvimento de terapias tópicas e alternativas. Os estudos selecionados destacaram diversos efeitos colaterais relacionados aos tratamentos utilizados, com predomínio de desconfortos locais e de menor impacto com o uso de terapias tópicas em comparação àquelas sistêmicas. Conclusões: Evidenciou-se o reduzido número de publicações, especialmente nacionais, relacionadas ao tema. Houve predomínio de estudos desenvolvidos em países do Oriente Médio e com uso de terapias físicas, como o laser, e naturais, como extratos de plantas.
\end{abstract}

Keywords: Leishmaniose cutânea, Cicatrização, Terapeutica, estomaterapia

\section{Referências Bibliográficas}

1. World Health Organization (WHO). Plan of action to strengthen the surveillance and control of Leishmaniasis in the Americas 2017-2022. Washington DC: PAHO, 2017. 2. World Health Organization (WHO). Leishmaniasis in the Americas: Treatment recommendations. Washington DC: PAHO, 2018. 3. Brasil. Ministério da Saúde. Manual de vigilância da leishmaniose tegumentar. Brasília: Ministério da Saúde, 2017. 4. Aronson N, Herwaldt BL, Libman M, Pearson R, LopezVelez R, Weina P, et al. Diagnosis and Treatment of Leishmaniasis: Clinical Practice Guidelines by the Infectious Diseases Society of America (IDSA) and the American Society of Tropical Medicine and Hygiene (ASTMH). Am J Trop Med Hyg. 2017 Jan 11; 96(1): 24-45. 5. Nassif PW, Mello TFP, Navasconi TR, Mota CA, Dermarchi IG, Aristides SMA, et al. Safety and efficacy of current alternatives in the topical treatment of cutaneous leishmaniasis: a systematic review. Parasitology. 2017; 144:995-1004. 


\title{
INCIDÊNCIA DE LESÃO POR PRESSÃO EM PACIENTES ADULTOS INTERNADOS EM HOSPITAL DA REDE PRIVADA
}

\author{
Author(s): Marcela Gama Santana Moreira ${ }^{1}$, Patrícia Gouveia do Couto Nascimento ${ }^{1}$, Luciana Maria Horta \\ Veras Andrade $^{1}$, Rafaela Rocha de Souza Aguiar ${ }^{1}$ \\ Institution(s) ${ }^{1}$ CENUT - Centro Especializado de Nutrição (Rua Tênisson Ribeiro, 126. Salgado Filho. Aracaju, \\ Sergipe), ${ }^{2}$ UFS - Universidade Federal de Sergipe (Rua Claudio Batista, s/n. Sanatório. Aracaju, \\ Sergipe)
}

\begin{abstract}
Introdução O desenvolvimento de uma lesão por pressão (LP) é a mais grave manifestação da integridade cutânea prejudicada, configurando-se como indicador de qualidade da assistência oferecida pelos serviços de saúde. No Brasil, existe uma grande dificuldade em mensurar esses dados. De acordo com o relatório nacional de incidentes relacionados à assistência à saúde, a LP foi considerada o terceiro evento mais notificado pelas instituições de saúde do país. Objetivo: Identificar a incidência de LP em adultos hospitalizados e descrever os estágios mais notificados e as regiões mais acometidas por LP. Material e Método: Estudo descritivo, retrospectivo, quantitativo. Os dados foram coletados por meio de relatórios de notificação de LP da comissão de pele de um hospital privado em Aracaju, Sergipe, no período de janeiro de 2018 a dezembro de 2018. Foram excluídos paciente menores de dezoito anos. Esse estudo seguiu as recomendações da Resolução 466/2012 do Conselho Nacional de Saúde (CNS) e foi aprovado pelo Comitê de Ética em Pesquisa da Universidade Federal de Sergipe (número do parecer: 2.769.672). Resultados: Foram notificadas 219 LP no ano de 2018, com o total de 156 pacientes acometidos. Oitenta e seis lesões $(39,26 \%)$ foram consideradas evitáveis, ou seja, foi evidenciado falha na assistência de enfermagem quanto à prevenção de LP. A incidência de LP em 2018 foi de $2,97 \%$. $O$ mês de setembro se destacou pela incidência de $7,1 \%$. 96 pacientes $(61,53)$ estavam internados na Unidade de terapia intensiva (UTI) quando desenvolveram a LP. Os pavilhões auriculares foram os mais acometidos, seguidos por região glútea e calcâneos, respectivamente. Os estágios 2 (33,7\%) e tissular profunda (33,7\%) foram os mais notificados. As lesões por dispositivo médico corresponderam a 13,15\% de todas as LP. Nenhuma LP estágio 4 foi notificada. Conclusões: A notificação dos casos de LP é necessária para mensurar a qualidade da assistência de enfermagem, com isso 0 conhecimento sobre a epidemiologia das LP nas instituições de saúde é fundamental para o planejamento de estratégias preventivas eficazes.
\end{abstract}

Keywords: Estomaterapia, Incidência, Lesão por pressão

\section{Referências Bibliográficas}

Agência Nacional de Vigilância Sanitária - Anvisa. Relatório nacional de incidentes relacionados à assistência à saúde Boletim Segurança do Paciente e Qualidade em Serviços de Saúde. Disponível em <

https://www20.anvisa.gov.br/segurancadopaciente/index.php/publicacoes/category/relatorios>. [Acesso em 20 maio 2019]. Lima AFC, Castilho V, Baptista CMC, Rogenski NMB, Rogenski KE. Custo direto dos curativos de úlceras por pressão em pacientes hospitalizados. Revista Brasileira de Enfermagem 2016; 69(2), 290-7. Park KH, Choi H. Prospective study on Incontinence-Associated Dermatitis and its Severity instrument for verifying its ability to predict the development of pressure ulcers in patients with fecal incontinence. International Wound Journal 2016; 13, 20-5. 


\title{
Assistência de enfermagem ao paciente idoso portador de úlcera de pressão em home care
}

\author{
Author(s): EIDE NASCIMENTO DA SILVA ${ }^{1,2}$, Rosangela Abreu ${ }^{1}$ \\ Institution(s) ${ }^{1}$ Solar Cuidados - Solar Cuidados e Serviço em Saúde (Av. Armando Lombardi,205), ${ }^{2}$ UERJ - \\ Universidade do Estado do Rio de Janeiro (São Francisco Xavier, 524)
}

\begin{abstract}
No sistema tegumentar, a conservação por extenso intervalo de tempo em um mesmo posicionamento gera em determinadas partes da pele uma espécie de isquemia, gerando lesões como úlceras por pressão. De acordo com Almeida et al (2016) as úlceras de pressão são detrimentos ocorridos na pele e partes moles do corpo, quando estas se encontram em pressão por um longo período de tempo podendo gerar dor, infecções e elevação da imobilidade. Descrever as assistências de enfermagem no cuidado aos idosos portadores de úlcera de pressão em domicílio. Trata-se de uma pesquisa bibliográfica abrangendo os anos de 2011 a 2017, efetuou-se uma pesquisa nas seguintes bases de dados: Lilacs, Scielo e Bdenf. Há aspectos inerentes ao próprio envelhecimento que predeterminam as úlceras por pressão. $\mathrm{E}$ quando relaciona tais aspectos à pressão, fricção e cisalhamento, que normalmente ocorrem quando o paciente idoso se encontra acamado, é normal o desenvolvimento de feridas. No presente estudo, averigua-se que há uma insuficiência de dados sobre a profilaxia de úlceras por pressão, essencialmente sobre as práticas preventivas que podem ser empregadas para reduzir os danos na pele. Posto que os idosos que precisam de assistência especial, é fundamental que as enfermeiras ajam na capacitação dos familiares, impedindo desta forma danos a saúde dos pacientes. Detectamos as seguintes intervenções para prevenir as úlceras por pressão: conservar a pele do idoso sempre limpa, avaliá-la e umidificála diariamente. Introduz-se neste cenário o profissional de enfermagem,encarregado pela elaboração de práticas preventivas, sejam elas desenvolvidas no espaço hospitalar ou em domicílio.
\end{abstract}

Keywords: Home Care, Idoso, ùlcera por pressão, Assistência de enfermagem

\section{Referências Bibliográficas}

DOMANSKY RC, BORGES EL. Manual para prevenções de lesão de pele. 2.ed. Rio de Janeiro: Rubio, 2014.Biológicas e da Saúde, Londrina, v. 37, n. 2, p. 25-38, jul./dez. 2016; BLANES L, FERREIRA LM. Prevenção e tratamento de úlcera por pressão. 1.ed. São Paulo: Atheneu, 2014.ALMEIDA, Cristiane Rosa de et al. O cuidado domiciliar a um paciente com úlcera por pressão: um relato de experiência. Revista Espaço Ciência \& Saúde, v. 3, p. 


\title{
Prevalência de lesão por pressão em pacientes internados em unidade de terapia intensiva e fatores associados
}

\author{
Author(s): Evellyn Lima da Silva Oliveira ${ }^{1}$, Rayanne Suélly da Costa Silva Santos ${ }^{1}$, Vera Lúcia Conceição de \\ Gouveia Santos ${ }^{1}$, Taís Milena Pantaleão de Souza ${ }^{1}$, Paula Cristina Nogueira ${ }^{1}$ \\ Institution(s) ${ }^{1}$ EEUSP - Escola de Enfermagem da Universidade de São Paulo (Av Dr. Enéas Carvalho de \\ Aguiar, 419 - Cerqueira César)
}

\begin{abstract}
Introdução: A lesão por pressão (LP) é um dos eventos adversos mais prevalentes na unidade de terapia intensiva (UTI) em destaque devido à sua etiologia multifatorial1. Objetivo: identificar a prevalência pontual de LP e fatores associados em pacientes internados em UTI. Método: Trata-se de um estudo transversal realizado em um único dia em nove hospitais localizados em São Paulo, Brasil. Os dados foram coletados por inspeção da pele dos pacientes e consulta em prontuários para coleta de dados demográficos e clínicos. A avaliação do risco de LP foi realizada utilizando a escala de Braden2 e as LP identificadas foram classificadas de acordo com National Pressure Ulcer Advisory Panel 20163,4. O estudo foi avaliado e aprovado pelo comitê de ética de todos os hospitais participantes. Os dados foram analisados por meio de estatística descritiva, teste exato de Fisher, teste Qui-quadrado de Pearson, teste T e teste de Wilcoxon-Mann-Whitney. Resultados: A amostra foi composta por 377 pacientes, sendo $52,8 \%$ do sexo masculino e a média de idade foi de 62,7 anos $(D P=17,2)$; 121 apresentaram LP, resultando em uma prevalência pontual global de 32,1\%. O escore médio da escala de Braden foi de 13,6 (DP 4,5). A maioria das LP eram de estágio 2 (31,2\%) e localizavam-se na região sacral (39,1\%). Os fatores associados que melhor identificaram o grupo com LP foram: pacientes em uso sedação e ventilação mecânica invasiva, traqueostomizados, em uso de dispositivos (venoso, nasogástrico ou vesical) e terapia renal substitutiva. Conclusões: Os resultados encontrados podem facilitar o planejamento de cuidados preventivos específicos para pacientes críticos.
\end{abstract}

Keywords: cuidados de enfermagem, estomaterapia, lesão por pressão, prevalência, unidades de terapia intensiva

\section{Referências Bibliográficas}

1. Chaboyer WP, Thalib L, Harbeck EL, Coyer FM, Blot S, Bull CF, et al. Incidence and Prevalence of Pressure Injuries in Adult Intensive Care Patients: A Systematic Review and Meta-Analysis. Crit Care Med. 2018;46(11):e1074-e1081. 2. Paranhos WY, Santos VLCG. Avaliação de risco para úlcera de pressão por meio da Escala de Braden na língua portuguesa. Rev da Esc Enferm da USP. 1999;33:194-204. 3. NATIONAL PRESSURE ULCER ADVISORY PANEL (NPUAP). NPUAP Pressure Injury Stages. 2016. Available from: http://www.npuap.org/national-pressure-ulcer-advisorypanel-npuapannounces-a-change-in-terminology-from-pressure-ulcer-to-pressureinjury-and-updates-the-stages-of-pressureinjury 4. Caliri MHL, Santos VLC de G, Mandelbaum MHS, Costa IG. Classificação das Lesões por pressão - Consenso NPUAP 2016 - Adaptada Culturalmente para o Brasil. Associação Brasileira de Estomaterapia - SOBEST. Associação Brasileira de Enfermagem em Dermatologia- SOBENDE. Disponível em: http://www.sobest.org.br/textod/35 


\title{
Prevalência de lesão por fricção em unidade de terapia intensiva
}

\author{
Author(s): Evellyn Lima da Silva Oliveira ${ }^{1}$, Rayanne Suélly da Costa Silva Santos ${ }^{1}$, Vera Lúcia Conceição de \\ Gouveia Santos ${ }^{1}$, Paula Cristina Nogueira ${ }^{1}$ \\ Institution(s) ${ }^{1}$ EEUSP - Escola de Enfermagem da Universidade de São Paulo (Av Dr. Enéas Carvalho de \\ Aguiar, 419 - Cerqueira César)
}

\begin{abstract}
Introdução: As lesões por fricção (LF) são feridas agudas, causadas por forças mecânicas, muitas vezes dolorosas e, em geral, resultante de trauma na pele. Apresentam maior incidência em indivíduos idosos decorrente da fragilidade e vulnerabilidade natural do processo de envelhecimento da pele, o adelgaçamento da hipoderme, e, consequentemente, da menor força necessária para causar uma lesão traumática1,2. Sua gravidade altera de acordo com a profundidade, não se estendendo além da camada subcutânea3. Objetivos: Identificar a prevalência de LF em pacientes internado em Unidades de Terapia Intensiva (UTI). Métodos: Estudo observacional, transversal realizado em UTIs clínicas e cirúrgicas de nove hospitais públicos e privados localizados na cidade de São Paulo. Participaram do estudo 377 pacientes com idade maior ou igual a 18 anos. Os pacientes foram avaliados quanto a presença de LF, número, localização e classificação dessas lesões. A coleta de dados ocorreu em um único dia e os dados demográficos, clínicos e informações sobre a LF foram coletados por meio da consulta ao prontuário e do exame físico da pele. As LF foram classificadas de acordo com o Skin Tear Classification System na versão adaptada para língua portuguesa do Brasil4. Os dados foram analisados por meio de estatística descritiva, teste exato de Fisher, teste Qui-quadrado de Pearson, teste T e teste de Wilcoxon-Mann-Whitney. Resultados: Dos 377 pacientes, 52,8\% eram do sexo masculino, com idade média de 62,7 anos (DP17,2). Desta amostra, 51 pacientes apresentaram LF, totalizando uma prevalência pontual de 13,5\%. O local de maior ocorrência das LF foram os membros superiores $(56 \%)$, predominando as lesões de categoria 1B $(32 \%)$. Conclusão: Os resultados desta pesquisa podem auxiliar no planejamento e implementação de cuidados preventivos na assistência de enfermagem, baseados em evidência, proporcionando uma assistência segura e qualificada.
\end{abstract}

Keywords: cuidados de enfermagem, estomaterapia, estudos epidemiológicos, lesão por fricção, unidades de terapia intensiva

\section{Referências Bibliográficas}

1. Consuegra RVG, Wilmar JLZ, Lizcano, KTR. Epidemiología de lesiones de piel relacionadas con el cuidado: estudio de la prevalencia en Colombia. Revista de Enfermagem Referência. 2017: 65-72. 2. ISTAP. International Skin Tear Advisory Panel (ISTAP). Disponível em: . Acesso em: 12 jul. 2019. 3. Leblanc, K. et al. Best practice recommendations for the prevention and management of skin tears in aged skin. Wounds International. 2018; 1-21. 4. Strazzieri-Pulido KC, Santos VLCG, Carville K. Adaptação cultural, validade de conteúdo e confiabilidade interobservadores do "STAR Skin Tear Classification System". Rev. Latino-Am. Enfermagem; 2015;23(1):155-61. 


\title{
PERFIL DE PACIENTES IDOSOS INTERNADOS EM UM HOSPITAL DE GRANDE PORTE QUE DESENVOLVERAM LESÃO POR PRESSÃO
}

\author{
Author(s): Eduarda Nascimento Carneiro Leão Guerra ${ }^{1}$, Patrícia Martins ${ }^{1}$, Renata Santana ${ }^{1}$ \\ Institution(s) ${ }^{1}$ RHP - Real Hospital Português de Beneficência em Pernambuco (Av. Gov. Agamenon \\ Magalhães, 4760 - Paissandu, Recife - PE, 52010-040)
}

\begin{abstract}
Introdução: Com o envelhecimento, algumas alterações ocorrem no tegumento fragilizando-o e comprometendo sua regeneração, tornando esse grupo etário uma população de alto risco ao desenvolvimento de lesões por pressão $0^{122}$. A ocorrência deste agravo no período de internamento hospitalar pode acarretar em diversas complicações ${ }^{3}$. Objetivo: Traçar o perfil da população idosa que desenvolveu lesão por pressão durante o internamento na instituição. Método: Trata-se de uma pesquisa quantitativa do tipo exploratório-descritivo. O local de estudo foi um hospital de alta complexidade localizado na cidade de Recife - PE. A amostra foi de 161 prontuários de pacientes idosos internados que desenvolveram lesão por pressão durante o internamento no ano de 2017. Resultados: Dos 161 prontuários analisados, 95 (59\%) eram do sexo masculino. As unidades de terapia intensiva obtiveram a maior incidência $89(55,28 \%)$ e o motivo de internamento mais frequente foram as causas infecciosas $58(36,02 \%)$. O uso de fralda descartável evidenciou-se como um fator predisponente, presente em $114(70,81 \%)$. A polifarmácia foi identificada como condição de risco. A região sacra liderou as ocorrências com $107(66,46 \%)$. Em relação ao estadiamento $95(59,01 \%)$ foram estágio 2. De acordo com a escala de Braden, $145(90,06 \%)$ apresentaram-se dentro dos grupos de riscos moderado e alto. Conclusões: Foram evidenciados como fatores de risco para lesões por pressão a imobilidade, a umidade, a polifarmácia e as doenças crônicas, demonstrando que essa é uma população complexa, que necessita de medidas de prevenção baseadas em evidências científicas, levando em consideração o quadro clínico e social que o envolve o paciente assistido.
\end{abstract}

Keywords: Lesão por Pressão, Planejamento de Assistência ao Paciente, Saúde do Idoso Institucionalizado

\section{Referências Bibliográficas}

1.Menoita, E., Santos, V., Santos, A. (2013) Skin in the Elderly. Journal of Aging \& Inovation, 2 (1): 18-33 2. Santo GS., Cunha ICKO. Perfil sociodemográfico de cuidadores familiares de idosos residentes em uma área de abrangência da Estratégia Saúde da Família no município de São Paulo. Saúde Coletiva, 2013; 10 (59):47-53. 3.Vieira CPB., Sá MS., Madeira MZA., Luz MHBA. Caracterização e fatores de risco para úlceras por pressão na pessoa idosa hospitalizada. Rev Rene. 2014 jul-ago; 15(4):650-8. 


\title{
UTILIZAÇÃO DA TÉCNICA LIMPA E ESTÉRIL NO CUIDADO DE FERIDAS: REVISÃO DE LITERATURA
}

\author{
Author(s): Ana Paula Oliveira ${ }^{1}$, Bruno Vinícius Pereira Costa ${ }^{1,1}$, Ana Savina da Rocha Amorim ${ }^{1,1,1}$ \\ Institution(s) ${ }^{1}$ UNINASSAU - Faculdade UNINASSAU - Campus Parnaíba (Rodovia BR-343, Km 7,5, S/N - \\ Floriópolis, Parnaíba - PI, 64204-260), ${ }^{2}$ UNINASSAU - Faculdade UNINASSAU - Campus \\ Parnaíba (Rodovia BR-343, Km 7,5, S/N - Floriópolis, Parnaíba - PI, 64204-260), ${ }^{3}$ UNINASSAU - \\ Faculdade UNINASSAU - Campus Parnaíba (Rodovia BR-343, Km 7,5, S/N - Floriópolis, \\ Parnaíba - PI, 64204-260)
}

\begin{abstract}
INTRODUÇÃO: A escolha da técnica limpa (TL) ou técnica estéril (TE) na realização de curativos, em feridas agudas ou crônicas, tem sido normalmente questionada, levando em consideração a segurança da TL versus o custo mais elevado da TE. Dessa forma, A TE compreende procedimentos que minimizam, a carga microbiana através de estratégias, que restrinjam a exposição aos micro-organismos. Por outro lado a TL compreende condutas para reduzir o número total de micro-organismos, evitando ou diminuindo o risco de transmissão de uma pessoa para outra, ou de um lugar para outro. OBJETIVO: Verificar na literatura os aspectos que envolvem a técnica limpa e estéril no cuidado de feridas. MÉTODOS: Trata-se de uma revisão de literatura, executada a partir das bases de dados Lilacs, PubMed, Medline e Cinahl. Os critérios de inclusão foram: publicações entre o período de 2014 a junho de 2019, estando em língua portuguesa, inglesa e espanhola, acessível na integra, artigos indexados em pelo menos uma das bases de dados supracitadas e localizáveis mediante palavras-chave e descritores: Ferimentos e Lesões; Técnicas de Fechamento de Ferimentos; Terapêutica; Assepsia. Critérios de exclusão: artigos científicos que não apresentassem pelo menos dois dos descritores utilizados, trabalhos que não tiveram relação direta com o tema, bem como os artigos que não foram encontrados textos completos disponíveis ou com link de acesso apresentando erro. Mediante os critérios de inclusão e exclusão foram selecionados 16 artigos que se enquadram nos objetivos. RESULTADOS: Evidencia-se que a utilização da TE no cuidado de feridas apresenta muita eficácia, visto que promove a diminuição ao máximo da carga microbiana em comparação com TL, em virtude da TE envolver a lavagem cautelosa das mãos, utilização de campo estéril, uso de luvas estéreis, utilização somente de instrumentos e materiais estéreis. Entretanto, o uso da TE é questionável, sobretudo, por estar associada a elevados custos, quando relacionado à TL, visto que a TL faz uso de luvas de procedimento e instrumentais estéreis, somados aos princípios de assepsia, mas não apresenta a redução por completo da carga microbiana, na qual propicia a possibilidade de infecção da ferida. Dessa forma, questiona-se com relação a consonância das técnicas empregadas, com as literaturas atuais e se o mesmo procedimento não poderia acarretar malefícios aos pacientes. CONCLUSÃO: Portanto, verificou-se que ainda não existe um consenso sobre a utilização da técnica adequada, em virtude de não existir conceitos absolutos referente a técnica limpa e estéril em todas as situações do paciente, na qual são poucas as orientações universalmente aceitas e usadas, apesar de pesquisas apresentarem resultados positivos com relação ao uso da TL. Dessa forma, é imprescindível que os profissionais apresentem a capacidade e habilidade por meio de experiências pessoais para escolher o procedimento conforme o ambiente e estado da ferida, na qual é essencial a capacidade de avaliação do custo benefício da técnica apropriada. No entanto, é primordial a elaboração de estudos fundamentados em evidências científicas, apresentando a utilização da técnica limpa ou estéril na realização de curativos avaliando a incidência de infecção e os custos.
\end{abstract}

Keywords: Ferimentos e Lesões, Técnicas de Fechamento de Ferimentos, Terapêutica, Assepsia

\section{Referências Bibliográficas}

Ferreira A, Andrade D. Revisão integrativa da técnica limpa e estéril: consensos e controvérsias na realização de curativos. Acta Paulista de enfermagem [revista em Internet] 2014 setembro-dezembro. [acesso 19 de junho de 2019]; 26(3). Disponível em: https://www.redalyc.org/pdf/3070/307023823019.pdf. Moreira R, Queiroz A, Araújo M. Condutas de enfermeiros no tratamento de feridas numa unidade de terapia intensiva. Revista da Rede de Enfermagem do Nordeste [revista em Internet] 2015 setembro-dezembro. [acesso 19 de junho de 2019]; 10(2). Disponível em: https://www.redalyc.org/pdf/3240/324027966005.pdf Martins E, Meneghin P. Avaliação de três técnicas de limpeza do sítio cirúrgico infectado utilizando soro fisiológico. Ciência, Cuidado e Saúde [revista em Internet] 2016 setembro-dezembro. [acesso 19 de junho de 2019]; 11(5). Disponível em: http://ojs.uem.br/ojs/index.php/CiencCuidSaude/article/view/17077 


\title{
PREVALÊNCIA DE LESÃO POR PRESSÃO EM UMA UNIDADE DE TERAPIA INTENSIVA DE UM HOSPITAL PRIVADO
}

Saskia Iasana Pontes Fleury ${ }^{1}$, Letícia Faria Serpa ${ }^{1}$, Daniela Cristina Solla Salvador ${ }^{1}$, Gledson Author(s): Souza Gimenez ${ }^{1}$, Shirley Gomes Romão ${ }^{1}$, Amanda Bacchiega Albuquerque dos Santos ${ }^{1}$, Amanda Tavares Leal ${ }^{1}$, Silvia Helena Conejo ${ }^{1}$, Elaine Cristina Ferreira Ianni ${ }^{1}$, Paula Cristina Nogueira ${ }^{2}$

Institution(s) ${ }^{1}$ HAOC - Hospital Alemão Oswaldo Cruz (Rua João Julião, 331), ${ }^{2}$ EEUSP - Escola de Enfermagem da Universidade de São Paulo (Av. Dr. Enéas de Carvalho Aguiar, 419)

\begin{abstract}
INTRODUÇÃO: Apesar da lesão por pressão (LP)1 ser considerada um indicador da qualidade da assistência, dados mostram alta prevalência nas instituições de saúde. A LP aumenta o tempo de internação, os custos relacionados ao tratamento dos pacientes e são dolorosas, portanto, pesquisas que ajudem atender o real cenário da prevalência de LP estão sendo desenvolvidas, para que estratégias eficientes na prevenção dessas lesões sejam implementadas.2 OBJETIVO: Verificar a prevalência pontual de LP em uma Unidade de Terapia Intensiva (UTI) e o perfil demográfico e clínico dos pacientes.

MÉTODO: Trata-se de um estudo transversal, prospectivo realizado na UTI geral de um hospital privado localizado na cidade de São Paulo. Este estudo faz parte de um projeto multicêntrico internacional sobre prevalência de LP em UTI, aprovado pelo o Comitê de Ética da instituição, CAAE 82211318.7.3006.070. Participaram do estudo pacientes com idade igual ou superior a 18 anos. Dados demográficos e clínicos foram coletados dos prontuários. Foi realizada inspeção da pele e as LP identificadas foram classificadas de acordo com as categorias propostas pela National Pressure Ulcer Advisory Panel 20161. Para avaliação do risco para LP foi utilizada a escala Braden4. Os dados foram inseridos na plataforma REDCap e analisados no Microsoft Excel® por meio de estatística descritiva.

RESULTADOS: Foram avaliados 28 pacientes, sendo 15 do sexo feminino $(53,5 \%)$, com média de idade 72 anos $(D P=12)$. Destes, 16 pacientes (57\%) apresentaram IMC acima de 25 (sobrepeso), cinco desnutridos (17,85\%) pela avaliação nutricional, sete eram diabéticos $(25 \%)$, sete com redução de mobilidade $(25 \%)$, cinco em terapia de substituição renal $(17,85 \%)$. Pela escala de Braden, $75 \%$ dos pacientes apresentavam risco para desenvolver LP, sendo: baixo risco (21\%), moderado risco $(21 \%)$, alto risco (21\%) e três com risco muito alto (11\%). A prevalência de LP foi de $14,28 \%$ : quatro pacientes apresentaram LP. O total de LP foram quatro, sendo dois categorizados em estágio 1, um estágio 2 e uma LP relacionada a dispositivo médico estágio 1. CONCLUSÃO: A prevalência de LP nessa amostra foi de $14,8 \%$. Mais estudos são necessários para evidenciar os principais fatores relacionados ao desenvolvimento de LP, para a implementação de ações e protocolos específicos de prevenção dessas lesões.

Descritores: Estomaterapia, Lesão por Pressão, Unidades de terapia intensiva, prevalência.
\end{abstract}

Keywords: Estomaterapia, Lesão por pressão, Unidades de Terapia intensiva, Prevalência

\section{Referências Bibliográficas}

REFERÊNCIAS: 1. NATIONAL PRESSURE ULCER ADVISORY PANEL (NPUAP). NPUAP Pressure Injury Stages. 2016. 2. ANVISA. NOTA TÉCNICA GVIMS/GGTES No 03/2017. Práticas seguras para prevenção de Lesão por Pressão em serviços de saúde. 2017. 3. Chaboyer WP et al. Incidence and Prevalence of Pressure Injuries in Adult Intensive Care Patients: A Systematic Review and Meta-Analysis. Crit Care Med. 2018;46(11):e1074-e1081. 4. Paranhos WY, Santos VLCG. Avaliação de risco para úlcera de pressão por meio da Escala de Braden na língua portuguesa. Rev da Esc Enferm da USP. 1999;33:194-204. 


\title{
O PAPEL DO ENFERMEIRO NA PREVENÇÃO DO PÉ DIABÉTICO E SUAS COMPLICAÇÕES: REVISÃO DE LITERATURA
}

\author{
Author(s): Ana Paula Oliveira ${ }^{1,2,2}$, Bruno Vinícius Pereira Costa ${ }^{1,2,1}$, Ana Savina da Rocha Amorim ${ }^{1,1,1}$ \\ Institution(s) ${ }^{1}$ UNINASSAU - Faculdade UNINASSAU - Campus Parnaíba (Rodovia BR-343, Km 7,5, S/N - \\ Floriópolis, Parnaíba - PI, 64204-260), ${ }^{2}$ UNINASSAU - Faculdade UNINASSAU - Campus \\ Parnaíba (Rodovia BR-343, Km 7,5, S/N - Floriópolis, Parnaíba - PI, 64204-260), ${ }^{3}$ UNINASSAU - \\ Faculdade UNINASSAU - Campus Parnaíba (Rodovia BR-343, Km 7,5, S/N - Floriópolis, \\ Parnaíba - PI, 64204-260)
}

\begin{abstract}
INTRODUÇÃO: A Diabetes Mellitus é uma doença metabólica de grande relevância na modernidade, constituindo-se em um grave problema de saúde pública e de epidemia mundial, na qual faz parte de um grupo de patologias caracterizadas como crônicas por apresentar hiperglicemia relacionado a complicações, como o pé diabético, que é entendido como um estado fisiopatológico multifacetado, determinado por lesões que surgem de traumas que acomete os pés da pessoa com diabetes e ocorre devido neuropatia em $90 \%$ dos casos de doença vascular periférica e de deformidades. OBJETIVO: Verificar na literatura o papel do enfermeiro na prevenção do pé diabético e suas complicações. MÉTODOS: Trata-se de uma revisão de literatura, executada a partir das bases de dados Lilacs, PubMed, Medline e Cinahl. Os critérios de inclusão dos materiais selecionados foram: publicações entre o período de 2014 a junho de 2019, estando em língua portuguesa, inglesa e espanhola, acessível na integra, artigos indexados em pelo menos uma das bases de dados supracitadas e localizáveis mediante palavras-chave e descritores: Pé diabético; Enfermagem; Diabetes Mellitus. Critérios de exclusão: artigos científicos que não apresentassem pelo menos dois dos descritores utilizados, trabalhos que não tiveram relação direta com o tema, bem como os artigos que não foram encontrados textos completos disponíveis ou com link de acesso apresentando erro. Mediante os critérios de inclusão e exclusão foram selecionados 17 artigos que se enquadram nos objetivos. RESULTADOS: Evidencia-se que o enfermeiro tem uma atuação essencial no processo da assistência aos pacientes tanto na prevenção do pé diabético, quanto nas suas complicações, na qual deve procurar realizar suas ações utilizando como instrumento de trabalho a consulta de enfermagem integralizada, a anamnese e o exame físico seguido pelos de testes de sensibilidade na busca de detectar precocemente as causas de riscos e possíveis complicações. No entanto, é necessário orientar os pacientes portadores de diabetes com referência aos cuidados apropriados que devem ser tomadas com os pés, tais como inspeção, higiene, hidratação, remoção de calos, uso de calçados apropriados, controle glicêmico, prática de atividade física e avaliação nutricional. Entretanto, verifica-se que o enfermeiro não está totalmente capacitado para lidar com o pé diabético, pois os cuidados ofertados pelos mesmos estão mais direcionados para a patologia, como o controle regular da glicemia, distribuição de fármacos, verificação de sinais vitais, entre outros. CONCLUSÃO: Portanto, o enfermeiro tem o papel imprescindível no processo dos cuidados aos pacientes portadores de diabetes, na qual deve atuar de forma holística e planejando estratégias educativas de caráter preventivo que promovam o autocuidado e a prevenção do pé diabético, visto que é maneira mais eficaz de evitar as complicações podológicas. Ademais, é essencial que sejam desenvolvidos novos estudos com o intuito de demonstrar com mais propriedade as ações dos enfermeiros diante do paciente com pé diabético, possibilitando a construção de conhecimento, capacitação e qualidade de vida da pessoa portadora de diabetes.
\end{abstract}

Keywords: Pé diabético, Enfermagem, Diabetes Mellitus

\section{Referências Bibliográficas}

Dantas D, Costa J. Atuação do enfermeiro na prevenção do pé diabético e suas complicações: revisão de literatura. Carpe Diem: Revista Cultural e Científica do UNIFACEX [revista em Internet] 2015 setembro-dezembro. [acesso 19 de junho de 2019]; 11(3). Disponível em: https://periodicos.unifacex.com.br/Revista/article/view/359 Hirota C, Haddad M. Pé diabético: o papel do enfermeiro no contexto das inovações terapêuticas. Ciênc cuid saúde [revista em Internet] 2015 setembrodezembro. [acesso 19 de junho de 2019]; 7 (1). Disponível em:

http://hiperbaricasantarosa.com.br/arquivos/PE_DIABETICO_O_CONTEXTO_DOS_ENFERMEIROS_NAS_INOVACOES_ TERAPEUTICAS.pdf Maia T, Silva L. O pé diabético de clientes e seu autocuidado: a enfermagem na educação em saúde. Escola Anna Nery Revista de Enfermagem, [revista em Internet] 2017 setembro-dezembro. [acesso 19 de junho de 2019]; 9 (1). Disponível em: https://www.redalyc.org/pdf/1277/127720494012.pdf 


\title{
ATUAÇÃO DO ENFERMEIRO NO MANEJO CLÍNICO DE PACIENTES COM ÚLCERA VENOSA: REVISÃO DE LITERATURA
}

\author{
Author(s): Ana Savina da Rocha Amorim ${ }^{1,1,1}$, Bruno Vinícius Pereira Costa ${ }^{1,1,2}$, Ana Paula Oliveira ${ }^{1,1,1}$ \\ Institution(s) ${ }^{1}$ UNINASSAU - Faculdade UNINASSAU - Campus Parnaíba (Rodovia BR-343, Km 7,5, S/N - \\ Floriópolis, Parnaíba - PI, 64204-260), ${ }^{2}$ UNINASSAU - Faculdade UNINASSAU - Campus \\ Parnaíba (Rodovia BR-343, Km 7,5, S/N - Floriópolis, Parnaíba - PI, 64204-260), ${ }^{3}$ UNINASSAU - \\ Faculdade UNINASSAU - Campus Parnaíba (Rodovia BR-343, Km 7,5, S/N - Floriópolis, \\ Parnaíba - PI, 64204-260)
}

\begin{abstract}
INTRODUÇÃO: A insuficiência venosa atinge com maior frequência os membros inferiores devido à perda de aporte sanguíneo, no sentido de conduzir adequadamente o sangue para as regiões periféricas. Dessa forma, surgem as úlceras venosas que é determinada pelo comprometimento e/ou perda da derme, epiderme, seguido do tecido subcutâneo, na qual é considerada como um relevante problema de saúde pública, principalmente, quanto à prevalência e custos terapêuticos. OBJETIVO: Verificar na literatura a relevância do enfermeiro no manejo clínico da úlcera venosa. MÉTODOS: Trata-se de uma revisão de literatura, executada a partir das bases de dados Lilacs, PubMed, Medline e Cinahl. Os critérios de inclusão dos materiais selecionados foram: publicações entre o período de 2014 a junho de 2019, estando em língua portuguesa, inglesa e espanhola, acessível na integra, artigos indexados em pelo menos uma das bases de dados supracitadas e localizáveis mediante palavras-chave e descritores: Úlcera venosa; Cuidados de enfermagem; Terapêutica. Critérios de exclusão: artigos científicos que não apresentassem pelo menos dois dos descritores utilizados, trabalhos que não tiveram relação direta com o tema, bem como os artigos que não foram encontrados textos completos disponíveis ou com link de acesso apresentando erro. Mediante os critérios de inclusão e exclusão foram selecionados 17 artigos que se enquadram nos objetivos. RESULTADOS: Evidencia-se que o enfermeiro é essencial no manejo clínico do paciente com úlcera venosa, desde a avaliação, prevenção de complicações, orientações para o autocuidado, assim como a assistência na tomada de decisão da terapêutica adequada. Entretanto, existe uma carência com relação as pesquisas que envolvem a valorização do enfermeiro diante de sua atuação na terapêutica das úlceras venosas, visto que os mesmos são essenciais na prevenção desta patologia, no reestabelecimento da saúde, na educação do paciente e no desenvolvimento de curativos, na qual são práticas rotineiros realizados pelos enfermeiros. CONCLUSÃO: Portanto, verificou-se que o enfermeiro desenvolve papel fundamental no manejo clínico da úlcera venosa, demostrando a necessidade da busca constante de conhecimento e especialização no cuidado ao portador para promoção de atendimento sistemático e holístico. No entanto, identificou-se que há poucos estudos voltados para o reconhecimento e valorização do enfermeiro no manejo clínico úlceras venosas. Dessa forma, é necessário investir em pesquisas com o intuito de reforçar a atuação do enfermeiro, na qual possuem habilidade e capacidade no desenvolvimento de práticas quem tem a finalidade da resolubilidade e no processo de cicatrização da úlcera venosa.
\end{abstract}

Keywords: Úlcera venosa, Cuidados de enfermagem, Terapêutica

\section{Referências Bibliográficas}

Souza H, Araújo M. O enfermeiro no manejo clinico de pacientes com ulcera venosa: revisão integrativa de literatura. Revista Humano Ser [revista em Internet] 2016 setembro-dezembro. [acesso 19 de junho de 2019]; 10 (5). Disponível em: https://periodicos.unifacex.com.br/humanoser/article/view/623 Oliveira B. Caracterização dos pacientes com úlcera venosa acompanhados no Ambulatório de Reparo de Feridas. Revista Eletrônica de Enfermagem [revista em Internet] 2017 setembro-dezembro. [acesso 19 de junho de 2019]; 17 (11). Disponível em:

https://www.revistas.ufg.br/fen/article/view/10322 Pires J, Oliveira R. Assistência de enfermagem no controle e manejo da úlcera venosa. Revista Transformar, [revista em Internet] 2017 setembro-dezembro. [acesso 19 de junho de 2019]; 11 (8). Disponível em: http://www.fsj.edu.br/transformar/index.php/transformar/article/view/59/0 


\title{
AS ÚLCERAS VASCULOGÊNICAS NA PERSPECTIVA DA ASSISTÊNCIA DE ENFERMAGEM: REVISÃO DE LITERATURA
}

\author{
Author(s): Ana Savina da Rocha Amorim ${ }^{1,1,1}$, Bruno Vinícius Pereira Costa ${ }^{1,1,1}$, Ana Paula Oliveira ${ }^{1,1,1}$ \\ Institution(s) ${ }^{1}$ UNINASSAU - Faculdade UNINASSAU - Campus Parnaíba (Rodovia BR-343, Km 7,5, S/N - \\ Floriópolis, Parnaíba - PI, 64204-260), ${ }^{2}$ UNINASSAU - Faculdade UNINASSAU - Campus \\ Parnaíba (Rodovia BR-343, Km 7,5, S/N - Floriópolis, Parnaíba - PI, 64204-260), ${ }^{3}$ UNINASSAU - \\ Faculdade UNINASSAU - Campus Parnaíba (Rodovia BR-343, Km 7,5, S/N - Floriópolis, \\ Parnaíba - PI, 64204-260)
}

\begin{abstract}
INTRODUÇÃO: As úlceras vasculogênicas (UV) são de origem venosa, arterial ou mista, são as mais prevalentes, caracterizando-se por um processo crônico, doloroso, recorrente, com impacto negativo na qualidade de vida, na mobilidade, no estado emocional e na capacidade funcional das pessoas acometidas, exigindo atendimento multidisciplinar, com intervenções de natureza local e sistêmica. OBJETIVO: Verificar os cuidados de enfermagem realizados ao paciente com UV. MÉTODOS: Trata-se de uma revisão de literatura, executada a partir das bases de dados Lilacs, PubMed, Medline e Cinahl. Os critérios de inclusão dos materiais selecionados foram: publicações entre o período de 2014 a junho de 2019, estando em língua portuguesa, inglesa e espanhola, acessível na integra, artigos indexados em pelo menos uma das bases de dados supracitadas e localizáveis mediante palavras-chave e descritores: Úlceras vasculogênicas; Cuidados de enfermagem; Terapêutica. Critérios de exclusão: artigos científicos que não apresentassem pelo menos dois dos descritores utilizados, trabalhos que não tiveram relação direta com o tema, bem como os artigos que não foram encontrados textos completos disponíveis. Mediante os critérios de inclusão e exclusão foram selecionados 17 artigos que se enquadram nos objetivos. RESULTADOS: Evidencia-se que o enfermeiro é imprescindível no manejo clínico das UV no que diz respeito as estratégias para a promoção do bem-estar, mantendo uma comunicação efetiva favorecendo um plano terapêutico e acompanhamento contínuo, em conjunto com esse paciente, além de conhecer a história clínica do paciente para uma eficácia no tratamento. Entretanto, existe uma carência com relação as pesquisas que envolvem a valorização do enfermeiro diante de sua atuação na terapêutica das UV, visto que os mesmos são essenciais na prevenção desta patologia, no reestabelecimento da saúde, na educação do paciente e no desenvolvimento de curativos, na qual são práticas rotineiros realizados pelos enfermeiros. CONCLUSÃO: Portanto, verificou-se que o enfermeiro desenvolve papel fundamental no manejo clínico da UV, demostrando a necessidade da busca constante de conhecimento e especialização no cuidado ao portador para promoção de atendimento sistemático e holístico. No entanto, identificou-se que há poucos estudos voltados para o reconhecimento e valorização do enfermeiro no manejo clínico UV . Dessa forma, é necessário investir em pesquisas com o intuito de reforçar a atuação do enfermeiro, na qual possuem habilidade e capacidade no desenvolvimento de práticas quem tem a finalidade da resolubilidade e no processo de cicatrização da UV.
\end{abstract}

Keywords: Úlcera vasculogênica, Cuidados de enfermagem, Terapêutica

\section{Referências Bibliográficas}

Souza H, Araújo M. O enfermeiro no manejo clinico de pacientes com ulcera venosa: revisão integrativa de literatura. Revista Humano Ser [revista em Internet] 2016 setembro-dezembro. [acesso 19 de junho de 2019]; 10 (5). Disponível em: https://periodicos.unifacex.com.br/humanoser/article/view/623 Reis D, Peres G, Zuffi F. Cuidados às pessoas com úlcera venosa: percepção dos enfermeiros da estratégia de saúde da família. Revista Mineira de Enfermagem [revista em Internet] 2017 setembro-dezembro. [acesso 19 de junho de 2019]; 11 (9). Disponível em: http://www.reme.org.br/artigo/detalhes/582 Figueiredo M. Cuidados aos portadores de úlcera venosa: percepção dos enfermeiros da Estratégia de Saúde da Família. Enfermeria global [revista em Internet] 2016 setembro-dezembro. [acesso 19 de junho de 2019]; 19 (10). Disponível em: https://revistas.um.es/eglobal/article/view/eglobal.11.4.145431 


\title{
TEMPO DE CICATRIZAÇÃO DE FERIDAS EM PACIENTES ACOMPANHADOS POR UM SERVIÇO DE ATENÇÃO DOMICILIAR
}

\author{
Author(s): $\begin{aligned} & \text { Amanda da Silva Miranda }{ }^{2} \text {, Mayara Letícia Matos de Menezes Rapôso }{ }^{2} \text {, Ivana de Oliveira } \\ & \text { Cordeiro }{ }^{2}\end{aligned}$ \\ Institution(s) ${ }^{2}$ Curativos - Curativos Serviços de Saúde Domiciliar (R. Almirante Barroso, no 358 - Rio \\ Vermelho Salvador - BA)
}

\begin{abstract}
Introdução: A Atenção Domiciliar $(A D)$ é uma modalidade de atendimento que visa à integralidade e às ações de promoção à saúde, cuidado paliativo, prevenção e tratamento de doenças e reabilitação no ambiente extra hospitalar. Existem, atualmente, cerca de 480 Serviços de atenção Domiciliar (SAD) e 930 equipes multiprofissionais de saúde em todo o Brasil. Uma prevalência considerável de pacientes com feridas acompanhados pelos SADs tem sido observada na prática clínica. As feridas cirúrgicas, úlceras de perna e as lesões por pressão (LPs) são relatadas como as mais prevalentes (MACHADO, 2019). Objetivo: Descrever o tempo para cicatrização de lesões em um serviço de atenção domiciliar. Metodologia: Estudo longitudinal, retrospectivo e observacional conduzido em um Serviço de Atenção Domiciliar particular de Salvador, Bahia. $O$ Serviço atua com ênfase no cuidado domiciliar em todos os níveis de atenção. Para modalidade gerenciamento, o tratamento de lesões é sua maioria, com equipe de enfermeiros e técnicos na capital e no interior do estado que revezam os atendimentos na frequência estabelecida pelo plano terapêutico assistencial, uma enfermeira estomaterapeuta gestora de feridas e sua diretora enfermeira dermatológica. Foi realizado uma busca de dados em sistema IW software, através de relatórios filtrando dados entre junho de 2018 à junho 2019, com as informações cruzadas de tipo de lesão versus tempo de atendimento com o motivo de alta fechamento de lesões, tabulado em documento Microsoft Excel, após isso feito cálculo de mediana para cada tipo de ferida. Resultados: Foram extraídos 31 prontuários com os diversos tipos de feridas e o tempo de atendimento. As LPs tiveram um $\mathrm{N}$ de 11 prontuários com tempo de fechamento de desde 5 dias à 6 meses, com mediana em 1 mês. Pé diabético foram encontrados três prontuários com tempo entre três a cinco meses, com mediana do tempo inicial. Úlceras de perna tiveram 8 prontuários com um tempo que variaram de 7 dias à 8 meses com mediana de 2 meses. Além destas, teve lesões por queimaduras, quatro prontuários que variaram entre 16 dias à quatro meses com mediana de um mês. Lesões cirúrgicas quatro casos entre 20 dias e quatro meses com tempo mediano de 50 dias. Uma lesão com classificação oncológica com tempo de fechamento de 1 mês. Não se tem dados em literatura brasileira para realização de comparações em tempo de cicatrização. Em 2018 foi feito um estudo em São Paulo que trouxe um dado de mediana para cicatrização de LP de 44 dias. Não foram utilizados dados de prontuários não comprometendo sua integridade. Conclusão: Considerando que o processo de cicatrização de lesões crônicas é algo complexo e multifatorial, neste estudo foi percebido uma evolução rápida de cicatrizações de lesões, embora não se tenha encontrado estudos descrevendo tempo de fechamento de lesões. Diante dos resultados, estudos que avaliem os fatores que interferem na cicatrização e que comparem isto à outros serviços de saúde e na $A D$ permitirão verificar similaridades e/ou divergências entre as características da amostra e a evolução cicatricial.
\end{abstract}

Keywords: Estomaterapia, Assistência domiciliar, Pacientes domiciliares, Lesão por pressão, Cicatrização

\section{Referências Bibliográficas}

Araújo AGCC, Sousa JTO, Vasconcelos SMBV, Pereira LAP, Gomes SKA. Feridas complexas e estomias Aspectos preventivos e manejo clínico [Internet]. Available from: www.ideiaeditora.com.br Machado ODMSJ, Coelho RP, Cecconi CO, Santos JGML, et al. Artigo Original cicatrização de lesões por pressão em pacientes acompanhados por um serviço de atenção domiciliar 1. [cited 2019 Aug 11]; Available from: http://dx.doi.org/10.1590/0104-07072018005180016 


\title{
Caracterização dos pacientes com úlcera venosa em tratamento na Atenção Primária à Saúde em cidade de médio porte do interior de Minas Gerais
}

\author{
Author(s): Hélio Martins do Nascimento Filho ${ }^{1}$, Natália Ferreira Gonçalves Perdigão de Castro ${ }^{2}$, Leila Blanes \\ ${ }^{1}$, Daniela Tinti Moreira Borges ${ }^{1}$, Flávia Carla Takaki Cavichioli ${ }^{1}$, Lydia Masako Ferreira ${ }^{1}$ \\ Institution(s) ${ }^{1}$ UNIFESP - Universidade Federal de São Paulo UNIFESP (Rua Botucatu, 740 - $2^{\circ}$ andar - Vila \\ Clementino, CEP:04023-062 - SP/SP), ${ }^{2}$ FASAR - Faculdade Santa Rita (Estrada Real Km 02 \\ (Cons. Lafaiete via Ouro Branco) Minas Gerais)
}

\begin{abstract}
Introdução

A Úlcera Venosa (UV) é considerada um problema de saúde pública mundial. Nos Estados Unidos da América cerca de um bilhão de dólares são gastos anualmente com o tratamento de pacientes com a ferida.

Ela é a ferida mais prevalente nos membros inferiores e geralmente ocorre no terço distal da perna, entre o tornozelo e o joelho. Estima-se que 1,0\% das pessoas que vivem no ocidente desenvolverão a lesão durante sua vida e que nos idosos com mais de 80 anos essa taxa chegue a 2,0\%.

Em Conselheiro Lafaiete, cidade de médio porte do interior de Minas Gerais, localizada a cerca de 100 quilômetros da capital Belo Horizonte, a prevalência de feridas crônicas em pacientes atendidos nas equipes de Unidade Saúde da Família (USF) é de 0,164\%. No Município 50\% das úlceras tratadas nas Atenção Primária à Saúde (APS) possuem etiologia venosa.

Objetivo: Caracterizar os pacientes com úlcera venosa em tratamento na Atenção Primária à Saúde em cidade de médio porte no interior de Minas Gerais.

Material e método: Estudo primário, exploratório, observacional, transversal e com análise descritiva dos resultados, realizado na Atenção Primária à Saúde (APS) de Conselheiro Lafaiete-MG que é composta por 28 equipes de Unidade Saúde da Família (USF) e 06 Postos de Saúde. Foram incluídos pacientes acima de 18 anos e com úlcera venosa ativa no momento da coleta dos dados. Não foram coletados dados específicos das UV.

Para coleta dos dados dos participantes foi utilizado a ficha de cadastro individual de pacientes na APS do Sistema Único de Saúde (SUS). Após a coleta das informações foi caracterizada a distribuição da frequência relativa (percentuais) das variáveis qualitativas através do Teste de Igualdade de Duas Proporções. Foi necessária uma análise de relação e/ou associação entre as questões. Utilizou-se o Teste de Qui-Quadrado para Independência. Para a comparação dos escores dos protocolos para as covariaveis qualitativas, quanto a média de variáveis quantitativas foi utilizado o teste de ANOVA. Com a Correlação de Pearson foi mensurado o quanto as variáveis estavam interligadas.
\end{abstract}

Resultados: Foram identificados 90 pacientes com UV ativa e convidados a participar da pesquisa e 75 pacientes aceitaram participar. A amostra foi compota por $60 \%$ de pacientes do gênero feminino com média de idade 68,9 anos (min. 38 anos e máx. 94), $16 \%$ se autodeclararam brancos, $57,3 \%$ pardos e $26,7 \%$ negros. Em relação a situação no mercado de trabalho $72 \%$ eram aposentados/pensionistas, $17,3 \%$ não trabalhavam, 6,7\% trabalhavam e 2,7\% estavam desempregados $2,7 \%$. São hipertensos $73,3 \% \%$ e diabéticos $32 \%$. Etilistas eram 6,7 e tabagistas $14,7 \%$.

Conclusões: Na Atenção Primária à Saúde de Conselheiro Lafaiete - Minas Gerais a úlcera venosa é mais prevalente em mulheres idosas da cor parda e que eram aposentados/pensionistas. A comorbidades mais comum encontrada foi a hipertensão arterial sistêmica.

Keywords: Úlcera Varicosa, Estomaterapia, Ferimentos e lesões, Estratégia Saúde da Família, Demografia

\section{Referências Bibliográficas}

Borges EL, Caliri MHL, Haas VJ, Ferraz AF, Spira JO, Tyrone AC. Use of the Diffusion of Innovation Model in venous ulcers by specialized professionals. Rev Bras Enferm. 2017;70(3): 610-7. Borges EL, Nascimento-Filho HM, Pires-Júnior JF. Prevalência de Lesões Crônicas de Município de Zona da Mata Mineira. Revista Mineira de Enfermagem. 2018;22: e-1143. Costa IKF, Dantas DV, Tibúrcio MP, Medeiros LP, Torres GV, Melo GSM. Protocolo de assistência a pessoas com úlcera venosa na Atenção Primária: revisão integrativa da literatura. Revista Online de Pesquisa 2017; abr./jun;9(2): 566-74. Heyer K, Protz K, Glaeske G, Augustin M. Epidemiology and use of compression treatment in venous leg ulcers: nationwide claims data analysis in Germany. International Wound Journal. 2016;14(2): 338-43. Salomé GM, Blanes L, Ferreira LM. The impact of skin grafting on the quality of life and self-esteem of patients with venous leg ulcers. World J Surg. 2014 Jan;38(1):23340. 


\title{
CUIDADOS COM OS PÉS DE PESSOAS COM DIABETES MELLITUS TIPO 2 E ÚLCERAS NEUROPÁTICAS ATENDIDAS EM UMA CLÍNICA INTEGRADA DE SAÚDE
}

\author{
Sherida Karanini Paz de Oliveira ${ }^{1}$, Larissa Emília Magalhães Oliveira ${ }^{2}$, Leonardo Cardoso de \\ Author(s): $\quad$ Sousa $^{2}$, Luciana Catunda Gomes de Menezes ${ }^{2}$, Georgia Catunda Gomes Neves ${ }^{2}$, Lidia Stella \\ Teixeira de Meneses ${ }^{1}$, Samira Raquel Valcacer Pinheiro ${ }^{1}$ \\ Institution(s) ${ }^{1}$ UECE - UNIVERSIDADE ESTADUAL DO CEARÁ (AV. DR SILAS MUNGUBA, 1700. \\ ITAPERI. FORTALEZA-CE.), ${ }^{2}$ UNIFAMETRO - CENTRO UNIVERSITÁRIO FAMETRO (Av. \\ Padre Ibiapina, 1243 Centro - Fortaleza/CE)
}

\begin{abstract}
INTRODUÇÃO: Diabetes mellitus (DM) é uma condição crônica não transmissível muito presente na atualidade, sendo o pé diabético uma de suas complicações acarretando em danos a população1. O enfermeiro, em sua prática clínica, estimula o autocuidado com vistas a mudanças nos hábitos de vida, possibilitando assim, a redução de complicações do diabetes2. OBJETIVOS: descrever as atividades de autocuidado de pessoas com diabetes mellitus tipo 2 e úlceras neuropáticas atendidas em uma Clínica Integrada de Saúde. MÉTODO: Estudo transversal realizado em uma Clínica Integrada de Saúde de uma Instituição de Ensino Superior de nível privado, em Fortaleza-Ceará-Brasil, entre abril a agosto de 2019. Compôs a amostra 17 pacientes que foram acompanhados e avaliados nas consultas ambulatoriais da Estomaterapia. Utilizaram-se uma entrevista semiestruturada contemplando dados sociodemográficos e clínicos, e o Questionário de Atividades de Autocuidado (QAD)3. Os dados foram expostos em tabelas e analisados por meio de estatísticas descritivas simples. Os aspectos éticos e legais foram respeitados e o estudo foi aprovado pelo Comitê de Ética em Pesquisa sob no 3164340 e CAAEE no 08284019.4.0000.5618. RESULTADOS: Nos resultados predominaram homens $(65 \%)$, casados $(65 \%)$, baixa escolaridade (47\%) com média de 7,0 $\pm 4,5$ anos de estudo, renda de até 2 salários mínimos $(76 \%)$ e média de idade de $50,7 \pm 10,6$ anos. Em relação aos aspectos clínicos, $47 \%$ dos participantes receberam o diagnóstico entre um a dez anos, com média de 13,4 $\pm 9,7$ anos, $59 \%$ faziam uso de hipoglicemiantes orais e insulina, $64,7 \%$ realizavam monitoração glicêmica diariamente, $65 \%$ seguiam um plano alimentar, $71 \%$ tinham lesões há mais de quatro meses, $74 \%$ eram hipertensos e deficientes visual, todos sedentários e $94 \%$ obesos. Com relação aos cuidados com os pés por meio do QAD, identificou-se um autocuidado que precisa ser estimulado e reforçado. Na variável "examinar os pés", obteve-se média de 3,35/7 dias, o "examinar dentro dos sapatos", era realizado pelos pacientes em 2,94/7 dias, revelando cuidados insatisfatórios. O item "secar entre os dedos dos pés" apresentou média de 4,94/7 dias, apresentando um valor próximo do satisfatório. A limitação visual representa uma das dificuldades no cuidado com os pés e o apoio familiar é um aspecto facilitado do autocuidado. CONCLUSÃO: Conclui-se que há necessidade de contínua sensibilização, estímulo e apoio para o desenvolvimento de habilidades e realização do autocuidado com foco na prevenção de complicações nos pés de pessoas com diabetes mellitus.
\end{abstract}

\section{Keywords: ESTOMATERAPIA , PÉ DIABÉTICO, AUTOCUIDADO}

\section{Referências Bibliográficas}

1. Menezes LCG. et al. Pesquisa ação: práticas de autocuidado das pessoas com pé diabético. Rerv. Enferm. UFPE online, Recife, 2017 v. 11, n.9, p3558-3566. 2. Grupo de Trabalho Internacional sobre o Pé Diabético. Consenso Internacional sobre o Pé Diabético. Tradução de Ana Claudia de Andrade, Hermelinda Cordeiro Pedrosa, Brasília: Secretaria de Estado de Saúde do Distrito Federal, 2015. z...3. MICHELS, M. J; et al. Questionário de Atividades de Autocuidado com o Diabetes: tradução, adaptação e avaliação das propriedades psicométricas. Arq Bras Endocrinol Metab, Florianópolis, v 54, n 7, p 644-651, Fevereiro-Agosto de 2010. Disponível em:. Acesso em: 12 out. 2018. 


\title{
Processo de enfermagem no paciente pós-operatório de bariátrica com lesão por pressão
}

\author{
Author(s): Camila Binsi Scopel ${ }^{1}$, Catrine Storch Moitinho ${ }^{1}$, Elisângela Ribeiro Chaves ${ }^{1}$, Danielle Castilho ${ }^{1}$, \\ Isabel Cussi ${ }^{1}$, Maria Delnides de Sousa Azevedo ${ }^{1}$ \\ Institution(s) ${ }^{1}$ HUCAM - Hospital Universitário Cassiano Antonio Moraes ( Av. Mal. Campos, 1355 - Santa \\ Cecilia, Vitória - ES, 29043-260)
}

\begin{abstract}
Introdução: A cirurgia bariátrica é destinada ao tratamento da obesidade e doenças associadas ou agravadas por ela; e Lesão por pressão (LP) é um dano na pele e/ou tecidos moles subjacentes, sobre proeminência óssea e como resultado da pressão intensa e/ou prolongada combinada com cisalhamento. Objetivo: relatar o caso de um paciente com complicações clínicas no pós-operatório de gastrectomia parcial. Materiais e método: busca das informações por revisão do prontuário, anamnese e exame físico, revisão da literatura, baseado no referencial teórico de Horta e taxonomia de NANDA. Paciente, sexo masculino, 32 anos, procurou o serviço para tratamento da obesidade mórbida $(200 \mathrm{~kg}$ e IMC=68,5). As necessidades humanas básicas comprometidas são turgor e elasticidade da pele diminuídos; paresia do membros inferiores e membro superior direito; dependência de grau parcial para o autocuidado; LP grau 4 em região sacral; polineuropatia periférica. Diagnósticos de Enfermagem: integridade da pele prejudicada; integridade tissular prejudicada. Evolução: acompanhamento terapêutico, com avaliação e implementação de medidas de conforto, indicação das coberturas, características do estadiamento da LP; controle das áreas de pressão tegumentar; auxílio e estímulo à mobilidade. A LP no período de 33 dias evoluiu de necrose de coagulação para tecido de granulação (80\%) e necrose de liquefação $(20 \%)$. Conclusão: melhora da LP, apesar da terapêutica complexa, acompanhada pelo enfermeiro referenciado teoricamente $\mathrm{e}$ com aplicação das taxonomias diagnósticas, de resultados e intervenções. Contribuições para Enfermagem: o enfermeiro deve participar na evolução clínica do paciente e intervir no processo de prevenção e tratamento da LP, com o cuidado fundamentado que possibilite a melhora da qualidade da assistência de enfermagem prestada e do bem-estar do paciente.
\end{abstract}

Keywords: Estomaterapia, Lesão por Pressão, Processo de Enfermagem

\section{Referências Bibliográficas}

1. Sociedade Brasileira Cirurgia Bariátrica e Metabólica. Disponível em: http://www.sbcbm.org.br/wordpress/tratamentocirurgico/cirurgia-bariatrica-e-metabolica/. 2. Associação Brasileira de Estomaterapia. Classificação das lesões por pressão. Consenso NPUAP 2016. Disponível em: http://www.sobest.org.br/textod/35. Acesso em: 01 de julho de 2019. 3. NANDA INTERNATIONAL. Diagnósticos de enfermagem da NANDA: definições e classificação 2018-2020. 11edição. Porto Alegre: Artmed, 2018. 4. HORTA, Wanda de Aguiar. Processo de enfermagem / Wanda de Aguiar Horta; com a colaboração de Brigitta E. P. Castellanos - [Reimpr.].- Rio de Janeiro: Guanabara Koogan, 2018. 


\title{
Infecção de ferida cirúrgica em pacientes após cirurgia bariátrica
}

\author{
Author(s): $\quad{ }_{1}^{\text {Ramon Araújo Santos }}{ }^{1}$, Celia Maria de Oliveira ${ }^{2}$, Camila Binsi Scopel ${ }^{1}$, Catrine Storch Moitinho \\ Institution(s) ${ }^{1}$ HUCAM - Hospital Universitário Cassiano Antonio Moraes ( Av. Mal. Campos, 1355 - Santa \\ Cecilia, Vitória - ES, 29043-260), ${ }^{2}$ UFMG - Universidade Federal de Minas Gerais (Av. Pres. \\ Antônio Carlos, 6627 - Pampulha, Belo Horizonte - MG, 31270-901)
}

\begin{abstract}
Introdução: A obesidade está em processo de crescimento e com isso, diminuindo a expectativa e a qualidade de vida da população. A cirurgia bariátrica nesse cenário representa uma alternativa eficaz para o tratamento da obesidade e seu crescimento como escolha terapêutica chama atenção visto que das complicações pós-operatórias a infecção da ferida operatória é uma das mais comuns, levando em consideração que a população obesa que é submetida ao procedimento operatório tem risco adicional devido a comorbidades presentes. Objetivo: Objetivou-se analisar a publicações científicas sobre prevalência e fatores de risco para infecção de ferida cirúrgica (ISC) em pacientes submetidos à cirurgia bariátrica. Material e Método: Revisão integrativa de literatura, realizada através de levantamento bibliográfico nas produções científicas na Biblioteca Virtual em Saúde (BVS), na Literatura Latino Americana e do Caribe em Ciências da Saúde (LILACS), Scientific Electronic Library Online (Sciello) e portal Medical Literature Analysis and Retrieval Sistem on-line (MEDLINE) em janeiro e fevereiro de 2018. Foram utilizados os descritores em Ciências da Saúde (DeCS): Infecção de ferida operatória. Complicações pós-operatórias. Gastroplastia. Cirurgia bariátrica. Prevalência. Epidemiologia. O estudo foi feito por etapas, a saber: $1^{\circ}$ Etapa: identificação do tema e problema de estudo; $2^{\circ}$ etapa: Busca na literatura de estudos primários, estratégias de busca/ extração dedados nas bases de dados e critérios de inclusão/exclusão; $3^{\circ}$ etapa: extração de dados dos estudos primários e categorização dos estudos. $4^{\circ}$ etapa: avaliação dos estudos primários incluídos. 5ำ etapa: interpretação dos resultados. 6ำ etapa: apresentação da revisão integrativa. Resultados: Os 19 estudos selecionados, os dados extraídos apresentaram número de casos, fatores de risco e critérios diagnósticos de ISC. A taxa de ISC ficou
\end{abstract}

Keywords: Cirurgia bariátrica, Complicações pós-operatórias., Estomaterapia , Gastroplastia, Infecção de ferida operatória

\section{Referências Bibliográficas}

1. Associação Brasileira para o Estudo da Obesidade e da Síndrome Metabólica. Diretrizes brasileiras de obesidade. 4 ed. São Paulo: ABESO; 2016. 2. Oliveira AC, Silva MVG. Teoria e prática na prevenção da infecção do sítio cirúrgico. Barueri: Manoel; 2015. 3. Pierpont YN, Dinh TP, Salas RE, Johnson EL, Wright TG, Robson MC et al. Obesity and surgical wound healing: a current review. ISRN Obesity [internet]. 2014 Feb. [cited 2019 Ap. 04]; 2014(1): 13p. Available from: https://doi.org/10.1155/2014/638936. 


\title{
Construção e implantação de manual de tratamento de feridas e lesões periestomais
}

Camila Binsi Scopel ${ }^{1}$, Catrine Storch Moitinho ${ }^{1}$, Danielle Castilho ${ }^{1}$, Juliana Corsini ${ }^{1}$, Elisângela

Author(s): $\quad$ Ribeiro Chaves ${ }^{1}$, Ramon Araújo de Santos ${ }^{1}$, Andressa Tomazini Borghardt ${ }^{1}$, Fabiana Goring Xavier $^{1}$

Institution(s) ${ }^{1}$ HUCAM - Hospital Universitário Cassiano Antonio Moraes ( Av. Mal. Campos, 1355 - Santa Cecilia, Vitória - ES, 29043-260)

\begin{abstract}
Introdução: O tratamento de uma ferida é uma atribuição complexa que requer conhecimento e a adoção de medidas sistematizadas de cuidado. Para garantir a confiabilidade à assistência de enfermagem a pacientes com feridas e lesões periostomais, por meio de procedimentos seguros, baseados em evidências científicas, é imprescindível a construção de um manual de tratamento de lesões. A implantação de um manual de tratamento fornece um conhecimento científico, com uma abordagem holística das necessidades do paciente, o que contribui para o raciocínio clínico na tomada de decisões. Objetivo: Este trabalho tem como objetivo relatar a experiência de enfermeiros membros de uma comissão de Cuidados com a pele na construção e implantação de um manual de tratamento de feridas e lesões periestomais. Materiais e método: Trata-se de um relato de experiência descrito através de um olhar qualitativo, abordando o tema a partir de métodos descritivos e observacionais vivenciados na construção e implantação de um manual de tratamento de feridas e lesões periestomais em um hospital universitário do Espírito Santo, entre o período de 2016 a 2019. Resultados: As atividades para construção do manual se iniciaram em 2016 quando os enfermeiros membros da Comissão Cuidados com a Pele (CCP) vislumbraram a necessidade de orientar e padronizar as condutas de tratamento de feridas e lesões periestomais na instituição, afim de prestar uma assistência de qualidade a pessoa afetada, uma vez que o tratamento adequado dessas comorbidades, diminui a morbimortalidade e melhoram a qualidade de vida da população em questão, e consequentemente reduz os gastos públicos. Formou-se um grupo de enfermeiros dentro da própria Comissão para otimizar o tempo com reuniões específicas a partir da revisão de literatura e artigos científicos, com a finalidade de fomentar o conhecimento contínuo na área de estomaterapia, além de promover o enfoque nas classificações e avaliação das lesões e tratamento com produtos e coberturas especiais. Após sua confecção, o manual passou pela validação do conteúdo elaborado. Atualmente, encontra-se disponível em sistema eletrônico compartilhado (Intranet), com divulgação de conteúdo e capacitações dos profissionais de enfermagem oferecidas pela própria Comissão. Conclusão: A construção do manual trouxe uma nova experiência de estruturação de um serviço de cuidados com lesões de pele, uma vez que a implementação de práticas inovadoras baseadas em evidências no cuidado aos indivíduos com feridas, proporcionam uma atuação segura e eficiente do enfermeiro sendo o maior beneficiado com essa abordagem o indivíduo com lesões de pele. Ademais, considera-se que essa metodologia de cuidado viabiliza a redução de custos, evita o desperdício de materiais e medicamentos, promove a diminuição do tempo dispensado pelos profissionais de enfermagem na realização dos cuidados com a lesão e com os demais problemas de saúde desses indivíduos.
\end{abstract}

Keywords: Assistência de Enfermagem, Educação em Saúde, Enfermagem , Estomaterapia

\section{Referências Bibliográficas}

1. Figueiredo TWB, Mercês NNA, Lacerda MR, Hermann AP. Construção de um protocolo de cuidados de enfermagem: relato de experiência. Rev. Bras. Enferm. [Internet]. 2018 [citado 2019 Ago 25]; 71(Suppl 6): 2837-2842. Disponível em: http://www.scielo.br/scielo.php?script=sci_arttext\&pid=S0034-71672018001202837\&lng=pt. http://dx.doi.org/10.1590/00347167-2017-0846. 2. Lima AFC, Castilho V, Rogenski NMB, Baptista CMC, Rogenski KE. Custos da implantação de um protocolo de prevenção de úlceras por pressão em um hospital universitário. Rev. Eletr. Enf. [Internet]. 2015 out. /dez.;17(4). Disponível em: http://dx.doi.org/10.5216/ree.v17i4.31051. 3. Mittag BF, Krause TCC, Roehrs H, Meier MJ, Danski MTR. Cuidados com lesão de pele: Ações de enfermagem. ESTIMA, v.15 n.1, p. 19-25, 2017. Disponível em: https://www.revistaestima.com.br/index.php/estima/article/view/447/pdf. 


\title{
APLICAÇÃO DE PAPAÍNA EM PÓ 15\% EM ÚLCERAS FALCÊMICAS
}

Dayse Carvalho do Nascimento ${ }^{1}$, graciete saraiva marques ${ }^{1}$, norma valeria dantas de oliveira Author(s): $\quad$ souza $^{2}$, Patricia Alves dos Santos Silva ${ }^{2}$, deborah dos Santos Machado ${ }^{2}$, rosangela guimarães machado ${ }^{1}$

Institution(s) ${ }^{1}$ HUPE/UERJ - HOSPITAL UNIVERSITÁRIO PEDRO ERNESTO (Av 28 de setembro,77- Vila Isabel - Rio de Janeiro), ${ }^{2}$ CEEBDR - Clínica de Enfermagem em Estomaterapia Benedita Deusdará Rod (Av Marechal Rondon, 381, $2^{\circ}$ andar - São Francisco Xavier- Rio de Janeiro)

\begin{abstract}
INTRODUÇÃO: Pessoas com úlceras falcêmicas exigem cuidados prolongados e contínuos, pois alternam períodos de agudização e estabilização da doença com alteração de autoimagem acompanhados de dores intensas. Nesse contexto, tem-se a maior incidência de úlceras falcêmicas em homens, podendo-se agravar o quadro clínico por questões de gênero, que culturalmente constroem o sentimento de invulnerabilidade e provedor familiar. Essas questões de gênero conduzem a uma dificuldade de procurarem os serviços de saúde postergando condutas de prevenção e tratamento, agravando a ferida e seu quadro levando à internação1,2. Com o avanço da tecnologia na área da saúde, novas terapias tópicas vêm sendo incorporadas na prevenção e tratamento de feridas. Entre estas, a papaína se destaca por seu custo e benefício científico: mistura complexa de enzimas proteolíticas e peroxidases, proveniente do látex do fruto do mamoeiro (Carica papaya), que atua como desbridante enzimático, bactericida, bacteriostático, anti-inflamatório, estimula a força tênsil, e ainda, proporciona alinhamento das fibras de colágeno para obtenção de cicatrização uniforme. Pode ser utilizada em lesões com diferentes etiologias, faixas etárias e fases do processo de cicatrização3,4. OBJETIVOS: Analisar a aplicação da papaína em pó $15 \%$ no tratamento de úlcera falcêmica. MATERIAL E MÉTODO: Pesquisa qualitativa, descritiva e exploratória desenvolvida em ambulatório do Hospital Universitário, no Rio de Janeiro. A avaliação e evolução realizadas através de exame clínico e registro fotográfico, com assinatura do Termo de Consentimento Livre e Esclarecido (CEP: 3.292.609, CAAE: 10523919.3.0000.5259), em 12 pacientes homens, idade entre 18 e 61 anos. As feridas apresentavam-se excessivamente dolorosas, pouco tecido de granulação, esfacelo e exsudato seroso abundantes, maceração e hiperemia em áreas periferidas. RESULTADO: Considerando a necessidade de desbridamento e de estimular o crescimento de tecido de granulação, optou-se pelo uso da papaína em pó em diferentes concentrações, de acordo com a avaliação do estomaterapeuta, associada soro fisiológico $0,9 \%$. E ainda, para proteção de área macerada e hiperemiada foi aplicado óxido de zinco $10 \%$ em pó. As trocas foram realizadas diariamente. As lesões apresentaram diminuição gradativa do tecido desvitalizado, aumento de tecido de granulação e contração de bordas. CONCLUSÃO: A evolução das feridas se deu de forma plena com sucesso do tratamento tópico atribuído à atuação sistematizada e especializada do Estomaterapeuta com seu conhecimento científico sobre aplicação da papaína em feridas.
\end{abstract} DESCRITORES: Doença Falciforme, Estomaterapia, Úlceras de perna

Keywords: doença falciforme, estomaterapia, úlceras de perna

\section{Referências Bibliográficas}

1.Espírito Santo FH, Carvalho EMMS, Debora KV. Desafios do homem com doença falciforme no processo de viver e ser saudável. In: Reis A, Pereira A. Saúde de homens: conceitos e prática de cuidados. Rio de Janeiro: Águia Dourada, 2017, p.149-165. 2.Alves RF, Silva RP, Ernesto MV, Lima AGB, Souza FM. Gênero e saúde: o cuidar do homem em debate. Psicol. Teor. Prát., São Paulo, 2011. 13(3), p.152-66. 3.Marques GS, Nascimento DC, Monteiro AP. Protocolo 4: Estomaterapia. In: Souza RD; Assad LG; Paz AFD (org.) Procedimentos Operacionais - padrão de Enfermagem. Volume IIParte I. São Paulo: Triunfal, 2015. p.142-6. 4. Tavares AS, Nascimento DC, Marques GS, Souza NVDO, Almeida PF, Silva PAS et al. Aplicação de papaína em pó em deiscência de ferida operatória infectada. In: semiologia de enfermagem [recurso eletrônico]/Organizadora Isabelle C.de N. Sombra. - Ponta Grossa, PR: Atena Editora, 2019. p . 261-5. 


\title{
IDENTIFICAÇÃO DOS FATORES DE RISCO DO DIAGNÓSTICO DE ENFERMAGEM "RISCO DE INTEGRIDADE DA PELE PREJUDICADA"
}

\author{
Author(s): IASMYM OLIVEIRA GOMES ${ }^{1}$, AMANDA DACAL NEVES ${ }^{1}$, SUZANA LINS DA SILVA ${ }^{1,2}$, \\ CARINA RIBEIRO DE OLIVEIRA ${ }^{1,3}$, MARIA DE FÁTIMA COSTA CAMINHA ${ }^{2,1}$ \\ Institution(s) ${ }^{1}$ FPS - FACULDADE PERNAMBUCANA DE SAÚDE (Av. Mal. Mascarenhas de Morais, 4861 - \\ Imbiribeira, Recife - PE, 51210-902), ${ }^{2}$ IMIP - INSTITUTO DE MEDICINA INTEGRAL \\ PROFESSOR FERNANDO FIGUEIRA (Rua dos Coelhos, No 300, Boa Vista - Recife - PE - \\ Brasil. CEP 50070-902), ${ }^{3}$ HOF - HOSPITAL OTÁVIO DE FREITAS (R. Aprígio Guimarães, s/n - \\ Tejipio, Recife - PE, 50920-460)
}

\begin{abstract}
Introdução: O prejuízo da integridade da pele em pacientes hospitalizados é apontado como um dos indicadores de qualidade da assistência de enfermagem nos serviços de saúde e, sua ocorrência, constitui um problema de saúde pública, considerando o impacto que tem para o paciente, família e sociedade. Objetivo: Identificar a existência dos fatores de risco do Diagnóstico de Enfermagem Risco de Integridade da Pele Prejudicada em pacientes internados. Métodos: estudo transversal cuja coleta de dados foi realizada nas unidades de internação (clínica médica, clínica cardiológica, clínica cirúrgica e UTIs) de um Hospital de referência do Sistema Único de Saúde (SUS). Aplicou-se um formulário com dados sociodemográficos e clínicos seguido de avaliação do risco de integridade da pele prejudicada com a escala de Braden. Os dados foram analisados no Stata 12.1 e os resultados apresentados em tabelas com frequências absoluta e relativa. $O$ estudo foi aprovado pelo Comitê de Ética em Pesquisa CAAE no 03395418.0.0000.5201. Resultados: Participaram do estudo 149 indivíduos. Predominou a faixa etária de 36 a 64 anos (55,0\%), do sexo masculino (55,7\%) e procedente do domicílio (73,2\%). Em relação ao setor de internamento, 52,3\% estavam na clínica médica e 44,3\% estavam internados há uma semana. Com relação ao comprometimento dos sistemas $30,9 \%$ dos pacientes estavam com sistema cardiovascular comprometido. A respeito dos fatores de risco relacionados ao Diagnóstico de Enfermagem Risco de Integridade da Pele Prejudicada, apenas $4 \%$ estavam com a temperatura acima de $39,5^{\circ} \mathrm{C}, 2,7 \%$ estavam em uso de ventilação mecânica e $4,7 \%$ em uso de drogas vasoativas. Observou-se que $61,7 \%$ não possuíam limitação quanto à percepção sensorial, por outro lado um pouco mais da metade $(54,4 \%)$ encontravam-se com algum tipo de limitação no que diz respeito à mobilidade. Considerando a nutrição $51,0 \%$ estavam adequados, seguidos de $22,8 \%$ com excelente alimentação. Após análise, a pontuação do escore total apontado pela Escala de Braden, foi que 61 (40,9\%) dos pacientes apresentaram risco, desses, 46 (30,9\%) eram baixo risco. Conclusão: Esse estudo possibilitou a identificação dos fatores de risco para o Diagnóstico de Enfermagem Risco de Integridade da Pele Prejudicada, em um Hospital de referência do Sistema Único de Saúde. Apesar da baixa incidência dos fatores de risco para a Integridade da Pele Prejudicada, utilizando a Escala de Braden, observamos que uma boa parte apresentava risco para a Integridade da Pele Prejudicada/LPP. Destaca-se a importância da adoção de medidas preventivas para a diminuição da ocorrência deste agravo, visto que constitui um problema de saúde importante, tendo como objetivo a utilização da Escala de Braden frequente e adequadamente como um instrumento preventivo.
\end{abstract}

Keywords: Diagnóstico de Enfermagem, Lesão por pressão, Enfermagem, Estomaterapia

\section{Referências Bibliográficas}

1. Galvão NS, Neto DL, Oliveira APP. Aspectos epidemiológicos e clínicos de pacientes com úlcera por pressão internados em uma instituição hospitalar. Universidade Federal do Amazonas, Manaus. Revista da associação brasileira de estomaterapia: estomias, feridas e incontinências, 2012 13(3). 2. Quirino DES, Faustino AM, Freitas RO, Oliveira AB, Medved IV. Fatores de risco para o desenvolvimento para Lesão por Pressão em unidade de internação clínica, Rev da Associação brasileira de estomaterapia 2014. Vol 12, n4; 3. Pereira AFM, et al. Pressure injury incidence in a university hospital - Rev Enferm UFPI. 2017 ; 7 Jan-Mar;6(1):36-9. 4. Silva MLN, Caminha RTÓ, Oliveira SHS, Diniz ERS, Oliveira JL, Nevez VSN. Ulcera por pressão em unidade de terapia intensiva: Análise das incidências e lesões instaladas. Rev Rene. 2013; 14(5):938-44.Disponível em: http://www.redalyc.org/html/3240/324028789010/. 5. Mallah Z, Nassar N, Kurdahi BL. The effective ness of a pressure ulcers intervention program on the prevalence of hospital acquired pressure ulcers: controlled before and after study. App1NursRes. 2015. 


\title{
EFICÁCIA DO USO DE PRATA IÔNICA EM FERIDA INFECTADA: UMA SÉRIE DE CASOS
}

\author{
Amanda da Silva Miranda ${ }^{1}$, Mayara Letícia Matos de Menezes Rapôso ${ }^{1}$, Ivana de Oliveira \\ Author(s): $\quad$ Cordeiro ${ }^{1}$, Ana Patrícia de Cerqueira Greco ${ }^{1}$ \\ Institution(s) ${ }^{1}$ HSR - Hospital São Rafael (Av. São Rafael, 2152 - São Marcos, Salvador - BA)
}

\begin{abstract}
Introdução: O controle do processo infeccioso no leito da ferida está diretamente relacionado com um retardo no processo cicatricial e aumento de área comprometida com necrose e biofilme. Tanto feridas agudas quanto crônicas podem ser acometidas, interferindo negativamente na qualidade de vida, podendo ser causa de óbitos e amputações. As coberturas especiais são uma das formas de tratamento, o uso da prata iônica associada à presença de EDTA (ácido etilenodiamino tetra-acético) possui a capacidade de desagregação do biofilme através da redução da resistência da matriz extracelular, desnaturando proteínas e enzimas, inibindo a síntese protéica e danificando a parede celular, interferindo na síntese do DNA. Objetivo: Descrever os resultados da utilização de cobertura composta por $100 \%$ de fibras de carboximetilcelulose, 1,2 \% de prata iônica, cloreto de benzetônio e EDTA no tratamento de lesões infectadas, de diferentes etiologias. Material e Método: Série de três casos, tipo descritivo, prospectivo e intervencionista, aplicado em um ambulatório especializado no atendimento de pessoas com feridas e estomias e em uma unidade de internamento pediátrica de um hospital particular, de alta complexidade, no município de Salvador, Bahia, no período de agosto a dezembro de 2017. Este estudo foi submetido e aprovado pelo CEP, com emissão de parecer consubstanciado. Como instrumento de avaliação das lesões foi utilizado a escala Bates- Jensen WoundAssistment Tool (BWAT), traduzida e validada para a língua portuguesa em 2015. Resultados: As lesões foram acompanhadas desde a admissão até a alta dos pacientes, e este tempo variou de 30 a 90 dias. Caso 1, paciente do sexo masculino, idade: 14 anos, portador de comprometimento neurológico após meningite, com paraplegia, apresenta lesão por pressão estágio 4 em região sacra, iniciou tratamento com terapia por pressão negativa por três semanas, sem evolução satisfatória. BWAT inicial de 40, com presença de tecido desvitalizado, presença de secreção purulenta, túneis e bordas maceradas. Após 30 dias de tratamento com hidrofibra com prata evoluiu com BWAT 28, em que realizou rotação de retalho e epitelização total da ferida. Segundo caso, paciente do sexo feminino, idade: 16 anos, sem doença pregressa, realizou exérese de cisto pilonidal, em que foi optado por fechamento da lesão por segunda intenção. Lesão evolui de BWAT de 32 para BWAT de $13 \mathrm{em} 90$ dias, com epitelização total da lesão. Terceiro caso, paciente do sexo feminino, 41 anos, diabética, apresenta pé diabético, lesão no local de antiga amputação do 4 pododáctilo $\mathrm{E}$, ulceração com área de exposição de cápsula articular e apresenta dificuldade na marcha devido a pé de Charcot. Evoluiu da BWAT inicial de 43 para 13 em 89 dias. Conclusão: O uso de prata iônica em lesões demonstrou resposta satisfatória em diferentes etiologias, estimulando a epitelização da lesão além de preparação do leito da lesão para enxertia. Devido aos escassos estudos sobre tempo de tratamento de lesões com coberturas, não foi possível realizar a comparação deste estudo com a literatura, o que demonstra a necessidade de mais pesquisas sobre tempo de tratamento das lesões.
\end{abstract}

Keywords: Estomaterapia, Infecção Da Ferida Cirúrgica, Ferimentos e Lesões, Prata, Lesão Por Pressão

\section{Referências Bibliográficas}

Blanco BJ, Jordi BT. Control local de la carga bacteriana em ún úlcera por presión infectada. Mediante um apósito hidropolimérico com plata iónica. Rev. Enfermagem. 32 (10): 647-654. Outubro, 2009. Cunha NA. Sistematização da Assistência de Enfermagem no Tratamento de Feridas crônicas. ABEn/PE. Olinda, 2016. Disponível em:www.abenpe.com.br. Gamba MA, Petri V, Costa, MTF. Feridas: prevenção, causas e tratamento. Editora Santos. 1. ed. Rio de Janeiro: Santos, 2016. Menoita E, Seara A, Santos V. Plano de Tratamento dirigido aos Sinais Clínicos da Infecção da Ferida.JournalofAging\&Inovation. 3 (2): 62 - 73; 2014. 


\title{
O sentido do trabalho para homens com úlceras falcêmicas
}

Author(s): Dayse Carvalho do Nascimento ${ }^{1}$, norma valeria dantas de oliveira souza ${ }^{2}$

Institution(s) ${ }^{1}$ HUPE/UERJ - HOSPITAL UNIVERSITÁRIO PEDRO ERNESTO (Boulevard 28 de setembro,77- Vila Isabel - Rio de Janeiro), ${ }^{2}$ ENF/UERJ - Faculdade de Enfermagem (Boulevard 28 de setembro,157 - Vila Isabel - Rio de Janeiro)

\begin{abstract}
INTRODUÇÃO: A presença de uma doença crônica associada à alteração de autoimagem torna o homem mais vulnerável no seu dia a dia, incluindo o desenvolvimento de suas atividades laborais, podendo repercutir no sentido que se tem do trabalho provocando reflexos sobre as relações sociais, pois vida e trabalho são compatíveis para caminharem juntos e interconectados1. A Doença Falciforme (DF) é uma enfermidade crônica que pode limitar para o trabalho, já que, entre outras questões, causa dor, fadiga intensa e alta predisposição a infeção2,3. OBJETIVOS: descrever o sentido do trabalho para o homem com úlcera falcêmica sobre sua inserção e/ou manutenção no mundo do trabalho; identificar dificuldades e facilidades que o homem com úlcera falcêmica tem para se inserir ou manter no mundo do trabalho; elaborar protocolo de orientação para o cuidado à pessoa com úlcera falcêmica visando a prevenção e tratamento com o foco voltado para favorecer sua inserção e/ou manutenção no mundo do trabalho, desenvolver um aplicativo em sistema web e dispositivo móvel, com usabilidade e de fácil navegação, para socialização do conhecimento sobre a Doença Falciforme (DF) e prevenção de complicações e recidivas. MATERIAL E MÉTODO: Projeto de Pesquisa da tese de doutorado, com desenvolvimento metodológico e abordagem qualitativa (CEP 3292609/2019). Realizada em dois cenários: Ambulatório de Curativos de um hospital universitário e Clínica de Enfermagem em Estomaterapia de uma policlínica especializada do hospital referido. Os participantes são homens com úlceras falcêmicas, maiores de 18 anos e em idade produtiva. Para coleta de dados está sendo utilizada a entrevista individual do tipo semiestruturada. E para validação do protocolo proposto será feita por 10 juízes com conhecimento sobre o objeto do estudo. Após validado será construído um software e um aplicativo móvel4. RESULTADO: Os achados até o momento apresentam homens afastados do trabalho, reclusos socialmente com feridas dolorosas em membros inferiores dificultando a inserção e/ou manutenção no mundo trabalho. CONCLUSÃO: Pretende-se contribuir para aprofundar a discussão sobre o sentido do trabalho para o homem com úlcera falcêmica e permitir também uma análise reflexiva visando atuar intensamente no cuidado às pessoas com DF, para que elas possam preservar a saúde prevenindo e/ou diminuindo os eventos agudos.
\end{abstract}

Keywords: doença falciforme, estudo de validação, trabalho

\section{Referências Bibliográficas}

1.Antunes RLC. Os sentidos do trabalho: ensaio sobre a informação e a negação do trabalho. São Paulo: Boitempo, 2009. 2.Espírito Santo FH, Carvalho EMMS, Debona KV. Desafios do homem com doença falciforme no processo de viver e ser saudável. In: REIS, A.; PEREIRA, A. Saúde de homens: conceitos e prática de cuidados. Rio de Janeiro: Águia Dourada, 2017. p. 149-165. 3. Veloso LO, Yamada BFA, Silva KB, Nascimento JC. Há Diferença na Qualidade de Vida e Sintomas Depressivos Entre Pacientes com Anemia Falciforme Com e Sem Feridas Decorrentes da Doença? Estima, Braz J Enterostomal Ther. 2011; 9(1): 10-15. Disponível em: https://www.revistaestima.com.br/index.php/estima/index. Acesso em: 01 ago. 2019. 4.Coluci MZO, Alexandre NMC, Milani D. Construção de instrumentos de medida na área da saúde. Ciênc. Saúde Coletiva, Rio de Janeiro, 2015; 20(3): 925-936, mar. 2015. Disponível em: . Acesso em: 01 ago. 2019. 


\title{
LESÃO POR PRESSÃO EM PACIENTES INTERNADOS EM UMA UNIDADE DE TERAPIA INTENSIVA NO RECIFE
}

\author{
Cynthya Maria dos Santos ${ }^{1}$, Erickson Luan Gomes ${ }^{1}$, Itamisin Carvalho Santos da Silva Freitas ${ }^{1}$, \\ Author(s): Maria de Fátima Costa Caminha Costa Caminha ${ }^{1,2}$, Suzana Lins da Silva ${ }^{1,2}$, Thamyres Skarleth \\ Rodrigues Santos ${ }^{2}$, Carina Ribeiro de Oliveira ${ }^{1,3}$, Janaína Natália Alves de Lima Belo ${ }^{1}$, Tacyanne \\ Fischer Lustosa ${ }^{1}$, Luana Cristina Queiroz Farias ${ }^{1}$ \\ Institution(s) ${ }^{1}$ FPS - FACULDADE PERNAMBUCANA DE SAÚDE (Av. Mal. Mascarenhas de Morais, 4861 - \\ Imbiribeira, Recife - PE, 51210-902), ${ }^{2}$ IMIP - INSTITUTO DE MEDICINA INTEGRAL \\ PROFESSOR FERNANDO FIGUEIRA (Rua dos Coelhos, No 300, Boa Vista - Recife - PE - Brasil \\ CEP 50070-902), ${ }^{3} \mathrm{HOF}$ - HOSPITAL OTÁVIO DE FREITAS (R. Aprígio Guimarães, s/n - \\ Tejipio, Recife - PE, 50920-460)
}

\begin{abstract}
Introdução: Mesmo com os avanços na área da saúde, as lesões por pressão continuam como uma das principais complicações entre os pacientes internados em unidades de tratamento intensivo, podendo ser considerada como um indicador de qualidade da assistência de enfermagem. Objetivos: Descrever a frequência e localização de lesão por pressão em pacientes internados em Unidade de Terapia Intensiva de um Hospital de Referência do Recife. Material e Método: Estudo tipo série de casos realizado no período de junho a julho/2017 em pacientes com idade $>18$ anos que se encontravam internados em uma Unidade de Terapia Intensiva Clínica de adulto. Foram excluídos aqueles que estavam inconscientes, não possuíam responsável legal e/ou apresentavam lesão por pressão ao internamento. As informações foram coletadas pelos pesquisadores através da observação, entrevista e com base em registro no prontuário dos pacientes. Os dados foram analisados no Stata 12.1. As variáveis categóricas foram resumidas através de frequência absoluta e relativa. Os dados contínuos, através da média e sua dispersão. Esta pesquisa foi aprovada pelo Comitê de Ética em Pesquisa Envolvendo Seres Humanos da unidade hospitalar, registro do CAAE oㅜ 68395817.5.0000.5201. Resultados: 24 pacientes foram avaliados. A frequência de lesão por pressão encontrada foi de $45,84 \%$ ( 11 pacientes). Destes, $81,82 \%$ desenvolveu em região sacra, tendo como principais condições predisponentes as alterações cardiorrespiratórias $(72,72 \%)$, crônico-degenerativas $(72,72 \%)$, nutricionais $(72,72 \%)$ e circulatórias $(81,82 \%)$. Quanto ao tempo de internamento, foi constatado que $63,63 \%$ se encontrava a menos de 5 dias na UTI e já apresentava lesão por pressão. Conclusões: Foi possível retratar a necessidade de um cuidado sistematizado, por parte dos profissionais de saúde, e principalmente da enfermagem, para identificação precoce dos fatores de risco e das condições predisponentes, além da implementação e execução de protocolos de prevenção de LPP em UTI's.
\end{abstract}

\section{Keywords: ESTOMATERAPIA, LESÃO POR PRESSÃO, UNIDADE DE TERAPIA INTENSIVA, SEGURANÇA DO PACIENTE}

\section{Referências Bibliográficas}

Mattia AL, Rocha AM, B MH, G MAMC, B MO, S SRR, Filho JPAF. Úlcera por Pressão em UTI: fatores de risco e medidas de prevenção. Saúde Coletiva, 2010, vol. 7, núm. 46, pp. 296-299; Júnior BSS, Duarte FHS, Souza FMLC, Mendonça AEO. Análise da assistência de enfermagem à idosos com risco de desenvolver úlcera por pressão. Anais CIEH, 2015, Vol. 2, N.1; Ferreira EM, Magnano TSBS, Ceron MD, Pasa TS, Reis TLR, Bordignon JS, Souto VT. Escala de Braden:

Responsabilidade do enfermeiro na promoção da segurança do paciente. II Jornada Internacional de Enfermagem UNIFRA, 2012; Pereira MO, Ludvich SC, Omizzolo JAE. Segurança do paciente: Prevenção de úlcera por pressão em unidade de terapia intensiva. Revista Inova Saúde, Criciúma, dez 2016, vol. 5, n. 2. 


\title{
VALIDAÇÃO DO APLICATIVO TELEFERIDAS® E UTILIZAÇÃO EM PACIENTES COM LESÃO POR PRESSÃ̃O
}

\author{
Author(s): Maria Emilia Gaspar Ferreira Del Cistia ${ }^{1}$, Amanda Cristina Maria Aparecida Gonçalves Brandão ${ }^{1}$, \\ Fernanda Amendola ${ }^{1}$, Danivea Bongiovanni Poltronieri Munhoz ${ }^{1}$ \\ Institution(s) ${ }^{1}$ HIAE - Hospital Israelita Albert Einstein (São Paulo, SP, Brasil)
}

\begin{abstract}
O monitoramento de lesões por pressão é um indicador de qualidade assistencial recomendado pela Organização Mundial da Saúde e corroborado pelo Ministério da Saúde. O desenvolvimento de um aplicativo para uso em aparelho móvel para auxiliar o enfermeiro na avaliação de lesões por pressão possibilitará ao profissional uma melhor avaliação do paciente e isto será de fundamental importância na elaboração do planejamento da assistência de enfermagem e redução na tomada de decisão pela melhor conduta. Objetivos: Validar o conteúdo e analisar os dados da utilização do aplicativo "Teleferidas ${ }^{\circledR}$ - módulo: lesão por pressão". Material e método: Trata-se de uma pesquisa descritiva, exploratória, de abordagem quantitativa. O estudo será realizado em duas etapas. A primeira etapa versa sobre o desenvolvimento do aplicativo, por meio da validação de conteúdo dos itens que o compõe e a segunda será a avaliação dos resultados da utilização do aplicativo. Na etapa de validação do conteúdo será avaliada a proporção de concordância entre os juízes experts. Para análise da concordância entre as avaliações do enfermeiro assistencial e do enfermeiro laudador foi utilizado o coeficiente de Kappa. O nível descritivo adotado para este estudo será de $\mathrm{p}$
\end{abstract}

Keywords: Lesão por Pressão, Aplicativo de celular, Estudos de Validação, Estomaterapia

\section{Referências Bibliográficas}

1. Guze PA. Using technology to meet the challenges of medical education. Trans Am Clin Climatol Assoc. 2015; 126: 26070. 2. Framingham: MA. International Data Corporation (IDC). Worldwide Business Use Smartphone 2013-2017 Forecast and Analysis [Internet]. 2013 [cited 2013 Jul 01]. Available from: http://www.idc.com/. 3. National Pressure Ulcer Advisory Panel (NPUAP), European Pressure Ulcer Advisory Panel and Pan Pacific Pressure Injury Alliance. Prevention and treatment of pressure ulcers: clinical practice guideline. Perth, Australia: Emily Haesler; 2016. 


\title{
AVALIAÇÃO DO GRAU DE IMPLEMENTAÇÃO DO PROTOCOLO DE FERIDAS EM UMA DAS CAPITAIS DO BRASIL
}

\author{
Author(s): \\ Isabella Andrade Jacinto Melo Franco ${ }^{1}$, Fabíola Carvalho de Almeida Lima Baroni ${ }^{1}$, Gleidyene \\ Erly Pinheiro Ferraz ${ }^{3,1}$, Eline Lima Borges ${ }^{1}$ \\ Institution(s) ${ }^{1}$ UFMG - Universidade Federal de Minas Gerais (Av. Prof. Alfredo Balena, 190 - Santa Efigênia, \\ Belo Horizonte - MG, 30130-100), ${ }^{3}$ FaSaR - Faculdade Santa Rita (KM 2 da Estrada Real, 0, \\ Conselheiro Lafaiete - MG, 36400-000)
}

\begin{abstract}
A Capital Mineira utiliza o "Protocolo de prevenção e tratamento de feridas desde o ano de 2003. A finalidade de instituição do mesmo pautou-se na necessidade de sistematizar e qualificar a assistência prestada aos pacientes com feridas, acompanhados na atenção Primária em Saúde. No ano de 2017 foram realizados 42.723 curativos, o que gera média de 3560 procedimentos/mês. Dada a relevância do atendimento destes pacientes, o presente estudo objetivou avaliar o grau de implementação do Protocolo de Prevenção e tratamento de feridas na Atenção Primária em Saúde do município em tela e caracterizar o perfil dos enfermeiros da Atenção Primária em Saúde que prestam assistência a estes pacientes. Trata-se de um estudo quantitativo, descritivo e exploratório, realizado com 75 enfermeiros que atuam nas salas de curativos da APS do município, que concordaram em participar do estudo e assinaram o Termo de Consentimento Livre e Esclarecido. A coleta de dados ocorreu no primeiro semestre de 2019, por meio de um questionário semiestruturado construído para o presente estudo e enviado aos enfermeiros via e-mail. Os dados retornados foram inseridos do programa Statistical Package for social Sciences Software versão 22.0 e analisados por meio de estatística descritiva. A maioria dos enfermeiros é do sexo feminino, servidores ocupantes de cargo efetivo, com formação e experiência profissional maior que 5 anos e especialização predominante nas áreas de Saúde da Família/Saúde Pública. O estudo identificou, por meio de questões técnicas, que a maior parte dos enfermeiros não apresenta uniformidade em suas condutas de assistência aos pacientes com feridas, embora refiram utilizá-lo integralmente em suas práticas. Mencionam que o Protocolo é atual, adequado e que o discute com seus pares, apesar de não terem sido capacitados. Também informam não terem agenda para atendimento, apesar de prescreverem e selecionarem as coberturas com base no Protocolo. Pode-se inferir que o protocolo não está sendo implementado em sua totalidade, em decorrência da falta de capacitação, limitações do conhecimento sobre a temática, sobrecarga de trabalho e falta de insumos. É premente que os gestores da Atenção Básica façam investimento na educação permanente dos enfermeiros, no que diz respeito ao acompanhamento dos pacientes com feridas, ampliando o conhecimento a utilização do Protocolo, bem como forneçam insumos para esta prática.
\end{abstract}

Keywords: ferimentos e lesões, enfermagem, estomaterapia

\section{Referências Bibliográficas}

BELO HORIZONTE. Prefeitura de Belo Horizonte. Protocolo de Prevenção e Tratamento de Feridas, 2011. Disponível em: . Acesso em: 29 mai. 18. WERNECK, M. A. F et al. Protocolo de cuidados à saúde e de organização do serviço. Belo Horizonte: Nescon/UFMG, Coopmed, 2009. 84p. BRASIL. Ministério da Saúde. Secretaria de Atenção à Saúde DAB. Departamento de Atenção Básica. Disponível em:

https://egestorab.saude.gov.br/paginas/acessoPublico/relatorios/relHistoricoCoberturaAB.xhtml. Acesso em: 26 de junho de 18 


\title{
INCIDÊNCIA DE ÚLCERA VENOSA RECIDIVADA EM PACIENTES ATENDIDOS EM UM AMBULATÓRIO DE ESTOMATERAPIA
}

\author{
Author(s): $\quad$ Michele Neves Brajão Rocha ${ }^{1}$, Paula Cristina Nogueira ${ }^{2}$ \\ Institution(s) ${ }^{1}$ Amil - Amil Saúde (Rua Conselheiro Rodrigues Alves, 180), ${ }^{2}$ EEUSP - Escola de Enfermagem \\ da Universidade de São Paulo (Rua Dr Enéas Carvalho de Aguiar, 419)
}

\begin{abstract}
Introdução: A úlcera de etiologia venosa ocorre como resultado da hipertensão venosa e insuficiência da bomba dos músculos, principalmente os gastrocnêmios. Cerca de $1 \%$ dos adultos nos países industrializados são afetados por alguma ulceração da perna em qualquer momento da vida Aproximadamente $70 \%$ das úlceras venosas recidivam após cicatrização. Para evitar a recidiva, a compressão deve ser mantida após a cicatrização. Objetivo geral: Analisar a incidência de úlceras venosas recidivadas de pacientes atendidos em um Ambulatório de Estomaterapia e os fatores de risco para a recidiva. Métodos: Trata-se de estudo epidemiológico, descritivo, exploratório, de coorte retrospectiva, com abordagem quantitativa onde a amostra foi composta de 197 pacientes adultos atendidos em um ambulatório de estomaterapia de uma Operadora de Saúde do Município de São Paulo, através do prontuário eletrônico no período de 01 de abril de 2014 a 01 de abril de 2018. Os dados foram coletados por meio de um impresso próprio que continha dados sócio demográficos e clínicos e variáveis relacionadas a recidiva da úlcera venosa. Os dados foram inseridos no RedCap e posteriormente analisados utilizando-se os testes qui-quadrado para variáveis categóricas e Mann-Whitney para variáveis numéricas, além de regressão logística para identificação dos fatores associados. Resultados e Discussão: A recidiva da úlcera venosa aconteceu em 65 pacientes, levando a uma incidência de 48,5\%., a mesma média encontrada em um estudo de prevenção de recidiva realizado por Borges (2016)12 acometendo na maioria mulheres e idosos e o maléolo medial sendo a localização anatômica mais comum. O tempo médio da recidiva foi de 8 meses. A comorbidade que mais acometeu os recidivados foi a hipertensão seguida da diabetes, mas a obesidade foi a única variável que mostrou evidência de associação, onde $62,5 \%$ dos pacientes obesos tiveram recidiva, enquanto para os demais, a taxa fica em torno de $30 \%$. Quanto ao tratamento da úlcera venosa da amostra, a terapia tópica sem a compressão associada foi a mais utilizada $(n=113)$, seguida da terapia tópica associada a terapia inelástica $(n=83)$ e a terapia tópica associada a compressão elástica foi a menos frequente $(n=1)$. Dos 134 pacientes que tiveram a úlcera venosa cicatrizada, $30(46,1 \%)$ recidivaram e tiveram alta. Porém, $12(18,46 \%)$ pacientes, ficaram inativos na Operadora de Saúde, sem a possibilidade de saber se tiveram suas úlceras cicatrizadas pós a recidiva. Conclusão: Ao final do estudo, foi possível conhecer as características sócio demográficas dos pacientes, os fatores de risco para o paciente com recidiva da ulcera e a incidência das recidivas em um ambulatório de Estomaterapia. O conhecimento desta situação, permite aos enfermeiros a elaboração de um planejamento adequado das necessidades e dos cuidados e criar programas estratégicos para a prevenção das recidivas, já que a taxa de incidência não foi baixa. Essas altas taxas de recorrência podem estar associadas a não adesão ao tratamento compressivo após a úlcera cicatrizar.
\end{abstract}

Keywords: Incidência, Úlcera venosa, Estomaterapia, Enfermagem

\section{Referências Bibliográficas}

1. Maffei FHA, Magaldi C, Pinho SZ, et al. Varicose veins and chronic venous insufficiency in Brazil: Prevalence among 1755 inhabitants of a country town. Int J Epidemiol. 1986;15(2):210-217. doi:10.1093/ije/15.2.210. 2. Martins C, Campos S, Chaves C. Qualidade de Vida e Dor no Doente com Úlceras Varicosas dos Membros Inferiores. Millenium.

2016;47(47):163-172. http://revistas.rcaap.pt/millenium/article/view/8117. 3. Langer V. Preventing leg ulcer recurrence. Indian Dermatol Online J. 2014;5(4):534. doi:10.4103/2229-5178.142558. 4. Guimarães JAB, Campos LMN. Diretrizes para o tratamento da úlcera venosa. Enferm Glob. 2010;20:1-13. 5. Borges EL, Ferraz AF, Carvalho DV, Matos SS de, Lima VL de AN. Prevenção de recidiva de úlcera varicosa: um estudo de coorte. Acta Paul Enferm. 2016;29(1):9-16.

doi:10.1590/1982-0194201600003 


\title{
USO DE COBERTURA DE POLIURETANO IMPREGNADA COM PRATA E SILICONE PARA TRATAMENTO DE QUEIMADURAS SOLARES DE MEMBROS INFERIORES DE UM PACIENTE DIABÉTICO E HIPERTENSO: ESTUDO DE CASO
}

\author{
Author(s): $\quad$ ANGELICA ROSA DIAS PAIXAO ${ }^{1}$ \\ Institution(s) ${ }^{1}$ VHC - Vidas Home Care (Avenida Carlos de Campos, 536)
}

\begin{abstract}
O PRESENTE ESTUDO RELATA A EVOLUÇÃO DO QUADRO CLÍNICO DE UM PACIENTE DIABÉTICO E HIPERTENSO, VÍTIMA DE QUEIMADURA SOLAR QUE OCASIONOU LESÕES BOLHOSAS E POSTERIORMENTE ULCERATIVAS EM REGIÃO HÁLUX D E REGIÃO DORSAL DO PÉ D E EM PODODACTILOS E REGIÃO DORSAL DO PÉ E, QUE FORAM TRATADAS, COM COBERTURA À BASE DE POLIURETANO IMPREGNADO COM PRATA E SILICONE. O CASO FOI SELECIONADO DENTRE OS DEMAIS ACOMPANHADOS EM USO COM A MESMA COBERTURA, PORÉM, SENDO ESTE O ÚNICO COM LESÃO OCASIONADA POR QUEIMADURA SOLAR. O PACIENTE RECEBEU ATENDIMENTO DOMICILIAR COM TRATAMENTO PARA OSTEOMIELITE COM ANTIBIOTICOTERAPIA EV E PROCEDIMENTOS PARA REALIZAÇÃO DE CURATIVOS. A ATENÇÃO DOMICILIAR É DIVIDIDA EM DUAS MODALIDADES: INTERNAÇÃO DOMICILIAR E ATENDIMENTO DOMICILIAR. O PACIENTE FOI ATENDIDO NA MODALIDADE DE ATENDIMENTO DOMICILIAR, QUE É DEFINIDA COMO O CONJUNTO DE ATIVIDADES DE CARÁTER AMBULATORIAL, PROGRAMADAS E CONTINUADAS DESENVOLVIDAS EM DOMICÍLIO. SÃO ATENDIMENTOS EM QUE OCORREM DE FORMA PONTUAL, DE ACORDO COM A NECESSIDADE DO PACIENTE: PROCEDIMENTO PARA APLICAÇÃO DE MEDICAÇÃO, REALIZAÇÃO DE CURATIVO, ATENDIMENTO DE FISIOTERAPIA, FONOTERAPIA, VISITA MÉDICA E/OU DE ENFERMAGEM, ENTRE OUTROS. A COLETA DE DADOS FOI EFETUADA ATRAVÉS DA ANAMNESE E EXAME FÍSICO DO PACIENTE, UTILIZANDO-SE UM INSTRUMENTO COM DADOS RELATIVOS ÀS CONDIÇÕES CLÍNICAS DO PACIENTE E DA LESÃO, BEM COMO ATRAVÉS DO REGISTRO FOTOGRÁFICO DA LESÃO. OS CURATIVOS FORAM REALIZADOS A CADA 3 DIAS E, AO FINAL DE APROXIMADAMENTE 12 SEMANAS, OBSERVOU-SE A CICATRIZAÇÃO TOTAL DA LESÃO. NÃO FORAM OBSERVADOS DESCONFORTOS OU COMPLICAÇÕES DECORRENTES DO USO DO PRODUTO, CONCLUINDO-SE QUE O MESMO APRESENTOU BOA TOLERABILIDADE E EFICÁCIA TERAPÊUTICA PARA ESTE CASO.
\end{abstract}

Keywords: Cicatrização de feridas, Estomaterapia, Home Care, Lesão, Protocolos

\section{Referências Bibliográficas}

1 - Disponível em: http://www.saude.gov.br/acoes-e-programas/melhor-em-casa-servico-de-atencao-domiciliar/atencaodomiciliar 2- Tavalori CEL. Fernandes F. Medina P. O desenvolvimento do home healt care no Brasil. Rev. Adm em saúde; 9 (3),2000. 3- Dal Ben LW. Instrumento para dimensionar horas diárias de assistência de enfermagem residencial [dissertação]. São Paulo: Escola de Enfermagem, Universidade de São Paulo; 2000. 4- CHAYAMITI, E.M.P.C, CALIRI M.H.L., Úlcera por pressão em pacientes sob assistência domiciliária, vol. 23, n. 1, PP. :29-34, Campos Universitário USP Acta paul. enferm, Ribeirão Preto, 2010. 


\title{
PERFIL EPIDEMIOLÓGICO DOS PACIENTES EM TRATAMENTO DE FERIDAS CRÔNICAS COM OXIGENOTERAPIA HIPERBÁRICA
}

\author{
Author(s): TAYNARA SANTOS DA SILVA ${ }^{1}$ \\ Institution(s) ${ }^{1}$ Cicatrimed - Cicatrimed Tratamento Integral de Feridas (Vitória da Conquista BA), ${ }^{2}$ UFBA - \\ Universidade Federal da Bahia (Vitória da Conquista BA), ${ }^{3}$ USP - Escola de Enfermagem da USP \\ (São `Paulo)
}

\begin{abstract}
As feridas crônicas têm se tornado um grande problema de saúde pública em todo o mundo, associado ao aumento da incidência de comorbidades, tais como diabetes, obesidade e doenças vasculares. Identificar as características sociodemográficas e clínicas de pacientes em tratamento de feridas crônicas em uma clínica especializada que utilizaram da Oxigenoterapia Hiperbárica (OHB) como tratamento adjuvante com o intuito de se alcançar a resolução da ferida e investigar a associação entre as variáveis estudadas. Apesar das diversas coberturas utilizadas para o tratamento das feridas crônicas, muitas vezes não se obtém uma cicatrização efetiva, sendo necessário a utilização de terapias complementares e auxiliadoras como a Oxigenoterapia Hiperbárica (OHB). Com essa terapia diferentes efeitos positivos para o processo de cicatrização são observados, como a melhora da hipóxia tecidual, aumento da perfusão, redução do edema, proliferação de fibroblastos, produção de colágeno e angiogênese. Este trabalho tem por objetivo, verificar o perfil epidemiológico dos pacientes portadores de feridas crônicas. Trata-se de um estudo quantitativo, transversal e retrospectivo, com amostra probabilística do tipo randômica onde serão analisados os prontuários clínicos dos pacientes que foram submetidos a esta terapia em uma clínica pioneira na prevenção e tratamento de feridas. Este projeto de pesquisa, encontra-se vinculado a um projeto de maior escala intitulado "Perfil epidemiológico dos pacientes submetidos ao tratamento de feridas em unidade de referência no sudoeste da Bahia" que já se encontra aprovado pelo Comitê de Ética em Pesquisa (CEP) do Instituto Multidisciplinar em Saúde da Universidade Federal da Bahia (UFBA/IMS). Palavras-chave: Ferimentos e lesões, Cicatrização, Oxigenação hiperbárica.
\end{abstract}

Keywords: Cicatrização, Ferimentos , Lesões, Oxigenação , Hiperbárica

\section{Referências Bibliográficas}

1. Mittag BF, Krause TCC, Roehrs H, Meier MJ, Danski MTR. Cuidados com Lesão de Pele: Ações da Enfermagem. Estima. 2017;15(1):19-25. 2. Santos El, Oliveira JGAD, Ramos RS, Silva ACSS, Belém LS, Silva AL. Facilidades e dificuldades à autonomia profissional de Enfermeiros no cuidado de pessoas com feridas: Estudos de representações sociais. Estima. 2017;15(1):3-9. 3. Macewan MR, Macewan S, Kovacs TR, Batts J. What Makes the Oprima Wound Healing Material? A review of Current Science an Introduction of a Synthetic Nanofabricated Wound Care Scaffold. Cureus.

2017;9(10):e1736. 16 4. Andrade SM, Santos ICRV. Oxigenoterapia para tratamento de feridas. Rev. Gaúcha Enfermagem. Porto Alegre. 2016;37(2):e59257. 5. Smaniotto PHS, Ferreira MC, Isaac C, Galli R. Sistematização de curativos para o tratamento clínico das feridas. Rev. Bras. Cir. Plást. [Internet]. 2012;27(4):623626. Available from:

http://www.scielo.br/scielo.php?pid=S198351752012000400026\&script=sci_abs tract\&tlng=pt. 6. Almeida WA, Ferreira AM, Ivo ML, Rigotti MA, Barcelos LS, Silva ALNV. Fatores associados à qualidade de vida de pessoas com feridas complexas crônicas. J. res.: fundam. care. [Internet]. Rio de Janeiro 2018jan/mar;10(1):9-16. Available from:

http://bases.bireme.br/cgibin/wxislind.exe/iah/online/?/sisScript=iah/iah.xis\&src =google\&base=BDENF\&lang=p\&nextAction=Ink\&exprSearch=32232\&indexS earch=ID>. 7. Júnior JAF, Almeida CEFA, Garcia FL, Lima RVKS, Marques RR, Cologna MHT. Tratamento multidisciplinar de feridas complexas. Proposta de Criação de "Unidades de Feridas" no Hospital das Clínicas da FMRP-USP. Medicina. 2013;46(4):355-60. 8. Filho ETA, Almeida KG, Gabriel RC, Gustavo SMO, Liva HFT, Aline SK. Perfil epidemiológico dos pacientes tratados com auxílio da oxigenioterapia hiperbárica no estado de mato grosso do sul de maio de 2007 a outubro de 2012. Rev. Bras. Cir. Plást. Campo Grande/MS 2013;28(4):651-655. 9. Sociedade Brasileira de Medicina Hiperbárica. Diretrizes de Segurança e Qualidade. In: Fórum de Segurança e Qualidade em Medicina Hiperbárica. São Paulo: SBMH; 2016-2018. 10. Resolução n. 1457 de 19 outubro de 1995 sobre oxigenoterapia hiperbárica do Conselho Federal de Medicina (BR). Diário Oficial da União, Seção 1: p. 16585 (19 outubro de 1995). . Disponível em: . 11. Harch PG. Hyperbaric oxygen in chronic traumatic brain injury: oxygen, pressure, and gene therapy. Medical Gas Research. Orleans/USA. 2015;5(9):5-9. 12. Lima ALM., Oliveira PR., Carvalho VC, Cimerman S, Savio E. Recommendations for the treatment of osteomyelitis. Braz J. Infect. Dis. 2014sepoct;18(5):52634. 13. Vieira CPB, Furtado AS, Almeida PCD, Luz MHBA, Pereira AFM. Prevalência e caracterização de feridas crônicas em idosos assistidos na atenção básica. Rev baiana enferm. 2017;31(3):e17397. 


\title{
PREVALÊNCIA DE ÚLCERAS DE MEMBROS INFERIORES EM UM MUNICÍPIO DE MINAS GERAIS.
}

\author{
Gleidyene Erly Pinheiro Ferraz ${ }^{1,2}$, Fabíola Carvalho de Almeida Lima Baroni ${ }^{1}$, Isabella Andrade \\ Jacinto Melo Franco ${ }^{1}$, Eline Lima Borges ${ }^{1}$ \\ Author(s): \\ Institution(s) ${ }^{1}$ UFMG - Universidade Federal de Minas Gerais (Av. Prof. Alfredo Balena, 190 - Santa Efigênia, \\ Belo Horizonte - MG, 30130-100), ${ }^{2}$ FaSaR - Faculdade Santa Rita (KM 2 da Estrada Real, 0, \\ Conselheiro Lafaiete - MG, 36400-000)
}

\begin{abstract}
Com o aumento da expectativa de vida houve aumento da prevalência de úlceras de membros inferiores, condição crônica, comum, complexa e dispendiosa. No entanto, há escassez de dados estatísticos sobre as mesmas e estes são importantes, tendo em vista os elevados gastos públicos com o tratamento. O estudo estimou a prevalência de pacientes com úlceras de membros inferiores em um município do interior de Minas Gerais, bem como caracterizou a clientela quanto a aspectos sociodemográficos e clínicos, categorizou clinicamente as úlceras de membros inferiores e identificou o tratamento destas. Estudo quantitativo, transversal, descritivo e exploratório, envolvendo todos os pacientes que possuíam úlceras de membro inferiores, com idade igual ou superior a 20 anos, que residiam no município, cadastrados na rede de Atenção Básica, atendidos pelas equipes da Estratégia Saúde da Família, no segundo semestre de 2018, período da coleta de dados, que concordaram em participar e assinaram o Termo de consentimento Livre e Esclarecido. Os dados foram coletados por meio de um formulário adaptado, lançados no Programa Excel e analisados por estatística descritiva simples. Para o cálculo da prevalência utilizou-se a equação apresentada pelo Wounds International. A prevalência das úlceras de membros inferiores na população geral foi de $0,11 \%$ ou $1,1 / 1000$ habitantes e na população do estudo (acima de 20 anos que aceitaram participar do estudo) de $0,17 \%$ ou 1,7/1000 habitantes, corroborando com estatísticas da literatura. A dominância da etiologia das úlceras de membros inferiores foram as de origem venosa constatada em $52 \%$ da população, apresentando-se localizada no 1/3 inferior da perna, com mais de 10 anos de acometimento, considerada dolorida, de odor imperceptível e área perilesão intacta. $O$ tratamento com sulfadiazina de prata foi o mais utilizado e os curativos trocados uma vez ao dia pelos técnicos de enfermagem. A terapia de compressão não é usual entre os $100 \%$ dos participantes com diagnóstico de úlcera de etiologia venosa. Conclui-se que o estudo de prevalência aqui apresentado vem colaborar para o planejamento da assistência da população com úlceras de membros inferiores, do município. Do mesmo modo que denota subsídios para uso de tratamentos adequados para o tipo de úlcera prevalente, pactuando com a assertividade da assistência, colaborando para qualidade de vida do paciente e auxiliando no cálculo do custo-efetividade dessa assistência.
\end{abstract}

Keywords: estomaterapia, saúde publica, úlceras de perna

\section{Referências Bibliográficas}

Silva, MH, Jesus, MCP, Merighi MAB, Oliveira DM, Santos SMR, Vicente EJD. Manejo clínico de úlceras venosas na atenção primária à saúde. Acta Paul Enferm. 2012. Disponível em: Acesso em: 09 ag. 18. Vieira CPB, Araújo TME. Prevalência e fatores associados a feridas crônicas em idosos na atenção básica. Rev Esc Enferm USP. 2018. Disponível em: Acesso em 10 ag. 18. Afonso A., Barroso P., Marques G., Gonçalves A., Gonzalez A., Duarte N., Ferreira MJ. Úlcera crônica do membro inferior - experiência com cinquenta doentes. Angiol Cir Vasc., 2013. Disponível em: Acesso em: 10 de ag. 18. 


\title{
A ATUAÇ̃̃O DO ENFERMEIRO NA AVALIAÇÃO DE FERIDAS NAS INSTITUIÇÕES DE SAÚDE DA REDE PỦBLICA
}

\author{
Author(s): Alana Furtado ${ }^{1}$, Cézar Mamedio Alcantara ${ }^{1}$, AUCELY CORREA FERNANDES CHAGAS ${ }^{1}$, \\ Karla de Toledo Candido Muller ${ }^{1}$ \\ Institution(s) ${ }^{1}$ UCDB - UNIVERSIDADE CATÓLICA DOM BOSCO (AV TAMANDARÉ 6000)
}

\begin{abstract}
INTRODUÇÃO: As lesões de pele acometem tanto as populações vulneráveis e não vulneráveis independente do sexo, idade, etnia ou classe social, sendo um sério problema de saúde pública, necessitando assim dos cuidados da equipe multidisciplinar para o tratamento destas feridas, entretanto, os cuidados prestados aos pacientes com lesões de pele sempre foram uma atribuição dos profissionais de enfermagem presente no seu processo de trabalho, bem como em sua graduação. Sendo assim uma etapa importante realizada pelo enfermeiro, pois a evolução do quadro clínico do paciente está relacionada diretamente com os resultados obtidos da avaliação, uma vez que a lesão é avaliada continuamente, desde o primeiro contato com a ferida até sua cicatrização. Portanto o enfermeiro tem o papel de avaliar, supervisionar e direcionar a equipe de enfermagem para um plano de cuidado baseado nos saberes práticos, técnicos e científicos para um tratamento adequado para cada tipo de lesão de pele. OBETIVO: Descrever e analisar a atuação do enfermeiro assistencial no processo de avaliação de feridas em pacientes com lesões de pele. MATERIAIS E MÉTODOS: Trata-se um estudo exploratório-descritivo, de natureza qualitativa, realizado no período compreendido entre abril a maio de 2018 em 05 UBSF e 01 Unidade de Pronto Atendimento no perímetro urbano de Sidrolândia - MS. Para a coleta de dados foi elaborado um questionário com perguntas específicas sobre o tema avaliação de feridas e as respostas foram gravadas por telefone celular dos pesquisadores. RESULTADOS E DISCUSSÃO: A amostra foi composta por 06 enfermeiras onde se verificou a inexistência de um protocolo de assistência ao portador de lesão de pele, a realização de múltiplas funções, a falta de recursos de materiais para avaliação, a falta de aperfeiçoamento e treinamento específico o que leva a uma assistência fragmentada. Pois quando a assistência na avaliação de feridas não é realizado adequadamente durante todo o processo do cuidado, pode acarretar danos na evolução da lesão se tornando uma ferida crônica afetando suas atividades diárias, havendo um impacto na qualidade de vida do indivíduo. CONCLUSÕES: pode se observar que é imprescindível que o enfermeiro se atualize permanentemente quanto às inovações, materiais e técnicas de curativos atuais, buscando constantemente o aperfeiçoamento. Mas também é necessário que as unidades de saúde promovam capacitação aos seus funcionários e a criação, a elaboração de um protocolo de atendimento para a avaliação de feridas para ser seguido, assegurando a uma assistência de qualidade.
\end{abstract}

Keywords: Avaliações de feridas, Lesões de pele, Enfermagem

\section{Referências Bibliográficas}

1. Morais GFC, Oliveira SHS, SoaresMJGO. Avaliação de feridas pelos enfermeiros de instituições hospitalares da rede pública. Texto Contexto Enfermagem, 2008. 20: 98-105. 2. Costa KS, Rodrigues APB, Silva AG, Feitosa MSL. Atuação do enfermeiro na assistência aos pacientes portadores de feridas, Revista Interdisciplinar UNINOVAFAPI. 2011;5: 9-14. 3. Gonçalves CC, Almeida IB, Cordeiro TM. O cuidado dos enfermeiros às lesões de pele em pacientes críticos em um hospital público na cidade de Campina Grande. Apresentação de Trabalho no 18ํㅡㄹ Congresso Brasileiro dos Conselhos de Enfermagem CBENF. 2015. 4. Smaniotto PHD, Ferreira MC, Isaac C, GalliR. Sistematização de curativos para o tratamento clínico das feridas. Revista Brasileira Cirúrgia Plástica, 2012. 27:623-626. 5. Jacondino CB, Severo DF, RODRIGUES KR, LIMA I, EINHARDT RR, AMESTOY SC. Educação em serviço: qualificação da equipe de enfermagem para o tratamento de feridas, Cogitare Enfermagem.2010;15: 314-318. 6. Machado F, Costa AEK, Pissaia LF, Beschrner CE, MoreschIC. Perspectiva do enfermeiro frente à assistência no tratamento de feridas em ambiente hospitalar. Revista de Epidemiologia e Controle de Infecção, Santa Cruz do Sul. 2017; 7: 134-139. 7. Brasil, COFEN - resolução no 523 de 2017: Código de Ética dos Profissionais de enfermagem. De 27 de julho de 2017. Disponível em: http://www.cofen.gov.br/resolucao-cofen5432017_51440.html 8. Brasil, CREMAM - parecer no12/2014, exame dermatológico. De 13 janeiro de 2014. Disponível em:http://sistemas.cfm.org.br/normas/visualizar/pareceres/AM/2014/12 9. Hospital das Clínicas de Porto Alegre - RS, Manual de Avaliação e tratamento de feridas, orientações para profissionais de saúde. Sem data de publicação. Acesso em 24 de maio de 2018.Disponível em: http: file://C:/Users/User/Downloads/HOSPITAL\%20DAS\%20CLINICAS.pdf 10. Pedrosa ICF, CorreA ACP, ManduENT. influências da infraestrutura de centros de saúde nas práticas profissionais: percepções de enfermeiros. Ciên. Cuid. Saúde. 2011;10: 058-065. 11.Brasil, COFEN - resolução no 523 de 2017: Código de Ética dos Profissionais de enfermagem. De 27 de julho de 2017. Disponível em:http://www.cofen.gov.br/resolucao-cofenno-567-2018_60340.html 12. Carneiro CM, Gama FN, Sousa FB. Tratamento de feridas: assistência de enfermagem nas unidades de atenção primária à saúde. Revista Enfermagem Integrada - Ipatinga: Unileste-MG. 2010;3: 494-505. 13. Silva AA,Rotenberg, L, Fischer FM. Jornadas de trabalho na enfermagem: entre necessidades individuais e condições de trabalho. Rev. Saúde Pública. 2011; 45:1117-1126. 


\title{
CONTROLE DE ODOR FÉTIDO DE FERIDA NEOPLÁSICA MALIGNA - RELATO DE CASO
}

\author{
Author(s): João Junior Gomes ${ }^{1}$, Suzana Aparecida da Costa Ferreira ${ }^{1}$, Flavia Harumi Higuti ${ }^{1}$ \\ Institution(s) ${ }^{1}$ CUSC - Centro Universitário São Camilo (R. Raul Pompeia, 144 - Vila Pompeia São Paulo - SP)
}

\begin{abstract}
Introdução: As feridas neoplásicas malignas (FNM) são formadas pela infiltração das células malignas do tumor, na pele. As lesões resultantes são dolorosas e possuem tecido friável que sangra facilmente; podendo ser colonizadas por bactérias que junto ao processo de morte celular, geram odor fétido de difícil tratamento1,2. Na literatura encontram-se como opções tópicas para manejo do odor: carvão ativado (adsorvente das moléculas de odor), metronidazol e Polihexametil-Biguanida (PHMB) como antimicrobianos3,4,5,6.. Em estudo clínico controlado, randomizado, duplo-cego com 24 pacientes com FNM, que comparou os efeitos de PHMB 0,2\% e metronidazol 0,8\% no manejo do odor da ferida maligna, mostrou-se que ambos reduziram o odor significativamente em 4 dias sem diferença estatística entre os dois6. Descrição do caso: Paciente com diagnóstico médico de câncer de mama, antecedente de mastectomia total esquerda e tratamento posterior de quimioterapia e radioterapia. Apresentava FNM em estadiamento 47 , em região torácica anterior e em região axilar esquerda, medindo $14 \times 10 \mathrm{~cm}$, com odor fétido escore 0 (odor evidente ao entrar na casa/ala/clínica) 8 . Observou-se que o odor fétido que provocava seu isolamento social era a principal queixa da paciente. O relato do caso e o registro fotográfico foram aprovados pelo comitê de ética, parecer 004/2019. Para controle do odor, foram utilizadas diversas abordagens: cobertura de carvão ativado com prata, efetuando-se trocas a cada 24 horas, constatando-se melhora do odor a escore 3 (odor evidente ao retirar a roupa); posteriormente, foi feita a troca a cada 7 dias com piora do escore a 0 . Como segunda medida foi realizada associação de metronidazol (pó diluído em água destilada) com o carvão ativado, trocado a cada 72 hs, porém, após 3 semanas observou-se piora do odor novamente, com retorno ao escore 0 . Finalmente foi utilizada solução de PHMB por 15 minutos em gaze embebida sobre a lesão, associada à cobertura já descrita e o resultado foi a obtenção de escore 4 (odor é detectado na remoção do curativo), com troca a cada 48 hs até o final do atendimento da cliente, por 6 meses. Com isso notou-se uma melhora da condição psicossocial da paciente. A adaptação da conduta foi satisfatória. Segundo a mesma, o curativo realizado permitiu que voltasse a se relacionar com as pessoas de seu convívio social, pois sentiu melhora permanente no odor da lesão. Percebeu-se assim melhora progressiva no seu estado emocional. Comentários: O cuidado de pacientes com FNMs exige conhecimento das tecnologias disponíveis para o seu manejo, incluindo as associações para o devido controle dos sintomas, buscando oferecer conforto a pacientes em cuidados paliativos. Nesse estudo a melhor e mais duradoura resposta obtida foi a associação da cobertura de carvão ativado com prata e a solução de PHMB para limpeza. O carvão ativado quando testado como proposta única de tratamento exerceu um controle baixo do odor, porém contínuo quando associado ao PHMB. Em consequência, é possível que além do uso do PHMB em solução, coberturas impregnadas com PHMB associadas ao carvão ativado, sejam uma opção de tratamento adequado.
\end{abstract}

Keywords: Ferimentos e Lesões, Oncologia, Estomaterapia, Odorantes, Cuidados de Enfermagem

\section{Referências Bibliográficas}

1. Agra G, Medeiros MVS, Brito DTF, Sousa ATO, Formiga NS, Costa MML. Conhecimento e prática de enfermeiros no cuidado a pacientes com feridas tumorais malignas. Rev Cuid. 2017; 8(3): 1849-62.

http://dx.doi.org/10.15649/cuidarte.v8i3.441 2. Beh SY, Leow LC. Fungating breast cancer and other malignant wounds: epidemiology, assessment and management. Expert Rev Qual Life Cancer Care. 2016;1:2:137-144. 3. Ramasubbu DA, Smith V, Hayden F, Cronin P. Systemic antibiotics for treating malignant wounds. Cochrane Database Syst

Rev.2017;24(8):CD011609. 


\title{
A UTILIZAÇÃO DE COBERTURAS OCLUSIVAS: INFLUÊNCIA SOBRE A CICATRIZAÇÃO DE FERIDAS EXCISIONAIS EM CAMUNDONGOS.
}

\author{
Author(s): $\quad$ Mariana Raquel Soares Guillen ${ }^{1}$, Eline Lima Borges ${ }^{1}$, Puebla Cassini ${ }^{1}$, Gilmara Lopes Amorim ${ }^{1}$, \\ Antônio Carlos Guedes ${ }^{1}$ \\ Institution(s) ${ }^{1}$ UFMG - Universidade Federal de Minas Gerais (Av. Prof. Alfredo Balena, 190. Santa Efigênia, \\ Belo Horizonte - MG.)
}

\begin{abstract}
INTRODUÇÃO: O cuidado do paciente com feridas é um constante desafio na prática clínica do enfermeiro. As coberturas oclusivas e não oclusivas são utilizadas no tratamento de feridas e existe uma lacuna de conhecimento sobre a influência dessas indicações no processo de cicatrização. OBJETIVO: O objetivo do presente estudo foi avaliar a influência de coberturas oclusivas sobre a cicatrização de feridas cutâneas excisionais em camundongos C57BL/6. MATERIAIS E MÉTODOS: Trata-se de um estudo translacional pré-clínico, comparativo e controlado. Os camundongos foram divididos em três grupos experimentais e o tratamento das feridas excisionais deles foram classificados como: animais que receberam oclusão com hidrocolóide (HD), animais que receberam oclusão com filme transparente de poliuretano (FT) e animais sem oclusão (SO). Os grupos foram avaliados quanto: a taxa de fechamento das feridas, o infiltrado de neutrófilos e macrófagos, dosagem da citocina TNF- $\alpha$, o fator de crescimento angiogênico VEGF, a expressão protéica de HIF-1 $\alpha$ e, histologicamente, o desenvolvimento de novos vasos sanguíneos. As cicatrizes das feridas foram analisadas por juízes independentes quanto à apresentação estética no décimo quarto dia de segmento. RESULTADO: No terceiro dia do processo de cicatrização, foi possível observar, macroscopicamente, que o fechamento das feridas cutâneas excisionais foi acelerado nos animais cuja ferida foi ocluída, utilizando-se tanto filme transparente quanto o hidrocolóide. Ainda no período de três dias, observou-se diminuição nos níveis da citocina pró-inflamatória TNF-a nas feridas ocluídas com hidrocolóide quando comparada com os grupos SO e FT. O acúmulo de neutrófilos também diminuiu, significativamente, ao terceiro dia de cicatrização no grupo tratado com hidrocolóide, quando comparado aos grupos SO e FT, respectivamente. O conteúdo dos macrófagos apresentou níveis significativamente mais altos ao terceiro dia no grupo FT quando comparado a SO. Ao sexto dia de estudo, evidenciaram-se dosagens significativamente aumentadas de macrófagos no grupo HD, contrastando com os grupos SO e FT. Os níveis de VEGF apresentaram-se expressivamente aumentados ao sexto dia de cicatrização, nos animais cujas feridas estavam ocluídas com filme transparente de poliuretano e hidrocolóide. Houve aumento dos níveis do fator indutor de hipóxia 1-alfa nos animais submetidos a oclusão quando comparados aos sem oclusão. A análise qualitativa do reparo em cicatriz das feridas permitiu afirmar que houve concordância moderada e significativa entre os juízes no grupo HD e concordância substancial e significativa nas cicatrizes dos animais SO. CONCLUSÕES: Considerando-se que a resposta inflamatória é um processo imunológico fundamental para o processo de reparo de feridas, quando ocorre de forma controlada, sugere-se que a oclusão modula a resposta inflamatória. Tal achado é evidenciado por meio da inibição parcial da citocina pró-inflamatória TNF- $\alpha$, da redução de acúmulo de neutrófilos e dos níveis mais altos de macrófagos. A oclusão das feridas não evidenciou aumento quantitativo de capilares em relação ao grupo sem oclusão.
\end{abstract}

Keywords: Feridas, Cicatrização de Ferida Cutânea, Coberturas Oclusivas, Inflamação, Enfermagem

\section{Referências Bibliográficas}

REFERÊNCIAS ALVES-FILHO, João Alberto Garcia; CABRERA, Renan Rocha; DO AMARAL, Valéria. Análise da atividade cicatrizante do complexo homeopático $\mathrm{m8}$ em feridas induzidas em ratos. Revista Uningá, v. 48, n. 1, 2018. ALVES, Helio; MACHADO, Michele Teixeira; NORONHA, Anaci Maria Nogueira Wood. Análise Qualitativa do Processo de Reparo em Cicatriz Cirúrgica de Ratos Tratados com Extrato de Musa Sapientum, Aloe Vera e Colagenase/Qualitative Analysis of the Repair Process in Surgical Scar in Treated Rats with Musa Sapientum Extract, Aloe Vera an. Revista Ciências em Saúde, v. 1, n. 2, p. 8-18, 2011. AMORIM, Gilmara Lopes. Ensaio pré-clínico de uma nova cobertura no tratamento de lesão cutânea. Monografia (Monografia em Enfermagem) - UFMG. Belo Horizonte, p. 45. 2016. ASADI, Mohammad Reza et al. Angiogenic effects of low-intensity cathodal direct current on ischemic diabetic foot ulcers: A randomized controlled trial. Diabetes research and clinical practice, v. 127, p. 147-155, 2017. BALBINO C.A. et al. Mecanismos envolvidos na cicatrização: uma revisão. Brazil J. of Pharmaceutic Science. 41(1):27-51.2005. BANDEIRA, Andrea Gonçalves et al. A utilização de um referencial metodológico na implementação de evidências como parte da investigação em enfermagem. Texto \& ContextoEnfermagem, v. 26, n. 4, 2017. 


\title{
ATUAÇÃO DA ENFERMEIRA NO PRIMEIRO AMBULATÓRIO DE LESÕES DE PELE EM UMA INSTITUIÇÃO DO ENSINO SUPERIOR (IES) PRIVADA EM SALVADOR-BAHIA
}

\author{
Author(s): $\quad$ Ronesca Sech de Santana Dias ${ }^{1}$, Mel Matos de Carvalho Espinheira ${ }^{1}$ \\ Institution(s) ${ }^{1}$ EBSMP - ESCOLA BAHIANA DE MEDICINA E SAÚDE PÚBLICA (Av. Dom João VI, 275 - \\ Brotas, Salvador - BA, 40290-000)
}

\begin{abstract}
Introdução: feridas podem ser definidas como interrupção da continuidade da superfície corpórea, podendo ser de etiologia acidental, cirúrgica, térmica, por pressão, ou mesmo resultante de uma doença de base. Apresentam maior incidência nos indivíduos com comorbidades associadas, como diabetes mellitus e doenças vasculares. $\mathrm{O}$ aparecimento da lesão tem impacto na qualidade de vida do paciente, além das repercussões psicológicas, sociais e emocionais associadas. Objetivo: descrever a vivência da enfermeira no primeiro Ambulatório de Lesões de Pele em uma Instituição do Ensino Superior (IES) Privada em Salvador, no atendimento aos pacientes, em 2019. Material e método: trata-se de um trabalho descritivo, tipo relato de experiência, quanto às atividades desenvolvidas pela enfermeira no Ambulatório de Lesões de Pele em uma Instituição do Ensino Superior (IES) Privada em Salvador, Bahia. Resultados: o Ambulatório de Lesões de Pele foi inaugurado em janeiro de 2019. O atendimento é iniciado pela consulta de enfermagem de forma sistemática, contemplando todas suas etapas. Na consulta, a enfermeira avalia e classifica a lesão, solicita exames, realizar coleta de fragmentação de cultura e debridamento. Planeja ainda, a periodicidade das trocas dos curativos, programação de retorno, orientações quantos aos critérios de adesão e desligamento ao tratamento, manejo das coberturas especiais e cuidados com a lesão em domicílio pelo paciente e familiares. Encaminha à equipe multidisciplinar quando necessário e promove capacitação da equipe de Enfermagem. Mesmo com pouco tempo de existência do Ambulatório, pacientes relatam retorno positivo sobre o serviço, ressaltando a otimização do tratamento, retorno precoce às suas atividades diárias, da autonomia e melhoria da qualidade de vida. Conclusão: as atividades desenvolvidas no Ambulatório de Lesões de Pele pela enfermeira além de proporcionarem aprimoramento técnico e científico, mostraram-se promissoras tendo em vista as potencialidades para atuação da enfermeira no campo da Estomaterapia, destacando o cuidar e ser cuidado, de gerenciar, de pesquisar e ensinar a prática necessária para o tratamento integral e efetivo aos pacientes, bem como as repercussões positivas na vida dos mesmos.
\end{abstract}

Keywords: Assistência de Enfermagem, Educação em Saúde, Estomaterapia, Ferimentos e lesões

\section{Referências Bibliográficas}

1 Sant'ana SMSC, Bachion MM, Santos QR et al. Úlceras venosas: caracterização clínica e tratamento em usuários atendidos em rede ambulatorial Revista Brasileira de Enfermagem, vol. 65, núm. 4, agosto, 2012, pp. 637-644 Associação Brasileira de Enfermagem Brasília, Brasil 2 Aquino OS, Moura LM, Florêncio MIB, Moura REF. Integração docenteassistencial no cuidado de feridas: relato de experiência. Revista da Rede de Enfermagem do Nordeste, vol. 7, núm. 2, maio-agosto, 2006, pp. 81-88 Universidade Federal do Ceará Fortaleza, Brasil 3 Kobayashi RM, Januário MMJ.

Desenvolvendo competências profissionais dos enfermeiros em serviço. Revista Brasileira de Enfermagem, vol. 63, núm. 2, abril, 2010, pp. 243-249 Associação Brasileira de Enfermagem Brasília, Brasil 


\title{
ASSISTÊNCIA DE ENFERMAGEM DOMICILIAR A PACIENTE COM LESÃO VASCULOGÊNICA MISTA
}

\author{
CARLA TELES DE CARVALHO HERDY BAPTISTA ${ }^{1}$, Fernanda Soares Pessanha ${ }^{1,1,1,1}$, \\ Author(s): Nathália Caldas Santos ${ }^{1,1,1,1}$, Beatriz Guitton Renaud Baptista de Oliveira ${ }^{1,1,1,1}$, Bianca Campos \\ Oliveira ${ }^{1,1,1,1}$ \\ Institution(s) ${ }^{1}$ UFF - Universidade Federal Fluminense ( RRua Dr. Celestino, 74 - Centro, Niterói - RJ, 24020- \\ 091)
}

\begin{abstract}
Introdução: Entre as úlceras de perna, as vasculogênicas (de origem venosa, arterial ou mista) são as mais prevalentes, caracterizando-se por um processo crônico, doloroso, recorrente, com impacto negativo na qualidade de vida. Objetivo: Descrever a sistematização da assistência de enfermagem domiciliar a uma paciente com úlcera vasculogênica mista. Método: Estudo descritivo, do tipo relato de experiência realizado com base no acompanhamento do caso de uma paciente com lesões vasculogênicas mistas. As consultas realizadas pela equipe de enfermagem até a cicatrização de todas as úlceras ocorreram no período de junho de 2016 à julho de 2017. Resultados: Paciente idosa com insuficiência vascular periférica mista apresentando lesões em membro inferior direito nas seguintes áreas: região anterior medial da perna; região ântero-inferior da perna, com exposição de tendão; região de dorso do pé, com exposição de tendão; região posterior da perna. O acompanhamento de saúde incluía consultas ambulatoriais com médico cirurgião vascular e com equipe multidisciplinar especializada em domicílio. Na sistematização da assistência de enfermagem foram encontrados dois diagnósticos prioritários: "Perfusão tissular periférica ineficaz" e "Integridade Tissular prejudicada". Para esses diagnósticos foram traçadas as seguintes intervenções prioritárias: avaliação periódica das lesões com descrição da evolução do tecido no leito da ferida; realização de curativo com soro fisiológico à 0,9\% para a limpeza da área, desbridamento instrumental conservador em áreas de necrose, aplicação de hidrogel amorfo com alginato e AGE óleo em tecido de granulação. O resultado de enfermagem alcançado foi a cicatrização completa das lesões após doze meses de tratamento. Conclusão: A assistência de enfermagem ocorreu com base em abordagem holística, mantendo o paciente em seu domicílio, orientado para o autocuidado, com ações de promoção à saúde e prevenção de complicações.
\end{abstract}

Descritores: Estomaterapia; Enfermagem; Úlcera da perna; Doença arterial periférica.

1- Enfermeira, Especialista em Estomaterapia (UERJ), Promoção da saúde (UFF) e Terapia Intensiva (Albert Einstein).

2- Enfermeira, Doutora, em Ciências do Cuidado em Saúde (UFF).

3- Enfermeira, Mestranda em Ciências do Cuidado em Saúde (UFF).

4- Enfermeira, Doutora, em Ciências do Cuidado em Saúde (UFF).

5- Enfermeira. Doutora, Professora Titular da EEAAC/UFF. Coordenadora do Programa de Pós-Graduação em Ciências do Cuidado em Saúde (UFF - Niterói, RJ, Brasil).

Keywords: Doença arterial periférica., Enfermagem, Estomaterapia, Úlcera de perna

\section{Referências Bibliográficas}

ABBADE LPF; LASTÓRIA S. Abordagem de pacientes com úlcera da perna de etiologia venosa. An Bras Dermatol. 2006; 81(6):509-22. BERSUSA, A. A. S., LAGES, J. S. Integridade da pele prejudicada: identificando e diferenciando uma úlcera arterial e uma venosa. Ciência, Cuidado e Saúde, v. 3, n. 1, p. 81- 92, Maringá, 2004. BRUNNER \& SUDDARTH: Tratado de de enfermagem médico-cirúrgica, volumes 1 e 2 / Janice L. Hinkle, Kerry H. Cheever: tradução Patrícia Lydie Voeux ... [et al.]. - 10 Ed. - Rio de Janeiro: Guanabara Koogan, 2005. DUNCAN, B.; SCHMIDT, M. I.; GIUGLIANI, E. R. J. Medicina ambulatorial: condutas de atenção primária baseada em evidências. 3. ed. Porto Alegre: Artmed, 2006. LIMA, L.V. et al. Conhecimento de Pessoas com Úlceras Vasculogênicas acerca da Prevenção e dos Cuidados com as Lesões. Revista Estima. v. 11, n. 3, 2013. Disponível em https://revistaestima.com.br/index.php/estima/article/view/85 Acesso em: 09 set. 2018. SILVA, R.C.L; Figueiredo, N.M.A. et al. Feridas: fundamentos e atualizações de enfermagem. São Paulo: Yendis, 2007. SOCIEDADE BRASILEIRA DE CARDIOLOGIA. VI Diretrizes Brasileiras de Hipertensão. Arquivos Brasileiros de Cardiologia, São Paulo, v. 95, n. 1, p. 1-51, 2010. Suplemento 1. 


\title{
CUIDADO CENTRADO NO PACIENTE COM PÉ DIABÉTICO
}

\author{
Sherida Karanini Paz de Oliveira ${ }^{1}$, Tayana Vivian Ribeiro Bastos ${ }^{1}$, Larissa Gomes de Lima ${ }^{1}$, \\ Author(s): Nicolle Porto Coelho ${ }^{1}$, Mariane Carlos de Sousa ${ }^{1}$, Joana da Silva Assunção ${ }^{1}$, Adécia Falcão \\ Freitas ${ }^{1}$, Larissa Freitas Xavier ${ }^{1}$, Maria Luiza Pereira Costa ${ }^{1}$ \\ Institution(s) ${ }^{1}$ UECE - Universidade Estadual do Ceará (Av. Dr Silas Munguba, 1700. Fortaleza-Ce.)
}

\begin{abstract}
IINTRODUÇÃO: Diabetes mellitus (DM) refere-se a um grupo de distúrbios metabólicos comuns que compartilham o fenótipo da hiperglicemia1 que exige acompanhamento de saúde contínuo e relaciona-se a diversas complicações, caso essa hiperglicemia se mantenha por longos períodos. Dentre as complicações, tem-se o pé diabético caracterizado por ulcerações, lesões e deformidades causadas por danos nos nervos, vasos ou ambos2. Assim, o cuidado centrado na pessoa é uma forma de cuidar efetiva uma vez que pondera que o cuidado deve ser personalizado, coordenado, capacitante e digno, conforme as necessidades do paciente com estímulo a autonomia e o autocuidado, princípios essenciais para a pessoa com uma condição crônica de saúde. Enfatiza-se, ainda, uma abordagem holística, levando em conta a pessoa como um todo, considerando também suas preferências, seu bem-estar e o contexto social e cultural. OBJETIVO: Assim, objetivou-se evidenciar os cuidados de Enfermagem centrado no paciente com pé diabético na literatura. MÉTODOS: Estudo do tipo revisão narrativa da literatura realizado em agosto de 2019. A busca foi realizada nas bases PUBMED, Lilacs e Libertpub por meio da Biblioteca Virtual de Saúde (BVS) com os descritores "pé diabético", "cuidados de Enfermagem", "estomaterapia" e auxílio do agente boleano "AND". Foi utilizado como critérios de inclusão estudos disponíveis na íntegra e nos idiomas português e inglês. E critério de exclusão, trabalhos do tipo editoria, resumos. Obtiveram-se 25 artigos dos quais seis foram selecionados. RESULTADOS: O diabetes e o pé diabético são condições complexas que exigem o acompanhamento e a colaboração de diversos profissionais e especialistas, dentre eles enfermeiros estomaterapeutas, cirurgiões vasculares, endocrinologistas, nutricionistas, psicólogos a fim de contemplar aspectos biológicos, físicos, emocionais, sociais e também as preferências da pessoa. Exige-se uma abordagem multi e interprofissional e a utilização de tecnologias leves e duras, favorecendo educação em saúde, envolvimento dos pacientes e familiares, autonomia, autocuidado e autogestão. O cuidado centrado na pessoa com pé diabético deve estar voltado não somente para a lesão, com avaliação e prescrição de tratamento tópico eficaz, cuidados com a pele adjacente, desbridamento, controle de infecção e umidade. É necessária uma abordagem holística com controle metabólico, manejo da glicemia, alimentação adequada, alívio de pontos de pressão nos pés, avaliação e acompanhamento do risco, segundo a neuropatia e doenças venosas e apoio emocional3. Nesse sentido, é oportuno considerar uma nova forma de pensar, planejar e fazer o processo de cuidado colocando realmente o paciente no centro da atenção á saúde e proporcionando espaços de diálogos e participação ativa e colaborativa dos próprios pacientes e familiares4. CONCLUSÃO: Foi possível identificar que ainda uma existe visão fragmentada do indivíduo e do cuidado com foco na ferida, em detrimento da visão integral da pessoa com pé diabético o que leva a reflexão quanto à necessidade de mudança da prática profissional de modo a realizar ações efetivas que possibilitem o bem-estar, a qualidade de vida, prevenção de complicações, promoção da saúde, além de autonomia e participação ativa desse processo de cuidado.
\end{abstract}

Keywords: Pé diabético. , Estomaterapia., Assistência Centrada no Paciente., Cuidados de Enfermagem.

\section{Referências Bibliográficas}

1. Ramirez-Perdomo C, Perdomo-Romero A, Rodríguez-Vélez M. Conhecimento e prática para a prevenção do pé diabético. Rev. Gaúcha Enferm 2019 Fev; 40(1):1-8. 2. BRASIL. Ministério da Saúde. Secretaria de Atenção à Saúde. Departamento de Atenção Básica. Manual do pé diabético: estratégias para o cuidado da pessoa com doença crônica / Ministério da Saúde, Secretaria de Atenção à Saúde, Departamento de Atenção Básica. - Brasília: Ministério da Saúde, 2016. 3. 2. Harding K, Armstrong D, Chadwick P, Choudhry ER, Edmonds M, Loots M, et al. Local management of diabetic foot ulcers. Florence: Wounds International; 2016. 4. Chibante CLP et al. Saberes e práticas no cuidado centrado na pessoa com feridas. Esc. Anna Nery [online]. 2017, vol.21, n.2, e20170036. 


\title{
MONITORAMENTO DA IMPLEMENTAÇÃO DO PROTOCOLO DE FERIDAS DA ATENÇÃO PRIMÁRIA EM SAÚDE NO MUNICÍPIO DE SALVADOR-BA.
}

\author{
Author(s): DANIELA ALENCAR VIEIRA ${ }^{1}$, LELIA MENDES SOBRINHO DE OLIVEIRA ${ }^{1}$, DENISE DE \\ JESUS SILVA $^{1}$, GEORGIA NEVES DA SILVA ${ }^{1}$, SANDRA MONTANHA GARGUR $^{1}$ \\ Institution(s) ${ }^{1}$ SMS - SECRETARIA MUNICIPAL DE SAÚDE DO SALVADOR (RUA DA GRÉCIA, S/N)
}

\begin{abstract}
Introdução: A implementação de normas e rotinas na sala de curativos visa promover a sistematização da assistência de enfermagem, para garantir melhoria da qualidade do serviço ao usuário com feridas crônicas.1,2 A avaliação da ferida constitui uma das etapas fundamentais para o planejamento do tratamento em todos os níveis de assistência à saúde. $3 \mathrm{~A}$ utilização de protocolo é indispensável, pois padroniza as escolhas das ações assistenciais, que devem estar pautadas no conforto do cliente, na qualidade da assistência prestada, na redução do número de dias com feridas e dos custos.1,2 Objetivo: elaborar indicadores para o monitoramento da implementação do Protocolo de Feridas da Atenção Primária do município de Salvador-Bahia. Materiais e Método: trata-se de um relato de experiência sobre a construção dos indicadores para avaliação da implementação do Protocolo de Feridas do município de Salvador-BA, ocorrido em 2017. Foram realizados encontros bimensais com profissionais de referência, objetivando a escuta das facilidades e dificuldades na execução do protocolo. Ademais, foi elencado junto as unidades executoras informações que integrariam instrumentos para melhor controle dos registros de procedimentos realizados, gastos de insumos, adesão e necessidade de treinamento dos profissionais. Resultados: foi estabelecido um cronograma de capacitações/treinamentos sobre técnicas de realização de curativos, indicações e técnicas para aplicação de coberturas especiais, estabelecida a rotina da consulta de enfermagem na sala de curativos, padronizados impressos de acompanhamento dos usuários e escala de avaliação de feridas, padronizado elenco de coberturas especiais e disponibilizado código para registro dos procedimentos realizados, por categoria profissional. Diante do exposto, foram elaborados alguns indicadores objetivando: avaliar a implementação do protocolo, identificar oportunidades de melhoria e traçar novas metas. São eles: 1. Visitas às unidades de saúde; 2. Implementação da consulta de enfermagem; 3. Utilização dos impressos de avaliação/registro padronizados; 4. Registro de procedimentos por categoria profissional; 5 . Número de altas por cura; 6 . Consolidado de procedimentos realizados e mapa mensal de solicitação de insumos (por paciente e patologia); 7. Participação em atividades de educação permanente; 8. Produção científica. Conclusões: o uso de protocolos proporciona mudanças significativas no cuidado com as feridas e na qualidade de vida dos usuários, caracterizando-se como um subsídio de grande relevância para um cuidado qualificado, humanizado e pautado nas necessidades de saúde de cada indivíduo. Nesse sentido, faz-se necessário que os protocolos sejam periodicamente avaliados/monitorados com vistas a garantir sua efetividade no cuidado aos usuários.
\end{abstract}

Keywords: Feridas, Estomaterapia, Atenção Primária, Protocolos

\section{Referências Bibliográficas}

1. Conselho Federal de Enfermagem - COFEN. Resolução 358/2009. [on line]. Disponível em: http://www.cofen.gov.br/resoluo-cofen-3582009_4384.html 2. Borges EL. Tratamento de Feridas: Avaliação de um Protocolo. [Dissertação]. Escola de Enfermagem da Universidade Federal de Minas Gerais; 2000. 3. Bates-Jensen B, Sussman C. Tools to measure wound healing. In Sussman C, Bates-Jensen B, editors. Wound Care, a Collaborative Practice Manual for Health Professionals, 4 ed. Baltimore (US): Lippincott Williams and Wilkins; 2012. p. 131-72; 


\title{
ÍNDICE DE POSITIVIDADE: AVALIAÇÃO DAS BOAS PRÁTICAS DE PREVENÇÃO DE LESÃO POR PRESSÃO
}

\author{
Author(s): Sherida Karanini Paz de Oliveira ${ }^{1}$, Ruhama de Oliveira Rebouças ${ }^{1}$, Antonio Dean Barbosa \\ Marques ${ }^{1}$, Sarah Vieira Figueiredo ${ }^{1}$, Rebeca Furtado Fernandes ${ }^{1}$, Clara Castelo Branco da Silva ${ }^{1}$ \\ Institution(s) ${ }^{1}$ UECE - Universidade Estadual do Ceará (A. Dr Silas Munguba, 1700. Itaperi. Fortaleza-Ce.)
}

\begin{abstract}
INTRODUÇÃO: A lesão por pressão (LP) é considerada um grave problema de saúde pública, especialmente devido o impacto que gera à pessoa doente, a família e a sociedade1. Muitos pacientes são acometidos por esse evento adverso, o qual é potencializado no contexto das unidades de terapia intensiva (UTI)2, apesar de poder ser prevenido. Os cuidados de prevenção de LP estão fortemente relacionados com a qualidade e segurança da assistência. A Aliança Mundial para Segurança do Paciente estabeleceu seis metas Internacionais para Segurança do Paciente, sendo a prevenção de LP a sexta meta2. Dessa forma, surgiu o seguinte questionamento: "Qual o índice de positividade da qualidade da assistência prestada por enfermeiros na prevenção de lesões por pressão na unidade de terapia intensiva?". OBJETIVO: Avaliar o índice de positividade da qualidade da assistência prestada por enfermeiros na prevenção de lesões por pressão em uma unidade de terapia intensiva. MATERIAL E MÉTODO: Estudo transversal realizado em uma unidade de terapia intensiva de um hospital público terciário de Fortaleza-Ce com 11 enfermeiros. Os dados foram coletados por meio do questionário de Prevenção de Lesão por Pressão para Pediatria - PLPP adaptado para o público adulto3. O questionário possui três domínios: medidas preventivas e detecção precoce de LP (9 itens), medidas de alívio da pressão (8 itens), além de avaliação e notificação (6 itens). Os dados foram avaliados por meio Índice de Positividade (IP) da Qualidade da Assistência4, classificando a assistência em: desejável (100\%), adequada (90-99\%), segura (80-80\%), limítrofe (71-79\%) e sofrível $(<70 \%)$ as ações: inspeção diária da pele e reavaliação diária do risco por meio de escalas; orientação quanto à limpeza da pele; não realização de massagem de áreas de proeminência óssea ou hiperemiada; utilização de coberturas para proteger a pele; mudança de decúbito e reposicionamento do paciente apoios para alívio e redistribuição da pressão; avaliação do estado nutricional e notificação ao nutricionista; e notificação à gerencia de risco. $O$ índice de positividade geral foi de 60,56\%, revelando um indicador de qualidade preocupante, já que aponta para um baixo percentual de realização de medidas de prevenção de LP e uma assistência de enfermagem com lacunas de segurança e qualidade, conforme o indicador utilizado4. CONCLUSÃO: foi possível inferir que existem fragilidades na realização de boas práticas na prevenção de lesão por pressão, sendo a assistência classificada como sofrível devido o baixo índice de positividade da qualidade da assistência. Diante disso, vislumbra-se a necessidade de encontrar e implementar estratégias para melhoria do cuidado com vistas à segurança do paciente e qualidade da assistência.
\end{abstract}

Keywords: Lesão por pressão., Indicadores de Serviços., Cuidados de Enfermagem., Estomaterapia.

\section{Referências Bibliográficas}

1. Mendonça PK, Loureiro MDR, Ferreira Júnior MA et al. Ocorrência e fatores de risco para lesões por pressão em centros de terapia intensiva. Rev enferm UFPE on line., Recife, 12(2):303-11, fev., 2018. 2. Mendonça PK, Loureiro MDR, Frota OP, Souza AS. Prevenção de lesão por pressão: ações prescritas por enfermeiros de centros de terapia intensiva. Texto Contexto Enferm, 2018; 27(4):e4610017 3. Ferreira MKM. Prevenção de lesão por pressão na pediatria: validação de instrumento com enfoque na segurança do paciente, 2018, 122f. Dissertação (Mestrado em Pós-Graduação em Enfermagem) - Universidade Federal do Ceará, Fortaleza. 4. Haddad MCFL. Qualidade da assistência de enfermagem: 0 processo de avaliação em hospital público [tese de doutorado]. Ribeirão Preto (SP): Escola de Enfermagem de Ribeirão Preto/USP; 2004. 


\title{
GEL DE PROTEÍNA SINTÉTICA EM DERMATITES ASSOCIADAS À INCONTINÊNCIA
}

\author{
Author(s): Diba Maria Sebba de Souza ${ }^{1}$, Viviane Aparecida de Souza Silveira ${ }^{1}$, Adriana Rodrigues dos Anjos \\ Mendonça ${ }^{1}$, Daniela Francescato Veiga ${ }^{1}$ \\ Institution(s) ${ }^{1}$ Univas - Mestrado Profissional em Ciências Aplicadas à Saúde (Av. Pref. Tuany Toledo,470 CEP \\ 37550-000 | Pouso Alegre | MG)
}

\begin{abstract}
Introdução: Dermatite Associada à Incontinência (DAI) é uma reação inflamatória na pele, devido contato com substâncias ácidas ou alcalinas, se manifesta através de lesões cutâneas, que causam erosão da epiderme, deixando-a com aspecto de pele macerada, tal situação é comum em pacientes com incontinência fecal ou urinária, devido ao contato da pele com a umidade. A Albumina é uma proteína presente em grande concentração no plasma humano, podendo ser encontrada também na clara de ovo. A albumina humana é um medicamento hemoderivado, no Brasil, é utilizado e a solução de albumina a $20 \%$, sendo esta comercializada em forma de solução injetável, onde cada frasco de $50 \mathrm{ml}$ possui $200 \mathrm{~g} / \mathrm{L}$ de albumina humana. Estas soluções são destinadas ao uso terapêutico endovenoso. O Polímero (INCI NAME: Polyacrylamide (and) C13-14 Isoparaffin (and) Laureth-7) trata-se de um agente espessante, emulsionante, préneutralizado, compatível com diferentes níveis de $\mathrm{pH}$ que permite a formulação de emulsões e estabiliza suspensões, sendo capaz de proporcionar uma textura cremosa como gel-creme. Objetivos: Desenvolver gel com albumina líquida $20 \%$ associada ao polímero INCI NAME: Polyacrylamide (and) C13-14 Isoparaffin (and) Laureth-7 na concentração de 10\% e avaliar sua eficácia como uso tópico no tratamento da DAI. Métodos: Estudo primário, randomizado, controlado, descritivo, intervencional, analítico, longitudinal e prospectivo. Locais: Hospital Universitário e duas Instituições de Longa Permanência para Idosos. Foram avaliados 55 participantes, durante cinco meses. Critérios de inclusão: ambos os sexos, acima de 50 anos, portadores de DAl. Critérios de não inclusão: participantes que recusaram assinar o TCLE e sensibilidade relatada ou comprovada à ingestão de clara de ovo e derivados. Instrumentos: Perineal Assesment Tool e Classificação da Localização das Lesões relacionadas a DAl. Randomização: 25 pacientes do Grupo A (estudo) gel com albumina associada ao Polímero na concentração de $10 \%$ e 30 do Grupo B (controle) pomada Oxido de Zinco a 10\% com Nistatina $25.000 \mathrm{UI} / \mathrm{g}$. Aplicação dos produtos nos 1은 $3^{\circ}, 7^{\circ}$ e $15^{\circ}$ dias. Resultados: Média de 66 a 69 anos; sexo masculino 30(54,5\%), 27(49,1\%) casados; $27(49,1 \%)$ ensino fundamental, $43(78,2 \%)$ portadores de doenças crônicas degenerativas $43(78,2 \%),(p<0,00)$. Conclusão: Albumina líquida a $20 \%$ associada ao Polímero INCI NAME: Polyacrylamide (and) C13-14 Isoparaffin (and) Laureth-7, demonstra eficácia para uso tópico em tratamento das Dermatites Associadas à Incontinência. O pedido de patente de invenção foi registrado no Instituto Nacional da Propriedade Industrial BR 102018 075181 6 em 05/12/2018
\end{abstract}

Keywords: Albuminas, Dermatite das Fraldas. , Incontinência Fecal. , Incontinência Urinária, Estomaterapia.

\section{Referências Bibliográficas}

Agência Nacional de Vigilância Sanitária - ANVISA. Resolução RDC n¹15: Diretrizes para o uso de Albumina [internet]. Maio 2004 [acesso em 09 Out 2018]. Disponível em: www.medicinaintensiva.com.br/albumina.htm.12. Brandão ACMAG, Gambim CC, Majado CA, Kunitake N, Alexandre NMC, Dantas SRPE. Adaptação do instrumento "Perineal Assessment Tool" para a Cultura Brasileira. Rev Estima. 2018; 17(06):1-7. Brennan MR, Milne CT, AGrell-Kann M, Ekholm BP. Clinical Evaluation of a Skin Protectant for the Management of Incontinence - Associated. J Wound Ostomy Continence Nurs. 2017; 44(2):172-80. Cunha CV, Ferreira D, Nascimento D, Felix F, Cunha P, Penna LHG. Dermatite associada à incontinência em idosos: Caracterização, prevenção e tratamento. Rev. Estima. 2015; 13(3):1-7. Domansky RC, Borges EM. Manual para a prevenção de lesões de pele. Recomendações baseadas em evidências. 20 ed. Rio de Janeiro: Rubio; 2014. Cap. 5, p. 93100, 113-115. Focus Química. Material do fabricante. [internet] 2015. [acesso em 09 Out 2018]. Disponível em: www.pharmanostra.com.br 


\title{
APLICAÇÃO DE PLASMA RICO EM PLAQUETAS EM PACIENTES COM PÉ DIABÉTICO
}

\author{
Author(s): Amelina de Brito Belchior ${ }^{1}$, Sherida Karanini Paz de Oliveira ${ }^{1}$, Lidiane do Nascimento Rodrigues \\ ${ }^{1}$, Edna Maria Camelo Chaves ${ }^{1}$, Nariane Monique Mendes de Lima ${ }^{1}$, Ricardo de Oliveira Lima ${ }^{1}$ \\ Institution(s) ${ }^{1}$ UECE - UNIVERSIDADE ESTADUAL DO CEARÁ ( Av. Dr. Silas Munguba, 1700 - Itaperi, \\ Fortaleza - CE, 60741-000)
}

\begin{abstract}
INTRODUÇÃO: As lesões do pé diabético são resultantes de uma combinação de diversos fatores tais como o estresse biomecânico, diminuição da perfusão cutânea, perda de sensibilidade e o trauma externo1. O cuidado dessas lesões é desafiador para a equipe multiprofissional. Avanços tecnológicos têm trazido alternativas e melhorias no tratamento destas lesões, destacando-se o plasma rico em plaquetas (PRP). O PRP é uma concentração de plaquetas em um pequeno volume de plasma obtida por meio da centrifugação do sangue total2,3. OBJETIVO: Verificar o efeito do Plasma Rico em Plaquetas autólogo para tratamento de pacientes com pé diabético. MATERIAL E MÉTODO: Trata-se de um estudo de caso sobre a aplicação injetável do PRP autólogo em dois pacientes com lesões de pé diabético. O estudo foi realizado em um ambulatório de um hospital terciário nos meses de fevereiro a abril de 2018. Foram respeitados todos os princípios éticos relativos à pesquisa com seres humanos, de acordo com a Resolução 466/2012. O projeto do presente estudo foi aprovado pelo Comitê de Ética em Pesquisa do Hospital Geral Dr. César Cals com no 2.124.452. RESULTADOS: Foram realizadas seis aplicações de PRP injetável em toda extensão das lesões, uma vez por semana e reavaliação na sétima semana. Na segunda e terceira aplicação do PRP, os pacientes relatam diminuição da dor na lesão no dia a dia. Ressaltando ainda que partir da quarta aplicação referiram dor durante a aplicação do PRP, o que antes não ocorria, evidenciando melhora da sensibilidade no local. Observou-se, nos dois pacientes, melhora na sensibilidade ao toque, inclusive quando comparado ao outro pé, com relato de aumento gradativo a cada aplicação do PRP. Destaca-se que esse aumento de sensibilidade foi descrito a partir da terceira aplicação, sendo citada pelos pacientes na quarta, quinta e sexta aplicação, como também na reavaliação. CONCLUSÃO: Com o estudo, foi possível verificar que houve melhora na sensibilidade do membro e relato de da dor a cada aplicação do PRP. Sugere-se, portanto, a realização de estudos clínicos para compreensão da atuação do PRP e sua eficácia na melhora da sensibilidade, cicatrização e dor nos pacientes com diabetes.
\end{abstract}

Keywords: Plasma Rico em Plaquetas, Pé diabético, Diabetes Mellitus, Fatores de crescimento, Estomaterapia

\section{Referências Bibliográficas}

1. International Working Group On The Diabetic Foot (Org.). Guidance on the diagnosis and management of foot infections in persons with diabetes: prepared by the IWGDF Working Group on Foot Infections. [publicação online]; 2015. [acesso em 05 fev 2017]. Disponível em http://iwgdf.org/guidelines/guidance-on-infection/> 2. Marx, RE; Carlson, E.R.; Eichstaedt, RM; Schimmel, SR; Strauss, JE; Georgeff, KR. Platelet-rich plasma: Growth factor enhancement for boné grafts. Oral Surg Oral Med Oral Pathol Oral Radiol Endod. 1998; 638-646 3. Marx, RE. Platelet-rich plasma: evidence to support its use. Journal Of Oral And Maxillofacial Surgery. 2004;62(4):489-496 


\title{
Pessoas em situação de rua: a presença de úlceras cutâneas e o sofrimento psíquico.
}

\author{
Author(s): Isabela de Faria Marques ${ }^{1}$, Carmen Lúcia Albuquerque de Santana ${ }^{1}$, Maria Cristina Mazzaia ${ }^{1}$, \\ Giovana Andrade Frederico ${ }^{1}$, Thiago Souza Reis ${ }^{1}$, Mônica Antar Gamba ${ }^{1}$ \\ Institution(s) ${ }^{1}$ UNIFESP - Universidade Federal de São Paulo (Rua Napoleão de Barros, 754), ${ }^{2}$ UNIFESP - \\ Universidade Federal de São Paulo (Rua Napoleão de Barros, 754.), ${ }^{3}$ UNIFESP - Universidade \\ Federal de São Paulo (Rua Napoleão de Barros, 754), ${ }^{4}$ EPE- UNIFESP - Escola Paulista de \\ Enfermagem (Rua Napoleão de Barros, 754), ${ }^{5}$ UNIFESP - Universidade Federal de São Paulo \\ (Rua Napoleão de Barros, 754 - Vila Gumercindo)
}

\begin{abstract}
Introdução: A úlcera cutânea crônica é um problema de saúde pública em latência, gera um alto gasto público, além de afetar diretamente na qualidade de vida da população. Pessoas em situação de rua geralmente são acometidas por ferimentos e lesões e vivem as dificuldades do tratamento causadas pela falta de condições adequadas e, em grande parte, pela presença do sofrimento psíquico. Objetivos:analisar as evidências científicas sobre a ocorrência de úlceras cutâneas e o sofrimento psíquico de pessoas em situação de rua. Metodologia: Trata-se de uma revisão integrativa da literatura que faz parte de uma pesquisa-ação desenvolvida pelo Núcleo de Políticas Públicas- UNIFESP. A questão norteadora foi elaborada pela estratégia PICO, ou seja:pessoas em situação de rua com feridas crônicas apresentam sofrimento psíquico? Utilizou-se os seguintes descritores: feridas, pessoa em situação de rua, saúde mental, wound, homeless, mental Health e Úlceras Cutâneas entre cruzados com o marcador boleano "and". A busca dos artigos foi realizada na Biblioteca Virtual em Saúde (BVS), aplicando os critérios de seleção/inclusão: artigos publicados entre 2015 e 2019, disponíveis na íntegra, nos idiomas inglês e português. Extraíram-se dos estudos autoria, título e ano, objetivos, delineamento e nível de evidência (NE), população e local de coleta de dados e principais resultados. A análise de conteúdo foi realizada para obtenção dos resultados. Resultados: Foram incluídos nesta revisão, 15 artigos, predominantemente brasileiros (33,3\%),publicados em 2016 (26,66\%) e 2017(26,66\%). Dentre os artigos, obtiveram 14 estudos originais e um de revisão. A metodologia de pesquisa empregada na maioria dos estudos foi a qualitativa $(26,66 \%)$ e a quantitativa $(26,66 \%)$, com nível de evidência VI.Não foram encontradas pesquisas que retratem o tema em sua completude. Destes, cinco estudos $(33,33 \%)$ envolvem pessoas em situação de rua e discutem as necessidades e expectativas,relacionadas à sobrevivência e ao acesso a equipamentos sociais e de saúde. Estas, apresentam tendência a transtornos de personalidade, desconfiança, impulsividade e comportamentos excêntricos. Embora não seja possível identificar na literatura a ocorrência de úlceras na população de interesse, impactos importantes assolam avida das pessoas para além da dimensão física, emocional, psíquica, social e econômica e merecem atenção das equipes de saúde.Considerações finais: Observam-se lacunas nesta área de investigação e na e proposição de políticas públicas voltadas à população em situação de rua com lesões cutâneas. Desta forma torna-se essencial o desenvolvimento de mais estudos de campo, com intuito de compreender as necessidades,vulnerabilidades e expectativas dessa população.
\end{abstract}

Keywords: Enfermagem, Ferimentos, Saúde Pública, Sofrimento psíquico , Úlceras cutâneas

\section{Referências Bibliográficas}

1. Frederico GA, Kolchraiber FC, Paquier DC, Rosa AS, Gamba MA. INTEGRALITY IN NURSING CARE FOR PEOPLE WITH CUTANEOUS ULCERS. Revista de Enfermagem UFPE Online-2018.https://doi.org/10.5205/1981-8963v12i7a234800p1997-2011-2018 2. Barbosa MLG, Salomé GM, Ferreira LM. Evaluetion of Anxiety and Depression in Patients With Venous Ulcers Treated With Acupunture. Revista de Enfermagem UFPE Online - 2017; 11:3574-82. 3. Hino P, Santos JO, Rosa AS. People living on the street from the health point of view. Rev Bras Enferm [Internet]. 2018;71(Suppl 1):684-92. [Thematic Issue: Contributions and challenges of nursing practices in collective health] DOI: http://dx.doi.org/10.1590/0034-7167-2017-0547 4. SOUZA, Diba Maria Sebba Tosta de et al. QUALIDADE DE VIDA E AUTOESTIMA DE PACIENTES COM ÚLCERA CRÔNICA. Acta paul. enferm. [online]. 2013, vol.26, n.3, pp.283-288. ISSN 1982-0194. http://dx.doi.org/10.1590/S0103-21002013000300013. 


\title{
Desenvolvimento e avaliação cicatricial in vivo de hidrogel à base de galactomanana veiculando óleo de pequi (Caryocar criaceum) e água de coco em pó $A C P \circledast$ em lesões excisionais
}

\author{
Author(s): Hérmerson Nathanael Lopes de Almeida ${ }^{1}$, Felipe Domingos de Sousa ${ }^{2}$, Renato de Azevedo \\ Moreira $^{2}$, Ana Cristina de Oliveira Monteiro Moreira ${ }^{2}$ \\ Institution(s) ${ }^{1}$ UECE - Universidade Estadual do Ceará (Rua Silas Munguba 1700), ${ }^{2}$ UNIFOR - Universidade \\ de Fortaleza ( Av. Washington Soares, 1321)
}

\begin{abstract}
Hidrogéis são redes tridimensionais, hidrofílicas, poliméricas capazes de absorver grandes quantidades de água ou fluidos biológicos e são amplamente utilizados para tratar lesões cutâneas. Os polímeros naturais, como quitina, quitosana, alginato, colágeno, elastina, gelatina, celulose são empregados na obtenção de hidrogéis e correlatos com eficácia comprovada. Neste contexto, esse trabalho teve como objetivo desenvolver um hidrogel a base de galatomanana (Caesalpinia pulcherrima) ao qual foi incorporado óleo de pequi (Caryocar coriaceum wittm) e água de coco em pó (ACP®) avaliando a sua eficácia no processo cicatricial em lesões excisionais induzidas em camundongos. A qualidade dos componentes da formulação (galacatomanana e óleo de pequi) foram analisadas por meio de sua composição centesimal, distribuição de massa molecular, caracterização físico-química, infravermelho e identificação de ácidos graxos; em relação a água de coco em pó $(\mathrm{ACP} \Theta)$, a composição foi fornecida pelo fornecedor. O protocolo para a realização dos ensaios in vivo foi submetido e aprovado pela Comissão de Ética para o Uso de Animais da Universidade de Fortaleza sob registro de $\mathrm{n}^{\circ}$ 006/2016. Foram utilizados 108 camundongos machos BALB/c ( $\left.25-30 \mathrm{~g}\right)$, da mesma idade, distribuídos em 6 grupos $(n=6)$ (HF0 - Salina; HFC - Dersani® Gel; HFG - Galactomanana; HF6, HF8 e HF11 - estes com concentrações diferentes do óleo de pequi e $A C P\left({ }^{\circledR}\right)$ com variações de $2,5 \mathrm{~g}$ a $20 \mathrm{~g}$ respectivamente. A aplicação do hidrogel na lesão excicional, feita no dorso do camundongo, foi realizada diariamente. Análise macroscópica (hiperemia, edema, sangramento, exsudato e tipo de tecido) e microscópica (histológica) foram realizadas no $3^{\circ}, 7^{\circ}$ e $14^{\circ}$ dia. A galactomanana apresentou um baixo teor de proteínas $(0,217 \%)$ e cinzas $(1,0 \%)$; No óleo do pequi, foi verificado índice de acidez $(0,961 \%)$ e peróxido $(4,34 \%)$, quanto aos grupos funcionais evidenciaram cadeias insaturadas $(\mathrm{C}=\mathrm{C})$ e ausência de hidroxila $(-\mathrm{OH})$ em relação aos ácidos graxos, os mais presentes foram o ácido palmítico $(28,4 \%)$ e oleico $(66,22 \%)$; a água de coco em pó, conforme fornecedor, é composta por vitaminas, minerais, lipídios entre outros. Na cicatrização o que mais evidenciou foi hiperemia, sangramento e tipo de tecido com relevância estatística de $\mathrm{p}<0,05$ principalmente para o grupo HF8, diminuindo o tempo de hiperemia, menor sangramento e prevalecendo tecido reepitelizado, nos dias avaliados, em relação aos demais grupos. Este grupo contem maior concentração de óleo e menor de água de coco em pó. Observou-se ainda que o grupo HFC - comercial, propicia maior período no processo inflamatório com marginação e extravasamento intersticial principalmente no $14^{\circ}$ dia de tratamento. Os resultados obtidos indicam que os biomateriais, obtidos de fontes renováveis, podem ser utilizados no desenvolvimento de formulações farmacêuticas inovadoras aplicadas ao tratamento de lesões teciduais agudas e crônicas, sendo uma alternativa terapêutica de baixo custo e genuinamente nacional.
\end{abstract}

Keywords: Cicatrização, Hidrogel, Polímero

\section{Referências Bibliográficas}

AOAC. Official Method. 965.33. Peroxide value of Oils and Fats (Titration Method). 18 ed. AOAC Official Methods of Analysis, 2005. CEchinel-filho V, Yunes R.A. Estratégias para a obtenção de compostos farmacologicamente ativos a partir de plantas medicinais: conceitos sobre modificação estrutural para otimização da atividade. Química Nova. v. 21, n. 1, p. 99-105, 1998. Phillipson JD. Phytochemistry and medicinal plants. Phytochemistry. v. 56, p. 237-243, 2001. Santos MFS, et al. Evaluation of the use of raw extract of Jatropha gossypii-folia $L$. in the healing process of skin wounds in rats. Acta Cir. Brás., v. 21, p. 2-7, 2006. Suplemento 3. 1. 


\title{
EVOLUÇÃO CICATRICIAL DE UMA ÚLCERA VENOSA ATRAVÉS DO TRATAMENTO ADJUNTO DA BOTA DE UNNA E A TERAPIA BIOFOTODINÂMICA: RELATO DE EXPERIÊNCIA.
}

\author{
Author(s): $\quad$ Flavia Cobuci Resende Rodrigues ${ }^{1}$, Jonathan de Oliveira Paiva ${ }^{2}$ \\ Institution(s) ${ }^{1}$ UERJ - Universidade Estadual do Rio de Janeiro (Faculdade de Enfermagem - Boulevard 28 de \\ Setembro, 157 - Vila Isabel.), ${ }^{2}$ IESPE - Instituto de Educação São Pedro (Av. Barão do Rio Branco \\ $3.480,3^{\circ}$ andar, Passos - Juiz de Fora - MG)
}

\begin{abstract}
As úlceras venosas são decorrentes da insuficiência vascular associada ao fracasso da musculatura da panturrilha, gerando a estase venosa e a hipertensão, que podem ainda ser acrescidos de alteração na circulação, isquemia e edema nos membros. São lesões crônicas, cujo processo cicatricial é lento e com alta taxa de reincidência que elevam o sofrimento dos pacientes e os custos do tratamento. Sua prevalência vem aumentando significadamente, sendo responsável por 70 a $90 \%$ das úlceras de membro inferiores, afetando aproximadamente $1 \%$ da população geral e de 3 a $5 \%$ da população com mais de 65 anos $^{1}$. Os cuidados em saúde visam a corresponsabilidade do paciente, e envolvem não só o cuidado com a lesão e as doenças de base, como também a educação em saúde e a busca por hábitos de vida saudáveis. O tratamento do edema através da terapia compressiva é considerado o padrão ouro para esse tipo de lesão², pois favorece o retorno venoso e diminui a hipertensão venosa. É realizada através do uso de meias de compressão, faixa elástica ou a bota de Unna. Existem ainda as terapêuticas adjuvantes, mais recentes e ainda pouco difusas no mercado, pelo alto custo ou por falta de conhecimento e poucas evidências científicas, que surgem como promissoras ferramentas de auxílio no tratamento desse tipo de lesão. Nesse cenário apresenta-se a terapia biofotodinâmica com propriedades de bioestimulação através da luz colimada, com reconhecidas propriedades analgésicas, antiinflamatórias e reparo tecidual. Através deste estudo buscou-se descrever a evolução cicatricial de uma lesão diante do uso combinado das terapias compressivas e biofotodinâmica. Estudo descritivo e qualitativo, realizado no período de maio a julho de 2019 , durante 10 sessões semanais com aplicação de terapia biofotodinâmica e troca da bota de Unna. Os registros e avaliações foram realizados através do prontuário e avaliação fotográfica periódica da lesão, respeitando-se os preceitos éticos. Os resultados alcançados ao final da implantação do plano terapêutico foram satisfatórios com diminuição da área de extensão da lesão, eliminação do esfacelo, presença de tecido de granulação, diminuição do edema do membro e discreta diminuição da dor referida.
\end{abstract}

Keywords: Úlcera Venosa., Terapia Compressiva., Terapia Biofotodinâmica., Estomaterapia.

\section{Referências Bibliográficas}

1. Bavaresco, Taline. O efeito do laser de baixa potência no tratamento de úlceras venosas avaliado pela Nursing Outcomes Classification (NOC): ensaio clínico randomizado. 137 f. Orientadora: Amália de Fátima Lucena. Tese (Doutorado). Universidade Federal do Rio Grande do Sul, Escola de Enfermagem, Programa de Pós Graduação em Enfermagem, Porto Alegre, BR-RS 2018. 2. Silva MH, Jesus MCP, Tavares RE, Caldeira EAC, Oliveira DM, Merighi MAB Experiência de pessoas adultas e idosas frente à adesão aos cuidados com a úlcera varicosa. Rev Gaucha Enferm. 2019; 40:e20180024. doi:https://doi.org/10.1590/1983-1447.2019.20180024. 3. Siqueira CPCM, Filho DOT, Lima FM, Silva FP, Durante H, Dias IFL et al. Efeitos biológicos da luz: aplicação de terapia de baixa potência empregando LEDs (Lights Emitting Diode) na cicatrização da úlcera venosa: relato de caso. Semina: Ciências Biológicas e da Saúde, Londrina, v. 30, n. 1, p. 37-46, jan./jun. 2009 4. Junior AMR, Oliveira RG, Farias RE, Andrade LCF, Aarestrup FM. Modulação da proliferação fibroblástica e da resposta inflamatória pela terapia a laser de baixa intensidade no processo de reparo tecidual. An Bras Dermatol., Rio de Janeiro, v. 81, n. 2, p. 150-156, mar/ 2006. 5. Lins RDAU, Dantas EM, Lucena KCR, Catão MHCV, Granville-Garcia AF, Neto LGC. Efeitos bioestimulantes do laser de baixa potência no processo de reparo. An Bras Dermatol., Rio de Janeiro, v. 85, n. 6, p. 849-855, dez./ 2010. 


\title{
AVALIAÇÃO EM ENFERMAGEM EM DERMATOLOGIA NO PÊNFIGO VULGAR
}

\author{
Author(s): $\quad$ Mariana Takahashi Ferreira Costa ${ }^{1}$, Luiza Keiko Matsuka Oyafuso ${ }^{1}$, Mônica Antar Gamba ${ }^{1}$ \\ Institution(s) ${ }^{1}$ UNIFESP - Universidade Federal de São Paulo (Rua Napoleão de Barros, 754 - Vila Gumercindo)
}

\begin{abstract}
Introdução: Pênfigo vulgar (PV) é uma dermatose bolhosa autoimune grave, que resulta na formação de bolhas intraepidérmicas, que afetam pele e mucosas. PV ocorre principalmente entre a quarta e a sexta décadas de vida. Além do acometimento cutâneo, no pênfigo vulgar também há comprometimento mucoso, indo além da mucosa oral, faringe, laringe, mucosa nasal e orelha. Esse comprometimento acaba agravando a doença, pois dificulta a alimentação. Devido sua severidade e caráter desfigurante, a patologia afeta diretamente a qualidade de vida, auto-imagem, dinâmica social e familiar. Objetivo: analisar por meio de uma revisão da literatura a classificação/terminologia das úlceras cutâneas no pênfigo segundo lesões elementares dermatológicas. Método: Trata-se de um estudo metodológico no qual a revisão integrativa foi utilizada parcialmente sob o foco da ciência dermatológica, relacionada pelas lesões elementares. Principais descritores utilizados: dermatologia, pênfigo, úlcera cutânea, enfermagem, diagnóstico, avaliação em enfermagem, sistema de pontuação, atividade da doença, escala de severidade. Os estudos foram selecionados para análise após aplicação dos critérios de elegibilidade e exclusão por duplicidade. As variáveis independentes investigadas foram as lesões elementares. Resultados: Foram localizados 1.558 publicações e 11 artigos foram analisados e comparados com o glossário dermatológico os termos utilizados na descrição das úlceras do pênfigo. Na classificação das úlceras utilizada em estudos primários e de validação, as seguintes descrições de lesões foram identificadas: cutâneas/mucosas: epitelização, eritema, eritema novo, hiperpigmentação pós-inflamatória, lesões orais, vesículas, bolhas, erosões, áreas erodidas, lesões erosivas exsudativas, erosivas secas e crostas. Conclusões: São necessários estudos com melhor evidência na temática para melhor avaliar e descrever as lesões utilizando o glossário dermatológico para avaliação em enfermagem.
\end{abstract}

Keywords: enfermagem, pênfigo, úlcera cutânea, avaliação em Enfermagem, dermatologia

\section{Referências Bibliográficas}

Azulay RD. Dermatologia. 7aㅡ Ed. Rio de Janeiro; Guanabara Koogan, 2017. Rivitti EA. Sampaio and Rivitti Dermatologia. 4aㅡ ed. São Paulo; Artes Médicas, 2018. Petri V. Guia de bolso de dermatologia. 1aㅡ ed. São Paulo; Atheneu, 2018. Brandão ES, Santos I, Lanzillotti RS. Validação de um instrumento para avaliação do cliente com afecções cutâneas. Acta Paul Enferm. 2013; 26(5):460-6. Brandão ES, Santos I. Teorias de enfermagem na pPromoção do conforto em dermatologia Rev enferm UERJ, Rio de Janeiro, 2019; $27:$ e38330 


\title{
PREVALÊNCIA DA LESÃO POR FRICÇÃO EM UMA UNIDADE DE TERAPIA INTENSIVA DE UM HOSPITAL PRIVADO
}

Saskia Iasana Pontes Fleury ${ }^{1}$, Leticia Faria Serpa ${ }^{1}$, Elaine Cristina Ferreira Ianni ${ }^{1}$, Daniela Author(s): Cristina Solla Salvador ${ }^{1}$, Shirley Gomes Romão ${ }^{1}$, Amanda Leal Tavares ${ }^{1}$, Silvia Helena Conejo ${ }^{1}$, Amanda Bacchiega A. dos Santos ${ }^{1}$, Gledson Sousa Gimenez ${ }^{1}$, Paula Cristina Nogueira ${ }^{2}$ Institution(s) ${ }^{1}$ HAOC - Hospital Alemão Oswaldo Cruz (Rua João Julião, 331), ${ }^{2}$ EEUSP - Escola de Enfermagem da Universidade de São Paulo (Av. Dr. Enéas Carvalho de Aguiar, 41)

\begin{abstract}
INTRODUÇÃO: As skin tears, lesões por fricções, se constituem como lesões advindas de trauma, seja por fricção, contusão ou cisalhamento da pele levando ao descolamento da epiderme da derme. Este tipo de lesão decorre, sobretudo, das fragilidades do corpo do idoso, como a redução da espessura das camadas da pele, redução de sua umidade, elasticidade e resistência, fragilidades que se potencializam após os 75 anos de idade 1 A lesão por fricção pode ser utilizada como indicador de qualidade do cuidado prestado por estarem relacionadas, em grande parte dos casos, à disposição dos objetos no ambiente no qual o indivíduo se encontra2. Para classificar as lesões por fricção foi utilizado o Skin Tear Classification System (STAR) um guia de tratamento, sistema de classificação e glossário adaptado e validado para o português.3 Mais estudos que descrevam a prevalência e incidência dessas lesões no Brasil não necessários. OBJETIVO: Verificar a prevalência pontual de Lesão por Fricção em uma Unidade de Terapia Intensiva (UTI) e os fatores relacionados.

MÉTODO: Trata-se de um estudo observacional, transversal, prospectivo realizado na UTI geral de um hospital privado localizado na cidade de São Paulo. Este estudo faz parte de um projeto sobre prevalência de lesão de pele em UTI do Brasil, aprovado pelo o Comitê de Ética da instituição, CAAE 82211318.7.3006.070. Participaram do estudo pacientes com idade igual ou superior a 18 anos. Dados demográficos e clínicos foram coletados dos prontuários. Foi realizada inspeção da pele e as lesões por friç̧ão identificadas foram classificadas de acordo com as categorias Skin Tear Classification System (STAR).3 Os dados foram inseridos na plataforma REDCap e analisados no Microsoft Excel $\AA^{\circledR}$. RESULTADOS: Foram avaliados 28 pacientes, sendo 15 do sexo feminino $(53,5 \%)$, com média de idade 72 anos (DP=12). Destes, 16 pacientes (57\%) apresentaram IMC acima de 25 (sobrepeso), cinco desnutridos (17,85\%) pela avaliação nutricional, sete eram diabéticos $(25 \%)$, sete com redução de mobilidade $(25 \%)$. Nessa amostra, oito $(28,5 \%)$ pacientes apresentavam lesão por fricção, idade média de 79,5 anos, cinco do sexo feminino, média de 14 dias de tempo de internação. Foram identificadas 11 lesões por fricção (39\%), quatro lesões classificadas na categoria $1 \mathrm{~A}$, cinco lesões classificadas na categoria 1B, uma classificada como $2 \mathrm{~A}$ e uma classificada na categoria $2 \mathrm{~B}$. CONCLUSÃO: A prevalência de lesão por fricção nessa amostra foi de $39 \%$. Mais estudos são necessários para evidenciar os principais fatores relacionados ao desenvolvimento de lesão por fricção nas instituições hospitalares.
\end{abstract}

Keywords: Estomaterapia, Unidades de terapia intensiva, Prevalência, Ferimentos e lesões

\section{Referências Bibliográficas}

1. Domansk RC, Borges EL. Manual para prevenção de lesões de pele: Recomendações Baseadas em Evidências. 2.ed. Rio de Janeiro: Rubio;2014. 2. Santos I. Cuidado e prevenção das skin tears por enfermeiros: revisão integrativa de literatura. Rev. Gaúcha Enferm.2014;35(2):142-149.. 3. Strazzieri-Pulido KC, Santos VLCG, Carville K. Adaptação cultural, validade de conteúdo e confiabilidade interobservadores do "STAR Skin Tear Classification System". Rev. Latino-Am. Enfermagem.2015;23(1):155-61 


\title{
CUIDADOS COM A FERIDA OPERATÓRIA NA RESSECÇÃO DE OSSIFICAÇÃO HETEROTÓPICA EM PESSOAS COM LESÃO MEDULAR
}

\author{
Author(s): Janaina Barbosa da Silva ${ }^{1}$, Lisabel Tabari ${ }^{1}$ \\ Institution(s) ${ }^{1}$ APS - Rede Sarah de Hospitais de Reabilitação (SMHS 501 BLOCO A BRASÍLIA - DF CEP: \\ 70335-901)
}

\begin{abstract}
A ossificação heterotópica neurogênica $(\mathrm{OH})$ é uma complicação comum em pacientes que sofreram lesão medular e atinge de $10 \%$ a $50 \%$ desta população, acometendo principalmente a articulação do quadril1. $\mathrm{Na} \mathrm{OH}$ ocorre um processo anormal de osteogênese em tecidos não esqueléticos que pode implicar em complicações, como a perda da mobilidade articular do quadril, compressão de nervos periféricos e lesão por pressão 1,2. Em alguns casos, em que ocorrem restrições da articulação, limitação do posicionamento, comprometimento do autocuidado e da independência funcional a ressecção cirúrgica da $\mathrm{OH}$ pode ser indicada2. Entre os riscos presentes no pós- operatório, estão os sangramentos, hematomas, deiscências e infecções do sitio cirúrgico. Prevendo minimizar os riscos, o enfermeiro deve planejar os cuidados no pré- operatório junto com o médico cirurgião, verificando a necessidade de uso de Terapias por Pressão Negativa (TPN), ou outras tecnologias, para favorecer a redução do edema e promover a angiogênese para cicatrização da ferida operatória. Este estudo objetivou identificar as principais complicações presentes em pessoas com lesões medulares submetidas à ressecção de $\mathrm{OH}$ e verificar se o uso da TPN favoreceu a qualidade da cicatrização e diminuição no tempo de internação. Trata-se de um estudo retrospectivo, com dados colhidos dos prontuários eletrônicos seguindo os preceitos éticos. Foi realizado um levantamento junto ao Controle de Qualidade de um Hospital de Reabilitação do Distrito Federal, sobre o número de pessoas submetidas na Instituição para ressecção de $\mathrm{OH}$ no período de fevereiro de 2017 a abril de 2019. A amostra foi constituída de 21 pessoas, que permaneceram em média com 18 dias de internação. A maioria era homem (76\%), com cirurgia no quadril (100\%), em uso de meias com sistema de compressão pneumática (100\%). Destes, $67 \%$ tiveram complicações em relação ao sítio cirúrgico, e a mais frequente foi o hematoma (38\%). Do total da amostra, entre os que fizeram o uso da TPN (29\%), $20 \%$ apresentaram deiscência e hematoma da ferida operatória. A média de internação nos pacientes que não foram reabordados cirurgicamente e fizeram uso de TPN foi de 14 dias, 4 dia a menos em relação ao tempo geral de internação. Sabe-se que a cirurgia para ressecção de $\mathrm{OH}$ na pessoa com lesão medular tem riscos de complicações para cicatrização da ferida operatória. Deste modo, cabe ao enfermeiro, junto com a equipe, identificar os fatores que podem interferir na cicatrização, e promover ações para redução dos riscos de complicações. Para melhor conclusão dos benefícios do uso da TPN no pós-operatório de pessoas com lesão medular submetidas à ressecção de $\mathrm{OH}$, sugerimos a realização de novos estudos com um numero maior de participantes.
\end{abstract}

Keywords: Lesão Medular, Ossificação heterotópica, Estomaterapia, Terapia por Pressão Negativa

\section{Referências Bibliográficas}

1- SUERO, E., et al. Clinical Prediction Rule for Heterotopic Ossification of the Hip in Patients with Spinal Cord Injury. SPINE. 43(22):1572-1578, nov 2018. 2- Souza JMFS, Aquino ALF, Basto AO. Tratamento de ossificação heterotópica de quadril com uso de aparelho gessado: relato de caso. Rev Bras Ortop. 2018;53(6):805-8 3- Marbourg J.M; Bratasz A. et al. Spinal Cord Injury Suppresses Cutaneous Inflammation Implications for Peripheral Wound Healing. JOURNAL OF NEUROTRAUMA 34:1149-1155, mar, 2017; 4- Lima R.V.K.S; Coltro P.S; Farina Jr., A.J.; et. al Terapia por pressão negativa no tratamento de feridas complexas Negative Rev. Col. Bras. Cir. vol.44 no.1 Rio de Janeiro Jan./Feb. 2017. Disponível em http://dx.doi.org/10.1590/0100-69912017001001 


\title{
PREVENÇÃO E TRATAMENTO DA DERMATITE INTERTRIGINOSA NO ADULTO E NO IDOSO: REVISÃO INTEGRATIVA.
}

\author{
Author(s): Mayara Letícia Matos de Menezes Rapôso ${ }^{1}$, Amanda da Silva Miranda ${ }^{3}$, Ivana de Oliveira \\ Cordeiro $^{2}$, Denise Nicodemo ${ }^{1}$, Leila Blanes ${ }^{1}$, Lydia Masako Ferreira ${ }^{1}$ \\ Institution(s) ${ }^{1}$ Unifesp - UNIVERSIDADE FEDERAL DE SÃO PAULO (Rua Botucatu, 740 - $2^{\circ}$ andar - Vila \\ Clementino, CEP:04023-062 - SP), ${ }^{2}$ HSR - Hospital São Rafael (Av. São Rafael, 2152 - São \\ Marcos, Salvador - BA), ${ }^{3}$ Curativos - Curativos Serviços de Saúde Domiciliar (R. Almirante \\ Barroso, $n^{\circ} 358$ - Rio Vermelho Salvador - BA)
}

\begin{abstract}
Introdução: Dermatite intertriginosa (DIT) é um dano cutâneo resultante do excesso de umidade da transpiração nas dobras cutâneas, friç̧ão entre as superfícies epidérmicas e ausência de circulação de ar nestes locais. É comumente encontrada nas áreas inframamárias, inguinais, axilares, perianal e interdigital. E é caracterizada por eritema leve, que pode progredir para inflamação mais severa com erosão, descamação, exsudação, maceração e infecção secundária, associado a dor, coceira, ardor e odor. Objetivo: Identificar a prevenção e o tratamento da dermatite intertriginosa na população adulta e idosa. Material e Método: Trata-se de uma revisão integrativa da literatura, em que foi realizado uma pesquisa através da estratégia de busca com os Decs nas bases de dados da BVS, EMBASE, PUBMED. Os critérios de inclusão foram: periódicos nacionais e internacionais, do período de 2009 a 2019, divulgados em língua portuguesa, inglesa e espanhola, na população adulta e idosa. Foram excluídos os artigos que não estão disponíveis em texto completo. Foram selecionados 113 artigos, sendo que oito artigos repetidos foram excluídos, e 95 não contemplavam o tema. Foram selecionados e lidos 10 artigos na íntegra. Resultados: As regiões potenciais para DIT devem ser avaliadas e registradas, porém não há instrumento norteador de avaliação. Uma medida preventiva eficaz é a secagem das dobras da pele. O limpador de pele ajuda a remover os detritos da pele, mas não deve ser friccionado. O uso de sabonetes com pH alcalino deve ser evitado, pois favorece o crescimento bacteriano. A hidratação da pele é o grande fator preventivo, pois a pele seca é propensa a descamação e rachaduras, e permite a penetração de agentes irritantes. Aplicação de hidratantes contendo aminoácidos, uréia, ceramidas, vitaminas, antioxidantes, ácidos graxos essenciais, pode modular respostas inflamatórias e imunológicas na pele. No cuidado com a DTI deve-se evitar produtos contendo gluconato de clorexidina, álcool ou perfumes, pois podem ser absorvidos. Em caso de lesão, a escolha deve ser as coberturas absorventes, que possui camada de filme de poliuretano com capacidade de fazer adsorção, para alcançar uma umidade equilibrada através da sua troca com o ambiente, e com camada de silicone para evitar traumas. $O$ uso de formulações de cianoacrilato, pomadas à base de vaselina ou de silicone, óxido de zinco e películas de polímero é indicado para proteção da pele potencialmente atingida. $\mathrm{Na}$ presença de infecção secundária deve ser tratada, e depois opta-se pelo uso de esteróides tópicos para reduzir o componente inflamatório e prurido, no entanto deve-se ter cautela pois podem promover o crescimento de microorganismos. Outra estratégia de tratamento é o controle da irritação e da transpiração através da omalizumabe, com resposta satisfatória para substituição dos esteróides. A toxina botulítica também apresenta resultados eficazes na redução da transpiração. Conclusões: A DIT é uma dermatose pouco estudada e por vezes negligenciada pela equipe de saúde. $O$ fato de não haver escala de avaliação e estadiamento dificulta a condução na prevenção e no tratamento. A comunidade científica deve focar os estudos nessa patologia para que as condutas sejam uniformizadas.
\end{abstract}

Keywords: Adulto, Idoso, Dermatite, Suor, Estomaterapia

\section{Referências Bibliográficas}

Katsura M., et al. Efficacy of a moisturizer containing a pseudo-ceramide and a eucalyptus extract for Japanese patients with mild atopic dermatitis in the summer J Cosmet Dermatol. 2018;1-7. Voegei, D. Moisture-associated skin damage: an overview for community nurses. British Journal of Community Nursing, 2013, Vol 18, n 1. Tanei R.; Hasegawa Y. Atopic dermatitis in older adults: A viewpoint from geriatric dermatology. Geriatrics and Gerontology International, 2016, vol.16, n 1. 


\title{
RECOMENDAÇÕES BASEADAS EM EVIDÊNCIAS PARA TRATAMENTO DE MEDIASTINITE PÓS - CIRURGIA CARDÍACA
}

\author{
Author(s): $\quad$ Carolina Letícia dos Santos Cruz ${ }^{1}$ \\ Institution(s) ${ }^{1}$ SCMBH - Santa Casa De Misericórdia de Belo Horizonte (Francisco Salles 1111)
}

\begin{abstract}
Introdução: As doenças cardiovasculares possuem grande impacto na Saúde Pública. As cirurgias cardíacas são consideradas cirurgias de grande porte devido a sua complexidade. Uma das complicações pós-cirúrgicas que possui impacto na morbimortalidade e elevação dos custos do tratamento destes pacientes é a mediastinite, apesar de ser pouco frequente.A infecção dos tecidos profundos da ferida operatória associada à osteomielite de esterno pode comprometer também o espaço retroesternal, o que caracteriza mediastinite.Desta maneira, os processos infecciosos da pele devem ser prevenidos e controlados como medida de prevenção de complicações das cirurgias cardíacas. O presente trabalho justifica-se pela necessidade de conhecer as melhores evidências para o tratamento das mediastinites pós-cirurgias cardíacas.

(SOUZA, et.al, 2002) Objetivo: Analisar na literatura cientifica as intervenções baseadas em evidências para mediastinite pós-cirurgia cardíaca. Método: Trata-se de uma revisão integrativa de literatura. Foram utilizados descritores controlados e não controlados em língua inglesa e portuguesa nas bases de dados: Medline via Pubmed, CINAHL, LILACS e na Biblioteca Virtual em Saúde. A pergunta norteadora construída foi: Quais as intervenções terapêuticas e coberturas mais eficazes para o tratamento de mediastinite em pacientes submetidos à cirurgia cardíaca?. Resultados: Foram incluídos na análise qualitativa final 8 estudos, todos em língua inglesa, publicados em revistas norte-americanas, europeias e asiáticas. A terapia por pressão negativa foi encontrada na maioria dos estudos como a intervenção mais indicada para pacientes com lesões esternais e diagnóstico de mediastinite, associada ou não à antibioticoterapia e cirurgia reconstrutora. As evidências científicas ainda carecem de melhoria da qualidade de recomendação. Conclusões: A utilização do sistema de fechamento por vácuo apresentou-se com maior efetividade do que coberturas convencionais. Novos estudos devem ser realizados para que evidências mais robustas possam embasar a propedêutica. Palavras-chave: Cirurgia Cardíaca; Mediastinite; Procedimentos Terapêuticos
\end{abstract}

Keywords: Mediastinite, Feridas, Tratamento

\section{Referências Bibliográficas}

BAPAT, Vinayak et al. Experience with Vacuum-Assisted Closure of Sternal Wound Infections Following Cardiac Surgery and Evaluation of Chronic Complications Associated with its Use. Journal of cardiac surgery, v. 23, n. 3, p. 227-233, 2008. BORGES, Eline Lima. Assistência a Pacientes com Ferida Cirúrgica Complexa. In: BORGES, et al. Feridas: como tratar. 2 ${ }^{\text {a }}$ Edição Belo Horizonte. Coopmed, 2008.cap.9, p. 95-111. BRASIL. Agência de Vigilância Sanitária. Medidas de prevenção de infecção relacionada a assistência a saúde. ํe ed. Anvisa: Brasília, 2017 BRAXTON, John H. et al. Mediastinitis and long-term survival after coronary artery bypass graft surgery. The Annals of thoracic surgery, v. 70, n. 6, p. 2004-2007, 2000. DOMKOWSKI, Patrick W. et al. Evaluation of vacuum-assisted closure in thetreatment of poststerno to my mediastinitis. The Journal of Thoracicand Cardiovascular Surgery, v. 126, n. 2, p. 386-389, 2003. FEO, Marisa De et al. Evolution in thetreatment of mediastinitis: single-center experience. Asian CardiovascularandThoracicAnnals, v. 19, n. 1, p. 39-43, 2011. GALVÃO, Cristina Maria; SAWADA, NamieOkino; TREVIZAN, Maria Auxiliadora. Revisão sistemática: recurso que proporciona a incorporação das evidências na prática da enfermagem. Revista Latino-Americana de Enfermagem, v. 12, n. 3, p. 549-556, 2004. MANSUR, Antonio de Padua; FAVARATO, Desidério. Mortalidade por doenças cardiovasculares no Brasil e na região metropolitana de São Paulo: atualização 2011. Arq. Bras. Cardiol, v. 99, n. 2, p. $755-$ 761, 2012. MENDES, Karina dalSasso; SILVEIRA, Renata Cristina de Campos Pereira; GALVÃO, Cristina Maria. Revisão integrativa: método de pesquisa para a incorporação de evidências na saúde e na enfermagem. Texto \& Contexto Enfermagem, v. 17, n. 4, 2008 SILVA, Carolina Giordani da; CROSSETTI, Maria da Graça Oliveira. Curativos para tratamento de feridas operatórias abdominais: uma revisão sistemática. Revista Gaúcha de Enfermagem. Porto Alegre. Vol. 33, n. 3 (2012), p. 182-189, 2012. SIMEK, Martin et al. Vacuum-assisted closure in thetreatment of sternalwound Infectio after cardiac surgery. Biomedical Papers, v. 151, n. 2, p. 295-299, 2007. VOS, Roemer J. et al. Vacuum-assisted closure of post-sternotomy mediastinitis as compared to open packing. Interactive cardiovascular andthoracicsurgery, v. 14, n. 1, p. 17-21, 2011. ZEITANI, Jacob et al. Superficial wounded hiscenceaftermediansternotomy: surgical treatment versus second arywoundhealing. The Annal softhoracicsurgery, v. 77, n. 2, p. 672-675, 2004 


\title{
O USO DA TECNOLOGIA DAAC ( CLORETO DE DIALQUIL CARBAMOIL) NO CONTROLE DA INFECÇÃO E PROCESSO DE CICATRIZAÇÃO DE ÚLCERA DE PERNA EM PORTADOR DE ANEMIA FALCIFORME
}

\author{
Author(s): Elaine Alboledo Monteiro ${ }^{3}$, Mauricio Couto ${ }^{2}$, Natália Barros ${ }^{3}$ \\ Institution(s) ${ }^{2}$ AME - Feridas - Prefeitura de Tatui (Rua Coronel Lucio Seabra, 21 - Centro - CEP 18270-240 - \\ Tatuí/SP), ${ }^{3}$ Essity - Essity do Brasil (Avenida das Nações Unidas, 8501 - 7o andar)
}

\begin{abstract}
Introdução:

- Úlceras crônicas de MMII atingem $1 \%$ da população adulta e a incidência aumenta com a idade, chegando a $4 \%$ em pacientes acima de 80 anos $^{1}$. A Anemia Falciforme ocorre por mutação no cromossomo 112 resultando a substituição de ácido glutâmico pela valina na posição 6 da extremidade $N$-terminal na cadeia $B$ da globina, dando origem à hemoglobina $\mathrm{S}$, e, os eritrócitos cujo conteúdo predominante é a hemoglobina $S$ assumem, em condições de hipóxia, de uma foice, daí falciforme, decorrente da polimerização da hemoglobina S3,4.Os glóbulos vermelhos em forma de foice não circulam adequadamente resultando em obstrução do fluxo sangüíneo capilar como em sua própria destruição precoce. Este mecanismo fisiopatológico acarreta graves manifestações clínicas, como a ulcera de perna. O DACC (Cloreto Diaquil Carbamoil) originário do ácido graxo hidrofóbico (repelente de água) é uma opção de tratamento antimicrobiano, o qual o mecanismo de ação é a atração das bactérias e os fungos que ficam ligados ao curativo, por interação hidrofóbica, método físico e seguro, sem efeitos colaterais ou contra-indicações, além dos microrganismos não liberarem exotoxinas prejudiciais e endotoxinas. Um outro benefício, é que não há risco de toxicidade para o tecido saudável ou absorção sistêmica.Objetivo: Avaliar a eficácia do DACC no processo de cicatrização e manejo da infeção em ferida, em portador de anemia falciforme.Metodologia: Estudo Descritivo, Tipo relato de caso, realizado em SPI, ambulatório de feridas. Paciente de 26 anos, masculino, com anemia falciforme diagnosticada aos 2 anos, mantendo acompanhamento clínico mensal. Aos 21 anos sofreu fratura nos MMII D e E com várias abrasões em MMII, com lesão em maléolo $E$ que evoluiu para úlcera. Em 2015 iniciou o tratamento neste ambulatório para tratamento da lesão do maléolo MIE com 8x4cm, com esfacelos,grande volume de exsudato seroso,odor fétido, edema em pele perilesional, e dor intensa, e utilizadas várias coberturas como papaína, kollagenase, hidrogel, alginato em fibra, acido fusidico e placa de hidrocoloide. Em fevereiro de 2019 iniciado tratamento: limpeza com Cutimed Sorbact Swab e SF 0,9\% uma vez por semana, cobertura primaria utilizou-se tecnologia DACC, troca a cada 7 dias. Coletas de dados realizadas por acompanhamento clinico, registro fotográficos, paciente assinou o termo conforme exigência do comitê de ética, acompanhada pela equipe do amb. De feridas da instituição. Resultados: dados clínicos, fotos e analise da equipe do amb., houve redução do tecido desvitalizado em $70 \%$ com a limpeza com Sorbact Swab ,após primeira troca em 7 dias da tecnologia DAAC + Terapia compressiva , melhora significativa do odor, apresentando retração das bordas de $25 \mathrm{~cm}^{2}$ para $10 \mathrm{~cm}^{2}$, sem sinais de infecção, com evolução para a fase de granulação.Conclusão: Concluiu-se que a tecnologia DACC foi eficaz no tratamento desta úlcera infectadas, removendo o tecido desvitalizado, e demonstrando boa evolução da cicatrização em apenas 10 dias, com retração de bordas e tecido de granulação em toda extensão da lesão. Após 70 dias cicatrização total da lesão
\end{abstract}

Keywords: Anemia falciforme, Cicatrização, DACC, Ulcera de perna

\section{Referências Bibliográficas}

1- Di Nuzzo DVP, Fonseca SF. Anemia falciforme e infecções. J Pediatr (Rio J). 2004;80:347-54. Disponivél em: http://www.scielo.br/pdf/\%0D/jped/v80n5/v80n5a04.pdf 2- CARMO, S. S. et al. Atualidades na assistência a portadores de úlcera venosa. Revista Eletrônica de Enfermagem [online], v. 09, n. 02, p. 506- 517, 2007. Disponível em:

http://www.fen.ufg.br/revista/v9/ficha.htm. Acesso em: 29.08.2018. 3- BORGES, E. L., CALIRI, M. H. L., HAAS, V. J.

Revisão sistemática do tratamento tópico da úlcera venosa. Revista Latino-Americana de Enfermagem [online], v. 15, n. 6 , p. 163-170, 2007. Disponível em: http://www.scielo.br/scielo.php?script=sci_arttext\&pid=S010411692007000600017\&lng=pt \&nrm=iso. Acesso em: 13.08.18. 4- Samantha Haycocks, Paul Chadwick, Karl Guttormsen, DACC antimicrobial technology: a new paradigm in bioburden management, 2011, (Vol 7, No 1) J Wound Care. 2;26(3):107-114. 5- Hampton, S. An evaluation of the efficacy of Cutimed Sorbact in different types of non-healing wounds. Wounds UK, 2007; 3: 4, 113-119. 


\title{
RELATO DE EXPERIÊNCIA DE ATENDIMENTO DE ESTOMATERAPIA A UM PACIENTE COM HANSENÍASE E DIABETES
}

\author{
Author(s): Josiane Santos Silva ${ }^{1}$, Sandra Marina Gonçalves Bezerra ${ }^{1}$, Aline Costa de Oliveira ${ }^{1}$, Leonilda \\ Cardoso Carvalho ${ }^{2}$, Leila Mendes da Silva ${ }^{2}$ \\ Institution(s) ${ }^{1}$ UESPI - Universidade Estadual do Piauí (Rua Olavo Bilac, 2335. Centro, 64015-017. Teresina.), ${ }^{2}$ \\ CMI - Centro Maria Imaculada ( R. Dezenove de Novembro, 4370 - Real Copagri, Teresina - PI, \\ 64006-193)
}

\begin{abstract}
INTRODUÇÃO

A hanseníase é uma doença infecciosa que acomete a pele e nervos periféricos, causadora de deficiências e incapacidades. Com o passar dos anos sem tratamento, pode ocorrer a redução e até perda da sensibilidade térmica, dolorosa, tátil e ocasionar parestesias e plegias musculares. ${ }^{1}$ Esses comprometimentos podem tornar os indivíduos propensos a acidentes, queimaduras, feridas e amputações, sendo responsáveis pelo surgimento de sequelas permanentes. Em pessoas com alteração da sensibilidade, durante e/ou após tratamento da hanseníase, é comum a presença de lesões em membros inferiores, principalmente na região plantar associado a traumas, ulcerações crônicas quando não tratadas adequadamente, e em situações avançadas, pode levar a amputação de membros.2,3

OBJETIVO:

Relatar a experiência de profissionais frente ao tratamento de úlceras crônicas em pessoa com hanseníase e diabetes METODOLOGIA

Trata-se de um relato de experiência de atendimento de estomaterapeuta, desenvolvido em um centro de tratamento e prevenção de agravos para pessoas com hanseníase, em Teresina, Piauí, no período de abril a junho de 2019 , sendo realizado a troca de curativos 2 vezes por semana. A evolução da lesão foi acompanhada por meio de mensuração e registro fotográfico a cada encontro e com orientações ao paciente sobre o autocuidado.

RESULTADOS E DISCUSSÃO
\end{abstract}

Paciente com três lesões em ambos os membros: duas na região plantar direita e uma em região de metatarsos esquerdo, com tempo de lesões acima de 1 ano. O paciente é acompanhado no serviço à 5 anos, desde que tratou a hanseníase, porém se ausentava dos atendimentos e comparecia ao serviço apenas uma vez no mês. Na avaliação das lesões pela estomaterapeuta utilizando o acrônimo TIME o leito das lesões apresentava esfacelo, exsudato em grande quantidade serosanguinolento, odor fétido, excesso de umidade com bordas maceradas e presença de hiperqueratose, Realizou-se desbaste de bordas com hiperqueratose, usou-se papaína em pó a 100\% diluída em 10 ml de soro fisiológico 0,9\% com objetivo de retirada de tecido desvitalizado do leito. Quanto a mensuração, a lesão em região de metatarsos direito media $5,46 \mathrm{~cm}^{2}$, lesão em calcâneo direito $0,56 \mathrm{~cm}^{2}$ e $0,4 \mathrm{~cm}$ de profundidade, e lesão em metatarsos esquerdo $0,06 \mathrm{~cm}^{2}$ e 0,5 de profundidade. Utilizou-se como cobertura a papaína $20 \%$ creme. Foi realizado as orientações ao paciente quanto a troca do curativo em domicilio diário, com técnica limpa e retorno duas vezes semanal ao serviço, e o uso de muletas, que foi ofertado pelo centro, para otimização da cicatrização das lesões, utilizando-a para descarga de pé direito. No mês de junho/2019 as lesões em metatarsos direito e calcâneo direito apresentaram epitelização total e lesão em metatarsos medindo $0,5 \mathrm{~cm}^{2}$ e 0,5 de profundidade, com aumento de área.

CONCLUSÃO:

No tratamento de leões crônicas em pessoas com hanseníase, o profissional estomaterapeuta otimizou o tratamento, acelerando o processo de cicatrização e melhora da qualidade de vida do paciente. O uso da papaína em pó e em creme de forma adequada reduziu consideravelmente o tecido desvitalizado e otimizou a cicatrização das lesões.

Keywords: Hanseníase, Ferimentos e lesões, Estomaterapia, Tratamento, diabetes

\section{Referências Bibliográficas}

1 Ribeiro MDA, Silva JCA, Oliveira SB. Estudo epidemiológico da hanseníase no Brasil: reflexão sobre as metas de eliminação. Rev Panam Salud Publica. 2018; 42:e42. 2 Santana EMF, Brito KKG, Nogueira JA, Leabedal ODCP, Costa MML, Silva MA, et al. Deficiências e incapacidades na hanseníase: do diagnóstico à alta por cura. Revista Eletrônica De Enfermagem, 20. 3 Ribeiro CR, Lana FCF. Incapacidades físicas em hanseníase: caracterização, fatores relacionados e evolução* Cogitare Enferm. 2015 Jul/set; 20(3): 496-503. 


\title{
APLICAÇÃO TÓPICA DE CREME CONTENDO NANOPARTÍCULAS COM VITAMINA E PARA PREVENÇÃO DE RADIODERMATITE EM MULHERES COM CANCER DE MAMA: ESTUDO PILOTO RANDOMIZADO
}

\author{
Author(s): Fernanda Mateus Queiroz Schmidt ${ }^{2}$, CAROL VIVIANA SERNA GONZALEZ ${ }^{2}$, Rodrigo Calixto Mattar ${ }^{3}$ \\ Luciana Biagini Lopes ${ }^{4}$, Marinilce Fagundes Dos Santos ${ }^{4}$, Vera lúcia Conceição de Gouveia Santos ${ }^{1}$ \\ Institution(s) ${ }^{1}$ EEUSP - Escola de Enfermagem da Universidade de São Paulo (Av. Dr. Enéas Carvalho de Aguiar, 419 - \\ Cerqueira César, São Paulo - SP, 05403-0), ${ }^{2}$ IFSULDEMINAS - Instituto Federal de Educação, Ciência e \\ Tecnologia do Sul d (R. Mario Ribola, 409 - Penha II, Passos - MG, 37903-358), ${ }^{3}$ Santa Casa Passos - \\ SANTA CASA DA MISERICORDIA DE PASSOS (Rua da Santa Casa, 164 CEP: 37904164), ${ }^{4}$ ICB-USP - \\ Instituto de Ciências Biomédicas da Universidade de São Paul (Av. Prof. Lineu Prestes , no 1524 - Butantã \\ - São Paulo/SP - CEP 05508-000)
}

\begin{abstract}
Introdução: Apesar da ação promissora dos agentes antioxidantes contra as radiodermatites, os estudos sobre esse tema ainda são pouco consistentes. Diante dessas considerações, questionou-se sobre a ação da vitamina $\mathrm{E}$, veiculada por meio de nanotecnologia, na prevenção das radiodermatites. Objetivo: Avaliar o potencial efeito da aplicação tópica de creme com nanopartículas lipídicas contendo vitamina E, na concentração final de $2 \%$, para a prevenção de radiodermatite aguda em mulheres com câncer de mama submetidas à teleterapia. Método: Estudo piloto randomizado e duplo cego, realizado em um hospital oncológico de Minas Gerais. A amostra foi constituída de 40 mulheres, divididas em três grupos: Intervenção realizaram a aplicação tópica de creme com nanopartículas lipídicas contendo vitamina E; Controle 1 - realizaram a aplicação tópica de creme sem nanopartículas lipídicas e sem vitamina E; Controle 2 - realizaram a aplicação tópica de creme com nanopartículas lipídicas sem vitamina E. A incidência de radiodermatite, o grau (pelas escalas RTOG e CTCAE) e o tempo para o aparecimento da reação foram considerados desfechos primários; a qualidade de vida, a temperatura da mama e os sintomas relatados como desfechos secundários. Todas as participantes seguiram as orientações padrão para prevenção de radiodermatites, realizaram a aplicação de creme três vezes por dia e foram avaliadas três vezes por semana. Para a coleta dos dados, utilizaram-se quatro instrumentos: dados sócio-demográficos e clínicos, registro das avaliações periódicas, e avaliação da qualidade de vida relacionada à saúde (QVRS) - EORTC-QLQ-30 e EORTC-QLQBR23. Os dados foram analisados por meio de: modelo ANOVA, teste de Kruskal-Wallis, qui-quadrado, exato de Fisher, modelo de riscos proporcionais de Cox e modelo de efeitos mistos. O projeto foi aprovado por Comitê de Ética em Pesquisa. Resultados: Todas as pacientes da amostra apresentaram radiodermatites em algum grau. As incidências de reações graus 1, 2 e 3 foram, respectivamente: $58 \%$, 25\% e $17 \%$ para o grupo Intervenção; $36 \%$, $29 \%$ e $36 \%$ para o grupo Controle 1; e $50 \%, 43 \%$ e $7 \%$ para o grupo Controle 2. Não houve diferenças significativas entre os grupos do estudo no que concerne ao grau de radiodermatite, QVRS e temperaturas das mamas. Observou-se uma tendência para potencial efeito protetor do creme com nanopartículas contendo vitamina $\mathrm{E}$ no que concerne ao tempo para aparecimento da radiodermatite nas pacientes que não receberam a dose de boost $(p=0,03)$ e ocorrência de eritema leve inframamário $(p=0,04)$. Prurido foi reportado por $90 \%$ das mulheres, apresentando por mais tempo naquelas do grupo Intervenção $(\mathrm{p}=0,05)$. Os dados encontrados permitiram subsidiar o cálculo amostral para o ensaio clinico definitivo, que deverá ser composto de 108 pacientes. Conclusões: Observou-se um potencial efeito protetor do creme com nanopartículas contendo vitamina E com relação ao tempo para aparecimento da radiodermatite e ocorrência de eritema leve inframamário. Não foram observadas diferenças significativas entre os grupos do estudo com relação a incidência e intensidade de radiodermatites, QVRS e temperatura das mamas. Amostra constituída de 108 pacientes deverá compor o ensaio clínico definitivo para evidenciar as hipóteses levantadas neste estudo piloto.
\end{abstract}

Keywords: Prevenção, Radiodermatite, Nanotecnologia, Vitamina E, Estomaterapia

\section{Referências Bibliográficas}

Amber KT, Shiman MI, Badiavas EV. The use of antioxidants in radiotherapy-induced skin toxicity. Integr Cancer Ther. 2014;13(1):38-45. Chan RJ, Webster J, Chung B, Marquart L, Ahmed M, Garantziotis S. Prevention and treatment of acute radiation-induced skin reactions: a systematic review and meta-analysis of randomized controlled trials. BMC Cancer [Internet]. 2014 [cited 2018 Sep 29];14(53):1-19. Available from: https://www.ncbi.nlm.nih.gov/pmc/articles/PMC3909507/ DOI: 10.1186/1471-2407-14-53. Montenegro L. Lipid-based nanoparticles as carriers for dermal delivery of antioxidants. Curr Drug Metab. 2017; 18(5):469-80. Wong RKS, Bensadoun RJ, Boers-Doets CB, Bryce J, Chan A, Epstein JB, et al. Clinical practice guidelines for the prevention and treatment of acute and late radiation reactions from the MASCC Skin Toxicity Study Group. Support Care Cancer [Internet]. 2013;21(10):2933-48. Singh M, Alavi A, Wong R, Akita S. Radiodermatitis: A Review of Our Current Understanding. Am J Clin Dermatol [Internet]. 2016 [cited 2018 Sep 29];17(3):277-92 


\title{
ASSISTÊNCIA ESPECIALIZADA DE ENFERMAGEM NO TRATAMENTO DE LESÕES EM PESSOAS COM HANSENÍASE: RELATO DE EXPERIÊNCIA
}

\author{
Author(s): \\ Josiane Santos Silva ${ }^{1}$, Sandra Marina Gonçalves Bezerra ${ }^{1}$, Aline Costa de Oliveira ${ }^{1}$, Joana Maria \\ da Costa $^{2}$ \\ Institution(s) ${ }^{1}$ UESPI - Universidade Estadual do Piauí (Rua Olavo Bilac, 2335. Centro, 64015-017. Teresina.), ${ }^{2}$ \\ CMI - Centro Maria Imaculada ( R. Dezenove de Novembro, 4370 - Real Copagri, Teresina - PI, \\ 64006-193)
}

\begin{abstract}
INTRODUÇÃO: A Hanseníase é uma doença crônica, infecto-contagiosa de notificação compulsória e investigação obrigatória em todo o Brasil, causada pela bactéria Mycobacterium leprae que atinge a pele e os nervos periféricos causando deficiências e incapacidades. ${ }^{1} \mathrm{O}$ dano neural está presente nas fases mais avançadas e pode ocasionar parestesias e plegias musculares. Esses comprometimentos tornam os indivíduos propensos a acidentes, queimaduras, feridas e amputações, sendo responsáveis pelo surgimento de incapacidades permanentes. ${ }^{2,3}$

OBJETIVO: Descrever assistência especializada de enfermagem em Estomaterapia no tratamento de lesões em pessoas com hanseníase.

MATERIAL E METÓDOS: Trata-se de um relato de experiência, o qual se realizou por meio da avaliação e tratamento de lesões em pacientes com hanseníase por enfermeira Estomaterapeuta e equipe de enfermagem, no período de abril de 2019 a julho de 2019. A assistência foi desenvolvida em uma parceria Universidades, Netherlands Hanseniasis Relief Brasil e o serviço de referência para tratamento de hanseníase, que já disponibilizava o atendimento de curativos semanalmente para feridas de $1^{\circ}$ grau e desbridamento mecânico agendado 1 vez ao mês, com poucos pacientes acompanhados e sem melhora das lesões.

RESULTADOS E DISCUSSÃO: A assistência diária do estomaterapeuta com avaliação e tratamento consistiu em realizar um plano terapêutico individual para cicatrização das lesões, desde a admissão com o preenchimento do histórico de enfermagem, a escala de estigma Emic, avaliação da lesão utilizando o acrônimo TIME, mensuração em cm3 (comprimento, largura e profundidade), fotografia das lesões mediante autorização escrita dos pacientes, uso da escala PUSH para o acompanhamento da cicatrização e indicação da coberturas adequadas, como hidrofibra, alginato, papaína, hidrogel, carvão ativado com e sem prata, de acordo a necessidade da lesão e o agendamento das trocas curativo, bem como orientações e encaminhamentos para equipe multiprofissional como sapataria, terapia ocupacional, fisioterapia, psicológos, serviço social e médico, favorecendo o complemento terapêutico individual. O centro de atendimento possui pacientes com lesões antigas que há algum tempo não frequentavam o centro, mas que ao iniciar o tratamento para cicatrização das feridas, passaram a participar rotineiramente das atividades do serviço. As lesões dos pacientes cadastrados nos 4 meses de atendimento especializado obtiveram melhora importante, trazendo benefícios na qualidade de vida dos pacientes, redução do estigma e maior autoestima. Mesmo os pacientes que ainda não obtiveram cicatrização, estão comprometidos na rotina dos curativos pela esperança de melhora total de suas lesões, sendo que $100 \%$ teve redução da exsudação e área da lesão no período do tratamento.

CONCLUSÃO

As lesões comprometem a qualidade de vida de muitos pacientes e aumentam o estigma da doença hanseníase. O serviço especializado com atendimentos na rotina para curativos adequados mostrou adesão positiva dos pacientes com melhora significativa de suas lesões, ainda influenciando na participação em outros serviços.
\end{abstract}

Keywords: Hanseníase, Ferimentos e lesões, Estomaterapia, Tratamento

\section{Referências Bibliográficas}

1 Ribeiro MDA, Silva JCA, Oliveira SB. Estudo epidemiológico da hanseníase no Brasil: reflexão sobre as metas de eliminação. Rev Panam Salud Publica. 2018; 42:e42. 2 Santana EMF, Brito KKG, Nogueira JA, Leabedal ODCP, Costa $M M L$, Silva MA, et al. Deficiências e incapacidades na hanseníase: do diagnóstico à alta por cura. Revista Eletrônica De Enfermagem, 20. 3 Ribeiro CR, Lana FCF. Incapacidades físicas em hanseníase: caracterização, fatores relacionados e evolução* Cogitare Enferm. 2015 Jul/set; 20(3): 496-503. 


\title{
Principais cuidados na terapia tópica e dietoterápica de acordo com as novas diretrizes internacionais.
}

\author{
Author(s): José Luís da Costa Alves de Souza ${ }^{1}$, Samira Barcelos ${ }^{1}$ \\ Institution(s) ${ }^{1}$ IGESP - Instituto de Gastroenterologia (rua Silvia, 276 - Bela Vista)
}

\begin{abstract}
As Lesões Por Pressão (LPP) são danos localizados na pele e/ou tecidos subjacentes, geralmente sobre uma proeminência óssea, resultante de pressão isolada ou combinada com forças de cisalhamento e/ ou fricção. O risco aumenta quando somado aos fatores predisponentes intrínsecos da pessoa (NPUAP - National Pressure Ulcer Advisory Panel, 2016).

As LPP são causadas por fatores extrínsecos como: calor, pressão, força de cisalhamento e friç̧ão. E por fatores intrínsecos: peso corpóreo, anemia, deficiência nutricional proteica, extremos de idade, hipotensão arterial sistêmica, incontinência urinaria/fecal, edema, hipertermia, tabagismo, desidratação, infecções sistêmicas ou locais, comorbidades crônicas (Diabetes Mellitus, imunossupressão, doença renal, cardiovascular, neuromuscular, gastrointestinal e outras), o uso de alguns tipos de medicamentos (corticoides, sedativos, anestésicos, vasoativos) (STACCIARINI, 2018).

Várias escalas para avaliar o risco de seu desenvolvimento estão disponíveis, sendo as mais utilizadas as de Braden e de Waterlow, ambas validadas para a população brasileira. A escala de Braden foi desenvolvida por Bergstrom et al. em 1987, como meio para otimizar estratégias de prevenção, e assim, diminuir a incidência desse tipo de lesão. Desta forma, foi estabelecido um esquema conceitual para classificar a LPP, envolvendo os dois determinantes críticos: intensidade e duração da pressão e a tolerância da pele e estruturas subjacentes para suporta-la. A nutrição compõe uma das sub escalas da Escala de Braden, destinada a avaliação da ingestão de nutrientes, considerada fundamental na etiopatogenia da lesão por pressão (SERPA,2008).

Assim sendo, a terapia nutricional aplicada à lesão por pressão deve fornecer nutrientes específicos para cicatrização das feridas, ação anti-inflamatória e melhora do estado nutricional do indivíduo, fornecendo resposta imunológica (FRANGELLA et al., 2016).

Neste contexto observa-se a importância da associação da terapia tópica e dietoterápica para o reparo tecidual na Lesão Por Pressão (LPP) de acordo com as novas diretrizes para o plano terapêutico. Foram utilizados os descritores "Lesão Por Pressão", Úlcera Por Pressão", "Terapia Nutricional", associados aos operadores booleanos AND e OR, além das diretrizes da NPUAP, EPUAP, PPPIA, ESPEN e AMB. Foram critérios de exclusão artigos publicados antes de 2010, porém houve abertura e a não exclusão de artigos de 2008 pois estes se adequam ao enfoque abordado. Após a leitura dos títulos e resumo de alguns artigos, aqueles que se repetiam nas diferentes bases e meios de pesquisa, além dos outros que não diziam respeito ao propósito deste estudo, também foram excluídos.
\end{abstract}

Keywords: Lesão por Pressão, Terapia Nutricional , Úlcera por Presão

\section{Referências Bibliográficas}

ASSOCIAÇÃO BRASILEIRA DE ESTOMATERAPIA - SOBEST; ASSOCIAÇÃO BRASILEIRA DE ENFERMAGEM EM DERMATOLOGIA - SOBENDE. Classificação das lesões por pressão - consenso NPUAP 2016 - adaptada culturalmente para o Brasil. São Paulo, 2016. Disponível em: http://www.sobest.org.br/textod/35. Acesso em 20 mar. 2019 BRASIL. Agência Nacional de Vigilância Sanitária - ANVISA NOTA TÉCNICA GVIMS/GGTES № 03/2017 Práticas seguras para prevenção de Lesão por Pressão em serviços de saúde. Disponível em: BRASIL. Ministério da Saúde. Protocolo para prevenção de úlcera por pressão, 2013. Disponível

em file:///C:/Users/14405180/Downloads/protoc ulceraPressao.pdf. Acesso dia 20/03/2019 Caliri MHL, Santos VLCG, Mandelbaum MHS, Costa IG. Classificação das lesões por pressão - consenso NPUAP 2016: adaptada culturalmente para o Brasil. Associação Brasileira de Estomaterapia (SOBEST). Associação Brasileira de Enfermagem em Dermatologia (SOBENDE). São Paulo; 2016. [cited 2017 Nov 8]. Available from: http:// www.sobest.org.br/textod/35 FRANGELLA, Vera S. Ulcera por Pressão e Cuidado Nutricional na Reabilitação. In: CHEMIN, Sandra M. Tratado de Alimentação, Nutrição e Dietoterapia. 3 ed. São Paulo: PAYA EIRELI, 2016. cap. 56, p. $1056-1064$. National Pressure Ulcer Advisory Panel, European Pressure Ulcer Advisory Panel and Pan Pacific Pressure Injury Alliance. Prevention and Treatment of Pressure Ulcers: Quick Reference Guide. Emily Haesler (Ed.). Cambridge Media: Osborne Park, Australia; 2014. TREVISAN, A. P. et al., Úlceras por Pressão: Tratamento. Associação Brasileira de Medicina Física e Reabilitação, 2013. Disponível em: SERPA, Leticia; SANTOS, Vera. Desnutrição como fator de risco para o desenvolvimento de Úlcera por pressão. Acta Paulista de Enfermagem, 2008 São Paulo, v. 21, n. 2 p.367-369 STACCIARINI, T.S. G.; MELO, A. F. Protocolo de assistência multiprofissional: Prevenção no tratamento de lesão por pressa. Ebserh: Uberaba, 26p, out. 2018. 


\title{
Tratamento de uma lesão utlilizando cobertura de alta tecnologia: relato de caso
}

\author{
Author(s): $\quad$ Priscila Paranhos Lebeis ${ }^{1}$, Cintia Lima ${ }^{1,1}$, Rita de Jesus Grijó e Silva de Jesus Grijó e Silva ${ }^{1}$ \\ Institution(s) ${ }^{1}$ HMLJ - Hospital Municipal Lourenço Jorgr (Av Ayrton Senna)
}

\begin{abstract}
Introdução: Uma ferramenta importante no manejo de uma ferida é a utilização adequada da tecnologia que junto com outros fatores tende a contribuir para uma boa evolução do tratamento da lesão. Para escolha adequada dos curativos é necessária uma análise cuidadosa e periódica da lesão, tendo em vista que o processo de cicatrização é muito dinâmico. $O$ curativo é determinado como um meio de tratamento que consiste na limpeza e administração de material sobre uma ferida para sua proteção, drenagem e absorção, com o propósito de favorecer as condições do leito da ferida e ajudar na cicatrização. Objetivo: Relatar o acompanhamento no processo de cicatrização de uma lesão utilizando cobertura de alta tecnologia composta por carboximetilcelulose. Método: Trata-se de um estudo descritivo , tipo relato de caso, desenvolvido em um Hospital da Zona Oeste do Rio de janeiro/RJ no período de 24/06/2019 a 16/08/19. A experiência partiu da realização do curativo no ambulatório utilizando uma cobertura de alta tecnologia, paciente vitima de acidente automobilístico onde sofreu ferimento corto contuso em face (região maxilar direita), e realizado sutura, evoluindo com deiscência, calor, vermelhidão, o que levou o retorno do paciente a Unidade e o encaminhamento ao ambulatório para acompanhamento da lesão. Resultados: Durante a realização dos curativos podemos observar a evolução satisfatória da lesão, sendo evidenciado pelas evoluções em prontuário e registro fotográfico. Em cada retorno ao ambulatório eram realizados curativos e orientações quanto aos cuidadodos domiciliares, tendo uma boa adesão do paciente .Conclusão: $O$ desenvolvimento deste estudo possibilitou a observação da cicatrização da lesão em pouco período de tempo mostrou a eficiência e eficácia da cobertura utilizada.
\end{abstract}

Keywords: ESTOMATERAPIA, FERIDAS, CICATRIZAÇÃO

\section{Referências Bibliográficas}




\title{
Efeito proliferativo do extrato etanólico de Punica granatum L. em fibroblastos humanos
}

\author{
FABIOLA ARANTES FERREIRA ${ }^{1}$, Vanessa Yuri Suzuki ${ }^{1}$, Liliane Carvalho Jamil ${ }^{1}$, Daniel \\ Author(s): $\quad$ Moreno Garcia ${ }^{3}$, Carlos Rocha Oliveira ${ }^{3}$, Hélio Martins do Nascimento Filho ${ }^{1}$, Lydia Masako \\ Ferreira ${ }^{1}$ \\ Institution(s) ${ }^{1}$ unifesp - Universidade Federal de São Paulo ((Rua Botucatu, 740, 2 andar, Vila Clementino, CEP \\ 04023-062, São Paulo, SP), ), ${ }^{2}$ unifesp - Universidade Federal de São Paulo ((Rua Botucatu, 740, 2 \\ andar, Vila Clementino, CEP 04023-062, São Paulo, SP), ), ${ }^{3}$ Anhembi - Universidade Anhembi \\ Morumbi (Rua Dr. Almeida Lima, 1134, Parque da Mooca, CEP 03164-000, São Paulo, SP))
}

\begin{abstract}
- Introdução: A Punica granatum L., uma planta da família Punicacea originária da região mediterrânea, conhecida como romã é rica em compostos fitoquímicos que têm sido aplicados na prevenção e tratamento de diabetes, infecções bacterianas e danos à pele por radiação ultravioleta, a ingestão diária de fotoquímicos na dieta desempenham um papel fundamental na prevenção dos sinais de envelhecimento e saúde da pele. Estomaterapia sempre em busca de tratamento baseados em evidencias na prevenção e tratamento de lesões de pele Objetivo: Este trabalho tem como objetivo avaliar a citotoxidade e/ou o efeito proliferativo do extrato etanólico de Punica granatum L. sobre a linhagem celular CCD1072Sk de fibroblastos humanos. Método: Através dos testes de MTT e incorporação do corante Azul de Tripano, avaliou-se a citotoxicidade e/ou a capacidade proliferativa de diferentes concentrações do PGEE (200 - $1000 \mu \mathrm{g} / \mathrm{mL})$ em diferentes períodos de tempo (24h, $48 \mathrm{~h}$ e $72 \mathrm{~h}$ ), sobre a linhagem de fibroblastos humanos CCD1072Sk. A quantificação de colágeno total foi avaliada pela incorporação do corante Sirius Red. Em todos os testes realizados, utilizou-se como controle positivo, o ácido ascórbico. Resultados: Foi possível verificar que a PGEE teve ação proliferativa e estimulou a síntese de colágeno sem apresentar citotoxicidade sobre a linhagem CCD1072Sk. Kang et al. (2015) desenvolveram um estudo in vitro para investigar o efeito da solução concentrada de romã em queratinócitos. Os resultados mostraram síntese aumentada de hialuronano, bem como suprimidas as atividades de elastase, colagenase, MMP-1 e tirosinase e produção de melanina, reforçando o efeito proliferativo e aumento da síntese de colágeno observado no presente estudo. Estudos adicionais são necessários para entender os mecanismos moleculares do PPEE na proliferação celular. Atualmente, a literatura científica aponta as propriedades medicinais da romã com potencial atividade antioxidante, anti-inflamatória, antifúngica, antineoplásica e quimioprotetora. Conclusão: Os resultados obtidos neste estudo mostraram que os fibroblastos expostos ao extrato de PPEE mantiveram sua viabilidade e aumentaram a proliferação e a produção de fibras colágenas. Estudos futuros são necessários para elucidar o mecanismo de ação do extrato etanólico de Punica granatum L, que contribuirá para prevenção de lesões de pele.
\end{abstract}

Keywords: Fitoquímicos,, fitoterapia,, colágenos , fibroblastos, romã

\section{Referências Bibliográficas}

- Kang SJ, Choi BR, Kim SH, Yi HY, Park HR, Park SJ, Song CH, Park JH, Lee YJ, Kwang S. Inhibitory effects of pomegranate concentrated solution on the activities of hyaluronidase, tyrosinase, and metalloproteinase. J Cosmet Sci. 2015 May-Jun;66(3):145-59. • Park HM, Moon E, Kim AJ, Kim MH, Lee S, Lee JB, Park YK, Jung HS, Kim YB, Kim SY. Extract of Punica granatum inhibits skin photoaging induced by UVB irradiation. Int J Dermatol. 2010 Mar;49(3):276-82. • Pirbalouti AG, Azizi S, Koohpayeh A, Hamedi B. Wound healing activity of Malva sylvestris and Punica granatum in alloxaninduced diabetic rats. Acta Pol Pharm. 2010 Sep-Oct;67(5):511-6. - Saeed M, Naveed M, BiBi J, Kamboh AA, Arain MA, Shah QA, Alagawany M, El-Hack MEA, Abdel-Latif MA, Yatoo MI, Tiwari R, Chakraborty S, Dhama K. The Promising Pharmacological Effects and Therapeutic/Medicinal Applications of Punica Granatum L. (Pomegranate) as a Functional Food in Humans and Animals. Recent Pat Inflamm Allergy Drug Discov. 2018;12(1):24-38. - Sreekumar S, Sithul H, Muraleedharan P, Azeez JM, Sreeharshan S. Pomegranate fruit as a rich source of biologically active compounds. Biomed Res Int. 2014;2014:1-12. 


\title{
O PACIENTE DIABÉTICO E SUA PERCEPÇÃO SOBRE O AUTOCUIDADO COM OS PÉS
}

\author{
Débora de Araújo Moreira Varela ${ }^{1}$, Jessica Kelly Oliveira Angelo ${ }^{1}$, Tatiana Santos de Brito ${ }^{1}$, \\ Author(s): Wena Lara da Silva França ${ }^{1}$, Bruna Michelle Belém Leite Brasil ${ }^{1}$, Francisca Alexandra Araújo da \\ Silva $^{2}$, Maria das Graças da Silva Guerreiro ${ }^{1}$, Carla Daniele Mota Rêgo Viana ${ }^{1}$ \\ Institution(s) ${ }^{1}$ ESTÁCIO/FIC - CENTRO UNIVERSITÁRIO ESTÁCIO DO CEARÁ (R. Eliseu Uchôa Beco, \\ 600 - Patriolino Ribeiro, Fortaleza - CE, 60810-270), ${ }^{2}$ HUWC/UFC - HOSPITAL \\ UNIVERSITÁRIO WALTER CANTÍDIO (R. Pastor Samuel Munguba, 1290 - Rodolfo Teófilo, \\ Fortaleza - CE, 60430-372)
}

\begin{abstract}
INTRODUÇÃO: O diabetes mellitus vem aumentando sua importância pela sua crescente prevalência e habitualmente está associado à dislipidemia, à hipertensão arterial e à disfunção endotelial. O Pé Diabético está entre as complicações mais frequentes e suas consequências podem ser permanentes para a vida do indivíduo, assim sendo o cuidado com os pés é de suma importância para evitar lesões. OBJETIVO: O estudo teve como objetivo identificar o conhecimento do autocuidado com os pés em pacientes diabéticos. MATERIAL e MÉTODO: A pesquisa foi desenvolvida em uma unidade básica de saúde, na cidade de Fortaleza que possui um núcleo do Centro especializado de atenção ao Diabético e Hipertenso- CEADH. Efetivando como amostra final, 75 participantes. A coleta de Dados se deu por meio de um Instrumento de Avaliação Mensurador da Adesão às Atividades de Autocuidado com os Pés em Diabéticos, que tem como objetivo conseguir prevenir úlceras e amputações. O trabalho possui parecer aprovado do Comitê de Ética com parecer de $n^{\circ} 2.865 .560$ de 31 de agosto de 2018. RESULTADOS: Em relação a frequência que os usuários examinam os pés, 44 (58\%) afirmam realizar o exame diariamente. Sobre secar entre os espaços interdigitais $45(60 \%)$ mencionaram que realizam a secagem diariamente ou a cada banho. No que se refere ao corte das unhas, quando questionados 42 (63\%) dos usuários responderam que sempre ou quase sempre cortam da maneira que é recomendada, de forma quadrada. Quanto a hidratação dos pés, $47(63 \%)$ dos avaliados afirma utilizar sempre ou quase sempre hidratante. Quanto ao seguimento da dieta prescrita, $42(56 \%)$ referiram realizá-la por orientação de um profissional de saúde e $33(44 \%)$ estavam praticando algum tipo de atividade física pelo menos uma vez por semana como caminhada e andar de bicicleta. CONCLUSÃO: Os usuários que realizavam acompanhamento rotineiramente na linha de cuidado do CEAHD possuíam uma compreensão e orientação adequada com cuidados mínimos necessários para o autocuidado com os pés. Porém se pode perceber que os usuários se encontravam na consulta de primeira vez neste serviço possuíam um menor nível de conhecimento dos clientes já acompanhados previamente. O enfermeiro deve promover ações educativas para conscientizar esses pacientes de que é possível prevenir e também sensibilizá-los quanto aos benefícios desses cuidados específicos com os pés, não esquecendo de dar continuidade às práticas de prevenção.
\end{abstract}

\section{Keywords: AUTOCUIDADO, DIABETES MELLITUS, ENFERMAGEM}

\section{Referências Bibliográficas}

Ministério da Saúde (BR). Secretaria de Atenção à Saúde. Estratégias para o cuidado da pessoa com doença crônica: diabetes mellitus. Cadernos de Atenção Básica, n. 36, Brasília, 2013. Sociedade Brasileira de Diabetes. Diretrizes da Sociedade Brasileira de Diabetes (2017-2018), Editora Clannad, 2017. Ministério da Saúde (BR). Secretaria de Atenção à Saúde. Departamento de Atenção Básica. Rastreamento. Cadernos de Atenção Primária, n. 29. V.II. ed., 1. reimpr. Brasília, 2013. Cubas MR, Santos OMD, Retzlaff EMA, Telma HLC, Andrade IPS, Moser AL. Pé diabético: orientações e conhecimento sobre cuidados preventivos.Fisioter Mov. 2013 jul/set;26(n.3): 647-55. Policarpo NS, Moura JRA, Júnior EBDM, Almeida PC, Macêdo SFD, Silva ARVS. Conhecimento, atitudes e práticas de medidas preventivas sobre pé diabético. Rev. Gaúcha Enferm. 2014; vol.35 (no.3): p.36-42. Santos GILS, Capirunga JBM, Almeida OSC. Pé diabético: condutas do enfermeiro. Rev Enferm Contemp. 2013; V. 2, (n.2): p.225-241. Silva FAA. Adesão ao autocuidado com os pés em diabéticos: desenvolvimento de um instrumento embasado na teoria da resposta ao item (TRI) [Tese]. Universidade Estadual do Ceará, Universidade Federal do Ceará e Universidade de Fortaleza. Fortaleza, 2014. 


\title{
RESULTADOS CLÍNICOS E ECONÔMICOS DO TRATAMENTO DE FERIDAS COMPLEXAS TRAUMÁTICAS USANDO TERAPIA POR PRESSÃO NEGATIVA COM INSTILAÇÃO: ESTUDO CLÍNICO CONTROLADO RANDOMIZADO
}

\author{
Author(s): Dimas André Milcheski ${ }^{1}$, Fernando Ramos de Freitas ${ }^{1}$, CAROL VIVIANA SERNA GONZALEZ \\ ${ }^{2}$, Mily Constanza Moreno Ramos ${ }^{2}$, Araldo Monteiro Ayres ${ }^{1}$, Rolf Gemperli ${ }^{1}$ \\ Institution(s) ${ }^{1}$ ICHC-FMUSP - Instituto Central do Hospital das Clínicas da FMUSP (Av. Dr. Enéas Carvalho de \\ Aguiar, 255 - Cerqueira César, São Paulo - SP, 05402-0), ${ }^{2}$ EEUSP - Escola de Enfermagem da \\ Universidade de São Paulo (Av. Dr. Enéas Carvalho de Aguiar, 255 - Cerqueira César, São Paulo - \\ SP, 05402-0)
}

\begin{abstract}
Introdução: A incidência de feridas traumáticas graves tem aumentado em grandes centros urbanos 1-2. Alguns centros internacionais para tratamento deste tipo de lesão indicam o uso de terapia por pressão negativa com instilação, entretanto ainda não existem estudos com alto nível de evidência que demonstrem a custoefetividade desta terapia 3,4,5.

Objetivo: comparar os resultados clínicos e econômicos do tratamento por pressão negativa com instilação (TPNi) e os controles: terapia por pressão negativa sem instilação (TPN) e curativos por camadas (CC), em pacientes com feridas traumáticas complexas de partes moles.

Métodos: Trata-se de estudo clínico controlado randomizado pragmático realizado em hospital público no município de São Paulo, aprovado pela comisão de ética em pesquisa. Nele, pacientes adultos (18-80 anos) vítimas de feridas traumáticas em partes moles, com até 3 dias de evolução da lesão, foram convidados a participar do estudo e divididos aleatoriamente em 3 grupos de tratamento após a obtenção do consentimento livre e esclarecido: Grupo 1 (TPNi, n=9) tratado com pressão negativa a $-125 \mathrm{mmHg}$ em modo contínuo por 2 horas e instilação de solução salina $0,9 \%$ seguida de imersão durante 20 minutos; Grupo 2 (TPN, $n=7$ ) com -125 mm Hg em modo contínuo; e Grupo 3 (CC, n=9) tratado com o protocolo padrão que consiste na limpeza com solução salina $0,9 \%$, aplicação de creme dermacério quando infecção e cobertura com rayon, gaze e faixa. $O$ atendimento muiltiprofissional dos pacientes seguiu os protocolos da instituição, que consistem na realização de desbridamentos seriados da ferida conforme as necessidades clínicas do paciente até o fechamento primário retardado, enxertia de pele ou retalhos cirúrgicos. Foram coletados dados socio-demográficos e clínicos. Os desfechos foram: número de curativos e cirurgias até a resolução da ferida, dias de internação, e custo da internação. Os dados foram analisados com medidas de tendência central e teste de Kruskal Wallis para comparação das variáveis quantitativas entre os grupos. A amostra foi composta por 25 pacientes, dos quais $64,3 \%$ do sexo masculino, com idade média de 37,1 anos (DP 12,63). O tipo de lesão mais frequente foi ferimento descolante secundário a acidente de trânsito com $53,6 \%$ dos casos $(n=15)$.

Resultados: A média de curativos para a resolução da ferida foi 1,44 (DP 0,53); 3,14 (DP 1,21); 7,37 (DP 7,41) respectivamente para os grupos 1,2 e 3 com diferença estatisticamente significante $(p$ Conclusão: A terapia por pressão negativa com instilação mostrou-se efetiva com resolução mais rápida da ferida traumática, porém sem diferença estatística no custo. Possivelmente, com a ampliação da casuística, devem ser encontradas diferenças estatísticas significativas entre os grupos.
\end{abstract}

Keywords: Ferida Traumática, Terapia por Pressão Negativa , Instilação , Cirurgia Plástica, Estomaterapia

\section{Referências Bibliográficas}

Ferreira MC, Batista B, Nakamoto H, Milcheski DA, Tuma Jr P. Role of plastic surgery on the treatment complex wounds. Rev Col Bras Cir. 2011; 38: 381-6. 2. Milcheski DA, Ferreira MC, Nakamoto H, Tuma Jr P, Gemperli R. Tratamento cirúrgico de ferimentos descolantes nos membros inferiores - proposta de protocolo de atendimento. Rev Col Bras Cir. 2010; 37: 195-203. 3. Kim P, Attinger C, Steinberg J, Evans K, Lehner B, Willy C, Lavery L, Wolvos T, et al. Negative Wound therapy with instillation International Consensus Guidelines. Plastic and Reconstructive Surgery. 2013, 1569-1579. 4. Milcheski DA, Portocarrero ML, Alvarez DM, Mazuca LG, Monteiro-Junior A, Gemperli R. Initial experience with negative-pressure wound therapy with instillation in complex wounds. Rev Col Bras Cir. 2017;44(4):348-53. 5. Kim PJ, Attinger CE, Steinberg JS, Evans KK, Powers KA, Hung RW, Smith JR, Rocha ZM, Lavery L. The impact of negative-pressure wound therapy with instillation compared with standard negative-pressure wound therapy: a retrospective, historical, cohort, controlled study. Plast Reconstr Surg. 2014;133:709-16. 


\title{
TECNOLOGIA DACC (CLORETO DE DIALQUIL CARBAMOIL): SEGURANÇA E EFETIVIDADE COMO COBERTURA ANTIMICROBIANA EM FERIDAS DE PACIENTES PEDIÁTRICOS
}

\author{
Author(s): \\ Elaine Alboledo Monteiro ', Andrezza Carla Cavalcanti Pires D’Azevedo ', Natália Barros ', Jane \\ Eyre Aparecida Gomes ${ }^{2}$ \\ Institution(s) ${ }^{1}$ Essity - Essity do Brasil (Avenida das Nações Unidas, 8501 - 7o andar), ${ }^{2}$ HCM de Rio Preto - \\ Hospital da Criança e Maternidade de São José do Rio Preto (Av. Jamil Feres Kfouri, 60 - Jardim \\ Panorama, São José do Rio Preto - SP, 15091-)
}

\begin{abstract}
Introdução: Segundo o Estatuto da Criança e do Adolescente, é considerada criança o indivíduo de até 12 anos de idade e adolescente, o entre 12 e 18 anos, sendo a população pediátrica todos aqueles com idade inferior a 18 anos. Em neonatos e crianças, uma ferida aberta pode ser motivada por injúrias traumáticas, como pressão, remoção incorreta de adesivos e fixações, além de acidentes da infância e automobilísticos, extravasamento de soluções hipertônicas ou vesicantes, infecções entre outras. A presença de uma ferida aberta em criança é causa de dor, privação de atividade e, quando não tratada adequadamente, pode prolongar a hospitalização, propiciando a exposição à infecções1. A utilização de coberturas antimicrobianas de ação ativa (biocidas) são as mais comumente utilizadas no tratamento dessas lesões infectadas porém, muitos agentes presentes nesses produtos podem afetar o tecido humano de forma adversa, sendo impreterível uma avaliação criteriosa quanto ao uso (contra-indicações, tempo de uso entre outros) e toxicidade, especialmente em populações específicas, como na pediatria. A utilização de uma cobertura de ação totalmente passiva (biostáticos) como o DACC (Cloreto de Dialquil Carbamoil) se faz segura, sendo a atração de bactérias e fungos ocorrida por interação hidrofóbica, onde esses se tornam inertes na camada de contato com a ferida, ou seja, não liberam as endotoxinas, de forma que não conseguem se multiplicar (mecanismo irreversível) e são removidos do ambiente da ferida, a cada troca de curativo2.

Objetivo: Demonstrar a segurança e a efetividade de coberturas com a tecnologia DACC (Cloreto de Dialquil Carbamoil) em feridas de pacientes pediátricos.

Metodologia: Foi realizada uma revisão integrativa da literatura, com publicações no período 2004 a 2019 sobre a tecnologia DACC, demonstrando suas segurança e efetividade em pacientes com feridas infectadas, especialmente em populações específicas, como na pediatria. Foram selecionados os artigos de acordo com os seguintes critérios de inclusão: publicações nos idiomas espanhol, inglês e português; estudos de intervenção, experimentais, coorte, caso controle e revisão sistemática, nas seguintes bases de dados: Biblioteca Virtual de Saúde; Medical Literature and Retrivial System OnLine; Web of Science.

Resultados: De acordo com a literatura, verificou-se que o uso de uma cobertura altamente hidrofóbica, como a da tecnologia DACC, reduz a carga microbiana e oferece uma alternativa atraente, segura e eficaz em todo e qualquer paciente, sem restrição de grupo etário ou de qualquer outra especificação, podendo ser utilizado como medida adicional, ao eliminar o uso de agentes bactericidas e atuar de maneira completamente bacteriostática.

Conclusão: Conclui-se, portanto, que coberturas com a tecnologia DACC são seguras, efetivas e sem contra-indicações para pacientes pediátricos, uma vez que não possuem restrições e tampouco risco de citotoxidade devido à sua ação totalmente passiva de atração de bactérias e fungos.
\end{abstract}

Keywords: DACC, PEDIATRIA, FERIDAS

\section{Referências Bibliográficas}

1- ECA - E. C. A., Estatuto da Criança e Adolescente, 2017; 31(3) 2- Tayar G., Peterline M. A. S., Pedreira M. L. G. Proposta de um algoritmo para seleção de coberturas, segundo o tipo de lesão aberta em crianças. Acta Paulista de Enfermagem. 2007; 20(3):284-90. 3- Monteiro E. A. DACC - Nova Tecnologia no gerenciamento da infecção em feridas. 2016; 03 ( 16 ) 16 -22. 4- Cutting K. James M . G . A Clinical Review of DACC Technology. Journal of Wound Care Vol 24, No 5, May 2015. 5- B. v. Hallern, F. Lang . ¿ Has Demostrado Cutisorb® Sorbact® su eficacia como apósito antibacteriano? Copyright 2005 by Verlag für MEDIZINISCHE PUBLIKATIONEN Bernd von Hallern Vogelsang 28, 21682 Stade. 


\title{
Manejo de radiodermite através da pratica baseada em evidência: Uma revisão da literatura
}

\author{
Author(s): $\quad$ Maria carolina bernardi dos santos ${ }^{1}$, Aline de Oliveira Ramalho ${ }^{1}$, eliane Mazócoli ${ }^{1}$, Elizabete \\ Duarte Alves ${ }^{1}$
}

Institution(s) ${ }^{1}$ HSL - Hospital Sírio -Libanês (Rua Dona Adma Jafet, 115)

\begin{abstract}
Estima-se que cerda de $50 \%$ dos pacientes com doença oncológica realizarão radioterapia em algum momento do tratamento e dos pacientes que recebem teleterapia até $95 \%$ deles serão acometidos por algum grau de radiodermite. As reações cutâneas provocadas pela radiação podem ocasionar dor devido à exposição das terminações nervosas, hipersensibilidade local, desconforto, irritação cutânea, prurido, edema, estresse e em alguns casos, limitar a dose terapêutica ou levar a interrupção do tratamento até melhora do quadro. Sendo considerada por muitos como inevitáveis, comumente a radiodermite é tratada de forma empírica ou não tratada. Desta forma objetivou-se com este estudo identificar e analisar as evidências disponíveis para prevenção e tratamento da radiodermite, afim de melhorar a padronização dos cuidados e assistência de enfermagem a esta população. Metodologia: Trata-se de uma revisão integrativa da literatura, com análise qualitativa, com busca nas bases de dados BVS, LILACS e SCIELO, incluindo artigos publicados nos últimos 5 anos, utilizando os seguintes descritores: radiodermatite, enfermagem oncológica, prevenção e tratamento, nos idiomas português, inglês e espanhol. A partir dos critérios de inclusão e exclusão pré-definidos foram relacionados 36 artigos para discussão. Resultados: Foram encontrados uma grande variabilidade dos agentes e cuidados com a pele, no entanto foi possível identificar os cuidados mais descritos e com maiores graus de evidência científica, permitindo assim, definir indicações e contraindicações de cuidados. Intervenções que se mostraram benéficas: educação do paciente pode diminuir a incidência de radiodermite e sua severidade; medidas de higiene e hidratação da pele na radiodermite aguda; a indicação de uso do corticoide tópico, como tratamento da descamação úmida; o creme a base de calêndula se mostrou seguro para o manejo da radiodermite, porém com pouca evidencia científica; Ainda para o tratamento, estudos apontam a utilização de curativos de silicone e/ou espumas de poliuretano como fator contribuinte para melhora da dor e do atrito nos pacientes acometidos. Alguns artigos começam a sinalizar a utilização da fotobiomodulação com laser de baixa intensidade para prevenção e tratamento, no entanto ainda com baixo nível de evidencia. Dentre as intervenções que não apresentam benefícios estão a utilização de ácido graxo essencial, creme de dexpantenol ou sucralfato, creme de aloe vera ou trolamina, corticoide preventivo; Creme de EGF; Ácido hialurônico; Curativo com hidrocolóide e hidrogel (podem piorar o grau de radiodermite). Conclusão: A padronização dos cuidados prestados e das orientações oferecidas aos pacientes submetidos a radioterapia pode contribuir com a prevenção e com o tratamento eficaz desta complicação, melhorando a qualidade e segurança do serviço prestado. Vale ressaltar que existem na literatura muitos estudos ainda experimentais, fortalecendo a necessidade de novas pesquisas, bem como implantação de protocolos baseados em evidencias nos serviços de saúde e monitorização da efetividade do mesmo.
\end{abstract}

Keywords: enfermagem oncológica, prevenção e tratamento, radiodermatite

\section{Referências Bibliográficas}

1. Schneider F, Pedrolo E , Lind J, Schwanke AA , Danski MTR. Prevenção e Tratamento de Radiodermatite: uma revisão integrativa. Cogitare Enferm [Internet] 20132014 [cited 2017 fev 01];18(3):579-86. 2. McQuestion M. Evidence-based skin care management in radiation therapy: clinical update.Semin Oncol Nurs. 2011;27(2):e1-17 3.Chan RJ, Webster J, Chung B, Marquart L, Ahmed M, Garantziotis S. Prevention and treatment of acute radiation-induced skin reactions: a systematic review and meta-analysis of randomized ntrolled trials. BMC Cancer. 2014;14:53 


\title{
ADAPTAÇÃO TRANSCULTURAL DO REVISED VENOUS CLINICAL SEVERITY SCORE PARA O PORTUGUÊS DO BRASIL E APLICABILIDADE NA ATENÇÃO PRIMÁRIA
}

\author{
Author(s): Julia Bacon ${ }^{1}$, Diba Maria Sebba de Souza ${ }^{1}$, Renato Rieira Toledo ${ }^{1}$, Maria José Azevedo de Brito \\ Rocha $^{1}$ \\ Institution(s) ${ }^{1}$ Univas - Mestrado Profissional em Ciências Aplicadas à Saúde (Av. Pref. Tuany Toledo,470 CEP \\ 37550-000 | Pouso Alegre | MG)
}

\begin{abstract}
Introdução: Considerando o grande impacto social da doença venosa crônica (DVC), é pertinente abordá-la precocemente na atenção primária, utilizando instrumentos de avaliação específicos. Objetivo: Traduzir e adaptar culturalmente para o português do Brasil o Revised Venous Clinical Severity Score (rVCSS), validar o instrumento na Atenção Primária à Saúde e criar um software que facilite sua aplicação. Métodos: estudo primário, observacional, transversal e descritivo. Trinta e oito cirurgiões vasculares participaram da adaptação cultural da versão brasileira do instrumento e 38 pacientes da Atenção Primária, de ambos os sexos, foram avaliados por dois observadores. Confiabilidade e reprodutibilidade foram testados pelo coeficiente de Correlação de Spearman e Coeficiente de Correlação Intraclasse. A validade do construto foi testada comparando-se a versão brasileira do rVCSS com instrumentos específicos para DVC já validados internacionalmente, como a classificação Clínica, Etiológica, Anatômica e Fisiopatológica (CEAP) e o Chronic Venous Insufficiency Questionnaire (CIVIQ), com análise de convergência através do coeficiente de Spearman, e discrepância pelo Mannwhitney. Resultados: O Índice de Validade do Conteúdo foi $>0,87$ para todos os itens da versão brasileira do rVCSS. O instrumento demonstrou boa reprodutibilidade intraobservador $[r=0,800(p<0,001)$. Conclusão: Este estudo traduziu, adaptou culturalmente e validou o rVCSS e desenvolveu um software para facilitar seu uso pelo médico. O pedido de Registro de Programa de Computador - RPC foi registrado no Instituto Nacional da Propriedade Industrial Número do Processo: 512018000009-6 em 03/01/2018
\end{abstract}

Keywords: Insuficiência Venosa, Estudos de validação, Atenção Primária à Saúde, Software., Estomaterapia.

\section{Referências Bibliográficas}

Eberhardt RT, Raffetto JD. Chronic venous insufficiency. Circulation. 130. United States2005; 333-46. Rutherford RB, Padberg FT, Jr., Comerota AJ, Kistner RL, Meissner MH, Moneta GL. Venous severity scoring: An adjunct to venous outcome assessment. J Vasc Surg. 31. United States2000. p. 1307-12. Leal JAR, Mansilha A. Como avaliar o impacto da doença venosa crónica na qualidade de vida. Angiol Cir Vasc. 2010; 6( 4 ): 173-187. Lima EL, de Brito MJ, de Souza DM, Salomé GM, Ferreira LM. Cross-cultural adaptation and validation of the neonatal/infant Braden $Q$ risk assessment scale. Journal of Tissue Viability. 2016 Feb; 25(1): 57-65. Guillemin F, Bombardier C, Beaton D. Cross-cultural adaptation of health-related quality of life measures: literature review and proposed guidelines. J Clin Epidemiol. 1993;46(12):1417-32. Vasquez MA, Rabe E, McLafferty RB, Shortell CK, Marston WA, Gillespie D, et al. Revision of the venous clinical severity score: venous outcomes consensus statement: special communication of the American Venous Forum Ad Hoc Outcomes Working Group. J Vasc Surg. 2010;52(5):1387-96. 


\title{
EPIDERMÓLISE BOLHOSA - EFICÁCIA NO MANEJO DA PELE COM O USO DE COBERTURAS DE ESPUMA SUPERABSORVENTE COM SILICONE E FORMATO ANATÔMICO: RELATO DE CASO
}

\author{
Author(s): \\ Elaine Alboledo Monteiro ${ }^{2}$, Andrezza Carla Cavalcanti Pires D’Azevedo ${ }^{2}$, Railson Canavieira \\ Araújo ${ }^{1}$, Eliane de Sousa Alves ${ }^{3}$ \\ Institution(s) ${ }^{1}$ Med Surgery - Med Surgery Hospitalar LTDA. (R. Alameda Primavera, 6 - Olho D'agua, São \\ Luís - MA, 65065-430, Brasil), ${ }^{2}$ Essity - Essity do Brasil (Avenida das Nações Unidas, 8501 - 7o \\ andar), ${ }^{3}$ HI Dr. Juvencio-MA - Hospital Infantil Dr. Juvêncio Mattos (R. São Pantaleão - Centro, \\ São Luís - MA, 65065-545)
}

\begin{abstract}
A Epidermólise Bolhosa (EB) é uma doença que corresponde a um grupo de genodermatoses infrequentes, clínica e geneticamente heterogêneas, caracterizadas pela fragilidade cutânea leve a severa e vesículas (bolhas) ou erosões na pele e nas mucosas, que podem ser expontâneas ou provocadas por mínimo trauma1,2. As crianças com essa enfermidade são conhecidas como "Crianças-Borboletas", pela semelhança de sua pele com as asas desse animal pela vulnerabilidade, que a faz descolar também pelo calor excessivo ou até mesmo de forma expontânea, logo após seu nascimento3. Existem quatro tipos principais de EB, de acordo com o nível de formação das bolhas, sendo: EB simples (EBS), EB juncional (EBJ), EB distrófica (EBD) e a Síndrome de Kindler. Para todas, há a necessidade do manejo adequado da pele, que inclui desde a forma de segurar a criança, roupas confortáveis e, especialmente, o uso de coberturas atraumáticas, como as espumas com silicone e tiras superabsorventes termo-seladas e a espuma de poliuretano em rolo para a fixação confortável e segura dos curativos.

Objetivo: Demonstrar a eficácia do uso de coberturas de espuma com silicone e tiras superabsorventes termo-seladas e espuma suave em rolo no manejo da pele de um paciente com EBD (tratamento de lesões e prevenção de novos traumas). Metodologia: Trata-se de um relato de caso em um paciente do sexo masculino, com aproximadamente 1 mês de vida, portador de EBD e internado num hospital infantil em São Luís, Maranhão. Apresentava extensas lesões bolhosas e crostosas por todo o corpo, que pioravam com sua movimentação. Após limpeza e desbridamento mecânico das crostas, foi iniciado o uso das coberturas de espuma com silicone e tiras superabsorventes termo-seladas nos membros superiores e inferiores, abdome e tórax, objetivando-se tratar as feridas já existentes e prevenir novos danos à pele. Para a fixação, foi utilizada a espuma de poliuretano em rolo. As trocas ocorreram a cada $72 \mathrm{~h}$, em média. A coleta dos dados foi realizada por acompanhamento clínico e registros fotográficos. O responsável pelo paciente assinou o termo de autorização do uso das imagens para fins didáticos.

Resultados: As coberturas de espuma com silicone e tiras superabsorventes termo-seladas foram utilizadas no tratamento das lesões por 14 dias (4 trocas no total), com a cicatrização total dessas. Nesse mesmo dia, seu uso foi continuado para a prevenção de novas lesões, principalmente devido à movimentação do corpo do paciente que levava a traumas na pele. Em todo o processo, a espuma de poliuretano foi utilizada também de forma positiva, permitindo o posicionamento das coberturas no corpo sem causar novas lesões, além de fornecer conforto ao paciente.

Conclusão: Pôde-se concluir que o uso das espumas com silicone e tiras superabsorventes termo-seladas para a prevenção e tratamento das lesões decorrentes da Epidermólise Bolhosa são efetivas, principalmente no que se refere ao seu uso atraumático e ao gerenciamento de exsudato, permitindo um meio assertivo para a cicatrização da pele. Conclui-se também que a espuma de poliuretano em rolo é eficaz para o posicionamento das coberturas na pele, fornecendo conforto e segurança ao paciente durante seu uso
\end{abstract}

\section{Keywords: EPIDERMÓLISE BOLHOSA, MANEJO DA PELE, ESPUMA SUPERABSORVENTE E SILICONE, ESPUMA PROTETORA EM ROLO}

\section{Referências Bibliográficas}

1- Vidal G., Carrau, F., Lizarraga M., Álvarez M. Epidermólisis Ampollar: a propósito de um caso clínico. Arch. Pediatr. Urug, 2018; 89(6): 382-388. 2- Benício C.D.A.V et al. Epidermólise Bolhosa:

Foco na assistência de Enfermagem. Revista ESTIMA. 2016. v.14 n.2, pp.91-98. 3- DEBRA Brasil. Disponível em: http://debrabrasil.com.br. Acesso em: 22.08.19. 4- Uitto J. et al. Progress in Epidermolysis Bullosa - Research toward Treatment and Cure. Journal Investigative of Dermatology, 2018. v. 138, pp. 1010-1016. 5- DEBRA International. International Consensus. Disponível em:

http://www.debrainternational.org/fileadmin/media_data/4_DEBRA_International/CPGs/Guidelines/International

Consensus_Best_Practice_Guidelines_Skin_and_Wound_Care_in_Epidermolysis_Bullosa.pdf. Acesso em: 22/08/2019. 


\title{
OS EFEITOS DA TERAPIA A LASER DE BAIXA INTENSIDADE NA REGENERAÇÃO TECIDUAL DE LESÕES EM PÉ DIABÉTICO: REVISÃO INTEGRATIVA
}

\author{
Talita Goncalves de Freitas ${ }^{1}$, Gabriela do Amaral Anastasi ${ }^{1}$, Rosana Pires Russo Bianco ${ }^{1}$, João \\ Junior Gomes ${ }^{1}$, Adriana Pelegrini dos Santos ${ }^{1}$, Donata Maria de Souza Pellegrino ${ }^{1}$ \\ Author(s): \\ Institution(s) ${ }^{1}$ CUSC - Centro Universitário São Camilo (av. Raul Pompéia,14 Bairro Pompeia cep; 05025010 )
}

\begin{abstract}
OS EFEITOS DA TERAPIA A LASER DE BAIXA INTENSIDADE NA REGENERAÇÃO TECIDUAL DE LESÕES EM PÉ DIABÉTICO: REVISÃO INTEGRATIVA
\end{abstract}

\begin{abstract}
Introdução: O pé diabético é uma das causas mais comuns de neuropatia e motivo de amputação, as feridas demoram para cicatrizar e comprometem a qualidade de vida do indivíduo e os recursos do sistema de saúde. Objetivo: Conhecer por meio da literatura, quais os efeitos da aplicação terapia a laser de baixa intensidade pés diabéticos, portanto a questão norteadora foi: quais resultados têm sido relatados na literatura nacional sobre os efeitos da laserterapia na reparação tecidual em feridas? Método: Foi realizada uma revisão integrativa de caráter descritivo, utilizando os seguintes descritores: Laserterapia, Pé Diabético e Cicatrização de Feridas com aplicação do recurso boleano "and". A busca foi realizada em bases de dados como Lilacs, BDENF e MEDLINE no período de 2013 a 2018. Resultados: O tratamento a laser de baixa intensidade promove bioestimulação, provocando efeitos sobre processos moleculares e bioquímicos, favorecendo o reparo de úlcera em pé diabético devido a ações analgésicas e anti-inflamatórias, além de atuar na redução no número de bactérias por meio da fotossensibilização. Conclusão: A prática multidisciplinar e a especialização da equipe são requisitos essenciais para o sucesso terapêutico. Com estratégias viáveis consegue-se reduzir custos, aumentar a eficiência dos procedimentos e reduzir a taxa de amputações.
\end{abstract}

Palavras-Chaves: Laser. Pé Diabético. Tratamento.

1- Tchanque-Fossuo CN, Ho D, Dalhe SE, Koo E, Li CS, Isseroff RR, Jagdeo J. A systematic review of low-level light therapy for treatment of diabetic foot ulcer. Wound Repair Regen. 2016 Mar; 24(2): 418-26.

2- Li S, Wang C, Wang B, Liu L, Tang L, Liu D, Yang G, Zhang L. Efficacy of low-level light therapy for treatment of diabetic foot ulcer: A systematic review and meta-analysis of randomized controlled trials. Diabetes Res Clin Pract. 2018 Sep; 143: 215-224.

3- Salvi M, Rimini D, Molinari F, Bestente G, Bruno A. Effect of low-level light therapy on diabetic foot ulcers: a near-infrared spectroscopy study. J Biomed Opt. 2017 Mar 1; 22(3): 38001.

Keywords: Estomaterapia, Laser, Pé Diabético , Tratamento

\section{Referências Bibliográficas}

1- Tchanque-Fossuo CN, Ho D, Dalhe SE, Koo E, Li CS, Isseroff RR, Jagdeo J. A systematic review of low-level light therapy for treatment of diabetic foot ulcer. Wound Repair Regen. 2016 Mar; 24(2): 418-26. 2- Li S, Wang C, Wang B, Liu L, Tang L, Liu D, Yang G, Zhang L. Efficacy of low-level light therapy for treatment of diabetic foot ulcer: A systematic review and meta-analysis of randomized controlled trials. Diabetes Res Clin Pract. 2018 Sep; 143: 215-224. 3- Salvi M, Rimini D, Molinari F, Bestente G, Bruno A. Effect of low-level light therapy on diabetic foot ulcers: a near-infrared spectroscopy study. J Biomed Opt. 2017 Mar 1; 22(3): 38001. 


\title{
Pessários vaginais na Incontinência urinária: revisão integrativa
}

Eliana de Fatima Martins Greghi ${ }^{1}$, Carolina Bueno Somense ${ }^{1,1}$, Natalia Aparecida de Barros ${ }^{1}$, Author(s): Priscilla Daun de Assis de Oliveira ${ }^{1}$, Neusa Maria Costa Alexandre ${ }^{1}$, Néria Invernizzi da Silveira 1, Sônia Regina Pérez Evangelista Dantas ${ }^{1}$

Institution(s) ${ }^{1}$ Unicamp - Universidade Estadual de Campinas (Rua:Tessália de Vieira Campos, 126)

\begin{abstract}
RESUMO

INTRODUÇÃO: Os pessários, dispositivos intravaginais minimamente invasivos, são uma opção de tratamento da Incontinência Urinária (IU) às mulheres que desejam evitar ou possuem contraindicações ao tratamento cirúrgico.1,2,3,4 Entre outras vantagens, possuem custo e risco relativamente baixos, proporcionam alívio imediato dos sintomas, além da possibilidade de serem utilizados complementarmente a outras terapias conservadoras, como exercícios da musculatura do assoalho pélvico.1,2,3,4 Suspeita-se que sejam subutilizados devido ao panorama atual de subnotificação e negligência no atendimento de pessoas com IU; formação teórico-prática incipiente dos profissionais de saúde sobre essa condição clínica, muitas vezes restrita a cursos de pós graduação; e falta de estudos randomizados controlados que respaldem a prática clínica, hoje baseada principalmente na opinião de especialistas, ocasionalmente conflitantes.1,5OBJETIVO: Analisar os tipos de pessários, as indicações e o impacto no tratamento da IU. MÉTODOS: Trata-se de revisão integrativa com publicações de 2007 a 2017 indexadas nas bases de dados Biblioteca Virtual em Saúde, Medical Literature Analysis and Retrieval System Online, Scopus Info Site, Cumulative Index to Nursing and Allied Health Literature e Web of Science. RESULTADOS: Selecionaram-se oito artigos. Os pessários indicados foram prato, anel, Uresta $\AA^{\circledR}$ e Contiform®. A redução ou resolução da IU de esforço (IUE) em mulheres foi observada por análise de parâmetros objetivos, como avaliação urodinâmica e questionários de qualidade de vida. Destacou-se viabilidade econômica. Evidenciaram-se desajuste, dificuldades no uso, incômodo e manutenção de perdas urinárias entre os motivos de não adesão. Prolapso avançado e comprimento vaginal curto foram preditivos de insucesso. Identificaram-se eventos adversos em baixa incidência: retenção urinária e leucorreia. CONCLUSÃO: A terapia pessária é eficaz no tratamento da IUE quando acompanhada por profissionais capacitados. Características individuais e percepções sobre o dispositivo são determinantes no sucesso terapêutico. Estudos de maior amostragem, tempo de seguimento e qualidade, bem como estimulo a publicações nacionais, são necessários para investigação de medidas objetivas de IU, fatores clínicos e demográficos em relação ao sucesso do pessário.

DESCRITORES: Incontinência Urinária; Pessários; Enfermagem; Estomaterapia.
\end{abstract}

Keywords: Incontinência urinaria, Pessários, Enfermagem, Estomaterapia

\section{Referências Bibliográficas}

REFERÊNCIAS 1. Abrams P, Cardozo L, Wagg A, Wein A. Incontinence. 6a ed. Bristol: International Continence Society; 2017. 2. Robert M, Schulz JA, Harvey MA, Lovatsis D, Walter JE; Urogynaecology Committee. Technical update on pessary use. J Obstet Gynaecol Can. 2013;35(7):664-74. https://doi.org/10.1016/S1701-2163(15)30888-4. 3. Kobashi KC, Albo ME, Dmochowski RR, Ginsberg DA, Goldman HB, Gomelsky A, et al. Surgical treatment of female stress urinary incontinence: AUA/SUFU Guideline. J Urol. 2017;198(4):875-83. https://doi.org/10.1016/j.juro.2017.06.061. 4. Von Bargen E, Patterson D. Cost utility of the treatment of stress urinary incontinence. Female Pelvic Med Reconstr Surg. 2015;21(3):150-3.

https://doi.org/10.1097/SPV.0000000000000159. 5. Atnip S, O' Dell K. Vaginal support pessaries: indications for use and fitting strategies. Urol Nurs. 2012;32(3):114-24. 


\title{
IMPLANTAÇÃO DE PROTOCOLO DE ATENDIMENTO DE ENFERMAGEM AMBULATORIAL À PACIENTES COM INCONTINÊNCIA.
}

\author{
Author(s): Priscila Sales de Lima ${ }^{1}$, Márcia Ramos do Nascimento Ramos do Nascimento ${ }^{1}$, Aline Lisa do \\ Amaral Diegues ${ }^{1}$, Paula Nogueira ${ }^{2}$ \\ Institution(s) ${ }^{1}$ AACD - Associação de Assistência a Criança com Deficiência (Rua Ascendino Reis 754), ${ }^{2}$ USP - \\ Universidade de São Paulo (Departamento de Enfermagem Médico-Cirúrgica)
}

\begin{abstract}
A história da assistência de Enfermagem na incontinência urinária se inicia em 1970, com os veteranos da Guerra do Vietnã, que evoluíram com graves lesões renais, secundárias a disfunções miccionais de origem neurogênica. Na percepção de cuidadores e pacientes a realização do auto cateterismo de técnica limpa melhora a qualidade de vida e promove a independência do paciente. Objetivo: Descrever as fases de planejamento e implantação do protocolo de atendimento de enfermagem à pacientes com incontinência associada à disfunção neurológica do trato urinário inferior em um centro de reabilitação da cidade de São Paulo. Materiais e Métodos: Trata-se de um estudo de natureza descritiva tipo relato de experiência. A implantação do protocolo ocorreu em duas fases: Fase pré-implantação: com criação de grupo de profissionais e levantamento bibliográfico e Fase de Implantação: apresentação do documento institucional, treinamento e utilização da sistematização da assistência de enfermagem em formato eletrônica. Resultados: O protocolo elaborado resultou em atendimento sistematizado, fortalecendo o conceito da consulta de enfermagem e possibilitando atendimento de qualidade ao cliente, com definições claras de critérios de inclusão, fluxo de encaminhamento e alta do paciente. $O$ serviço foi estruturado da seguinte maneira: Realizar quatro consultas de enfermagem e um retorno em 30 dias de forma que seja abordado todo conteúdo de educação em saúde selecionada, avaliação da técnica a ser realizada pelo paciente e reeducação de ingesta hídrica e avaliação de diário miccional Conclusão: A implantação de protocolo baseado em evidências científicas e em diretrizes internacionais possibilitou intervenções de enfermagem com ações abrangentes. $O$ uso de protocolos e indicadores de qualidade são ferramentas importantes para o processo de melhoria da qualidade e na segurança na assistência ao paciente.
\end{abstract}

Keywords: cateterismo urinário, educação em saúde, centros de reabilitação, estomaterapia

\section{Referências Bibliográficas}

Abrams P, Cardozo L, Fall M, Griffiths D, Rosier P, Ulmsten T, et al. The standardization of terminology in lower urinary tract function: Report from the standardization sub-committee of the International Continence Society. Urology. 2003;61:37-49.

Lapides J, Diokno AC, Silber SJ, Lowe BS. Clean intermittent self-catheterization in the treatment of urinary tract disease. J Urol. 1972:107:458-61. Alencar V.P: Cateterismo vesical intermitente limpo em crianças e adolescentes: análise da qualidade de vida do binômio cuidador-criança e dos fatores envolvidos. Tese(Doutorado)—São Paulo 2016. AZEVEDO, R.V.M., et al. Impacto de uma abordagem interdisciplinar em crianças e adolescentes com disfunção do trato urinário inferior (DTUI). Jornal Brasileiro de Nefrologia. Vol. 36, no 4. São Paulo. Out/Dez. 2014. 


\title{
INSTRUMENTOS DE RASTREIO PARA DISFUNÇÃO DO TRATO URINÁRIO INFERIOR EM CRIANÇAS: REVISÃO INTEGRATIVA
}

\author{
Author(s): Jabiael Carneiro da Silva Filho ${ }^{1}$, Isabel Cristina Ramos Vieira Santos ${ }^{1}$, Marilia Perrelli Valença ${ }^{1}$, \\ Jéssica Emanuela Mendes Morato ${ }^{1}$ \\ Institution(s) ${ }^{1}$ UPE - Universidade de Pernambuco (Rua Arnóbio Marques,310. Recife - PE. Brasil)
}

\begin{abstract}
Introdução: A disfunção do trato urinário inferior aplica-se ao distúrbio que acontece em qualquer das fases da micção. Seus sintomas afetam a vida das crianças e de seus cuidadores, resultando em baixa autoestima, isolamento social e mudanças comportamentais inclusive dificuldade de aprendizado. Mediante a isso, a utilização de instrumentos de auxílio para o diagnóstico tem aumentado principalmente quando se trata de uma prática da urologia pediátrica ${ }^{1-4}$. Objetivo: analisar os instrumentos de rastreio para disfunção do trato urinário inferior em crianças quanto a: sintomas, características e propriedades psicométricas. Material e Método: Trata-se de uma revisão integrativa revisão integrativa, fundamentada na prática baseada em evidências, na busca de estudos primários nas bases de dados MEDLINE e LILACS, sem restrição temporal, nos idiomas português, inglês e espanhol. Para orientar a metodologia aplicada a formulação da pergunta foi utilizada a estratégia "PICO": a letra "P" do acrônimo trata da população alvo, a letra "l" considera a intervenção de interesse, a letra " $\mathrm{C}$ " reflete a comparação entre os tipos de instrumentos, o "O" (outcome) diz respeito aos resultados alcançados. Na busca inicial 73 artigos foram selecionados, lidos e categorizados quanto aos títulos e resumos fez-se uma triagem quanto à relevância no que tange ao objetivo deste estudo, perfazendo uma amostragem final de 09 artigos. Resultados: Cada artigo apresentou um instrumento diferente, todos validados. O constructo observado por todos os instrumentos foi a disfunção da bexiga e 07 deles o intestino, abordando 30 diferentes manifestações sintomatológicas. 08 instrumentos tinham como respondentes os pais. A faixa etária da população alvo variou de três a dezoito anos e quanto ao número de itens observou-se uma média de 21,8 itens. Quanto as propriedades psicométricas três deles realizaram as validades de conteúdo, face, constructo e confiabilidade, os outros apresentavam no mínimo uma das validades. Conclusões: os instrumentos abordavam uma vasta gama de sintomas relacionados à disfunção. Apenas três realizaram todos os testes, atendendo as propriedades psicométricas desejáveis para instrumentos de avaliação em saúde, tornandose elegíveis ao processo de adaptação transcultural e validação para uso no Brasil.
\end{abstract}

Keywords: Criança, Estomaterapia, Incontinência urinária, Inquéritos e questionários, Psicometria

\section{Referências Bibliográficas}

1. Veloso LA, Mello MJG, Ribeiro Neto JPM, Barbosa LNS, Silva EJC. Qualidade de vida, nível cognitivo e desempenho escolar em crianças portadoras de distúrbio funcional do trato urinário inferior. Jornal Brasileiro de Nefrologia. 2016; 38(2): 234-244. 2. Mota DM, Barros AJ, Matijasevich A, Santos IS. Prevalence of enuresis and urinary symptoms at age 7 years in the 2004 birth cohort from Pelotas. Brazil. J Pediatr. 2015; 91:52-8. 3. Vasconcelos MMA, Lima EM, Vaz GB, Silva THS. Lower urinary tract dysfunction - a common diagnosis in the pediatrics practice. Jornal Brasileiro de Nefrologia. 2013; 35(1):57-64. 4. Alazab RS, Saqan RS, Abu Shamma F. Advanced Uropathy in a Child With Underactive Bladder: Unusual Presentation, Treatment, and Long-term Follow Up. Urology Case Reports. 2015; 3(2): 37-39. 5. Santos CMC, Pimenta CAM, Nobre RC. A estratégia PICO para a construção da pergunta de pesquisa e busca de evidências. Rev Latino-am Enferm. 2007 maio-jun; 15(3):508-11 


\title{
ADAPTAÇÃO TRANSCULTURAL DO PEDIATRIC LOWER URINARY TRACT SYMPTOM SCORE (PLUTSS)
}

\author{
Jabiael Carneiro da Silva Filho ${ }^{1}$, Isabel Cristina Ramos Vieira Santos ${ }^{1}$, Marilia Perrelli Valença ${ }^{1}$, \\ Author(s): Liana Gabriele da Cruz Mendes ${ }^{1}$, Jéssica Emanuela Mendes Morato ${ }^{1}$, Marcos Antônio de Oliveira \\ Souza ${ }^{1}$
}

Institution(s) ${ }^{1}$ UPE - Universidade de Pernambuco (Rua Arnóbio Marques, 310. Recife - PE. Brasil)

\begin{abstract}
Introdução: A disfunção do trato urinário inferior é um termo amplo que se refere a alteração anatômica e/ou funcional do processo natural da micção. É fundamental um diagnóstico rápido e preciso, principalmente na infância. No Brasil, existe apenas um instrumento adaptado transculturalmente e validado, porém, o instrumento PLUTSS, validado em outras línguas apresenta uma consistência interna maior justificando sua adaptação transcultural para o Brasil ${ }^{1-3}$. Objetivo: realizar a adaptação transcultural do "PLUTSS" para o idioma português do Brasil. Material e Método: Trata-se de um estudo metodológico de tradução e adaptação transcultural, as pesquisas metodológicas são aquelas com objetivo de validar e avaliar métodos de ferramenta e de pesquisa atendendo as necessidades junto ao instrumento que se pretende adaptar para uso no Brasil ${ }^{4}$. Para isso, o estudo seguiu as etapas estabelecidas na literatura ${ }^{5}$. Etapa I: Tradução Inicial, foi traduzido do inglês para o português por dois tradutores diferentes; Etapa II: Síntese destas Traduções; Etapa III: Retrotradução, as duas traduções iniciais foram retrotraduzidas para língua original do instrumento; Etapa IV: Comitê de Especialistas, o comitê foi formado por um metodologista, uma enfermeira estomaterapeuta, um linguista, além dos tradutores participantes das etapas anteriores, bem como o autor do questionário original, o instrumento foi analisado e consolidado para uma versão pré-final. Resultados: Foi necessário para à versão brasileira a modificação da forma de aplicação do instrumento, idealizado para ser auto administrado, mas devido à diversidade de escolaridade da população a que será aplicado no Brasil precisou ser convertido ao formato de formulário. Após a avaliação do comitê de especialista, o instrumento obteve excelentes resultados quanto ao seu entendimento, alguns termos precisaram ser modificados, como: "intermitente" que foi convertido em "jato partido". Foram redigidas duas questões que remetiam a elas mesmas, para melhor entendimento, item 2: "Se sim, responder a 2" e item 4: "Se sim, responder a 4", foram substituídas por: "Se sim, qual a intensidade". Além dessas alterações foi necessário modificar o pronome: "meu filho" para "seu filho". Conclusão: O método utilizado permitiu conservar a equivalência semântica entre o instrumento original e a sua tradução sem modificar a denotação das palavras. Itens de um determinado instrumento relatam o cotidiano em um país ou cultura diferente daquele para qual se pretende adaptar, por isso surgem as necessidades de modificações de terminologias. A versão final mostra-se apta às avaliações de suas qualidades psicométricas para aplicação e validação no Brasil.
\end{abstract}

Keywords: Criança, Estomaterapia, Incontinência urinária, Inquéritos e questionários, Transculturação

\section{Referências Bibliográficas}

1. Vasconcelos MMDA et al. Lower urinary tract dysfunction - a common diagnosis in the pediatrics practice. Jornal Brasileiro de Nefrologia, 2013; 35(1): 57-64. 2. Akbal C et al. Dysfunctional voiding and incontinence scoring system: quantitative evaluation of incontinence symptoms in pediatric population. The Journal of urology,2005; 173(3): 969-973. 3. Calado AA et al. Cross-cultural adaptation of the dysfunctional voiding score symptom (DVSS) questionnaire for Brazilian children. International braz j urol, 2010; 36(4): 458-463. 4. Polit DF, Beck CT, Hungler BP. Fundamentos de pesquisa em enfermagem: avaliação de evidências para a prática da enfermagem. 2011. 5.Beaton DE et al. Guidelines for the process of cross-cultural adaptation of self-report measures. Spine, 2000; 25(24): 3186-3191. 


\title{
INCONTINÊNCIA URINÁRIA EM MULHERES QUE PRATICAM ATIVIDADE FÍSICA DE IMPACTO: UMA REVISÃO INTEGRATIVA
}

\author{
Author(s): $\quad$ Aldrya Ketly pedrosa ${ }^{1}$, Aline Maria de Santana ${ }^{1}$, Fernanda Medeiros Omena Magalhães ${ }^{1}$, Jaciara \\ Maria da Silva ${ }^{1}$ \\ Institution(s) ${ }^{1}$ UNIT-AL - Centro Universitário Tiradentes (Av. Comendador Gustavo Paiva, 5017 - Cruz das \\ Almas, Maceió - AL, 57038-000)
}

\begin{abstract}
Introdução: A incontinência urinária (IU) é definida pela Internacional Continence Society como qualquer perda involuntária de urina que gere desconforto social ou higiênico. Conforme a incontinência urinária se manifeste, traz ao indivíduo importantes repercussões físicas e sociais. Objetivo: Analisar o que se tem publicado sobre a prática de atividade física como um fator de risco para o desenvolvimento da incontinência urinária em mulheres que praticam atividade física de impacto. Metodologia: Trata-se de uma revisão integrativa, que busca uma análise na literatura especializada, acerca da prática de atividades físicas de impacto como um fator de risco para o desenvolvimento da incontinência urinária (IU) em mulheres. Para a coleta de dados, foi realizada uma pesquisa nas seguintes bases de dados: PUBMED, Literatura LatinoAmericana e do Caribe em Ciências da Saúde (LILACS), Base de dados de Enfermagem (BDENF) e Sistema de Busca e Análise de Literatura Médica (MEDLINE). Para a escolha dos artigos, foram utilizados os seguintes critérios: artigos publicados na íntegra entre os anos de 2015 a 2019 e disponíveis na língua portuguesa e inglesa. Através da seleção dos artigos, foram realizadas análises e discussões e, dessa forma, foram elaboradas duas categorias: "IU relacionada à prática de exercício físico de impacto" e "IU relacionada à modalidade esportiva". Resultados: por meio das pesquisas nas bases de dados foram encontrados 110 artigos. Após a leitura dos títulos foram excluídos 89 artigos, pois não respondiam à pergunta norteadora; e selecionados apenas 23 , que tinham relação com a temática do estudo. Posteriormente foram lidos os resumos e excluídos 12 artigos os quais não se encaixavam no critério de inclusão e exclusão da pesquisa e selecionados 11 para a leitura na íntegra. Verificou-se após a leitura na íntegra que os 06 artigos se encaixavam no critério de inclusão e tratavam da temática. Conclusão: Desta forma, a modalidade e a carga de treino são fatores relevantes para a prevalência de IU entre mulheres que praticam atividades físicas de impacto. Estudos investigam a premanência de IU de acordo com a modalidade esportiva, enquanto outros estudos levam em conta a carga de treinamento para avaliação. Algumas atletas de modalidades esportivas específicas sentem de forma mais acentuada os sintomas.
\end{abstract}

Keywords: Atividade física, Incontinência urinária, Mulheres, Estomoterapia

\section{Referências Bibliográficas}

Virtuoso FJ, Menezes CE, Mazo ZG. Fatores de risco para incontinência urinaria em mulheres idosas praticantes de exercícios físicos. Rev Bras Ginecol Obstet. 2015. v 37. n. 2. Pompeo DA, Rossi LA, Galvão CM. Revisão integrativa: etapa inicial do processo de validação de diagnóstico de enfermagem. Acta Paul Enferm. 2009. Martines GA, Tamanini JTN. Relação entre atividade física e incontinência urinária: informações relevantes ao educador físico. Revista saúde e Pesquisa. 2015. v. 8, pág 140-155. 


\title{
REDES SOCIAIS PARA DIVULGAÇÃO E ACONSELHAMENTO SOBRE DISFUNÇÕES MICCIONAIS: UM RELATO DE EXPERIÊNCIA
}

\author{
Author(s): Camilla Pinheiro Cristaldi da Silva ${ }^{1}$, Gisela Maria Assis ${ }^{2}$, Franciele Freitas ${ }^{3}$, Gisele Martins ${ }^{2}$ \\ Institution(s) ${ }^{1}$ PUC/Pr - Pontifícia Universidade Católica do Paraná (R. Imac. Conceição, 1155 - Prado Velho, \\ Curitiba - PR, 80215-901), ${ }^{2}$ UnB - Universidade de Brasília (Campus Universitário Darcy Ribeiro, \\ Brasília-DF | CEP 70910-900 ), ${ }^{3}$ HC/UFPR-Pr - Universidade Federal do Paraná - Hospital de \\ Clínicas (R. Gen. Carneiro, 181 - Alto da Glória, Curitiba - PR, 80060-900)
}

\begin{abstract}
Introdução: As redes sociais estão presentes na rotina diária dos brasileiros e da população mundial. O aumento global das relações humanas e trocas de saberes no ciberespaço é evidente. Essa realidade se mostra útil na divulgação de informações e troca de experiência na área da saúde, em especial, em assuntos velados, pouco abordados nas rodas de conversas, como as disfunções miccionais. Objetivo: Relatar a experiência sobre a divulgação e o aconselhamento sobre disfunções miccionais realizados em redes sociais. Material e Método: Relato de experiência. Uso de página no Instagram e Facebook. Aplicativo Canva® para criação de imagens para os posts. Publicação duas vezes por semana e acompanhamento semanal do número de inscritos, característica dos seguidores, mensagens enviadas e número de curtidas por post. Resultados: Em cinco meses, com 54 publicações, o número de inscritos no canal do Instagram chegou em 915 seguidores e no Facebook em 1214. O aumento de seguidores ocorria, em média, por 20 novos inscritos por semana, com diferença crescente entre o início da página até o momento (aproximadamente 35 por semana no último mês). Esse número quase duplicava após posts com muito alcance (maiores curtidas e compartilhamentos). No Instagram, $26 \%$ dos seguidores são de Curitiba, $74 \%$ entre 25 a 44 anos, $89 \%$ são mulheres, majoritariamente profissionais de saúde (principalmente enfermeiros). No Facebook as porcentagens são semelhantes. Os posts com maior alcance foram os relacionados às evacuações (constipação, posicionamento para sentar, encoprese, etc.). Quanto ao alcance geral das páginas, no último mês, 1744 novas contas do Instagram visualizaram pelo menos um post do canal, enquanto que no Facebook esse número foi para 13,2 mil. Os seguidores leigos, que não são da área da saúde, foram os que mais comentaram com dúvidas sobre quadros de saúde pessoais. Enviavam perguntas tanto por comentários abertos quanto por mensagens particulares. Utilizou-se dos dias de publicação para responder as mensagens e comentários. Conclusões: As redes sociais se mostraram satisfatórias como espaço de divulgação e aconselhamento sobre disfunções miccionais. Possibilitaram, ainda, trocas de experiências sobre o exercício profissional com enfermeiros de todo o Brasil, ampliação do contato com as pessoas que têm alguma disfunção e divulgação sobre a atuação do enfermeiro nessa área, tanto para a população geral como para outros profissionais de saúde.
\end{abstract}

Keywords: Distúrbios do Assoalho Pélvico, Estomaterapia, Incontinência Urinária, Meios de Comunicação em Massa, Mídias Sociais

\section{Referências Bibliográficas}

Abrams P, Cardozo L, Wagg A, Wein A. Incontinence: 6th Edition 2017. 6th International Consultation on Incontinence, Tokyo, September 2016. Agarwal BK, Agarwal N. Urinary incontinence: prevalence, risk factors, impact on quality of life and treatment seeking behaviour among middle aged women. International Surgery Journal, 2017; 4(6): 1953-1958. Rüdiger F. As teorias da cibercultura: perspectivas, questões e autores. Porto Alegre-RS: Sulina, 2011. 


\title{
TIPO E GRAVIDADE DE INCONTINÊNCIA URINÁRIA EM MULHERES
}

\author{
Aurenice Gomes da Silva ${ }^{1}$, Rayne Raissa Correia de Carvalho ${ }^{1}$, Isabel Cristina Ramos Vieira \\ Author(s): $\quad$ Santos $^{1,2}$, Marília Perrelli Valença ${ }^{2}$, Jabiel Carneiro da Silva Filho ${ }^{2}$, Steffany de Almeida Ferreira
}

Institution(s) ${ }^{1}$ UNICAP - Universidade Católica de Pernambuco (Rua do Principe, 526 Boa Vista - Recife, PE Cep: 50050-900), ${ }^{2}$ UPE - Universidade de Pernambuco ( Av. Gov. Agamenon Magalhães - Santo Amaro, Recife - PE, 50100-010)

\begin{abstract}
Objetivo: Verificar fatores associados a incontinência urinária em mulheres por tipo e gravidade. Metodologia: Estudo transversal, realizado de novembro de 2018 a abril de 2019, com 30 mulheres, idade a partir de 18 anos, em um hospital escola de Pernambuco. Foi utilizado o instrumento Gaudenz-Fragebogen para identificar os tipos de incontinência e o Incontinence Severity Index para classificar a gravidade da perda urinária.Os dados coletados foram digitados e analisados utilizando-se o Programa SPSS for Windows versão 25.0. através de estatística descritiva, com uso de distribuição de frequências, de média ( ) como medida de tendência central e, desvio padrão $(\sigma)$ como medida de dispersão, além dos limites mínimo (Lmin) e máximo (Lmax) das distribuições. Para verificação da existência de associação entre tipo de IU e fatores associados foi utilizado o teste Exato de Fisher para analisar variáveis qualitativas, t-Student para variáveis racionais e o teste de Levene foi considerado para se testar a hipótese de igualdade das variâncias. O nível de significância foi considerado através do valor de $p<0,05$. Resultados: A incontinência urinária de esforço foi o tipo mais frequente $(66,7 \%)$, na forma moderada $(43,3 \%)$ e esteve associada a baixa escolaridade ( $p$
\end{abstract}

Keywords: Estomaterapia, Fatores de risco, Incontinência urinária de esforço, Incontinência urinaria de urgência, Saúde da mulher

\section{Referências Bibliográficas}

1. Jerez-Roig $\mathrm{J}$ et al Prevalence ofurinary incontinence and associated factors in nursing home residents, Neurourol. Urodyn. 35 (January (1)) (2016) 102-107. 2. Emily S et al. Urinary Incontinence in Women A Review. JAMA. 2017;318(16):15921604. 3. Silva JCPS, Soler ZASG. Anneliese Domingues Wysocki2 Fatores associados à incontinência urinária em mulheres submetidas ao exame urodinâmico. Rev Esc Enferm USP • 2017;51:e03209. 4. Luana FM, Luz et al. Caracterização e Fatores de Risco de Incontinência Urinária em Mulheres Atendidas em uma Clínica Ginecológica. ESTIMA, v. 15 n.2, p. 82-91, 2017. 5. Oliveira LDR, Lopes MHBM. Validação da versão brasileira do Gaudenz-Fragebogen: utilizado para o diagnóstico diferencial da incontinência urinária feminina. Escola Anna Nery 20(2): 332-6 Abr-Jun 2016. 


\title{
ANÁLISE DO CENÁRIO DE ATENÇÃO A PESSOA COM DISFUNÇÃO MICCIONAL NO BRASIL PELO USO DA FERRAMENTA GERENCIAL “ÁRVORE DE PROBLEMAS”.
}

\author{
Author(s): \\ GISELA MARIA ASSIS ${ }^{1}$, Camilla Pinheiro Cristaldi da Silva ${ }^{1}$, Franciele de Freitas ${ }^{1}$, Gisele \\ Martins ${ }^{1}$ \\ Institution(s) ${ }^{1}$ UNB - Universidade de Brasília (Campus Universitário Darcy Ribeiro)
}

\begin{abstract}
Introdução: As disfunções miccionais constituem um problema social negligenciado. Publicações apontam para uma alta prevalência e impacto na qualidade de vida, apesar disso, políticas públicas brasileiras não contemplam sua resolução na atenção básica, sendo que grande parte do tratamento de primeira linha é constituído por orientações de medidas comportamentais simples 1,2,3. Considerando que o conhecimento apontado é derivado de publicações internacionais e prática assistencial local, identificou-se a necessidade de levantar e organizar dados referentes ao cenário de atenção a pessoa com Disfunção Miccional no Brasil, a fim de identificar lacunas com potencial de atuação pelo enfermeiro especialista. Objetivo: Analisar o cenário de atenção a pessoa com Disfunção Miccional no Brasil. Método: Adotou-se como ferramenta para compreensão do problema, a ferramenta gerencial "Árvore de Problemas"4, diagrama composto pelo tronco (problema que se pretende analisar), raízes (causas do problema) e galhos (consequências do problema). Para alimentar a árvore foram seguidos dois passos, a estratégia de organização de conhecimentos prévios, proposta pelo método de Design Thinking5 e um aprofundamento no tema por meio de uma revisão integrativa de literatura. Questão norteadora: "Qual é o cenário brasileiro de atenção a pessoa com disfunções miccionais?". Bases: Pubmed (medline), Lilacs e CINAHL. Estratégia de busca: "urinary incontinence", enuresis e Brazil. Incluídos artigos originais, realizados no Brasil, publicados nos últimos cinco anos. Foram coletadas variáveis que pudessem alimentar a árvore de problemas, ou seja, dimensão do problema (dados de prevalência e incidência), causas e consequências do problema (fatores associados às disfunções miccionais). As variáveis coletadas foram organizadas posteriormente no diagrama da árvore de problemas de acordo com a análise causal, por meio do programa Coggle. Resultados: A Revisão Integrativa resultou em 251 artigos inicialmente e 104 após aplicação dos critérios de elegibilidade. Na construção do tronco da árvore, o problema social analisado foi a prevalência de disfunção miccional, as taxas variaram entre 10,4\% e 92,3\%, de acordo com a população estudada, o problema foi prevalente entre populações diversas como mulheres pós menopausa, jovens praticantes de jump, pessoas com alterações neurológicas, crianças e adolescentes hígidos. Na construção da raiz da árvore foram identificadas diversas causas como condições de nascimento e situações da infância, cirurgias pélvicas, esportes de alto impacto, envelhecimento não saudável e comorbidades, hábitos de vida não saudáveis e falta de conhecimento dos profissionais. Nos galhos da árvore (consequências do problema), foram identificados impacto na qualidade de vida, saúde física, mental e sexual, na vida escolar e infância, aumento da dependência e gastos no sistema de saúde. Conclusões: A prevalência de disfunções miccionais no Brasil é alarmante e seus impactos na vida da pessoa e sobre o sistema de saúde são devastadores. O uso da árvore de problemas e a decisão de alimentá-la com uma revisão integrativa foram estratégias inovadoras que permitiram uma visualização esquemática das relações causais, facilitando a escolha das raízes sobre as quais o enfermeiro especialista pode agir, para transformação da realidade.
\end{abstract}

Keywords: Retenção Urinária, Incontinência Urinária, Brasil

\section{Referências Bibliográficas}

1. Abrams P, Cardozo L, Wagg A, Wein A. Incontinence. 6th ed. International Continence Society, editor. Tokyo: ICUD; 2017. 2. Austin PF, Bauer SB, Bower W, Chase J, Franco I, Hoebeke P, et al. The standardization of terminology of lower urinary tract function in children and adolescents: Update report from the standardization committee of the International Children's Continence Society. Neurourol Urodyn. 2016;35(4):471-81. 3. Brito FA de, Gentilli R de ML. Desatenção à mulher incontinente na atenção primária de saúde no SUS TT - Inattention to incontinent woman in primary care unit. Fisioter Bras [Internet]. 2017;18(2):f: 205-I: 213. Available from:

http://portalatlanticaeditora.com.br/index.php/fisioterapiabrasil/article/view/799/1744 4. Cavalcanti CC, Filatro A. Design Thinking na educação presencial, a distância e corporativa. 1st ed. São Paulo: Saraiva; 2016. 253 p. 5. CEPAL. Manual de formulação e avaliação de projetos sociais division de desarrollo social cepal 1. 


\title{
MANEJO DAS DERMATITES DE FRALDAS UTILIZANDO CREME BARREIRA A BASE DE PHMB
}

\author{
Author(s): Kátia Cristina tosta de Siqueira noventa ${ }^{1}$, YALES ROMENNA FERREIRA COSTA E SILVA ${ }^{2}$, NARYLLENNE MACIEL \\ Institution(s) 1 CLÍNICA VIMAGEM - CLÍNICA VIMAGEM (AV. JOÃO PESCARINI 480 JARDIM FLORA VINHEDO SP), ${ }^{2}$ LIGA DO \\ NORTE RIOGRA - LIGA DO NORTE RIOGRANDENSE CONTRA O CÂNCER (Av. Miguel Castro, 1355 - Dix-Sept \\ Rosado, Natal - RN), ${ }^{3}$ LIGA DO NORTE RIOGRA - LIGA DO NORTE RIOGRANDENSE CONTRA O CÂNCER (Av. \\ Miguel Castro, 1355 - Dix-Sept Rosado, Natal - RN)
}

\begin{abstract}
INTRODUÇÃO - A dermatite de fraldas é a forma mais frequente de dermatite de contato por irritante na primeira infância. Estima-se que até os 2 anos de vida 25\% a 65\% das crianças apresentarão esta dermatose(1,2). Caracterizada como dermatite multifatorial, dependendo da umidade, $\mathrm{pH}$ elevado, enzimas fecais e agentes microbianos, é uma erupção inflamatória aguda da pele polpando dobras com eritema e prurido, levando a desconforto e ocasionando incontinência fecal e urinária se persistir(3). Aumentada pela limpeza e utilização de lenços úmidos contendo álcool ou sabões com pH alcalino, favorece à quebra da barreira cutânea, causando dor e perda na qualidade de vida do paciente pediátrico. Como estes fatores são constantes, enquanto a criança estiver utilizando fraldas, medidas preventivas devem ser aplicadas(1). Nisso, o processo de enfermagem visa aplicar estas medidas, aumentando a qualidade de vida e cuidado com a pele. Nas quais, estudos mostram que a utilização correta de cremes pode ser uma alternativa(4), como o creme protetor a base de Polihexanida (PHMB) que fornece hidratação, previne a irritação cutânea, manutenção da umidade natural da pele e serve para proteção contra agentes externos(5). OBJETIVO - Este trabalho objetiva relatar um caso clínico no tratamento de dermatite de fralda no qual foi testado os efeitos cicatrizantes do creme barreira a base de Polihexanida. METODOLOGIA Estudo do tipo relato de caso, realizado no mês de junho de 2019 por enfermeiras do programa de Pós-graduação na área de Estomaterapia do Hospital Israelita Albert Einstein. Foram realizados visitas diárias a criança, ocorrendo avaliação da lesão e tratamento com aplicação do creme barreira Dermaid Bio Baby. Carta patente No PI 0305735-6. Sem conflito de interesses pela utilização do produto. Estudo aprovado pelo comitê de ética da Liga Norte Riograndense Contra o Câncer, parecer no3.497.423. RESULTADO - Criança, sexo feminino, 2 anos e 6 meses, reside na cidade de Campinas, São Paulo - SP, apresentou "assadura", dermatite de fralda com ardência e prurido nas micções. As enfermeiras realizaram a assistência com a orientação sobre os cuidados e aplicação do creme barreira Dermaid Bio Baby durante as trocas de fralda, observou-se a reparação tecidual na região perineal. É nítido a importância da assistência de enfermagem no tratamento domiciliar. CONCLUSÃO - Conclui-se que o enfermeiro tem papel fundamental no planejamento do cuidado com a pele e que a utilização de um creme a base de PHMB demonstrou eficácia na recuperação cutânea, servindo de agente terapêutico na cicatrização com melhora no prurido e dor. O fato do tratamento ter sido feito domiciliar proporcionou conforto e aceitação da criança. É necessário mais pesquisas no cuidado a pele de crianças.
\end{abstract}

Keywords: Dermatite, Crianças, Incontinência, Enfermagem

\section{Referências Bibliográficas}

1. Sociedade Brasileira de Pediatria. Dermatite na área das fraldas - Diagnóstico diferencial. Departamento Científico de Dermatologia. Documento científico. 2016 out; 1: 1-6. 2. Fernandes JD, Machado MCR, Oliveira ZNP. Fisiopatologia da dermatite da área das fraldas - parte I. An Bras Dermatol. 2008. 83(6): 567-71. 3. Alcoforado CLGC, Machado BO, Campos CC, Gonçalves PC, Ercole FF, Chianca TCM. Fatores de risco para dermatite associada à incontinência: uma revisão integrativa.Rev Enf do Centro-Oeste Mineiro.[Internet] 2018 [Acesso em 29 jul 2019]; 8: 1-12. Disponível em: http://www.seer.ufsj.edu.br/index.php/recom/article/view/2512/2052. 4. Filho JSR, Carvalho CGN. Dermatite das fraldas, fisiopatologia e tratamento: revisão de literatura. Rev Med [Internet]. 2017 jul.-set.[Acesso em 29 jul 2019]; 96(3):183-6. Disponível em: https://www.revistas.usp.br/revistadc/article/view/121238/133972. 5. Silva MJS. Protocolo de cuidados e tratamento para lesão por pressão.Santa Cruz-RN. Tratalho de Conclusão de Cuso, Graduação em Enfermagem. Universidade Federal do Rio Grande do Norte. 2018. 


\title{
PREVENÇÃO DE DERMATITE ASSOCIADA À INCONTINÊNCIA X REDUÇÃO DE LESÃO POR PRESSÃO
}

\author{
Author(s): Daiany Santos Fernandes ${ }^{1}$, Patricia Pedroso da Silva ${ }^{1}$, Camila Freitas Gambim ${ }^{1}$, Elisandra Leites \\ Pinheiro ${ }^{1}$, Daniela Tenroller de Oliveira ${ }^{1}$ \\ Institution(s) ${ }^{1}$ HMV - hospital moinhos de vento (Rua Ramiro Barcelos, 910)
}

\begin{abstract}
Introdução: A dermatite associada à incontinência (DAl) conceitua-se como a resposta inflamatória da pele devido ao contato crônico com eliminações urinárias e fecais. 1 Trata-se de uma complicação frequente em pessoas com perda do controle esfincteriano, que induz irritação e ruptura da pele, com impacto na qualidade de vida e vulnerabilidade para infecções secundárias,2 em casos mais graves progredindo a uma lesão por pressão (LP): Lesão localizada na pele e/ou tecidos moles subjacentes, geralmente sobre uma proeminência óssea, ou relacionada a dispositivos médicos, podendo se apresentar em pele íntegra ou como úlcera aberta e dolorosa.3 Acrescenta-se o fato de que, o envelhecimento e a institucionalização aumentam o risco da integridade da pele prejudicada, o que torna ainda mais necessário que os enfermeiros façam um diagnóstico mais precoce possível com vistas a implementação de ações que contribuam para a melhoria do cuidado.4 Objetivos: Orientar e capacitar as intervenções de enfermagem dirigidas à prevenção de DAI, e o risco iminente ao desenvolvimento de LPs. Método: Trata-se de um estudo transversal de caráter comparativo, que faz parte de um projeto guarda-chuva da instituição, como parecer CAAE: 57679316.9.0000.5330, que avalia as melhores práticas aplicadas na assistência aos pacientes com riscos de desenvolver lesão, de 2016 a 2018 em um hospital privado de Porto Alegre. Foi desenvolvido um protocolo com fluxograma para prevenção de DAI e colocado em todos os murais das unidades de internação, orientando a troca de fraldas com freqüência, a fim de manter pele limpa e seca e evitar irritação cutânea; abordado sobre o uso indiscriminado de duas fraldas, pois favorece o aquecimento e desenvolvimento de dermatite, e também sobre a importância da utilização e prescrição de cremes barreira como forma de prevenção de DAl. Resultados: Observou-se envolvimento das equipes na intensificação dos cuidados com a aplicação do protocolo de prevenção, impactando na redução da densidade de novos casos com lesões, onde respectivamente os dados representam: 1,14\% em 2016, 0,61\% em 2017 e 0,31\% em 2018. Conclusão: Após treinamento efetivo da equipe, o uso de um protocolo de cuidados que envolva adequada higiene, utilização de produtos de barreira e hidratação, bem como a escolha da fralda compatível com a necessidade do paciente conforme fluxograma, evidenciou-se mudanças de comportamento positivas, e um olhar mais minucioso por parte dos profissionais capacitados, ao paciente com fatores de risco de desenvolvimento a dermatite ou lesão por pressão. Estratégias de prevenção como o treinamento efetivo da equipe de enfermagem a estes agravantes e o papel do enfermeiro na identificação a necessidade de prevenção e tratamento da dermatite é essencial, considerando que esses profissionais cuidam diretamente da população mais predisposta ao problema.
\end{abstract}

Keywords: Dermatite, Estomaterapia, Incontinência Fecal, Incontinência Urinária, Lesão por Pressão

\section{Referências Bibliográficas}

REFERÊNCIAS: 1. Beeckman D, Van Lancker A, Van Hecke A, Verhaeghe S. A Systematic Review and Meta-Analysis of incontinence-Associated Dermatitis, Incontinence, and Moisture as Risk Factors for Pressure Ulcer Development. Research in Nursing \& Health. Volume 37, Issue 3, pages 204-218, June 2014 2. CHIMENTÃO, DMN, DOMANSKY, RC. Dermatite Associada à Incontinência: Recomendações baseadas em evidências. Rio de janeiro: Editora Rubio; 2012. 3. National Pressure Ulcer Advisory Panel, European Pressure Ulcer Advisory Panel and Pan Pacific Pressure Injury Alliance. Prevention and Treatment of Pressure Ulcers: Clinical Practice Guideline. Emily Haesler (Ed.). Cambridge Media: Osborne Park, Austrália Ocidental; 2014. 4. ROSA, NM, Inoue KC, SILVINO, MCS, OLIVEIRA, MLF. Tratamento da dermatite associada à incontinência em idosos institucionalizados: Revisão integrativa. Rev Rene 2013; 14(5):1031-40. 


\title{
PRINCIPAIS FATORES QUE FAVORECEM O DESENVOLVIMENTO DE INCONTINÊNCIA URINÁRIA EM PUÉRPERAS
}

\author{
Author(s): Elisangela Soares da Silva Reis ${ }^{1}$, Miguir Terezinha Vieccelli Donoso ${ }^{1}$, Salete Maria Silqueira ${ }^{1}$, \\ Elis Regina Silva Pinheiro ${ }^{1}$, Selme Silqueira ${ }^{1}$, Fernanda Torcata Amorim ${ }^{1}$ \\ Institution(s) ${ }^{1}$ UFMG - Universidade Federal de Minas Gerais (Av. Alfredo Balena, 190, Santa Efigênia/ CEP \\ 30130-100 - Belo Horizonte/MG)
}

\begin{abstract}
Introdução: A incontinência urinária é a perda involuntária de urina levando desconforto as pessoas que sofrem deste transtorno. A disfunção do soalho pélvico pode estar relacionada a vários aspectos podendo ser causado pela gravidez ou ao parto que levam a deficiência na força de contração muscular pélvica, fato que é considerado por autores como um problema sério que interfere no dia a dia da mulher, fazendo com que as mesmas se privem de ter uma vida social ou mesmo relacionamento íntimo com o parceiro devido o desconforto causado pela incontinência urinária. Objetivo: identificar os fatores que favorecem o desenvolvimento de incontinência urinária em puérperas. Material e Método: $O$ referencial metodológico adotado no estudo em questão foi a Revisão Integrativa de Literatura. Um total de 52 artigos avaliados entre o ano de 2012 e 2017 que abordam a incontinência urinária no puerpério. Dos artigos encontrados, foram selecionados 18, por atenderem os critérios de inclusão desta pesquisa: publicados na forma de artigo, resultantes de pesquisa primária, quantitativos, nos idiomas português, inglês ou espanhol, publicados entre o período de 2012 a 2017 e que contemplassem aspectos relacionados à Incontinência Urinária no puerpério. As bases de dados selecionadas na BVS foram: Medical Literature Analysis and Retrieval System Online (Medline); Índice Bibliográfico Espanhol de Ciências da Saúde (IBECS); Literatura Latino-Americana em Ciências da Saúde (LILACS). Resultados: Os fatores que mais favorecem a incontinência urinária no pós-parto são alterações fisiológicas da gravidez, condições preexistentes e falta de orientações, além do não preparo da musculatura pélvica. Conclusão: Os estudos reiteram a importância de um pré-natal bem assistido, com equipe multidisciplinar e que despertem na gestante o interesse pela qualidade de vida no pós-parto.
\end{abstract}

Keywords: Estomaterapia, Incontinência urinária, Estomaterapia

\section{Referências Bibliográficas}

Brown S, Gartland D, Perlen S, McDonald E, MacArthur C.Consultation about urinary and faecal incontinence in the year after childbirth: a cohort study. BJOG 2015 Jun; 122(7): 954-62. Li H, Wu RF, Qi F, Xiao AM, Ma Z, Hu Y, et al. Postpartum pelvic floor function performance after two different modes of delivery. Genet Mol Res 2015 Apr 10; 14(2): 2994-3001. Lopes DBM, Praça NS. Prevalência de incontinência urinária autorreferida no pós-parto e fatores relacionados. Acta paul enferm 2012; 25(4): 574-80. 


\title{
CUIDADOS DE ENFERMAGEM E SUAS REPERCUSSÕES NA VIDA DA PESSOA COM INCONTINÊNCIA ANAL: REVISÃO INTEGRATIVA
}

\author{
Author(s): $\quad{ }_{1}$ Livia Nunes Rodrigues Leme ${ }^{1}$, Norma Valéria Dantas de Oliveira Souza ${ }^{1}$, Priscilla Farias Chagas
Institution(s) ${ }^{1}$ UERJ - UNIVERSIDADE DO ESTADO DO RIO DE JANEIRO (BOULEVARD 28 DE SETEMBRO, VILA ISABEL, RJ.)

\begin{abstract}
Introdução: A incontinência anal (IA) é definida pela Sociedade Internacional de Continência (ICS) como qualquer perda involuntária de material fecal e/ou gases, em local inadequado e em qualquer faixa etária, após a obtenção do controle esfincteriano. O enfermeiro desempenha papel fundamental no cuidado a pessoa IA, aplicando ou orientando diversas modalidades de tratamento. Objetivos: identificar o desenho metodológico de pesquisas sobre cuidados de enfermagem à pessoa com IA; descrever os cuidados de enfermagem à pessoa com IA; discutir as repercussões dos cuidados de enfermagem na vida da pessoa com IA. Método: Estudo descritivo, do tipo revisão integrativa, com busca nas bases BVS, Scielo, PUBMED, além de publicações da Revista Estima, entre junho e julho de 2018. A busca inicial resultou em 3370 resumos, dos quais 51 foram selecionados para leitura completa. Foram excluídos 38 estudos por não atenderem aos objetivos da pesquisa e a amostra final contou com 13 artigos. Resultados: Os estudos revisados foram publicados no período de 2006 a 2017, sendo quatro revisões bibliográficas, um estudo prospectivo, dois comparativos descritivos, dois longitudinais, três descritivos e um comparativo. Identificaram-se três categorias analíticas: Tecnologias para o manejo da IA; Principal complicação - dermatite associada à IA; e Complexidade dos cuidados de enfermagem e ações terapêuticas. Conclusões: A enfermagem desempenha importante papel na produção do conhecimento nesta temática, apesar de ainda incipiente, visto a captação de apenas 13 artigos, sem recorte temporal. Os cuidados descritos nos estudos são passíveis de aplicabilidade, visto serem de fácil aplicação, sem necessidade de tecnologias de alto custo. Os cuidados de enfermagem podem repercutir positivamente na vida da pessoa com IA na medida em que podem prevenir complicações e trazer melhorias na qualidade de vida.
\end{abstract}

Keywords: Cuidados de enfermagem, Estomaterapia, Incontinência anal, Incontinência fecal

\section{Referências Bibliográficas}

1. Abrams P, Andersson L, Birder L. Fourth International Consultation on Incontinence - Recommendations of the International Scientific Committee: evaluation and treatment of urinary incontinence, pelvic organ prolapsed and fecal incontinence. Neurourol. Urodyn. 2010 [cited 2018, Jun 01]; 29 (1):213-240. Avaliable from:

http://onlinelibrary.wiley.com/doi/10.1002/nau.20870/epdf 2. Silveira BL, Catarucci F, Macedo GM, Cunha LD, Romano VC, Gomes JJ. O enfermeiro na atenção à pessoa com incontinência anal / The nurse in attention to the person with anal incontinence. CuidArte, Enferm. 2017 [cited 2018, Jun 01]; 11(2): 215-222. Avaliable from:

http://pesquisa.bvsalud.org/brasil/resource/pt/bde-32949 3. Azevedo M, Guilhem DB, Hobo TMW, Goulart MV. Avaliação da predominância da incontinência anal nos partos vaginal e cesáreo. Universitas: Ciências da Saúde 2017 [cited 2018, Jun 01]; v. 15, n. 2, p. 101-106, 2017. DOI: 10.5102/ucs.v15i2.4240. 4. Bliss DZ, Funk T, Jacobson M, Savik K. Incidence and characteristics of incontinence- associated dermatitis in community-dwelling persons with fecal incontinence. J. wound ostomy continence nurs. 2015 [cited 2018, Jul 01]; 42(5): 525-30. DOI:10.1097/WON.0000000000000159 5. Bliss DZ, Savik $\mathrm{K}$, Jung HJ, Whitebird R, Lowry A. Symptoms associated with dietary fiber supplementation over time in individuals with fecal incontinence. Nurs. Res. 2011 [cited 2018, Jun 01]; 60(3 Suppl):S58-67. DOI:10.1097/NNR.0b013e3182186d8c 


\title{
Perfil sociodemográfico, clínico e necessidades de pacientes e cuidadores praticantes do cateterismo intermitente limpo
}

\author{
Author(s): Telma Maria Evangelista de Araújo ${ }^{1,1,1,1}$, Elaine Maria Leite Rangel Andrade 1,1,1,1, Lídya Tolstenko \\ Nogueira ${ }^{1,1,1,1}$
}

Institution(s) ${ }^{1}$ UFPI - Universidade Federal do PiauiUFPI (Campus Universitário Ministro Petrônio Portella Bairro Ininga Teresina - PI -), ${ }^{2}$ UFPI - Universidade Federal do Piaui (Campus Universitário Ministro Petrônio Portella Bairro Ininga - Teresina - PI -), ${ }^{3}$ UFPI - Universidade Federal do Piaui (Campus Universitário Ministro Petrônio Portella Bairro Ininga - Teresina - PI -), ${ }^{4}$ UFPI - Universidade Federal do Piaui (Campus Universitário Ministro Petrônio Portella Bairro Ininga - Teresina - PI -), ${ }^{5}$ UFPI - Universidade Federal do Piaui (Campus Universitário Ministro Petrônio Portella Bairro Ininga - Teresina - PI -), ${ }^{6}$ UFPI - Universidade Federal do Piaui (Campus Universitário Ministro Petrônio Portella Bairro Ininga - Teresina - PI -)

\begin{abstract}
Introdução. Apesar de ser procedimento padronizado desde a segunda Guerra mundial, o cateterismo intermitente limpo ainda suscita resistência e dúvida por parte dos praticantes. Objetivo: conhecer o perfil sociodemográfico e clínico de pessoas que realizam o cateterismo intermitente limpo, assim como as necessidades dos pacientes e cuidadores quanto à prática. Método: Estudo observacional, transversal e analítico realizado em Centro de Reabilitação Pública de Teresina, após aprovação do Comitê de Ética em Pesquisa da Universidade Federal do Piauí. A amostra foi constituída por 41 pacientes e 16 cuidadores, de ambos os sexos, com idade igual ou superior a 18 anos. Utilizou-se um formulário para caracterização, avaliação clínica e identificação das necessidades dos pacientes e cuidadores. Os dados foram processados pelos Softwares livres "R" versão 3.5.1 e Program for Statistical Analysis of Sampled - PSPP versão 1.1.0. As variáveis quantitativas foram avaliadas por meio de estatística descritiva e as qualitativas usando proporção, com intervalos de confiança de 95\%. Resultados: Prevaleceram pacientes do sexo masculino 50(87,72\%), entre 30 a 45 anos 23(40,35), casados ou em união estável $27(47,37 \%)$, cursando o ensino médio ou graduados $35(61,40 \%)$, sem ocupação laboral $43(75,74 \%)$, com renda familiar de até 01 salário mínimo $20(35,09 \%)$ e com até 3 ou mais pessoas sustentadas com essa renda $31(54,39 \%)$. Os cuidadores eram em sua maioria do sexo feminino $14(24,56 \%)$, com vínculo materno $7(12,28 \%)$, idade igual ou superior a 30 anos, do lar $13(22,81 \%)$ e ensino médio ou superior $10(17,54 \%)$. Quanto à etiologia da disfunção vesicoesfincteriana, predominou o trauma raquimedular $49(85,96 \%)$, sem doenças associadas $51(89,47 \%)$, não deambulantes 51(89,47\%), necessitando de auxílio para locomoção 56(98,25\%) em cadeira de rodas 52(91,23\%), orientados por enfermeiros para a prática do cateterismo $49(85,96 \%)$. Praticavam o autocateterismo $41(71,92 \%)$, na cadeira de rodas $33(57,89 \%)$, fora do domicílio $40(70,18 \%)$, pela uretra $56(98,25 \%)$ e não apresentam complicação no local de inserção 53(92,98\%) e nem da pele periestoma 56(92,98\%). O tempo do cateterismo era entre 1 a 5 anos 20(35,09\%); $21(36,84 \%)$ não apresentam perda de urina nos intervalos do cateterismo, e a mesma quantidade tem perdas, precisando usar fraldas ou coletor urinário constantemente. Todos os participantes utilizam cateter de nelaton simples fabricados sem lubrificação, com calibre de número 12 49(85,96\%); 20(35,09\%) realizavam o cateterismo de 4 a 5 vezes ao dia e não reutilizam o cateter $50(87,72 \%)$. A maioria $47(82,46 \%)$ já apresentou complicação do trato urinário, sendo mais frequente os processos infecciosos $45(78,95 \%)$, porém 23(40,35\%) não apresentaram nenhuma infecção urinária nos últimos 12 meses anterior a coleta de dados - janeiro a março $2018 ; 35(61,40 \%)$ dos pacientes negaram prejuízos na prática sexual em decorrência da realização do cateterismo e 17(29,82\%) não têm vida sexual ativa após a vivência na condição de lesados medulares. As necessidades mais citadas pelos pacientes foram as que se associaram à 'dispensação dos cateteres', assim como a necessidade de 'conhecer outro tipo de cateter'. Conclusão: a identificação do perfil e das necessidades dos participantes, subsidiarão a assistência de enfermagem na realização do cateterismo intermitente limpo favorecendo a adoção de estratégias que atendam às demandas semelhantes às evidenciadas neste estudo
\end{abstract}

Keywords: Paciente, Cuidadores, Cateterismo Intermitente Limpo, Estomaterapia

\section{Referências Bibliográficas}

Assis, GM et al. Uso de cateteres vesicais para cateterismo intermitente limpo: satisfação da pessoa com lesão medular. Cogitare enferm., Curitba, 20(4): 01-08, Out-Dez., 2015. Disponível em: http://revistas.ufpr.br/cogitare/article/view/41585. Acesso em: 07 jun 2019. Benício, CDAV et al. Fatores associados ao conhecimento de pacientes e cuidadores acerca do cateterismo vesical intermitente limpo: revisão integrativa. Rev Esc Enferm USP; 52: e03362, 2018 Sep 13.. Disponível em: http://dx.doi.org/10.1590/s1980-220x2017033703362. Acesso em: 10 jun. 2019. Ercole, FF et al. Revisão integrativa: evidências na prática do cateterismo urinário intermitente/demora. Rev. Latino-Am. Enfermagem, Ribeirão Preto, 21(10), Jan-Fev. 2013. Disponível em: http://www.scielo.br/pdf/rlae/v21n1/pt_v21n1a23.pdf. Acesso em: 10 jun. 2019. Fumincelli, L et al. Qualidade de vida de pacientes usuários do cateterismo urinário intermitente. Rev. Latino-Am. Enfermagem, Ribeirão Preto, 25(1):01-08, Abr. 2017. Disponível em: http://www.scielo.br/scielo.php?script=sci_arttext\&pid=S0104$11692017000100356 \&$ Ing=pt\&nrm=iso. Acesso em: 17 junho 2019. 


\title{
COMPREENSÃO A CERCA DA INCONTINÊNCIA FECAL SEGUNDO MÃES DE CRIANÇAS INCONTINENTES
}

\author{
Marionescu Purcaru ${ }^{1}$, João Henrique Freitas Colares ${ }^{1}$, Maria Helena Carneiro de Souza ${ }^{1}$, Rejane \\ Author(s): Maria Eneas Lourenço ${ }^{1}$, Deidiane Rodrigues de Sousa Cruz ${ }^{1}$, Caroline Pinto Camelo de Morais ${ }^{1}$, \\ Tiago da Silva Nascimento ${ }^{1}$ \\ Institution(s) ${ }^{1}$ HIAS-CE - HOSPITAL INFANTIL ALBERT SABIN (Rua Tertuliano Sales, 544 Fortaleza- \\ Ceará)
}

\begin{abstract}
A Incontinência Fecal (IF) é uma doença crônica que causa grande impacto na qualidade de vida das crianças acometidas, com graves repercussões na vida social e psicológica (1). Engloba tanto a encoprese como a sujidade (soilling), sendo a principal diferença a quantidade de fezes a ser perdida.(2). E um problema gastroenterológico com profundos impactos pessoais e familiares. Crianças incontinentes têm mais baixa qualidade de vida, desempenho ruim na escola e apresentam ambiente familiar comprometido e os pais dessas crianças apresentam maior índice de impulsividade e timidez e uma dinâmica familiar precária (3) Objetivou-se analisar os sentidos atribuídos à IF na Infância a partir da narrativa de mães de crianças com IF. Estudo com abordagem qualitativa, sendo utilizada a técnica da narrativa. A analise se baseou no método de interpretação de sentidos com base em princípios hermenêutico-dialéticos, Desenvolvido com aprovação do comitê de ética com parecer de n. 515.272, em serviço especializado em atendimento a crianças /adolescentes com IF, de um hospital pediátrico referência em saúde da criança e adolescente no nordeste brasileiro, com equipe de estomaterapia. Foram entrevistadas 29 mães acompanhadas no serviço. Excluíu-se as que não se encontravam aptas a falar de sua experiência. Os significados atribuídos à IF foram: dor, renúncia, perda de independência e estigma. O desconhecimento da patologia é motivo de conflitos que despertam sentimentos de culpa em algumas mães que deixaram de procurar ajuda para tratar o problema por associam a mesma à preguiça, ou a um motivo para a criança chamar atenção. Conclui-se ser fundamental maior divulgação sobre a IF, e a necessidade de se rever as ações de saúde voltadas para inclusão da mãe cuidadora de criança com IF, possibilitando um atendimento mais humanizado, onde as intervenções em saúde possam atingir uma dimensão social. Sugere-se a expansão de serviços onde o atendimento a crianças com IF seja realizado de forma integral, por equipe multiprofissional, abrangendo os familiares dessas crianças e a organização de grupos de apoio.
\end{abstract}

Keywords: CRIANÇA, ESTIGMA, ESTOMATERAPIA, INCONTINÊNCIA FECAL, QUALIDADE DE VIDA

\section{Referências Bibliográficas}

Yusuf SA, Jorge JM, Habr-Gama A, Kiss DR, Gama Rodrigues J (2004) Evaluation of quality of life in anal incontinence: vali- dation of the questionnaire FIQL (Fecal Incontinence Quality of Life). Arq Gastroenterol 41:202-208. doi:10.1590/S0004- 28032004000300013 Bischoff A, Levitt MA, Bauer C, Jackson L, Holder M, Peñ a A (2009) Treatment of fecal incontinence with a comprehensive bowel management program. J Pediatr Surg 44:1278-1283.

doi:10.1016/j.jpedsurg.2009.02.047 Bongers ME, van Dijk M, Benninga MA, Grootenhuis MA (2009) Health related quality of life in children with constipation- associated fecal incontinence. J Pediatr 154:749-753. doi:10. 1016/j.jpeds.2008.11.029 Har AF, Rescorla FJ, Croffie JM (2013) Quality of life in pedi- atric patients with unremitting constipation pre and post Malone Antegrade Continence Enema (MACE) procedure. J Pediatr Surg 48:1733-1737. doi:10.1016/j.jpedsurg.2013.01.045 


\title{
A organização de um programa de atendimento especializado para pacientes com complicações relacionadas ao Cateterismo Vesical Intermitente em um município do Paraná
}

\author{
Author(s): Andressa Nogueira Da Silva ${ }^{1}$, Marthyna Pereira de Mello ${ }^{1}$, Priscila Estefani Lagos ${ }^{1}$ \\ Institution(s) ${ }^{1}$ NROOP - Nucleo Regional dos Ostomizados do Oeste do Parana (Rua carijos, No 294, Bairro \\ Santo Onofre-Cascavel - PR)
}

\begin{abstract}
O funcionamento adequado do trato urinário inferior depende da ação sinérgica da bexiga e do mecanismo esfincteriano ${ }^{1},{ }^{2}$. Para os pacientes com disfunção neurogênica do trato urinário inferior, resultante do esvaziamento incompleto da bexiga, 0 Cateterismo Vesical Intermitente (CVI) a longo prazo, é seguro e bem aceito 2,10,4. Grande parte dos pacientes executa essa técnica de forma independente, porém, muitos têm dificuldade na execução adequada no que se refere à frequência recomendada, favorecendo complicações como a infecção do trato urinário2,1. No entanto, avanços mais recentes na tecnologia de cateteres podem oferecer potenciais benefícios6.

Esta pesquisa trata-se de um relato de experiência, vivenciado no "Núcleo Regional dos Ostomizados do Oeste do ParanáRenascer", no período de dezembro de 2018 a abril de 2019.

Atualmente o Núcleo atua com o atendimento e distribuição de material para 300 estomizados e 80 usuários com DNTUI, são realizados encontros mensais para troca de experiências e palestras com profissionais de saúde, além do atendimento diário de uma enfermeira estomaterapeuta.

Diante do trabalho desempenhado na assistência aos usuários, foi realizado um encontro com as pessoas cadastradas que apresentam, DNTUI, com o intuito de levantar as necessidades desse público diante do desafio da realização do CVI. Na sequência as informações foram organizadas em um projeto, que foi submetido e aprovado pela Secretária Municipal de Saúde, os três objetivos principais foram: tornar o núcleo uma referência de atendimento a pessoas com complicações no CVI, contemplando um atendimento especializado através da consulta de enfermagem, e a inclusão do cateter avançado como rotina diária para realização do CVI em usuários que apresentam complicações.

Com o projeto aprovado pela Secretária Municipal de Saúde, se deu início a um chamamento para a consulta de Enfermagem. Os dados pertinentes a saúde do trato urinário foram coletados e também foi realizada a revisão da técnica do CVI. Todos os usuários tiveram a oportunidade de realizar a técnica com o cateter convencional (pvc) e cateter avançado, com o intuito de conhecer as diferenças de tecnologias hoje disponíveis para realização do CVI.

Os usuários que se enquadravam nas indicações de utilização de cateter avançado, descrito em fluxo pela Sociedade Brasileira de Urologia (SBU), tiveram acesso ao insumo em sua rotina diária através da distribuição mensal pelo núcleo. Já os demais pacientes que não se enquadravam nos critérios, permaneceram em uso do cateter convencional de pvc + gel lubrificante, distribuídos na unidade básica de saúde do município.

Ações planejadas coletivamente com a participação do usuário, enfermeiro estomaterapeuta e órgão público, neste caso uma secretaria municipal de saúde, evidenciam a sustentabilidade das ações e possibilitam o impacto positivo em todas as esferas, uma vez que se reduzem complicações, sobrecarga dos serviços para reavaliações, prescrições de medicações que aumentam os custos municipais dedicados a esse usuário e melhoram a qualidade da assistência.
\end{abstract}

Keywords: Estomaterapia, Bexiga Urinária Neurogênica, Incontinência Urinária, Qualidade de Vida

\section{Referências Bibliográficas}

1. A Krassioukov, JJ Cragg, C West, C Voss5 and D Krassioukov-Enns. The good, the bad and the ugly of catheterization practices among elite athletes with spinal cord injury: a global perspective. Spinal Cord (2015) 53, 78-82. 2. Benício Claudia Daniella Avelino Vasconcelos, Rocha Daniel de Macêdo, Dourado Giovanna Oliveira Libório, Bezerra Sandra Marina Gonçalves, Andrade Elaine Maria Leite Rangel, Nogueira Lídya Tolstenko. Fatores associados ao conhecimento de pacientes e cuidadores acerca do cateterismo vesical intermitente limpo: revisão integrativa. Rev. esc. enferm. USP [Internet]. 2018 [citado 2019 Ago 12] ; 52: e03362. Disponível em:

http://www.scielo.br/scielo.php?script=sci_arttext\&pid=S008062342018000100806\&lng=pt. Epub 13-Set-2018. http://dx.doi.org/10.1590/s1980-220x2017033703362. 3. Cavalcante BLL, Lima UPS. Relato de experiência de uma estudante de Enfermagem em um consultório especializado em tratamento de feridas. J. Nurs Heath. 2012; 1(2): 94-103. 4. D.J.M.K. De Ridder, K. Everaert, L. García Fernández, J.V. Forner Valero, A. Borau Durán, M.L. Jauregui Abrisqueta, M.G. Ventura, A. Rodriguez Sotillo. Cateterismo intermitente com cateteres com revestimento hidrofílico (SpeediCath) reduz o risco de infecções clínicas do trato urinário em pacientes com lesões na medula espinhal: um estudo comparativo paralelo randômico e prospectivo. Urologia Européia (2005). 5. Decreto 3.298, de 20 de dezembro de 1999. Disponível em: http://www.planalto.gov.br/ccivil_03/decreto/d3298.htm. Acesso em 5 de agosto de 2019. 


\title{
RELATO DE EXPERIÊNCIA: INCLUSÃO DE SERVIÇO DE ATENDIMENTO À CRIANÇA COM INCONTINÊNCIA FECAL.
}

\author{
Marionescu Purcaru ${ }^{1}$, João Henrique Freitas Colares ${ }^{1}$, Maria Helena Carneiro de Souza ${ }^{1}$, Rejane \\ Author(s): Maria Eneas Lourenço ${ }^{1}$, Deidiane Rodrigues de Sousa Cruz ${ }^{1}$, Caroline Pinto Camelo de Morais ${ }^{1}$, \\ Tiago da Silva Nascimento ${ }^{1}$ \\ Institution(s) ${ }^{1}$ HIAS-CE - HOSPITAL INFANTIL ALBERT SABIN (Rua Tertuliano Sales, 544 Fortaleza- \\ Ceará)
}

\begin{abstract}
Introducao A IF causa graves problemas na vida social e psicológica, impedindo o desfralde no período previsto, ocasionando estigma e bulling $(1,2,3)$. Em um hospital pediátrico publico do Ceará, a equipe de estomaterapia em conjunto com a equipe de cirurgia, identificaram haver uma lacuna no tratamento de crianças que apos se submeterem a cirurgia para correção de algumas anomalias, passavam a apresentar incontinência fecal, que lhes causava grande sofrimento.. Buscou-se então qual o mais adequado tratamento de IF para crianças. Objetivos : Identificar os passos a serem seguidos para inclusão de tratamento da IF e seus agravos em pacientes pediátricos. Material e metodo: Trata-se de um estudo do tipo Relato de Experiência, descritivo, retrospectivo, no período de Agosto de 2011 a Novembro de 2011, a pesquisa foi realizada pela equipe de Estomaterapia e cirurgia, com o intuito de desenvolver um fluxo de análise e inclusão de novas tecnologias no cuidado em saúde. Resultados: Iniciou-se a busca por tratamentos eficazes de IF em pediatria. Verificou-se ser o Bowel Management Program(4) o tratamento mais eficaz que consiste em esvaziar o cólon com a escolha do clister ideal, mantendo a criança limpa por 24horas. Um cirurgião do hospital acompanhou por algum tempo o idealizador do programa, Prof. Dr. Alberto Peña em Ohio, U.S.A. Uma estomaterapeuta do hospital realizou treinamento com a enfermeira da equipe de Ohio, aqui no Brasil. A etapa seguinte representou o mapeamento dos processos que envolvem o tratamento e o caminho para inclusão de novas tecnologias, tendo como meta reduzir os danos decorrentes da IF. e implantaram juntos, o ambulatório de atendimento de crianças e adolescentes com IF. Conclusão: $O$ trabalho em equipe multiprofissional, baseada em evidencias, em que os seguimentos foram mapeados, planejados e executados, visando a melhoria da assistência, proporcionou a inclusão de uma tecnologia segura que proporciona melhoria na qualidade de vida de crianças e adolescentes.
\end{abstract}

\section{Keywords: CRIANÇA, ESTOMATERAPIA, IMPACTO PSICOSSOCIAL , INCONTINÊNCIA FECAL}

\section{Referências Bibliográficas}

Neves, AJ,.Calais, SL( 2012) Efeitos do manejo comportamental de incontinência fecal em adolescente. Manejo comportamental de incontinência fecal. Psicol Cienc Prof, Brasília, v.32, n.3, Nobrega, V.M. et al. (2012). Imposições e conflitos no cotidiano das famílias de crianças com doença crônica. Esc Anna Nery, Rio de Janeiro, v.16, n.4,. Grano C, Aminoff D, Lucidi F, Violani C (2012) Long-term disease-specific quality of life in children and adolescent patients with ARM. J Pediatr Surg 47:1317-1322. doi:10.1016/j.jpedsurg. 2012.01.068 Bischoff A, Levitt MA, Bauer C, Jackson L, Holder M, Peña A (2009) Treatment of fecal incontinence with a comprehensive bowel management program. J Pediatr Surg 44:12781283. doi:10.1016/j.jpedsurg.2009.02.047 Rajindrajith, S.;Devanarayana, N.M.; Benningna, M. (2013). Faecal incontinence in children: epidemiology, pathophysiology, clinical evaluation and management. Aliment Pharmacol Ther, Amsterdam, v.37, n.1, p.37-48, 


\title{
AVALIAÇÃO DA QUALIDADE DE VIDA DE GESTANTES INTERNADAS COM INFECÇÕES E/OU INCONTINÊNCIA URINÁRIA EM UMA MATERNIDADE PÚBLICA DE TERESINA
}

\author{
Author(s): JULIANA OLIVEIRA DE SOUSAl ${ }^{1}$, ELAINE CARININY LOPES DA SILVA ${ }^{1}$, THALITA \\ MORAES LIMA ${ }^{1}$, CLICIANE FURTADO RODRIGUES ${ }^{1}$ \\ Institution(s) ${ }^{1}$ FACIME - FACULDADE DE CIÊNCIAS MÉDICAS - FACIME (RUA OLAVO BILAC N2335 \\ - CENTRO 64015-017 TERESINA)
}

\begin{abstract}
INTRODUÇÃO: A incontinência urinária é considerada como a perda involuntária de urina que afeta muitas mulheres, em diversas idades, dentre elas as gestantes, trazendo diversas consequências a saúde, bem como as infecções do trato urinário, ambas podem induzir a diminuição na qualidade de vida (QV). O objetivo principal foi o de analisar a QV e as consequências às gestantes internadas com infecções e/ou incontinência do trato urinário e investigar as características clínicas e sociodemográficas das mesmas. MÉTODOS: Trata-se de uma pesquisa de campo, com caráter descritivo, e abordagem quantitativa, realizada com 11 gestantes internadas em uma maternidade de referência em Teresina. Foi elaborado um formulário sobre o perfil clínico e sociodemográfico e utilizado o questionário específico sobre QV, o ShortForm (SF-36), e assim, interpretadas a incidência e prevalência da ocorrência desses problemas durante o período de internação destas gestantes. Os dados obtidos foram apresentados e analisados segundo índices absolutos e percentuais. RESULTADOS: Dentre as 11 gestantes estudadas, o perfil sociodemográfico evidenciou que $54,54 \%$ delas apresentavam faixa etária de 21 a 30 anos, $36,36 \%$ possuem peso entre 51 a $60 \mathrm{~kg}, 72,72 \%$ delas são solteiras e $72,72 \%$ se consideraram pardas. O perfil clínico mostrou que a patologia de maior frequência foi a ITU com 90,9\%, 54,54\% tiveram apenas uma gestação, $81,81 \%$ tiveram partos cirúgicos e $72,72 \%$ delas não tiveram uma gestação planejada, $90,09 \%$ delas estavam apresentando diurese espontânea, 81,81\% não apresentavam nenhuma comorbidade, $72,72 \%$ eram sedentárias e $72,72 \%$ não faziam uso de medicamentos contínuos. CONCLUSÃO: Os resultados obtidos estão em concordância com a literatura. Avaliar a qualidade de vida dessas gestantes internadas contribui para melhorar a qualidade da assistência de enfermagem prestada a elas.

PALAVRAS-CHAVE: Qualidade de vida, Doenças urológicas, Gestantes.
\end{abstract}

Keywords: DOENÇAS UROLÓGICAS, GESTANTES, QUALIDADE DE VIDA

\section{Referências Bibliográficas}

RIBEIRO, J. P.; RAIMUNDO, A. Satisfação sexual e percepção de saúde em mulheres com incontinência urinária. Anál. Psicol., v. 3, n. 23, p. 305-314, 2005. RISS, P.; KARGL, J. Quality of life and urinary incontinence in women. Maturitas, v. 68, n. 2, p. 137-142, 2011. SANTOS, A. R.; OKAZAKI. E. L. J. Intervenções de enfermagem para a incontinência urinária durante o ciclo gravídico-puerperal. Rev. Enferm. UNISA, n. 6, p. 5-8, 2005. 


\title{
ATUAÇÃO DO ENFERMEIRO NO CUIDADO INTERDISCIPLINAR EM UROPEDIATRIA: O USO DA UROTERAPIA
}

\author{
Author(s): Fernanda Henriques da Silva ${ }^{1}$, Maria José da Silva ${ }^{1}$, Maria de Lourdes Alves ${ }^{1}$, Eliane Maria \\ Garcez Oliveira da Fonseca ${ }^{1}$, Caren Moreira dos Santos ${ }^{1}$ \\ Institution(s) ${ }^{1}$ UERJ - UNIVERSIDADE DO ESTADO DO RIO DE JANEIRO (Av. Mal. Rondon, 381 - São \\ Francisco Xavier, Rio de Janeiro - RJ)
}

\begin{abstract}
Introdução: Uroterapia é um termo utilizado para designar um conjunto de medidas comportamentais que objetivam contribuir com a continência urinária de crianças e adolescentes com disfunções no trato urinário inferior. A associação com constipação intestinal e escape fecal, por disfunção do assoalho pélvico, é frequente e caracteriza Síndrome de Disfunção das Eliminações. A Uroterapia visa além do tratamento clínico redução das repercussões psicológicas e sociais da incontinência. Este estudo tem como objetivo descrever ações do enfermeiro como membro da equipe multiprofissional na assistência ambulatorial a crianças e adolescentes com Disfunção do Trato Urinário Inferior dentre outras complicações. Material e Método: Trata-se de um relato de Experiência sobre a atuação multiprofissional e interdisciplinar na assistência a crianças e adolescentes com disfunção do trato urinário inferior no uso da uroterapia. Utiliza-se ações educativas voltadas à criança, ao adolescente e à família, instrumentos para investigações de sintomas como Diário de Eliminações (Vesical e intestinal), orientação para reeducação alimentar, Mapa de Disfunção Miccional documentos estes elaborados pela equipe somada ao uso de Escalas e instrumentos validados como Escala de Bristol e Dysfunctional Voiding Symptom Score (DVSS). Alguns documentos são elaborados em alguns casos em que a escola precisa ser comunicada sobre o tratamento. Orientação sobre posicionamento correto no vaso sanitário, uso de apoio de pés e redutor de assento sanitário também fazem parte da ação educativa. Resultados: Espera-se com a utilização desta metodologia assistencial criar um protocolo institucional baseado em quatro pilares: assistência qualificada, educação em saúde, ensino, pesquisa, extensão. Desde a inauguração do serviço os benefícios do uso da uroterapia para o usuário e sua família são visíveis. Com isto, o reconhecimento da importância do profissional enfermeiro nesta equipe vem sendo construído de forma substancial, favorecendo a ampliação da prática de enfermagem na assistência a usuários com este perfil. Conclusão: Com este trabalho foi possível descrever ações do enfermeiro como membro da equipe multiprofissional na assistência ambulatorial a crianças e adolescentes com Disfunção do Trato Urinário Inferior dentre outras complicações. A metodologia tem se mostrado eficaz no tratamento destes usuários e tem despertado a equipe para a importância do trabalho interdisciplinar para a qualidade do cuidado no âmbito da atenção secundária.
\end{abstract}

Keywords: estomaterapia, atenção secundaria, pediatria, equipe multiprofissional

\section{Referências Bibliográficas}

Fonseca EM, Monteiro LM. Diagnóstico clínico de disfunção miccional em crianças e adolescentes enuréticos. J Pediatr. 2004; 80(2):147-53. Campos RM et al . Estudo comparativo, prospectivo e randomizado entre uroterapia e tratamento farmacológico em crianças com incontinência urinária. Einstein (São Paulo), São Paulo , v. 11, n. 2, p. 203-208, 2013. Souza BML, Salviano CF, Martins G. Advanced Practice Nursing in Pediatric Urology: experience report in the Federal District: relato de experiência no Distrito Federal . Rev Bras Enferm [Internet]. 2018;71(1):223-7. 


\title{
PREVALÊNCIA E IMPACTO DOS SINTOMAS DO TRATO URINÁRIO INFERIOR EM MULHERES PRIVADAS DE LIBERDADE
}

\author{
Author(s): Dayana Maia Saboia ${ }^{1}$, Purdenciana Ribeiro de Menezes ${ }^{1}$, Camila Teixeira Moreira Vasconcelos ${ }^{1}$, \\ José Ananias Vasconcelos Neto ${ }^{2}$ \\ Institution(s) ${ }^{1}$ UFC - Departamento de enfermagem da Universidade Federal do Ceará (Alexandre Baraúna, \\ 1115 - Rodolfo Teófilo - CEP 60430-160), ${ }^{2}$ HGF - Hospital Geral de Fortaleza ( R. Ávila \\ Goularte, 900 - Papicu, Fortaleza - CE, 60150-160)
}

\begin{abstract}
Devido à falta de privacidade dentro e fora da cela e ao elevado nível de vigilância, o funcionamento do sistema prisional, por si, pode contribuir para o surgimento ou exacerbação de sintomas urinários. Nesse contexto, o estudo dos Sintomas do Trato Urinário Inferior (STUI) tem ganhado destaque, não só por conta da alta prevalência, como também por ter um grande impacto na Qualidade de Vida (QV). O Objetivo do estudo foi estimar a prevalência dos STUI e seu impacto na QV de mulheres privadas de liberdade. Estudo transversal, realizado com a população carcerária feminina de três unidades penais do estado do Ceará, no período de junho a setembro de 2018. A amostra foi composta por 307 mulheres. A coleta de dados se deu por meio de questionário estruturado para investigação detalhada das queixas urinárias e da aplicação do "King's Health Questionnaire" (KHQ) nas mulheres com queixa de Incontinência Urinária (IU). Os dados foram analisados por meio do Programa Statistical Package for the Social Sciences versão 22.0. A pesquisa foi aprovada pelo Comitê de Ética em Pesquisa da Universidade Federal do Ceará sob número 2.541.779. A maioria das participantes era jovem com idade média de 32,9 anos ( $\mathrm{dp} \pm 11,8)$, sem companheiro, que se autodeclararam não brancas, procedentes do estado do Ceará, presas entre 2015 e 2017, condenadas a penas de, em média, 6 anos, variando de 21 a 196 meses; majoritariamente presas por crimes relacionados ao tráfico de drogas. Dentre os sintomas de armazenamento, os três mais citados foram: noctúria $(42,7 \%)$, incontinência $(21,5 \%)$ e urgência urinária (16,3\%). Dos sintomas de esvaziamento, a disúria e a infecção do trato urinário inferior recorrente, foram os mais apontados. O único sintoma pós-miccional identificado foi a sensação de esvaziamento vesical incompleto referido por $49(21,4 \%)$ mulheres. Os domínios da QV mais afetados, avaliados pelo $\mathrm{KHQ}$, foram percepção geral da saúde ( $M d=50,00 ; P 25=25,0-p 75=75,0)$ e impacto da IU $(\mathrm{Md}=33,0 ; \mathrm{P} 25=00,0-\mathrm{P} 75=33,3)$. Conclusão: Os STUI são prevalentes nas mulheres em situação de cárcere, havendo maior destaque para os sintomas de armazenamento.
\end{abstract}

Keywords: Sintomas do Trato Urinário Inferior, Presídio, Saúde da Mulher, Estomaterapia

\section{Referências Bibliográficas}

Abrams P; Cardozo L; Khoury S; Wein A. Incontinence. Tokyo, Japan. 2016. Abrams P, Cardozo L, Khoury S, Wein A. Incontinence. Bristol: ICUD; 2013. 


\title{
INCONTINÊNCIA URINÁRIA EM PROFISSIONAIS DE ENFERMAGEM: PREVALÊNCIA E FATORES DE RISCO OCUPACIONAIS
}

\author{
Author(s): Dayana Maia Saboia ${ }^{1}$, Lia Gomes Lopes ${ }^{1}$, Vielceketlin Franco Viana ${ }^{1}$, Livia Cintia Maia Ferreira \\ ${ }^{1}$, Camila Teixeira Moreira Vasconcelos ${ }^{1}$, José Ananias Vasconcelos Neto ${ }^{2}$ \\ Institution(s) ${ }^{1}$ UFC - Departamento de Enfermagem da Universidade Federal do Ceará (R. Alexandre Baraúna, \\ 1115 - Rodolfo Teófilo, Fortaleza - CE, 60430-160), ${ }^{2}$ HGF - Hospital Geral de Fortaleza (R. Ávila \\ Goularte, 900 - Papicu, Fortaleza - CE, 60150-160)
}

\begin{abstract}
Introdução: As queixas urinárias são objetos comuns de estudo devido à sua alta prevalência e impacto na qualidade de vida, em especial, a Incontinência Urinária (IU). Em profissionais de enfermagem, a prevalência para IU vem sendo apontada como bastante alta e, no Brasil, esse índice chegou a 27,5\% em um estudo em São Paulo. No entanto, a escassez de dados em território brasileiro indica que a prevalência seja subestimada nessa população. Objetivo: Investigar a prevalência de IU e os fatores de risco ocupacionais entre enfermeiras e técnicas de enfermagem. Método: Trata-se de um estudo transversal com 264 participantes, realizado em um hospital terciário de Fortaleza, Ceará durante o período de abril a agosto de 2018. A coleta de dados foi feita por meio da aplicação de um formulário eletrônico com questões sobre a presença de queixas urinárias, incluindo a IU, e baseadas nas recomendações da International Continence Society. A pesquisa foi aprovada sob parecer № 2.396 .335 da Universidade Federal do Ceará (UFC). Resultados: Dentre as 264 participantes, $31,8 \%(n=84 / 264)$ eram enfermeiras e $68,2 \%(n=180 / 264)$ eram técnicas de enfermagem. No que diz respeito a prevalência e classificação da IU, $14,8 \%(n=39)$ apresentaram incontinência urinária de esforço, $11,0 \%(n=29)$ incontinência urinária de urgência, $10,6 \%(n=28)$ incontinência urinária mista e 4,4\% $(n=11 / 253)$ incontinência ao coito. Não houve diferença entre os grupos quanto a prevalência $(p>0,05)$. Trabalhar em dois ou mais locais teve associação com a presença de queixas de incontinência urinária de urgência $(p=0,005$; $O R=3,06$; IC 1,36 - 6,87) e incontinência urinária mista $(p=0,003 ; O R=3,27 ;$ IC $1,44-7,40)$. Conclusão: Observou-se prevalência de IU variando de $4,4 \%$ a $14,8 \%$, não havendo diferença entre os grupos analisados (enfermeiras e técnicas). Ainda assim, houve associação entre o número de locais de trabalho e os subtipos de IU investigados, o que pode indicar que a sobrecarga de trabalho exerceu influência no aparecimento de queixas urinárias entre a população do estudo.
\end{abstract}

Keywords: Incontinência Urinária, Saúde do Trabalhador, Estomaterapia

\section{Referências Bibliográficas}

1) Abrams P; Cardozo L; Khoury S; Wein A. Incontinence. Tokyo, Japan. 2016. 2) Haylen BT, De Ridder D, Freeman RM, Swift SE, Berghmans B, Lee J, et al. An International Urogynecological Association (IUGA)/International Continence Society (ICS) Joint Report on the Terminology for Female Pelvic Floor Dysfunction. Neurourology and Urodynamics [Internet]. 2010 Nov [cited 2019 Aug 06] ; 29:4-20. Available from: https://onlinelibrary.wiley.com/doi/abs/10.1002/nau.20798. 3) Higa R; Lopes MHBM. The impact of urinary incontinence on female nursing personnel. Rev. bras. enferm. [Internet]. 2007 Apr [cited 2019 Aug 06] ; 60 ( 2 ): 213-216. Available from: http://www.scielo.br/scielo.php?script=sci_arttext\&pid=S0034$71672007000200016 \&$ Ing=en. http://dx.doi.org/10.1590/S0034-71672007000200016. 


\title{
CATETER RETAL DE SILICONE COMO ADJUVANTE NO TRATAMENTO DE PACIENTE COM DERMATITE ASSOCIADA A INCONTINÊNCIA - RELATO DE CASO
}

\author{
Author(s): \\ CAROL VIVIANA SERNA GONZALEZ ${ }^{1}$, Suzana Aparecida da Costa Ferreira ${ }^{2}$, Vera Lucia \\ Conceição de Gouveia Santos ${ }^{3}$
}

Institution(s) ${ }^{1}$ EEUSP - Escola de Enfermagem da Universidade de São Paulo (Av. Dr. Enéas Carvalho de Aguiar, 419 - Cerqueira César, São Paulo - SP, 05403-0), ${ }^{2}$ EEUSP - Escola de Enfermagem da Universidade de São Paulo (Av. Dr. Enéas Carvalho de Aguiar, 419 - Cerqueira César, São Paulo SP, 05403-0), ${ }^{3}$ EEUSP - Escola de Enfermagem da Universidade de São Paulo (Av. Dr. Enéas Carvalho de Aguiar, 419 - Cerqueira César, São Paulo - SP, 05403-0)

\begin{abstract}
Introdução: A dermatite associada à incontinência (DAI) se manifesta clinicamente com lesões de espessura parcial ou total, na região perineal, genital e proximidades, em pacientes com incontinência fecal e / ou urinária1,2. A umidade excessiva, pH e moléculas de efluentes corrosivos intestinal e urinário, juntamente com fricção e possível colonização local, resultam em inflamação da pele seguida de maceração e erosão epidérmica2,.3. Sua incidência é de $20,4 \%$ com tempo médio de surgimento de 9 dias, em unidades de terapia intensiva4. Isolar a pele afetada dos fatores causais, principalmente do efluente, são de vital importância. Em estudo de coorte5, cujo objetivo foi avaliar os resultados de um programa de cuidados da pele para pacientes com incontinência fecal, concluiu-se que o uso de cateter de silicone retal em pacientes com evacuações líquidas (tipo 7 na escala de Bristol), diminuiu a gravidade da dermatite associada umidade.

Objetivo: Descrever o uso do cateter de silicone retal como adjuvante no tratamento de casos de dermatite associada incontinência fecal, secundária a infecção intestinal por Clostridium Difficile.

Método: Estudo descritivo, tipo de relato de caso, realizado em hospital privado. O registro fotográfico e clínico semanal do caso foi aprovado pelo comitê de ética em pesquisa.

Resultados: Paciente internado com diagnóstico de gastroenterite por Clostridium Difficile, após diarréia em casa por 15 dias. Durante a hospitalização apresentou evacuações líquidas ininterruptas por 24 horas adquirindo uma dermatite importante na região interglútea, anal, perineal e nas pernas, com eritema brilhante, fissuras, vesículas, descamação, ulcerações e crostas em todas as regiões mencionadas. Foi proposta como tratamento para a incontinência fecal, a passagem de cateter de silicone retal com balão de retenção de baixa pressão e longa permanência, e também o cateter vesical de demora, a fim de evitar o contato dos efluentes com as lesões da pele. Para o tratamento de dermatite foi indicada hidrocolóide pó colocado depois do banho diário. Após 20 dias houve uma melhora significativa em todas as regiões afetadas,mesmo com lesões abertas na região anal. No 29을 dia o cateter retal foi retirado, de acordo com a permanência máxima orientada pelo fabricante; O cateter vesical de demora foi mantido. Paralelamente, o paciente teve melhora do quadro clínico devido ao tratamento médico. Durante a inserção, permanência e retirada do cateter retal não houve alteração ou complicação, indicando segurança na sua utilização. O período total de tratamento foi de 36 dias, onde ocorreu a cicatrização das áreas de dermatite, sendo retirado o cateter vesical de demora.

Conclusão: A recuperação das lesões de DAl foi observada em 36 dias, após o isolamento da pele perineal e perigenital, do efluente intestinal e urinária por meio de cateter retal de silicone e do cateter vesical de demora, associado ao tratamento tópico com hidrocolóide pó.
\end{abstract}

Keywords: cuidados de enfermagem, dermatite associada à incontinência, estomaterapia, incontinência fecal

\section{Referências Bibliográficas}

1. Bliss DZ, Savik K, Thorson MAL, Ehman SJ, Lebak K, Beilman G. Incontinence associated dermatitis in critically adults: time to development, severity, and risk factors. J Wound Ostomy Continence Nurs. 2011;38(4):433-45. 2. Gray M, Black JM, Baherastani MM , et al. Moisture associated skin damage: an overview . J Wound Ostomy Continence Nurs . 2011 ; 38 ( 3 ): 233-241. 3. Domansky RC, Chimentão DMN. Prevenção de Lesões de pele associadas a umidade. In: Domansky RC, Borges EL (orgs). Manual para prevenção de lesões de pele: recomendações baseadas em evidências. Rio de Janeiro: Rubio; 2014. p. 93-150. 4. Chianca TCM, Gonçales PC, Salgado PO, Machado BO, Amorim GL, Alcoforado CLGC. Dermatite associada à incontinência: estudo de coorte em pacientes críticos. Rev GaúchaEnferm.2016;37(esp):e68075.doi:http://dx.doi.org/10.1590/1983-1447.2016.esp.68075. 5. Park KH, Kim KS, Effect of a Structured Skin Care Regimen on Patients With Fecal Incontinence: A Comparison Cohort Study. J Wound Ostomy Continence Nurs. 2014;41(2):161-167. 


\title{
ATENDIMENTO REMOTO A PESSOAS COM DISFUNÇÕES MICCIONAIS (PROGRAMA ADOTE UM CASO): UMA SOLUÇÃO EFETIVA E DE BAIXO CUSTO NA ESTOMATERAPIA
}

\author{
Author(s): $\begin{aligned} & \text { Franciele de Freitas de Oliveira } \\ & \text { Martins }\end{aligned}$
}

Institution(s) ${ }^{1}$ UNB - Universidade de Brasília ( UnB - Brasília, DF, 70910-900), ${ }^{2}$ IF - Instituto Fluir (Curitiba)

\begin{abstract}
Introdução: As disfunções miccionais, manifestadas por sintomas de armazenamento ou esvaziamento urinário, acometem homens e mulheres, de todas as idades e classes sociais. Possuem consequências para a saúde física, emocional e social do indivíduo1. A primeira linha de tratamento consiste em medidas comportamentais que envolvem mudanças de hábitos e treinamento da bexiga e/ou assoalho pélvico. Essas medidas são efetivas na resolução dos sintomas e de simples aplicação, dependendo apenas de um profissional com conhecimento e habilidade na comunicação para motivação e adesão por parte do paciente2,3. Objetivo: Relatar a experiência de prestar orientações e acompanhar casos de disfunções miccionais por via telefônica. Método: Relato de experiência. Ao final dos cursos de atualização em Disfunções Miccionais, ministrados por nós, os enfermeiros interessados em contribuir voluntariamente com pessoas que apresentam o problema e em queiram exercitar raciocínio clínico, passam seus dados a nós e compõem uma lista de enfermeiros cadastrados no programa "Adote um Caso". Cada vez que alguma pessoa solicita orientações a respeito dos temas divulgados em nossas páginas sociais, uma de nós, que é responsável pelo programa, faz contato online com a pessoa para saber do interesse em ser acompanhada por um enfermeiro capacitado e solicitar o número de telefone. Os dados da pessoa são passados para um dos enfermeiros cadastrados que entra em contato com a pessoa, investiga o caso e faz orientações de medidas comportamentais que possam ajudar na resolução do problema, de acordo com seu entendimento clínico do caso. A qualquer momento o enfermeiro pode compartilhar o caso no grupo de enfermeiros cadastrados, em que somos mentoras, para solicitar ajuda. O atendimento pode ser realizado por ligação ou mensagem, de acordo com o que a pessoa preferir. Resultados: Hoje temos 09 enfermeiros cadastrados no programa. Somos em 03 mentoras para auxiliar na condução dos casos. Tivemos 14 pessoas que entraram em contato por meio de comentários nos posts ou mensagem privada solicitando ajuda por apresentarem sintomas de Disfunções Miccionais. As pessoas se mostram disponíveis a passar o contato telefônico e motivadas ao receberem essa forma de atenção. Houveram 06 casos de resolução completa de sintomas e melhora em todos os casos onde houve adesão às medidas. Os enfermeiros se mostram mais seguros a cada novo caso conduzido e motivados em observar os resultados dessa ação simples. Conclusões: $O$ atendimento remoto adianta o processo terapêutico e de reabilitação. Além de auxiliar de forma precoce pessoas que poderiam passar anos em filas para atendimento especializado, pode ser uma ferramenta educacional que auxilie enfermeiros/especialistas a exercitarem o raciocínio clínico, desde que tenham apoio de algum mentor nesse processo.
\end{abstract}

Keywords: Incontinência urinária, Retenção urinária, Enfermagem, Estomaterapia, Educação em saúde

\section{Referências Bibliográficas}

1. Abrams P, Cardozo L, Wagg A, Wein A. Incontinence. 6th ed. International Continence Society, editor. Tokyo: ICUD; 2017. 2. Austin PF, Bauer SB, Bower W, Chase J, Franco I, Hoebeke P, et al. The standardization of terminology of lower urinary tract function in children and adolescents: Update report from the standardization committee of the International Children's Continence Society. Neurourol Urodyn. 2016;35(4):471-81. 3. Brito FA de, Gentilli R de ML. Desatenção à mulher incontinente na atenção primária de saúde no SUS TT - Inattention to incontinent woman in primary care unit. Fisioter Bras [Internet]. 2017;18(2):f: 205-I: 213. Available from:

http://portalatlanticaeditora.com.br/index.php/fisioterapiabrasil/article/view/799/1744 


\title{
RADIOFREQUÊNCIA NO TRATAMENTO DA INCONTINÊNCIA URINÁRIA DE ESFORÇO
}

\author{
Author(s): João Junior Gomes ${ }^{1}$, Beatriz Nakashima ${ }^{1}$, Raquel Costa e Silva Scarpa ${ }^{1}$, Donata Maria de Souza \\ Pellegrino ${ }^{1}$, Rosana Pires Russo Bianco ${ }^{1}$, Adriana Pelegrini dos Santos Pereira ${ }^{1}$ \\ Institution(s) ${ }^{1}$ CUSC - Centro Universitário São Camilo (R. Raul Pompeia, 144 - Vila Pompeia São Paulo - SP)
}

\begin{abstract}
A incontinência urinária é a perda involuntária de urina, considerada um problema social ou higiênico de significativa prevalência no mundo, tornando assim um problema de saúde pública. Embora não seja uma condição de saúde que coloque a vida das pessoas em risco, é uma condição que pode trazer sérias implicações saúde, sociais e psicológicas, afetando adversamente sua qualidade de vida. Dentre os tipos mais comuns está a Incontinência Urinária de Esforço (IUE). Atualmente tem aumentado o interesse dos pesquisadores, por novas formas de tratamento com abordagens mais conservadoras, dentre essas está à radiofrequência (RF). Dessa forma, esse estudo buscou identificar na literatura estudos sobre o tratamento da incontinência urinária de esforço com Radiofrequência. Foi realizada uma revisão de literatura no período de dezembro de 2018 a fevereiro de 2019, na base de dados PUBMED, utilizando os descritores Urinary Incontinence Stress; Radiofrequency; Therapeutic. Foram selecionados sete estudos e os resultados demonstraram que a RF é uma técnica que tem apresentado eficácia no tratamento da IUE, porém algumas reações adversas foram

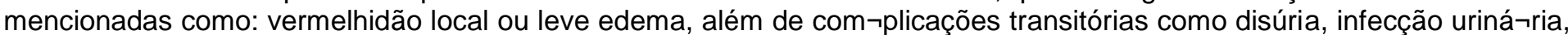
hematúria e disúria, tais complicações não foram relatadas nos casos em que a técnica foi aplicada na região vaginal. $A$ RF tem sido utilizada como terapia alternativa para o tratamento da IUE, uma opção promissora e viável, inclusive com vantagens sobre o tratamento cirúrgico. No entanto, é válido ressaltar, a necessidade de realização de mais estudos, que explorem questões como: definições acerca do tempo de tratamento, vias de administração, número de sessões e possíveis complicações.
\end{abstract}

Keywords: Incontinência Urinária por esforço, Radiofrequência, Estomaterapia, Terapêutica

\section{Referências Bibliográficas}

1- CESTÁRI, C. E.; SOUZA, T. H. C.; SILVA, A. S. Impact of urinary incontinence in the quality of living of elderly. Revista Ciência e Estudos Acadêmicos de Medicina, n. 7, p. 27-37, jan./jul., 2017. 2- LEIBASCHOFF, G. et al. Radiofrequência controlada por temperatura transcutânea (TTCRF) para o tratamento dos sintomas vaginais / geniturinários da menopausa. Surg Technol Int. v. 29, p. 149-159, out., 2016. 3- MARTINS, J. T. C.; SILVA, V. R. Dialogando sobre incontinência urinária feminina, qualidade de vida e políticas públicas de saúde para a mulher brasileira. Serv. Soc. \& Saúde, Campinas, SP v.16, n. 2 (24), p. 257-278, jul./dez. 2017. 


\title{
TECNOLOGIAS NA EDUCAÇÃO EM SAÚDE DE PACIENTES COM BEXIGA NEUROGÊNICA: CAPACITAÇÃO PARA AUTOCATETERISMO INTERMITENTE LIMPO
}

\author{
Author(s): Fernanda Henriques da Silva ${ }^{1}$, Maria de Lourdes Alves ${ }^{1}$, Maria José da Silva ${ }^{1}$, Jacira Florencia de \\ Paula Moura ${ }^{1}$ \\ Institution(s) ${ }^{1}$ PPC/UERJ - POLICLINICA PIQUET CARNEIRO/UERJ (AVENIDA MARECHAL RONDON, \\ $381)$
}

\begin{abstract}
INTRODUÇÃO: A Educação em Saúde busca dentre outros objetivos aprimorar o conhecimento do indivíduo sobre seu estado de saúde, dando subsídios para a instrumentalização destes para o autocuidado, corresponsabilização e autonomia. A combinação de variadas tecnologias na educação em saúde pode contribuir para o estabelecimento da relação de confiança entre os profissionais e os pacientes, o que poderá determinar a concretização efetiva das práticas em saúde. $\mathrm{O}$ objetivo deste trabalho é apresentar o uso de diferentes tecnologias para educação em saúde aplicadas a indivíduos com bexiga neurogênica para a realização do autocateterismo intermitente limpo no Núcleo de Disfunção Miccional (NDM). MATERIAL E MÉTODO: Trata-se de um relato de experiência sobre o uso de diferentes tecnologias para educação em saúde aplicadas a indivíduos com bexiga neurogênica para a realização do autocateterismo intermitente limpo no NDM. O Núcleo de Disfunção Miccional é um Ambulatório de Urologia localizado em uma Unidade de Atenção Secundária, a Policlínica Piquet Carneiro vinculada à Universidade do Estado do Rio de Janeiro, que integra o Sistema Único de Saúde e objetiva oferecer a usuários de todas as faixas etárias assistência multiprofissional e interdisciplinar para o tratamento de Disfunções do Trato Urinário Inferior. RESULTADOS: Das tecnologias implementadas na capacitação para o autocuidado dos usuários que necessitam realizar o autocateterismo intermitente limpo para esvaziamento vesical, temos o folder, uma tecnologia impressa que é entregue no primeiro contato do paciente com a Enfermeira que irá orientá-lo, é utilizado para que haja uma aproximação sobre o procedimento e o objetivo do mesmo. No dia agendado para a capacitação utilizamos o recurso multimídia na apresentação de um vídeo disponível gratuitamente no site YouTube® que versa sobre o funcionamento do trato urinário inferior e a realização do procedimento. Como modalidade tátil temos o uso do brinquedo terapêutico para as crianças e seus responsáveis, com a finalidade de auxiliar de forma lúdica o processo de ensinoaprendizagem sobre sua condição de saúde. A tecnologia dialógica na capacitação busca permitir que o sujeito se torne corresponsável pelo seu cuidado deliberando sobre os aspectos facilitadores e desfavoráveis na realização do procedimento e repercussões na qualidade de vida. A telenfermagem é o mecanismo utilizado pelas enfermeiras e pelos pacientes como metodologia avaliativa do cuidado implementado e para esclarecimento de dúvidas que surjam na realização do cateterismo no domicílio. CONCLUSÕES: A educação em saúde aliada ao uso de tecnologias tem sido uma ferramenta importante na assistência dos pacientes do NDM, para todas as faixas etárias, condições sociais e diferentes níveis de escolaridade. Tal estratégia tem se mostrado eficaz para a sensibilização das pessoas para o desenvolvimento de uma consciência crítica e reflexiva sobre o seu processo saúde doença e da necessidade do autocuidado.
\end{abstract}

\section{Keywords: BEXIGA NEUROGÊNICA, CATETERISMO URETRAL INTERMITENTE, EDUCAÇÃO EM SAÚDE, TECNOLOGIA EM SAÚDE, ESTOMATERAPIA}

\section{Referências Bibliográficas}

Truzzi JC et al. Recomendações SBU 2016: Cateterismo Vesical Intermitente. Sociedade Brasileira de Urologia, 2016 Mauro PCS. Elaboração de protocolo e cartilha sobre autocateterismo intermitente limpo em pacientes com bexiga neurogênica secundária à infecção por HTLV-1. Rio de Janeiro: Fundação Oswaldo Cruz; 2013. Souza Junior VD de, Mendes IAC, Mazzo A, Santos CA dos, Andrade EMLR, Godoy S de. Manual de telenfermagem para atendimento ao usuário de cateterismo urinário intermitente limpo [Internet]. Escola Anna Nery. 2017 ; 21( 4). Maniva SJCF, Carvalho ZMF, Gomes RKG, Carvalho REFL, Ximenes LB, Freitas CHA. Educational technologies for health education on stroke: an integrative review. Rev Bras Enferm [Internet]. 2018;71(Suppl 4):1724-31. Silva S, Assis M. O cuidar da enfermeira na saúde da família: fragilidades e potencialidades no Sistema Único de Saúde. Rev. Esc. Enferm. USP [Internet]. 1ago.2015. 


\title{
Manejo de Constipação em pacientes críticos: uma revisão integrativa
}

\author{
Author(s): Ana Patrícia de Cerqueira Greco ${ }^{1}$, Ivana Oliveira Cordeiro Oliveira Cordeiro ${ }^{1,1}$, Amanda da Silva \\ Miranda ${ }^{1,1,1}$, Mayara Leticia de Menezes raposo ${ }^{1,1,1,1}$ \\ Institution(s) ${ }^{1}$ HSR - Hospital São Rafael (Av Sao Rafael, 2152, São Marcos, Salvador, Bahia)
}

\begin{abstract}
A disfunção gastrointestinal é um dos problemas mais frequentes em Unidades de Terapia Intensiva atingindo $83 \%$ de prevalência. A imobilidade, uso de drogas vasoativas, sedação e ventilação mecânica, além de outras complicações inerentes as comorbidades e condições clínicas, influenciam diretamente na fisiologia do trato gastrointestinal. O manejo inadequado da constipação em pacientes com este risco pode agravar um cenário já crítico. Quadros de desnutrição proteico-calórica, êmese, distúrbios hidroeletrolíticos, translocação bacteriana e lesões decorrentes de incontinência pela indução da diarréia estão associados à constipação e podem aumentar a morbidade, mortalidade, tempo de internação e custos hospitalares. OBJETIVO Identificar na literatura evidências acerca da prevenção e dos tratamentos mais utilizados para pacientes críticos constipados sob cuidado em Unidades de Terapia Intensiva. MÉTODO Realizada uma revisão integrativa da literatura com artigos publicados no Portal PUBMED e Biblioteca Virtual de Saúde, foram encontrados trabalhos indexados nos bancos de dados da LILACS, MEDLINE e IBECS, na língua portuguesa, inglesa e espanhola. Utilizados 18 artigos completos de 2014 a 2019. RESULTADOS A realização de massagem abdominal três vezes ao dia com duração de 15 minutos apresentou redução no refluxo gástrico e tempo de evacuação, sendo sugerido como terapia adjunta na melhora da motilidade gastrointestinal. A terapia laxativa diária apresentou resultados satisfatórios em pacientes sob ventilação mecânica. O uso de Metilnatrexona subcutâneo apresentou melhores resultados no estímulo laxativo em relação à terapia convencional com supositório glicerinado e picosulfato de sódio em constipações induzidas por opioides. Apesar da dieta isenta de fibra ter sido bastante utilizada, estudos estimulam uso de fibras solúveis em pacientes graves desde a admissão, além da associação de laxantes e procinéticos diários. O uso de polietilenoglicol precoce esteve associado a resolução mais rápida da paralisia do trato intestinal em pacientes graves quando comparado com a Lactulose. O tratamento com Senalina apresentou-se mais eficaz em relação ao tratamento com Bisacodil devido menores complicações associadas. Relatos de caso envolvendo estímulo laxativo com Ruibarbo apresentaram resultados promissores por reduzir volume de resíduo gástrico e melhorar motilidade intestinal. O estudo que avaliou a eficácia da implementação de protocolo institucional para manejo do intestino encontrou baixa adesão da equipe assistencial, sobretudo médica, apresentando impacto limitado. CONCLUSÃO É unanime que o tempo de constipação apresentou impacto no desfecho do paciente crítico. Dessa forma, é necessário um instrumento de classificação de risco de constipação para início precoce das medidas profiláticas e a criação de um protocolo que uniformize as condutas no tratamento.
\end{abstract}

Keywords: Constipation, Critical patient, Intensive Therapy

\section{Referências Bibliográficas}

1. Warren D, Kent B. Determining the impact of a bowel management protocol on patients and clinicians' compliance in cardiac intensive care: A mixed-methods approach. J Clin Nurs. 2019;28(1-2):89-103. 2. Dehghan M, Fatehi poor A, Mehdipoor R, Ahmadinejad M. Does abdominal massage improve gastrointestinal functions of intensive care patients with an endotracheal tube?: A randomized clinical trial. Complement Ther Clin Pract [Internet]. 2018 Feb 1 [cited 2019 Jul 7];30:122-8. Available from: https://www.sciencedirect.com/science/article/pii/S1744388117304693?via\%3Dihub 3. Dos Reis AM, Fruchtenicht AV, Loss SH, Moreira LF. Use of dietary fibers in enteral nutrition of critically ill patients: A systematic review. Rev Bras Ter Intensiva. 2018;30(3):358-65. 4. Patel PB, Brett SJ, O'Callaghan D, Anjum A, Cross M, Warwick J, et al. Protocol for a randomised control trial of methylnaltrexone for the treatment of opioid-induced constipation and gastrointestinal stasis in intensive care patients (MOTION). BMJ Open. 2016;6(7):e011750. 


\title{
CONSTRUÇÃO DE MANUAL EDUCATIVO SOBRE CATETERISMO VESICAL INTERMITENTE LIMPO: RELATO DE EXPERIÊNCIA
}

\author{
Author(s): $\quad \begin{aligned} & \text { Vivian Brito Silva } \\ & \text { Shirley Martins }\end{aligned}{ }^{1}$, Dilcilene Aguiar ${ }^{1}$, Tamires Barradas ${ }^{1}$, Kezia Cristina ${ }^{1}$, Apoana Câmara ${ }^{1}$, \\ Institution(s) ${ }^{1}$ HUUFMA - Hospital Universitário da Universidade Federal do Maranhão (RUA BARÃO DE \\ ITAPARI ,227, CENTRO)
}

\begin{abstract}
Introdução: O cateterismo vesical intermitente limpo (CVIL) é o procedimento de escolha para tratamento da disfunção neurogênica do trato urinário inferior, anteriormente conhecido como bexiga neurogênica, nos pacientes portadores de lesões na medula espinhal. O CVIL é indicado para prevenir a infecção do trato urinário, tratar o refluxo vesico-uretral e alcançar a continência urinária, consequentemente, prevenindo a doença renal crônica1. Pacientes com lesão neurológica podem apresentar uma série de alterações motoras e sensitivas, sendo muito comum o surgimento de alterações vesicointestinais nesses pacientes, destacando-se a bexiga neurogênica(BN) como uma das principais manifestações clínicas2. A BN é uma doença crônica que ocasiona impacto significativo nas atividades de vida diária e na qualidade de vida tanto dos pacientes quanto de seus familiares3, sendo de fundamental importância o desenvolvimento de materiais informativos como o manual educativo por ser um instrumento de orientação e difusão de conhecimentos importante para o trabalho do enfermeiro pois contribui para o aprendizado do paciente e seu cuidador/familiar. Objetivo: relatar a experiência da construção de manual educativo com informações e orientações sobre cateterismo vesical intermitente limpo. Material e Método: estudo descritivo, do tipo relato de experiência que trata da construção de um manual educativo sobre o CVIL realizado entre os meses de junho e agosto de 2018 por profissionais residentes de enfermagem e equipe de enfermagem do setor de traumatologia e neurocirurgia do Hospital Universitário da Universidade Federal do Maranhão, São Luís, Maranhão, Brasil. Os procedimentos teóricos para a construção do manual educativo iniciaram com levantamento bibliográfico sobre o CVIL em manuais do Ministério da Saúde(MS), além de, busca de artigos científicos nas bases de dados Google Scholar, LILACS e SCIELO adaptando-os a uma linguagem de fácil compreensão com uso de textos explicativos claros e sucintos. Buscou-se o emprego de figuras ilustrativas oriundas de manuais do MS e do manual da Sociedade Brasileira de Urologia 2016(SBU). Resultados: o manual discorreu sobre a técnica do CVIL, com orientações e figuras ilustrativas voltados aos pacientes com disfunção neurogênica do trato urinário inferior como sequela de trauma raquimedular. O manual foi intitulado“Autocateterismo Vesical: Manual llustrado". O material é constituído por componentes pré-textuais (capa, contracapa, sumário e apresentação), textuais (oito capítulos que se referem às perguntas mais frequentes e que correspondem as principais dúvidas levantadas pelos pacientes vítimas de TRM, sendo elas: 1. O que acontece após o trauma raquimedular? 2. O que é cateterismo vesical? 3. Como higienizar as mãos? 4. Quais os materiais necessários para a realização do cateterismo? 5. Quantas vezes devo fazer o CVIT? 6. Qual a importância do cateterismo? 7. Quando devo procurar assistência medica? 8. Como conseguir o cateter pelo SUS?; e pós textuais (e referências bibliográficas). Conclusão: Identificou-se a importância da elaboração deste manual, como um material de apoio para o fornecimento de instruções e ensinamentos para realização do cateterismo vesical intermitente limpo visando a prevenção / redução de infecções urinárias, insuficiência renal, e ainda reinserção do paciente lesado medular ao convívio social $\begin{array}{llllll}\text { proporcionando } & \text { melhoria } & \text { sua } & \text { qualidade vida. }\end{array}$
\end{abstract}

\section{Keywords: CATETERISMO URETRAL INTERMITENTE, BEXIGA URINÁRIA UROGÊNICA, CATETERISMO URINÁRIO}

\section{Referências Bibliográficas}

1. Truzzi JC, Canalini AF, Prezotti JA, Resplande J. Recomendações SBU 2016 Cateterismo Vesical Intermitente. Sociedade Brasileira de Urologia (SBU). 2016, 36p. 2. Santos RCR, Fumicelli L, Nassiff A, Souza Júnior VD, Jorge BM, Mazzo A. Paciente com bexiga neurogênica: cateterismo urinário intermitente e cuidados intestinais. Rev enferm UFPE on line. 2015;9(Supl. 7):8953-60. 3. Marques LP, Schneider IJC, Giehl MWC, Antes DL, d'Orsi E. Fatores demográficos, condições de saúde e hábitos de vida associados à incontinência urinária em idosos de Florianópolis, Santa Catarina. Rev. bras. epidemiol. 2015; 8(3):595-606 


\title{
EDUCAR PARA PREVENIR: AÇÃO EDUCATIVA PARA PREVENÇÃO DA INCONTINÊNCIA URINÁRIA ENTRE ESTUDANTES DE ENFERMAGEM
}

Amelina de Brito Belchior ${ }^{1}$, Sherida Karanini Paz de Oliveira ${ }^{1}$, Dháfine Mazza Nunes ${ }^{1}$, Ernandes Author(s): Félix Sales ${ }^{1}$, Germana Pinheiro Correia Lima ${ }^{1}$, Jardeson de Sousa Tavares ${ }^{1}$, Natália Duarte de Carvalho ${ }^{1}$, Rebeca Nogueira Feitosa ${ }^{1}$, Rosenilda Marques Bezerra ${ }^{1}$, Maria Eurideia Castro ${ }^{1}$ Institution(s) ${ }^{1}$ UECE - UNIVERSIDADE ESTADUAL DO CEARÁ ( Av. Dr. Silas Munguba, 1700 - Itaperi, Fortaleza - CE, 60741-000)

\begin{abstract}
INTRODUÇÃO: A incontinência urinária (IU) é a perda involuntária de urina, sendo mais frequente em mulheres, sobretudo a partir dos 50 anos. Contudo, pode afetar mulheres mais jovens. A IU, além dos problemas de ordem física, também ocasiona necessidades psicossociais importantes que podem afetar a interação social, autopercepção e até as atividades diárias da mulher incontinente. As causas são diversas e incluem desde a posição adotada para urinar até infecções. A falta de conhecimento sobre o assunto contribui para que mulheres jovens negligenciem alguns cuidados de saúde. Assim, considera-se importante abordar o assunto por meio de atividades educativas a fim de ampliar o conhecimento de mulheres e desmistificar mitos que favorecem o desenvolvimento da IU. OBJETIVO: Relatar a experiência de acadêmicos de enfermagem acerca de uma atividade educativa sobre prevenção de IU. MATERIAL E MÉTODO: Estudo descritivo do tipo relato de experiência realizada em agosto de 2019, em uma instituição pública de ensino superior, utilizando um material educativo em forma de cartaz e panfletos, elaborados conforme evidências científicas sobre prevenção de IU encontradas em artigos na Biblioteca Virtual de Saúde (BVS). Os assuntos contemplados foram fortalecimento do assoalho pélvico, prevenção de infecções urinárias e fatores que contribuem para a ocorrência da IU. Além do material, os membros da Liga Acadêmica de Enfermagem em Estomaterapia (LEE) esclareceram mitos e realizaram orientações aos estudantes quanto à prevenção de IU, adoção de hábitos simples. RESULTADOS: Para a realização das atividades, os membros da LEE se dividiram nas principais áreas da instituição na qual a ação ocorreu, a fim de alcançar um público maior. A explanação sobre a prevenção da IU foi facilitada pelo material confeccionado, cartazes e panfletos, que direcionou a ação educativa de promoção da saúde. Durante a ação, observou-se que a ação provocou surpresa nas participantes com o conteúdo da ação e do material educativo apresentados, uma vez que acredita-se que não há uma posição correta para urinar e que isso não teria relação com incontinência urinária. CONCLUSÕES: O desenvolvimento da ação com as estudantes de enfermagem da instituição de ensino mostrou-se de grande relevância, pois possibilitou aos ligantes uma abordagem educativa sobre um assunto que levou esclarecimentos e quebras de tabus. Percebeu-se, ainda, a necessidade de mais atividades que contemplem a temática devido a existência de mitos e conhecimento deficiente dos estudantes sobre os fatores de riscos para o desenvolvimento da IU. Assim, essa experiência contribuiu para a ampliação do estudo e conhecimento dos ligantes sobre uma das áreas da estomaterapia, a incontinência.
\end{abstract}

Keywords: Incontinência Urinária , Educação em Saúde, Estomaterapia

\section{Referências Bibliográficas}

1. Higa, R.; Lopes, M. H. B. M.; Reis, M. J. Fatores de risco para incontinência urinária na mulher. Rev. Esc. Enferm. 2008;42(1): 187-192. 2. Higa, R.; Lopes, M. H. B.M. Fatores associados com a incontinência urinária na mulher. Rev. bras. Enferm. 2005;58(4):422-428. 3. Higa, R.; Lopes, M. H. B. M.; Turato, E. R. Significados psicoculturais da incontinência urinária feminina: uma revisão. Rev. Latino-am. Enf. 2008;16(4):779-786. 4. Oliveira, E. et al. Avaliação dos fatores relacionados à ocorrência da incontinência urinária feminina. Rev. Assoc. Med. Bras. 2010;56(6):688-690. 5. Patrizzi, L. J. et al. Incontinência urinária em mulheres jovens praticantes de exercício físico. Rev. bras. ciênc. Mov. 2014;22(3):105-110. 


\title{
INCONTINÊNCIA URINÁRIA EM MULHERES RESIDENTES DE INSTITUIÇÕES DE LONGA PERMANÊNCIA NA CIDADE DO RECIFE
}

\author{
Marília Perrelli Valença ${ }^{1}$, Jabiael Carneiro da Silva Filho ${ }^{1}$, Jair Luiz dos Santos Junior dos Santos \\ Author(s): Junior ${ }^{1}$, Tayne Fernanda Lemos da Silva ${ }^{1}$, Natália Maria Santana de Albuquerque ${ }^{1}$, Isabel \\ Cristina Ramos Vieira Santos Ramos Vieira Santos ${ }^{1}$ \\ Institution(s) ${ }^{1}$ UPE - Universidade de Pernambuco - Faculdade de Enfermagem Nossa S (Rua Arnóbio Marques \\ SN Santo Amaro)
}

\begin{abstract}
Introdução: O processo de envelhecimento no Brasil é acompanhado por um aumento de doenças crônicas como incontinência urinária (IU). Existem variações na prevalência de incontinência urinária em todo o mundo, bem como entre as regiões do Brasil (Milsom et al., 2014). A prevalência mundial da incontinência em mulheres foi estimada em mais de 275 milhões em 2013, com um aumento de mais de 300 milhões até 2018.

Objetivo: Identificar quais variáveis relacionadas à pessoa e seus aspectos clínicos podem estar associados aos tipos de incontinência urinária em mulheres idosas

Material e Métodos: Trata-se de estudo de corte transversal, prospectivo, realizado com 120 idosas internadas em instituições de longa permanência, onde utilizou-se o IQC Form (Incontinence Questionnaire Consultation Form), Questionário sobre Incontinência Urinária, foi usado como ferramenta de coleta de dados, além de um questionário sociodemográfico elaborado pelas autoras. A pesquisa foi aprovada pelo comitê de ética em pesquisa da Universidade de Pernambuco sob o parecer de número: 1.268.923.

Resultados: A prevalência de IU encontrada foi de $67,5 \%$. Em relação ao tipo de IU, foram encontradas as seguintes frequências: urgência $(29,2 \%)$, estresse $(23,3 \%)$ e mista $(15,0 \%)$. A Urge-incontinência foi significativamente associada à idade (média: 81,1 anos, P: 0,05) e circunferência abdominal (média: $97,9 \mathrm{~cm}, \mathrm{P}: 0,01$ ). O diabetes mellitus foi associado com incontinência de urgência $(P<0,001)$.

Conclusões: A incontinência urinária esteve presente em $67,5 \%$ das idosas residentes em instituições de longa permanência, com maior ocorrência da incontinência de urgência e estresse, e estatísticas paramétricas mostraram associação entre incontinência de urgência e idade e circunferência abdominal.
\end{abstract}

Keywords: incontinência urinária, saúde da mulher, mulher idosa, estomaterapia, fatores de risco

\section{Referências Bibliográficas}

1. Instituto Brasileiro de Geografia e Estatística. Projections and Estimates of the Population of Brazil and of the Units of the Federation. http://www.ibge.gov.br/apps/populacao/projecao/. 2017. Accessed June 20, 2018. 2. Dezan SZ. The aging in the contemporaneity: reflections on the care in a institution of long staying for elderly. Rev Psicol. UNESP. 2015;14 (2):2842. http://pepsic.bvsalud.org/pdf/revpsico/v14n2/a04.pdf. Accessed June 14 2017. 3. Milsom I, Coyne KS, Nicholson S, Kvasz M, Chen $\mathrm{Cl}$, Wein AJ. Global prevalence and economic burden of urgency urinary incontinence: a systematic review. Eur Urol. 2014;65(1):79-95. 


\title{
TECNOLOGIAS EDUCATIVAS EM SAÚDE PARA O CATETERISMO INTERMITENTE LIMPO.
}

\author{
Marília Perrelli Valença ${ }^{1}$, Isabel Cristina Ramos Vieira Santos Ramos Vieira Santos ${ }^{1}$, Jabiael \\ Author(s): Carneiro da Silva Filho ${ }^{1}$, Natália Beatriz Tavares de Sousa ${ }^{1}$, Caio Freire Pessoa Filho ${ }^{1}$, Emanuela \\ Batista Ferreira e Pereira ${ }^{1}$ \\ Institution(s) ${ }^{1}$ UPE - Universidade de Pernambuco - Faculdade de Enfermagem Nossa S (Rua Arnóbio Marques \\ SN Santo Amaro)
}

\begin{abstract}
Introdução: O Cateterismo Intermitente Limpo (CIL) consiste na drenagem periódica da urina através da introdução de um cateter específico pela uretra até a bexiga com a finalidade de esvaziá-la. É indicado para pacientes incontinentes, cujos mecanismos de armazenamento ou esvaziamento vesical estejam alterados por vários fatores como o envelhecimento e disfunções neurogênicas do trato urinário inferior, causadas por doenças congênitas ou adquiridas . (LIMA et al. 2017). Tal processo poderá impactar também em fatores psicológicos ao que se refere a ansiedade, medo, dúvidas e questionamentos. Dessa forma, constata-se a necessidade clara de uma estratégia de educação em saúde eficaz, que vá além de colaborar com o aprendizado total da técnica que necessitará ser realizada, estabelecendo também um vínculo que venha a gerar conforto ao paciente no que se refere a realização de todo procedimento já que o indivíduo poderá, naturalmente, manifestar certa angústia prévia pelo processo de adoecimento (FEIO \& OLIVEIRA, 2015). Diante disso, para alcançar o que a educação em saúde propõe, são necessárias novas estratégias que vão além da intervenção preventiva e curativa realizada pela equipe em níveis hospitalares ou ambulatoriais. Surge assim a noção de promoção em saúde que visa a capacitação dos indivíduos no enfrentamento e controle dos seus determinantes de saúde, seja ela uma medida profilática ou alguma maneira de encarar seu condicionante. Para alcançar a promoção em saúde há a necessidade de educar e instruir, como o proposto pelo processo de educação em saúde. Sabe-se então que educação e saúde são processos interdependentes (COGO et al. 2009). Portanto, a educação em saúde se mostra como uma relevante aliada no processo de orientação aos pacientes submetidos ao Cateterismo Intermitente Limpo, visto que é de suma importância que o indivíduo tenha um grau de instrução para alcançar uma compreensão satisfatória do procedimento a ser executado seja de forma temporária ou permanente, a nível domiciliar e sem auxílio de um profissional de saúde. Objetivo: Realizar revisão integrativa sobre a utilização de tecnologias educativas em saúde para o cateterismo intermitente limpo. Método: Trata-se de uma revisão integrativa, cujo levantamento bibliográfico foi feito de maio a setembro de 2018 em base de dados online, utilizando os seguintes descritores: Educação em Saúde, Tecnologia Educacional Cateterismo Urinário e Cateterismo Uretral Intermitente. Resultados: Foram identificados 5 artigos, sendo o Brasil como país de origem com maior número de publicações e prevalência de estudos metodológicos. Permitiu-se conhecer mais sobre as ferramentas disponíveis de educação em saúde, sendo, portanto, importante no processo de ensino-aprendizagem. Dentre as ferramentas abordadas, a construção de um conteúdo audiovisual se mostrou bastante efetivo, sendo capaz de deter maior atenção do telespectador. Conclusão: Há uma escassez de estudos envolvendo a Tecnologia Educacional e que esta pode ser grande aliada nos processos de educação em saúde.
\end{abstract}

Keywords: Cateterismo Urinário, Cateterismo Uretral Intermitente, Educação em Saúde, Tecnologia Educacional, estomaterapia

\section{Referências Bibliográficas}

BIAZIOLO, C.F.B.; MAZZO A.; MARTINS J.C.A.; JORGE B.M.; BATISTA R.C.N.; JÚNIOR S.T. Validation of selfconfidence scale for clean urinary intermittent self-catheterization for patients and health-caregivers. Jornal de Urologia. Brasil. 2017. 43: 505-11. CIPRIANO M.A.B.; FONTOURA F.C.; LÉLIS A.L.P.A.; PINHEIRO P.N.C.; CARDOSO M.V.L.M.L.; VEIRA N.F.C. Revisão integrativa de estudo sobre ações educativas para portadores de bexiga neurogênica. Revista de Enfermagem da UERJ, Rio de Janeiro, 2012. 20: 819-24 COGO, A.L.P.; PEDRO, E.N.R.; SILVA, A.P.S.S. Digital Educational Materials In Nursing: Assessment By Professors From An Undergraduate Course. Revista da Escola de Enfermagem da USP, São Paulo, 2009. COSCRATO G.; PINA J.C.; MELLO D.F. Utilização de atividades lúdicas na educação em saúde: uma revisão integrativa de literatura. Acta Paulista de Enfermagem. São Paulo, 2010. V, 23, p257-263 FEIO, A.; OLIVEIRA, C.C. Confluências e divergências conceituais em educação em saúde. Saúde Soc., São Paulo, 2015. V. 24 , n. 2 , p. $703-715$ 


\title{
PREVENÇÃO E TRATAMENTO DE DERMATITE ASSOCIADA À INCONTINÊNCIA NA NEONATOLOGIA E PEDIATRIA: UMA REVISÃO INTEGRATIVA.
}

\author{
Mayara Letícia Matos de Menezes Rapôso ${ }^{1,2}$, Amanda da Silva Miranda ${ }^{3}$, Ivana de Oliveira \\ Author(s): Cordeiro $^{2}$, Denise Nicodemo ${ }^{1}$, Leila Blanes ${ }^{1}$, Lydia Masako Ferreira ${ }^{1}$ \\ Institution(s) ${ }^{1}$ Unifesp - UNIVERSIDADE FEDERAL DE SÃO PAULO (Rua Botucatu, 740 - $2^{\circ}$ andar - Vila \\ Clementino, CEP:04023-062 - SP), ${ }^{2}$ HSR - Hospital São Rafael (Av. São Rafael, 2152 - São \\ Marcos, Salvador - BA), ${ }^{3}$ Curativos - Curativos Serviços de Saúde Domiciliar (R. Almirante \\ Barroso, $n^{\circ} 358$ - Rio Vermelho Salvador - BA)
}

\begin{abstract}
Introdução: A dermatite associada à incontinência (DAI) são danos à pele, caracterizados por inflamação e erosão, e causados por urina e fezes. $\mathrm{O}$ pH da superfície cutânea do recém-nascido tende a neutralidade, promovendo maior perda transepidérmica de água e alteração da função barreira. A maturação da pele reduz progressivamente essa permeabilidade e sempre se mantém inferior à do adulto. Esta é mais facilmente agredida mecanicamente na área de contato com as fraldas ou através da higiene. Objetivo: Descrever as intervenções para prevenção e tratamento da DAl em neonatologia e pediatria. Metodologia: Trata-se de uma revisão integrativa de literatura, a estratégia de busca foi acessada nos sites das bases indexadoras como Lilacs, Scielo, Bireme, Science Direct, Medline e Cochrane Library. Utilizou-se o acrômio PICO. Os critérios de inclusão foram ensaios clínicos com população de zero a cinco anos, em português, inglês e espanhol, na íntegra on-line publicados entre 2008 à 2018. Foram excluídos os que não apresentavam resumo, não citaram o público, e os não primários. Destes, foram selecionados 27 estudos, lidos na íntegra, e incluídos 11 artigos. Após a seleção final, os artigos foram submetidos ao teste de relevância aplicado por dois pesquisadores, mediante utilização de instrumento validado. Resultado: Os artigos são da língua inglesa e portuguesa, ensaios clínicos publicados entre 2012 e 2018. Conduzidos com crianças desde o nascimento até três anos, com n entre 30 a 280 crianças. Discussão: Para prevenção de DAl foi observado que, com a redução da frequência de banho a cada dois dias associada a uma hidratação obteve-se redução significativa quando comparado com banhos diários sem hidratação. Em relação aos sabonetes líquidos, especialmente os sindets, são mais recomendados que os em barra, por garantir a eficácia da barreira cutânea através do $\mathrm{pH}$ levemente ácido. Os lenços umedecidos em comparativos com água e algodão mostraram-se equivalentes em termos de hidratação da pele, e não apresentaram efeitos adversos. Quanto ao creme de óxido de zinco apresentou melhor resultado que talco para a prevenção. Para tratamento quando este é comparado com o uso de leite materno mostra-se mais eficaz, porém deve ser evitado produtos químicos. No entanto, este creme não demonstrou uma eficácia maior que o Hidrocolóide placa. Em relação aos produtos fitoterápicos, as evidências sugerem que Aloe Vera tópico e a Calêndula podem servir como opções seguras e eficazes, com alívio da irritação e prurido. A Calêndula quando associada ao Magnésio o tempo de tratamento é muito menor. Entretanto, em comparação com a Bentonita não teve o mesmo efeito. Entre a pomada de Coriandrum manipulada e a hidrocortisona 1\% não se confirmou a superioridade do agente fitoterápico, porém reduziu a irritação. Conclusão: Na prevenção e tratamento da DAI na neonatologia e pediatria são encontrados diversos produtos para o cuidado que podem ser selecionados conforme idade, custos, disponibilidade. Não foram encontrados estudos com a utilização de spray barreira à base de silicone, ou hidrocolóides em pó, que são utilizados de forma significativa na prática clínica, necessitando de novos estudos para embasamento destas práticas.
\end{abstract}

Keywords: Criança, Dermatites das Fraldas, Estomaterapia, Prevenção e controle, Terapêutica

\section{Referências Bibliográficas}

Gozen D, Caglar S, Bayraktar S, Atici F. Diaper dermatitis care of newborns human breast milk or barrier cream. J Clin Nurs. 2014. Nourbakhsh SMK, Rouhi-Boroujeni H, Kheiri M, Mobasheri M, Shirani M, Ahrani S, et al. Effect of topical application of the cream containing magnesium $2 \%$ on treatment of diaper dermatitis and diaper rash in children a clinical trial study. J Clin Diagnostic. 2016; Qiao XP, Ge YZ. Clinical effect of hydrocolloid dressings in prevention and treatment of infant diaper rash. Exp Ther Med. 2016; Panahi Y, Sharif MR, Sharif A, Beiraghdar F, Zahiri Z, Amirchoopani G, et al. A Randomized Comparative Trial on the Therapeutic Efficacy of Topical Aloe vera and Calendula officinalis on Diaper Dermatitis in Children. Sci World J. 2012;2012:1-5. Yonezawa K, Haruna M, Matsuzaki M, Shiraishi M, Kojima R. Effects of moisturizing skincare on skin barrier function and the prevention of skin problems in 3-month-old infants: A randomized controlled trial. J Dermatol . 2018 Jan;45(1):24-30. 


\title{
CATETERISMO INTERMITENTE LIMPO NO PACIENTE COM LESÃO MEDULAR: CONHECIMENTO DOS ENFERMEIROS
}

\author{
Author(s): \\ João Junior Gomes ${ }^{1}$, Aline Maria Benedita Messias ${ }^{1}$, Ana Claudia Lima Dornellas ${ }^{1}$, Roberta \\ Silmara Miranda ${ }^{1}$, Valéria Teles Batista ${ }^{1}$, Gisela Maria Assis ${ }^{1}$ \\ Institution(s) ${ }^{1}$ FAMERP - Faculdade de Medicina de São Jose do Rio Preto (Av. Brig. Faria Lima, 5416, Vila \\ São Pedro, São José do Rio Preto CEP 15.090-000)
}

\begin{abstract}
A lesão medular espinhal provoca prejuízo às estruturas medular, alterações no padrão miccional, nas fases de enchimento e esvaziamento urinário. Devido à interrupção da comunicação do trato urinário inferior com o SNC. O cateterismo intermitente limpo (CIL) é eficaz, com baixo custo e baixo risco, empregada por pacientes ou cuidadores no domicílio, proporcionando qualidade de vida e reduzindo infecções recorrentes. O objetivo do estudo foi avaliar o conhecimento dos enfermeiros, relacionado à orientação do $\mathrm{Cl}$, que atuam em hospitais que prestam atendimento a pessoa com lesão medular. Estudo exploratório descritivo de corte transversal com abordagem quantiqualitativa, amostra probabilística, por conveniência. Pesquisa foi realizada em um Hospital Universitário, no interior Mineiro, referência no atendimento às vítimas de trauma raquimedular, com a participação de 18 enfermeiros que responderam um questionário elaborado pelos pesquisadores, baseado no Guideline da Associação Europeia de Enfermeiros Urológicos, nas Recomendações da Sociedade Brasileira de Urologia e em literaturas científicas. O Questionário possuía duas partes: caracterização dos participantes e o conhecimento sobre os cuidados e a técnica do CIL. Os resultados revelaram um perfil de enfermeiros predominantemente do sexo feminino, com idade média de 37,6 anos, média de 11 anos de atuação e com pós-graduação. Os enfermeiros demonstraram e alto nível de conhecimento a respeito CIL, indicando capacidade para orientar à técnica, porém evidenciou falhas na orientação para alta hospitalar. Conclui-se que os enfermeiros da instituição estudada possuem conhecimento a respeito da DNTUI e CIL, entretanto, a orientação para a alta não atende às indicações preconizadas. Recomenda-se atividades motivacionais ou de discussões em grupo, a fim de compreender a não implementação da orientação obrigatória para a alta à criação de protocolos para esta ação.
\end{abstract}

Keywords: Cateterismo Urinário, Educação em Saúde, Estomaterapia

\section{Referências Bibliográficas}

1- Antônio VA. Importância do enfermeiro especialista em enfermagem de reabilitação na promoção do autocuidado eliminação vesical à pessoa/família com paraplegia resultante de lesão vertebro medular. Escola Superior de Saúde. Santarém, Abril de 2018. http://hdl.handle.net/10400.15/2254 2- BRASIL. Ministério da Saúde. Secretaria de Políticas de Saúde. Diretrizes de Atenção à pessoa com Lesão Medular. Brasília-DF 2 ed. 2015. 70 páginas. 3- EUROPEAN ASSOCIATION OF UROLOGY NURSE. Evidence based guidelines for Best Practice in Uological Heath Care. Catheterisation Urethral intermitente in adults. Dilatation, urethral intermitente in adults, 2013, 98 páginas. Disponível em:< https://nurses.uroweb.org/nurses/guidelines/>Acesso em: 20 de agosto de 2018. 


\title{
PERFIL DE MULHERES COM INCONTINÊNCIA URINÁRIA EM UM HOSPITAL UNIVERSITÁRIO
}

\author{
Átila Sâmia Oliveira Rodrigues ${ }^{1}$, FRANCISCA DAS CHAGAS SHEYLA ALMEIDA GOMES \\ Author(s): $\quad$ BRAGA $^{2}$, CLAUDIA DANIELLA AVELINO VASCONCELOS BENÍCIO ${ }^{3}$, BIANCA MARIA \\ AGUIAR DE OLIVEIRA ${ }^{3}$, ROXANA MESQUITA DE OLIVEIRA TEIXEIRA SIQUEIRA ${ }^{2}$, \\ ALICE DA COSTA $^{3}$, ALLYNE QUARESMA COSTA ${ }^{3}$
}

Institution(s) ${ }^{1}$ Unifor - Universidade de Fortaleza ( Av. Washington Soares, 1321 - Edson Queiroz - CEP 60811905 - Fortaleza-CE Bras), ${ }^{2}$ HUPI - Hospital Universitario - Piaui (Campus I Campus Universitário Ministro Petrônio Portela, SG 07 s/n - Ininga, Ter), ${ }^{3}$ UFPI - Universidade Federal do Piaui (Campus Universitário Ministro Petrônio Portella Bairro Ininga - Teresina - PI -)

\begin{abstract}
INTRODUÇÃO: A Incontinência Urinária (IU) é a perda involuntária de urina, condição estigmatizante para muitas populações, existindo carência de trabalhos na área ${ }^{1}, 2$. Estudos populacionais gerais mostram que a prevalência da IU variou entre $25 \%$ a $45 \%$ em mulheres adultas ${ }^{3}$. OBJETIVO: Conhecer o perfil sociodemográfico e clínico das mulheres com incontinência urinária atendidas nos ambulatórios de ginecologia em um Hospital Universitário (HU). MATERIAL E MÉTODO: Estudo de caráter, analítico e transversal, realizado no ambulatório de ginecologia em um HU, cuja a mostra foi constituída por mulheres a partir de 18 anos, com queixa de perda involuntária de urina. Os dados foram coletados por meio de formulário. A análise se deu de forma simples, utilizando a planilha excel e regra de três. A pesquisa faz parte de um macroprojeto, sob o CAAE 01564818.2.0000.5214 e aprovado pelo parecer de no 3.305.182. Foram obedecidas às diretrizes da Resolução oㅡ 466/2012 do Conselho Nacional de Saúde (CNS)4. RESULTADOS: Foi realizado um total de 96 abordagens, 21 mulheres apresentaram queixa de perda involuntária de urina, todavia apenas 20 aceitaram responder às perguntas propostas no formulário. A idade média das pacientes foi de 55 e variou entre 25 a 77 anos. A faixa de idade mais recorrente foi a de 50 a 59 anos, com um total de $40 \%$ das pacientes, seguido das idosas (65 a 79 anos) com $30 \%$. Igual valor (15\%) obteve-se nas faixas etárias de 40 a 49 anos e nas mulheres mais jovens (25 a 39 anos), demonstrando desse modo a alta ocorrência desta problemática em pacientes com idade mais avançada, que se consultaram nesse hospital. Quanto à escolaridade, $45 \%$ afirmaram ter o ensino fundamental incompleto, $40 \%$ terem o ensino médio completo, e obteve-se igual porcentagem, $5 \%$, as mulheres que tinham o ensino médio incompleto, não alfabetizadas e que possuíam curso superior completo. A renda familiar mais expressiva foi a de até um salário mínimo para $45 \%$ das entrevistadas, seguidas por aquelas que recebiam entre um e dois salários (30\%), 15\% entre dois e três salários e $10 \%$ uma renda mensal de três a quatro salários. A situação conjugal das pacientes mostrou que mais da metade (55\%) são casadas, $15 \%$ encontravam-se em uma união estável, $15 \%$ solteiras, $10 \%$ viúvas e em menor quantidade as que eram separadas, apenas 5\%. Quando questionadas a respeito das relações sexuais 50\% afirmaram ter vida sexual ativa. E relacionando a incontinência com a prática sexual, a maioria $(75 \%)$ afirmou que tal problemática não interfere ou interferiu em suas relações, enquanto que as demais (25\%) disseram que sim. CONCLUSÃO: O estudo mostrou resultados que corroboram $\mathrm{com}$ as literaturas nacional e internacional referentes à idade, à escolaridade e renda familiar 5 . O número de mulheres que têm sua vida sexual, com algum grau de interferência devido a IU, deve ser valorizado. Pode-se observar também a importância de conhecer o perfil das mulheres incontinentes na instituição para que possam ser desenvolvidas estratégias para o cuidado e tratamento dessa clientela, assim como subsidiar novos trabalhos.
\end{abstract}

Keywords: Incontinência urinária, Mulheres, Enfermagem, Estomaterapia

\section{Referências Bibliográficas}

1 Ferolla EC, Santos VL, Gouveia C. Incontinência urinária de esforço: um perfil da clientela. Estima 2003; 12 Sociedade Portuguesa de Ginecologia, Consenso Nacional sobre Uroginecologia. Incontinência Urinária de Esforço: um perfil da clientela, Portugal: jun de 2018; Secção portuguesa de uroginecologia. 3 Abrams P, Cardozo L, Wagg A, Wein A. Incontinence. 6th international consultation on incontinence. International contnence society. Tokyo. 2016. 4 Brasil. Conselho Nacional de Saúde. Resolução n 466, de 12 de dezembro de 2012. Aprova normas regulamentadoras de pesquisas envolvendo seres humanos. Diário oficial da união 12 dez 2012; Seção 1. 5 Benício CDAV, Luz MHBA, Lopes MHBM, Carvalho NAR. Incontinência urinária: prevalência e fatores de risco em mulheres em uma unidade básica de saúde. Estima 2016; 14: 161-168. 


\title{
DISTÚRBIO NA IMAGEM CORPORAL EM PACIENTES CIRURGICOS DE RETIRADA DE ÓRGÃO
}

\author{
Author(s): \\ Thais Martins Gomes de Oliveira ${ }^{1}$, Cristine Alves Costa de Jesus ${ }^{1}$, Larissa Fernanda de Carvalho \\ Lourenco $^{1}$
Institution(s) ${ }^{1}$ UnB - Universidade de Brasília (Universidade de Brasília-UnB - Campus Universitário Darcy Ribeiro - Asa Norte-Br)

\begin{abstract}
Introdução: Mudanças na imagem corporal derivadas da realização de procedimento cirúrgico motivam a implementação da sistematização da assistência de enfermagem. Enfatiza-se a segunda etapa do processo de enfermagem o diagnóstico de enfermagem ${ }^{1}$. O diagnóstico Distúrbio da imagem corporal está presente no domínio Auto percepção, classe: Imagem Corporal. É definido por "Confusão na imagem mental do eu físico" ${ }^{2}$. Remete a auto-percepção do paciente quanto à forma que interpreta os acontecimentos e a forma que os ajusta em seu esquema cognitivo. Objetivos: Investigar a presença do diagnostico Distúrbio da Imagem Corporal presente na NANDA-I e levantar as características definidoras e fatores relacionados em pacientes cirúrgicos de retirada de órgão. Material e Método: Estudo descritivo e transversal realizado em um Hospital Universitário. Amostra de 60 pacientes no período de setembro a dezembro de 2017. A participação na pesquisa foi condicionado à anuência do Termo de Consentimento Livre e Esclarecido. Foram incluídos pacientes internados na clínica cirúrgica, maiores de 18 anos, em pósoperatório superior a 24 horas por procedimento cirúrgico de retirada órgãos. A coleta de dados foi por meio do prontuário físico e aplicação do instrumento de coleta para subsidiar a elaboração dos Diagnósticos de enfermagem de acordo com a NANDA-I

Resultados: Foram identificados em $55 \%$ dos participantes o diagnostico Distúrbio da imagem corporal, que apresentou seis fatores relacionados: procedimento cirúrgico, alteração na autopercepção, doença, alteração em função do corpo, regime de tratamento e trauma. As principais características definidoras foram: alteração na visão do próprio corpo, comportamento de reconhecimento do próprio corpo, ausência de parte do corpo, alteração em função corporal, foco na aparência anterior e alteração na estrutura corporal, sentimentos negativos em relação ao corpo, percepções que refletem uma visão alterada da aparência do próprio corpo, foco na função do passado, medo da reação dos outros e mudança no estilo de vida $^{3}$.

Conclusões: O diagnóstico se destacou em função da problemática do estudo, por envolver pacientes que sofreram retiradas de um ou múltiplos órgãos. A retirada desses órgãos gerou incerteza e sofrimento em grande parte dos participantes, além das alterações sofridas pela própria doença de base. A aparência externa mostrou-se relevante nas mulheres pesquisadas, muitas demonstraram preocupações quanto ao aspecto exterior da cirurgia, receio de cicatrizes e outras marcas no corpo. Mudanças drásticas da imagem corporal influenciou na forma como passaram a se enxergar, a ausência de uma parte do corpo que possui significados culturais e sociais pode afetar sua relação com a sexualidade e autoimagem ${ }^{4}$. O estudo identificou a presença desse importante diagnostico de enfermagem. Destaca-se a importância da implementação da sistematização da assistência de enfermagem. O manejo dessa condição implica em medidas como: modificação da auto percepção, promoção da esperança, copying, presença de familiares e amigos, reforço positivo da autoestima, equilíbrio do processo familiar, maior socialização, estruturamento emocional, religiosidade, espiritualidade e melhoria da auto imagem corporal ${ }^{5}$.
\end{abstract}

Keywords: Estomaterapia, Diagnóstico de enfermagem, Imagem Corporal, Retirada de órgão, Cirurgia

\section{Referências Bibliográficas}

Conselho Federal de Enfermagem (COFEN). Resolução COFEN no 358/2009, de 15 de outubro de 2009. Dispõe sobre a Sistematização da Assistência de Enfermagem e a implementação do Processo de Enfermagem em ambientes, públicos ou privados, em que ocorre o cuidado profissional de Enfermagem, e dá outras providências. In: Conselho Federal de Enfermagem [legislação na internet]. Brasília; 2009. Disponível em: < http: // www.portalcofen.gov >. Acesso em: 19 de abril de 2019. North American Nursing Association International (Nanda-I). Diagnósticos de Enfermagem da NANDA-I: definições e classificação 2018-2020. Tradução: Regina Machado Garcez. 10. ed. Porto Alegre: Artmed, 2018 Oliveira TMG. Diagnósticos de enfermagem em pacientes submetidos à cirurgia para retirada de órgão à luz da teoria da incerteza na doença. [dissertação]. Brasília: Universidade de Brasília- UnB; 2018. Oliveira S K P, Viana M T M P, Bilhar S P O, Lima F E T. Sistematização da assistência de enfermagem às mulheres mastectomizadas. Cogitare Enferm. 2010 Abr/Jun; 15(2):319-26 Ribeiro J P, Cardoso L S, Pereira C M S, Silva B T, Bubols B K, Castro C K. Assistência de enfermagem ao paciente oncológico hospitalizado: diagnósticos e intervenções relacionadas às necessidades psicossociais e psico espirituais. J. res. fundam. care. online 2016. out./dez. 8(4): 5136-5142. 


\title{
O enfermeiro da atenção primária integrando a saúde suplementar: Caracterização de um serviço Nacional de estomaterapia
}

\author{
Author(s): Michele Neves Brajão Rocha ${ }^{1}$, Paula Cristina Nogueira ${ }^{2}$, Andrea Christina Borella ${ }^{1}$, Monica \\ Franco Coelho ${ }^{1}$ \\ Institution(s) ${ }^{1}$ Amil - Amil Saúde (Rua Conselheiro rodrigues Alves, 180 - Vila Mariana SP), ${ }^{2}$ EEUSP - Escola \\ de Enfermagem da Universidade de São Paulo (Av Dr Enéas Carvalho de Aguiar, 419 - Cerqueira \\ Cesar - SP)
}

\begin{abstract}
Com o aumento da expectativa de vida, tem aumentado o número de indivíduos com condições crônico-degenerativas e consequentemente há uma predisposição dessa população às complicações advindas de tais condições, entre elas a ocorrência de feridas crônicas. Com a reestruturação do setor saúde, diminuição de leitos, desospitalização e ênfase na atenção primária, a enfermagem depara-se com novos desafios e espaços de atuação. Isto tem exigido maior integração entre os diferentes cenários de assistência. Nesse sentido, destaca-se a integração do enfermeiro que atua na Atenção Primária à Saúde com o enfermeiro especialista (Estomaterapeuta) para que haja um atendimento resolutivo e de qualidade a pacientes com feridas. Objetivo: descrever a implementação de um Serviço Nacional de Estomaterapia (SNE) de uma Operadora de Saúde em ambulatórios com equipes de APS e caracterizar o atendimento a pacientes com feridas. Métodos: Trata-se de um estudo de natureza descritiva tipo relato de experiência sobre a implementação de um SNE e caracterização dos atendimentos a pacientes com feridas agudas e crônicas pelo serviço. Resultados: $O$ serviço foi implementado em 4 Estados Brasileiros, visando atender a demanda de pacientes com feridas agudas e crônicas. $O$ serviço é coordenado por uma enfermeira Estomaterapeuta, com 32 ambulatórios de feridas, onde a enfermeira da Estratégia de Saúde da Família avalia e acompanha, integralmente, o paciente com ferida. No período de 01 de julho de 2018 a 31 de dezembro de 2018 foram atendidos 1900 pacientes, onde a maioria são do sexo masculino (53\%) e idosos, com idade maior ou igual a 60 anos (58\%), seguido de 455 pacientes com idade entre 40 a 59 anos. A maioria são encaminhados ao SNE através de outros ambulatórios (70\%) seguidos pelos que são encaminhados através dos Pronto Socorros (19\%). Quanto a classificação da ferida, há predomínio das feridas crônicas (52\%), destacando-se as úlceras varicosas $(45 \%)$, seguidos das úlceras diabéticas $(12 \%)$ e as lesões por pressão (6\%), seguido das feridas agudas, cirúrgicas (15\%) e traumáticas (14\%). Quanto aos tipos de coberturas utilizadas nas feridas, as de uso padrão (83\%) e as especiais (17\%). Conclusão: A integração do enfermeiro da estratégia de saúde da família no SNE possibilitou um atendimento mais eficiente, resolutivo e de qualidade a pacientes com feridas agudas e crônicas.
\end{abstract}

Keywords: estomaterapia, enfermagem, atenção primária

\section{Referências Bibliográficas}

Rabeh SAN; Gonçalvez MBB; Caliri MHL; Nogueira PC; M Miyazaki MY. Construção e validação de um módulo educativo virtual para terapia tópica em feridas crônicas. Rev. enferm. UERJ, Rio de Janeiro, 2012 dez; 20(esp.1):603-8. Consensus Jornal do Conselho Nacional de Secretários de Saúde. Disponível em:

http://bvsms.saude.gov.br/bvs/periodicos/consensus05.pdf Agência Nacional de Saúde Suplementar. Disponível em: http://www.ans.gov.br/aans/quem-somos/historico Ziroldo RR, Gimenes RO, Júnior . A importância da Saúde Suplementar na demanda da prestação dos serviços assistenciais no Brasil. O Mundo da Saúde, São Paulo - 2013;37(2):216-221 


\title{
Mínimo Produto Viável para aplicativo de apoio à decisão na prevenção, diagnóstico de enfermagem e tratamento de Lesão por Pressão e Lesão por Fricção em idosos.
}

\author{
Author(s): Juliana Balbinot Reis Girondi ${ }^{1}$, Francisco Reis Tristão ${ }^{2}$, Monica Stein ${ }^{1}$, Leonardo Tristão ${ }^{1}$, Lúcia \\ Nazareth Amante ${ }^{1}$, Ana Graziela Alvarez ${ }^{1}$, Karina Silveira de Almeida Hammerschmidt ${ }^{1}$ \\ Institution(s) ${ }^{1}$ UFSC - Universidade Federal de Santa Catarina (Campus Reitor João David Ferreira Lima, s/n - \\ Trindade. Depto Enfermagem), ${ }^{2}$ SMS São José - Secretaria Municipal Saúde São José (Av. Acioni \\ Souza Filho, 403 - Centro, São José - SC, 88111-330)
}

\begin{abstract}
Introdução: O enfermeiro no cuidado com a pele do idoso pode adotar tecnologias capazes de apoiar a decisão clínica. Dentre as estratégias utilizadas estão as Tecnologias da Informação e Comunicação, as quais constituem-se como ferramentas pautadas em recursos computacionais, que subsidiam a execução de atividades. Objetivo: Desenvolver um Mínimo Produto Viável (MPV) para aplicativo de apoio à decisão a enfermeiros na prevenção, diagnóstico de enfermagem e tratamento de Lesão por Fricção e Lesão por Pressão em idosos. Material e Método: Estudo qualitativo com produção tecnológica realizado em três etapas: revisão integrativa, investigação junto a enfermeiros e construção do MPV. Na primeira foi realizado pesquisa em artigos científicos nas bases de dados: Medline, Scielo, Literatura Latino Americana y del Caribe en Ciencias de la Salud, Cumulative Index to Nursing and Allied, publicados entre 2012 e 2017. Na segunda realizou-se pesquisa qualitativa descritiva com 25 enfermeiros atuantes na Estratégia Saúde da Família de um município do sul do Brasil para investigar as intervenções adotadas relativas aos cuidados com a pele do idoso. Na terceira etapa para construção do MPV utilizou-se o método Lean Startup utilizando a técnica das personas para construção dos perfis de usuário. Para definição do conteúdo do MPV foram extraídos dados de revisão integrativa. O produto foi desenvolvido em formato Hypertext Markup Language (HTML) e Cascading Style Sheets (CSS) e convertido à formato compatível com o Sistema Android®. Para a testagem do produto utilizou-se o Teste de Usabilidade. A pesquisa foi aprovada pelo Comitê de Ética sob parecer consubstanciado $\mathrm{n}$-2.697.902. Resultados: Os resultados da primeira etapa do estudo evidenciaram que 31 artigos, onde $26(83,87 \%)$ eram estudos relacionados à Lesão por Pressão e apenas cinco $(16,12 \%)$ abordaram Lesão por Fricção. Sobre a investigação qualitativa a maior parte dos enfermeiros possui dificuldade para gerenciar esse tipo de cuidado. Após análise dos resultados da primeira e segunda etapa construiu-se MPV. Foram criados três perfis de usuários, que permitiram identificar as funcionalidades necessárias ao produto. As funcionalidades foram organizadas em formato de mapa de navegação e deram origem a primeira versão do produto, que dispunha de tela inicial, permitindo além de outros, acesso às caixas de seleção: Lesão por Pressão e Lesão por Fricção. Em cada caixa era possível selecionar fatores de risco e ter acesso ao plano de cuidados bem como definição de diagnóstico de enfermagem e estadiamento de ambas as lesões, com sugestões de tratamento. Após aplicação do Teste de Usabilidade foram identificadas e avaliadas as necessidades de ajuste. Dada a realização dos ajustes, o produto foi resubmetido a testagem, não sendo apontada necessidade de novas alterações. Conclusão: A versão final do modelo para um aplicativo de apoio à decisão a enfermeiros intitulada SKIN-HELP constituiu uma proposta exequível à prática, haja vista seu potencial científico, capaz de fomentar o julgamento crítico e a gestão do cuidado de enfermagem ao idoso em risco ou com Lesão por Fricção e/ou Lesão por Pressão. O referido produto está em processo de patenteação.
\end{abstract}

Keywords: Tecnologia Biomédica, Idoso, Estomaterapia, Lesão por Pressão

\section{Referências Bibliográficas}

1. Alberti GF, Espindola RB, Carvalho SORM. A qualificação profissional do enfermeiro da atenção primária no cuidado com o idoso. Rev enferm UFPE. 2014; 8(8): 2805-10. 2. Araujo D, Pereira T. Princípios de dermatologia na cicatrização de feridas. In: Geovanini T. Tratado de Feridas e Curativos: Enfoque Multiprofissional. 1.ed. São Paulo: Rideel; 2014. p. 11927. 3. Arrais RF, Crotti PLR. Revisão: aplicativos para dispositivos móveis (“Apps") na automonitorização em pacientes diabéticos. J. Health Inform. 2015; 7(4):127-33. 4. Baranoski S, Leblanc K, Gloeckner MCE. American Journal Of Nursing. 2016; 116(11):24-30. 5. Bianchi J. Preventing, assessing and managing skin tears. Nursing Times. 2012; 108(13): 12-16. 


\title{
APLICAÇÃO DO BRAINSTORMING NA MELHORIA DO PROCESSO DE PREVENÇÃO DE LESÃO POR PRESSÃO EM UMA UNIDADE DE TERAPIA IINTENSIVA ADULTO: RELATO DE EXPERIÊNCIA
}

\author{
GABRIELA BETTONI FIGUEIROA ${ }^{1}$, Debora Alves de Freitas Antonio ${ }^{1}$, Juan Pablo Pereira da \\ Author(s): $\quad$ Silva ${ }^{1}$, Lizzandra Varela da Costa ${ }^{1}$, José Carlos de Oliveira ${ }^{1}$, Paula Rocco Gomes Lima ${ }^{1}$, Gleice \\ Guarnieri Rossanez ${ }^{1}$, Gisela Carla Ferreira Rodrigues ${ }^{1}$ \\ Institution(s) ${ }^{1}$ PUC Campinas - Pontifícia Universidade Católica de Campinas (Av. John Boyd Dunlop - Jardim \\ Ipaussurama, Campinas - SP, 13034-685)
}

\begin{abstract}
Introdução: O Brainstorming é uma ferramenta de gestão da qualidade baseada em estímulo de criatividade, conhecida como "tempestade de ideias" por gerar ampla variedade de sugestões sobre um assunto em específico1. Essa ferramenta é composta por uma técnica conhecida como uma nova maneira de pensar, antes da execução de ações para a melhoria do processo1,2. Mediante à essa metodologia da qualidade e a latente necessidade de aprimorar os processos assistenciais, frente aos meios de prevenção de lesão por pressão (LP), fundamentou-se a proposta de execução do brainstorming na Unidade de Terapia Intensiva Adulto (UTI-Ad). Objetivos: Descrever a vivência dos enfermeiros residentes na aplicação do Brainstorming no intuito de promover a melhoria da prevenção de LP em uma UTI Ad. Metodologia: Estudo qualitativo descritivo do tipo relato de experiência, realizado em um Hospital Universitário e filantrópico do interior do estado de São Paulo, como parte do cumprimento da disciplina pedagógica "Projetos aplicativos". Baseou-se na participação ativa de enfermeiros residentes na aplicabilidade do Brainstorming, para o aprofundamento sobre os fatores causadores de LP na prática assistência desta unidade foco do relato e acarretando gatilhos para a composição de métodos educativos para o aprimoramento das ações de prevenção de LP. Resultados: A ferramenta de gestão da qualidade foi aplicada com $100 \%$ da equipe técnica de enfermagem da UTI-Ad como parte de um projeto desenvolvido de prevenção de LP de setembro a outubro/2018. O Brainstorming fez-se com o objetivo de alcançar os conhecimentos da equipe sobre o que ocasiona e como prevenir a LP e a partir dessa reflexão obter sugestões para implementar no setor. Foram realizados encontros, em todos os turnos, com no máximo seis profissionais, com o intuito de terem uma maior participação na aplicação da ferramenta. Durante a aplicação do Brainstorming foram elencados temas a serem discutidos: o que ocasiona, formas de prevenir a LP, dificuldade de implementação das ações de prevenção na unidade e ideias a serem mudadas em seus cotidianos, as ideias foram anotadas painel durante o diálogo, e após foram digitalizadas em tabelas, divididas pelos temas expostos. As ideias foram filtradas e discutidas no grupo desenvolvedor do projeto e a partir das mesmas foi dado continuidade no projeto de prevenção de LP. Frente a esse processo foi desenvolvido um treinamento como estratégia de educação continuada, juntamente com métodos variados para prevenção de LP, tornando-se continuas as medidas de prevenção da LP. Conclusões: Nesse contexto a execução do brainstorming na área hospitalar viabiliza um melhor conhecimento, e quando relacionado ao tema de prevenção de LP, sua aplicabilidade com os profissionais da saúde é de grande valia, pois são profissionais com uma grande carga de conhecimento. Evidencia-se na prática que o brainstorming, auxilia na visualização das necessidades da assistência, possibilitando a realização de medidas de qualificação do atendimento ao paciente internado, sendo aplicada de forma eficaz, principalmente em temas pertinentes a medidas de prevenção de LP1,3.
\end{abstract}

Keywords: Educação em enfermagem, Estomaterapia, Lesão por pressão, Gestão da Qualidade

\section{Referências Bibliográficas}

1. Anais do Seminário "Gestão da Qualidade na Educação: Em Busca da Excelência", dias 9 e 10 de novembro de 1995, no Centro de Tecnologia de Gestão Educacional, São Paulo-(SP) : SENAC — SP; 1996; [acesso em 20 jun 2019]; Disponível em: http://repositorio.ipea.gov.br/bitstream/11058/1722/1/td_0397.pdf. 2. Buchele GT, Teza P, Souza JÁ, Dandolini GA. Métodos, Técnicas e Ferramentas oara Inovação: O uso do Brainstorming no processo de design contribuindo para a inovação. Rev. Pensamento e Realidade. [Internet] 2017; 31(1) [acesso em 25 jun 2019]. Disponível:

https://revistas.pucsp.br/pensamentorealidade/article/view/28373. 3. Souza NR, Freire DA, Souza MAO, Melo JTS, Santos LV, Bushatsky M. Fatores predisponentes para o desenvolvimento da lesão por pressão em pacientes idosos: uma revisão integrativa. Rev. Estima. [Internet] 2017; 15(4) [acesso em 25 jun 2019]. Disponível: http://dx.doi.org/10.5327/Z1806- 


\title{
EXPERIÊNCIA DE ENFERMEIROS RESIDENTES NO PROCESSO DE ANÁLISE DO ÍNDICE DE EFETIVIDADE DE PREVENÇÃO DE LESÃO POR PRESSÃO EM UMA UNIDADE DE TERAPIA INTENSIVA ADULTO
}

\author{
DEBORA ALVES DE FREITAS ANTONIO ${ }^{1}$, Gabriela Bettoni Figueiroa ${ }^{1}$, Juan Pablo Pereira da
} Author(s): $\quad$ Silva ${ }^{1}$, Lizzandra Varela da Costa ${ }^{1}$, José Carlos de Oliveira ${ }^{1}$, Paula Rocco Gomes Lima ${ }^{1}$, Gleice Guarnieri Rossanez ${ }^{1}$, Gisela Carla Ferreira Rodrigues ${ }^{1}$

Institution(s) ${ }^{1}$ PUC-CAMPINAS - PONTIFÍCIA UNIVERSIDADE CATÓLICA - CAMPINAS (Rua Prof Dr. Euryclides de Jesus Zerbini, $\mathrm{n}^{\mathrm{o}} 1.516$ - Campinas)

\begin{abstract}
Introdução: Em 2013, por meio da Portaria 529, o Ministério da Saúde (MS) instituiu o "Programa Nacional de Segurança do Paciente", colocando a segurança na assistência como um preditor de qualidade. Neste cenário, a lesão por pressão toma destaque sendo classificada: "como dano ao paciente, um evento adverso que fragiliza a segurança do usuário". Com foco na prevenção de lesão por pressão (LP), o MS preconizou ações para promoção de segurança ao paciente pelos serviços de saúde por meio de gestão de riscos. Esse processo foi estruturado em etapas, como: identificação e avaliação de riscos, desenvolvimento e implementação de estratégias aumejando prevenção, controle e diminuição de possíveis impactos ${ }^{1,2}$. Evidências científicas demonstram que em Unidade de Terapia Intensiva a incidência de LP é maior, esta diretamente relacionada ao grau de complexidade e a vulnerabilidade de seus pacientes, tornando-se um cenário de risco ${ }^{3}$. A avaliação e monitoramento da efetividade das ações preventivas torna-se imprescindível para o controle de processos, para qualificar a assistência e gerenciar fragilidades. Objetivo: Descrever a experiência pela perspectiva do enfermeiro residente sobre o processo de análise dos índices de efetividade de prevenção de lesão por pressão, antes e após aplicação de estratégia educacional com equipe de enfermagem em uma Unidade de Terapia Intensiva Adulto. Material e Método: Trata-se de um estudo descritivo, exploratório, qualitativo, tipo relato de experiência, efetivado a partir da aplicação do projeto de prevenção de LP, originado da disciplina pedagógica 'Projetos Aplicativos', em uma unidade de Terapia Intensiva Adulto de um hospital filantrópico do interior do Estado de São Paulo, no período de agosto de 2018 a março de 2019. O projeto de prevenção de LP, foi composto pelas etapas de Brainstorming com a equipe de enfermagem da unidade foco, sendo base para estruturar um treinamento e um instrumento contemplando medidas preventivas (Bundle) e como etapa final a mensuração da efetividade do projeto por meio da análise dos índices de efetividade de prevenção de LP. Resultados: A análise do índice de efetividade de prevenção de LP encontra-se dentro do escopo de responsabilidades do enfermeiro gestor da unidade, sendo o residente de enfermagem inserido nesta atividade na proposta de completude do projeto de prevenção de LP. Foi realizada em duas etapas, uma antecedendo a aplicação do projeto de ação educativa, e a segunda sucedendo as suas etapas, na tentativa de evidenciar se as ações tomadas foram efetivas. Tal prática foi de demasiada importância para construir a prática na vertente gerencial, agregando conhecimento único e experiência no âmbito da residência de enfermagem. Conclusões: A experiência como profissional residente de participar ativamente das etapas do gerenciamento de riscos sobre prevenção de LP e observar sua repercussão nos resultados gerenciais, tornou-se mais integral a construção da perspectiva do cuidado. Os índices de efetividade sugerem a multifatoriedade do desenvolvimento de LP e que outros indicadores devem ser estudados para aprimorar a avaliação ${ }^{3}$.
\end{abstract}

\section{Keywords: ESTOMATERAPIA, INDICADORES BÁSICOS DE SAÚDE, INTERNATO NÃO MÉDICO, LESÃO POR PRESSÃO , UNIDADES DE TERAPIA INTENSIVA}

\section{Referências Bibliográficas}

1. Ministério da Saúde ( Brasil). Portaria $\mathrm{n}^{\circ}$. 529, de $1^{\circ}$ de abril de 2013. Institui o Programa Nacional de Segurança do Paciente (PNSP). Diário Oficial da União 02 abr 2013; Seção 1. 2. Agência Nacional de Vigilância Sanitária . Gestão de Riscos e Investigação de Eventos Adversos Relacionados à Assistência a Saúde. Brasília: ANVISA, 2017. 3. Vasconcelos JMB, Caliri MHL. Ações de enfermagem antes e após um protocolo de prevenção de lesões por pressão em terapia intensiva. Esc Anna Nery 2017;21(Supl 1): e20170001. 


\title{
A ESTOMATERAPIA NO MERCADO DE TRABALHO
}

\author{
Author(s): MÁRCIA DOMINGOS DE OLIVEIRA DA SILVA ${ }^{1}$ \\ Institution(s) ${ }^{1}$ UNITAU - UNIVERSIDADE DE TAUBATÉ (R. Visc. do Rio Branco, 210 - Centro, Taubaté - \\ SP, 12010-020)
}

\begin{abstract}
A ampliação do conhecimento e a atuação do profissional no mercado de trabalho competitivo trouxeram questionamento sobre o enfermeiro estomaterapeuta no mercado de trabalho. A especialização possibilita ao profissional a aplicação e o progresso dos conhecimentos e das habilidades específicas adquiridas, bem como contribui para o reconhecimento e valorização profissional. Objetivo: Conhecer quais são os campos de atuação do enfermeiro estomaterapeuta. Método: Estudo descritivo-exploratório com abordagem quantitativa, realizado com 57 enfermeiros egressos do curso de especialização de enfermagem em estomaterapia da Universidade de Taubaté, desde a abertura do curso no ano de 2000 até o ano de 2016. Para tabulação e análise dos dados coletados por meio de um questionário, foi utilizado o programa Excel, e os resultados foram discutidos a luz da literatura sobre a temática em questão. Resultados: a pesquisa mostrou que a especialidade tem sido um diferencial na vida profissional do estomaterapeuta, proporcionando autonomia, satisfação pessoal e profissional. Quanto aos campos de atuação a maioria 53 (93\%) atuavam na área de feridas e estomias .Em relação ao campo de trabalho o maior quantitativo 19 (33\%) a atuação se deu no ambiente hospitalar, seguido de 09 (16\%) que estavam atuando em negócio próprio e $08(12 \%)$ no ramo comercial. Quanto à remuneração os participantes mostraram satisfação, com salários em torno de $R \$ 4.000,00$ á $R \$ 5.000,00$, podendo chegar a $R \$ 10.000,00$ ou mais. Nas questões abertas sobre ser especialista os participantes referiram que ser estomaterapeuta teve impacto positivo na vida pessoal do egresso $(51,89 \%)$.Conclusão: Os campos de atuação deste profissional são vastos, envolvendo hospitais, clínicas, ambulatório de especialidades, saúde pública, assistência domiciliar, área gerencial, área de docência, comercial e também o trabalho autônomo. O impacto positivo da realização da especialização na vida pessoal e profissional dos pósgraduandos foi evidenciado pelas colocações referentes as novas oportunidades de trabalho, desenvolvimento pessoal e profissional, realização profissional, valorização, maior autonomia, e flexibilidade.
\end{abstract}

Keywords: Estomaterapia, Mercado de trabalho, Especialidades em enfermagem.

\section{Referências Bibliográficas}

1. Costa CMM, Chagas HMA, Matsukura TS, Vieira GI, Marquese EC, Lopez CG, Ghelardi IR, Lefévre A, Lefévre F. Contribuições da pós-graduação na área da saúde para a formação profissional: relato de experiência. Saúde Soc. [periódico online]. 2018 23(4). Disponível em: http://www.scielo.br/pdf/sausoc/v23n4/0104-1290-sausoc-23-4-1471.pdf 2. Thuler SR, Paula MAB, Silveira NI. Sobest 20 anos. Campinas: Arte Escrita; 2012. p. 124. 3. Costa CPM, Squarcina DF, Paula MAB. O especialista em Estomaterapia. In: Paula MAB, Paula PR, Cesaretti IUR, editores. Estomaterapia em foco. São Caetano do Sul: Yends Editora; 2014. p. 2-11. 4. Cesaretti IUR, Dias SM. Estomaterapia: Uma especialidade em Evolução. Acta Paulista Enf. [periódico online]. 2002; 15(4). Disponível em:

http://www2.unifesp.br/acta/index.php?volume=15\&numero=4\&item=res9.htm 5. Machado MH, Oliveira E , Lemos W, Lacerda WF, Filho WA, Wermelinger M, et al. Mercado de trabalho da enfermagem: aspectos gerais [periódico online] . Enferm. Foco 2015; 6 (1/4). Disponível em: http://revista.cofen.gov.br/index.php/enfermagem/article/view/691/301 


\title{
ESTRATÉGIA DE ENSINO APRENDIZAGEM: VÍDEO EDUCATIVO PARA MEDIDAS DE PREVENÇÃO DE LESÃO POR PRESSÃO
}

\author{
Author(s): Angélica Olivetto de Almeida ${ }^{1}$, Ivan Rogério Antunes ${ }^{1}$, Daniela Fernanda dos Santos Alves ${ }^{1}$, \\ Caroline Tosi Bela ${ }^{1}$, Rafael Marques da Silva ${ }^{1}$, Silvia Angélica Jorge ${ }^{1}$ \\ Institution(s) ${ }^{1}$ HC UNICAMP - Hospital de Clínicas da Unicamp (Rua Vital Brasil, 251)
}

\begin{abstract}
Introdução: O vídeo educativo é um recurso didático e tecnológico, disseminador de conhecimentos, o qual pode ser utilizado como estratégia para a formação da consciência crítica e promoção da saúde[1]. Objetivo: Relatar a experiência das etapas para a construção de um vídeo educativo com as medidas de prevenção de lesão por pressão. Método: As etapas de análise e planejamento, modelagem, implementação, avaliação, manutenção e distribuição foram seguidas para a produção do vídeo educativo[2]. Na etapa de modelagem utilizamos o referencial do National Pressure Ulcer Advisory Panel [3] para transformar o conteúdo teórico em linguagem audiovisual. As filmagens foram realizadas com câmera Sony ${ }^{\circledR}$ HXR-NX5N e a edição pelo Software Adobe Premiere $\AA$ e After Effects $\AA$. Os termos de uso das imagens dos profissionais que participaram do vídeo foram obtidos. A autorização do Comitê de Ética em Pesquisa e da Assessoria de Imprensa da instituição foram dispensadas. Resultados: $O$ vídeo educativo, com duração de seis minutos, teve por finalidade orientar profissionais de saúde em relação às medidas de prevenção da lesão por pressão. O conteúdo foi apresentado na forma de narrativa com sobreposição de imagens. Utilizamos o leito hospitalar para dar fidelidade ao vídeo e profissionais especialistas em estomaterapia foram os atores que simularam as medidas de prevenção da lesão por pressão. Para o papel do paciente utilizou-se um paciente padronizado. Os conteúdos abordados no vídeo foram: prevenção de evento adverso, segurança do paciente, definição de lesão por pressão, avaliação da pele, identificação do risco de desenvolvimento da lesão, medidas para minimizar o contato com a umidade, posicionamento e frequência de reposicionamento, uso de superfícies de suporte para evitar fricção e cisalhamento, elevação da cabeceira em $30^{\circ}$ e uso de colchões para reduzir a pressão. Na fase de avaliação e manutenção, especialistas em estomaterapia verificaram o roteiro e fizeram sugestões de correção do conteúdo e de alteração na edição do vídeo. $\mathrm{Na}$ etapa de distribuição o vídeo foi apresentado em uma sessão com a equipe de gerentes e profissionais assistenciais, no anfiteatro da instituição e depois disponibilizado nas redes sociais. $O$ vídeo está disponível no endereço eletrônico $\mathrm{https}: / / \mathrm{www}$.youtube.com/watch?v=UHRxcF91UfE\&t=41s para que outros profissionais de saúde possam ter acesso à informação. Conclusão: O vídeo educativo foi uma estratégia inovadora de ensino aprendizagem e que possibilitou transmitir o conhecimento teórico de forma lúdica aos profissionais, aproximando-os da realidade do seu ambiente de trabalho.
\end{abstract}

Keywords: Educação em Saúde, Estomaterapia, Lesão por pressão, Mídia audiovisual

\section{Referências Bibliográficas}

1. Razera APR; Buetto LS; Lenza NFB; Sonobe HM. Vídeo educativo: Estratégia de ensino-aprendizagem para pacientes em tratamento quimioterápico. Cienc.Cuid.Saude 2013, abr/jun; 13(1):172-177. 2. Falkembach GAM. Concepção e desenvolvimento de material educativo digital. Rev Novas Tecnologias na Educação.2005;3(1):1-15. 3. National Pressure Ulcer Advisory Panel, European Pressure Ulcer Advisory Panel and Pan Pacific Pressure Injury Alliance. Prevention and Treatment of Pressure Ulcers: Quick Reference Guide. Emily Haesler (Ed.). Cambridge Media: Osborne Park, Western Australia; 2014. 


\title{
ATENDIMENTO AMBULATORIAL E DOMICILIAR DO ENFERMEIRO NO TRATAMENTO DE FERIDAS EM ESTADO DO NORDESTE BRASILEIRO
}

\author{
Author(s): Rhaylla Maria Pio Leal Jaques ${ }^{1}$, Pryscila Ravene Carvalho Oliveira Carvalho Oliveira ${ }^{2}$, William \\ Caracas Moreira ${ }^{2}$, Maria Tamires Pio da Silva Alves ${ }^{1}$, Francisco Gilberto Fernandes Pereira ${ }^{2}$ \\ Institution(s) ${ }^{1}$ UESPI - UNIVERSIDADE ESTADUAL DO PIAUI (Rua Olavo Bilac 2335, Teresina, PI, 64001- \\ 280), ${ }^{2}$ UFPI - UNIVERSIDADE FEDERAL DO PIAUI (Universidade Federal do Piauí - UFPI \\ Campus Senador Helvídio Nunes de Barros-Pic)
}

\begin{abstract}
INTRODUÇÃO: A assistência aos pacientes com de lesões de pele é uma atividade característica da atuação profissional na enfermagem ${ }^{1}$, exigindo um cuidar especializado e dinâmico, sobretudo quando se trata de feridas crônicas ou infectadas ${ }^{2}$. Nesse cenário o enfermeiro é o profissional capacitado para avaliar e intervir de forma autônoma no tratamento dos mais diversos tipos de lesões ${ }^{3}$. OBJETIVO: Relatar as práticas do enfermeiro frente ao cuidado ambulatorial e domiciliar de pacientes com feridas em cidade do nordeste brasileiro. MATERIAL E MÉTODO: Trata-se de um relato de experiência, de natureza descritiva. Foi realizado a partir da vivência prestada por enfermeiros de consultório privado especializado no tratamento de feridas, fundado em 2011 e situado na cidade de Picos, localizada na região centro-sul do Piauí. RESULTADOS: Os atendimentos de enfermagem ocorrem desde 2011, quer seja em consultório ou em domicilio, previamente agendados e/ou referenciados pelos diversos serviços de saúde da cidade ou até mesmo por mídia social, tendo uma rotina de pelo menos 4 consultas por dia. Todas as consultas são realizadas por duas enfermeiras, com capacitação para assistência a lesões. Os pacientes assistidos são geralmente egressos de internação em hospitais públicos e/ou privados e portadores de lesões de pele decorrentes de procedimentos cirúrgicos, complicações vasculares, imobilização prolongada, diabéticos descompensados, entre outros. Nas consultas, os pacientes são atendidos individualmente de forma integral, avaliando-os através de protocolos específicos, como: a Sistematização da Assistência de Enfermagem e a ficha de protocolo de atendimento de enfermagem, para cada tipo de lesão a ser tratada. Além disso, há também a avaliação do paciente com relação ao seu estado psicológico, nutricional, presença de morbidades, terapia farmacológica e condições socioeconômicas. E através desta análise, é indicado o tipo de tratamento adequado para cada caso. Vale ressaltar a importância da instrução dos pacientes e acompanhantes sobre as trocas de curativos, cuidados com higiene e sobre o curso do tratamento, bem como seus custos e benefícios, demonstrando como procedê-los. Os resultados positivos são colhidos a partir da percepção de melhora da qualidade de vida do paciente, sendo este um dos marcadores positivos indicados pela Organização Mundial de Saúde no tratamento de feridas. CONCLUSÃO: Percebe-se que a experiência de atendimento de enfermagem a pacientes com lesões de pele, a nível ambulatorial e domiciliar, é caracteriza pela autonomia do enfermeiro, pautada na educação em saúde. A Assistência especializada contribui para prevenção de amputações, redução da cronicidade das feridas e recuperação mais rápida e eficaz, consequentemente promoção da qualidade de vida aos pacientes e cuidadores.
\end{abstract}

Keywords: Cuidados de enfermagem, Ferimentos e Lesões, Estomaterapia

\section{Referências Bibliográficas}

1 - CAUDURO, F. P. et al, atuação dos enfermeiros no cuidado das lesões de pele. Rev. Enf. UFPE on line, v. 12, n. 10, 2018. ${ }^{2}$ - ANDRADE, L. L. et al. Caracterização e tratamento de úlceras do pé diabético em um ambulatório. J. res.: fundam. care. on line, v. 11 n.1, p. 124-128, 2019. ${ }^{3}$ - OLIVEIRA, A. C. et al. Qualidade de vida de pessoas com feridas crônicas. Acta Paul Enferm. v. 32, n. 2, p 194-201, 2019. 


\title{
EDUCAC̄ÃO PERMANENTE COMO ESTRATÉGIA PARA PREVENÇÃO DE LESÃO POR PRESSÄO EM UNIDADE DE TERAPIA INTENSIVA ADULTO: RELATO DE EXPERIÊNCIA
}

\author{
LIZZANDRA VARELA DA COSTA ${ }^{1}$, Debora Alves de Freitas Antonio ${ }^{1}$, Juan Pablo Pereira da \\ Author(s): $\quad$ Silva ${ }^{1}$, Gabriela Bettoni Figueiroa ${ }^{1}$, José Carlos de Oliveira ${ }^{1}$, Paula Rocco Gomes Lima ${ }^{1}$, Helena \\ Ciavatta ${ }^{1}$, Gleice Guarnieri Rossanez ${ }^{1}$, Gisela Carla Ferreira Rodrigues ${ }^{1}$ \\ Institution(s) ${ }^{1}$ PUCCAMP - Pontifícia Universidade Católica - Hospital da PUC Campinas (Av. John Boyd \\ Dunlop, s/no Jardim Ipaussurama - Campinas - SP CEP: 13060-904)
}

\begin{abstract}
Introdução: No cenário assistencial, pacientes de Unidade de Terapia Intensiva (UTI), devido ao alto grau de complexidade, são mais susceptíveis ao desenvolvimento de Lesão por Pressão (LP) e suas complicações, como sepse, maior tempo de hospitalização, acarretando sofrimento do paciente e sua família. A LP é descrita como: "área de lesão de pele e/ou tecidos moles subjacentes, desenvolvida quando o tecido é pressionado de forma excessiva e/ou prolongada, sobre proeminência óssea ou dispositivos".1 Ela é apontada como evento adverso pela Organização Mundial de Saúde (OMS)2, e considerada indicador de qualidade da assistência prestada, tornando constante a busca para mover os profissionais de saúde quanto a esta realidade. Uma estratégia para redução de LP é a educação permanente, como medida de prevenção, estabelecendo relação entre conhecimento e práticas clínicas. Objetivo: Descrever a experiência do enfermeiro residente a partir da execução da educação permanente por meio de treinamentos, com foco nas medidas de prevenção de LP em uma UTI Adulto, no cenário da prática da Residência Multiprofissional em Intensivismo. Material e método: Trata-se de uma pesquisa descritiva, exploratória, qualitativa, tipo relato de experiência, realizada na UTI Adulto de um Hospital filantrópico, universitário, do interior do Estado de São Paulo, que teve como população alvo a equipe de enfermagem, durante o mês de dezembro de 2018. Resultados: O treinamento da equipe de enfermagem da UTI Adulto para prevenção de lesões por pressão, foi desenvolvido como estratégia de educação permanente, a fim de promover a redução dos indicadores de LP deste setor. Inicialmente foram expostos dados obtidos em momento prévio com os técnicos de enfermagem, onde através de brainstorm foram discutidos seus conhecimentos sobre o que ocasiona a LP, formas de prevenção, dificuldades para implementação desses meios e ideias tangíveis para mudar a realidade do setor. Em seguida, foi apresentado a cartilha de práticas seguras do Ministério da Saúde3 e o protocolo institucional de prevenção de LP, demonstrando que os pontos expostos pela equipe estavam de acordo com o preconizado. A partir disso, explanou-se o plano de ação elaborado, sendo inserido na rotina da unidade da seguinte maneira: primeiramente, inserção de "relógios" beira-leito para padronização da mudança de decúbito dos pacientes de acordo com sua escala de Braden; em seguida, exposição do NAS4 para dimensionamento de pessoal; desenvolvimento de atividades de conscientização, maior frequência de reuniões sobre o tema, elaboração de painel criativo e torneio para estímulo da equipe; uso correto de recursos, com exposição de fatores associados a infusão adequada das dietas enterais, uso de colchões e outras barreiras de prevenção; e por fim, o desenvolvimento de um bundle de LP a ser incluído como responsabilidade do enfermeiro. Conclusões: A realização do treinamento permitiu aprofundamento científico, identificação de aspectos a serem trabalhados na prática clínica, com intervenções adequadas a realidade da unidade. A educação permanente utilizada como estratégia de aperfeiçoamento da equipe multiprofissional, particularmente de enfermagem, pode proporcionar uma assistência de maior qualidade, culminando na redução de eventos adversos relevantes, como a lesão por pressão, e consequentemente melhores prognósticos para os pacientes. 5
\end{abstract}

Keywords: Educação Continuada, Estomaterapia, Internato não Médico, Lesão por Pressão, Unidades de Terapia Intensiva

\section{Referências Bibliográficas}

1. National Pressure Ulcer Advisory Panel (NPUAP); 2016. Disponível em: http://www.npuap.org/resources/educational-andclinicalresources/pressure-injury-stagingillustrations/2. Pereira AFM, et al. Pressure injury incidence in a university hospital. Rev Enferm UFPI. 2017 Jan-Mar;6(1):36-9. [Acesso Jun 2019] Disponível em: http://www.ojs.ufpi.br/index.php/reufpi/article/view/5771/pdf 3. Conselho regional de enfermagem. Rede Brasileira de Enfermagem e Segurança do Paciente. 10 passos para a segurança do paciente. São Paulo: COREN-SP; 2010. 4. Queijo AF. Tradução para o português e validação de um instrumento de medida de carga de trabalho de enfermagem em unidade de terapia intensiva: Nursing Activities Score (NAS) [dissertação]. São Paulo: Escola de Enfermagem da Universidade de São Paulo; 2002. 5. Rolim JÁ, Vasconcelos JMB, Caliri MHL, Santos IBC. Prevenção e tratamento de úlceras por pressão no cotidiano de enfermeiros intensivistas. Rev Rene. 2013;14(1):148-50. 


\title{
DIRETRIZES ÉTICAS PARA O EXERCÍCIO DA ESTOMATERAPIA: CONHECIMENTO E GRAU DE IMPORTÂNCIA PARA ENFERMEIROS ESTOMATERAPEUTAS
}

\author{
Author(s): $\quad$ Cristiano Dias ${ }^{1}$, Érica de Cássia Almeida ${ }^{1}$, Maria Angela Boccara de Paula ${ }^{1}$ \\ Institution(s) ${ }^{1}$ UNITAU - Universidade de Taubaté (Rua Visconde do Rio Branco 210, Taubaté/SP)
}

\begin{abstract}
Introdução: A Diretoria da Associação de Brasileira de Estomaterapia: estomias, feridas e incontinências (SOBEST) elaborou em 2016 as Diretrizes Éticas para o exercício da enfermagem em Estomaterapia, frente as necessidades e como consequência do crescimento e evolução da especialidade. Diretrizes estas, que visam contribuir para o direcionamento de condutas profissionais éticas nas áreas de abrangência da Estomaterapia, e ampliar os espaços para o especialista, bem como manter sua credibilidade no contexto social. Objetivos: Verificar o conhecimento dos enfermeiros estomaterapeutas (ETs) sobre as diretrizes éticas e conhecer o grau de importância deste conhecimento no exercício da especialidade. Método: estudo exploratório e descritivo com abordagem quantitativa, participaram 66 ETs que responderam o formulário enviado por e-mail aos associados da SOBEST, contendo 36 perguntas fechadas e cinco abertas. Projeto aprovado pelo Comitê de Ética e Pesquisa (CEP) da Universidade de Taubaté - CAAE: 94980918.2.0000.5501. Resultados: Dos 66 (100\%) participantes, $87,9 \%$ (58) atuavam na estomaterapia, 77,3\% (51) na área de feridas, 30,3\% (20) nas incontinências e $69,7 \%$ (46) junto a pessoas com estomias. Os ETs da região sudeste foram os mais participantes $45 \%$ (30). Afirmaram ter conhecimento sobre a diretriz ética para o exercício da enfermagem em estomaterapia $56(84,8 \%), 29$ participantes (43,9\%) informaram que já emitiram parecer técnico relacionado a estomaterapia. $30(45,5 \%)$ sabiam quais as condições que o ET pode pleitear cargo na diretoria da SOBEST nacional e seção, $42(78,8 \%)$ encaminhavam seus projetos de pesquisa para aprovação pelo CEP, 30 (45,45\%) consideram de fundamental a participação de empresas ou distribuidoras de materiais e equipamentos e apresentação dos portfólios de produtos no local em que trabalhavam; $62(93,94 \%)$ achavam essencial utilizar na assistência produtos e equipamentos com o registro na ANVISA; 36 (54,55\%) utilizavam descrições genéricas de produtos e equipamentos; $27(40,91 \%)$ faziam prescrição com nome comercial de produtos de empresas produtoras ou distribuidoras de materiais e equipamentos em receituários; 49 (74,24\%) achavam fundamental afastar-se de seu atendimento por conflito que não possa ser resolvido e documentar os fatos em prontuário. Conclusão: Os resultados do estudo mostraram que as diretrizes éticas para o exercício da estomaterapia ainda não é conhecida por todos os ETs, ainda existem dúvidas, mas os participantes consideravam importante sua contribuição para o direcionamento de condutas éticas profissionais.
\end{abstract}

Keywords: Estomaterapia, Ética em Enfermagem, Códigos de Ética

\section{Referências Bibliográficas}

Associação Brasileira de Estomaterapia (SOBEST). Diretrizes Éticas para o exercício da Estomaterapia no Brasil. São Paulo, 2016; 1-15p. Disponível em:http://www.sobest.org.br/arquivos/codigo-de-etica-sobest.pdf>. Acessado em 01/07/2019. Paula MAB, Santos VLCG. O significado de ser especialista para o enfermeiro estomaterapeuta. Rev Latinoam Enfermagem. 2003; 11(4):474-82. Yamada BFA, Rogenski NMB, Oliveira PA. Aspectos Históricos Éticos e Legais da Estomaterapia. Estima. 2003; 1(2). 


\title{
A EDUCAÇÃO PERMANENTE COMO PERCURSO PARA A CONSTRUÇÃO DE UMA TECNOLOGIA EDUCATIVA PARA PREVENÇÃO E TRATAMENTO DE LESÃO POR PRESSÃO E DERMATITE ASSOCIADA À INCONTINÊNCIA
}

\author{
Author(s): JAQUELINE APARECIDA DOS SANTOS SOKEM ${ }^{1}$, Fabiana Perez Rodrigues Bergamaschi ${ }^{2}$, \\ Elaine Aparecida Mye Takamatu Watanabe ${ }^{2}$ \\ Institution(s) ${ }^{1}$ HU-UFGD/Ebserh - Hospital Universitário da UFGD (Rua Ivo Alves da Rocha, n. 558. Altos do \\ Indaiá. CEP: 79823-501. Dourados-MS), ${ }^{2}$ UEMS - Universidade Estadual de Mato Grosso do Sul \\ (Cidade Universitária de Dourados. Caixa postal 351. CEP: 79804-970. Dourados-MS )
}

\begin{abstract}
Introdução: A educação permanente em saúde é entendida como uma prática de ensino-aprendizagem no trabalho, que busca concretizar a ideologia do SUS quanto à atenção integral à saúde das populações com melhorias das práticas realizadas. Em âmbito hospitalar, os profissionais de enfermagem são os mais envolvidos nos cuidados com a pele dos pacientes. Portanto, estes necessitam empoderar-se de informações embasadas cientificamente para a promoção da segurança do paciente. Identificam-se como lesões prevalentes em hospitais, a lesão por pressão (LP) e a dermatite associada à incontinência (DAI). A LP é uma lesão de pele, decorrente de uma pressão não aliviada ou da combinação da pressão com o cisalhamento. Já a DAI é definida como uma inflamação da pele, decorrente da umidade excessiva, comum em pacientes incontinentes. Dessa maneira, a educação permanente deve ser adotada como estratégia para atualização dos profissionais em saúde1-2. Objetivo: Construir um guia técnico para educação em saúde de profissionais, voltado ao cuidado de clientes com lesão por pressão e dermatite associada à incontinência, baseado em uma intervenção educativa. Material e Método: Estudo de intervenção educativa, com amostra não probabilística por conveniência, desenvolvido em duas etapas. Na primeira etapa, ocorreu a intervenção em si, com abordagem qualitativa, na qual desenvolveu-se encontros educativos sobre LP e DAl. Os sujeitos do estudo foram sete servidores de enfermagem da Clínica Médica do $X X X X X X X X X$. Pesquisa aprovada pela Comissão de Ética da instituição e pelo Comitê de Ética em Pesquisa da XXXXXXXXXXX XXXXXXX XX XXXX XXXXXX XX XXX, com parecer n. XXXXXXX e CAAE n. XXXXXXXX. Na segunda etapa, elaborou-se um guia, baseado nesta intervenção, construído conforme orientações para elaboração de tecnologias educativas. O material é proveniente de dissertação do $X X X X X X X X X X X X X X X X$ em $X X X X X X X X X X X$ da $X X X X$. O guia baseou-se nos referenciais teóricos de Paulo Freire, da Metodologia da Problematização e da Educação Permanente em Saúde.1,3-5.

Resultados: O intuito do guia é subsidiar profissionais para o desenvolvimento de atividades educativas sobre essas lesões. O material tem a intenção de direcionar a prática educativa em serviço partindo da problematização e da construção de um conhecimento e de um processo de ensino mais significativo e transformador. As atividades descritas são voltadas para pequenos grupos, para discussão no local de trabalho, buscando o diálogo e reflexão das práticas. Este material possui três seções. A primeira seção aborda conceitos teóricos, trazendo referenciais do autor Paulo Freire, da Educação Permanente em Saúde e da Metodologia da Problematização. Na segunda seção, estão descritas as atividades realizadas sobre LP e os conceitos teóricos sobre este agravo. Na terceira seção, estão relatadas as atividades sobre DAl e os subsídios conceituais sobre $\quad$ este $\quad$ evento. Conclusões: Este guia pode auxiliar tanto no aprofundamento do conhecimento sobre estas lesões, como pode contribuir para profissionais que já dominam este assunto, mas desejam trabalhar estes conteúdos conforme os pressupostos da Educação Permanente em Saúde. Espera-se que este guia possa contribuir para a implementação de processos educativos e para a melhoria da assistência prestada aos clientes.
\end{abstract}

Keywords: Estomaterapia , Lesão por Pressão, Dermatite, Educação em Enfermagem, Segurança do Paciente

\section{Referências Bibliográficas}

1. Brasil. Ministério da Saúde. Portaria no. 198/GM/MS de 13 de fevereiro de 2004. Institui a Política Nacional de Educação Permanente em Saúde como estratégia do Sistema Único de Saúde para a formação e o desenvolvimento de trabalhadores para o setor. Brasília (DF): Ministério da Saúde; 2004. 2. National Pressure Ulcer Advisory Panel, European Pressure Ulcer Advisory Panel, Pan Pacific Pressure Injury Alliance. Prevention and Treatment of Pressure Ulcers: Quick Reference Guide [Internet]. Emily Haesler (Ed.). Cambridge Media: Osborne Park, Australia; 2014 [citado 2018 Set 27]. Disponível em: https://proqualis.net/manual/prevenção-de-úlceras-de-pressão-guia-de-consulta-rápido. 3. Teixeira E, Mota VMSS. Tecnologias educacionais em foco. São Caetano do Sul, SP: Difusão Editora; 2011. 4. Freire PRN. Pedagogia da autonomia: saberes necessários à prática educativa. São Paulo: Paz e Terra; 2011. 5. Berbel NAN. A metodologia da problematização com o Arco de Maguerez: uma reflexão teórico-epistemológica. Londrina: EDUEL; 2012. 


\title{
CONSTRUÇÃO E ANÁLISE DE DADOS DE UM AMBULATÓRIO DE CUIDADOS COM A PELE NUM SETOR PRIVADO DE CURITIBA-PR NOS ANOS DE 2017 E 2018 - RELATO DE EXPERIÊNCIA
}

\author{
Author(s): $\quad$ Tamires Alves da Silva ${ }^{1}$ \\ Institution(s) ${ }^{1}$ CLINIPAM - CLÍNICA PARANAENSE DE ASSISTÊNCIA MÉDICA (XV DE NOVEMBRO, \\ $556,1^{\circ}$ ANDAR, GALERIA LUSTOZA)
}

\begin{abstract}
Introdução: O setor de saúde privado está em grande ascensão no Brasil, consequentemente o número de clientes com doenças crônicas aumentou. $\mathrm{O}$ trabalho de gerenciamento e cuidado desses pacientes em potencial risco de desenvolver complicações, deve ser realizado com foco na prevenção (4). Nesse contexto, o ambulatório de cuidados com a pele foi criado em 2017 para prevenir e tratar lesões cutâneas. Objetivo: Descrever o processo de construção e análise de dados de um ambulatório de cuidados com a pele no setor privado de Curitiba/PR nos anos de 2017 e 2018. Método: Relato de experiência, desenvolvido no setor de gerenciamento de crônicos que atua desde 01/01/2004, com população atual de 21.244 indivíduos, sendo 5.497 com diabetes. A metodologia utilizada para a construção do projeto foi o CANVAS (Quadro de modelo de negócios), uma ferramenta que proporciona uma visão geral de uma empresa em nove blocos, descritos em uma só folha de papel, mostrando a lógica de como uma organização pretende funcionar $(1,3)$. O ambulatório foi crescendo junto com o aumento de atendimentos e foi criado um protocolo, aonde se padronizou coberturas, procedimentos, tipos de lesões e descrito funções de cada membro da equipe multiprofissional. Resultados: O número de pacientes novos atendidos em 2 anos foi de 315, sendo 234 pacientes com feridas com total de 110 altas, tendo uma taxa de $47 \%$ de lesões cicatrizadas. O atendimento de podiatria foi iniciado em 2018 e beneficiou 81 pacientes que não desenvolveram pé diabético nesse período. O perfil de feridas dos pacientes atendidos no ambulatório em 2017 foram: $38 \%$ úlceras, $29 \%$ pé diabético, $13 \%$ trauma, $7 \%$ lesão por pressão, $7 \%$ deiscência cirúrgica, $4 \%$ rara, $2 \%$ erisipela. No ano de 2018, houve redução de úlceras para $28 \%$, pois a rede de atendimento já conhecia o ambulatório e fidelizou os pacientes e pé diabético para 17\% através do atendimento de podiatria. A adesão em 2017 era 50\% e aumentou para $64 \%$ em 2018 e a desistência foi 15,9\% em 2017, reduziu para 14,8\% em 2018. A taxa de produtividade de agenda nesses anos variou de $65 \%$ a $70 \%$. Conclusão: A criação de um ambulatório é um processo amplo e dinâmico, principalmente se ele for desenvolvido dentro de um setor privado, aonde o custo se sobressai em todo o momento, o ideal é ter sempre uma análise de dados mostrando resultados, principalmente positivos. É necessário ter um bom planejamento, muita força de vontade para implementar o processo de trabalho e uma equipe disposta a se doar e inovar (2). Vivenciar a prática e a rotina do enfermeiro estomaterapeuta dentro de um ambulatório de cuidados com a pele é uma aprendizagem constante, são poucos os profissionais que conseguem trabalhar na área clínica e ao mesmo tempo na gestão ou criando e desenvolvendo algo, e se faz notório que, o número de publicações nos guiando para uma nova metodologia de inovação é escassa. Dessa forma, a criação de projetos de inovação e empreendedorismo no interior dos setores de trabalho se faz necessário.
\end{abstract}

Keywords: Empreendedorismo, Enfermagem, Estomaterapia, Inovação em saúde

\section{Referências Bibliográficas}

(1) BONAZZI, Fábio Luiz Zandoval; ZILBER, Moises Ari. Inovação e Modelo de Negócio: um Estudo de Caso Sobre a Integração do Funil de Inovação e o Modelo Canvas. Revista Brasileira de Gestão de Negócios, São Paulo, v. 16, n. 53, p. 616-637, out./dez. 2014. DOI: 10.7819/rbgn.v16i52.1812 (2) COLICHI, Rosana Maria Barreto; LIMA, Stella Godoy Silva; BONINI, Andrea Bueno Benito; LIMA, Silvana Andrea Molina. Empreendedorismo de Negócios e Enfermagem: Revisão Integrativa. Revista Brasileira de Enfermagem, 72, volume 1, p. 335-45, 2019. DOI: http://dx.doi.org/10.1590/0034-71672018-0498 (3) DORF, Bob; BLANK, Steve. The Startup Manual - The Step-by-step Guide for Building a Great Company. K\&Ranch, Inc. Publishers. Pescadero, California, USA - 2012. P. 571 (4) LIEDKE, Deise Cristina Furtado; JOHANN, Derdried Athanasio; DANSKI, Tania Reichembach. Consultório de Enfermagem para Tratamento de Feridas em Hospital de Ensino. Cogitare Enfermagem, V. 19, n. 3, p. 590-6, Jul/Set 2014. Disponível em: < https://revistas.ufpr.br/cogitare/article/view/34486/23254> Acesso em: 01/08/2019 


\title{
Desafios na prevenção e tratamento da Lesão por pressão: Percepção de enfermeiros intensivistas
}

\author{
Author(s): Paula de Souza Silva Freitas ${ }^{1}$, Amanda de Souza Laranjeiras ${ }^{3}$, Fabiana Gonring Xavier ${ }^{1}$, Larissa \\ Carolina Xavier Lacerda Lamonato ${ }^{3}$, Aline de Oliveira Ramalho ${ }^{2}$ \\ Institution(s) ${ }^{1}$ UFES - Universidade Federal do Espirito Santo (Av. Fernando Ferrari, 514 - Goiabeiras, Vitória - \\ ES, 29075-910), ${ }^{2}$ EEUSP - Escola de Enfermagem da Universidade de São Paulo (Av. Dr. Enéas \\ Carvalho de Aguiar, 419 - Cerqueira César, São Paulo - SP, 05403-0), ${ }^{3}$ UFES - 2 Universidade \\ Federal do Espírito Santo/Centro Universitári (Rod. Gov. Mário Covas, BR-101 - km 60 - \\ Litorâneo, São Mateus - ES, 29932-540)
}

\begin{abstract}
Introdução: A Lesão por Pressão (LP) é um evento adverso definido como dano localizado na pele e/ou tecidos moles adjacentes relacionado a pressão, fricção e cisalhamento1. Sua alta incidência é considerada um indicador de má qualidade do cuidado de enfermagem. Na Unidade de Terapia Intensiva a incidência de LP é alarmante, devido à presença de pacientes com maior risco de desenvolvimento2. Os enfermeiros são profissionais responsáveis pela avaliação de risco desse dano, bem como fundamentais na sua prevenção3. Objetivo: Identificar a percepção dos enfermeiros intensivistas sobre os desafios encontrados no processo de prevenção e tratamento da LP. Metodologia: Trata-se de um estudo qualitativo, desenvolvido em dois hospitais de um município do estado do Espírito Santo, sendo um público e outro privado. Foram entrevistados 15 enfermeiros assistenciais das unidades de terapia intensiva das instituições. Os dados foram coletas por meio de entrevistas semiestruturadas. Para a análise dos dados utilizou-se a Análise de Conteúdo Temática proposta por Bardin4. Resultados: Os desafios e dificuldades encontrados para assistência de enfermagem na prevenção e tratamento de LP foram agrupados em três categorias: 1) Recursos humanos subdimensionado e pouco qualificado. 2) Escassez de recursos materiais, com falta de dispositivos para prevenção de LP. Quanto à disponibilidade de coberturas para tratamento, notou-se a existência de mais opções no hospital público e um acesso facilitado, quando comparado ao hospital privado, que possui um quantitativo menor de coberturas e um processo de liberação mais burocrático. 3) Entraves associados ao processo de trabalho, como a sobreposição de papéis do enfermeiro, descontinuidade das condutas adotadas e comunicação ineficaz entre a equipe de enfermagem. Também foi relatado o descomprometimento da equipe de enfermagem, com baixa adesão às rotinas, fluxos e protocolos referente a prevenção e tratamento de LP. Discussão: No que se refere aos recursos humanos insuficientes, às instituições de saúde carecem de utilizar o sistema de classificação de pacientes à fim de estabelecer uma assistência de enfermagem adequada com equipe dimensionada qualiquantitativamente. É preciso dimensionar a equipe a partir dos parâmetros do Conselho Federal de Enfermagem e não conforme os paramentos mínimos estabelecidos pela ANVISA. Quanto à baixa qualificação dos profissionais no tratamento de lesões de pele, pesquisas demonstram que os enfermeiros apresentam um déficit de atualização em algumas áreas específicas, como a Estomaterapia. Já na esfera de recursos materiais, estudos evidenciam que a gestão de suprimento de material médico-hospitalar é delegada à colaborados não qualificados e há o mau uso dos materiais nas instituições. No que tange ao processo de trabalho, deve ser considerado a implementação de protocolos de tratamento, com investimento em comunicação efetiva entre os profissionais. Considerações finais: Para uma melhor atuação dos enfermeiros na prevenção e tratamento de LP é necessário investir em dimensionamento adequado, bem como em conhecimentos e habilidades, obtidos por meio de cursos de treinamento, atualização ou de especialização na área de tratamento de feridas. É fundamental incentivar os enfermeiros a serem protagonista desse cuidado.
\end{abstract}

Keywords: Lesão por pressão, Enfermagem, prevenção, Cuidados Intensivos, Estomaterapia

\section{Referências Bibliográficas}

1 PETZ F F C. et al. Úlcera por pressão em unidade de terapia intensiva: estudo epidemiológico. Revista de Enfermagem UFPE. 2017 (11) 1: 287-295. 2 PALAGI S. et al. Laserterapia em úlcera por pressão: avaliação pelas Pressure Ulcer Scale for Healing e Nursing Outcomes Classification. Revista da Escola de Enfermagem da USP. 2015 (49) 5: 826-833. 3 CONSELHO FEDERAL DE ENFERMAGEM (COFEN) - Resolução COFEN no 567/2018 - Regulamenta a atuação da Equipe de Enfermagem no Cuidado aos pacientes com feridas. 4 LACERDA M R, COSTERANO R G S. Metodologias da Pesquisa para Enfermagem e Saúde. 1. ed. Rio de Janeiro: Moriá, 2016. 


\title{
ELABORAÇÃO DE UM PROTOCOLO PARA PREVENÇÃO DE LESÃO POR PRESSÃO EM PACIENTES CRÍTICOS SUBMETIDOS A POSIÇÃO PRONA
}

\author{
Author(s): $\quad$ Aline de Oliveira Ramalho ${ }^{1}$, Raíssa Marcandalli Deliberai ${ }^{1}$, Eliane Mazócoli ${ }^{1}$ \\ Institution(s) ${ }^{1}$ HSL - Hospital Sírio Libanês (Rua Adma Jafet, 91)
}

\begin{abstract}
Introdução: O Decúbito Ventral mais conhecido como posição Prona, é uma técnica indicada para pacientes com insuficiência respiratória hipoxêmica refrataria ao uso de oxigênio, muito utilizada na Síndrome do Desconforto Respiratório Agudo1, existe grande evidência na literatura de que esses pacientes se beneficiam do suporte ventilatório realizado nessa posição .2 Porém os pacientes submetidos a posição prona apresentam riscos elevados para desenvolvimento de Lesão por Pressão (LP), com uma incidência de $34 \%$ dos casos, causando de modo geral um aumento no tempo de internação, aumento no custo do tratamento e impacto na qualidade de vida dos pacientes.1 As LP são consideradas um grande desafio para a equipe e sua ocorrência gera impacto negativo sobre a assistência prestada, pois grande número dos casos poderia ser evitado através de medidas preventivas.3 Objetivo: Elaborar um protocolo institucional e um folder para ser consultado a beira leito sobre prevenção de LP nos pacientes críticos submetidos a posição prona nas Unidades de Terapia Intensiva (UTI) do hospital onde o trabalho foi realizado. Método: Trata-se de um projeto aplicativo interventivo com abordagem metodológica qualitativa, realizado para conclusão de residência multiprofissional no cuidado ao paciente crítico. Para atingir o objetivo foram realizadas as seguintes etapas: 1) Revisão da literatura para embasamento científico; 2) Realização de fotos no centro de simulação realística como método didático a ser inserido no protocolo e no folder, demonstrando no manequim vivo os cuidados que devem ser realizados; 3) Construção da estrutura do protocolo com base nas evidências encontradas; 4) Elaboração do folder contendo os principais cuidados. Conclusões: A elaboração do protocolo se mostrou viável e relevante, por se tratar de um procedimento com risco elevado para desenvolvimento de LP, que necessita de medidas especificas para prevenção, com evidência científica de que protocolos/diretrizes diminuem a incidência de complicações e pelo fato da instituição em questão não possuir um documento interno, disponível a todos, a respeito do assunto.1,5,6 Concluímos então, que a criação de um documento institucional e um folder de orientações a ser usado beira leito, poderá auxiliar a equipe multiprofissional a prestar uma assistência mais segura, colocando o paciente como centro do cuidado.
\end{abstract}

Keywords: Lesão por pressão, Estomaterapia, prevenção, Paciente crítico

\section{Referências Bibliográficas}

1. Mora-Artiaga JA, Bernal-Ramirez OJ, Rodriguez SJ. Efecto de La ventilación mecánica em posición prona em pacientes com síndrome de dificultad respiratoria aguda. Uma revisión sistemática y metanálisis. Rev. Méd. La Paz [Internet]. 2015 [citado em: 2018 dez. 26]; 21( 2 ): 100-100. Disponível em:

http://www.scielo.org.bo/scielo.php?script=sci_arttext\&pid=S1726-89582015000200014 2. Aguiar FJ, Zampieri FG. Síndrome do desconforto respiratório agudo. In: Besen BAMP, Nassar Junior AP, Azevedo LCP. Medicina Intensiva Revisão Rápida. Santana de Parnaíba (SP): Manoele; 2018. P. 483-93. 3. Fitzpatrick MA. Pressure Injeuries... Prevention across the acute-care continuum. American Nurse Today [internet] 2018 maio [citado em : 2018 dez.]; P. 1-1. Disponível em: https://www.americannursetoday.com/wp- content/uploads/2018/05/DabirSupplement_May2018.pdf 4. Caleman G, Lima VV,Oliveira MS, Silva SF, Massaro A, Gomes R, et al. Projeto Aplicativo: termos de referência. 1 ed., São Paulo: Instituto Sírio Libanês de Ensino e Pesquisa; Ministério da Saúd,2016. 54p. (Projetos de Apoio ao SUS). 5.Sullivan N, Schoelles KM. Preventing In-Facility Pressure Ulcers as a Patient Safety Strategy: A Systematic Review. Ann Intern Med. [Internet] 2013 [Citado em janeiro 2019]; 158:410-416. Disponível em: https://www.ncbi.nlm.nih.gov/pubmed/23460098 6. Oliveira VM, Weschenfelder ME, Deponti G, Condessa R, Loss SH, Bairros PM et al. Good practices for prone positioning at the bedside: Construction of a care protocol. AMB rev. Assoc. Med. Bras.[Internet]. 2016 junho [citado em: 2018 ago. 21]; . Disponível em: http://dx.doi.org/10.1590/1806-9282.62.03.287 


\title{
REDUÇÃO dOS EVENTOS ADVERSOS RELACIONADO A LESÃO POR PRESSÃO EM UM HOSPITAL PÚBLICO DO ESTADO DE SERGIPE
}

\author{
Author(s): Mônica Rabelo santos ${ }^{1}$, Priscilla Alcântara dos Santos ${ }^{1}$ \\ Institution(s) ${ }^{1}$ HUSE - HOSPITAL DE URGÊNCIA DE SERGIPE (AV: TANCREDO NEVES, BAIRRO \\ CAPUCHO)
}

\begin{abstract}
Lesão por pressão é definida como um dano localizado na pele e/ou tecido mole subjacente, geralmente sobre proeminência óssea, ou relacionada ao uso de dispositivo médico ou artefato. A lesão ocorre como resultado de intensa e/ou prolongada pressão ou pressão combinada com cisalhamento e pode se apresentar em pele íntegra ou como úlcera aberta, e ser dolorosa. Os fatores para o desenvolvimento de lesão são multicausais, a tolerância do tecido mole à pressão e ao cisalhamento pode também ser afetada pelo microclima, nutrição, perfusão, comorbidades e pela sua condição. Com o propósito de reduzir danos decorrentes da internação do pacientes em unidades hospitalares, o Ministério da saúde criou o Programa Nacional de Segurança do Paciente, lançando protocolos de prevenção de incidentes,entre eles, está a de prevenção de lesão por pressão. Segundo o protocolo, as principais medidas de prevenção são a avaliação dos pacientes em risco; o manejo do estado nutricional incluindo a hidratação, inspeção e avaliação diária da pele; o manejo da umidade e a redistribuição da pressão. A escala de Braden é o instrumento utilizado para classificar o paciente quanto ao risco de ocorrência dos eventos adversos. É um problema grave e os danos causados têm implicações significativas na mortalidade, morbidade, qualidade de vida, pois afetam negativamente os pacientes em todos os contextos da assistência à saúde.A LP representa um grave problema envolvendo o sofrimento de pessoas, aspectos econômicos e um desafio interdisciplinar, uma vez que consome grande quantidade de recursos do sistema de saúde e horas de assistência de enfermagem, devido ao seu tratamento prolongado e de alto custo.A construção de protocolos pelo núcleo de segurança do paciente, e as capacitações realizadas pela comissão de prevenção e tratamento de lesão na pele do hospital, para as equipes multidisciplinar, foi um fator primordial para disseminar as medidas preventivas necessárias para prevenção de LP. Objetivo- Mostrar a redução da incidência de lesão por pressão em um hospital público do estado de Sergipe após medidas preventivas adotadas pele instituição. Material e Método - Foi realizado coleta de dados em planilhas do núcleo de segurança do ano 2018 do hospital. Resultado - Os dados coletados mostram que houve uma redução de danos leves de $27 \%$ para $6 \%$, danos moderados $37 \%$ para $26 \%$ e de danos graves de $45 \%$ para $19 \%$, e consequentemente a redução de LP em todo o hospital. Conclusão - Diante do exposto, observamos que a construção do protocolo pelo núcleo de segurança e a implementação pela equipe da comissão de prevenção e tratamento na pele com as capacitações, mostrando as medidas preventivas adotadas foram o sucesso do resultado alcançado. Com isso, houve uma melhora na assistência ao paciente internado na instituição e redução do tempo de permanência e gastos com insumos hospitalares.
\end{abstract}

\section{Keywords: EVENTOS ADVERSOS, LESÃO POR PRESSÃO, CUIDADOS DE ENFERMAGEM}

\section{Referências Bibliográficas}

1- GEOVANINI, T. Tratado de feridas e curativos: enfoque multiprofissional. São Paulo: Rideel, 2014. 2-MALAGUTTI, W. Feridas; Conceito e Atualidades. Editora Martinari, São Paulo,2014. 3-OLIVEIRA, B. G. R. B. et al. Uso do curativo de alginato de cálcio e sódio em úlcera venosa: relato de caso. Revista Enfermagem Atual In Derme, v. 72. 2015. 4BORGES,E.L.DOMANSKY,R.T. Manual para Prevenção de Lesões de Pele. Editora Rubio,Rio de Janeiro,2012. 


\title{
O ENVOLVIMENTO DE UM GRUPO DE REFERÊNCIA DE PELE NA REDUÇÃO DAS LESÕES POR PRESSÃO
}

\author{
Elisandra Leites Pinheiro ${ }^{1}$, Daniela Tenroller de oliveira ${ }^{1}$, Sandra Maria Cezar Leal Cezar Leal ${ }^{1}$, \\ Author(s): Cátia Cilene dos santos Naziazeno ${ }^{1}$, Caroline Focchesatto ${ }^{1}$, Vanessa da Silva ${ }^{1}$, Patricia pedroso da \\ Silva ${ }^{1}$ \\ Institution(s) ${ }^{1}$ HMV - hospital moinhos de vento (Ramiro Barcelos 530 )
}

\begin{abstract}
Introdução: Lesão por pressão (LPP) é uma lesão localizada na pele e/ou no tecido subjacente, resultante de pressão isolada ou combinada com fricção e/ou cisalhamento, ou ainda por dispositivos médicos.1 Quando ocorrem causam maior tempo de hospitalização, riscos de infecção, dor e aumento dos custos.2 Resultados de estudos mostram que medidas preventivas, assim como a atuação de grupos de referência em cuidados com a pele em ambiente hospitalar, reduzem significativamente a ocorrência de lesões.3 Objetivo: Investigar a prevalência de LP em um hospital privado, antes e após a implantação de protocolo de avaliação diária de risco de LP. Método: Estudo quantitativo descritivo como parecer CAAE: 57679316.9.0000.5330, em 2016, o Grupo de Referência em Estomaterapia (GREST) criou um para avaliação diária com escala de Braden, para identificar precocemente risco de o paciente desenvolver LP, durante a hospitalização. A cada avaliação é disparado um "gatilho" via e-mail, para o GREST com a informação dos pacientes internados, classificados com alto risco para desenvolver LPP. Assim, está sendo possível analisar o percentual de pacientes que estão recebendo o cuidado preventivo, constituído por sete processos: fluxograma de prevenção de LP; pacientes hemodinamicamente instáveis no Centro de terapia intensiva adulto; prevenção de LP no bloco cirúrgico; na pediatria; em lesões por dispositivo e adesivo médico; tratamento de LP e recusa do paciente frente às medidas preventivas, a prevalência de LPP foi comparada nos anos de 2016, 2017 e 2018, considerando o período antes de (2016) e depois de (2017 e 2018) da implantação do protocolo. Resultados: Em 2016 a prevalência de LPP foi de 4,86\%, 2017 foi de 3,98\% e 2018 foi de 2,94\%. As taxas de prevalência mostraram uma grande melhora de 2016 para os dias atuais, em torno de $60 \%$ de redução. Conclusão: Observa-se que as medidas preventivas e o envolvimento de profissionais engajados nas melhores práticas, mostram-se eficazes e importantes para um cuidado efetivo e de qualidade, são determinantes no tempo de internação e redução de custos para instituição, e que a tecnologia é aliada da assistência para um processo verdadeiro de cuidado centrado ao paciente.
\end{abstract}

Descritores: Estomaterapia; Lesão por Pressão; Indicadores de Qualidade em Assistência à Saúde.

Keywords: Estomaterapia;, Lesão por Pressão, Indicadores de Qualidade em Assistência

\section{Referências Bibliográficas}

1. Agência Nacional de Vigilância Sanitária: Práticas seguras para prevenção de lesão por pressão em serviços de saúde.ANVISA Outubro/2017. 2. Documento de consenso da Word Union Healing Societies (WUWHS). O papel das coberturas na prevenção da lesão por pressão.WoundsInternational, 2016. 3. Krause TCC, Assis GM, Danski TR. Implantação de uma Comissão de Cuidados com a Pele em um Hospital de Ensino. v.14 n.1, p. 13-20, 2016 


\title{
DESENVOLVIMENTO DE UMA ESTRATÉGIA PEDAGÓGICA PARA UTILIZAÇÃO DA ESCALA DE BRADEN EM HOSPITAL UNIVERSITÁRIO PÚBLICO
}

\author{
Margarete de Araújo Andrade ${ }^{1}$, Desirée Ariane Modos Figueira ${ }^{2}$, Mariana Sbeghen Menegatti ${ }^{2}$, \\ Author(s): $\quad$ Renata Pedrão Leme Motomatsu ${ }^{1}$, Elisana Agatha I. Camargo Cabulon ${ }^{1}$, Magali Godoy Pereira \\ Cardoso ${ }^{1}$, Larissa Gutierrez de Carvalho Silva ${ }^{2}$, Alexsandro Dias de Oliveira ${ }^{1}$ \\ Institution(s) ${ }^{1}$ HUL - Hospital Universitário de Londrina (Avenida Robert Koch, $\mathrm{n}^{\circ} 60$ ), ${ }^{2}$ UEL - Universidade \\ Estadual Londrina (Avenida Robert Koch, nº6)
}

\begin{abstract}
Introdução: A lesão por pressão (LP) é uma lesão cutânea que se dá principalmente sobre proeminências ósseas em consequência de pressão prolongada e pode estar associada ao cisalhamento. Além da pressão, existem fatores condicionantes como: nutrição, perfusão tecidual, comorbidades, entre outros. Sabe-se que é significativa a incidência e a prevalência de LP durante internações hospitalares prolongadas ${ }^{1}$. Com a intenção de instrumentalizar a avaliação de risco e possibilitar o emprego de medidas de prevenção às lesões de pele foi implementada a utilização de instrumentos de mensuração como a Escala de Braden (EB). Objetivo: O presente estudo tem como objetivo descrever o desenvolvimento de estratégia pedagógica com o objetivo de aperfeiçoar e qualificar a utilização da Escala de Braden (EB) em hospital universitário público. Método: Estudo descritivo, do tipo relato de experiência, realizado por enfermeiras que atuam junto à Comissão de Prevenção de Lesão de Pele (CPLP) da instituição, serviço implantado com o intuito de prestar assessoria especializada às unidades assistenciais. $O$ estudo foi desenvolvido em hospital universitário público de alta complexidade, situado no norte do Paraná. Resultado: A identificação de fragilidade quanto à compreensão da EB e sua adequada utilização pela equipe de enfermagem foi o disparador para o desenvolvimento de uma estratégia pedagógica que resultou na elaboração de um instrumento impresso em papel sulfite A4 e plastificado na gráfica da instituição, que associou a ES aos devidos cuidados de enfermagem. Com o intuito de deixa-lo mais atrativo foram utilizados recursos visuais, como cores para organização do instrumento, relacionando-as ao risco para desenvolver uma LP: a cor azul para pontuação (>19) Sem Risco; cor verde para Risco Baixo (15 a 18 pontos); cor amarela para Risco Moderado (13 a 14 pontos); cor laranja para Risco Alto (10 a 12); e cor vermelho para Risco Muito Alto (
\end{abstract}

Keywords: Estomaterapia, Lesão por pressão, Educação em Enfermagem

\section{Referências Bibliográficas}

1. Wechi, JS, Amante, LN, Salum, NC, Matos, E, Martins, T. Escala de Braden: instrumento norteador para a prevenção de úlceras por pressão. ESTIMA, Braz J Enterostomal Ther. 2017;15(3). 2. Moraes, JT, Borges, EL, Lisboa, CR, Cordeiro, DCO, Rosa, EG, Rocha, NA. Conceito e classificação de lesão por pressão: atualização do National Pressure Ulcer Advisory Panel. Rev. enferm. Cent.-Oeste Min. 2016; 6(2). 3. National Pressure Ulcer Advisory Panel (NPUAP). Pressure Injury Stages [periódico na Internet]; 2016. [acesso em 10 Jul 19]; Disponível em: http://www.

npuap.org/resources/educational-and-clinical-resources/ npuap-pressure-injury-stages. 


\title{
Implantação de um grupo de atenção à pele e estomias em um hospital de grande porte da cidade de São Paulo
}

\author{
Author(s): Mitsue da Silva Hatanaka ${ }^{1}$, Fabiana Cristina de Oliveira Silva ${ }^{1}$, Patricia Lippi da Cruz ${ }^{1}$, Vanessa \\ Ferreira Malta Paravani ${ }^{1}$, Vanessa Faustino Eugenio ${ }^{1}$ \\ Institution(s) ${ }^{1}$ BP - Beneficência Portuguesa de São Paulo (Rua Maestro Cardim 769)
}

\begin{abstract}
Objetivo: Descrever a implantação de um grupo de atenção à pele e estomias em um hospital de grande porte da cidade de São Paulo.

Método: Pesquisa descritiva documental, realizada no período de Agosto de 2016 à Julho de 2019, por meio de consulta a documentos institucionais.

Introdução: Desde a década de 80, os cuidados com a pele já faziam parte do cotidiano da enfermagem dentro da instituição. Eram realizados pela comissão de curativos (COC), composta por enfermeiro e auxiliares de enfermagem responsáveis pela realização de todos os curativos das unidades de internação. Em 2013, com a implantação de ações voltadas para a segurança do paciente, evidenciou-se a necessidade de consolidar a qualidade da assistência prestada em consonância com a política nacional, sendo inserida a especialidade de estomaterapia no cenário das atividades da COC, 0 que proporcionou mudanças na percepção da magnitude dos desafios a serem superados, a falta de qualificação do profissional enfermeiro, padronização no tratamento das feridas, planejamento integral do cuidado, controle no desfecho do tratamento das lesões e o uso indiscriminado de materiais de curativos, levando a insatisfação dos clientes médicos, pacientes e familiares. Em 2016 a COC deixa de existir e dá espaço ao novo modelo de trabalho sendo denominado Grupo de Atenção à Pele e Estomias (GAPE).

O objetivo do GAPE foi desenvolver e aprimorar o conhecimento dos enfermeiros das unidades assistenciais e fornecer assistência integral, uniformizada e especializada no tratamento de lesões de pele, qualificando os enfermeiros, padronizando o tratamento e otimizando os recursos materiais, acompanhando a evolução, garantindo o planejamento terapêutico e a continuidade do cuidado, com orientações para alta e consequentemente melhorando a satisfação dos médicos, pacientes e familiares.

Para efetivar a implantação do GAPE foram realizados encontros com a gestão de enfermagem, serviço de estomaterapia e educação continuada, com intuito de definir o número necessário de integrantes, planejamento do treinamento teórico e prático, determinação de metas, alinhamento das expectativas e definição do escopo de trabalho.

Resultados: Ampliou o atendimento especializado a pacientes com estomias e lesões latentes ao tratamento atual, empregando assim o conhecimento e a atuação da enfermeira estomaterapeuta. O GAPE comprovou sua efetividade com o impacto positivo na instituição evidenciado pelo reconhecimento por parte da equipe multidisciplinar, aumento de acionamentos para avaliação, evolução favorável das lesões, satisfação dos clientes, além do engajamento e envolvimento dos profissionais na prevenção e tratamento de lesões em consonância com o movimento mundial de segurança do paciente.

Conclusão: Mediante a implantação do grupo, foram capacitados 33 enfermeiros para avaliação e acompanhamento dos pacientes internados: adultos e pediátricos, de todas as classes de atendimento com foco em lesões: crônicas, dermatites associada à umidade, por fricção, deiscências, por extravasamento de medicações, por pressão a partir do estágio $3 \mathrm{e}$ latentes ao tratamento atual.

Posteriormente, oportunidades de melhorias foram identificadas, onde aumentou-se para 100 enfermeiros habilitados e ampliou-se o escopo de trabalho, com atendimento à todos os tipos de lesões de pele e disseminando a cultura de prevenção de LP.
\end{abstract}

Keywords: Estomaterapia , Implantação, Grupo de atenção à pele

\section{Referências Bibliográficas}

Associação Brasileira de Estomaterapia: estomias, feridas e incontinências. Competências do Enfermeiro Estomaterapeuta (ET) ou do Enfermeiro Pós-graduado em Estomaterapia (PGET). Estima. 2008. BRASIL. Ministério da Saúde. Documento de referência para o Programa Nacional de Segurança do Paciente. Brasília DF: Ministério da Saúde, 2014. CONSELHO REGIONAL DE ENFERMAGEM DE SÃO PAULO (COREN-SP). Disponível em: http://www.portaldaenfermagem.com.br Acesso em: 31/07/2019. KRAUSE TCC, ASSIS GM, DANSKI MTR. Implantação de uma Comissão de Cuidados com a Pele em um Hospital de Ensino. ESTIMA, v.14 n.1, p. 13-20, 2016. NATIONAL PRESSURE ULCER ADVISORY PANEL (NPUAP). Pressure ulcer stages revised by NPUAP. April, 2014. Disponível em: http://www.npuap.org Acesso em: 03/08/2019. PROGRAMA DE QUALIDADE HOSPITALAR (CQH). Manual de indicadores de enfermagem NAGEH. São Paulo: APM/CREMESP 2016. 


\title{
A ATUAÇÃO DO ENFERMEIRO EM UMA ASSOCIAÇÃO DE APOIO À PESSOAS COM EPIDERMÓLISE BOLHOSA: RELATO DE EXPERIÊNCIA
}

\author{
Author(s): Ana Paula Hey ${ }^{1}$, ELOISA SEEGMULLER DE CARVALHO ${ }^{1}$ \\ Institution(s) ${ }^{1}$ UTP - UNIVERSIDADE TUIUTI DO PARANÁ (Rua Sydnei Antonio Rangel Santos, 238 - \\ cURITIBA PR), ${ }^{2}$ UTP - UNIVERSIDADE TUIUTI DO PARANÁ (Rua Sydnei Antonio Rangel \\ Santos, 238 - cURITIBA PR)
}

\begin{abstract}
Introdução: A epidermólise bolhosa (EB) é uma doença hereditária, rara e não contagiosa; que em suas manifestações clínicas, provoca, dentre outros sinais e sintomas, as feridas na pele e mucosas. A atuação do enfermeiro em associações de apoio à essa doença, é de extrema importância para a contribuição na promoção do bem estar; para que se evitem complicações e; para a manutenção da qualidade de vida. Além da atuação para mehoria das políticas públicas voltadas ao público em questão. Objetivo: Descrever um relato de experiência acerca da importância do enfermeiro em uma associação de apoio à pais e pessoas com epidermólise bolhosa. Materiais e Método: Trata-se de relato de experiência realizado com três enfermeiras, participantes de uma associação sem fins lucrativos, que presta apoio a pais, amigos e pessoas com EB, na região sul do Brasil. O período de atuação dos enfermeiros na associação, inicia com sua fundação, em fevereiro de 2016 e vem até o presente momento. Após aprovação do CEP, dob o parecer número 3.245.096, o estudo se deu em três etapas: entrevista com os enfermeiros; posterior análise de respostas e; correlação dos relatos com referências sobre o tema. Resultados: Foram entrevistados três enfermeiros, que compõe o quadro de enfermeiros voluntariado da referida associação. As especialidades desses enfermeiros são: estomaterapia; obstetrícia e; neonatologia. O processo de trabalho narrado pelos mesmos foi dividio em cinco esferas, sendo elas: 1) Assistir: onde se encontrou o maior papel desempenhado por eles. As narrativas apontam a assistência ao recém nascido, no que se refere aos cuidados com a higiene corporal e à pele e, ainda, ao aleitamento materno. Referem ainda o atendimento à pessoas com EB em diferentes faixas etárias; 2 ) Administrar: as narrativas evidenciaram a solicitação de coberturas e outros materiais necessários ao cuidado; bem como encmainhamentos de referência contra referência; 3) Ensinar: os relatos evidenciaram o ensino para o autocuidado às pessoas com EB, envolvendo familiares e profissionais de saúde. Além disso, evidenciou-se participação em várias esferas sociais para a divulgação da doença e; apoio à inserção escolar das pessoas com EB. 4) Pesquisar: na pesquisa, evidenciou-se nos relatos, a revisão de estudos de profissionais interessados no estudo da EB e, da participação em bancas sobre o tema; porem com pouco desenvolvimento de pesquisas próprias e: 5) Atuar politicamente: nesse aspecto evidenciou-se a luta por melhores políticas públicas à pessoas com $\mathrm{EB}$, com a participação em eventos e reuniões em diversas esferas governamentais sobre o tema. Conclusões: $O$ enfermeiro, ao participar de uma associação de apoio à pessoas com EB, amplia seu processo de trabalho; participando não apenas de processos assistenciais, mas também atuando nas esferas da educação, pesquisa e atuação política. Esse profissional, contribui sobremaneira no cuidado à esse público; participando intensamente das questões sociais e históricas que fazem interface com sua realidade
\end{abstract}

Keywords: ESTOMATERAPIA, EPIDERMÓLISE BOLHOSA, ENFERMEIROS, CUIDADOS DE ENFERMAGEM

\section{Referências Bibliográficas}

1. Denyer J, Pillay E, Clapham J. Best practice guidelines for skin and wound care in epidermolysis bullosa. An International Consensus. Wounds International, 2017 2. Mandelbaum, MH; Barreiros, DCZ; Mouassab, PA. Epidermólises Bolhosas: Assistência de Enfermagem aos Portadores e seus Familiares. Rev. Estima, 2004 (acesso em 03 de junho de 2019); Vol.2 (3). Disponível em https://www.revistaestima.com.br/index.php/estima/article/view/153 3. Bernardes, LCC.; Paula, RAB. Assistência do profissional enfermeiro frente à pessoa com epidermólise bolhosa. Rev. Revela, 2018 (acesso em 20 de fevereiro de 2019). Ed.22. Disponível em http://www.fals.com.br/revela/ed22/ED22_T3.pdf 4. Brasil. Lei n. 7.498, de 25 de junho de 1986. Dispõe sobre a regulamentação do exercício da Enfermagem e dá outras providências. Diário Oficial da União. 26 jun 1986. 5. Pitta AL, Magalhães RP, Silva JC. Epidermólise bolhosa congenita: importância do cuidado de enfermagem. Rev Cuid 2016 (acesso em 02 mar 2019); 10(2):201-208. Disponível em http://bases.bireme.br/cgibin/wxislind.exe/iah/online/?IsisScript=iah/iah.xis\&src=google\&base=BDENF\&lang=p\&nextAction=Ink\&exprSearch=30352\&i ndexSearch=ID 


\title{
REDUÇÃO DO INDICADOR LESÃO POR PRESSÃO X REDUÇÃO DE CUSTOS COM A PREVENÇÃO
}

\author{
Elisandra Leites Pinheiro ${ }^{1}$, Daiany Santos Fernandes ${ }^{1}$, Patricia pedroso da Silva ${ }^{1}$, Anelissie Liza \\ Author(s): Hul Liza Hul ${ }^{1}$, Silvania Martins Almeida ${ }^{1}$, Daniela Tenroller de Oliveira ${ }^{1}$ \\ Institution(s) ${ }^{1}$ HMV - hospital moinhos de vento (Ramiro Barcelos 530 )
}

\begin{abstract}
Introdução: A lesão por pressão e a sua prevenção são consideradas metas de segurança do paciente e responsabilidade da equipe multidisciplinar em todos os níveis de atenção do sistema de saúde. Desde o final da década de 1980, existem evidências que a maioria das lesões por pressão são evitáveis e ocorrem em pacientes em risco no início do processo de hospitalização ou de admissão em instituições de longa permanência. A realização de cuidados preventivos completos pode reduzir de 50 a $60 \%$ o aparecimento de lesão por pressão e o custo-efetivo é menor do que qualquer outro tratamento. Estudos mostram que medidas preventivas como o uso de tecnologia para prevenção, reduzem o número de lesões, como por exemplo: Uso de cobertura de múltiplas camadas em região sacra, calcâneos e o uso do colchão de fluxo de ar que alivia a pressão e estimula os tecidos inativos promovendo circulação vital da pele. Essas tecnologias assistenciais necessitam da formulação de um saber técnico-científico resultante de investigações, aplicações de teorias e da experiência cotidiana dos profissionais, constituindo-se, portanto, num conjunto de ações sistematizadas, para a prestação de uma assistência qualificada ao ser humano em todas as suas dimensões. Objetivo: Reduzir a prevalência de lesão por pressão no ambiente hospitalar, proporcionando a ele a melhor experiência através das boas práticas assistências com o uso da tecnologia ao seu favor. Método: Trata-se de um estudo transversal de caráter comparativo, que faz parte de um projeto guarda-chuva da instituição, como parecer CAAE: 57679316.9.0000.5330, que avalia as melhores práticas aplicadas na assistência aos pacientes com riscos de desenvolver lesão por pressão, de 2014 a 2018 em um hospital privado de Porto Alegre. Resultados: A prevalência de lesão por pressão entre os anos de, 2014 a 2018 são: 2014 : 4,76\%; 2015: 4,33\%, 2016: 4,86\%, 2017: 4,30\% e 2018: 2,94\%, com isso, evidenciou-se a redução do índice de prevalência após a implementação do protocolo de prevenção de lesão por pressão em pacientes com alto risco para desenvolvê-las. Conclusão: As superfícies de apoio têm sido concebidas para reduzir os efeitos de carga tecidual controlando a intensidade e duração da pressão, forças de cisalhamento e fricção. Salientamos que o uso de superfície de apoio não anula a necessidade de posicionamento frequente em diferentes decúbito. Desse modo, a enfermagem encontra-se hoje, com um conjunto de tecnologias que podem cada vez mais serem desenvolvidas e especializadas por todos aqueles profissionais motivados para uma melhoria do cuidado à saúde do ser humano. Com tudo, as implementações de novas tecnologias para prevenção de desenvolver lesões por pressão, assim como, a educação continuada da equipe de enfermagem e dos cuidadores, irão permitir uma melhoria na qualidade de vida do paciente, permitindo otimizar os cuidados com a pele do indivíduo, racionalizar os custos e não prolongar sua internação. Através dessa medida padronizada e aplicada no cuidado a prevenção, estamos minimizando os possíveis danos na vida dos pacientes com o desenvolvimento de uma lesão por pressão, sendo assim, tornamos os cuidados mais seguros e com qualidade.
\end{abstract}

Keywords: Estomaterapia;, Lesão por Pressão, Indicadores de Qualidade em Assistência

\section{Referências Bibliográficas}

1. Tristão AF, Padilha SAM. Prevenção e tratamento de lesões cutâneas: Perspectivapara o cuidado. Editora Moriá $1^{\circ}$ edição, Porto Alegre - RS 2018 pág.179,180). 2. Documento de Consenso da World Union of Wound Healing Societies (WUWHS). O papel das coberturas na prevenção da lesão por pressão. WoundsInternational, 2016. 3. Mendes I, Carvalho MD, Almeida RT, Moreira ME. Uso da tecnologia como ferramenta de avaliação no cuidado clínico de recém-nascidos prematuros. J Pediatr, 2006; 82(5):371-6. 4. WILSON M. Heel Pressure Ulcers: An overview of pressure relieving Equipment. Wound Essentials, 2007, Vol.12 p.115-120. 5. Studartl RMB, et al. Tecnologia de enfermagem na prevenção da úlcera por pressão em pessoas com lesão medular. RevBrasEnferm, Brasília 2011 mai-jun; 64(3): 494-500. 


\title{
USO DE METODOLOGIAS ATIVAS PARA O ENSINO DE PREVENÇÃO DE LESÕES DE PELE PARA A EQUIPE DE ENFERMAGEM
}

\author{
Aurilene Lima da Silva ${ }^{2,1}$, Jacqueline Guabiraba Forte ${ }^{1}$, Fabrícia Maia Leite ${ }^{1}$, Renata Mayra Reis \\ Author(s): Maia ${ }^{1}$, Karla Mirelle Campelo Martins ${ }^{1}$, Michele Pontes Moreira ${ }^{1}$, Daniela Sousa de Oliveira ${ }^{1}$, \\ Rocilda Custódio Moura ${ }^{1}$, Amelina de Brito Belchior ${ }^{2}$ \\ Institution(s) ${ }^{1} \mathrm{HM}$ - Hospital de messejana Dr. Carlos Alberto Studart Gomes (Av. Frei Cirilo, 3480 - \\ Messejana, Fortaleza - CE.), ${ }^{2}$ UECE - Universidade Estadual do Ceará (Av. Dr. Silas Munguba, \\ 1700 - Itaperi, Fortaleza - CE.)
}

\begin{abstract}
Introdução: Nas últimas décadas, a formação dos profissionais de saúde, bem como a metodologia envolvida nesse processo, tornou-se ponto relevante a ser discutido devido à influência na resolução dos problemas de saúde da população em geral1. Por isso, é fundamental que o ensino em saúde incorpore os avanços pedagógicos das metodologias ativas de ensino-aprendizagem, estabelecendo novas diretrizes para a integração entre teoria e prática e rompendo com a tradicional dicotomia entre ensino básico e formação clínica2. Assim, o conhecimento de estratégias educacionais acerca da prevenção de lesões de pele representam uma poderosa ferramenta no cuidado de pacientes de risco3, visto que, grande parte das lesões poderiam ser evitadas a partir do conhecimento por parte dos profissionais de saúde a respeito das características principais desses pacientes e das escalas de avaliação de risco, com a possibilidade de realizar prognósticos e, assim, preveni-las4. Objetivo: Relatar o uso de metodologias ativas aplicadas a equipe de enfermagem para a prevenção de lesões de pele em pacientes internados. Material e Método: Trata-se de um relato de experiência sobre a criação e aplicação de jogos educativos realizado pelo serviço de estomaterapia, à equipe de enfermagem de um hospital quaternário, na semana de enfermagem de 2019. Os jogos foram elaborados com embasamento na literatura consultada e no conhecimento técnico dos autores a partir de uma revisão bibliográfica, sobre metodologias ativas, educação em saúde e prevenção de lesões. Foram construídos três jogos educativos, sendo, um jogo de tablado com foco na prevenção de lesões de pele, um jogo da memória, sobre o conhecimento dos estágios de lesão por pressão e uma pescaria voltada a prevenção de dermatite associada a umidade. Resultados: Foi montado um stand próximo ao local de biometria dos funcionários, por haver maior circulação. Enfermeiros e técnicos eram convidados a participar. Após explicação das regras dos jogos, eram iniciadas as atividades. Estimulou-se a construção do saber a partir do conhecimento prévio dos participantes sobre o assunto, sendo mediados sempre que necessário pelas enfermeiras estomaterapeutas, propiciando a autonomia dos participantes, a reflexão acerca das necessidades reais e potenciais dos pacientes e a compreensão do ser humano na perspectiva da integralidade do cuidado, em especial no cuidado com a pele. Conclusões: O uso das metodologias ativas para a prevenção de lesões de pele evidenciou um método que envolveu a participação das pessoas de forma atrativa proporcionou uma postura crítica e reflexiva, tornando-os protagonistas no processo de aprendizagem e na construção de seu conhecimento, favorecendo a performance profissional na prevenção de lesões de pele.
\end{abstract}

Keywords: Metodologias ativas, Educação em saúde, estomaterapia

\section{Referências Bibliográficas}

1 Silva SL et al. Estratégia educacional baseada em problemas para grandes grupos: relato de experiência. Rev Bras Educ Med. 2015;39(4):607-613. 2 Roman C. et al. Metodologias ativas de ensino-aprendizagem no processo de ensino em saúde no Brasil: uma revisão narrativa. Clinical Biomedical Research. 2017;37(4):349-357. 3 Domansky RDC, Borges EL. Manual para prevenções de lesão de pele: recomendações baseadas em evidências. 2. ed. Rio de Janeiro: Rubio; 2014.318 p. 4 Blanes L, Ferreira LM. Prevenção e tratamento de úlcera por pressão. São Paulo: Atheneu; 2014. 360 p. 


\title{
RELATO DE EXPERIÊNCIA: CERTIFICAÇÃO DE ENFERMEIROS EM TERAPIA POR PRESSÃO NEGATIVA
}

\author{
Bruna Correia Lopes ${ }^{1}$, Daiany Santos Fernandes ${ }^{1}$, Patricia Pedroso da Silva ${ }^{1}$, Luisa Juliana da \\ Author(s): Silva Pavinatto ${ }^{1}$, Jeycilene Pereyra Machado ${ }^{1}$, Elisandra Leites Pinheiro ${ }^{1}$, Daniela Tenroller de \\ Oliveira $^{1}$
}

Institution(s) ${ }^{1}$ HMV - Hospital Moinhos de Vento (Ramiro Barcellos, 910)

\begin{abstract}
Introdução: A terapia por pressão negativa (TPN) é uma tecnologia atual, que pode ser utilizada em feridas crônicas ou agudas, em ambiente hospitalar ou domiciliar.1 Em feridas abertas, visam criar um ambiente que favoreça a cicatrização por segunda ou terceira intenção, estimulando a formação de tecido de granulação, promovendo a perfusão, diminuindo o edema, removendo exsudato e material infeccioso.2 Exemplos de lesão aberta que pode ser aplicada a essa tecnologia são: por pressão, diabéticas ou vasculares, queimaduras de espessura parcial, deiscências ou enxertos.3 Objetivo: Capacitar os profissionais enfermeiros para aplicação da terapia por pressão negativa á beira leito, gerando mais domínio da temática, segurança na indicação do tratamento, otimizando os resultados terapêuticos para o paciente, prevenindo possíveis agravos relacionados. Método: Trata-se de um estudo transversal que faz parte de um projeto guarda-chuva da instituição, como parecer CAAE: 57679316.9.0000.5330, que relata a experiência de uma certificação, realizada em forma de um curso de 10 horas para 16 enfermeiros do grupo de referência em estomaterapia de um hospital privado de Porto Alegre. Através de aula teórica e prática, foi também aplicado um questionário pré-capacitação e pós-capacitação, com o intuito de avaliar o nível de conhecimento dos profissionais. Resultados: A nota média dos 16 enfermeiros no pré-curso foi de 4,0 e após o curso obtiveram nota de 9,4. Durante a capacitação, observamos que após as primeiras aulas, já houve aumento da segurança por parte das equipes, para a indicação dessa terapia e envolvimento no acompanhamento dos casos onde a TPN foi aplicada. Constatando-se que 100\% dos enfermeiros alcançaram a nota máxima ao final da certificação, pela eficácia do conteúdo e conhecimento adquirido no próprio curso. Conclusão: Acredita-se que ações de educação continuada são importantes para a qualificação, desenvolvimento e aprimoramento das equipes de saúde, impactando de maneira positiva na qualidade da assistência. A TPN também retomou a esperança de pessoas que já tentaram diversos métodos de cicatrização e não obtiveram sucesso. É possível observar e admitir que o número de pacientes com feridas, venha crescendo tanto no âmbito hospitalar, como a nível ambulatorial de forma significativa. $O$ enfermeiro deverá estar preparado com embasamento científico para lidar com as situações, e elaborar estratégias para melhores condições de vida dos pacientes. Diante da problemática, surge à necessidade de uma nova e ampla mentalidade que venha para aperfeiçoar a prática de todos profissionais que se propõe a realizar a ação do cuidar e aplicar a terapia por pressão negativa. Essa visão moderna propõe-se a construir novas perspectivas de tecnologias relacionadas ao tratamento de feridas.
\end{abstract}

Keywords: Enfermagem, Estomoterapia, Lesão por pressão, Tratamento de ferimentos, Terapia por Pressão Negativa

\section{Referências Bibliográficas}

REFERÊNCIAS: NPUAP, National Pressure Ulcer Advisory Panel (US). Conceito e classificação de úlceras por pressão: Atualização do NPUAP 2016. DOMANSKY, R.C, BORGES, E.L, FERNANDES, F.P, et al. Manual para Prevenção de Lesões de pele.2 edição. Rio de Janeiro; Editora RubioLtda; 2014.P.10-13. LIMA, R.V.K.S, COLTRO P.S, JÚNIOR, J.A.F. Terapia por pressão negativa no tratamento de feridas complexas. Rev. Col. Bras. Cir. vol.44 n.1 Rio de Janeiro Jan./Fev. 2017. 


\title{
INSERÇÃO DA VIVÊNCIA AMBULATÓRIAL NO CRONOGRAMA PRÁTICO DE RESIDENTES DE ENFERMAGEM-INTENSIVISMO: AGREGANDO CONHECIMENTOS NA ÁREA DE TRATAMENTO DE FERIDAS.
}

\author{
Author(s): \\ JUAN PABLO PEREIRA DA SILVA ${ }^{1}$, Paula Gomes Lima ${ }^{1}$, Deborah Alves de Freita Antonio ${ }^{1}$, \\ Gabriela Bettoni Figueiroa ${ }^{1}$, Lizzandra Varela da Costa ${ }^{1}$ \\ Institution(s) ${ }^{1}$ HMCP - Hospital e Maternidade Celso Pierro- PUC Campinas (Av. Jonh Boyd Dunlop, SN. Jd. \\ Ipaussurama, Campinas SP)
}

\begin{abstract}
Introdução: O ambulatório de tratamento de feridas do hospital foco deste relato, começou as atividades no ano de 1998, a partir da iniciativa de um grupo de enfermeiros, que identificaram a necessidade de executar um projeto para direcionar a ação dos profissionais dentro do ambulatório frente ao cuidado com feridas. Mediante a isto o intuito é oferecer aos pacientes uma assistência diferenciada e individualizada, baseada em evidências científicas de qualidade. Reconhecendo a latente relevância de se capacitar enfermeiros com olhar diferenciado para o paciente com feridas, foi inserido ao cronograma prático do Residente de enfermagem do segundo ano do programa multiprofissional em intensivismo, a vivência no ambulatório de tratamento de feridas. A Residência Multiprofissional em Saúde se constitui em modalidade de ensino de pós-graduação lato sensu, baseada na educação em serviço.1 Partindo-se deste pressuposto, o maior objetivo a ser alcançado nessa proposta seria a agregação das melhores práticas voltadas a esta temática, no intuito de se aplicar aos pacientes no âmbito da terapia intensiva. Objetivo: Descrever a experiência do enfermeiro residente a partir da execução do estágio no ambulatório de tratamento de feridas, frente ao cenário da prática da Residência Multiprofissional em Intensivismo. Material e método: Trata-se de uma pesquisa descritiva, exploratória, qualitativa, tipo relato de experiência, a partir da execução do estágio em um ambulatório de tratamento de feridas de um Hospital filantrópico, universitário do interior do Estado de São Paulo. Resultados: O estágio no ambulatório de tratamento de feridas foi estruturado em 15 dias, no período matutino, onde os residentes de enfermagem acompanharam as enfermeiras assistenciais deste setor. Avaliou-se pacientes de 5 especialidades, entre elas: Cirurgia Vascular, Neurocirurgia, Cirurgia do trauma, entre outras, tendo a oportunidade inclusive de reaver pacientes que estiveram internados na Unidade de Terapia Intensiva Adulto em seu período pós alta, dando seguimento a linha do cuidado deste paciente a nível ambulatorial. Foram avaliados, dado conduta e realizado curativos em lesões do tipo cirúrgica, lesões agudas e crônicas, utilizando diferentes tipos de coberturas, assim ampliando o leque de experiência dos residentes. Conclusão: Observou-se em campo prático que a realização do estágio no ambulatório de tratamento de feridas permitiu aprofundamento técnico-científico, agregando segurança e autonomia profissional ao residente de enfermagem na área assistencial intra-hospitalar, principalmente no âmbito do cuidado intensivo2. Constata-se ainda que tal experiência pode proporcionar uma assistência de maior qualidade, culminando na conduta correta e redução de custos inadequados frente ao tratamento do paciente com lesão3.
\end{abstract}

Keywords: Ambulatório hospitalar, Internato não Médico, Estomaterapia

\section{Referências Bibliográficas}

1 Silva Cristiane Trivisiol. RESIDÊNCIA MULTIPROFISSIONAL COMO ESPAÇO INTERCESSOR PARA A EDUCAÇÃO PERMANENTE EM SAÚDE. Texto Contexto Enferm [Internet]. 2016 [citado em 2019 Jul. 23]; Disponível em: http://dx.doi.org/10.1590/0104-0707201600002760014. 2 Morais Gleicyanne Ferreira da Cruz, Oliveira Simone Helena dos Santos, Soares Maria Julia Guimarães Oliveira. AVALIAÇÃO DE FERIDAS PELOS ENFERMEIROS DE INSTITUIÇÕES HOSPITALARES DA REDE PÚBLICA. Texto Contexto Enferm [Internet]. 2008 [citado em 2019 Jul. 23]; Disponível em: http://www.scielo.br/pdf/tce/v17n1/11.pdf. 3 Santana Adriana Cristina, Maria Márcia Bachion, Malaquias Suelen Gomes, Vieiral Flaviana, Carneiro Diana Alves, Lima Jacqueline Rodrigues, et al. CARACTERIZAÇÃO DE PROFISSIONAIS DE ENFERMAGEM QUE ATENDEM PESSOAS COM ÚLCERAS VASCULARES NA REDE AMBULATORIAL. Revista Brasileira de Enfermagem [Internet]. 2013 novembro [citado em 2019 Jul. 23]; Disponível em: http://dx.doi.org/10.1590/S0034-71672013000600002. 


\title{
O PROCESSO DE ELABORAÇÃO DO INSTRUMENTO BUNDLE PARA PREVENÇÃO DE LESÃO POR PRESSÃO EM UMA UNIDADE DE TERAPIA INTENSIVA: RELATO DE EXPERIÊNCIA
}

\author{
JUAN PABLO PEREIRA DA SILVA ${ }^{1}$, DEBORA ALVES DE FREITAS ANTONIO ${ }^{1}$, \\ GABRIELA BETTONI FIGUEIROA ${ }^{1}$, LIZZANDRA VARELA DA COSTA ${ }^{1}$, JOSE CARLOS \\ Author(s): $\quad$ DE OLIVEIRA $^{1}$, PAULA ROCCO GOMES LIMA ${ }^{1}$, GLEICE GUARNIERI ROSSANEZ ${ }^{1}$, \\ GISELA CARLA FERREIRA RODRIGUES ${ }^{1}$, VIVIANA APARECIDA DE LIMA ${ }^{1}$
}

Institution(s) ${ }^{1}$ PUC-CAMPINAS - pontifícia universidade católica campinas (Av. John Boyd Dunlop S/NJardim Ipaussurama, Campinas - SP, 13034-685)

\begin{abstract}
Introdução: Diante ao cenário de saúde mundial a segurança do paciente é um dos temas de maior relevância quando tratar-se de eventos adversos, e criar ferramentas que reduzam danos aos pacientes é de fundamental importância 1. Frente a isto, o IHI (Institute of Healthcare Improvement) visou um instrumento que contempla um conjunto de ações com o propósito de aperfeiçoar o processo de cuidado e prevenção de danos em pacientes, denominado Bundle 2. Esta ferramenta encontra-se inserida em grande parte das instituições hospitalar com o principal objetivo de prevenir lesão por pressão (LPP) 2. Objetivo: Descrever a experiência de enfermeiros residentes, no processo de construção de um instrumento Bundle para prevenção de lesão por pressão em uma Unidade de Terapia Intensiva Adulto. Material e método: Trata-se de uma pesquisa descritiva, exploratória, qualitativa, tipo relato de experiência, realizada na UTI Adulto de um Hospital filantrópico, universitário, do interior do Estado de São Paulo, que teve como população alvo a equipe de enfermagem, durante o mês de dezembro de 2018. Resultados: Para iniciar o processo de criação do instrumento foi executado um levantamento bibliográfico utilizando a estratégia PICO (Population, Intervetion, Context, Outcomes)3. Como população alvo foi abordado os profissionais de enfermagem e paciente que apresentam perfil de risco para desenvolver lesão por pressão. Foram selecionados bibliografias que trazem o que há de mais atual para a prevenção de lesão por pressão e comparado com o contexto hospitalar na qual foi estudado. Como passo seguinte realizou-se uma dinâmica brainstorm com a equipe de enfermagem com objetivo de descobrir o domínio da mesma sobre o assunto LPP. Diante dos dados pesquisados e vistos os recursos que a instituição disponibiliza, criou-se uma ferramenta Bundle com os seguintes tópicos a serem avaliados diariamente2: Mudança de decúbito de acordo com a escala de braden, aplicação de filmes transparente não estéril em proeminências ósseas de acordo com nível de risco como barreira preventiva, utilização correta de fixação de TOT, acompanhamento da nutrição, apresentação do leito do paciente de forma que esteja sem dispositivos expostos que apresentam risco para desenvolver LPP, colchão piramidal ou pneumático de acordo o peso do paciente. Vistos esses tópicos no instrumento há um espaço destinado para identificar conformidade, não conformidade (CO e NC) e não se aplica (NA), há também um campo para justificativa de NC e consequentemente descrever quais recurso estão sendo utilizados para paciente que já apresentam LPP, com objetivo de minimizar ao máximo os danos que o tempo de média e longa internação possa ocasionar nos pacientes1. Conclusões: O Bundle auxilia a supervisão das medidas preventivas e direciona os profissionais de enfermagem a utilizar melhor e de maneira eficiente os recursos disponibilizados pela instituição, ampliando assim a visão e a gestão do enfermeiro para melhoria de resultados.
\end{abstract}

Keywords: Lesão por Pressão, Estomaterapia, Unidades de Terapia Intensiva, Internato não Médico, Bundle

\section{Referências Bibliográficas}

REFERÊNCIAS BIBLIOGRÁFICAS 1. Antônio Francisco Machado Pereira, Wlairton Carvalho Beserra, Maria do Carmo Campos Pereira, Elaine Maria Leite Rangel Andrade, Maria Helena Barros Araújo Luz. Pressure injury incidence in a university hospital. Rev Enferm UFPI. 2017 Jan-Mar;6(1):36-9. [Acesso Jun 2019] Disponível em:

http://www.ojs.ufpi.br/index.php/reufpi/article/view/5771/pdf 2. Roger Resar, Peter Pronovost, Carol Haraden, Terri Simmonds Thomas Rainey, Thomas Nolan. Using a bundle approach to improve ventilator care processes and reduce ventilator-associated pneumonia. Joint Commission Journal on Quality and Patient Safety. 2005;31(5):243-248.Disponível em: http://www.ihi.org/resources/Pages/ImprovementStories/WhatlsaBundle.aspx 3. Santos Cristina Mamédio da Costa, Pimenta Cibele Andrucioli de Mattos, Nobre Moacyr Roberto Cuce. A estratégia PICO para a construção da pergunta de pesquisa e busca de evidências. Rev. Latino-Am. Enfermagem [Internet]. 2007 June [cited 2019 Aug 12] ; 15( 3 ): 508-511. Disponível em: http://www.scielo.br/scielo.php?pid=S010411692007000300023\&script=sci_arttext\&tlng=pt. 


\title{
CONSTRUÇÃO e IMPLEMENTAÇÃO DE PRONTUÄRIO ELETRÔNICO EM ESTOMATERAPIA
}

\author{
Author(s): $\quad$ Michele Neves Brajão Rocha ${ }^{1}$, Maria Angela Boccara de Paula ${ }^{2}$, Victoria Angelotti ${ }^{1}$, Edson Goltz \\ Bernucio ${ }^{1}$ \\ Institution(s) ${ }^{1}$ Amil - Amil Saúde (Rua Conselheiro Rodrigues Alves, 180. Vila Mariana, São Paulo), ${ }^{2}$ UNITAU \\ - Universidade de Taubaté (Rua Visconde do Rio Branco, 210 Centro - Taubaté)
}

\begin{abstract}
O prontuário eletrônico na área da saúde diz respeito a documento único constituído do conjunto de informações, sinais e imagens registradas, geradas a partir de acontecimentos sobre a saúde do paciente e a assistência prestada. Tem caráter legal, sigiloso e cientifico e possibilita a comunicação entre os membros da equipe multiprofissional e a continuidade da assistência prestada1. A enfermagem é uma profissão fortemente dependente de informações precisas e oportunas para executar a grande variedade de intervenções envolvidas no cuidado. Os registros de enfermagem são elementos imprescindíveis ao processo do cuidar, favorecendo a comunicação entre a equipe de saúde, além de servir para ensino, pesquisas, auditorias, processos jurídicos, planejamento, estatísticas e indicadores2,3. É responsabilidade e dever dos profissionais de enfermagem registrar, no prontuário do paciente e em outros documentos próprios da área, seja em meio de suporte tradicional (papel) ou eletrônico4. O objetivo deste estudo foi relatar a experiência na construção e implementação de prontuário eletrônico específico para o serviço de Estomaterapia em uma rede privada de serviços de saúde no Brasil. O instrumento foi elaborado em conjunto pela enfermeira estomaterapeuta e equipe de Tecnologia da informação da instituição, se baseando no modelo já existente, que é o Registro Clínico Orientado por Problemas (RCOP), que constitui o SOAP (Subjetivo, Objetivo, Avaliação e Plano), que abrange a lista de problemas e o CIAP-2 (Classificação Internacional de Atenção Primária)5, foi elaborada abas com exame físico voltado a temática, escalas específicas de acordo com a área de demanda, diagnóstico e intervenções de enfermagem, tudo isso voltado para as três áreas de abrangência da especialidade (estomias, feridas e incontinências), além de condutas adotadas, encaminhamentos e textos auxiliares. O prontuário eletrônico foi $100 \%$ personalizado, com detalhamento das informações dos pacientes com demandas nas áreas da Estomaterapia, atendendo as necessidades da rotina e principalmente contribuindo para a centralização das informações, o que favorece os processos de atenção à saúde, monitoramento de gastos, elaboração de indicadores relacionados a área de estomaterapia, bem como a confecção de relatórios e pesquisas.
\end{abstract}

Keywords: Enfermagem, Estomaterapia, Implantação, Prontuário Eletrônico

\section{Referências Bibliográficas}

1. CONSELHO FEDERAL DE MEDICINA RESOLUÇÃO CFM nำ1.638/2002 (Publicada no D.O.U. de 9 de agosto de 2002 , Seção I, p.184-5) Define prontuário médico e torna obrigatória a criação da Comissão de Revisão de Prontuários nas instituições de saúde. 2. CONSELHO FEDERAL DE ENFERMAGEM. Guia de Recomendações para Registro de Enfermagem no Prontuário do Paciente e outros documentos de enfermagem. Agosto 2016. 3. CONSELHO REGIONAL DE ENFERMAGEM DE SAO PAULO. Livreto sobre Anotações de Enfermagem. Junho 2009. 4. BRASIL. Resolução COFEN no 429/2012, que dispõe sobre o registro das ações profissionais no prontuário do paciente, e em outros documentos próprios da enfermagem, independente do meio de suporte - tradicional ou eletrônico. Disponível em: http://www.portalcofen.gov.br 5. PEREIRA et al. O uso do prontuário familiar como indicador de qualidade da atenção nas Unidades Básicas De Saúde: Cadernos de Saúde Pública, v. 24, Suplemento 1, p. S123-S133, 2008. 


\title{
Gerenciamento do risco de Lesão por Pressão em Pacientes oncológicos em hospital público: Intervenções Educacionais em Estomaterapia.
}

\author{
Author(s): Rita de Cássia Freitas Bandeira ${ }^{1}$, Gabrielle Begido Gonzaga de Faria ${ }^{1}$, Andrea de Paula Rabelo ${ }^{1}$, \\ Priscila Rangel de Souza ${ }^{1}$ \\ Institution(s) ${ }^{1}$ ICESP - Instituto de câncer do Estado de São Paulo (Av. Dr. Arnaldo , 251, Cerqueira César SP), \\ 2 ICESP - Instituto de câncer do Estado de São Paulo (Av. Dr. Arnaldo , 251, Cerqueira César SP)
}

\begin{abstract}
Introdução: Muito se tem discutido no âmbito nacional e internacional sobre causas e consequências das lesões por pressão (LP), persistindo ainda como grave problema de hospitalização. Segundo o Programa Nacional de Segurança do Paciente, a notificação de eventos adversos como a LP, é obrigatória para análise de riscos e intervenções, entretanto o gerenciamento e análise dos indicadores vêm apresentando como fator limitante subnotificações. Prevenir, avaliar e tratar adequadamente uma lesão, são atribuições da enfermagem, demandando conhecimentos sobre fisiopatologia, anatomia e fatores de riscos, fundamentais para a realização do diagnóstico da lesão, objetivando excelência na qualidade da assistência. Objetivos: Avaliar a efetividade de um plano de intervenção educacional permanente para equipe de enfermagem, conduzido pela Estomaterapia, no que diz respeito a capacitação da equipe na prevenção e notificação da LP. Material e Métodos: Estudo descritivo, retrospectivo, comparativo, do tipo antes e depois, com abordagem quantitativa, através da análise documental das notificações de LP em um hospital público de alta complexidade, referência em oncologia. Foram analisadas a quantidade e a qualidade das notificações feitas pela equipe de enfermagem antes e após 0 plano educacional, intitulado "Bate Papo com a Estoma", aplicado pela Estomaterapia em todas as áreas assistenciais do hospital, com a finalidade de conscientizar e capacitar com enfoque na prática, a equipe quanto a prevenção, classificação e tratamento da LP. Resultados: Após o plano educacional, observou-se um aumento de $69 \%$ dos casos notificados em $2018(n=310)$, comparado ao ano anterior $(n=183)$. Com o aumento dos casos notificados, foi possível realizar análise dos registros identificando-se alta frequência de pacientes admitidos na instituição provenientes do domicílio apresentando LP ( $35 \%$ ). Referente à qualidade, verificou-se (48\%) de anotações da escala de Braden não correspondentes ao tipo de LP, evidenciando necessidade de treinamento. Conclusões: Implementar o plano educacional objetivando conscientizar e capacitar a equipe de enfermagem evidenciou a importância dessa ferramenta, contribuindo não somente para o aumento das notificações de LP, proporcionando também melhorias na assistência e aquisição de recursos materiais e tecnológicos.
\end{abstract}

Descritores: Lesão por pressão; segurança do paciente; Estomaterapia; Educação em enfermagem; Gestão de riscos; Indicadores.

Keywords: Lesão por pressão, Segurança do paciente, Estomaterapia, Educação em enfermagem , Gestão de riscos

\section{Referências Bibliográficas}

Referências: Silva AE, Teixeira TC, Cassiani SH. Ferramentas Utilizadas para a gestão dos riscos; FMEA- análise do modo e efeito da falha e RCA - análise de causa raiz. In: Feldman LB. Gestão de risco e segurança hospitalar. 2 ed. São Paulo: Martinari;2009. P.301-16. Haesler E. National Pressure Ulcer Advisory Panel. European Pressure Ulcer Advisory Panel. Pan Pacific Pressure Injury Alliance. Prevention and Treatment of pressure ulcers: quick reference guide. Cambridge Media: Osborne Park, Australia;2014 Mittag BF, Krause TCC, Roehrs H, Meier MJ, Danski MTR. Cuidados com lesões de pele: ações de enfermagem. Ver. Estima. 2017;15(1):19-25. Vasconcelos JMB, Caliri MHL. Ações de enfermagem antes e após um protocolo de prevenção de lesões por pressão em terapia intensiva. Esc Anna Nery, 2017;21(1):1-9. 


\title{
COMISSÃO DE PREVENÇÃO DE LESÕES DE PELE: IMPLEMENTAÇÃO DE ESTRATÉGIAS DE MELHORIA DA QUALIDADE DOS CUIDADOS POR MEIO DO CICLO PLANEJAR-FAZER- ESTUDAR-AGIR EM UM HOSPITAL UNIVERSITÁRIO PÚBLICO
}

\author{
ALGIMIRO SANTANA ${ }^{1}$, Renata Pedrão Leme Motomatsu ${ }^{1}$, Alexsandro Dias de Oliveira ${ }^{1}$, \\ Author(s): Desirée Ariane Modos Figueira ${ }^{2}$, Elisana Agatha I. Camargo Cabulon ${ }^{1}$, Magali Godoy Pereira \\ Cardoso ${ }^{1}$, Margarete Araújo Andrade ${ }^{1}$, Mariana Sbeghen Menegatti ${ }^{2}$, Larissa Gutierrez de \\ Carvalho Silva ${ }^{2}$
}

Institution(s) ${ }^{1}$ HUL - Hospital Universitário de Londrina (Avenida Robert Koch, no60), ${ }^{2}$ UEL-CCS -

Universidade Estadual Londrina- Centro de Ciências da Saúde (Avenida Robert Koch, n60)

\begin{abstract}
Introdução: As lesões por pressão (LPP) estão entre as maiores preocupações dos serviços de saúde e relacionam-se diretamente à assistência em saúde ${ }^{1}$. A presença de LPP é um dos principais indicadores de qualidade, sendo utilizada como orientador para o estabelecimento de planos de ação e metas ${ }^{2}$. O desenvolvimento de protocolos e comissões junto ao emprego de ferramentas inovadoras são estratégias empregadas na busca por resultados com reflexo significativo na melhoria dos serviços prestados ${ }^{3}$. Objetivo: Descrever ações implementadas por uma Comissão de Prevenção de Pele em um hospital universitário público de alta complexidade por meio do ciclo Planejar-Fazer-Estudar-Agir. Método: trata-se de um estudo descritivo das atividades implantadas pela Comissão de Prevenção de Lesões de Pele em um Hospital Universitário Público de Alta Complexidade, onde foram realizadas ações de prevenção de lesão por pressão, no decorrer do desenvolvimento de atividades divididas em seis ciclos da ferramenta Planejar-Fazer- Estudar- Agir, no período de junho de 2018 a junho de 2019. Resultados: foram implementados seis ciclos Planejar-Fazer-Estudar-Agir, sendo que no Ciclo 1 priorizou-se a atualização dos protocolos de prevenção da lesão por pressão, os critérios de utilização do relógio de Lohman e padronização de tratamentos para as lesões de pele. Neste momento, foi realizado o treinamento para equipe de enfermagem, e também para os novos colaboradores, sobre as atualizações e fornecida cópia para todas as unidades assistenciais. No Ciclo 2 se deu a atualização da $3^{\underline{a}}$ versão do instrumento geral de notificação de LPP, implantação da $1^{\underline{a}}$ versão dos instrumentos de notificações de LPP por adesivos médicos e LPP por dispositivos médicos. No Ciclo 3 as equipes de Enfermagem foram capacitadas para a assistência segura no contexto do mês da Segurança do Paciente. Ainda nesta etapa aconteceram reuniões administrativo-científicas entre os integrantes da Comissão de pele da instituição visando o planejamento e desenvolvimento de ações de educação permanente para enfermeiros. No Ciclo 4 efetivou-se a aquisição de dispositivos de prevenção como: colchões de visco elástico, creme com propriedades que conferem barreira cutânea, película de proteção cutânea, bem como produtos de tratamento: placa de hidrocolóide, hidrofibra com prata e hidrogel. Já no Ciclo 5 foram validados tutores informatizados específicos de prevenção e tratamento de pele na prescrição eletrônica de Enfermagem, a fim de potencializar a cultura de segurança do paciente. Por fim, no Ciclo 6 realizou-se a divulgação mensal dos indicadores de incidência, prevalência e risco para LPP nos murais de Gestão à Vista, alocados em pontos estratégicos dos setores. Nestes murais os dados são apresentados por meio de gráficos em barras, o que facilita a visualização e interpretação pelos profissionais. Conclusão: $O$ implemento de ações preventivas mobiliza a instituição de modo que corresponsabiliza os envolvidos, qualifica a assistência em saúde, além de favorecer a avaliação e reformulação de intervenções estratégicas que fortaleçam a cultura de segurança do paciente. A utilização da ferramenta Planejar-FazerEstudar-Agir como metodologia para o planejamento das ações garantiu a organização e controle sobre as ações implementas, além de proporcionar força e credibilidade para as atividades.
\end{abstract}

Keywords: Estomaterapia, Pele, Segurança do Paciente, Cuidados de Enfermagem, Qualidade da assistência à saúde

\section{Referências Bibliográficas}

1. Moraes, JT, Borges, EL, Lisboa, CR, Cordeiro, DCO, Rosa, EG, Rocha, NA. Conceito e classificação de lesão por pressão: atualização do National Pressure Ulcer Advisory Panel. Rev. enferm. Cent.-Oeste Min. 2016; 6(2). 2. Nascimento SJ, Barbieri, AR, Cheade, MFM. Situação dos hospitais de referência para implantação/funcionamento do núcleo de segurança do paciente. Cogitare enferm. 2016; 21(5):1-9. 3. Torres, RC, Oliveira,SJ, Abud, ACF, Rego, RMV. Implantação da Comissão de Prevenção e Tratamento de Lesões na Pele em um Hospital Público. Enferm. atual. 2018; 86(24). 


\title{
RESULTADOS PRELIMINARES DA IMPLEMENTAÇÃO DO CICLO PLANEJAR-FAZER-ESTUDAR- AGIR PARA POTENCIALIZAR AS AÇÕES DA COMISSÃO DE PREVENÇÃO DE LESÃO DE PELE EM UM HOSPITAL UNIVERSITÁRIO PÚBLICO DE ALTA COMPLEXIDADE
}

\author{
RENATA PEDRÃO LEME MOTOMATSU ${ }^{1}$, Alexsandro Dias de Oliveira ${ }^{1}$, Desirée Ariane \\ Author(s): Modos Figueira ${ }^{2}$, Elisana Agatha I. Camargo Cabulon ${ }^{1}$, Mariana Sbeghen Menegatti ${ }^{2}$, Margarete \\ Araújo Andrade ${ }^{1}$, Magali Godoy Pereira Cardoso ${ }^{1}$, Larissa Gutierrez de Carvalho Silva ${ }^{2}$ \\ Institution(s) ${ }^{1}$ HUL - Hospital Universitário de Londrina (Avenida Robert Koch, $\left.n^{\circ} 60\right),{ }^{2}$ UEL-CCS - \\ Universidade Estadual Londrina- Centro de Ciências da Saúde (Avenida Robert Koch, n60)
}

\begin{abstract}
Introdução: Segurança do paciente e prevenção de lesões por pressão são alvo contínuo das instituições de saúde, o interesse dos profissionais e gestores volta-se para a realização de uma assistência de qualidade e eficaz ${ }^{1}$. $O$ ciclo Planejar- Fazer-Estudar-Agir é uma ferramenta metodológica para o planejamento de ações e intervenções nos mais diversos cenários corporativos ${ }^{3}$ e ganha espaço nas instituições de saúde, contribuindo para melhoria no gerenciamento dos serviços. Objetivo: Apresentar resultados da implementação do ciclo Planejar-Fazer-Estudar-Agir para potencializar ações da Comissão de Prevenção de Lesões de Pele em um hospital universitário público de alta complexidade. Método: Estudo descritivo, para o qual foram elencados indicadores da abrangência de seis ciclos Planejar-Fazer -Estudar-Agir aplicados por uma Comissão de Prevenção de Lesões de Pele (CPLP), bem como indicadores pós ciclos: incidência, prevalência e risco para lesões por pressão (LPP). As atividades foram desenvolvidas entre julho de 2018 e junho de 2019 , sendo: ciclo 1: capacitações no período admissional da equipe de Enfermagem com webquest abordando risco e prevenção de LPP; ciclo 2: realizadas atualizações dos instrumentos de notificação para: LPP geral, LPP por dispositivos médicos e LPP por adesivos médicos; ciclo 3: realizadas capacitações, com estandes educativos, simulações realísticas para assistência segura com profissionais de Enfermagem e reuniões administrativas para planejamento de capacitações para Enfermeiros; ciclo 4: aumento do número de dispositivos de prevenção; ciclo 5: validados tutores informatizados para prevenção e tratamento de lesões de pele na prescrição eletrônica de Enfermagem; ciclo 6: divulgação dos indicadores de LPP nos murais de Gestão à Vista. Resultados: Foi alcançado a capacitação de 146 profissionais Enfermeiros e Técnicos de Enfermagem recém contratados. Foram tabulados pela Gerência de Risco 609 formulários de notificações de LPP, 14 notificações de LPP por dispositivo médico e 11 LPP por adesivo médico, totalizando 1107 lesões notificadas no período. Identificou-se medianas de incidência, prevalência e risco de desenvolver LPP de $34,2 \%, 18,5 \%$ e $40,4 \%$ respectivamente. Predominaram notificações de lesões em região sacral, de estágio I, sendo faixa etária de maior predominância de 60 a 71 anos. Foram capacitadas 700 pessoas nos estandes educativos e 200 profissionais da Enfermagem participaram de atividades de simulação realística. Foram adquiridos 68 colchões de viscoelástico, 40 para adultos, 15 infantis e 13 para mesa cirúrgica. Como medidas profiláticas padronizou-se na instituição: película de proteção cutânea, creme barreira, curativos para cateter e liberador de adesivo médico. Os Enfermeiros das unidades de internação foram instruídos para introdução do prontuário eletrônico e utilização da escala de Braden como pré requisito para elaboração da prescrição de Enfermagem eletrônica e individualizada. Por fim, houve aquisição e instalação de murais para dados de Gestão à Vista nas unidades assistenciais, o que facilitou a publicação dos principais indicadores de LPP que norteiam a equipe para estratégias de prevenção, acompanhamento e monitoramento in loco. Conclusão: Assim como foram realizadas as ações da CPLP apresentadas acima, é essencial que a equipe de saúde reflita, desenvolva e aplique estratégias de prevenção da LPP, uma problemática geradora de desconforto, riscos e gastos.
\end{abstract}

Keywords: Estomaterapia, Pele, Segurança do paciente, Cuidados de Enfermagem, Qualidade da assistência à saúde

\section{Referências Bibliográficas}

1. Torres, RC, Oliveira,SJ, Abud, ACF, Rego, RMV. Implantação da Comissão de Prevenção e Tratamento de Lesões na Pele em um Hospital Público. Enferm. atual. 2018; 86(24). 2. Hora, FD, Oliveira, TML, Branco, EMSC. Cuidados de enfermagem para a prevenção de lesão de pele por adesivos em feridas cirúrgicas/Nursing care in the prevention of adhesive-related skin injuries in surgical wounds. Ciênc. cuid. saúde. 2017; 16(2). 3. Solon, F. PDCA como proposta metodológica associada à Auditoria em Saúde: relato de experiência de Sobral-Ceará. Tempus (Brasília). 2015; 8(4):61-76. 


\title{
CONHECIMENTO DA EQUIPE DE ENFERMAGEM QUANTO AO TRATAMENTO A PACIENTES VÍTIMAS DE QUEIMADURA
}

\author{
MANUELE RAIANE DA SILVA SOUSA ${ }^{1}$, POLYANA ALVES BERNARDINO ${ }^{1}$, AMANDA \\ DA SILVA FERREIRA ${ }^{1}$, CHRISLAINY LOPES DE AGUIAR ${ }^{2}$, JULIANA KAROLINY DOS \\ SANTOS $^{2}$, CLÁUDIA GONÇALVES LOBO ${ }^{2}$, TALITA BARBOSA DE SOUZA SANTOS ${ }^{2}$, \\ Author(s): LARISSA VALESKA MARIA DA SILVA BRITO ${ }^{2}$, TACIANA DA SILVA GONÇALVES ${ }^{2}$, \\ VÂNIA MARIA SILVA DE MORAES ${ }^{2}$, BIANCA LEÃO BARRETO ${ }^{2}$, CRISTIANE BATISTA \\ DOS SANTOS $^{2}$ \\ Institution(s) ${ }^{1}$ UNICAP - UNIVERSIDADE CATÓLICA DE PERNAMBUCO (R. do Príncipe, No 526 - Boa \\ Vista, Recife - PE, 50050-900), ${ }^{2}$ FACHO - FACULDADE DE CIÊNCIAS HUMANAS DE \\ OLINDA (Rod. PE-015 KM 3, 6 - Santa Tereza, Olinda - PE, 53330-740)
}

\begin{abstract}
INTRODUÇÃO: O atendimento ao queimado requer manejo e determina melhor prognóstico, diminuindo o risco de mortalidade. Quanto maior a profundidade, maior a gravidade. O cálculo de Superfície Corporal Queimada origina os riscos dos queimados nas primeiras horas. São causada por agentes, químicos, físicos, elétricos ou radioativos. Os tratamentos dependem do diagnóstico e classificação da área queimada. As sequências de técnicas promovem conforto, prevenção de sequelas e melhoria da qualidade de vida, no meio hospitalar e ambulatorial. A enfermagem executa de forma organizativa e equidade no gerenciamento da dor, levando em consideração queixa verbal e conforme prescrição médica, oferta analgésicos. OBJETIVO: Avaliar o conhecimento de equipe de enfermagem quanto ao atendimento a pacientes vítimas de queimaduras. METODOS: Estudo do tipo quantitativo, caráter descritivo. CAAE: 97128718.3.0000.5198. Realizada com a Enfermagem do Centro de Tratamento de Queimados (CTQ), do Hospital referenciado. Amostra 26 funcionários, 4 enfermeiros, 1 residente, 21 técnicos de enfermagem. A coleta feita por meio de questionário estruturado, elaborado pelas pesquisadoras. Foram estabelecidas tabelas e gráficos e o resultado confrontado com a literatura. RESULTADOS: Faixa etária 51 a 60 anos, representando 9 (35\%); 41 à 50 anos 5 (19\%); 20 à 30 anos 4 (15\%) e $3(12 \%) 61$ a 70 anos. 25 (96\%) sexo feminino e 1 (4\%) do sexo masculino. Habilitações acadêmicas $21(81 \%)$ de técnicos de enfermagem, seguido 5 (19\%) de enfermeiros especialista. No atendimento ao grande queimado 26 (100\%) é válido realizar punção calibrosa do acesso venoso periférico, mesmo em área queimada. Limpeza das lesões, na admissão com água fria em torneira corrente e clorexidina $2 \%$. Sulfadiazina de prata $1 \%$ e colagenase quando prescrita pelo médico. Os curativos realizados em dias alternados, infectados diariamente, pós-enxertos, quinto dia. Agua fria e agentes antibacterianos na limpeza das lesões, 9 (35\%) água fria. A finalidade dos antimicrobianos tópicos 20 (77\%) cobertura da área queimada, redução do número de microrganismo, restauração total do tecido lesionado, $6(23 \%)$ a redução do número de microrganismo. CONCLUSÃO: As queimaduras são urgências clínicas que merecem vigilância, trabalho multidisciplinar, destacando-se o Enfermeiro. A equipe de enfermagem é responsável pela prestação de cuidados, diminuir as dores físicas, emocionais, medos e ansiedade. São indispensáveis conhecimentos técnicos e científicos, habilidades e cuidados integral de qualidade e humanizado.
\end{abstract}

Keywords: Queimaduras; Cuidados de Enfermagem; , Estomoterapia.

\section{Referências Bibliográficas}

REFERÊNCIAS: 1. SILVA, Aniquellem Jesus da. Atuação precoce da fisioterapia intensiva na reabilitação do paciente queimado. 2011. 40 f. Monografia (Especialização) - Curso de Fisioterapia em Terapia Intensiva, Universidade Católica de Brasilia.Brasilia,2011.; 2. FERREIRA,Tereza Cristina dos Reis; SILVA, Layse Caroline Felix; SANTOS, Maria Isabel Galletti dos. Abordagem fisioterapêutica em queimados: revisão sistemática. Revista da Universidade Vale do Rio Verde, Minas Gerais, v. 12, n. 2, p.821-830, set. 2014.; 3. PAZOS, A.L. Feridas Fundamentos e atualizações em enfermagem. 3. ed. São Paulo: Yendis, 2011. 


\title{
MANUAL SOBRE A TÉCNICA DE APLICAÇÃO DA BOTA DE UNNA EM PACIENTES COM ÚLCERAS VENOSAS:
}

\author{
Author(s): Edmundo Martins Junior ${ }^{1}$, Leila Blanes ${ }^{1}$, Christiane Sobral Schimidt ${ }^{1}$, Lydia Masako Ferreira \\ Institution(s) ${ }^{1}$ UNIFESP - UNIVERSIDADE FEDERAL de SÃO PAULO (Rua Sena Madureira, 1500 - São \\ Paulo)
}

\begin{abstract}
Cuidar de pessoas com lesões cutâneas causadas por doenças do sistema venolinfático é um desafio. Inúmeras publicações tratam da importância das terapias de compressão/contenção, contudo poucos estudos descrevem a técnica de colocação da Bota de Unna e a importância dos diferentes materiais utilizados na fabricação destes produtos, contribuindo para subutilização desta tecnologia. A utilização de manuais é uma das estratégias para a orientação de profissionais. Objetivo: Desenvolver e validar um manual sobre a técnica de aplicação da Bota de Unna em pacientes com úlceras venosas, para profissionais de saúde. Método: Estudo descritivo sobre o desenvolvimento de manual aprovado pelo CEP da Universidade CAAE: 92331318.5.0000.5505. Para o levantamento bibliográfico foram utilizados os Descritores em Ciências da Saúde (DeCS) do portal da Biblioteca Virtual da Saúde (BVS) e suas combinações na língua portuguesa, espanhola e inglesa ("manuais", "úlceras venosas", "úlceras varicosas", "úlceras de perna", "diagnóstico", "terapêutica", "cicatrização", "bandagens compressivas", "tecnologias de educação em saúde"). Foram incluídos artigos indexados ou catalogados eletronicamente na íntegra nas bases de dados Cochrane, PubMed, LILACS, biblioteca virtual SCIELO e site de busca Google Acadêmico, no período de período de 2000 a 2018. Foram incluídos artigos que tiveram como conteúdo temas relacionados aos cuidados com Bota de Unna, terapia compressiva, úlcera venosa, impacto da úlcera venosa, educação em saúde e desenvolvimento de manuais. A seguir foi elaborado o texto, as ilustrações, diagramação e gravação e edição de um vídeo demonstrativo. Após a finalização do manual o mesmo foi validado por especialistas utilizando a Técnica de Delphi e o Índice de Validade de Conteúdo (IVC). Resultados: A validação com juízes especialistas alcançou IVC global de 0,98 em duas rodadas de Delphi e foi considerado com conteúdo, aparência e relevância adequada pelos profissionais de saúde para conhecimento sobre a técnica de aplicação da Bota de Unna em pacientes com úlcera venosa. O Manual possui 29 páginas com textos e imagens ilustrativas e inclui um vídeo demonstrativo da técnica. Conclusão: Foi desenvolvido e validado um manual sobre a técnica de aplicação da Bota de Unna em pacientes com úlceras venosas, para profissionais de saúde.
\end{abstract}

Keywords: Aplicação, Bota de Unna, Manual, Pacientes, Úlceras Venosas

\section{Referências Bibliográficas}

Abbade LPF. Abordagem do paciente portador de úlcera venosa. In: Malagutti W, Kakihara CT, orgs. Curativos, estomias e dermatologia: uma abordagem multiprofissional.1st Ed. São Paulo: Martinari; 2010. p. 95-107. Abreu AM, Oliveira BGRB. Estudo da Bota de Unna comparado à bandagem elástica em úlceras venosas: ensaio clínico randomizado. Rev Latino-Am Enfermagem. 2015;23(4): 571-7. Correia TA, Abilio ES, Alvarenga MRM, Cordeiro MJJA. Reflexões frente a um material educativo em saúde norteado pelo referencial teórico de Zabala. Processos e Materiais Educativos na Educação em Ciências. X Encontro Nacional de Pesquisa em Educação em Ciências; 2015. Echer IC. Elaboração de manuais de orientação para o cuidado em saúde. Rev Latino-Am Enfermagem. 2005;13(5): 754-7. Harding K, Dowsett C, Fias L, Jelnes R, Mosti G, Oien R, Partsch H, Reeder S, Senet P, Soriano JV, Vanscheidt W. Simplifying venous leg ulcer management. Consensus recommendations. Wounds International 2015. Available to download from www.woundsinternational.com. 


\title{
A INFLUÊNCIA SOCIAL, POLÍTICO E ECONÔMICO NA ANÁLISE DE CUSTO EM UMA CLÍNICA DE ENFERMAGEM EM ESTOMATERAPIA
}

\author{
Author(s): $\quad$ Priscilla Farias chagas ${ }^{1}$, Norma Valéria Dantas de Oliveira Souza ${ }^{1}$, Ricardo de Mattos Russo ${ }^{1}$, \\ Lívia Nunes Rodrigues Leme ${ }^{1}$ \\ Institution(s) ${ }^{1}$ UERJ - Universidade do Estado do Rio de Janeiro (Blvd 28 de Setembro, 157 Vila Isabel, Rio de \\ Janeiro - RJ), ${ }^{2}$ UERJ - Universidade do Estado do Rio de Janeiro (Blvd 28 de Setembro, 157 Vila \\ Isabel, Rio de Janeiro - RJ), ${ }^{3}$ UERJ - Universidade do Estado do Rio de Janeiro (Blvd 28 de \\ Setembro, 157 Vila Isabel, Rio de Janeiro - RJ), ${ }^{4}$ UERJ - Universidade do Estado do Rio de Janeiro \\ (Blvd 28 de Setembro, 157 Vila Isabel, Rio de Janeiro - RJ)
}

\begin{abstract}
Introdução: Nesse estudo, buscou-se estabelecer um diálogo reflexivo entre os campos social, político e econômico, afim de discutir o custo despendido com os procedimentos oferecidos aos pacientes acometidos por lesão de pele, prestados em uma clínica de enfermagem em estomaterapia, vinculada a uma universidade pública, ao qual seu financiamento é oriundo do serviço público. Objetivo: Refletir sobre a influência dos campos social, político e econômico na análise de custo em uma clínica de enfermagem em estomaterapia. Material e método: Trata-se de um estudo de reflexão ao qual buscou discutir o tema central "o custo despendido no tratamento de feridas em uma clínica de enfermagem especializada em estomaterapia" com um olhar para as questões sociais, políticas e econômica que envolve o processo do tratamento a pessoas acometidas por lesão de pele, além da percepção da autora a respeito do assunto abordado. Resultado: Ao trazermos essa reflexão, temos como base a constituição federal de 1988 em seu artigo 196, ao qual deu fundamento para formulação da Lei no 8.080 de 19/09/1990, ao qual foi um grande marco histórico e uma conquista para saúde pública no Brasil, garantindo direitos para toda a população de maneira a trazer equidade na prestação de assistência à saúde, pautado como direito universal. Deixando de lado o modelo anterior a implementação do SUS, ao qual promovia segregação do acesso a prestação da saúde. A análise de custo, contribui para a implementação dos direitos garantidos por lei, vislumbrando melhor alocação de recursos. Refletisse ainda, sobre o entendimento da interação desses campos, a partir da discussão dos determinantes sociais, que vão influenciar no processo saúde doença do indivíduo. Conclusão: A reflexão feita veio discutir a importância da análise de custo no setor da saúde pública, e para isso o nosso olhar objetivou ser holístico. Pois, devemos entender que existem diversos fatores que implicam na vida daqueles que utilizam o serviço de saúde pública, tais como sociais, políticos e econômicos; estes impactam diretamente no cotidiano dos indivíduos, aos quais entendemos que interferem no processo saúde doença. Bem como, vemos a necessidade da análise de custo na saúde pública, afim de compreender de que maneira o recurso tem sido distribuído e aplicado, comprovando assim, por meio de dados, a assistência prestada à população.
\end{abstract}

Keywords: Estomaterapia, Custo, Determinantes social

\section{Referências Bibliográficas}

CARRAPATO, P. CORREIA, P. GARCIA, B. Determinante da saúde no Brasil: a procura da equidade na saúde. Saúde Soc. São Paulo, v.26, n.3, p.676-689, 2017. SALDIVA, P.; VERAS, M. Gastos públicos com saúde: breve histórico, situação atual e perspectivas futuras. Estudos Avançados, v. 32, n. 92, p.47-61, 2018. SILVA, E. N.; SILVA, M. T.; PEREIRA, M. G. Estudos de avaliação econômica em saúde: definição e aplicabilidade aos sistemas e serviços de saúde. Epidemiol. Serv. Saúde [online]. v. 25, n.1, pp.205-207, 2016. 


\title{
O impacto no indicador de lesão por pressão após a implantação de um comitê multidisciplinar em um hospital de grande porte de São Paulo
}

\author{
Mitsue da Silva Hatanaka ${ }^{1}$, Patricia Lippi da Cruz ${ }^{1}$, Vanessa Ferreira Malta Paravani ${ }^{1}$, Fabiana \\ Author(s): Cristina de Oliveira Silva 1, Vanessa Faustino Eugenio ${ }^{1}$, Anamaria Aparecida Santiago Martins ${ }^{1}$, \\ Debora Dalle Molle ${ }^{1}$
}

Institution(s) ${ }^{1}$ BP - Beneficência Portuguesa de São Paulo (Rua Maestro Cardim 769)

\begin{abstract}
Introdução: A lesão por pressão (LP) é o terceiro evento adverso mais notificado no Brasil de 2014 a 2017. É ocasionado durante a internação hospitalar, pode gerar danos irreversíveis e graves consequências para o paciente e sua família, podendo levar a morte. Além disto, compromete a qualidade da assistência prestada e a segurança do paciente. Mediante aos resultados obtidos em 2018, identificou-se a necessidade da implantação de um comitê multiprofissional com o objetivo de prevenção de LP. A atuação do grupo tem como foco unificar as ações realizadas na instituição, bem como, agilizar os processos para implantar e implementar medidas preventivas, proporcionar o compartilhamento de informações relacionadas aos vários setores do hospital entre os representantes das áreas de enfermagem, fisioterapia e nutrição permitindo uma análise crítica ampla e participativa, que impacta na prestação do serviço e aumento da qualidade assistencial. O foco é ser facilitador das ações, aperfeiçoar e divulgar as medidas descritas no protocolo institucional e propor melhorias contínuas. Objetivando a redução da densidade de incidência de LP.

Objetivo: Apresentar os resultados alcançados na melhoria do indicador de densidade de incidência de lesão por pressão com a implantação do comitê multidisciplinar.

Método: Trata-se de um trabalho descritivo, realizado de 2018 a 2019, baseado em uma ferramenta de melhoria contínua, PDSA a qual se utilizou o indicador Densidade de Incidência de LP, que tem como parâmetro o número de pacientes com novas lesões multiplicadas por mil e divididos pelo número total de pacientes por dia, conforme orientação da ANAHP. Resultados: O comitê é multiprofissional, a periodicidade das reuniões é mensal, na qual são apresentados os resultados da incidência de LP do mês anterior e estabelecidos planos de melhorias.

Conclusão: Houve um aumento no número de notificações de lesão por pressão estágio I, que significa uma intervenção precoce, além da melhoria na identificação do risco e assistência ao paciente. Mediante a implantação do grupo, oportunidades de melhorias foram identificadas, disseminando a cultura de prevenção de LP.

Considera-se efetiva a estratégia utilizada para implantação de um Comitê voltado para a atenção em prevenção descrito neste estudo.

Os resultados podem ser obervados atualmente pelo impacto positivo e descrente no indicador. Houve uma diminuição de $8 \%$ na média de incidência de LP, confirmando que as discussões com intuito de construir e instituir políticas de educação em prevenção de lesão por pressão, são fundamentais e de impacto nos números alcançados. Sugere-se que novas pesquisas, merecem ser realizadas, para assim identificar os fatores de risco importantes no desenvolvimento de LP, análises detalhadas das escalas de riscos, custo/efetividade da prevenção, versus custo do tratamento. Pode se destacar a colaboração no aperfeiçoamento e a atuação de uma equipe multidisciplinar na aquisição de novos conhecimentos e, acima de tudo, evidenciar o propósito de valorizar a vida.
\end{abstract}

Keywords: Estomaterapia , comitê, LP

\section{Referências Bibliográficas}

BRASIL. Ministério da Saúde. Documento de referência para o Programa Nacional de Segurança do Paciente. Brasília DF: Ministério da Saúde, 2014. CONSELHO REGIONAL DE ENFERMAGEM DE SÃO PAULO (COREN-SP). Disponível em: http://www.portaldaenfermagem.com.br Acesso em: 31/07/2019. KRAUSE TCC, ASSIS GM, DANSKI MTR. Implantação de uma Comissão de Cuidados com a Pele em um Hospital de Ensino. ESTIMA, v.14 n.1, p. 13-20, 2016. NATIONAL PRESSURE ULCER ADVISORY PANEL (NPUAP). Pressure ulcer stages revised by NPUAP. April, 2014. Disponível em: http://www.npuap.org Acesso em: 03/08/2019. PROGRAMA DE QUALIDADE HOSPITALAR (CQH). Manual de indicadores de enfermagem NAGEH. São Paulo: APM/CREMESP 2016. 


\title{
REDUÇÃO DOS ÍNDICES DE LESÃO POR PRESSÃO APÓS ADOÇÃO DE MEDIDAS PREVÉNTIVAS NA UTI DE UM HOSPITAL PÚBLICO DO ESTADO DE SERGIPE
}

\author{
Author(s): Priscilla Alcântara dos Santos ${ }^{1}$, Mônica Rabelo Santos ${ }^{1}$ \\ Institution(s) ${ }^{1}$ HUSE - Hospital de Urgência de Sergipe (Av. Tancredo Neves. Bairro Capucho)
}

\begin{abstract}
Introdução- Lesão por pressão é um dano localizado na pele e/ou tecidos moles subjacentes, geralmente sobre uma proeminência óssea ou relacionada ao uso de dispositivo médico ou a outro artefato. A lesão pode se apresentar em pele íntegra ou como úlcera aberta e pode ser dolorosa. Tem um grande impacto social, econômico e na qualidade de vida dos pacientes e instituições de saúde. A uti é um ambiente mais favorável para surgimento de LPP, em virtude de terem muitos pacientes críticos, mais retidos ao leito devido gravidade das patologia, e dependentes da equipe multiprofissional e equipamentos para manutenção de suportes básicos de vida. Os pontos mais suscetíveis são calcanhares, tornozelos, quadris e cóccix, locais em que o peso do corpo mais se concentra quando estamos deitados ou sentados. Uma sonda colocada no nariz de forma inadequada pode provocar uma lesão por pressão na aba do nariz. Oxímetros, aqueles pequenos aparelhos colocados na ponta do dedo para medir a oxigenação, também podem causar o problema, se permanecerem durante muito tempo. A redução da incidência desse agravo nos hospitais é um grande desafio para equipe multiprofissional. A avaliação do risco para seu desenvolvimento é realizado pela Escala de Braden, instrumento amplamente utilizado para esse fim. É imprescindível que os profissionais da saúde atuem com a finalidade de prevenir o surgimento das lesões. Em 2013 foi instituído no país pelo Ministério da Saúde, o Programa Nacional de Segurança do Paciente, por meio da publicação da Portaria $n^{\circ}$. 529. O objetivo geral dessa portaria é contribuir para a qualificação do cuidado em saúde em todos os estabelecimentos do território nacional. As medidas preventivas são a melhor forma de atuar com o intuito de redução dos índices de lesão por pressão. Objetivo - Mostrar a redução dos índices de lesão por pressão após adoção de medidas preventivas nas utis adultas de um hospital público do estado de Sergipe. Método - Foi utilizado coleta de dados em planilhas de incidência das LPP do núcleo de segurança da instituição de janeiro a dezembro de 2018. Nesse mesmo período foi realizado capacitações voltadas para medidas preventivas de LPP, em todos os setores do hospital inclusive nas utis. Resultado - Nas utis as incidências passaram de 13\% em janeiro para $3 \%$ em dezembro mostrando que a adoção das medidas preventivas foi um fator muito importante para essa redução significativa dos dados. Conclusão - Diante do exposto, concluímos que os índices de Lesão por pressão, podem ser reduzidos com o empenho da equipe multiprofissional atuando as medidas preventivas seguras. Garantindo que o paciente terá um assistência de qualidade com relação aos cuidados com a pele.
\end{abstract}

Keywords: ESTOMATERAPIA, INCIDÊNCIA , LESÃO POR PRESSÃO, MEDIDAS PREVENTIVAS, PACIENTE CRÍTICO

\section{Referências Bibliográficas}

1 - BORGES,E.L.DOMANSKY,R.T. Manual para Prevenção de Lesões de Pele. Editora Rubio,Rio de Janeiro,2012. 2 GEOVANINI, T. Tratado de feridas e curativos: enfoque multiprofissional. São Paulo: : Rideel, 2014. 3 - MALAGUTTI, W. Feridas; Conceito e Atualidades.Editora Martinari, São Paulo,2014. 4 - ASSOCIAÇÃO BRASILEIRA DE ESTOMATERAPIA - SOBEST; ASSOCIAÇÃO BRASILEIRA DE ENFERMAGEM EM DERMATOLOGIA - SOBENDE. Classificação das lesões por pressão - consenso NPUAP 2016 - adaptada culturalmente para o Brasil. São Paulo, 2016. Disponível em: . Acesso em 30 abr. 2017. 


\title{
PAPEL DO ENFERMEIRO NA INDICAÇÃO DE ESPUMA DE POLIURETANO COM PRATA NO TRATAMENTO LESÕES CARCINOMATOSAS ESPINOCELULARES: RELATO DE EXPERIÊNCIA
}

\author{
Author(s): SILVIA KARLA SILVA CAVALCANTE ${ }^{1}$, ISABELLE CRISTINE SANTANA DE OLIVEIRA \\ ${ }^{1}$, CLEOCINA DE OLIVEIRA SOUZA ${ }^{2}$, OLGA VIEIRA SILVA ${ }^{2}$ \\ Institution(s) ${ }^{1}$ SANTA CASA - SANTA CASA DE MISERICÓRDIA DE MACEIÓ \\ (SILVIA.KARLA@SANTACASADEMACEIO.COM.BR), ${ }^{2}$ ALAGOAS MEDICAL - \\ ALAGOAS MEDICAL (CSBARROS@HOTMAIL.COM)
}

\begin{abstract}
Introdução: O carcinoma espinocelular é o segundo tipo mais comum de câncer de pele, sendo o responsável pelos constantes procedimentos cirúrgicos para extirpação de tumores cutâneos. Os melanomas: localizam-se nas regiões corporais mais expostos ao sol. Como couro cabeludo e orelhas, sendo mais predominantes nas faixas etárias acima de 60 anos. O procedimento cirúrgico resulta, em lesões cutâneas extensas, evoluindo na grande maioria com exposição da calota craniana, e com isso, a necessidade de preenchimento, controle de infecção e estimulação do crescimento celular, preparando o leito para procedimentos corretivos como: rotação de retalhos ou enxertias ${ }^{1}$. Objetivo: Relatar a experiência da efetividade do tratamento convencional/uso de espumas de poliuretano com prata, na preparação do leito da lesão de um paciente submetido a uma retirada de tumores carcinoma espinocelular moderado grau 2 do couro cabeludo. Método: É um estudo descritivo, do tipo relato de experiência, onde há vivências dos enfermeiros do grupo de pele de uma instituição hospitalar filantrópica de Maceió. Resultado:

O enfermeiro se destaca na assistência aos portadores de lesão de pele por avaliar a lesão, planejar e coordenar os cuidados, acompanhar sua evolução, supervisionar e executar os curativos, ou seja, mantém contato prolongado com esse paciente. $O$ tratamento ideal de uma lesão deve considerar o leito da ferida, mantendo ambiente úmido ideal para 0 crescimento e desenvolvimento do tecido de granulação, enquanto a borda e a pele perilesional devem ser preservadas, para não aumentar a lesão. Com relação à preparação do leito de uma lesão cirúrgica por exérese de tumor de couro cabeludo, geralmente é necessário a hidratação do tecido ósseo seguido do preenchimento com espumas de poliuretano com prata para controle dos sinais logísticos. Conclusão: Evidencia-se que o uso de espumas de poliuretano com prata para o preenchimento e absorção das lesões carcinomatosas espinocelulares acometidas no coro cabeludo pelo enfermeiros do grupo de pele de uma instituição hospitalar filantrópica de Maceió,tem sido efetivo para acelerar o processo de cicatrização. Também é constatada a importância do enfermeiro especialista na avaliação e tratamento oportunos das lesões de pele, visto ser o profissional que se encontra em contato contínuo com o paciente.
\end{abstract}

Descritivos: Carcinoma, Couro cabeludo e Enfermeiro.

Keywords: Carcinoma, Couro cabeludo, Enfermeiro

\section{Referências Bibliográficas}

Brasil. Agencia nacional de vigilância sanitária-ANVISA. Resolução da Diretoria Colegiada da ANVISA- NOTA TÉCNICA GVIMS/GGTES № 03/2017. SOARES RS.O perfil epidemiológico e as várias relacionadas a ferida neoplásica no paciente em cuidado paliativo. SOARES MF. Levantamento de custo e análise dos produtos utilizados no tratamento de feridas crônicas no hospital universitário. 


\title{
Elaboração e aplicação de protocolo operacional padrão (POP) avaliação do portador de ferida em hospital universitário do Rio de Janeiro: relato de experiência
}

\author{
Author(s): Camila Castanho Cardinelli ${ }^{1}$, KARINA CHAMMA DI PIERO ${ }^{1}$, HELLENN CRISTINA NUNES \\ SANTOS $^{1}$, ANA LÚCIA ALMEIDA ${ }^{1}$ \\ Institution(s) ${ }^{1}$ HUCFF - Hospital Universitáro Clementino Fraga Filho (R. Prof. Rodolpho Paulo Rocco, 255 - \\ Ilha do Fundão, Rio de Janeiro - RJ)
}

\begin{abstract}
Introdução: O cuidado a uma ferida exige atenção e critérios para atingir a cicatrização devido a sua complexidade. Assim sendo, é importante que seja determinado um método para melhorar a assistência ao portador de feridas. A partir desta demanda, a Comissão de Métodos Relacionados à integridade da Pele (COMEIP) desenvolveu um POP visando sistematizar a assistência a essa clientela. Para Sales et al. (2018), o POP é uma ferramenta gerencial que o enfermeiro pode utilizar para melhorar a qualidade da assistência prestada. Este deve ser construído pela equipe de trabalho envolvida na ação realizada, levando em consideração a realidade do serviço. Objetivo: Descrever a elaboração e aplicação na prática clínica pela COMEIP do POP - avaliação do portador de ferida. Metodologia: Trata-se de um relato de experiência de enfermeira trainee da COMEIP com base na revisão integrativa sobre o tema para elaboração de POP conforme recomendação da literatura e institucional, através da coordenação de educação permanente (COEP). Resultados: A elaboração do POP deu-se em quatro etapas: revisão integrativa sobre o tema (1), elaboração do POP pela COMEIP (2), validação de POP pela Coordenação de Educação Permanente(3), treinamento e aplicação na prática clínica do POP (4). O POP determina consenso para o método de avaliação do portador de ferida: anamnese do paciente, exame clínico geral e exame macroscópico da ferida/sinais e sintomas relacionados (etiologia, tempo de existência, localização topográfica anatômica, estadiamento/estruturas anatômicas afetadas, coloração do leito da ferida, tipo de tecidos presentes (granulação, epitelização, necrose - esfacelo ou necrose de coagulação/escara), características do exsudato, mensuração, aspectos das margens/pele perilesional, presença de sinais clínicos de infecção superficial (NERDS), infecção profunda (STONES), presença de fístulas, flutuações ou tunelizações e características de dor. Conclusão: A avaliação dos portadores de feridas realizada de forma sistematizada, conforme preceitos da sistematização da assistência de enfermagem (SAE), que refere como etapa inicial do processo de enfermagem, o levantamento de dados, é fundamental para a construção do diagnóstico mais adequado para a elaboração e implementação de um cuidado científico baseado em evidências (COFEN, 2002). Além disso, o cuidado sistematizado determina consenso, e nesse aspecto do tratamento de feridas é fundamental, pois a definição do manejo terapêutico depende do diagnóstico correto e as melhores evidências da literatura na abordagem a cicatrização de feridas.
\end{abstract}

Keywords: feridas, protocolo operacional padrão, sistematização da assistência

\section{Referências Bibliográficas}

1-SALES, Camila Balsero et al . Protocolos Operacionais Padrão na prática profissional da enfermagem: utilização, fragilidades e potencialidades. Rev. Bras. Enferm., Brasília, v. 71, n. 1, p. 126-134, Feb. 2018. Disponível em . Acesso em 25 abr 2019. 2-Conselho Federal de Enfermagem. Resolução Cofen no 272/2002. Sistematização da Assistência de Enfermagem - SAE - nas Instituições de Saúde Brasileiras [Internet]. [citado em 2010 Jul 14]. Disponível em: http://www.portalcofen.gov.br/Site/2007/materias.asp?ArticlelD=7100\&sectionID. Acesso em 25 abr 2019. 


\title{
Comissão Multidisciplinar de Cuidados com a Pele: relato de experiência do processo de implantação
}

\author{
Camila Binsi Scopel ${ }^{1}$, Catrine Storch Moitinho ${ }^{1}$, Elisângela Ribeiro Chaves ${ }^{1}$, Ramon Araújo \\ Author(s): $\quad$ Santos ${ }^{1}$, Fabiana Goring Xavier ${ }^{1}$, Juliana Corsini ${ }^{1}$, Danielle Castilho ${ }^{1}$, Andressa Tomazini \\ Borghardt ${ }^{1}$ \\ Institution(s) ${ }^{1}$ HUCAM - Hospital Universitário Cassiano Antonio Moraes ( Av. Mal. Campos, 1355 - Santa \\ Cecilia, Vitória - ES, 29043-260)
}

\begin{abstract}
Introdução: O tratamento de indivíduos com lesões na pele é um desafio multiprofissional. Trato o referido trabalho de um relato de experiência sobre a implantação da Comissão de Cuidados com a pele de um Hospital Universitário de Vitória. A presença desse espaço colegiado permite a atuação do enfermeiro na equipe nos cuidados com a pele, principalmente como articulador das ações institucionais de assistência a essa clientela. Objetivo: Relatar a experiência de implantação da Comissão de Cuidados com a Pele (CCP) em um Hospital Universitário do estado Espírito Santo. Materiais e método: Trata-se de um estudo descritivo, do tipo relato de experiência, realizado a partir da percepção dos autores enquanto enfermeiros membros da Comissão de Cuidados com a Pele. Resultados: Em 2015 a partir da necessidade de acompanhar a evolução das lesões, a prevenção de lesões de pele, bem como padronizar condutas e produtos surge a oportunidade da criação da Comissão de Cuidados com a pele, que é composta por médicos, enfermeiros, farmacêuticos, nutricionistas que atuam na fomentação de um ambiente mais seguro, com o intuito de melhorar as práticas institucionais de cuidado com a pele e lesões, melhorando desta forma a qualidade da assistência, com possibilidade de otimização de custos. Entre as atividades desse grupo priorizou-se a segurança do paciente com criação de protocolo de prevenção de lesões de pele. Em seguida, foi construído de Procedimentos Operacionais Padrão e aperfeiçoado os descritivos para aquisição de materiais. Além disso, elaboraram ferramentas para o registro do acompanhamento aos pacientes com lesão, corroborando no desenvolvimento do processo de enfermagem, além do protocolo de tratamento de lesões de pele que já se encontra disponível para todas as áreas assistenciais. Conclusão: Pelo relato de experiência dos enfermeiros membros da comissão de Cuidados com a Pele, a efetividade da implantação da CCP é observada atualmente pelo impacto positivo na instituição, pelo número de pedidos de consultas por diversas categorias proffissionais, pelas capacitações aos profissionais e pelo envolvimento de proffissionais de diversas áreas nos cuidados com a pele. $O$ enfermeiro tem um papel fundamental nesse processo, atuando de forma estratégica, uma vez que é quem coordena a comissão, tem maior número de membros desta categoria profissional e documenta suas ações de forma sistematizada.
\end{abstract}

Keywords: Assistência de Enfermagem, Equipe Multiprofissional , Estomaterapia

\section{Referências Bibliográficas}

1. Lima AFC, Castilho V, Rogenski NMB, Baptista CMC, Rogenski KE. Custos da implantação de um protocolo de prevenção de úlceras por pressão em um hospital universitário. Rev. Eletr. Enf. [Internet]. 2015 out. /dez.;17(4). Disponível em: http://dx.doi.org/10.5216/ree.v17i4.31051. 2. Mittag BF, Krause TCC, Roehrs H, Meier MJ, Danski MTR. Cuidados com lesão de pele: Ações de enfermagem. ESTIMA, v.15 n.1, p. 19-25, 2017. Disponível em:

https://www.revistaestima.com.br/index.php/estima/article/view/447/pdf. 3. Silva PLN, Souza EJ, Gonçalves RPF, Souto SGT, Alves CR, Santos CLS. Importância da comissão de curativos no tratamento das lesões cutâneas: um relato de experiência. REAS, Revista Eletrônica Acervo Saúde, 2017. Vol. Sup. 7, S310-S315. Disponível em: https://www.acervosaude.com.br/doc/S-25_2017.pdf. 


\title{
A CAPTAÇÃO DE RECURSOS COMO DESAFIO DA GESTÃO MUNICIPAL E PARA A ENFERMAGEM NA ESTRUTURAÇÃO DE UM SERVIÇO ESTOMATERAPIA
}

\author{
Author(s): $\quad$ Luana Agnoletto Reis ${ }^{1}$, Rita de Cassia Domanski ${ }^{1}$ \\ Institution(s) ${ }^{1}$ PUC-PR - Pontificia Universidade Católica do Paraná (Curitiba)
}

\begin{abstract}
A Atenção Domiciliar no âmbito do SUS está organizada em três modalidades, definidas a partir da caracterização do paciente e do tipo de atenção e procedimentos utilizados para realizar o cuidado humanizado. Para estabelecer em qual modalidade de atenção que o município de Xanxerê se enquadra seguimos o manual instrutivo do Ministério da Saúde baseando na Portaria n.963 de 27 de maio de 2013. Este trabalho tem como objetivo analisar os desafios da gestão e da equipe de enfermagem na estruturação de serviço de estomaterapia no município de Xanxerê, interior do estado de Santa Catarina, vinculado a Política Nacional de Atenção Domiciliar e ao Projeto Melhor em Casa. O método empregado para tal foi o proposto por LÜCK (2012) na qual os gestores têm a responsabilidade estabelecer unidade de ação, concentração de energia e direcionamento para promoção da efetivação dos objetivos e para a obtenção de resultados. O Projeto para implantação do Serviço de Estomaterapia (SE) foi apresentado aos gestores municipais, Secretário de Saúde, Diretor de Saúde e Diretoria de Atenção Básica que, e apoiaram a criação do serviço. O serviço foi coordenado pelo enfermeiro, e constituído pelo grupo multiprofissional composto por enfermeira estomaterapeuta, clínico geral, infectologista, assistente social, fisioterapeuta, psicóloga, nutricionista e técnicos de enfermagem. O espaço selecionado para o serviço seguiu as NBRs e RDCs em vigor. Os pacientes atendidos no SE foram encaminhados pelas Unidades Básicas de Saúde (UBS) e/ou Hospital Regional, estes foram atendidos pela enfermeira estomaterapeuta. A capacidade máxima de atendimentos prevista por mês foi inicialmente de 90 pacientes, considerando os acamados que recebem visita no domicilio com acompanhamento periódico. O levantamento demostrou a existência de uma demanda reprimida de 180 pacientes com lesões crônicas (Ulceras venosas, Arteriais, Lesão por Pressão) e agudas. A cada mês eram elaborados relatórios completos, financeiros e técnicos. O serviço se viabilizaria pelo recurso da Política Nacional de Atenção Domiciliar e pelo fundo municipal de saúde, porém, após alguns meses o município não aderiu ao projeto Melhor em Casa, inviabilizando este a continuidade do projeto. Durante o funcionamento do projeto ficou comprovado que o tratamento adequado por especialista diminuiu o tempo de cura das lesões crônicas de pele, e os pacientes estomizados eram orientados imediatamente no pós alta hospitalar, onde era fornecido os dispositivos para estomia e capacitado o paciente e o familiar para a troca da bolsa de colostomia, diminuindo as complicações, o paciente com tratamento adequado não procurou mais o serviço hospitalar, nem a unidade de pronto atendimento. A pesquisa conclui que o principal desafio encontrado foi a captação de recursos, as verbas municipais escassas tornaram a manutenção do serviço inviável. Desta forma por falta de recursos financeiros e interesse governamental, o serviço manteve seu funcionamento por onze meses e foi encerrado. Este trabalho apresenta a importância da implantação do serviço e propõe a divulgação para mobilização de gestores em saúde na estrutura de atendimento especializado em saúde pública.
\end{abstract}

Keywords: Enfermagem, Gestão de Saúde, Estomaterapia

\section{Referências Bibliográficas}

Cadastro Naciona de estabelecimento de Saúde - CNES. DATASUS: Orientações; Disponível em: http://sinpsi.org/orientacao/cnes.pdf, acesso em 09 de novembro de 2013. YAMADA, Beatriz. Associação Brasileira de Estomaterapia: Histórico da Estomaterapia. 2013. Disponível em: http://www.sobest.org.br. Acesso em Abril de 2011. YAMADA, B.F.A.; FERROLA, E.C.; AZEVEDO, G.R.; BLANES, L.; ROGENSKI, N.M.B.; SANTOS, V.L.C.G. Competências do Enfermeiro Estomaterapeuta (ET) ou do Enfermeiro Pós-graduado em Estomaterapia (PGET). Revista Estima - vol 6 (1) 2008, p. 33-43. MARTINS, Margareth Linhares et al. A trajetória do grupo de apoio à pessoa ostomizada: projetando ações em saúde e compartilhando vivências e saberes. Texto contexto - enferm. [online]. 2005, vol.14, n.4, pp. 594-600. ISSN 0104-0707. Sobest, 2013. CURSOS DE ESPECIALIZAÇÃO EM ESTOMATERAPIA RECONHECIDOS PELA

SOBEST/WCET. Disponível em: http://www.sobest.org.br/index.php?option=com_content\&view=article\&id=48\&ltemid=48. Acesso em 10 nov 2013. . 


\title{
RELATO DE EXPERIÊNCIA EXITOSA DO PRIMEIRO AMBULATÓRIO DE ESTOMATERAPIA NO SUS REGULADO DA ATENÇÃO PRIMÁRIA À SAÚDE NA CIDADE DO RECIFE-PERNAMBUCO
}

\author{
Author(s): $\quad$ GRACIELY MARIA DE OLIVEIRA CASTRO ${ }^{1}$, ADRIANA CAVALCANTI BEZERRA ${ }^{1}$ \\ Institution(s) ${ }^{1}$ MPGE/UniFBV - Programa de Mestrado Profissional em Gestão Empresarial (Campus UniFBV | \\ Wyden, rua Jean Émile Favre, 422 - Imbiribeira Recife-PE)
}

\begin{abstract}
O Recife é a capital do estado de Pernambuco e de acordo com o Instituto Brasileiro de Geografia e Estatística1 possui cerca de 1.537.704 habitantes, sendo a terceira cidade mais populosa da região Nordeste do Brasil. A saúde pública da cidade do Recife é dividida em seis distritos sanitários2. Diante da falta de profissionais de enfermagem especializados, da falta de coberturas adequadas e na dificuldade de continuidade das lesões nas Unidades de Saúde da Família (USF) tornou-se importante a existência de um serviço de estomaterapia, inicialmente um projeto piloto para contribuir com o fortalecimento da atenção primária. Esse estudo tem como objetivo descrever a experiência exitosa do primeiro ambulatório de estomaterapia de um serviço público em Recife. O estudo realizado é de natureza descritiva, tipo relato de experiência de uma enfermeira estomaterapeuta em uma Unidade Pernambucana de Atenção Especializada (UPAE), a qual exerce sua autonomia baseada nas diretrizes da Associação Brasileira de Estomaterapia (SOBEST) e no protocolo da instituição. $O$ ambulatório é referência na cidade do Recife por ser o primeiro serviço no atendimento a pacientes com lesões complexas regulados da atenção primária à saúde. O serviço possui 01 ambulatório de estomaterapia, composto por 01 enfermeira estomaterapeuta que exerce as atividades assistenciais e administrativas do setor. $O$ início de atendimento pela estomaterapia tem seu fluxo de entrada via regulação por meio do encaminhamento do enfermeiro/médico da USF do Recife para os médicos especialistas (vascular, endocrinologista, dermatologista e hematologista) da rede pública, os quais realizam a avaliação e se necessário, encaminham para o ambulatório da UPAE. Ao chegar no serviço é realizada a admissão com anamnese, exame físico, mensuração e o registro fotográfico das lesões crônicas. Posteriormente, prescreve-se a terapêutica planejada para o acompanhamento contínuo. Quinzenalmente ocorre a reavaliação para manutenção da terapêutica ou redefinição da conduta. Atualmente, o ambulatório atende, em média, 40 pacientes com lesões complexas. É válido relatar que entre janeiro de 2018 a maio de 2019 foram realizadas 17 altas por cura (cicatrização total da lesão) o que demonstra a importância do manejo e da autonomia do enfermeiro3 estomaterapeuta no cuidado de lesões. No momento da alta é realizado um plano de cuidados, bem como a contrareferência com o retorno do cliente à sua USF de origem. No tocante ao gerenciamento administrativo, a estomaterapeuta realiza diariamente uma planilha de atendimento diário e provisão de material especial de forma individualizada evitando desperdícios. Portanto, o ambulatório de estomaterapia preenche uma lacuna assistencial por se tratar de uma especialidade que proporciona aos seus usuários uma assistência especializada, exercendo um papel importante no acompanhamento de lesões crônicas. A abertura do ambulatório foi uma experiência exitosa, pois proporcionou uma reorientação do fluxo de atendimento entre a rede primária e secundária do SUS, acarretando em melhoria da qualidade de vida. Como sugestão se faz necessário implementar outros ambulatórios para ampliar o número de atendimentos.
\end{abstract}

Palavras-chaves: assistência ambulatorial; autonomia profissional; estomaterapia

Keywords: Assistência ambulatorial, Autonomia profissional, Estomaterapia

\section{Referências Bibliográficas}

1. IBGE (Instituto Brasileiro de Geografia e Estatística). Panorama Brasil/Pernambuco/Recife. Último Censo 2010.

Disponível em: https://cidades.ibge.gov.br/brasil/pe/recife/panorama 2. Bastos PF. Território e redes de atenção à saúde no Recife: relação entre a atenção básica e os serviços de maior complexidade assistencial do SUS. Recife. Tese [Doutorado em Geografia] - Universidade Federal de Pernambuco; 2015. 3. Fentanes LRC, Hermann AP, Chamma RC, Lacerda MR. Autonomia profissional do enfermeiro: revisão integrativa. Cogitare Enferm. 2011.16(3): 530-5 


\title{
CONHECIMENTO DOS ENFERMEIROS DA ESTRATÉGIA DE SAÚDE DA FAMÍLIA SOBRE A REDE DE ATENÇÃO A PESSOA COM NECESSIDADES NA ÁREA DA ESTOMATERAPIA
}

\author{
Author(s): Lívia Rocha Martins Mendes ${ }^{1}$, Larissa Cruz Tancredo Norte ${ }^{1}$ \\ Institution(s) ${ }^{1}$ UNITAU - Universidade de Taubaté (Rua Visconde do Rio Branco, 210 Centro - Taubaté - SP \\ CEP 12.020-040)
}

\begin{abstract}
O atendimento ao paciente com estomia, lesão e incontinência ocorre nos três níveis da atenção à saúde, primário, secundário e terciário. A interação entre estes níveis juntamente com sistemas de apoio, logístico e de governança estruturam operacionalmente a rede de atenção a saúde possibilitando uma atenção integral e continua. A atenção primária a saúde é a ordenadora da rede de atenção a saúde sendo o enfermeiro um profissional essencial para organizar o fluxo de referencia e contra referencia de atendimento dos pacientes com necessidades na área da estomaterapia. Objetivo: Identificar o conhecimento dos enfermeiros da Estratégia de Saúde da Família (ESF) em relação à rede de serviço a pessoas com necessidades na área da estomaterapia. Método: Trata-se de pesquisa de natureza aplicada, descritivo e exploratório, com abordagem quantitativa. O estudo foi realizado em 21 centros de saúde da família de um município do Sul de Minas Gerais e o questionário com 15 perguntas foi respondido por 21 enfermeiros. O preenchimento foi realizado em local privativo, nos diferentes turnos de trabalho e respeitando a manifestação de interesse dos sujeitos da pesquisa em fornecer as informações. Resultados: Todos entrevistados tinham conhecimento do serviço de Estomaterapia, sendo o atendimento a pessoas com lesões identificado por $100 \%$ dos entrevistados como atuação do enfermeiro estomaterapeuta. Os enfermeiros da ESF referenciavam pacientes para o ambulatório e informaram não ter dificuldades para tal encaminhamento, consideraram o agendamento rápido, 19 enfermeiros (90,5\%) negaram insatisfação na contra referência, apesar do sistema de referência e contra referência da ESF para o ambulatório de Estomaterapia não ser padronizado. Conclusões:Concluiu-se que o entendimento dos enfermeiros sobre aspectos relacionados à rede de serviço para a assistência em estomaterapia ao usuário foi adequado. Mediante diversos benefícios mencionados, suscita-se a urgência em agilizar o processo de informatização nessa cidade, para a documentação do serviço, principalmente da comunicação no sistema de referência e contra referência na área de Estomaterapia.
\end{abstract}

Keywords: Enfermeiros da ESF, Estomaterapia, Referencia e contra referencia

\section{Referências Bibliográficas}

Mendes EV. As redes de atenção à saúde. Ciênc. saúde coletiva [Internet]. 2010; jan-ago; 15(5):2297-2305. Disponível em: http://dx.doi.org/10.1590/S1413-81232010000500005 Juliani CMCM, Ciampone MHT. Organização do serviço de referência e contra-referência no contexto do sistema único de saúde: a percepção de enfermeiros. Rev. Esc. Enf. USP. 1999; dez; 33:323-33. Paim JS. Atenção Primária à Saúde: uma receita para todas as estações? Saúde em Debate. 2012; 36(94):343347. Disponível em: http://www.scielo.br/pdf/sdeb/v36n94/a04v36n94.pdf Borges EL. A atuação do enfermeiro na estomaterapia e a legislação brasileira: avanços e crescimentos da área. Revista de Enfermagem do Centro Oeste Mineiro. 2016; 6(2). Disponível em: http://www.seer.ufsj.edu.br/index.php/recom/article/view/1467/1112 


\title{
IMPLANTAÇÃO DO PRIMEIRO AMBULATÓRIO DE LESÕES DE UMA ESCOLA MÉDICA
}

\author{
Ronesca Sech de Santana Dias ${ }^{1}$, Thaís Fagundes Barreto ${ }^{1}$, Emanuele Barreto de Lima Sousa ${ }^{1}$, \\ Author(s): Marília Leite de Castro Flores ${ }^{1}$, Yasmin Da Conceição Mac-Allister ${ }^{1}$, Taiara Lohana Figueiredo \\ Oliveira ${ }^{1}$, Andressa Thaíse Gondim Brito ${ }^{1}$ \\ Institution(s) ${ }^{1}$ EBMSP - Escola Bahiana de Medicina e Saúde Pública (Avenida Dom João VI, 275 - Brotas \\ Salvador Cep 40290-000)
}

\begin{abstract}
Introdução: As feridas podem ser definidas como uma interrupção da continuidade da superfície corpórea, interna ou externa, que pode ser resultante de lesões acidentais, cirúrgicas, térmicas, por pressão ou doença previamente instalada. A maior parte das feridas crônicas são úlceras associadas a doenças vasculares, Diabetes Mellitus, isquemia ou úlceras por pressão. $\mathrm{O}$ aparecimento da lesão implica na redução da qualidade de vida do paciente, com prejuízo das funções diárias e laborais, além de impacto psicológico associado a essa limitação. O Ambulatório de Lesões oferece, através de uma abordagem interdisciplinar, o acompanhamento do paciente portador de úlceras crônicas. Dando enfoque a instrumentalização das ações profissionais e a sistematização da assistência prestada de forma a organizar, oferecer subsídios e possibilitar escolhas apropriadas e disponíveis para o enfrentamento de problemas relativos ao tratamento de lesões. Objetivos: Relatar a experiência da implantação do Primeiro Ambulatório de feridas em uma escola médica. Material e método: Em janeiro de 2019, deu-se a inauguração do Ambulatório de Lesões. O serviço é composto por enfermeiras estomaterapeutas, cirurgiã plástica, cirurgião vascular, infectologista e técnicas de enfermagem. Os atendimentos são conduzidos pelas enfermeiras e acadêmicos de medicina do oitavo semestre da mesma faculdade. Cada grupo de seis alunos permanecem no ambulatório um mês. Durante o atendimento, é feito a classificação e avaliação da lesão, solicitação de exames, coleta de fragmentação de cultura e debridamento. Realiza e planeja a periodicidade das trocas dos curativos, programação de retorno, orientações quantos aos critérios de adesão e desligamento ao tratamento, manejo das coberturas especiais e cuidados com a lesão em domicílio pelo paciente e familiares. Posteriormente os pacientes são encaminhados à equipe médica para o controle da doença de base, os mesmos avaliam o estado geral, classificam a doença de base, avaliam as condições da lesão, prescrevem o tratamento sistêmico, coletam biopsia da lesão, aplicação de espuma, enxertia conforme a necessidade. As técnicas de enfermagem mantém a sala de curativos organizada, controlam estoque, prazo de validade, recebem o usuário, acomodando em posição confortável, realizam curativos simples e reposição de materiais. Resultados: A implantação do ambulatório de lesões e sua introdução na grade curricular do curso de medicina representa um momento singular para os acadêmicos, pois, foi oferecido a oportunidade de ampliar inquietações e reflexões sobre o tratamento e cuidado aos clientes com lesões crônicas. Além de beneficiar os usuários, pois, com pouco tempo de abertura do ambulatório, a assistência ofertada aos usuários tornou-se de qualidade promovendo alívio, conforto, cicatrização e prevenção de complicações, todos os profissionais envolvidos contribuem com a otimização dos recursos de maneira universal, equânime e racional. Conclusão: Finaliza-se este estudo com a perspectiva de que tanto os profissionais envolvidos quanto os acadêmicos de medicina aprendem cada vez mais e compreendem que se faz necessário a adoção e a implementação de um cuidado cada vez mais efetivo, reconhecendo o cliente como um ser dotado de múltiplas faces, e que necessita de assistência contínua para o enfrentamento do seu adoecimento, devendo ser fornecida pelo profissional que tem o cuidado com seu saber-fazer.
\end{abstract}

Keywords: Assistência Ambulatorial, Educação em Saúde, Educação Médica, Estomaterapia, Úlcera

\section{Referências Bibliográficas}

1. Clancy J, McVicar A, Muncaster D. The Physiology of Wound Healing and Wound Assessment. Br J Perioper Nurs (United Kingdom) [Internet]. 2001 [20 mai 2019] 11(8):362-70. Available from:

http://journals.sagepub.com/doi/10.1177/175045890101100805 2. Guo S, DiPietro LA. Factors Affecting Wound Healing. J Dent Res [Internet]. 2010 [20 mai 2019];89(3):219-29. Available from:

http://journals.sagepub.com/doi/10.1177/0022034509359125 3. Galvão NS, Serique MAB, Santos VLCG, Nogueira PC. Knowledge of the nursing team on pressure ulcer prevention. Rev Bras Enferm [Internet]. 2017[27 ago 2019];70(2):294-300. DOI: http://dx.doi.org/10.1590/0034-7167-2016-0063 


\title{
Simulação Realística para o ensino da enfermagem em estomaterapia: revisão integrativa
}

\author{
Author(s): $\quad$ Patrícia Alves dos Santos Silva ${ }^{1}$, Caroline Rodrigues de Oliveira ${ }^{1}$, Norma Valéria de Souza Dantas \\ ${ }^{1}$, Camila Cantarino Nascente Souza ${ }^{1}$, Déborah Machado dos Santos ${ }^{1}$ \\ Institution(s) ${ }^{1}$ UERJ - Universidade do Estado do Rio de Janeiro (Avenida Marechal Rondon, 381, São \\ Francisco Xavier)
}

\begin{abstract}
A simulação realística é uma metodologia de ensino que favorece inúmeras vantagens no processo de ensino aprendizagem de graduandos, especializandos e profissionias de enfermagem, que utiliza inúmeras ferramentas tecnológicas, podendo ser instrumentos de baixa, média ou alta fidelidade, bonecos estáticos, peças anatômicas, pacientes simulados, entre outras. Na estomaterapia, especialidade exclusiva do enfermeiro, existem técnicas e procedimentos que exigem enorme destreza e habilidade, como o desbridamento instrumental conservador, a demarcação de estomia e a irrigação intestinal; fazendo-se imperioso seu ensino e treinamento. Objetivo geral: analisar o referencial teórico sobre o uso da simulação realística no ensino das áreas de abrangência da estomaterapia. Objetivos específicos: identificar como a simulação realística é utilizada como estratégia de ensino das áreas de abrangência da estomaterapia e discutir a sua efetividade como ferramenta de ensino para a estomaterapia. Metodologia: trata-se de uma revisão integrativa da literatura, a partir de busca de periódicos especializados e posterior análise e discussão dos conteúdos. Justificativa: apresentar a sociedade científica de que forma a simulação realística tem sido utilizada no ensino das áreas de abrangências da estomaterapia, podendo sugerir práticas para melhoria do ensino dos cursos de especialização em estomaterapia, favorecendo o aperfeiçoamento da expertise profisional. Conclusão: é possível identificar que a simulação realística é uma ferramenta efetiva para o desenvolvimento dos saberes e fazeres dos discentes e profissionais de enfermagem e concluíse como uma importante ferramenta no processo de ensino - aprendizagem nas áreas de abrangências da estomaterapia. Entretanto, carece de pesquisas para diminuir a lacuna identificada pelo presente estudo.
\end{abstract}

Descritores: Simulação. Ensino. Enfermagem. Feridas. Estomias. Incontinências

Keywords: Simulação, Ensino, Enfermagem, Estomaterapia

\section{Referências Bibliográficas}

1. Ferreira C, Carvalho JM, Carvalho FLQ. Impacto da Metodologia de Simulação realística enquanto tecnologia aplicada a educação nos cursos de saúde. (III Seminário de Tecnologia Aplicada em Educação e Saúde). [acesso 15 fev 2019].

Disponível em: https://www.revistas.uneb.br/index.php/staes/article/view/1617. 2. Costa RRO, Medeiros S, Martins J, Araújo MS. O uso da simulação no contexto da educação e formação em saúde e enfermagem: uma reflexão acadêmica. Revista Espaço para a Saúde. 2015; 16(1):59-65. 3. Barreto DG, Silva KGN, Moreira SSCR, Silva TS, Magro MCS. Simulação realística como estratégia de ensino para o curso de graduação em enfermagem: Revisão Integrativa. Revista Baiana de Enfermagem. 2014; 28(2):208-2014. 4. Martins JCA, Mazzo A, Baptista RCN, Coutinho, Godoy S, Mendes IAC, et.al. A experiência clínica simulada no ensino de enfermagem: retrospectiva histórica. Acta Paul Enferm.2012;25(4):619-25. 5. David, HMSL, et.al. Laboratório de Habilidades: ambientes de tecnologia e inovação para o cuidado de enfermagem. [acesso $02 \mathrm{abr}$ 2019]. Disponível em: http://buscatextual.cnpq.br/buscatextual/visualizacv.do?id=K4790030P2 6. Souza MT, Silva MD, Carvalho R. Revisão Integrativa: o que é e como fazer. Rev Einstein. 2010; 8(1):102-6. 


\title{
IMPLEMENTAÇ̃̃O DE UM SERVIÇO DE ESTOMATERAPIA E PODIATRIA CLÍNICA EM UMA CIDADE DO SULL DE MINAS GERAIS: RELATO DE EXPERIÊNCIA
}

\author{
Author(s): $\quad$ Rosemary Vieira Souza Spenazato ${ }^{1}$, Valdecir Boeno Spenazato Junior ${ }^{1}$ \\ Institution(s) ${ }^{1}$ HCSL - Hospital das Clínicas Samuel Libânio (Rua Comendador José Garcia, 777 Pouso Alegre- \\ $\mathrm{MG)}$
}

\begin{abstract}
INTRODUÇÃO: A estomaterapia permite que o enfermeiro atue na área do empreendedorismo, conquistando a cada dia seu espaço no mercado de trabalho. O empreendedorismo é a criação de algo novo a partir da identificação de uma oportunidade, dedicação, persistência e ousadia aparecem como atitudes imprescindíveis neste processo para se alcançar os objetivos pretendidos ${ }^{1}$. A complexidade do cuidar de feridas é de responsabilidade da enfermagem. As múltiplas especialidades da enfermagem trouxeram mudanças que beneficiaram o perfil do enfermeiro na conquista de sua autonomia, principalmente em áreas onde possui relevância ativa como a estomaterapia e dermatologia ${ }^{2}$. É importante que o profissional da saúde enfermeiro seja capaz de desenvolver competências específicas na sua área, como também seja capaz de repensar e protagonizar novos espaços e práticas, pela busca da autonomia e emancipação dos sujeitos na condução de suas vidas, nos diferentes cenários sociais ${ }^{3}$. OBJETIVO: O estudo consiste em um relato de experiência sobre as etapas da implementação de um serviço de Estomaterapia e Podiatria Clínica em uma cidade do Sul de Minas Gerais no ano de 2018. MATERIAL E MÉTODO: O estudo é do tipo descritivo, exploratório com delineamento transversal e abordagem qualitativa dos dados.

RESULTADO: Em 2017 eu atendia pacientes em domicílio e então surgiu a vontade de montar um espaço para trabalhar com mais conforto e segurança, um serviço de Estomaterapia e Podiatria Clínica. Iniciei o serviço em uma cidade vizinha, junto à duas enfermeiras estomaterapeutas no ano de 2017. Na cidade não havia nenhum serviço de Estomaterapia $e$ Podiatria Clínica. Minha intenção era mudar para lá, porém quando comecei a divulgar meu serviço em redes sociais a repercussão foi maior do que eu imaginava em minha cidade então tive que montar o serviço ali também. Chamei uma amiga, enfermeira dermatoterapeuta para iniciar comigo e então começamos a correr atrás. A primeira etapa foi encontrar um local apropriado para montar o espaço. Depois fomos à vigilância sanitária e eles não sabiam nos orientar como teria que ser o espaço físico, então, corremos atrás do que conhecíamos e fomos montando de acordo com o que achávamos que seria o certo e no final foi aprovado o Alvará Sanitário. A parte da contabilidade também foi bem burocrática, o contador teve que pesquisar muito para nos ajudar a montar a empresa. A questão do Alvará de localização da prefeitura também nos enrolou um pouco, precisou estar pronto o consultório para eles liberarem o Alvará. Todo esse processo de escolha, preparo, execução e finalização já com os Alvarás de localização e sanitário duraram exatos nove meses da primeira vez e quatro da segunda para ser concluído. O serviço na cidade vizinha foi inaugurado em março de 2018 e na minha cidade em outubro de 2018. Atualmente atuo somente em minha cidade devido à grande demanda. CONCLUSÃO: A enfermagem em Estomaterapia me proporcionou empreender e correr atrás dos meus sonhos fazendo o que eu mais amo e atendendo 0 meu cliente com amor, dedicação, conforto e segurança.
\end{abstract}

Keywords: Enfermagem, Cuidado, Inovação

\section{Referências Bibliográficas}

1 Bispo CS, Souza DJ, Araújo FP, Cardoso NH, Silva PS, Santos Junior VR. Empreendedorismo e Inovação. Acesso em: 22/07/2019. Disponível em: http://www.uniceusa.edu.br/aluno/arquivos/artigo_empreendorismo_inovacao.pdf. 2 Salomé GM, Espósito VHC. Vivências de acadêmicos de enfermagem durante o cuidado prestado às pessoas com feridas. Rev Bras Enferm. 2008 nov-dez; 61(6): 822-7. 3 Bornstein D. How to change the world: social entrepreneurs and the power of new ideas. Oxford: University Press; 2007. 


\title{
A ATUAÇÃO DO ENFERMEIRO EM UMA ASSOCIAÇÃO DE APOIO À PESSOAS COM EPIDERMÓLISE BOLHOSA: RELATO DE EXPERIÊNCIA
}

\author{
Author(s): $\quad$ Ana Paula Hey ${ }^{1}$, ELOISA SEEGMULLER DE CARVALHO ${ }^{1}$ \\ Institution(s) ${ }^{1}$ UTP - UNIVERSIDADE TUIUTI DO PARANÁ (Rua Sydnei Antonio Rangel Santos, 238 - \\ cURITIBA PR), ${ }^{2}$ UTP - UNIVERSIDADE TUIUTI DO PARANÁ (Rua Sydnei Antonio Rangel \\ Santos, 238 - cURITIBA PR)
}

\begin{abstract}
Introdução: A epidermólise bolhosa (EB) é uma doença hereditária, rara e não contagiosa; que em suas manifestações clínicas, provoca, dentre outros sinais e sintomas, as feridas na pele e mucosas. A atuação do enfermeiro em associações de apoio à essa doença, é de extrema importância para a contribuição na promoção do bem estar; para que se evitem complicações e; para a manutenção da qualidade de vida. Além da atuação para mehoria das políticas públicas voltadas ao público em questão. Objetivo: Descrever um relato de experiência acerca da importância do enfermeiro em uma associação de apoio à pais e pessoas com epidermólise bolhosa. Materiais e Método: Trata-se de relato de experiência realizado com três enfermeiras, participantes de uma associação sem fins lucrativos, que presta apoio a pais, amigos e pessoas com EB, na região sul do Brasil. O período de atuação dos enfermeiros na associação, inicia com sua fundação, em fevereiro de 2016 e vem até o presente momento. Após aprovação do CEP, dob o parecer número 3.245.096, o estudo se deu em três etapas: entrevista com os enfermeiros; posterior análise de respostas e; correlação dos relatos com referências sobre o tema. Resultados: Foram entrevistados três enfermeiros, que compõe o quadro de enfermeiros voluntariado da referida associação. As especialidades desses enfermeiros são: estomaterapia; obstetrícia e; neonatologia. O processo de trabalho narrado pelos mesmos foi dividio em cinco esferas, sendo elas: 1) Assistir: onde se encontrou o maior papel desempenhado por eles. As narrativas apontam a assistência ao recém nascido, no que se refere aos cuidados com a higiene corporal e à pele e, ainda, ao aleitamento materno. Referem ainda o atendimento à pessoas com EB em diferentes faixas etárias; 2) Administrar: as narrativas evidenciaram a solicitação de coberturas e outros materiais necessários ao cuidado; bem como encmainhamentos de referência contra referência; 3 ) Ensinar: os relatos evidenciaram o ensino para o autocuidado às pessoas com EB, envolvendo familiares e profissionais de saúde. Além disso, evidenciou-se participação em várias esferas sociais para a divulgação da doença e; apoio à inserção escolar das pessoas com EB. 4) Pesquisar: na pesquisa, evidenciou-se nos relatos, a revisão de estudos de profissionais interessados no estudo da EB e, da participação em bancas sobre o tema; porem com pouco desenvolvimento de pesquisas próprias e: 5) Atuar politicamente: nesse aspecto evidenciou-se a luta por melhores políticas públicas à pessoas com EB, com a participação em eventos e reuniões em diversas esferas governamentais sobre o tema. Conclusões: O enfermeiro, ao participar de uma associação de apoio à pessoas com EB, amplia seu processo de trabalho; participando não apenas de processos assistenciais, mas também atuando nas esferas da educação, pesquisa e atuação política. Esse profissional, contribui sobremaneira no cuidado à esse público; participando intensamente das questões sociais e históricas que fazem interface com sua realidade
\end{abstract}

\section{Keywords: ESTOMATERAPIA, EPIDERMÓLISE BOLHOSA, ENFERMEIROS, CUIDADOS DE ENFERMAGEM}

\section{Referências Bibliográficas}

1. Denyer J, Pillay E, Clapham J. Best practice guidelines for skin and wound care in epidermolysis bullosa. An International Consensus. Wounds International, 2017 2. Mandelbaum, MH; Barreiros, DCZ; Mouassab, PA. Epidermólises Bolhosas: Assistência de Enfermagem aos Portadores e seus Familiares. Rev. Estima, 2004 (acesso em 03 de junho de 2019); Vol.2 (3). Disponível em https://www.revistaestima.com.br/index.php/estima/article/view/153 3. Bernardes, LCC.; Paula, RAB. Assistência do profissional enfermeiro frente à pessoa com epidermólise bolhosa. Rev. Revela, 2018 (acesso em 20 de fevereiro de 2019). Ed.22. Disponível em http://www.fals.com.br/revela/ed22/ED22_T3.pdf 4. Brasil. Lei n. 7.498, de 25 de junho de 1986. Dispõe sobre a regulamentação do exercício da Enfermagem e dá outras providências. Diário Oficial da União. 26 jun 1986. 5. Pitta AL, Magalhães RP, Silva JC. Epidermólise bolhosa congenita: importância do cuidado de enfermagem. Rev Cuid 2016 (acesso em 02 mar 2019); 10(2):201-208. Disponível em http://bases.bireme.br/cgi-

bin/wxislind.exe/iah/online/?lsisScript=iah/iah.xis\&src=google\&base=BDENF\&lang=p\&nextAction=Ink\&exprSearch=30352 \&indexSearch=ID 


\title{
CRITÉRIOS DE AVALIAÇÃO DE ESTOMAS DE ELIMINAÇÃO EM UM AMBULATÓRIO DE FERIDAS E ESTOMIAS
}

\author{
Author(s): $\quad$ PAULO SÉRGIO GOMES DA SILVA ${ }^{1}$, Fabianny Torres de Oliveira ${ }^{1}$, Hilma Keylla de \\ Amorim ${ }^{1}$, Lázaro Betel Eustaquio da Silva ${ }^{2}$, Lucy Kelly Brito Bomfim Eustaquio ${ }^{1}$ \\ Institution(s) ${ }^{1}$ HUPAA - Hospital Universitário Professor Alberto Antunes (AV Lourival melo Mota, SN, \\ Cidade Universitária, Maceió/AL), ${ }^{2} \mathrm{HM}$ Assist Domiciliar - Homedical Assistência Domiciliar \\ (Rua do Uruguai, 114, Jaraguá, Maceió/AL)
}

\begin{abstract}
Introdução: o paciente portador de estoma de eliminação necessita de uma atenção especial dos profissionais da saúde, destacando-se o cuidado de enfermagem como imprescindível no período pré e pós-operatório, uma vez que sua assistência é pautada na avaliação, realização do manejo do dispositivo coletor do efluente e orientação ao paciente e família quanto aos cuidados necessários. Dessa forma, é notório que avaliação do estoma e pele periestomal é uma das etapas fundamentais, visto que influenciará diretamente nas condutas do profissional frente ao processo de reabilitação. Objetivo: descrever os critérios de avaliação de estomas de eliminação e pele periestomal instituídos em um ambulatório de feridas e estomias. Método: Trata-se de um estudo descritivo e exploratório com abordagem qualitativa dos principais critérios de avaliação de estomas de eliminação realizados por enfermeiros durante assistência de enfermagem ao paciente admitido no Ambulatório de Pesquisa, Prevenção e Tratamento de Feridas e Estomias do Hospital Universitário Professor Alberto Antunes, na cidade de Maceió/AL. Resultados/Discussão: Os enfermeiros do ambulatório de feridas e estomias elaboraram uma ficha de Consulta de Enfermagem Admissional para os pacientes atendidos no serviço, na qual constam dados de identificação do paciente, história clínica e dados relacionados ao estoma e pele periestomal (tipo de estomia, localização no abdome, tempo de permanência, diâmetro e protusão do estoma, aspecto do estoma, tipo de efluente, condições da pele periestomal, complicações, conduta de enfermagem, dispositivo adaptado, orientações de enfermagem e se faz uso de irrigação intestinal. Nesta ficha também possui o campo para agendamento de retorno para reavaliação, bem como informações inerentes ao registro de óbito, transferência de cadastro e reversão do estoma. Dessa forma, é de extrema importância que o enfermeiro desempenhe sua assistência embasada nas evidências científicas, promovendo uma avaliação fundamentada que possibilite o processo de reabilitação do paciente estomizado. Conclusão: portanto, é perceptível que a implementação dos critérios de avaliação de estomas de eliminação adotados no ambulatório de feridas e estomias contribuam para que o enfermeiro desempenhe a sistematização da assistência de enfermagem, promova à uniformidade do cuidado prestado e contribua no tratamento adequado às condições clínicas do paciente. $O$ conhecimento a respeito da avaliação de estomias de eliminação é fundamental para prestação do cuidado de enfermagem, pois possibilita uma assistência com mais rigor científico e resolutividade nas ações assistenciais.
\end{abstract}

Keywords: Assistência de Enfermagem, Estomas, Avaliação de Estomas, Paciente

\section{Referências Bibliográficas}

BRASIL. Ministério da Saúde. Portaria no 400 de atenção à saúde das pessoas com estoma. Brasília-DF, 2009. Disponível em: http://bvsms.saude.gov.br/bvs/saudelegis/sas/2009/prt0400_16_11_2009.html. Acesso em 20 de agosto de 2019. Manual de orientação aos serviços de atenção às pessoas ostomizadas. Disponível em:

HTTPS://saude.es.gov.br?Media/sesa/Consulta\%20P\%C3\%BAblica/Ostomizado/MANUAL_OSTOMIZADOS_Consulta\%20 publica\%202017\%20(1).pdf. Acesso em: 20 de agosto de 2019. MAURíCIO, Vanessa Cristina; SOUZA, Norma Valéria Dantas de Oliveira; LISBOA, Márcia Teresa Luz. O enfermeiro e sua participação no processo de reabilitação da pessoa com estoma. Escola Anna Nery Revista de Enfermagem, v. 17, n.3, p. 416-422, 2013. SOUSA, Clementina Fernandes de; SANTOS, Célia; GRAÇA, Luís Carlos Carvalho. "Construção e validação de uma escala de adaptação a estomia de eliminação". Revista de enfermagem (2015): 21-30. 


\title{
ESTRATÉGIAS EDUCATIVAS UTILIZADAS PARA ORIENTAÇÃO À PACIENTES E CUIDADORES NA REALIZAÇÃO DO CATETERISMO VESICAL INTERMITENTE LIMPO: REVISÃO INTEGRATIVA
}

\author{
Author(s): \\ Shirley Santos Martins ${ }^{1}$, Jordana Maria Freitas Alves Alves ${ }^{1}$, Luciany Barbosa da Silva Fernandes Fernandes \\ Institution(s) \\ Walna Luisa Barros e Ramos Ramos ${ }^{1}$ \\ ${ }^{1}$ HUUFMA - Hospital Universitário Presidente Dutra (Rua Barão de Itapary, Centro, São Luís-Ma)
}

\section{Abstract \\ 1 INTRODUÇÃO}

A disfunção neurológica da unidade vesicouretral são decorrentes de processos patológicos que acomete as vias nervosas envolvidas no processo miccional. O cateterismo vesical intermitente (CVI) é o método de escolha para o esvaziamento periódico da bexiga realizado pela introdução de um cateter via uretral, ou através de um conduto cateterizável (como os condutos de Mitrofanoff ou Monti) até a bexiga ou reservatório urinário.

O cuidado urológico prestado pelo enfermeiro compreende a prevenção de complicações através do estabelecimento de efetiva drenagem urinária, preservação da função renal, obtenção de continência urinária e promoção de qualidade de vida, no sentido de reintegrá-los na comunidade, através do treinamento e orientação do paciente, familiares e cuidadores sobre a necessidade do cateterismo intermitente e a correta técnica de execução.

O presente estudo tem como objetivo conhecer na literatura estratégias educativas utilizadas para orientação à pacientes e cuidadores sobre a realização do autocateterismo e cateterismo vesical intermitente técnica limpa.

2 OBJETIVOS: • Conhecer na literatura estratégias educativas utilizadas para orientação à pacientes e cuidadores sobre a realização do cateterismo vesical intermitente limpo;

- Destacar a funcionalidade do cateterismo vesical intermitente limpo na prevenção de infecções do trato urinário.

3 MATERIAL E MÉTODOS

Utilizou-se o método de revisão integrativa com formulação da questão norteadora do estudo; estabelecimento dos critérios de inclusão e exclusão; definição das informações a serem extraídas das pesquisas selecionadas; avaliação dos estudos incluídos na revisão integrativa; interpretação dos resultados; apresentação da revisão e síntese do conhecimento.

Formulou-se uma questão norteadora: Quais as estratégias educativas disponíveis na literatura utilizadas para orientação à pacientes e cuidadores sobre a realização do cateterismo vesical intermitente limpo?

A pesquisa foi na Biblioteca Virtual em Saúde com as bases de dados BDENF, Lilacs, e Medline no período de 2002 à 2017. Realizou a seguinte estratégia de busca nas bases de dados: enfermagem and cateterismo urinário; cateterismo urinário and autocuidado; cateterismo urinário and educação em saúde e cateterismo urinário and segurança do paciente. Ao final, 05 estudos foram incluídos na presente revisão integrativa, destaca-se a limitação de publicações nacionais.

\section{RESULTADOS}

Das publicações selecionadas, os cinco artigos eram de autoria de enfermeiros. Na literatura pesquisada dentre as estratégias educativas utilizadas para disseminar a técnica limpa destaca-se: Materiais Ilustrativos com descrição detalhada; cartilhas; materiais impressos; desenhos e vídeos, todos com linguagem simples. Salienta-se que a técnica deve ser explicada claramente, passo a passo com demonstração dos materiais necessários. O paciente e cuidador realiza a técnica no consultório com discussão após a realização. Outra estratégia refere-se a atividade em grupo com os pacientes e/ou cuidadores para a troca de experiências, orientação e treinamento.

É crescente e inovador a utilização de tecnologias em saúde. A informática educativa serve como um instrumento a mais de apoio ao professor, funcionando como meio didático.

Evidencia-se na literatura estudada a predominância do profissional enfermeiro na aplicação do diário miccional à pacientes em uso do CVI.

5 CONCLUSÃO:O cateterismo vesical intermitente técnica limpa é um procedimento com vários benefícios, torna o paciente independente e preserva o sistema urinário, quando bem orientado, proporciona ao paciente oportunidade de convivência social.

Keywords: Autocuidado, Cateterismo Urinário, Estomias, Educação em Saúde, Segurança do paciente

\section{Referências Bibliográficas}

Mazzo A, Júnior, V.D.S, Jorge, B.M, Fumincelll, L, Trevizan, M.A, Ventura, C.A.A, Mendes, I.A.C. Qualidade e segurança do cuidado de enfermagem ao paciente usuário de cateterismo urinário intermitente. 2017 [acesso em 21 ago 2017]. Disponível em

file://C:/Users/Usuário/Desktop/artigos\%20para\%20apesquisa/PESQUISA\%20CATETERISMO\%20URINARIO\%20AND\%20ENFERMAG EM/MAZZO,\%20ET\%20AL,\%202017. Oliveira, F.M. Educação continuada do Enfermeiro na atenção à pessoa com lesão medular. 2015 [ acesso em 18 ago 2017] Disponível em

file://C:/Users/Usuário/Desktop/artigos\%20para\%20introducao/Dissertação_atuallIII_7_de_janeiro_modificações_FERNANDA_OLIVEIRA .pdf SOCIEDADE BRASILEIRA UROLOGIA. Recomendações SBU 2016: Cateterismo Vesical Intermitente. 2016 [acesso em 29 abr 2019]. Disponível em file://C:/Users/Usuário/Desktop/artigos\%20para\%20introducao/Recomendações_Cateterismo-Vesical-SBU2016_final.pdf. 


\title{
Implementação de bundle para prevenção de lesão por pressão peniana causada por dispositivo médico
}

\author{
Author(s): \\ Ivan Rogério Antunes ${ }^{1}$, Angélica Olivetto de Almeida ${ }^{1}$, Vanessa Abreu da Silva Silva ${ }^{1}$, Renata Fagnani \\ Author $(\mathrm{s})$ : \\ Institution(s) \\ Eliete Boaventura Bargas Zeferino ${ }^{1}$, Antônio Gonçalves de Oliveira Filho ${ }^{1}$, Renata Cristina Gasparino ${ }^{2}$ \\ ${ }^{1}$ HC-Unicamp - Hospital de Clinicas de Unicamp (Rua Vital Brasil, 251), ${ }^{2}$ Fenf - Faculdade de \\ Enfermagem Unicamp (Rua Tessália Vieira de Camargo, 126. Cidade Universitária Campinas/SP )
}

\begin{abstract}
Introdução: A preocupação em promover uma assistência segura e livre de danos aos pacientes ganhou destaque a partir de 1999. Nas décadas seguintes, inúmeros documentos e protocolos foram descritos com o intuito de auxiliar as instituições na implementação de medidas de prevenção de eventos adversos. Dentre esses eventos, merece destaque as Lesões por Pressão (LP) que ocasionam dor, infecção, atraso na recuperação funcional levando ao aumento do período de internação, custos e sofrimentos aos pacientes e seus familiares1. A LP relacionada a Dispositivos Médicos é ocasionada pelo uso de dispositivos criados e aplicados para fins diagnósticos e terapêuticos e, geralmente, apresenta o padrão ou forma do próprio dispositivo.2,3 $\mathrm{Na}$ análise dos indicadores de LP da instituição do ano de 2016, foi observado elevado número de lesões penianas nos pacientes internados, ocasionadas pelo cateter vesical de demora. Assim, o objetivo do presente estudo foi descrever os resultados da implementação de um pacote de medidas (bundle) para prevenção de LP por dispositivo médico (cateter vesical de permanência - CVP).

Método: Trata-se de um estudo retrospectivo, de avaliação dos resultados, realizado em um hospital público de ensino do interior do estado de São Paulo. Após identificação da elevada taxa de lesões penianas relacionadas aos CVP, o Núcleo de Estomaterapia, identificou como falhas: calibre acentuado do CVP dispensado pelo almoxarifado para maioria dos pacientes, CVP com balonete de $30 \mathrm{~mL}$ preenchidos de maneira inadequada e ausência de fixação dos CVP. Com base nos achados foi elaborado um bundle que abordou as seguintes medidas: a) padronização de aquisição e dispensação de cateteres (CVP) de menor calibre e com balonetes de $5 \mathrm{~mL}$; b) capacitação das equipes multiprofissionais com relação a escolha do CVP, preenchimento uniforme do balonete e resgate da importância da fixação do CVP. Para adoção das medidas "a" do bundle foram necessárias medidas administrativas relacionadas aos setores de compras e almoxarifado para revisão da logística de aquisição e distribuição dos CVP, já as medidas "b" foram realizadas por meio de reuniões disciplinares e informativos visuais (folders e banners). Onze meses foram necessários para elaboração e instituição do bundle em todas unidades assistenciais do hospital. Para análise dos indicadores de LP por tipo, dos anos de 2016 a 2018 , foi utilizado o sistema informatizado do Núcleo de Estomaterapia, sendo os resultados apresentados por frequências absolutas e relativas.

Resultados: Após a implementação do bundle, foi observada uma alteração no perfil do calibre dos cateteres utilizados no hospital com aumento na utilização dos CVP de menor calibre (14F) e redução na utilização dos de maior calibre (16, 18 e 20F). A distribuição em anos das LP, $2016(n=13) ; 2017(n=9)$ e $2018(n=6)$ demonstra que houve uma diminuição de $54 \%$ no indicador de LP peniana por CVP ao comparamos 2018 e 2016 . Conclusão: A implementação do bundle de medidas para prevenção de LP peniana mostrou-se eficaz, para redução do número de LP penianas relacionadas ao CVP no hospital.
\end{abstract}

Keywords: Prevenção, Lesão por pressão, Dispositivo médico, Estomaterapia

\section{Referências Bibliográficas}

Galetto SGS, Nascimento ERP, Hermida PMV, Malfussi LBH. Medical device-related pressure injuries: an integrative literature review. Rev Bras Enferm. 2019;72(2):505-12. doi: http://dx.doi.org/10.1590/0034-7167-2018-0530 Caliri MHL, Santos VLCG, Mandelbaum MHS, Costa IG. Classificação das lesões por pressão - Consenso NPUAP 2016 - adaptado culturalmente para o Brasil. Associação Brasileira de Estomaterapia e Associação Brasileira de Enfermagem em Dermatologia. Disponível em: http://www.sobest.org.br/textod/35. Acesso em 14/06/2019. Lo E, Nicolle LE, Coffin SE, et al. Strategies to Prevent Catheter-Associated Urinary Tract Infections in Acute Care Hospitals: 2014 Update SHEA/ IDSA Pract e recommendation. Infection Control and Hospital Epidemiology 2014;35(S2). Disponível em: https://www.cambridge.org/core/services/aop-cambridge-

core/content/view/3301D1C20170F3258EE773CFDEF6BD12/S0899823X00193845a.pdf/strategies_to_prevent_catheterassociated_urinar y_tract_infections_in_acute_care_hospitals_2014_update.pdf 


\title{
O PAPEL DO ENFERMEIRO NA PREVENÇÃO DO PÉ DIABÉTICO E SUAS COMPLICAÇÕES: REVISÃO DE LITERATURA
}

\author{
Author(s): $\quad$ Ana Paula Oliveira ${ }^{1,2,2}$, Bruno Vinícius Pereira Costa ${ }^{1,2,1}$, Ana Savina da Rocha Amorim ${ }^{1,1,1}$ \\ Institution(s) ${ }^{1}$ UNINASSAU - Faculdade UNINASSAU - Campus Parnaíba (Rodovia BR-343, Km 7,5, S/N - \\ Floriópolis, Parnaíba - PI, 64204-260), ${ }^{2}$ UNINASSAU - Faculdade UNINASSAU - Campus \\ Parnaíba (Rodovia BR-343, Km 7,5, S/N - Floriópolis, Parnaíba - PI, 64204-260), ${ }^{3}$ UNINASSAU \\ - Faculdade UNINASSAU - Campus Parnaíba (Rodovia BR-343, Km 7,5, S/N - Floriópolis, \\ Parnaíba - PI, 64204-260)
}

\begin{abstract}
INTRODUÇÃO: A Diabetes Mellitus é uma doença metabólica de grande relevância na modernidade, constituindo-se em um grave problema de saúde pública e de epidemia mundial, na qual faz parte de um grupo de patologias caracterizadas como crônicas por apresentar hiperglicemia relacionado a complicações, como o pé diabético, que é entendido como um estado fisiopatológico multifacetado, determinado por lesões que surgem de traumas que acomete os pés da pessoa com diabetes e ocorre devido neuropatia em $90 \%$ dos casos de doença vascular periférica e de deformidades. OBJETIVO: Verificar na literatura o papel do enfermeiro na prevenção do pé diabético e suas complicações. MÉTODOS: Trata-se de uma revisão de literatura, executada a partir das bases de dados Lilacs, PubMed, Medline e Cinahl. Os critérios de inclusão dos materiais selecionados foram: publicações entre o período de 2014 a junho de 2019, estando em língua portuguesa, inglesa e espanhola, acessível na integra, artigos indexados em pelo menos uma das bases de dados supracitadas e localizáveis mediante palavras-chave e descritores: Pé diabético; Enfermagem; Diabetes Mellitus. Critérios de exclusão: artigos científicos que não apresentassem pelo menos dois dos descritores utilizados, trabalhos que não tiveram relação direta com o tema, bem como os artigos que não foram encontrados textos completos disponíveis ou com link de acesso apresentando erro. Mediante os critérios de inclusão e exclusão foram selecionados 17 artigos que se enquadram nos objetivos. RESULTADOS: Evidencia-se que o enfermeiro tem uma atuação essencial no processo da assistência aos pacientes tanto na prevenção do pé diabético, quanto nas suas complicações, na qual deve procurar realizar suas ações utilizando como instrumento de trabalho a consulta de enfermagem integralizada, a anamnese e o exame físico seguido pelos de testes de sensibilidade na busca de detectar precocemente as causas de riscos e possíveis complicações. No entanto, é necessário orientar os pacientes portadores de diabetes com referência aos cuidados apropriados que devem ser tomadas com os pés, tais como inspeção, higiene, hidratação, remoção de calos, uso de calçados apropriados, controle glicêmico, prática de atividade física e avaliação nutricional. Entretanto, verifica-se que o enfermeiro não está totalmente capacitado para lidar com o pé diabético, pois os cuidados ofertados pelos mesmos estão mais direcionados para a patologia, como o controle regular da glicemia, distribuição de fármacos, verificação de sinais vitais, entre outros. CONCLUSÃO: Portanto, o enfermeiro tem o papel imprescindível no processo dos cuidados aos pacientes portadores de diabetes, na qual deve atuar de forma holística e planejando estratégias educativas de caráter preventivo que promovam o autocuidado e a prevenção do pé diabético, visto que é maneira mais eficaz de evitar as complicações podológicas. Ademais, é essencial que sejam desenvolvidos novos estudos com o intuito de demonstrar com mais propriedade as ações dos enfermeiros diante do paciente com pé diabético, possibilitando a construção de conhecimento, capacitação e qualidade de vida da pessoa portadora de diabetes.
\end{abstract}

Keywords: Pé diabético, Enfermagem, Diabetes Mellitus

\section{Referências Bibliográficas}

Dantas D, Costa J. Atuação do enfermeiro na prevenção do pé diabético e suas complicações: revisão de literatura. Carpe Diem: Revista Cultural e Científica do UNIFACEX [revista em Internet] 2015 setembro-dezembro. [acesso 19 de junho de 2019]; 11(3). Disponível em: https://periodicos.unifacex.com.br/Revista/article/view/359 Hirota C, Haddad M. Pé diabético: 0 papel do enfermeiro no contexto das inovações terapêuticas. Ciênc cuid saúde [revista em Internet] 2015 setembrodezembro. [acesso 19 de junho de 2019]; 7 (1). Disponível em:

http://hiperbaricasantarosa.com.br/arquivos/PE_DIABETICO_O_CONTEXTO_DOS_ENFERMEIROS_NAS_INOVACOES_ TERAPEUTICAS.pdf Maia T, Silva L. O pé diabético de clientes e seu autocuidado: a enfermagem na educação em saúde. Escola Anna Nery Revista de Enfermagem, [revista em Internet] 2017 setembro-dezembro. [acesso 19 de junho de 2019]; 9 (1). Disponível em: https://www.redalyc.org/pdf/1277/127720494012.pdf 


\title{
EPIDERMÓLISE BOLHOSA - EFICÁCIA NO MANEJO DA PELE COM O USO DE COBERTURAS DE ESPUMA SUPERABSORVENTE COM SILICONE E FORMATO ANATÔMICO: RELATO DE CASO
}

Author(s): Elaine Alboledo Monteiro 2, Andrezza Carla Cavalcanti Pires D’Azevedo 2, Railson Canavieira Araújo 1, Eliane de Sousa Alves 3

Institution(s): 1 Med Surgery - Med Surgery Hospitalar LTDA. (R. Alameda Primavera, 6 - Olho D'agua, São Luís - MA, 65065-430, Brasil), 2 Essity - Essity do Brasil (Avenida das Nações Unidas, 8501 - 70 andar), 3 HI Dr. JuvencioMA - Hospital Infantil Dr. Juvêncio Mattos (R. São Pantaleão - Centro, São Luís - MA, 65065-545)

\begin{abstract}
A Epidermólise Bolhosa (EB) é uma doença que corresponde a um grupo de genodermatoses infrequentes, clínica e geneticamente heterogêneas, caracterizadas pela fragilidade cutânea leve a severa e vesículas (bolhas) ou erosões na pele e nas mucosas, que podem ser expontâneas ou provocadas por mínimo trauma1,2. As crianças com essa enfermidade são conhecidas como "Crianças-Borboletas", pela semelhança de sua pele com as asas desse animal pela vulnerabilidade, que a faz descolar também pelo calor excessivo ou até mesmo de forma expontânea, logo após seu nascimento3. Existem quatro tipos principais de EB, de acordo com o nível de formação das bolhas, sendo: EB simples (EBS), EB juncional (EBJ), EB distrófica (EBD) e a Síndrome de Kindler. Para todas, há a necessidade do manejo adequado da pele, que inclui desde a forma de segurar a criança, roupas confortáveis e, especialmente, o uso de coberturas atraumáticas, como as espumas com silicone e tiras superabsorventes termo-seladas e a espuma de poliuretano em rolo para a fixação confortável e segura dos curativos. Objetivo: Demonstrar a eficácia do uso de coberturas de espuma com silicone e tiras superabsorventes termo-seladas e espuma suave em rolo no manejo da pele de um paciente com EBD (tratamento de lesões e prevenção de novos traumas).

Metodologia: Trata-se de um relato de caso em um paciente do sexo masculino, com aproximadamente 1 mês de vida, portador de EBD e internado num hospital infantil em São Luís, Maranhão. Apresentava extensas lesões bolhosas e crostosas por todo o corpo, que pioravam com sua movimentação. Após limpeza e desbridamento mecânico das crostas, foi iniciado o uso das coberturas de espuma com silicone e tiras superabsorventes termo-seladas nos membros superiores e inferiores, abdome e tórax, objetivando-se tratar as feridas já existentes e prevenir novos danos à pele. Para a fixação, foi utilizada a espuma de poliuretano em rolo. As trocas ocorreram a cada $72 \mathrm{~h}$, em média. A coleta dos dados foi realizada por acompanhamento clínico e registros fotográficos. O responsável pelo paciente assinou o termo de autorização do uso das imagens para fins didáticos. Resultados: As coberturas de espuma com silicone e tiras superabsorventes termo-seladas foram utilizadas no tratamento das lesões por 14 dias (4 trocas no total), com a cicatrização total dessas. Nesse mesmo dia, seu uso foi continuado para a prevenção de novas lesões, principalmente devido à movimentação do corpo do paciente que levava a traumas na pele. Em todo o processo, a espuma de poliuretano foi utilizada também de forma positiva, permitindo o posicionamento das coberturas no corpo sem causar novas lesões, além de fornecer conforto ao paciente. Conclusão: Pôde-se concluir que o uso das espumas com silicone e tiras superabsorventes termo-seladas para a prevenção e tratamento das lesões decorrentes da Epidermólise Bolhosa são efetivas, principalmente no que se refere ao seu uso atraumático e ao gerenciamento de exsudato, permitindo um meio assertivo para a cicatrização da pele. Conclui-se também que a espuma de poliuretano em rolo é eficaz para o posicionamento das coberturas na pele, fornecendo conforto e segurança ao paciente durante seu uso
\end{abstract}

Keywords: EPIDERMÓLISE BOLHOSA, MANEJO DA PELE, ESPUMA SUPERABSORVENTE E SILICONE, ESPUMA PROTETORA EM ROLO

\section{Referências Bibliográficas}

1- Vidal G., Carrau, F., Lizarraga M., Álvarez M. Epidermólisis Ampollar: a propósito de um caso clínico. Arch. Pediatr. Urug, 2018; 89(6): 382-388. 2- Benício C.D.A.V et al. Epidermólise Bolhosa: Foco na assistência de Enfermagem. Revista ESTIMA. 2016. v.14 n.2, pp.91-98. 3- DEBRA Brasil. Disponível em: http://debrabrasil.com.br. Acesso em: 22.08.19. 4- Uitto J. et al. Progress in Epidermolysis Bullosa - Research toward Treatment and Cure. Journal Investigative of Dermatology, 2018. v. 138, pp. 1010-1016. 5- DEBRA International. International Consensus. Disponível em:

http://www.debrainternational.org/fileadmin/media_data/4_DEBRA_International/CPGs/Guidelines/International_Consens us_Best_Practice_Guidelines_Skin_and_Wound_Care_in_Epidermolysis_Bullosa.pdf. Acesso em: 22/08/2019. 


\title{
DESENVOLVIMENTO DE SOFTWARE DE APOIO À DECISÃO DO ENFERMEIRO NA PREVENÇÃO DE LESÕES DE PELE EM NEONATOS HOSPITALIZADOS
}

\author{
Author(s): $\quad$ Simone Vidal Santos 1, Flávia Regina Souza Ramos 1, Roberta Costa 1
}

Institution(s) 1 UFSC - Universidade Federal de Santa Catarina (Campus Reitor João David Ferreira Lima. Trindade, Fpolis/SC - CEP: 88040-900)

\begin{abstract}
Introdução: A pele é o maior e o mais dinâmico órgão do corpo humano e sua propriedade de barreira serve como primeira linha de defesa do organismo. Seu desenvolvimento histológico se completa na vida intrauterina, com 34 semanas de gestação, mas sua maturidade funcional permanece se desenvolvendo durante o primeiro ano de vida pósnatal. Por esse motivo, o recém-nascido, principalmente o pré-termo, apresenta pele anatomofisiologicamente imatura, expondo-o ao risco de injúrias e infecção1. Associada às questões anatômicas e fisiológicas, a internação na Unidade Neonatal também potencializa os riscos de lesão de pele e de infecção, tendo em vista os procedimentos invasivos e os dispositivos necessários para a preservação da vida destes bebês. Nada obstante, estas lesões podem ser evitadas através do cuidado delicado, realizado pela equipe de enfermagem1. O enfermeiro precisa conhecer e estar atento aos potenciais riscos, a fim de planejar uma assistência adequada, através de medidas preventivas e protetivas, garantindo segurança do paciente neonatal. Deste cenário, optou-se por desenvolver este estudo, a fim elaborar instrumentos que contribuam para o cuidado. Objetivo: desenvolver e avaliar a qualidade de um aplicativo móvel de apoio à decisão clínica do enfermeiro sobre cuidados de prevenção de lesões de pele de recém-nascidos internados. Material e Método: pesquisa metodológica, aprovada pelo Comitê de Ética em Pesquisa da Universidade Federal de Santa Catarina sob CAAE: 69500917.1 .0000 .0121 e desenvolvida em quatro etapas. Primeira etapa: revisão integrativa de literatura nas bases de dados Cochrane, Medline, Lilacs e Bdenf para identificar evidências científicas2 sobre cuidados de prevenção de lesões de pele em recém-nascidos. Segunda etapa: validação de conteúdo por comitê de experts3, composto por cinco especialistas, a fim de determinar a validade de conteúdo de domínios, itens e intervenções de enfermagem para prevenir lesões de pele em recém-nascidos, considerando-se o Índice de Validade de Conteúdo mínimo de $80 \%$ e a Taxa de Concordância de Comitê mínima de 0,80. Terceira etapa: desenvolvimento do aplicativo móvel, para plataformas Android® e iOS $\AA$, utilizando a metodologia Extreme Programing4. Quarta etapa: avaliação da qualidade do software, conforme Norma ISO/IEC 25010-20115, por 10 enfermeiros e 10 especialistas em tecnologia da informação, considerando concordância acima de $70 \%$. Os dados foram analisados por estatística descritiva. Resultados: revisão: identificados 37 artigos. Os tópicos abordados foram: termorregulação; antisséptico; emolientes; coto umbilical; oxigenação; banho; dermatite de fralda; e, acesso venoso. Estes, juntamente com outros materiais e com a experiência da pesquisadora principal, propiciaram a construção de 298 intervenções de enfermagem que, remetidos à validação, finalizaram com 310 intervenções. Na terceira etapa foi desenvolvido o Neonatal Skin Safe $\AA$, um software para dispositivos móveis que permite avaliar as condições clinicas e da assistência, identificar riscos e tomar decisões sobre o planejamento do cuidado com a pele do recém-nascido. A avaliação da qualidade do software demonstrou mais de $80 \%$ de concordância. Conclusão: O Neonatal Skin Safe® é uma tecnologia que apresenta conteúdo baseado em evidências, válido e que demonstra qualidade técnica para direcionar o enfermeiro nos cuidados de prevenção de lesões de pele em recém-nascidos de forma segura.
\end{abstract}

Keywords: Enfermagem Neonatal, Recém-nascido, Estomaterapia, Projetos de Desenvolvimento Tecnológico, Avaliação da Tecnologia Biomédica

\section{Referências Bibliográficas}

1 Visscher MO, Adam R, Brink S, Odio M. Newborn infant skin: physiology, development, and care. Clin Dermatol. 2015;33(3):271-80. DOI: http://dx.doi.org/10.1016/j.clindermatol.2014.12.003 2 Phillips B, Ball C, Sackett D, Badenoch D, Straus S, Haynes B, et al. Oxford Centre for Evidence-based Medicine. Levels of evidence [Internet]. Oxford: CEBM; 2009 [cited 2017 Jul 02]. Available from: https://www.cebm.net/2009/06/oxford-centre-evidence-based-medicine-levelsevidence-march-2009/ 3 Ehrich J, Somekh E, Pettoello-Mantovani M. The importance of expert opinion-based data: lessons from the European Paediatric Association/Union of National European Paediatric Societies and Associations (EPA/UNEPSA) Research on European Child Healthcare Services. J pediatr. 2018;195:310-11. Doi: http://dx.doi.org/10.1016/j.jpeds.2017.12.064 4 Nunes RD. A implantação das metodologias ágeis de desenvolvimento de software Scrum e Extreme Programming (XP): uma alternativa para pequenas empresas do setor de tecnologia da informação. ForSci: R Cient IFMG. 2016;4(2):e00117. DOI: http://dx.doi.org/10.29069/forscience.2016v4n2.e117 5 ISO/IEC 25010 - System and Software engineering - System and software Quality Requirements and Evaluation (SQuaRE) - System and software quality models. Switzerland; 2011 [cited 2017 Apr 20]. Available from: https://www.iso.org/standard/35733.html 


\title{
ANÁLISE DA ATIVIDADE CICATRIZANTE IN VIVO DE MEMBRANAS DE NANOCELULOSE BACTERIANA COM SUPERFÍCIE MODIFICADA
}

Author(s): $\quad$ Camila Quinetti Paes Pittella 1, Edney Márcio Vitória 1, Mariana Domiciano Delage Moura 1, Taciely Campana Colli 1, Samara Silva de Souza 3, Kelli Borges Dos Santos 1, Frederico Pittella Silva 1, Alice Belleigoli Rezende 1, Luismar Marques Porto 2, Thiago César Nascimento 1

Institution(s) 1 UFJF - Universidade Federal de Juiz de Fora (Campus Universitário, Rua José Lourenço Kelmer, s/n São Pedro, MG, 36036-900), 2 UFSC - Universidade Federal de Santa Catarina (R. Eng. Agronômico Andrei Cristian Ferreira, s/n - Trindade, Florianópolis - SC), 3 UTFPR - Universidade Tecnológica Federal do Paraná (Estr. p/ Boa Esperança, km 04 - Zona Rural, Dois Vizinhos - PR, 85660-000)

\begin{abstract}
Introdução:

A aplicação de biomateriais no tratamento de feridas é uma área da saúde que tem grande avanço recente, o que incentiva pesquisas e incorporação de tais tecnologias no cuidado de saúde[1]. A Nanocelulose Bacteriana (BNC) sintetizada pela bactéria Gluconacetobacter hansenii é um biomaterial promissor que possui uma estrutura nanofibrosa, na forma de hidrogel, que tem sido amplamente utilizado para a regeneração de uma variedade de tecidos[2]. Recentemente a modificação/funcionalização da BNC tem sido foco de diversas pesquisas[3]. Neste trabalho, uma nova membrana de Nanocelulose Bacteriana/Poli-L-lisina-colesterol (BNC-PLC) foi desenvolvida e testada in vivo.

Objetivo:

Avaliar a eficácia (potencial cicatrizante) da aplicação tópica da membrana BNC-PLC através do modelo experimental in vivo de excisão de pele em camundongos C57BL/6.

Materiais e Métodos:

As superfície das membranas de BNC (Cellfate ${ }^{\circledR}$, Bioceltis Bioengineering, Brasil) foi modificada através da adsorção do polímero Poli- L-lisina-colesterol (PLC). A atividade cicatrizante foi analisada utilizando um modelo de ferida excisional em camundongos C57BL/6. Para tanto, os animais foram tricotomizados, anestesiados e feridas foram criadas em seu dorso utilizando-se um punch circular $(6 \mathrm{~mm})$. Os animais foram divididos em 3 grupos $(\mathrm{n}=8 \mathrm{cada})$ : Controle, BNC e BNC-PLC. As membranas foram afixadas nas bordas das feridas através de pontos de sutura e o grupo controle foi tratado com solução salina. Após os tratamentos, foi realizada cobertura com filme de poliuretano transparente. As feridas foram fotografadas em intervalos diferentes e mensuradas utilizando-se um paquímetro digital. A taxa de cicatrização foi calculada comparando-se a área inicial da ferida com a área após 3, 7 e 10 dias. Os experimentos foram realizados em acordância com o Comitê de Ética em Experimentação Animal da Universidade Federal de Juiz de Fora (protocolo aprovado ํㅡㄴ 049/2018).

Resultados:

As membranas BNC-PLC foram produzidas com sucesso e o ensaio in vivo demonstrou uma atividade cicatrizante satisfatória quando comparado ao grupo controle. Foi possível observar um aumento significativo na contração das feridas no grupo BNC-PLC nos dias 3 e 7 em relação ao controle. No dia 10, foi possível observar uma redução na área da ferida tanto no grupo BNC-PLC quanto no BNC em relação ao controle, entretanto este resultado não foi estatisticamente significativo.

Conclusões:

Estes dados sugerem que a membrana BNC-PLC desenvolvida aumenta a eficácia da reparação de feridas in vivo. Análises histológicas e moleculares adicionais irão elucidar seu mecanismo de ação.
\end{abstract}

Keywords: Celulose, Gluconacetobacter, Cicatrização, Modelos animais, Estomaterapia

\section{Referências Bibliográficas}

[1] Pires ALR; Bierhalz ACK; Moraes ÂM. Biomateriais: tipos, aplicações e mercado. Quím. Nova. 2015; v. 38; 957-971.

[2] Fischer MR et al. Biossíntese e caracterização de nanocelulose bacteriana para engenharia de tecidos. Revista Matéria. 2017; v. 22; e11934. [3] Pittella CQP. Desenvolvimento de scaffold de nanocelulose bacteriana com modificação de superfície para aplicações tópicas. Florianópolis: Universidade Federal de Santa Catarina, 2017. Tese de Doutorado em Engenharia Química. 


\title{
SIMULAÇÃO IN SITU: OPORTUNIDADES LATENTES DE MELHORIA NA PREVENÇÃO DE LESÃO POR PRESSÃO
}

\begin{abstract}
Author(s): $\quad$ Angélica Olivetto de Almeida 1, Vanessa Abreu da Silva 1, Ivan Rogério Antunes 1, Maria Carolina Martins 2, Renata Cristina Gasparino 2, Bruna Henrique Bueno 1, Renata Bigatti Bellizzotti Pavan 1, Ana Paula Bordin 1, Luciana Alves Zapparoli 1, Elenita Aparecida de Castro Recco 1, Alessandra Nazareth Caine P Roscani 1
\end{abstract}

Institution(s) 1 HC UNICAMP - Hospital de Clínicas da Unicamp (Rua Vital Brasil, 251), 2 FEnf Unicamp - Faculdade de Enfermagem Unicamp (R. Tessália Vieira de Camargo, 126)

\begin{abstract}
Introdução: A simulação clínica é uma metodologia ativa, centrada no aprendiz, que replica um ambiente real de saúde com o objetivo de praticar, aprender, avaliar, testar ou entender sistemas ou ações humanas. Promove aprendizado ativo, em ambiente livre de risco, minimizando a ocorrência de eventos adversos[1]. Experiências de aprendizagem baseadas em simulação são projetadas para preparar o aprendiz para a prática clínica. A simulação in situ ocorre no ambiente de trabalho da equipe de saúde aproximando-a da situação real, o que favorece o pensamento crítico e a tomada de decisão[2,3]. Objetivo: Avaliar o atendimento e as ações realizadas para prevenção de LP segundo as recomendações do Consenso da NPUAP[4]. Método: Estudo descritivo e longitudinal, realizado em um hospital de ensino do interior do estado de São Paulo. Todos os profissionais de enfermagem (181) das enfermarias de Gastroclínica e cirúrgica, Enfermaria geral de adultos e Emergência Clínica/Cirurgia do Trauma foram convidados a participar do estudo. Para a simulação, o cenário foi elaborado segundo a proposta da National League for Nursing/Jeffries Simulation Framework[5], com a finalidade de fundamentar a criação, execução e avaliação da simulação. Participaram dois profissionais de enfermagem que desempenharam os papéis de enfermeiro e técnico de enfermagem. O cenário para simulação foi montado na enfermaria de gastroclínica e cirúrgica, utilizou-se manequim de média fidelidade (Resusci Anne®, Laerdal Medical), que representou uma mulher de 80 anos, com pneumonia e classificada em alto risco para LP pela escala de Braden. A documentação foi baseada em um checklist previamente elaborado com 21 itens. Para a resolução do problema foram fornecidas informações sobre as condições clínicas do paciente e todos os recursos materiais necessários para as medidas de prevenção de LP estavam disponíveis no ambiente de simulação. Os facilitadores tinham conhecimento prévio sobre o tema e conduziram a cena e o debriefing e, neste momento, foram abordados aspectos emocionais, teóricos e reflexivos. O projeto foi aprovado pelo Comitê de Ética em Pesquisa, sob parecer ㄲo 3.045.941. Resultados: O cenário contou com a participação de 131 profissionais de enfermagem das unidades de internação acima descritas, dos três turnos, correspondente à $72 \%$ do total. $O$ cenário foi repetido por 18 vezes e teve duração média de dez minutos. Do check list de verificação das ações esperadas dos participantes obteve-se oportunidades de melhoria em cinco itens, sendo, realização da higienização das mãos prévia ao contato com o paciente $(67 \%)$, ler as anotações e prescrição de enfermagem $(78 \%)$, verificar previamente ao cuidado a pontuação da escala de Braden (83\%), verificar previamente ao cuidado a pontuação da escala de risco nutricional MUST (89\%) e aplicar a hidratação de pele (56\%). Conclusão: A estratégia de ensino aprendizagem da simulação in situ mostrou que as equipes aplicam a maioria das medidas de prevenção de LP seguindo o consenso internacional e são necessárias algumas intervenções em habilidades específicas para favorecer a segurança e qualidade da assistência e promover melhoria nesse processo de trabalho.
\end{abstract}

Keywords: Educação Continuada em Enfermagem, Estomaterapia, Lesão por pressão, Treinamento

\section{Referências Bibliográficas}

1.Flato UAP; Guimaraes HP. Educação baseada em simulação em medicina de urgência e emergência: a arte imita a vida. Rev Bras Clin Med. São Paulo, 2011 set-out;9(5):360-4. 2.Victor J, Ruppert W, Ballasy S. Examining the Relationships Between Clinical Judgment, SimulationPerformance, and Clinical Performance. Nurse Educator: September/October 2017 - Volume 42 - Issue 5 - p 236-239. 3.Kaneko RMU, Couto TB, Coelho MM, Taneno AK, Barduzzi NN, Barreto JKS, et al. Simulação in Situ, uma Metodologia de Treinamento Multidisciplinar para Identificar Oportunidades de Melhoria na Segurança do Paciente em uma Unidade de Alto Risco. Rev Bras Educ Med [Internet]. 2015;39(2):286-93. Available from: http://www.scielo.br/scielo.php?script=sci_arttext\&pid=S010055022015000200286\&lng=pt\&nrm=iso\&tIng=en 4.National Pressure Ulcer Advisory Panel, European Pressure Ulcer Advisory Panel and Pan Pacific Pressure Injury Alliance. Prevention and Treatment of Pressure Ulcers: Quick Reference Guide. Emily Haesler (Ed.). Cambridge Media: Osborne Park, Western Australia; 2014. 5.Jeffries PR; Rogers K. Theoretical framework for simulation design. In: Simulation in nursing education: From conceptualization to evaluation. 2nd ed. New York: National League for Nursing; 2012. p. 25-41. 


\section{USO DE PLANTAS MEDICINAIS PARA O TRATAMENTO DE FERIDAS}

Author(s): MANUELE RAIANE DA SILVA SOUSA 1, MONALIZA EVELYN PEREIRA DE SOUSA 1, MANOELA RODRIGUES DE SANTANA 1, GLENDA ISABELLE MONTE DA CUNHA 1, ISABEL CRISTINA RAMOS VIEIRA DOS SANTOS 1

Institution(s) 1 UNICAP - UNIVERSIDADE CATÓLICA DE PERNAMBUCO (RUA DO PRINCIPE, 526 - BOA VISTA, RECIFE/PE, 50050-900.)

Abstract

Introdução: A pesquisa sobre o cuidado de feridas pode melhorar o atendimento ao paciente e os resultados clínicos, provendo subsídios para a padronização da avaliação, do planejamento e a implementação do tratamento, procurando associar benefícios a um custo acessível ${ }^{1}$. O uso de tecnologias avançadas é frequentemente considerado mais caro do que o tratamento padrão de feridas, embora seja muitas vezes custo-efetivo, quando se considera os gastos com recursos adicionais, como tempo de enfermagem associado a trocas de curativos e a duração do tratamento, ainda não é plenamente disponível a população de lugares sub ou em desenvolvimento². Embora uma porção relativamente pequena de todas as plantas seja usada como agentes medicinais, sua importância não deve ser subestimada, já que quase $65 \%$ da população mundial as incorporaram como modalidade de atenção primária à saúde. E mesmo assim, existem muitas plantas medicinais a serem pesquisadas na procura por novos agentes de cicatrização que sejam eficazes e custo-efetivos, principalmente para locais menos favorecidos ${ }^{3}-4$. Objetivo: analisar o conhecimento sobre as plantas medicinais utilizadas durante o processo de cicatrização de feridas por pacientes com lesões aberta na clínica médica e cirúrgica dos hospitais: Universitário Oswaldo Cruz - HUOC, Hospital da Restauração - HR e Hospital Otávio de Freitas - HOF. Materiais e Métodos: Estudo descritivo, transversal, realizado com 107 pacientes - sendo 32 HUOC, 44 HR, 31 HOF- internado na clínica médica e cirúrgica com lesões abertas, agudas ou crônicas, infectadas ou não, internado no período de coleta de dados novembro de 2018 a março de 2019. As informações foram obtidas através de entrevista, utilizando um formulário confeccionado pelos pesquisadores com as variáveis de interesse. Os dados foram analisados segundo estratégias de estatística descritiva. A pesquisa encontra-se de acordo com a resolução 466/12 aprovado pela Universidade Católica de Pernambuco, com CAEE n 83223318.1.0000.5206. Resultados: apresentaram uma amostra constituída de pessoas de faixa etária compreendida entre 20-50 anos, predominantemente do sexo feminino, com baixa escolaridade e renda, oriundos, em maior frequência da região Metropolitana do Estado, principalmente do Recife. A maior frequência dos entrevistados conhecia alguma planta medicinal para o tratamento de feridas $(81 \%)$. Os pacientes entrevistados identificaram 45 plantas com potencial para o tratamento de feridas e destas as mais citadas foram a Aroeira, Babosa e Sete dores ambas com $(96,9 \%)$. Os modos de preparo por infusão $(37,5 \%)$ e decocção (29\%) foram os mais indicados. Conclusão: Os resultados apresentaram um perfil sociodemográfico da população com feridas. A maior frequência desta conhece alguma planta medicinal, permitindo identificar 45 tipos de plantas, das quais as mais citadas foram: Babosa, Aroeira e Sete Dores. A busca na literatura permitiu verificar que de fato a Aroeira apresenta efeito anti-inflamatório e cicatrizante comprovado, diferentemente do que ocorre com a Babosa e a sete dores. $\mathrm{O}$ acervo obtido nesta pesquisa possibilitará o planejamento de novos estudos voltados à verificação da ação farmacológica e a descoberta de produtos eficazes e custos efetivos para o tratamento de feridas.

Keywords: Cuidados de Enfermagem, Estomaterapia, Ferimentos e Lesões, Plantas Medicinais

\section{Referências Bibliográficas}

1. RAMALHO MP, SANTOS SLF, CASTRO NM, VASCONCELOS LMO, MORAIS ICO, PESSOA CV. Plantas medicinais no processo de cicatrização de feridas: revisão de literatura. Revista expressão católica saúde [internet]. 2018 [cited 2019 Jan 24]; 3(2). Available from: http://dx.doi.org/10.25191/recs.v3i2.2429. 2. GONZALEZ ACO, COSTA TF, ANDRADE ZA, MEDRADO ARAP. Wound healing - A literature review. An Bras Dermatol [internet]. 2016 [cited 2019 Apr 04]; 91(5). Available from: https://www.ncbi.nlm.nih.gov/pmc/articles/PMC5087220/pdf/abd-91-05-0614.pdf. 3. BODAKHE SH, RAM A. Hepatoprotective properties of Bauhinia variegata bark extract. Yakugaku zasshi journal of the Pharmaceutical Society of Japan [internet]. 2007 [cited 2019 June 04]; 217(9): 1503-1507. Available from: https://pdfs.semanticscholar.org/be25/4b431ce8b1bf088574233192493a70bea4d7.pdf. 4. JARBRINK K, NI G, SONNERGRE H, SCHMIDTCHEN A, PANG C, BAJPAI R, et al. Prevalence and incidence of chronic wounds and related complications: a protocol for a systematic review. Syst. Rev [internet]. 2016 [cited 2019 Mar 03]; 5(1). Available from: https://www.ncbi.nlm.nih.gov/pmc/articles/PMC5017042/. 


\section{PERFIL UROLÓgICO DE PACIENTES COM LESÃo MEDULAR EM PROGRAMA DE REABILITAÇÃO}

Author(s): $\quad$ Deyse Cardoso de Oliveira Braga 1, Zuila Maria de Figueiredo Carvalho 2, Fabiana Faleiros SantanaCastro 3, Miroval Leo Andrade Galvão 1

Institution(s) 1 Rede Sarah - Rede Sarah de Hospitais de Reabilitação (Av. Pres. Juscelino Kubitschek, 4500, Passaré, Fortaleza - CE, 60861-634), 2 UFC - Universidade federal do Ceará (R. Alexandre Baraúna, 1115 - Rodolfo Teófilo, Fortaleza - CE, 60430-160), 3 EERP-USP - Escola de Enfermagem de Ribeirão Preto da USP (R. Prof. Hélio Lourenço, 3900 - Vila Monte Alegre, Ribeirão Preto - SP, 14040-90), 4 Rede Sarah - Rede Sarah de Hospitais de Reabilitação (Av. Pres. Juscelino Kubitschek, 4500, Passaré, Fortaleza - CE, 60861-634)

\section{Abstract}

Introdução

A lesão medular (LM) é um evento secundário a um dano na medula, que leva a alteração da função motora, sensorial e autonômica. Entre as alterações resultantes, uma que constitui grande preocupação é a disfunção miccional neurogênica, pois devido ao inadequado manejo da bexiga, historicamente, a doença renal tem sido a principal causa de morte de pessoas com LM. Estudos demonstram que a incontinência urinária está intimamente relacionada à qualidade de vida (QV) bem como a depressão após LM. Diante do exposto, surgiu a necessidade de estudar as questões relacionadas a esta temática. Este trabalho é um recorte de um trabalho maior que deu origem a uma tese de doutorado intitulada DISFUNÇÃO VESICAL NA QUALIDADE DE VIDA DE PESSOAS COM LESÂO MEDULAR: TRADUÇÃO, ADAPTAÇÃO E VALIDAÇÃO DE UM INSTRUMENTO.

\section{Objetivos}

O estudo objetiva descrever o perfil urológico de pessoas com bexiga neurogênica secundária à LM.

Material e Métodos

Trata-se de estudo quantitativo, de delineamento transversal, cuja operacionalização se deu com a aplicação do questionário Spinal Cord Injury Bowel and Bladder Treatment Index(SCI-BBTI), seção Bladder. A população foi de 50 pacientes com bexiga neurogênica secundária à lesão medular em programa de reabilitação. A amostragem foi selecionada por conveniência. Foram obedecidos os princípio éticos da resolução 466/12 e 510/16.

Resultados

O perfil geral dos participantes foi: homens, solteiros, baixa renda e escolaridade, com idade média de 31,22 anos, com tempo médio de lesão de 27,74 meses.Foi observado um alto índice de cateterismo urinário (64\%) (Tabela 2), 96\% dos pacientes apresentam incontinência e com uso de dispositivos para incontinência (82\%), $64 \%$ haviam passado por mudanças no manejo urinário no último ano (Tabela 3), 48\% fizeram uso de antibiótico no último ano sendo que $40 \%$ do total da amostra apresentou pelo menos um episódio de infecção urinária no último ano (Tabela 4), 44\% da amostra considerou que o manejo da bexiga era um problema que interferia muito na rotina. Em relação a qual alteração póslesão medular tem mais efeito na vida em geral, pela mediana, "Mudanças na função sexual" e "Viver com dor crônica tiveram os maiores escores", enquanto que "Cuidar da bexiga" veio em segundo lugar.

Conclusões

É marcante que a maioria dos entrevistados tenha LM por etiologia de arma de fogo, baixa renda e baixa escolaridade. É o retrato do mapa da violência no Brasil. Este fato nos chama a atenção para o quão urgente é necessário voltar as políticas públicas para a educação de jovens e adultos (capacitação para o trabalho) e melhorar as medidas de segurança pública. Pessoas jovens em idade produtiva com a barreira da deficiência e da falta de qualificação. Além disso, são pessoas claramente afetadas pela incontinência, o que interfere sobremaneira na reinserção social, e com predisposição a alterações urológicas que podem ser evitadas pelo acesso à informação e cuidado de saúde.

Keywords: Estomaterapia, Incontinência urinária, Traumatismos da medula espinal

\section{Referências Bibliográficas}

Adriaansen JJ. E cols. Bladder-emptying methods, neurogenic lower urinary tract dysfunction and impact on quality of life in people with long-term spinal cord injury. J Spinal Cord Med. 2017; 40 (1): 43-53. Lane Gl. E cols. A cross-sectional study of the catheter management of neurogenic bladder after traumatic spinal cord injury. Neurourol Urodyn. 2018; 37 (1): 360-367. Yildiz N. e cols. Neurogenic bladder in patients with traumatic spinal cord injury: treatment and follow-up. Spinal Cord. 2014; 52 (6): 462-467. 


\title{
CARACTERÍSTICAS DE PACIENTES ADULTOS INCONTINENTES DA CLÍNICA MÉDICA DE UM HOSPITAL DE ENSINO
}

\author{
Author(s): Rafaela Cabral Belini 1, Fabiana Perez Rodrigues Bergamaschi 1, Jaqueline Aparecida Santos Sokem 2 , \\ Fernanda Guimarães Felix Lima 2
}

Institution(s) 1 UEMS - Universidade Estadual de Mato Grosso do Sul (Cidade Universitária de Dourados. Caixa postal 351. CEP: 79804-970. Dourados-MS ), 2 HU-UFGD/Ebserh - Hospital Universitário da UFGD (Rua Ivo Alves da Rocha, n. 558. Altos do Indaiá. CEP: 79823-501. Dourados-MS)

\begin{abstract}
Introdução: entende-se por incontinência urinária qualquer perda não voluntária de urina e por incontinência fecal a perda involuntária de fezes. O termo incontinência anal compreende a perda de material fecal, mas também está associada com episódios não voluntários de flatulência1. Em estudo conduzido no Brasil, verificou-se uma prevalência de incontinência em idosos de $23,2 \%$ em homens e de 31,3\% em mulheres2. A presença de incontinência, independente de qual tipo, causa uma perda na qualidade de vida dos pacientes e é considerada um fator de risco para o aparecimento de lesões na pele3. Além das lesões cutâneas, os pacientes incontinentes estão predispostos ao surgimento de infecções associadas na pele, ao desenvolvimento de infecções urinárias e até problemas renais mais graves, quando incontinentes urinários4. Essas complicações podem acometer esses clientes, principalmente quando houver outras patologias associadas, que coloquem em risco ainda mais essa população1. Desse modo, faz-se necessário identificar as comorbidades comuns que afetam esses pacientes, com o objetivo de evitar complicações e fornecer cuidados de enfermagem adequados. Objetivo: identificar as características sociodemográficas e as comorbidades associadas dos pacientes incontinentes urinários e fecais da Clínica Médica de um hospital de ensino. Material e Método: estudo de corte, transversal, descritivo, com amostra não probabilística por conveniência, realizado no Hospital XXXXXX XX XXXXXXXX XXXXXX XX XXXXX XXXXXXX. A população foi composta por todos os pacientes internados na clínica médica da instituição, à época da coleta de dados, realizada em dois dias não sequenciais do mês de março de 2019. Como critérios de inclusão, adotou-se: idade igual ou superior a 18 anos e presença de incontinência, seja observada pelos pesquisadores através do exame físico ou relatada pelos pacientes. Foram excluídos os pacientes indígenas. Estudo aprovado por Comitê de Ética em Pesquisa pelo parecer n. XXXXXXX e CAAE n. XXXXXXXXXXXXXXXXX. Resultados: dentre os pacientes internados no período $(N=58), 16(27,5 \%)$ possuíam algum tipo de incontinência. A maioria dos pacientes incontinentes era do sexo masculino (43,8\%), na faixa etária de 70 a 79 anos $(56,2 \%)$, casados $(62,5 \%)$, com ensino fundamental incompleto $(56,3 \%)$. Identificou-se nos pacientes incontinentes, as seguintes patologias: infecção por vírus da imunodeficiência humana $(12,8 \%)$, hipertensão arterial sistêmica $(12,8 \%)$ e doença pulmonar obstrutiva crônica $(12,8 \%)$. Outras patologias também foram identificadas, porém, com menor prevalência: diabetes mellitus tipo 2, insuficiência renal crônica, acidente vascular encefálico, insuficiência cardíaca congestiva, epilepsia, retocolite ulcerativa, ataxia cerebelar, fibrilação atrial crônica, câncer de mama e tuberculose pulmonar. Corroborando com os achados, outros autores identificaram diversas patologias presentes em pacientes incontinentes1. Conclusões: verificou-se uma elevada prevalência de incontinência em pacientes da Clínica Médica de um hospital público, porém, as patologias associadas à incontinência foram diversas. Dessa forma, conclui-se que os profissionais de saúde devem se atentar para patologias que ocasionem rebaixamento no nível de consciência, redução da sua percepção sensorial, redução na mobilidade ou capacidade de ir sozinho ao banheiro nos pacientes, já que várias doenças podem evoluir para a perda dessas habilidades e, assim, acarretar no desenvolvimento de incontinência.
\end{abstract}

Keywords: Estomaterapia , Cuidados de Enfermagem, Incontinência Urinária, Incontinência Fecal

\section{Referências Bibliográficas}

Abrams P, Cardoso L, Wagg A, Wein A. (Eds) Incontinence. 6th International Consultation on Incontinence. International Incontinence Society. Bristol, Reino Unido; 2017. [citado 2019 Jul 07]. Disponível em: https://www.ics.org/publications/ici_6/Incontinence_6th_Edition_2017_eBook_v2.pdf 2. Carneiro JA, Ramos GCF, Barbosa ATF, Medeiros SM, Lima CA, Costa FM et al. Prevalência e fatores associados à incontinência urinária em idosos não institucionalizados. Cad. Saúde Colet. [Internet]. 2017 [citado 2019 Jul 07]; 25(3): 268-277. DOI: 10.1590/1414-462X201700030295 3. Cunha CV, Ferreira D, Nascimento D, Felix F, Cunha P, Penna LHG. Artigo de Revisão - Dermatite associada à incontinência em idosos: caracterização, prevenção e tratamento. Braz. J. Enterestomal Ther. [Internet]. 2015 [citado 2019 Jul 07]; $13(3) . \quad$ Disponível em: https://www.revistaestima.com.br/index.php/estima/article/view/218 4. Assis GM, Fraga R. Cateterismo intermitente limpo: manual ilustrado de orientação ao usuário (adulto). Curitiba: Universidade Federal do Paraná - Hospital de Clínicas; 2015. 


\title{
Impacto de blog na autoconfiança de pacientes e cuidadores praticantes do cateterismo intermitente limpo
}

\begin{abstract}
Author(s): $\quad$ Claudia Daniella Avelino Vasconcelos Benício 1, Telma Maria Evangelista de Araújo 1,1, Elaine Maria Leite Rangel Andrade 1,1,1, Lídya Tolstenko Nogueira 1,1,3,3

Institution(s) 1 UFPI - Universidade Federal do Piaui (Campus Universitário Ministro Petrônio Portella Bairro Ininga Teresina - PI -), 2 UFPI - Universidade Federal do Piaui (Campus Universitário Ministro Petrônio Portella Bairro Ininga Teresina - PI -), 3 UFPI - Universidade Federal do Piaui (Campus Universitário Ministro Petrônio Portella Bairro Ininga Teresina - PI -), 4 UFPI - Universidade Federal do Piaui (Campus Universitário Ministro Petrônio Portella Bairro Ininga Teresina - PI -)
\end{abstract}

\begin{abstract}
Introdução. A internet possibilitou inovação nas áreas da Educação e Saúde, favorecendo o acesso a conteúdos pouco explorados, como o Cateterismo Intermitente Limpo, cujo desconhecimento repercute negativamente na vida das pessoas comprometendo o seu cotidiano e bem-estar em vários aspectos. Objetivo: Avaliar o impacto do blog sobre o cateterismo intermitente limpo na autoconfiança de pacientes e cuidadores. Materiais e métodos: Trata-se de estudo multimétodos, constituído por dois subestudos. O primeiro, metodológico: Construção e Validação em aparência, conteúdo e ergonomia de blog acerca dos cuidados de enfermagem no Cateterismo intermitente limpo e, o segundo: quase experimental, comparando a autoconfiança dos participantes antes e após a implementação do blog. A pesquisa foi realizada em estabelecimento de saúde pública, localizado em Teresina, após aprovação do Comitê de Ética em Pesquisa da Universidade Federal do Piauí, sob o CAAE 80803417.6.0000.5214 e parecer de oㅜ 2.445.826. A amostra foi constituída por 41 pacientes e 16 cuidadores, homens e mulheres, com idade a partir de 18 anos. Os dados foram processados pelos Softwares livres "R" versão 3.5.1 e PSPP versão 1.1.0. As variáveis quantitativas foram avaliadas por meio de estatística descritiva e as qualitativas usando proporção, com intervalos de confiança de $95 \%$. Aplicaram-se o teste binomial para verificar a concordância entre os juízes $(\geq 85 \%)$, e o teste de proporções para estimar a autoconfiança entre os participantes. Na análise inferencial, não paramétrica, utilizou-se o teste de McNemar, ao nível de 0,05 de significância entre duas proporções com as amostras pareadas, avaliando se os participantes melhoraram ou não a autoconfiança após a apresentação do blog. Resultados: o blog PortalCIL apresenta menu com seis abas: 'PortalCIL'; 'Contato Direto e Opinião'; 'Links Úteis e Referências'; 'Equipe'; 'Ferramentas' e 'Perguntas Frequentes'. Foi validado por 08 juízes em Enfermagem, quanto ao conteúdo; e por 05 juízes em Informática, quanto à aparência e ergonomia. As recomendações dos juízes foram atendidas quase em sua totalidade. Em seguida o blog foi apresentado aos participantes para avaliação e comparação da autoconfiança, antes e depois. Verificou-se que os participantes avaliaram o blog satisfatoriamente - avaliação global 95,1\% ( $p$-valor 0,951 ). Houve impacto positivo na autoconfiança dos participantes quanto à prática do CIL, de forma global $(22,2 \%)$ e por item avaliado da Escala de autoconfiança $(28,4 \%)$. Os itens mais impactantes positivamente foram os que questionam sobre a 'escolha de usar ou não o lubrificante no momento de introduzir o cateter na bexiga' (66,7\%); seguidos da 'capacidade de realizar o CIL'; 'escolher o material a ser utilizado durante o CIL' e 'lavar as mãos antes do procedimento' $(50,0 \%)$. Não houve impacto negativo na autoconfiança dos participantes após a apresentação do blog. Conclusão: A adoção de tecnologia - blog como estratégia educacional na assistência à saúde, demonstrou resultados positivos quanto à prática do cateterismo intermitente limpo por pacientes e cuidadores, visto que impactou na melhoria da autoconfiança dos participantes quanto à aspectos importantes inerentes à prática do CIL.
\end{abstract}

Keywords: Blog, Autoconfiança, Paciente, Cateterismo Intermitente Limpo, Estomaterapia

\section{Referências Bibliográficas}

Jackson, Debra; Waine, Melissa Lauren; Hutchinson, Marie. Blogs as a way to elicit feedback on research and engage stakeholders. Nurse Res; 22(3): 41-7, Jan 2015. Prybutok G.; Ryan S. Social media: The Key to Health Information Access for 18- to 30-Year-Old College Students. CIN: Computers Informatics Nursing, 33(4):132-141, Apr. 2015. GalindoNeto NM, Alexandre ACS, Barros LM, Sá GGM, Carvalho KM, Caetano JÁ. Creation and validation of an educational video for deaf people about cardiopulmonary resuscitation. Rev. Latino-Am. Enfermagem. 2019;27:e3130. [Access 0807 2019; Available in: http://www.scielo.br/pdf/rlae/v27/pt_0104-1169-rlae-27-e3130.pdf. DOI: http://dx.doi.org/10.1590/15188345.2765.3130 Assis GM et al. Uso de cateteres vesicais para cateterismo intermitente limpo: satisfação da pessoa com lesão medular. Cogitare enferm., Curitba, 20(4): 01-08, Out-Dez., 2015. Disponível em: http://revistas.ufpr.br/cogitare/article/view/41585. Acesso em: 07 jun 2019. Benício CDAV et al. Fatores associados ao conhecimento de pacientes e cuidadores acerca do cateterismo vesical intermitente limpo: revisão integrativa. Rev Esc Enferm USP; 52: e03362, 2018 Sep 13.. Disponível em: http://dx.doi.org/10.1590/s1980-220x2017033703362. Acesso em: 10 jun. 2019. 


\title{
A GESTANTE COM DISFUNÇÃO NEUROLÓGICA DO TRATO URINÁRIO INFERIOR: O CUIDADO NO MANEJO DA BEXIGA
}

\author{
Author(s): GÉSSICA CAROLINE DA SILVA MAMINHAQUI 1, MARIA EDUARDA DE FARIAS TELMA 1, TALYAN \\ CLAVISSO PEREIRA 1, ANA ROTILIA ERZINGER 1
}

Institution(s) 1 PUCPR - PONTIFÍCIA UNIVERSIDADE CATÓLICA DO PARANÁ ( R. Imac. Conceição, 1155 - Prado Velho, Curitiba - PR, 80215-901)

\begin{abstract}
Introdução: A gestação é um período marcado por inúmeras alterações fisiológicas, entre as quais pode-se destacar as alterações no sistema urinário1. As alterações anatômicas no trato urinário inferior (TUI) podem levar a uma hidronefrose fisiológica e maior propensão a Infecção do Trato Urinário (ITU). Pelo fato da Lesão Medular (LM) alterar o processo de micção, somada às alterações advindas da gestação, como condições de aumento de peso e volume corporal, a capacidade no manuseio da bexiga pode ser afetada2. Objetivo: Descrever os aspectos relacionados ao controle urinário na mulher com LM durante o período gestacional. Método: Estudo exploratório, descritivo com abordagem qualitativa por meio de análise de conteúdo proposta por Bardin. O projeto foi aprovado pelo CEP da PUCPR, Parecer oㅜ 2.971.434. A coleta de dados foi realizada mediante uma entrevista semiestruturada. As entrevistas foram gravadas e posteriormente transcritas manualmente pelas autoras. Os relatos foram lidos e relidos para que se pudesse extrair as categorias de análise. Após a eleição destas categorias, foram extraídas as falas das participantes e a discussão foi embasada no referencial teórico. Resultados e Discussão: Obteve-se a participação de 05 mulheres com LM que engravidaram após a LM, destas quatro são paraplégicas e uma é tetraplégica. A idade variou entre 29 e 35 anos, o tempo de lesão ficou entre 02 e 16 anos. Sobre o tipo de parto, três foram cesáreos e dois normais, destes, um fórceps. Em relação ao número de filhos, quatro tiveram 01 filho e uma teve 02 , sendo que uma delas já tinha filhos antes da lesão. Sobre o trato urinário, foram levantados os seguintes problemas: perda urinária, infecção urinária, redução do intervalo entre os cateterismos necessidade do uso de fraldas. Em relação ao cateterismo, apenas uma não conseguia se autocateterizar no final da gestação, necessitando de auxílio. O controle miccional necessita de sintonia e integridade entre Sistema Nervoso Central e o Sistema Urinário3. As alterações anatomofuncionais da gestação interferem na função urinária1. A Oxibutinina utilizada frequentemente para auxiliar no controle vesical nas Disfunções Neurológicas do TUI é contraindicada na gestação levando à necessidade de diminuir o intervalo entre os cateterismos, mesmo com a redução dos intervalos apresentavam perdas necessitando utilizar fraldas. Para contornar estes problemas, a maioria reduziu a ingestão hídrica contribuindo para infecção urinária. Frequentemente as pessoas com LM apresentam bacteriúria assintomática, dependendo do agente causador e das condições do organismo pode ocorrer infecção e complicações graves como à sepsis4. A ITU é a infecção bacteriana mais comum durante a gestação5. Neste estudo, duas participantes tomaram antibiótico durante toda a gestação, e outra foi orientada que só deveria ser medicada no caso de bacteriúria sintomática. Considerações Finais: Percebe-se que a mulher com LM pode engravidar e tem condições de ser mãe. Para terem seus filhos enfrentam riscos, aceitam as mudanças advindas da gestação, fazem adaptações para manter o esvaziamento da bexiga. Desta forma, ressalta-se a importância da equipe multidisciplinar em especial do enfermeiro(a) Estomaterapeuta para 0 atendimento às necessidades destas mulheres e a redução dos riscos neste período.
\end{abstract}

Keywords: CATETERISMO URETRAL INTERMITENTE, ESTOMATERAPIA, GESTAÇÃO, LESÕES DA MEDULA ESPINHAL, TRANSTORNO NEUROGÊNICO DA BEXIGA

\section{Referências Bibliográficas}

Montenegro CAB, Rezende J. Obstetrícia. 13.ed. Rio de Janeiro: Guanabara Koogan; 2017. 2. Matias AC, Santos JM, Cerqueira ME. Gestação em lesionadas medulares: ricos, prevenção e complicações. 2014. Acesso em 2019 ago 02; 26: 27-35. Disponível em: http://citeseerx.ist.psu.edu/viewdoc/download?doi=10.1.1.686.8091\&rep=rep1\&type=pdf 3. Juc $\mathrm{RU}$, Colombari E, Sato MA. Importância do sistema nervoso no controle da micção e armazenamento urinário. 2011. Acesso em 2019 ago 02; 36: 55-60. Disponível em: https://www.portalnepas.org.br/abcs/article/view/76 4. Figueiredo JA, Gomes CM, Nardozza JA, Zerati FM, Reis RB. Urologia Fundamental - Sociedade Brasileira de Urologia - SBU. 2010. Acesso em 2019 ago 02; 274-279. Disponível em: http://www.sbu-sp.org.br/admin/upload/os1688-completourologiafundamental-09-09-10.pdf 5. Fernandes FA, Oliveira CNT, Souza CL, Oliveira MV. Relevância do diagnóstico e tratamento da infecção do trato urinário em gestantes: uma revisão da literatura. 2015. Acesso em 2019 ago 02; 08: 5470. Disponível em: http://srv02.fainor.com.br/revista237/index.php/memorias/article/viewFile/364/219 


\section{O CAMPO DE ESTÁGIO VOLUNTÁRIO NA CLÍNICA DE ENFERMAGEM PARA A FORMAÇÃO DO ENFERMEIRO}

Author(s): Maria Leoni Valle 1, Marcia Regina Cubas 1,1, Ana Paula Cordeiro de Melo 1,1, Luciana Gonçalves Amaral 1,1, Patricia Ilnicki Gritti 1, Thais Pinto Ribeiro 1

Institution(s) 1 PUCPR - Pontifícia Universidade Católica do Paraná (Curitiba PR), 2 PUCPR - Pontifícia Universidade Católica do Paraná (Curitiba PR), 3 PUCPR - Pontifícia Universidade Católica do Paraná (Curitiba PR), 4 PUCPR - Pontifícia Universidade Católica do Paraná (Curitiba PR), 5 PUCPR - Pontifícia Universidade Católica do Paraná (Curitiba PR), 6 PUCPR - Pontifícia Universidade Católica do Paraná (Curitiba PR)

\section{Abstract}

INTRODUÇÃO: A formação acadêmica de enfermagem pode ser impactada, pela possibilidade do estudante em participar durante a sua formação, de oportunidades que envolvam o atendimento do indivíduo, despertando interesse pelas atividades da profissão e de aquisição de habilidades técnicas de modo a facilitar sua inserção no mercado de trabalho1. Para consolidar esta formação a o Curso de Graduação em Enfermagem da PUCPR ofereceu aos estudantes a possibilidade de estágio voluntário na Clínica de Enfermagem, onde atende usuários com feridas e lesões complexas que é uma especificidade da Estomaterapia. Os professores que atuam e acompanham os estudantes na Clínica são Enfermeiros Estomaterapeutas. O instrumento norteador é o processo de enfermagem, que possibilita uma assistência de enfermagem com base nas necessidades dos indivíduos que procuram o atendimento, permitindo desenvolver nos estudantes a compreensão da teoria com a prática no desenvolvimento de conhecimentos, habilidades e atitudes OBJETIVO: Analisar a contribuição na formação acadêmica do estágio voluntário desenvolvido na Clínica de Enfermagem da PUCPR. MÉTODO: Estudo exploratório descritivo com abordagem quantitativa, com 48 acadêmicos e egressos do Curso de Enfermagem da PUCPR, que participaram das atividades entre os anos de 2014 a 2017, com aprovação do CEP da PUCPR sob o parecer no 2.838.759. Foi aplicado um instrumento com questões estruturadas, baseadas na escala likert e enviado pela plataforma Qualtrics, para avaliar benefícios do estágio; observação e participação nos procedimentos, aprendizado em relação a avaliação da necessidade de cuidado das pessoas, raciocínio clinico, intervenções de enfermagem; associação da teoria com a prática, aprimoramento dos conhecimentos e para os egressos ainda a contribuição do estágio para o aprimoramento da assistência de enfermagem e as exigências do mercado de trabalho. RESULTADOS: A amostra foi composta por 35 participantes, 15 enfermeiros e 20 graduandos. Os principais motivos que levaram os estudantes a realizarem o estágio foram: adquirir conhecimentos (57,6\%); interesse pela Estomaterapia $(10,5 \%)$; adquirir novas experiências (10,5\%). Além de observar e auxiliar, 94,3\% dos participantes afirmaram que realizaram procedimentos e acolheram pessoas sob supervisão da professora, os estudantes afirmaram que foi possível aprender e realizar as etapas do processo de enfermagem e desenvolver raciocínio clinico, $94,3 \%$ relataram que as explicações do professor proporcionaram segurança para realizar procedimentos. Os egressos afirmaram que 0 estágio é capaz de capacitar para as exigências do mercado e influenciam no aperfeiçoamento das práticas de enfermagem, 91,4\% dos entrevistados relataram que a realização do estágio voluntário permitiu conciliar a teoria com a prática2. CONCLUSÔES: O estágio voluntário na clínica de enfermagem PUCPR foi capaz de contribuir para a formação do enfermeiro, trouxe benefícios para os acadêmicos e egressos, permitiu conciliar teoria com a prática, realizar procedimentos de forma segura. Foi evidenciado que a realização do estágio é um fator que contribui para a inserção, sentimento segurança e transição da graduação para o mercado de trabalho3. O estágio também favorece a divulgação da especialidade, captando enfermeiros para o Curso de Especialização em Estomaterapia da Escola de Ciências da Vida da PUCPR

\section{Keywords: Aprendizagem, Enfermagem, Estomaterapia, Estágios}

\section{Referências Bibliográficas}

1.SALOMÉ, Geraldo Magela; ESPÓSITO, Vitória Helena Cunha. Vivências de acadêmicos de enfermagem durante o cuidado prestado às pessoas com feridas. Revista Brasileira de Enfermagem, 2008. Disponível em: . Acesso em: 07 nov. 2018 2. ECHER, Isabel Cristina et al. O estágio voluntário na percepção de acadêmicos de enfermagem. Revista Gaúcha de Enfermagem, Porto Alegre, RS. Vol. 24, n. 2 ago. 2003, p. 238-246, 2003. Disponível em: Acesso em: 27 nov. 2017. 3.MATTOSINHO, Mariza Maria Serafim et al. Mundo do trabalho: alguns aspectos vivenciados pelos profissionais recém- formados em enfermagem. Acta Paul. Enferm, São Paulo, v. 23, n. 4, p. 466-471, 2010. Disponível em: . Acesso em 07 Nov. 2018. 


\section{SERVIÇO DE ESTOMATERAPIA EM UM CENTRO DE SAÚdE PÚBLICO- RELATO DE EXPERIÊNCIA}

Author(s): Alessandra Garcia de Figueiredo Agostini 1, Andréia Inês Engelmann 2, Carla Dipra Pereira 1, Giulia Pedroso Perini 2, Rosaura Soares Paczek 1

Institution(s) 1 PMPA - Prefeitura Municipal de Porto Alegre (Avenida João Pessoa, 1110, - Farroupilha, Porto Alegre - RS, 90040-001), 2 ESP - Escola de Saúde Publica do Estado do Rio Grande do Sul (Av. Ipiranga, 6311 Partenon, Porto Alegre - RS, 90610-001), 3 PMPA - Prefeitura Municipal de Porto Alegre (Avenida João Pessoa, 1110, - Farroupilha, Porto Alegre - RS, 90040-001), 4 ESP - Escola de Saúde Publica do Estado do Rio Grande do Sul (Av. Ipiranga, 6311 - Partenon, Porto Alegre - RS, 90610-001), 5 PMPA - Prefeitura Municipal de Porto Alegre (Avenida João Pessoa, 1110, - Farroupilha, Porto Alegre - RS, 90040-001)

\section{Abstract}

Introdução - A estomaterapia tem sua atuação fundamentada em bases sólidas, dando condições ao Enfermeiro Estomaterapeuta (ET) realizar o cuidado especializado, detectando, avaliando e buscando o alívio das dificuldades físicas e emocionais das pessoas com estomia, feridas e incontinências. A estomaterapia evoluiu desde Norma Gill, conhecida mundialmente como "a primeira estomaterapeuta". A especialização avança no conhecimento científico e transcende o desempenho e saber comum, surge como reconhecimento do profissional que assume o compromisso de especialista em buscar aprofundar conhecimentos técnicos e científicos, visando melhorar sua prática assistencial e exercer ações de sua competência junto a equipe de saúde. Objetivo - Relatar experiência da criação do serviço de estomaterapia no Sistema Único de Saúde em um município do Rio Grande do Sul. Material e método - Trata-se de um estudo descritivo, do tipo relato de experiência, no contexto de atuação de duas enfermeiras estomaterapeutas no município de Porto Alegre, Rio Grande do Sul, Brasil. Resultados e Discussão - O atendimento a pacientes com estomias neste centro de saúde existe desde 1984, e a partir de $1990 \mathrm{com}$ a criação do SUS ampliou 0 atendimento a todas as pessoas com estomias que eram referenciadas a este serviço, o qual era realizado por uma enfermeira e dois auxiliares de enfermagem. A partir de 2015 iniciou atendimento a pacientes com feridas, atualmente temos duas enfermeiras ETs, um médico coloproctologista, uma psicóloga, uma nutricionista, uma assistente social, três auxiliares de enfermagem e uma técnica de enfermagem. O serviço dispõe de consultórios para realização de curativos e atendimento de consultas a pacientes com estomias, temos uma média mensal de 140 consultas de enfermagem nas estomias, e de 250 atendimentos às pessoas que necessitam de curativos. Sendo que uma enfermeira ET é responsável pelas estomias e a outra pelos curativos especiais. O atendimento ocorre de segunda a sexta-feira, mediante agendamento prévio, porém, em casos de necessidade também são atendidos pacientes por demanda espontânea. O serviço de estomaterapia também faz a dispensação dos materiais utilizados para estes cuidados. O perfil da população atendida é bastante variado, com usuários de diferentes faixas etárias, nível socioeconômico, causas dos agravos e comorbidades de saúde. Normalmente, os pacientes atendidos em consulta de enfermagem com a estomaterapeuta apresentam lesão de pele periestomal, ou alguma dificuldade na troca ou adaptação aos materiais, sendo necessária a avaliação do estoma e condições gerais da pele, assim como na realização dos curativos existe a necessidade de acompanhamento, tratamento e evolução da lesão. A avaliação do usuário, capacidade do autocuidado e/ou cuidador e condições de vida influenciam na escolha do material utilizado. Conclusão - É necessário destacar a importância do trabalho multiprofissional, considerando que o usuário é um ser singular em suas necessidades, que dificilmente serão contempladas por uma especialidade. O trabalho em equipe também facilita a troca de informações, experiências e o aprimoramento das técnicas em conjunto. Da mesma forma, podemos destacar que o vínculo entre usuários e profissionais favorecem a confiança no plano de cuidados que é estabelecido e o sucesso do tratamento.

Keywords: Sistema Único de Saúde, Estomia, Feridas, Estomaterapia

\section{Referências Bibliográficas}

BRASIL. Lei Orgânica da Saúde, de no 8.080, de 19 de setembro de 1990. [acesso em 13 de jun de 2019]. Disponível em : http://www.planalto.gov.br/ccivil_03/leis//8080.htm Dias MSC, Paula MAB, Morita ABPS. Perfil Profissional de Enfermeiros Estomaterapeutas Egressos da Universidade de Taubaté. Rev Estima, v. 12 n. 3.2014. Acesso em 12 de jun 2019. Disponível em: https://www.revistaestima.com.br/index.php/estima/article/view/92 Teixeira AKS , Menezes LCG , Oliveira RM. Serviço de Estomaterapia na Perspectiva dos Gerentes de Enfermagem em Hospital Público de Referência. Rev Estima, v.14 n.1, p. 3-12, 2016 DOI: 10.5327/Z1806-3144201600010002. 


\title{
PREVALÊNCIA DE LESÕES CUTÂNEAS E A ASSISTÊNCIA PRESTADA EM AMBULATÓRIO DE ENFERMAGEM
}

\author{
Author(s): Ana Elisa Rodrigues 1, Kelli Borges dos Santos 2, Fernanda Vieira Nicolato 3, Anadelle de Souza Teixeira \\ Lima 1,3, Alfeu Gomes Junior 3
}

Institution(s) 1 HU-UFJF - Hospital Universitário Universidade Federal de Juiz de Fora (Av. Eugênio do Nascimento s/no - Dom Bosco CEP: 36038-330 Juiz de Fora/MG), 2 UFJF - Universidade Federal de Juiz de Fora (R. José Lourenço Kelmer s/n São Pedro CEP: 36036-900 Juiz de Fora/MG), 3 IESPE - IESPE (Av. Barão do Rio Branco 3.480 3o andar Passos CEP: 36025-020 Juiz de Fora/MG)

\section{Abstract}

A assistência ao paciente portador de lesão é uma prática comum na atuação da enfermagem, que desde seu surgimento como profissão, esteve na condição de principal área atuante neste cuidado'. $O$ enfermeiro vem buscando aumentar seu conhecimento relativo à prevenção de danos teciduais e do tratamento e cuidado com este tipo de agravo que possam melhorar a qualidade da assistência. Desta forma, há algum tempo o tratamento de lesões deixou de ser apenas a técnica de curativo e passou a incluir uma metodologia assistencial, com avaliação integral do paciente, exame físico direcionado de acordo com a etiologia da lesão, além da escolha da terapia adequada e registro de enfermagem com projeção prognóstica ${ }^{2}$. Devido a estas especificidades, o conhecimento do perfil dos pacientes atendidos, possibilita um direcionamento do atendimento prestado, tanto do ponto de vista assistencial como de gestão e organização do serviço ofertado ${ }^{3}$. Diante disso, a pesquisa objetivou caracterizar o perfil clínico e a assistência prestada em um Ambulatório de Enfermagem em Lesões Cutâneas de um hospital público de ensino. A presente pesquisa foi aprovada pelo Comitê de Ética da Universidade Federal de Juiz de Fora, através da emissão do Parecer de número 2.890.031. Trata-se de um estudo transversal, prospectivo, de caráter observacional e abordagem quantitativa descritiva. A coleta de dados foi realizada por meio de questionário estruturado, observação direta da lesão e entrevista ao paciente. $O$ atendimento ambulatorial ocorre às sextas-feiras à tarde, com uma frequência de 5 atendimentos por semana. Utilizou-se o programa Microsoft Excel para criação do banco de dados e construção de gráficos. Participaram da pesquisa 15 pacientes, que foram atendidos no período de julho de 2018 a junho de 2019. Os resultados mostraram a predominância de lesão venosa (60\%), seguida pelas lesões mistas (27\%). Este dado está de acordo com o alto índice de insuficiência venosa relatado pelos participantes (60\%). Quanto ao tempo de surgimento da lesão, 11 pacientes relataram ter surgido há mais de 6 meses. Quanto a realização do curativo para dar continuidade ao cuidado, dada a frequência dos atendimentos no ambulatório, $93,33 \%$ dos participantes relataram que é realizado no próprio domicílio, sendo $46,66 \%$ realizado pelo próprio paciente e a mesma proporção por algum familiar. Dentre as coberturas padronizadas na instituição, $40 \%$ dos pacientes faziam uso de alginato com prata no período da coleta de dados. A pesquisa possibilitou identificação das lesões de maior prevalência e a necessidade um tratamento mais específico para lesões venosas, que deve estar baseado no Modelo $A B C$ de gerenciamento de lesão venosa, a terapia com bota de Unna ou compressão elástica multicamadas4. Destaca-se a relevância na orientação para o autocuidado e apoio familiar para a realização do cuidado domiciliar. Através do presente estudo, será possível buscar melhorias funcionais e materiais, além da qualidade da assistência de enfermagem. $O$ profissional que atua nesta prática precisa estar capacitado, 0 enfermeiro Estomaterapeuta possui embasamento teórico e prático necessário para se prestar uma assistência com segurança e qualidade.

Keywords: Assistência Ambulatorial, Enfermeiro, Estomaterapia, Ferimentos e Lesões

\section{Referências Bibliográficas}

Dealey C. Cuidando de feridas: um guia para enfermeiras. 3. ed. São Paulo: Atheneu; 2013. 2- Cavalcante BLL, Lima UTS. Relato de experiência de uma estudante de enfermagem em um consultório especializado em tratamento de feridas. J. Nurs. Health [Internet]. 2012 [acesso em 2019 mai 30]; 2(1): 94-103. Disponível em: https://periodicos.ufpel.edu.br/ojs2/index.php/enfermagem/article/view/3447/2832 3- Squizatto RH, Braz RM, Lopes AO, Rafaldini BP, Almeida DB, Poletti NAA. Perfil dos usuários atendidos em ambulatório de cuidado com feridas. Cogitare Enferm. [Internet]. 2017 [acesso em 2019 mai 29]; 22(1): 01-09. Disponível em: https://revistas.ufpr.br/cogitare/article/view/48472 4- Borges EL, Santos CM, Soares MR. Modelo ABC para o manejo da úlcera venosa de perna. Estima [Internet]. 2017 [acesso em 2019 jun 5]; 15(3): 182-187. Disponível em: https://www.revistaestima.com.br/index.php/estima/article/view/350 


\title{
A RELEVÂNCIA DO OLHAR MULTIPROFISSIONAL NAS INTERVENÇÕES DAS LESÕES POR PRESSÃO
}

\author{
Author(s): Arian Santos de Jesus 1, Marcele de Jesus Lasse dos Reis Pessoa 1, Lourde Mile Pereira de Sá 1, \\ Cristiane Costa Reis da Silva 1, Yara Cordeiro Guimarães 1 \\ Institution(s) \\ Bahia. CEP. 41.720-200) \\ 1 UNIFACS - Universidade Salvador (Av. Luís Viana Filho no 3146 / 3100 Pituaçu, Salvador -
}

\section{Abstract}

Introdução: A Lesão por pressão (LPP) é a perda de pele e/ou tecido, relacionada a proeminência óssea ou até mesmo por dispositivos médicos que promovem pressão intensa e/ou prolongada, reduzindo a perfusão local. A atuação e interação da equipe multiprofissional trazem grandes benefícios, tanto para o paciente quanto para a organização, pois tais lesões são indicativos de qualidade assistencial dos serviços de saúde e de enfermagem. Objetivo: Descrever estratégias de prevenção das LPP's pela equipe multiprofissional juntamente com as terapias adjuvantes. Método: Pesquisa integrativa, com abordagem qualitativa de natureza exploratória. Utilizando a pergunta norteadora: Como identificar e intervir nas lesões por pressão evidenciando a importância da atuação multiprofissional no tratamento ao paciente? A extração de dados foi realizada nas bases de dados da Biblioteca Virtual em Saúde (BVS), Literatura Latino-Americana e do Caribe em Ciências da Saúde (LILACS), US National Library of Medicine (PUBMED), Banco de Dados em Enfermagem (BDENF) e ScientificElectronic Library Online (SciELO). Foram incluídos estudos completos e disponíveis integralmente nos periódicos nacionais e internacionais, nos idiomas português, inglês e espanhol, com recorte temporal entre 2005 a 2018 Resultado: Foram encontrados 868, excluídos 842 e utilizados 26 artigos, onde trazem todo conhecimento sobre lesão por pressão e atuação multiprofissional, além de terapias adjuvantes relacionados à lesão por pressão. Foi percebido a prevalência de profissionais enfermeiros na produção e publicação de artigos com o tema abordado, contendo o total de 11 artigos, onde entre os autores constavam apenas enfermeiros (47,82\%). Considerando a equipe multiprofissional os enfermeiros são responsáveis por monitorar a integridade cutânea, definir os cuidados tópicos com as lesões, instruir e realizar a limpeza correta, realizar manuseio adequado das lesões e identificar a frequência adequada das trocas de curativo, realizando avaliações recorrentes direcionando-se através da sistematização da assistência de enfermagem (SAE). Os fisioterapeutas na prevenção promovem exercícios ativos e passivos, evitando pressões nas proeminências ósseas e repouso e nas intervenções utilizam recursos adjuvantes eletrotermofototerápicos como a radiação infravermelha, a terapia por ultrassom, o laser de baixa intensidade, dentre outros. Em relação à nutrição estudos indicam que a desnutrição contribui para o desenvolvimento da lesão por pressão e retardo na cicatrização. Determinados nutrientes podem intervir positivamente no processo de cicatrização, os principais são: Glutamina, cobre, zinco, arginina, vitaminas e antioxidantes. Os psicólogos trazem como proposta cuidar da parte psicossocial, apoio emocional, do paciente e familiar, administrando conflitos trazidos pela mudança da imagem corporal indesejada. Os médicos intervêm nas enfermidades crônicas, atuam no tratamento da dor, solicitações de exames complementares quando necessário e tratamento farmacológico e cirúrgico. Com o crescimento de atingidos se faz necessário investigar novos tratamentos e intervenções com resultados rápidos e eficazes. Atualmente a laserterapia e a oxigenoterapia hiperbárica são as maiores terapias adjuvantes aliadas ao tratamento das lesões. Conclusão: Desta forma, conclui-se que a abordagem multiprofissional em pacientes com lesão por pressão é de grande importância. Trabalhando em equipe, cada profissional atuando em sua especialidade, é possível reduzir o tempo de internação, diminuir gastos e custos do hospital, além de uma recuperação holística para o paciente.

\section{Keywords: Lesão por Pressão, Equipe multiprofissional, Estomaterapia, Pele}

\section{Referências Bibliográficas}

1- Borghardt Andressa Tomazini, Prado Thiago Nascimento do, Bicudo Sheilla Diniz Silveira, Castro Denise Silveira de, Bringuente Maria Edla de Oliveira. Pressure ulcers in critically ill patients: incidence and associated factors. Rev. Bras. Enferm. [Internet]. Junho de 2016 [citado em 11 de agosto de 2019]; 69(3): 460-467. Disponível em: http://www.scielo.br/scielo.php?script=sci_arttext\&pid=S0034-71672016000300460\&lng=en.

http://dx.doi.org/10.1590/0034-7167.2016690307i. 2- Oliveira Karina Díaz Leyva de, Haack Adriana, Fortes Renata Costa. Terapia nutricional na lesão por pressão: revisão sistemática. Rev. bras. geriatr. gerontol. [Internet]. Agosto de 2017 [citado em 11 de agosto de 2019]; 20(4): 562-570. Disponível em: http://www.scielo.br/scielo.php?script=sci_arttext\&pid=S1809-98232017000400562\&lng=pt.

http://dx.doi.org/10.1590/1981-22562017020.160195. 3- Santos Cássia Teixeira dos, Almeida Miriam de Abreu, Oliveira Magáli Costa, Victor Marco Antônio de Goes, Lucena Amália de Fátima. Desenvolvimento do diagnóstico de enfermagem risco de úlcera por pressão. Rev. Gaúcha Enferm. [Internet]. Junho de 2015 [citado em 11 de agosto de 2019]; 36(2): 113-121. Disponível em: http://www.scielo.br/scielo.php?script=sci_arttext\&pid=S198314472015000200113\&lng=pt. http://dx.doi.org/10.1590/1983-1447.2015.02.49102. 


\section{INTERVENÇÃO EDUCATIVA MULTIDISCIPLINAR PARA PESSOAS COM ÚLCERAS DE PERNA E SEUS FAMILIARES/CUIDADORES: ACOMPANHADOS EM AMBULATÓRIO ESPECIALIZADO}

Author(s): $\quad$ Camila Barroso Martins 1, Beatriz Moreira Alves Avelino 1, Ingrid Caroline Uchôa Alexandre 1, Débora Lira Correia 1, Letícia Ellen Vieira Rocha 1, Viviane Mamede Vasconcelos Cavalcante 1, Saionara Leal Ferreira 2, Francisca Alexandra Araújo da Silva 2, Synara Cavalcante Lopes 2, Alba Paula Mendonça Lima 2, Solange Gurgel Alexandre 2

Institution(s) 1 UFC - Universidade Federal do Ceará (Rua Alexandre Baraúna, no 1115- Fortaleza -Ce), 2 HU Hospital Universitário Walter Cantídio (R. Pastor Samuel Munguba, 1290 - Rodolfo Teófilo, Fortaleza - CE)

\section{Abstract}

INTRODUÇÃO: As úlceras de pernas são consideradas condições crônicas. Segundo a Conferência Nacional de Consenso sobre Úlceras de Perna da Extremidade Inferior, essas feridas acometem cerca de 2 a 5 pessoas em cada $1000^{1}$, produzindo impactos negativos e incapacitando o indivíduo para a realização de suas atividades, além de trazer desconforto físico, mudanças no convívio social, comprometimentos da capacidade funcional, sensação de desamparo e distúrbios da autoimagem que interferem na vida social e pessoal². Nesse contexto, os familiares são de suma importância, tendo em vista que muitas vezes, fazem parte dos cuidados no domicílio ${ }^{3}$. Para dar suporte a essas pessoas, o profissional de enfermagem, junto à equipe multidisciplinar deve prestar uma assistência integral, individualizada e focada nas reais necessidades de cada pessoa, buscando novas estratégias educativas para orientação e empoderamento para o autocuidado, podendo contribuir para adesão ao tratamento, diminuição do tempo de cicatrização e, consequentemente, melhora na qualidade de vida. OBJETIVO: Descrever intervenção educativa com abordagem multidisciplinar voltada para pessoas com úlceras de perna acompanhados em um ambulatório e seus familiares e/ou cuidadores. MATERIAL E MÉTODO: Trata-se de estudo descritivo de ação educativa multiprofissional sobre úlceras de pernas, realizada em julho de 2019, na cidade de Fortaleza-CE. RESULTADOS: Estiveram presentes 50 participantes, entre pacientes e familiares, que foram acolhidos pelos profissionais e acadêmicos, sendo dispostos em círculo, com a intenção de aproximar e tornar o momento mais acolhedor. Os conteúdos propostos foram reproduzidos em equipamentos de multimídia. No primeiro momento, foi realizada pelos acadêmicos de enfermagem integrantes de uma liga acadêmica de Enfermagem em Estomaterapia, uma dinâmica, com o propósito de descontrair os participantes e prepará-los para o segundo momento, quando foi iniciada uma conversa sobre as doenças relacionadas às úlceras de perna, os principais cuidados para a prevenção e tratamento e a importância da alimentação para uma maior efetividade do cuidado. Atuaram como facilitadoras, duas enfermeiras estomaterapeutas e uma nutricionista. Durante toda a conversa, foi dada a oportunidade de participação do público, com retirada de dúvidas e compartilhamento de experiências. A atividade teve duração de quatro horas. Os presentes mostraram-se bem participativos, ouvindo atenciosamente, colocando suas dúvidas e relatando suas experiências, o que sinalizou sua necessidade de informações e de maior aproximação com os profissionais e com outras pessoas que vivenciam histórias semelhantes às suas. Foi possível perceber também a necessidade de novos encontros, abordando outros temas relacionado a úlceras de perna e proporcionando essa proximidade que permite a criação de vínculos que impactam no processo de cuidado. CONCLUSÃO: O profissional estomaterapeuta, em parceria com equipe multidisciplinar, tem um papel fundamental na assistência à pessoa com úlceras venosas e arteriais, articulando a promoção de atividades educativas que forneçam subsídios para a redução de agravos, além de promover saúde, ajudando assim na melhoria da qualidade de vida.

Keywords: Estomaterapia, Feridas e Lesões, Úlcera da Perna

\section{Referências Bibliográficas}

1.Roura MJ, Soriano VJ. Conferencia nacional de consenso sobre las úlceras de la extremidad inferior (C.O.N.U.E.I.). Documento de consenso 2018. $2^{\underline{a}}$ ed. Madrid: Ergon, 2018. 2.Lima LV, Sousa ATO, Costa ICP, Silva V. Conhecimento de Pessoas com Úlceras Vasculogênicas Acerca da Prevenção e dos Cuidados com as Lesões. São Paulo: Estima - Brazilian Journal of Enterostomal Therapy, 2016. 11(3). 3.Reis DB, Peres GA, Zuffi FB, Ferreira LA, Poggetto MTD. Cuidados às pessoas com úlcera venosa: percepção dos enfermeiros da estratégia de saúde da família. Minas Gerais: Revista Mineira de Enfermagem, 2013. 17(1), 102-112 


\section{SÍNDROME DE FOURNIER: ESTUDO DE CASO}

Author(s): $\quad$ Edivania Anacleto Pinheiro Simões 1, Cristiane Maria Mendes Parente 4, Adla Lopes Nascimento 3, Daline Bezerra Balonecker de Aguiar 5, Flávia Cristina dos Santos Pacheco 4, Amanda Cintra Mapelli 4, Juliana Balbinot Reis Girondi 2

Institution(s) 1 HSJ - Hospital São Julião (Lino Villacha no 1250 ), 2 UFSC - Universidade Federal de Santa Catarina ( R. Eng. Agronômico Andrei Cristian Ferreira, s/n), 3 CAISM - Centro de Atenção Integrada em Saúde Mental (Major Maragliano, 241), 4 HIAE - Hospital Israelita Albert Einstein (Av. Albert Einstein 627), 5 HMASP Hospital Militar de Área de São Paulo (Ouvidor Portugal, 230)

\section{Abstract}

Introdução: A síndrome de Fournier é uma fasciite necrosante do períneo e parede abdominal causada por bactérias gram positivas, negativas ou anaeróbios, decorrente da oclusão vascular das artérias de membros inferiores, seguida de isquemia e trombose dos vasos subcutâneos. Comumente resulta em necrose da pele, do tecido subcutâneo e adjacentes; tendo como manifestações clínicas: dor local, eritema, edema, necrose e febre $(1,2)$. O tratamento ocorre pela correção dos distúrbios hidroeletrolíticos, antibioticoterapia de amplo espectro, debridamento cirúrgico de emergência e terapia tópica(3). Objetivo: Relatar caso clínico de uma paciente com Síndrome de Fournier. Material e métodos: O estudo foi aprovado pelo Comitê de Ética em Pesquisa da Universidade Católica Dom Bosco, sob parecer n².049.316 e CAAE nº.66189317.7.0000.5162. Foi desenvolvido em um hospital filantrópico no Mato Grosso do Sul. Para coleta de dados utilizou-se instrumento semi - estruturado contendo as variáveis: dados de identificação (idade, sexo, ocupação, renda familiar, admissão, especialidade, diagnóstico); condições inerentes ao paciente (tabagismo, etilismo, condições nutricionais, mobilidade, história da doença atual, tratamentos anteriores, medicamentos em uso); avaliação da lesão (tipo, localização, conteúdo microbiano, exsudato, bordas, pele adjacente, dor, mensuração), e espaço para observações adicionais/companhamento. Inicialmente foi realizado exame físico e anamnese, todas as observações foram registradas no instrumento, assim como registros fotográficos. A limpeza da lesão com irrigação foi realizada com Solução Fisiológica a 0,9\% morna, utilizando seringa de 20cc e agulha 40x12. Posteriormente procedeu-se aplicação da cobertura alginato de cálcio com prata sobre a lesão úmida, sendo esta coberta com gaze seca, fixado com fita adesiva a troca era realizada a cada 24 horas . Resultados: R.S, sexo feminino, 39 anos, com ensino fundamental incompleto. Nega etilismo, tabagismo, comorbidades: obesidade grau II, diabética insulinodependente, hipertensa. Em 24/12/18 foi diagnosticada com Sindrome de Fournier e submetida à debridamento cirúrgico, recusou-se as intervenções propostas de colostomia e sonda vesical de demora. Em 19/01/19 foi transferida para a unidade de reabilitação. Ao exame físico: bom estado geral, consciente, orientada, ativa, normocorada, deambulando com apoio da enfermagem MID edemaciada (4+/4+) pele ressecada, higiene intima prejudicada com vaginose bacteriana, apresentando lesão em glúteo contaminada com as características: margens irregulares com presença de tumefação em margem superior, leito da lesão apresenta tecido granulação de caracteristicas roseo palido, com presença de esfacelo aderido, com exsudato seropurulento em grande quantidade com odor fetido, medindo $17,5 \mathrm{~cm}$ de largura, $6 \mathrm{~cm}$ de comprimento e $10 \mathrm{~cm}$ de profundidade. A partir de então recebeu assistência multiprofissional, antibioticoterapia (gentamicina, piperaciclina e tazobactan), associado pela terapia tópica com curativo de alginato de cálcio com prata. Após 55 dias de internação sob as intervenções da equipe, recebe alta hospitalar com a lesão medindo $3 \mathrm{~cm} \times 2 \mathrm{~cm}$ com ausência de profundidade, feito a contra referência para continuidade na cidade de origem. Conclusão: A sistematização do cuidado de enfermagem é essencial para o adequado desfecho no cuidado da pessoa com Síndrome de Founier, em virtude da complexidade desse cuidado. Ações interprofissisonais devem ser implementadas em associação à adequada terapêutica para sua efetividade.

Keywords: Estomaterapia, gangrena de founier, fasciite necrosante

\section{Referências Bibliográficas}

DORNELAS, M. T et al. Síndrome de Fournier - 10 anos de avaliação. Rev Bras Cir Plást. v. 27, n. 4. 2012. p. 6004. Disponível em; http://www.scielo.br/pdf/rbcp/v27n4/22.pdf. Acesso em; 25 junho 2019. 2. CARDOSO, J. B, FÉRES, O. Fournier's Gangrene. Medicina (Ribeirão Preto) 2007; 40 (4): 493-9, oct./dec. Disponível em; http://revista.fmrp.usp.br/2007/vol40n4/1_gangrena\%20de\%20fournier.pdf. Acesso em; 29 maio 2019.3. SMANIOTTO, P.H.S. et al. Sistematização de curativos para o tratamento clínico das feridas. Rev Bras Cir Plást.v. 27.n.4.p:623-6, 2012. Disponível em: http://www.scielo.br/pdf/rbcp/v27n4/26.pdf. Acesso em: 26 abr 2019. 


\section{UTILIZACÃO DE LASERTERAPIA DE BAIXA POTÊNCIA NO TRATAMENTO DE LESÃO TRAUMÁTICA EM PÉ DE DIABÉTICO}

Author(s): $\quad$ Edivania Anacleto Pinheiro Simões 1, Cristiane Maria Mendes Parente 5, Adla Lopes Nascimento 3, Flávia Cristina dos Santos Pacheco 5, Amanda Cintra Mapelli 5, Daline Bezerra Balonecker de Aguiar 4, Juliana Balbinot Reis Girondi 2

Institution(s) 1 HSJ - Hospital São Julião (Lino Villacha no 1250 ), 2 UFSC - Universidade Federal de Santa Catarina ( R. Eng. Agronômico Andrei Cristian Ferreira, s/n), 3 CAISM - Centro de Atenção Integrada em Saúde Mental (Major Maragliano, 241), 4 HMASP - Hospital Militar de Área de São Paulo (Ouvidor Portugal, 230), 5 HIAE Hospital Israelita Albert Einstein (Av. Albert Einstein 627)

\section{Abstract}

Introdução: Diabetes mellitus (DM) é um importante e crescente problema de saúde para todos os países, suas complicações constituem as principais causas de mortalidade precoce na maioria dos países e são categorizadas como distúrbios microvasculares e macrovasculares.(1,2) A terapia a laser de baixa intensidade é apresentada como um recurso terapêutico de baixo custo e eficiência comprovada no tratamento de úlceras, capaz de acelerar o processo de reparo em tecidos distintos por meio do emprego de fontes de luz de baixa potência $(3,4)$. Objetivo: Relatar caso de pé diabético tratado com laserterapia de baixa potência. Material e métodos: O estudo foi aprovado pelo Comitê de Ética em Pesquisa da Universidade Católica Dom Bosco, sob parecer n².049.316 e CAAE nº.66189317.7.0000.5162. Foi desenvolvido em um hospital filantrópico no Mato Grosso do Sul. Para coleta de dados utilizou-se instrumento semi - estruturado contendo as variáveis: dados de identificação (idade, sexo, ocupação, renda familiar, admissão, especialidade, diagnóstico); condições inerentes ao paciente (tabagismo, etilismo, condições nutricionais, mobilidade, história da doença atual, tratamentos anteriores, medicamentos em uso); avaliação da lesão (tipo, localização, conteúdo microbiano, exsudato, bordas, pele adjacente, dor, mensuração), e espaço para observações adicionais/companhamento.Inicialmente foi realizado exame físico e anamnese, todas as observações foram registradas no instrumento, assim como registros fotográficos. A limpeza da lesão com irrigação foi realizada com solução fisiológica a 0,9\% morna, utilizando seringa de 20 cc e agulha $40 \times 12$. Posteriormente procedeu-se aplicação de terapia fotodinâmica, sendo realizada duas sessões, e em seguida na reparação tecidual o laser utilizado apresentava comprimento de onda de $660 \mathrm{~nm}$ e foi utilizada a técnica pontual com contato na margem das lesões e pontual sem contato no leito a distância entre os pontos era de $1 \mathrm{~cm}$. A energia aplicada por ponto foi de $200 \mathrm{~mJ}(0,2 \mathrm{~J})$ aplicada em 4 disparos de $50 \mathrm{~mJ}$. O procedimento foi mantido três vezes por semana, durante 12 semanas. Resultados: A.G.S, sexo masculino, 67 anos, analfabeto, etilista, tabagista, hipertenso há 10 anos e diabético há 30 anos. Em 10/01/2019 sofreu trauma em pé direito, permanecendo 18 dias em internação hospitalar, onde foi realizado debridamento cirúrgico com amputação de hálux direito, com evolução para infecção. Ao exame físico: bom estado geral, consciente, orientado, ativo, normocorado, deambulando sem auxilio, pele ressecada. Lesão em membro inferior direito em hálux com as características: lesão mensurada em $97,5 \mathrm{~cm} 2$, leito com esfacelo aderido, exsudato seropurulento em pouca quantidade, exposição de tendão, ausência de odor, margens irregulares, escala de dor com escore 10, diminuição de sensibilidade em área perilesional. A partir de então recebeu assistência multiprofissional, antibioticoterapia (gentamicina, meropenem ), associado a laserterapia de baixa potência. Após 12 semanas de internação sob as intervenções da equipe, recebe alta hospitalar com a lesão medindo $3,5 \mathrm{~cm} 2$ escala de dor com escore zero, tecido de granulação em leito, bordas irregulares e epitelizadas, ausência de exsudato e odor, ausência de algia e edema. Conclusão: O laser de baixa potência se mostrou eficaz no tratamento de pé diabético.

Keywords: Estomaterapia, Diabetes Mellitus, Lasers

\section{Referências Bibliográficas}

1. Carvalho AFM, Feitosa MCP, Coelho NPMF, Rebêlo VCN, Castro JG, Sousa PRG, et al. Low-level laser therapy and Calendula officinalis in repairing diabetic foot ulcers. Rev Esc Enferm USP. 2016;50(4):626-632. 2. MOREIRA, A. P. L; MALTA, D. C; VIANNA, R. P. T; MOREIRA, P. V. L; CARVALHO, A. T. Fatores de risco e proteção para hipertensão e diabetes auto-relatados em João Pessoa, Brasil. Um estudo transversal. São Paulo Med. J. vol.135 n.5, São Paulo set./out. 2017. 3. ANDRADE, F. S. S.D; CLARK, R.M.M.O; FERREIRA, M.L. Efeitos da laserterapia de baixa potência na cicatrização de feridas cutâneas. Revista Col. Cir. 2014, 41 (2). 4. MATOS, A.S; BERRENTINFELIX, G; BANDEIRA, R.N; ALMEIDA, L.N.A; ALVES, G.A.S. Laserterapia aplicada à motricidade orofacial: percepção dos membros da Associação Brasileira de Motricidade Orofacial - Abramo. Revista CEFAC, 2018,20 (1). 


\section{Suporte nutricional na úlcera venosa: uma revisão.}

Author(s): $\quad$ PAULA PENS ALVES 1, FABIOLA ARANTES FERREIRA 1, HÉLIO MARTINS DO NASCIMENTO FILHO 1, VANESSA YURI SUZUKI 1, ANDREA FERNANDES DE OLIVEIRA 1, RENATO SANTOS DE OLIVEIRA FILHO 1, LYDIA MASAKO FERREIRA 1

Institution(s) 1 UNIFESP - Universidade Federal de São Paulo (Rua Botucatu, 720, São Paulo(SP))

\section{Abstract}

A úlcera venosa, também denominada úlcera varicosa e úlcera de estase, é considerada um problema de saúde pública no mundo com significativo impacto no bem estar social. Sua prevalência no ocidente é estimada em $1 \% \mathrm{e}$ pode chegar a 3\% nos idosos com mais de 70 anos (WHITE-CHU \& CONNER-KERR, 2014; PARKER et al., 2015). No Brasil ainda são escassos estudos epidemiológicos sobre úlcera venosa. Em Botucatu, no interior de São Paulo, a prevalência do agravo na população é de 1,5\%. Já em Minas Gerais, na cidade de Conselheiro Lafaiete, a prevalência de feridas crônicas encontrada por pesquisadores foi de $1,64 \%$ e a UV representou $50 \%$ das lesões avaliadas(DE SOUZA et al., 2013; RESENDE et al., 2017; BORGES et al., 2018).

A úlcera venosa é um problema de saúde pública mundial e apresenta significativo impacto socioeconômico. É comum pacientes com úlcera venosa apresentarem índice de massa corpórea alterado e deficiências nutricionais que contribuem para a cronicidade da ferida. Objetivo: Investigar o impacto do suporte nutricional para auxiliar no processo de cicatrização de úlcera venosa. Método: Foi realizada uma revisão bibliográfica nas principais bases de dados em saúde Pubmed, Lilacs e Scielo, comos descritores em ciências da saúde: cicatrização, ferimentos e lesões, terapia nutricional e úlcera varicosa nos idiomas português e inglês, considerando o período de 2014 a 2019. Conclusão: De acordo com a literatura científica, a suplementação nutricional em pacientes com úlcera venosa comproteínas, lipídeos, vitaminas e mineraisestão associados a melhora da cicatrização, contudo, novos estudos que novos estudos com maior rigor metodológico sejam desenvolvidos para confirmação destes efeitos.

Keywords: CICATRIZAÇÃO, FERIMENTOS, LESÕES, MANUAIS, TERAPIA NUTRICIONAL

\section{Referências Bibliográficas}

Barber, GA, Weller, CD, Gibson, SJ. Effects and associations of nutrition in patients with venous leg ulcers: A systematic review. Journal of advanced nursing. 2018; 74(4): 774-787. Borges EL, Nascimento-Filho HM, PiresJúnior JF. Prevalência de Lesões Crônicas de Município de Zona da Mata Mineira. Revista Mineira de Enfermagem. 2018;22:e-1143. Brandão ES, Santos I, Lanzillotti RS. Validação de um instrumento para avaliação do cliente com afecções cutâneas. Act Paul Enferm. 2013; 26(5): 460-466. Cassar FA, Marshall S, Cordina M. Use of the Delphi technique to determine safety features to be included in a neonatal and pediatric prescription chart. Int $\mathrm{J}$ Clin Pharm. 2014; 36(6): 1179-1189. Cavassan NRV, et al. Correlation between chronic venous ulcer exudate proteins and clinical profile: A cross-sectional study. Journal of proteomics. 2019; 192: 280-290. da Silva Revorêdo L, Maia RS, de Vasconcelos Torres G, Maia EMC. O uso da técnica delphi em saúde: uma revisão integrativa de estudos brasileiros. Arquivos de Ciências da Saúde. 2015; 22(2): 16-21. de Souza, EM, Yoshida, WB, de Melo, VA, Aragão, JA, de Oliveira, LAB. Ulcer due to chronic venous disease: a sociodemographic study in northeastern Brazil. Annals of vascular surgery. 2013; 27(5): 571-576. Haughey, L \& Barbul, A. Nutrition and Lower Extremity Ulcers: Causality and/or Treatment. The international journal of lower extremity wounds. 2017; 16(4): 238-243. Lal, BK. Venous ulcers of the lower extremity: definition, epidemiology, and economic and social burdens. In Seminars in vascular surgery. WB Saunders. 2015; 28(1): 3-5. McDaniel JC, Szalacha L, Sales M, Roy S, Chafee S, Parinandi, N. EPA+ DHA supplementation reduces PMN activation in microenvironment of chronic venous leg ulcers: A randomized, doubleblind, controlled study. Wound Repair and Regeneration. 2017; 25(4): 680-690. O'Donnell-Jr TF, Passman MA. Clinical practice guidelines of the Society for Vascular Surgery (SVS) and the American Venous. J Vasc Surg. 2014;60:1-2. Parker, CN, Finlayson, KJ, Shuter, P, Edwards, HE. Risk factors for delayed healing in venous leg ulcers: a review of the literature. International journal of clinical practice.2015; 69(9): 967-977. Pieper, B \& Templin, TN. Sleep Quality. Journal of Wound, Ostomy and Continence Nursing. 2016; 43(5): 471-476. Resende NM, Nascimento TC, Lopes FRF, Júnior AGP, Souza NM. Cuidado de pessoas com feridas crônicas na Atenção Primária à Saúde. JMPHC| Journal of Management \& Primary Health Care. 2017; 8(1): 99-108. Stolzenburg-Veeser L \& Golubnitschaja O. Mini-encyclopaedia of the wound healing-Opportunities for integrating multi-omic approaches into medical practice. Journal of proteomics. 2018; 188: 71-84. Wilkinson, EA. Oral zinc for arterial and venous leg ulcers. Cochrane database of systematic reviews. 2014; 9: 1-36. White-Chu, EF \& Conner-Kerr, TA. Overview of guidelines for the prevention and treatment of venous leg ulcers: a US perspective. Journal of multidisciplinary healthcare. 2014; 7: 111. 


\title{
Custo-Efetividade de Agentes Tópicos para Tratamento de Dermatite Associada à Incontinência: Revisão Rápida da Literatura
}

\author{
Author(s): $\quad$ Fernanda Silva dos Santos 1, Priscila Schmidt Lora 1, Sandra Maria Cezar Leal 1 \\ Institution(s) 1 UNISINOS - Universidade do Vale do Rio dos Sinos (Av Dr Nilo Peçanha, 1600; Bairro Boa \\ Vista, Porto Alegre-RS)
}

\begin{abstract}
Introdução: A Dermatite Associada à Incontinência (DAI) consiste em lesão causada pela exposição prolongada e repetida a urina e fezes, que além de causar dor e desconforto para o paciente, constitui fator de risco para infecções da pele e para lesões por pressão, aumenta o tempo de permanência hospitalar, custos do tratamento, carga de trabalho da enfermagem, afetando em torno de 10-33\% dos pacientes hospitalizados. Tradicionalmente, o tratamento se baseia no uso de pomada de óxido de zinco como uma barreira mecânica, com algumas limitações. O spray barreira constitui alternativa, este forma uma barreira semipermeável, de longa duração, protegendo a pele do contato com fluídos e contra os efeitos da fricção1. Uma parcela expressiva do custo de tratamento de DAI provém do tempo de trabalho nos cuidados, que aumenta com a ruptura da pele. Assim uso de produtos que simplifiquem o cuidado e reduzam o tempo despendido nestas atividades podem gerar economia aos serviços2.

Objetivo: Avaliar o custo-efetividade do uso de spray barreira em comparação ao óxido de zinco para tratamento de DAl em pacientes adultos hospitalizados.

Método: Revisão rápida de literatura, caracterizada pela hierarquização das evidências, menor tempo de realização sem perda da qualidade, constituindo resposta rápida para tomada de decisão3. A questão norteadora da revisão foi: em pacientes hospitalizados o custo-fetividade do spray de barreira é inferior ao do óxido de zinco para prevenção de DAI?. A busca foi realizada nas bases Medline, NICE, Trip e CINAHL, pelos mesh terms: "Dermatitis" AND "Urinary Incontinence" OR "Fecal Incontinence" AND "dermatologic agents". Os critérios de inclusão foram a disponibilidade na íntegra e tempo de publicação máximo de três anos3. A análise da qualidade metodológica foi realizada conforme critérios do Joanna Briggs Institute (JBI).

Resultados: Segundo escalonamento de busca e síntese de evidências foi incluído uma revisão sistemática, realizada pela Cochrane. Essa, avaliou treze estudos, dos quais dois comparam diretamente o óxido de zinco e o spray barreira4. O primeiro comparou os dois produtos quanto ao custo em diferentes intervalos de aplicação. Obteve custo maior para o tratamento com produto barreira não informando significância estatística. $O$ segundo, obteve menor custo de produto, materiais e tempo de trabalho de enfermagem relacionados para o spray barreira $e$ melhor resposta quanto à severidade das lesões $(p=0,04) 4$. Os estudos analisados, por limitações e diferenças metodológicas, não possibilitaram realização de metanálise, dessa forma, evidências quanto à custo efetividade não são conclusivas. Estes achados vão ao encontro de revisões prévias que identificaram evidências fracas para a recomendação de produtos para a tratamento de DAI devido a limitações metodológicas5.

Conclusões: As evidências apresentadas não são conclusivas quanto a custo-efetividade dos produtos para tratamento de DAl. Contudo, considerando-se que está estabelecido que os custos do tratamento aumentam com a severidade da lesão e que parte expressiva desses custos referem-se ao trabalho de enfermagem, pode-se inferir que intervenções que se mostrem eficazes no controle da severidade da DAl e que diminuam o tempo de trabalho de enfermagem tenham impacto positivo na redução dos custos.
\end{abstract}

Keywords: Dermatite Associada à Incontinência, Análise Custo-Benefício, Estomaterapia

\section{Referências Bibliográficas}

1 Micheli C, Palese A, Canzan F, Ambrosi E .No Sting Barrier Film to Protect Skin in Adult Patients: Findings From a Scoping Review With Implications for Evidence- Based Practice. Worldviews Evid Based Nurs. 2017 Out; 14(5):40311. 2 Avsar P, Karadag A. Efficacy and Cost-Effectiveness Analysis of Evidence-Based Nursing Interventions to Maintain Tissue Integrity to Prevent Pressure Ulcers and Incontinence-Associated Dermatitis. Worldviews EvidBased Nurs, 2018 Fev; 15(1):54-61. 3 Dobbins M. Manual de Revisão Rápida: passos para elaborar uma revisão rápida. [monografia na Internet]. São Leopoldo RS: Ed UNISINOS; 2019. Acesso em 20 jul 20019]. Disponível em: https://www.moodle.unisinos.br/pluginfile.php/1158573/

mod_resource/content/0/Manual_RevisaoRapida_McMaster.pdf 4 Beeckman D, Van Damme N, Schoonhoven L, Van Lancker A, Kottner J, Beele $\mathrm{H}$ et al. Interventions for preventing and treating incontinence-associated dermatitis in adults. Cochrane Database Syst Rev 2016 Nov; 11: CD011627. Disponível em: . Acesso em: Acesso em:10 fev. 2019. 5 Corcoran E, Woodward S. Incontinence-associated dermatitis in the elderly: treatment options. Br J Nurs Abr-Mai 2013;22(8):450-7. 


\section{REVISÃo DE UMA DIRETRIZ ASSISTENCIAL PARA REDUÇÃO DA PREVALÊNCIA DE DERMATITE ASSOCIADA À INCONTINÊNCIA}

Author(s): $\quad$ Priscila Gomes de carvalho Vasquez 2, Gabriela Nogueira dos Santos 1, Eliane Mazócoli 1, Aline De Oliveira Ramalho 1

Institution(s) 1 HSL - Hospital Sírio Libanês (Rua Dona Adma Jafet 115, Bela Vista, São Paulo), 2 BSL - Brail Sênior living (Rua Ibiapinópolis, 55 - Jardim Paulistano, São paulo)

\section{Abstract}

\section{INTRODUÇÃO}

Dermatite associada à incontinência (DAl) é uma manifestação clínica de lesões de pele associadas à umidade, comum em pacientes com incontinência fecal e/ou urinária. Trata-se de uma inflamação cutânea que ocorre em consequência do contato da pele perineal, perianal e áreas adjacentes com a urina e fezes. As lesões causadas pela DAI caracterizam-se por erosão da epiderme e aparência macerada da pele. (1)

A preocupação com a prevenção da DAI vem em concordância com as diretrizes do Ministério da Saúde que através do Programa Nacional de Segurança do Paciente e, a partir dele, a publicação do Protocolo de prevenção de úlceras por pressão, destacam a relevância da prevenção de eventos adversos ao paciente e objetivam a prevenção da ocorrência das lesões por pressão e de outras lesões de pele, onde se incluiriam as dermatites por umidade. (2)

Atualmente existe a recomendação da utilização de limpadores sem enxague, sendo que estes contemplam as três etapas de cuidado adequado da pele perineal (limpeza, umectação e proteção) em um único produto, sendo interessante para prevenção de DAl.(3)

\section{OBJETIVOS}

Descrever a revisão da diretriz institucional de prevenção de DAI, bem como as intervenções de melhoria realizadas para redução do indicador de prevalência.

\section{MÉTODO}

Trata-se de um projeto aplicativo interventivo com enfoque na redução dermatite associada à incontinência em pacientes críticos, visto que foi observado no indicador a prevalência de DAl em $60,5 \%$ durante o período de março a junho. Desta forma, foi realizado uma revisão da literatura, afim de fundamentar e padronizar as condutas baseadas em evidencias. No segundo momento, foi realizado a elaboração de um diagrama direcionador, contendo as principais oportunidades de melhoria, sendo estas implantadas durante os mês de setembro a dezembro.

\section{RESULTADOS}

Após revisão da literatura, foi realizado a revisão do documento institucional, estabelecendo novas práticas e/ou reforçando práticas já existentes. Visando aumentar a adesão a estas intervenções, também foram realizadas outras ações, com destaque para a alteração na dispensação dos produtos de higiene, de forma mais rápida e fácil, criação de um card com orientações a beira-leito e treinamentos/workshop com as equipes envolvidas no cuidado. Após estas intervenções, notou-se queda substancial no indicador de DAI, de 60\% para 16.7\%

\section{CONCLUSÃO}

A DAl é problema que requer monitorização constante e a revisão de protocolos assistenciais torna-se fundamental para garantia dos processos neles estabelecidos. Desta forma, julga-se necessário o planejamento de ações constantes, para que os resultados obtidos sejam mantidos e melhorados. Espera-se que a partir da explanação do problema, esta análise operacional possa contribuir para a sistematização das práticas clínicas, adesão e revisão de protocolos assistenciais, visando a qualidade do cuidado e a segurança do paciente.

\section{Keywords: dermatite , incontinência urinária, incontinência fecal, enfermagem, estomaterapia}

\section{Referências Bibliográficas}

Gray M et al. Moisture-associated skin damage: overview and pathology. J Wound Ostomy Continence Nurs. 2011; 38(3):233-41 2) Ministério da Saúde. Protocolo para Prevenção de Úlcera por Pressão. Brasília, DF: Ministério da Saúde, Anvisa, Fiocruz, 2013 3) Domansky RC, Borges EL. Manual de prevenção de lesões de pele: recomendações baseadas em evidências. Editora Rubio. 2 ed. Rio de Janeiro, 2014. 


\title{
FOTOGRAFIA CLÍNICA APLICADA À AVALIAÇÃO SEMIOLÓGICA DE ENFERMAGEM
}

Author(s): $\quad$ Gustavo Lopes Soares 1, Maria Elena Echevarria Guanilo 2, Natalia Gonçalves 2, Sayonara de Fátima Faria Barbosa 2, Pattrícia da Rosa Damiani 2, Fernanda Sant'Ana Tristão 3, Raphaella da Silva Fernandes 1, Milena Amorim Zuchetto 1, Luciane Buchner 1

Institution(s) 1 HOSPITAL BAÍA SUL - HOSPITAL BAÍA SUL (R. Menino Deus, 63 - Centro, Florianópolis - SC), 2 UFSC - UNIVERSIDADE FEDERAL DE SANTA CATARINA (FLORIANÓPOLIS), 3 UFPel - UNIVERSIDADE FEDERAL DE PELOTAS (PELOTAS)

\begin{abstract}
Introdução: A gestão de feridas e outras lesões teciduais, objetiva resultados significativos para indivíduos com agravos dermatológicos ou que apresentem riscos para integridade da pele ${ }^{1}$. Necessita de uma abordagem avaliativa que considere também recursos tecnológicos para a tomada de decisão clínica adequada e o planejamento efetivo de cuidados. ${ }^{2} \mathrm{~A}$ fotografia aplicada na prática clínica como instrumento de análise de lesões cutâneas, pode ser utilizada em conjunto com as demais práticas avaliativas de enfermagem fundamentada nas ciências biológicas. ${ }^{3}$ Objetivo: Compreender como enfermeiros especialistas na saúde da pele utilizam a fotografia clínica para a avaliação semiológica em feridas. Metodologia: Trata-se de um estudo de abordagem quantitativa, do tipo exploratório descritivo, utilizando-se a técnica Delphi. A coleta dos dados foi realizada a partir de um instrumento de pesquisa com perguntas semi-estruturadas, construído pelos autores através da ferramenta Google Forms ${ }^{\circledR}$. Realizou-se a tabulação dos dados por meio de planilhamento para, sequencialmente, formular análise através de estatística descritiva onde foram realizadas análises de frequência absoluta e relativa. $O$ estudo recebeu aprovação de comitê de ética da Universidade Federal de Santa Catarina sob o CAAE 80349817200000121. Resultados: Participaram da pesquisa 110 especialistas, entre as ciências de enfermagem dermatológica, estomaterapia, enfermagem forense, feridas e enfermagem estética. Em relação ao uso da fotografia clínica, 86,4\% (95 participantes) apontaram adotar a tecnologia em sua prática clínica, sendo que $75,8 \%$ a utilizava para fotodocumentação de lesões, formando parte do histórico clínico do paciente; 74,7\% para avaliar a evolução do processo cicatricial de lesões, alteração de perímetro lesional, aspecto geral, tecidos presentes, coloração e demais características semiológicas verificáveis na planimetria fotográfica; $55,8 \%$ para o desenvolvimento de pesquisas, apresentando o acompanhamento das lesões de forma padronizada, com fundo de mesma cor, data do registro e angulação/posição/distanciamento uniforme da câmera para a lesão em todas as fotos. Ainda, $60 \%$ para discutir casos clínicos com outros profissionais enfermeiros e/ou recorrer a programas de teleassistência quando necessário; $63,2 \%$ para se ter um acervo fotográfico do seu trabalho e 7,4\% em casos de lesões que se apresentem como evidências criminais, exigindo registro comprovatório. Nas respostas relacionadas ao não uso, destacou-se por $69,2 \%$ o custo elevado do equipamento. Destes profissionais ainda surgiu respostas referente ao tipo de equipamento, onde $61,1 \%$ faz uso da fotografia clínica em câmera e lentes não desenvolvidas necessariamente para registro dermatológico, e 16,8\% tem preferência por fotografia clínica em câmera e lentes especialmente desenvolvidas para esta finalidade. Conclusão: Como tecnologia de captação de imagem, a fotografia clínica foi apontada como um veículo importante para a análise e interpretação de lesões de pele, pois fornece informações semiológicas mais precisas sobre seu estadiamento, coloração e comprometimento tecidual, aspecto perilesional, além de contribuir para a avaliação de resposta terapêutica e desta forma, ser uma evidente ferramenta da gestão do processo de tratamento de lesões cutâneas e de discussão de casos clínicos entre enfermeiros, com outros membros da equipe multidisciplinar ou para recorrer a programas específicos de teleassistência.
\end{abstract}

Keywords: Fotografia, Feridas, Estomaterapia, Tecnologias Biomédicas, Pesquisa em Enfermagem Clínica

\section{Referências Bibliográficas}

1 JONES RE, FOSTER DS, LONGAKER MT. Management of chronic wounds. American Medical Association (AMA), 2018; 14(320). Disponível em: http://dx.doi.org/10.1001/jama.2018.12426 2 THIOLLENT, M. Metodologia da pesquisa-ação. 4. ed. São Paulo: Brasiliense; 1998. CARVILLE K, SCOTT J, HAESLER E. Standard for wound prevention and management. Australian Nursing and Midwifery, 2017; 24(8). Disponível em: http://search.proquest.com/openview/.d8b11a569c2fc05a7f3acd0e7e07df44/1?pq-origsite 3 SANTO, P. R. Q. E. et al. Getting to know the types of JPEG and RAW photo files used in research. Revista Brasileira de Cirurgia Plástica (rbcp) - Brazilian Journal Of Plastic Sugery, [s.l.], v. 33, n. 1, p.89-95, jan. 2018. Disponível em: Doi: http://dx.doi.org/10.5935/2177-1235.2018rbcp0013. 


\title{
COBERTURAS PRIMÁRIAS EM PESSOAS COM LESÕES POR PÊNFIGO VULGAR: REVISÃO INTEGRATIVA DE LITERATURA
}

\author{
Author(s): $\quad$ Hayana Pereira Leal Soares 1, Euzeli da Silva Brandão 2, Renato Tonole 3
}

Institution(s) 1 HUAP/UFF - Hospital Universitario Antonio Pedro (Av. Marques do Parana, 303- Centro, NiteroiRJ, 24033900), 2 EEAAC/UFF - Escola de Enfermagem Aurora de Afonso Costa (R.Dr. Celestino, 74-Centro, Niteroi-RJ, 24020091), 3 INCA - Instituto Nacional do Câncer (Praça da Cruz, 23-Centro, Rio de Janeiro-RJ, 20230130)

\section{Abstract}

Introdução: O pênfigo é uma dermatose bolhosa induzida por autoimunidade, de evolução crônica e ilimitada. A pele da pessoa diagnosticada com pênfigo vulgar sofre uma degeneração intraepidérmica que dá origem a bolhas que ao se romperem revelam áreas erosivas exsudativas que podem ocasionar prurido, "queimação", dor e odor fétido semelhante ao "ninho de rato". Outra característica importante é o sinal de Nikolsky que é marcado por friç̧ão ou pressão na pele aparentemente normal próximo à lesão, resultando em deslocamento epidérmico. Considerando a especificidade e a complexidade dessas lesões, a escolha de uma cobertura para o curativo das mesmas deve ser bem criteriosa.

Método: Revisão integrativa de literatura, utilizando os descritores "bandages", "nursing care", "nursing", "skin diseases/vesiculobollous" e "pemphigus"; critérios de inclusão: abordar a cobertura primária para o curativo de pessoas com lesões cutâneas por pênfigo vulgar; publicados entre 2010 e 2017; em português, inglês ou espanhol; indexados na BDENF, LILACS, PubMed e Scopus.

Resultados: Constatou-se um número considerável de indicações de medicamentos como cobertura primária nos curativos. Em contrapartida, alguns artigos abordaram o uso de tecnologias que podem ser prescritas por enfermeiros.

Dois estudos de caso indicaram coberturas com prata para a prevenção e/ou o tratamento da infecção relacionada ao comprometimento da integridade da pele. Nesse contexto, em relação ao uso de antibiótico tópico, citado em outros dois artigos, ressalta-se que esse produto não tem eficácia comprovada cientificamente no tratamento de lesões. Contudo, em caso de infecção, a antibioticoterapia sistêmica é indispensável.

Sabendo-se da contraindicação do uso de coberturas adesivas em lesões por pênfigo, devido ao risco de descolamento da pele durante a retirada do curativo, pode-se inferir que o hidrocolóide autoadesivo é uma indicação inadequada, porém dois artigos indicaram o hidrocolóide como cobertura primária.

Considerando a natureza exsudativa das lesões por pênfigo é possível questionar a indicação do hidrogel e do hidrocolóide como coberturas primárias, visto que, esses produtos não promovem a absorção do alto volume de exsudato drenado. Em contrapartida, dois dos artigos destacaram o controle dessa drenagem a partir do uso de uma cobertura composta por hidrofibra.

Dois estudos de caso concordaram que o curativo com hidrofibra aumenta o bem-estar/conforto da pessoa acometida pelo pênfigo. Um desses artigos elegeu o aumento do intervalo entre as trocas como o responsável pela redução do referido desconforto. O outro estudo atribuiu esse benefício à capacidade de gelificação dessa cobertura. Um artigo com nível de evidência 3 justificou o conforto da pessoa com pênfigo pela redução do odor e da dor proporcionada pelo curativo oclusivo com gaze vaselinada. Segundo as autoras do artigo, tal cobertura mantém a umidade no leito das lesões não aderindo às mesmas. Além disso, a retirada diária do exsudato através da higienização do paciente reduz o odor fétido exalado.

Em relação aos ácidos graxos insaturado, citados em um único artigo, cabe ressaltar que não há comprovação científica sobre os benefícios desse material no tratamento de lesões.

Conclusão: A gaze vaselinada estéril, preparada conforme protocolo, foi a cobertura apresentada em estudo com nível de evidência mais significativo.

Keywords: Curativos, Cuidados de enfermagem, Dermatopatias vesiculobolhosas, Estomaterapia, Pênfigo

\section{Referências Bibliográficas}

Hanauer L, Abulafia LA, Azulay DR, Azulay RD. Buloses. Azulay - Dermatologia. 7ed. Rio de Janeiro: Guanabara Koogan, 2017.p.267-82. 2. Brandão ES, Santos I dos, Costa MTF, Jesus PBR. Pênfigos. In: Gamba MA, Petri V, Costa MTF. Feridas - prevenção, causas e tratamento. Rio de Janeiro: Santos Ed; 2016.. p. 223-27. 3. Aron S, Bergo AMA, Marcondes MGSG. Curativos e coberturas. In: Gamba MA, Petri V, Costa MTF. Feridas - prevenção, causas e tratamento. Rio de Janeiro: Santos Ed; 2016. p. 283-6. 4. Grupo Anima Educação. Manual Revisão Bibliográfica Sistemática Integrativa: a pesquisa baseada em evidências. Belo Horizonte: Grupo Anima Educação; 2014. 5. Brandão ES, Santos I. Evidências do cuidar de pessoas com pênfigo vulgar: desafio à enfermagem. Online Braz J Nurs [on line] 2013 [citado 2018 mar 15]; 12(1):162-77. Disponível em: http://www.objnursing.uff.br/index.php/nursing/article/view/3674. 


\title{
CARTILHA EDUCATIVA PARA UTILIZAÇÃO DO OCLUSOR DA COLOSTOMIA
}

Author(s): $\quad$ IRAKTANIA VITORINO DINIZ 1, ANA ELZA OLIVEIRA DE MENDONÇA 2, Isabelle Katherinne Fernandes da Costa 2, Arthur Vitorino Di Pace 4, Celio Maroja Di Pace Neto 4, Lais Rodrigues Pinto 3, Maria Julia Guimarães Oliveira Soares 1

Institution(s) 1 UFPB - UNIVERSIDADE FEDERAL DA PARAIBA (Campus I - Lot. Cidade Universitaria, PB, 58051-900), 2 ufrn - universidade federal do rio Grande do norte (Av. Sen. Salgado Filho, 3000 - Lagoa Nova, Natal - RN, 59078-900), 3 FCM - Faculdade de Ciências Médicas da Paraiba (BR-230 Km 9 - Amazonia Park, Cabedelo PB, 58106-402), 4 UNIPE - CENTRO UNIVERSITÁRIO DE JOÃO PESSOA (Rodovia BR-230,km 22, s/n - Água Fria, João Pessoa - PB, 58053-000)

\begin{abstract}
RESUMO: A confecção da estomia se traduz em muitas mudanças relacionadas a nova condição de eliminação de excretas, as quais culminarão na necessidade de adaptar-se à essa situação1. Lidando com a realidade do indivíduo com estomia, constata-se numerosas dificuldades relacionadas à hábitos alimentares, vestuário, realização de atividades física e de lazer, além do retorno das atividades laborais e da atividade sexual2.Diante das repercussões provocadas pela confecção dos estomas e frente as necessidades de educar e orientar as pessoas estomizadas, a produção de impressos, como a cartilha, são importantes para ajudar neste processo, propicia novos horizontes na promoção da saúde por ser um método palpável em que as informações são visualizadas facilmente, com acesso direto, prático de modo a melhorar a captação do conteúdo se comparadas às instruções verbais isoladas 3 OBJETIVO: construir uma cartilha educativa com anotações diárias e treinamento para utilização do uso do oclusor em pessoas colostomizadas. MÉTODO: trata-se de estudo do tipo metodológico com abordagem qualitativa, consiste na elaboração de uma cartilha que é uma tecnologia leve e dura, para a promoção da saúde, que se conduziu por fases: iniciou-se com uma revisão integrativa acerca das definições, indicações, seguidos pelas etapas de treinamento, orientações sobre o uso do oclusor, posteriormente confecção do texto, layout e imagens do conteúdo proposto. A cartilha passou por avaliação de cinco especialistas da área e por cinco pessoas colostomizadas, para averiguação do conteúdo proposto.Esta cartilha foi desenvolvida como parte integrante da Tese de Doutorado intitulada: adaptação e qualidade de vida de pessoas estomizadas, aprovada sob parecer 2.562.857. Ressalta-se que, respeitaram-se os critérios éticos e jurídicos que regulamentam a utilização de textos e imagens. RESULTADOS: para facilitar a compreensão a cartilha ilustrada se iniciou com uma breve apresentação das definições de estomas intestinais e complicações mais frequentes, apresentação de matérias, sistemas de continências com foco na utilização do oclusor, suas indicações e manuseio. Na cartilha foi idealizado também, o diário de anotações para acompanhamento do treinamento da utilização do oclusor, composto por quatro etapa, dicas de motivação e perguntas mais frequentes. CONCLUSÃO: a cartilha se apresenta como uma tecnologia educacional com foco na utilização do oclusor da colostomia, que poderá ser um importante material adicional no processo de cuidar continuado as pessoas colostomizadas. Como etapa subsequente da produção desta cartilha será realizada a validação de conteúdo e aparência.
\end{abstract}

Descritores: Educação em Saúde; Colostomia; Reabilitação; Promoção de Saúde; Enfermagem; Estomaterapia.

Keywords: COLOSTOMIA, EDUCAÇÃO EM SAÚDE, ENFERMAGEM, ESTOMATERAPIA, REABILITAÇÃO Referências Bibliográficas

REFERÊNCIAS: 1. Mota MS, Gomes GS, Petuco, VM. Repercussions in the living process of people with stomas. Texto Contexto - Enferm, v. 25, n. 1, p.1-8, abr. 2016. DOI: http://www.dx.doi.org/10.1590/0104070720160001260014 2. Coelho AR, Santos FS, Poggeto MTD. A estomia mudando a vida: enfrentar para viver. Reme Rev Min Enferm. 2013; 17(2):258-67 DOI: http://www.dx.doi.org/10.5935/1415-2762.20130021 3.Benevides JL, Coutinho JFV, Pascoal LC, Joventino ES, Martins MC, Gubert FA, et al. Construção e validação de tecnologia educativa sobre cuidados com úlcera venosa. Rev Esc Enferm USP [Internet]. 2016 [cited 2018 Feb 21];50(2):30612. DOI: http://dx.doi.org/10.1590/S0080-623420160000200018 


\section{IRRIGAÇÃO INTESTINAL: AS EVIDÊNCIAS CIENTÍFICAS}

Author(s): Janderson Cleiton Aguiar 1, Karen Martins 1, André Aparecido da Silva Teles 1, Júlia Casemiro Barioni 2, Tatiana Mara da Silva Russo 1, Lorena Alves Pantoni 1, Camila Maria Silva Paraizo Horvath 1, Helena Megumi Sonobe 1

Institution(s) 1 EERP - USP - Escola de Enfermagem de Ribeirão Preto - USP (Avenida dos Bandeirantes 3900), 2 HCFMRP - USP - Hospital das Clínicas de Ribeirão Preto - USP (Avenida dos Bandeirantes 3900)

\section{Abstract}

Introdução: Um dos aspectos da reabilitação de pacientes com colostomia está vinculado à possibilidade do alcance da continência, por meio da irrigação intestinal. Ainda não existe consenso sobre aspectos como o momento de início do ensino no pós-operatório, volume de infusão de água, frequência, horário e tempo utilizado para sua realização. Objetivo: analisar as evidências científicas sobre a irrigação intestinal para pacientes com colostomia. Material e método: Trata-se de Revisão Integrativa (RI), fundamentada na Prática Baseada em Evidências, cujo desenvolvimento contemplou seis etapas: identificação do problema com definição da questão de pesquisa; estabelecimento de critérios para inclusão e/ou exclusão de estudos; definição das informações a serem extraídas e categorização dos estudos selecionados; avaliação dos estudos; interpretação dos resultados; e a apresentação da revisão/síntese do conhecimento produzido. A questão de pesquisa formulada foi "Quais as evidências científicas sobre a irrigação intestinal para pessoas com colostomia?", elaborada mediante a estratégia PICO, para a busca de estudos primários nas bases de dados: Literatura Latino-Americana e do Caribe em Ciências da Saúde (LILACS), National Library of Medicine National Institutes of Health (PubMed), Cumulative Index to Nursing and Allied Health Literature (CINAHL) e Scopus, com os descritores irrigação e colostomia, com total inicial de 417 artigos científicos, que foram selecionados mediante critérios de inclusão e de exclusão. Realizou-se a seleção com verificação de itens essenciais de RI segundo Preferred Reporting Items for Systematic reviews and Meta-Analyses (PRISMA), associada à ferramenta de filtragem Rayyan, por dois revisores independentes, e a amostra final foi constituída por 12 artigos científicos. Resultados: Os 12 artigos da amostra apresentaram nível de evidência VI, sendo que sete artigos foram categorizados em "Indicações da irrigação intestinal", que indicou o início deste método, entre o terceiro dia de pós-operatório com $500 \mathrm{ml}$, evoluindo até sétimo dia com $1000 \mathrm{ml}$ ou até mesmo após três e seis meses de pós-operatório; tempo de infusão entre cinco a 10 minutos; frequência entre 48 e 72 horas; duração do procedimento entre 35 minutos e uma hora, bem como a melhora da qualidade de vida. Cinco artigos foram categorizados em "Capacitação profissional para o ensino da irrigação", evidenciando-se a falta de conhecimento e de experiência clínica do enfermeiro para aquisição de segurança para realizar o ensino aos pacientes, além de dificuldades vinculadas ao paciente como a condição clínica, comodidade, medo e insegurança; e para o abandono da técnica identificou-se o tempo necessário para a sua realização, dificuldade para infusão da água, perda de fezes nos intervalos e dificuldade para a saída de água. Há escassez de produção científica sobre este tema e o seu protocolo clínico deverá considerar aspectos técnicos, as características individuais dos pacientes, além da infraestrutura da instituição para a sua implementação, bem como a capacitação do estomaterapeuta e do enfermeiro. Conclusão: há necessidade de estudos com delineamento consistente para obtenção de evidências mais fortes para a definição do início do ensino, volume e tempo de infusão, tempo e frequência de sua realização e avaliação clínica do candidato para estabelecer o protocolo.

Keywords: Irrigação terapêutica, Colostomia, Revisão de Literatura como Assunto, Estomaterapia.

\section{Referências Bibliográficas}

Stillwell SB, Fineout-Overholt E, Melnyk BM, Williamson KM. Searching for the evidence: strategies to help you conduct a successful search. Am J Nurs. 2010; 110(5):41-7. Liberati A, Altman DG, Tetzlaff J, Mulrow C, Gotzche PC, loannidis JPA, et al. The PRISMA statement for reporting systematic reviews and meta-analyses of studies that evaluate health care interventions: explanation and elaboration. BMJ. 2009; 339:2700. Cobb MD, Grant M, Tallman NJ, Wendel CS, Colwell J, McCorkle R, et al. Colostomy irrigation: Current knowledge and practice of WOC nurses. J Wound, Ostomy Cont Nurs. 2015;42(1):65-70. Pace S, Manuini F, Maculotti D. Innovate technology for colostomy irrigation: assessing the impact on patients. Minerva Chir. 2015 Jan 01;(70)311-8 Carlsson E, Gylin M, Nilsson L, Svensson K, Alverslid I, Persson E. Positive and negative aspects of colostomy irrigation: A patient and WOC nurse perspective. J Wound, Ostomy Cont Nurs. 2010;37(5):511-6. 


\section{A IMPORTÂNCIA DA SISTEMATIZAÇÃO DA ASSISTÊNCIA DE ENFERMAGEM FRENTE AO CUIDADO EXERCIDO PELA ESTOMATERAPIA ÀS PESSOAS COM ÚLCERA VENOSAS}

Author(s): $\quad$ jennifer ferreira figueiredo cabral 1, Luis Rafael Leite Sampaio 2, Saionara Leal Ferreira 1, Islene Victor Barbosa 1, Fernanda Jorge Magalhães 3, Francisco Antonio da Cruz Mendonça 4, Fernanda Maria Silva 2, Yterfânia Soares Feitosa 1

Institution(s) 1 UNIFOR - Universidade de Fortaleza (Av. Washigton Soares), 2 URCA - UNIVERSIDADE REGIONAL DO CARIRI (CAMPUS PIMENTA), 3 FAMETRO - FACULDADE METROPOLITANA DE FORTALEZA (Fortaleza/CE), 4 FIC - CENTRO UNIVERSITÁRIO ESTÁCIO DO CEARÁ (Fortaleza/CE)

\section{Abstract}

INTRODUÇÃO: As úlceras venosas (UV) são lesões decorrentes da hipertensão venosa e acometem os membros inferiores, geralmente no terço inferior da perna. Devido seu caráter recidivante e lenta cicatrização são consideradas feridas crônicas e compreendidas como agravo de saúde pública pela alta incidência e prevalência, cronicidade, impacto socioeconômico e custo elevado de tratamento. Estas condições além de afetar de forma negativa a qualidade de vida, levam a dependência de visitas regulares ao serviço especializado de saúde, tornando-se relevante neste contexto, a utilização da Sistematização da Assistência de Enfermagem (SAE) pela estomaterapia. OBJETIVO: Descrever a importância da SAE frente ao cuidado exercido pela estomaterapia às pessoas com UV. MATERIAL E MÉTODO: Trata-se de uma pesquisa não sistemática, narrativa, de abordagem qualitativa exploratória realizada no serviço de busca Google Acadêmico, na base de dados LILACS e em uma revista específica da área de estomaterapia, versão online. Foi utilizada como estratégia de busca, o cruzamento dos descritores: processo de enfermagem e úlcera venosa combinados com o boleano AND. RESULTADOS: No cuidado às pessoas com UV, o estomaterapeuta busca utilizar a SAE de forma efetiva ao perfazer todas as etapas do processo de enfermagem, sistematizando o cuidado implementado durante a consulta de enfermagem especializada, utilizando-se das habilidades técnicas e teóricas para identificar os problemas, determinar metas, planejar, escolher o curativo adequado, efetivar os registros de enfermagem e avaliar o cuidado com foco na avaliação contínua e holística, objetivando a adequação de uma terapêutica eficiente para a sua progressão. Tais ações elevam a qualidade da assistência e identificam com precisão as necessidades do paciente. Existe uma enorme variedade de curativos e técnicas utilizados para o tratamento local da úlcera venosa, sendo que estudos de melhor qualidade e em grandes populações demonstram que a sistematização e avaliação constante do paciente e da UV por profissional qualificado são melhores que curativos aleatórios e não supervisionados. CONCLUSÃO: A utilização da SAE pela estomaterapia frente ao cuidado às pessoas com UV contribui para uma assistência de qualidade, com o manejo adequado pertinente à fase de cicatrização que a úlcera se encontra, realizando a escolha da cobertura apropriada, bem como terá subsídio para orientações de educação em saúde, possibilitando a otimização dos recursos finitos em saúde mantendo a qualidade e segurança no cuidado, uma vez que a SAE quando realizada de forma efetiva, busca ver o paciente como um todo, com o intento de atender às reais necessidades. Desta forma, ela fornece subsídios que possibilitam ao enfermeiro estomaterapeuta planejar e implementar ações de estímulo à participação ativa do paciente no seu tratamento, cooperando com a manutenção do tratamento no domicílio.

Keywords: Estomaterapia, Processo de Enfermagem, Úlcera Venosa

\section{Referências Bibliográficas}

Harding K, Dowsett C, Fias L, Jelnes R, Mosti, G, Oien R, Partsch H et al. Simplifying venous leg ulcer management. Consensus recommendations. Wounds International. 2015. 28p. Reis Diego Borges do; Peres Graziella Araujo; Zuffi Fernanda Bonato; Ferreira Lúcia Aparecida; Poggetto Márcia Tasso Dal. Cuidados às pessoas com úlcera venosa: percepção dos enfermeiros da estratégia de saúde da família. Rev Min Enferm. 2013 jan/mar; 17(1): 101-106. Disponível em: http://www.reme.org.br/artigo/detalhes/582. Acesso em 20 de jun 2018. Diretrizes sobre Diagnóstico, Prevenção e Tratamento da Sociedade Brasileira de Angiologia e Cirurgia Vascular (SBACV). Disponível em: https://www.sbacv.org.br/lib/media/pdf/diretrizes/insuficiencia-venosa-cronica.pdf. Acesso em 20 de jun de 2018. Borges Eline Lima. Modelo ABC para o manejo da úlcera venosa de perna. Rev. Estima. 2015. vol 15,n.3. Disponível em: https://www.revistaestima.com.br/index.php/estima/article/view/350. Acesso em 10 de jun de 2018. 


\title{
Análise dos desfechos de eficácia/efetividade das intervenções terapêuticas dos ensaios clínicos randomizados de lesões por pressão em adultos: pesquisa sistemática.
}

\author{
Author(s): $\quad$ JESSICA STEFFANY MIRANDA 1
}

Institution(s) 1 FMB - Unesp - Faculdade de Medicina de Botucatu - Unesp (Av. Prof. Mário Rubens Guimarães Montenegro, s/n - UNESP - Campus de Botucatu - ), 2 ConvaTec - ConvaTec (Rua Alexandre Dumas, 2100 - 15은 Andar - Chácara Santo Antônio São Paulo - SP - B)

\begin{abstract}
Introdução: as úlceras por pressão ou lesões por pressão (LPs) têm alta incidência, principalmente nas unidades hospitalares. Ensaios clínicos randomizados (ECRs) de intervenções terapêuticas para LP devem incluir uma descrição clara dos desfechos e resultados para aumentar a transparência, replicabilidade e melhorar a construção da evidência científica. Objetivos: avaliar a completude das descrições dos desfechos de intervenções terapêuticas em ECRs de pacientes adultos com LP, descrevendo a frequência de ECRs com desfechos primários relatados, métodos de medição ou ferramentas usadas para avaliar os desfechos e os resultados dos desfechos relatados. Métodos: foi realizada pesquisa sistemática dos ECRs publicados no período de janeiro de 2006 a abril de 2018 nas bases de dados: PubMed, Cochrane, Cinahl, Embase, Lilacs, Scopus e Web of Science. O processo de seleção dos estudos foi realizado em duas etapas de triagem: título e resumo, e revisão do texto completo, sempre por dois pesquisadores de forma independente. A completude do desfecho foi avaliada de acordo com cinco critérios: domínio, medida específica, métrica específica ou formato dos dados de resultado que foram usados para análise, método de agregação e tempo que foi utilizado para análise. A qualidade dos resultados do desfecho foi classificada como completa, incompleta ou não reportada. Conduzimos uma análise descritiva do número, tipo e graus de especificação dos desfechos nos ECRs incluídos. A frequência das categorias em cada domínio dos desfechos também foi relatada. Resultados: sessenta estudos foram incluídos para análise. Foram relatados 242 desfechos e 40 ECRs $(66,7 \%)$ apresentaram 65 desfechos primários, os quais eram, principalmente, do tipo intermediário/substituto (81,5\%). O principal desfecho avaliado nos ECRs foi a redução da área da úlcera (38\%) e apenas $21,1 \%$ dos resultados dos desfechos foram relatados de forma completa. Verificou-se que mais da metade dos desfechos $(61,6 \%)$ tiveram pontuação máxima de 5 na avaliação da completude do desfecho. $O$ elemento menos descrito é o método de agregação dos dados (71,9\%). Apenas $48,3 \%$ dos desfechos com técnica especificada tinham referência ou validação da mesma. Os desfechos relatados de forma mais incompleta foram associados a estudos com ano de publicação mais antigo, menor tamanho amostral, revistas com fatores de impactos menores e patrocinados pela indústria. Conclusões: houve uma heterogeneidade de desfechos nos ECR em LP, a maioria deles foram substitutos ou intermediários e quase $40 \%$ dos estudos descreveram os desfechos de forma incompleta. Os resultados relatados também estavam, em sua grande maioria, incompletos, dificultando a análise do efeito da intervenção nos desfechos propostos. Estes resultados caracterizam que a descrição dos desfechos e de seus resultados nos ECRs de LPs precisam ser melhor relatados para aumentar a clareza dos estudos e das evidências científicas.
\end{abstract}

Keywords: lesão por pressão, ensaio clínico randomizado, desfecho de tratamento, revisão

\section{Referências Bibliográficas}

1 European Pressure Ulcer Advisory Panel and National Pressure Ulcer Advisory Panel PPPIA. Prevention and Treatment of Pressure Ulcers : Quick Reference Guide. Clin Pract Guidel 2014; : 1-75. 2 Costa MP, Sturtz G, Costa FPP Da, Ferreira MC, Barros Filho TEP. Epidemiologia e tratamento das úlceras de pressão: experiência de 77 casos. Acta Ortopédica Bras 2005; 13: 124-33. 3 Lima ACB, Guerra DM. Avaliação do custo do tratamento de úlceras por pressão em pacientes hospitalizados usando curativos industrializados. Cien Saude Colet 2011; 16: 267-77. 4 Sinha IA, Altman DG, Beresford MW, et al. Standard 5: Selection, Measurement, and Reporting of Outcomes in Clinical Trials in Children. Pediatrics 2012; 129: S146--52. 5 Williamson P, Altman D, Blazeby J, Clarke $\mathrm{M}$, Gargon E. Driving up the quality and relevance of research through the use of agreed core outcomes. $J$ Health Serv Res Policy 2012; 17: 1-2. 


\title{
O USO DE POLIHEXANIDA MAIS ASSOCIAÇÕES PARA O MANEJO DO PÉ DIABÉTICO
}

Author(s): Kátia Cristina tosta de Siqueira noventa 1, YALES ROMENNA FERREIRA COSTA E SILVA 3, KALYANY KEYLY E ALMEIDA RAULINO 3, VERA LUCIA MIRANDA DA SILVA 2

Institution(s) 1 CLÍNICA VIMAGEM - CLÍNICA VIMAGEM (AV. JOÃO PESCARINI 480 JARDIM FLORA VINHEDO SP), 2 HOSPITAL UNIVERSITÁR - HOSPITAL UNIVERSITÁRIO DE LONDRINA-HU-UEL (RUA ROBERT KOCH, 60 JARDIM OPERÁRIA, LONDRINA PR), 3 LIGA DO NORTE RIOGRA - LIGA DO NORTE RIOGRANDENSE CONTRA O CÂNCER (Av. Miguel Castro, 1355 - Dix-Sept Rosado, Natal - RN)

\begin{abstract}
Introdução - As Doenças Crônicas Não Transmissíveis são atualmente a principal causa de mortalidade no mundo. Destacando o Diabetes Mellitus, o qual pode ter como complicação o pé diabético, ferida que exige da enfermagem uma assistência sistematizada a fim de favorecer a reabilitação da pele, sucesso do tratamento com melhor qualidade de vida e prevenção de amputações(1-3). Neste contexto, o cuidado à esses pacientes é assumido, em parte, por familiares e cuidadores informais, tornando-se mais comum o manejo domiciliar das lesões crônicas sendo uma área que a enfermagem pode adentrar (4). Pesquisas vem se desenvolvendo com eficácia antisséptica local, como a adição de polietileno glicol, uma polihexanida biguanida capaz de desinfectar e ter efeito antibactericida com eficiência. Estudos com desinfecção de feridas, uma avaliação com mais de 10.000 casos e 20 anos de tratamento confirma o auto nível de eficácia e os mínimos efeitos colaterais da polihexanide (5).. Objetivo relatar um caso clínico no tratamento de uma lesão de pé diabético no qual foi testado os efeitos desbridantes e cicatrizantes do agente Polihexanida biguanida. Metodologia - Relato de caso clínico com acompanhamento de um paciente por alunas de enfermagem do Programa de Pós-graduação na área de Estomatoterapia do Hospital Israelita Albert Einstein. Ocorreu no domicílio do paciente no período de 16 de julho 2018 á janeiro 2019. As visitas aconteceram a cada dois dias e foram sendo espaçadas de acordo com a evolução da lesão. Houve a avaliação da ferida e seu acompanhando durante todas as visitas, sendo utilizado o tratamento com os produtos: Aquasept Gel, Aquasept Plus Spray e creme barreira Dermaid Bio. Carta patente No PI 0305735-6. Sem conflito de interesses pela utilização dos produtos. Pesquisa autorizada pelo comitê de ética da Liga Norte Riograndense Contra o Câncer, parecer no 3.489.881. Resultados - Paciente, sexo masculino, 75 anos, hipertenso, diabético, residente na cidade de Vinhedo, São Paulo - SP, apresenta ferida em Membro Inferior Direito que iniciou-se com uma lesão conhecida popularmente por frieira entre os dedos o que o levou à amputação do 30 pododáctilo, o mesmo teve contato com água contaminada durante uma enchente em sua residência o que fez com que uma infecção se instale-se significamente uma lesão no MID. Neste trabalho, foi possível também ver a importância da enfermagem bem como o tratamento no domicilio com diculdades encontradas e vivenciadas. A assistência de enfermagem visou um tratamento que reduz risco de amputação do membro acometido e garantisse qualidade de vida ao paciente. Para isso, foi associado o uso da Polihexanida biguanida (PHMB) junto ao creme barreira, sendo vista a melhora na evolução da lesão. Conclusão - Logo, o enfermeiro tem papel fundamental no planejamento do cuidado da lesão do pé diabético implicando em uma interação entre o cuidador-família-paciente para a troca de conhecimentos, proporcionando resultado positivo através da assistência adequada. Observou-se resultados satisfatórios com PHMB como agente terapêutico na cicatrização da ferida e o tratamento domiciliar trouxe qualidade de vida para 0 paciente e familiares, minimizando custos e tempo no tratamento realizado.
\end{abstract}

\section{Keywords: PÉ DIABÉTICO, ESTOMATERAPIA, VISITA DOMICILIAR, PHMB}

\section{Referências Bibliográficas}

1 - Manton KG. The global impact of noncomunicable diseases: estimates and projections. World Health Statistus Q. 1998; 41(3):255-266. 2 - Guyton AC. Tratado de fisiologia médica. 10. ed. Rio de Janeiro: Guanabara Koogan. 2002. p.827-840. 3 - Levin ME. Diabetic foot lesions: pathogenesis and management. In: Kerstein MD, White JV, editors. Alternatives to open vascular surgery. Philadelphia: J.B. Lippincott Company; 1995.p.94-126 4 - Barros MPL, Ferreira PJO, Maniva SJCF, Holanda RE. Caracterização de feridas crônicas de um grupo de pacientes acompanhados no domicílio. Rev Interd [Internet]. 2016 [citado 2019 jul. 02]; 9(3): 1-11. Disponível em: https://revistainterdisciplinar. uninovafapi.edu.br/index.php/revinter/ article/view/926/pdf_333 5- Switzerland BBB, Germany HGPB. Polihexanide for would Treatment How It Began .Skin Pharmacol Physiol 2010; 23(suppl1):4-6. Disponivel em: https://www.karger.com/Article/Pdf/318236 


\section{Tratamento de lesão cutânea maligna na Atenção Domiciliar: Importância clínica e financeira da escolha correta dos materiais}

Author(s): $\quad$ Katucha Maia Ayres Maria 1, Caroline Batisteli Meneses 1, Heloisa Gaspar 1, Claudio Flauzino 1

Institution(s) 1 Home Doctor - Home Doctor - Empresa de Atenção Domiciliar (Rua Capitão Francisco Teixeira Nogueira, 154 Água Branca São Paulo SP 05037030 )

\section{Abstract}

Introdução

Lesões vegetantes malignas (LVM) resultam da proliferação neoplásica com infiltração cutânea e usualmente se apresentam com aspecto de lesão vegetante, com dor fétido, grande quantidade de secreção e dor. Desta forma, despertam sentimento de rejeição, ansiedade, tristeza e isolamento social nestes pacientes 1,2.

A escolha do material utilizado para o curativo das LVM é crucial e capaz de interferir na evolução clínica do paciente. O custo dos materiais utilizados é bastante variável e a escolha do mesmo deve se basear em indicação técnica, porém o custo não deve ser excluído desta análise3.

Objetivo

O objetivo do trabalho foi evidenciar a importância clínica e financeira da escolha adequada das coberturas para tratamento de feridas em pacientes oncológicos.

Método

Relato de caso do paciente F.A.C , 59 anos, com história pregressa de tumor de cólon, apresentando lesão vegetante neoplásica em rebordo costal. Em ambiente hospitalar foi realizado tratamento com SF 0,9\%, Solução de Polihexanida, Sulfadiazina de Prata, spray barreira, hidrofibra com prata e fita adesiva com trocas $2 x /$ dia por período de 6 anos e sem resolução do quadro. Após alta hospitalar paciente iniciou seguimento domiciliar com equipe de estomatoterapia da empresa de Atenção Domiciliar e foi proposta a modificação do esquema de tratamento da ferida para SF 0,9\%, Solução de Polihexanida, spray barreira, carvão ativado, gaze estéril e filme transparente com trocas iniciais a cada 24 horas devido a saturação e posteriormente a cada 72 horas.

O paciente não realizou outro tipo de tratamento no período e recebeu acompanhamento de enfermeiro especialista semanalmente, com registro fotográfico e mensuração da lesão.

O paciente assinou o Termo de Consentimento Livre e Esclarecido (TCLE) consentindo com a participação no estudo.

\section{Resultado}

No início do atendimento domiciliar o paciente apresentava tumefação em região costal direita, com 10 x $8,5 \mathrm{~cm}$ de diâmetro e $5 \mathrm{~cm}$ de altura, exsudato serohemático intenso e odor fétido. Após 12 dias de tratamento, apresentava $1,5 \mathrm{~cm}$ de altura, com $7 \times 6 \mathrm{~cm}$, exsudato hemático em pouca quantidade com controle do odor. Ao término do tratamento de curativo (93 dias) ocorreu involução tumoral mantendo apenas um óstio com cavidade de $1 \mathrm{~cm}$, pouco exsudativa com aspecto seroso, sendo suspenso todos as coberturas.

Um estudo de custo, comparando o custo do material utilizado em ambiente hospitalar com o realizado no ambiente domiciliar demonstrou redução de $67 \%$ de custo material utilizado em domicílio.

Conclusão

O tratamento de feridas neoplásicas é um pilar fundamental dentro da abordagem do paciente oncológico seja na fase de tratamento curativo da doença ou em fase de paliação, pois é capaz de melhorar a qualidade de vida destes pacientes e aliviar sintomas desconfortáveis.

A escolha correta do material de cobertura de feriadas utilizado para o tratamento das LMV é importante e capaz de acelerar a resolução do quadro de forma custo-efetiva.

Keywords: Cuidados Paliativos, Ferimentos, Oncologia, Serviços de assistência domiciliar, técnicas de fechamento de feridas

\section{Referências Bibliográficas}

Referências bibliográficas 1. Silva S.P. O desafio do enfermeiro no controle do odor das feridas tumorais em pacientes sob internação domiciliar. Rio de Janeiro; s.n; 2004. 31 p. tab. 2. Haisfield-Wolfe ME1, Rund C. Malignant cutaneous wounds: a management protocol. Ostomy Wound Manage. 1997;43(1):56-60. 3. Santos, Cristina Mamédio da Costa; Pimenta, Cibele Andrucioli de Mattos. Lesões vegetantes malignas: diretrizes para o cuidado / Malignant Vegetative Lesion - Guidelines for Palliative Care. Mundo saúde;27(1):124-132, jan.-mar.2003 


\title{
BIOMEMBRANA DA PROTEÍNA DO LÁTEX DA CALOTROPIS PROCERA VERSUS HIDROCOLPOIDE PÓ PARA O TRATAMENTO DE ÚLCERAS NEUROPÁTICAS: ENSAIO CLÍNICO CONTROLADO E RANDOMIZADO
}

\author{
Author(s): $\quad$ LUCIANA CATUNDA GOMES DE MENEZES 1, Larissa Emília Magalhães Oliveira 1, Leonardo \\ Cardoso de Sousa 1, Ana Kare Lessa Sampaio 1, Flavia Karolyne Sousa Alves 1
}

Institution(s) 1 UNIFAMETRO - CENTRO UNIVERSITÁRIO FAMETRO (RUA CONSELHEIRO ESTELITA BAIRRO JACARECANGA), 2 UFC - UNIVERSIDADE FEDERAL DO CEARÁ (Av. da Universidade, 2853 - Benfica, Fortaleza - CE, 60020-181)

\begin{abstract}
INTRDOUÇÃO: O diabetes mellitus tipo 2 (DM2) e mais especificamente as úlceras neuropáticas representam problema de saúde pública em crescente ascensão1, que muitas vezes evoluem para amputações, sendo essa complicação passível de intervenções que podem ser evitadas. As úlceras neuropáticas configuram como complicação complexa, incapacitante e de alto custo2. Existem no mercado diversos tratamentos eficazes para os cuidados com as úlceras neuropáticas, porém o custo é alto, sendo inviável a aquisição desses pela população de baixa renda. Além disso, o próprio Sistema Único de Saúde não consegue adquirir esses tratamentos por conta do orçamento reduzido. A biomembrana vegetal é um produto biotecnológico composto pela fração isolada obtida do látex de Calotropis procera (BioMem CpLP) que tem demonstrado potencial cicatrizante por estimular a fase inflamatória da cicatrização estimulando a liberação de citocinas proinflamatórias acarretando em uma notável melhora das fases subsequentes do processo de cicatrização3. Reconhecendo a importância do tratamento eficaz e de baixo custo das úlceras neuropáticas, essa pesquisa tem como OBJETIVO: Testar a eficácia do uso de uma biomembrana da proteína do látex da calotropis procera versus hidrocolóide pó para o tratamento de úlceras neuropáticas nas pessoas com DM2. MÉTODO: Trata-se de um Ensaio Clínico Controlado e Randomizado realizado em uma Clínica Escola Integrada de Fortaleza-Ceará-Brasil nos meses de abril a julho de 2019, com uma amostra de 12 pacientes adultos, os quais dividiram-se aleatoriamente em: Grupo Controle (GC) com cinco pacientes em uso do tratamento com o hidrocoloide pó e Grupo de Intervenção (Gl) com sete pacientes em tratamento com BioMem CpLP 10\%. O desfecho primário foi redução da área da úlcera (em centímetros quadrados) depois de 120 dias de tratamento. O estudo foi aprovado pelo Comitê de Ética e Pesquisa da Unifametro sob CAAE no 08284019.4.0000.5618. RESULTADOS: Verificou-se homogeneidade dos grupos, pois não houve associação estatisticamente significante nas variáveis sociodemográficas,

relacionadas à doença e à clínica $(p>0,05)$. Em relação as úlceras neuropáticas, o local mais frequentemente acometido foi a região do hálux e do primeiro metatarso. Os pacientes do GI não apresentaram hipersensibilidade à biomembrana pelo "patch test" e tiveram resultados benéficos no tratamento da úlcera neuropática. A área das úlceras dos pacientes do $\mathrm{Gl}$, quando comparadas entre o período de tratamento, apresentou diferença significativa ( $p$-valor=0,006). As úlceras do GC não apresentaram alteração estatisticamente significativa em relação à área, com p-valor de 0,408. Quanto aos desfechos secundários, o tecido de esfacelo e da área de hiperqueratose, desfavorável à cicatrização, apresentou redução estatisticamente significativa, tanto nas úlceras no $\mathrm{Gl}(\mathrm{p}=0,001)$ quanto no $G C(p=0,004)$. O tecido de epitelização, que representa o fechamento da úlcera, apresentou aumento significativo apenas no $\mathrm{Gl}(\mathrm{p}=0,004)$, enquanto o $\mathrm{GC}$ apresentou o $p$-valor de 0,063 . Ressalta-se que duas úlceras neuropáticas $(28,5 \%)$ no Gl cicatrizaram completamente. CONCLUSÃO: Os resultados mostram que a BioMem CpLP 10\% pode ser uma opção terapêutica eficaz e de baixo custo para o tratamento de úlceras em pessoas com DM2. Sugere-se a realização de estudos multicêntricos para evidenciar a efetividade da BioMem CpLP $10 \%$ na cicatrização de úlceras neuropáticas.
\end{abstract}

Keywords: Enfermagem, Pesquisa clínica, Cicatrização de feridas, Pé diabético, Calotropsi procera

\section{Referências Bibliográficas}

Armstrong DG, Cohen K, Courric S, Bharara M, Marston W. Diabetic foot ulcers and vascular insufficiency: our population has changed, but our methods have not. J Diabetes Sci Tech. 2011, v. 5, n. 6, p.:1591-1595. http://dx.doi.org/10.1177/193229681100500636. PMid:22226282. 2. International Working Group on the Diabetic Foot. International consensus on the diabetic foot and practical guidelines on the management and the prevention of the diabetic foot, 2015. 3. Lima Filho, J.V. et al. Proteins from latex of Calotropis procera prevent septic shock due to lethal infection by Salmonella enterica serovar Typhimurium. Journal of Ethnopharmacology, 2010. 


\title{
ASSISTÊNCIA DE ESTOMATERAPIA A PESSOA COM ÚLCERA NEUROPÁTICA EM USO DE UMA BIOMEMBRANA VEGETAL: UM ESTUDO DE CASO CLÍNICO
}

\author{
Author(s): \\ LUCIANA CATUNDA GOMES DE MENEZES 1
}

Institution(s) 1 UNIFAMETRO - Faculdade Metropolitana da Grande Fortaleza (RUA CONSELHEIRO ESTELITA BAIRRO JACARECANGA), 2 UFC - UNIVERSIDADE FEDERAL DO CEARÁ (Av. da Universidade, 2853 - Benfica, Fortaleza - CE, 60020-181)

\section{Abstract}

INTRODUÇÃO: A úlcera neuropática é a complicação crônica mais comum da pessoa com diabetes mellitus (DM), além de complexa, incapacitante e de alto custo, representando um problema de saúde pública, que muitas vezes, se não for tratada adequadamente, evoluem para amputações1. Diante dos diversos tratamentos das úlceras, destaca-se o uso de biomembrana vegetal. A biomembrana da Calotropis procera (BioMem CpLP 10\%) é um produto biotecnológico composto pela fração isolada obtida do látex da Calotropis procera que tem demonstrado potencial cicatrizante por estimular a fase inflamatória da cicatrização estimulando a liberação de citocinas pró inflamatórias acarretando em uma notável melhora das fases subsequentes do processo de cicatrização2. OBJETIVO: Apresentar estudo de caso de uma pessoa com úlcera neuropática em uso de uma biomembrana vegetal. MÉTODO: Estudo de caso realizado no ambulatório de Estomaterapia em uma Clínica Escola Integrada de um Centro Universitário privado em Fortaleza-Ceará-Brasil, no mês de abril de 2019. O estudo foi aprovado pelo Comitê de Ética e Pesquisa sob o CAAE 08284019.4.0000.5618. Os dados foram coletados por meio de um instrumento que abordou os seguintes dados: sociodemográficos; clínicos e sobre a avaliação da úlcera neuropática. RESULTADOS: Dados sociodemográficos: F.F.C.M, 58 anos, sexo masculino, casado, ensino fundamental incompleto, mototaxista com renda de 1-2 salários e residente em Fortaleza. Possui amputação do $1^{\circ}$ ao $4^{\circ}$ pododáctilo do membro inferior direito, com úlcera plantar há 7 meses na região de amputação do hálux. Apresenta deambulação prejudicada, em função do desequilíbrio devido a amputação, fazendo uso de muleta como apoio. Dados Clínicos sobre o DM: Apresenta os seguintes diagnósticos médicos: Hipertensão Arterial Sistêmica e DM tipo 2 há aproximadamente 15 anos. Faz uso dos seguintes medicamentos: Losartana, Metformina, Enalapril, Hidroclorotiazida, ASS e insulina diariamente. Avaliação da úlcera neuropática: Antes da participação na pesquisa fazia uso de colagenase e papaína. Após a realização do patch test, com resultados negativos para o uso da BioMem CpLP 10\%, iniciou a primeira avaliação. No dia 01/04/2019, a úlcera apresentava as seguintes características: comprometimento de derme e epiderme, medindo $3,0 \mathrm{~cm}$ por $3,0 \mathrm{~cm}=9,0 \mathrm{~cm}^{2}$, presença de exsudato sero-sanguinolento de moderado a intenso, hipergranulação, esfacelos, biofilme e margens com tecido macerado. A partir da avaliação, estabeleceu-se o tratamento tópico da úlcera com as seguintes etapas técnicas: avaliação completa, limpeza com soro fisiológico a $0,9 \%$, desbridamento instrumental conservador mecânico da hiperqueratose, aplicação de cobertura primária com a biomembrana vegetal de Calotropis procera, com troca a cada 48h, aplicação da cobertura secundária estéril e faixa de crepe. Na avaliação do dia 22/04/2019, aproximadamente 20 dias após o início do tratamento, pôde-se observar evolução satisfatória da úlcera, com redução do tamanho, presença de tecido de granulação em grande quantidade e diminuição do exsudato. Continuando as avaliações aproximadamente com mais 15 dias após a data da última avaliação descrita, pôde-se observar a epitelização completa da lesão. CONCLUSÃO: Os resultados mostraram que a BioMem CpLP 10\% pode ser uma opção terapêutica eficaz para a cicatrização de úlceras neuropáticas, no entanto, sugere-se a realização de estudos multicêntricos para evidenciar sua efetividad

Keywords: Enfermagem, Estomarerapia, Cicatrização de feridas, Pé diabético, Calotropsi procera

\section{Referências Bibliográficas}

1 Brasil, Cadernos de Atenção Básica: Estratégia para o cuidado da pessoa com doença crônica/ Diabetes Mellitus. Ministério da Saúde. Secretaria de Atenção à Saúde. Departamento de Atenção Básica. Saúde na escola / Ministério da Saúde, Secretaria de Atenção à Saúde, Departamento de Atenção Básica. - Brasília: Ministério da Saúde, 2013. 2 Armstrong, D.G.; Cohen, K.; Courric, S.; Bharara, M.; Marston, W. Diabetic foot ulcers and vascular insufficiency: our population has changed, but our methods have not. J Diabetes Sci Tech. v. 5, n. 6, p.:1591-1595, 2011. http://dx.doi.org/10.1177/193229681100500636. PMid:22226282. 3. Lima Filho, J.V. et al. Proteins from latex of Calotropis procera prevent septic shock due to lethal infection by Salmonella enterica serovar Typhimurium. Journal of Ethnopharmacology, 2010. 


\title{
A Importância da Inserção do Enfermeiro Estomoterapeuta em um Serviço de Atenção a Pessoa Ostomizada.
}

Author(s): $\quad$ Clarissa de Paula Silva 1, Emerson Alves Chaves 1, Patrícia Rosa da SilvaP 1

Institution(s) 1 SASPO - Serviço de Atenção a Pessoa Ostomizada (Rua Bicas, 58, Sagrada Família, Belo

Horizonte)

\begin{abstract}
Introdução: O Serviço de Atenção à Pessoa Ostomizada (SASPO) desenvolve ações de reabilitação que incluem as orientações para o autocuidado, a prevenção, o tratamento de complicações no estoma, a capacitação de profissionais e o fornecimento de dispositivos coletores e adjuvantes de proteção e segurança para pessoas com estoma intestinal e/ou urinário assim como os serviços de apoio nutricional e psicológico em regime ambulatorial. A educação para o autocuidado, a adequada orientação sobre o uso de equipamentos coletores e adjuvantes de proteção e segurança e a avaliação local durante a higienização constituem ações de Enfermagem com vistas à prevenção de complicações da estomia e pele periestomal.2 A ênfase no autocuidado tem sido descrita como alternativa para possibilitar que a pessoa participe ativamente do seu tratamento, estimulando a responsabilidade na continuidade dos cuidados em seu domicílio. Objetivo: Apresentar as experiências e as atividades vividas em um SASPO, destacando-se a assistência de enfermagem ao portador de estoma. Método: Trate-se de um relato de experiência sobre a participação dos autores na assistência de enfermagem ofertada aos clientes do SASPO. Relato de Experiência: Os autores acompanharam a enfermeira estomoterapeuta nas consultas de enfermagem dos pacientes estomizados cadastrados na área de abrangência do SASPO. O serviço conta com uma enfermeira estomoterapeuta e uma enfermeira generalista.. Os principais serviços ofertados são atendimento individual, acompanhamento de complicações; orientações à família; planejamento quantitativo e qualitativo dos equipamentos; atividades de orientação aos profissionais da rede de atenção do respectivo município. Na consulta de enfermagem é realizada anamnese, exame físico e o preenchimento da ficha de atendimento, contendo informações necessárias de cada paciente. A consulta de enfermagem fornece subsídios para o diagnóstico e elaboração de um plano de cuidados. Sua realização exige do profissional uma série de conhecimentos e constante treinamento que o instrumentalize a desenvolver esta prática. Através do plano de cuidados é realizada a indicação do dispositivo ideal ao tipo de estoma, prescrição de adjuvantes, se necessários, além de orientações quanto os cuidados para prevenção de complicações e cuidados gerais no domicilio. Outra atividade desempenhada é o acompanhamento do perfil da clientela, que é realizado periodicamente através de tabulação de dados dos usuários, isto tem possibilitado, a ampliação e consolidação do serviço. Assim, consideramos que atuação do profissional enfermeiro estomoterapeuta no SASPO, é de suma importância, pois possibilita uma assistência de qualidade tanto nos aspectos preventivos, terapêuticos e de reabilitação deste público.1 Conclusão: Evidenciou-se que, atualmente, quando se fala em assistência a pacientes com estomas, o enfermeiro estomoterapeuta, contribui para a solidificação e construção do conhecimento técnico e cientifico, corroborando para qualificação do cuidado, de forma a desenvolver habilidades nos estomizados para a realização de suas atividades de vida diária e prevenção de complicações nas estomias. A ideia norteadora deste relato de experiência foi a de que ele possa contribuir para discussões e reflexões sobre a importância da inserção do enfermeiro estomoterapeuta no SASPO.
\end{abstract}

Keywords: Enfermagem , Estomoterapia, Reabilitação

\section{Referências Bibliográficas}

Moraes Juliano Teixeira, Amaral Carlos Faria Santos, Borges Eline Lima, Ribeiro Mauro Souza, Guimarães Eliete Albano de Azevedo. Serviços de atenção ao estomizado: análise diagnóstica no Estado de Minas Gerais, Brasil. Cad. saúde colet. [Internet]. 2014 Mar [cited 2019 Aug 05] ; 22( 1 ): 101-108. Available from: http://www.scielo.br/scielo.php?script=sci_arttext\&pid=S1414-462X2014000100101\&lng=en.

http://dx.doi.org/10.1590/1414-462X201400010015. 2. Moraes Juliano Teixeira, Oliveira Rita de Cassia, Reis Lígia Helena, Silva Mariana Nogueira. Conhecimento do enfermeiro da Atenção Primária de Saúde de um município de Minas Gerais sobre o cuidado em estomias. Rev Estima [Internet]. 2012 [cited 2019 Aug 05] ;10(4):12-21. Available from: https://www.revistaestima.com.br/index.php/estima/article/view/78 3. Paula Maria Angela Boccara de, Santos Vera Lúcia Conceição de Gouveia. O significado de ser especialista para o enfermeiro estomaterapeuta. Rev. Latino-Am. Enfermagem [Internet]. 2003 Aug [cited 2019 Aug 05] ; 11( 4 ): 474-482. Available from: http://www.scielo.br/scielo.php?script=sci_arttext\&pid=S0104-11692003000400010\&lng=en.

http://dx.doi.org/10.1590/S0104-11692003000400010. 


\section{AVALIAÇÃO DO CONHECIMENTO DE ENFERMEIROS SOBRE A ÚLCERA TERMINAL DE KENNEDY}

Author(s): POLYANA ALVES BERNARDINO 1, MANUELE RAIANE DA SILVA SOUSA 1, AMANDA DA SILVA FERREIRA 1, VÂNIA MARIA SILVA DE MORAES 2, BIANCA LEÃO BARRETO 2, CLÁUDIA GONÇALVES LOBO 2, FABIANA SANTOS DA SILVA OLIVEIRA 2, JANICLER CORREIA DA SILVA 2, RHAYANA MARQUES DOS SANTOS 2, LARISSA VALESKA MARIA DA SILVA BRITO 2, CHRISLAINY LOPES DE AGUIAR 2, TACIANA DA SILVA GONÇALVES 2, JOSIANA MARTINS DA SILVA 2, YASMIM THAWANNA SILVA 2

Institution(s) 1 UNICAP - UNIVERSIDADE CATÓLICA DE PERNAMBUCO (R. do Príncipe, № 526 - Boa Vista, Recife - PE, 50050-900), 2 FACHO - FACULDADE DE CIÊNCIAS HUMANAS DE OLINDA (Rod. PE-015 KM 3, 6 Santa Tereza, Olinda - PE, 53330-740)

\section{Abstract}

INTRODUÇÃO: Úlcera Terminal de Kennedy - UTK, subgrupo específico de lesão por pressão que indivíduos desenvolvem quando estão em processo de finitude de vida. Notificada em 1983 por Karen Kennedy, tem início repentino e a deterioração do tecido acontece rapidamente, no decorrer de um único dia. Causada por fatores intrínsecos, incluindo hipoperfusão e isquemia tecidual, está associada à síndrome de disfunção múltipla de órgãos e se apresenta inicialmente como uma abrasão, bolha, categoria II ou área escurecida (vermelho, amarelo, preto ou roxo), bordas irregulares, formato de pera, borboleta ou ferradura, ocorrendo piora drástica em 48 horas. A expectativa máxima de vida é de seis semanas. OBJETIVO: Desvelar o conhecimento de enfermeiros sobre a Úlcera Terminal de Kennedy. METODO: Trata-se de um estudo do tipo descritivo, abordagem quantitativa, com CAAE: 95476318.0.0000.5198, realizado no período de 10 a 19 de janeiro de 2019, onde participaram 21 enfermeiros, sendo 3 plantonistas e 18 diaristas da UTI A, B e C do Hospital da Restauração em Recife - PE. Considerado maior hospital público da Região Nordeste do Brasil, referência em atendimento de queimaduras graves, intoxicação exógena e por animais peçonhentos, vítimas de agressões por arma de fogo e arma branca e acidentes de trânsito. RESULTADOS: $70 \%$ dos entrevistados tem entre 27 e 44 anos de idade, gênero predominante é de $80 \%$ mulheres, $55 \%$ de etnia branca, $70 \%$ solteiros, $65 \%$ com mais de 5 anos de graduação, todos possuem especialização, $80 \%$ dos enfermeiros relatam não conhecer a Úlcera Terminal de Kennedy, os que responderam o questionário obtiveram conhecimento em artigo, $60 \%$ relataram já ter visto uma lesão com piora drástica em até 24 horas, em sua minoria essa lesão tinha características para UTK, 50\% respondeu buscar meios de minimizar danos, $55 \%$ reconhecem a importância de tratar corretamente visando um custo/benefício eficiente. A maioria mesmo sem o conhecimento da lesão tratava corretamente. SCALE (2009), como nas demais lesões por pressão, o que você vê é o que você trata. Quando está na categoria de pele intacta ou não branqueável, a finalidade é aliviar a pressão e proteger a área. Na categoria II ou uma lesão de espessura parcial geralmente não há exsudado e uma película fina, hidrocolóide, espuma ou gel podem ser indicados. A lesão de espessura total, categoria III ou IV, dependendo da quantidade de exsudato é indicado hidrocolóide, espuma, gel ou alginato de cálcio. Se houver tecido esquelético necrótico, é recomendado um agente de desbridamento enzimático. Caso se torne clinicamente infectado é indicado o uso de cobertura com prata. CONCLUSÃO: O estudo aponta que os enfermeiros não conhecem a lesão, devido à baixa publicação literária, informaram dificuldade em buscar conhecimentos, mas apresentaram interesse sobre o tema após aplicação do questionário. Os resultados contribuirá para o desenvolvimento do conhecimento e melhor categorização desse fenômeno, assim gerando registros para uma melhor qualidade da assistência prestada para o conforto quando estão em processo de finitude de vida.

Keywords: Úlcera terminal de Kennedy, Lesão por pressão, Estomoterapia

\section{Referências Bibliográficas}

REFERÊNCIAS: 1. CARVALHO, E. S. S.; AMARAL, Juliana Bezerra do. Perda da Integridade Cutânea nos Processos de Finitude: Medidas de Prevenção, Proteção, e Controle de Danos. In: SILVA, Rudval Souza da; AMARAL, Juliana Bezerra do; MALAGUTTI, William (Org.). Enfermagem em Cuidados Paliativos: Cuidando pra uma boa morte. São Paulo: Martinari, 2013. Cap. 10. pp. 165-191. 2. LANGEMO DK, BROWN G. Skin fails too: acute, chronic, andend-stage skin failure. ADV SKIN WOUND CARE 2006; 19:206 - 11. 3. MINER, Kimberly J. Discharge to Hospice: A Kennedy Terminal Ulcer Case Report. The Journal of the American College of Certified Wound Specialists. v. 1, n. 3, p. 84 - 85, 2009. 4 .REITZ, Megan; SCHINDLER, Christine A. Pediatric Kennedy Terminal Ulcer.Journal of Pediatric Health Care, 2016. 5. SCHANK, J. E. (2009). Kennedy terminal ulcer: the "ahha!" moment and diagnosis. Ostomy Wound Management , 40-44. 


\title{
MANUAL EDUCATIVO DE CUIDADOS À CRIANÇA COM GASTROSTOMIA: CONSTRUÇÃO E VALIDAÇÃO
}

\author{
Author(s): $\quad$ Priscila Sales de Lima 1, Leila Blanes 1, Lydia Masako Ferreira Masako Ferreira 1
}

Institution(s) 1 Unifesp - Universidade Federal de São Paulo (Rua Napoleão de Barros - 737 Vila Clementino), 2 AACD - Associação de Assistencia a Criança com Deficiência (Rua Ascendino Reis 754)

\begin{abstract}
INTRODUÇÃO: a gastrostomia é um procedimento no qual um cateter é inserido no estômago, através de uma abertura na parede abdominal anterior. Há escassez de trabalhos voltados para orientações e cuidados com do uso da gastrostomia e a influência para os familiares e cuidadores.

OBJETIVO: desenvolver e validar um manual educativo sobre cuidados com gastrostomia em crianças.

MÉTODO: realizado levantamento bibliográfico para desenvolvimento do conteúdo do manual e validação do mesmo realizada com 11 especialistas com base na técnica de Delphi e com cinco pais e cuidadores de crianças com gastrostomias mensurado por meio da escala de Likert.O estudo foi aprovado pelo Comitê de Ética em Pesquisa da Universidade Federal de São Paulo - UNIFESP - número do parecer: 1.899.234 de CAAE 62552416.8.0000.5505. Também houve a aprovação do Comitê de ética em Pesquisa da Associação de Assistência à Criança Deficiente (AACD), instituição coparticipante, número do parecer: 1.902 .516 CAAE: 62552416.8.3001.0085.

RESULTADOS: o material elaborado foi validado por especialistas em dois ciclos por meio da técnica de Delphi, com a participação de 11 juízes no primeiro ciclo e seis juízes no segundo ciclo. A porcentagem de concordância absoluta de todo o manual alcançou valor de 97,91\%. O menor valor encontrado no segundo ciclo foi de $83,3 \%$, com sete de oito questões apresentando concordância de $100 \%$. A validação com público-alvo apresentou taxa de concordância de $100 \%$ e todos os participantes pontuaram três na escala de Likert para todas as questões. 0 manual validado possui registro em ISBN de número: 978-85-924327-0-6, com 21 páginas, oito capítulos e 38 figuras de linguagem simples e acessível, abordando temas como o conceito e indicação da gastrostomia, 0 cuidado domiciliar e a prevenção de complicações.

CONCLUSÃO: O manual educativo foi validado, segundo conteúdo e aparência, por juízes especialistas e também por pais e cuidadores. A construção do manual educativo foi embasada por conhecimento científico, disponível na literatura, bem como pelas sugestões dos participantes, que contribuíram para a elaboração da versão final do referido manual.Espera-se que este estudo seja um incentivo para novas pesquisas sobre educação em saúde de pacientes com gastrostomias em literatura nacional e que possam surgir outras formas de exploração do conteúdo, como: e-books, protocolos, aplicativos, realidade virtual, entre outros.
\end{abstract}

Keywords: Gastrostomia, Cuidados de Enfermagem, Educação em Saúde, Estudos de Validação, Estomaterapia

\section{Referências Bibliográficas}

Forest-Lalande L, Dreyer E. Gastrostomias para nutrição enteral. Campinas: Editora Lince; 2011. 2. Tyng CJ, Santos EFV, Guerra LFA, Bitencourt AGV, Barbosa PNVP, Chojniak R. Gastrostomia percutânea guiada por tomografia computadorizada: experiência inicial de um centro oncológico. Radiol Bras. 2017[citado em 2018 jan.05];50(2):109-14. Disponível em: http://www.scielo.br/pdf/rb/v50n2/pt_0100-3984-rb-20150219.pdf 3. Rosário MDL, Marchini JS. Sonda nasogástrica/nasoentérica: cuidados na instalação, na administração da dieta e prevenção de complicações. Rev Med. 2002[citado em 2016 set.12];35(1):95-101. Disponível em: http://revista.fmrp.usp.br/2002/vol35n1/sonda_nasogastrica.pdf 4. Sleigh G, Brocklehurst P. Gastrostomy feeding in cerebral palsy: a systematic review. Arch Dis Child. 2004[citado em 2016 nov. 25];89(6):534-9. Disponível em: https://www.ncbi.nlm.nih.gov/pmc/articles/PMC1719963/ 5. Rodrigues L, Borges L, Chaves E. Sentimentos vivenciados por mães de crianças com gastrostomia. Rev Enferm Atual. 2017[citado em 2018 jan.05];83:24-9. Disponível em: http://revistaenfermagematual.com.br/revistas/revista_21-03.pdf 6. Kirk L, Shelley A, Battles M, Latty C. Educating parents on gastrostomy devices: necessary components to achieve sucess. J Pediatr Nurs. 2014[citado em 2018 jan. 05];29(5):457-65. Disponível em: https://www.ncbi.nlm.nih.gov/pubmed/24905434 7. Echer IC. The development of handbooks of health care guidelines. Rev Latino-Am Enferm. 2005[citado em 2016 out. 10];13(5):754-7. Disponível em: www.scielo.br/scielo.php?script=sci_arttext\&pid =S0104-11692005000500022 8. Castro AV, Rezende M. A técnica Delphi e seu uso na pesquisa de enfermagem: revisão bibliográfica. REME - Rev Min Enferm. 2009[citado em 2016 out. 25];13(3):429-34.Disponível em: http://www.reme.org.br/artigo/detalhes/209 9. Faro ACM. Técnica de Delphi na validação das intervenções de enfermagem. Rev Esc Enferm USP. 1997[citado em 2016 maio15];31(1):259- 73. Disponível em: www.scielo.br/scielo.php?script=sci_arttext\&pid=S008062341997000200008 


\title{
CAUTERIZAÇÃo QuímicA de GRANULOMAS PERIESTOMAIS COM ÁCIDO TRICLOROACÉTICO A 50\%
}

\author{
Author(s): $\quad$ Luisa Passberg 2, Rosaura Paczek 1 \\ Institution(s) 1 PMPA - Prefeitura Municipal de Porto Alegre (Rua Capitão Montanha 27), 2 HNSC - Hospital \\ Nossa Senhora da Conceição (AVENIDA FRANCISCO TREIN, 596- CRISTO REDENTOR -PORTO ALEGRE)
}

\begin{abstract}
Introdução: Granulomas são reações inflamatórias desencadeadas pela irritação da pele nos locais de sutura pela retenção dos fios por tempo prolongado. Os granulomas surgem no pós-operatório imediato ou tardio, ocorrendo nos estomas gástricos, intestinais e urinários, ricos em capilares sangram com facilidade ao serem manuseados, seu diagnóstico é visual devido as características macroscópicas. Apesar muito utilizado, existe dificuldade de encontrar referências sobre o uso do ácido tricloroacético (ATA), assim como sobre os granulomas periestomais. Os granulomas eram tratados com a aplicação de bastão de nitrato de prata, devido a indisponibilidade do produto no mercado, passou-se a utilizá-lo na fórmula líquida, e após, iniciou-se a aplicação do ATA. Atua favorecendo a repitelização do tecido, utilizado em diversas especialidades médicas com o objetivo de remover os granulomas com cauterização química. Devido a ação cáustica, o ATA faz com que as lesões tornem-se esbranquiçadas logo após sua aplicação, e a pele ao redor pode tornar-se hiperemiada e edemaciada. Tal irritação local faz com que os pacientes sintam ardência durante o procedimento. É necessário ressaltar que a pele periestomal e também a mucosa do estoma devem ser preservadas do ácido, e por isso a aplicação de forma cautelosa é indispensável. Objetivo: Identificar a eficácia do tratamento de granulomas periestomais com o uso do ácido tricloroacético à $50 \%$. Material e método: Relato de experiência, realizado num serviço destinado ao atendimento de pacientes com estomias no município de Porto Alegre, Rio Grande do Sul. A amostra foi constituída por 13 pacientes cadastrados na unidade que realizaram acompanhamento para o tratamento de granulomas periestomais. Aprovado pelo Comitê de Ética sob número 2.091.735. Resultados: Houve predomínio do sexo feminino (69,2\%), as idades variaram entre quatro e 84 anos, com idade média de 59,54 anos entre a amostra. Prevaleceu colostomia (61,5\%) dentre os tipos de estoma, seguidos pela ileostomia (15,4\%). Participaram também do estudo pacientes com jejunostomia $(7,7 \%)$, gastrostomia $(7,7 \%)$ e nefrostomia $(7,7 \%)$. Quanto às doenças base predominaram as neoplasias $(69,23 \%)$, sendo identificadas também doença diverticular, paralisia cerebral e hidronefrose. Oito pacientes (61,5\%) fizeram tratamento regular com ATA semanalmente, até a completa regressão das lesões granulomatosas, cinco (38,5\%) iniciaram o tratamento, porém não retornaram às consultas para avaliar desfecho. Do total de oito pacientes que completaram o tratamento, três (37,5\%) necessitaram de duas aplicações, um (12,5\%) precisou de três aplicações, três $(37,5 \%)$ de cinco aplicações e um (12,5\%) de oito aplicações para resolução completa dos granulomas periestomais. Conclusão: O tratamento com ATA regrediu os granulomas até seu total desaparecimento, melhorando a assistência ao paciente com estomia. Os motivos para poucas publicações podem relacionar-se ao fato de que os granulomas não causam desconforto aos pacientes, com isto há poucas pesquisas envolvendo os mesmos, além de suas modalidades terapêuticas. Nesse sentido, o estudo torna-se fundamental, uma vez que trará informação e servirá de base científica para o conhecimento e tratamento dos granulomas. O processo de cauterização química dos granulomas com esse ácido é procedimento exclusivo dos enfermeiros estomaterapeutas, e deve ser realizado uma vez por semana até completo desaparecimento das lesões.
\end{abstract}

Keywords: granuloma, cauterização, estomia, estomaterapia

\section{Referências Bibliográficas}

CORRÊA L. Disciplina de Patologia Geral do Departamento de Estomatologia da Faculdade de Odontologia da Universidade de São Paulo. Inflamação crônica e granulomas. 2000 . Disponível em: < http://143.107.240.24/lido/patoartegeral/patoarteinfl10.htm>. Acesso em: 18 abr. 2017. SOCIEDADE BRASILEIRA DE DERMATOLOGIA (SBD). Cauterização Química. 2016. Disponível em: . Acesso em: 15 abr. 2017. YAMADA BFA, PERES CSV, SANTOS VL. Granuloma em gastrostomia: uma alternativa inovadora de tratamento tópico. Rev. Estima, v. 2, n.4, 2004. ZULKOWSKI K. Ostomy terms and definitions. The World Council of Enterostomal Therapists Journal (WCET), v. 35, n.3, July/september 2015. P. 48-50. PAULA MAB, SANTOS VLCG. O significado de ser especialista para o enfermeiro estomaterapeuta. Rev. Latino-Am. Enfermagem, Ribeirão Preto , v. 11, n. 4, p. 474-482, Aug. 2003 . Available from . access on 11 Apr. 2018. http://dx.doi.org/10.1590/S010411692003000400010 . 


\title{
Evidências científicas sobre eficácia de coberturas na prevenção e tratamento de lesões por pressão estágios 1 e 2
}

Author(s): $\quad$ Sônia Regina Pérez Evangelista Dantas 1, Tereza Setsuko Toma 2, Eliane Molina Psaltikidis 1, Ana Aparecida Sanches Bersusa 2, Angélica Olivetto de Almeida 1, Ivan Rogério Antunes 1, Vanessa Abreu da Silva 1, Rosana Evangelista Poderoso 1, Taís Rodrigues Tesser 1

Institution(s) 1 UNICAMP - UNIVERSIDADE ESTADUAL DE CAMPINAS (Cidade Universitária Zeferino Vaz Barão Geraldo - Campinas SP), 2 SES-SP - Secretaria de Estado da Saúde de São Paulo (Av. Dr. Enéas Carvalho de Aguiar,188 - São Paulo)

\begin{abstract}
Introdução: As lesões por pressão (LP) são um problema de saúde pública devido a magnitude, complexidade dos cuidados e custos envolvidos. Medidas de prevenção das LP referem-se à avaliação de risco, avaliação da pele e cuidados preventivos para manutenção de sua integridade, tais como o reposicionamento, mobilização, uso de superfícies de distribuição da pressão e hidratação. Objetivo: analisar evidências científicas sobre eficácia de três tipos de coberturas: filme transparente de poliuretano, placa de hidrocolóide e espuma de poliuretano, na prevenção e/ou no tratamento de LP estágios 1 e 2. Método: Revisão de revisões sistemáticas, cujo método incluiu: pergunta estruturada, busca abrangente de literatura, seleção dos estudos, avaliação da qualidade dos estudos selecionados, extração e análise dos dados. Os estudos foram selecionados para atender os critérios definidos em perguntas de investigação elaboradas com o acrônimo PICO: P (População de interesse: pacientes adultos com risco moderado ou alto pela Escala de Braden, sem lesão ou com LP estágios 1 e 2); I (Intervenção ou tecnologia: uso de filme transparente de poliuretano, placa de hidrocolóide ou cobertura de espuma de poliuretano); C (Comparadores: medidas convencionais de prevenção e tratamento de LP ou placebo); O (Outcomes ou desfechos: não ocorrência de lesão ou redução da área lesada em LP estágios 1 e 2). A busca de artigos foi feita em abril de 2015 e atualizada em junho de 2016, nas seguintes bases: PubMed, Embase, Portal Regional da BVS, Center for Reviews and Dissemination, Scopus, Web of Science, Cumulative Index to Nursing and Allied Health Literature, Banco de teses da CAPES e Google. A avaliação da qualidade metodológica das revisões sistemáticas selecionadas foi realizada em duplas, de forma independente, utilizando-se a ferramenta AMSTAR - A Measurement Tool to Assess the Methodological Quality of Systematic Reviews. Resultados: Analisaram-se dez revisões sistemáticas e uma revisão de revisões sistemáticas, publicadas de 1999 a 2015, três de alta qualidade metodológica e oito de qualidade moderada. Apenas três revisões sistemáticas analisaram o uso das coberturas na prevenção de lesão por pressão e indicaram que o filme de poliuretano reduziu em $50 \%$ as LP (RR=0,50; IC95\% 0,32-0,76; I2=23\%); o hidrocolóide reduziu em $80 \%$ nos pacientes em geral ( $R R=0,20$; IC95\% 0,12-0,36; I2=0) e em $70 \%$ nos pacientes sob ventilação mecânica ( $R R=0,30$; IC95\% 0,18-0,52; I2=57\%); e a espuma reduziu em $83 \%$ nos pacientes em geral (RR=0,17; IC95\% 0,12-0,26) e em $87 \%$ nos pacientes sob ventilação mecânica (RR=0,13; IC95\% 0,05-0,36). Quanto ao tratamento de LP nos estágios 1 e 2, oito revisões sistemáticas mostraram eficácia do hidrocolóide em comparação ao tratamento convencional. Entretanto, a comparação do hidrocolóide com filme ou espuma não mostrou diferenças estatisticamente significantes. Duas revisões sistemáticas analisaram o tratamento com espuma, não mostrando diferenças em relação a outras coberturas. Conclusão: As coberturas podem ser utilizadas na prevenção e no tratamento de LP estágios 1 e 2. No entanto, a confiança nos resultados é comprometida pela baixa qualidade metodológica dos estudos primários.
\end{abstract}

Keywords: Avaliação da Tecnologia Biomédica, Curativos Oclusivos, Estomaterapia, Lesão por pressão

\section{Referências Bibliográficas}

1. Caliri M, Santos Vd, Mandelbaum M, Costa I. Classificação das lesões por pressão - consenso NPUAP 2016 adaptada culturalmente para o Brasil 2017 [cited 2017 March 13]. 2. Brasil. Ministério da Saúde. Agência Nacional de Vigilância Sanitária. Resolução - RDC № 36, DE 25 DE Julho DE 2013. Institui ações para a segurança do paciente em serviços de saúde e dá outras providências. 2013 [cited 2015 March 13]. 3. European Pressure Ulcer Advisory Panel. National Pressure Ulcer Advisory Panel. Prevention and treatment of pressure ulcers: quick reference guide. Washington DC: National Pressure Ulcer Advisory Panel; 2009 [cited 2015 March 13]; 1-26. 4. Caliri MHL. Feridas crônicas: prevenção e tratamento: Grupo de Estudos e Pesquisa em Segurança do Paciente, Escola de Enfermagem de Ribeirão Preto 2017 [cited 2017 March 13]. 5. Canadian Agency for Drugs and Technologies in Health. Dressing materials for the treatment of pressure ulcers in patients in long-term care facilities: comparative clinical effectiveness and guidelines - RC0496. Canada: CADTH, Rapid Response Report 2013 [cited 2015 March 13]. 